

\section{DISCLAIMER}

This report was prepared as an account of work sponsored by an agency of the United States Government. Neither the United States Government nor any agency Thereof, nor any of their employees, makes any warranty, express or implied, or assumes any legal liability or responsibility for the accuracy, completeness, or usefulness of any information, apparatus, product, or process disclosed, or represents that its use would not infringe privately owned rights. Reference herein to any specific commercial product, process, or service by trade name, trademark, manufacturer, or otherwise does not necessarily constitute or imply its endorsement, recommendation, or favoring by the United States Government or any agency thereof. The views and opinions of authors expressed herein do not necessarily state or reflect those of the United States Government or any agency thereof. 


\section{DISCLAIMER}

Portions of this document may be illegible in electronic image products. Images are produced from the best available original document. 


\title{
NUCLEAR SAFETY
}

\section{A BIMONTHLY REVIEW JOURNAL PREPARED BY NSIC}

\begin{abstract}
safety.
Nuclear Safety covers significant developments in the field of nuclear
\end{abstract}

The scope is limited to topics relevant to the analysis and control of hazards associated with nuclear reactors, operations involving fissionable materials, and the products of nuclear fission.

Primary emphasis is on safety in reactor design, construction, and operation; however, safety considerations in reactor fuel fabrication, spent-fuel processing, nuclear waste disposal, handling of radioisotopes, and related operations are also treated.

Qualified authors are invited to submit interpretive articles, which will be reviewed for technical accuracy and pertinency. Authors will be advised as soon as possible of acceptance or suggested changes. Send inquiries or 3 copies of manuscripts (with the draftsman's original line drawings plus 2 copies, and with continuous-tone glossy prints of photographs plus 2 copies) to J. P. blakely, Oak Ridge National Laboratory, P. O. Box Y, Oak Ridge, Tennessee 37830 .

Nuclear Safety is prepared by the Nuclear Safety Information Center at Oak Ridge National Laboratory for the U.S. Atornic Energy Commission, Division of Technical Information. For subscriptions, address Superintendent of Documents, U.S. Government Printing Office, Washington, D. C. 20402. The subscription rate is $\$ 3.50$ per year. Below is an order blank for your convenience.

U.S. GOVERNMENT PRINTINC OFFICE DIVISION OF PUBLIC DOCUMENTS

WASHINGTON, D.C. 20402

OFFICIAL BUSINESS

RETURN AFTER 5 DAYS

Name
Address
City_ State__ Z Z _ _ _ _ _

POSTACE AND FEES PAID U.S. GOVERNMENT PRINTING OFFICE

TO INSURE PROMPT, ACCURATE SHIPMENT, PLEASE PRINT OR TYPE CORRECT ADDRESS ON MAILING LABEL ABOVE

MAIL ORDER FORM TO:

Superintendent of Documents, Government Printing Office, Washington, D.C. 20402

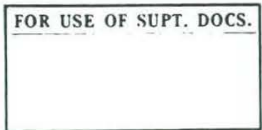

Enclosed find $\mathrm{S}$

(check, money order, or Supt. of Documents coupons). Please enter my subscription to NUCLEAR SAFETY for one $\square$, two $\square$, or three $\square$ years, at $\$ 3.50$ a year; $\$ 1.00$ additional for foreign mailing.

Please charge this order to my Deposit Account

No.

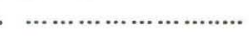

Name

Address

City and State

ZIP Code 
Thls report was prepared as an account of Government sponsored work. Netther the United States, nor the Commiooton, nor any peroon acting on behalf of tue Cotaulisalun:

A. Makes any warranty or representation, expressed or Implied, with respect to the accuracy, completeness, or usefuiness of the information contained in this report, or that the use of any information, apparatus, method, or process disclosed in this report may not infringe privately owned righta; or

B. Assumes any liablities with respect to the use of, or for damages resulting from the se of any Information, apparatus, method, or process disclosed in this report.

As used in the sbove. "person acting on behalf of the Commission" Includes any employee or contractor of the Commission, or employee of such contractor, to the extent that such employee or contractor of the commission, or employee of such contractor prepares, disseminates, or provldes access to, any Information pursuant to his employment or contract with the Commission, or his employenent with such contractor.

CONTRACT NO. $W-7405-E N G-26$

NUCLEAR SAFETY INFORMATION CENTER

\author{
INDEXED BIBLIOGRAPHY OF CURPENT \\ NUCLEAR SAFETY LITERATURE - 18
}

NSIC STAFF

APRIL 1969

OAK RIDGE NATIONAL L DBORATORY

OAK. RIDGE. TENNESSEE

OPERATED BY

UNION CARBIDE CORPORATION

FOR THE

U.S. ATOMIC ENERGY COMMISSION 
Printed in the United States of America. Available from Clearinghouse for Federal Scientific and Technical Informotion, National Bureau of Standards,

U.S. Department of Commerce, Springfield, Virginia 22151

Price: Printed Copy $\$ 3.00$; Microfiche $\$ 0.65$

\section{LEGAL NOTICE}

This report was prepared as an account of Government sponsored work. Neither the United States, nor the Commission, nor any person acting on behalf of the Commission:

A. Makes any warranty or representation, expressed or implied, with respect to the accuracy, completeness, or usefulness of the information contained in this report, or that the use of any informotion, apparatus, method, or process diselosed in this report may not infringe privotely owned rights; or

B. Assumes any liabilities with respect to the use of, or for damages resulting from the use of any information, opparatus, method, or process disclosed in this report.

As used in the above, "person acting on behalf of the Commission" includes any employee or contractor of the Commission, or employee of such contractor, to the extent that such employeo or controctor of the Commission, or employee of such contractor prepares, disseminates, or provides access to, any information pursuant to his employment or contract with the Commission, or his cmployment with such contractor. 
THE INDEXED BIBLIOGRAPHY OF CURPENT NUCLEAR SAFETY LITERATURE IS PUBLISHED SIX TIMES ANNUALLY UNDER THE DUSPICES OF THF NUCLELR SAFETY INFORMATION CENTER. THE CENTER WAS ESTABLISHED IN MARCH 1OG.3 AT THE CAK RIDGE NATIONAL LABORATORY UNDER THE SPCNSDRSHIP OF THE U.S. ATDMIC ENERFY COMMISSION AND SERVES AS A FOCAL POINT FDR THS COLLECTION, STORAGE, SVALUATION, AND DISSEMINATION OF NUCLEAR SAFETY INFORMATION. THE CENTEPS EXTENSIVE REFERENCE FILES ARE STOPED ON MAGNETIC TAPE AT THE DAK FIDGE COMPUTING TECHNOLOGY CENTER (CTC) $\triangle N D$ ARE READILY $\triangle V \triangle I L \triangle B L E$ FOR USE GY THE NSIC STAFF IN GIVING GUIDANCE ON PR.OBLEMS THAT ARISE IN THE FIELO DF NIJTLEAR SAFETY. THE PRODUCTION OF THIS BIBLIOGRAPHY WAS MADE PCSSIBLE THFOUIGH IEM-TOQC CCMPUTER PROGRAMS DEVELOPED BY THE INFCRMATION SYSTEMS DEFADTMENT" OF CTC.

BIBLIOGRAPHIC ITEMS HAVE BEEN SCRTED INTO 19 CATEGERIES ORF NUCLEAE SAFETY INFORMATION. ITEMS MAY $\triangle P D E \triangle R$ IN AS MANY AS THREE CLTEGORIES. A SELECTOR INDEX AND AN AUTHOP. INDEX ARE PROVIDED FOR THE CUNVENIENCE GF THE USER.

EACH SIBLIOGRAPHIC ITEM CONSISTS OF AUTHOR(S), TITLE, CORPCFATE AUTHOR(S), NUMBER OF PAGES, TABLES, FIGURES, PEFERENCES, DATE, DOCUMFNT NUMRCE(SI, AVAILABILITY (IF NOT EBVIOUS), AN INFCRMATIVF $\triangle B S T R A C T$ CF LESS THAN 1OC WDRDS, $\triangle N D$ SEVERAL SELECTOR TERMS. THE SELECTOR TERMS OR KEYWORDS $\triangle R F$ ASSIGNED BY NSIC PERSONNEL TO SERVE AS CCORDINATE INDEXING TERMS FOR STORAGE AND FUTUIRE P.ETRIEVAL OF INFORMATICN. THF MOST SIGNIFICANT SELECTOR TERMS FOR EACH EIBLIOGRAPHIC ENTRY ARE ASTERISKED AS WEIGHTING FACTCRS. SELECTOR TFRMS $\triangle R E$ INCLUDEO WITH THIS BIBLIOGRAPHY SINCE THEY CAN, THRQUGH THE SELECTOR INEEX, EE OF AID TO THE READER IN! LCCATING ITEMS OF INTCREST. MANY RFADEFS, HGVEVER, WILL PREFER TO SCAN THE CATEGORIES MOST RELATED TO THEIR FIELD OF INTEPEST.

NSIC STAFF MEMBERS SELECTED, EXTRACTEC, ANIO KEYWOFOCD THF VAFIJUS ENTRIFS IN THE BIBLIOGRADHY. THE ASSIGNMENTS OF THE STAFE MEMBFPS, MOST OF WHOY WOPK HALF TIME FOR THE CENTER, AKE AS FOLLOWS

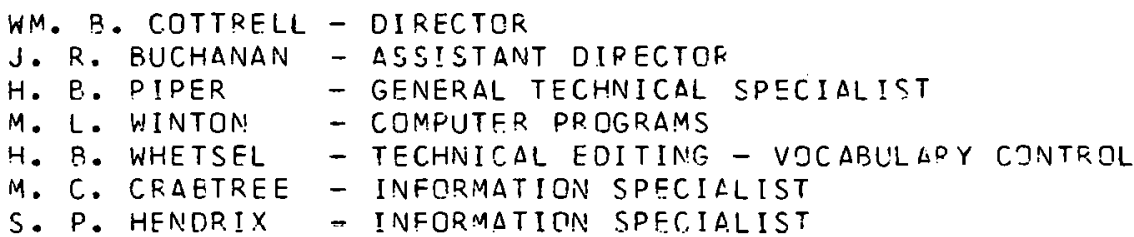

\section{CATEGORY}

$\begin{array}{ll}l & \text { J. P. ELAKELY } \\ 2 & \text { H. B. PIPER, W. C. MCCLAIN } \\ 3 & \text { L. S. SHAPPERT } \\ 4 & \text { S. P. HENOPIX } \\ 5 & \text { M. H. FONTANA, C. G. LAWCON, } \\ & \text { W. R. GAMBILL } \\ 6 & \text { J. V. WILSON, H. F. BAUMAN, } \\ & \text { B. E. PRINCE, J. O. SMITH. } \\ 7 & \text { G. W. KEILHCLTZ } \\ 8 & \text { H. D. MCLAIN }\end{array}$

\section{CATEGOFY}

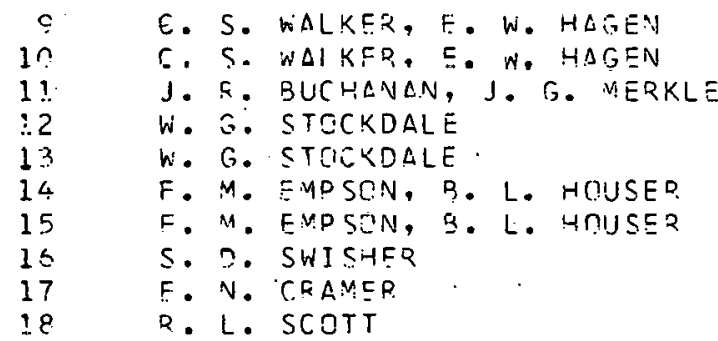


THE SERVICES OF THE CENTER INCLUDE PRINCIPALLY (I) PREPARATION gF STATE-OF-THE-ART REPORTS (ISSUED WITH ORNL-NSIC REPORT NUMBERS) IN THE CATEGORIES LISTED ABOVE WITH STAFF ASSIGNMENTS, (2) PREPARATIDN OF THE BIMONTHLY TECHNICAL PRCGRESS REVIEW, NUCLEAR SAFETY, (3) ANSWERING TECHNICAL INQUIRIES AS TIME IS AVAILABLE, ANO-14) CCUNSEL AND GUIDANCE ON NUCLEAR. SAFETY PROBLEMS IN THE ABOVE SUBJECT AREAS. THE COMPUTER CODE USED IN THE PREPARATION OF THIS BIBLIOGRAPHY IS ALSO USED FOR SELECTIVE DISSEMINATION OF INFURMATION AND SPECIAL LITERATURE SEARCHES.

SERVICES OF THE NSIC ARE AVAILABLE WI THOUT CHARgE TO GOVERNMENT DGENCIES, RESEARCH AND EDUCATIONAL INSTITUTIONS, AND THE NUCLEAR INDUSTFY. THE NSIC SERVICES ARE AS LISTED ABOVE BUT UNDER NO CIRCUMSTANCES DO THEY INCLUDE FURNISHING COPIES OF ANY DOCUMENTS (EXCEPT NSIC, REPORTS) ALTHOUGH $\triangle L L$ DOCUMENTS MAY BE EXAMINED AT THE CENTER BY QUALIFIED PERSONNEL. INQUIRIES CONCERNING THE CAPABILITIES AND OPERATION OF THE CENTER MAY BE ADDRESSED TR

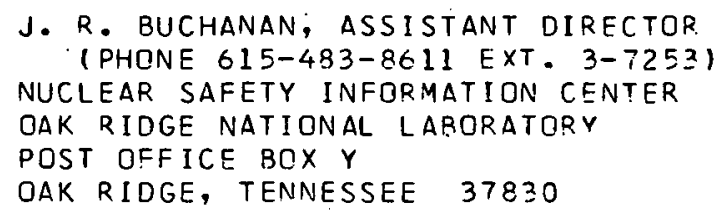

THE PUBLICATICNS CONTAINED IN THIS REPORT WERE PROCESSED BY THE NSIC STAFF DURING DCIOBER AND NDVEYBER. 1968.

PREVIOUS NUCLEAR SAFETY INFORMATION CENTER BIBLIOGRAPHIC FEPORTS, NONE OF. WHICH ARE CUMULATIVE, AR.E AS FOLLOWS

\begin{tabular}{|c|c|c|}
\hline ORNL-NSIC-8 & NO. 1 & APR.IL, 1.065 \\
\hline ORNL-NSIC-9 & NO. 2 & AUGUST, 1965 \\
\hline$O R N L-N S I C-12$ & NO. 3 & NOVEMBER, 1965 \\
\hline ORNL-NSIC-14 & NO. 4 & MARCH, 1966 \\
\hline$O R N L-N S I C-16$ & NO. 5 & JUNE, 1966 \\
\hline ORNL-NSIC-IS & NO. $t$ & SEPTEMBER, 1966 \\
\hline ORNL-NSIC-2C. & NO. 7 & NOVEMBFR, 1966 \\
\hline QRNL-NSIC-32 & NO. \& & MARCH, $106 ?$ \\
\hline$O R N L-N S I C-34$ & NO. 9 & MAY, $1 \subseteq 67$ \\
\hline ORNL-NSIC-36 & ND. 10 & AUGUST, 1967 \\
\hline ORNL-NSIC- $\angle O$ & NO: 11 & NOVEMRER, $196 ?$ \\
\hline ORNL-NSIC-42. & NO. 12 & FFBRUAFY, $19 S 8$ \\
\hline ORNL-NSIC-44 & NO. 13 & MAY, 1568 \\
\hline ORNL-NSIC-45 & NO. 14 & JULY, 2068 \\
\hline ORNL-NSI C-52 & NO. 15 & DCTOBER, $1 \subseteq 68$ \\
\hline ORNL-NSIC-5.4 & NO. 16 & JANUARY, $1 \subseteq E \subseteq$ \\
\hline ORNL-NSIC 58 & NO. 17 & FEBRUARY, 1969 \\
\hline
\end{tabular}




\section{PARTS AND METHOD OF INDEXING ABSTRACTS}
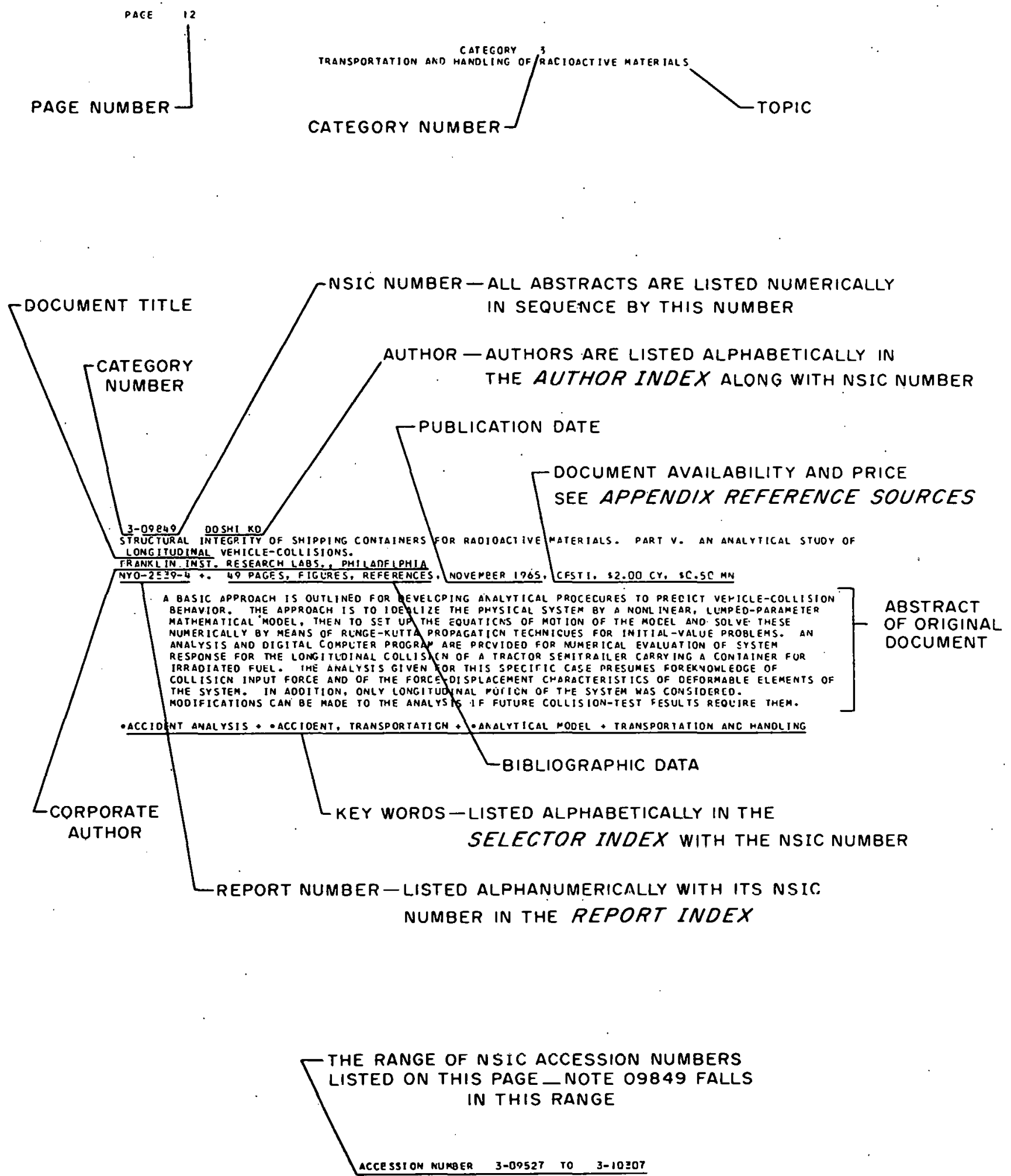
THIS PAGE

\section{WAS INTENTIONALLY LEFT BLANK}


TABLE OF CONTENTS

FORE WORD

PARTS AND METHCD OF INOEXING ABSTRACTS

$D \triangle G E$

I I I

CATEGORY SCOPE NOTES

B I BL I OGRAPHY

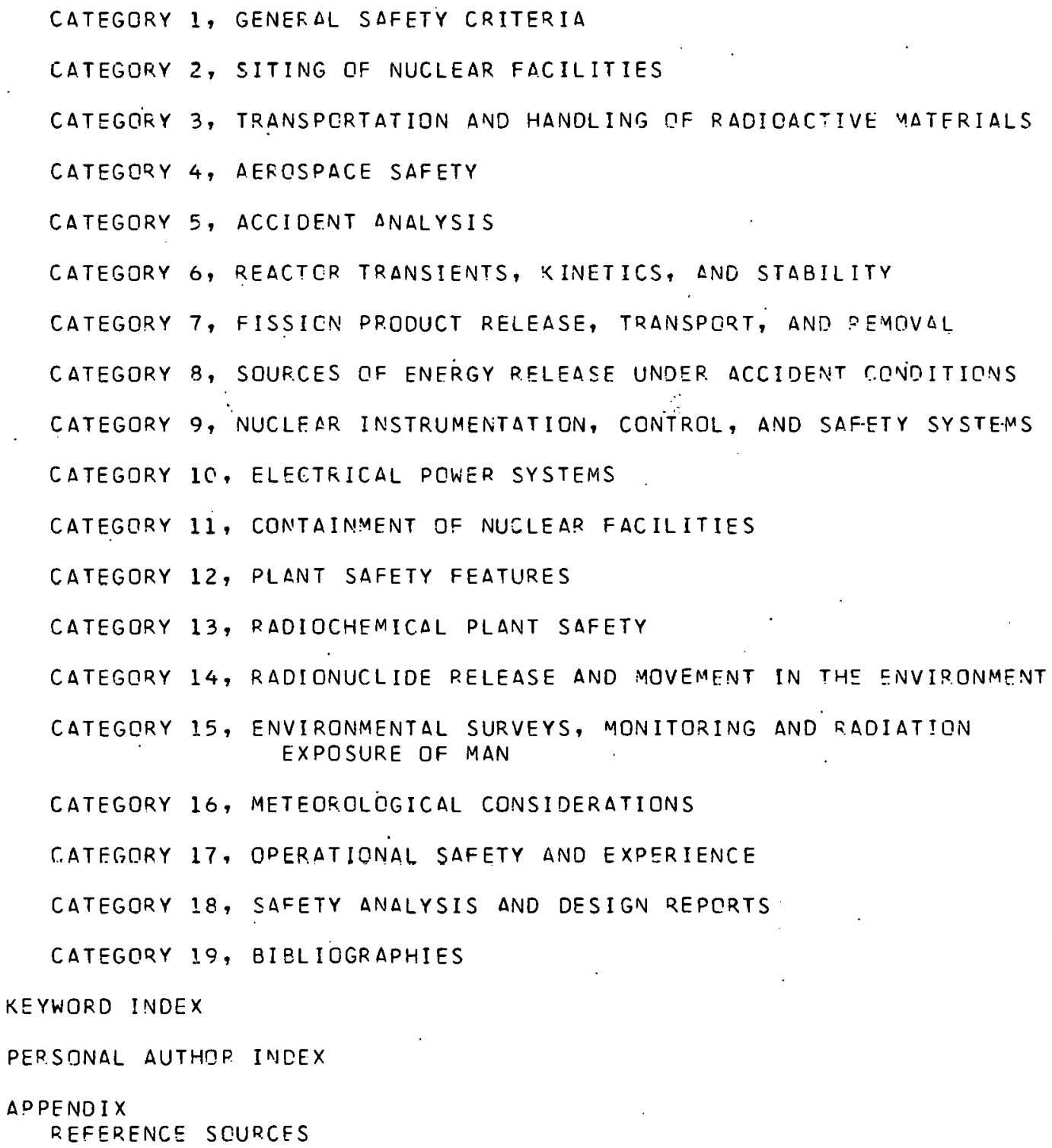




\section{CATEGORY SCOPE NOTES}

A BRIEF EXPLANATION OF THE COMPOSITION OF EACH CATEGOPY WITHIN THE SCOPE OF THE NUCLEAR SAFETY INFORMATION CENTER FOLLOWS

\section{1. general safety CPITER. IA}

THIS CATEGORY ENCCMPASSES ALL SAFETY ASPECTS OF RADIATION PHILOSOPHY, STANDARDS, CODES, COST, FINANCIAL LIABILITY AND INSURANCE. OTHER ITEMS OF INTEREST ARE THE CCMPARATIVE RISK TO THE PUBLIC HEALTH DND SAFETY FROM NUULEAR AND NONNUCLEAR. HAZARDS.

\section{SITING DF NUCLEAR FACILITIES}

THIS CATEGORY DEALS WITH DJCUMENTS RELATED TO THE FACTOF:S USED IN EVALUATING SITES SUCH AS CHARACTERISTICS OF THE FACILITY DESIGN, FRGPOSEC OPERATION, POPULATION CENSITY, USE CHARACTERISTICS OF THF SITE ENVIP.ONS, PHYSICAL CHARACTERISTICS OF THE SITE, EARTHQUAKE CONSIDERATIONS, AND THE RELATICNSHIP OF ENGINEERED SAFEGUARDS TO NUCLEAR FACILITY'SITING.

\section{TRANSPOR.TATION and handling of RADiOACTIVE Materials}

THIS CATEGORY CONTAINS ARTICLES DEALING WITH SHIPDING CONTAINEPS, SHIPOING REGULATIONS, CRITICALITY SAFETY AS RELATED TO SHIDPING ANO HANCLING, TRANSPORTATICN ACCIDENTS, AND ALL OTHER ITEMS DEALING WITH SAFETY DURING THE TRANSPORTATION ANOIOR HANOLING OF RAOIOACTIVE MATERIALS.

\section{AEROSPACE SAFETY}

THIS CATEGCRY COVERS. SAFETY CONSIDER.ATIONS SUCH AS LAUNCH AND REENTRY PROBLEMS THAT $\triangle R E$ UNIQUE TO NUCLEAR SYSTEMS USED IN AEROSDACE. VEHICLES.

\section{ACCIDENT ANALYSIS}

ALL FACETS OF THE ANALYSIS GF POSTULATED ACEIDENTS ARE CONSIDEFEO IN THIS CATEGORY. INCLUDED ARE BURNOUT HEAT FLUX, CRITICAL HEAT TRANSFER, RELIARILITY ANALYSIS, IN PILE EXPERIMENTS, COOLANT ACTIVITY BUILDUP, PIPE RUPTUPE, ANI EXPERIMENTS, I.E. LOFT. EXPERIMENTS RELATED TO REACTOR KINETICS ARE CATALOGED IN CATEGORY 6:

6. REACTOR TRANSIENTS, KINETICS, AND STABILITY

THIS CATEGORY INCLUDES THE VAFIOUS STUDIES, BOTH ANALYTICAL ANU EXPERIMENTAL, SUCH AS TREAT AND SPERT IN WHICH THE TRANSIENT BEHAVIOR OF REACTORS AND CRITICALITY ACCIDENTS ARE EXAMINED.

\section{FISSION PRCDUCT RELEASE, TRANSPORT, AND REMOVAL}

THE RELEASE GF FISSICN PROOUCTS FROM VARIOUS MATER.IALS AND THEIP. MCVEMENT WITHIN A NUCLEAR. FACILITY CONTAINMENT SYSTEM ARE INCLUDED IN THIS CATEGULY. TRANSPORT OF THE FISSION PRODUCT INVOLVES THE PHYSICAL. AND CHEMICAL CHARACTERIZATICN OF THE RELEASED FADIOACTIVE MATERIALS, AS WELL AS THE VARIOUS MECHANISMS SUCH AS UEPOSITION, ADSORPTION, FILTRATION, FALLOUT, ETC., THAT WOULD ATTENUATE THEIR CONCENTRATION WITHIN THE CONTAINMENT SYSTEM.

\section{SOURCES OF ENERGY RELEASE UNDER ACCIDENT CIJNDITIONS}

SOURCES OF ENERGY CONSIDERED IN THIS CATEGORY INCLUDE NUCLEAR, WIGNER, AND GAMMA ENERGIES, AS WELL AS CHEMICAL REACTIONS, METAL-WATER REACTIONS, DND ANY OTHER. TYPES OF ENERGY THAT MTSHT BE RELEASED AS THE RESULT OF A NUCLEAR ACC I DENT.

\section{NUCLEAR INSTRUMENTATION, CONTROL, AND SAFETY SYSTEMS}

THE DESIGN OF CONTROL AND SAFETY SYSTEMS FOR VARIOUS NUCLEAR PROCESSES, AS WELL AS THE REQUIRED INSTRUMENTATION AND HARDWARE, AFE INCLUDEO IN THIS C.ATEGORY. THE PROBLEMS INVOLVED ARE THE PER.FORMANCE F.EQUIRFD OF SAFETY SYSTEMS THE SPECIFICATION OF INSTRUMENTATION THF CONCEOTS JF COINCIUENLL, REDUNDANCE, FAILURE MODES, AND RELIASILITY THE ADEQUACY OF SHUTDOWN MARGINS THE DESIGN FEATURES OF DIFFERENT MECHANICAL DEVICES ANO RELATED SUBJECTS. 
10. ELECTRICAL POWER SYSTEMS

INFORMATION RELATED TO ROUT INE AND EMERGENCY MEANS OF SUPPLYING ELECTEICAL POWER TO NUCLEAR FACILITIES IS CCVERED IN THIS CATEGOPY.

\section{CONTAINMENT OF NUCLEAR FACILITIES}

THIS CATEGORY ENCOMPASSES ALL ASPECTS OF DPESSUPF CONTAINMENT, PRESSURE RELEASE CONTAINMENT, AND MULTIPLE BARRIER CONTAINMENT FOR Q.EACTORS, RADIOCHEMICAL PLANTS, HOT CELLS, SOURCES, ETC., ANO WILL INCLUDE SUCH $\triangle S P E C T S$ AS DESIGN CONSIOERATIONS, LEAKAGE, PENETRATIONS, STRUCTUJEAL INTSGD ITY, AND LEAK TEST I NG.

\section{PLANT SAFETY FEATURES}

THE SAFETY ASPECTS OF MAINTENANCE, DECONTAMINATION, REACTIR SYSTEMS, URANIUM MINING AND MILLING, AND FUEL FABEICATIJN AND STOFAGE ARE COVEREO IN THIS CATEGORY. ENGINEERING DEVICES SUCH AS PFFSSURE AND TFMDEPATURE REDUCING SYSTEMS, AIR CLEANINE SYSTEMS, AND COPE SPRAY AND SAFETY INJECTION SYSTEYS THAT ARE DESIGNED TO MINIMIZE THE CONSEQUENCES GF NUCLEAR ACC IOENTS ARE INCLUDED.

\section{RADIOCHEMICAL PLANT SAFETY}

NUCLEAR SAFETY INFORMATION RELATED SPECIFICALLY TG RADIOCHEMICAL PLANTS IS COVERED IN THIS CATEGQRY.

\section{RADIONUCLIDE release AND MOVEMENT IN THE ENVIPONMENT}

ALL ASPECTS OF THE INTENTIONAL OR ACCIDENTAL RELEASE OF PAOIOACTIVITY TO THE ENVIRONMENT ARE INCLUDED IN THIS CATEGQRY. RADIOACTIVE WASTE MANAGEMENT, INCLUDING WASTE TRANSPCRTATICN, TREATMENT, DISPOSAL AND EFFLUENT CONTPOL IS OF PRIMARY IMPORTANCE AS IS R.ADIONUCLIDE OCCURRENCE $\triangle N D$ MOVEMENT. THE LATTES. INCLUDES FALLOUT, GEOLCGICAL CONSIDERATI ONS, COLNTERMEASIJPES, ANALYTICAL TECHNIQUES, HYOROLGGIC CONSIDERATIONS, AND RAOIONUCLIOE MOVEYENT IN SOIL AND WATER .

\section{ENVIRONMENTAL SURVEYS, MONITORING, AND RACIATICN EXPCSUEE OF MAN}

THIS CATEGQRY INCLUCES ITEMS RELATED TO (1) ENVIRONMENTAL AND PERSCNNEL MONITORING DURING POUTINE ANO ACCIDENTAL RAOICNUCLIDE FELFASE, 121 , VINITOPING METHODS AND TECHNIOUES, (3) DOSE MEASUPEMENT ANO CALCULATIOV, (L) DETSRMINATIOV OF MAXIMUM PERMISSIBLE CCSE AND CONCENTEATION, $\triangle N D$ (5) INTEFVAL $\triangle$ NC EXTERNAL EXPOSURE TO RACIONUCLIDES.

\section{METEOROLOGICAL CONSIOERATIONS}

THIS CATEGORY CONSIDERS NCT ONLY DIFFUSION AND CEPOSITION DF PACICICTIVE MATERIAL NFAR THE EARTHS SURFACE IN CONNECTION WITH REACTCR TPEZATIONS SUT ALSO THE ATMOSPHERIC TRANSPORT AND FALLQUT IN THE TROOESSPHEDE ANO STRATOSPHEPE AS A RESULT OF NUCLFAR WEAPONS TESTS.

17. OPERATIONAL SAFETY AND EXPEPIENCE

THIS CATEGORY INCLUDES COVERAGE OF THE SAFFTY ASPFCTS OF ROUTINE REACTOP OPERATION AND OF INCIDENTS OR UNUSUAL OPERATING CCCURRENCFS, LARGE OR SMALL. POWEF, RESEARCH, AND TEST REACTOPS $\triangle N D$ FUEL REPROCESSIVS FLAVTS WILL OE COVERED. ALL AVAILABLE DPERATING, INCIDENTS, SAFEGUADOS, AND INSPECTITN REPORTS WILL BE COLLECTED AND INDEXED.

18. SAFETY ANALYSIS ANO DESIGN REPORTS

ROUTINE LISTINGS OF THE LATEST NUCLEAR FACILITY SAFETY ANALYSIS AND DESIGN REPORTS ARE TO BE FOUND IN THIS CATEGORY. INCLUDED ARE BITH ANALYSFS DN? REPORTS BY FACILITY DESIGNFPS AND BY THE $\triangle E C$ REGULATOPV STAFF.

\section{BIBLIOGRAPHIES}

THIS CATEGORY CATALQGUES DOCUMENTS ON NUCLEAR SAFETY TOOICS THAT ARE EXCLUSIVELY BIBLIOERAPHIES AS WELL AS THOSE THAT INCLUDE EXTENSIVE BIBL IOGRAPHIES WITH CTHER MATERIAL. 
CATEGORY 1
GENERAL SAFETY CRITERIA

$1-24694$

JACCHIA E

NUCLEAR ENERGY AND SOCIAL ETHICS

EUROPEAN ATOMIC ENERGY COMMUNITY

EUR-2722. E +. 8 PAGES, MARCH 2, 1966, PAPER PRESENTED AT THE CONFERENCE MAN AND NUCLEAR ENERGY TOKYO,

SEPTEMBER $11-26,1965$

THE PROBLEM OF RADIATION EFFECTS, AND PARTICULARLY OF GENETIC DAMAGE, IS ONE WHICH IS DIFFICULT TO EXPRESS IN QUANTITATIVE TERMS OR IN MATHEMATICAL FORMULAE, BUT FROM THE STANDPOINT OF SOCIAL ETHICS SUCH A QUESTION CANNOT REMAIN UNANSWERED EVEN IF THE ANSWER CANNOT BE IMMEOIATE OR CATEGORIAL. WE MUST MAKE EVERY EFFORT TO REDUCE AS FAR AS POSSIBLE THE DANGERS BOUND UP WITH RADIATIONS, WHILE CONTINUING TO EXPLOIT THEM AS A SOURCE DF THE IMMENSE BENEFITS WHICH CAN REDOUND TO OUR HEALTH AND MATERIAL WELL-BEING. THE TWO AIMS SEEM TO BE CONTRADICTORY. IN ACTUAL FACT THE TRUE AIM IS ONE AND THE SAME - TO ACHIEVE A JUDICIOUS BALANCE BETWEEN THE RISKS AND ADVANTAGES OF NUCLEAR ENERGY, THE USE OF HHICH MAN WOULD CERTAINLY NOT LIKE TO FOREGO.

* RADIATION EFFECT + *RAdIATION IN PERSPECTIVE + EuRATOM + RADIATION, PUBLIC EDUCATION/ACCEPTANCE + RAOTORIOLOGY

$1-25935$

ALSO IN CATEGORIES 17 ANO 5

MACPHERSON RE

-FAST REACTOR SAFETY CONFERENCE

OAK RIDGE NATIONAL LABORATORY, DAK RIDGE, TENNESSEE

8 PAGES, TABLE, REFERENCE, NUCLEAR SAFETY, 9(3), PAGES 202-209 (MAY-JUNE, 1968)

BRIEFLY SUMMARIZES THE SESSIONS COVERING 11 ) CORE MELTDOWN ACCIDENTS, $(2)$ SODIUM BOILING AND SUPERHEATING, (3) INCIOENTS IN REACTORS, AND (4) SAFETY. MALFUNCTIONS IN THE BRS WERE (I) FUEL-ELEMENT LEAKS CAUSED BY HEATER SHORTING, PLUS AIR IN LEAKAGE CAUSING MASSIVE SODIUM OXIDE PLUGGING, AND (2) REACTIVITY PERTURBATIONS OUE TO ENTRAINMENT OF ARGON BY THE STDIUM STREAM. \#PLUGGING OF SUBASSEMBLIES BY OXIDE HAS BEEN DETECTEO PRIMARILY BY THE EFFECT ON PRIMARY FLOW. A PANEL DISCUSSION SHOWED THAT ATTENTION IS SWITCHING FROM THE LARGE; LESS PROBABLE ACCIOENT TO THF. SMALLER, MORE FREQUENT ACCIDENTS WHICH AFFECT PLANT USE.

* REACTOR, FAST + \#SAFETY PRINCIPLES AND PHILOSOPHY + ACCIDENT . ANALYSIS + ACCIDENT, MAXIMUM CREDIBLE (MCA) + COOLANT QUALITY + FLOW 8LOCKAGE + INCIDENT, GENERAL + R.EACTOR, LMCR + REVIEW

1-26005 ALSO IN CATEGORY 17

FUEL CLADDING FAILURE

USAEC, DIVISIDN OF OPERATIONAL SAFETY

ROE 68-7 +. 2 PAGES, AEC BULLETIN, OPERATING EXPERIENCES, REACTOR SAFETY, MAY 27,1968

ALUMINUM-CLAD, 168-G U235, FLAT-PLATE, ETR-TYPE ELEMENTS WERE NORMALLY USEO TO 200,000 MWD/T. SPENT ELEMENTS WERE NORMALLY STOREO IN CADMIUM-LINED HOLSTERS INSIDE THE REACTOR VESSEL. A CHANGE REQUIRED STORAGE IN THE STORAGE POOL, WITH ONLY FILTRATION FOR TREATMENT. A

LOW-BURNUP ELEMENT (I R AT CONTACT), EXAMINEO BEFORE REPLACEMENT, HAD A BLISTER COMPLETELY

THROUG THE 0.015-IN. CLAD. ALTHOUGH CORROSION WAS NOTED ON ALL II ELEMENTS STORED ISOME FOR AS LONG AS 13 MONTHSI THIS WAS THE ONLY DEFECT.

USAEC, DIVISION OF OPERATIONAL SAFETY, WASHINGTON, D.C. 20545

* COOLANT QUALITY + \#FAILURE, CLADDING + \#FUEL STORAGE + ALUMINUM + COOLANT PURIFICATION SYSTEM + FAILURE, ADMINISTRATIVE CONTROL + REACTOR, AEC OWNED + REACTOR, RESEARCH

1-26413 ALSO IN GATEGRRTFS 7 ANM 11

NUCLEAR SAFETY PROGRAM ANNUAL PROGRESS REPORT FOR PERIOD ENDING DECEMBER 31,1967

OAK RIDGE NATIONAL LABORATORY

ORNL-4228 + 443 PAGES, FIGURES, TABLES, REFERENCES, APRIL 1960

THE ORNL NUCLEAR SAFETY PROGRAM INVOLVES TASKS IN SEVERAL LABORATORY DIVISIONS AND IS CLOSELY RELATED TO PROGRAMS AT OTHER LABORATORIES. THIS REPORT IS ONE OF A CONTINUING SERIES STARTING WITH ORNL-3319 IN 1962. IT CONTAINS PROGRESS REPORTS ON VARIOUS ASDECTS OF CHARACTER IZATION AND BEHAVIOR OF ACCIDENT-RELEASES, FISSION PRODUCTS, FILTRATION AND ADSORPTION TECHNOLOGY, SPRAY AND ADSORPTION TECHNOLOGY, SAFETY STUOIES FOR HIGH-TEMPERATURE GAS-CGOLED REACTORS, SAFETY STUDIES FOR MSBR, PRESSURE VESSEL AND PIPING TECHNOLOGY, GENERAL NUCLEAR SAFETY STUUIES, ANU NUCLEAR SAFETY INFORHATION.

AVAILABILITY - CLEARINGHOUSE FOR FEDERAL SCIENTIFIC AND TECHVICAL INFORMATION, SPRINGFIELD, VA. 22151 $\$ 3.00$ COPY, $\$ 0.65$ MICP:OF ICHE

\#AOSORPTION + \#FILTRATION + \#FISSION PRODUCT RELEASE, GENERAL + \#INFORMATION RETRIEVAL + \#NSIC + \#PIDING + *PRESSURE VESSEL + \#REACTOR, BREEDER + \#REACTOR, HTGR + \#REACTOR, MOLTEN SALT + \#SAFETY PRJGRAM + *SPRAY, GENERAL 
CATEGORY 1

GENERAL SAFETY CRITERIA

1-26515 ALSO IN CATEGORIES 17 AND 18

QUESTIONAIRE ON PROPOSED WATER-REACTOR SAFETY SCHOOL

IDAHO OPERATIONS OFFICE, AEC

16 PAGES, LETTER FROM W. L. GINKEL, JULY 1,1968

PROPOSED SCHOOL (AT NRTS, IDAHO) WOULD PROVIDE 9- TO 12-WEEK SESSIONS (RUNNING SUCESSIVELY FOR FOUR YEARS) TO OISSEMINATE (WITH REDUCED TIME IAG) THE LATEST REACTOR-SAFETY TECHNOLDGY AND PHILOSOPHY TO INOUSTRY, UNIVERSITIES, AND GOVERNMENT. CURR ICULUM COULD BE LIFTED ALMOST DIRECTLY FROM THE WATER-REACTOR ACCIDENT TREE AND WOULD INCLUDE BASIC PHENOMENA AND ANALYTICAL TECHNIQUES. SYLLABUS INCLUDES - BACKGROUND (6 HR), NATURE OF REACTOR SAFEGUARDS $(24 \mathrm{HR})$, HISTORY OF ACCI DENTS $(6$ HR), REACTOR SAFEGUAROS $(24 \mathrm{HR})$, REGULATORY AND R-AND-D FUNCTIONS ( 6 HR), ACCIDENT ANALYSIS (48 HR), QUALITY ASSURANCE (I2 HR), CLASS PROJECTS (66 HRI, AND SUMMATION SESSIONS (28 HRI. TUITION - \$2000-\$4000.

AVAILABILITY - R. F. MAKEUS, EDUCATION OFFICER, USAEC, IDAHO QPERATIONS OFFICE, P. O. BOX 2IOS, IDAHO FALLS, IDAHO 83401

* SAFETY PROgRAM + \#STAFFING, TRAINING, QUALIFICATION + NRTS + REACTOR, BWR + REACTOR, PHR + REACTOR, WATER

$1-26558$

COTTRELL WB

ALSO IN CATEGORIES 7 AND 11

ORNL NUCLEAR SAFETY RESEARCH AND DEVELOPMENT PROGRAM BIMONTHLY REPORT FOR MARCH-APRIL 1968

DAK RIOGE NATIONAL LABORATORY, OAK RIOGE, TENNESSEE

ORNL-TM-2230 +. 164 PAGES, FIGURES, TABLES, MAY 30,1968

INCLUDED IN THIS PROGRESS REPORT IS WORK ON VARIOUS CHEMICAL REACTIONS, AS WELL AS THE RELEASE, CHARACTERIZATION, AND TRANSPORT OF FISSION PRODUCTS IN CCNTAINMENT SYSTFMS UNDER VARIOUS ACCIDENT CONDITIONS ANO ON PROBLEMS ASSOCIATED WITH THE REMOVAL OF THESE FISSION PRODUCTS FROM GAS STREAMS. ALTHOUGH MOST OF THE WORK HAS BEEN AND CONTINUES TOBE IN GENERAL SUPPORT OF WATER POWER-REACTOR TECHNOLOGY, INCI.UDING SOME IN DIRECT SUPPORT DF THE LOFT. AND CSE PROGRAMS, SEVERAL PROJECTS WERE STARTED THE FIRST OF THE CALENDAR YEAR IN SUDPORT OF THE HIGH-TEMPERATURE GAS-COOLED REACTOR (HTGR) PROGRAM. THESE PROJECTS INCLUDE BOTH IN-PILE AND OUT-PILE STUDIES OF REACTION RATES AND FISSION PRODUCT RELEASE AND TRANSPDRT PHENOMENA

RELEVANT TO POTENTIAL. HTGR ACCIDENT SITUATIONS. OTHER MAJOR PROJECTS INCLUDE FUEL TRANSPORT SAFETY INVESTIGATIONS, A SERIES OF DISCUSSION PAPERS DN VARIOUS ASPECTS OF SAFETY

INVESTIGATIONS, A SERIES OF DISCUSSION PAPERS ON VARIOUS ASPECTS OF WATER REACTOR TEEHNOLOGY, AND THE STUDIES ON PRESSURE VESSEL TECHNOLOGY. EXPERIMENTAL WORK RELATIVE TO PRESSURE VESSEL TECHNOLOGY INCLUDES INVESTIGATIONS DF THE ATTACHMENT OF NOZZLES TO SHELLS AND THE VAZIABILITY OF IMPACT DATA ON LOW-ALLOY STEELS.

AVAILABILITY - CLEARINGHOUSE FOR FEDERAL SCIENTIFIC AND TECHNICAL INFORMATION, SPRINGFIELD, VIRGINIA $22151 \$ 3.00$ COPY, \$0.65 MICROF ICHE

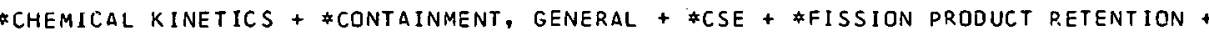

\#FISSION PRODUCT TRANSPORT + \#FISSION PRODUCT, AIRBORNE + \#IMPACT PROPERTY + \#IN PILE EXPEZIMENT +

\#LOFT (S-RR) + \#NOZZLE + \#QUT OF PILE LOQPS AND EXPERIMENTS + \#STEEL + CDNTAINMENT SDRAY +

FISSION PRODUCT RELEASE, GENERAL + PRESSURE VESSEL + REACTOR, HTGR

$1-26143$ ALSO IN CATEGORIES 17 AND 11

ELK RIVER TECHNICAL SUPPORT CONTRACT, REACTOR VESSEL LEAKS

RURAL. C.OOPERATIVE POWER ASSDCIATION

COD-651-57+. 22 PAGES, 5 FIGURES, FEBRUARY, 1968, OOCKET NO. 115-1, TYPE--BWR, MFG--A.C., AS--SGY + LUNDY

REACTOR SHUT DOWN ENTIRE MONTH BECAUSE RCPA AND AGC CONTRACTURAL NEGOTIATIONS WERE IN PROGRESS REGARDING THE TECHNICAL-SUPPORT SUBCONTRACTOR ITECHNICAL SPECIFICATIONS REQUIRE THERE BE ONE 1. \#\#RACTOR CAVITY WATER, WHICH HAD ACCUMULATED AT ABOUT I GAI IDAY IN THE LAST THREE MONTHS, ACCUMULATEO AI ABOUT 250 MLIDAY, MAINLY DUE TO CONDENSATION. CAVITY DRAIV SAMPLES WERE MAINLY NA-24, BUT CAVITY VENT SAMPLES HAO LESS RB-88 THAN CONTAINMENT AIR.

AVAILABILITY - USAEC, PUBLIC DOCUMENT ROOM, 1717 H. ST., WASHINGTON, 0. C. 20545 (\$SO.25 CEVTS/PAGE)

\#FAILURE, PRESSURE VESSEL + \#LEAK RATE + \#SAFETY REVIEW + ELK RIVER (BWR) + REACTOR, AEC OWNED + REACTOR, BWR + REPORT, OPERATIONS + SAMPLING + TECHNICAL SPECIFICATIONS

1-27042 ALSO IN CATEGORY 19

NUCLEAR SAFETY INFORMATION

OAK RIDGE NATIONAL LABORATORY, DAK RIDGE, TENNESSEE

ORNL-4228 +. 58 PAGES, 5 FIGURES, 3 TABLES, 10 REFERENCES, PAGES $379-436$ OF THE NSP ANNUAL PR.OGRESS

REPORT, APRIL, 1968

PROGRESS REPORT, DEALING WITH THF FOLLOWING - NUCLEAR SAFETY INFORMATION CENTER - URGANIZATION AND SCOPE, COMPUTERIZEO OPERATIONS, MEETINGS $\triangle N D$ CONFERENCES, STATUS OF REVIEWS AND REPORTS, SUMMARY OF INFORMATION ACTIVITIES. COMPUTER HANOLING OF REACTOR DATA - SAFETY (CHORD-S) INITIAL OEVELOPMENT OF COMPUTERIZED INFORMATION SYSTEM, PREPARATION OF REACTOR SAFETY INFORMATION FOR COMPUTER PROCESSING, COMPUTER OUTPUT OF REACTOR SAFETY DATA TO USERS DF INFORMATION SYSTEM. NUCLEAR SAFETY (A TECHNICAL PROGRESS REVIEW) - PUBLICATION SCHEDULE, FEATURE ARTICLES. BIBLIOGRAPHY. ORGANI ZATION CHART. 
CATEGORY 1

GENERAL SAFETY CRITERIA

1-27042 *CONTINUED*

\#BIBL IOGRAPHY + \#COMPUTER PROGRAM + \#NSIC + \#REVIEW + \#SAFETY PRINCIPLES AND PHILOSOPHY + \#SAFETY REVIEH + ACCIDENT ANALYSIS + AEROSPACE SAFETY + FISSION PRODUCT TRANSPORT + INSTRUMENTATION, GENERAL + METEOROLOGY + REACTOR TRANSIENT + SHIPPING ANALYSIS + SITING, GENERAL

$1-27296 \quad A L S O$ IN CATEGORY 18

BOLSA ISLAND PROJECT CANCELLED

SOUTHERN CALIFORNIA EOISON CO.

1 PAGE, ATOMIC ENERGY CLEARING HOUSE 14131), PAGE 2, (JULY 29, 1968)

AN OFFICIAL AEC STATEMENT SAYS THAT ALTERNATE PLANS FOR A NUCLEAR POWER AND DESALTING PLANT FOR SOUTHERN CALIFORNIA ARE BEING EXAMINED BECAUSE ALL PARTICIPANTS AGREE THAT THE BJLSA ISLAND PROJECT IS NOT ECONOMIC AT \$765 MILLION. PARTICIPANTS AGREED THAT CONCEPT SHOULD BE CONTINUED ANO WILL EXPLORE MEANS TO RECONSTITUTE IT ON A MORE ECONOMIC BASIS.

*ECONOMICS + BOLSA ISLANO + REACTOR, DESAL INATION

1-27435 ALSO IN CATEGORY 17

SAFETY GUIDELINES FOR HIGH ENERGY ACCELERATOR FACILITIES

UNITED STATES ATUMIC ENERGY COMMISSION

TID-23992 +. 33 PAGES, 1967

FOR ORGANIZATION ANO REVIEW OF SAFETY PROGRAMS IN ACCELERATOR LABORATORIES. TUU BE CONSIDERED BY MANAGEMENT IN DEVELOPING POLICIES AND STANDARDS. SECTIONS INCLUDE (I) MANAGEMENT SACETY GUIDELINES, 2 PG. (II) BUILOING AND FACILITY GUIDELINES, 4 PG. (III) EXPERIMENTAL EQUIPMENT, 9 PG. (IV) OPERATING PROCEDURES, 17 PG. \#\# IN MOST CASES, ADVICE IS RENDERED IN SHORT, SEPARATE ITEMS. (E.G., DESIGN ANO TEST PRESSURES FOR ... SHOULD BE SPECIFIED. PRESSURE GAGES .... IN PLACES WHERE SYSTEMS MAY BE ISOLATEO BY VALVESI.

AVAILABILITY - CLEARINGHOUSE FUR FEDERAL SCIENTIFIC AND TECHNICAL INFORMATIMN, SPRINGFIELC, VA. 2 ?ISI \$3.00 COPY, \$0.65 MICROF ICHE

\# ACCELERATOR + \#SAFETY REVIEW + ADMINISTRATIVE CONTROL + OESIGN CRITERIA + OPERATING EXPERIENCE SUMMARY + RADIATION SAFETY AND CONTROL + SAFETY PRINCIPLES AND PHILOSOPHY

1-27827 ALSO IN CATEGORIES 17 AND 11

MANUAL OF LECTURE NOTES - REACTOR SAFETY COURSE NO: 7

UNITED KINGDOM ATOMIC ENERGY AUTHORITY, RISLEY, WARRINGTON, LANCASHIRE

200 PAGES, FIGURES, TABLES, REFERENCES, SEPTEMBER 23, 1968

NINE SECTIONS. (I) INTRDDUCTION, 5 LECTURES. (II) FISSION PRODUCT RELEASE, 5 LECTURES, (III) CONTAINMENT ENGINEER ING, 7 LECTURES. (IV) CONTROL AND INSTRUMENTATION, 7 LECTURES. (V) GAS COOLED REACTORS, 11 LECTURFS. (VI) WATER REACTORS, 12 LECTURES. (VII) GENERAL, 5 LECTURFS. (VIII) FAST REACTORS, 7 LECTURES. (IX) SITING AND EMERGENCY PROCEDURES, 4 LECTURES. NEW

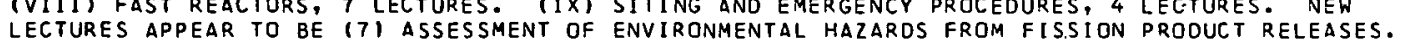
(BA) FISSION PRODUCT BEHAVIOR IN LIQUID CODLEO REACTORS. (1OA) CONTAINMENT OF FISSIJN PRODUCTS WITHIN FUEL ELEMENTS. (24A) METHODS AND PROBLEMS IN REACTOR ASSESSMENTS. (4O) PROBABILITY TECHNIQUES APPLIED TO WATER REACTORS.

AVAILABILITY - AUTHORITY HEALTH AND SAFETY BRANCH, U.K.A.E.A., 11 CHARLES II STREET, LONOON, S. W. I. * SAFETY ANALYSIS + \$SAFETY REVIEW + FISSION PRODUCT RETENTION + FUEL ELEMENT + PARTITION COEFFICIENT + PROBABILITY + REACTOR, GCR + REACTOR, HTGR + REACTOR, IMFBR + REACTOR, WATER + SAFETY PRINCIPLES AND PHILOSOPHY + UNITED KINGDOM

$1-27836$ ALSO IN CATEGORIES 18 ANO 2

DEPT. OF INTERITR SPEAKS ON THERMAL PQLLUTION

DEPT. OF INTERIOR, WASHINGTON, D. C.

6 PAGES, ATOMIC ENERGY CLEARING HOUSE, 14(34), PAGE 1-6, (AUGUST 19., 1968)

J. I. BREGMAN (DEPUTY ASST. SEC. OF INTERIOR FOR WATER POLLUTION CONTROL) IN $\triangle$ KFYNOTE ADORESS AT A NATIONAL SYMPOSIUM ON THERMAL POLLUTION AT VAVDERBILT U NOTEO THE ELECTRIC POWER

INDUSTRY IS THE PRIMARY SOURCE OF THERMAL POLLUTION. CITEO 4 SOLUTIONS IINCREASEO EFFICIENCY IN GENERATION AND DISSIPATION, DISPOSAL TO AIR; ANO PRODUCTIVE USEI URGEO USE OF WASTE HEAT

PRODUCTIVELY. URGED DEPT. OF INTERIOR CERTIFICATION OF A PLANT DISPOSAL MEANS ANO LIMITS.

\#THERMAL PMI. I.UTION + REgULATION, gENERAL

1-27840 ALSO IN CATEGORIES 17 ANO 18

EVESR TECHNICAL SPECIFICATION - SECTION IX - G OPERATIUNAL PRINCIPLES AND REQUIREMENTS

GENERAL ELECTRIC COMPANY, SAN JOSE, CALIFORNIA

PAGE 37 OF AMENDMENT 11 (TECHNICAL SPECIFICATION) TO THE EVESR LICENSE APPLICATION JUNE 7, 1963, DOCKET 50-183

IF IT IS DISCOVERED THAT A SYSTEM IS INOPERABLE OR DOES NOT MEET ITS SPECIFIED CONOITIONS OF 
CATEGORY 1

GENERAL SAFETY CRITERIA

$1-27840$ \#CONTINUED*

OPERATION WHILE IN AN OPERATING MODE WHERE THE SYSTEM IS REQUIRED BY THESE TECHNICAL

SPECIF ICATIONS TO BE OPERABLE OR TO MEET PARTICULAR CONOITIONS OF OPERATION, IMMEOIATE STEPS WILL BE TAKEN TO CORRECT THE CONDITION PROMPTLY OR TO PLACE THE REACTOR IN A MODE FOR WHICH OPERABILITY OF THE PARTICULAR SYSTEM IS NOT REQUIRED. SUCH PERIODS OF OPERATION AS FALL UNOER THE REQUIREMENTS OF THIS PARAGRAPH WILL NOT BE CONSIDERED A VIOLATION OF THESE TECHNICAL SPECIFICATIONS.

USAEC, PUBLIC DOCUMENT ROOM, 1717 H ST., WASHINGTON, D.C. 20545 (25 CENTS/PAGE)

\#FAILURE, EQUIPMENT + \#TECHNICAL SPECIFICATIONS + EMERGENCY PROCEDURE + INCIDENT, EQUIPMENT + REACTOR, INTERNAL SUPERHEAT + REACTOR, POWER + REACTOR, RESEARCH + SAFETY PRINCIPLES AND PHILOSOPHY + VESR (ISR)

$1-27841$ ALSO IN CATEGORIES 18 AND 2 EASTON BWR PROJECT CANCELLED DUE TO THERMAL EFFECTS CRITERIA NI AGARA MOHAWK POWER CORPORATION

1 PAGE, ATOMIC ENERGY CLEARING HOUSE, 14(33), (AUGUST 12, 1968), DOCKET 50-300, TYPE--BWR, MFG--G.E., $A E--S T O N E$ + WEBSTER

DIFFICULTIES AND DELAYS IN SECURING REGULATORY APPROVAL FOR THE EASTON SITE HAVE LEAO TO ITS CANCELLATION. OECISIVE FACTOR WAS CONTINUOUS SITUATION WHEREBY STATE HEALTH AGENCIES COULD NOT MAKE UP THEIR MIND AS TO THERMAL EFFECTS CRITERIA. NIAGARA MOHAWK WILL PARTICIPATE IN $\triangle N$ OIL FIREO PLANT READY IN LATE 1971. NY STATE POWER AUTHORITY HILL $\triangle S S U M E$ THE CONTRACT, AND BUilo the plant next to the nine mile poInt plant, hith niagara mohawk to operate the plant BEGINNING IN 1973 .

\#CONSTRUCTION PERMIT PROCESS + \#REGULATION, STATE + \#THERMAL POLLUTION + EASTON (BWR) + REACTOR, BWR + SITING, REACTOR + STATE PROGRAM

$1-27856 \quad$ ALSO IN CATEGORIES 17 AND 15

TRAINING MANUAL - MANAGEMENT OF RADIATION ACCIDENTS

U.S. DEPARTMENT OF HEALTH, EDUCATION, AND WELFARE

150 PAGES, FIGURES, TABLES, 39 REFERENCES, SEPTEMBER 12, 1966

A SET OF COURSE NOTES FOR 29 LECTURES IN THE GENERAL SUBJECT AREAS OF - I, RADIATION ACCIDENT CONTROL PLANNING AND RESPONSE (4). II, TYPES OF ACCIOENTS (5). III, RADIATION CONTAMINATION MONITORING (3). IV, EVALUATION ANO CONTROL OF ACCIDENTAL EXPOSURE (7). V, NUCLEAR REACTOR HAZARDS (6). MEDICAL ASPECTS OF RADIATION ACCIOENTS (4). \#\#OR USE IN PRESENTEO BY NCRH.

AVAILABILITY - DIVISION OF RADIOLOGICAL HEALTH, ROCKVILLE, MARYLANO 20852

* STAFFING, TRAINING, QUALIFICATION + HEALTH PHYSICS TRAINING + RADIATION INJURY, TREATMENT OF + RADIATION SAFETY ANO CONTROL + RAOIOLOGICAL ASSISTANCE + SURVEY, RAOIATION, EMERGENCY

$1-27 \overline{7} 902$

RAMEY JT

ALSO IN CATEGORIES IB ANO 17

THE PDQS OF NUCLEAR POWER PLANT LICENSING

$\triangle T O M I C$ ENERGY COMMISSION

37 PAGES, 14 REFERENCES, REMARKS AT THE AIF WORKSHOP ON POWER REACTOR LICENSING, FEBRUARY 12,1968

REVIEWS HISTORY OF REGULATORY PROCESS, THEN CONCENTRATES ON (1) DEVELOPMENT OF MANAGEMENT KNOW-HOW, BY UPGRAOING UTILITY PERSONNEL AND HIRING NEW GRADUATES. (2) THE AEC LICENSING PRUCESS, TOO LITTLE PREPARATION BY UTILITIES IN A RACE TO GET THEIR PAPERHORK IN FIRST. (3) PUBLIC UNDERSTANDING OF NUCLEAR POWER, DISQUIETING RESULTS OF A FEW UTILITIES WHO DID NOT DO PUBLIC UNDERSTANDING OF NUCLEAR POWER, DISQUIETING RESULTS OF A FEW UTILITIES WHO DIN
THEIR HOMEWORK WELL, SHNIUI.D EXPECT OUTAGES OURING INITIAL OPERATION. (4) ENGINEERING THEIR HOMEWORK WELL, SHMII. EXPECT OUTAGES OURING INITIAL OPERATION. I I I ENGINEERING
STANDARDS AND QUALITY ASSURANCE. AMONG PROBLEMS MENTIONED WERE OPTIMUM CONSTRUCTION

SCHEDULING, BACK FIT. APPENDIX A IS AEC PROGRAM FOR TRAINING UTILITY STAFF AND MANAGEMENT.

AVAILABILITY - ATOMIC INDUSTRIAL FORUM, 850 THIRD AVE, NEW YORK, N.Y, 10022

\#CONSTRUCTION PERMIT PROCESS + \#REACTOR, POHER + \#STAFFING, TRAINING, QUALIFICATION + QUALITY CONTROL + RADIATION, PUBLIC EDUCATION/ACCEPTANCE + REGULATION, AEC

$1-27904$

ALSO IN CATEGORIES 18 ANO 17

JOSLIN $M$

SOME OBSERVATIONS ON THE REGULATORY PROCESS

ATOMIC ENERGY COMMISSION

7 PAGES, REMARKS AT THE AIF WORKSHOP ON POHER REACTOR LICENSING, FEBRUARY 12, 1968

NEWS OF FAILURES ALERTS THE OTHER FELLOW TO PROFIT BY THE EXPERIENCE OF OTHERS. OISCUSSES EVOLUTION OF UTILITY-REGULATORY RELATIONS, AVOID DEPENDENCE ON SUPPLIER, UTILITY IS ALONE RESPONSIBLE TO AEC. DRESDEN 3 WAS GIVEN EXTENSIVE CORE COOLING SYSTEMS, WHICH COULD HAVE BEEN DONE AT LOWER COST IF THOUGHT OUT IN ADVANCE. URGES UTILITIES TO EOUCATE AEC ON SPECIAL BEEN DONE AT LOWER COST IF THOUGHT OUT IN ADVANCE. URGES UTILITIES TO EOUCATE AEC ON SPE
FEATURES OF UTILITY ECONOMICS. NOTES NEED FOR UTILITIES OWN EXPERTS AND TOP MANAGEMENT INVOLVEMENT. CONSIDERS MOST SIGNIFICANT FOR UNBIASED COOPERATION. 
CATEGORY

GENERAL SAFETY CRITERIA

1-27904 *CONTINUED*

AVAILABILITYY - ATOMIC INDUSTRIAL FORUM, 850 THIRD AVE., NEW YORK, N.Y. 10022

\#OPERATING EXPERIENCE SUMMARY + \#REGULATION, AEC + CODES AND STANDARDS + CORE SPRAY + DRESOEN 3 (BWR) + ECONOMICS + INFORMATION RETRIEVAL + STAFFING, TRAINING, QUALIFICATION

1-27987 ALSO IN CATEGORY 17

WORK EXPERIENCE PROGRAM

UNITED STATES ATOMIC ENERGY COMMISSION

6 PAGES, CHAPTER 7604 FROM THE AEC MANUAL, FEBRUARY 20,1964

PROVIDES FOR SPECIALIZED WORK EXPERIENCE AT AEC OWNED FACILITIES BY NON-AEC PERSQNNEL EVGAGED IN CIVILIAN APPLICATIONS OF ATOMIC ENERGY. DUTLINES AEC QESPONSIBILITIES IDIV. INDUSTRIAL PARTICIPATION, DIV. LABOR RELATIONS, FIELD OFFICESI. DSSIGNMENTS INTENDEJ FOR THJSE ALREADY GENERALLY EDUCATEDITRAINED, NOT FOR BASIC INSTRUCTION OR EXPERIENCE, OR FOR THESIS NITR, OR FOR FACULTY OR FOREIGN NATIONALS, OR FOR TEMPORARY STAFF INCREASE OF CONTRACTORS. NO CHARGES. \#* ANNEX A (ACREEMENT BETWEEN CONTRACTORS AND PARTICIPANTS!. ALL EXPENSFS DAID BY TRAINEES COMPANY, INCLUDING INDEMNIFICATION OF TRAINEES LIABILITY.

\#STAFFING, tRAINING, QUALIFICATION + USAEC

1-27989 AL5O IN CATEGORIES 17 ANO 18

NUCLEAR TRAINING PR.OGRAMS

BABCOCK AND WILCOX

TRG-68-68 +.65 PAGES, 3 FIGURES, AUGUST 1968

DESCRIBES B AND W SERVICES AND FACILITIES AT THEIR LYNCHBURG, VA. TRAINING CENTED

(CLASSROOMS, PWR SIMULATORS, POOL REACTOR). PROGRAMS AVAILABLE TO ALL UTILITY PERSJVVEL INCLUDE, AT MANAGEMENT $(2$ DAY SEMINAR) AND STAFF LEVEL (4\& LECTURE HOURS), PLANT OPERATIOV LEVEL 15 PHASES - THEORY 3 MO., PHR OBSERVATION 3 MO., PWR TECHNOLOGY 2 MO., PWR DPERATION AT POOL REACTOR AND SIMULATOR 3 MO., ANO ON JOB TRAINING AT TECHNICAL STAFF DROGRAMS II AND C FAMILIARIZATION, BAILEY 855 COMPUTER FAMILIARIZATION, WATER AND RADIOCHEMISTRY, MAINTENANCE, SIMULATOR SIMULATES 83 FAULTS. SUGGESTEO PERSONNEL QUALIFICATIONS LISTED.

AVAILABILITY - BABCOCK AND WILCOX, NUCLEAR TRAINING CENTER, D.J. BOX 1260, LYNCHGURG, VA. 245OS * STAFFING, TRAINING, QUALIFICATION + REACTOR, PWR + SIMULATION

1-27991 ALSO IN CATEGORY 17 $\triangle E C$. SPFC.IAL FELLOWSHIPS IN NUCLEAR SCIENCE AND ENGINEERING OAK RIDGE ASSOCIATED UNIVERSITIES

36 PAGES, SEPTEMBER 1966

DESCRIBES WHO MAY APPLY AND TYPE OF PROGRAMS, TENURE, CONDITION, FEES $\triangle N D$ STIPENDS (6 DAGES). OTHER PAGES LIST 66 PARTICIPATING SCHOJLS, GIVING FELLOWSHID $\triangle D V I S O R$, DEGREES OFFERED, ANJ AREAS OF EMPHASIS.

AVAILABILITY - OAK RIDGE ASSOCIATED UNIVERSITIES, OAK RIOGE, TENNESSEE

* STAFFING, tRAINING, QUALIFICATION + USAEC

1-27992 ALSO IN CATEGORY 17

ENGINEERING MAHROHER NEEDS OF THE INVESTRR MWNF FI.FCIRIC UTILITY INDUSTRY EDISON ELECTRIC INSTITUTE

EEI-PUB-68-27 +. 52 PAGES, FIGURES, TABLES, FEBRUAKY 1968

REPORT OF COMMITTEE FORMED IN 1966. RECOMMENOS (1) UTILITIES REINSPECT NEEDS, AS INDUSTRY UNDERESTIMATES NEEOS. IN 5 YEARS 15-20 PERCENT OF ENGINEERS HIRED WILL BE MS. (2) UTILITIES SHOULO REPORT 10-20 SCHOOLS OF EXCELLENCE. 13,41 BETTER CDMMUNICATION AND SUPPORT OF SCHOOLS. (5,6) UTILIZE TECHNICIAN EMPLOYEES BETTER, AND RECRUIT HIGH SCHOOL GRADUATES. \#\#APPENDICES PROVIDE MANPOWER SURVEY, UNIVERSITY DEGREE PRODUCTION, AND AN ANALYSIS OF ONE UTILITIES NEEDS. \#\#UTILITY ESTIMATES ARE FOR 1100 ENGINEEPS/YEAR ANO 75 MS/YEAR IIJ NUCLEAR POWER). COMMITTEE ESTIMATES ARE 2500-5000/YEAR - $7-14$ PERCENT OF CURRENT GRADUATE ENGINEER RATEI, AND 40/YEAR MS NUCLEAR ENGINEER ING.

AVAILABILITY - EDISON ELECTRIC INSTITUTE, 750 THIRD AVE., NEW YORK, N.Y. 10017

+STAFFING, TRAININC, QUALIFICATION + RFAC.TMR, PDHER

1-27996 ALSO IN CATEGORIES 17 AND 18

SCHUMAN SD

OESCRIPTION WESTINGHOUSE REACTOR OPERATOR TRAINING PROGRAM

WESTINGHOUSE ELECTRIC CORP., PITTSBURGH, PA.

WCAP-7170+. 45 PAGES, FEBRUARY 1968 
CATEGORY 1

GENERAL SAFETY CRITERIA

$1-27996$ \#ONTINUED*

INTENDED FOR CONTRACTED PWR STAFF TRAINING. INCLUDES SELECTION HELP IAPTITUDE TEST FOR 24

PERSONNEL, AOMINISTERED 6 MONTHS BEFORE START OF TRAIVING RESULTING IN SELECTION OF $S$

SUPERVISORS, 6 SHIFT SUPERVISORS, ANO 10 OPERATORSI. PHASE I 111 WEEKS BASIC LECTURE WITH

POOL REACTOR DPERATION AT WREC), PHASE 11 (24 WEEKS SAXTON PWR OPERATING EXPERIENCE AND.

LICENSE EXAM), PHASE III (6 WEEKS LECTURE SERIES AT WAPD), PHASE IV (ONE YEAR ON-SITE

TRAINING FOR OPERATOR LEVEL MATER IALI. LESSON OUTLINES GIVEN FOR EACH LECTURE.

AVAILABILITY - S. D. SCHUMAN, WESTINGHOUSE ELECTRIC CORPORATION, ATOMIC POWER OIVISION, PENN CENTEP. SITE,

P. D. BOX 355, PITTSBURGH, PA. 15230

* STAFFING, TRAINING, QUALIFICATION + REACTOR, POWER + REACTOR, PWR + SAXTON (PWR)

1-27997 ALSO IN CATEGORIES 18 ANO 17

COMMENTS FROM BRIEFING CONFERENCE ON NUCLEAR POWER, SEPT, 3-5, 1968

YANKEE ATOMIC ELECTRIC CO.

15 PAGES, ATOMIC ENERGY CLEARING HOUSE, 14(37), PAGE 8-11 ANO 19-29, (SEPTEMBER 9, 1968)

(ROGER COE) - INNUMERABLE ECONOMIC FORECASTS BUT LITTLE HINDSIGHT INFORMATION. DISCUSSED

YANKEE, CONN. YANKEE, AND HUMBOLDT BAY ECONOMICS, (JAMES T. RAMEY) - NOT LIKELY TO SSPARATE

REGULATORY FUNCTION FROM AEC FOR AT LEAST 5 YEARS. EVOLUTION EXPECTEO. (JOHN B. ANDERSON) -

DETAILED DISCUSSION OF LEGISLATIVE BILLS ON SITING, THERMAL EFFECTS, SMALL UTILITY

PARTICIPATION, PRACTICAL VALUE. (H. L. PRICE) - SUGGESTEO APPROVING A NUCLEAR STEAM SUPPLY

SYSTEM OUTSIDE THE CONSTRUCTION.PERMIT PROCESS. (P. A. MORRIS) - CONSTRUCTION PERMIT TAKE

12.4 MONTHS BECAUSE OF 12 TECHNICAL ANO 4 GENERAL IIEMS NOT SPECIFICALLY TREATEO IN PSAR.

(R. LOWENSTEM) - LICENSING DELAYS COST APPLICANT ONE MILLION \$/MONTH. HE ADVISES APPLICANT

TO PLAN ON 18 MONTHS FOR A CONSTRUCTION PERMIT, ONE YEAR FOR OPERATING LICENSE AFTER FILING

FSAR (WHICH TAKES 6 MONTHS TO PREPARE).

AEC QUESTION + CONGRESSIONAL ACTIVITY + CONSTRUCTION PERMIT PROCESS + ECONOMICS +

OPERATING LICENSE PROCESS + REACTOR, POWER + REACTOR, WATER + REGULATION, AEC + REPORT, PSAR +

REPORT, SAR + RESPONSE TIME

1-28003 ALSO IN CATEGORIES 17 AND 13

AEC PLANS REVISION OF RADIDISOTOPE LICENSING PROCEDURES

U.S. ATOMIC ENERGY. COMMISSION

$\triangle E C$ PRES.S RELEASE IN-866 *. 3 PAGES, APRIL 29,1968

REVISIONS PROPOSED TO IOCFR33 WOULD BE ALONG LINES OF PRESENT BROAD LICENSES (TYPE A INSTITUTIONS ALLOWED TO POSSESS LARGE MULTI-CURVE QUANTITIES. RADIOLOGICAL SAFETY OFFICER AND AN ISOTOPE SAFETY COMMITTEE REQUIRED.). ADDED WOULD BE TYPE B IINSTITUTION MAY POSSES UP TO 10,000 TIMES THE QUANTITY WHICH IOCFR2O WOULD ALLOW TO BE INHALED BY ONE PERSON IN ONE YEAR, MUST HAVE A QUALIFIED RAOIOLOGICAL SAFETY OFFICER ANO ADMINISTRATIVE PROCEDURES FOR CONTROLLING USAGE) AND TYPE C (INOIVIDUAL USER MUST HAVE SCIENTIFIC BACKGROUND AND RADIATION PROTECTION TRAINING, MAY POSSES UP TO 100 TIMES THE QUANTITY WHICH 10 CFR 20 WOULD ALLDW ONE PERSON TO INHALE IN ONE YEAR I. * COMMENT REQUESTED ON FEDERAL REgISTER PUBLICATION OF APRIL $30,1968$.

\#RAOIOISOTOPE + \#REGULATION, AEC + APPLICATION FOR AEC LICENSE

$1-28004$ ALSO IN CATEGORIES 17 AND 13

HOW TO GET A LICENSE TO USE RADIOISOTOPES

U. 5. ATOMIC ENERGY COMMISSION

35 PAGES, JULY 1967

BRIEFLY REVIEWS (FOR AN APPLICANT WITHOUT PRIOR KNOWLEDGE) THE OBJECTIVES AND REQUIREMENTS OF THE REGULATORY PROGRAM, PLUS THE SAFETY RESPONSIBILITIES OF THE USER. A STARTING POINT FOR FURTHER INFORMATION. \#\#\#EVIEUS RADIOISOTOPE LICENSING, STATE REGULATION, AEC SAFETY

STANDAROS AND REGULATIONS, QUALIFYING FOR A SPECIFIC LICENSE, RESPONSIBILITY OF LICENSEES. APPENDICES INCLUDE RULES AND REGULATIONS, INSTRUCTION SHEETS, AND SAMPLE APPLICATION/LICENSE. REFERENCES.

AVAILABILITY - SUPERINTENDENT OF DOCUMENTS, U.S. GOVERNMENT PRINTING OFFICE, WASHINGTON, D. C. $2040 ?$

*RADIOISOTOPE + \#REgULATION, AEC + APPLiCATION FOR AEC liCENSE + guide 
CATEGORY 2

SITING OF NUCLEAR FACILITIES

2-25164 ALSO IN CATEGORY 5

BOWEN JH

PROGRESS IN THE U.K. ON THE SAFETY ASSESSMENT OF A.G.R., USING THE PROBABILITY METHOD

UNITEO KINGDOM ATOMI ENERGY AUTHORITY, RISLEY

10 PAGES, 6 REFERENCES, PRESENTED AT THE THIRD CREST MEETING, NQVEMBER 15-17, 1967 , PAPIS

THE ADVANCE TO URBAN SITING HAS BEEN ACCOMPLISHED BY THE DETERMINATION TO REFINE AND IMPROVE THE SAFETY CHARACTERISTICS OF THE AGR. THE MCA CONCEPT WOULD BE INAPPROPRIATE FOR THIS PURPOSE SO THE PROBABILISTIC METHOD OF SAFETY ASSESSMENT IS DISCUSSED (SEE ALSO NSIC IBZIOI. THE ANALYSIS IS MADE BY ASSIGNING OR CALCULATING A PERCENTAGE RELEASE FOR A GIVEN FISSION-PRODUCT INVENTORY AND THUS DETERMINING THE EXPECTED PROBABILITY AND FREQUENCY OF SUCH A RELEASE.

AVAILABILITY - J. H. BOWEN, SAFEgUAROS DIVISION, UNITEO KINGOOM ATOMIC ENERGY AUTTHORITY, RISLEY ACCIDENT, PROBABILITY OF + CREST + REACTOR, GCR + SAFETY EVALUATION + SITING, REACTOR + SITING, URBAN + UNITED KINGDOM

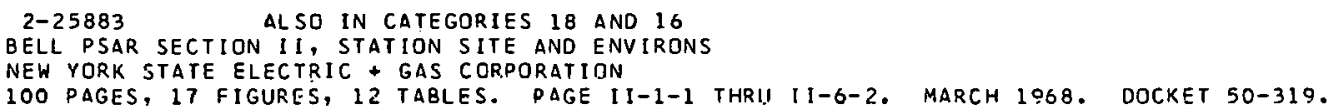

INCLUDES PR.ELIMINARY (JAN. 68) REPORTS ON METEOROLOGY (3. E. DETHIER) AND LIMNOLOGY OF CAYUGA LAKE ANO INTERRELATIONS WITH NUCLEAR POWER PLANT (J. F. STORR). \#\$NOCTURNAL DRAINAGE WINO FLOWS UP RIVER FROM ITHACA (13 MILES AWAY) TOWARD THE SITE. ON-SITE TOWER BEING INSTALLED. * * \#TTENSIVE MIXING OF WATER EXPECTED. A SURVEY IS SE.ING MADE, BASED ON FDSSIL PLANT OISCHARGE. A HATCHERY FOR TROUT AND COHO SOLUTION IS PLANNEO TO USE THE THERMAL ENRICHMENT PROVIDEO BY CONDENSER DI SCHARGE.

AVAILABILITY - CLEARINGHOUSE FOR FEDERAL SCIENTIFIC AND TECHVICAL INFORMATION, SPRINGFIELO, VIRGINIA, 22151 , \$3. 30 COPY, \$O.65 MICROFICHE

* LAKE + *THERMAL POLLUTION + BELL (BWR) + DIFFUSION + ON SITE WORK + REACTOQR, BWR + REPORT', PSAR + TOPOGR APHY

2-26564 ALSO IN CATEGORY 17

COMMENTS ON THE PROPOSED NUCLEAR POWER PLANT ON THE HUOSON RIVER OPPOSITE THE SARATOGA NATIJNAL HISTDRICAL PARK, AS REQUESTEO BY AEC LETTER MARCH 20, 1968.

OIVISION OF REACTOR LICENSING, $\triangle E C$

8 PAGES, LETTER TO G. T. SEABORG, AEC. MAY 27, 1968, DOCKET 50-300. TYPE--BWR, MFG--G.?., AE--STONE + WEBSTER

REPORT CONCLUDES THAT MASS AND SCALE OF STRUCTURES wOULO HAVE A SIGNIFICANT AOVERSE VISUAL IMPACT ANO WOULO MATERIALLY DETRACT FROM INTERPRETATION OF THE EVENTS EMBODIED BY THE DARK. REFERRING TO SECT. 106 OF NATIONAL HISTORICAL PRESERVATION ACT OF $19 E 6$ IREQUIRING AES TO TAKE INTO ACCOUNT -EFFECT ON NATIONAL-REGISTER PROPERTIESI, COUNCIL CONCLUDES AEC SHOULD NOT ISSUE A CONSTRUCTION PERMIT UNLESS THERE IS NO FEASIBLE ALTERNATIVE SITE, ANO THEN WITH ALL PISSIBI.E PLANNING TO MINIMIZE AOVERSE (VISUAL) EFFECT. CRITERIA INCLUDED.

AVAILABILITY - PUBLIC DOCUMENT ROOM, WASHINGTON, D.C.

CONSTRUCTION PERMIT PROCESS + EASTON (BWR) + REACTOR, BWR + SITING, REACTOR

257290

ALSO IN TATFERRY I

SEISMICITY OF VERMONT YANKEE

VERMONT YANKEE NUCLEAR POWER CORP.

2 PAGES, ATOMIC ENERGY CLEARING HOIISF 14131), PAGE 29 AND 30, (JULY 29, 1968), DOCKET 50-271, TYDE--3WD,

$M F G--G . E ., \triangle E--E B A S C O$

(LETTER, JULY 10) YOUR LETTER OF MAR. 8, 1968, HAS NOT CLEAREO UP MY CONCGRN REGARDINJ

SEISMICITY OF VERMONT YANKEE, 4 MILES AWAY. YOUR. EXPLANATION OF COMDATABILITY IBEIWTCV NJ VERIFIED RECORD JF SEISYIC ACTIVITY WITHIN 45 MILFS, AND NO DEMONSTRARLE T.ONTROLSI IS A PLAY ON WORDS, A DISTINCTION WITHOUT A DIFFERENCE. IT. MATTERS NDT WHERE CONTROLS MAY CONCENTRATE EFFECTS IF IAS HAPPENED IN MY HOME 4 MILES AWAY) AN EARTHZUAKE SFFECT IS VIOLENT ENOJSH TO CRACK WALLS AND CEILINGS AND TO CAUSE DOOR TO SPRING OPEN SUDOENLY FOR $\triangle$ LONG TIME THEREAFTER. WHAI PRUGRESS HAS BEEN MADE ON FROVIDINC ACRS WITH INTERIM GUIDFI. INES FOR REACTOR DESIGN AGAINST EARTHQUAKES.

- EARTHQUAKE ENGINEERING + aC.RS + EARTHUIJAKE P.CORDS + RADIATION, PUBLIC EDUCATION/ACCEPTANC.E + REACTOR, BWR + VERMONT YANKEE (BWR)

2-27615 ALSO IN CATEGORIES 18 AND 17

ACRS REPORT ON ZION 1 AND 2 
2-27615 \#CONT INUED*

U.S. ATOMIC ENERGY COMMISSION

8 PAGES, LETTER TO G.T. SEA8ORG (AEC PRESS RELEASE L-178), AUGUST 24, 1968, DOCKETS 50-295/304, TYPE--PWR, MFG--WEST. AE- $-S G T+$ LUNOY

ZION IS LARGEST REACTOR TO DATE IN A RELATIVELY HIGH POPULATION DENSITY. REACTOR CAVITY FLOODING FOLLOWING A LONGITUDINAL SPLIT IN THE REACTOR VESSEL MAY BE INSTALLED FOLLOWING STUDY OF VESSEL FAILURE PROBABILITY FROM THERMAL SHOCK FOLLOWING CORE FLOODING ACTION. CONTROL AND SAFETY SIGNALS SHOULP BE INDEPENDENT. CONTAINMENT SPRAY SHOULD HAVE A FULL TEST. * * IN 3 PAGES OF REMARKS BY OKRENT, HE DISCUSSES VESSEL SPLIT PROBLEM. RECOMMENDS (FOR HIGH POPULATION DENSITIESI ADDITIONAL DESIGN CONSERVATISM ANO QUALITY ASSURANCE, HELL DEFINED R AND D FOR SAFETY I SSUES NOT RESOLVED AT CONSTRUCTION PERMIT STAGE, EXTRA MARGIN IN. EVGINEERED SAFETY FEATURES IN LIEU OF A DEMONSTRATION UNDER ACCIDENT CONDITIONS, AND MORE STUDY TO REDUCE PROBABILITY DF SMALL ACCIDENTAL RELEASES.

USAEC, PUBLIC DOCUMENT ROOM, 1717 H ST., WASHINGTUN, O.C. 20545 (25 CENTS/PAGE)

* FAILURE, PRESSURE VESSEL + ACRS + CONTAINMENT SPRAY + CORE REFLOODING SYSTEM + REACTOR, PWR + REPORT, PSAR + REVIEW + SAFETY MARGIN + TEST, PREQPERATIJNAL + TEST, PRJOF + THERMAL MECHANICAL EFFECT + $Z I O N$ I AND 2 (PWR)

2-27833 ALSO IN CATEGORIES 18 AND 16

BRUNSWICK STEAM ELECTRIC PLANT UNITS $1+2$, PRELIMINARY SAFETY ANALYSIS REPORT, VOLUME III CAROL INA POWER + LIGHT COMPANY

275 PAGES, FIGURES, TABLES, JULY 1968, DOCKET 50-324/325

FOUR APPENOICES - (A) GEOLOGICAL ANALYSIS, FOUNDATION ENGINEERING, SEISMIC DESIGN CRITERIA, SEISMIC DESTGN RESPONSE SPECTRA, PRELIMINARY MARINE BIJLOGY AND OCEANOGRAPHY, STJRY TIDES, AND WILMINGTON 1959-63 WINOIF WIND DIFFUSION STUDY. THEN FOLLOWS THE USUAL - (B) JET PUMP DEVELOPMENT, (C) CORE SPRAY TEST PROGRAM, AND (D) COMPARATIVE FVALUATION WITH AEC DESIGN CRITERIA (A EISTING OF APPROPRIATE PSAR SECTIONS FOR EACH (RITERIA).

AVAILABILITY - USAEC PUBLIC DOCUMENT ROOM, WASHINGTON, D. C.

\# AEC DESIGN CRITERIA + *EARTHQUAKE ENGINEERING + BRUNSWICK (BWR) + REACTOR, BWR + REPORT, PSAR

2-27836 ALSO IN CATEGORIES 18 AND 1

OEPT. OF INTERIOR SPEAKS ON THERMAL POLLUTION

DEPT. OF INTERIOR, WASHINGTON, D. C.

6 PAGES, ATOMIC ENERGY CLEARING HOUSE, 14134), PAGE 1-6, (AUGUST 19, 1968)

J. I . BREGMAN (UEPUIY ASST. SEC. OF INTERIOR FOR WATER POLLUTION CONTROLI IN A KEYNOTE ADOPESS AT A NATIONAL SYMPOSIUM ON THERMAL POLLUTION AT VAVDERBILT U NOTEO THE ELECTRIC POWER

INDUSTRY IS THE PRIMARY SOURCE OF THERMAL POLLUTION. CITED 4 SOLUTIONS (INCREASED EFFICIENCY

IN GENERATION AND DISSIPATION, DISPOSAL TO AIR, ANO PRODUCTIVE USE) URGED USE OF WASTE HEAT

PRODUCTIVELY. URGED DEPT. OF INTERIOR CERTIFICATION OF A PLANT DISPOSAL MFANS AND LIMITS.

* THERmal pOllutidon + Regulation, general

2-27841 ALSO IN CATEGORIES 18 AND 1

EASTON BWR PROJECT CANCELLED DUE TO THFRMAL EFFECTS CRITERIA

NI AGARA MOHAWK POWER CORPORAT ION

1 PAGE, ATOMIC ENERGY CLEARING HOUSE, 14(33), (AUGUST 12, 1968), DOCKET 50-300, TYPE--8WR, MFG--G.E., $A E--S T O N E+$ WEBSTER

DIFFICULTIES AND OELAYS IN SECURING REGULATORY APPROVAL FOR THE EASTON SITE HAVE LEAD TJ ITS CANCELLATION. DECISIVE FACTOR WAS CONTINUOUS SITUATION WHEREBY STATE HEALTH ACENCILS COULD NOT MAKE UH THEIR MINO AS TO THERMAL EFFECTS CRITERIA. NIAGARA MOHAWK WILL PARTICIPATE IN AN OIL FIRED PLANT REAOY IN LATE 1971. NY STATE POWER AUTHORITY WILL ASSUME THE CONTRACT, AND. BUILD THE PLANT NEXT TO THE NINE MILE POINT PLANT, WITH NIAGARA MOHAWK TO OPERATE THE PLANT BEGINNING IN 1973 .

*CONSTRUCTION PERMIT PROCESS + *REGULATION, STATE + \#THERMAL POLLUTION + EASTON (BWR) + REACTOR, BWR + SITING; REACTOR + STATE PROGRAM

2-27975 ALSO IN CATEGORY 11

CURRENT STATUS AND FUTURE TECHNICAL AND SCONOMIC POTENTIAL OF LIGHT WATER REACTORS

JACKSON AND MORELAND, S. M. STROLLER ASSOC.TATES

WASH-1082 +. 125 PAGES, FIGURE, TABLES, REFERENCES, MARCH 1968

THIS TASK-FORCE STUDY OF LIGHT-WATER REACTORS DISCUSSES (1) THE CURRENT AND FUTURE ECCNOMIC POSITION OF BOILING AND PRESSURIZED WATER REACTORS (2) FUELS, FUEL MANAGEMENT, FUEL ECONOMICS, AND (3) REACTOR SITING. OF GREATEST SAFETY INTEREST IS THE SECTION ON NEUTRON PLANT SITING (SECTION 4). THIS SECTION DISCUSSES THE PROBLEM, THE NEED FOR GREATER FLEXIBILITY, ANTICIPATED DEVELOPMENTS, AND TRENDS IN SITING PRACTICES. THE ASPECTS OF FUTURE SITING TRENOS ARE DISCUSSED (GENERALLY) WITH REGARD TO THE USE OF ENGINEERED SAFETY FEATURES.

AVAILABILITY - SUPERINTENDENT OF DOCUMENTS, U.S. GOVERNMENT PRINTING OFFICE, WASHINGTON, D. C. 2O4O? 
CATEGORY 2
SITING OF NUCLEAR FACILITIES

2-27975 *CONTINUED*

*CONTAINMENT, GENERAL + *ECONOMICS + \#SITING, REACTOR + ENGINEERED SAFETY FEATURE + REACTOR, 8WR + REACTOR, POWER + REACTOR, PWR + REACTOR, WATER + REGULATION, AEC + SAFETY PRINCIPLES AVO PHILOSOPHY 
3-25973

KARANAGH MT + GUALTIERI G

TRANSPORTATION OF IRRADIATED FUEL FROM THE LATINA ELECTRONUCLEAR POWER PLANT

8 PAGES, 4 FIGURES, RIVISTA DI INGERIA NUCLEARE, 3, PAGES 851-859 (SEPT.-0EC., 1965) IN ITALIAN

TRANSPORTATION OF THE FIRST IRRADIATED FUEL FROM THE LATINA ELECTRONUCLEAR POWER PLANT TO THE WINOSCALE PROCESSING PLANT IS OESCRIBED. THE DESIGN AND TESTIVG OF THE CONTAINER FJR IRRADIATED FUEL AND THE TECHNICAL CONSIDERATIONS IN THE TRANSPORTATION ARE DISCUSSED. THE TRUCKING, RAIL, AND SHIPPING MODIFICATIONS FOR THE TRANSPORTATION ARE INDICATED. EMERGENCY PRECAUTIONS ARE GIVEN.

FUEL REPROCESSING + ITALY + OPERATING EXPERIENCE + SHIPPING CONTAINER + TRANSPORTATION AND HANDLING

3-25974

FUEL CONTAINER FOR NUCLEAR REACTORS

BROWN, BOVERI AND CIE. - KRUPP ARBEITSGEMEINSCHAFT, GERMANY

BRITISH PATENT 1,082,706 +. 5 PAGES, 8 FIGURES, SEPTEMBER 13, 1967

A FUEL CONTAINER FOR FISS IONABLE NUCLEAR MATERIALS COMPRISES A SPHERICAL BODY OF MODERATOR MATERIAL, PARTICULARLY GRAPHITE, HAVING AN INNER HOLLOW OF ROUNDED SHAPE CONCENTRIC WITH THE OUTER SPHERICAL SURFACE OF THE BODY. A ROTATIONALLY SYMMETRICAL ROD OF MODERATOR MATERIAL IS DISPOSED IN THE HOLLOW TO FORM A RING-SHAPED ROTATIONALLY SYMMETRICAL INTERSPACE WITH THE BODY. THE ROD MAY BE SHAPED IN SUCH A MANNER AS TO COMPLETELY CLOSE OFF THE HOLLOH IN THE CONTAINER.

AVAILABILITY - THE PATENT OFFICE, 25 SOUTHAMPTON BUILDING, LONOON, W.C. 2, ENGLAND (49 CENTS/COPY)

PATENT + SHIPPING CONTAINER + UNITEO KINGDOM

$3-25975$

VERTUT J + FRADIN J + RAGGENBASS A

DEVICE FOR LOAOING AND UNLOAOING FLASKS OF THE TYPE EMPLOYEO FOR TRANSPORTING IRRAOIATED,MATERIALS COMMISSARIAT A L ENERGIE ATOMIQUE, FRANCE

BRITISH PATENT $1,083,796+7$ PAGES, FIGURE, SEPTEMBER 20,1967

A DEVICE USED IN LOADING AND UNLOADING FLASKS AT HOT CELLS IS DESCRIBED. THE FLASKS ARE USED IN TRANSPORTING IRRADIATEO MATERIALS. THE FLASKS ARE PLACED ON A ROCKING SUPPORT WHICH MOVES THE FLASK FROM A VERTICAL TO HORI ZONTAL OR HORILONTAL TO VERTICAL POSITION. THE SUPPORT HAS AN EPICYCLIC MOTION PRODUCED BY THE ROLLING MOTION OF A TOOTHED SECTOR. THE SUPPORT RUNS ON A HORI ZONTAL RACK CARRIED BY A STATIONARY, HEIGHT-ADJUSTABLE TABLE. A DEVICE FOR REMOVING THE FLASK PLUG AND a MEANS FOR ForMING a LEAK TIGHT SEAL ARE PROVIDED.

AVAILABILITY - THE PATENT OFFICE, 25 SOUTHAMPTON BUILDING, LONDON, W.C. 2 , ENGLAND (49 CENTS/COPY) PATENT + SHIPPING CONTAINER + UNITEO KINGOOM

$3-25976$

TRANSPORT OF RADIDACTIVE MATERIALS BY INLAND WATFR CRAFT

1 PAGE, PIB-MITTEILUNGEN 77 , PAGE 225 (JUNE 1967 ) IN GERMAN

THE IAEA REgULATIONS FOR THE SAFE TRANSPORT OF RADIOACTIVE MATERIALS, 1967 EDITION, CONTAINS IN PART O ADOITIONAL REQUIREMENTS RELATING TO DIFFERENT MODES OF TRANSPORT HITH THE EXCEPTION OF CARRIAGE BY INLAND WATER CRAFT. THE AUTHOR DRAWS ATTENTION TO TWO PROBLEMS RELATING TO. CARRI IGE OF RADIOACTIVE MATERIALS BY INLAND WATER CRAFT - (1) RISK OF CONTAMINATION AFTER AN ACCIDENT IN WHICH LOW SPECIFIC ACTIVITY MATER. IAL IS INVOLVED, (2) MAXIMUM PERMISSIBLE DOSE RATE ON BOARD INLANO WATER CRAFT.

CONTAMINATION + GERMANY + MAXIMUM PERMISSIBLE DOSE (MPD) + OCEAN AND SEA + REGULATION, IAEA

3-25977

BLECHSCHMIDT MG

THE PRESENT SITUATION DF THE OFFICIAL REGULATIONS FOR TRANSPORTS OF NUCLEAR FUEL

2 PAGES, PTB-MITTEILUNGEN 77, P. 151-152 (APRIL 1967 ) IN GERMAN

THE TECHNICAL REQUIREMENTS AND OFFICIAL REGULATIONS FOR APPROVALS ARE DISCUSSED. THE GERMAN COMPETENT AUTHORITY CONFORMS TO THE REGULATIONS OF THE IAEA REGULATIONS FOR THE SAFE TRANSPORT OF RADIOACTIVE MATERIALS, 1967 EDITION. AT THE MOMENT, GERMAN ATOMIC LAW REOUIRES PERMISSION FOR EVERY SINGLE TRANSPORT. THIS MEANS THAT ALL TRANSPORTS MUST BE CARRIED OUT ON THE FISSILE CLASS-III PREMISES. EXCEPTIONS ARE POSSIBLE IN LIMITED CIRCUMSTANCES. THE APPROVAL FOR THE SHIPMENTS ARE TO BE GIVEN TO THE CARRIER AND NOT TO THE CONSIGNOR. MOREOVER, THE REGULATIONS FOR SHIPMENTS BY RAIL, ROAD, SEA-GOING VESSELS, AND AIR ARE STATED CHANGES IN THE GERMAN ATOMIC LAW ARE EXPECTED.

GERMANY + LAW + REgULATION, IAEA + TRANSPORTATION AND HANDLING 
CATEGORY

TRANSPORTATION AND HANOL ING OF RADIOACTIVE MATERIALS

$3-26368$

ALSO IN CATEGORIES 17 AND 15

FIRE CONSUMES TRUCK TRANSPORTING RADIOGRAPHY SOURCE

LANE-WELLS, HOUSTON, TEXAS

3 PAGES, LETTER TO AEC DIVISION OF STATE ANO LICENSE RELATIONS FROM J.C. WILSON, AUGUST 29.1066

A FiRE CONSUMEO A TRUCK TRANSPORTING A I-CURIE CESIUM SOURCE. WHEN THE FIRE WAS EXTINGUISHED, THE SOURCE WAS FOUND FLOATING ON THE MOLTEN LEAD FROM THE SHIELO. THE SOUREE WAS RSTRIEVED, UNDAMAGED, AND PLACED ON A LIO OF A TOOL BOX. WHILE WAITING FOR A RADIOLOGICAL ASSISTANCE TEAM CALLED BY A HIGHWAY PATROLMAN ON THE SCENE, THE PATROLMAN PICKEO UP THE SOURCE AND HELO IT FOR I MIN. HE RECEIVED A DOSE OF 100 MILLIREMS NHOLE BOOY AND 10 REMS TO HANDS. OTHER EXPOSURES WERE MINIMAL.

USAEC, PUBLIC DOCUMENT ROOM, $1717 \mathrm{H} \mathrm{ST.,} \mathrm{WASHINGTON,} \mathrm{0.C.} 20545$ (25 CENTS/PAGE)

*FIRE + \#RADIOGRAPHY + \#TRANSPORTATION AND HANOLING + INCIOENT, NONREACTOR. +

PERSONNEL EXPOSURE, RADIATION + SOURCE, RADIATION

3-26742 ALSO IN CATEGORIES 17 ANO 11

ERR COLO HYDROTEST AT 240 PSIG.

RURAL COOPERATIVE POWER ASSOCIATION, ELK RIVER, MINNESOTA

COO-651-60 +. 25 PAGES, 3 FIGURES, 4 TABLES, RURAL COOPERATIVE POWER ASSOCIATIOVRS FLK RIVER REACTJR

SIXTY-SE VENTH MONTHLY OPERATINC REPORT, MAY, 1968 DOCKET NO: 115-1, TYPE--BWR, MFG--A.C., AE--SGT + LUNDY

REACTOR HAS NOT OPERATED SINCE .IANUARY. A 240-PSIG COLD HYDROTEST WITH SR-85 DISPERSED IN THE.

PRIMARY SYSTEM WAS TERMINATED AFTER 7 DAYS, WITH NO SR-BS FOUND IN CAVITY WATEP. RUPTURE

OISK RUPTURE ON FUEL SHIPPING CASK HAS TRACED TO ALCONOX SOLUTION USED IN DECONTAMINATION AT

SRL. APPENDIX A -OESCRIBES 240-PSIG HYDROTEST AND RESULTS. APPENDIX B -PROCEDURE FOR

$1000-P S I G$ HYDROTEST AT $300 \mathrm{~F}$, USING SR-85 AND RB-86.

AVAILABILITY - USAEC, PUBLIC DOCUMENT ROOM, 1717 H. ST., WASHINGTON, 0. C. (SO.25 CENTS/PAGE)

\#MAIN COOLING SYSTEM + \#TEST, PROOF + CORROSION + DECONTAMINATION + ELK RIVER (BWR) + FAILURE, EaUIPMENT + FAILURE, PRESSURE VESSEL + PRESSURE RELIEF + PRESSURE VESSEL + PRESSURE, INTERNAL +

PROCEDURES AND MANUALS + REACTOR, $\triangle E C$ OWNED + REACTOR, BWR + REPORT, OPERATIONS + RUBIDIUM \&

SHIPPING CONTAINER + STRONTIUM + TRACER, RAOIOACTIVE

3-27041

GENERAL NUCLEAR SAFETY STUDIES

DAK RIDGE NATIONAL LABORATORY, OAK RIDGE, TENNESSEE

ORNL-4228 +. 33 PAGES, 5 FIGURES, 7 REFERENCES, PAGES 347-379 OF THE NSP ANNUAL PROGRESS REPORT, APRIL, 1968

PROGRESS REPORT, DEALING WITH - FUEL TRANSPORT SAFETY STUDIES - STPUCTURAL DESIGN ANO PHILOSOPHY, HEAT TRANSFER, CRITICALITY, SHIELOING, AEC CQNSULTING WDRK. HTGR SAFETY PZOGRAM OFFICE - HIGH-TEMPERATURE PHYSICS, FISSION-PRODUCT TRANSPORT AND COOLANT CHEMISTRY, FUTURE TOPICAL EVALUATIONS. SUPPLEMENTARY ACTIVITIES. OISCUSSION PAPERS ON VARIOUS ASDECTS OF WATER-COOLED REACTDR SAFETY. RDT REACTOR STANDARDS - PROGRAM ORGANIZATION, STANDARDS PREPARATION, SPECIAL STUDIES, LIST OF STANDARDS ISSUED. ANTISEISMIC OESIGN OF NUCLEAR FACILITIES - CDNCEPTUAL ANTISEISMIC OESIGN STUDIES, MDOEL STUDIES, GENERAL STUOIES.

*CRITICALITY SAFETY + *DESIGN CRITERIA + *CARTHQUAKE, GENERAL + * FIJEL HANOLING + *REACTOR, WATER + * SAFETY PRINCIPLES AND PHILOSOPHY + * SAFETY REVIEH + *SHIELDING + *SHIPPING ANALYSIS +

* SHIPPING CONTAINER + ANALYTICAL MOOEL + COOLANT CHEMISTRY + DECAY HEAT + FISSION PROOUCT TRANSPOPT + FUEL STORAGE + HIGH TEMPERATURE + THERMAL PROPERTY

$3-27424$

BACKSH + GOOIN O + MAULARO J + RIVET C

GRABS FOR HANDLING NUCLEAR FUEL ELEMENTS

COMMISSARIAT A LENERGIE ATOMIQUE, FRANCE

BRITISH PATENT 1,088,969+. 4 PAGES, 4 FIGUKES, OCTOBER 25, 1967

THE DESIGN FOR A GRAB FOR HANDLING REACTOR FUEL ELEMENTS IS PRESENTED. THE GRAB IS COMPRISER OF A CYLINDR ICAL BODY WIIH AN ELECTRICAL MOTOR AND SCREH-NUT SYSTFM FOR TRAYSLATIOYAL MOVEMENT. THE GRAB MECHANISM IS LOCATED ON A STATIONARY GRID ABOVE THE REACTOR CDRE.

AVAILABILITY - THE PATENT OFFICE, 25 SOUTHAMPTON BUILDING, LONDON, W.C. 2 , ENGLANO (49 CENTS/COPY) FUEL haNDLING MACHINE + PATENT + REFUEL ING + UNITED KINGDOM

3-27425

DELISLE JP

APPARATUS FOR HANULING THE FUEL ELEMENTS IN A NUCLEAR REACTOR

COMMISSARIAT A LENGERIE ATOMIQUE, FRANCE

BRITISH PATENT $1,089,559+4$ PAGES, I FIGURE, NOVEMBER 1,1967 
CATEGORY 3

TRANSPORTATION AND HANDLING OF RADIOACTIVE MATERIALS

3-27425 \#CONTINUED*

THE DESIGN OF A FUEL HANOLING APPARATUS FOR SOOIUM-COOLED REACTORS IS PRESENTED. THE FUEL HANDLING APPARATUS HAS AN ARM CONNECTED BY A HORIZONTAL PIVOT PIN TO A VERTICAL SUPPJRT COLUMN WHICH ROTATES ABOUT ITS AXIS IN A PLUG MOUNTED IN THE REACTOR COVER. A SECOND ARM PIVOTED TO THE FREE END OF THE FIRST ARM HAS A FUEL-ELEMENT GRAB PIVOTED TO THE SECOND ARM FREE END.

AVAILABILITY - THE PATENT OFFICE, 25 SOUTHAMPTON 8UILOING, LONDON, W.C. 2 , ENGLAND (49 CENTS/COPY)

FUEL HANOLING MACHINE + PATENT + REACTOR, FAST + SODIUM + UNITED KINGDOM

$3-27426$

KARTTUNEN JO

A TECHNIQUE FOR HANDLING HIGHLY RADIOACTIVE OR TOXIC MATERIALS FOR X-RAY FLUORESCENCE ANALYSIS

ARGONNE NATIONAL LABORATORY, ARGONNE, ILLINOIS

2 PAGES, 1 TABLE, 4 REFERENCES, CHEMIST-ANALYST, 56, PAGES 33-34 (JANUARY 1967 )

A TECHNIQUE FOR haNDLING THE PLACEMENT OF THE DISSOLVED RADIOACTIVE MATERIAL WITHIN A GLASS CELL $\triangle N D$ THEN WITHIN A NYLON-FILM POUCH IS DISCUSSED. THIS NYLON ENVELOPE DOES NOT INTERFERE IN THE ALIGNMENT OF THE CELL, AND IN EVENT DF RUPTURE THE SAMPLE IS STILL RETAINED. THIS METHOO IS CONTRASTED TO OTHER HANDLING METHODS COMMONLY EMPLDYED, AND ADVANTAGES ARE GIVEN.

PLUTONIUM + TRACER, FLUORESCENT + X-RAY

3-27427

NELMS HA

STRUCTURAL ANALYSIS OF SHIPPING CASKS VOL. 3. EFFECTS DF JACKET PHYSICAL PROPERTIES AND CURVATURF ON PUNCTURE RESISTANCE

OAK RIDGE NATIONAL LABORATORY, UAK RIDGE, TENNESSEE

ORNL-TM-1312 +. 84 PAGES, 23 FIGURES, 7 TABLES, 13 REFERENCES, VOL, 3, JUNE 1968

AN EXPERIMENTAL INVESTIGATION WAS MADE OF THE PUNCTURE RESISTANCE OF LEAD-SHIELDED STEEL-JACKETED SHIPPING CASKS, AND THE RESULTS ARE REPORTED. THIS INVESTIGATION WAS

CONCENTRATED UPON DETERMINING THE EFFECTS OF THE MATERIAL PROPERTIES AND THE CURVATURE OF THE CASK JACKET UPON PUNCTURE RESISTANCE. AN EMPIRICAL EQUATION FOR PRISMATIC CASKS HAS

DEVELOPED TO RELATE THE THICKNESS OF THE JACKET MATERIAL NECESSARY TO RESIST PUNCTURE TO THE

ULTIMATE TENSILE STRENGTH OF THE JACKET MATERIAL AND THE WEIGHT OF IHE CASK. THE EQUATION

DEVELOPED WAS THEN COMPARED WITH DATA PREVIOUSLY OBTAINED FROM TESTS WITH A PROTOTYPE CASK.

A PROCEDURE FOR SELECTING THE JACKET THICKNESSES DF CYLINDRICAL CASKS WAS ALSO OUTLINED.

AVAILABILITY - CLEARINGHOUSE FOR FEDERAL SCIENTIFIC AND TECHNICAL INFORMATION, SPRINGFIELO, VA. 22151 $\$ 3.00$ COPY, \$0.65 MICROF ICHE

*IMPACT SHOCK + \#SHIPPING CONTAINER + \#TEST, DROP + IMPACT PROPERTY + STPUCTURAL INTEGRITY

3-27877 ALSO IN CATEGORIES 13 ANO 12

FINNEY BC + LOWRIE RS + WATSON CD

A CONCEPTUAL DESIGN: AND A COST ESTIMATE OF AN ON-SITE FACILIIY FOR CLEANING, DISASSEMBLING, ANO CANNING SHORT-COOLED LMFBR FUEL IN PREPARATION FOR SHIPMENT TO A CENTRAL REPROCESSING PLANT

OAK RIDGE NATIONAL LABORATORY, DAK RIDGE, TENNESSEE

ORNL-TM-2050 +. 29 PAGES, 3 FIGURES, 4 TABLES, 9 REFERENCES, MAY 1968

THIS REPORT PRESENTS A CONCEPTUAL DESIGN AND A PRELIMINARY COST ESTIMATE FOR A FUEL PRESHIPMENT PREPARATION FACILITY THAT WOULO BE LOCATED AT A 1000-14W (ELECTRICAL)

SODIUM-COOLED FAST-BREEDER-REACTOR STATION. THIS FACILITY WOULD PROVIDE MEANS FOR CLEANING, DISASSEMBLING, SORTING (SEPARATING BEO RODS FROM FUEL RODS), CANNING, ANO LOADING SPEND FUEL RODS (INTO CASKS) PRIOR TO SHIPMENT TO A CENTRAL REPROCESSING PI.ANT. THE FUEL WOULD BE ALLOWED TO COOL 10 TO 25 DAYS BEFORE THE START OF THESE OPERATIONS. THE FACILITY WOULD CONSIST OF A SODIUM REMOVAL AREA, A SPENT-FUEL STORAGE POOL, A MECHANICAL CELL CONTAINING EQUIPMENT FOR DISASSEMBL ING FUEL ELEMENTS, AND A POOL IN WHICH FUEL CANS CDULD BE STORED AND CASKS WOULD BE LOADED. A PRELIMINARY ESTIMATE GIVES $\$ 5$ MILLION IN CAPITAL COST AN ANNUAL OPERATING COST OF $\$ 1$ MILLION. CONCLUSION - SUCH A FACILITY WOULD BE PROHIBITIVE FOR A SINGLE REACTOR.

AVAILABILITY - CLEARINGHOUSE FOR FEDERAL SCIENTIFIC AND TECHNIT.AL INFORMATION, SPRINGFIELD, VA. 22151 $\$ 3.00$ COPY, \$O:05 MICROFICHE

\#DESIGN STUDY + \#FUEL HANOLING + \#FUEL STORAGE + \#REACTOR, GENERAL + REACTOR, BREEDER + REACTOR, FAST 
CATEGORY 4

AEROSPACE SAFETY

$4-27027$

WALKER JAJ + FRANCE ED

DETERMINATION OF CARBONATE IN SODIUM

UKAEA, CULTHETCH, ENGLAND

TRG-REPORT $1635+12$ PAGES, 4 FIGURES, 4 TABLES, 8 REFERENCES, 1068

A METHOD IS DESCRIBEO. FOR THE DETERMINATION OF SODIUM CARBONATE IN SODIUM IN THE RANGE 7-15O

PPM WITH A STANDARD DEVIATION OF NOT GREATER THAN 1-5 PPM. THE DRINCIPLE OF THE METHOD INVOLVES THE REMOVAL OF SODIUM BY OISTILLATION AND THE CONDUCTOMETRIC DETERMINATION OF THE CARBON OIOXIDE EVOLVED AFTER ACIOIFICATION OF THE DISTILLATION RESIDUE. IT IS SHINN THAT WHEN A MAXIMUM OISTILLATION TEMPERATURE OF 350 C IS USED, THF DECOMPCSITION OF SODIUM CARBONATE IN NICKEL CRUCIBLES IS NEGLIGIBLE.

AVAILABILITY - CLEARINGHOUSE FOR FEDERAL SCIENTIFIC AND TECHNICAL INFORMATION, SPRINGFIELO, VA. 22151 $\$ 3.00$ COPY, $\$ 0.65$ MICROF ICHE

\#ANALYTICAL TECHNIQUE, CALIBRATION + \#CARBON + \#METAL, LIQUIO + \#SODIUM + CAREON DIOXIDE + DECONTAMINATION + REACTOR, LMCR

4-27028 ALSO IN CATEGORY 7

EICHELBERGER RL. + MCKISSON RL

SOLUBILITY OF COPPER IN SONIIUM

$\triangle T O M I C S$ INTERNATIONAL

$A I-\triangle E C-12671+.22$ PAGES, 8 FIGURES, 3 TABLES, 4 REFERENCES, MAY, 1968

THE SOLUBILITY OF COPPER IN SODIUM HAS BEEN STUDIED IN THE TEMPERATURE RANG5 DF 250 TD $72 E$ C, USING A VERY HIGH PURITY SODIUM AND OXYGEN FREE HIGH CONDUCTIVITY COPPER, A CAPSULE WAS USED, WITH THE SODIUM EXPOSED ONLY TO HIGH VACUUM. CHEMICAL ANALYSIS WAS DEREORMEO USSING COLORIMETRY ANO ATOMIC ABSORPTION SPECTROMETRY RESULTS OF THE 21 EXPERIMENTS REPORTED BETWEEN 350 AND 726 C WERE COMBINED WITH THOSE FROM TWO OTHER STUDIES TO GIVE AN EXPRESSION BASED ON 39 DATA POINTS AND COVERING THE TEMPERATURE RANGE OF 245 TO $726 \mathrm{C}$

OVAILABIL.ITY - CLEARINGHOUSE FOR FEDERAL SCIENTIFIC. AND TECHNICAL INFORMATION, SPRINGFIELD, VA. 22515 $\$ 3.00$ COPY, \$O.65 MICROFICHE

* ANALYTICAL TECHNIOUE, CALIBRATIDN + \#COPPER + \#METAL, LIQUID * \#OOIUM + PROPERTY, PHYSICAL + KEACTOR, LMCR

4-27029 ALSO IN CATEGORY 7

MOREWITZ HA + KODNTZ RL + NELSONCT + GREENFIELO MA + HAUSKNECHT DF

SODIUM BURNING, AEROSOL GENERATION, AND CONTROL OF FISSION PRJDUCT FELEASE DURING AN ACCIDENT PART II. AEROSOL GENERATION AND CONTROL OF FISSION PRODUCT RELEASE

ATOMICS INTERNATIUNAL +

29 PAGES, 16 FIGURES, TASLE, 4 REFERENCES, FROM THE INTERNATIONAL CONFERENCE ON THE SAFETY OF FAST NUCLFAR REACTORS, SEPTEMBER, 1967

RESULTS ARE PRESENTED FOR WORK IN PROGRESS AT ATOMICS INTERNATIONAL TO DEVELOD EXPERIMENTAL INFORMATION AND ANALYTICAL METHODS WHICH CHARACTERIZE THE RELEASE AND TRANSPCRT OF EFFLUENTS GENERATED DURING A SODIUM FIRE IN AN LMFBR. DATA ARE PRESENTEO FROM EXPERIMENTS. NHICH DESCRIBE THE TIME-HISTORY OF PARTICLE SIZE AND MASS DISTRISUTION OF AEROSOLS GENERATED DURING SOOIUM FIRES. EXPERIMENTAL OBSERVATIONS $\triangle R E$ MADF TO STUDY AEROSOL OEPLETION RESULTIVG FROM AGgLDMERATION, FALLOUT, AND WALL PLATING MECHANISMS. PREOICTION OF SODIUM OXIDE AEROSOL BEHAVIOR USING A THEORETICAL MODEL IS IN AGREEMENT WITH EXPERIMENTAL OBSERVATIONS IN THE LABORATORY. THE INTERACTION OF THE DOMINANT AEROSOL SPECIES, SODIUM OXIDE, WITH FUEL AND FISSIDN PRODUCT AERTSOLS IS ALSO DESCRIBED.

AVA.II ARIIITY - H.A. MOREWITZ, P.O. BOX 309, CANOGA PARK, CALIFORNIA

* AEROSOL PRODUCTION + \#AEROSOL PROPERTIES + \#ANALYTICAL MODEL + \#FIRF + \#METAL, LIQUID + \#OXIDE + \#REACTOR, LMCR + \$SODIUM + AGGLOMERATE + DEPOSITION + FALLOUT + FISSION PRODUCT TRANSPORT

4-27030 ALSD IN CATEGORY 7

MACPHERSON RE

OAK RIDGE NATIONAL LABORATORY, OAK RIDGE, TENNESSEE

OAK RIDGE NATI ONAL 'LABORATORY, OAK RIDGE, TENNESSEE
ORNL-TM-I937+. 33 PAGES, 26 REFERENCES, MAY 6,1968

IN A SODIUM-COOLED REACTOR, THE PDSSIBILITY OF SODIUM FIRES ANO THE RESULTANT RELEASE OF AEROSOLS STRONGLY INFLUENCE CONTAINMENT VESSEL DESIGN AVD OPERATING SAFETY. OUALITATIVE INVESIIGATIONS OF SODIUM POOL FIRES AND SPRAY FIRES HAVE BEEN C ARRIED OUT IN CONJUNCTION UITH EACH MAJOR SODIUM-COOLED REACTOR PROJECT. RECENTLY, MORE QUANTITATIVE STUDIES WERE UNOERTAKEN IN THESE AREAS, AND THE PROBLEM OF EXPLOSIVE INJECTION OF SODIUM SPRAYS INTO CONTAINMENT VOLUMES WAS INVESTIGATED. WORK IS ALSO UNDER WAY TO CHARACTERIZE AEROSOLS RELEASED FROM SUOIUM FIRES ANO TO DEFINE THEIR PERFORMANCE IN THE CONTAINMENT VRI.UME. THIS DOCUMENT BRIEFLY SUMMARIZES THE WORK TO DATE ON SODIUM FIRES ANO AEROSOL RELEASE, REVIEWS THF SCOPE OF CURRENT PROGRAMS, AND THEN PROPOSES ADOITIONAL EFFORT TO PROVIDE SAFETY CRITERIA FOR LIOUID-METAL-COOLED FAST-REACTOR OESIGN. 
4-27030 \#CONTINUED*

AVAILABILITY - CLEARINGHOUSE FOR FEDERAL SCIENTIFIC AND TECHNICAL INFORMATION, SPRINGFISLO, VA. 22151 $\$ 3.00$ COPY, $\$ 0.65$ MICROFICHE

\#FIRE + \#METAL, LIQUID + \#REACTOR, LMCR + AEROSOL PRODUCTION + AEROSOL PROPERTIES + OXIDE + SAFETY REVIEW + SOD I UM

4-27031

GORLANDS + BILSKI R

CONTROL OF CONTAMINANTS IN LIOUID-METAL SYSTEMS

NASA, LEWIS RESEARCH CENTER

NASA-TM-X-1432 +. 9 PAGES, 7 FIGURES, TABLE, 10 REFERENCES, DECEMBER, 1967

THE CONTAMINANT CONTROLS AND CLEANING PROCEDURES USED IN THE SNAP-8 SIMULATION LODP, CONSISTING OF TWO SODIUM-POTASSIUM (NAK) LOOPS AND JNE MERCURY LODP, MINIMIZED BOTH STARTUP AND OPERATIONAL PROBLEMS. MERCURY WETTING WAS INDUCED IN THE BOILER AND CONDENSER $\triangle S$ DETERMINEO BY PROGRESSIVE IMPROVEMENT IN THE HEAT-TRANSFER PERFORMANCE. THE DEGREE DF WETTING IS AN INDICATION OF THE SYSTEM CLEANLINESS. THE BOILER WAS CONDITIONED IN APPROXIMATELY 250 HOURS OF OPERATION WITHOUT WETTING $\triangle O D I T I V E S$. AFTER 384 HOURS OFF OPERATION, ANALYSIS OF A HG SAMPLE BY A DISTILLATION METHOD INDICATED NO CONTAMINATION. OXIDE PLUGGING IN THE NAK LOOPS WAS MINIMI ZED USING THE LOOP-ENTRY PROCEDURES DEVELOPED IN THE INVESTIGATION. NO PLUGS OCCUPRED BECAUSE OF CHANGED OR OF REPAIRS THAT REQUIRED SYSTEM ENTRY, AND ONLY MINOR PARTIAL PLUGS OCCURRED IN OVER 1500 HOURS OF OPERATION JF THE NAK LOOPS.

AVAILABILITY - CLEARINGHOUSE FOR FEDERAL SCIENTIFIC AND TECHNICAL INFDRIATION, SPRINGFIELD, VA. 22I5I $\$ 3.00$ COPY, \$0.65 MICROF ICHE

*MERCURY + \#METAL, LIOUID + \#OPERATING EXPERIENCE + *OUT OF PILE LOOPS AND EXPERIMENTS + *OXIDE + \#SODIUM + DECONTAMINATION + NAK + PIPING + REACTOR, LMCR + REACTOR, SPACE + SNAP 8 (SR)

4-27043 ALSO IN CATEGORY 5

AN EXPERIMENT EMPLOYING ULTRASTNIC ENERGY TO PROMOTE BOILING IN LIQUIO METAL

OAK RIDGE NATIONAL LABORATORY, OAK RIDGE, TENNESSEE

30 PAGES, 13 FIGURES, 14 REFERENCES, FROM THE INTERNATIONAL CONFERENCE ON THE SAFETY OF FAST NUCLEAR

REACTORS, SEPTEMBER, 1967

$$
\begin{aligned}
& \text { THE TENDENCY FOR LIQUIO METALS SUCH AS NA AND K TO UNDERGO SUBSTANTIAL LIQUID SUPERHEATING AND } \\
& \text { SUBSEQUENT EXPLOSIVE BOILING HAS BEEN DEMONSTRATED AT OAK RIDGE NATIONAL LABJRATIRY AND AT } \\
& \text { OTHER RESEARCH INSTALLATIONS. AN EXPER IMENT WAS CONDUCTED EMPLOYING ULTRASONIC ENERGY } \\
& \text { EXCITATION TO INITIATE AND MAINTAIN STABLE BOILING IN K UNDER CONDITIONS THAT.NORMALLY } \\
& \text { PRODUCED LIQUID SUPERHEATING AND UNSTABLE, EXPLOSIVE BOILING. UNSTABLE BOILING IS } \\
& \text { CHARACTERIZED BY LARGE ANDERRATIC TEMPERATURE DIFFERENCES BETWEEN THE TEMPERATURES JF THE } \\
& \text { LIQUID AND VAPOR. THESE TEMPERATURE DIFFERENCES WERE SIGNIFICANTLYREDUCED OR ELIMINATED } \\
& \text { UPON EXCITATION OF THE ULTRASONIC PROBE. THE TENDENCY TOWARD LIQUID SUPERHEATING WAS }
\end{aligned}
$$
SUBSTANT IALLY ELIMINATED UNDER MANY OPERATING CONDITIONS.

AVAILABILITY - M.M. YAROSH, OAK RIDGE NATIONAL LABORATORY, OAK RIDGE, TENNESSEE

* METAL, LIQUID + \#NUCLEATE BOILING + \#POTASSIUM + *SODIUM * BUB8LE NUCLEATIDN + REACTOR, LMCR. + THERMAL PROPERTY

$4-27128$

NEWBY GA

THE USAEC SPACE NUCLEAR ELECTRIC PTWER. PROGRAM - ITS OBJECTIVES AND STATUS

UNITED STATES ATOMIC ENERGY COMMISSION, WASHINGTON, D.C.

I PAGE, FIGURE, PAGE 13 OF THE AMERICAN NUCLEAR SOCIETY AND CANADIAN NUCLEAR ASSOCIATION TRANSACTIONS,

1968 ANNUAL MEETING, TORONTO, CANAOA, JUNE 10-18, 1968

PRESENTS APPRAISAL CF SPACE NUCLEAR SYSTEMS REQUIREMENTS. POSSIBLE CATEGORIZATIONS NOTEO FOR SPECTRUM OF MISSIONS TO BE PERFORMED.

\#ELECTRIC POWER, genERAL + \#REACTOR, SPACE + AEROSPACE SAFETY + R AND D PROGRAM

$4-27461$

KING LOP + BILLS CB

SOME FEASIBILITY STUDIES OF THE NUCLEAR DESTRUCT CONCEPT FOR ROVER REACTOR DISPOSAL

LOS ALAMOS SCIENTIFIC LABORATORY

1 PAGE, 5 REFERENCES, PAGES 565-66 OF TRANSACTIONS OF THE 1965 WINTER MEETING OF THE AMERICAN NUCLEAR

SOC IETY, HINSOALE, ILLINOIS, 8(2), NOVEMBER, 1965

A NUMBER OF POTENTIAL MEANS FOR ELIMINATING PUBLIC SAFETY PROBLEMS FROM ROCKET REENTRY ARE

CONSIDERED, SUCH AS FRAGMENTING REACTOR CORE AND GRANULATION OF CORE BY NUCLEAR TRANSIENT.

\# AEROSPACE SAFETY + \#REENTRY, ATMOSPHERIC + \#ROVER PROGRAM + NUCLEAR ROCKET 
CATEGORY

AEROSPACE SAFETY

$4-27462$

CLARK AJ + BERRY RE

AEROSPACE SAFETY RESULTS FROM A NERVA POST-OPERATIONAL DESTRUCT TEST

SANDIA CORPORATION

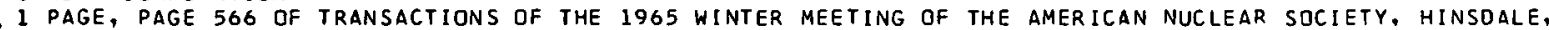

ILLINOIS, 8(2), NOVEMBER, 1965

A SUITABLE NON-NUCLEAR EXPLOSIVE-DESTRUCT SYSTEM HAS BEEN DEVELOPED FOR POSTOPERATIONAL

DESTRUCTION, BUT THE CHARACTERIZATION OF THE RESULTING DEBRIS HAS NOT BEEN FULLY DEFINED.

THE OBJECTIVE DF THE FULL-SCALE DESTRUCT TEST WAS TO COMPLETELY CHARACTERIZE THE DERRIS

FORMED AS A RESULT OF THE NON-NUCLEAR EXPI.OSIVE DESTRUCT.

*NUCLEAR EXPLOSION OEBRIS + \#TEST, DESTRUCTIVE + AEROSPACE SAFETY + NERVA PROGRAM + REACTOR, AIRCRAFT

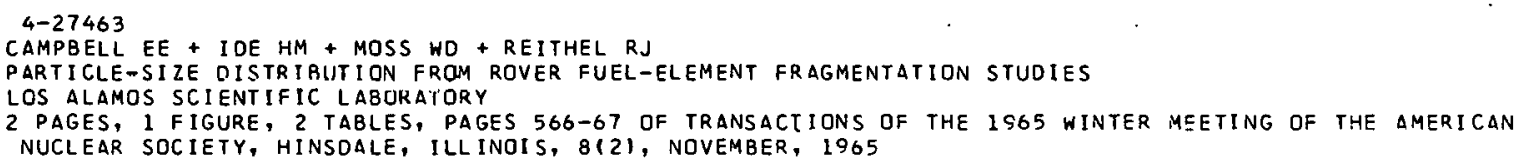

THE PRIMARY PUIRPOSE OF THIS STUDY WAS TO DETERMINE THE PARTICLE-SIZE DISTRIBUTION RESULTING FROM HIGH-EXPLOSIVE DESTRUCTION OF ROVER FUEL ELEMENTS. THIS INFJRMATION IS OF INTEREST IN DETERMINING THE HEALTH HAZARD ASSOCIATED WITH THE RADIOACTIVE PARTICULATES FROM VARIOUS DESTRUCT SYSTEMS FOR NUCLEAR-ROCKET-PRÜPULSION MOTORS

*FUEL ELEMENT + \#PARTICLE SIZE DISTRIBUTION + *ROVER PROGRAM + aEROSPACE SAFETY + NUCLEAR EXPLOSION DEBRIS + NUCLEAR ROCKET

4-27464

HARGROVE HG + TRAMMELL MR

AN ANALYSIS FOR CORRELATING GROUND DESTRUCT TESTS WITH IN-FLIGHT DESTRUCT OF NUCLEAR ROCKETS

WESTINGHOUSE ELECTRIC CORPORATIUN

1 PAGE, PAGES 567-68 OF TRANSACTIONS OF THE 1965 WINTER MEETING OF THE AMERICAN NUCLEAR SOCIETY, HINSDALE,

ILLINOIS, $8(2)$, NOVEMBER, 1965

A HIGH-EXPLOSIVE DESTRUCT SYSTEM IS BEING CONSIDERED AS A SAFETY COUNTERMEASURE SYSTEM FOR USE IN NUCLEAR ROCKETS DURING EARTH-JRBITAL AND SUBORBITAL FLIGHT. THE PURPOSE OF THE SYSTCM IS TO FRAGMENT THE RADIOACTIVE CORE INTO A CLOUD OF SMALL PARTICLES, THE MAJORITY OF WHICH WILL SURVIVE ATMOSPHERIC RE-ENTRY AND DEPOSIT ON THE EARTHS SURFACE.

*NUCLEAR ROCKET + \#TEST, DESTRUCTIVE + *TESTING + aEROSPACE SAFETY + PARTICLE, RADIDACTIVE + DARTICULATE

4-27466

ELLETT WH + BERGER MJ + HCGAN OL

DOSE MODELS FOR EVALUATING THE RADIATION HAZARD FROM REACTOR JEBR IS

NAVAL RESEARCH LABORATORY + NATIONAL BUREAU OF STANDAROS

1 PAGE, I FIGURE, 5 REFERENCES, P. 968 OF TRANSACTIONS OC THE 1965 WINTFR MEETING OF THF $\triangle M E R I C A N$ VUCLEAR SOCIETY, HINSDALE, ILLINOIS, 812). NOVEMBER 15-18, 1965

THE RAOI OLOGICAL EFFECTS WORKING GROUP OF THE SPACE NUCLEAR PROPULSION OFFICE WAS QRGANIZEN TO PREPARE DATA ANO STUDIES FOR USE IN THE EVALUATION DF POSSIBLE RAJIATIUN HAZARD FRJY VJCLEAO ROCKET OFBRIS, SEVERAL MODELS FOR CALCULATING THE ABSORBED DOSE FROM FISSION-PROOUCT SOUFCES WERE DEVELOPED. THESE BETA- ANO GAMMA-DOSE MOUELS HAVE GENERAL APPLICABILITY TO OTHEO HOT-PARTICLE HAZARD PROBLEMS ASSOCIATED WITH REACTOR ACCIDENTS.

* dose calculation, internal + \#nuClear explosion debris + aerospace safety + nuClfar pockft

$4-27467$

SPEIS TP + ORTENBERG LI + MOWERY AI

THE DESIGN AND ANALYSIS OF A PIISON SYSTEM FOR SAFE SHIPPING THE NERVA REACTOR

WESTINGHOUSE ELECTRIC COMPANY

2 PAGES, 1 TABLE, 2 REFERENCES, PAGES 568-569 OF THE TRANSACTIONS OF THE 1965 WINTER MEETING OF THF AMER ICAN NUCLEAR SOCIETY, HINSDALE, ILLINOIS, $9(2)$, NOVEMBER 1365

ALTHOUGH THE NERVA REACTOR IS HIGHLY UNOERMODERATED, D NUCLEAR POISON SYSTEM HAS BEEN PESIGNED TO KEEP THE EFFECTIVE MULTIPLICATION BELOW C.9 EVEN WHEN COMPLETELY WATER FLODDEN.

* AER OSPACE SAFETY + *POISON, SOLUBLE + \#SHUTDÜWN SYSTElA, SECONDARY + NERVA PR.DGRAM + RFACTDY, AIRCRAFT

4-27579 ALSO IN CATEGORIES 9 ANO 6 
4-27579 \#CONTINUED*

FRIEOMAN ST + RANKIN WD

INDIRECT MEASUREMENT OF NUCLEAR HEATING RATES IN POISON CONTROL VANES

LOS ALAMOS SCIENTIFIC LABORATORY

1 PAGE, ANS TRANSACTIONS 11111 , PAGE 25, 1968 ANNUAL MEETING OF THE AMERICAN NUCLEAR SOCIETY AND CANADIAN

NUCLEAR ASSOCIATION, TORONTO, CANADA, JUNE' 10-13, 1968

\begin{abstract}
THE ACCURATE PREDICTIDN OF NUCLEAR HEATING RATES IN HIGH CAPTURE CRCSS-SECTION CONTROL MATERIALS IS A MAJOR RADIATION ANALYSIS PROBLEM. THE PROBLEM IS PARTICULARLY ACUTE IN NUCLEAR ROCKET REACTOR SYSTEMS SUCH AS NERVA WHERE THE RELATIVELY THIN CONTROL VANES ARE LOCATED IN HIGHLY MODERATING BERYLLIUM REFLECTOR REGION IMMEDIATELY ADJACENT TO A HIJH-POWER

DENSITY CORE. OPERATIONAL CONSIDERATIONS, INCLUOING EFFECTS ON REACTOR SAFETY AND

RELIABILIYY, REQUIRE ACCURATE PREDICTIONS OF VANE HEATING RATES AND AN ADEQUATE FLOW OF LI QUID HYOROGEN TO THE VANES, DRUMS, REFLECTOR, AND PRESSURE VESSEL, BUT ESPECIALLY TO THE VANES SINCE THESE INVOLVE THE CONTROL SYSTEM.
\end{abstract}

*MEASUREMENT, TEMPERATURE + *NuCLEAR ROCKET + HEAT TRANSFER + INSTRUMENTATION, CONTROL + NERVA PROGRAM

4-27818 ALSO IN CATEGORY 7

POUCHER FW + KOHL AL

CLEANING TECHNIQUES FOR SODIUM SYSTEM COMPONENTS

ATOMICS INTERNATIONAL, C ANOGA PARK, CAL I FORNIA

2 PAGES, 2 REFERENCES, ANS TRANS, 11(1), PAGES 114-115, 1968 ANNUAL MEETING OF THE AMERICAN NUCLEAR

SOCIETY AND CANAOI AN NUCLEAR ASSOCIATION, TORONTO, CANADA, JUNE 10-13, 1968

SPECIALIZED TECHNIQUES ARE REQUIRED FOR CLEANING SURFACES THAT HAVE BEEN IN CONTACT WITH

LIQUID SODIUM. ALTHOUGH A GREAT MANY PRDCESSES HAVE BEEN INVESTIGATED, ONLY TWO HAVE PROVED GENERALLY USEFUL FOR A WIDE VARIETY OF APPLICATIONS AT ATOMICS INTERNATIONAL. THESE ARE REACTION WITH STEAM (WITH OR WITHOUT AN INERT GAS DILUENT) FOR MAJOR SYSTEMS AND COMPONENTS, AND REACTION WITH LIQUID 2-BUTOXYETHENOL IETHYLENE GLYCOL MONOBUTYL ETHER, BUTYL CELLOSOLVE, DOWANOL E.B.I FOR SMALIFR ITEMS AND HOT-CELL APPLICATIONS. IN ADOITIUN, DIPPING COMPONENTS IN HOT OIL HAS PROVED HELPFUL AS AN INITIAL STEP TO REDUCE THE QUANTITY OF SODIUM REQUIRING REACTION. LIQUID AMMONIA WASHING HAS BEEN SHOWN TO BE APPLICABLE FOR SPECIAL CASES WHERE HYOROGEN EVOLUTION MUST BE MINIMIZED.

*COOLANT CHEMISTRY + \#OECONTAMINATION + \#SODIUM + \#STEAM + METAL, ALKALI + METAL, LIQUID + REACTOR, LMCR. + REACTOR, LMFBR

4-27819 ALSO IN CATEGORY 7

MCPHEETERS CC + BIERY JC

THE DYNAMIC CHARACTERISTICS OF A SODIUIM OXIDE PLUGGING INDICATOR

LOS ALAMOS SCIENTIFIC LABORATORY, NEW MEXICO

2 PAGES, 6 REFERENCES, ANS TRANS. $11(1)$, PAGES 115-11E, 1968 ANNUAL MEETING OF THE AMERICAN NUCLEAR

SOCIETY ANO THE CANADIAN NUCLEAR ASSOCIATION, TORONTO, CANADA, JUNE 10-13, 1968

WORK AT LOS ALAMOS SCIENTIFIC LABORATORY HAS INDICATED THAT THE PLUGGING INDICATOR CAN BE A USEFUL ANALYTICAL INSTRUMENT FOR INDICATING OXYGEN CONCENTRATIONS IN SODIUM. AS COMOARED TO THE DISTILLATION SAMPLER OF EMF CELLS, THE PLUGGING INDICATOR DATA HAD A MUCH LOWER STATISTICAL STANDARC DEVIATION. HOWEVER, THE METER RLQUIRED CALIBRATION. IHE PLUGGING TEMPERATURE WAS CORRELATED WITH FLOW RATE, COOLING RATE, AND OXYGEN CONCENTRATION.

\#ANALYTICAL TECHNIOUE, CALIBRATIUN + \#COOLANT CHEMISTRY + \#FLOW ORIFICE + \#OXIDE + \#SODIUM + METAL, ALKALI + METAL, LIQUID + REACTOR, LMCR + REACTOR, LMFBR

4-27820 ALSO IN CATEGORY 7

MCPHELIERS CC

MASS TRANSFER OF OXYGEN IN SODIUM COLD TRAPS

LOS ALAMOS SCIENTIFIC LABORATORY

2 PAGES, 5 REFERENCES, ANS TRANS. 11111 , PAGES 116-117, 1968 ANNUAL MEETING OF THE AMERICAN NUCLEAR

SOCIETY ANO THE CANADIAN NUCLEAR ASSOCIATION, TORONTG, CANADA, JUNE 10-13, 1968

COLD TRAPS HAVE BEEN USED EXTENSIVELY FOR CONTROLLING OXYGEN CONCENTRATION IN SODIUM SYSTEMS. COLD TRAPS UTILIZE THE POSITIVE TEMPERATURE OEPENDENCE OF THE SOLJBILITY OF SODIUM MJVJXIDE IN SDOIUM AND THE RESULTANT PRECIPITATION OF SODIUM MONOXIDE AT LOW SODIUM TEMPERATURES. SODIUM MONGXIDE PRECIPITATION IS HERE ASSUMEO TO BE HETEROGENEOUS BECAUSE OF THE STRJNG EFFECT OF SUIRFACE AREA ON THE PRECIPITATION RATE SHOWN IN HREVIOUS PACKLESS COLD TRAP EXPERIMENTS. A PACKLESS COLD TRAP OF SIMPLE GEOMETRY AND OPERATING WITH A TEMPERATURE GRADIENT WAS USEO IN THIS STUDY. IN THE PRESENCE OF THE TEMPERATURE GRADIENT, THE EFFECTIVE GRADIENT WAS USEO IN THIS STUDY. IN THE PRESENCE OF THE TEMPERATURE GRADIENT, THE EFFECTIVE
PRECIPIRATION SURFACE AREA WAS. A FUNCTION OF THE OXYGEN CONCENTRATION IN THE SODIUM ENTERING PRECIPIRATION
THE COLO TRAP.

* ANALYTICAL TECHNIQUE, CALIBRATION + \#COOLANT CHEMISTRY + \#FLOW ORIFICE + \#DXIDE + \#SODIUM + FILTER, TRAP + METAL, ALKALI + METAL, LIQUID + REACTOR, LMCR + REACTOR, LMFBR 
CATEGORY 4

AEROSPACE SAFETY

4-27821 *CONTINUED*

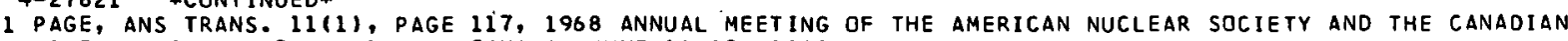
NUCLEAR ASSOCIATION, TORONTO, CANADA, JUNE 10-13, 1968

A PROgRAM AT OAK RIDGe NATIONAL LABORATORY EVALUATED THE METALLURGICAL OESIGN OF A SNAP-50-TYPE RADIATOR CIRCUIT. THE SNAP-5O CONCEPT EMPLOYS A URANIUM CARBIDE- OR URANIUM NITRIDE-FUELED LITHIUM-COOLED FAST REACTOR WITH A RANKINE-CYCLE POTASSIUM POHER-CONVERSION SYSTEM. THE TEST LEO TO A BETTER DEFINITION OF ACCEPTABLE RESIOENCE TIMES AND TEMPERATURE CONDITIONS FOR NB-1\%ZR. ALLOY AND TYPE-316 STAINLESS STEEL IN NAK.

*CORROSION + \#METAL, LIQUID + \#NAK + \#NIOBIUM + \#SNAP 50 (SR) + *STEEL, STAINLESS + CARBON + FILTER, TRAP + LITHIUM + METAL, ALKALI + NITROGEN + POTASSIUM + REACTOR, SPACE + ZIRCALOY

$4-27822$

ROMANO AJ + WACHTEL SJ + KLAMUT CJ

CORROSION BEHAVIOR OF COBALT, IRON, AND MOLYBDENUM BASE ALLOYS IN HIGH-TEMPERATURE SODIUM BROOKHAVEN NATIONAL LABORATORY

1 PAGE, 2 FIGURES, ANS TRANS. $11(1)$, PAGES 118-119, 1968 ANNUAL MEETING OF THE AMERICAN NUCLEAR SOCIETY

AND CANADIAN NUCLEAR ASSOEIATION, TORONTO, CANADA, JUNE 10-13, 1968

CORROSION STUDIES ARE BEING CARRIED OUT WITH POTENTIAL FUEL-CLADDING MATERIALS FOR ADVANCER

LIQUID-METAL FAST-BREEDER REACTORS. THE MATERIALS UNDER TEST AT TEMPERATURES AS HIGH AS 760

C INCLUDE REFRACTORY METAL BASE ALLOYS, COBALT BASE ALLOYS, AND STAINLESS STEELS. TWO PUMPED

LOOPS, MADE ENTIRELY OF STABILIZED STAINLESS STEELS, ARE BEING USED TO CARRY OUT THE

INVESTIGATIONS. THE SPECIMENS ARE EXPOSED TO HIGH-VELOCITY SODIUM IN A $24-I N$. -LONG RISINC

TEMPERATURE REGION. A $1655-\mathrm{H}$ CORROSION RUN WAS COMPLETED AT THE FOLLOWING OPERATING

CONDITIONS - (1) SPECIMEN TEMPERATURE RANGE--710 TO $760 \mathrm{C}$, (2) OXYGEN CONCENTRATION IN

SODIUM--4. TO 8 PPM, (3) SODIUM VELOCITY--22 FT/SEC. THE MATERIALS EVALUATED WERE HAYNES-25

AND UMCD-51 (COBALT-BASE ALLOYS), TYPES-304 AND -231 STAINLESS STEELS, AND UNALLOYED

MOLYBDENUM.

*CORROSION + \#METAL, LIOUID + \#METAL, REFRACTORY + \#SODIUM + \#STEEL, STAINLESS + CLADDING + COBALT +

FUEL ELEMENT + HIGH TEMPERATURE + IRON + MMI.YBDENUM + REACTOR, LMCR + REACTOR, LMFBR + THERMAL EXPERIMENT

$4-27823$

ROMANO AJ + KLAMUT CJ

CORROSION OF OXYGEN-CONTAMINATED NB-1ZR AND TA-8W-2HF ALLOYS BY REFLUX-BDILING SOOIUM AT IOZS C BROOKHAVEN NATIONAL LABORATORY

3 PAGES, 2 FIGURES, ANS TRANS. $11(1)$, PAGES 118-20, 1968 ANNUAL MEETING OF THE AMERICAN NUCLEAR SOCIETY

AND CANADIAN NUCLEAR ASSOCIATION, TORONTO, CANAOA, JUNE 10-13, 1968

REFRACTORY-METAI. AI,LOYS ARE OF INTEREST AS CONTAINMENT MATERIALS FOR HIGH-TEMPERATURE ALKALI-METAL-COOLED REACTORS PROPOSED FOR RANKINE-CYCLE POWER CONVERSION SYSTFMS. DF PARTICULAR INTEREST ARE NB-1ZR AND TA-8W-2HF IN WHICH THE ZR ANO HF ACT $A S$ OXYGEN GETTERS.

\#CORROSION + \#METAL, LIQUID + *METAL, REFRACTORY + \#SODIUM + HAFNIUM + HIGH TEMPERATURE + METAL, ALKALI + NIOBIUM + REACTOR, LMCR + REACTOR, LMFBR + TANTALUM + THERMAL EXPERIMENT

$4-27859$ ALSO IN CATEGORY 15

BILLINGHAM $J+$ ROBBINS DE + EWING D

A METHOD OF EVALUATING RADIATION RISKS FOR MANNED SPACE FLIGHTS

$\triangle M E S$ RESEARCH CENTER + MANNED SPACECRAFT CENTER

16 PAGES, 8 FIGURES, 1 TABLE, 14 REFERENCES, PADIATION RESEARCH, 30, PAGES 541-546 (MARCH 1967 )

PRUBLEMS CONCERNING AN EVALUATION OF THF HAZARD FROM DOSES OF IONIZING RADIATION DURING MANNED SPACE FLIGHT ARE DISCUSSED. A METHOD IS GIVEN FOR STATISTIICALLY CUMBINING SOLAR FLARE DATA. WITH ASSESSMENTS OF THE LIKELIHOOD FOR BIOLOGICAL RESPONSES. THIS APPROACH IS AIMED AT SYNTHESIZING RADIOPHYSICAL AND RADIOBIOLOGICAL DATA SO THAT THE INTERFACES BETWEEN RADIATION, CREW SAFETY, $\triangle N D$ MISSION SUCCESS CAN BE BETTER RELATED TO OTHER HAZARDS UURING MISSION PLANNING.

*AIRCRAFT + \#DDSE CALCULATION, EXTERNAL + \#DOSE CALCULATION, INTERNAL + \#RADIATION SAFETY AND CONTROL + \#RADIOBIOLOGY + \#SPACECRAFT + ATMOSPHERIC PÜLLUTION + HAZARDS ANALYSIS + METEOROLOGICAL SUPPORT 
5-25160 ALSO IN CATEGORY 8

MORRISON DL + WILSON TR

CURRENT RESEARCH ON COOLANT BLOWDOWN IN THE USA

BATELLE MEMORIAL INSTITUTE + PHILLIPS PETROLEUM COMPANY, IDAHD FALLS, IDAHO

34 PAGES, 17 FIGURES, 18 REFERENCES, FROM THE RECORD OF THE THIRD CREST MEETING, PARIS, NOVEMBER, 1967

THE COURSE AND CONSEQUENCES OF A LOSS-OF-CODLANT ACCIDENT ARE DIRECTLY RELATED TO THE BLOWDOWN AFTER RUPTURE, AND CURRENT RESEARCH IS CARRIED OUT TO CHARACTERIZE THIS OCCURRENCE. AREAS OF INTEREST ARE - DECOMPRESSION, TWO-PHASE FLOW, MECHANICAL EFFECTS, ETC. THE EFFORT IS BEING PURSUED AT LOFT, CSE, AND IIT. THE DEVELOPMENT OF ANALYTICAL MODELS AND COMPUTER CODES IS ALSO DISCUSSED, AND COMPARISON BETWEEN EALCULATIONS ANO EXPERIMENTS IS MADE.

AVAILABILITY - D.L. MORRISON, BATTELLE MEMORIAL INSTITUTE, COLUMBUS LABORATORIES

\#ACCIDENT, LOSS OF COOLANT + \#BLOWDOWN + \#CREST + \#CSE + \#LOFT (S-RR) + ANALYTICAL MODEL + COMPUTER PROGRAM + REACTOR, SAFETY RESEARCH

$5-25161$

MONTAGNANI M + HOLTBECKER H

PROGRESS OF ISPRA SAFETY ACTIVITIES IN THE MECHANICAL FIELD

EUROPEAN ATOMIC ENERGY COMMISSION

4 PAGES, 6 REFERENCES, PRESENTEO AT THE THIRD CREST MEETING, NOVEMBER 15-17, 1967, PARIS

BASIC STUOIES IN PRESSURE-WAVE GENERATION, PROPAGATION OF HAVES AND THEIR INTERACTION WITH OBSTACLES, MATERIAL AND STRUCTURAL RESPONSE TO OYNAMIE LOADING, AND HIGH-FREQUENCY SHORT-RESPONSE-TIME INSTRUMENTATION IS DISCUSSED. SPECIFIC SAFETY PROBLEMS IN. THE CIREM BOILING-WATER PRESSURE-TUBE REACTOR, ANO FLAMMAB ILITY AND EXPLOSION PROBLEMS IN ORGANIC-COOLED REACTORS ARE ALSO DISCUSSED.

AVAILABILITY - M. MONTAGNANI OR H. HOLTBECKER, EUROPEAN ATOMIC ENERGY COMMISSION

*CREST + EXPLOSION + INSTRUMENTATION, PRESSURE + REACTOR, ORgANIC COOLEO + REACTOR, PRESSURE TUBE + . REACTOR, PRESSURE TUBE, BOILING + WAVE, STRESS

$5-25162$

$V O L T A$

PROGRESS OF RELIABILITY STUDIES CARRIED OUT AT CCR EURATOM ISPRA

EUROPEAN ATOMIC ENERGY COMMISSION

3 PAGES, PRESENTED AT THE THIRD CREST MEETING, NOVEMBER 15-17, 1967, PARIS

MECHANICAL AND ELECTROMECHANICAL COMPONENTS WERE CODIFIED FOR DATA COLLECTION FOR APPLICATION OF LIFE-EXPECTANCY ANALYSIS IN ESSOR REACTOR PRIMARY CIRCUITS. RELIABILITY ANALYSIS IS USED IN THE ESSOR SAFETY REPORT BY ASSIGNING OEGREES DF RELIABILITY TO EACH PROTECTIVE ACTION. ONE OF THE PROBLEMS WAS IN THE USE OF EXPERIMENTAL FAILURE DATA.

AVAILABILITY - G. VOLTA, EUROPEAN ATOMIC ENERGY COMMISSION

CREST + RELIABILITY ANALYSIS + RELIABILITY, COMPONENT + RELIABILITY, SYSTFM

$5-25163$

GRASS G

PROGRESS OF ISPRA SAFETY ACTIVITIES IN THE HEAT TRANSFER FIELD

EUROPEAN ATOMIC ENERGY COMMISSION

4 PAGES, PRESENTED AT THE THIRD CREST MEETING, NOVEMBER 15-17, 1967, PARIS

TESTS WERE PERFORMEO ON BOILING AND SUPERHEATED SODIUM TO DETERMINE EJECTION VELOCITIES

THROUGH SMALL-DIAMETER TUBES. RESULTS ARE REPORTED RATHER SUPERFICIALLY. EJECTION STUDIES

FOR WATER AFTER RAPIO DEPRESSURIZATION (BOTH FROM STAGNANT AND FORCED CIRCULATION CONDITIONS)

ARE SIMILARLY REPORTED.

AVAILABILITY - G. GRASS, EUROPEAN ATOMIC ENERGY COMMISSION

BLOWDOWN + CREST + HEAT TRANSFER + SODIUM + WATER, GENERAL

$5-25164$

ALSO IN CATEGORY

BOWEN JH

PROGRESS IN THE U.K. ON THE SAFETY ASSESSMENT OF A.G.R., USING THE PROBABILITY METHOD

UNITED KINGDON ATOMI ENERGY AUTHORITY, RISLEY

10 PAGES, 6 REFERENCES, PRESENTED AT THE THIRO CREST MEETING, NOVEMBER 15-17, 1967 , PARIS

THE ADVANCE TO URBAN SITING HAS BEEN ACCOMPLISHED BY THE DETERMINATION TO REFINE ANO IMPROVE THE SAFETY CHARACTERISTICS OF THE AGR. THE MCA CONCEPT WOULD BE INAPPROPRIATE FOR THIS PURPOSE SO THE PROBABILISTIC METHOD OF SAFETY ASSESSMENT IS DISCUSSED (SEE ALSO NSIC IB2IO). THE ANALYSIS IS MADE BY ASSIGNING OR CALCULATING A PERCENTAGE RELEASE FOR A GIVEN 
CATEGORY 5

ACCIDENT ANALYSIS

5-25164 *CONT INUEO*

FISSION-PRODUCT INVENTORY ANO THUS DETERMINING THE EXPECTED PROBAEILITY ANO FREQUENCY OF SUCH A. RELEASE.

AVAILABILITY - J. H. BOWEN, SAFEGUARDS OIVISION, UNITED KINGDOM ATOMIC ENERGY AUTHORITY, RISLEY ACCIOENT, PROBABILITY OF + CREST + REACTOR, GCR + SAFETY EVALUATION + SITING, REACTOR + SITING, URBAN + UNITED KINGDOM

$5-25165$

KARWAT H

STUDIES RELATED TO THE DEPRESSURIZATION OF WATER-COOLED POWER REACTORS PERFORMEO IN LO67 IN THE FEDERAL REPUBLIC OF GERMANY

TECHNISCHE HOSCHULE MUNICH, GERMANY

13 PAGES, 4 FIGURES, 3 REFERENCES, PRESENTED AT THE THIRD CREST MEETING, NDVEMBER 15-17, 1957 , PAPIS

STUDIES ARE REPORTEO WHICH ARE CONCERNED WITH (1) DEVELOPMENT OF ANALYTICAL METHODS TO PREDICT THERMOHYDRAULIC EFFECTS RELATEO TO THE. DEPRESSURIZATION OF THE PRIMARY CODLANT SYSTEM AND (?.) EXPER IMENTAL STUDIES TO INVESTIGATE SPECIFIC PROBLEMS AND BACK UP ANALYTICAL MODELS. SEVERAL COMPUTER CODES HAVE BEEN DEVELOPED AND TESTED AS A PART OF THIS STUDY.

AVAILABILITY - H, KARWAT, INSTITUT FUR MEBETA- UND REGULUNGSTECHNIK, TECHNISCHE, MUNICH, GERMANY ACCIDENT ANALYSIS + ACCIOENT, LOSS OF COOLANT + BLOWDOWN + CONTAINMENT VESSEL LOAOING + CREST + GERMANY + HEAT TRANSFER

5-25884 ALSO IN CATEGORIES 18 AND 17

BELL PSAR SECT 3.3 .7 DESCRIPTION OF CORE ANALYSIS

NEW YORK STATE ELECTRIC + GAS CORPORATION

85 PAGES, 20 FIGURES, 5 TABLES, PAGE III-3-5 THRU -7. MARCH $196850-319$.

A COMPUTER PROGRAM IUNSPECIFIEDI IS USED TO ANALYZE THE THERMAL AND HYDRAULIC CHARACTERISTICS OF THE CORE AS A WHOLE. OUTPUT AND INPUT DISCUSSED BRIEFLY. RECENT MODIFICATIONS IV CORE DESIGN AND IN THERMAL HYDRAULIC EVALUATION TECHNIOUES ALLOW HIGHER FEEDWATER TEMP. WITHOUT ENCROACHING ON THERMAL MARGINS. THE ITEMS AND THEIR EFFECT ON INLET SUBCOOLING (BTU/LB) MCHFR ARE - (1) INLET ENTHALPY NOW BASED ON 1920 PSIA DOME PRESSURE, RATHER THAN IJSJ INLET $(+41+.06)$. (2) CORE BYPASS FLOW NOW ESTABLISHED $\triangle S 7 \%(-1+0.03)$. (3) CORE MIDPLANE PRESSURF OF 1035 NOW USED INSTEAD OF INLET PRESSURE $(-1-.02)$. $(4)$ 2IRCONIUM SPACER TEST DATA 1 $-1-.02)$. \$THE NET EFFECT, WHEN FEEDWATER INCREASED TJ $420 \mathrm{~F}$, IS TO INCREASS SUBCQJLING 0.3 BTU/LB AND MCHFR BY 0.02 .

AVAILABILITY - CLEARINGHOUSE FOR FEDERAL SCIENTIFIC AND TECHNICAL INFORMATION, SPRINGFIELD, VIRGINIA, $22151, \$ 3.00$ COPY, \$O.65 MICROFICIIC

* ANALYTICAL MODEL + \#COMPUTER PROGRAM + \#SUBCOOLING + BELL (8WR) + COMPARISON, THEORY AND EXDERIENCE + HEAT FLUX, CRITICAL + HEAT TRANSFER, BOILING + REACTOR, BWR + P.EPORT, PSAR + SAFETY MARGIN

5-25903 ALSO IN CATEGURIES 18 AND 12

ORAY AP + IANNI P + MUP.R.AY JL

GENERAL ELECTRIC COMPANY ANALYTICAL AND EXPERIMENTAL PROGRAMS FOR RESOLUTIDN OF ACRS SACETY CONCERNS ATOMIC POWER EOUIPMENT DEPARTMENT, GENERAL ELECTRIC COMPANY, SAN JOSE, CALIFORNIA

APED-5608 +. 40 PAGES, 5 FIGURES, 4 TABLES, APRIL, 1968

ACRS REVIEW OF BROWNS FERRY IMAR. 14, 1967 I INOICATED THAT ADDITIONAL TESTING OR ANALYSIS WAS REQUIRED. THE TEST OR ANALYSIS PROGRAM IS DESCRIBED FJR THE FOLLOWING - (1) EFFECTS DF FUEL-ROD FAILURE CN ECCS PERFORMANCE, (2) ERTELIS UF FUEL=BUIVOLE PLOW BLOCKAGL, (3) VERIFICATION OF FUEL-DAMAGE-LIMIT CRITERION, (4) EFFECTS OF CLADDING TEMPERATURE AND MATERIAL ON ECCS PERFORMANCE, (5) CLOSURE OF MAIN-STEAM-LINE ISOLATION VALVE, (6) TESTS OF DIESEL-GENERATOR PERFORMANCE, (7) STEAM-LINE-RREAK AT.C.IDENI, ANO (8) DEPRESSURIZATION PERFORMANCE OF HPCI SYSTEM.

AVAILABILITY - USAEC, PUBLIC DOCUMENT ROOM

\#ENGINEERED SAFETY FEATURE + \#R AND D PROGRAM + ACCIDENT, LOSS OF COOLANT + ACCIDENT, STEAM LINE RUPTURE + ACRS + AEC OUESTION + BROWNS FERRY (BWRI + CONTAINMENT ISOLATION + CJRE SPRAY + FLOW BLOCKAGE + FUEL ELEMENT + GENERATOR, ENGINE + PERFORMANCE LIMIT + SYSTEM OPERABILITY IN ACCIDENT

5-25904 ALSO IN CATEGORIES 12 ANO 18

EFFECTS OF FUEL ROD FAILURE ON ECCS PERFORMANCE

ATOMIC POWER EQUIPMENT DEPARTMENT, GENERAL ELECTRIC COMPANY, SAN JOSE, CAL IFORNIA

APED-5608 +. 4 PAGES, PAGES 2-1 THROUGH 2-5 OF THE GENERAL ELECTRIC COMPANY ANALYTICAL AND EXPERIMENTAL PROGRAMS FOR RESOLUTION OF ACRS SAFETY CONCERNS, APRIL+ 1968

ACRS REVIEH OF BROWNS FERRY VOICED CONCERN FOR EFFECT ON HEAT-TRANSFER EFFECTIVENESS OF ECCS RESULTING FROM FUEL-CLAD BULGING OR PERFORATION IN LOSS-OF-COOLANT ACCIDENTS. ANALYTICAL AND EXPERIMENTAL PROGRAMS TO RESOLVE THE CONCERN ARE DESCRIBEO. FAILURE TEMPERATURES, WITH SINGLE RDD TESTS HAVING GAS-PLENUM PRESSURES FROM 130 TO 1500 PSIG, WERE 1348 TO $1732 \mathrm{~F}$. NIN-ROD-BUNDLE TESTS SHOWED THAT GROSS FLOW BLOCKAGE DJES NOT OCCUR AS A RESULT OF MULTI-ROO 
$5-25904$ *CONTINUED*

PERFORATIONS. FULL-SIZE HEATER-BUNOLE TESTS WILL BE PERFORMED. ANALYSIS TO BE MAOE OF WORST CONFIGURATION OF FLOW PATH AND INCLUOE RADIATION EFFECTS ON CHANNEL WALLS. PROGRESS TO BE COMPLETED IN 1969.

AVAILABILITY - USAEC, PUBLIC DOCUMENT ROOM

\#ACCIDENT, LOSS OF COOLANT + \#SYSTEM OPERABILITY IN ACCIDENT + ACRS + AEC QUESTION + BROWNS FERRY (BWR) + CORE SPRAY + EMERGENCY COOLING CONSIDERATIONS + FAILURE, CLADDING + FLOW BLOCKAGE + PERFORYANCE LIMIT + REACTOR, BWR + SYSTEM CAPABILITY + TEST, PROOF

5-25905 ALSO IN CATEGORY 18

EFFECTS ON FUEL BUNDLE FLOW BLOCKAGE

ATOMIC POWER EQUIPMENT DEPARTMENT, GENERAL ELECTRIC COMPANY, SAN JOSE, CALIFORNIA

APED-5608 +. 4 PAGES, 1 TABLE, PAGES 3-1 THROUGH 3-3 OF THE GENERAL ELECTRIC COMPANY ANALYTICAL AND

EXPERIMENTAL PROGRAMS FOR RESOLUTION OF ACRS SAFETY CONCERNS, APRIL, 1968

ACRS REVIEW OF BROWNS FERRY VOICED CONCERN ABOUT FISSION-PRODUCT RELEASE, HIGH PRESSURE, AND SEQUENTIAL FUEL-ELEMENT FAILURE RESULTING FROM INLET-COOLANT-JRIF ICE BLOCKAGE. PRQGRAM TO RESOLVE CONCERN EARLY IN 1969 IS DESCRIBED. THE TWO ASPECTS TO BE INVESTIGATED ARE (I) BOILOUT AND HEATUP FOLLOWING PARTIAL OR COMPLETE FLOW BLOCKAGE AND (2) WATER EXPULSIJN AND PRESSURE-RISE EFFECTS DUE TO OVERHEATING AND REENTRY OF WATER TO THE DVERHEATED PORTION.

AVAilability - USAEC, PUBLIC DOCUMENT ROOM

* ACC IDENT, CONSEQUENCES + \#FLOW BLOCKAGE + ACCIDENT, LOSS OF FLOH + ACRS + AEC QUESTION + BROWNS FERRY (BWR) + FAILURE, FUEL ELEMENT + FAILURE, SEQUENTIAL + FLOW ORIFICE +

FLOW THEORY AND EXPERIMENTS + R AND D PROGRAM + REACTOR, BWR

5-25906 ALSO IN CATEGORY 18

VERIFICATION OF FUEL DAMAGE LIMIT CRITERION

ATOMIC POWER EQUIPMENT DEPARTMENT, GENERAL ELECTRIC COMPANY, SAN JOSE, CALIFORNIA

APED-5608 +. 6 PAGES, 3 TABLES, PAGES 4-1 THROUGH 4-6 OF THE GENERAL ELECTRIC COMPANY ANALYTICAL AND

EXPERIMENTAL PROGRAMS FOR RESOLUTION OF ACRS SAFETY CONCERNS, APRIL, 1968

ACRS RECOMMENDS THAT TESTS INCLUDE HEAT-GENERATION RATES IN EXCESS OF THOSE CALCULATED FOK WORST TRANSIENT AND FUEL BURNUPS. GE STATES LIMIT OF 28 HW/FT ICORRESPONDING TO 19 PLASTIC STRAIN) IS ADEQUATELY SUPPORTED BY 6 TO 7 YEARS OF DEVELOPMENT PROGRAMS AND EXPER IENCE. SEVEN HEAVILY (1400 PPM) HYDRIDED ZIRCALOY-CLAD RODS OPERATING HITH CENTERLINE MELTING WERE TESTED IN GETR AT HEAT-GENERATION RATES UP TO $22 \mathrm{KW/FT,} \mathrm{WITH} \mathrm{CLAO} \mathrm{STRAINS} \mathrm{UP} \mathrm{TO} 0.6 \%$ NO DETRIMENTAL EFFECTS. TABLES SUMMARIZE PROOUCT-FUEL AND DEVELOPMENT-FUEL IRRADIATION

EXPERIENCE, LISTING EXPOSURE, HEAT FLUX, PEAK GENERATION RATE, AND TIME IN CORF.

AVAILABILITY - USAEC, PUBLIC DOCUMENT ROOM

\#CENTERLINE MELTING + \#FUEL BURNUP + \#OPERATING EXPERIENCE SUMMARY + \#PERFORMANCE LIMIT + ACRS + AEC QUESTION + BROWNS FERRY (BWR) + FAILURE, CLADDING + FUEL ELEMENT + FUEL INTEGRITY + HYORIDE + IRRADIATION TESTING + REACTOR, BWR + ZIRCALOY

5-25907 ALSO IN CATEGQRY 18

EFFECTS OF CLADOING TEMPERATURE AND MATERIALS ON ECCS PERFORMANCE

ATOMIC POWER EQUIPMENT DEPARTMENT, GENERAL ELECTRIC COMPANY, SAN JOSE, CALIFORNIA

APED-5608 t. 4 PAGES, PAGES 5-1 THROUGH 5-4 OF THE GENERAL ELECTRIC COMPANY ANALYTICAL AND EXPERIMENTAL PROGRAMS FOR RESOLUTION OF ACRS SAFETY CONCERNS, APRIL, 1968

ACRS RECOMMENDS TESTING ECCS EFFECTIVENESS AT FUEL TEMPERATURES HIGHER THAN THOSE USED TO

DATE. TESTS HAVE BEEN MADE WITH PEAK TEMPERATURES OF $2400 \mathrm{~F}$. GE RESPONDS THAT TESTS WILL BE

EXTENDED AFTER DLVLLOPING A ZIRCALOY-CLAD ELECTRICAL HEATER AND SUITABLE INSTRUMENTATION FOR

USE AT TEMPERATURE IN EXCESS OF $2500 \mathrm{~F}$. TEST PROGRAM IS DESCRIBED.

AVAILABILITY - USAEC, PUBLIC DOCUMENT ROOM

*CLADDING + *CORE REFLOODING SYSTEM + \#CORE SPRAY + \#HIGH TEMPERATURE + *SYSTEM OPERABILITY IN ACCIDENT + *TEST, PROOF + ACCIDENT, LOSS OF COOLANT + ACRS + AEC QUESTION + BROWNS FERRY (BWR) + EMERGENCY COOLING CONSIDERATIONS + FUEL ELEMENT + INSTRUMENTATION, TEMPERATURE + REACTOR, BWR + STEEL, STAINLESS + ZIRCALOY

5-25910 ALSO IN CATEGORIES 18 AND 11

REEVALUATION OF STEAM LINE BREAK ACCIDENT

ATOMIC POWER EQUIPMENT DEPARTMENT, GENERAL ELECTRIC COMPANY, SAN JOSE, .CAL I FORNIA

APED-5608 +. 2 PAGES, PAGES 8-1 THROUGH 8-2 OF THE GENERAL EL.ECTRIC COMPANY ANALYTICAL AND EXPERIMENTAL PROGRAMS FOR RESOLUTION OF ACRS SAFETY CONCERNS, APRIL, 1968

ACRS RECOMMENDS IN JUNE 15, 1967, VERMONT YANKEE REVIEW FURTHER EVALUATION OF FUEL CLAD. TEMPERATURES FOLLOWING A STEAM-LINE BREAK. GE WILL DEVELOP AN IMPROVED ANALYTICAL MODEL, AND ANALYSIS WILL BE COMPLETED IN FALL OF 1968, BASED ON STEAM-LINE-ISOLATION-VALVE CLOSURE IN 3-10 SEC. 
CATEGORY 5
ACCIDENT ANALYSIS

5-25؟10 *CONTINUED*

AVAILABILITY - USAEC, PUBLIC DOCUMENT ROOM

* ACCIOENT ANALYSIS + *ACCIDENT, STEAM LINE RUPTURE + ACCIDENT MODEL + ACCIDENT, CONSEQUENCES + ACRS + AEC QUESTION + BROWNS FERRY (BWR) + CONTAINMENT ISOLATION + REACTOR, BHR + RESPOVSE TIYE

$5-25935$

ALSO IN CATEGORIES 17 AND 1

MACPHERSON RE

FAST REACTOR SAFETY CONFERENCE

OAK RIDGE NATIONAL LABORATORY, OAK RIDGE, TENNESSEE

8 PAGES, TABLE, REFERENCE, NUCLEAR SAFETY, 9(3), PAGES 202-209 (MAY-JUNE, 1968 )

BRIEFLY SUMMARIZES THE SESSIONS COVERING $(1)$ CORE MELTDOWN ACCIDENTS, (2) SDDIUM BOILING LND SUPERHEATING, (3) INCIDENTS IN REACTORS, AND (4) SAFETY. MALFUNCTIONS IN THE BRS WERE (I) FUEL-ELEMENT LEAKS CAUSED BY HEATER SHORTING, PLUS AID IN. LEAKAGE CAUSING MASSIVE SODIUM OXIDE PLUGGING, ANE (2) REACTIVITY PERTURBATIONS DUE TO ENTRAINMENT OF ARGON GY THE SDOIUM STREAM. \#LUGGING OF SUBASSEMBLIES BY OXIDS HAS BEEN DETECTED PRIMAPILY BY THE. EFFECT ON PRIMARY FLOW. A PANEL DISCUSSION SHOWED THAT ATTENTION IS SWITCHING FPTM THE LARGE. LESS PROBABLE ACCIDENT TO THE SMALLER, MORE FREQUENT ACCIDENTS WHICH AFFECT DLANT USE.

*REACTOR, FAST + \#SAFETY PRINCIPLES ANO PHILOSOPHY + ACCIDENT ANALYSIS + $\triangle C C I D E N T$, MAXIMUM CREDIBLE (MCA) + COOLANT QUALITY + FLOW BLOCKAGE + INCIOENT, GENERAL + REACTOR, LMCR + REVIFW

5-25944 ALSO IN CATEGORIES 6 AND 7

MORRISON DL + CARBIENER WA + RITZMAN RL + BLUTREICH JN + CLARK WE +. DENNING RS + GIESEKE JA + WOOTON RO AN EVALUATION OF THE APPLICABILITY OF EXISTING DATA TO THE ANALYTICAL DESCRIDTION OF A NUCLEAD-REACTOR

ACCIDENT, QUARTERLY PROGRESS REPORT FOR JANUARY THROUGH MARCH, 1969

BATTELLE MEMORIAL INSTITUTE, COLUMBUS, OHIO

BMI-1835+. 30 PAGES, 4 FIGURES, 8 TABLES, 30 REFERENCES, ADRIL 1, 1963

PROGRESS REPORT ON THE FOLLOWING AREAS - ECCSA COMPUTER CODE DEVELOPMENT, CALCULATIONS DS ACCIDENT HEAT TRANSFER, EVALUATION OF REACTOR KINETICS PROBLEMS, REACTIVITY-ACCIUENI INITIATION OF A LOSS-OF-COOL ANT ACCIDENT, FISSION PRODUCT RELEASE FROM UOZ, AFROSOL-PARTICLF CHARGING, PARTICLE COLLECTION IN PRESSURE-SUSPENSION PDOLS, FISSION-PRODUCT TRANSPJRT AND DEPOSITION MODELS, AND CONDITIONS ANO CRITERIA FOR DAINT DERFORMANCE IN REACTOR CONTAINMENT.

AVAILABILITY - CLEARINGHOUSE FOR FEDERAL SCIENTIFIC AND TECHNICAL INFORMATION, SPRINGFIELD, VIRGINIA $22151, \$ 3.00$ COPY, \$0.65 MICROFICHE

\#ACCIDENT ANALYSIS + \#ACCIDENT, LOSS OF COOLANT + \#FISSION PRODUCT TRANSPORT + \#REACTOR KINETICS + ACCIDENT, REACTIVITY + AEROSOL + COMPUTER PROGRAM + CONTAINMENT PAINT + FISSION PPOOUCT RELEASE, GENERAL + FISSIDN PRODUCT RETENTION + HEAT TRANSFER + SPACE DEPENDENT DYNAMICS

$5-26113$

LAWRENCE WT + CHATO JC

HEAT-TRANSFER EFFECTS ON THE DEVELOPING LAMINAR FLOW INSIDE VERTICAL TUBES

UNIVERSITY OF ILLINOIS, IIRBANA, ILLINOIS

9 PAGES, 10 FIGURES, 20 REFERENCES, JOURNAL OF HEAT TRANSFER, TRANSACTIONS UH ASME, SERIES C, 8812 I, PAGES

214-222 IJUNE 14,19601

A NUMERICAL METHOD WAS DEVELOPEO FOR THE CALCULATION OF ENTRANCE FLOWS IN VERTICAL" TURES EOR THE CASES OF UPFLOW OR DOWNFLOW AND CONSTANT WALL HEAT FLUX OR IONSTANT WALL TEMPERATURE. THE SOLUTIONS WERE IN EXCELLENT AGREEMENT WITH EXPERIMENTAL DATA OBTAINED WITH WATER FLCWING UPWARD IN A VERTICAL HEATED TUBE. THE TRANSITION TO TURBULENT FLOW WAS ALSO STUOIED. THE CXTCRIMEMTAL MEASUP.EMENTS RFMNNSTRATFN THAT THE TRANSITION PROCESS DEPENDS ON THE DEVELOPING VELOCITY PROFILES. FOR THE EXPERIMENTAL RESULTS, A TENTATIVE TRANSITION CRITERIUN HAS DBTAINED, WHICH DEPENDS ONLY ON THE VELOCITY PROF ILE SHAPE, FLUID VISCOSITY, AND THE ENTRANCE REYNOLDS NUMBER.

*FLOW THEORY AND EXPERIMENTS + \#FLOW, TUBE + *HEAT TRANSFER, CONVECTION + FLOW, LAMINAR + FLJW, TURBULENT + HEAT TRANSFER

$5-26114$

MELESE-D HOSPITAL G

THERMAL PERFÓRMANCE OF CERAMIC-CLAU GAS-CÜOĹRO REACTOR CORES

GENERAL DYNAMICS, GENERAL ATOMIC OIVISION

12 PAGES, 6 FIGURES, 6 REFERENCES, NUCLEAR ENGINEERING AND DESIGN, 7(4), PAGES 323-333 (APRIL, 1968 )

SIMPLE RELATIONSHIPS BETWEEN OIMENSIONLESS CORE PARAMETER SAVE BEEN DERIVED FOR THE CASE WHERE THE MAXIMUM INTERNAL FUEL TEMPERATURE IS FIXED. THE LINEAR RATING IS FOUND TD BE NEARLY PROPORTIONAL TO THE DIFFERENCE BETWEEN MAXIMUM FUEL AND COOLANT TEMPERATURES IT.-SUB-M MINUS T-SUB-EI ANO TO THE EFFECTIVE FUEL CONOUCTIVITY. NUMERICAL RESIILTS FOR A TYPICAL HIGH TEMPERATURE GAS COOLED REACTOR DESIGN SHOW THE LACK OF SENSITIVITY OF THERMAL POWER TO CHANNEL DIMENSIONS AND THE RAPID VARIATIONS OF PUMPING POWER WITH CHANNEL GEOMETRY.

\#CLADOING + \#HEAT TRANSFER ANALYSIS + \#REACTOR, GCR + \#REACTOR, HTGR + \#THERMAL ANALYSIS + CERAMICS + HEAT TRANSFER + HEAT TRANSFER CORRELATI ON + REACTOR, PEBBLE BEO 
$5-25115$

BEDENIG D + RAUSCH W + SCHMIDT

PARAMETER STUDIES CONCERIING THE FLOW BEHAVIOUR OF A PEBSLE WITH REFERENCE TO THE FUEL ELEMENT MOVEMENT IN THE CORE OF THE THTR 300 MWE PROTOTYPE REACTOP.

BROWN BOVERI/KRUPP REAKTORBAU GMBH., JULICH, GERMANY

12 PAGES, 14 FIGURES, 8 REFERENCES, NUCLEAR ENGINEERING ANO DESIGN, 7(4), PAGES 367-378 (APRIL, 1068)

THE KNOWLEDGE OF THE PEBBLE-BED FLOW BEHAVIOUR IS OF GREAT IMPORTANCE FOR GAS-COOLED HIGH TEMPERATURE REACTORS DF THE PEBBLE BED TYPE. COMPREHENSIVE EXPERIMENTAL INVESTIGATIONS WERE CARRIED OUT IN THIS RESPECT. AFTER A SHORT DESCRIPTION OF THE METHODS OF MEASUREMENT THE RESULTS OF PARAMETER STUDIES WITH REFERENCE TO THE FLOW BEHAVIOUR OF A PEBBLE BEO ARE DISCUSSED. VARIOUS PARAMETERS OF GEOMETRY ARE INVESTIGATED AS WELL AS THE INFLUENCE OF FRICTION, OF SPECIFIC BALL WEIGHT AND OF RELATIVE BALL DIAMETFR AS FUNCTIONS OF PEBBLE BED HEIGHT. RESULTS ARE PLOTTED IN FORM OF RESIDENCE SPECTRA. FROM THESE RESULTS THE FLOW BEHAVIDUR OF THE THTR 300-MWE PROTOTYPE REACTDR IS PREDICTED BY INTERPOLATION.

\#REACTOR, CIRCULATING FUEL + \#REACTOR, HTGR + \#REACTOR, PEBBLE BED + FLOW THEORY AND EXPERIMENTS

$5-26116$

NEBRENSKY J

MECHANISM OF HEAT TRANSFER TO A MECHANICALLY MIXED BED OF GRANULAR MATERIAL

CESKOSLOVENSKA AKADEMIE VED

12 PAGES, 5 FIGURES, 3 TABLES, 20 REFERENCES, COLL. CZECH. CHEM. COMMS, 31(10), PAGES 3960-3971 IOCTOBER, $1966)$

IN THE PROPOSED MECHANISM OF HEAT TRANSFER FROM A CYLINDRICAL WALL TO A MECHANICALLY MIXED RED IT IS ASSUMED THAT THE STEADY-STATE PROCESS CAN BE CONCEIVED AS ONE CONSISTING DF REPEATING EQUAL CYCLES DURING WHICH THE MATERIAL IN THE PROXIMITY OF THE WALL IS HEATED UNDER UNSTEADY CONDITIONS OF HEAT TRANSFER. ON THE BASIS OF THIS CONCEPTIDN, THE THEORETICAL EQUATION WAS DERIVEO FOR THE CALCULATION OF THE HEAT TRANSFER COEFFICIENT, AND THE SIMPLIFIED FORM JF THIS EQUATION WAS COMPARED WITH THE PREVIOUSLY PUBLISHED EXPERIMENTAL RESULTS. THIS COMPARISON IS YET THE ONLY POSSIBILITY OF EVALUATING QUANTITATIVELY THE RADIAL EFFECTIVENESS OF MIXING OF GRANULAR MATERIALS.

* HeAT transfer anALYSIS + \#HIGH TEMPERATURE + hEAT TRANSFER + HEAT TRANSFER, CONDUCTION +

HEAT TRANSFER, CONVECTION

$5-26118$

KUMAR R

HEAT TRANSFER IN STEADY RORATORY FLOW OF BINGHAM MATERIAL BETWEEN TWO CO-AXIAL CYLINOERS

INDIAN INSTITUTE OF TECHNOLOGY

13 PAGES, FIGURE, 9 REFERENCES, JOURNAL OF THE FRANKLIN INSTITUTE, $281(2)$, PAGES $136-142$ (FEBRUARY, 1966 )

ANALYZES HEAT TRANSFER IN STEAOY ROTATORY FLOW OF BINGHAM MATERIAL BETWEEN TWO COAXIAL

CYLINDERS SUCH THAT THE INNER CYLINDER IS AT REST WHILE THE OUTER CYLINDER IS ROTATING WITH A CONSTANT ANGULAR VELOCITY. THE HEAT ENERGY EQUATION ADMITS AN EXACT SOLUTION AND THE

TEMPERATURE DISTRIBUTIONS ARE FOUND TO DEPEND ON THE RATIO OF THE RADII OF TWO CYLINDERS, THE

POSITION OF YIELD SURFACE AND THE BRINKMAN NUMBFR. THE EFFECT OF DISSIPATIQN IS TR INT.RFASF

TII TCMFERATURE AT A PLALE. A LKIIILAL VALUE OF THE BRINKMAN NUMBER, ABOVE OR BELOW WHICH

THE HEATING MQR CDOLING OF THE INNER CYLINDER TAKES PLACE, IS FOUND.

*FLOW THEORY AND EXPERIMENTS + \#FLOW, ANNULAR + \#FLOW, LAMINAR + \#FLOW, NONNEWTONIAN + \#HEAT TRANSFER +

HEAT TRANSFER ANALYSIS + HEAT TRANSFER, CONDUCTION + HEAT TRANSFER, CONVECTION

$5-26185$

DELCHAMBRE PP + MILLOT JP

STUDY OF FLOW INSTABILITIES AND OF THEIR CONSEQUENCES ON THE SAFETY OF WATER REACTORS

COMMISSARIAT A L ENERGIE ATOMIQUE, FRANCE

16 PAGES 10 FIGURES, 8ULL. INFORM. SCI. TECH., NO. 112, PAGES 71-86 (FEBRUARY 1.967) IN FRENCH

THE POWER THRESHOLD FOR NUCLEATE BOILING AND FLOW INSTABILITY WAS MEASURED IN OUT-DF-PILE EXPERIMENTS PERFORMED. IN GRENOBLE AS A FUNCTION OF THE FLOW RATE (WITH A GIVEN WATER CHANNEL). THE TESTS PERFORMED ON CABRI, TAKING INTO ACCOUNT THE COUPLING BETWEEN VOID AND POWER, SHED LIGHT ON THE CONSEQUENCES OF THESE PHENOMENA FOR THE WHOLE CORE. WE HAVE MEASURED FOR A GIVEN CORE AND UP TO THE INSTABILITY THRESHOLD, THE POWER VARIATION AS A FUNCTION OF THE REACTIVIIY INSERTION NECESSARY TO OBTAIN A GIVEN LEVEL, FROM CRITICAL POINT AT ZERO POWER. IN CASE OF INSTABILITY, WE HAVE INVESTIGATED SOME INSTANCES OF THE BEHAVIOUR of POWER AND OF FUEL PLATES TEMPERATURES AFTER THE BEgINNING OF THE PHENOMENA.

\#BUBBLE NUCLEATION + \#FRANCE + \#NUCLEATE BOILING + \#OUT OF PILE LOOPS AND FXPERIMENTS + BUBBLE + FLOW, GENERAL

$5-26186$

BIASIL + CLERCI GC + GARRIBBA S + SALAR + TOZZIA 
CATEGORY 5

ACCIDENT ANALYSIS

5-26186 \#CONTINUED*

STUDIES ON BURNOUT, PART 3 - A NEW CORRELATION FOR ROUND DUCTS AND UNIFORM HEATING AND ITS COMPARISON WITH WORLD DATA

COMITATO NAZIONALE PER LE RICERCHE NUCLEARI, ITALY

5 PAGES, 13 FIGURES, 5 TABLES, 11 REFERENCES, ENERGIA NUCLEARE, 14(9), PAGES 530-536 (SEPTEMBER 1967 )

A NEW BURNOUT CORRELATION HAVING A LARGE RANGE OF VALIDITY AND APPLICABLE TO CIRCULAR DUCTS WITH UNIFORM HEAT FLUX DISTRIBUTION IS OESCRIBED. THE PREDICTED VALUES ARE COMPARED WITH NEARLY ALL THE BURNOUT DATA WITH NEGATIVE INLET QUALITY PRESENTLY AVAILABLE. THE RESULTING MEAN OUADRATIC ERROR OF OVER 455I EXPERIMENTAL DATA IS $7.26 \%$ AND 85.5\% OF THE EXAMINED DATA HAS AN ABSOLUTE ERROR LESS THAN 10\%. A STUOY UF THE ERROR DEPENDENCE ON THE VARIOUS PARAMETERS IS ALSO PRESENTED.

* HEAT FLUX, CRITICAL + *HEAT TRANSFER ANALYSIS + \#HEAT TRANSFER CORRELATION + HEAT TRANSFER + HEAT TRANSFER, CONVECTION

5-26187

FALLON TA

GAS SIDE HEAT TRANSFER - MEASUREMENT AND PREDICTION

BABCOX AND WILCOX COMPANY

4 PAGES, 5 FIGURES, 11 REFERENCES, CHEMICAL AND PROCESS ENGINEERING, 48(9) PAGES 147-150 (AUGUST 1967)

DESIGNERS ARE ABLE TO PRODUCE TECHNICALLY SOUNO, ECONOMICALLY JUSTIFIED HEAT-TRANSFER

EUUIPMENT, GIVEN DATA FROM THE MEASUP.EMENT AND CORREIATION OF GAS-SIDE HEAT TRANSFER ANO

PRESSURE LOSS. THE AUTHOR INDICATED HOW THIS INFORMATION IS OBTAINED AND OESCRIBES THE RIGS AND TECHNIQUES USED IN AN INDUSTRIAL HEAT TRANSFER LAGORATORY TO INVESTIGATE THE PERFORMANCE OF PLAIN AND FINNED TUBES AS APPLIED TO GAS-COCLED REACTOR BOILER DESIGN.

\#HEAT TRANSFER + \#HEAT TRANSFER ANALYSIS + \#REACTOR, GCR + FLOW, AXIAL + FLOW, CROSS +

. FUEl ELEMENT CLUSTER + HEAT TRANSFER, CONVECTION

5-26188

GRANT. ID

PROGRESS IN HEAT TRANSFER - REVIEW OF 1966 LITERATURE

BABCOX AND WILCOX COMPANY

11 PAGES, 302 REFERENCES, CHEM. PROCESS ENG. 48(8), PAGES 125-135 (AUGUST 1967)

OVER 300 REFERENCES ON HEAT TRANSFER ARE REVIEWEO IN THIS ARTICLE, SELECTED FRTM THE $195 S$ LITERATURE WITH THE NEEDS OF THE CHEMICAL ENGINEER IN MIND. SOME IOEA OF THE SIZE JF THIS FIELD IS GIVEN BY THE 7,000 RFFERENCES ON HEAT TRANSFER WHICH HAVE GONE TO MAKE UP THE 1966 NEL HEAT SIBLIOGRAPHY. THE REVIEW IS DIVIOED INTO SECTIONS ON CONOISCTION, RADIATION, CONVECTIMN, PHANGE OF PHASE, HEAT-EXCHANGER OYNAMICS, UNSTEAOY HEAT TRANSFER, AND HEAT EXCHANGERS.

\#HEAT TRANSFER + \#REVIEW + *SOURCE MATERIAL + BIBLIOGRAPHY + HAZARDS ANALYSIS + HEAT TRANSFED ANALYSIS

$5-26189$

HOLY ZJ

TEMPERATURE AND THERMOELASTIC STRESS FIELDS IN A HEAT PRDDUCING SPHERE DUE TO AXISYMMETRIC SURFACF HEAT TRANSFER

UNIVERSITY OF NEW SOUTH WALES, AUSTRALIA

13 PAGES, 8 FIGURES, 9 REFERENCES, NUCLEAR ENGINEER.ING AND DESIGN, 4(5) PAGES 435-445 12766$)$

AN ITERATIVE PERTURBATION-SERIES METHOD IS REVELOPED FOR SOLUTION OC TEMDEPATUPE AND STRESS FIELOS DUE TO AXISYMMETITIC HEAT TCANSFER TOMFFFITIFNT VARIATION OVER THE SURFACE OF A HEAT PRODUCING SPHERE. THE METHOD IS APPLIEO TO A NUMEER DF HEAT TRANSFER DISTRIBUTIONS UF PRACTICAL INTEREST AND RESULTS ARE PLOTTED. CONCLUSIONS ARE DRAWN REGARDINJ THE EFFECT OFF VARIOUS DISTRIBUTIONS AND THEIR AMPLITHDE VARIATIONS ON THE TEMPERATURES AND STRESSES.

*HEAT tRANSfER ANALySIS + \#REACTOR, PEBBLE SED + \#SPHERE + \#STRESS aNALYSIS + HEAT TRANSFER + HEAT TRANSFER, CONVECTION + HEAT TRANSFER, GAS + TEMDERATIJRE GRADIENT

$5-26260$

ULYBTN SA

COOLANTS FOR NUCLEAR POWER ENGINEER ING INSTALLATIJNS (TRANSLATION FROM RUSSIAN)

JPRS $-38717+.5$ PAGES, 1966

LONSIOERS THE OPCRATIONAL CHARACTEPISTICS DF CMOLANTS IN DOWER REACTORS. THE OATA ON DIFFERENT PROPERTIES OF COOLANTS HAVE BEEN SYSTEMATIZFD. THE EFECCTS OF RADIATION ON THE PROPERTIES OF COOLANTS AND CORRDSION DF STRUCTURAL MATERIALS HAVE BEEN DESCPIBED. APPROXIMATE METHODS FOR THE CALCULATION OF THE RADIOACTIVITY OF CODLANTS APE CITED. THERMOPHYSICAL, CORROSIVE, ANO OTHER PROPERTIES OF WATEP, OHSANIC, LIOUID-METAL, ANO GAS COOLANTS WHICH ARE USED IN NUCLEAR POWER ENGINEERING ARE DESCRIBED IN DETAIL. THE CHARACTERISTICS OF CONSTRUCTION AND ODERATION OF REACTORS AS DETERMINED BY THE USE OF DIFFERENT COOLANTS ARE DISCUSSED. THIS BOOK IS EOR STUDENTS TF INSTITUTES SPFCIALIZING INN DESIGN AND OPERATION OF POWER REACTORS. IT MAY ALSO BE USEFUL FOR CNGINEERING AND TECHNICAL PERSONNEL. 
CATEGORY 5

ACCIDENT ANALYSIS

$5-26260$ \#CONTINUED*

AVAILABILITY - CLEARINGHOUSE FOR FEDERAL SCIENTIFIC AND TECHNICAL INFORMATION, SPRINGFIELD, VIRGINIA $22151, \$ 3.00$ COPY, \$0.65 MICROFICHE.

\#COOLANT QUALITY + \#HEAT TRANSFER + \#REACTOR COOLANT + COOLANT CHEMISTRY + FLOW THETRY AND EXPERIMENTS

$5-26283$

BLANCH+LIONS N+MILLOT JP

THE CABRI SODIUM LOOP

CENTRE D ETUDES NUCLEAIRES DE CADARACHE, FRANCE

28 PAGES, 10 FIGURES, 2 REFERENCES, FROM THE INTERNATIONAL CONFFRENCE ON THE SAFETY OF FAST NUCLEAR

REACTORS, SEPTEMBER 1967

THE USE OF A WATER REACTOR FOR THE IRRADIATION OF FAST REACTOR PINS OFFERS MANY AOVANTAGES BY PROVIDING A LARGE FLEXIBILITY IN THE EXPERIMENTS AS WELL AS A HIGH POWER JENSITY CAPABILITY DESPITE THE PRECAUTIONARY MEASURES SET BY SAFETY CONSIDERATIONS. THE BASIC KNOWLEOGE OF SODIUN BOILING AND THE BEHAVIOR DURING THE MELTDOWN OF A FAST REACTOR FUEL PIN IS VERY LIMITEO. FOR THIS REASON WE CONSIDERED THE CONSTRUCTION OF A LOOP LOCATED IN THE CENTER OF THE CABRI REACTOR CORE TO STUDY THESE TWO PROBLEMS. DURING A LOSS OF COOLING ACCIOENT IT WILL PERMIT THE MEASUREMENT OF TEMPERATURE, FLOW AND PRESSURE HISTORIES OF THE SODIUM AS WELL AS CLADDING AND FUEL TEMPERATURES. IN ADDITION, IT WILL PROVIDE USEFUL INFORMATION ON THE RELEASE OF FISSION PRODUCTS INTO SODIUM.

AVAILABILITY - H. BLANC, J.P.MILLOT, C.E.N. CADARACHE, FRANCE

\# ACCIDENT, LOSS OF COOLANT + \#IN PILE LOOP + \#SODIUM + FRANCE + IN PILE EXPERIMENT + OUT OF PILE LOOPS AND EXPERIMENTS + REACTOR, FAST

$5-26284$

GRASS G + KOTTOWSKI H + SPILLER KH

MEASUREMENTS OF THE SUPERHEATING AND STUDIES ABOUT BOILING PHENOMENA IN LIQUID METALS EUROPEAN ATOMIC ENERGY COMMUNITY, ISPRA, ITALY

25 PAGES, 13 FIGURES, 10 REFERENCES, FROM THE INTERNATIONAL CONFERENCE ON THE SAFETY OF FAST NUCLEAR REACTORS, SEPTEMBER 1967

BOILING OF POTASSIUM AND SODIUM HAS BEEN STUDIED IN STAGNANT CONDITIONS AND IN THE CASES OF NATURAL AND FORCED CONVECTION. THE MAXIMUM SUPERHEATIVG TEMPERATURE OF THE LIOUID METAL WAS MEASURED BEFORE BOILING. THE MEASURED SUPERHEATING VARIED FROM ABOUT 20 TO 820 C DEPENDING OF THE USED LIQUID METAL AND THE TEST CONOITIONS. VAPORISATION WAS GENERALLY FOLLOWEO BY EXPULSION OF LIQUID METAL COLUMNS DUE TO THE GENERATED VAPOUR. THE EXPANSION OF THE FORMED VAPOUR VOLUMINA WAS MEASURED. IMPORTANT PARAMETERS FOR THE EJECTION TIME WERE THE INITIAL VAPOUR PRESSURE (CORRESPONDING TO THE INITIAL SUPERHEATING AT THE MOMENT OF INCIPIENT BOILINGI AND THE PRESSURE EVOLUTION WHILE EJECTION. A MODEL DESCRIBING THE PHENOMENON IS GIVEN.

AVAILABILITY - K.H. SPILLER, ISPRA, D.B. NO. 1, IVARESE) ITALY

* POOL BOILING + *POTASSIUM + \#SODIUM + CONVECTIVE BOILING + EURATOM + HEAT TRANSFER, BOILING +

HEAT TRANSFER, BOILING + HEAT TRANSFER, CONVECTION + HEAT TRANSFER, NATURAL CONVECTION + REAETOR, FAST

$5-26285$

PINCHERA GC + TOMASSETTI G + GAMBARDELLA G + FARRELLO GE

EXPER IMENTAL BOILING STUDIES RELATED TO FAST REACTOR SAFETY

COMITATO NAZIONALE PER L ENERGIA NUCLEARE, ITALY

35 PAGES, 16 FIGURES, 23 REFERENCES, FROM THE INTERNATIONAL CONFERENCE ON THE SAFETY OF FAST NUCLEAR REACTORS, SEPTEMBER 1967

THE RESEARCH PROGRAM ENA IS AIMEO TO STUDY, EXPERIMENTALLY AND THEORETICALLY, THE BEHAVIOUR OF SODIUM DURING REACTOR ACCIDENTS THAT LEAD TO THE COOLANT BOILING IN A SIMULATED CLUSTER DF ROOS. REQUIRED HYDRODYNAMIC SIMULATION ANO FLOW DIAGRAMS FOR EXPERIMENTAL SODIUM LOOPS ARE DISCUSSED. THE DEVELOPMENT OF AN INSTRUMENTED SIMULATED FUEL ROD IS DESCRIBED. DURING THE BOILING OF SODIUM ON THE SURFACE OF A VERTICAL CYLINDRICAL HEATER, STEADY-STATE BOILING CURVES ANO POWER TRANSIENT LIQUIO SUPERHEATS HAVE BEEN MEASURED AS A FUNCTION OF SYSTEM PRESSURE, SURFACE FINISH AND HISTORY. TRANSIENT TESTS GIVE VERY DIFFERENT SUPERHEAT VALUES, GENERALLY UP TO 10 C WALL SUPERHEAT FOR ROUGH SURFACES AND UP TO 60 C LIDUIT SUPSR.HEAT FOR. AS-RECEIVEO SURFACES. INIIIAL TRANSIENT BOILING STUDIES IN A WATER ANALOG FORCED CONVECTION LOOP ARE DESCRIBED.

AVAILABILITY - G.C.PINCHERA + G. TOMASSETTI, CNEN, CSN, CASACEIA, S. MARIA DI GALERIA, ROME, ITALY

*REACTOR, FAST + \#SAFETY ANALYSIS + \#SODIUM + CONVECTIVE BOILING + FUEL ELEMENT CLUSTER +

HEAT TRANSFER, BOILING + HYDRODYNAMIC ANALYSIS + OUT OF PILE LOOPS AND EXPERIMENTS + REACTOR TRANSICNT

$5-26286$

KOSKY PG

SOME ASPECTS OF BOILING AND VAPQUR VOIDAGE GROWTH PROBLEMS IN A LIQUID-METAL-COOLED REACTOR

UKAEA, BERKS HARWELL

24 PAGES, 14 FIGURES, 21 REFERENCES, FROM THE INTERNATIDNAL CONFERENCE ON THE SAFETY OF FAST NUCLEAR 
CATEGORY 5

ACCIDENT ANALYSIS

5-26286 \#CONTINUED*

REACTORS, SEPTEMBER 1967

PRESENTS SOME THEORETICAL STUDIES OF THE INITIATION OF BOILING OF A LIQUID METAL IN FORCED CONVECTIVE FLOW WHICH SUGGEST THAT THE BURN-OUT HEAT FLUX MAY BE EXCEEDED WHEN THE FIRST VAPOUR VOID IS FORMED. THE HYPOTHESIS IS DISCUSSED IN THE LIGHT OF PUBLISHED EXPERIMENTAL DATA. IT LEADS OIRECTLY TO AN INTEREST IN THE GROWTH RATE ANO CONFIGURATION OF VAPOUR VOIDS. PUBLISHED ASYMPTOTIC-GROWTH-RATE EQUATIONS CANNOT BE DIRECTLY APPLIED TO THIS PARTICULAR VOID-GROWTH PROBLEM BECAUSE OF THE ENHANCED RATE OF HEAT TRANSFER TO THE EVAPORATION INTERFACE DUE TO THE VERY HIGH THERMAL CONDUCTIVITY OF LIQUIO METAL. A SIMPLE MODEL IS THEREFORE PROPOSED TO TAKE ACCOUNT OF THIS EFFECT AND CALCULATIONS BASED ON THIS MEDEL ARE GIVEN FOR SODIUM UNOER VARIOUS CONDITIONS.

AVAILABILITY - P.G. KOSKY, CHEMICAL ENGINEERING AND PROCESS TECHNOLOGY DIVISION. A.E.R.E. HARWELL, ENGLAND \# BURNOUT HEAT FLUX + *CONVECTIVE BOILING + \#METAL, LIQUID + HEAT TRANSFER, BOILING + HEAT TRANSFER, CONVECTION + REACTOR, FAST + REACTOR, LMCR

$5-26287$

JUDD AM

BOILING AND CONDENSATION OF SODIUM IN RELATION TO FAST REACTOR SAFETY

ATOMIC ENERGY ESTABLISHMENT, WINFRITH

38 PAGES, 11 FIGURES, 3 TABLES, 21 REFERENCES, FROM THE INTERNATIUNAL CONFERENCE ON THE SAFETY OF FAST NUCLEAR REACTORS, SEPTEMBER 1967

THIS PAPER DEALS WITH VARIOUS ASPECTS OF SODIUM BOILING WHICH ARE OF IMPORTANCE IN $\triangle S S E S S I N G$ THE COURSE AND CONSEQUENCES OF AN OVERHEATING ACCIDENT IN A SODIUM-COOLED FAST REACTOR. BUBBLE NUCLEATION AND THE LIQUID SUPERHEAT NECESSARY TO START VAPOUR FORMATIDN $\triangle R E$ DISCUSSED, AND AN APPROXIMATE METHODD OF CALCULATING THE DYNAMICS OF SODIUM VAPOUR BUBBLES IS DESCRIBED. THIS IS USED TO PREDICT THE EFFECTS WHEN SEVERAL BUBBLES GROW SIMULTANEOUSLY, AND THE RESULTS ARE APPLIED TO THE VOIDING OF AN OVERHEATEO FAST REACTOR COOLANT CHANNEL TO FIND THE RATES OF COOLANT EXPULSION AND THE PRESSURE TRANSIENTS INVOLVED. THE CONOENSATION OF VAPOUR BUSBLES HHICH MOVE INTD REGIONS OF COOLER LIQUID IS ALSO DISCUSSEO, AND THE RAIES OF COLLAPSE AND ACCOMPANYING PRESSURE PULSES ARE CALCULATED.

AVAILABILITY - A.M. JUDD, U.K.A.E.A., ATOMIC ENERGY ESTABLISHMENT, WINFRITH, DORCHESTER, DORSET, ENGLAND * ACCIDENT ANALYSIS + \#NUCLEATE BOILING + \#REACTOR, FAST + \#SODIUM + BUBBLE + BUBBLE NUCLEATION + REACTOR DYNAMICS + REACTOR TRANSIENT

$5-26454$

ROUHANI $\$ 7$

VOID MEASUREMENTS IN THE REgIONS UR SUB-CODLED AND LOW-QUALITY BOIIING AKIE BOLAGET ATOMENERGI, STOCKHOLM (SWEDEN)

$A E-238+.18$ PAGES, FIGURES, TABLES, REFERENCES, JULY 1966

BY THE APPLICATIONS OF THE (GAMA. NEUTRON) REACTION TO BOILING HEAVY WATER, VOID VDLUME FRACTIONS HAVE BEEN MEASURED IN A VERTICAL ANNULAR CHANNEL WITH 25 MM 30 AND 12 YM.1.D. AT A HEATEO LENGTH OF $1090 \mathrm{MM}$. THE EXPERIMENTS COVERED PRESSURES FROM 10 TO 50 BARS, MASS VELOCITIES FROM 50 TO 1450 KG/M2-SEC, HEAT FLUXES FROM 30 TO 90 W/CM? SUBCOOLINGS FPOM 30 TO $0 \mathrm{C}$, AND STEAM QUALITIES FROM O TO 15. THE RESULTS INOICATE NOTICEABLE EFFECTS OF PRESSURE, HEAT FLUX AND EVEN MASS VELOCITY UPON THE VARIATIONS OF VOIO WITH SUBCUULLING AND STEAM QUALITY. A NOVEL EXPLANATION OF THE MECHANISM OF THEIR EFFECTS HAS BEEN FOUND AND PROVED BY QUALITATIVE ANALYSIS.

AVAILABILITY - AEC DEPOSITORY LIBRARIES IN THE U.S. AND OVERSEAS

\#FLOW, ANNULAR + \#FLOW, TWO PHASE + \#VOID FRACTION + FLOW OISTRIOUTION + FLOW THERRY AND EXPERIMENTS + STEAM

5-26455

RDUHANI SZ

VOID MEASUREMENTS IN THE REGIONS OF SUB-COOLED AND LOW-OUAI,ITY BOILING. PART 2

AKT IE BOLAGET ATOMENERGI, STOCKHCLM (SWEDEN)

$A E-239+.9$ PAGES, FIGURES, TABLES, REFERENCES, JULY 1966

THIS REPORT CONSISTS MOSTLY OF TABLES OF EXPERIMENTAL DATA OBTAINED IN VOID MEASUREMENTS. IT IS A CONTINUATION AND THE COMPLETING PART OF A PREVIOUS REPORT WITH THE SAME TITLE: THE DATA $\triangle R E$ FROM THE MEASUREMENTS IN A VERTICAL ANNULAR CHANNEL WITH 25 MM 0.0 . AND 12 MM I.D. AT A HEATED LENGTH OF $1090 \mathrm{MM.} \mathrm{THESE} \mathrm{EXPERIMENTS} \mathrm{COVERED} \mathrm{DRESSURES} \mathrm{FROM} 10$ TO 50 BARS, MASS VELOCITIES FROM 650 TO $1450 \mathrm{KGIMZ-SEC,} \mathrm{HEAT} \mathrm{FLUXES} \mathrm{FROM} \mathrm{GO} \mathrm{TO} 120$ W/CM2, SUIB-COOLINGS FROM 30 TO $0 \mathrm{C}$, AND STEAM QUALITIES FROM OTO 12 THE TABLES INCLUDE THE INLET TEMPERATURES AND MEASIIRED WALL SUPERTHEAT.

AVAILABILITY - AEC DEPOSITORY LIBRARIES IN THE U.S. AND OVERSEAS

*FLOW, ANNULAR + \#LLW, TWO PHASE + \#VOID FRACTION + FLOW DISTRIBUTION + FLOW THEORY AND EXPERIMFNTS + STEAM 
CATEGORY 5

ACCIDENT ANALYSIS

$5-26478$

REILLY IG + TIEN C + ADELMAN M

EXPER IMENTAL STUDY OF NATURAL CONVECTIVE HEAT TRANSFER IN A NON-NEHTONIAN FLUID

UNIVERSITY OF WINOSOR, WINDSOR, ONTARIO

3 PAGES, 5 FIGURES, 6 REFERENCES, THE CANADIAN JOURNAL OF CHEMICAL ENGINEERING, $44(2)$, PAGES $61-63$ (APRIL $1966)$

EXPERIMENTAL DATA OF NATURAL CONVECTION HEAT TRANSFER FROM A HEATED HORIZONTAL PLATE, BOTH FACING UPWARD AND DOWNWARD, TO A NON-NEWTONIAN FLUID ARE REPORTED. EMPIRICAL EXPRESSIONS ESSENTIALLY SIMILAR TO THOSE OEVELOPED FOR THE VERTICAL PLATE CASE ARE OBTAINED WHICH CORRELATE THE DATA WITH REASONABLE ACCURACY.

*FLOW, NONNEWTONIAN + \#HEAT TRANSFER CORRELATION + \#HEAT TRANSFER, NATURAL CONVECTION + HEAT TRANSFER + HEAT TRANSFER EXPERIMENT

$5-26481$

LYS LA

EINIGE PROBLEME DER THERMISCHEN BERECHUNG DES KERNES EINES DAMPFGEKUEHLTEN DRUCKROHRLEISTUNGSTREAKTORS EIDGEOSSISCHES INSTITUT FUR REAKTORSCHUNG, SWITZERLAND

11 PAGES, 14 FIGURES, 16 REFERENCES, NUCLEAR ENGINEERING AND OESIGN, 512), PAGES 123-133 (MARCH 1967$)$ IN GERMAN

THE ARTICLE DESCRIBES SOME THERMAL ANALYSIS PROBLEMS ANO THE MANNER IN WHICH THEY WERE SOLVED WITHIN THE FRAMEWORK OF A CONCEPTUAL DESIGN STUDY FOR A STEAM COOLED PRESSURE-TUSE POWER REACTOR. CORRELATIONS FOR DETERMINING THE HEAT TRANSFER IN A.FUEL CHANNEL, TOGETHER WITH THE MEASUREMENTS PERFORMED TO DETERMINE THEM, ARE DESCRIBED, FURTHERMORE, THE PROCEDURE USED FOR CALCULATING THE AVERAge MASS FLOW RATE OF THE COOLANT PER FUEL CHANNEL AND THE NUIMBER OF CHANNELS IS GIVEN.

* HEAT tRANSfER anALYSIS + \#HOT CHANNEL + \#REACTOR, BWR + FUEL ELEMENT CLUSTER + HEAT TRANSFER + HEAT TRANSFER EXPERIMENT + REACTOR, PRESSIIRE TUBE

5-26586 ALSO IN CATEGORY 18

TWISTED TAPE BOILING WATER REACTOR

ALIGENEINE ELEKTRICITAETS-GESELLSCHAFT, FRANKFURT AM MAIN, WEST GERMANY

EUR-3651 +. 109 PAGES, REFERENCES, FINAL REPORT, JULY 1965-SEPTEMBER, 1966, SOCIETE NATIONALE D ETUDE ET DE CONSTRUCTION DE MOTEURS D AVIATION, SURESNES (FRANCE), SEPTEMBER 15, 1967

AN OUT-OF-PILE EXPERIMENT WAS CONDUCTED ON A 9-ROD TWISTED-TAPE BUNDLE. NO FRETTING CORROSION WAS OBSERVED. THERMAL TESTS WERE PERFORMED, AND A ROD SURFACE TEMPERATURE RISE WAS DETECTED AT THE OUTLET BUT COULO NOT BE CORRELATED WITH THE LOCATION OF BURNOUT. DISCUSSES PARAMETRIC ANO ECONOMIC STUDIES, PLUS FABRICATION DF A PROTOTYTE TUEL BUNDLE.

AVAILABILITY - AEC DEPOSITORY LIBRARIES IN THE U.S. AND OVERSEAS

* HEAT TRANSFER AUGMENTATION + *R AND D PROGRAM + BURNOUT HEAT FLUX + CORROSION + ECONOMICS + EURATOM + FLOW THEORY AND EXPERIMENTS + FRANCE + GERMANY + HEAT TRANSFEP EXPERIMENT +

OUT OF PILE LOOPS ANO EXPERIMENTS + REACTOR, BWR

$5-26589$

BANNELLA, R

BEHAVIOR OF GARGILIANO REACTOR CORE IN SIMULATED CYCLE AT INCREASED POWER

ENTE NAZIONALE PER L ENERGIA ELETTRICA, ROME, ITALY

EURAEC-1956 + EUR-3766 +. 38 PAGES, SPECIAL REPORT NO. 4, CONTRACT 101-63-11-RDI, NOVEMBER, 1966

USING PLANT COMPUTER, POWER OF $620 \mathrm{MWT}(122.46 \%$ OF RATED POWER OF 506.3 MWT $)$ WAS STUDIEO.

RESULTS INDICATE CORE CAN OPERATE AT THAT LEVEL WITHOUT EXCEEDING THE LIMIT OF THERMAL FLUX

OR BURNOUT RATIO. HOWEVER, IMPROVEMENT IN FUEL ELEMENT REQUIRED. THE PIJRPOSE OF STUDY WAS

TO FINO THE SHAPE OF LIMITING FUEL PARAMETERS - OTHER COMPONENTS ARE DISREGARDED.

AVAILABILITY - CLEARINGHOUSE FOR FEDERAL SCIENTIFIC ANO TECHNICAL INFORMATION, SPRINGFIELD, VIRGINIA $22151, \$ 3.00$ COPY, \$0.65 MICROFICHE

\#PERFORMANCE LIMIT + \#REACTOR POWER + \#THEORETICAL INVESTIGATION + EURATOM + GARIGLIANO (BWR) + HEAT TRANSFER ANALYSIS + POWER UPRATING + REACTOR, BWR -

$5-26590 \quad A L S O$ IN CATEGORY 17

FRESHLEY MD + GOLDSMITH S

OPERATING EXPERIENCE WITH PLUTONIUM FUELS IN PRTR

BATTELLE-NORTHWEST, RI CHLAND, WASHINGTON

BNWL-SA-1204 +31 PAGES, AUGUST 25,1967

BASIC FUEL-ELEMENT DESIGN IS DESCRIBED. HIGH-POWER-DENSITY FUEL IRR AOIATIDNS WERE SATISFACTORY. IRRADIATED UO2-PUO2 FUEL SPECIMEN WERE RADIOGRAPHED 48 HR AFTER SHUTOOWV. 
CATEGORY 5

ACCIDENT ANALYSIS

\section{$5-26590$ *CONT INUED*}

HIGH CONCENTRATIONS OF FISSION PRODUCTS WERE OBSERVED ON INNER SURFACES AND CRACKS BUT DISAPPEARED WITH TIME. FURTHER STUDIES UNDERWAY. GAS-RELEASE AND PRESSURE-BUILDUP STUDIES DISCUSSED (MOSTLY A DISCUSSION OF PRESENT PROGRAM). AVAILABILITY - CLEARINGHOUSE FOR FEDERAL SCIENTIFIC ANO TECHNICAL INFORMATION, SPRINGFIELD, VIRGINIA
$22151, \$ 3.00$ COPY, \$0.65 MICROFICHE

\#FUEL BURNUP + *IRRADIATION TESTING + \#PLUTONIUM DIOXIDE + *URANIUM DIOXIDE + FUEL ELEMENT + OPERATING EXPERIENCE SUMMARY + PRTR (TR) + REACTOR, TEST

$5-26600$

SHOTKIN LM

STABILITY CONSIDERATIONS IN TWO-PHASE FLOW

BROOKHAVEN NATIONAL LABORATORY, UPTON, NEW YORK

8 PAGES, 10 FIGURES, TABLE, 18 REFERENCES, NUCLEAR SCIENCE AND ENGINEERING, $28(3)$, DAGES $317-224$ (JUNE, 19671

A SPATIAL-AVERAGED MODEL OF BOILING FLOW IN AN ELECTRICALLY HEATED VERTICAL PIDE IS USED TO INVESTIGATE AND EXPLAIN EXPERIMENTAL DATA OF VARIOUS LABORATORIES. THE AGREEMENT WITH DATA IS GODD OVER A VARIETY OF CONDITIONS RANGING IN PRESSURE FROM ATMJSPHERIC TO IOOO PSIA, AND IN HEATED LENGTH FRUM 2 TO 16 FT. TWO SLIP-RATIO RIRRELATIONS ARE COMPARED IN TESTING THE MODEL AGAINST THE STABILITY DATA. THE CORRELATION OF BANKOFF BEING LESS SUCCESSFUL AT LOH SUBCOOLING THAN THE MODIFIED BAVKOFF CORREIATION DUE TO JONES. A VALUE OF BANKOFFS K RECOMMENDED BY KHOLODOVSKI IS ALSO COMPARED FOR SPIGTS EXPERIMENT. THE CRUCIAL BOILING LENGTH, WHERE THE SYSTEM IS LEAST STABLE, IS USED TO DEMONSTRATE THE DEPENDENCE OF STABILITY ON HEATING RATE, FLOW RATE, AND DEGREE OF SUBCOOL ING.

*FLOW THEORY AND EXPERIMENTS + \#FLW, TWO PHASE + \#MATHEMATICAL STUDY + 8NL + CONVECTIVE BOILING + FLOW, TUBE + HEAT TRANSFER, BOILING

$5-26604$

LEE DH

BOILING BURNOUT - A REVIEW OF RECENT WORK

6 PAGES, 7 FIGURES, 69 REFERENCES, BRITISH CHEMICAL ENGINEERING 12191 , PAGES 1363-68 (SEPTEMBER 1967)

GENERAL REVIEW OF DEVELOPMENTS IN BOILING WATER BURNOUT OVER THE PAST THREE YEARS. DESCRIBES IN OETAIL THE TREND OF THE VARIOUS PARAMETERS AFFECTING BURNOUT, TOGETHER WITH A SUMMARY OF SOURCES DF DATA FOR TUBES, ANNULI AND ROD CLUSTERS. THEN FOLLOWS A REVIEW OF CORRELATIONS FOR PREDICTING BURNOUT IN THESE GEOMETRIES, AND AN ACCOUNT OF A NEH TECHNIQUE WHICH USES OTHER FLUIOS AT LOW PRESSURE TO SIMULATE QUANTITATIVELY SURNOUT WITH HIGH PRESSURE WATER. SELECTED REFERENCES ARE GIVEN FOR RECENT DEVELOPMENTS IN TWO-PHASE FLOW, PRESSURE DRJP, NATURAL-CIRCULATION BOILING, AND WETTING OF HOT SURFACES.

* BURNOUT HEAT.FLUX + \#CONVECTIVE BOILING + \#HEAT FLUX, DRYOUT + BIBLIOGRAPHY + HEAT FLUX, CRITICAL + HEAT TRANSFER, BOILING + HEAT TRANSFER, CONVECTION

$5-26605$

RESHOTKO E

AN ANALYSIS OF THE LAMINAR INSTABILITY PROBLEM IN GAS-COOLED NUCLEAR REACTOR PASSAGES

CASE INSTITUTE OF TECHNOLOGY, CLEVELAND, OHIO

IO PAGES, 7 FIGURES, REFERENCES, AIAA JOURNAL 5(9), PAGES 1606-15 (SEPTEMBER 1967)

NUCLEAR REACTOR PASSAGES IN LAMINAR FLOW HAVE LONG BEEN REGARDED AS UNSTABLE IN THAT REGION OF OPERATIUN WHERE THE RATE OT CHANGE DF PRFSSIIRE DROP WITH WEIGHT FLOW AT CONSTANT HEAT INPUT IS NEGATIVE. IN THE PRESENT PAPER A TIME-DEPENDENT STABILITY ANALYSIS UF THE PROOLCM AFFIRMS THAT THIS CRITERION IS VALIO FOR EXCURSIONS AT CONSTANT PRESSURE DROP AND SHOWS THAT THE INSTABILITY IS ASSOC IATED WITH THE THERMAL RESPONSE OF THE REACTOR CORE TO AN INFINITESIMAL DISTURBANCE. THE ANALYSIS ALSO ALLOWS THE CALCULATION OF A COMPLETE EXCIJRSION AT CONSTANT PRESSURE DROP FROM AN INITIALLY UNSTABLE LAMINAR EQUILIBRIUM POINT. THROUGHOUT, THE METHOD OF ANALYSIS IS SULH THAT GROWTH RATES MAY BE OBTAINED FOR ANY REACTOR WHOSE STEADY-STATE CONDITIONS ARF KNOWN WHETHER THEY BE FOR UNIFORM HEATING, COSINE HEATING, UR ANY FORM OF ZONED HEATING.

\#FLOW, LAMINAR + \#HOT CHANNEL + *REACTOR, GCR + FLOW THEORY AND EXPERIMENTS + HYDROOYNAMIG ANALXSIS + PRESSURE DROP

5-26606

GRANT ID

PROGRESS IN HEAT TRANSFER - REVIEW OF 1966 LITERATURE

BABCOCK AND WILCOX LTD.

11 PAGES, 302 REFERENCES, CHEMICAL AND PROCESS ENGINEËKING 48, PAGES 125-35 (AUGUST 1967)

DVER 300 REFERENCES ON HEAT TRANSFER ARE REVIEWED. THEY HERE SELECTED FROM THE 1966 LITERATURE, WITH THE NEEDS OF THE CHEMICAL ENGINEER IN MIND. SDME IDEA DF THE SIZE JF THIS FIELD IS GIVEN BY THE 7000 REFERENCES ON HEAT TRANSFER HHICH HAVE GONF TO MAKE UP THE 1966 NEL HEAT BIBLIOGRAPHY. THE REVIEW IS DIVIDED INTO SECTIONS ON CONDUCTION, RADIATION, CONVEGTION, C.HANGE OF PHASE, HEAT-EXCHANGER DYNAMICS, UNSTEADY HEAT TRANSFER, AND HEAT 
5-26606 \#CONTINUED*

EXCHANGERS. FOR THE FIFTH YEAR IN SUCCESSION IT IS COMPILED BY NEL.

* HEAT TRANSFER + 8I BL IOGRAPHY + HEAT TRANSFER CORRELATION + HEAT TRANSFER EXPERIMENT +

HEAT TRANSFER, BOILING + HEAT TRANSFER, CONDENSATION + HEAT TRANSFER, CONOUCTION +

HEAT TRANSFER, CONVECTION + HEAT TRANSFER, GAS + HEAT TRANSFER, NATURAL CONVECTION +

HEAT TRANSFER, RADIANT + HEAT TRANSFER, TWO PHASE + METAL, LIQUID + REVIEW

$5-26607$

MAINES D

SLIP RATIOS AND FRICTION FACTORS IN THE BUBBLE FLOW REGIME IN VERTICAL TUBES

INSTI TUTT FOR ATOMENERGI, KJELLER, NORWAY

KR-110 . 174 PAGES, REFERENCES, MAY 1966

SLIP RATIOS IN THE VERTICAL BUBBLE FLOW REgIME HAVE BEEN MEASURED IN ADIABATIC AIR-WATER AND STEAM-WATER FLOW. THE EXPERIMENTAL DATA CONFIRM THAT THE SLIP RATIO IN BUSBLE FLOW MAY BE REPRESENTED BY TWO TERMS. THE FIRST TERM IS DUE TO THE RELATIVE VELOCITY BETWEEN BUBBLES AND

WATER. THE SECOND TERM IS CAUSED BY THE RELATIVE DISTRIBUTION OF GAS AND LIQUIO.

AVAILABILITY - AEC DEPOSITORY LIBRARIES IN THE U.S. AND OVERSEAS

*FLOW THEORY ANO EXPERIMENTS + \#LLW, TUBE + \#FLOW, TWO PHASE + AIR + BUBBLE + STEAM + VOID FRACTION + WATER, GENERAL

$5-26608$

KEMME JE

HEAT PIPE CAPABILITY EXPER IMENTS

LOS ALAMOS SCIENTIFIC LAB., NEW MEXICO

LA-DC-7938 + CONF-661116-1+. 10 PAGES, REFERENCES, FROM THERMIONIC CONVERSION SPECIALIST CONFERENCE, HOUSTON, TEXAS, 1965

AXIAL HEAT TRANSFER LIMITS WERE DETERMINED FOR SEVERAL HEAT PIPE SYSTEMS TO SHOW METHODS FOR INCREASING HEAT TRANSFER CAPABILITY ANO TO CHECK THE VALIDITY OF EXISTING HEAT PIPE EQUATIONS. MEASUREMENTS WERE MADE AT OPERATING TEMPERATURES FROM 450 TO 850 C. SODIUM AND POTASSIUM WERE USEO AS WORKING FLUIOS. TWD-COMPONENT WICKS WERE TESTEO BECAUSE THEY PROVIOE MEANS FOR INCREASING HEAT PIPE PERFORMANCE BY UTILIZING FINE PORES FOR FLUID PUMPING AND A LESS RESTRICTIVE PATH FOR LIQUID RETURN. IN THIS PAPER, HEAT PIPE CONSTRUCTION AND PREPARATION TECHNIQUES ARE DESCRIBED. PERTINENT FLUID PRDPERTIES ARE PLOTTED AS A FUNCTION OF TEMPERATURE. HEAT PIPE EQUATIONS ARE LISTED AND THE EXPERIMENTAL RESULTS ARE COMPARED WITH CALCULATED HEAT, TRANSFER LIMITS

AVAILABILITY - CLEARINGHOUSE FOR FEDERAL SCIENTIFIC AND TECHNICAL INFORMATION, SPRINGFIELD, VA. 22151 , $\$ 3.00$ COPY, \$0.65 MICROFICHE

\#HEAT PIPE + \#HEAT TRANSFER ANALYSIS + \#HEAT TRANSFER EXPERIMENT + HEAT TRANSFER + LASL + POTASSIUM + SOD I UM

$5-26609$

KUGEY + ISHIKAWA M + NAITOHY + ITOH T

NUCLEAR, THERMAL-HYDRAULIC PERF QRMANCE ANALYSIS OF JPOR CORE BY THE ONE-DIMENSIONAL BWR CORE PERFORMANCE ANALYSER CODE, KINAK

JAPAN ATOMIC ENERGY RESEARCH INST , TOKYO

JAERI-1114 +. 43 PAGES, TABLES, REFERENCES, MAY 1966

THE CORE PERFORMANCE OF JPOR (A NATURAL CIRCULATION BWR) WAS ANALYZED BY THE ONE-DIMENSIONAL BWR CORE PERFORMANCE ANALYZER CODE, KINAK. THIS CODE COMPUTES THE NUCLEAR, THERMAL-HYDRAULIC PERFORMANCE OF A BWR CORE BY A COMPREHENSIVE SCHEME. THE AXIAL POWER DISTRIBUTION, THE POHER ANO VOID COEFFICIENTS OF REACTIVITY ANO THE EXCESS REACTIVITY AT THE RATED POWER LEVEL WERE CALCULATED AND COMPAREO WITH THOSE MEASURED AT JPDR (OR THE GE DESIGN VALUESI. THROUGH THESE COMPARATIVE STUDIES. THE AUTHORS CONCLUDE THAT THE COMPUTATIONAL MODEL OF THE CODE AND NUCLEAR GROUP CONSTANTS USED ARE ABLE TO REPRESENT THE NUCLEAR PERFORMANCE OF THE JPDR CORE NUCLEAR GROUP CONST ANTS USED ARE ABLE TO REPRESENT THE NUCLEAR PERFORMANCE OF THE JPDR
WITHIN REASONABLE ACCURACY. THERE IS A DESCREPANCY OF ABOUT 10\% BETWEEN THE CALCULATEO VALUES AND THOSE MEASURED BY THE INSTRUMENTED FUEL ASSEMBLY OF THE RECIRCULATION FLOW RATE AND THE CDRE EXIT QUALITY.

AVAILABILITY - AEC DEPOSITORY LIBRARIES IN THE U.S. AND OVERSEAS

*COMPUTER PROGRAM + *HEAT TRANSFER ANALYSIS + \#HYORODYNAMIC ANALYSIS + \#REACTOR, BWR + JAPAN + REACTOR DESCRIPTION

5-26611

POPPENDIAK HF + SABIN CM + FEIGENBUTS LV + MORTON WA + CONNELLY DA

OYNAMIC ANALYSIS OF A LITHIUM-BOILING POTASSIUM REFRACTORY METAL RANKINE CYCLE PONER SYSTEM-FOR THE JET PROPULSION LABORATORY

GEOSCIENCE LTD. L LA JOLLA, CALIF.

N-66-19135 + NASA-CR-70371 + GLR-39+. 133 PAGES, NOVEMBER 1965

THIS REPORT CONTAINS A NUMBER OF STEADY STATE AND TRANSIENT ANALYSES OF IDEALIZED MDDELS OF 
5-26611 *CONTINUED*

- THE JET PROPULSION LABORATORY LITHIUM-BOILING POTASSIUM RANKINE CYCLE SPACE POWER SYSTEM. A NUMBER OF THE PROCESSES WHICH TAKE PLACE IN A SOILING LIQUID METAL SYSTEM ARE ONLY APPROXIMATELY UNDERSTOOD. SUITABLE IDEALIZATIONS MUST EE MADE TO ALLOW ITS STUDY BY ANALYSIS. THE ANALYSES PRESENTED IN THIS REPORT ARE BASED ON SUCH IDEALIZATIJNS WHICH YIELD SOLUTIONS WHICH ADEQUATELY REPRESENT THE MAIN FEATURES OF THE LOOP UNDER CONSTRUCTION.

AVAILABILITY - CLEARINGHOUSE FOR FEDERAL SCIENTIFIC AND TECHNICAL INFURMATION, SPRINGFICLD, VA. 221 I, $\$ 3.00$ COPY, \$0.65 MICROFICHE

\#CONVECTIVE BOILING + \#LITHIUM + \#METAL, LIQUID + FLOW, TWO DHASE + HEAT TRANSFER ANALYSIS + POTASSIUH

$5-26614$

HETSRONI G

USE OF HYDRAULIC MODELS IN NUCLEAR REACTOR DESIGN

WESTINGHOUSE ATOMIC POWER DIVISION, PA.

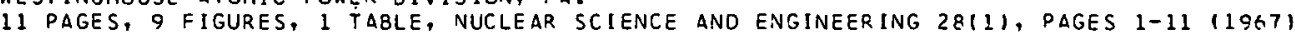

EXPER IMENTAL STUOIES WERE CONDUCTED ON SCALED HYDRAUL IC MOOELS OF LARGE PRESSLRIZED-WATSR REACTORS. MEASUREMENTS WERE MADE OF THE EFFECT DF VARIDUS INTERNAL GE OMETRIES ON THE FLOW DISTRIBUTION AT THE CORE INLET AND ON THE EULER NUMBERS. ATTENTION WAS FDCUSED ON THE RELATI ONSHIP BETWEEN THE FLOW DISTRIBUTION ANO THE LENGTH OF THE FLOW SKIRT, THE LENGTH OF THE LOWER PLENUM AND THE LAYOUT OF INSTRUMENTATION TUBES. THE DESIGN DF THESE COMPONENTS HAS OPTIMIZED. FLOW DISTRIBUTIONS IN THE ANNULI GORMED. EY THE THERMAL SHISLD AND IN THE LOWER PLENUM WERE DETERMINED ANALYTICALLY AND CONFIRMED EXPERIMENTALLY.

\#FLOW THEORY AND EXPERIMENTS + \#FUEL ELEMENT CLUSTER + \#REACTOR, PWR + 3ETTIS + FLOW', TURSULENT + WATER, GENERAL

$5-20624$
HEAT TRANSFER

10 PAGES, 35 FIGURES, BRITISH CHEMICAL ENGINEERING EQUIPMENT SUPPLEMENT, 111111, PAGES 4!-50 INOVEMBER, 19661

$\triangle$ SU:MMARY OF CURRENT DEVELOPMENTS ANO TRENOS (1966) IN THE OESIGN, CONSTRUCTIDN, AND APPLICATION OF HEAT-TRANSFER EQUIPMENT, AN APPFECIATION OF NEW MATERIALS, AND COMMINTS UPON THE PERFORMANCE OF NEW TYPES OF EQUIPMENT. REFERENCFS TO 1.4 PAPERS.

*EQUI PMENT DESIGN + \#HEAT TRANSFER + \#MATERIAL + BIBLIOGRAPHY + EQUIPMENT, GENERAL + HEAT EXCHANGER

$5-26625$

DEEV VI + DUBROVSKII GP + KOKOREV LS + NOVIKOV II + PETROVICHEV VI

HEAT TRANSFER IN FREE-CONVECTION SODIUM BOILING

2 PAGES, 2 FIGURES, 6 REFERENCES, SOVIET ATOMIC ENERGY, 22, DAGES 56-57 (JANUARY, 1967)

THE LACK OF EXPERIMENTAL DATA GN THE HEAT-TRANSFER CHADACTER ISTICS OF BOILING SODIUM MAKES IT DIFFICULT TO DETERMINE THE RANGE WITHIN WHICH THIS OPERATION IS UNSTABLE. TO MEET THIS NEED, $\triangle$ SERIES OF HEAT-TRANSFER EXPERIMENTS WERE CARRIED OUT ON THE POOL BOILING OF SODIUM AT VARIOUS PRESSURE AND HEAT-LOAD CONDITIONS. A WIDE RANGE OF THESE CONDITIONS WERE INVESTIGATED. THE RESULTS INDICATED THAT AT LOW PRESSURES NO SURFACE BOILING DCCURS. IN THE PRESSURE RANGE DF 4000 TO 20,000 N/SQ. METER, THE BOILING PROCESS WAS UNSTABLE, EXHIRITING STRONG TEMPERATURE FLUCTUATIONS. AT THE UPPER LIMIT OF THE ABOVE-MENTIONED PRESSURE RANGE, THE DOILING BECAME STABLE, WITH A MINIMUM OF TEMPERATURE FLUCTUATIONS.

- CONVECTIVg 80ILING + \#HEAT TRANSFER, NATURAL CONVECTION + \#ODIUM + HEAT TRANSFER, BOILING + POOL BOILING + USSR

$5-26627$

SCHROCK VE

HEAT-TRANSFER MODES FOR A CYLINDRICAL SOURCE EMBEDDEO IN LIOUID-FILLED PULUUS MEOIA UNIVERSITY OF CALIFURNIA, BERKELEY

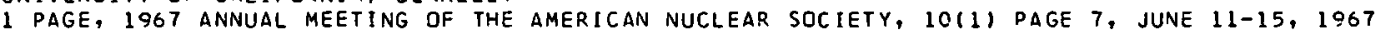

RADIONUCLIDES ARE USED AS NUCLEAR ENERGY SOURCES FOR SMALL POWER UNITS FOR A WIDE VARIETY OF APPLICATIUNS, PRINCIPALLY IN THE SNÁT PROCRAM. AS THIS USF TF ISOTOPES BECOMES MORE EXTENSIVE, QUESTIONS OF SAFETY MUST BE ANSWERED. ONE OF THE CIRCUMSTANCES THAT REQUIRTS EVALUATION IS THE BEHAVIOR OF A RADIOISOTOPE FUEL ELEMENT THAT IS ACCIOENTALLY LOST IN THE OCEAN AND SUBSEQUENTLY BURIED. THE THERMAL ENVIRONMENT EXPERIENCEO WIIL PLAY A PROMINENT ROLE IN DETERMINING THE LONG-TERM INTEGRITY OF ENCAPSULATION. THIS PAPER DESCRISES THE FIRST RESULTS OF A RESEARCH PROGRAM TO DETERMINE THE MODES OF HEAT TRANSFER THAT MAY SE ENCDUNTERED AND TO IDENTIFY THE PARAMETERS THAT GOVERN TRANSITION BETWEEN MODES.

* ACCIDENT aNALYSIS + \#HEAT GENERATION, INTERNAL + *ISOTOPIC geNERATOR + HEAT TRANSFER +

HEAT TRANSFER ANALYSIS + OCEAN AND SEA + SOURCE, RADIATIDN, LOST 
$5-26628$

REUSCHER JA

THERMAL SIRESS ANALYSIS FOR THE SANOIA PULSED REACTOR II

LOS ALAMOS SCIENTIFIC LAB

2 PAGES, 3 REFERENCES, ANS TRANSACTIONS 10111 , PAGES 242-243 OF THE 1967 ANNUAL MEETING OF AMERICAN NUCLEAR SOCIETY, JUNE $11-15,1967$

THE SANDIA PULSEO REACTOR II IS A GODIVA-TYPE FAST-BURST REACTOR CAPABLE OF PRODUCING POWER PULSES WITH HALF-WIDTHS OF 30 MICROSEC AND A TOTAL FISSION YIELO OF $1.9 \times 10(17$ TH). DUE TO THE INERT IA OF THE FUEL AND THE RAPID RATE OF FISSION ENERGY DE POSITION, THE TEMPERATURE IN THE REACTOR RISES FASTER THAN THE CORE MATERIAL CAN RESPONO BY THERMAL EXPANSION. SOME OF THE THERMAL ENERGY IS THEN CONVERTED INTO MECHANICAL ENERGY, STRESS WAVES ARE PRODUCED IN THE CORE, ANO THE FUEL MATERIAL IS SUBJECTED TO LARGE DYNAMIC STRESSES. AT PRESENT, THERE IS NO SUITABLE TECHNIQUE AVAILABLE FOR SOLVING THE LINEAR THERMOELASTIC EOUATIONS, WHICH INCLUDE THE INERTIA TERMS, FOR FINITE CYLINDRICAL GEOMETRY.

*MATHEMATICAL STUOY + *STRESS ANALYSIS + GOUIVA (FBR) + REACTOR, AEC OWNED + REACTOR, FAST BURST + STRESS + STRUCTURAL ANALYSIS, DYNAMIC + THERMAL MECHANICAL EFFECT

5-26629

RHOADES WA

SNAPTRAN TEMPERATURE COEFFICIENT CALCULATION VS EXPERIMENT

ATOMICS INTERNATIONAL

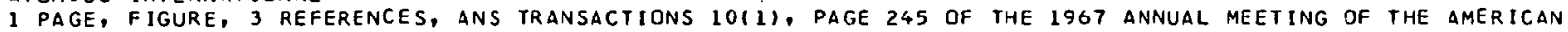
NUCLEAR SOCIETY, JUNE 11-15, 1967

THE SNAPTRAN EXPERIMENTS RESULTED IN MEASUREMENTS OF TEMPERATURE, FEEOBACK COEFFICIENTS OVER SIDE RANGES OF TEMPERATURES, PERIODS, AND POWER LEVELS. A PREVIOUS PAPER REPORTED LARGE VARIATIONS IN THE DATA, APPARENTLY DEPENDENI ON THE TEMPERATURE AND PER IOD RANGES INVOLVED. WE HAVE NOW SIMULATED THESE EXPERIMENTS IN COMPUTER CALCULATIONS. THE CALCULATIONS INCLUDE SOME RELATIVELY UNUSUAL TECHNIQUES, INCLUDING A SPATIALLY DEPENDENT KINETICS CALCULATION WITH TEMPERATURE FEECBACK.

\#COMPUTER PROGRAM + \#REACTOR DYNAMICS + *SNAPTRAN (S-RR) + COMPARISON, THEORY AND EXPERIENCE + MATHEMATICAL TREATMENT + REACTOR, SAFETY RESEARCH + TEMPERATURE COEFFICIENT

5-26630 ALSC IN CATEGORY 6

KLICKMAN AE + HIRAKAWA N

AN ANALYSIS OF THE KIWI-TNT EXPERIMENT WITH MARS

ATOMIC POWER DEVELOPMENT ASSOCIATES, INC.

1 PAGE, TABLE, 4 REFERENCES, ANS TRANSACTIONS 10111 , PAGE 246 OF THE 1967 ANNUAL MEETING OF THE AMERICAN NUCLEAR SOCIETY, JUNE 11-15, 1967

THE KIHI-TNT EXPER IMENT HAS BEEN ANALYZED SY APPLYING A NEH TWO-OIMENSIONAL EXPLOSION COOE, MARS. TO AN APPROPRIATE MODEL. THE CORE WAS CONSIOERED TO BE A CYLINDER 14O CM HIGH AND BS CM IN DIAM. THE REACTOR WAS CONSIOEREO TO BE 50 CENTS SUBCRITICAL, AND SB.5 OF REACTIVITY WAS INSERTED ANC THE RATE OF \$300/SEC. THE EQUATION OF STATE HAS TAKEN TO BE THE

HIGH-TEMPERATURE. VAPOR-PRESSURE EOUATION, AND THE SPECIFIC HEAT WAS AN ANALYTICAL FIT TO THE

AVAILABLE DATA. THE TEMPERATURE COEFFICIENT WAS ASSIGNED THE NOMINAL VALUE OF $1.32 \times 10 / C$.

HOWEVER, IT HAS ALSO ASSIGNED PARAMETRIC VALUES OF $0.5,1.0,1.5$, AND $2.0 \times 10 / \mathrm{C}$.

*EXPLOSION + \#KIWI TNT (S-RR) + *MATHEMATICAL TREATMENT + \#REACTOR DYNAMICS + COMPUTER PROGRAM + EXCURSION, LARGE + REACTOR, SAFETY RESEARCH

$5-26631$

ROBINSON LE + PURVIANCE R + WILLIS L

RESULTS FROM HIGH SPECIFIC ENERGY INPUT SINGLE-PIN, SOOIUM LOOP MELTDOWN EXPERIMENTS IN TREAT ARGONNE NATIONAL LABORATORY, ARGONNE, ILLINOIS

1 PAGE, 4 REFERENCES, ANS TRANSACTIONS $1011 \%$, PAGE 343 OF THE 1967 anNUAL MEETING OF THE AMERICAN NUCLEAR

SOC IETY, JUNE $11-15,1967$

THREE MELTDOWN SAMPLES HAVE BEEN RUN IN TRANSIENT LOOP EXPERIMENTS IN THE TRANSIENT REACTOR

TEST FACILITY (TREAT) USING THE MARK-I INTEGRAL SODIUM LOOP. EACH SAMPLE CONSISTED OF A

SINGLE EBR-II MARK-I PROTOTYPE FUEL PIN, EITHER OF 4.1 OR $6 \%$ ENRICHMENT, SURROUNDED BY SIX

ARGON-FILLED HOLLOW CLADDING TUBES, IN A HEXAGONAL CLUSTER ON AN FBR-II PITCH. EXPERIMENTAL

CONOITIONS INCLUDED AN INITIAL LOGP SODIUM COOLANT TEMPERATURE OF 260 C, FLOW CONDITIONS

RANGING FROM $1.5 \mathrm{M} / S E C$ TO THE MAXIMUM PUMP OUTPUT OF 4 M/SEC SODIUM VELOCITY IN THE TEST

SECTION, AND BOTH CONSTANT ANO CHOPPEO-COSINE AXIAL POWER DISTRIBUTIONS.

*FUEL MELTOOWN + \#IN PILE LOOP + \#TREAT (PRR) + aCCIDENT ANALYSIS + IN PILE EXPERIMENT + REACTOR, PULSED + REACTOR, SAFETY RESEARCH 
CAT.EGORY

ACCIDENT ANALYSIS

5-26632 *CONTINUED*

ANALYTICAL INVESTIGATION OF THE EFFECT OF VARIABLE WALL HEAT FLUX ON TURBULENT LIQUID-METAL HEAT-TRANSFER

COEFFICIENTS IN REACTOR COOLANT CHANNELS

MASSACHUSETTS INSTITUTE OF TECHNOLOGY

2 PAGES, FIgURE, 4 REFERENCES, ANS TRANSACTIONS 10111, PAGES 352-353 OF THE 1967 ANNUAL MEETING OF THE AMERICAN NUCLEAR SOCIETY, JUNE 11-15, 1967

THE FOLLOWING INVESTIGATION OEALS WITH THE PROBLEM OF FORCED CONVECTION HEAT TRANSFER TO A LIOUID METAL FLDWING TURBULENTLY BETWEEN PARALLEL PLATES WITH A VARIABLE WALL HEAT FLUX IN THE FLOW DIRECTION. THE IOEALIZED MOOEL UNDERLYING THIS APPROXIMATION WAS PROPOSED BY POPPENDIEK AND IS BASED ON THO MAIN POSTULATES - (1) THE ESTABLISHEO TURRULENT VELDCITY PROFILE IS INVARIANT WITH THE TRANSVERSE CHANNEL CODRDINATE $Y$, I 2 ) THE EODY DIFFUSIVITY DISTRI BUTION OF MOMENTUM EMIY) VARIES LINEARLY WITH Y AND AS THE NINETENTHS POWER OF THE REYNOLDS NUMBER.

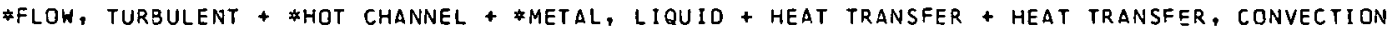

5-26633

WITTE LC + BAKER L + HAWORTH DR

HEAT TRANSFER FROM HIGH-TEMPERATURE SPHERES TO LIQUID SODIUM

ARGONNE NATIONAL LABORATORY, ARGONNE, ILLINOIS + UNIVERSITY OF NEBRASKA

2 PAGES, FIGURE, 2 REFERENCES, ANS TRANSACTIONS 10111, PAGES $351-352$ IF THE 1967 ANNUAL MEETING OF THE AMER ICAN NUCLEAR SOCIETY, JUNE $11-15,1967$

HEAT-TRANSFER RATES FROM HIGH-TEMPERATURE SPHERES HAVE BEEN CBTAINED AS THE SPHERES MOVED THROUGH LIQUID SODIUM. KNOWLEDGE OF THE RATE, OUAVTITY, AND MECHANISM DF EVERGY TRAVSFER THAT OCCURS BETWEEN FUEL PARTICLES AND THE COOLANT IS NECESSARY TO ANALYZE THE CONSEQUENCES OF A FAST-REACTOR INCIDENT IN WHICH HOT FUEL MATERIALS MAY BE DISDCRSED INTO THE LIOUID COOLANT. BEFORE THIS STUDY, NEITHER EXPERIMENTAL NOR THEORETICAL HEAT-TRANSFER RATES FROM SPHERICAL PARTICLES MOVING THROUGH LIQUIO SODIUM WERE AVAILABLS. THE HEAT-TRANSFER DATA WERE OBTAINED USING A TRANSIENT TECHNIOUE IN WHICH A SPHERE ATTACHED TO A SWINGING APM APPARATUS WAS PASSED THROUGH A PÜUL OF LIQUID SODIUM.

\#HEAT TRANSFER + \#METAL, LIQUID + *SODIUM + *SPHERE + HIGH TEMPERATURE

$5-26634$

HOCHREITER LE + SESONSKE A

TURBULENT TEMPERATURE FLUCTUATIONS IN FLOWING SODIUM-POTASSIUM

PURDUF UNIVERSITY

2 PAGES, 2 FIGURES, 5 REFERENCES, ANS TRANSACTIONS 10111, PAGES 353-254 OF THE 1967 ANNUAL MEETING OF THE AMER ICAN NUCLEAR SOCIETY, JUNE $11-15,1967$

AS PART OF A STUDY OF THE MECHANISM OF LIGUID-METAL HEAT TRANSFER ADPLICABLE TD SODIUM-COOLED REACTORS, MEASUREMENTS WERE MADE OF TURBULENT TEMPERATURE-FLULTUATION CHARACTERISTICS IN NAK-56. VERTICAL TRAVERSES VERE MADE WITH AN ESPECIALLY DESIGVED FAST-RESPONSE THERMOCOUPLE ACROSS A 1.O-IN.-I.D. HDRIZONTAL TEST SECTION WITH THE FLUIO AT ABOUT 200 F HEATED BY A CONSTANT WALL FLUX $(12,000$ BTU/HR-FT.2). THE TEST SECTION WAS DRECERED SY A 40-DIAM NONHEATEO SECTION FOLLOWED BY A 5O-DIAM THERMAL ENTRANCE SECTION.

*FLOW, TURBULENT + \#NAK + \#TEMPERATURE TRANSIENT + HEAT TRANSFER + HEAT TRANSFER EXPEFIMCNT + REACTOR, LMCR.

5-26635

MACFARLANE DR

THEORETICAL STUDIES OF THE TRANSIENT BOILING OF SODIUM IN FAST-REACTOR COOLANT CHANNELS

ARGONNE NATIONAL LABORATORY, ARGONNE, ILLINOIS

1 PAGE, FIGURE, 2 REFER ENCES, NNS TRANSACTIONS 1011), PAGE 354 OF THE 196ל ANNUAL MEETING OF THE AMERICAN NUCLEAR SOCIETY, JUNE 11-15, 1957

THE WORK DESCRIBEO IS PART OF A CUNTINUING PROGRAM TO OBTAIN A BETTFR UNOERSTANDING DFF SODIUM COOLANT VAPORIZATION EFFECTS IN LARGE CERAMIC-FUELEO FAST-POWER BRSEDER REACTORS. THE AYPKOACH TAKEN IN THE ANALYSIS WAS TO SEFK NUMFRICAL SOLUTIONS DN THE COMPUTER FOR THE COUPLED, NONLINEAR, PARTIAL DIFFERENTIAL EQUATIONS OF FLUID DYNAMICS ANO HEAT CONDUCTION WRITTEN FOR A SINGLE REACTOR CUULANT CHANNEL ANO FUEL ROD.

\#CONVECTIVE BOILING + \#ODIUM + \#TEMPERATURE TRANSIENT + hOT CHANNEL + MFTAL, LIQUID + REACTOR, LMFBR

$5-26636$

KASCAK AF

THE EFFECT OF TURBULENCE ON RADIANT TRANSFER IN A GASEOUS-CORE NUCLEAR KULKET EINGINE NASA, LEWIS RESEARCH CENTER

2 PACES, 2 FIGURES, REFERENCE, ANS TRANSACTIONS 10111, PAGES 354-355 OF THE 1967 ANNUAL MEETING OF THE

AMER ICAN NUCLEAR SOCIETY, JUNE 11-15, 1967

THE GASEDUS-FUELED NUCLEAR ROCKET IS A PROPOSED PROPULSION SYSTEM WHICH FEATUPES A HIGH SPECIFIC IMPULSE (SAY 1500 OR 2000 SEC) AND RELATIVELY HIGH THRUST. JNE TYPE OFF CONFIGURATION IS KNOWN AS THE COAXIAL FLOW CONCEPT. THE REGIONS IN THF REACTOR WHERE TURBULENCE CAN BE EXPECTED TO HAVE AN EFFECT ON HEAT TRANSFER ARE - (1) NEAR THE INLST BETWFEN THE LOW-VELOCITY FUEL STREAM AND FASTER MOVING PROPELLANT STREAM, (2) AT THE WALLS OF 
5-26636 *CONTINUED*

THE REACTOR AND THE NOZZLE, AND (3) DOHNSTREAM IN THE MIXING REgIONS OF THE REACTOR. THE OBJECT OF THIS STUDY IS TO INVESTIGATE TURBULENCE IN THE DOWNSTREAM MIXING REGION OF THE REACTOR AND TO ESTIMATE ITS EFFECT ON FUEL TEMPERATURE.

\#HEAT TRANSFER + \#REACTOR, SPACE + \#TURBULENCE, CONVECTIVE + FLOW, TURBULENT + ROVER PROGRAM

$5-26637$

PUTRE HA

PERFORMANCE LIMITATIONS ON A RAOIATING LIQUID-CORE NUCLEAR ROCKET DUE TO SUPPORT-WALL TEMPERATURE REQUIREMENTS

NASA, LEWIS RESEARCH CENTER

1 PAGE, 2 FIGURES, ANS TRANSACTIONS 1011), PAgE 356 OF THE I967 ANNUAL MEETING OF THE AMERICAN NUCLEAR

SOCIETY, JUNE $11-15,1967$

A RECENT EVALUATION OF A NEW LIQUID-FUEL NUCLEAR ROCKET CONCEPT INDICATES THAT A I430-SEC SPECIFIC IMPULSE COULD BE ATTAINED WITH A URANIUM AND NIOBIUM CARBIDE FUEL MIXTURE RADIATING HEAT AT $9500 R$ TO SEEDED HYDROGEN PROPELLANT, PROVIDED THE FRACTION OF NUCLEAR HEAT GENERATION USED TO COOL THE SOLID SUPPOPT WALL IS LESS THAN 0.25 . THE LIQUID ROCKET PERFORMANCE, HOWEVER, WAS FOUND TO BE STRONGLY AFFECTED BY THE WALL COOLING FRACTION NECESSARY TO MAINTAIN THE SUPPORT-WALL TEMPERATURE BELOW REALISTIC WALL-MATERIAL MELTING POINTS. THIS PAPER GIVES THE RESULTS OF A DETAILED ANALYSIS OF HEAT-TRANSFER MECHANISMS IN THE LIQUIO FUEL, THEN EVALUATES THE LIMITATIONS DN ROCKET PERFORMANCE BY REALISTIC SUPPORT-WALL TEMPERATURES.

*HEAT TRANSFER ANALYSIS + *REACTOR, SPACE + *ROVER PROGRAM + HEAT TRANSFER + HEAT TRANSFER, CONVECTION

$5-26638$

ROSEN M + SHUSTER WW

THE BEHAVIOR OF AIR BUBBLES IN CIRCULAR TUBES

RENSSELAER POLYTECHNIC INSTITUTE

3 PAGES, 4 FIGURES, 4 REFERENCES, ANS TRANSACTIONS 10111 , PAGES $357-359$ OF THE 1967 ANNUAL MEETING OF THE AMER ICAN NUCLEAR SOCIETY, JUNE $11-15,1967$

INFORMATION ON THE BEHAVIOR OF GAS SUBBLES IN LIQUIDS IS PERTINENT TO AN UNDERSTANOING OF REACTOR PROBLEMS, SUCH AS TWO-PHASE PRESSURE OROPS ANO REACTIVITY EFFECTS DUE TO VOIDS. MOST AVAILABLE EXPERIMENTAL DATA ON BUBBLE BEHAVIOR, WITH THE NOTABLE EXCEPTION OF THAT OF BAKER ANO CHAO, IS RESTRICTED TO SINGLE BUBBLE RISE VELOCITIES IN A STAGNANT FLUID. OUR INVESTIGATION WAS AN ATTEMPT TO EXPAND THE EXISTING DATA BY OBTAINING INFORMATION AND REACHING CONCLUSIONS ON SINGLE BUBBLE BEHAVIOR IN VERTICAL TUBES UNDER FORCED FLOW AS WELL AS STAGNANT CONOITIONS. ALSO INCLUDEO IN THE STUDY WAS SOME MULTI-BUBBLE BEHAVIOR, AND THE UTILIZATION OF INCLINED TUBES.

*FLOW, TWO PHASE + *REACTIVITY EFFECT, VOIO + *VOID FRACTION + AIR + BUBBLE + REACTIVITY EFFECT

$5-26639$

ST.HRTCK VE + JOHNSON HA

TRANSIENT VOID AT HIGH PRESSURE

UNIVERSITY OF CALIFORNIA, BERKELEY

1 PAGE, 2 FIGURES, 3 REFERENCES, ANS TRANSACTIONS 1011), PAGE 359 OF THE 1967 ANNUAL MEETING OF THE AMER ICAN NUCLEAR SOCIETY, JUNE $11-15,1967$

THE ANALYSIS OF SUPERPROMPT CRITICAL EXCURSIONS IN REACTORS, COOLED AND MODERATED BY WATER, DEPENDS UPON THE TRANSIENT VOID DEVELOPED IN THE COPE. TRANSIENT BOILING FXPERIMENTS WERE PERFORMED ON EXPONENTIALLY HEATED RIBBONS TO SIMULATE THE ACTUAL REACTOR TRANSIENT. THE RIBBONS SERVED AS RESISTANCE THERMOMETERS TO DBTAIN THE AVERAGE RIBBON TRANSIENT TEMPERATURE. AN X-RAY DENSITOMETER WAS USED TO MEASURE THE TRANSIENT VOID GROWTH WITH A RESOLUTION OF O.O3 $C C / S Q . M M$.

\#REACTIVITY EFFECT, VOID + \#REACTOR, WATER + \#VOID FRACTION + ACCIOENT ANALYSIS + REACTIVITY EFFECT

$5-26640$

$B \triangle S S O G$

A NEW THEPMOOYNAMIC INTERPRETATIUN OF THE BOILING CRISIS

COMITATO NAZIONALE PER L ENERGIA NUCLEARE, ITALY

2 PAGES, 3 REFERENCES, ANS TRANSACTIONS $10(1)$, PAGES 360-361 OF THE 1967 ANNUAL MEETING OF THE AMERICAN NUCLEAR SOCIETY, JUNE $11-15,1967$

THE FLOW OF LIQUIUS THROUGH CHANNELS OF CONSTANT CROSS-SECTION WITH AN INTENSIVE HEAT ADDITION GIVES RISE TO INSTABILITIES WHICH ARE TO A CERTAIN EXTENT SIMILAR TO THOSE OCCURRING IN GASES AT SONIC OR SUPERSONIC VELOCITIES, AND NAMELY, STRONG DENSITY DISCONTINUITIES IN THE FLOW FIELD AT THE LIQUID-VAPOR INTERFACE, EXPLOSIVE BUBBLE-FORMATION PATTERNS, LIQUID JET SEPARATION FROM THE WALLS IN THE CASE OF FILM BOILING, ETC. A NEW ANALYSIS OF WAVE PROPAGATION IN VISCO-ELASTIC FIUIOS DEVELOPEO IN THIS REPORT SHOWS THAT THE SONIC VELOCITY IN AN INDEFINITE AND ISOTROPIC MEDIUM IBOTH CONDITIONS FORMING THE BASIC ASSUMPTION IN ACOUSTICSI DIFFERS SUBSTANTIALLY FROM THE SONIC VELOCITY WHEN (1) THE FLOW FIELD IS LIMITED, AND (2) AN INTENSIVE HEAT aDDITION TAKES PLACE THROUGH THE CHANNEL WALLS. 
CATEGORY 5

ACCIDENT ANALYSIS

5-26640 *CONTINUED*

* CONVECTIVE BOILING + *HOT CHANNEL + *SHOCK WAVE + HEAT TRANSFER + HEAT TRANSFER ANALYSIS + HEAT TRANSFER, BOILING + THERMODYNAMICS

5-26641

JORDAN ED + STEFFENS J

AN INVESTIGATION OF THE EFFECT OF VIBRATIONS ON HEAT TRANSFER IN A PRESSURIZED WATER SYSTEM

CATHOLIC UNIVERSITY OF AMERICA

2 PAGES, 2 FIGURES, 9 REFERENCES, ANS TRANSACTIONS $10(1)$, PAGES $361-362$ TF THE 1967 ANNUAL MEETING OF THE AMER ICAN NUCLEAR SOCIETY, JUNE 11-15, 1967

EXPERIMENTS INVOLVING ACOUSTIC VIBRATIONS IN AIR AND WATER AND MECHANICAL VIBRATIONS OF A HEATER IN AIR AND WATER HAVE SHOWN THAT THE HEAT TRANSFER GENERALLY INCREASES WHEN THE VI BRATIONAL FIELO IS STRONG ENOUGH TO AFFECT THE BOUNOARY LAYER. IN AN INVESTIGATION IN A PRESSURIZED WATER LOOP, A $0.5-I N-0.0$. THIN-WALLED STAINLESS-STEEL TUBE, WHICH SERVEO AS THE INNER MEMBER IN VERTICAL ANNULAR FLOH AND AS A RESISTANCE HEATER, HAS MECHANICALLY VIBPATED SINUSOIDALLY IN A DIRECTION NORMAL TO ITS AXIS BY AN ELECTRODYNAMIC VIBRATION SYSTEM.

*HEAT TRANSFER + *VIBRATION ANALYSIS + AIR + REACTOR, PWR + VIBRATION + WATER, GENERAL

5-26642

LAFFERTY JF + HAMMITT FC

EXPER IMENTAL INVESTIGATION OF A VAPDR-DRIVEN TWO-PHASE VORTEX

UNIVERSITY OF MICHIGAN

2 PAGES, FIGURE, 5 REFERENCES, ANS TRANSACTIONS 10111, PAGES 362-363 0F THE 1967 ANNUAL MEETING DF THE AMER ICAN NUCLEAR SOCIETY, JUNE $11-15,1967$

ALTHOUGH THE TWO-PHASE VORTEX HAS BEEN CONSIDERED IN SOME ANALYTICAL INVESTIGATIONS IN CONNECTION WITH THE LIOUID-CORE (CAVITY REACTOR) NUCLEAR-ROCKET CONCEPT AND THE VORTEX MHD GENERATOR, LITTLE ATTENTION HAS BEEN CIVEN TO EXPERIMENTAL INVESTIGATIONS OF THIS FLOW REGIME: THERE HAVE BEEN, TO OUR KNOWLEDGE, NO DATA PUBL ISHED ON TWO-PHASE GAS-DRIVEN VURTEX FLOW. THE EXPERIMENTS REPORTED HERE WERE PERFORMED USING AIR AND WATER AS THE THO PHASES. THE VORTEX WAS CONTAINED IN A CYLINDRICAL CHAMBER 5.0 IN. IN DIAM X 1.0 IN. LONG. THE CYLINORICAL WALL OF THE CHAMBER CONTAINED EIGHT CONVERGING NOZZLES WHICH DIRECTED AIR TANGENTIALLY. INTO THE CHAMBER AT VELOCITIES OF 200 TO $660 \mathrm{FTISEC.}$

\#FLOW THEORY AND EXPERIMENTS + \#FLOW, TWO PHASE + *FLOW, VORTEX + aIR + WATER, GENERAL

$5-26698$

MUHURI PK. + MOITI MK

FREE CONVECTION OSCILLATORY FLOW FROM A HORIZUNIAL PLATE

INDIAN INSTITUTE OF TECHNOLOGY

15 PAGES, 5 FIGURES, 3 TABLES, 4 REFERENCES, INTERNATIONAL JOURNAL OF HEAT AND MASS TRANSFER, IO(6), PAGES

$717-732$ (JUNE, 1967 )

UNSTEADY FREE CONVECTION FROM A SEMI-INFINITE HORIZONTAL PLATE IS ANALYZED WHEN THE PLATE TEMPERATURE VARIES PERIODICALLY IN TIME ABOUT A CONSTANT MEAN. SEDARATE SOLUTIONS FOR LOW AND HIGH FREQUENCY RANGES ARE DEVELOPED. IT IS FOUNÜ THAT FOR LOH FREQUENCIES THE OSCILLATORY COMPONENI ÜF THE NUSSELT NUMBER AT THE PLATE INCREASES AS THE PRANDTL NUMBER INCREASES. FOR VERY HIGH FREQUENCIES THE TEMPERATURE FIELD IS OF THE SHEAR-WAVE TYPE UNAFFECTED BY THE STEADY MEAN FLOW.

\#FLOW, TURBULENT + GHEAT TRANGFER, NATURAL CONVFCTION + \#MATHEMATICAL STUDY + HEAT TRANSFER + HEAT TRANSFER ANALYSIS

$5-26699^{\circ}$

BRAIN TJS

NEW THERMAL CONDUCTIVITY MEASUREMENTS FOR ARGON, NITROGEN AND STEAM

GLASGOW UNIVERSITY

8 PAGFS, 5 FIGURES, 2 TABLES, 19 REFERENCES, INTERNATIDNAL JOURNAL OF HEAT ANO MASS TRANSTER, IO(S), DAGES 737-744 (JUNE, 1967 )

THIS PAPER DESCRIBES THE EXPERIMENTAL MEASUREMENT OF THE COEFFICIENT OF THERMAL CONDUCTIVITY DF ARGOTN AND NITROGEN IN THE RANGE 100-300 C AT ATMOSPHERIC PRESSURE UTILIZING A GIJARDED CONCENTRIC CYLINOER CELL MAUE OF SILVER. ALSO CIVEN AP.E RF SIII TS FOR ARGON, NITROGEN, AND STEAIA IN THE RANGE 140-180 C AT ATMOSPHERIC PRESSURE UTILIZING A CONCENTRIC CYLINDER CELL MADF OF BRASS. THE RESULTS SHOW GOOD AGREEMENT WITH RECENT PUBLISHED VALUES. THE MEAN DEVIATION OF THE POINTS FR TM THF RECENTLY PUBLISHED CORRELATIONS, FOR THESE GASES, OF VARGAFIK ANO ZIMINA IS ABOUT $1 \%$.

*ARGON + \#NITRIGGEN + \#STEAM + \#THERMAL PROPERTY + HEAT TRANSFER EXPERIMENT

$5=26700$

ROSE JW

ON THE MECHANISM OF DROPWISE CONOENSATION 
5-26700 \#CONTINUED

UNIVERSITY DF LONDON

8 PAGES, 6 FIGURES, 23 REFERENCES, INTERNATIONAL JOURNAL OF HEAT AND MASS TRANSFER, 10(6), PAGES 755-7.6 2

(JUNE, 1967 )

AN EXTENSION TO A RECENT THEORY OF HEAT TRANSFER BY DROPHISE CONDENSATION IS PROPOSEO. THE MODIFIED THEORY IS COMPARED WITH RECENT HEAT-TRANSFER MEASUREMENTS. GRAPHS SHOW PREDICTIONS OF' THE THEORY FOR HEAT FLUXES OUTSIDE THE PRESENT EXPERIMENTAL RANGES AND FOR DIFFERENT PRESSURES.

\#CONOENSATION + HEAT TRANSFER, CONDENSATION + HEAT TRANSFER + HEAT TRANSFER ANALYSIS + HEAT TRANSFER EXPERIMENT

$5-26701$

SZUCSL + TASNADI CS

A PROCESS FOR THE DIMENSIONING OF THE HIGH EFFICIENCY PLATE FINS OF COMPACT HEAT EXCHANGERS

11 PAGES, 8 FIGURES, 6 REFERENCES, INTERNATIONAL JOURNAL OF HEAT AND MASS TRANSFER, 1O(6), PAGES T7I-781 (JUNE, 1967 )

IT IS POINTED OUT THAT THE NONUNIFORM TEMPERATURE CHANGES OF A MEDIUM FLOWING ALONG PLATE FINS, RESULTING FROM DIFFERENT TEMPERATURE CHANGES TAKING PLACE ADJACENT TO THE FIN BASE AND AT THE FIN TIP AND THE HEAT CONDUCTANCE OF THE FIN IN THE OIRECTION OF FLOW, MUST NOT BE NEGLECTED WHEN DIMENSIONING THE FINNED SURFACE. IT IS SHOWN THAT WITH SMALL MASS RATES OF FLOW, WITH EFFICIENT FIN OESIGN, OR WITH LONG FINS IN THE DIRECTION OF LOW, AS FOR INSTANCE WITH COMPACT FINS HAVING VERY GOOD HEAT-TRANSFER COEFFICIENTS, TUBES FINNED LONGITUDINALLY IN AN AXIAL DIRECTION, ETC., SUCH NEGLECT MAY LEAD TO ERRORS OF 10-30 PER CENT. THE AUTHORS FINALLY DESCRIBE A PROCEDURE, BASED ON THEIR CHARTS, WHICH ENABLES THE RESULTS OF MEASUREMENTS ON FINNEO SURFACES TO BE EVALUATED MORE SIMPLY, QUICKLY AND ACCURATELY THAN WITH THE USUAL FIN EFFICIENCY FORMULA WHICH NEGLECTS THE ABOVE AFFECTS.

*EQUIPMENT DESEGN + \#FIN + \#HEAT EXCHANGER + EQUIPMENT, GENERAL + HEAT TRANSFER + HEAT TRANSFER, CONVECTION + HEAT TRANSFER, NATURAL CONVECTION

5-26702 ALSO IN CATEGORY 19

ECKERT ERG + SPARROW EM + IBELE WE + GOLDSTEIN RJ

HEAT TRANSFER BIBLIOGRAPHY

UNIVERSITY OF MINNESOTA

17 PAGES, INTERNATIONAL JOURNAL OF HEAT AND MASS TRANSFER, 1016), PAGES 823-839 (JUNE, 1967)

AN EXTENSIVE BIBLIOGRAPHY COVERING ALL ASPECTS OF HEAT TRANSFER DURING 1965-66. PREPAREO BY THE DEPARTMENT OF MECHANICAL ENGINEERING OF THE UNIVERSITY DF MINNESOTA.

* BIBLIOGRAPHY + *HEAT TRANSFER + BOUNDARY LAYER + FLOW, TWO PHASE + FLUIDIZED BED + HEAT TRANSFER, CONDUCTION + HEAT TRANSFER, NATURAL CONVECTION + HEAT TRANSFER, RADIANT + HEAT TRANSFER, TWO PHASE + HOT CHANNEL + HYDRODYNAMIC ANALYSIS + MASS TRANSFER + MEASUREMENT, GENERAL + METAL, LIQUID + THERMODYNAMICS + TRANSPORT PROPERTY + TRANSPORT THEORY

$5-26772$

MOERK-MOERKENSTEIN P + HERKENRATH H

TKANSFER OF HEAT TO WATER DURING FORCED FLOW WITHIN THE CRITICAL PRESSURE RANGE UNDER CONOITIONS OF HIGH LOADS ON THE HEATING SURFACE

EUROPEAN ATOMIC ENER.GY COMMUNITY, ISPRA, ITALY

4 PAGES, 4 FIGURES, 2 TABLES, 15 REFERENCES, CHEMIE-INGENIEUR-TECH, 39, PAGES 250-253 (MARCH 20,1967 I IN GERMAN

IN DESIGNING REACTORS, A KNOWLEOGE OF THE HEAT TRANSFER CONOITIONS IS OF GREAT IMPORTANCE, ESPECIALLY AT CRITICAL LOADING CONDITIONS OF THE HEATED SIIRFACE. THE HEAT TRANSFER NUMBERS HAVE BEEN MLASURED FOR A PRESSURE ANO BOILING-WATER CIRCULATING SYSTEM AT PRESSURES DF 170 TO 240 SARS, AND THEIR DEPENDENCE ON VARIOUS PARAMETERS, SUCH AS HEAT FLOW DENSITY, MASS FLOW AND PRESSURE, WAS INVESTIGATED. THUS, THE HEAT TRANSFER CAN BE CONTROLLED, EVEN AT PRESSURES OF UP TO 240 BARS, BY AN APPROPRIATE CHOICE OF PARAMETERS.

*HEAT TRANSFER + *HEAT TRANSFER CORRELATION + \#REACTOR, WATER + CONVECTIVE BOILING + REACTOR, BHR + REACTOR, PWR

$5-26773$

BOGDANOV FF

ITENSIFICATION OF HEAT TRANSFER IN CHANNEL

5 PAGES, 3 FIGURES, TABLE, 4 REFERENCES, ATOMNAYA ENERGIYA, $22(6)$, PAGES $428-432$ (1967) IN RUSSIAN

EXPERIMENTS ON THE EFFECT OF ARTIFICIAL ROUGHNESS ON HEAT EXCHANGE AND HYDRAULIC RESISTANCE IN THE EXOTHERMIC SURFACE OF A HEAT-EXCHANGE APPARATUS ARE DESCRIBED. EMPIRICAL RELATIONS FOR CALCULATING THE HEAT LOSS ANO HYDRAULIC RESISTANCE IN HEAT EXCHANGERS WITH SUCH SURFACES ARE GI VEN. 
CATEGORY 5

ACCIDENT ANALYSIS

5-26774

WASMUND B + SMITH JW

WALL TO FLUIO HEAT TRANSFER IN LIQUID FLUIDIZEO SEDS

UNIVERSITY OF TORONTD, CANADA

10 PAGES, 12 FIGURES, 2 . TABLES, 34 REFERENCES, CANAOIAN JOURNAL JF CHEMICAL ENGINEERING, $45(3)$, PAGES $156-165(1967)$

WALL TO FLUID HEAT TRANSFER COEFFICIENTS AND RADIAL TEMPERATURE PROFILES HAVE BEEN OBTAINED FOR BEDS OF HYORODYNAMICALLY SIMILAR SPHERES FLUIDIZEO WITH WATER IN A 2.058 INCH PIPE AT A CONSTANT HEAT FLUX. FROM PACKED BED TO OPEN PIPE CONDITIONS, HEAT TRANSPORT OCCURS MAINLY BY TURBULENT MIXING, ALTHOUGH CONDUCTION THROUGH THE PARTICLES AND POSSIBLE PARTICLS CONVECTION HAVE SOME EFFECT AT LOW POROSITIES. THIS RESULT CONTRAOICTS A PREVIOUSLY PUBLISHED PREDICTION BASED ON MODEL CALCULATIONS USING ERRONEOUS TEMPERATURE PRDFILES. THE MODEL PREDICTS A MINOR ROLE FOR PARTICLE CONVECTION WHEN APPROPRIATE TEMPERATURE PROFILES ARE USED. A SERIES MODEL BASED ON THE OBSERVED SHIFT OF THERMAL RESISTANCE FROM THE WALL PEGION TO THE BULK DF THE BED WITH DECREASING POROSITY IS USED TO CDRRELATE HEAT TRANSFER COEFFICIENTS.

THE SHIFT IN RESISTANCE LARGELY ACCOUNTS FOR THE MAXIMUM IN HEAT TRANSFER COEFFICIENT PLOTS.

\#FLUIDIZEO BED + \#HEAT TRANSFER, CONVECTION + \#LIQUID + HEAT TRANSFER + HEAT TRANSFER COEFEICIENT + TEMPERATURE GRAOIENT

$5-26775$

MURTHY MLR + RAMACHANDRAN A

SHAPE FACTORS IN CONDUCTION HEAT TRANSFER

2 PAGES, 5 FIGURES, 3 REFERENCES, BRITISH CHEMICAL ENGINEERING, 12(5), PAGES 730-731 (MAY, 1967 )

FOR CALCULATING THE HEAT TRANSFER BETWEEN TWO SURFACES IN CONTACT SHAPE FACTORS ARE WIDELY USED - HOWEVER, THERE ARE MANY CONFIGURATIONS FOR WHICH NO SUCH FACTORS ARE AVAILABLE. HERE BY MEANS OF DETERMINATIONS CARRIED DUT WITH AN ELECTRICAL ANALOGUE, SHAPE FACTORS HAVE BEEN OBTAINED FOR THREE SHAPES, THE CIRCLE WITH SOUARE HOLE, CIRCLE WITH HEXAGONAL HOLE, AND HEXAGON WITH A CIRCULAR HOLE.

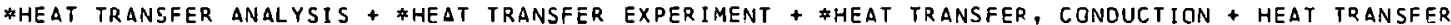

5-26776

FELDMAN KT + WHITING GH

HEAT PIPE

UNIVERSITY OF NEW MEXICD, ALBUQUERQUE; NEW MEXICO

4 PAGES, 4 FIGURES, TABLE, 11 REFERENCES, MECHANIGAL ENGINEERING, 89(2), PAGES 30-33 (FEBRUARY, 1967 )

THE PRINCIPLE OF THE HEAT PIPE IS AN AMAZINGLY SIMPLE ONE. PHENOMENA INVOLVED ARE SURFACE TENSION ANO LATENT HEAT OF THE WORKING FLUID. THERE ARE NO MOVING PARTS. ITS EFFECTIVE THERMAL CONDUCTIVITY IS HUNOREDS OF TIMES MORE THAN SOLID CONDUCTOR LIKE COPPER AND SILVER. A OVERVIEW OF HEAT-PIPE PRINCIPLES IS PRESENTEO, WITH ELEVEN REFERENCES.

*HEAT PIPE + \#HEAT TRANSFER, CONOUCTION + hEAT TRANSFER + HEAT tRANSFER ANALYSIS

$5-26778$

HOLY ZJ

TEMPERATURE AND THERMOELASTIC STRESS FIELDS IN AN INF INITE HALF-SPACE DUE TO AXISYMMETRIC SURFACE HEAT TRANSFER

UNIVERSITY OF NEW SOUTH WALES, AUSTRALIA

8 PAGES, 5 FIGURES, 5 REFERENCES, NUCLEAR ENGINEER ING AND DESIGN, 5(4), PAGES 367-374 1 JULY, 1967$)$

SOLUTIONS FOR TEMPERATIIRF ANR THERMOELASTIC STRESS FIELDS ARE DEVELOPED FOR AX.ISYMMETRIC HEAT TRANSFER COEFFICIENT VARIATION OVER THE SURFACE OF A HEAT PRDOUCING INFINITE HALF-SPACE, INH TERMS OF A TRUNCATED SER IES OF WEIGHTED MUTUALLY ORTHOGONAL POLYNOMIALS. THE METHED IS APPLIED TO A NUMBER OF HEAT TRANSFER DISTRIBUTIONS. THE RESULTS ARE COMPARED WITH KNOWN SOLUTIONS, AND CONCLUSIONS ARE DRAWN AS TO THE ACCURACY AND APPLICABILITY DF THE METHOD.

\#HEAT TRANSFER, CONDUCTION + \#MATHEMATJCAL. TREATMENT + \#STRESS ANALYSIS + HEAT TRANSFER + HEAT TRANSFER COEFFICIENT

5-26779

TONG LS + KITZES AS + GREEN J + STORMER TD

DEPARTURE FROM NUCLEATE BOILING ON A FINNED-SURFACE HEATER ROD

WESTINGHOUSE ELECTRIC CORPORATION, ATOMIC POWER DIVISION, PITTSBURGH, PENNSYLVANIA

5 PAGES, 8 FICURES, 3 TARIFS, G REFERENCES, NUCLEAR ENGINEERING, 5(1), PAGES 386-390 (JULY, 1967)

TESTS WERE PERFORMED TO DETERMINE THE DNB HEAT FLUXES AND POST-DNB HEAT TRANSFER COEFFICIENTS ON A SINGLE UNIFORMLY ELECTRIC HEATED ROD CENTERED IN AN UNHEATED SOUARE CHANNEL. THE HEATED ROU HAS A SERIES OF 0.00025 -IN.-HIGH FINS AT THE DOWNSTREAM END. TEST RESULTS ARE PRESENTED FOR THE UPWARD FLOW OF WATER AT PRESSURES OF 1600 TO 2300 PSIA, INLET TEMPERATURES OF $5 Z 0$ ANO $600 \mathrm{~F}$, AND FLOW RATES OF $1,000,000$ TO $3,000,000$ LB/HR-SO. FT. THEY SHOW THAT THE DNB HEAT 
CATEGORY 5

ACC IDENT ANALYSIS

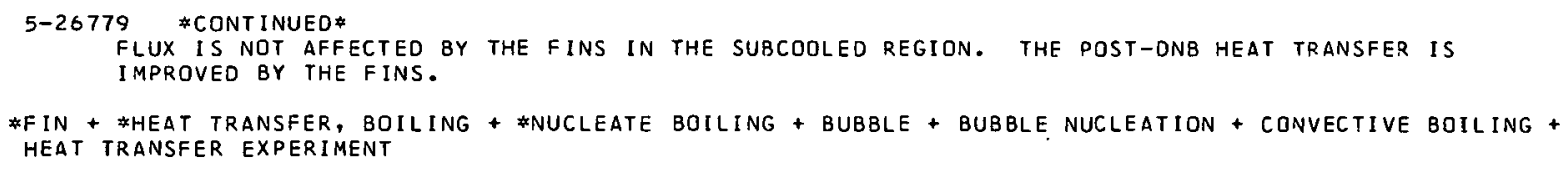

A LINEARIZED THEORY IS USED TO STUDY HEAT-TRANSFER RESPONSES OF A LAMINAR FREC-CONVECTION BOUNDARY LAYER ALONG A VERTICAL HEATED PLATE TO SURFACE TEMPERATURE OSCILLATIONS, HHEN THE MEAN SURFACE TEMPERATURE VARIES AS A POWER, $N$, OF THE DISTANCE FROM THE LEADING EOGE. FOR N EQUALS I, IT IS SHOWN THAT EXACT SOLUTIONS ARE POSSIBLE FOR THE ENTIRE FREQUENCY RANGE CONSIDERED. FOR N LESS THAN 1, ASYMPTOTIC SERIES SOLUTIONS FOR LOW- AND HIGH-FREQUENCY RANGES ARE FORMALLY OBTAINED. "RESPONSE CHARACTERISTICS OF THE VELOCITY AND TEMPERATURE RANGES ARE FORMALLY OBTAINED. RESPONSE CHARACTERISTICS OF THE VELOCITY AND TEMPERA TURE
PROFILES AND OF THE LOCAL RATE OF SURFACE HEAT FLUX ARE DERIVED. NUMERICAL CALCULATIONS HAVE BEEN CARR IED OUT FOR $N$ VALUES OF $0,0.2$, AND 1.0 , PRANDTL NUMBERS OF $0.72,1.0$, AND 10.0 , AND FOR A COMPLETE RANGE OF FREQUENCIES.

*FLOW, LAMINAR + *HEAT TRANSFER, NATURAL CONVECTION + *MATHEMATICAL TREATMENT + FLOW DISTRIBUTION + HEAT TRANSFER ANALYSIS + TEMPERATURE GRADIENT

5- 26782

TALHAR HJ

THERMAL CONVECTION NEAR A PARTLY INSULATED VERTICAL FLAT PLATE

23 PAGES, 4 FIGURES, 7 REFERENCES, ZEITSCHRIFT FUR ANGEXENDTE MATHEMATIK AND PHYSIK, $19(1)$, PAGES $45-57$ $(1968)$

A NUMERICAL SOLUTION OF THE PROBLEM OF FREE-CONVECTION HEAT TRANSFER NEAR AN INSULATEO PLATE IS PRESENTED FOR PRANDTL NUMBERS RANGING FROM 0.1 TO 10.0. A STUOY IS MADE OF THE CONVECTION PRODUCED BY HEATING A SEMI-INFINITE VERTICAL FLAT-PLATE OF LENGTH. 1. THF HEATED PORTION STARTS AT THE BOTTOM EDGE OF THE PLATE, WHICH IS ASSUMEO TO BE THERMALLY INSULATED APART FROM THE HEATED REGION. AT A GREAT HEIGHT ABOVE THE HEATED PART, THE VELOCITY AND TEMPERATURE DISTRIBUTION WILL BE AS IF ALL THE HEAT HAD BEEN PUT IV AS A LINE SOURCE NEAR THE BASE OF THE PLATE, AND A SIMILARITY SOLUTION WILL RESULT. THIS SIMILARITY SOLUTIDN IS FIRST STUDIED BY MEANS OF A POHLHAUSEN TYPE METHOD. THE SOLUTION CONTAINS AN ARBITRARY CONSTANT THAT REPRESENTS THE AMOUNT OF HEAT PUT IN AT THE BASE, AND HENCE THE HEAT FLUX IN THE CONVECTION FLOW. FOR THE CASE IN WHICH THE LOWEST PORTION OF THE PLATE IS HEATED TO A UNIFORM TEMPERATURE, A POHLHAUSEN SOLUTION IS GIVEN, AND FROM IT THE POSITION OF THE EFFECTIVE ORIGIN OF THE SIMILARITY SOLUTION IS ESTIMATED IN TERMS OF THE LENGTH OF THE HEATED PART DF THE PLATE.

\# BOUNDARY LAYER* + \#HEAT TRANSFER, CONVECTION + \#MATHEMATICAL TREATMENT + FLOW DISTRIBUTION + HEAT TRANSFER ANALYSIS + TEMPERATURE GRADIENT

$5-26921$

ZERKLERD + SUNDERLAND JE

THE EFFECT OF LIQUID SOLIDIFICATION IN A TUBE UPON LAMINAR-FLOW HEAT TRANSFER AND PRESSURE DROP

UNIVERSITY OF CINCINNATI + GEORGIA INSTITUTE OF TECHNOLOGY, GA.

8 PAGES, 11 FIGURES, 2 TABLES, 7 REFERENCES, JOURNAL OF HEAT IRANSFER 90(2) SERIES C, PAGES 183-90 (MAY

1968I. TRANSACTION DF THE ASME

THE EFFECT OF LIQUID SOLIDIFICATION AT THE INNER SURFACE OF A CIRCULAR TUBE UPON LAMINAR-FLOH HEAT TRANSFER ANO PRESSURE DROP IS INVESTIGATED. STEAOY-STATE CONOITIONS AND A UNIFORM WALL TEMPERATURE, WHICH IS LOWER THAN THE LIQUID FREEZING TEMPERATURE, ARE ASSUMED. THEDRETICAL 
CATEGORY 5

ACCIDENT ANALYSIS

5-26921 *CONTINUED*

SOLUTIONS FOR HEAT TRANSFER, RADIUS OF THE LIOUID-SOLIO INTERFACE, AND PRESSURE DRQP ARE DETERMINED ASSUMING NEGL IGIBLE FREE CONVECTION. EXPERIMENTATION SHOWS THAT FREE CONVECTION MAY PRODUCE CONSIDERABLE DEVIATIONS BETWEEN THEORETICAL AND OBSERVEO RESULTS. A SEMIEMPIRICAL METHOD FOR OBTAINING APPROXIMATE SOLUTIONS IS OEVELOOED. A NUMERICAL EXAYOLE WHICH DEMONSTRATED HOW FREE CONVECTION EFFECTS THE SOLID-PHASE SHELL PROFILF IS PRESENTFD.

\#FLOW, LAMINAR + \#HEAT TRANSFER, CONVECTION + \#PRESSURE DROP + HEAT TRANSFER + LIQUIO +

MATHEMATICAL TREATMENT + SOLID

$5-26922$

HABERSTROH RD + BALDWIN LV

APPLICATION OF A SIMPLIFIED VELOCITY PROFILE TO THE PREDICTION OF PIPE-FLOW HEAT TRAVSFER COLORADO STATE UNIVERSITY, COLO.

10 PAGES, 11 FIGURES, 2 TABLES, 21 REFERENCES, JOURNAL OF HEAT TRANSFER 90(2), SERIES C, PAGES IO1-20O

(MAY 1968), TRANSACTIONS OF ASME

THE TEMPERATURE PROFILES AND HEAT-TRANSFER COEFFICIENTS ARE PREDICTEO FOR FULLY DEVELOPED TURBULENT PIPE FLOW WITH CONSTANT WALL HEAT FLUX FOR A WIDE RANGF DF PRANOTL ANO REYNOLDS NUMBERS. THE BASIS FOR INTEGRATING THE ENERGY EOUATION COMES FROM A CONTINUOUSLY DIFFERENTIABLE VELOCITY PROEILE WHICH FITS THE PHYSICAL BDUNDARY CONOITIONS AND IS A RIGOROUS (THOUGH NOT NECESSARILY UNIQUE) SOLUTIIN OF THE REYNOLDS EQUATIONS. THE RESULTS DESENERATE I DENT ICALLY TO THE CASE OF LAMINAR FLOW. THE HEAT-TRANSFER CALCULATION REOUIRES NEITHER ADJUSTABLE FACTORS NOR DATA-FITTING BEYOND THE EMPIRICAL CONSTANTS IN THE MOMENTUY EQUATION. THUS THIS ANALYSIS CONSTITUTES A HEAT-TRANSFER PRERICTION TO BE TESTED AGAINST HEAT-TRANSFED DATA.

\#FLOW DISTRIBUTION + \#FLOW, TUBE + \#HEAT TRANSFER CORRELATION * \#HEAT TRANSFER, CONVECTICN + FLOW, LAMINAR + FLOW, TURBULENT + HEAT TRANSFER + HEAT TRANSFER ANALYSIS + MATHEMATICAL TREATMENT

$5-25923$

ANDEEN GB + GRIFFITH P

MOMENTUM FLUX IN TWO-PHASE FLOW

CHRISTINA LABORATORY, E. I. DU PONT DE NEMOURS AND CO.. DEL. + MASS. INSTITUTE OF TECHNDLOGY, MASS.

12 PAGES, 21 FIGURES, I TABLE, 14 REFERENCES, JOURNAL TF HEAT TRANSFER 9CI2I, SERIES C, DAGES $211-222$ IMAY

1968), TRANSACTIONS OF ASME

MEASUREMENTS OF THE MOMENTUM FLUX THROUGH A SECTION OF PIPE WITH STEAM-WATER AND AIR-WATER TWO-PHASE FLOW ARE REPORTED. THE RESULTS ARE USED TO SVALUATE THE UTILITY DF VARIOUS TWO-PHASE FLOW MODELS ANO THE UNDERLYING ASSUMPTIONS. THE SLIP MODEL WAS FOUND TO YIELD LOW VALUES. THE HOMOGENEOUS MODEL CORRELATEO THE DATA WELL, BUT THIS IS BECAUSE OF COMPENSATING ERRORS IN THE ASSUMPTIONS. THE STEADY FLOW ASSUMPTION OF MOST TWO-PHASE FLOW MODELS IS CONSIDERED TO BE INADEQUATE FOR PREDICTION OF THE MOMENTUM FLUX $\triangle T$ LOW QUALITY. AT HIGHER QUALITY THE VELOCITY PROFILE IS THE DOMINANT CONSIDERATION.

*Flow, TUBE + *Flow, TWO PHASE + \#MATHEMATICAL STUDY + Flow THEORY aND EXPERIMENTS + PRESSURE OROD

$5-26924$

KOUMOUTSOS N + MOISSIS R + SDYRIDONOS A

A STUDY OF BUBBLE DEPARTURE IN FORCED-CONVECTION BOLLING

GREECE ATOMIC ENERGY COMMISSION, NUCLEAR RESEARCH CENTER, DEMOCRITUS

8 PAGES, 6 FIGURES, 2 TABLES, 16 REFERENCES, JOURNAL OF HEAT TRANSFER 90(2), SERIES C, PAGES $223-230$ (MAY 1968I, TRANSACTIONS OF ASME

VISUAL OBSERVATIONS IN A BRII. ING LIQUID FLOW INDICATE THAT, AS THE FLOW VELOCITY IS INCREASED, THE SIZE OF BUBBLES LEAVING THE HEATING SURFACE DECREASES. THE PURYUSE UF THIS INVESTIGATION IS TO ARRIVE AT A CRITERION FOR BUBBLE DEPARTURE IN FORCED-CONVECTION NUCLEATE BOILING. PHOTOGRAPHIC STUDIES INDICATE THAT A LITTLE BEFDRE DEPARTURE A NECK IS FORMED JOINING THE ALMOST SPHERICAL BUBBLE TO THE HEATING SURFACE. FROM A CONSIDERATION DF IHE HYORODYNAMIC STABILITY OF THE BUBBLE-AND-NECK MODEL, THE DEPARTURE-SIZE-TO-VELOCITY RELATIONSHIP MAY BE PREDICTED. MEASURED OEPARTURE RADII IN A FORCED-CONVECTION BOILING WATER SYSTEM TAKEN BY MEANS OF HIGH-SPEED PHOTOGRAPHY ARE SATISFACTDRILY CORRELATED WITH THE RESULTS OERIVED ANALYTICALLY.

* CONVECTIVE BOILING + *FLoh THEORY AND EXPERIMENTS + \#HYDROOYNAMIC aNALYSIS + HEAT TRANSFER + HEAT TRANSFER, BOILING + NUCLEATE BOILING

$5-20925$

VACHONRI + TANGER GE + DAVIS OL + NIX GH

POOL BOILING ON POL I SHED AND CHEMICALLY ETCHED STAINLESS-STEEL SURFACES

AUBURN UNIVERSITY, AUBURN, ALA.

8 PAGES, 13 FIGURES, 4 TABLES, 28 REFERENCES, JOURNAL DF HFAT TRANSFER 90(2), SERIES C, PAGES $231-238$ (MAY

19681 , TRANSACTIONS OF ASME

THIS PAPER PRESENTS POOL. BOILING DATA AT ATMOSPHERIC PRESSURE FOR MECHANICALLY POL ISHEO ANO CHEMICALLY ETCHED 304 STAINLESS-STEEL SURFACES IN CONTACT WITH DISTILLED HATER. THE SURFACES WERE PREPARED BY THESE TECHNIQUES TO PRODUCE VARIATION IN NUCLEATION SITES. SURFACE ROUGHNESS WAS VARIED FROM 2-61 RMS. THE RESULTS SHOW THE CHANGES IN HEAT TRANSFER WITH 
5-26925 \#CONT I NUED*

VARYING RMS SURFACE ROUGHNESS AND PREPARATION TECHNIQUE. THE ROHSENOW POJL BOILING CORRELATION WAS USED TO DISCUSS THE DATA.

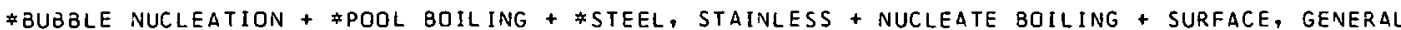

$5-26926$

VACHON RI + NIX GH + TANGER GE

EVALUATION OF CONSTANTS FOR THE ROHSENOW POOL-BOILING CORRELATION

AUBURN UNIVCRSITY, AUBURN, ALA

9 PAGES, 12 FIGURES, 4 TABLES, 21 REFERENCES, JOURNAL OF HEAT TRANSFER 90(2), SERIES C, PAGES $239-247$ (MAY

1958), TRANSACTIONS OF ASME

THE PAPER CONTAINS RESULTS OF APPLYING THE ROHSENOW POOL-BOILING CORRELATION TO DATA FROM THE LITERATURE. RECENT EVIDENCE SUPPORTS THE PREMISE THAT THE COEFFICIENT C-SUB-SF AND THE EXPONENT R OF THE ROHSENOW EQUATION VARY WITH SURFACE PREPARATION TECHNIOUE AS WELL AS WITH LIQUIO-SURFACE COMBINATION. ELEVEN SEPARATE STUOIES INVOLVING SEVEN LIQUID-SIJRFACE COMBINATIONS AND SEVEN DIFFERENT SURFACE PREPARATION TECHNIQUES HAVE BEEN COR.RELATEO. APPROPRIATE VALUES OF R AND C-SUB-SF HAVE BEEN DETERMINED USING LEAST SOUARES TECHNIQUES IN CONJUNCTION WITH THE ROHSENOW EQUATION TO REPRESENT THE VARIOUS DATA INVESTIGATED.

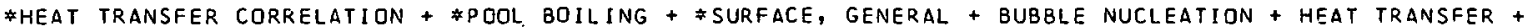
HEAT TRANSFER, SOILING + MATHEMATICAL STURY

$5-26927$

VISKANTA R + MERRIAM RL

HEAT TRANSFER BY COMBINED CONOUCTION AND RADIATION BETWEEN CONCENTRIC SPHERES SEPARATED BY RADIATING MEDIUM PURDUE UNIVERSITY, LAFAYETTE, IND.

9 PAGES, 11 FIGURES, 7 TABLES, 14 REFERENCES, JOURNAL OF HEAT TRANSFER 90121, SERIES C, PAGES $248-256$ (MAY 19681 , TRANSACTIONS OF ASME

STEADY-STATE HEAT TRANSFER BY SIMULTANEOUS CONDUCTION AND RADIATION THROUGH A SPHERICAL SHELL OF ABSORBING, EMITTING, AND SCATTERING MEDIUM HAS BEEV TINVESTIGATED ANALYTICALLY. THE MEDIUM IS CONFINED BETWEEN TWO GRAY, DIFFUSE, ISOTHERMAL SPHERES KEPT AT DIFFERENT BUT UNIFORM IS CONFINED BETWEEN TWO GRAY, DIFFUSE, ISOTHERMAL SPHERES KEPT AT DIFFERENT BUT UNIFORM
TEMPERATURES AND IS CAPABLE OF GENERAT ING HEAT. THE PROBLEM IS FORMULATED RIGOROUSLY USING EXACT RADIATIVE TRANSFER METHOOS. THE GOVERNING EQUATIONS WERE SOLVED NUMERICALLY USING AN I.TERATIVE SCHEME. THE RESULTS REPORTED ILLUSTRATE THE INTERACTION OF CONDUCTION WITH

RADIATION HEAT TRANSFER AS HELL AS REVEAL THE EFFECTS OF THE PARAMETERS ON THE HEAT TRANSFER CHARACTERISTICS. A SIMPLE APPROXIMATION IS SUGGESTED FOR PREDICTING TOTAL HEAT TRANSFER

THROUGH A SPHERICAL SHELL FROM THE RESULTS THROUGH A PLANE LAYER. THE RESULTS ARE COMPARED WITH AVAILABLE SOLUTIONS AND SUPERPDSITION APPROXIMATIONS.

* HEAT tRANSFER, CONDUCTION + \#HEAT TRANSFER, RADIANT + \#SPHERE + HEAT TRANSFER + HEAT TRANSFER aNALYSIS + MATHEMATICAL STUDY

$5-26928$

TALTEL Y + HARTNETT JO

EQUILIBRIUM TEMPERATURES IN A BOUNDARY-LAYFR FLOW OVER A FLAT PLATL OF ABSORBING EMITTING GAS

UNIVEKSITY OF ILLINOIS, CHICAGO, ILL.

10 PAGE3, 12 FIGURES, 15 REFERENCES, JOURNAL OF HEAT TRANSFER 90(2), SERIES C, PAGES $257-266$ (MAY 1968)

TRANSACTIONS OF ASME

THE EFFECT OF RADIATION ON THE EQUILIBRIUM TEMPERATURE FOR A FLOW OF EMITTING-ABSORBING GAS OVER A FLAT PLATE IS STUDIEO. THREE METHODS OF SOLUTION ARE FORMULATED - ANO APPROXIMATE SOLUTION FDR A THIN BOUNDARY I.AYER, A SIMILARITY SOLUTION FOR THE LIMITING CASE WHEN THE BOUNDARY LAYER IS OPTICALLY THICK, AND AN EXACT SOLUTIOV. IT IS SHOWN THAT, FOR SMALL AB SORPTION COEFFICIENT, HIGH WALL EMISSIVITY, ANO MACH NUMBER, THE RESULTS APPROACH THE T.ASE WHERE THE GAS IS TRANSPARENT.

* boundar laYer + *heat transfer analysis + gas + heat transfer + heat transFer, radiant + MATHEMATICAL TREATMENT + TEMPERATURE GRADIENT

$5-26929$

SOLIMAN M + SCHUSTER JP. + BERENSON PJ

A GENERAL HEAT TRANSFER CORRELATION FOR ANNULAR FLOW CONOENSATION

AIRESEARCH MANUFACTUR ING COMPANY, CALIF.

10 PAGES, 11 FIGURES, 18 REFERENCES, JOURNAL OF HEAT TRANSFER 90(2), SERIES C, PAGES 267-7B (MAY 1968)

TRANSACTIONS OF ASME

THE INTERACTION BETWEEN FRICTION, MOMENTUM, AND GRAVITY, AS THEY AFFECT THE HEAT TRANSFER PROCESS DURING ANNUL AR FLOW CONDENSATION INSIDE TUBES, IS STUDIED. ANALYTICAL FORMS FOR EACH OF THESE FORCES ARE DERIVED AND INCORPORATED IN A CORRELATION THAT PREDICTS THE LOCAL HEAT TRANSFER COEFFICIENT. THE PREDICTIONS AGREE WELL WITH THE AVAILABLE EXPERIMENTAL OATA OVER A WIDE RANGE OF VAPOR VELOCITIES AND OVER A RANGE OF PRANDTL NUMBERS FROM 1 TO 10. ANALYSIS ALSO YIELDS A MEANS FOR PREDICTING THE ONSET OF LIQUID RUNBACK IN THE PRESENCE OF AN ADVERSE GRAVITATIONAL FIELD.

*FLOW, TUBE + \#HEAT TRANSFER CORRELATION + *HEAT TRANSFER, CONDENSATION + HEAT TRANSFER aNALYSIS + 
CATEGORY 5

ACCIDENT ANALYSIS

5-26929 \#CONTINUED*

MATHEMATICAL TREATMENT

\begin{abstract}
5-27043
YAROSH MM

AN EXPERIMENT EMPLOYING ULTRASONIC ENERGY TO PROMOTE BOILING IN LIQUID METAL

OAK RIDGE NATIONAL LABORATORY, OAK RIDGE, TENNESSEE

30 PAGES, 13 FIGURES, 14 REFERENCES, FROM THE INTERNATIONAL CONFERENCE DN THE SAFETY OF FAST NUCLEAR

REACTORS, SEPTEMBER, 1967

THE TENDENCY FOR LIQUID METALS SUCH AS NA AND K TO UNDERGO SUBSTANTIAL LIQUID SUPERHEATING AND SUBSEQUENT EXPLOSIVE BOILING HAS BEEN DEMONSTRATED AT OAK RIDGE NATIONAL LABORATORY AND AT OTHER RESEARCH INSTALLATIONS. AN EXPER IMENT WAS CONDUCTED EMPLOYING ULTRASONIC ENERGY EXCITATION TO INITIATE AND MAINTAIN STABLE BOILING IN K UNDER CONDITIONS THAT NORMALLY PRODUCED LIOUID SUPERHEATING AND UNSTABLE, EXPLOSIVE BOILING. UNSTABLE BOILING IS

CHARACTER IZED BY LARGE AND ERRATIC TEMPERATURE DIFFERENCES BETWEEN IHE TEMPERATURES JF THE LIQUID AND VAPOR. THESE TEMPERATURE DIFFERENCES WERE SIGNIFICANTLY REDUCED OR ELIMINATEO UPON EXCITATION DF THE ULTRASONIC PROBE. THE TENOENCY TOWARO LIQUIO SUPERHEATING WAS SUBSTANTIALLY ELIMINATED UNDER MANY OPERATING CONDITIONS.
\end{abstract}

AVAILAGILITY - M.M. YAROSH, OAK RIDGE NATIONAL LABORATORY, DAK RIDGE, TENNESSEE

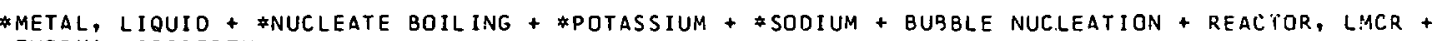
THERMAL PROPERTY

$5-27044$

GOSE EE + MUCCIAROI AN + BAERE

MODEL FOR DROPWISE CONDENSATION OF RANDOMLY DISTRIBUTED SITES

8 PAGES, 6 FIGURES, 12 REFERENCES, INTERNATIONAL JOURNAL OF HEAT AND MASS TRANSFER, ICIII. PAGES 15-22

(JANUARY, 19671

A MODEL FOR HEAT TRANSFER DUR ING DROPWISE CONOENSATION OF R ANUÜMLY OLSTRIBUTED NUCLEATION SITES WAS DEVELOPED AND SIMULATED ON A DIGITAL COMPIJTER. THE THEJRY ACCOUNTED FQR DROP NUCLEATION AND GROWTH, COALESCENCE WITH NEIGHBORS, REMOVAL, AND RENUCLEATION ON SITES EXPTSED BY THE REMOVAL AND COALESCENCE MECHANISMS. FOR STEADY-STATE DROP CONDENSATION, THE THEORY SHOWED THAT SMALL OROPS GROW BY VAPOR CONDENSATION AND THAT LARGER DROPS GROW PREDIMINFNTLY BY COALESCENCES. LARGER HEAT-TRANSFER CDFFFICIENTS THAN HAVE BSEN OBSERVED TO DATE SHOULD BS POSSIBLE IF CONDENSER SURFACES CONTAINING BETWEEN ¿.E+OT TO 1.E+D8 SITES/CM2 AND DROD-REMOVAL TECHNIQUES FOR VERY SMALL (LT 5.E-04CM) CAN BE DEVELOPED.

* COMPUTER PROGRAM + \#DROPLET + \#HEAT TRANSFER, CONDENSATION + HEAT TRANSFER ANALYSIS + MATHEMATICAL STUDY

$5-27045$

MORI Y + NAKAYAMA

STUDY ON FORCED CONVECTIVE HEAT TRANSFER IN CURVED PIPES (2ND REPORT, TURBULENT REGIJN)

13 PAGES, 15 FIGURES, 11 REFERENCES, INTERNATIONAL JOURNAL OF HEAT AND MASS TRANSEER, $13(11$, DAGES $37-5$ \% (JANUARY, 1967

FOR THIS PAPER THE EFFECT OF CURVATURE ON HEAT TRANSFFR FOR FULLY DEVELOPED TUPQULENT FLOW IN CURVED PIPES ON THE CONDITION DF CONSTANT HEAT FLUX WAS STUDIED THEORETICALLY AND

EXPERIMENTALLY. IN THE ANALYSIS A BOUNDARY LAYER IS CONSIDEREO TO EXIST ALONG THE PIPE WALL. LOCAL SHEAR STRESS AND LOCAL HEAT FLUX AT THE WALL ARE GIVEN DN THE BASIS OF OTOUCING THF. RESISTANCE AND THE NUSSELT NUMBER FORMULA.FOR STRAIGHT DIPES TO THE LOCAL RELATION OF FRICTION ANO HEAT TRANSFER. THE NUSSELT NUMBERS OBTAINED FROM MEASUKEMENT CF THE VELOCITY ARD TEMTERATUP.E OISTRTRIITIMNS IN THE AIR FLOW THROUGH THE CURVED DIOES OF R/A = 4O $A V D 19.7$ ARE IN GOOD AGREEMENT WITH THE THEORETICAL RESULLTS.

\#FLOW, TUBE + \#FLOW, TURBULENT + \#HFAT TRANSFER CORRELATION + \#HEAT TRANSFER, CONVECTION + HEAT TRANSFER + HEAT TRANSFER ANALYSIS + HEAT TRANSFE? EXPERIMENT

5-27046

DVORAK FA + HEAD MR

HEAT TRANSFER IN THE CONSTANT PROPERTY TURBULENT BOUNDARY LAYER

21 PAGES, 27 FIGURES, 27 REFERENCES, INTERNATIONAL JOURNAL OF HEAT AND MASS TRANSFER, $10(1.1$, PAGES GI-BI

(JANUARY, 1967

A NEW METHOD HAS BEEN DEVELDPED FOR CALCULATING HEAT TRANSFER IN THE CCNSTANT DROPERTY TURBULENT BOUNDARY LAYER WITH ARBITRARY DISTRIDUTIONS JF WALL TEMOERATURE AVD STREAM VELOCITY. THE PROCEDURE IS AS FOLLOWS. THE DEVELODMENT DF THE BOUNDARY LAYER IS CALCULATER BY ONE OR ANOTHER OF THE METHODS CURRENTLY AVAILABLE AND FROM THE CALCULATED VALUES IF H AND O VELOCITY PROFILES ARE SPECIFIED BY THE USE OF A SUITABLE TWO-PARAMETER FAMILY. WITH SOME PLAUSI BLE ASSUMPTION FOR TURBULENT PRANDTL NIMMAER THE HEAT-TRANSFER EQUATION CAN THEN BE SOLVED DIRECTLY BY A DIGITAL CDMPUTER TO OBTAIN TEMPERATURE PROFILES AND THE HEAT TRANSFER AT THE WALL. THE METHOD HAS BEEN GPPLIED IN ZERO AND ADVERSE PRESSURE GRADIENTS WITH A STED IN HALL TEMPERATURE FOLLOWING AN INITIAL UNHEATED ENTRY LENGTH. TEHDERATURE PRQEILFS ARF NELL BEHAVED AND SHOW A REGION UF NEAR SIMILARITY IN THE WALL REGION AS OBSERVED EXDEPIMEVTALLY ELSEWHERE. IT IS NOTICEABLE THAT IN THE ADVERSE PRESSURE GRADIENT HEAT TRANSFER FALLS OCF VERY MUCH LESS RAPIDLY THAN SKIN FRICTION AS SEPARATION IS APPR DACHED. 
CATEGORY 5

ACCIDENT ANALYSIS

5-27046 \#CONT INUED*

*BOUNDARY LAYER + *FLOW, TURBULENT + *HEAT TRANSFER ANALYSIS + HEAT TRANSFER + MATHEMATICAL STUDY

$5-27047$

VAN WI JNGAARDEN.L

THE GROWTH OF SMALL CAVITATION BUBBLES BY CONVECTIVE DIFFUSION

8 PAGES, 2 FIGURES, 9 REFERENCES, INTERNATIONAL JUURNAL OF HEAT AND MASS TRANSFER, 10121 , PAGES $127-134$ (FEBRUARY, 1967 )

SOME YEARS AGO BEAUTIFULLY CONDUCTEO EXPERIMENTS ON THE GROWTH OF SMALL CAVITATION BUBBLES WERE REPORTED BY KERMEEN ET AL. AN APPROXIMATIVE CALCULATION FOR THE TIME IN WHICH BUBBLES GROW TO A CERTAIN SIZE BY CONVECTIVE DIFFUSION WAS GIVEN BY TWO OF THESE AUTHORS AS WELL. HOWEVER, VAPOR CONTENT OF THE BUBBLES AND SURFACE TENSION AT THE INTERFACE WITH THE FLUID WERE LEFT OUT OF ACCOUNT. IN THE PRESENT PAPER THE THEORY IS RE-EXAMINED. ALLOWANCE IS MADE FOR THE ABOVE-MENTIONED EFFECTS. A MODEL DUE TO LEVICH IS PROPOSED GOR THE CALCULATION OF THE MASS FLUX BY DIFFUSION IN THE BUBBLES. RESULTS ARE OBTAINED FOR THE DATA OCCURRING IN THE EXPERIMENTS OF PARKIN AND KERMEEN AND DISCUSSED IN CONNECTION WITH THESE FXPERIMENTS. AN EXPLANATION FOR THE OIFFERENCE BETWEEN THEORETICAL AND EXPERIMENTAL VALUES IS SUGGESTED.

* BUBBLE + \#UEL ELEMENT CLUSTER + \#MASS TRANSFER + FLOW, AXIAL + FLOW, TURBULENT + REACTOR CONTROL + REACTOR DYNAMICS

$5-27048$

LARSEN FW

RAPID CALCULATION OF TEMPERATURE IN A GENERATIVE HEAT EXCHANGER HAVING ARBITRARY INITIAL SOLID AND ENTERING FLUID TEM̈PERATURES

20 PAGES, 6 FIGURES, 5 TABLES, 9 REFERENCES, INTERNATIONAL JOURNAL OF HEAT AND MASS TRANSFER, $10(2)$, PAGES

149-168 (FEBRUARY, 1968 )

BY MEANS OF SIMPLE HAND CALCULATIONS IT IS POSSIBLE TO DETERMINE FLUID AND SOLID TEMPERATURES AT ANY TIME AND LOCATION IN THE REGENERATIVE HEAT EXCHANGER. THE METHODS DESCRIBED APPLY TO CASES WHERE THE INITIAL TEMPERATURE VARIES ARBITRARILY WITH LONGITUDINAL POSITION IN THE MATRIX AND THE ENTERING FLUID TEMPERATURE VARIES ARBITRARILY WITH TIME. THE SOLUTIONS FOR THE LINEAR INITIAL MATRIX TEMPERATURE AND LINEAR ENTERING FLUID TEMPERATURES ARE ALSO

PRESENTED IN THE FORM OF TABLES AND CURVES FOR THE SAME RANGE OF PARAMETERS. BY SUPERPOSITION, THESE RESULTS ARE EXTENDED TO THE CASES OF ARBITRARY INITIAL MATRIX TEMPERATURE AND ARBITRARY ENTERING FLUID TEMPERATURE. EITHER OF TWO METHODS IS USEFUL IN OBTAINING NUMERICAL RESULTS. ONE IS TO EVALUATE A CONVOLUTION INTEGRAL WHICH INVOLVES THE ARBITRARY CONOITION. THE OTHER IS TO APPROXIMATE THE ARBITRARY INITIAL (AND/OR BOUNDARY) CONDITION BY. A NUMBER OF LINEAR SEGMENTS ANO TO SUPERIMPOSE THE TABULATED SOLUTIQNS.

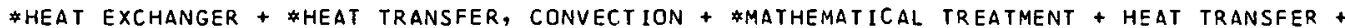
HEAT TRANSFER ANALYSIS + TEMPERATURE GRADIENT

$5-27049$

SUL IMAN M + CHAMBRE PL

DN THE TIME-DEPENDFNT LEVEOUE PROBLEM

12 PAGES, 5 FIGURES, TABLE, 13 REFERENCES, INTFRNATIONAL JOURNAL OF HEAT ANO MASS TRANSFER, 13121 . PAGLS $169=180$ (FEBRUARY, 1968 )

THE CLASSICAL STEAOY-STATE LEVEQUE PROBLEM IS GENERALIZED TO INCLUDE THE TIME DEPENDENCE. EXACT ANALYTICAL SOLUTIONS ARE PRESENTED FOR THE SURFACE HEAT FLUX DUE TO A TIME STEP IN THE SURFACE TEMPERATURE AND FOR THE CASE OF THE SURFAC.E TEMPERATURE DUE TO A TIME STEP IN THE WALL HEAT FLUX. THE INITIAL AND FINAL TIME BEHAVIOR OF THE SOLUTION IS EXPLORED ANALYTICALLY, AND THIS IS SUPPLFMENTED BY A NUMERICAL EVALUATION FÜR. THE ENTIRE TIME SPAN IN THE CASE OF A STEP IN THE SURFACE TEMPERATURE.

*HEAT TRANSFER, CONVECTIIN + \#ATHEMATICAL TREATMENT + *TEMPERATURE GRADIENT + HEAT TRANSFER + HEAT TRANSFER ANALYSIS

$5-27052$

ST. PIERRE CC + BANKAFF SG

VAPOR VOLUME PROFILES IN DEVELOPING TWO-PHASE FLOW

13 PAGES, 7 FIGURFS, TABLE, 2\% REFERENCES, INTERNATIUNAL JOURNAL OF HEAT AND MASS TRANSFER, IOI2I, PAGES

237-249 (FEBRUARY, 19681

TRANSVERSE VOID-FRACTION DISTRIBUTIONS AND AXIAL, CROSS-SECTIONAL AVERAGE VOID-FRACTION DATA HAVE BEEN OBTAINED FOR A RECTANGULAR FLOW CHANNEL AT ELEVATED PRESSUP.ES EMPLOYING THE Y-ATTENUATION TECHNIQUE. THE ABILITY OF SEVERAL CROSS-SECTIONAL MODELS AND CORRELATIONS TO PREDICT THE AXIAL, AVERAGE VOID DISTRIBUTIONS HAS ALSO BEEN TESTED. THE DEVELOPMENT DF VOID PROFILES IN BOTH THE AXIAL AND TRANSVERSE DIRECTIONS IN A FLOWING TWO-PHASE SYSTEM IS OF CURRENT INTEREST.

\#FLOW THEORY AND EXPERIMENTS + \#FLOW, TWO PHASE + *VOID FPACTION + FLOW, AXIAL + FLOW, CROSS +

HEAT TRANSFER, TWO PHASE + HOT CHANNEL 
CATEGORY 5

ACCIDENT ANALYSIS

$5-27053$

KAUTZKY DE + WESTHATER JW

FILM BOILING OF A MIXTURE ON A HORIZONTAL PLATE

4 PAGES, 3 FIGURES, 7 REFERENCES, INTERNATIONAL JOURNAL OF HEAT AND MASS TRANSFER, IOI2I, PAGES $253-256$

(FEBRUARY, 1968

THE GOAL OF THIS NEW RESEARCH WAS TO OBTAIN ACCURATE FILA-BOILING DATA FOR A MISCIBLE MIXTURE OF VOLATILE LIQUIDS. IT WAS OF INTEREST TO SHOW WHETHER THE RESULTS WOULD AGREE WITH PREDICTIONS BASED ON THE USE OF HEIGHTED PHYSICAL PROPERTIES IN THE EXISTING EQUATIONS FOR PURE LIQUIOS. THE FLAT-PLATE GEOMETRY WAS CHOSEN BECAUSE THE FILM-BOILING THEORY HAS BSEN WELL WORKED OUT FOR THIS GEOMETRY.

*FILM BOILING + *HEAT TRANSFER EXPERIMENT + *HEAT TRANSFER, BOILING + HEAT TRANSFER

$5-27054$

LOWE PA

A TWO DIMENSIONAL TURBULENT-FLOW MIXING MOOEL FOR PARALLEL-FLOW ROD BUNDLES

BROOKHAVEN NATIONAL LABORATORY

8 PAGES, 5 FIGURES, 2 TABLES, 13 REFERENCES, NUCLEAR SCIENCE ANO ENGINEERING, 32(1), PAGES 1-7 (APRIL, 19681

A TWO-DIMENSIONAL STEADY-STATE ENERGY EQUATION, IN TERMS OF THE FLUIO ENTHALPY RISE, FOR A NUCLEAR REACTOR CHANNEL IS FORMULATED AND SOLVED. TO FACILITATE ITS USEFULNESS TO THE REACTOR DESIGNER, THE SOLUTION IS PRESENTED IN THE FORM OF A HOT-CHANNEL FACTOR. PARAMETRIC RESULTS ARE PRESENTED SO THE INFORMATION MAY BE RELATEO TO OTHER CHANNEL DIMENSIONS. MIXING WAS FOUND TO BE A FUNCTION OF THE NONOIMENSIONAL GEOMETRY FACTOR AND THE PECLET NUMBER.

\#FLOW, TURBULENT + FUEL ELEMENT CLUSTER + \#MATHEMATICAL TREATMENT + FLOW THEORY AND EXPERIMENTS + FLOW, $A X I A L+F L O W$, MIXING

5-27055

BRANDON CA + KIDD GJ

IN-PILE HEAT-TRANSFER STUDIES OF ROUGHENED HELIUM-COOLED REACTOR FUEL ELEMFNTS

DAK RIDGE NATIONAL LABORATORY, OAK RIDGE, TENNESSEE

8 PAGES, 7 FIGURES, TABLE, 14 REFERENCES, NUCLEAR SCIENCE ANO ENGINEERING, 32(1), PAGES 8-15 (APRIL, 1968).

DURING A SERIES OF IN-PILE EXPERIMENTS DESIGNED TO STUDY IRRADIATION EFFECTS ON HIGH-PERFORMANCE OXIDE FUEL ELEMENTS FOR AOVANCED GAS-COOLED REACTORS, HEAT-TRANSFER DATA WERE OBTAINED FROM FOUR SPECIALLY INSTRUMENTAL FUEL RODS. AN ANNULAR GEOMETRY WAS UTILIZED HITH RODS OF 1.9- AND 2.18-CM DIAM BEING CONTAINED IN CHANNELS OF 2.44- AND 2.67-CM DIAM, RESPECTIVELY. THE EFFECTS OF WIRE-WRAPPED AND MACHINED SQUARE-THREAO SURFACE ROUGHNESS HERE MEASURED AND COMPARED WITH THE RESULTS OBTAINED FROM A SMOOTH ROD. ROUGHENING THE RODS INCREASED THE HEAT TRANSFER BY APPROXIMATELY A FACTDR DF $?$ WITH NO SIGNIFICANT DIFFERENCS BETWEEN THE WIRE-WRAPPED AND MACHINED ROUGHNESSES.

*FUEL ELEMENT + *HEAT TRANSFER, CONVECTION + *IN PILE LOOP + HEAT TRANSFER EXPERIMENT + ORR. (RR) + REACTOR, TEST

5-27056

FONTANA MH

ALSO IN CATEGORY 7

THE CHEMICAL EQUILIBRIA OF FISSION PRODUCT NUCLEAR FUEL MIXTURES -- THE URANIUM OXYGEN AND THE URANIUM OXYGEN STRONTIUM SYSTEM

OAK RIDGE NATIONAL LABORATORY, OAK RIDGE, TENNESSEE

ORNL-TM-2105 +. 272 PAGES, 31 FIGURES, 28 TABLES, 74 REFERENCES, SUBMITTED TO THE FACULTY OF PURDUE

UNIVEP.SITY IN PARTIAL FULFILLMENT OF THE REQUIREMENTS FOR THE DEGREE DOCTDR OF PHILDSOPHY, JULY IOGB

THE TRANSPORT OF FISSICN PRODUCTS RELEASED DURING A REACTOR ACCIDENT DEPENDS IN PART UPDN THE CHEMICAL STATE IN WHICH THEY EXIST. COMPUTATION DF CHEMICAL EQUILIBRIA IN THE GAS PHASE AROUND A MELTEO FUEL ELEMENT IS DIFFICULT BECAUISE THE FUEL MAY ACT AS A SOLVENT FDR FISSION. PRODUCTS. ALSO, FUELS SUCH AS URANIUM OXIDE FORM A NOVSTOICHIOMETRIC CONDENSEU PHASE. METHODS OF USING MULTICOMPONENT CHEMICAL-EQUILIBRIUM COMPUTER TECHNIQUES HAVE BEEN DEVELDPED FOR TREATING THIS PROBLEM, AND THEY HAVE BEEN TESTED AGAINST PUBLISHED KNUDSEN CELL-MASS SPECTRUMETER DATA FOR THE U-O SYSTEM. THIS SFRVED. AS A BASE POINT FROM WHICH THE U-SR-D SYSTEM WAS EXTENDED.

AVAILABILITY - CLEARINGHOUSE FOR FEDERAL SCIENTIFIC AND TECHNICAL INFORMATION, SPRINGFIELD, VA. 22.15I $\$ 3.00$ COPY, \$0.65 MICROFICHE

\#CHEMICAL EQUILIBRIUM + \#FISSION PRODUCT RELEASE, GENERAL + \#FISSION PRJOUCT TRANSPORT + OXYGEN + STP.ONTIUM + IIRANIUM DIOXIOE + URANIUM, NATURAL

$5-27057$

SMITH EC + GUNTER AY + VICTORY SP

FIN TUBE PERFORMANCE 
5-27057 \#CONTINUEO*

RICE UNIVERSITY, HOUSTON, TEXAS

11 PAGES, 14 FIGURES, 5 TABLES, 22 REFERENCES, CHEMICAL ENGINEERING PROGRESS, 62(7), PAGES 57-67 (JULY, 19661

SINGLE-TUBe HEAT TRANSFER AND MECHANICAL-STRAIN-GAUge TEST dATA ARE PRESENTED FoR 8 IMETAL EXTRUDED AND FOOTED-TENSION-WOUND INTERFERENCE-FIT FIN TUBES. THESE TUBES HERE ALSO TESTED ON A SEMIPLANT-SCALE APPARATUS AT STEAOY-STATE AND CYCLING CONDITIONS WITH AIR AND WATER.

\#FIN + \#HEAT TRANSFER, CONVECTION + AIR + EQUIPMENT DESIGN + HEAT EXCHANGER + HEAT TRANSFER

$5-27059$

FROST W + DZAKOWIC GS

GRAPHICAL ESTIMAT'ION OF NUCLEATE BOLLING HEAT TRANSFER

UNIVERSITY OF TENNESSEE SPACE INSTITUTE, TULLAHOMA, TENNESSEE

2 PAGES, FIGURE, 2 TABLES, 4 REFERENCES, I + EC PROCESS DESIGN AND DEVELOPMENT, 6(3), PAGES 346-347 (JULY, 19671

A METHOD FOR GRAPHICALLY PRESENTING FULLY DEVELOPED NUCLEATE-BOILING HEAT-TRANSFER

CORRELATIONS CURRENTLY USED FOR DESIGN PURPOSES ENABLES THE ENGINEER TO COMPUTE A NUMERICAL

VALUE OF THE BOILING HEAT FLUX, OR CORRESPONDING WALL SUPERHEAT, RAPIDLY AND WITHOUT

KNOWLEDGE OF THE PHYSICAL PROPERTIES OF THE FLUID, OTHER THAN AT ONE ARBITRARY REFERENCE

STATE.

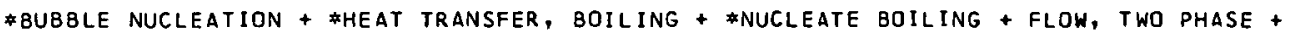

HEAT TRANSFER CORRELATION + HEAT TRANSFER, TWO PHASE

$5-27060$

THOMAS DG

ENHANCEMENT OF FORCEO CONVECTION HEAT TRANSFER COEFFICIENT USING DETACHED TURBULENCE PROMOTERS OAK RIDGE NATIONAL LABORATORY, OAK RIDGE, TENNESSEE

6 PAGES, 4 FIGURES, 2 TABLES, 16 REFERENCES, I + EC PROCESS DESIGN ANO DEVELOPMENT, 6(3), PAGES 385-390

(JULY, 1967 )

THE EFFECT OF SQUARE-CROSS-SECTION RINGS SUPPORTED AWAY FROM THE HEAT-TRANSFER SURFACE (DETACHED TURBULENCE PROMOTERS) ON THE RATE OF FORCED CONVECTION FROM CONDENSING STEAM TO WATER WAS STUDIED IN A VERTICAL-TUBE GEDMETRY. UNIFORMLY SPACED DETACHEO PROMOTERS PROOUCEO SIGNIFICANT INCREASES IN HEAT-TRANSFER COEFFICIENTS, BUT THE PRESSURE DROP WAS RELATIVELY LARGE. BY COMBINING RINGS IN PAIRS WITH CONSIDERABLE SEPARATION BETWEEN PAIRS, IT WAS

POSSIBLE TO INCREASE THE OVERALL HEAT-TRANSFER COEFFICIENT WITH SIGNIFICANTLY SMALLER

INCREASE IN PUMPING POWER THAN WOULD HAVE BEEN REQUIRED BY SIMPLY INCREASING THE VELOCITY.

\#FLOW, TURBULENT + \#HEAT TRANSFER, CONVECTION + HEAT TRANSFER + HEAT TRANSFER COEFFICIENT + HEAT TRANSFER EXPERIMENT + ORNL

5-27C61

CLERICI GC + GARRIRRA $S$ SALA B TOIII A

SFUDIÉS ON BURNOUT. PART I - ALTERNATIVE FORMS FOR SOME BURNOUT CORRELATIONS.

CENTRO STUDI NUCLEARI DELLA CASACCIA, GNEN, ITALY

9 PAGES, 5 FIGURES, 17 REFERENCES, ENERGIA NUCLEARE, 1415), PAGES 280-288 (MAY, 1967 )

IN THIS PAPER IT IS SHOWN HOW SOME CORRELATIONS CAN BE REOUCED TO THE LINEAR FORM T EQUALS AIB-XI BY MEANS OF SUITABLE TRANSFORMATIONS OF APPROXIMATIONS. THE EXPRESSIONS OBTAIVED IN SUCH A WAY HAVE CONSIDERABLE SIMILARITY IN THE DEPENDENCE OF A AND B ON THE PHYSICAL AND GEOMETRICAL PARAMETERS. GRAPHIT.AL COMPARISONS, GIVEN FOR A PARTICULAR CASE, SHOH A GOOD AGREEMENT AMONGST THE ALTERNATIVE FORMS ANO THE ORIGINAL DNES.

* BURNOUT HEAT FLUX + \#FI IW, THO PHASE + \#HCAT TRANSFER CORRELATION + HEAT FLUX, CRITICAL + HEAT FLUX, DRYOUT + HEAT TRANSFER + HEAT TRANSFER, TWO PHASE

$5-27064$

SHOTKIN LM

EFFECT OF SLIP RATIO DN THE CRUCIAL BOILING LENGTH IN TWO-PHASE INSTABILITY

BROOKHAVEN NATINNAL LABORATORY, UFTON, NEW YORK

BNL-11532 + CONF-670912-2 +. 16 PAGES, 14 REFERENCES, FROM SYMPOSIUM ON THE DYNAMICS OF TWO PHASE FLOW, EINDHOVEN, NETHERLANDS, JUNE, 1967

THE CRUCIAL BOILING LENGTH FOR A SINGLE CHANNEL IS THAT POSITION OF THE BOILING BOUNDARY WHEP.E THE CHANNEL IS LEAST STABLE, OR WHERE THE RATIO OF HEAT INPUT TO COOLANT FLOW RATE, Q/G, IS A MINIMUM. THE ANALYTICAL RELATION BETWEEN O/G AND THE REST OF THE CHANNEL PARAMETERS DEPENDS VERY MUCH ON THE THEORET ICAL MODEL USED AND, IN PARTICULAR, ON THE EMPIRICAL FORM OF THE SLIP RATIO. WE HAVE USED A SPATIALLY AVERAGED MODEL TO COMPUTE Q/G SUB-MIN AND COMPARED IT WITH EXPERIMENT FROM SEVERAL LABORATORIES.

AVAILABILITY - CLEARINGHOUSE FOR. FEDERAL SCIENTIFIC AND TECHVICAL INFORMATION, SPRINGFIELD, VIRGINIA $22151, \$ 3.00$ COPY, $\$ 3.65$ MICROFICHE

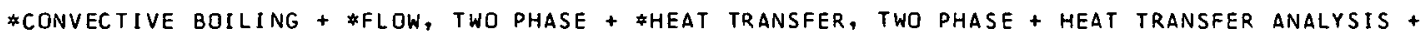


A THEORETICAL STUDY IS MADE OF STEADY TWO-DIMENSIONAL LAMINAR FILM CONDENSATION OF PURE SATURATED STEAM AT $100 \mathrm{C}$ AND ATMOSPHERIC PRESSURE ON AN ISOTHERMAL VERTICAL WALL. THE VARIABLE PHYSICAL PROPERTIES OF THE LIQUIO CONOENSATE ARE TAKEN TO $3 E$ THOSE OF SATURATFO WATER AT THE APPROPRIATE TEMPERATURES. THE RELATED RESULTS ON WALL HEAT TRANSFER AND MASS FLOW IN THE LIQUIO PHASE ARE PRESENTED ANO COMPARED IN DETAIL WITH THOSE FROM EXISTING THEORIES.

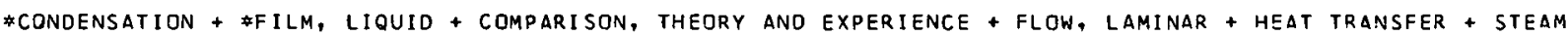

5-27302

HSU C

ANALYTICAL STUOY OF HEAT TRANSFER TO LIQUID METALS FLDWING ALONG A ROW OF SPIIERES

BROOKHAVEN NATIONAL LABORATORY, UPTON, NFW YORK

16 PAGES, 3 FIGURES, 2 TABLES, 11 REFERENCES, INTERNATIONAL JOURNAL OF HEAT AND MASS TRANSFER, 101121, PAGES 1693-1708 (DECEMBER 1967 )

ON THE POSTULATION OF INVISCIO POTENTIAL FLOW, THEORETICAL ANALYSES HAVE BEEN PERFORMED FOR HEAT TRANSFER TO LIQUID METALS FLOWING ALONG A QOW OF EQUALLY-SPACEO SPHERES, THE PITCH-TO-DIAMETER RATIO OF WHICH RANGFS FROM UNITY (TOUCHING SPHERES) TO INFINITY (A SINGLE SPHERE IN THE FLUID STREAMI. EXPLICIT EXPRESSIONS FOR THE AVERAGE NUSSELT NUMBER WERE OBTAINED FOR UNIFORM SURFACE TEMPERATURE AND FOR UNIFORM SURFACE HEAT FLUX. IT WAS REVEALED THAT THE SURFACE VELOCITY POTENTIAL FACTOR IS SOLELY A FUNCTION OF THE PITCH-TO-DIAMETER RATIO. NUMERICAL VALUES OF THE PHI PRIME SUB PI/R CUBED WERE DETERMINED BY MEANS OF AN IBM DIGITAL COMPUTER. IT WAS FOUNO TO VARY FROM 20 FOR FLOW PAST A SINGLE SPHERE TO ABDUT I-SG39 FOR FLOW ALONG A ROW OF TOUCHING SPHERES.

* METAL, LIQUID + heAT TRANSFER + heAT TRANSFER anALYSIS + LiQUID + SPHERE

$5-27305$

BARD $Y+$ LEONARD EF

HEAT TRANSFER IN SIMULATED BOILING

COLUMBIA UNIVERSIIY, NEW YORK, N.Y.

'8 PAGES, 6 FIGURES, 19 REFERENCES, INTERNATIONAL JOURNAL OF HEAT AND MASS TRANSFER, 101121 , PAGES

1727-1734 (DECEMBER 1967 )

AN EXPER IMENTAL STUDY WAS UNDERTAKEN TO DETERMINE THE VARIATIONS OF HEAT-TRANSFER COEFFICIENT ON A SUBMERGED HEATING SURFACE WHILE AIR BUBBLES HERE INJECTED INTO THE LIQUID THPQDUSH AN URIFICE IN THE PLATE. THE RESULTS INDICATED THAT HEAT TRANSFER IS MOST INTENSIVE DURING THE TIME THAT THE BUBBLE DETACHES FROM THE SURFACE. THIS CASTS DOUBTS ON BOILING HEAT-TRANSFER CORRELATIONS BASED ON BUBBLE GROWTH DR RISING PHASE CONSIDERATIONS. IN CONCLUSION, IT SUGGESTEO THAT THE AGITATION ANO LATENT HEAT VIEWS OF BOILING HEAT TRANSFER MAY BE COMBINEO IN A UNIFIED MODEL.

\$HEAT TPANSFFR FXPFRIMENT + \#HEAT TRANSFER, TWO PHASE + \#NUCLEATE BOILING + CONVECTIVE BOILING + HEAT TRANSFFR

5-27306

PY B

RAYONNEMENT THERMIQUE DES METAUX MICRORUGUEUX OU DISPERSES

LABORATOIRE DE MECANIQUE, ECOLE NATIONALE SUPERIEURE D ELECTRICITE ET DE MECANIQUE, NANCY

8 PAGES, 9 FIGURES, I TABLE, 6 REFERENCES, INTERNATIONAL JOURNAL OF HEAT AND MASS TRANSFER, $10(12$ ), PAGES 1735-1742 (DECEMBER 1967 )

THE INCKEASE OF THERMAL RADIATION OF ALUMINUM. AND TITANIUM WITH SURFACES HAVING A GREAT NUMBER OF DIMENSIONS INFERIOR TO THE WAVELENGTH OF RADIATION HAS BEEN STUDIED IBY COMPARISUN WITH POLISHED METALS). WE DBSERVE AN INCREASE IN THE ENERGY RADIATED WHEN MICRO PARTICLES OF PLATINUM ARE EMBEUUEO IN A THIN FILM OF ALUMINA ON WIRES OR STRIPS OF ALUMINUM. THE RESULTS SHOW THE DIFFERENCE BETWEEN THE PHENOMENON OF RAOIATION AND THAT DF THERMAL ACCOMMODATION FROM THE POINT OF VIEW OF EFFECT OF ROUGHNESS.

\#HEAT TRANSFER EXPERIMENT + \#HEAT TRANSFFR, RADIANT + \#THEORETICAL INVESTIGATION + ALUMINUM + TITANIUM 
CATEGORY 5

ACCIDENT ANALYSIS

5-27308 *CONTINUED*

MASS TRANSFER TO THE REAR OF A SPHERE IN STOKES FLOW

UNIVERSITY OF CALIFORNIA, BERKELEY

8 PAGES, 2 FIGURES, 3 REFERENCES, INTERNATIONAL JOURNAL OF HEAT AND MASS TRANSFER, $10(12)$, PAGES $1749-1756$ IDECEMBER 1967 )

MASS TRANSFER TO A SPHERE, INCLUDING THE REAR REgION, IN STOKES FLOW AND AT LARGE PECLET NUMBERS, IS INVESTIGATED. BY THE SINGULAR-PERTURBATION TECHNIQUE, SIX DISTINCT REGIONS OF DIFFERENT MASS-TRANSFER MECHANISMS ARE FOUND. ONE OF THESE REGIONS, THE DIFFUSION LAYER, HAS ALREADY BEEN SOLVED BY THE BDUNDARY-LAYER METHOD. ANOTHER AREA, THE REGION AT THE REAR OF THE SPHERE, IS SOLVED HERE. TO PREDICT THE MASS TRANSFER RATE EVERYWHERE ON THE SPHERE, $\triangle$ COMPOSITE SOLUTION CAN BE FORMED FROM THE BOUNDARY-LAYER SOLUTION AND THE REAR-REGION SOLUTION. IN HEAT- AND MASS-TRANSFER PROBLEMS, THE METHOD USEO HERE COMPLEMENTS THE BOUNDARY-LAYER METHODS IN PREDICT ING THE HEAT- OR MASS-TRANSFER RATE AT THE REAR OF AXISYMMETRIC OBJECT.

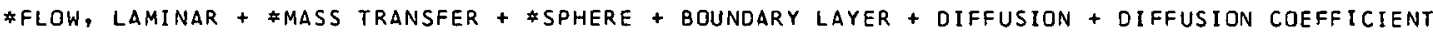

$5-27309$

ESHGHY S + HORNBECK. RW

FLOW AND HEAT TRANSFER IN THE AXISYMMETRIC BOUNDARY LAYER OVER A CIRCULAR CYLINDER

CARNEGIE-MELL ON UNIVERSITY, PITTSBURGH, PENNSYLVANIA

10 PAGES, 6 FIGURES, 2 TABLES, 7 REFERENCES, INTERNATIONAL JOURNAL OF HEAT AND MASS TRANSFER, IOIIII, PAGES 1757-1766 (DECEMBER 1967 )

THE PROBLEM OF LAMINAR BOUNDARY-LAYER FLOW AND HEAT TRANSFER OVER A LONG THIN CYLINDER IN UNIFORM FLOW HAS BEEN ANALYZED. SOLUTIONSARE OBTAINED FOR SMALL AS WELL AS LARGE VALUES OF THE CURVATURE PARAMETER. SOLUTIONS VALID FDR SMALL VALUES OF CURVATURE ARE EXTENDED TO APPLY TO INTERMEDIATE VALUES OF CURVATURE AS WELL. THIS IS DONE BY CASTING THE EXPRESSIONS INTO FRACTIONS. FINALLY, THESE FRACTIONS ARE JOINED WITH THE ASYMPTOTIC SOLUTION TO PRODUCE HEAT-TRANSFER ANO SKIN FRICTION RESULTS OF ALL VALUES DF THE CURVATURE PARAMETER. THE SHAPES DF THE VELOCITY AND TEMPERATURE PROFILES ARE GIVEN GRAPHICALLY.

*CYLINDER + \#FLOW, AXIAL + *HEAT TRANSFER, CONVECTION + FLOW, gENERAL + HEAT TRANSFER ANALYSIS + MATHEMATICAL TREATMENT

$5-27310$

CHISHOLM D

A THEORETICAL BASIS FOR THE LOCKHART MARTINELLI CORRELATION FOR TWO-PHASE FLOH

NATIONAL ENGINEERING LABORATORY, APPLIED HEAT TRANSFER DIVISION, EAST KILBRIDE, GLASGOW

12 PAGES, 6 FIGURES, 5 TABLES, 15 REFERENCES, INTERNATIONAL JOURNAL OF HEAT AND MASS TRANSFFR, $10(12)$, PAGES 1767-1778 (DECEMOER 1967)

EQUATIONS ARE DEVELDPED IN TERMS OF THE LOCKHART-MARTINELI CORRELATING GROUPS FOR THE FRICTION PRESSURE GRADIENT DURING THE FLOW OF GAS-LIOUID OR VAPOUR-L IQUID MIXTURES IN PIPES. THE THEORETICAL DEVELOPMENT DIFFERS FROM PREVIOUS IREATMENTS IN THE METHOD OF ALLOWING FOR THE INTERFACIAL SHEAR FORCE BETWEEN THE PHASES. SOME OF THE ANOMALIES OCCURRING IN PREVIOUS JUMPED FLOW MODELS ARE AVDIDED. GOOD AGREEMENT WITH LOCKHART-MARTINEI.I FMPIRICAL CURVES ARE OBTAINCD. SIMPLIFIED EQUATIUNS FOR USE IN ENGINEERING DESIGN ARE ALSO GIVEN.

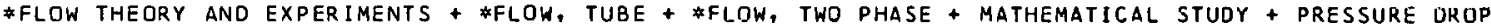

$5-27312$

ZABROOSKY SS

ON SOLID-TD-FLUID HEAT TRANSFER IN FLUIDIZED SYSTEMS

B.S.S.R. ACADEMY OF SCIENCES, MINSK, R.S.S.R., U.S.S.R.

8 PAGES, 4 FIGURES, 13 REFERENCES, INTERNATIONAL JOURNAL OF HEAT ANO MASS TRANSFER, IOII I, PAGES

1793-1800 (DECEMBER 1967)

THE COMPARISON OF THE HEAT-TRANSFER COEFFICIENTS FOR PARTICLES AND FOR BDOIES IMMERSED IN A FLUIDIZED BED, CONFIRMS THE OPINION THAT LOW EFFECTIVE VALUES OF NU OF SOLID PARTICLES APPEAR HERE SIMULTANSOUSLY WITH HIGH TRUE VALUES OF NU MAINLY BECAUSE OF THE NON-UNIFORMITY OF GAS DISTRIBUTION. AN APPROXIMATE SIMPLE INTERPRETATION IS GIVEN OF THE REDUCTION OF THE

SOLIO-TO-FLUID HEAT TRANSFER IN CONVENTIONALLY UNIFORM GRANULAR BEDS AT LOW PECLET NUMBERS. ALSO SHOWN IS THE INFLUENCE OF SYSTEMS OF GRANULAR BED HEAT EXCHANGERS AND OF SOLIO MIXING ON THE POSTTION OF THE ZONE OF ACTIVL HEAT EXCHANGE.

\#FLUIDIZED BED + \#HEAT TRANSFER, TWO PHASE + HEAT TRANSFER + HEAT TRANSFER COEFFICIENT +

HEAT TRANSFER CORRELATION + HEAT TRANSFER, CONVECTION

$5-27313$

MORI Y + FUTAGAMI K

FORCED CONVECTIVE HEAT TRANSFER IN UNIFORMLY HEATED HORIZONTAL TUBES (2ND REPORT, THEORETICAL STUDY)

DEPAR TMENT OF MECHANICAL ENGINEERING, TOKYO INSTITUTE OF TECHNOLOGY, MEGURO-KU, TOKYO

13 PAGES, 9 FIGURES, 7 REFERENCES, INTERNATIONAL JOURNAL OF HEAT AND MASS TRANSFER, IOII2I, PAGES

$1801-1813$ (DECEMBER 1967 )

EFFECTS OF BUOYANCY FORCE ON FORCED LAMINAR CONVECTIVE HEAT TRANSFER IN A UNIFORMLY HEATED 
CATEGORY 5

ACCIDENT ANALYSIS

$5-27313$ \#ONTINUED*

HORI ZONTAL TUEE MAY NOT BE NEGLECTEO AT LARGE RE RA. THIS 2ND REDORT DEALS WITH A

THEORETICAL INVESTIGATION OF THIS PROBLEM ON A FULLY DEVELOPED LAMINAR FLJW AND COMPARES THE RESULTS WITH EXPERIMENTAL RESULTS REPORTED IN THE IST KEPORT. IN ORDER TO $3 A C K$ UP

ASSUMPTIONS MADE IN THE FOLLOWING ANALYSIS, PATTERNS OF SECONDARY FLOW DUE TO BUOYANCY ARE OBSERVED IN FLOW OBSERVED IN FLOW VISUALIZATION EXPERIMENTS. AN APPROXIMATE SOLUTION FOR VERY LARGE RE RA IS OBTAINED. NUSSELT NUMBERS ARE SHOWN $\triangle S$ A FUNCTION OF RE RA AND PR AND ARE SHOWN TO BE IN FAIRLY GOOD AGREEMENT WITH EXPERIMENTAL RESULTS ON AIR. RESISTANCE COEFFICIENTS ARE ALSO OBTAINED AS A FUNCTION OF RE RA AND PR.

\#FLOW, LAMINAR + \#LLOW, TUBE + \#HEAT TRANSFER, CONVECTION + \#THFORETICAL INVESTIGATION + HCAT TRANSFCR + HEAT TRANSFER ANALYSIS

$5-27314$

MILLS AF + SEBAN RA.

THE CONDENSATION COEFFICIENT OF WATER

UNIVERSITY OF CALIFORNIA, LOS ANGELES + UNIVERSITY OT CALICORNIA, BERKELEY

13 PAGES, 4 FIGURES, 4 TABLES, 36 REFERENCES, INTERNATIONAL JOURNAL OF HEAT AND MASS TRANSFER, IRII2I, PAGES 1815-1827 (DECEMBER 1967)

FILMWISE CONDENSATION OF STEAM AT LOW'PRESSUR. TN A VERTICAL FLAT PLATE WAS INIVESTIGATED EXPERIMENTALLY IN OROER TO ASTERTAIN THE EXISTENCE OF AN INTERFACIAL HEAT-TRANSFER RESISTANCE AND HENCE DEDUCE A VALUE OF THE MASS ACCOMMODATION OR CONDENSATION CGEFEICIENT OF WATER. DATA IS PRESENTED FOR THE CONDENSATION OF SATURATEO STEAM BETWEEN 45 ANO 50 O AT HEAT FLUXES BETWEEN 9000 ANO 12000 BTU/H-FT2-DEGF. IT WAS FOUNO THAT NC SIGNIFICANT INTERFACIAT RESISTANCE WAS PRESENT AND THE CONDENSATION COEFFICIENT WAS DEOUCEO TO HAVE A VALUE BETINEEN 0-45 AND INITY. THAT THE CONDENSATION COEFFICIENT IS AT LEAST GREATER THAN O-45 ENSURES THAT THE INTERFACIAL RESISTANCE WILL BE NEGLIGIBLE IN INDUSTRIAL APPLICATION OF FILMWISE CONDENSATION. THE INABILITY TO OETERMINE A MORE EXAC.T VALUE FOR THE CJEFEICISNT WAS DUE TO AN INHERENT LIMITATION IN THE TECHNIQUE AND THE RANGE OUOTEO MUST NOT BE TAKEN TO FAVDR AN INTERMEOIATE VALUE.

\#HEAT TRANSFER, CONDENSATION + \#MASS TRANSFER + *WATER, GENERAL + HEAT TRANSFFR EXPERIMEN'i + STEAM

$5-27315$

SPARROW EM + MINKOWYCZ WJ + SADOY M

FORCEO CONVECTION CONOENSATION IN THE PRESENCE OF NONCONDENSABLES AND INTERFACIAL RESISTANCE UNIVERSIDADE DO BRASIL, RIO DE JANEIRO + UNIVERSITY OF ILLINOIS AT CHICAGO CIRCLE, CHICAFO, ILLINOIS 17 PAGES, 9 FIGURES, 1 TABLE, 12 REFERENCES, INTERNATIONAL JOURNAL OF GEAT AND MASS TRANSFER, IO (I2), PAGES $1829-1845$ (DECEMBER 1967 )

THE EFFECT OF A NONCONDENSABLE GAS ON CONDENSATION IN A FORCED CONVECTION LAMINAR BOUNDARY-LAYER FLOW IS EXPLUREO ANALYTICALLY. THE GEVERAL FORMIJLATIMN IS ADPLIED TD THE STEAM-AIR SYSTEM, AND THE HEAT TRANSFER WITH AND WITHOUT THE NONCONDENSABLE IS COMPARED FOR A HIDE RANGE OF OPERATING CONDITIONS. THE REDUCTIONS IN HEAT TRANSFER DUE TO THE NONCONDENSABLE ARE ACCENTUATED AT LOW OPERATING PRESSURES. IN GENERAL, CONDENSATION IN THE FORCED CONVECTION FLOW IS MUCH LESS SENSITIVE THAN THAT IN A GRAVITY FLOH. THE EFFECT OF AN INTERFACIAL RESISTANCE (I.E., A TEMPERATURE JUMP AT THE LIQUID-VAPOR INTERFACE) IS ALSO EXAMINED. THE COMPUTED RESULTS REVEAL A NEGLIGIBLE EFFECT ON THE HEAT' TRANSFER.

* BOUNDARY LAYER + \#HEAT TRANSFER, CONDENSATION + \#HEAT TRANSFER, CONVECTION + \#MASS TRANSEER + DIFFUSION COEFFICIENT + HEAT TRANSFER

5-27316

CIICESEWIICHT D

NATURAL CONVECTION FROM A PLANE, VERTICAL SURF̈ACE IN NON-ISUIHLKMAL SURROUNDINGS UNIVERSITY OF MICHIGAN

13 PAGES, 4 FIGUPES, 2 .TABLES, 17 REFERENCES, INTERNATIONAL JOURNAL OF HEAT $\triangle N D$ MASS TRANSFER, IOII 2 , PAGES 1847-1859 (DECEMBER 1967)

THIS PAPER PRESENTS A THEORETICAL INVESTIGATION OF LAMINAR NATURAL CONVECTION FROM A PLANE, VERTICAL SURFACE IN NON-ISOTHERMAL SURROUNDINGS. CONDITIJNS ARE DERIVED FOR THE EXISTENCE OF SIMILARITY SOLUTIONS A METHOD IS PROPOSED FOR GENERALIZING THE CONDITIONS PERT.AINING TO EXISTING SIMILARITY SOLUTIONS SO AS TO INCLUDE THE EFFECT OF NON-ISOTHERMAL SURROUNDINGS. NUMERICAL SOLUTIONS OF THE OROINARY DIFFERENTIAL EQUATIONS RESULTING FROM THE SIMILARITY TRANSFORMATION ARE REPDRTED FOR THE SPECIAL CASE DF AN ISOTHERMAL SURFACE. THESE RESULTS SUGGEST IHAI SUME VARIATION3 OF SURMOUNDING TEMDERATIIRF MAY LEAD TO FLOW REVERSAL IN THE BOUNDARY LAYER. EXPERIMENTAL EVIDENCE SUGGESTS THAT THIS MAY BE AN UNSTABLE CONDITIUN.

HLOH, LAMINAP + HFAT TRANSFER, NATURAL CONVECTION + THEORETICAL INVESTIGATION + HEAT TRANSFER + HEAT TRANSFER ANALYSIS

$5-27317$

INCROPERA FP + LEPPERT G

LAMINAR FLOW HEAT TRANSFER FROM ARGON PLASMA IN A CIRCULAR TUBE

STANFORD UNIVERSITY, STANFURD, CALIFORNIA

13 PAGES, 6 FIGURES, 2 TABLES, I6 REFERENCES, INTERNATIONAL JOURNAL OF HEAT AND MASS TRANSFER, IOI 12 ),

PAGES 1861-1873 (DECEMBER 1967) 


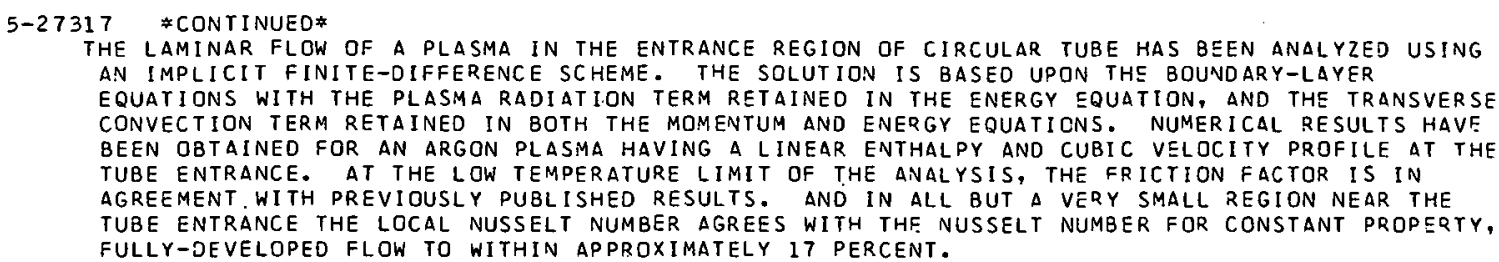

\#FLOW, TUBE + \#FLOW, TURBUI,FNT + HENT TRANSFER, CONVECTION + HEAT TRANSFER + HEAT TRANSFER ANALYSIS

$5-27321$

LEWIS GK

SHAPE FACTORS IN CONOUCTION HEAT FLOW. FOR CIRCULAR BARS AND SLABS WITH VARIOUS INTERNAL GEOMETRIES UNIVERSITY OF ASTON IN BIRMINGHAM, ENGLAND

8 PAGES, 4 FIGURES, 2 TABLES, 5 REFERENCES, INTERNATIONAL JOURNAL OF HEAT AND MASS TRANSFFR, II (6), PAGES $985-992$ (JUNE 1968 )

SHAPE FACTORS OESCRIBING THE STEADY-STATE, TWO-OIMENSIONAL FLOW OF HEAT IN CIRCULAR BARS AND SLABS WITH VARIOUS INTERNAL GEOMETRIES AND ISOTHERMAL BOUNDARY CONDITIONS ARE COMPUTED BY A CONFORMAL MAPPING PROCEDURE.

*HEAT TRANSFER, CONDUCTION + \#THERMAL ANALYSIS + HEAT TRANSFER + hEAT TRANSFFR ANALYSIS

$5-27322$

KATTOY + YOKOYA S

PRINCIPAL MECHANISM OF BOILING CRISIS IN POOL BOILING

DEPARTMENT OF MECHANICAL ENGINEER ING, UNIVERSITY OF TOKYO, HONGO, TOKYO, JAPAN

8 PAGES, 13 FIGURES, 15 REFERENCES, INTERNATIONAL JOURNAL OF HEAT AND MASS TRANSFER, 11161, PAGES $993-1002$ (JUNE 1968 ) 
CAT.EGORY

ACCIDENT ANALYSIS

$5-27322 *$ CONT INUED*

HIGH-SPEED PHOTOGRAPHY WAS USED TO STUDY THE MECHANISM OF THE BOILING CRISIS IN POOL BDILING OF SATURATED WATER AT HIGH HEAT FLUXES. THREE CONF IGURATIONS HAVE BEEN EXAMINED - NJRMAL FREE BOILING ON A HEATED IO-MM DIA. HORIZONTAL COPPER DISC AND THE SAME SYSTEM SUBJECTED TO THE INTERFERENCE OF A FLAT PLATE AND A SHORT TUBE HELO ABOVE THE HEATED DISC. PREVIOUS THEORIES OF BOILING CRISIS AND TRANSITION BOILING ARE OISCUSSED IN RELATION TO THE MECHANISM REVEALED BY THE PRESENT STUDY.

\#POOL BOILING + \#THEORETICAL INVESTIGATION + HEAT TRANSFER EXPERIMENT + HEAT TRANSFER, BOILING + HEAT TRANSFER, SUPERCRITICAL

$5-27324$

LEE K + BARROW H

TRANSPORT PROCESSES IN FLOW AROUNO A SPHERE WITH PARTICULAR P.EFERENCE TO THE TRANSFER OF MASS UNIVERSITY OF LIVERPOOL, ENGLAND

14 PAGES, 14 FIGURES, 25 REFERENCES, INTERNATIONAL JOURNAL OF HEAT ANO MASS TRANSFER, II(G), PAGES 1013-1026 (JUNE 1968 )

THE INTEGRATED BOUNOARY-LAYER EQUATIONS ARE SOLVED TO CALCULATE THE DEVELODMENT OF THE DIFFUSION IOR THERMAL) BQUNDARY LAYER FROM THE FORWARD STAGNATION POINT OF A SPHERE UP TO THE POINT OF SEPARATION, FOR VARIOUS VALUES OF THE SCHMIOT (OP PRANDTL) NUMBER. THE POHIHAUSEN POLYNUMIAL PROFILES ARE USED TO DESCRIBE THF SHAPES OF THE TRANSFER LAYERS IN THE LAMINAR REGIDN. THE EXPERIMENTAL RESULTS FOR THE LAMINAR REGION ARE COMPARED WITH THOSE ACCORDING TO THE THEORY. FOR THE WAKE, A STUDY OF THE EXPERIMENTAL DATA SHOWS THAT IT IS POSSIBLE TO SPECIFY THREE SEPARATE REGIMES CORRESPONDING TO DIFFERENT REYNOLDS NUMBER RANGES. THE PRESENT RESULTS ARE COMB INED WITH THOSE OF OTHER EXDERIMENTERS IN HEAT AND MASS TRANSFER TO OBTAIN AN OVERALL TRANSFER COEFFICIENT FROM A SPHERE FOR A REYNOLDS NUMBER RANGE DF $200-200,000$.

*MASS TRANSFER + \#MATHEMATICAL TREATMENT + \#SPHERE + BOUNDARY LAYER + COMPARISON, THEORY AND EXPERIENCE + DIFFUSION + DIFFUSION COEFFICIENT

5-27325

HAUPTMANN EG

THE INFLUENCE OF TEMPERATURE DEPENDENT VISCOSITY ON LAMINAR BOUNOARY-LAYER STABILITY

THE UNIVERSITY OF BRITISH COLUMBIA, VANCOUVER, 3.C., CANADA

4 PAGES, 2 FIGURES, 6 REFERENCES, INTERNATIONAL JOURNAL OF HEAT AND MASS TRANSFER, 1!(E), DAGSS IO49-1OS 2

(JUNE 1968 )

THE TITLE PROBLEM IS ANALYZED GOR SMALL VARIATION IN VISCOSITY BY USING A PERTURBATION PROCEDURE. CONSIDERATION IS RESTRICTED TO INCOMPQESSIBLE, FLAT PLATE FLOW. THE QFSULTS SHOW THAT APPRECIABLE STABILIZATION MAY OCCUR IN WATER OR OTHER LIQUIDS, WHILE AIR IS SLIGHTLY DESTABILIZED. REASONABLE AGREEMENT WITH PREVIOUS CXRFRIMENTAL RESIIITS IN AIR IS OBTAINED.

*BOUNDARY LAYER + \#FLOW, LAMINAR + \#TRANSPORT PROPERTY + FLOW STABILITY + FLOW THEQRY $\triangle N D$ EXDERIMENTS + FLOW, GENERAL

$5-27326$

APELBLAT A + KATCHALSKY A

MASS TRANSFER WITH A MOVING INTERFACE

ISRAEL ATOMIC ENERGY COMMISSION, NUCLEAR RESEAP.CH CENTER, NEGEV AND DOLYMCR DEDAPTMENT, THE WEIZMANN

INSTITUTE OF SCIENCE, REHOVOTH, ISRAEL

15 PAGES, 6 FIGURES, 14 RETERENCES, INTERNATIIINAL JOURNAL OF HEAT AND MASS TRANSFER, IIIGI, PAGSS

1053-1067 (JUNE 1968 )

MASS TRANSFER IN THE LAMINAR, CD-CURENT FLOW OF T'HO FLUIUS IN A RgCTANOULAR CITANNEL IS INVESTIGATED. DISTRIBUTION OF CONCENTRATIONS AND THE LOCAL MASS-TOANSFER CJEFEICIENTS ARE CALCULATEO FOR TIIE IDEAL FLOW. THE T.DUETTE FLOW AND FOR THE FLOW WITH PARABOLIC DRQFILE ANALYTICAL AND APPROXIMATE SULUTIONS FOR FINITE AND SEMI-INFINITE FLOWS IN A TWO DHASE SYSTEM ARE PRESENTEO. THE RESULTS OBTAINED SHOW THAT THE FORMAL MATHEMATICAL SOLUTIONS FO? ONL- DNU TWO-PHASE SYSTEMS ARE SIMILAR. IN THE LATTER CASE, THE DIFFUSIONAL RESISTANCE TO THE MASS TRANSFER IS GREATER BY A FACTOR WHICH IS CLOSE TO THF VALUE OF 'THE DISTRIBUTION COEEETSISNT.

\#FLOW, LAMINAR + \#FLOW, TWO PHASE + \#MASS TRANSFER + DIFFUSION + DIFFUSION COEFFICIENT

\author{
$5-27327$
}

SATO T

HEAI TRANSFER BIBLIOGRAPHY - JAPANESE WORKS

DEPAR TMENT OF MECHANICAL ENGINEERING, KYOTO UNIVERSITY, JADAN

2 PAGES, INTERNATIONAL JOURNAL OF HEAT AND MASS TRANSFER, 11(6), PAGES 1069-1070 (JUNF 1968)

A BIBLIOGRAPHY UF JAPANESE HEAT AND MASS TRANSFER 1. ITERATURE OREPARED BY THE DEPARTMENT DF MECHANICAL ENGINEERING OF KYOTO UNIVERSITY. FIFTY-TWO REFERENCES.

\# BI8LIOGRAPHY + HEAT TRANSFER + \#MASS TRANSFER + HEAT TRANSFER, CONDUCTION + HEAT TRANSFER, CONVECTION + HEAT TRANSFER, RAOIANT + TRANSPORT PRUPERTY 
CATEGORY 5

ACCIDENT ANALYSIS

$5-27329$

SCHLUNDER EU

HEAT ANO MATERIAL TRANSFER IN PIPES FILLED WITH PARTICLES

2 PAGES, CHEM-ING-TECH, 38(11), PAGES 1161-1163 (NOVEMBER. 1966)

AFTER A THEORY ON HEAT ANO MASS TRANSFER BETWEEN FLOW-TRAVERSED PACKINGS AND ADJOINING SURFACES HAD BEEN FORMULATED, THE USEFULNESS COULD BE CONFIRMED BY THE EXPERIMENTAL RESULTS OBTAINED WITH A SINGLE BODY IMBEDDED IN FLOW-TRAVERSED PACKINGS, THIS THEORY IS NOW APPLIED TO THE CASE OF HEAT AND MASS TRANSFER IN PACKED TUBES. A COMPARISON OF THE RESULTS WITH THE MEASUREMENTS OF OTHERS AND OF THE PRESENT AUTHOR SHOWS GOOD AGREEMENT ANO THUS DEMONSTRATES THE JUSTIFICATION OF THE PHYSICAL MODEL UTILIZED ALSO FOR THIS CASE.

\#FLOW, TUBE + \#HEAT TRANSFER + \#MASS TRANSFER + COMPARISON, THEORY AND EXPERIENCE + FLOW, GENERAL + HEAT TRANSFER, CONVECTION

$5-27330$

NISHIKAWA K + MIYABE K

ON THE BOILING-LIKE PHENOMENA AT SUPERCR ITICAL PRESSURES

KYUSHU TECHNICAL COLLEGE

25 PAGES, 16 FIGURES, 1 TABLE, 16 REFERENCES, MEM. FAC. ENG., KYUSHU UNIV., 25111, PAGES 1-25 IDECEMBER 19651

THE PROBLEM OF HEAT TRANSFER TD FLUIDS NEAR THE CRITICAL PRESSURE HAS ARISEN BECAUSE DF THE INDUSTRI AL NEED FOR SUPERCRITICAL PRESSURE BOILERS, COOLING OF ROCKET MOIORS AND GAS TURBINE BLADES, AND HEAT REMOVAL FROM NUCLEAR REACTORS. A STUDY WAS MADE TO ELUCIDATE THE HEAT TRANSFER MECHANISM OF A SUPERCRITICAL FLUID. WITH THE EXPERIMENTAL APPARATUS OF FREE CONVECTION, THE BOILING-LIKE PHENOMENON WAS EXAMINED BY PHOTOGRAPHIC OBSERVATION AND HEAT TRANSFER COEFFICIENT MEASUREMENT. FOR. THE HEATING SURFACE A PLATINUM WIRE WAS USED, AND CARBON DIOXIDE AS THE TEST FLUID.

\#CONVECTIVE BOILING + \#HFAT TRANSFER EXPERIMCNT + \#HEAT TRANSFER, SUPERCRITICAL + HEAT TRANSFER + HEAT TRANSFER, BOILING

$5-27436$

A METHOD OF FINDING SIMULTANEOUSLY THE VALUES OF THE HEAT TRANSFER COEFFICIENT, THE DISPERSION

COEFFICIENT, AND THE THERMAL CONDUCTIVITY OF PACKING IN A PACKED BED OF SPHERES- PART I. MATHEMATICAL ANALYSIS

UNIVERSITY OF WATERLOO

5 PAGES, 1 TABLE, 18 REFERENCES, ALCHE JOURNAL, 13(4), PAGES 678-682 (JULY 1967)

THE RESPONSE OF A PACKER BED TO A SINE WAVE OF TEMPERATURE IN A STREAM OF FLUID THROUGH IT WILL DEPEND UPON THE AMOUNT OF DISPERSION IN THE FLUID, THE RESISTANCE TO TRANSFER BETNEEN FLUID AND SOLID, AND THE THERMAL PROPERTIES OF THE SOLID. A METHOD IS PRESFNTED THAT ALLOWS THE EFFECTS OF THESE THREE PHENOMENA ON THE AMPLITUDE AND PHASE ANGLE TO BE UNRAVELLED AND HENCE ALL THEIR MAGNITUDES TO BE COMPUTED SIMULTANEOUSLY. IT THUS PRESENTS A WAY OF DETERMINING THESE THREE QUANTITIES IN SITUATIONS WHERE THEY WERE PREVIOUSLY OBTAINABLE EITHER WITH GREAT UNCERTAINTY OR NOT AT ALL. THE METHOD REQUIRES MEASUREMENTS OF THF RFI ATIUF AMPLITUDFS ANM PHASF AMIELES AT TIIREC FREQUEIVLIES, ANU INREFERABLY) AT W APPROACHES ZERO, AS WELL, ALL TO BE CARRIED. OUT WITH HIGH ACCIIRACY.

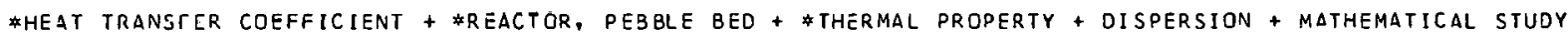

$5-27437$

VAN MEEL DA + VAN GASSELT MLG

RESEARLH UN THE INFLUENCE OF CONOITIONS OF FLOW, SUBCOOLING, AND COMPOSITION ON THE BURNOUT HEAT FLUX OF POLYPHENYL REACTOR COOLING AGENTS

TOEGEPAST NATUURWETENSCHAPPEL I JK ONDERZOCK, CENTRAAL LABÜRATOR IUM

EUR-3120.E +. 50 PAGES, JUNE 5,1966

SUMMARIZES RESEARCH CARRIEO OUT BY THE CENTRAL TECHNICAL INSTITUTE TNO HOLLAND FROM JUNE 1,

1964, UNOER CONTRACT NO. $166-64-6$ ORGN WITH EURATOM DN FDRCED CONVECTION NON-BOILING,

SUBCOOLEO BOILING, ANO SUBCDOLED BURNOUT HEAT TRANSFER ANO PRESSURE DROP OF TERPHENYL

MIXTURES IN VERTICAL TEST SECTIONS, RECOMMENDFD CORRELATIONS ARE PRESENTED FIR HEAT TRANSFER

AND PRESSURE DROP, FOR UPFLOW THROUGH THE ROUND, 5-MM VERTICAL TUBE, 500 M IN LENGTH.

AVAILABILITY - AEC DEPOSITORY LIBRARIES IN THE U.S. AND OVERSEAS

*HEAT TRANSFER, BOILING + *HEAT TRANSFER, CONVECTION + FREACTOR, ORgANIC COOLED + BURNOUT HEAT FLUX + CONVECTIVE BOILING + EURATOM + PRESSURE DROP

$5-27438$

SEMERIA R

SODIUM BOILING IN FAST NEUTRON REACTOR CORES 
CATEGORY 5

ACCIDENT ANALYSIS

5-27438 *CONTINUED*

CENTRE D ETUDES NUCLEAIRES DE GRENOBLE, FRANCE

5 PAGES, 16 REFERENCES, BULLETIN DINFORMATIONS SCIENTIFIQUES ET TECHNIQUES, 122, PAGES 19-23 (JANUARY 1968)

A DESCRIPTION OF THE PHYSICAL PHENOMENA WHICH OCCUR DURING SODIUM BOILING, AND FLASHING OUT OF THE REACTOR CORE, IS ATTEMPTED. THE CHARACTERISTICS OF THE CALCULATION CODES AS WELL AS THE GOALS OF THESE CODES ARE BRIEFLY PRESENTED. THE IMPORTANT RESULTS GAINEO FROM THE CURRENT STUDIES ARE OUTLINED.

\#ACCIDENT, LOSS OF COOLANT + *HEAT TRANSFER, BOILING + *SODIUM + COMPUTER PROGRAM + REACTOR, CAST + REACTOR, LMFBR

$5-27439$

GRASS G + KOTTOWSKI H + SPILLER JH

SUPERHEAT MEASUREMENT AND STUDY OF LIQUID METAL BOILING

EUROPEAN ATOMIC ENERGY COMMUNITY

10 PAGES, 13 FIGURES, 10 REFERENCES, BULLETIN OINFORMATIONS SCIENTIFIOIJS ET TECHNIQUES, 122 , PAGES $25-34$ (JANUARY 1968 )

TO STUDY THE MECHANISM OF LIQUID METAL BOILING, ITS MAXIMUM POSSIBLE SUPERHEAT HAS BEEN MEASURED. TO START HITH, POTASSIUM WAS CHOSEN AS A WORKING LIQUID. THIS PERMITS TO AVOID STUDYING IMMEDIATELY AT VERY HIGH TEMPERATURE. VERY IMPORTANT SUPERHEATING--GOING UP AS FAR AS 800 C IN PARTICULAR CASES--HAVE BEEN OBTAINED IN HIGHLY PURIFIED STAGNANT PDTASSIUM. IN
THE LOOP, WHERE THE DEGREE OF PURIFICATION IS LESSER, THE OBSERVED SUPERHEATINGS HAVE BEEN MUCH LOWER AND REMAIN BELOW $130 \mathrm{C}$. TAK ING INTO ACCOUNT THE TECHNIQUE USED, THE BOILING MECHANISM SHOWED TO BE A SERIES OF LIQUID METAL EJECTIONS, EXPELLED BY THE VAPOR BUBBLES. THE FREQUENCY AND EXPULSION RATE DEPEND ON THE ORIGINAL SUPERHEAT AND ON THE CORRESPONDING VAPOUR PRESSURE.

\#EXPERIMENT, GENERAL + \#HEAT TRANSFER, BOILING + \#METAL, LIQUID + CONVECTIVE BOILING + POTASSIUM

$5-27440$

FARL ANE M

THEORETICAL STUDIES OF THE RESPONSE OF FAST REACTORS DURING SODIUM BOILING ACCIDENTS

ARGONNE NATIONAL LABORATORY, ARGONNE, ILLINOIS

18 PAGES, 13 FIGURES, 2 TABLES, 10 REFERENCES, BULLET IN DINFORMATION SCIENTIFIQUES AND TECHNIQUES, 122,

PAGES 35-52 (JANUARY 1968)

THIS PAPER DESCRIBES A CALCULATIONAL METHOD FOR THE TRANSIENT PHENOMENA WHICH CAN TAKE PLACE DURING COOLANT BOILING IN A REACTOR CORE. IT IS THUS POSSIBLE TO STUOY THE WEAK OVERPOWER TRANSIENTS ORIGINATING FROM THE REACTIVITY ADDITION OR THOSE ORIGINATING FROM THE CQOLANT FLOW SHUT DOWN. THE MODEL SHOULD ALSO PERMIT THE FORMULATION AND ANALYSIS OF TRANSIENT BOILING EXPERIMENTS WHICH SHOULO SUPPLY STILL MISSING DATA. THE CALCULATIONS APPLY PARTICULARLY TO CERAMICS-FUELED ANO SODIUM-COOLED FAST-BREEDER POWER REACTORS.

\#ACCIDENT ANALYSIS + *CONVECTIVE BOILING + \$SODIUM + HEAT TRANSFER, BOILING + REACTOR, FAST + REACTOR, LMFBR

$5-27452$

SPARROW EM + FARIAS FN

UNSTEADY HEAT TRANSFER IN DUCTS WITH TIME-VARYING INLET TEMPERATURE AND PARTICIPATING WALLS UNIVERSIDADE DO BRASIL, RIO. DE JANEIRO

17 PAGES, 8 FICURES, 1 TABLE, 9 REFERENCES, INTERNATIONAL JOURNAL OF HEAT AND MASS TRANSFER, 11 (5), PAGES 837-853 (MAY 1968 )

AN ANALYSIS IS MADE OF UNSTEADY LAMINAR HEAT TRANSFER IN A DUCT WITH PEP.IOOIRALIY VARYING INLET TEMPERATURE AND TIME- AND SPACE-DEPENDENT WALL TEMPERATURE. THE WALL TEMPERATURE VARIATION IS NOT SPECIFIED IN ADVANCE, BUT RATHER, IS OYNAMICALLY DETERMINED BYA BALANCE OF THE HEAT-TKANSFER RATE AND THE ENERGY STORAGE. IN IHE ANALYTICAL FORMULATION, THE COMMONLY AND QUASI-STEADY ASSUMPTION IS LIFTED IN FAVOR OF THE LOCAL APPLICATION OF THE ENERGY EQUATION, THE SOLUTION OF WHICH LEADS TO AN EIGENVALUE PROBLEM IN WHICH THE EIGENVALUES ARE COMPLEX (REAL AND IMAGINARY PARTS). IT WAS FOUND THAT, FOR A RANGE OF DPERATING CONDITIONS, THE QUASI-STEADY MODEL IS ABLE TO GIVE ACCURATE PERFORMANCE PREDICTIONS, ESPECIALLY WHERE IT IS USED IN CONJUNCTION WITH SPATIALLY VARYING HEAT-TRANSFER COEFFICIENTS.

*HEAT TRANSFER ANALYSIS + *HEAT tRANSFER, CONVECTION + \#HOT CHANNEL + COMPARISON, THEORY AND EXPERIENCE + FLOW, LAMINAR + HOT CHANNEL ANALYSIS + MATHEMATICAL STUDY

$5-27453$

KUBAIRVG + PEI DCT

COMBINED LAMINAR FREE AND FORCED CONVECTION HEAT TRANSFER TO NON-NEHTONIAN FLUIDS

UNIVERSITY OF HATERLDOS, WATERLOO, ONTARIO, CANADA

15 PAGES, 12 FIGURES, 5 TABLES, 17 REFERENCES, INTERNATIONAL JOURNAL OF HEAT AND MASS TRANSFER, IIISI, PAGES 855-869 (MAY 1968)

A THEORETICAL ANALYSIS FOR THE COMBINED LAMINAR FREE ANO FORCED CONVECTION HEAT TRANSFER TO NON-NEWTONIAN FLUIDS IN EXTERNAL FLOWS IS PRESENTED. THE PARAMETER CONTROLLING THE FREE ANO FORCED CONVECTION IS FOUND TO BE GR/RE $\$(2 /(2-N)$ WHER. N IS THE FLOW-BEHAVIDUR INDEX. 
5-27453 *CONTINUED*

NUMERICAL SOLUTION OF THE TRANSFORMEO BOUNDARY-LAYER EZUATIONS HAS BEEN CARRIED OUT FOR THE CASE OF A FLAT PLATE WITH UNIFORM WALL TEMPERATURE, FOR DIFFERENT FLOW-BEHAVIOUR INDICES AND DIFFERENT VALUES OF THE CONTROLLING PARAMETER. THE RESULTS OF HEAT TRANSFER, SHEAR STRESS, VELOCITY AND TEMPERATURE PROFILES AS FUNCTIONS OF FLOH-BEHAVIOUR INDEX AND THE CONTROLLING PARAMETER AT DIFFERENT PRANDTL NUMBERS ARE DISCUSSED FOR OPPOSING AND AIOING FLOWS.

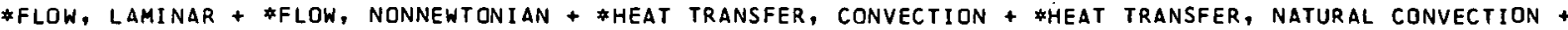
FLOW THEORY AND EXPERIMENTS + HEAT TRANSFER + HEAT TRANSFER ANALYSIS

$5-27454$

ARPACI I S

EFFECT OF THERMAL RADIATION ON THE LAMINAR FREE CONVECTION FROM A HEATED VERTICAL PLATE

UNIVERSITV OF MICHIGAN, ANN ARBOR, MICHIGAN

11 PAGES, 4 FIGURES, 9 REFERENCES, INTERNATIONAL JOURNAL OF HEAT ANO MASS TRANSFER, 11(5I, PAGES B71-881 (MAY 1968 )

AN ANALYTICAL ATTEMPT IS MADE TO UNDERSTAND THE NONEOUILIBRIUM INTERACTION BETHEEN THERMAL RADIATION AND LAMINAR FREE CONVECTION IN TERMS OF A HEATED VERTICAL PLATE IN A STAGNANT RADIATING GAS. THE EFFECT OF RADIATION IS TAKEN INTO ACCOUNT IN THE INTEGRAL FORMULATION OF THE PRDBLEM AS A ONE-DIMENSIONAL HEAT FLUX, EVALUATED BY INCLUDING THE ABSORPTION IN THIN GAS APPROXIMATION AND THE WALL EFFECT IN THICK GAS APPROXIMATION. THE LOCAL NUSSELT NUMBERS THUS OBTAINED HELP TO INTERPRET THE GAS DOMAINS FROM TRANSPARENT TO OPAQUE AND FROM COLD TO HOT.

*HEAT TRANSFER, NATURAL CONVECT ION + \#HEAT TRANSFER, RADIANT + \#MATHEMATICAL TREATMENT + FLOW, LAMINAR + HEAT TRANSFER + HEAT TRANSFER ANALYSIS + HEAT TRANSFER CORRELATION

$5-27455$

TOOR JS + VISKANTA R

A NUMERICAL EXPER IMENT OF RADIANT HEAT INTERCHANGE BY THE MONTE CARLO METHOD

PURDUE UNIVERSITY, LAFAYETTE, INDIANA

15 PAGES, 9 FIGURES, 5 TABLES, 18 REFERENCES, INTERNATIONAL JOURNAL OF HEAT AND MASS TRANSFER, IIISI,

PAGES 883-897 (MAY 1968)

RADIANT HEAT INTERCHANGE BETWEEN SIMPLY ARRANGED SURFACES HAVING DIRECTION DEPENOENT CHARACTERISTICS HAS BEEN STUDIED BY THE STATISTI CAL METHOD KNOWN AS MONTE CARLO. THE DIFFUSE ANO SPECULAR CONSISTANT PROPERTY, THE SPECULAR DIRECTIONAL EMISSION AND REFLECTION, AND THE OIRECTIONAL EMISSION ANO THE BIOIRECTIONAL REFLECTION MODELS HAVE BEEN EXPLORED WITH THE PRELIMINARY GOAL OF UNDERSTANDING WHAT LEVEL OF DETAIL IS IMPORTANT IN THE DESCRIPTION OF THE RADIATION PROPERTIES OF SURFACES. FOUR SIMPLE CONFIGURATIONS WHICH PERMIT A CRITICAL EXAMINATION OF THE DIRECTIONAL EFFECTS HAVE BEEN EXAMINED. RESULTS SHOWED THAT UNDER SOME CONDITIONS THE CHOICE OF THE MOOEL FIR RAOIATION SURFACE CIIARACTERISTICS CAN HE VERY CRITICAL FUR BOTH THE LOCAL RADIANT HEAT FLUX AND FOR OVERALL RADIANT INTERCHANGE CALCULATIONS.

\#HEAT TRANSFER ANALYSIS + \#HEAT TRANSFER, RADIANT + \#MONTE CARLO + HEAT TRANSFER + NUMERICAL METHOD

5-27456 ALSO IN CATEGORY 19

FCKERI ERG + SPARROW EM + IBELE WE + GOLDSTEIN RJ

HEAT TRANSFER BIBLIOGRAPHY

UNIVERSITY OF MINNESOTA, MINNEAPOLIS, MINNESOTA

17 PAGES, INTERNATIONAL JOURNAL OF HEAT ANO MASS TRANSFER, 11(5), PAGES 899-915 (MAY 1968)

AN EXTENSIVE BIBLIOGRAPHY OF HEAT AND MASS TRANSFER LITERATURE. PREPARED BY THE HEAT TRANSFER LABORATORY OF THE UNIVERSITY OF MINNESOTA.

* BIBLIOGRAPHY + \#HEAT TRANSFER + \#MASS TRANSFER + BOUNDARY LAYER + FLOW, TWO PHASE + FLUIDIZED BEO + HEAT TRANSFER, CONDUCTION + HEAT TRANSFER, NATURAL CONVECTION + HEAT TRANSFER, RADIANT + HOT CHANNEL + MEA SUREMENT, GENERAL + METAL, LIQUID + REACTOR, PEBBLE BED + THERMODYNAMICS + TRANSPORT PROPERTY + IRANSPORT THEORY

$5-27457$

LYNCH JH

TWO NEW THEOREMS IN HEAT CONDUCTION

LEWIS RESEARCH CENTER, CLEVEIANR, OHIO

8 PAGES, 2 FIGURES, 3 REFERENCES, INTERNATIONAL JOURNAL OF HEAT AND MASS TRANSFER, $11(5), 9 A G E S$ 917-924 (MAY 1968 )

FREQUENTLY, IN PARAMETRIC SURVEY AND DESIGN FEASIBILITY STUDIES, ONE IS INTERESTED IN SOME PARAMETER THAT CHARACTERIZES THE OVERALL PERFORMANCE QATHER THAN THE DETAILED BEHAVIOUR OF THE SYSTEM IN QUESTION. EXAMPLES OF SUCH PARAMETERS WOULD BE THE EFFECTIVE MULTIPLICATION CONSTANT FOR NUCLEAR REACTORS DR THE TOTAL HEAT-TRANSFER RATE FOR HEAT EXCHANGERS. THIS PAPER DESCRIBES THE DEVELOPMENT AND APPL ICATION OF THEOREMS WHICH MAY BE USED TO RELATE CHANGES IN THE PARAMETERS THAT CHARACTERIZE AN EXCLUSIVELY STEADY-STATE HEAT CONDUCTING SYSTEM IGEOMETRY, CONDUCTIVITIES AND SOURCE STRENGTHSI TO THE AVERAGE SOURCE TEMPERATURE IN ALL SOURCE REGIONS. IF THIS SOURCE TEMPERATURE IS TAKEN AS THE CHARACTERISTIC INDEX OF THE SYSTEM PERFORMANCE, SEVERAL AREAS OF PRACTICAL APPLICATION ARE POSSIBLE.

\#HEAT TRANSFER, CONOUCTION + \#THEORETICAL INVESTIGATION + HEAT TRANSFER + HEAT TRANSFER ANALYSIS + 
CATEGORY 5

ACCIOENT ANALYSIS

5-27457 \#CONTINUED*

MATHEMATICAL STUDY

$5-27458$

SMITH AG + HAY N

RECALCULATION OF THE SPALDING FUNCTION FOR CONTINUOUS AND SOURCE HEAT FLUX

UNIVERSITY OF NOTTINGHAM, ENGLAND

5 PAGES, 4 FIGURES, 1 TABLE, 4 REFERENCES, INTERNATIONAL JOURNAL OF HEAT AND MASS TRANSFER, 1.1 (5), PAGES

$924-928$ (MAY 1968 )

THE EXACT SOLUTION TO THE PROBLEM OF PREOICTING THE TEMPERATURE FIELD WITHIN THE FULLY

DEVELOPED TURBULENT BOUNDARY LAYER HAS BEEN FORMULATED BY SPALOING. IN THE PRESENT PAPER A RECALCULATION OF THE SMITH AND SHAH SOLUTION FOR THE CASE OF CONSTANT HEAT FLUX PARAMETER IS PRESENTED. THE PRESENT SOLUTION REMOVES SOME ERRORS IN THE EARLIER ONE. AN $\triangle D D I T I O V A L ~ F O R M$ OF THE SPALOING FUNCTION FOR A SOURCE HEAT FLUX IS DERIVED FROM THE SOLUTION, $\triangle N D$ A NEW METHOD OF PRESENTATION IS ADOPTED WHICH WILL GIVE $\triangle$ MORE ACCURATE AND EASIER DETERMINATION OF THE TEMPERATURE $\triangle T$ THE WALL ANO WITHIN THE BOUNDARY LAYER.

* bounoary layer + \#TEMPERATURe gradient + \#HEORETICAL INVESTIGATION + HEAT TRANSFER + HEAT TRANSFER ANALYSIS

$5-27459$

KOSKY PG

NUCLEATION SITE INSTABILITY IN NUCLEATE BOILING

UKAEA, BERKS HARWELL

4 PAGES, 6 FIGURES, 1 TABLE, 10 REFERENCES, INTERNATIONAL JOURNAL OF HEAT AND MASS TRANSFER, 11 (5), PAGES 929-932 (MAY 1968 )

THE INITIATION OF BOILING FROM A HEATEO SOLID SURFACE HAS BEEN NORMALLY TREATED IN TERMS OF A CRITICAL RADIUS OF NUCLEATION SITE AND THE PREPARATION OF BOILING SURFACES HAS NORMALLY BEEN THOUGHT OF IN TERMS OF ROUGHNESS. THE SIGNIFICANCE OF NUCLEATION SITF DEP.TH HAS BEEN MOOTED BY MARTO AND ROHSENOW AS A RESULT OF THEIR STUDIES OF POOL BOILING OF LIOUID SOOIUM. THEY OBSERVED SMALL SCALE IRREGULARITIES IN THE SURFACE TEMPERATURE OF THEIR BOILER AND OCCASIONAL LARGE TEMPERATURE CYCLES COINCIDENT WITH EVIDENCE THAT BOILING HAD BEEN SUPDRESSED. THE WORK DESCRIBED IN THIS PAPER USES AN ARTIFICIAL GLASS CAVITY SO THAT THE MOTION, IF ANY, OF THE FLUIO HITHIN THE CAVITY COULD BE STUOIEO BY HIGH SPEED PHOTOGRAPHY IN ORDER TO CONFIRM OR REFUTE THE FUNDAMENTAL ASSERTIONS OF T.HE MARTO ANO RDHSENOW MODEL.

\#BUBBLE NUCLEATION + *HEAT TRANSFER EXPERIMENT + \#NUCLEATE BOILING + CONVECTIVE BDILING + FLOW, TWO PHASE + HEAT TRANSFER, BOILING

$5-27469$

BAW PS + PESKIN RL

SOLID DENSITY DISTRIBUTION IN GAS-SOLID PIPE FLOW

RUTGERS-THE STATE UNIV. OF NEW JERSEY, NEW SRUNSWICK, NEW JERSEY

NYO-2930-6.+. 48 PAGES, FIGURES, REFERENCES, APRIL, 1966

THE SOLID PHASE DENSITY DISTRIBUTION IN GAS-SOLID TURBIN.FNT FLOW WAS MEASURED BY OPTICAL

TECHNIQUES. DENSITY PROFILE COMPUTATIONS WERE ATTEMPTED USING A REYNOLDS AVERAGING TECHNIQUE AND IT WAS FOUND THAT THE MEAN DENSITY PROFILE DEPENDS UN IME CURRELATION OF AXIAL AND TRANSVERSE PARTICLE VELOCITY.

AVAILABILITY - CLEARINGHOUSE FOR FEDERAL SCIENTIFIC AND TECHNICAL INFORMATION, SPRINGFIELD, VA. 22151 $\$ 2.00$ COPY, \$O.5O MICRUF ICHE

\#FLOW THEORY AND EXPERIMENTS + \#FLOW, TURBULENT + \#FLDW, TWO PHASE + FLOW DISTRIBUTION + FLOW, GENERAL + FLOW, TUSE

$5-27470$

TRANSITION BOILING HEAT TRANSFER PROGRAM

GENERAL EIECTRIC CO., SAN JOSE, CALIFORNIA

EURAEC-17041 + GEAP-5191+. 22 PAGES, JULY 1, 1966

THE OBJECTIVE OF THE PROGRAM IS TO OBTAIN EXPERIMENTAL MEASUREMENTS ANO PERFORM THEORETICAL ANALYSES TO DEVELOP THE MEANS FOR PREDICTING THE HEAT TRANSFER COEFFICIENTS FOR

FULLY-DEVELOPED FILM BOILING TO FORCED CONVECTION, DISPERSEO FLOHS. THE LUNUITIONS OF INTEREST FOR BOILING WATER ARE PRESSURES OF 1000,600, AND 1400 PSIA, AND MASS VELOCITIES OF 0.5 TO 1.5 MIILION I.B/H-FT OVER THE STEAM QUALITY RANGE OF 0.15 TO 0.60 . FILM BOILING COEFFICIENTS WERE MEASURED IN ORDER TO RESOLVE DIFFERENCES FOUND IN PREVIOUS ANNULAR TEST COEFFICIENTS WERE MEASURED IN ORDER TO RESOLVE OIFFERENCES FOUND IN PREVIOUS ANNULAR TEST
DATA. INCREASING THE DISTANCE BET WEEN SPACERS WAS FOUND TO REDUCE THE FULLY-DEVELOPED FILM BOILING COEFFICIENT. THE DROPLET SLIP VELOCITY FOR MIST FLOW AND THE CONTRIBUTION OF CONVECTION TO DROPLET HEAT TRANSFER ARE EVALUATED.

AVAILABILITY - CLFARINGHOUSE FOR FEDERAL SCIENTIFIC ANO TECHNICAL INFORMATION, SPRINGFIELO, VA. 22151 $\$ 3.00$ COPY, \$0.65 MICROFICHE

* DROPLET + \#FILM BOILING + *HEAT TRANSFER EXPERIMENT + CONVECTIVE BOILING + HEAT TRANSFER + HEAT TRANSFER ANALYSIS + HEAT TRANSFER, BOILING 
CATEGORY 5

ACCIDENT ANALYSIS

5- 27472

ALSO IN CATEGORY 7

PITTS SH

FACTORS INFLUENCING THE IGNITION OF METALLIC PLUTONIUM

DOW CHEMICAL COMPANY

8 PAGES, 14 FIGURES, 1 TABLE, 17 REFERENCES, NUCLEAR SAFETY, 9121 , PAGES 112-120 (MARCH-APRIL 1968)

THE FACTORS THAT INFLUENCE THE IGNITION OF PLUTONIUM WERE INVESTIGATEO EXPERIMENTALLY AND FOUNO TO BE RELATED TO SAMPLE SIZE ANO GEOMETRY OR TO THE SURFACE COMPOSITION. THE IGNITION TEMPERATURE DECREASED AS THE SAMPLE SURFACE AREA WAS INCREASED, $\triangle S$ THE WEIGHT OF PLUTONIUM FILINGS WAS INCREASED, AND AS SLOWER HEATING RATES WERE USED. SAMPLES HEATED AT. CONSTANT, ELEVATEO TEMPERATURES IGNITED AT LOWER TEMPERATURES THAN THOSE HEATED AT A CONSTANTLY INCREASING TEMPERATURE. THIN FOIL COUPONS IGNITED AT LOWER TEMPERATURES WHEN THEY CONTAINED INDUCED INTERNAL STRESSES. LOWER IGNITION TEMPERATURES WERE OBTAINEO BY FORMING PUO ON THE SAMPLE SURFACE.

\#ACCIDENT ANALYSIS + \#CHEMICAL REACTION + \#PLUTONIUM + EXPERIMENT, GENERAL + FIRE + IGNITION + IGNITION TEMPERATURE

$5-27473$

DISCHINGER RH

PERFORMANCE EVALUATION OF HEAT EXCHANGERS FOR SODIUM-COOLED REACTORS

UNITED NUCLEAR CORP. ELMSFORD; N.Y.

UNC-5162 +. 26 PAGES, 1 TABLE, DCTOBER 20, 1966

THIS IS THE FIFTH QUARTERLY PROGRESS REPORT CONCERNING THE EVALUATION OF THE THERMAL-HYDRAULIC ANO STRUCTURAL PERFORMANCE OF HEAT EXCHANGERS FOR SODIUM-COOLED REACTOR PLANTS. THE EVALUATION WILL BE BASED ON THE RESULTS OF TESTS OF MODEL HEAT EXCHANGERS (APPROXIMATELY 30 MWTI IN THE SOOIUM COMPONENTS TEST INSTALLATION. AN INTERMEOIATE HEAT EXCHANGER DESIGNED AND MANUFACTUREO BY ALCO PRODUCTS, INC., AND A STEAM GENERATOR DESIGNED BY ALCO PRODUCTS, INC. AND MANUFACTURED BY BALOWIN-LIMA-HAMILTON CORPORATION ARE THE FIRST UNITS TO BE TESTED. THE BABCOCK AND WILCOX STEAM GENERATOR IS TO BE TESTED NEXT.

AVAILABILITY - CLEARINGHOUSE FOR FEDERAL SCIENTIFIC AND TECHNICAL INFORMATION, SPRINGFIELD, VA. 22I5I $\$ 3.00 \mathrm{COPY}, \$ 0.65 \mathrm{MICROFICHE}$

\#HEAT EXCHANGER + METAL, LIOUID + \$SODIUM + HEAT TRANSFER + HEAT TRANSFER EXPERIMENT

$5-27480$

HSIA HM + LOVE TJ

RADIATIVE HEAT TRANSFER BETWEEN PARALLEL PLATES SEPARATED BY A NONISOTHERMAL MEDIUM hITH ANISOTROPIC SCAT TER ING

DEPT. OF MECHANICAL ENGINEERING, NORTH DAKOTA STATE UNIVERSITY + SCHOOL OF AEROSPACE AND MECHANICAL ENGINEERING, UNIVERSITY OF OKLAHOMA, NORMA, OKLA.

8 PAGES, 8 FIGURES, 11 REFERENCES, JOURNAL OF HEAT TRANSFER, 89(3), PAGE 197-204, (AUGUST 1967)

THE PROBLEM OF RADIATIVE heAT TRANSFER IN A NONISOTHERMAL MEDIUM IS CONSIDERED. THE ANALYSIS IS CARRIED DUT FOR A PLANE PARALLEL ATMOSPHERE SEPARATEO BY. A CLOUD OF PARTICLES WHICH SCATTERS RADIANT ENERGY IN AN ANISOTROPIC FASHION. LINEAR. ANO ISOTHERMAL TEMPERATURE PROFILES ARE COMPARED FOR ENCLOSURES WITH PARTIALLY REFLECTING OIFFUSE BOUNDARIES. THE SOLUTIONS ARE OBTAINED BY REPRESENTING THE INTEGRAL TERM OF THE RADIATIVE TRANSPORT EQUATION BY A QUADRATURE.

\#HEAT TRANSFER ANALYSIS + \#HEAT TRANSFER, RADIANT + HEAT TRANSFER + MATHEMATICAL STUDY + MATHEMATICAL TREATMENT

$5-27481$

MERONEY RN + GIEOT WH

THE EFFECT OF MASS INJECTION ON HEAT TRANSFER FROM A PARTIALLY DISSOCIATED GAS STREAM

COLORADO STATE UNIVERSITY, FORT COLLINS, COLO. + UNIVERSITY OF CALIFORNIA, DAVIS, CALIF.

14 PAGES, 15 FIGURES, JOURNAL OF HEAT TRANSFER, 89(3), PAGE 205-218, (AUGUST 1967)

AN INVESTIGATION OF THE EFFECT OF HYDROGEN AND HEL IUM INJECTION ON LOCAL HEAT TRANSFER TO A POROUS SURFACE FROM AN OXYGEN-ACETYLENE COMBUSTION GAS STREAM IS OESCRIBED. THE FREE-STREAM TEMPERATURE VARIEO FROM 6200 TO 5200 DEG RANKINE AND THE VOLUMETRIC PERCENTAGE OF ATOMIC HYOROGEN FROM 20 TO 8 . FLOW IN THE BOUNDARY LAYER WAS FOUND TO BE TURBULENT. STUDY OF THE RESULTS LED TO SUCCESSFUL CORRELATION OF THE RATIO OF THF HFOT FLUX WITH INJECTIUN TO THE HEAT FLUX WITHOUT INJECTION IN TERMS OF A OIMENSIONLESS BLOWING PARAMETER IN WHICH PROPERTIES ARE EVALUATED AT AN AVERAGE REFERENCE STATE. A METHOD FOR PREDICTING HEAT FLUX WITH INJECTION WAS THEN DEVELOPEO. THIS IS BASED ON A TEMPERATURE RATHER THAN AN ENTHALPY POTENTIAL BECAUSE THE LATTER RESULTED IN ANOMALOUS VALUES FOR THE STANTON NUMBER UNDER SOME OF THE TEST CONDITIONS.

*HEAT TRANSFER EXPERIMENT + \#HEAT TRANSFER, GAS + \#MASS TRANSFER + HEAT TRANSFER +

HEAT TRANSFER CORRELATION 
CATEGORY 5

ACCIOENT ANALYSIS

$5-27482$

EDWARDS DK + GLASSEN LK + HAUSER WC + TUCHSCHER JS

RADIATION HEAT TRANSFER IN NONI SOTHERMAL NONGRAY GASES

UNIVERSITY OF CALIFORNIA, LOS ANGELES, CALIF, + AERONUTRONIC DIVISION OF PHILCD CORD., NEWPORT BFACH,

CALIF. + R. O. ROBERTS, INC., SANTA FE SPRINGS, CALIF. + HUGHES AIRCRAFT CO., CULVER CITY, CALIF.

11 PAGES, 6 FIGURES, 4 TABLES, 49 REFERENCES, JOURNAL OF HEAT TRANSFER, 89(3), PAGE $219-230$, (AUGUST 1967)

EXPERIMENTAL MEASUREMENTS OF ABSORPTION AND EMISSION BY NONISOTHERMAL CO-2 AND STEAM ARE REPORTED. ANALYTICAL FORMULATIONS AND CALCULATIONS OF RADIANT HEAT TRANSFER USING A SIMDLE NONGRAY GAS MODEL ARE PRESENTED. IT IS FOUNO THAT A GRAY GAS MOOEL CANNDT PREDICT EVEN QUALITATIVELY THE EXPERIMENTAL RESULIS, WHILE THE BANO MODEL METHOD OF CALCULATION YIELDS RESULTS IN QUANTITATIVE AGREEMENT FOR TOTAL EMISSION AND ABSORPTION IN A BAND. EFFECTS OF LINE STRUCTURE ARE SHOWN TO BE OF SECONOARY IMPORTANCE COMPAREO TO MAND ENVELJPE STPUCTURE FOR LINE-WIDTH-TO-SPACING RATIOS ABOVE O.OI IN SATURATED BANOS. AN ANALYTICAL SOLUTION FOR COUPLED CONVECTION AND RADIATION IN A PLANE-PARALLEL-WALL DUCY IS DERIVED TO ILLUSTRATE THE UTILITY OF THE EXPONENTI AL BAND MODEL FOR ANALYSIS OF RADIANT TRANSFER IN NONISOTHERMAL, NONGRAY GASES.

\#HEAT TRANSFER ANALYSIS + \#HEAT TRANSFER, GAS + \#HEAT TRANSFER, RADIANT + CARGON OIOXIDE. + HEAT TPANSFER + STEAM

$5-27483$

ELROD WC + CLARK JA + LADYER + MERTEH

BOILING HEAT-TRANSFER DATA AT LOW HEAT FLUX

MECHANICAL ENGINEERING, CLEMSON UNIVERSITY, CLEMSON, S. C. + MECHANICAL FNGINEERING DEPT., JNIVSZSITY TF MICHIGAN, ANN ARBOR, MICH.

9 PAGES, 13 FIGURES, 7 REFERENCES, JJURNAL OF HEAT TRANSFER, 89(3), PAGE 235-243, (AUGUST 1967)

DATA ARE PRESENTED FOR NATURAL ANO FORCED CONVECTION HEAT TRANSFER FROM THE OUTSIDE OF A SINGLE 3/4-IN.-DIA TUBE TO SATURATED WATER IN THE PRESSURE RANGE FROM 535 TO 1550 DSIA. NONBOILING ANO NUCLEATE BOILING AT LOW HEAT FLUX ARE CONSIDEREO FOR VERTICAL AND HORIZONTAL TUBES. WATER CHEMISTRY CONTRDL IS SHOW TO BE IMPORTANT IN OSTAINING REPRODUCIBLE DATA. D NEW FACTOR, SUSPENDED SOLIOS IN THE BOILING MEDIUM, IS FDUND TO INFLUENCE THE NUCLEATE BOILING OATA IN A MANNER SIMILAR TO THAT OF A DISSOLVFD GAS.

\#CONVECTIVE BoILING + \#HEAT TRANSFER EXPERIMENT + HEAT TRANSFER, BCILING + HEAT TRAINSFER + HEAT TRANSFER, CONVECTION + HEAT TRANSFER, NATURAL CONVECTION

$5-27484$

MERCER WE + PEARCE WM + HITCHCOCK JE

LAMINAR FORCED CONVECTION IN THE ENTRANCE QEgION BETHEEN PARALLEL FLAT PLATES

BALLISTIC SYSTEMS DIVISION, AFSC, NORTON AFB, CALIF. + HEADQUARTERS SAAMA, AFLC, KELLY AFB, TEXAS +

MECHANICAL ENGINEERING DEPT., AIF FORCE INSTITUTE OF TECHNOLOGY, WRIGHT-PATTERSON AFB, OHIO

7 PAGES, 7 FIGURES, 16 REFERENCES, JOURNAL OF HEAT TRANSFER, 89(3), PAGE 251-257, (AUGUST 1967)

INTERFEROMETER MEASUREMENTS OF LAMINAR FORCED CONVECTION TO AIR IN THE ENTRANCE REGION BETWEEN PARALLEL FLAT PLATES ARE REPORTED. EXPERIMENTAL LOCAL AND MEAV NUSSELT NUMBSRS ARE GIVEN FOR REYNOLDS NUMBERS FROM 300 TO 1500 AND LENGTH-TO-PLATE SPACING RATIOS FROM 2 TO 8. EXPERIMENTAL OATA ARF C.MMPARED WITH CORRESPONDING VALUES FROM THEORETICAL ANALYSES OF SIMULTANEOUSLY DEVELOPING MOMENTUM AND THERMAL BOUNDARY LAYERS FOR THE TWO CASES CONSIDERED AIR HEATED BY BOTH PLATES WIIH THE SAME UNIFORM TEMPERATURE, AND AIR HEATED BY GNE PLATE WITII A UNIFORM TEMPERATURE AND OTHER INSULATEO. EQUATIONS ARE ALSO GIVEN WHICH SUMMARIZE THE THEORETICAL RESULTS.

* Flow, laminar + *heat transfer experiment + \#hEat transfer, gas + heat transfer + HEAT TRANSFER, CONVECTION

$5-27485$

BRADF IELO WS

ON THE EFFECT OF SUBCOOLING ON WALL SUPERHEAT IN POOL BOILING

STATE UNIVERSITY OF NEW YORK AT STONY BRDOK, NEW YORK

2 PAGES, 2 FIGURES, JUURNAL UF HEAI TRANSFER, 89(3), PAGE 269-270, (AUGUST 1967)

ONE OF THE PROBLEMS OF INTEREST IN THE AREA OF TRANSITION BOILING IS THE EFFECT OFF SUBCOOLING OF THE BULK LIQUIO ON THE TRANSITION CURVE. A NUMBER JF INVESTIGATIONS HAVE BEEN MADE OF THE EFFECTS OF SUBCDOLING ON PEAK HEAT FLUX BOTH FOR POOL BOILING AND WITH FORCED CONVECTION. MANY OF THESE DATA ARE SUMMARIZED FOR COMPARISON WITH THE DATA OF VLIET AND LSPPERT. HOWEVER, MOST OF THESE INVESTIGATIONS OMITTED THE CONSIDERATION OF WALL SUPERHEAT. BERGLES AND ROHSENOW OBTAINED DATA INDICATING THAT A SHIFT OF THE POOL BOILING CURVE TOWARD HIGHER WALL SUPEP.HENTS CAN BE EXPECTSO WITH INC.RFASING SIIRCOMI. ING. OBSERVATIONS OF IHE TRANSIIIIUN FROM FILM BOILING TO NUCLEATE POOL BOILING BY THE PRESENT WRITER SHOH THIS TREND ALSO FOR THE TRANSITION BOILING REGION. THE PRESENT DATA WERE OBTAINED FROM OUENCHING EXPERIMENTS IN WATER AT ATMOSPHERIC PRESSURE.

*HEAT TRANSFER EXPERIMENT + \#POOL BOILING + \#SUBCOOLING + HEAT TRANSFER + HEAT TRANSFER, BOILING 
CATEGORY 5

ACCIDENT ANALYSIS

$5-27486$

EMERGY AF + BAILEY DA

HEAT TRANSFER TO FULLY DEVELOPED LIOUID METAL FLOW IN TUBES

MECHANICAL ENGINEER ING DEPT., UNIVERSITY. OF WASHINGTON, SEATTLE, WASH.

4 PAGES, 2 FIGURES, 5 REFERENCES, JOURNAL OF HEAT TRANSFER, 99(3), PAGE 272-275, (AUGUST 1967)

HEAT TRANSFER COEFFICIENTS FOR FULLY DEVELOPED LIQUID METAL FLOW IN A TUBE WITH A CONSTANT

WALL HEAT FLUX ARE GIVEN FOR LAMINAR AND TRANSITIONAL FLOW. THESE EXPERIMENTAL VALUES AGREE WITH THE GRAETZ VALUE OF 4.36, AND SUPPORT THE WORK OF PETUKHOV AND YUSHIN IN CONTRADICTION

TO THAT OF JOHNSON, HARTNETT, AND CLABAUGH.

*FLOW, TUBE + \#HEAT TRANSFER EXPERIMENT + \#ETAL, LIQUIO + heAT tRANSFER + hEAT TRANSFER, CONVECTION + NAK

5-27488 ALSO IN CATEGORY 18

HEALZER JM + HENCH JE + JANSSEN E + LEVY S

DESIGN BASIS FOR CRITICAL HEAT FLUX CONDITION IN BOILING WATER REACTORS

GENERAL ELECTRIC, SAN JOSE, CALIF.

APED-5286 +. 50 PAGES, FIGURES, TABLES, 11 REFERENCES, SEPTEMBER 1966, D0CKETS 50-259/260, TYPE--BWR, $M F G--G . E ., A E-T V A$

$\triangle$ NEW DESIGN BASIS FOR PREDICTING THE CRITICAL HEAT FLUX IN BOILING WATER REACTORS WAS OEVELOPED. THE DESIGN BASIS IS FORMULATED UPON EXTENSIVE TESTS WITH MULTIROO GEOMETRIES WHICH ACCURATELY OUPLICATE THE REACTOR FUEL ASSEMBLY. FLOW CCNOITIONS. THE TEST RESULTS WERE EMPLOYED TO FORMULATE LIHIT LINES NHICH FALL BELOW THE EXPERIMENTAL DATA. AN ANALYTICAL MODEL TO PREDICT LOCAL FLOW ANO STEAM QUALITY. IN COMPLEX GEOMETRIES WAS ALSO DEVELOPEO. THE MODEL WAS APPLIEO TO THE REACTOR FUEL ASSEMBLIES AND TO THE MULTIROD TEST SECTIONS TO SHOW THAT THE TEST SECTIONS SATISFACTORILY MOCKUP THE IN-REACTOR BEHAVIOR.

AVAILABILITY - USAEC PUBLIC DOCUMENT ROOM, 1717 H ST., WASHINGTON, 0.C., 20545 (\$0.25 CENTS/COPY)

*HEAT FLUX, CRITICAL + BROWNS FERRY (BWR) + REACTOR, SWR

$5-27491$

WALTERS CT + GENCO JM + RAINES GE

HEAT-TRANSFER ANALYSIS IN LOSS-OF-COOLANT ACCIDENTS

BATTELLE MEMORIAL INSTITUTE, COLUMBUS LABORATORIES, COLUMBUS, OHIO

18 PAGES. 11 FIGURES, 1 TABLE, 44 REFERENCES, NUCLEAR ENGINEERING AND DESIGN, 7(2), PAGE 123-140, (FEB. 19581

A COMPUTER PROGRAM HAS BEEN WRITTEN FOR THE COMPREHENSIVE ANALYSIS OF CORE-PRESSURE-VESSEL HEAT TRANSFER DURING A LOSS-OF-COOLANT ACCIDENT. THE PZOGRAM, NURLOC-1.0, IS BASED UPJN A GENERALIZED PROCEDURE FOR NUMERICALLY SOLVING THE TWO-DIMENSIONAL HEAT-CONOUCTION EQUATION OVER MULTI-CONNECTED REGIONS WITH VARIOUS COMPI.TCATING FACTMRS SPFCIFIC TO THIS APPLICATION. THE NUMERICAL PROCEDURE CONSISTS OF SOLVING THE EXPLICIT FINITE-DIFFERENCE FORM OF THE CONOUCTION EQUATION AT MESH INTERSECTIONS. BOUNDARY CONDITIONS AND HEAT-GENERATION RATES ARE SET BY MODELS THAT CHARACTERIZE VARIOUS COMPLEX CHEMICAL AND PHYSICAL PROCESSES WHICH CAN OCCUR DURING AN ACCIDENT. THE PROCESSES CONSIDERED IN NURLOC-1.O INCLUDE BOIL-OFF OF RESIDUAL CGOLANT WATER, METAL-WATER REACTIONS, RADIATIVE EXCHANGF, ANO PRMOIIT.T-RFIAY HFATING, ANU UELAYLU-NEUTRON HEATING.

* ACCIDENT, LOSS OF COOLANT + \#COMPUTER PROGRAM + \#HEAT TRANSFER aNALYSIS + ACCIDENT ANALYSIS + HEAT YRANSFER + REACTOR, POWER

5-27494 ALSO IN CATEGORIES 9 AND 17

WYLIL RD

IENSILE AND IMPACT PROPERTIES OF ELK RIVER REACTOR CONTROL ROD MATERIAL. FINAL REPORT

SOUTHWEST RESEARCH INST., SAN ANTONIO, TEX.

SWRI-1228-55 +. 21 PAGES, FIGURES, 5 REFERENCES, FEB. 19, 1965

THE BORON STAINLESS STEEL SPECIMENS WHICH WERE REMOVED FROM THE ELK RIVER REACTOR DURING THE SHUT OOWN IN EARLY NOVEMBER 1964 WERE TESTEO AT SOUTHWEST RESEARCH INSTITUTE. BOTH SUBSIZE TENSILE AND IMPACT SPECIMENS WERE INCLUDED IN THE SURVEILLANCE PROGRAM. AN ESTIMATE OF THE FLUX LEVEL WAS MADE BY ALLIS CHALMERS AS $1.3 \times 10120 T H)$ NVT THERMAL AS OF AUGUST 31 , 1964. THIS CORRESPONDS TO APPROXIMATELY 0.22 ATOM PERCENT BURN-UP. THE DUCTILITY OF THE SPECIMENS WAS MEASURED AS 1-2\% ELONGATION WHICH WAS BELOW THE 3.4\% REQUIRED BY THF TECHNICAL SPECIFICATIONS. A LITERATURE REVIEW INDICATED THAT THE MEASURED DUCTILITY WAS IN THE RANGE OF THE OTHER TEST DATA AVAILABLE ON BORON STAINLESS STEELS WITH APPROXIMATELY $2 \%$ B.

AVAILABILITY - CLEARINGHOUSE FOR FEDERAL SCIENTIFIC AND TECHNICAL INFORMATION, SPRINGFIELO, VIRGINIA, 22151

*CONTROL ROO + \#IMPACT PROPERTY + \#TENSILE PROPERTY + ELK RIVER (BWR) + EXPERIMENT, GENERAL + MATER IAL + REACTOR, BWR + SURVEILLANCE PROGRAM 
CATEGORY 5

ACCIDENT ANALYSIS

5-27533

TAYLOR MF

A METHOD OF CORRELATING LOCAL ANO AVERAGE FRICTION COEFFICIENTS FOR BOTH LAMINAR AND TURBIJLET FLOW OF

GASES THROUGH A SMOOTH TUBE WITH SURFACE TO FLUID BULK TEMPERATURE RATIOS FROM 0.35 TO 7.35

LEWIS RESEARCH CENTER, CLEVELAND, OHIO

6 PAGES, 5 FIGURES, 1 TABLE, 13 REFERENCES, INTERNATIONAL JOURNAL OF HEAT AND MASS TRANSFER, IOI8I, PAGE

$1123-1128$, (AUGUST 1967)

THERE HAS LONG BEEN A NEED OF A MEANS OF CORRELATING BOTH LAMINAR AND TURBULENT FRICTION COEFFICIENTS FOR GASES WITH LARGE VARIATIONS IN THE PHYSICAL PROPERTIES FLOWING THROJSH SMOOTH TUBES. THIS PAPFR PRESENTS METHODS OF CORRELATING BOTH LOCAL DND AVERAGE FRICTION COEFFICIENTS FOR LAMINAR AND TURBULENT FLOW OF GASES THROUGH SMOOTH TUBES WITH SURFACE TO FLUID BULK TEMPERATURE RATIOS FROM 0.35 TO 7.35 , ANO FOR THE GASES, HELIUM, HYDROGEN, NITROGEN, AIR AND CARBON DIOXIDE, WHICH REPRESENT THE WORK OF.SEVEN INVESTIGATORS.

*FLOW CORRELATION + \#FLOW THEORY ANO EXPERIMENTS + \#FLOW, TUBE + Flow, generaL + FLOW, LAMINAR + FLOW, TURBULENT + FRICTION FACTOR

$5-27545$

LINDAUER GC

HEAT TRANSFER IN PACKED AND FLUIOIZEO BEDS BY THE METHOD OF CYCLIC TEMPERATURE VARIATIONS BROOKHAVEN NATIONAL LABORATORY, UPTON, NEW YORK

7 PAGES, 8 FIGURES, 20 REFERENCES, ALCHE JUURNAL, 13(6), PAGES 1181-1187 (1967)

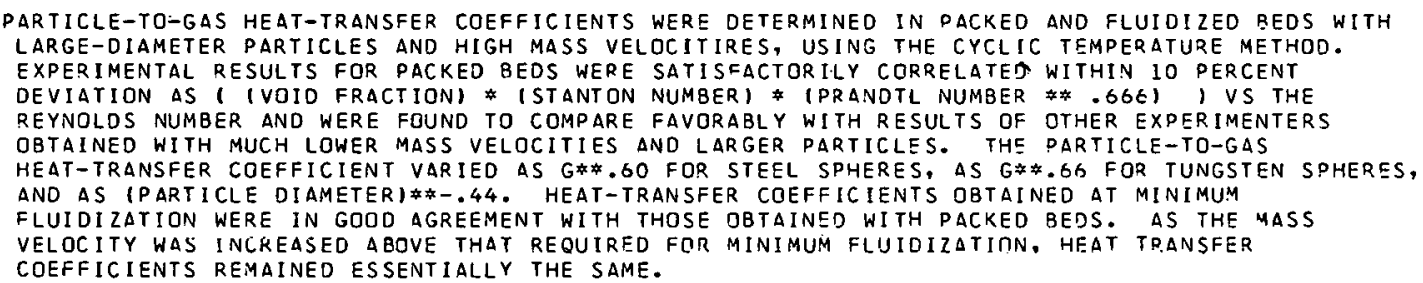

PARTICLE-TO-GAS HEAT-TRANSFER COEFFICIENTS WERE DETERMINED IN PACKED AND FLUIDIZED REDS WITH LARGE-DIAMETER PARTICLES AND HIGH MASS VELOCITIRES, USING THE CYCLIC TEMPERATURE METHOD. EXPERIMENTAL RESULTS FOR PACKED BEOS WERE SATISFACTORILY CORRELATED WITHIN 10 PERCENT DEVIATION AS I (VOID FRACTION) \# (STANTON NUMBER) \# (PRANDTL NUMBER \#\#.666) IVS THE REYNOLDS NUMBER AND WERE FOUND TO COMPARE FAVORABLY WITH RESULTS OF OTHER EXPERIMENTERS OBTAINED WITH MUCH LOWER MASS VELOCITIES AND LARGER PARTICLES. THE PARTICLE-TO-GAS HEAT-TRANSFER COEFFICIENT VARIED AS G*\#.60 FOR STEEL SPHERES, AS G*\#.GS FOR TUNGSTEN SPHERES, ANO AS (PARTICLE DIAMETERI\$*-.44. HEAT-TRANSFER COEFFICIENTS OBTAINED AT MINIMUM FLUIDIZATION WERE IN GOOD AGREEMENT WITH THOSE OBTAINED WITH PACKED BEDS. AS THE MASS VELOCITY WAS INCREASED ABOVE THAT REQUIRED FQR MINIMUM FLUIDIZATIMN, HEAT TRANSFER COEFFICIENTS REMAINED ESSENTIALLY THE SAME.

*FLUIDIZED BEO + \#HEAT TRANSFER CORRELATION + \#PACKED BED + HEAT TRANSFER + HEAT TRANSFER COEFFICIENT + HEAT TRANSFER EXPERIMENT + SPHERE + STEEL + TUNGSTEN

$5-27546$

BERTOLETTIS + GASPARI GP + LOMBARDI C + SOLDAINI G + ZAVATTARELLIR

HEAT TRANSFER CRISIS IN STEAM-WATER MIXTURES - EXPERIMENTAL DATA IN ROUND TUSES AND VERTICAL UPFLOW DBTA INED DUR ING THE CAN-2 PP.OGPAM

CENTRO INFORMAZIONI STUDI ESPERIENZE, MILAN

EURAEC-1084 +. 67 PAGES, 4 FIGURES, 41 TABLES, 8 REFERENCES, JUNE 1964

PRESENTS ALL THE EXPERIMENTAL DATA ON THE HEAT TRANSFER CRISIS WITH STEAM-WATER MIXTURE5 FLOWING UPWARDS IN ROUND TUBES, INCLUDING THE DATA EARLISR PUBL ISHED AND ALSO THE SIGNIFICANT DATA OBTAINED WITH CISE TEST PLANT NO. 1, DURING THE CAN-2 PROGPAM. DURING THE PERIJO UNDER CUNIRACT, HEAT-TRANSFER-CRISIS DATA IN ANNULI AND CLLISTFRS WERE ALSO CCLLECTED. THESE DATA TOGETHER WITH THOSE COLLECTED IN ANALOGOUS GEJMETRIES IN CISE TEST PLANT NO. 2 WILL BE PUBLISHED IN THE NEXT TOPICAL REPORT. NO ATTEMPT IS MADE TO GIVE AN INTERPRETATION DE OR TD DISCUSS THE DATA. THIS WILL BE MADE IN CISE R-99 (1964)-REPORT IN PREPARLTION- WHERE A NEW HEAT-TRANSFER-CRISIS CORRELATION IS ALSO PROPOSED.

AVAILABILITY - USAEC DEPOSITORY LIBRARIES IN THE U.S. AND OVERSEAS

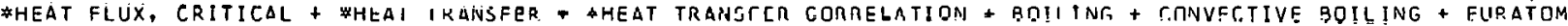

5-27547

BECKMAN WA

RADIATION AND CONVFC.TION HEAT TRANSFER. IN A POROUS BED

UNIVERSITY OF WISCONSIN, MADISON, WIS.

4 PAGES, 5 FIGURES, 4 REFERENCES, JOURNAL OF ENGINEER ING FOR POWER, 9011), PAGES $51-5413 A N U A R Y 19681$

THE ONE-DIMENSIONAL STEADY-STATE TEMPERATURE DISTRIBUTION WITHIN A ISOTRDPIC PDROUS BED SUBJECTED TO A COLLIMATFN AND/OR DIFFUSE RADIATION HEAT FLUX AND A TRANSPARENT FLOWINJ FLUID HAS BEEN DETERMINED BY NUMERICAL METHODS. THE POROUS BED WAS ASSUMEU TU BE NDNSCATTERING ANO TO HAVE A CONSTANT ABSORPTION COEFFICIENT. PART OF THE RADIATION $\triangle B S O R B E C$ BY THE PORJUS BER IS RERADIATED AND THE REMAINOER IS TRANSFERRED TO THE FLUID BY CONVECTION. DUE TO THE IS RERADIATEO AND THE R.EMAINOER IS TRANSFERRED TO THE FLUTO BY CONVECTION. DUE TO THE ASSUMED FINITE VULUML!KIL HEAT TRANSFER COCTFICIENT, THE BED ANO FIIIN HAVE DILFER ENT
TEMPERATURES. A BED WITH AN OPTICAL DEPTH OF SIX AND WITH A NORMAL INCIDENT COLLIMATED RADIATION HEAT FLUX WAS INVESTIGATED IN DETAIL. THE RADIATION INCIDENT ON THE BED AT THE FLUID FXIT WAS ASSUMED TO ORIGINATE FROM A BLACK SURFACE AT THE FLUID EXIT TEMPERATURE.

\# HEAT TRANSFER, CONVECTION + \#HEAT TRANSFER, RADIANT + \#PACKED BED + HEAT TRANSFER + MATHEMATICAL TREATMENT + NUMERICAL METHOD + THEORETICAL INVESTIGATION 
CATEGORY 5

ACCIDENT ANALYSIS

$5-27557$

BOURE

HYDRODYNAMIC INSTABILITIES LIMITING THE POWER OF BOILING WATER REACTORS

CENTRE DETUDES NUCLEAIRES DE GRENOBLE

EURAEC-1464 (VOL.2)+EUR-2389+. 300 PAGES, FIGURES, TABLES, REFERENCES, JUNE 1965 , CENTRE DETUDES NUCLEAIRES DE GRENOBLE

A BIBL IOGRAPHIC STUDY IS MADE ON THE HYDRODYNAMIC OSCILLATIONS PHENOMENON. THIS PHENOMENON OCCURS, UNDER SOME CONDITIONS, IN HEATED CHANNELS IN HHICH BOILING OF THE FLUID IS ALLOWED (SUCH AS NUCLEAR REACTORS CHANNELS). IT IS SHOWN THAT THE UNDERSTANDING OF THE MECHANISM OF THESE OSCILLATIONS CAN ONLY BE DBTAINED BY MEANS DF VERY SIMPLIFIED MODELS. TWO SUCH MODFLS ARE PROPOSED BUT ONLY ONE, THE DENSITY EFFECT MOOEL IS STUDIED HERE. OUALITATIVE AND QUANTITATIVE RESULTS SHOW VERY GOOD AGREEMENTS WITH EXPERIENCE. THEY DEMONSTRATE THE REALITY of the above mechanism. THE general Value of the. model dimensionaless parameters and the heak ACAION ON OSCILLATION THRESHOLDS OF THE PHENOMSNDNS NEGLECTED IN THE MODEL. THE GREAT IMPORTANCE OF THE SUBCOOLING PARAMETER AND OF THE LOCAL BOILING PHENOMENON IS SHOWN: A NUMBER OF POSSIBLES MODIFICATIONS OR USES DF THE DENSITY-EFFECT MODEL ARE GIVEN.

AVAILABILITY - USAEC, DIVISION OF TECHNICAL INFORMATION EXTENSION, P.0. 8OX 62, OAK RIDGE, TENN.

\#CONVECTIVE BOILING + *HOT CHANNEL + \#HYRODYNAMIC ANALYSIS + HEAT TRANSFER, BOILING + INSTABILITY + OSCILLATION

$5-27560$

LITTMAN H

STUDIES OF GAS-PARTICLE HEAT TRANSFER COEFFICIENTS IN PACKEO AND FLUIDIZED BEDS BY FREQUENCY RESPONSE

TECHNIOUES

RENSSELAER POLYTECHNIC INST, TROY, N.Y.

RPI-3639-1 +. 48 PAGES, REFERENCES, OCTOBER 1966

PART A DEALS WITH THE WORK IN PACKED BEDS DISCUSSING FIRST THE MODFIS USED FOR INTERPRETING THE HEAT TRANSFER MEASUREMENIS FOLLOWED BY A DISCUSSION OF THE DATA DBTAINED HEAT TRANSFER COEFFICIENTS, SOLID PHASE CONOUCTIVITIES AND GAS PHASE DISPERSION COEFFICIENTS. BEDS OF COPPER, LEAD AND GLASS PARTICLES WERE STUOIED IN THE REYNOLDS NUMBER RANGE FROM 1.9? TO 99.2 BY FREQUENCY RESPONSE TECHNIQUES USING A PERIOOIC TEMPERATURE WAVE IN THE GAS ENTERING THE BED. PART B DETAILS THE HORK IN FLUIDIZED BEDS AND IS BASED MAINLY ON THE PAPER BY LITTMAN, HEALY, AND BARILE (A COMPARISON OF GAS-PARTICLE HEAT TRANSFER COEFFICIENTS IN FLUIDIZED BEDS OBTAINED FROM PERIODIC AND NON-PERIODIC INPUTSI.

AVAILABILITY - CLEARINGHOUSE FOR FEDERAL SCIENTIFIC AND TECHNICAL INFORMATION, SPRINGFIELD, VA. 22151 $\$ 2.00$ COPY, SO.5O MICROFICHE

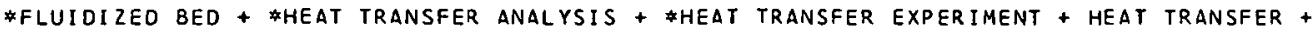

HEAT TRANSFER, CONVECTION

5-27576 ALSO IN CATEGORY 17

HBWR QUARTERLY PROGRESS REPORT, JULY TO SEPTEMBER 1966

INSTITUTT FOR ATOMENERGI, HALDEN, NORWAY

HPR-69+. 102 PAGES, 34 FIGURES, 12 TABLES, 16 REFERENCES, NAVFMRFR 1 OKA

THIS DUARTFRLY PROGRESS REPORT IS THE TWENTY-SECUNU FROM THE OECD HALDEN REACTOR PROJECT TO RECEIVE GENERAL OISTRIBIITIINN, AND COVERS ACTIVITIES WITHIN THE THREE YEAR JOINT PROGRAM COMMENCED ON 1 JANUARY 1964 . THE PROGRAM COMPRISES FUEL IRRADIATION AND DEVELOPMENT OF IN-CORE INSTRUMENTATION. OTHER PROGRAM ITEMS ARE BURNUP AND STABILITY STUDIES AVD WATER-CHEMISTRY EXPERIMENTS. THE REPORT DOES NOT INTEND TO GIVE A SUMMARY OF ALL ACTIVITIES WITHIN THE OECO HALDEN REACTOR PROJECT BUT RATHER CONCENTRATE ON ITEMS OF GENERAL INTEREST ABOUT THE DEVELOPMENTS AT THE HALOEN BOILING WATER REACTOR.

ÁVAILABILITY - USAEC DEPOSITORY LIBRARIES IN THE U.S. ANO OVERSEAS

* ACCIUENT ANALYSIS + \#HEAT TRANSFER + \#REACTOR TEST FACILITY + CHEMICAL REACTION +

FISSION PRODUCT RELEASE, GENERAL + FUEL BURNUP + OECD

5-27595 ALSO IN CATEGORIES 9 AND 17

HARRIGAN PM + MATTEL J + TOTH WL

OPTICAL, LIGHTING, ANO PHOTOGRAPHIC EQUIPMENT FOR THE ENRICO FERMI ATOMIC POWER PLANT REPAIR DROGRAM

POWER REACTOR DEVELOHMENT COMPANY + ATOMIC POWER DEVELDPMENT ASSOCIATES

1 PAGE, 1 FIGURE, ANS TRANSACTIJNS $11(1)$, PAGE 358, 1968 ANNUAL MEETING OF THE AMERICAN NUCLEAR SDCIETY AND CANADIAN NUCLEAR ASSOCIATION, TORONTO, CANADA, JUNE $10-13,1968$

A MELTOOWN OF TWO CORE SUBASSEMBLIES REQUIREO THE USE OF VERY LONG OPTICAL INSTRUMENIS AND LIGHTING EQUIPMENT FOR THE PURPOSE OF INSPECTIINN TF THE CORE AND REACTOR COMPONENTS. BECAUSE LITTLE INTURMATION WAS AVAILABLE ON THE OESIGN OF SUITABLE VIEWING AND LIGHTING EQUIPMENT FOR USE IN SODIUM REACTOR ENVIRONMENTS, MUCH DEVELOPMENTAL WORK ANO TESTING HAD TO BE DONE TO PROVIDE SUITABLE EQUIPMENT. MUCH DEVELOPMENT WAS REQUIRED TO PROVIOE LIGHTING EQUIOMENT WITH ADEQUATE LAMP LIFE AND MANEUVERABILITY. THE USE DF PHOTOGRAPHY THROUGH THE VIEWING INSTRUMENTS WAS NOT SUCCESSFUL INITIALLY, BUT IMPROVEMENTS BOTH IN TECHNIQUE AND EOUIPMENT 
CATEGORY 5

ACCIDENT ANALYSIS

5-27595 *CONTINUED*

LED TO REMARKABLY GOOD RESULTS IN THE LATTER PART OF THE PROGRAM.

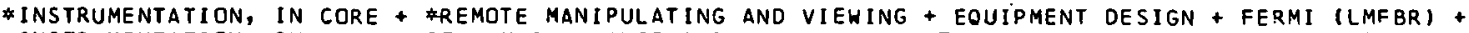
INSTRUMENTATION, SURVEILLANCE + MAINTENANCE ANO REPAIR + MAINTENANCE, REMOTE + REACTOR, BREEDER + REACTOR, FAST + REACTOR, LMCR

5-27596 ALSO IN CATEGORIES 9 AND 17

DUFFY JG + MATTE $J+R Y A N$ JD + WARBFRG HS

OBJECT RETRIEVAL TOOLS FOR THE ENRICO FERMI ATOMIC POWER PLANT REPAIR PROGRAM

ATOMIC POWER DEVELOPMENT ASSOCI ATES, INC., DETROIT, MICHIGAN

3 PAGES, 2 FIGURES, ANS TRANSACTIONS 11 ii), PAGES 358-360, 1968 ANNUAL MEETING OF THE AMERICAN NUCLEAR SOCIETY AND CANAOIAN. NUCLEAR ASSOCIATION, TORONTO, CANADA, JUNE 10-13, 1968

THE METHOD OF RETRIEVING FROM THE BOTTOM OF THE FERMI REACTOR AN OBJECT THAT CAUSED A MELTDOWN INVOLVED PROCEDURES ANO TOOLS WHICH ARE UNIQUE AND COULD HAVE APPLICATION IN FUTURE PROBLEMS. TOOLS WERE DEVELOPEO TO CUT THE OBJECT INTO PIECES SMALL ENOUGH TO BE REMOVED UPWARD THROUGH THE SUPPORT PLATE. SEVERAL GRIPPERS FOR THIS PURPOSE WERE ALSO DEVELOPED. SIMULTANEOUSLY, SPECIAL TOOLS WERE DEVELOPEO TO REMOVE THE OBJECT INTACT VIA THE SODIUM INLET PIPE.

* INSTRUMENTATION, IN CORE + *REMOTE MANIPULATING AND VIEWING + EOUIPMENT DESIGN + FERMI (LMFBR) + MAINTENANCE. AND REPAIR + MAINTENANCE, REMOTE + REACTOR, BREEOER + REACTOR, FAST + REACTOR, LMCR

5-27620 ALSO IN CATEGORIES 18 AND 16

RUSSELVILLE SUPPLEMENT 6 - TORNADO ANALYSIS

ARKANSAS POWER AND LIGHT COMPANY

8 PAGES, 12 REFERENCES, PAGES $1-8$ OF SUPPLEMENT 6 TO THE APPLICATION FOR RUSSELVILLE LICENSES IDOCKET

$50-3131$ JULY 11,1968

PROVIOES REVISED PSAR PAGES ANO (RESPONDING TO INFORMAL DRL QUESTIONS) JUSTIFICATION OF TORNADO DESIGN CRITERIA AND BEHAVIOR OF SPENT FUEL PODL DURING TORNADO. DESCRIBES BEST OBSERVATIONAL DATA FOR WIND VELOCITY IUSE 300 MPH BROAO FR.ONT HIND INSTEAD OF 200 MPH VORTEX), PRESSURE DROP (1.7 PSI/4 SEC), HATER LOSS FROM PQOLS AND WELLS 12 FT MOUND OF HATER APPEARS FROM LOW PRESSURE, SPRAY AND SUCKING DISPLACE WATER, SURVEY REOUESTED IN PILGRIM STATION REVIEW WILL BE COMPLETED SEPT. 1968 BUT SO FAR RESULTS NEGATIVE), AND MISSILES (ONLY, LIGHT WEIGHT MISSILES WOULO REACH REFUELING FLOOR 50 FT ABOVE GRADE, MISSILES FROM REFUELING FLOOR ARE MOSTLY SIDING AND HAND (ARTSI.

USAEC, PUBLIC DOCUMENT ROOM, $1717 \mathrm{H} \mathrm{ST.,} \mathrm{WASHINGTON,} \mathrm{D.C.} 20545125$ CENTS/PAGEI

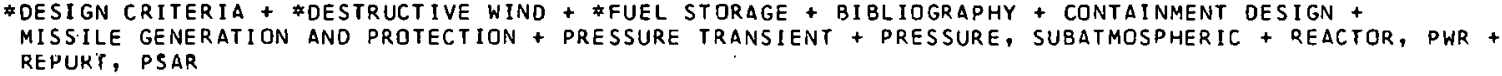

* ACCIDENT ANALYSIS + \#REACTOR, PחWER + *REACTOR, RESEARCH + COOLING, GENERAI + CDOLING, SHUTDOWN + SAFETY REVIEW

5-27647 ALSO IN CATEGORY

BRIGHT GO OF THE GENERALIZED REACTIVITY ACCIDENT FOR WATER-COOLEO AND -MODERATED UDZ-FUELED POWER REACTORS PHILLIPS PETROLEUM COMPANY

12 PAGES, 1 FIGURE, 69 REFERENCES, NUCLEAR SAFETY 8(2), PAGES 116-127 (WINTER 1966-1967)

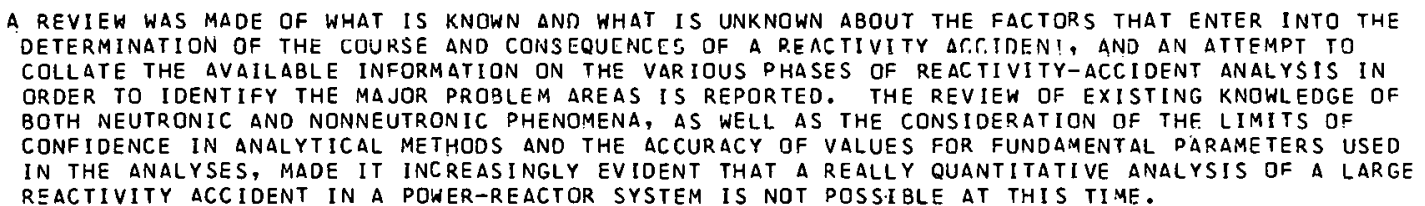

ACCIDENT ANALYSIS + ACCIDENT, REACTIVIYY + HAZARDS ANALYSIS + HEAT TRANSHEK ANALYSIS + REACTOR KINETICS + REACTOR, BWR + REACTOR, PWR + REACTOR, WATER 
CATEGORY 5

ACCIDENT ANALYSIS

5-27651

ALSO IN CATEGORY 8

WHITE JF

PHYSICO-CHEMICAL STUDIES OF CLAO UO2 IN POTENTIAL MELTDOWN ENVIRONMENT (TASK NO. 1175 )

GENERAL ELECTRIC COMPANY, CINCINNATI, OHIO

GEMP-1104 + 35 PAGES, FIGURES, TABLES, EXTRACTED FROM SEVENTH ANNUAL REPORT - AEC FUELS AND MATERIALS

DEVELOPMENT PROGRAM, MARCH 29,1968

SUMMARY OF EXPERIMENTAL WORK BY GE-NMPO DURING CY-67 TOWAROS DETERMINING THE FUEL PIN BEHAVIOR OURING A LOSS-OF-COOLANT ACCIDENT. WORK INCLUDED 11 DYNAMIC DEFORMATION AVD FAILURE STUDIES OF ZIRCALOY-4 TUBES WITH HIGH INTERNAL PRESSURES AT HIGH TEMPERATURES IN ARGON OF STEAM ENVIRONMENTS, (2) CHEMICAL KINETIC STUDIES OF THE OXIDATION OF TYPE 304 STAINLESS STEEL BY STEAM OR AIR, (4) CHEMICAL KINETIC STUDIES OF THE OXIDATION OF UO2 BY STEAM, (5) MEASUREMENTS OF THE TENSILE STRENGTH AND THE THERMAL CONOUCTIVITY OF TYPE 304L STAINLESS STEEL, AND (6) MEASUREMENTS OF THE TOTAL EMITTANCE OF UNOXIOIZEO ANO OXIOIZED AIRCALOY -4.

* AIR + *BURST PRESSURE + *CHEMICAL KINETICS + \#CHEMICAL REACTION + \#DEFORMATION + \#FUEL ELEMENT + \#METAL WATER REACTION + \#STEAM + \#STEEL, STAINLESS + \#THERMAL PROPERTY + \#URANIUM DIOXIDE + \#ZIRCALOY + ACCIDENT, LOSS OF COOLANT + CREEP BEHAVIOR + OXIDATION + STRUCTURAL ANALYSIS, OYNAMIC + THERMAL EXPERIMENT

5-27707 ALSO IN CATEGORY 6

MOORE KV + RETTIG WH

RELAP2--A OIGITAL PROGRAM FOR REACTOR BLOWDOWN ANO POWER EXCURSION ANALYSIS

PHILLIPS PETROLEUM COMPANY

IO0-17263 +. 75 PAGES, 4 FIGURES, 4 TABLES, 8 REFERENCES, MARCH 1968

RELAP2 IS A FORTRAN-IV OIGITAL PROGRAM WHICH CALCULATED FLOW, MASS INVENTORIES, TEMPERATURES, PRESSURES, REACTIVITIES, AND TRANSIENT POWER FOR THE PRIMARY SYSTEN OF A HATER REACTOR DURING A REACTIVITY OR A LOSS-DF-COOLANT ACCIDENT. ALTHOUGH RETAINING THE SIMPLIFIED GEOMETRY (THREE VOLUMES PLUS A CORE REGION) OF THE FLASH AND RELAPSE PROGRAMS, MANY IMPROVEMENTS AND EXTENSIONS HAVE BEEN MAOE. THE GEOMETRY CAN BE MADE TO APPROXIMATE EITHER A PRESSURIZEO OR A BOILING WATER REACTOR SYSTEM. THE CORE IS TREATEO AS A TWO-POINT MODEL FOR POWER GENERATION, HEAT TRANSFER, AND REACTIVITY FEEDBACKS AND AS A ONE-POINT MODEL FOR THE REACTOR KINETICS, PRESSURE BALANCES, AND FLOW BALANCES.

AVAILABILITY - CLEARINGHOUSE FOR FEDERAL SCIENTIFIC AND TECHNICAL INFORMATION, SPRINGFIELD, VA. 22ISI, $\$ 3.00$ COPY, \$0.65 MICROF ICHE

\#ACCIDENT, LOSS OF COOLANT + \#COMPUTER PROGRAM + BLOWDOWN + REACTOR DYNAMICS + REACTOR KINETICS + REACTOR, BWR + REACTOR, PWR

5-27709 ALSO IN CATEGORIES 17 ANO 12

SAXTON-LOSS OF COOLANT ACCIDENT PREVENTION AND PROTECTION

SAXTON NUCLEAR EXHLRIMENTAL CORPORATION

150 PAGES, FIGURES, TABLES, JUNE, 1968, DOCKET 50-146, TYPE--PWR, MFG--WEST., AE--GILBERT ASSOC.

RESPONOS TO DEC. 1966, DRL REQUEST FOR REANALYSIS WITH MOOERN TECHNIOUES. SYSTEMS WILL LIMIT CLAD MELT TO LESS THAN 3 PER CENT OF CLAD AREA FOR A DOUBLE ENJED COOLANT LINE RUPTURE. NO EVIDENCE OF REACTOR VESSEL OR STEAM GENERATOR LEAKS. SAFETY VALVE LEAKS HAVE BEEN SHOWN BY BORIC ACID CRYSTALS. \#PAST VISIIAI, AND RADIOGRAPH INSPCCTIDNS HAVE BEEN GUOD, BUT A

SHECIFIC INSPECTION PROGRAM WILL BE REPEATED EVERY 5 YEARS. MODIFICATIONS TO BE MADE INCLUDE BETTER I SOLATION DETWEEN BUILUING COMPARTMENTS, RECIRC. PUMP PRESSURE INDICATORS, RELAY REDUNDANCF IN SAFETY INJECTION SYSTEMS, AND TÖ YREVENT A SINGLE FAILURE FROM CLOSING INJECTION ISOLATION VALVE. APPENDIX D DESCRIBES COMPUTER PROGRAMS USED IFLASH, CHICK-KIN, LOCTA-R2I.

USAEC, PUBLIC DOCUMENT ROOM, 1717 H ST. , WASHINGTON, D.C. 20545 (25 CENTS/PAGE)

* ACCIDENT ANALYSIS + HACCIDENT, LUSS OF COOLANT + CORE REFLOODING SYSTEM + EXAMINATION + LEAK + MODIFICATION, SYSTEM OR EQUIPMENT + PIPING + PLANT PROTECTIVE SISTEM + PRESSURE RELIEF + PRESSURE VESSEL + REACTOR, PWR + SAXTON (PWR) + SURVEILLANCE PROGRAM + TEST, NONDESTRUCTIVE

$5-27714$

PATE NC

HYDRODYNAMIC STABILITY OF A ROD BUNDLE AT ATMOSPHERIC PRESSURE

THOMPSDN RAMO WOOLDRIDGE INC.

2 PAGES, 1 FIGURE, 2 REFERENCES, ANȘ TRANS. 9(2). PACES $573-74$ (NOVEMBER 1968)

THE ROD BUNDLE IS THE ONLY COMMERCIAL BOILING-WATER REACTOR-FUEL CONFIGURATION, YET THERE ARE VERY FEW EXPERIMENTAL DATA AVAILABLE ON ITS HYORODYNAMIC STABILITY. THE PURPOSE OF THIS EXPERIMENT WAS TO DETERMINE THE SIGNIFICANT DIFFERENCES AND SIMILARI TIES BETWEEN THE HYORODYNAMIC STABILITIES OF A ROD BUNDLE AND A RECTANGULAR CHANNEL OPERATED UNOER SIMILAR CONDITIONS. MEASUREMENTS WERF. MADE IN AN ATMOSPHERIC LOOP CONSISTING UF INLET ANO EXIT PLENUMS CONNECTEO BY A TEST SECTION ANO A DOWNCOMER.

*FUEL ELEMENT CLUSTER + *HYORODYNAMIC ANALYSIS + *REACTOR, BWR + FLOW, GENERAL + FLOH, THO PHASE + HOT CHANNEL 
CATEGORY 5

ACCIDENT ANALYSIS

$5-27716$

LAWSON CG + KEDL RJ + MCDONALD RE

ENHANCED HEAT-TRANSFER TUBES FOR HORIZONTAL CONDENSERS WITH POSSIBLE APPLICATIONS IN NUCLSAR POWER PLANT OESIGN

OAK RIDGE NATIONAL LABORATORY

1 PAGE, I FIGURE, ANS TRANS. $9(2)$, PAGE 656 (NOVEMBER 1966)

THE DEVELOPMENT OF IMPROVED PERFORMANCE HEAT TRANSFER SURFACE FOR. THE CONDENSERS JF LARGE MULT ISTAGE, FLASH-DISTILLATION, SEAWATER-CONVERSION PLANTS HAS LEO TO TUBE DESIGNS THAT WE BELIEVE WOULO LOWER COSTS IN NUCLEAR POWER PLANTS. THESE TUBES, HAVING SHAPES APPROACHING HYOROFOIL SURFACES (WHEN VIEWEO AXIALLY) AND CERTAIN EXTERNAL METALLIC PLATINGS, PROMOTE TURBULENCE ON THE INSIDE AND DROP-WISE CONDENSATIIUN ON THE OUTSIDE. SUCH SIMULTANEOUS MODIFICATION OF A SMOOTH TUBE RESULTED IN DOUBLING THE OVERALL HEAT-TRANSFER COEFFICIENT FOR THE SAME COOLANT FLOW RATE, STEAM TEMPERATURE, AND OTHER PROCESS BOUNOARY CONDITIONS. WHILE THE PRESSURE-DROP GRADIENT ALSO DOUBLED, HALVING THE TUBE LENGTH WOULD LEAVE THE OVERALL PRESSURE DROP UNCHANGED.

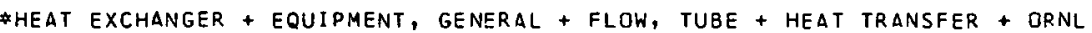

5-27719

LIIMATAINEN RC + TESTA FJ

THERMAL-REACTOR SAFETY STUDIES ON UO2 CORE FUEL-PIN CLUSTERS - TRANSIENT MELTDOWNS

ARGONNE NATIUNAL LABORATORY

1 PAGE, 1 FIGURE, 1 REFERENCE, ANS TRANS. $9(2)$, PAGE 561 (NOVEMBER 1966)

ONE OF THE PROBLEMS OF IMPORTANCE IN THE EVALUATION OF THE SAFETY OF NUCLEAR REACTORS HAS BEEN SIMULATED QUITE REALISTICALLY IN THIS EXPER IMENTAL INVESTIGATION. THIS PROBLEM IS THE HIGH-TEMPERATURE MELTDOWN BEHAVIOR DF A PORTION OF THE CORE OF A WATER-COOLED NUCLEAR REACTOR HAVING FUEL ELEMENTS OF METAL-CLAD UO2. THE DATA REPORTED HERE ON. FUEL CLUSTERS REPRESENT A SCALEUP (BY A FACTOR OF ABOUT 100 ) OF EARLIER TESTS CONOUCTED IN THIS TREAT PROGRAM. THESE SCALEUP EXPERIMENTS WERE CONTAINED WITHIN A STAINLESS-STEEL AUTOCLAVE APPROXIMATELY 4-IN. IN DIAM X 4 FT LONG.

\#FUEL ELEMENT CLUSTER + *FUEL MELTOOWN + \#URANIUM DIOXIDE + ACCIDENT ANALYSIS + EXPERIMENT, GENERAL + REACTOR, PULSED + REACTOR, SAFETY RESEARCH + TEMPERATURE TRANSIENT + TREAT (PRR)

5-27725

HIRAKAWA N + KLICKMAN AE

A COMPARISON OF THE METHODS USED IN FAST-REACTOR MELTDOWN CALCULATIONS

ATOMIC POWER DEVELOPMENT ASSOCIATES, INC. + JAPAN ATOMIC ENERGY COMMISSION

1 PAGE, 1 TABLE, 4 REFERENCES, ANS TRANS. 9(2), PAGE 552 (NOVEMBER 1966 )

BECAUSE LITTLE INFORMATION HAS BEEN MADE AVAILABLE ON THE COMPARISON OF VARIOUS METHODS USED IN THE CALCULATION OF THE ENERGY RELEASE IN A FAST-REACTOR MELTDOWN, A STUDY EMPLOYING THE VARIOUS METHODS ON A SIMPLIFIED MODEL OF THE CORE OF THE ENRICO FERMI REACTOR HAS BEEN COMPLETED. FOUR METHODS WERE USED - THE JANKUS METHOD, THE NICHOLSON METHOD, THE AX-1 METHOD, AND THE WEAK EXPLOSION CODE. THE FIRST TWO ARE HAND CALCULATIONS, AND THE LATTSR TWD ARE. DIGITAL COMPUTER METHODS.

\#ACC IDENT ANALYSIS + \#FERMI (LMFBR) + \#FUEL MEITDOWN + REACTOR, FAST + REACTOR, LMFBR

$5-27726$

SINGER RM

EXPER IMENTS ON WATER EXPULSION FOLLOWING RAPID TRANSIENT HEATING

ARGONNE NAT IONAL L ABORATORY

1 HAGE, 1 PIGURE, ANS TRANS. $3(2)$, PAGE 550 (NOVEMBER 1966)

TO INVESTIGATE THE MECHANICS OF EXPULSION OF WATER FROM A SIMULATED REACTOR CHANNEL DURING RAPIU POWER EXCURSIONS, AN EXPERIMENT WAS CONDUCTED IN WHICH WATER WAS RAPIDLY HEATED. THE WATER WAS CONTAINED IN A TRANSPARENT ANNULUS, 0.750 IN. 1.0. ANU 1.00 IN. 0.D., CLOSED AT THE BOTTOM, OPEN AT THE TOP, AND THE INNER STEEL CYLINDER WAS HEATEO OVER ITS LOWER IO IN. THE HEATING WAS ACCOMPLISHED BY STORAGE BATTERIES AND YIELDED RECTANGULAR POWER BURSTS WITH RISE TIMES OF 1 MSEC, DURATIONS OF 60 TO 100 MSEC, ANU PEAK POWERS OF $110 \mathrm{KW}$.

\#ACCIDENT ANALYSIS + \#ACCIOENT, LOSS OF COOLANT + *TEMPERATURE TRANSIENT + HEAT TRANSFER EXPERIMENT + WATER, GENERAL

$5-27728$

PLAK $\overline{R O}$

DESIGN OF THE LOFT REACTOR INTERNALS

PHILLIPS PETROL EUM COMPANY

1 PAGE, 1 TABLE, 3 REFERENCES, ANS TRANS. 9(2), PAGE 549 (NOVEMBER 1966)

AN IMPRRTANT OBJECTIVE FOR THE LOSS-OF-FLUID TEST (LOFT) HAS BEEN TO DESIGN A 50-MW(TH) 
CATEGORY 5

ACCIDENT ANALYSIS

\section{5-27728 *CONTINUED*}

REACTOR THAT MAY BE CONSIDERED REPRESENTATIVE OF THE PRESSURIZED-WATER POWER REACTORS NOW UNDER CONSTRUCTION OR UNDER DESIGN FOR CONSTRUCTION IN THE NEAR FUTURE. THE LOFT REACTOR INTERNALS ARE AN ATTEMPT TO ACHIEVE A DESIGN REPRESENTATIVE OF THIS CURRENT DESIGN

TECHNOLOGY. THE DESIGN AND ANALYSIS OF THE REACTOR INTERNALS ARE UNIQUE IN THE SENSE THAT THE REACTOR WILL EXPERIENCE A LOSS-OF-COOLANT MAXIMUM ACCIDENT.

\#EQUIPMENT, GENERAL + *LOFT (S-RR) + \#REACTOR DESCRIPTION + EQUIPMENT DESIGN + REACTOR, PWR + REACTOR, SAFETY RESEARCH

5-27737

LEE OI + BONILLA CF

THE VISCOSITY OF THE ALKALI METAL VAPORS

COLUMBIA UNIVERSITY, NEW YORK

15 PAGES, 11 FIGURES, 5 TABLES, 44 REFERENCES, NUCLEAR ENGINEERING AND OESIGN 7, PAGES 455-469 (1968)

THE VISCOSITIES OF CS, RB, K, ANO NA VAPORS WERE MEASURED UP TO 1000 C IN THE PRESSURE RANGE OF 0.4 TO 5 ATM BY A STEAOY FLOW HIGH-TEMPERATURE COILED CAPILLARY VISCOMETER. THE INTERACTION POTENTIAL ENERGIES FOR THE SINGLET AND TRIPLET STATES OF ALKALI METAL ATOMS HAVE BEEN OBTAINED FROM THOSE OF HYDROGEN ATOMS BY A SEMI-EMPIRICAL SCALING PRDCEDURE BASED ON THE REPULSIVE-CORE THEORY, AND THOSE FOR THE OIMER-DIMER, ANO MONOMER-DIMER INTERACTIONS HAVE ALSO BEEN CALCULATEO FROM THOSE FOR THE TRIPLET STATES BY A SEMI-EMPIRICAL PAIRING PROCEDURE. THERE IS GOOD AGREEMENT BETWEEN VALUES EXTRAPOLATED FROM THE EXPERIMENTAL RESULTS AND THE CALCULATED VALUES OF THE VISCOSITY OF THE ALKALI METAL MONATOMIC VAPORS, BUT THOSE OF THE EQUILIBRIUM VAPORS DIFFER FROM THE CALCULATED VALUES. THIS SUGGESTS THAT THE CHAPMAN-ENSKOG METHOD MAY NOT BE APPLICABLE TO THE VISCOSITY OF CHEMICALLY ASSOCIATING GASES.

\#METAL, ALKALI + \#TRANSPORT PROPERTY + CESIUM + POTASSIUM + RUBIDIUM + SOOIUM

$5-27740$

BURCHILL WE + JONES BG

THE INFLUENCE OF AXIAL CONOUCTION ON HEAT TRANSFER TO LIQUID METALS IN REACTOR COOLANT CHANNELS UNIVERSITY OF ILLINOIS

2 PAGES, 1 FIGURE, 1 TABLE, 4 ReFERENCES, ANS TRANS. $9(2)$, PAGES 568-69 (NDVEMBER 1966)

PRESENTS AN ANALYTICAL INVESTIGATION OF THE EFFECT DF AXIAL CONOUCTION ON THE HEAT TRANSFER TO A LIQUID-METAL COOLANT IN A CIRCULAR TUBE (PIPE) OR BETWEEN PARALLEL FLAT PLATES (CHANNELI AS WOULD BE FOUND IN A NUCLEAR REACTOR. A NUMERICAL EVALUATION OF THE ANALYTICAL RESULTS FOR THE TEMPERATURE PROFILES, NU VARIATIONS, AND THERMAL ENTRY AND EXIT LENGTHS WAS PERFORMED FOR A CONSTANT WALL FLUX. THE EXTENSION TO ARBITRARY WALL FLUX IS PRESENTLY BEING PURSUED.

* HEAT TRANSFER, CONDUCTION + \#HOT CHANNEL + \#METAL, LIQUID + FLOW, AXIAL + HEAT TRANSFER + HEAT TRANSFER ANALYSIS

$5-27741$

MORGAN RP + PAGE RJ

THE EFFECT OF VARIABLE WALL HEAT FLUX ON HEAT TRANSFER IN THE THERMAL ENTRANCE REgION OF REACTOR COOLANT CHANNELS

UNIVERSITY OF MISSOURI

2 PAGES, 1 FIGURE, 2 REFERENCES, ANS TRANS, 9(2), PAGES 567-68 (NQVEMBER 1966)

IN RECENT YEARS, LINEAR SUPERPOSITION TECHNIQUES HAVE BEEN EMPLOYED TO ANALYZE HEAT TRANSFER TO SINGLE-PHASE, CONSTANT-PROPERTY, BOUNDARY-LAYER FLOWS WITH VARIABLE WALL TEMPERATURE OR HEAT FLUX. IN DUR STUDY, A STEP IN WALL HEAT FLUX TECHNIQUE DEVELOPED BY HANNA WAS USED TO COMPUTE LOCAL HEAT-TRANSFER COEFFICIENTS IN THE THERMAL ENTRANC, REG IDN OF A COOLANT CHANNEL IN WHICH THE WALL HEAT FLUX FOLLOWS THE CHOPPED-COSINE DISTRIBUTION CHARACTERISTIC OF NUCLEAR REACTORS. RESULTS FOR BOTH FULLY OEVELOPED LAMINAR ANO TURBULENT FLOW WERE OBTAINED.

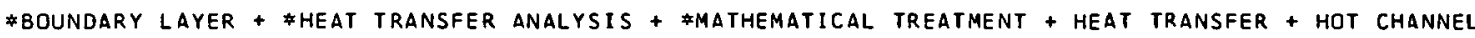

$5-27742$

MACPHEE J + LUMB RF + HALL WF

COMPARISON OF NATURAL- AND FORCED-CONVECTION COOLING FOR A PULSED URANIUM-OXIDE REACTOR

METAL FI IW T.MRP. + NATIMNAI OR.AMFMY RF STIFNCFS

1 PAGE, ANS TRANS. $9(21$, PAGE 567 (NOVEMBER 1966)

PULSTAR REPRESENTS A UNIQUE CONCEPT AMONG RESEARCH REACTOR DESIGNS IN THAT USE OF LOW-ENRICHMENT OXIOE FUEL PERMITS THE ALTERNATIVES OF PULSE OR STEADY-STATE OPERATION. IT WAS CONCLUDEO THAT DEPARTURE FROM NUCLEATE BOILING (DNB) HAD OCCURRED IN ALL SIX TEST PINS AND IN THE HOTTER CORE PINS.

\#HEAT TRANSFER, CONVECTION + \#HEAT TRANSFER, NATURAL CONVECTION + \#REACTOR, PULSED + ACCIOENT ANALYSIS + ONB + HEAT TRANSFER EXPERIMENT + REACTOR DESCRIPTION + URANIUM.OXIDE 
CATEGORY 5

ACCIDENT ANALYSIS

5-27747 *CONTINUED*

BEASLEY EG + COFFEY JA + MILLS LM

PRQCEDURE FOR DETERMINING THE DEPRESSUR IZATION RATE OF THE EGCR PRIMARY SUSTEM IN THE EVENT OF COMPQNENT FAILURE

TENNESSEE VALLEY AUTHORITY, UAK RIDGE, TENNESSEE

TID-22740 +. 21 PAGES, TABLES, SEPTEMBER 1964

THE PURPOSE OF THIS PAPER IS TO ESTABLISH A CALCULATIONGL PROCECURE FOR OETERMINING THE PRESSURE DIFFERENT IAL ACROSS THE EGCR PRIMARY SYSTEM COMPONENTS AND THE DATE OF DEPRESSURIZATION OF THE PRIMARY SYSTEM IN THE EVFNT RUPTURES OF VARIOUS SIZFS DND LOCATIONS OCCUR IN THE PRIMARY SYSTEM. THE COMPONENTS OE SPECIFIC INTEREST ARE THE REACTOR CORE, THE STEAM GENERATORS, AND THE BLOWERS. IN BRIEF, THE SYSTEM HAS BEEN DIVIUEU INTO SIX NODES, WHERE EACH NODE CONSISTS OF A BODY WITH NO INTERNAL FLOW RESISTANCE, AND THE NODES WERE CONNECTED BY FLOW RESISIANCE THAT DID NOT HAVE VOLUME.

AVAILABILITY - CLEARINGHOUSE FOR FEDERAL SCIENTIFIC AND TECHNICAL INFORMATION, SPPINGFIELD, VA. 22 I5I $\$ 1.00$ COPY, \$O.50 MICROF ICHE

\#PRESSURE DRDP + \#PRESSURE TRANSIENT + \#PEACTOR, GCR + ACCIDENT ANALYSIS + CONTAINMENT, ORESSURE VENTING

$5-27748$

GAMBIUL W R

RECENT STUDIES OF BOILING BURNOUT

OAK RIDGE NATIONAL LABORATORY, OAK RIDGE, TENNESSEE

ORNL-P-18 + CONF-537-3+. 12 PAGES, 5 REFERENCES, FROM USAEC-EURATOM CONFERENCE ON TWO-PHASE FLOW PROBLEMS, WASHINGTON, D.C., APR-MAY, 1964

FIVE RECENT INVESTIGATIONS OF THE CRITICAL HEAT FLUX IN WATER SYSTEMS APE SUMMARIZED. THESE STUDIES WERE CONDUCTED IN THE INTERNAL FROM EARLY 1963 THRCUGH THE PRESENT. A. DOJL STUDIES - (1) INHERENT UNCERTAINTY IN THE CRITICAL HEAT FLUX. (2) HEAT TRANSFER INSIDE OF HORIZONTAL, OPEN ENDED HEATED TUBES IMMERSEO IN A POOL. I3I NATURAL-CONVECTION BURNOUT OF CLOSED VERTICAL CHANNELS. S. FORCED CONVECTIDN INVESTIGATIONS - II) SUBCDOLFO BOILING $\triangle N D$ BURNOUT WITH HEATED TWISTED TAPES. (2) SWIRL-FLOW FORCEO-CONVECTION. BULK-BDILING LDOD.

AVAILABILITY - USAEC DEPOSITORY LIBRARIES IN THE U.S. AND DVERSEAS

\#HEAT FLUX, CRITICAL + \#HEAT TRANSFER, CONVECTION + \#HEAT TPANSFER, NATURAL CONVECTION + HEAT TRANSFER EXPERIMENT + ORNL

$5-27751$

GRASS G + KOTTOWSKI H + WARNSING R

BOILING OF LIQUID ALKALI METALS

EURUPEAN ATUMIC ENERGY COMMUNITY, ISPRA (ITALY), INTNT NUCLEAR FESEARCH CENTER

ANL-TRANS-390 +. 37 PAGES, TRANSLATED FROM REPORT, SEPT. 1966

BOILING OF LIQUID METALS AT LOW PRESSURES IS UNSTABLF UNOER STAGNANT CONDITIONS AS WELL AS UNDER CONDITIONS OF NATURAL AND FORCED CONVECTIDN. THIS UNSTARLE TYPE OF BOILING MAY BE INTERPRETED AS AN EJECTION SEQUENCE OF SINGLE BUBBLES. THE KINETICS INVOLVEO IN THIS EJECTION PROCESS ARE SIGNIFICANTLY INFLUENCED BY THE VAPOR PRESSURE IN THE BUBSLE. IN THE WORK HERE DESCRIBEO INITIAL SUPERHEAT, INITIAL ORESSURE AND SIIRSEQUENT PRESSURE VARIATIONS, WERE FOR VARIOUS EXPERIMFNTAL CONDITIONS COMPARED WITH THE KINETICS OF THE SINGLE BUBBLE

EJECTIONS. A CALCULATION MODEL WAS SET UP TO CORRELATE OUANTIIATIVELY THE PHENOMENA.

AVAILABILITY - SPECIAL LI RRARIES ASSOCIATION TRANSLATION CENTER, JOHN CRERAR LIBRARY, 35 WEST 33 RD STREET, CHICAGO, II.LINOIS 60616

*BIILING + *CONVECTIVE BOILING + \#METAL, ALKALI + BUBBLE + BUBBLE NUCLEATION + NUCLEATE 8OILING + REACTDR, LMFBR + SODIUM + VOID FRALIIUN

$5-27802$

COATFS NH + GALLI AF

FILM COEFFICIENTS OF HEAT TRANSFER FOR HELIUM AT 2,000 DEg TO 2,500 DEC C IN TURBULENT FLOW BUREAU OF HINES, WASHINCTON, D. C

BM-RI-6856 +. 25 PAGES, 10 FIGURES, 2 TABLES, 1966

THE BUREAU OF MINES DETERMINEO AVERAGE FILM COEFF́ ICIENTS OF HEAT TRANSFER FOR HELIUM FLDWING THROUGH SMOOTH, WATER-COOLEO TIIRFS AT REYNOLDS NUMBERS OF 5,000 TO 25,000, HELIUM INLET TEMPERATURES OF 1,600 TO $2,600 \mathrm{~F}$, AVERAGE TEMPERATURE DIFFERENCE ACROSS IHE HELIUM FILM OF 900 TO $1,300 \mathrm{~F}$, AND HEAT FLUX TO 215,000 BTU/(HRI(SO FT). SINCE HELIUM WAS THE ONLY GAS USEO, THE RANGES OF VALUES FOR PHYSICAL PRIPERTIES OF THE FLUIO ARE LIMITED--THERMAL

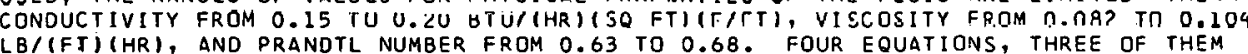
DIMENSIONLESS, CORRELATE THESE COEFFICIENTS WITH OTHER PROPERTIES OF THE HELIUM--BULK TEMPERATURE, FII.M TEMPERATURE, DIMENSIONLESS PARAMETERS BASEO ON TEMPERATURE, AND THE RATIO OF WALL TEMPERATURE TO BULK TEMPERATURE, VALUES OF THE AVERAGE INSIDE FILM COEFFICIENT OF HEAT TRANGFCR DETERMINEO FROM THESE FQUIATIONS AGREE WITHIN 10 PERCENT.

AVAILABILITY - CLEARINGHOUSE FOP. FEDERAL SC.IFNTIFIC ANO TECHNICAL INFORMATION, SPEINGFIELO, VIRGINIA 22151

\#HEAT TRANSFER COEFFICIENT + \#HEAT TRANSFER CORRELATION + \#HELIUM + FLOW, TURBULENT + HEAT TRANSFER + HEAT TRAINGER EXPERIMENT + HEAT TRANSFER, CONVFCTION 
ANL-TRANS-392 +. 11 PAGES, TRANSLATED FROM INZH. FIZ, ZH., 10(5), PAGE 668-75 (1966)

THE VARIATION METHOD CONSIDERED HHICH REDUCES THE SOLUTION DF THE TWO-DIMENSIONAL

HEAT-CONDUCTION EQUATION TO A SET OF LINEAR DIFFERENTIAL EQUATIONS IS VERY SIMPLE ANJ SHOWS

GODD CONVERGENCE. THE METHOO SUGGESTED FOR CHOOSING THE COORDINATE FUNCTIONS AND THE

POSSIBILITY OF APPLICATION OF THE SIMPLEST INTEGRATORS FOR CALCULATION OF COEFFICIENTS OF

EULERS EQUATION SET MAKE THIS METHOD VERY CONVENIENT FOR PRACTICAL USE.

AVAILABILITY - CLEARINGHOUSE FOR FEDERAL SCIENTIFIC ANO TECHNICAL INFORMATION, SPRINGFIELD, VIRGINIA 22I5I

*HEAT TRANSFER, CONDUCTION + \#MATHEMATICAL STUDY + \#MATHEMATICAL TREATMENT + HEAT TRANSFER +

HEAT TRANSFER ANALYSIS

5-27805 ALSO IN CATEGORY 11

BIRSS IR

CALCULATION JF RELATIVE OISPLACEMENT DAMAGE RATES IN DIFFERING REACTOR TYPES

UNITED KINGDOM ATOMIC ENERGY AUTHORITY, DOUNREAY (SCOTLAND)

TRG-REPORT-1561 +. 18 PAGES, 6 FIGURES, 3 TABLES, 10 REFERENCES, 1967

A NUMBER OF MATERIALS NOT NECESSARILY DESTINED FOR USE IN FAST REACTORS, IN WHICH ATOMIC DISPLACEMENTS ARE THE MAIN OAMAGE MECHANISM UNDER OBSERVATION, ARE PRESENTLY BEING IRRADIATED IN THE DOUNREAY FAST REACTOR. IN THIS PAPER IT IS SHOWN THAT, IF IT CAN BE ACCEPTEO THAT THE RATIO OF ATOMIC OISPLACEMENT RATE IN THE TEST REACTOR TO OISPLACEMENT RATE IN THE PARENT REACTOR IS AN ACCEPTABLE PARAMETER FOR COMPARISON PURPOSES, THEN THE ATOMIC OISPLACEMENT ENERGY AND THE ELECTRONIC CUT OFF ENERGY OF A MATER IAL $\triangle R E$ NOT CRITICAL PARAMETERS IN THE OERIVATION OF THIS RATIO. IT IS ALSO SHOWN THAT, IF THE EOUIVALENT FISSION FLUX CONCEPT IS USED TO DESCRIBE RFACTOR SPECTRA, IT CAN LEAD TO APPRECIABLE ERRORS IN DERIVING THE DAMAGE RATIO, BUT THAT INTEGRATION OVER THE REAL SPECTRUM IS UNNECESSARY BELOW ABDUT O.1 MEV.

AVAILABILITY - CLEARINGHOUSE FOR FEDERAL SCIENTIFIC ANO TECHVICAL INFORMATION, SPRINGFIELD, VA. 22151 $\$ 3.00$ COPY, \$0.65 MICROFICHE

* DAMAGE + \#IRRADIATION TESTING + *MATERIAL + IN PILE EXPERIMENT + METAL

5-27834 ALSO IN CATEGORIES 18 AND 16

BRUNSWICK STEAM ELECTRIC PLANT UNITS $1+2$, PRELIMINARY SAFETY ANALYSIS REPORT, VOLUMF II

CAROL INA POWER + LIGHT COMPANY

400 PAGES FIGURES, TABLES, ,IJLY 1968 , DOCKET 50-324/325

VOL. II CONTAINS SECT. VII (INSTRUMENTATION AND CONTROL - INCLUDES AUTO LOAD OISPATCH FROM RALEIGH, N. C.), VIII (ELECTRICAL POWER - 4 DIESELS), IX (RAD WASTE), X (AUXILIARIES), XI (POWER CONVERSION), XII (PLANT OPERATIONS - PERSONNEL WILL BE AVAILABLE FROM ROBINSON 2 ), $X I I I$ (TECH. SPECS.), AND XIV (SAFETY AND ACCIDENT ANALYSISI. 40 PAGES DESCRIBE THE OFFSITE DOSE CALCULATION MODEL USED IN RADOS COMPUTER CODE, ISOTOPE FRACTIONS. RELEASED FROM FUEL IN EXPFR IMFNTS ANR IN THFSF A.CEIDENTC, AND RROYIDEJ OOTH A CUIVSEKVAIIVE BASE CASE AND A BEST ESTIMATE (MARGINS RANGE FROM FACTORS OF 8400 TO 16,700$), 6$ PAGES PROVIDE A SENSITIVITY

ANALYSIS AND A SPECIAL COMPARISON WITH TIO 14844 ANO RECENT AEC-DRI SAFETY EVALUATIDN.

AVAILABILITY - USAEC PUBLIC DOCUMENT ROOM, WAȘHINGTON, D. C.

* DOSE + \#OFF SITE + ACCIDENT MODEL + BRUNSWICK (BWR) + COMPARISON, THEORY AND EXPERIENCE + ERROR ANALYSIS + REACTOR, BWR + REPORT, PSAR + SAFETY EVALUATION + STAFFING, TRAINING, QUALIFICATION

$5-27881$

TOUBARF + MCFADOEN PW

COMB INED TURBULENT CONVECTION HEAT TRANSFER TO NEAR CRITICAL WATER

PURDUE RESEARCH FOUNDATION, LAFAYETTE, IND.

COO-1177-18+. 255 PAGES, FIGURES, TABLES, JANUARY 1966

THIS EXPERIMENTAL STUOY DEALS WITH AN INVESTIGATION OF HEAT TRANSFER TO NEAR CRITICAL WATER FLOWING THROUGH A HEATED VERTICAL TUBE. TURBULENT FREE ANO FORCED CONYECTION FLOW WAS

PRESENT. I OC. AL HEAT TRANSFER AND STANTON NUMBERS WERE COMPUT'EU FROM THE DATA. THE DATA WAS CHECKED AGAINST THE DITTUS-BDELTER EOUATION ANO GOOD AGREEMENT WAS OBTAINED FOR TEMPERATURES BELOW $650 \mathrm{~F}$ OR PRANDTL NUMBER, BASED ON THE BULK FLUID TEMPERATURE, NOT EXCEEDING 1.20.

AVAILABILITY - CLEARINGHOUSE FOR FEDERAL SCIENTIFIC AND TECHNICAL INFORMATION, NATIONAL BUREAU OF STANDARDS, SPRINGFIELD, VA. $22151, \$ 3.00$ COPY, \$0.65 MICROFICHE

\#FLOW, TURBULENT + \#HEAT TRANSFER, CONVECTION + \#WATER, GENERAL + FLOW, TUBE + HEAT TRANSFER EXPERIMENT + TRANSPORT PROPERTY 
THIS PIPE-RUPTURE STUDY IS CONCERNED WITH IMPROVING CURRENT UNCERSTANDING OF FAILURE-CAUSING MECHANISMS AND PROVIDING IMPROVED CAPABILITY FOR EVALUATING AND MONITORING REACTOR PIPING SYSTEMS TO MINIMI ZE THE PROBABILITY OF FAILURES. THIS STATUS REPORT SUMMARIZES THE ACCOMPLISHMENTS DURING THE INITIAL YEAR OF A BROAD 4-YEAR PROGRAM IN (I) RELIABILITY ENGINEERING OF ACTUAL REACTOR PIPING SYSTEMS, (2) SOLUTION OF HERETOFORE INTRACTABLE PROBLEMS IN STRESS ANALYSIS, (3) APPLICATION OF FRAC.TIIRE MECHANICS TO DUCTILE MATERIALS, AND (4) Fatigue stUdies throUgh BOTH BENCH-SCALE AND LARGE-COMPONENT TESTS.

\#ACCIDENT ANALYSIS + \#FAILURE, PIPE + \#PIPING + ACCIOENT, STEAM LINE RUPTURE + FAILURE, TUBING + PLANT PRDTECTIVE SYSTEM

$5-27883$

TURNEY GE

AN EXPER IMENTAL INVESTIGATION OF THE LAMINAR FLOW INSTABILITY PROBLEM RELATEO TO STRONG HEATING OF. NORMAL-HYDROGEN GAS IN A SMALL-DIAMETER TUBE

UNIVERSITY OF CINCINNATI, OHIO

$X 65-13748+N A S A-T M-X-56224+, 60$ PAGES, FIGURES, REFERENCES, 1965

THE STEADY-STATE PRESSURE-DROP CHARACTERISTICS OF NORMAL HYDROGEN GAS FLOHING IN AN ELECTRICALLY HEATED TEST SECTION WERE DETERMINED EXPERIMENTALLY OVER A LIMITED RANGF DF REYNOLDS NUMBERS IN THE REGION OF THE LAMINAR-TURBULENT FLOW TRANSITION POINT. THE EXPER IMENTAL INVESTIGATION WAS CONDUCTED AT AVERAGE OPERATING HEAT FLUX VALUES OF 0.320 , 0485, AND 0.640 8TU/SEC-FT2. THE REYNOLOS NUMBERS (BASED ON INLET CONDITIONS) RANGED FROM 600 TO 5600, AND THE RATIO OF OUTLET TO INLET FLUID TEMPERATURES RANGES FROM APPRJXIMATELY 2.6 TO 10.8. THE TEST SECTION USED IN THESE EXPERIMENTS WAS A NICHROME-V TUBE WITH AN INSIDE 2.6 TO 10.8. THE TEST SECTION USED IN THESE EXPERIMENTS WAS A NICHQOME-V TUBE WITH AN INSIME
OIAMETER OF 0.116 INCH AND A HEATED LENGTH OF APPROXIMATELY SO INCHES. FROM A QUALITATIVE STANDPOINT, THE RESULTS OBTAINED FROM THE ANALYSIS AGREE REASONABLY WELL WITH THE EXPERIMENTAL VALUES.

AVAILABILITY - G. E. TURNEY, UNIVERSITY OF CINCINNATI

*FLOW STABILITY + \#HYOROGEN + \#PRESSURE OROP + FLOW THEORY AND EXPERIMENTS + FLOW, LAMINAR + FLOW, TUBE

$5-27884$

MAT ZNER B

CRITICAL HEAT FLUX FOR LARGE OIAMETER, INTERNALLY HEATED ANNULI IN FORCED CONVECTION BOILING AT IOOO PSIA.

TOPICAL REPOR.T NO. 6

COLUMBIA UNIVERSITY, NEW YORK

TID-22321 +. 46 PAGES, 4 REFERENCES, SEPTEMBER 1965

THE WORK SUMMARIZEO IN THIS REPORT WAS PERFORMEO AT COLUMBIA UNIVERSITY AS PART OF THE USAECIAECL COOPERATIVE PROGRAM FOR THE DEVELOPMENT OC HFAVY WATER REACTDRS. THE

SHELL-IN-TUBE FUEL ELEMENT CONCEPT HAS TENTATIVELY BEEN SELECTEC FOR THE SECOND CORE OF THE $\triangle E C L$ 250-MW BOILING LIGHT-WATER REACTOR. IN THIS FUEL DESIGN A CYLINDER OF FUEL IS PIERCED BY ABOUT 24 AXIAL COOLANI CHANNELS. COOLING IS ALSO REQUIPED ARDUND THF C.IRCUMFERENCE DF THE ELEMENT. THE EXPERIMENTS DESGRIRFD WERE DESIGNED TO GIVE THERMAL ANO HYORAULIC INFORMATION FOR TYPICAL SIMULATIONS OF THE OUTER ANNULUS OF THE SHELL-IN-TUBE FUEL ELEMENT.

AVAILABILITY - CLEARINGHOUSE FOR FEDERAL SCIENTIFIC AND TECHNICAL INFORMATION, NATIONAL BUREAU OF STANDARDS, SPRINGFIFID, VA. 22151,\$3.00 COPY, \$0.65.MICROFICHE

\#FInW, ONNIII AR + \#HEAT FLUX, CRITICAL + \#HEAT GENERATION, INTERNAL + HEAT EXCHANGER + REACTOR, BWR

$5-27885 \quad$ ALSO IN CATEGORY 9

KARTLUKE H + WICHNER RP + HOFFMAN HW

AN ACOUSTIC INSTRUMENT FOR MEASURING SUBCOOLING IN BOILING SYSTEMS

OAK RIDGE NATIONAL LABORATORY

ORNL-P-1678 +.CONF-650946-3 +. 8 PAGES, I REFERENCES, FROM 4TH HIGH TEMPERATURE LIOUIC-METAL HEAT

TRANSFER TECHNOLOGY CONFERENCE, ARGONNE, ILLINOIS, SEPTEMBER 28-2\%, 1965

DESCRIBES AN ACOUSTIC INSTRUMENT CAPABLE OF INDICATING THE DEGREE OF UNDERSATURATION IN A KINOWIN FLUID AT UPKNOWN LOCAL TEMPFRATIIRF AND PRESSURE CONDITIONS. THIS IVCIPIENT-BOILING DETECTOR HAS BEEN TESTED WITH WATER ANO SHOWN TO BE EFFECT IVE IN MONITORING IHE HLOW IN PRESSURI 2ED WATER REACTORS, WHERE BOILING IS UNDESIRABLE ANO DANGEROUS. THE CURRENT STUDY IS DIRECTEO TO EVALUATING THIS DEVICE FOP. POSSIBLE SIMII.AR APPLICATION IN LIQUIO-METAL

COOLED-FAST REACTORS. PRELIMINAKY TESTS IN LIQUIO POTASSIUM ARE DISCUSSFR. THE RESULIS WERE INCONCLUSIVE, ANO EXPERIMENTS WITH A HIGHER POWER OSCILLATGR ARE DLANNED.

AVAILABILITY - CLEARINGHOUSE FAR FEDERAL SCIENTIFIC AND TECHINICAL INFORMATIDN, NATIONAL BUREAU OF STANDARDS, SPRINGFIELD, VA. $22151, \$ 3.00$ COPY, \$0.65 MICROFICHE

\#INSTRUMENTATION, COOLANT QUALITY + \#NOISE + \#SUBCOOLING + BOILING + INSTRUMENTATION, GENERAL + 
5-27885 \#CONTINUED*

NOISE ANALYSIS

5-27886

FONT ANA MH

CORE MELT-THROUGH AS A CONSEQUENCE OF FAILURE OF EMERGENCY CORE COOLING

OAK RIDGE NATIONAL LABORATORY

11 PAGES, 1 FIGURE, 21 REFERENCES, NUCLEAR SAFETY 9(1), PAGES 14-25 (JAN.-FEB. 1968 )

THIS ARTICLE IS A CONDENSED COMPILATION OF SOME OF THE TECHNICAL FINDINGS OF A TASK FORCE COMMISSIONED TO INVESTIGATE THE POSSIBILITY AND CONSEQUENCES OF THE CORE MELTING THRJUGH THE PRESSURE VESSEL AND THE CONT AINMENT VESSEL IN THE EVENT GF LOSS OF EMERGENCY CORE COQLING. REASONABLE SEQUENCE OF EVENTS DURING THE HYPOTHETICAL ACCIDENT IS DESCRIBED, AND TIMES REQUIRED FOR INITIATION AND COMPLETION OF EACH EVENT ARE ESTIMATED. THE SUBSEQUENT HANDLING OF THE MOLTEN MASSES IS THEN CONSIDERED. A OUALITATIVE DESCRIPTION OF FISSION-PRODUCT BEHAVIOR IS GIVEN, AND THE POSSIBILITIES AND EFFECTS OF STEAM EXPLOSIONS ARE THEN PRESENTED, ALONG WITH ADDITIONAL OBSERVATIONS BY THE COMPILER.

*COOLING, GENERAL + \#CORE MELTDOWN + \#EMERgENCY SYSTEM + \#FAILURE, EQUIPMENT + ACCIDENT ANALYSIS + ACCIDENT, LOSS OF COOLANT + FISSION PRODUCT TRANSPORT

$5-27887$

TONG LS

HEAT TRANSFER IN WATER-COOLEO NUCLEAR REACTORS

WESTINGHOUSE ELECTRIC CORPORATION, PITTSBURGH, PA.

24 PAGES, 34 FIGURES, 5 TABLES, 8 REFERENCES, NUCLEAR ENGINEERING AND DESIGN 6(4), PAGES $301-324$ (NOVEMBER 19671

A NUCLEAR POWER REACTOR IS A THERMAL MACHINE. ITS SERVICE AND ECDNOMIC VALUE DEPEND STRONGLY DN THERMAL PERFORMANCE OF THE FUEL AND COOLANT IN THE CJRE. SOME PARAMETERS INDICATIVE OF THE CORE THERMAL PERFORMANCE ARE THE FUEL SURFACE HEAT FLUX, THE COOLANT ENTHALPY RISE, THE FUEL ROD LINEAR POWER RATE (KW/FT) AND THE FUEL SPECIFIC POWER (KW/KG U). THE HIGH THERMAL RATINGS OF THESE PARAMETERS CAN ONLY BE ACHIEVEO THROUGH ADEQUATE HEAT TRANSFER MECHANISMS AND CAPABILITIES WITHIN THE FUEL ROD AND AT THE CLAO-WATER INTERFACE. THIS PAPER DRESENTS

(1) THE EVALUATION OF CORE THERMAL PERFORMANCE AND 121 THE PREDICTION OF ADEQUATE HEAT

TRANSFER MECHANISMS AND CAPABILITIES.

\#HEAT TRANSFER + \#HEAT TRANSFER ANALYSIS + \#REACTOR, WATER + REACTOR POWER + REACTOR, GENERAL

$5-27888$

BIOT MA

GENERALI ZED VARIATIONAL PRINCIPLES FOR CONVECTIVE HEAT TRANSFER AND IRREVERSIBLE THERMODYNAMICS

10 PAGES, 7 REFERENCES, JOURNAL OF MATHEMATICS AND MECHANICS $15(2)$, PAGES 177-86 11966)

VARIATIONAL PRINCIPLES FOR CONVECTIVE HEAT TRANSFER ARE EXTENDED TO NONHOMOGENEOUS FLUIDS AND TO FLUIDS WITH THERMAL EXPANSION. THE RESULTS APOLY TO NONLINEAR PROBLEMS WITH

TEMPERATURE-DEPENDENT PROPFRTIES, THE CONTEXT IS RESTRICTED TO HEAT TRANSFER, HUT THE

OERIVATION AND A DISCUSSION OF THE PHYSICS BRINGS MIIT THE GENERAL VALIDITY OT TIIE VARIATIONAL. PRINCIPLES FOR A LARGE CATEGORY OF IRREVERSIBLE PROCESSES.

* heat transfer, convection + \#mathematical treatment + \#Thermodynamics + heat transfer + mathematical study

$5-27889$

TUNG LS + CURRIN HB + LARSENPS + SMITH OG

INFLUENCE OF AXIALLY NON-UNIFORM HEAT FLUX ON DNB

WESTINGHOUSE ELECTRIC C.ORPRRATION, PITTSBURGH, PA. + GENERAL ELECTRIC

AICHE PREPRINT $17+27$ PAGES, 9 FIGURES, 9 REFERENCES, PRESENTED AT 8TH NATIONAL HEAT TRANSFER

CONFERENCE, AICHE-ASME, LOS ANGELES, AUGUST 8-11, 1965

MOST OF THE EXISTING DNB DATA HAVE BEEN OBTAINED FROM TEST SECTIONS WITH AXIALLY UNIFORM HEAT FLUXES. HOWEVER, IN A NUCLEAR REACTOR, WHERE DNB INFORMATION IS OF GREAT IMPORTANCE, THE AXIAL HEAT FLUX DISTRISUTION IS NOT UNIFORM. THE FLCW, IN PARTICULAR IN THE BOUNDARY LAYER REGION, COMING FROM THE UPSTREAM SURFACE CARRIES SUPERHEAT ANO BUBBLES WHEN IT CONTACTS THE SURF ACF DOWMSTREAM. IN THIS WAY, THIC EFFECT OF THE UPSTREAM HEAT FLUX DISTRIBUTION IS

CONVEYED TO THE DOWNSTREAM BOUNDARY LAYER WHERE DNB OCCURS. THIS EFFECT ACTS AS A MEMORY OF CONVEYED TO THE DOWNSTREAM SOUNDARY LAYER WHERE DNB OCCURS. THIS EFFECT ACTS AS A MEMORY OF HEAT FLUX OISTRIBUTION IS EXPECTED TO BE DIFFERENT FROM A UNIFORM ONE, AND A CORRECTION FACTOR MAY BE DEVELOPED TO ACCOUNT FOR THE EFFECT OF FLUX NONUNIFORMITY.

\#DNB + \#FLOW, TWO PHASE + \#HEAT TRANSFER ANALYSIS + HEAT FLUX, CRITICAL + HEAT FLUX, DRYOUT

$5-27890$

NIJSING R + GARGANTINI I + EIFLER W

FUNDAMENTAL STUDIES OF FLUID FLOW ANO HEAT TRANSFSR IN FUEL ELEMENT GEDMETRIES. I. ANALYSIS OF FLUID AND HEAT TRANSFER IN A TRIANGULAR ARRAY OF PARALLEL HEAT GENERATING RODS 
CATEGORY 5

ACCIDENT ANALYSIS

5-27890 \#CONTINUED*

EUROPEAN ATOMIC ENERGY COMMUNITY, ISPRA, ITALY

EUR-2193.E +. 104 PAGES, FIGURES, REFERENCES, 1964

FOR REASONS OF A NUCLEAR-PHYS ICAL AND TECHNOLOGICAL NATURE, THE FUEL ELEMENT GEDMETRY IN NUCLEAR REACTORS OFTEN OIFFERS GREATLY FROM SIMPLE GEOMETRIES LIKE THE CIRCULAR OUCT. THIS IS FOR INSTANCE THE CASE FOR CLUSTER FUEL ELEMENTS. A FUEL ELEMENT OF THIS TYPE CONSISTS OF A NUMBER OF PARALLEL FUEL RODS FROM WHICH THE HEAT GENERATED BY NUCLEAR FISSION IS REMOVED BY AN AXIAL FLOW OF COOLANT. IN THE DESIGN OF THESE FUEL ELEMENTS IMPORTANT PROBLEMS ARISE WHICH PERTAIN TO FLUID FLOW AND HEAT TRANSFER. THE PURPOSE OF THE STUOY IS TO EVALUATE THEORETICALLY THE MAGNITUDE OF SEVERAL HYDROOYNAMIC AND THFRMAL PARAMETERS AT VARIOUS POSITIONS IN THE CROSS-SECTION OF A ROD CLUSTER.

AVAILABILITY - USAEC DEPOSITORY LIBRARIES IN THE U.S. AND DVERSEAS

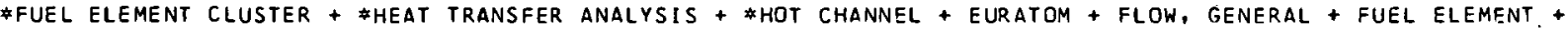
HEAT TRANSFER

$5-27891$

WAAGE JM

DESCRIPTION OF CALCULATIONAL METHODS AND DIGITAL-COMPUTER CODES FOR ANALYZING COOLANT-BLOWDOWN AND CORE-HEATUP PHENOMENA

PHILLIPS PETROLEUM COMPANY

10 PAGES, 4 TABI.ES, 16 REFERENCES, NUCLEAR SAFETY 8(6), PAGES 549-50 (NOV:-0EC. 1967)

AN IMPORTANT PART OF LIGHT-WATER-REACTOR ACCIOENT ANALYSIS IS THE PREDICTION OF SYSTEM AND CORE TEMPERATURES, PRESSURES, AND FORCES FOLLOWING A PJSTULATED RUPTURE OF THE PRIMARY SYSTEM. THE PROGRAMS IN CURRENT USE FOR BLOWOOWN AND CORE-HEATUP STUDIES ARE REVIEWED. THIS REVIEW INCLUDES A COMPARISON OF FEATURES AND APPROXIMATION CONTAINED IN THE PROGRAMS, A SHORT SUMMARY OF THE PURPOSE AND LIMITATIONS OF EACH PROGRAM, AND A BRIEF DESCRIPTION OF THE INPUT AND OUTPUT DATA. NO ATTEMPT IS MADE, HOWEVER, TO EVALUATE THE VALIDITY OR ACCURACY OF THE AND OUTPUT
PROGRAMS.

* ACCIDENT ANALYSIS + \#BLOWDOWN + \#COMPUTER PROGRAM + ENERGY SOURCE + HEAT GENERATION, INTERNAL + REACTOR, WATER

$5-27892$

OLIVER DR

FLOW AND HEAT TRANSFER PROPERTIES OF NON-NEWTONIAN LIQUIDS

UNI VERSIIY OF BIRMINGHAM

3 PAGES, 3 FIGURES, 27 REFERENCES, BRITISH CHEM. ENGINEERING 11(4), PAGES 258-260 (APRIL 1966)

NON-NEWTONIAN FLOW IS BRIEFLY INTRODUCED AND THE EFFECTS OF PSEUDO-PLASTIC FLOW PROPERTIES ON LAMINAR-FLOW HEAT TRANSFER DETAILED. A SLIGHT BUT BENEFICIAL CHANGE OF HEAT TRANSFE?

COEFFICIENT IS REPORTED. NATURAL CONVECTION IS SHOWN TO BE IMPORTANT IN SOME CASES AND THE AMNITINN IF GAS SLUGS TO THE FLOWING LIQUID TO INCREASE THE HEAT TRANSFER COEFFICIFNT BY AS MUCH AS $200 \%$.

* FlOW, gENERAL + *FLOW, NONNEHTONIAN + *HEAT TRANSFER + FLOW THEORY AND EXPERIMENTS + HEAT TRANSFER ANALYSIS

$5-27894$

BERCLES AE + GOLOBERG P + R.LAHSON LG + ROOS J + BOURNE JG

INVESTIGATION OF BOILING FLOW REGIMES AND CRITICAL HEAT FLUX. REPORT NO. 602 DYNATFY.H T.MRPORATION, CAMBRIDGE, MASS.

NYO-3304-6 + , 38 PAGES, FIGURES, REFERENCES; OCTOBER 1b, 14b5

THE RESULTS FOR THE FIRST SERIES OF FLOW REGIME TESTS INVOLVING THE CORE ELECTRICAL PROBE ARE UISCUSSED IN DETAIL. IN ADDITION TO THE NORMAL DEPENDFNCE ON MASS VELOCITY AND QUALITY, THE FLOW REGIME BOUNDARIES ARE SIGNIFICANTLY AFFECTED BY INLET TEMPERATURE, LENGTH, AND PRESSURE. THE FLOW PATTERNS WERE NOT ALTERED BY MINOR CHANGES IN PROBE INSTRUMENTATION DR VARIATIONS IN WATER PURITY. CRITICAL HEAT FLUX DATA ARF PRESENTED AND COMPARED WITH SEVERAL CORRELATIONS WHICH. HAVE BEEN PROPOSED FOR BULK BOILING OF WATER AT HIGH PRESSURE. TEST-SECTION OSCILLATIONS WERE OBSERVED UNDER CERTAIN CONDITIONS. HOWEVER, THIS INSTABILITY DOES NOT APPEAR TO HAVE SIGNIFICANTLY AF FECTED FLOW CONDITIONS IN THE TEST SECTION. A SIMPLIFIED ANALYTICAL MODEL IS PRESENTED WHICH $\triangle P P E A R S$ TO EXPLAIY THE EXPERIMENTAL TRENDS AS WELL $\triangle S$ IINOICATE THE CURRENT HAGNITUDE OF THE UNSTARLF OSTIIIATIITN FREQUENCY.

AVAILABILITY - CLEARINGHOUSE FOR FEDERAL SCIENTIFIC AND TECHNICAL INFORMATION, SPRINGFIELD, VA. 2215 I, \$3. ON R.NPY, \$O.65 MICROFICHE

\#BOILING + \#CONVECTIVE BOILING + \#HEAT FLUX, CRITICAL + BUBBLE + BUBBLE NUCLEATION + FLOW, TWO PHASE + HEAT TRANSFER + HEAT TRANSFER EXPERIMENT + NUCLEATE BOILING + REACTOR, AEC OWNED

$5-27895$

KUDRYAVTSEV EV + TURCHIN IA

DEPENDENCE OF TRANSIENT HEAT TRANSFER ON HEAT FLUX DENSITY

ARGONNE NATIONAL LABORATORY, ARGONNE, ILLINOIS 
CATEGORY 5

ACCIDENT ANALYSIS

5-27895 *CONTINUED*

ANL-TRANS-393 +. 6 PAGES, TRANS. FROM INZH-FIZ. 2H., 10- 573-6 (1966)

TRANSIENT NATURAL CONVECTION HEAT TRANSFER AT A THIN NICHROME RIBBON IS STUDIED. THE

TEMPERATURE DISTRIBUTIONS AT DELTA T EQUALS CONST ARE PRESENTED, AVD THE RELATION BETWEEN THE

HEAT-TRANSFER COEFFICIENT AND THE HEAT FLUX AT THE. HEAT-TRANSFER SURFACE IS FOUND.

AVAILABILITY - CLEARINGHOUSE FOR FEDERAL SCIENTIFIC AND TECHNICAL INFORMATION, SPRINGFIELO, VA. 22151 , \$3. OO COPY, S0.65 MICROF ICHE

* HEAT TRANSFER CORRELATION + \#hEAT tRANSFER, NATURAL CONVECTION + *TEMPERATURE TRANSIENT + heAT TRANSFER + TEMPERATURE GRADIENT

$5-27896$

PROFOS P

THE OYNAMICS OF FORCED-FLOW EVAPORATOR SYSTEMS

ORNL-TR-1436 t. 18 PAGES, FIGURES, REFERENCES, DECEMBER 5, 1966 , TRANSLATED FROM REGELUNGSTECHNIK 10,

PAGES 529-36 (1962)

DIMENSIONLESS EQUATIONS FOR THE CALCULATION OF THE TRANSFER CHARACTERISTICS OF FDRCED-FLOW EVAPORATOR SYSTEMS ARE GIVEN FOR DIFFERENT TYPES OF MALFUNCTIONS. THE CHARACTERISTIC PARAMETERS OF THE SYSTEM CAN BE DETERMINED RAPIDLY AND SIMPLY FOR THE DESIGN DATA WITH THE USE OF AUXILIARY TABLES. SUBSEQUENTLY, THE DIFFERENT TRANSFER FUNCTIONS CAN BE CALCULATED FROM THE EQUATIONS OR IN MANY CASES, CAN BE DERIVED DIRECTLY FROM DIAGRAMS. IN ADDITION,

THESE DIAGRAMS GIVE GENERAL INFORMATION CONCERNING THE INFLUENCE OF THE MOST IMPORTANT

PARAMETERS OF THE SYSTEM, PARTICULARLY OF THE PRESSURE, ON THE TRANSFER CHARACTERISTICS.

AVAILABILITY - SPECIAL LIBRARIES ASSOCIATION TRANSLATION CENTER, JOHN CRERAR LIBRARY, 35 WEST $33 R D$ STREET, CHICAGO, ILL. 60616

*EVAPORATION + \#FLOW, HIGH SPEED + \#MASS TRANSFER + EQUIPMENT, genERAL + FLOH, GeNERAL

$5-28538$

NISHIKAWA K + MIYABE K

ON THE BOILING-LIKE PHENOMENA AT SUPERCRITICAL PRESSURES

KYUSHU TECHNICAL COLLEGE

25 PAGES, 16 FIGURES, 1 TABLE, 16 REFERENCES, MEM. FAC. ENG., KYUSHU UNIV., 25(1), PAGES 1-25 (DECEMBER 19651

THE PROBLEM OF HEAT TRANSFER TO FLUIDS NEAR THE CRITICAL PRESSURE HAS ARISEN BECAUSE OF THE INDUSTRIAL NEED FOR SUPERCRITICAL PRESSURE BOILERS, COOL.ING OF ROCKET MOTORS $A N O$ GAS TURBINE BLADES, AND HEAT REMOVAL FROM NUCLEAR REACTORS. A STUDY WAS MADE TO ELUCIOATE THE HEAT TRANSFER MECHANISM OF A SUPERCRITICAL FLUID. WITH THE EXPERIMENTAL APPARATUS OF FREE CONVECTION, THE BOILING-LIKE PHENOMENON WAS EXAMINED SY PHOTOGRAPHIC OBSERVATION AND HEAT TRANSFER COEFFICJENT MEASUREMENT. FOR THE HEATING SURFACE A PLATINUM WIRE WAS USED, AND CARBON DIOXIDE AS THE TEST FLUID.

*CONVECTIVE BOILING + *HEAT TRANSFER EXPERIMENT + *HEAT TRANSFER, SUPERCRITICAL + HEAT TRANSFER + HEAT TRANSEED, BDILING.

$5-28539$

BEDENIG D + RAUSCH W + SCHMIDT G

PARAMETER STUDIES CONCERNING THE FLOW BEHAVIOUR OF A PEBBLE WITH REFERENCE TO THE FUEL ELEMENT MOVEMENT IN THE CORE OF THE THTR 300 MWE.PROTOTYPE REACTOR

BROWN BOVERI/KRUPP REAKTORBAU GMBH., JULICH, GERMANY

12 PAGES, $1 \mathrm{~J}$ FIGURES, 8 REFERENCES, NUCLEAR ENGINEERING AND DESIGN, 7(4), PAGES 367-378 (APRIL, 1968)

THE KNOWLEDGE OF THE PEBBLE-BED FLOW BEHAVIOR IS OF GREAT IMPORTANCE FOR GAS-COOLED HIGH TEMPERATURE REACTORS OF THE PEBBLE BEO TYPE. COMPREHENSIVE EXPERIMENTAL INVESTIGATIDNS WERE CARRIED OUT IN THIS RESPECT. AFTER A SHORT DESCRIPTION DF THE METHODS OF MEASUREMENT THE RESULTS OF PARAMETER STUDIES WITH REFERENCE TO THE FLOW BEHAVIOUR OF A PEBBLE BED ARE DISCUSSED. VARIOUS PARAMETERS OF GEDMETRY ARE INVESTIGATED AS WELL AS THE INFLUENCE DF FRICTION, OF SPECIFIC BALL WEIGHT AND OF RELATIVE BALL DIAMETER AS FUNCTIONS OF PEBBLE BED HEIGHT. RESULTS ARE PLOTTED IN FORM OF RESIDENCE SPECTRA. FROM THESE RESULTS THE FLOH BEHAVIOUR OF. THE THTR 3O0-MWE PROTOTYPE REACTOR IS PREDICTED BY INTERPOLATION.

\#REACTOR, CIRCULATING FUEL + \#REACTOR, HTGR + \#REACTOR, PEBBLE BED + FLOW THEDRY AND EXPERIMENTS 
CATEGORY 6

REACTOR TRANSIENTS, KINETICS, AND STABILITY

6-25362

BREHM RL

ESTIMATES OF DOPPLER COEFFICIENTS FOR IN-PILE THERMIONIC REACTOR MATERIALS

CALIFORNIA INSTITUTE OF TECHNOLOGY, PASADENA, CALIFORNIA

JPL-TR-32-1077 +. 17 PAGES, 10 FIGURES, 3 TABLES, 23 REFERENCES, OCTOBER 1, 1967

RECENT EXPERIMENTAL DATA HAVE BEEN USEO TO ESTIMATE TEMPERATURE COEFFICIENTS OF REACTIVITY DUE TO DOPPLER BROADENING OF RESONANCES IN MATERIALS OF INTEREST FIR COMPACT IN-PILE

THERMIONIC-REACTOR-CORE CONCEPTS. MATERIALS CONSIDERED ARE U-235, U-238, AND THE REFRACTORY METALS $W$, TA, MO, AND NB. EQUATIONS GIVING THE MAGNITUDE AND TEMPERATURE DEPENDENCE OF THE DOPPLER COEFFICIENT ARE GIVEN FOR EACH OF THESE ELEMENTS. ESTIMATES $\triangle R E$ GIVEN DF THE POSSIBLE ERROR IN THE DOPPLER COEFFICIENT INTRODUCED BY EXTRAPOLATING THE EXPER IMENTAL DATA TO THE HIGHER TEMPERATURES OF INTEREST IN THERMIONIC REACTOR CONCEPTS. A COMPARISON OF THIS METHOD WITH THE USUAL THEORETICAL METHOD IS MADE FOR THE FERMI REACTOR.

AVAILABILITY - CLEARINGHOUSE FOR FEDERAL SCIENTIFIC ANO TECHNICAL INFORMATION, SPRINGFIELD, VA. 22151 , $\$ 3.00$ COPY, \$0.65 MICROFICHE

* DOPPLER COEFFICIENT + \#REACTOR, SPACE + REACTIVITY EFFECT + REACTOR, FAST + TEMPERATURE COEFFICIENT

$6-25363$

NISLE RG + STEPAN LE + MILLSAP DA + FASTE

FISSION PRODUCT TRANSIENT MEASUREMENTS IN THE AOVANCEO REACTIVITY MEASUREMENT FACILITIES

I DAHO NUCLEAR CORPORATION

IN-1096 +. 27 PAGES, 5 FIGURES, 1 TABLE, 16 REFERENCES, SEPTEMBER 1967

YIELDS OF 1-135, IN FISSION OF U-233, PU-239, AND PU-241, RELATIVE TO THAT FOR U-235, WERE MEASURED BY AN INTEGRAL METHOD USING THE ARMF I ANO 11 . XENON REACTIVITY TRANSIENT WAS MEASURED FOLLOWING IRRADIATION OF FISSILE ISOTOPE IN THE MTR FOR PERIODS OF $21 / 2$ TO 110 DAYS. USE OF TWO ARMF REACTORS PERMITTED CALCULATION OF THE ABSORPTION CROSS SECTIONS OF BOTH SIMPLE ABSORBERS AND FISSILE ATOMS. CALIBRATION AND OATA REDUCTION TECHNIQUES MAKE EXTENSIVE USÊ OF DIGITAL COMPUTER PROGRAMS. THE I-135 YIELD RATIOS, RELATIVE TO U-235, WERE FOUND TO BE 0.825 PLUS OR MINUS 0.072 FOR U-233, 1.006 PLUS OR MINUS 0.067 FOR PU-239 AND 1.221 PLUS OR MINUS 0.089 FOR PU-241. QUOTED UNCERTAINTIES ARE CONFIDENCE INTERVALS AT THE $90 \%$ CONFIDENCE INTERVALS AT THE $90 \%$ CONFIDENCE LEVEL.

AVAILABILITY - CLEARINGHOUSE FOR FEDERAL SCIENTIFIC AND TECHNICAL INFORMATION, SPRINGFIELD, VA. 22151 , $\$ 3.00$ COPY, \$0.65 MICROFICHE

\#FISSION PRODUCT, IODINE + \#MEASUREMENT, REACTIVITY + PLUTONIUM + URANIUM-2.33

6-25944 ALSO IN CATEGORIES 5 AND 7

MORRI SON OL + CARBIENER WA + RITZMAN RL + BLUTREICH JN + CLARK WE + DENNING RS + GIESEKE JA + WOOTON RO AN EVALUATION OF THE APPLICABILITY OF EXISTING DATA TO THE ANALYTICAL DESCRIPTIDN OF A NUCLEAR-REACTOR

ACCIDENT, QUARTERLY PROGRESS REPORT FOR JANUARY THROUGH MARCH, 1968

BATTELLE MEMORIAL INSTITUTE, COLUMBUS, OHIO

BMI-1835 +. 30 PAGES, 4 FIGURES, 8 TABLES, 30 REFERENCES, APRIL 1,1968

PROGRESS REPORT ON THE FOLLOWING AREAS - ECCSA COMPUTER CODE DEVELOPMENT, CALCULATIONS OF ACCI UENT HEAT TKANSFER, EVALUATION OF REACTOR KINETICS PROBLEMS, REACTIVITY-ACCIDENT INITIATION OF A LOSS-OF-COOLANT ACCIDENT, FISSION PRODUCT RELEASE FROM UO2, AEROSOL-PARTICLE CHARGING, PARTICLE COLLECTION IN PRESSURE-SUSPENSION POOLS, FISSION-PRODUCT TRANSPORT AND DEPOSITION MOOELS, ANO CONOITIONS AND CRITERIA FOR PAINT PERFORMANCE IN REACTOR CONTAINMENT.

AVAILABILITY - CLEARINGHOUSE FOR FEOERAL SCIENTIFIC AND TECHNICAL INFORMATION, SPRINGFIELD, VIRGINIA $22151, \$ 3.00$ COPY, \$0.65 MICROFICHE

* $A C C I D E N T$ ANALYSIS + \#ACCIDENT, LOSS OF COOLANT + \#FISSION PRODUCT TRANSPORT + \#REACTOR KINETICS * ACCIDENT, REACTIVITY + AEROSOL + COMPUTER PROGRAM + CONTAINMENT PAINT + FISSION PRODUCT RELEASE, GENERAL + FISSION PRODUCT RETENTION + HEAT TRANSFER + SPACE DEPENDENT OYNAMICS

$6-25946$

JANSEN A

THE LONG TERM BEHAVIOR OF FAST POWER REACTORS WITH PU-RECYCLING

GESELLSCHAFT FUR KERNFORSCHUNG, KARLSRUHE, GERMANY

KFK630+FUR-3674E + CONF $671043-7+$ EURFNR-399+. 22 PAGES, 4 FIGURES, 3 TABLES, 5 REFERENCES, OCTOBER

1967, FROM SYMPOSIUM ON FAST REACTOR PHYSICS AND RELATED SAFETY PROBLEMS, KARLSRUHE, GERMANY.

STUDIED THE LONG-TERH BEHAVIOR OF FAST POHER REACTORS DURING MANY RELOADING CYCLES, INCLUDING THE TIME DEPENDENCE OF THE ISOTOPIC COMPOSITION OF PLUTONIUM, THE URANIUM AND PLUTONIUM CONTENT OF THE FUEL, THE BREEDING GAIN, ETC. AFTER STARTING, THE ONLY FISSIONABLE NATERIAL CONSUMED IS THAT BRED IN THE SAME REACTOR. LOADING ANO UNLOADING THE CORE AND 8LANKET ARE TREATED AS DISCONTINUOUS PROCESSES, AND EXTERNAL FUEL MANAGEMENT AND TIMES FOR REPROCESSING AND REFABRICATION ARE CONSIDEREO. NUMERICAL RESULTS ARE GIVEN FOR SODIUM-COOLED REACTOR NAI.

AVAILABILITY - CLEARINGHOUSE FOR FEDERAL SCIENTIFIC ANO TECHNICAL INFORMATION, SPRINGFIELD, VIRGINIA $22151, \$ 3.00$ COPY, $\$ 0.65$ MICROFICHE 
CATEGORY
REACTOR TRANSIENTS, KINETICS, AND STABILITY

6-25946 \#CONT INUED*

FUEL REPROCESSING + PLUTONIUM + REACTOR, BREEOER + REACTOR, FAST + REACTOR, LMCR + REACTOR, POWER

6-25987 ALSO IN CATEGORY 17

COSTNER RA + CRAMER EN + SCOTTRL

REACTOR OPERATOR STUOY HANDBOOK VDLUME III - REACTOR PHYSICS

OAK RIDGE NATIONAL LABORATORY

ORNL-TM-2034, VOL. III +222 PAGES, 51 FIGURES, JUNE 1968

A SELF-TEACHING (PROGRAMMED INSTRUCTION) MANUAL COVERING NEUTRON REACTIONS, DESCRIPTION OF

REACTORS, REACTIVITY AND REACTOR PERIOD, FUEL BURNUP, XENON- AND SAMARIUM-POISONING EFFECTS, TEMPERATURE EFFECTS, AND NEUTRON FLUX DISTRIBUTION. EACH SECTION CONTAINS BACKGROUNO

MATERIAL FOR UNDERSTANDING, EXAMPLE TO CLARIFY UNDERSTANDING, AND QUESTION FOR SELFTESTING.

MATERIAL IS PRESENTED IN FORM OF PARAGRAPHS, AND IN FOLLOWING PARAGRAPHS, A BLANK MAY BE LEFT

FOR STUDENT TO FILL IN WITH THE MAIN WORD OR IDEA.

AVAILABILITY - CLEARINGHOUSE FOR FEDERAL SCIENTIFIC AND TECHNICAL INFORMATION, SPRINGFIELO, VA. 22I5I, $\$ 3.00$ COPY, \$0.65 MICROF ICHE

* PROCEDURES AND MANUALS + \#REACTOR PHYSICS + \#STAFFING, TRAINING, QUALIFICATION + FLUX OISTRIBUTION + FUEL BURNUP + NEUTRON INTERACTION + REACTIVITY EFFECT + REACTOR DESCRIPTION + REACTOR, RESEARCH + SAMARIUM + TEMPERATURE REACTIVITY EFFECT + XENON

$6-26147$

$6-26147$
CHALMERS JH

HANDBODK OF EXPERIMENTAL CRITICALITY DATA PART I - CHAPTERS 1 TO 4

UNITED KINGDOM ATOMIC ENERGY AUTHORITY, RISLEY (ENGLAND)

AHSBISIHANOBOOK-5 +. 90 PAGES, FIGURES, TABLES, 67 REFERENCSS, 1967

RELATIVELY DETAILED DATA ON CPITICALITY EXPERIMENTS ON CLEAN SYSTEMS ARE COMPILED, AND

REFERENCES TO DATA SOURCES ARE LISTED. PART I COVERS SINGLE UNMOJERATED U-235. CORES, SINGLE

UNMODERATED PLUTONIUM CORES, SINGLE U-235 CORES MODERATED BY DEUTERIUM, BERYLLIUM OR CARBON,

AND SINGLE PLUTONIUM CORES MODERATEO BY DEUTERIUM, BERYLLIUM, OR CARBON

AVAILABILITY - CLEARINGHOUSE FOR FEDERAL SCIENTIFIC AND TECHNICAL INFORMATION, SPRINGFIELD, VIRGINIA $22151 \$ 3.00$ COPY, \$0.65 MICROFICHE

CRITICAL MASS + CRITICALITY EXPERIMENT + MEASUREMENT, REACTIVITY + PLUTONIUM + URANIUM-235

6-26411

COFFMAN WA + DUNCKHORST FT + LYNN LL + MEYER JE

ANALYSIS OF A WATERLOGGED FUEL ELEMENT SUBJECTED TO A POWER EXCURSION

BROOKHAVEN NATIONAL LABORATORY

11 PAGES, 7 FIGURES, TABLE, 10 REFERENCES, NUCLEAR APPLICATIONS, 4(6), PAGES 372-382 (JUNE, 1968 I

PRESENTS A MATHEMATICAL MODEL. COMPARISON WITH TWO OUT-OF-PILE EXPERIMENTS AND ONE IN-PILE INCIDENT IS FAIR. MODEL INCLUDES HEAT TRANSFER, LINEAR ELASTIC STRESS, AND DEFORMATION, PRESSURE, CLAD STRESS AND STRAIN, MODEL LIMITATIONS ARE - (I) IT WAS FORMULATED FOR

TRANSIENTS IN HHICH PRESSURE INCREASE OF SEVERAL THOUSAND PSI OCCURS, AND (2) STRESS AND

DEFORMATION EQUATIONS MAY BE INADEQUATE FOR MANY CASES WHERE PRESSURE CAUSES STRESSES NEAR RUPTURE CONDITION.

* ANALYTICAL MODEL + *FAILURE, FUEL ELEMENT WATERLOGgING + FAILURE, CLADDING + FUEL BURNUP + HEAT TRANSFER + MATHEMATICAL TREATMENT + PRESSURE, INTERNAL + REACTOR TRANSIENT + STRESS RUPTURE

6-26561 ALSO IN CATEGORY 9

ROUX DP + FRY ON + ROBINSON JC

$\triangle P P L I C A T I O N$ OF GAMMA-RAY DETECTION FOR REACTOR DIAGNOSIS

OAK RIDGE NATIONAL LABORATORY, OAK RIDGE, TENNESSEE

ORNL-TM-2144 +. 17 PAGES, 3 FIGURES, 3 TABLES, MARCH 20, 1968

POWER SPECTRAL DENSITY (PSO) MEASUREMENTS OF THE FLUCTUATING CURRENT FROM A GAMMA-SENSITIVE AND A NEUTRON-SENSITIVE IONIZATION CHAMBER ARE COMPARED AS A REACTOR DIAGNOSTIC TOOL IN THE HFIR OPERATING AT POWER. AN ANALYTICAL MODEL IS PRESENTEO TO DEMONSTRATE THAT WHEN BOTH OBSERVED. GAMMA AND NEUTR ON PSD ARE NORMALIZED BY THE SQUARE OF THE PROMPT MEAN-CURRENT OF THE CHAMBERS, THEY YIELD THE SAME ABSOLUTE PSO. THE ANALYTICAL RESULT IS VERIFIED EXPERIMENTALLY WITH A MÚLTISECTION IONI ZATION CHAMBER COMPOSED OF ELECTRICALLY INDEPENDENT CLOSELY LOCATED NEUTRON-SENSITIVE AND GAMMA-SENSITIVE CHAMBERS. IN THE CASE OF THE GAMMA CHAMBER, AN ESTIMATE OF THE CURRENT COMPONENT CAUSED BY THE DELAYED PHOTONS EMITTED BY THE RADIOACTIVE FISSION PRODUCTS IS NECESSARY TO MEASURE THE ABSOLUTE PSO. IN THIS EXPERIMENT THE DELAYED CURRENT COMPONENT HAS BEEN ESTIMATED TO BE 13 PER CENT OF THE TOTAL GAMMA CURRENT.

AVAILABILITY - CLEARINGHOUSE FOR FEDERAL SCIENTIFIC AND TECHNICAL INFORMATION, SPRINGFIELD, VIRGINIA $22151 \$ 3.00$ COPY, \$0.65 MICROFICHE

\# NOISE CROSS CORRELATION + \#REACTOR DYNAMICS + ANALYTICAL MODEL + CHAMBER, ION +

COMPARISON, THEORY AND EXPERIENCE + GAMMA + HFIR (FTR) + INSTRUMENTATION, NUCLEAR + NEUTRON + NOISE ANALYSIS + ORNL + REACTOR, AEC OWNED + REACTOR, FLUX TRAP + REACTOR, RESEARCH 
CATEGORY

REACTOR TRANSIENTS, KINETICS, AND STABILITY

$6-26584$

STABILITY TESTS ON BOILING WATER REACTORS

ALIGEMEINE ELEKTRICITAETS-GESELLSCHAFT, FRANKFURT AM MAIN, WEST GERMANY

EURAEC-1964 + EUR-3773 +. 49 PAGES, FIGURES, TABLES, QUARTERLY REPORT NO. 11, JULY 1-SEPTEMBER 30, 1967

PROGRESS REPORT. FLOW-OSCILLATION TESTS ON FOUR-ROD ELEMENTS WERE COMPLETED. EFFECT ON

TRANSFER FUNCTION MEASUREO FOR VARYING SPEEOS OF CIRCULATION PUMPS AND VOID-FRALTION

OSCILLATIONS. DISCUSSES PREPARATIONS FOR MEASUREMENT OF HEAT FLUX VS LOCAL VOID-FRACTION

FREQUENCY RESPONSES AT CONSTANT CHANNEL PRESSURE DP.DP.

AVAILABILITY - CLEARINGHOUSE FOR FEDERAL SCIENTIFIC AND TECHNICAL INFORIATION, SPEINGHIELO, VIRGINIA $22151, \$ 3.00$ COPY, S0.65 MICROFICHE

*FLOW STABILITY + \#FLOW THEORY AND EXPERIMENTS + \#REACTIVITY EFFECT, VOID + FURATOM + GEQMANY +

R ANO D PROGRAM + REACTIOR STABILITY + REACTOR, BWR + TESTING + TRANSFFR FUNCTIQN

6-26591 ALSO IN CATEGORY 17

SAXTON PLUTONIUM PROJECT. QUARTERLY PROGRESS LETTER FOR THE PERIDD EVDING MARCH 31 , 1967

WESTINGHOUSE ELECTRIC CORP., ATOMIC POWER DIVISION, PITTSRURG, PA.

EURAEC-1826 +. 17 PAGES, MAY, 1967

PROGRESS REPORT. A DISCREPANCY EXISTS BETWEEN CALCULATEO AND OBGERVID JUST-CRITICAL BOPON CONCENTRATION. SOURCE OF ERROR IN ANALYSIS WAS FAILURE TO INCLUDE ECFECTS OF NONUNIFORM AXIAL DEPLETION AND DIFFERENCES IN FISSION PRODUCT CROSS SECTION. \#\#\#THE HOT-CELL VENTILATION SYSTEM WAS MODIFIED, AND DESTRUCTIVE EXAMINATION OF PELLETIZED RODS WILL BEGIN WHERE CELL ALPHA-CONTAINMENT SYSTEM IS OPERATIONAL.

AVAILABILITY - CLEARINGHOUSE FOR FEDERAL SCIENTIFIC AND TECHNICAL INFURMATION, SPRINGFIELD, VIP.GINIA $22151, \$ 3.00 \mathrm{COPY}, \$ 0.65$ MICROFICHE

\#FUEL BURNUP + \#PLUTONIUM + ALDHA EMITTER + CHEMICAL SHIM + COMPARISON, THEORY AND EXDERIENCE + EXAMINATIDN + FUEL, PELLET TYPE + HOT CELL + HOT CELL + MODIFICATION, SYSTEM OR EQUIPMENT + REACTIVITY EFFECT, ANOMALOUS + REACTOR PHYSICS + REACTOR, PWR + REPORT, OPERATIONS + SAXTON (PWR) + THEORETICAL INVESTIGATION

6-26621 ALSO IN CATEGORY 17

CORE VII STARTUP REACTIVITY EFFECTS

CONNECT ICUT YANKEE ATOMIC POWER COMPANY

10 PAGES, 2 FIGURES, 2 TABLES, OPERATION REPORT 89 FOR MAY, 1968. FROM A LETTER TO DRL FROM W. D.

JOHNSON. JUNE 24, 1968. DOCKET 50-29. TYPE--PWR, MFG--WEST., AE--STONE + WEBSTER

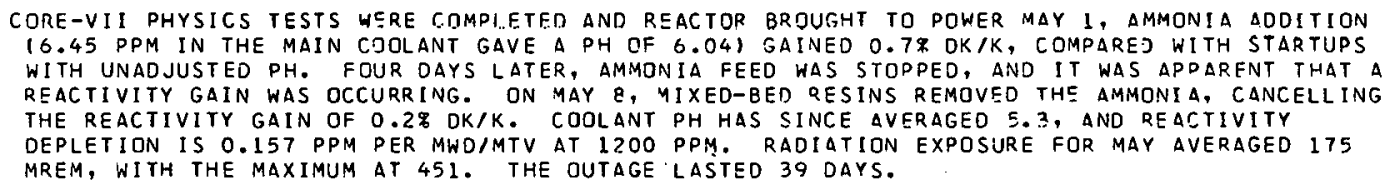

AVAII.ABILITY -- PUBLIC DOCUMENT ROOM, WASHINGTON, D.C.

\#PERSONNEL EXPOSURE, RADIATION + \#PH REACTIVITY EFFECT + CHEMICAL SHIM + FUEL BURNUP + FUEL HANOLING + MAINTENANCE AND REPAIR + REACTOR, PWR + REFUELING + REPORT, OPERATIONS + YANKEE (PWR)

6-26630 ALSU IN CATEGORY

KLICKMAN AE + HIRAKAWA N

AN ANALYSIS OF THE KIWI-TNT EXPERIMENT WITH MARS

ATOMIC POWER DEVEIOIPMENT ASSOCIATES, INC.

1 PAGE, TABLE, 4 REFERENCES, ANS TRANSACTIONS 1011), DAGE 246 OF THE 1967 ANNUAL MEEIING OF THE AMERICAN NUCLEAR SOCIETY, JUNE $11-15,1967$

THE KIWI-TNT EXPERIMENT HAS BEEN ANALYZED BY APPLYING A NEW THO-DIMENSIONAL EXPLOSION CODE, MARS, TO AN APPROPRIATE MODEL. THE CORE WAS CONSIDERED TO BE A CYLINDER 140 CM HIGH AND 85 CM IN DIAM. THE REACTOR WAS CONSIDEREO TO BE 50 CENTS SUBCRITICAL, AND \$8.5 OF REACTIVITY WAS INSERTED AND THE RATE OF \$3OO/SEC. THE EQUATION DF STATE WAS TAKEN TO BE THE HIGH-TEMPERATURE VAPOR-PRESSURE EQUATION, AND THE SPECIFIC HEAT WAS AN ANALYTICAL FIT TO THE AVAILABLE DATA. THE TEMPERATURE COEFFICIENT WAS ASSIGNED THE NOMINAL VALUE DF $1.32 \times 10 / C$. HOWEVER, IT WAS ALSO ASSIGNED PARAMETRIC VALUES OF $0.5,1.0,1.5$, AND $2.0 \times 10 / C$.

\#EXPLUSION + \#KIWI TNT (S-RR) + *MATHEMATICAL TREATMENT + \#REACTOR OYNAMTSS + COMPUTER PROGRAM + EXCURSION, LARGE + REACTOR, SAFETY RESEARCH 
CATEGORY 6
REACTOR TRANSIENTS, KINETICS, AND STABILITY

$6-26721$ \#CONTINUED*

NEUTRON DYNAMICS OF BROOKHAVEN(S) HIGH FLUX BEAY REACTOR

BROOKHAVEN NATIONAL LABORATORY, UPTON, N.Y.

STI/PUB/115+CN-22/52+. 17 PAGES, 13 FIGURES, 7 REFERENCES, PAGES $395-411$ OF NUCLEAR ELECTRONICS CONFERENCE PROCEEDINGS, BOMBAY, NOVEMBER 22-26, 1965

BROOKHAVEN(S) HIGH FLUX BEAM REACTOR (HFBR) IS A HIGH-POWER-DENSITY RESEARCH REACTOR WITH MANY NOVEL FEATURES. THESE INCLUDE A COMPACT UNDERMODERATED CORE, COOLED, MODERATED, AND

REFLECTED BY HIGH-VELOCITY D2C. THE LARGE D2O REFLECTOR PLAYS THE DOMINANT ROLE IN NEUTRON MODERATION AND IN CONTROLIING THE REACTOR. RESULTING SAFETY CEATURES INCLUDE A LONG NEUTRON GENERATION TIME, PLUS NEGATIVE TEMPERATURE AND VOID COEFFICIENTS THROUGHOUT THE CORE AND REFLECTOR. DYNAMIC CHARACTERISTICS OF THE REACTOR HAVE BEEN EXPLORED BOTH BY ANALOG AND DIGITAL COMPUTING MACHINES.

AVAILABILITY - NATIONAL AGENCY FOR INTERNATIONAL PUBLICATIONS, INC., 317 EAST 34 TH STREET, VEW YORK, N.Y. $10016, \$ 13.50 \mathrm{COPY} / \mathrm{BOOK}$

FREACTOR CONTROL + \#REACTOR DYNAMICS + HEAVY WATER + HFBR (RR) + REACTOR, AEC OWNFD + REACTOR, RESEARCH + REACTOR, RESEARCH + REACTOR, WATER

6-26746 ALSO IN CATEGORY 17

PULSTAR DOPPLER COEFFICIENT WITH A GRAPHITE REFLECTOR

WESTERN NUCLEAR RESEARCH CENTER

4 PAGES, 2 FIGURES, LETTER TO D. J. SKOVHOLT, DRL, FROM LETTER TO D.J. SKOVHOLT FROM P. T. BURNETT. JUNE 21, 1968. DOCKET 50-57.

AS REQUIRED IN LICENSE CHANGE 30 , SEVEN PULSES WERE MADE AT 4 DIFFERENT REACTIVITIES WITH FOUR GRAPHITE ELEMENTS ALDNG ONE SIDE OF THE $4 \times 5$ CORE. THE COEFFICIENT HAS OBTAINED BY DIVIDING THE PROMPT REACTIVITY INSERTEO SY THE TEMPERATURE RISE FROM A PREVIOUSLY PUBLISHED CURVE OF FUEL TEMP. VS ENERGY DENSITY (WNY-?O). THE 7 POINTS FELL WITHIN 1OQ-OE A CURVE OF OK/DEG F VS AV. FUEL TEMP. FLOTTED FOR WATER REFLECTOR. ON JUNE 2 , THE REVISEO STEADY-STATE CORE SHOWED A REACTIVITY LOSS OF 0.00581 DK AND A TEMP. RISE OF $245 \mathrm{~F}$ ON GOING TO $1.25 \mathrm{MW}$. THIS DOPPLER COEFFICIENT IS $97 \%$ OF THE WATER-REFLECTED VALUE, AND WE CONCLUDE THAT THE GPAPHITE HAS NOT CHANGED THE COEFFICIENT.

AVAILABILITY - PUBLIC DOCUMENT ROOM, WASHINGTON, D.C.

\#DOPPLER. COEFFICIENT + \#MEASUREMENT, REACTIVITY + \#REFLECTOR + COMPARISON, THEORY AND EXPERIENCE + GRAPHIIE + PULSTAR (RR) + REACTOR, PULSED + REACTOR, RESEARCH

$6-26783$

TAUBE M

REACTIVITY CHANGES IN SALT-BOILING FAST REACTORS OF HARS AND SAWA TYPES

NATIONAL INSTITUTE OF RADIOLOGICAL SCIENCES, JAPAN

4 PAGES, FIGURES, 10 REFERENCES, NUKLEONIKA, 12 , PAGES 231-234 (1967)

OISCUSSES A SPECIFIC EFFECT OF BUBBLE DILUTION IN THE FUSEO CHLORIDES IN SALT-BOILING

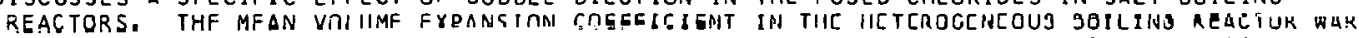
WITH MERCURY AS COOLANT IS ABOUT $0.002 / D E G(C)$, AND IN THE HOMOGENEOUS ROILING REACTOR SAWA WITH. ALUMINUM TRICHLORIDE AS COOLANT ABOUT .025/DEGICI. A FAST IO PER CENT INCREASE IN FOWER DECREASLS K-EFF ABOUT 10 PER CENT IN SAWA AND 0.8 PER CENT IN WARS.

REACTIVITY COEFFICIENT + REACTIVITY EFFECT + REACTIVITY EFFECT, EXPANSION + REACTOR, FAST + REACTOR, LMCR + REACTOR, MOLTEN SALT + VOID COEFFICIENT

6-26966 ALSO IN CATEGORY 18

FLUHARTY RG + SIMPSON FB + RUSSELL G.I + MRRRIS RH

A PROPOSAL FOR A REPETITIVELY PULSED TEST FACILITY (RPTFI

IDAHO NUCLEAR CORP. IDAHO FALLS

IN-1149+119 PAGES, FIGURES, TABLES, REFERENCES, DECEMBER 1967

STUDY TO BE COMPLETED BY JULY 1968, DESIGN BY 1971, AND CONSTRUCTION COMPLETION IN 1973.

REACTOR IS A SMALL PLUTONIUM REACTOR 13 TO 10 MW AVERAGE POWERI PULSED BY ROTATING FUEL OR $\triangle$

CHARGED-PARTICLE NEUTRON SOURCE AT'O TO 200 PULSES/SEC, WITH POWER PEAKS OF 3000 MW,

PRODUCING NEUTRON FLIIX INTENSITY PEAKS OF 10(18TH).

RESEARCH TOOL ANO PROGRAM TO DESIGN ANO BUILD IT. APPENDIX (A) REVIEWS GENERAL PROPERTIES OF REPETITIVELY PULSED SYSTEMS, IF) MDDERATOR OPTIMIZATION.

AVAILABILITY - CLEARINGHOUSE FOR FEDERAL SCIENTIFIC AND TECHNICAL INFORMATION, SPRINGFIELO, VA. 22151 , $\$ 3.00$ COPY, \$O.65 MICROFICHE

\#DESIGN STUOY + \#IRRADIATION FACILITY + PLUTONIUM + REACTOR KINETICS + REACTOR, PULSED

6-27039 ALSO IN CATEGORY 7

SAFETY STUDIES FOR MSBR

OAK RIDGE NATIONAL LABORATORY, OAK RIDGE, TENNESSEE

ORNL-4228+. 23 PAGES, 8 FIGURES, TABLE, 8 REFERENCES, PAGES $289-311$ OF THE NSP ANNUAL PROGRESS REPART, APRIL, 1968 
CAT.EGORY

REACTOR TRANSIENTS, KINETICS, AND STABILITY

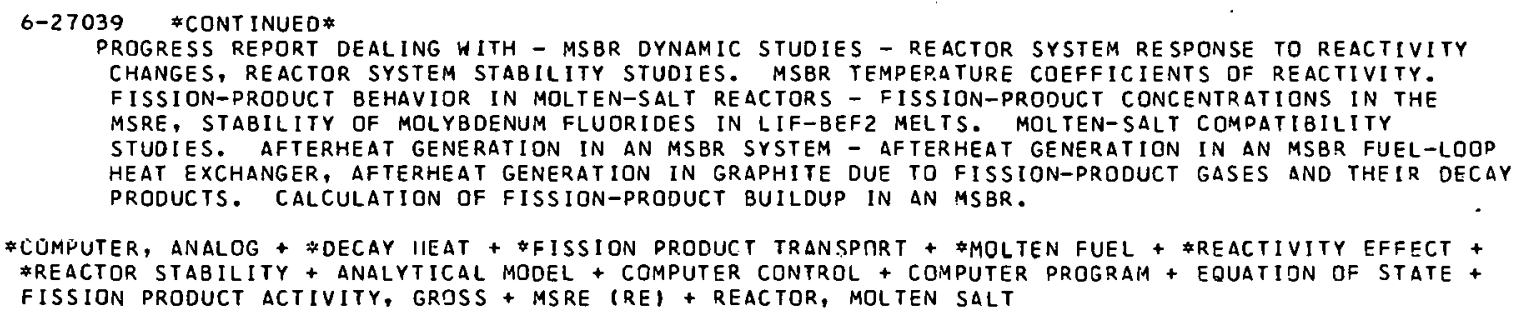

OPERATING CHARACTERISTICS OF A 1000-MWIEI SODIUM-COOLEO PLUTONIUM-URANIUM CARGIDE REACTOR HAVING NEUTRONICALLY UNCOUPLED THREE-MODULE CORE ARE GIVEN. COUPLED-KINETICS/HEAT-TRAVSFER CODE SCARE WAS USED FOR SAFETY ANALYSES OF RAMP REACTIVITY INSERTIONS. IT IS CONCLUDED THAT A NEGATIVE TEMPERATURE COEFFICIENT IS VERY IMPORTANT FOR IU-PUIC FUELED DESIGNS, AND THAT FUEL RODS USING HELIUM FOR THERMAL BINDING BETWEEN FUEL AND CLADDING HAVE BETTER SAFETY CHARACTERISTICS THAN SODIUM-BONDED RODS.

AVAILABILITY - G.A.SOFER, UNITEO NUCLEAR CORPORATION, RESEARCH AND ENGINEERING CENTER, ELMSFORO, N.Y.

FUEL ELEMENT + REACTOR KINETICS + REACTOR, BREEDER + REACTOR, FAST + REACTDR, LMCR + SAFETY ANALYSIS + TEMPERATURE COEFFICIENT + URANIUM CARBIDE

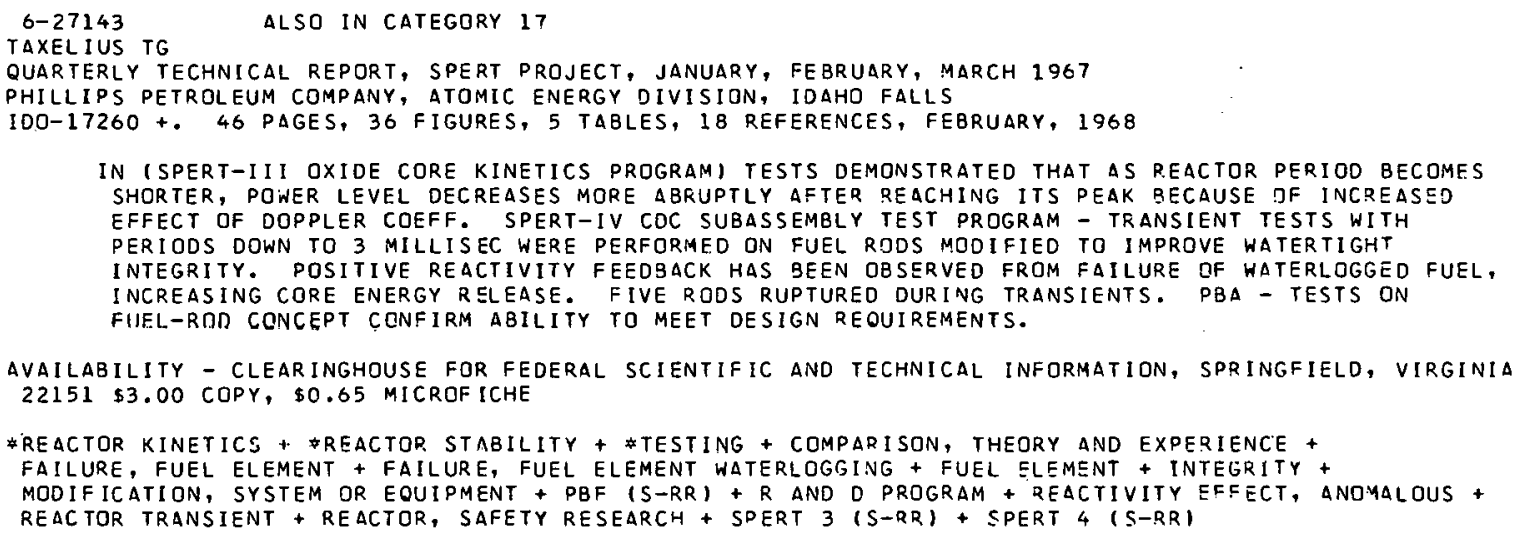

* REACTOR KINETICS + \#REACTOR STABILITY + \#TESTING + COMPARISON, THEORY AND EXPERIENCE + FAILURE, FUEL ELEMENT + FAILURE, FUEL ELEMENT WATERLOGGING + FUEL ELEMENT + INTEGRITY + MODIFICATION, SYSTEM OR EOUIPMENT + PBF (S-RR) + R AND D PROGRAM + REACTIVITY EFFECT, ANOMALOUS + REACTOR TRANSIENT + REACTOR, SAFETY RESEARCH + SPERT $3(S-R R)+$ SPERT 4 (S-RR)

t:-27579 ALSO IN CATEGORIES 9 AND 4

FRIEDMAN ST + RANKIN WO

INDIRECT MEASUREMENT OF NUCLEAR HEATING RATES IN POISON CONTROL VANES

LOS ALAMOS SCIENTIFIC LABORATORY

1 PAGE, ANS TRANSACTIONS 11(1), PAGE 25, 1968 ANNUAL MEETING OF THE AMERICAN NUCLEAR SOCIETY ANÜ CANADIAN NUCLEAR ASSIC.IATION, TORONTO, CANADA, JUNE 10-13, 1968

THE ACCURATE PREOICTION DF NUCLEAR HEATING RATES IN HIGH CAPTURE CROSS-SECIIUN CONTROL MATERIALS IS A MAJOR RADIATION ANALYSIS PROSLEM. THE PROBLEM IS PARTICULAPLY ACUTE IV NUCLEAR ROCKET REACTOR SYSTEMS SUCH AS NERVA WHERE THE RELATIVELY THIN CONTROL VANES ARE LOCATED IN HIGHLY MODERATING BERYLLIUM REFLECTOR REGIDN IMMEDIATELY ADJACSNT TO A HIGH-POHER DENSITY CORE. OREFATIONAL CONSI OERATIONS. INCLUDING EFFECTS ON REACTOR SAFETY AND

RELIABILITY, REQUIRE ACCURATE PREDICTIONS OF VANE HEATING RATES AND AN ADEDUAIE HLUW ÜF LIOUID HYDROGEN TO THE VANES, DRUMS, REFLECTOR, AND PRESSURE VESSEL, RUT ESPECIALLY TO THE VANES SINCEE THESE INVOLVE THE CONTROL SYSTEM.

\#MEASUREMENT, TEMPERATURE + \#NUCLEAR ROCKET + HEAT TRANSFER + INSTRUMENTATION, CONTROL + NERVA DR. OGRAM

6-27616 ALSO IN CATEGORIES 17 AND SELECTED SHIPPINGPORT OPERATING EXPERIENCE BETTIS ATUMIC POWER LABORATORY

WAPD-MRP-122 +. 14 PAGES, PAGES 6, 20-41 AND 43 OF PRESSURIZED WATER PEACTOR (PWR) PROJECT. IIECHNICAL PRDGRESS REPORT, JULY 22, OCTOBER, 20, 1967 
CATEGORY 6

REACTOR TRANSIENTS, KINETICS, AND STABILITY

6-27616 *CONTINUED*

(PAGE 6) NH4OH ADDITION AND DEGASIFICATION RATES INCREASE ORASTICALLY WITH COOLANT PH $\triangle$ SBOVE 10.3. (PAGE 20-41) POWER LIMITS FOR VARIOUS CONTROL ROD PROGRAMS PAST 10,0O0 EFPH WERE CALCULATED. FOR VARIOUS LOAO SWINGS, XENON BURNOUT RATES AND AXIAL PEAK/AV NEUTRON FLUXES WERE MEASURED AND COMPAREO WITH TURBO-ZIP CALCULATIONS. ON THE RETURN TO 100 MHE ON AUGUST 21, XENON OSCILLATION SET IN, GIVING +-9 IN. CONTROL ROD MOTION. OPERATIONAL DETECTORS LOCATED AT CORE MIDHEIGHT WERE IN PHASE WITH ROD BANK MOTION, WHILE TEST CHAMBERS ABOVE THE CORE WERE OUT OF PHASE. OPERATING LIMITS FOR PEAK SINGLE CHANNEL NUCLEAR INSTRUMENT READINGS WERE CALCULATED, AS WAS A CONTROL RDD PROGRAM. (PAGE 43 ) COMPUTER PROGRAM MO 795 WAS PLACED INTO PRODUCTION. MO 795 PERFORMS ALL FUEL ELEMENT PERFORMANCE LIMITS CALCULATIONS FOR CORE

2, INCLUDING MAXIMUM PERMISSIBLE SINGLE CHANNEL, NUCLEAR INSTRUMENT READINGS.

AVAILABILITY - CLEARINGHOUSE FOR FEDERAL SCIENTIFIC AND TECHNICAL INFORMATION, NATIONAL BUREAU OF STANDAROS, SPRINGFIELD, VA. $22151, \$ 3.00$ COPY, \$0.65 MICROFICHE

*CONTROL ROD PROGRAM + \#FUEL ELEMENT + \#INSTRUMENTATION, ABNORMAL INOICATION + \#PERFORMANCE LIMIT + \#XENON OSCILLATION + COMPUTER PROGRAM + COOLANT CHEMISTRY + POWER DISTRIBUTION + REACTOR, PHR + REPOFT, OPERATIONS ANALYSIS + SHIPPINGPORT (PWR)

6-27618 ALSO IN CATEGORY 17

SHIPPINGPORT REACTOR PHYSICS

BETTIS ATOMIC POWER LABORATORY

WAPD-MRP-123 + 16 PAGES, FIGURES, PAGES $21-36$ OF TECHNICAL PROGRESS REPORT FOR THE PERIOD OCTOBER 21 ,

1967 TO JANUARY 26, 1968 , PRESSURIZED WATER REACTOR (PWR) PROJECT

FOLLOWING THE 4TH $100 \%$ PDWER DEMONSTRATION ON NOVEMBER 19, XENON BURNOUT AT PEAK XENON AT $72 \%$ POWER WAS ESTIMATED AT 0.0000026 OKISEC BASED ON A TEST AT 63\%. FLUX WIRES AT IOCR POWER SHOWED THE EXIAL FLUX UNDER ESTIMATED IN THE LOWER AND OVER ESTIMATED IN THE UPPER PORTION OF THE CORE (TURBO-ZIP CODE). INCLUSION OF AN AXIALLY VARIABLE MODERATOR TEMP. GAVE BETTER FLUX SHAPES, BETTER ROD POSITION PREOICTIONS AND RFSULTANT BETTER POWER SHAPES AND FUEL

DISTRIBUTIONS. THE FUEL DISTRIBUTION WITH AND W/O THIS CORRECTION DIVERGES WITH BURNUP, BEING $4 \%$ DIFFERENT AT 7700 EFPH.

AVAILABILITY - CLEARINGHOUSE FOR FEDERAL SCIENTIFIC AND TECHNICAL INFORMATION, NATIONAL BUREAU OF STANDARDS, SPRINGFIELD, VA. ?2151, \$3.00 COPY, S0.65 MICROFICHE

\#COMPARISON, THEORY AND EXPERIENCE + \#COMPUTER PROGRAM + \#FUEL BURNUP + \#POWER DISTRIBUTIDN + FLUX DISTRIBUTION + REACTOR, PWR + SHIPPINGPORT (DWR) + XENON

$6-27628$

BRAESS D + KUSTERS H + THURNAY K

IMPROVEMENT IN SECOND EXCURSION CALCULATIONS

23 PAGES, 8 FIGURES, 25 REFERENCES, BULLET IN DINFORMATIONS SCIENTIFIQUES ET TECHNIQUES, 122 , PAGES 6I-83 (JANUARY 1968 )

THE CALCULATION OF SECOND EXCURSIONS IS PERFORMED WITH A FORMALISM DEVELOPED BY BETHE AND TAIT, IMPROVED BY TAKING INTO ACCOUNT FFFECTS OF DELAYED VEUTRONS AND DOPPLER FEEDSALK ANU APPLIED TO CYLINDRICAL CORES. THF PARAMFTFRS NF THE SQUNTIOM OT GTATE III FIIE CALLULAIIUIVS UR EXCURSIUNS ARE ESTIMATED BY THE KINETIC THEORY OF GASES FOLLOWING THE MODFI PROPOSED BY H. EYRING. TIIE CRITICAL DATES ANO IHE THERMOOYNAMIC FUNCTIONS ARE OBTAINED BY AN APPROXIMATF PARTITION FUNCTION. THE RESULTS OBTAINED BY THE USL DF AXIAL AND SPHERICAL GEOMETRIES ARE COMPARED. THE IMPORTANCE OF A DELAYED DOPPLER FEEDBACK ON THE QUANTITY OF ENERGY RELEASED IS ALSO ESTIMATED.

\#DELAYED NEUTRON + \#ENERGY SOURCE + \#EXCURSION, LARGE + DOPPLER EFFECT + THEORETICAL INVESTIGATION

\author{
6-27647 \\ ALSO IN CATEGORY 5
}

BRIGHT GO THE GENERALIZED REACTIVITY ACCIOENT FOR WATER-COOLEO ANO -MODERATEO UOZ-FUELED POWER REACTORS A REVIEW OF THE GENERALIZED
PHILLIPS. PETROLEUM COMPANY

12 PAGES, 1 FIGURE, 69 REFERENCES, NUCLEAR SAFETY 812), PAGES 116-127 (WINTER 1966-1967)

A REVIEW WAS MADE OF WHAT IS KNOWN AND WHAT IS UNKNOWN ABOUT THE FACTORS THAT ENTER INTO THE DETERMINATION OF THE COURSE AND CONSEQUENCES OF A REACTIVITY ACCIDENT, AND AN ATTEMPT TO COLLATE THE AVAILABLE INFORMATION ON THE VARIOUS PHASES OF REACTIVITYLACCIOENT ANALYSIS IN OROER TO IDENTIFY THE MAJOR PROBLEM AREAS IS REPORTED. THE REVIEW OF EXISTING KNOWLEDGE OF OROER TO IDENT IFY THE MAJOR PROBLEM AREAS IS REPORTED. THE REVIEW OF EXISTING KNOWLEDGE
BOTH NEUTRONIC AND NONNEUTRONIC PHENOMENA, AS WELL AS THE CONSIOERATION OF THE LIMITS OF CONFIDENCE IN ANALYTICAL METHODS AND THE ACCURACY OF VALUES FOR FUNDAMENTAL PARAMETERS USED IN THE ANALYSES, MADE IT INCREASINGLY EVIDENT THAT A REALLY QUANTITATIVE ANALYSIS JF A LARGE REACTIVITY ACCIDENT IN A POWER-REACTOR SYSTEM IS NOT POSSIBLE AT THIS TIME.

ACCIDENT ANALYSIS + ACCIDENT, REACTIVITY + HAZAROS ANALYSIS + HEAT TRANSFER ANALYSIS + REACTOR KINETICS + REACTOR, BWR + REACTOR, PWR + REACTOR, WATER

$6-27705$

BROWN PS + WATTS JL + DOYAS RJ

EFFECTS OF CROSS-SECTION UNCERTAINTIES IN COMPACT SPACE PONER REACTORS

CALIFORNIA UNIV., LIVERMORE. LAWRENCE RADIATION LAB. 
CATEGORY 6

REACTOR TRANSIENTS, KINETICS, AND STABILITY

6-27705 \#CONTINUEO*

UCRL-70797 + CONF-680307-3 + 10 PAGES, FIGURES, TABLES, 3 REFERENCES, FEB, 28, 1968, PRESENTEO AT 2NO CONFERENCE ON NEUTRON CROSS SECTIONS ANO TECHNOLOGY, WASHINGTON, D. C.

THE EFFECTS OF CROSS-SECTION UNCERTAINTIES HAVE BEEN STUDIED IN COMPACT $(20$ KHE TO 10 MHE) SPACE POHER REACTORS, HAVING CORE SIZES OF 12,78, AND 525 LITERS ANO MEOIAN FISSION ENERGIES OF 560,380 , AND $200 \mathrm{KEV}$. EACH CORE CONTAINED UN FUEL, W-RE-MO ALLOY CLADDING, ANO LI COOLANT WITHIN A TA PRESSURE VESSEL AND BEO REFLECTOR. CALCULATIONS WERE DONE TO OETERMINE THE SENSITIVITY OF THE SPECTRUM SHAPE, FISSION RATIOS, REACTIVITY WORTHS, AND NEUTRON LIFETIME TO CROSS-SECTION UNCERTAINTIES, AND TO EVALUATE WHETHER MEASUREMENT OF SUCH PARAMETERS IN CRITICAL EXPERIMENTS CAN BE USEFUL IN TESTING CROSS-SECTION DATA.

AVAILABILITY - CLEARINGHOUSE FOR FEDERAL SCIENTIFIC AND TECHNICAL INFORMATION, SPRINGFIELD, VIRGINIA $22151, \$ 3.00 \mathrm{COPY}, \$ 0.65 \mathrm{MICROFICHE}$

CROSS SECTION + REACTIVITY COEFFICIENT + REACTOR, SPACE + THEORETICAL INVESTIGATION

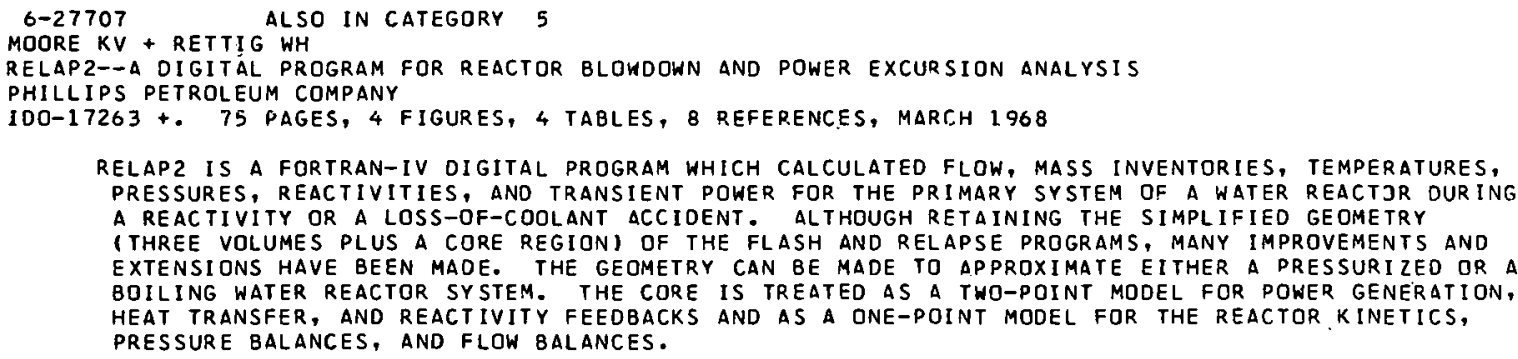

RELAP2 IS A FORTRAN-IV DIGITAL PROGRAM WHICH CALCULATED FLOW, MASS INVENTDRIES, TEMPERATURES, PRESSURES, REACTIVITIES, AND TRANSIENT POWER FOR THE PRIMARY SYSTEM OF A WATER REACTOR DURING A REACTIVITY OR A LOSS-OF-COOLANT ACCIOENT. ALTHOUGH RETAINING THE SIMPLIFIED GEOMETRY (THREE VOLUMES PLUS A CORE REgION) OF THE FLASH AND RELAPSE PROGRAMS, MANY IMPROVEMENTS AND EXTENSIONS HAVE BEEN MADE. THE GEOMETRY CAN BE MADE TO APPROXIMATE EITHER A PRESSURIZED OR A BOILING WATER REACTOR SYSTEM. THE CORE IS TREATED AS A TWO-POINT MODEL FOR POWER GENERATION, HEAT TRANSFER, AND REACTIVITY FEEDBACKS AND AS A ONE-POINT MODEL FOR THE REACTOR KINETICS, PRESSURE BALANCES, AND FLOW BALANCES.

AVAILABILITY - CLEARINGHOUSE FOR FEDERAL ST.IFNTIFIC AND TECHNICAL. INFORMATION, SPRINGFIELO, VA. 2215 I, $\$ 3.00$ COPY, $\$ 0.65$ MICROF ICHE

*ACCIDENT, LOSS OF COOLANT + \#COMPUTER PROGRAM + BLOWOOWN + REACTOR DYNAMICS + REACTOR KINETICS + REACTOR, BWR + REACTOR, PWR

$6-27743$

BRAESS D + K.USTERS H + THURNAY K

IMPROVEMENT IN SECOND EXCURSION CALCULATIONS

INSTITUT FUR NEUTRONENPHYSIK AND REAKTORTECHNIK KERFCRSCHUNGSZENTRUM KARLSRUHE

47 PAGES, 8 FIGURES, 2 TABLES, 25 REFERENCES, FROM THE INTERNATIONAL CONFERENCE DN THE SAFETY OF FAST

REACTORS, SEPTEMBER 1967

THE DESCRIPTION OF LARGE POWER EXCURSIONS IN A FAST REACTOR WITH A FOLLOWING DISASSEMBLY OF CORE MATERIAL BY THE METHOD OF BETHE-TAIT WAS IMPROVED AND EXTENDED TO CYLINDRICAL GEOMETRY. THE EFFECTS OF DELAYED NEUTRONS ANO OF DOPPLER FEEOBACK WERE INCLUDED. KINETIC THEORY CALCULATIONS WERE MADE ABOUT THE LIQUID STATE OF URANIUM OXIDE. DIFFERENCES BETWEEN CYLINDRICAL AND SPHERICAL MODEL CALCULATIONS ARE GIVEN.

AVAILABILITY - D. BRAESS, INSIITUT FUR NEUTRONENPHYSIK AND REAKTORTECHNIK KERNFORSCHUNGSZENTRUM KARLSRUHE *EXCURSION, LARGE + DOPPLER EFFECT + EQUATION OF STATE + REACTOR, FAST + THEORETICAL INVESTIGATION + URANIUM UIIOXIDE

$6-27744$

C.ARPENTER SG + MOUTNFORD LA I TUTTLE RJ

SMALL-SAMPLE SURF ACE-TO-MASS ANO HOMOGENEIIY EFFECTS IN FAST NEUTRON STÉCTRA ATOMICS INTERNATIONAL

15 PAGES, 11 FIGURES, 2 TABLES, 5 REFERENCES, FROM THF INTERNATIONAL CONFERENCE ON THE SAFETY OF FAST NEUTRON REACTORS, SEPTEMBER 1967

MEASUREMENTS OF THE REACTIVITY EFFECTS OF THE SURFACE-TJ-MASS RATIOS OF VARIOUS NUCLEAR FUEL SAMPLES WERE PERFORMEO IN ORDER TO SEPARATE THE REACTIVITY EFFECTS OF THE TEMPERATURE

COEFFICIENT AND THE DOPPLER COEFFICIENT IN FAST NEUTRON SPECTRA. TEMPERATURE AND DOPPLER

COEFFICIENTS OF REACTIVIIY AKE GIVEN FUR A NUMBER OT TUEL MATERIALS.

AVAILABILITY - S.G, CARPENTER, P.O. BOX 309, CANOGA PARK, CALIFORNIA

DOPPLER COEFFICIENT + FUEL COEFFICIENT + FUEL EXPANSION COEFFICIENT + MEASUREMENT, GENEKAL + REACTIVITY COEFFICIENT + TEMPERATURE COEFFICIENT

6-27842 ALSO IN CATEGORIES 17 AND 9

LEAD PI ATE SHIFT TO CORE ADDS $0.168 \%$ REACTIVITY

PENNSYLVANIA STATE UNIVERSITY

3 PAGES, ATOMIC ENERGY CLEARINGHOUSE, 14(35), PAGES 12-14 (AUGUST 26, 1968 ) 
6-27842 \%ONTINUED*

(LETTER TO DRL, AUG. 9) ON JULY 24, THE REACTOR OPERATOR WAS OBSERVING XENON BEHAVIOR ANO PLOTTING ROD POSITION VS TIME. HE NOTED A 37 UNIT REG ROD WITHDRAWAL IN A FEW SECONDS, A SLIGHT LOG INCREASE, AND A 10 C FUEL TEMP. DECREASE. REACTOR WAS SHUT DOWN. CAUSE WAS A THICK LEAD PLATE (MOUNTED BETWEEN CORE AND THERMAL COLUMN) HHICH HAD SWUNG TOWARD THE CORE AS NYLON-RDPES SAGGED. LEAD ADDED $0.084 \%$ AND REFLECTED MORE NEUTRONS TOWARD THE SERVDCHAMBER, CAUSING A $40 \mathrm{KW}$ POWER DECREASE, WITH THIS FUEL COOLING ADD ING $0.084 \%$.

* INSTRUMENTATION, ABNORMAL INDICATION + \#OPERATOR ACTION + BEAM HOLE + CONTROLLER + INCIDENT, EQUIPMENT + INSTRUMENTATION, POWER RANGE + LEAD + POWER COEFFICIENT + REACTIVITY EFFECT +

REACTIVITY EFFECT, ANOMALOUS + REACTOR POWER + REACTOR, RESEARCH + REFLECTOR + TRIGA (RR

6-28002 ALSO IN CATEGORY 17

NUCLEAR PHYSICS MADE VERY, VERY EASY

USAEC + NATIONAL AERONAUTICS AND SPACE ADMINISTRATION

NTO-T-0026 +. 81 PAGES, 27 FIGURES, 6 TABLES, JULY 1968

INTENDED TO INTRODUCE BASIC REACTOR PRINCIPLES TO VARIOUS GROUPS OF NONNUCLEAR NERVA TEST OPERATIONS PERSONNEL. SECTIONS ARE ATOMIC PHYSICS 19 PAGESI, NUELEAR PHYSICS (25 PAGESI, AND REACTOR PHYSICS (33 PAGES). \#\#TREATMENT IS QUITE BASIC AND READABLE. COVERS USUAL GROUNDS. NOT RESTRICTED TO A PARTICULAR TYPE, EXCEPT REACTOR EQUATIONS IMPLY MODERATION.

*REACTOR 'PHYSICS + \#TAFFING, TRAINING, QUALIFICATION + NERVA PRDGRAM +, REACTOR, POHER + REACTOR, SPACE

6-28010 AL SO IN CATEGORY 17

THE STARTUP TEST PROGRAM FOR THE CONNECTICUT YANKEE YANKEE REACTOR

CONNECTICUT YANKEE ATOMIC POWER COMPANY, HADDAM

NYO-3250-11 +. 37 PAGES, FIGURES, TABLES, DOCKET 50-213, TYPE--PWR, MFG--WEST., AE--STONE + HEBSTER

REPORTS WORK DURING MONTH OF JULY 1967. FUEL LOADED WITH WATER AT 2650 PPM BORON, THEN BORON DILUTED SLOWLY TO GO CRITICAL. ZERO POWER MEASUREMENTS WERE MADE AT. IO MHTH. AGREEYENT ON COLD TOTAL EXCESS REACTIVITY ANO WORTHS OF GROUPS AB WAS EXCELLENT WITH PREDICTION, BUT THE HOT WORTH OF CO WAS LOW BY 0.035 REACTIVITY \%. MEASUREMENTS MADE OF SINGLE ROD WORTHS IFOR STUCK ANO EJECTED RODSI AGREED WELL WITH PREOICTIONS. DIFFERENTIAL BORON WORTH CURVE IS STEEPER THAN EXPECTED, PERHAPS BECAUSE RODS ARE IN CORE. TEMPERATURE COEFFICIENTS TAKEN BY USING BORON CHANGES IS ALSO STEEPER THAN PREDICTEO.

AVAILABILITY - CLEARINGHOUSE FOR FEDERAL SCIENTIFIC AND TECHNICAL INFORMATION, SPRINGFIELD, VA. 22151 ; $\$ 3.00$ CPY, \$0.65 MICROFICHE

\#CONTROL ROD WORTH + \#REACTOR STARTUP TESTING + COMPARISON. THEDRY AND EXPERIENCE + HADDAM VECK (PWR) + REACTIVITY, EXCESS + REACTOR, PWR 
CATEGORY 7

$7-25944$

ALSO IN CATEGORIES 5 AND 6

MORRISON DL + CARBIENER WA + RITZMAN RL + BLUTREICH JN + CLARK WE + DENNING RS + GIESEKE JA + WOOTON RO AN EVALUATION OF THE APPLICABILITY OF EXISTING DATA TO THE ANALYTICAL DESCRIPTION OF A NUCLEAR-REACTOR ACC IDENT, QUARTERLY PROGRESS REPORT FOR JANUARY THROUGH MARCH, 1968

BATTELLE MEMORIAL INSTITUTE, COLUMBUS, OHIO

BMI-1835 +. 30 PAGES, 4 FIGURES, 8 TABLES, 30 REFERENCES, APRIL 1,1968

PROGRESS REPORT ON THE FOLLOWING AREAS - ECCSA COMPUTER CODE DEVELOPMENT, CALCULATIONS DF ACCIOENT HEAT TRANSFER, EVALUATION OF REACTOR KINETICS PROBLEMS, REACTIVITY-ACCIDENT

INITIATION OF A LOSS-OF-COOLANT ACCIDENT, FISSION PRODUCT RELEASE FROM UD2, $\triangle E R O S O L-P A R T I C L E$ CHARGING, PARTICLE COLLECTION IN PRESSURE-SUSPENSION POOLS, FISSION-PROOUCT TRANSPORT AND DEPOSITION MODELS, AND CONDITIONS AND CRITERIA FOR PAINT PERFORMANCE IN REACTOR CONTAINMENT.

AVAILABILITY - CLEARINGHOUSE FOR FEDERAL SCIENTIFIC AND TECHNICAL INFORMATION, SPRINGFIELD, VIRGINIA $22151, \$ 3.00$ COPY, \$O.65 MICROFICHE

*ACCIDENT ANALYSIS + \#ACCIDENT, LOSS OF COOLANT + \#FISSION PRODUCT TRANSPORT + \#REACTOR KINETICS + ACCIDENT, REACTIVITY + AEROSOL + COMPUTER PROGRAM + CONTAINMENT PAINT + FISSION PRODUCT RELEASE, GENERAL + FISSION PRODUCT RETENTION + HEAT TRANSFER + SPACE DEPENDENT DYNAMICS

$7-26413$

ALSO IN CATEGORIES 1 AND 11

COTTRELL WB

NUCLEAR SAFETY PROGRAM ANNUAL PROGRESS REPORT FOR PERIOD ENDING OECEMBER 31,1967

OAK RIDGE NATI ONAL LABORATORY

ORNL $-4228+.443$ PAGES, FIGURES, TABLES, REFERENCES, APRIL 1968

THE ORNL NUCLEAR SAFETY PROGRAM INVOLVES TASKS IN SEVERAL LABORATORY DIVISIONS AND IS CLOSELY RELATED TO PROGRAMS AT OTHER LABORATORIES. THIS REPORT IS ONE OF A CONTINUING SERIES STARTING WITH ORNL-3319 IN 1962. IT CONTAINS PROGRESS REPORTS ON VARIOUS ASPECTS OF CHARACTER IZATION ANO BEHAVIOR OF ACCIDENT-RELEASES, FISSION PRODUCTS, FILTRATION AND ADSORPTION TECHNOLOGY, SPRAY ANO ADSORPTION TECHNOLOGY, SAFETY STUDIES FOR HITH-TEMPERATURE GAS-COOLEO REACTORS, SAFETY STUDIES FOR MSBR, PRESSURE VESSEL AND PIPING TECHNOLOGY, GENERAL NUCLEAR SAFETY STUDIES, AND NUCLEAR. SAFETY INFQRMATION.

AVAILABILITY - CLEARINGHOUSE FOR FEDERAL SCIENTIFIC ANO TECHVICAL INFORMATION, SPRINGFIELO, VA. 22151 $\$ 3.00$ COPY, \$0.65 MICROFICHE

\# ADSORPTION + \#FILTRATION + \#FISSION PRODUCT RELEASE, GENERAL + \#INFORMATION RETRIEVAL + \#NSIC + \#PIPING + \#PRESSURE VESSEL + \#REACTOR, BREEDER + \#REACTOR, HTGR + \#REACTOR, MOL TEN SALT + \$SAFETY PRJGRAM + *SPRAY, GENERAL

7-26558 ALSO IN CATEGORIES 11 AND 1

ORNL NUCLEAR SAFETY RESEARCH AND DEVELOPMENT PROGRAM BIMONTHLY REPORT FOR MARCH-APRIL 1968 DAK RIDGE NATIONAL LABORATORY, DAK RIDGE, TENNESSEE

UKNL-IM-2230 -. 164 PAGLS, TIGURES, TABLES, MAY 3O, IOAR

INCLUDED IN THIS PROGRESS REPORT IS WORK ON VARIOUS CHEMICAL REACTIONS, AS WELL AS THE RELEASE, CHARACTERI ZATION, AND TRANSPORT OF FISSION PRDDUCTS IN CONTAINMENT SYSTEMS UNDER. VARIOUS ACCIDENT CONDITIONS AND ON PROBLEMS ASSOCIATED WITH THE REMOVAL OF THESE FISSION PRODUCTS FROM GAS STREAMS. ALTHOUGH MOST OF THE WORK HAS BEEN AND CONTINUES TO BE IN GENERAL SUPPORT OF WATER POHER-REACTOR TECHNOLOGY, INCLUDING SOME IN DIRECT SUPPORT OF THE LOFT AND CSE PROGRAMS, SEVERAL PROJECTS WERE STARTED THE FIRST OF THE CALENDAR YEAR IN SUPPORT OF THE CSE PROGRAMS, SEVERAL PROJECTS WERE STARTED THE FIRST OF THE CALENDAR YEAR IN SUPPORT OF THE
HIGH-TEMPERATURE GAS-COOLED REACTOR (HTGR) PROGRAM. THESE PROJECTS INCLUDE BOTH IN-PILE AND OUT-PILE STUDIES OF REACTION RATES AND FISSION PRODUCT RELEASE AND TRANSPORT PHENOMENA RELEVANT TO POTENTIAL. HTGR ACCIOENT SITUATIDNS. OTHER MAJOR PROJECTS INCLUDE FUEL TRANSPORT SAPETY INVESTIGATIONS, A SERIES OF DIST.ISSTIN PAPFRS TN VARIOUS ASPECTS OF SAFETY INVESTIGATIONS, A SERIES OF OISCUSSION PAPERS ON VARIOUS ASPECTS OF WATER REACTOR TECHNOLOCY, AND THE STUDIES ON PRESSURE VESSEL TECHNOLOGY. EXPERIMENTAL WORK RELATIVE TO PRESSURE VESSEL TECHNOLOGY INCLUDES INVESTIGATIONS OF THE ATTACHMENT OF NOZZLES TO SHELLS AND THE VARIABILITY OF IMPACT DATA ON LOW-ALLOY STEELS.

AVAILABILITY - CLEARINGHOUSE FOR FEDERAL SCIENTIFIC AND TECHNICAI. INFORMATION, SPRINGFIELD, VIRGINIA $22151 \$ 3.00$ COPY, \$0.85 MICROF ICHE

*CHEMICAL KINETICS + \#CONTAINMENT, GENERAL + \#CSE + \#FISSION PRODUCT RETENTION +

\#FISSION PRODUCT TRANSPORT + \#FISSION PRODUCT, AIRBORNE + \#IMPACT PROPERTY + *IN PILE EXPERIMENT + *LOFT (S-RR) + \#NOZZLE + *OUT OF PILE LOOPS AND EXPERIMENTS + \#STEEL + CONTAINMENT SPRAY +

FISSION PRODUCT RELEASE, GENERAL + PRESSURE VESSEL + REACTOR, HTGR

7-27028 ALSO IN CATEGORY 4

EICHELBERGER RL + MCKISSON RL

SOLUBILITY OF COPPER IN SOOIUM

ATOMICS INTERNATIONAL

AI-AEC-12671 +. 22 PAGES, 8 FIGURES, 3 TABLES, 4 REFERENCES, MAY, 1968

THE SOLUBILITY OF COPPER IN SOOIUM HAS BEEN STUDIED IN THE TEMPERATURE RANGE OF 250 TO 726 C, 
CATEGORY 7

FISSION PRODUCT RELEASE, TRANSPORT, AND REMOVAL

\section{7-27028 \#CONTINUED*}

USING A VERY HIGH PURITY SODIUM AND OXYGEN FREE HIGH CONOUCTIVITY COPPER. A CAPSULE WAS USED, WITH THE SODIUM EXPOSED ONLY TO HIGH VACUUM. CHEMICAL ANALYSIS WAS PERFDRMED USING COLORIMETRY AND ATOMIC ABSORPTION SPECTROMETRY. RESULTS OF THE 21 EXPERIMENTS REPDRTED BETWEEN 350 AND 726 C WERE COMBINED WITH THOSE FROM THO OTHER STUDIES TO GIVE AN EXPRESSION BASED ON 39 DATA POINTS AND COVERING THE TEMPERATURE RANGE OF 245 TO $726 \mathrm{C}$.

AVAILABILITY - CLEARINGHOUSE FOR FEDERAL SCIENTIF IC AND TECHNICAL INFORMATION, SPRINGFIELD, VA. 22515 $\$ 3.00$ COPY, $\$ 0.65$ MICROF ICHE

\# ANALYTICAL TECHNIQUE, CALIBRATION + \#COPPER + \#METAL, LIQUID + \#SODIUM + PROPERTY, PHYSICAL + REACTOR, LMCR

$7-27029$

ALSO IN CATEGORY 4

MOREHITZ HA + KOONTZ RL + NELSONCT + GREENFIELD MA + HAUSKNECHT DF

SODIUM BURNING, AEROSOL GENERATION, AND CONTROL OF FISSION PRJDUCT RELEASE DURING AN ACCIDENT PART II. AEROSOL GENERATION AND CONTROL OF FISSION PRODUCT RELEASE

ATOMICS INTERNATIONAL

29 PAGES, 16 FIgURES, TABLE, 4 REFERENCES, FROM THE INTERNATIONAL CONFERENCE ON THE SAFETY OF FAST NUCLEAR REACTORS, SEPTEMBER, 1967

RESULTS ARE PRESENTED FOR WORK IN PROGRESS AT ATOMICS INTERNATIONAL TO DEVELOP EXPERIMENTAL INFORMATION AND ANALYTICAL METHODS WHICH CHARACTERIZE THE RELEASE AND TRANSPORT OF EFFLUENTS GENERATED DURING A SODIUM FIRE IN AN LMFBR. DATA ARE PRESENTED FROM EXPERIMENTS WHICH DESCRIBE THE TIME-HISTORY OF PARTICLE SIZE AND MASS OISTRIBUTION DF AEROSOLS GENERATED DURING SDDIUM FIRES. EXPERIMENTAL OBSERVATIONS ARE MADE TO STUDY AEROSOL DEPLETION RESULTIVG FROM AGGLOMERATION, FALLOUT, AND WALL PLATING MECHANISMS. PREDICTION OF SODIUM OXIDE AEROSOL BEHAYIOR USING A THEORET ICAL MODEL IS IN AGREEMENT WITH EXPER IMENTAL OBSERVATIONS IN THE LABORATORY. THE INTERACTION OF THE DOMINANT AEROSOL SPECIES, SODIUM OXIDE, WITH FUEL AND FISSION PROOUCT AEROSOLS IS ALSO DESCRIBED.

AVA ILABILITY - H.A. MOREWITZ, P.0. BOX 309, CANOGA PARK, CALIFORNIA

*AEROSOL PRODUCTION + \#AEROSOL PROPERTIES + \#ANALYTICAL MODEL + \#FIRE + \#METAL, LIOUID + \#OXIDE + \#REACTOR, LMCR + \$SODIUM + AGGLOMERATE + DEPOSITION + FALLOUT + FISSION PRODUCT TRANSPORT

$7-27030$

ALSO IN CATEGORY 4

MACPHERSON RE

SODIUM BURNING AND AEROSOL RELEASE - AN EVALUATION OF THE STATE OF THE ART

OAK RIDGE NATIONAL LABORATORY, OAK RIDGE, TENNESSEE

ORNL-TM-1937+. 33 PAGES, 26 REFERENCES, MAY 6,1968

IN A SOOIUM-COOLEO REACTOR, THE POSSIBILITY OF SODIUM FIRES ANO THE RESULTANT RELEASE OF AEROSOLS STRONGLY INFLUENCE CONTAINMENT VESSEL DESIGN AND OPERATING SAFETY. OUALITATIVE INVESTIGATIONS OF SODIUM POOL FIRES AND SPRAY FIRES HAVE BEEN CARRIED OUT IN CONJUNCTION WITH EACH MAJOR SODIUM-COOLED REACTOR PROJECT. RECENTLY, MORE QUANTITATIVE STUDIES WERE UNDERTAKEN IN THESE AREAS, AND THE PROBLEM OF EXPLOSIVE INJECTION OF SODIUM SPRAYS INTO CONTAINMENT VOLUMES WAS INVESTIGATEO. WRRK IS AI SO IINMFR WAY TO THAPACTERIIE ACROSOLS RELEASEO FROM SODIUM FIRES AND TO DEFINE THEIR PERFORMANCE IN THE CONTAINMENT VOLUME. THIS DOCUMENT BRIEFLY SUMMARI ZES THE WORK TO DATE ON SODIUM FIRES AND AEROSOL RELEASE, REVIEWS THE SCOPE OF CURRENT PROCRAMS, ANO THEN PROPOSES ADDITIONAL EFFOR'T TO PROVIOE SAFETY CRITERIA FOR LIQUID-METAL-COOLED FAST-REACTOR DESIGN.

AVAILABILITY - CLEARINGHOUSE FOR FEDERAL SCIENTIFIC AND TECHNICAL INFORMATION, SPRINGFIELD, VA. 22151 $\$ 3.00$ COPY, \$0.65 MICROFICHE

*FIRE + AMETAL, LIQUID + FREACIUR, LMCR + AEROSOL PRODUCTION + AEROSOL PROPERTIES + TXIDE + SAFETY REVIEH + SODIUM

7-27031 ALSO IN CATEGORY 4

GORLAND $S+B I L S K I R$

CONTROL OF CONTAMINANTS IN LIQUID-METAL SYSTEMS

NASA, LEWIS RESEARCH CENTER

NASA-TM-X-1432 +. 9 PAGES, 7 FIGURES, TABLE, 10 REFERENCES, DECEMBER, 1967

THE CONTAMINANT CONTROLS AND CLEANING PROCEDURES USED IN THE SNAP-8 SIMULATIDN LOOP,

CONSISTING OF THO SODIUM-POTASSIUM (NAK) LOOPS AND ONE MERCURY LODP, MINIMIZED BOTH STARTUP AND OPERATIONAL PROBLEMS. MERCURY WETTING WAS INOUCED IN THE BOILER AND CONDENSER AS DETERMINED BY PROGRESSIVE IMPROVEMENT IN THE HEAT-TRANSFER PERFORMANCE. THE DEGREE OF WETTING IS AN INDICATION RF THE SYSTEM CLEANLINESS. THE BOILER HAS CONOITIONED IN APPROXIMATELY 250 HOURS OF OPERATION WITHOIT WETTING ADDITIVES. AFTER 384 HOURS OF APERATION, ANALYSIS OF A HG SAMPLE BY A DISTILLATION METHOD INDICATED NO CONTAMINATION. OXIDE PLUGGING IN THE NAK LOOPS WAS MINIMIZEO USING THE LOOP-ENTRY PROCEDURES DEVEL.OPED IN THE INVESTIGATION. NO PLUGS OCCURRED BECAUSE OF CHANGED OR OF REPAIRS THAT REQUIRED SYSTEM

ENTRY, AND ONLY MINOR PARTIAL PLUGS OCCURRED IN OVER 1500 HOURS OF OPERATION OF THE NAK LOOPS.

AVAILABILITY - CLEARINGHOUSE FOR FEDERAL SCIENTIFIC AND TECHNICAL INFORMATION, SPRINGFIELO, VA. $2215 I$ $\$ 3.00$ COPY, \$0.65 MICROF ICHE

*MERCURY + *METAL, LIQUID + *OPERATING EXPERIENCE + *OUT OF PILE LOOPS AND EXPERIMENTS + *OXIDE + *SODIUM + OECONTAMINATION + NAK + PIPING + REACTOR, LMCR + REACTOR, SPACE + SNAP 8 (SR) 
CATEGORY 7

FISSION PRODUCT RELEASE, TRANSPORT, AND REMOVAL

$7-27032$

PARKER GW + LORENZ RA + RITTENHOUSE PL + OSBORNE MF + CRCEK GE

CHARACTERIZATION AND BEHAVIOR OF ACCIDENT-RELEASED FISSION PRODUCTS (PART I)

OAK RIDGE NATIONAL LABORATORY, OAK RIDGE TENNESSEE

ORNL-4228 +. 70 PAGES, 38 FIGURES, 10 TABLES, PAGES 3-72 OF THE NSP ANNUAL DQOGRESS REPORT, APPIL, 1 OGE

PROGRESS REPORT DEALING NITH - PROMPT RELEASE OF FISSION PROOUCTS FROM ZIRCALOY-CLAS UOZ FUELS - OUT-OF-PILE EXPERIMENTS WITH FUELS IRRAOIATED AT HIGH HEAT-GENERATION RATES, PROMPT FISSION-DRODUCT RELEASE STUDIES IN TREAT, CALCULATION OF AMOUNT OF VOLATILE RADIOACTIVITY IN FUEL ROD VOID SPACES, STUODIES OF ZIRCALOY TUBE-BURST PHENOMENA. CHARACTERIZATIDN OF SIMULATEO ACCIDENT AEROSOLS - PORTABLE SAMPLER FIR CHARACTEPIZATION OF SIHULATED ACD.JSOLS OUT-OF-PILE TESTS OF CSE SIMULANT, IN-PILE TESTS DF CSE SIMULANT. IN-PILE RELEASE OF FISSION PRODUCTS IN SIMULATED REACTOR. ACCIDENTS - SIMULATED LOSS-DF-COOLANT ACCIDENTS IN ORR, SIMULATED TRANSIENT ACCIDENTS IN TREAT. LOFT ASSISTANCE PRQGRAM - EXPERIMENTAL FACILITIES, EXPERIMENTAL PROGRAM.

AVAILABILITY - CLEARINGHOUSE FOR FEDERAL SCIENTIFIC AND TSCHVICAL INFORMATION, SPRINGFIELD, VA. $2215 !$ $\$ 3.00$ CUPY, \$O.65 MICROT ICHE

* AEROSOL PROPERTIES + *ALLOY + \#FISSION PRODUCT RELEASE, GENERAL + \#IN PILE EXPERIMENT +

*OUT OF PILE LOOPS ANO EXPERIMENTS + \$SAMPLING + \#SIMULATION + \#ZIRCJNIUM + AEROSOL PRODUCTION + CSE + FILTER, CASCADE IMPACTOR + FISSION GAS RELEASE + FISSION PRDDUCT TRANSPORT + FISSION DRODUCT, VDLATILE + LOFT (S-RR) + NSDP + ORR (RR) + PARTICLE SIZE + TREAT (PRR)

$7-27033$

FONTANA MH

CHARACTERIZATION AND BEHAVIOR OF ACCIDENT RELEASED FISSION PRODUCTS (PART II)

OAK RIDGE NATIONAL LABORATORY, OAK RIDGE, TENNESSEE

ORNL-4228 +. 28 PAGES, 47 FIGURES, 37 REFERENCES, PAGES 72-99 FROM THE NSP ANNUAL PROGRESS REOORT, APRIL, 1968

PROGRESS REPORT DEALING WITH - CHEMICAL EQUILIBRIA OF FISSIDN-PRODUCT FUEL MIXTURES - THE URANI UM-OXYGEN ANO URANIUM-OXYGEN-STRONTIUM SYSTEMS, ESTIMATIOY OF THERMOOYNAMIC PQJPERTIES FISSION-PRODUCT TRANSPORT BEHAVIOR IN CONTAINMENT VESSELS DUE TO NATURAL PHENOMENA TRANSPORT STUDIES IN THE NUCLEAR SAFETY PILOT DLANT, STUDIES OF CONVFCTION IN CONTAINMENT VESSELS, BOUNDARY-LAYER ANALYSIS OF THE EFFECT OF. CJNDENSATION ON FISSION-PRODUCT DEPOSITION.

*CHEMICAL EQUILIBRIUM + \#FISSION PRODUCT RELEASE, GENERAL + \#FISSION PRODUCT TRANSPDRT + *THERMAL PROPERTY + \#THERMODYNAMICS + CONDENSATION + DEPOSITIJY + FISSION PRODUCT RETENTION + FUEL MELTDOWN + NSPP + URANIUM DIOXIDE + VAPOR, VAPOR PRESSURE

$7-27034$

ADAMS RE + ACKLEY RD + CGMBS Z

FILTRATION AND ADSORPTION TECHNOLOGY (PART II

OAK RIDGE NATIONAL. LABORATORY, OAK RIDGE, TENNESSEE

ORNL-4228+. 48 PAGES, 15 FIGUKES, 16 TABLES, PAGES 99-148 FROM THE NSP ANNUAL PROGRESS REPORT, ADRIL, 1968

PROGRESS REPORI UEALING WITH - TRAPPING OF RADIOACTIVE IOOINE AND METHYL IOCIDE BY IODIZED CHARCOAL - REMOVAL OF METHYL IODIDE FROM MOIST AIR SYSTEMS, REIOVAL OF ELEMENIAL IODINE FROM MOIST AIR SYSTEMS, LOSS OF IMPREGNANT FROM IODIZED CHARCOAL AT ELEVATED TEMPFRATURES, EFFECI OF WEATHER ING ON METHYL IODIDE REMOVAL EFFICIENCY OF IODIZED CHARCDAL. REACTIONS OF IDOINE VAPOR UNDER ACCIDENT CONDITIONS - REACTIONS OF IODINE IN CONTAINMENT SYSTEMS, ANALYTICAL STUDIES OF METHYL IODIDE FORMATION. MECHANISM OF SORPTION OF MOLECULAR IODINE. DEVELOPMENT OF IODINE-CHARACTERIZATI ON SAMPLERS - TESTING OF IODINE-CHARACTERIZATION DACK (MAY PACK), DEVELOPMENT AND TESTING OF HONEYCOMB IODINE SAMPLER. FILTRATION OF STAINLESS STEEL-UO? AEROSOLS - FILTRATION UL ALKUSULS SY HIGII CTIICIENGY FILTFR MFOIA, BEHAVIDR OF AEROSJLS IN HUMID A TMOSPHERES.

\#AEROSOL PROPERTIES + \#CHAPCOAL $\triangle$ DSTRBER + \#FILTER EFTICIENCY + \#FISSIDN DRODUCT, IDOINF +

\#ORGANIC IODIDE + *SAMPLING + AIR CLEANING + FILTER CHARACTERISTICS + FILTER SYSTEM +

FILTER, C.ASCADE IMPACTOR + HUMIDITY + IOOINE + OUT OF PILE LOOPS AND EXPERIMENTS +

PARTICLC SIZE DISTRIBUTION + SIMULATIUN + STEAM

$7-27035$

AÜAMS RW + DAVIS RJ + GILL JS + TRIITTY J + BUCHHOLZ.H

FILTRATION AND AOSORPTION TECHNOLOGY (PART II)

ORNL-4228 + 46 PAGES, 34 FIGURES, 18 TABLES, 51 REFERENCES, PAGES $148-193$ FROM THE NSP ANNUAL PROGRESS

RFPIRT, APRIL, 1968

PROGRESS REPORT DEALING WITH - CHARACTERIZATION OF RADIOACTIVE PARTICULATE AEROSOLS -

AGGLOMERATION OF AEROSOLS, CHARACTERIZATION OF AEROSOLS BY THE FIBROUS-FILTER ANALYZER, DEVELOPMENT OF A MIILTISTAGE INERTIAL IMPACTOR FOR CHARACTERIZING SOLID AEROSOLS, DEVELOPMENT OF A LOW-PRESSURE IMPACTOR FOR THE CLASSIFICATIUN OF SUBMICRON PARTICLES. IGNITIDN OF CHARCOAL ADSORBERS BY FISSION-PRODUCT DECAY HEAT - IN-PILLE CHARCOAL IGNITION EXPERIMENTS LABORATORY CHARCOAL IGNITION EXPERIMENTS, ANALYTICAL CORRELATION ÜF IGNITION DATA. SEPARATION OF NOBLE GASES FROM AIR BY PERMSELECTIVE MEMBRANES - CRITERIA FOR REACTOR ACCIDENT 
CATEGORY 7

FISSION PRODUCT RELEASE, TRANSPORT, AND REMOVAL

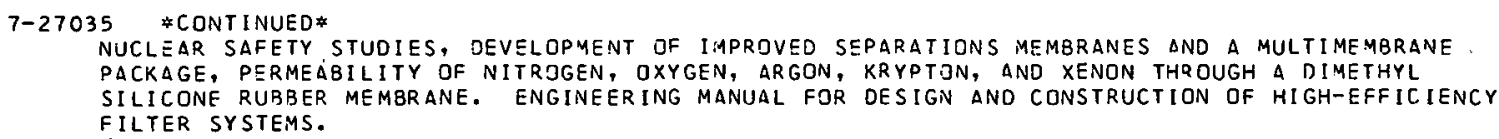

PROGRESS REPORT DEALING WITH - DISSOLUTION AND HYOROLYSIS OF METHYL IODIDE IN MISTING SPRAY SOLUTIONS - EXPERIMENTAL EQUIPMENT, EXPERIMENTAL PROCEDURE. SPRAY TESTS IN THE NUCLEAR SAFETY PILOT PLANT - EQUIPMENT AND EXPERIMENTAL DROCEDURE, FIRST SERIES OF EXPERIMENTS, SECOND SERIES OF EXPERIMENTS, THEORETICAL STUDIES, CONTINUATION OF PROGRAM. RADIATION STABILITY OF SPRAY SOLUTIONS - EFFECT OF RADIATION ON PH, I2 EQUIVALENCE, AND SOLIDS FORMATION, RADIOLYTIC HI PRODUCTION. SCAVENGING OF FISSION PRODUCTS BY SUPPRESSIDN POOLS.

\#CONTAINMENT, PRESSURE SUPPRESSION + \#HYDROGEN + \#NSPP + \#ORGANIC IODIDE + \#RAOIATION EFFECT + DECONTAMINATION FACTOR + DECONTAMINATION SPRAY + IONINE + MIST + RAOIATION OAMAGE + SPRAY, FFNERAL

$7-27038$

BAKER JE + BLOOD CM + HEBERT GM + OVERHOLSER LG

SAFETY STUDIES FOR HIGH-TEMPERATURE GAS-COOLED REACTORS

OAK RIOGE NATIONAL LABORATORY, OAK RIDGE, TFNNFSSFF

ORIN-4220+.41 HAliES, 13 FIGURES, 6 TADLES, 15 REFERENCES, PAGES $243-289$ OTF THE NSP ANNUAL DRDGRESS RFPORT, APRIL, 1968

PROGRESS REPORT DEALING WITH - STEAM-CARBON REACTION AND FISSION-PRODUCT RELEASE AND TRANSPORT STUDIES - OXIDATION OF BONDED COATED-PARTICLE FUEL COMPACTS, OXIDATION OF

PYROLYTIC-CARBON-COATED FUEL PARTICLES BY WATER VAPOR, STEAM-GRAPHITE FEACTION, TRANSPORT OF BARIUM BY HELIUM. IN-PILE BEHAVIDR OF HTGR FUEL ELEMENTS IN MIXTURES OF STEAM AND HELIUM ENGINEERING-SCALE STEAM-GRAPHITE REACTION STUDIES - ENGINFFRING-SCALE TEST FACILITY, ANALYTICAL STUDIES OF STEAM-GRAPHITE REACTION. HTGR FUEL TESTS IN THE ORR POOLSIDE CAPSULE FACILITY - TEST DESCRIPTION, POSTIRRADIATION EVALUATION. THERMODYNAMIC AND TRANSPIRT PROPERTIES OF FISSION PRODUCTS - EFFECT OF HATFR VAPOR ON THE VOLATILITY OF FISSIUN-PRODUCT OXIDES, FISSIUN-PROOUCT OEPOSITION CHARACTERISTICS IN THERMAL GRADIENTS.

*CARBON + *CHEMICAL REACTION + *CQATED PARTICLE + *FISSION PRODUCT RETENTION + \#GRAPHITE +

*IN PILE EXPERIMENT + \#OXIDATION + \#STEAM + ANALYTICAL TECHNIQUE, CALIBRATIQN + DEPOSITION + DIFFUSION + FISSION PROOUCT TRANSPORT + FISSION RECOIL + IRRAOIATION TESTING + THERMAL PROPERTY + THERMDOYNAMICS + WATER VAPOR

7-27039 ALSO IN CATEGORY 6

SAFETY STUDIES FOR MSBR

OAK RIDGE NATIONAL LABORATORY, OAK RIDGE, TENNESSEE

ORNL-4228 +. 23 PAGES, 8 FIGURES, TABLE, 8 REFERENCES, PAGES 289-311 OF THE NSP ANNUAL PROGRESS REPORT,

APRIL, 1968

PROGRESS REPORT DEALING WITH - MSBR DYNAMIC STUDIES - REACTOR SYSTEM RESPDNSE TO REACTIVITY CHANGES, REACTOR SYSTEM STABILITY STUOIES. MSBR TEMPERATURE COEFFICIENTS OF REACTIVITY. FISSION-PRODUCT BEHAVIOR IN MOLTEN-SALT REACTORS - FISSION-PROOUCT CONCENTRATIONS IN THE MSRE, STABILITY OF MOLYBDENUM FLUORIOES IN LIF-BEF 2 MELTS. MOLTEN-SALT COMPATIBILITY STUDIES. AFTERHEAT GENERATION IN AN MSBR SYSTEM - AFTERHEAT GENERATION IN AN MSBR FUEL-LOOP HEAT EXCHANGER, AFTERHEAT GENERATION IN GRAPHITE DUE TO FISSION-PRODUCT GASES AND THEIR OECAY PRODUCTS. CALCULATION OF FISSION-PRODUCT BUILDUP IN AN MSBR. 
7-27039 \#CONTINUED*

\#COMPUTER, ANALOG + \#DECAY HEAT + \#FISSION PRODUCT TRANSPORT + \#MOLTEN FUEL + \#REACTIVITY EFFECT + \#REACTOR STABILITY + ANALYTICAL MODEL + COMPUTER CONTROL + COMPUTER PROGRAM + EQUATION OF STATE + FISSION PRODUCT ACTIVITY, GROSS + MSRE 'RE) + REACTOR, MOLTEN SALT

$7-27056$

FONTANA MH

ALSO IN CATEGORY 5

THE CHEMICAL EOUILIBRIA OF FISSION PRODUCT NUCLEAR FUEL MIXTURES -- THE URANIUM OXYGEN AND THE URANIUM OXYGEN STRONTIUM SYSTEM

OAK RIDGE NATIONAL LABORATORY, OAK RIDGE, TENNESSEE

ORNL-TM-2105 +. 272 PAGES, 31 FIGURES; 28 TABLES, 74 REFEREVCES, SUBMITTED TO THE CACULTY OF PURDIJE

UNIVERSITY IN PARTIAL FULFILLMENT OF THE REQUIREMENTS FOR THE DEGREE DOCTOR OF PHILOSOPHY, JULY I968

THE TRANSPORT OF FISSION PRODUCTS RELEASEO DURING A REACTOR ACCI DENT DEPENOS IN PART UPON THE CHEMICAL STATE IN WHICH THEY EXIST. COMPUTATION OF CHEMICAL EQUILIBRIA IN THE GAS PHASE AROUND A MELTED FUEL ELEMENT IS DIFFICULT BECAUSE THE FUEL MAY ACT AS A SOLVENT FOR FISSION PRODUCTS. ALSO, FUELS SUCH AS URANIUM OXIDE FORM A NONSTOICHIOMETRIC CONDENSFM PHASE. METHOOS. DF USING MULTICOMPONENT CHEMICAL-EQUILIBRIUM COMPUTER TECHNIQUES HAVE BEEN DSVELOPED FOR TREATING THIS PROBLEM, AND THEY HAVE BEEN TESTED AGAINST PUBLISHED KNUDSEN CELL-MASS SPECTRDMETER DATA FOR THE U-O SYSTEM. THIS SERVED AS A BASE POINT FROM WHICH THE U-SR-D SYSTEM WAS. EXTENDED.

AVAILABILITY - CLEARINGHOUSE FOR FEDERAL SCIENTIFIC AND TECHNICAL INFORMATION, SPRINGFIELO, VA. 221 IS $\$ 3.00$ COPY, \$0.65 MICROFICHE

*CHEMICAL EQUILIBRIUM + \#FISSION PRODUCT RELEASE, GENERAL + FFISSION PRODUCT TRANSPCRT + OXYGEN + STRONTIUM + URANIUM DIOXIDE + URANIUM, NATURAL

$7-27065$

LUDWIG FL

BEHAVIOR OF A NUMERICAL ANALOG TO A CASCAOE IMPACTOR

STANFORD RESEARCH INSTITUTE, MENLO PARK, CALI HURNIA

4 PAGES, 4 FIGURES, 6 REFERENCES, ENVIRONMENTAL SCIENCE ANO TECHNOLOGY, 2(7), PAGES 547-550 (JULY, 1968)

A SIMPLE NUMERICAL ANALOG TO CASCADE IMPACTORS AND THE RESULTS OF ITS AP.PLICATION TD THE ANDERSEN SAMPLER ARE DESCRIBED. COMMUNLY USED DATA REDUCTION TECHNIQUES OVERSSTIMATE THE GE OMETRIC STANDARD DEVIATION OF SAMPLED SIZE DISTRIBUTIONS. THE OVERESTIMATE IS SMALL FOR GEOMETRIC STANOARD DEVIATIONS GREATER THAN ABOUT 4 BUT BECOMES SIGNIFICANT FOR VALUES LESS THAN 2. THE EFFECIS OF THIS ARTIFACT JN THE ESTIMATE DF MEDIAN DIAMETER ARE SMALL. THE MAGNITUDES OF THE ERRORS ARE RELATED TO THE SHAPE OC THE PARTICLE-SIZE SPECTRUM OVER THE DI AMETER RANGE SAMPLED BY THE IMPACTOR.

* ANALOG SIMULATION + \#FILTER, CASCADE IMPACTOR + \#PARTICLE SIZE DISTRIBUTION + \#THEORETICAL INVESTIGATION + AEROSOL + COMPUTER, ANALOG + SAMPLING

$7-27066$

GENCO JM + ROSENBERT, HS + MORRISON OL

IODINE DEPOSITION ANU ITS ENCHANCEMENT UNDER REACTOR ACCIOCNT CONOITIONS

BATELLE MEMORINL INSTITUTE

13 PAGES, 12 FIGURES, 4 TABLES, 16 REFERENCES, NUCLEAR SAFETY, $9(3)$, PAGES 226-238 (MAY-JUNE, 1068)

THE CURRENT STATUS OF FUNDAMENTAL IODINE DEPOSITION STUOIES AT THE COLUMBUS LABORATORIES OF BATELLE MEMORI AL INSTITUTE IS SUMMARI ZEO. DEPOSITION EXPERIMEVTS WERE CONDUITES DN PRIMARY ANO CONTAINMENT-SYSTEM SURFACES, AND IT WAS FOUND THAT HI EXHIBITS CONSIDERABLY GREATER DEPOSITION THAN I2 ON PRIMARY SURFACES, ESPECIALLY AT ELEVATED TEMPERATURES. THERMOOYNAMIC AND KINETIC DATA ON SEVERAL TYHICAL CONTAINMENT-VESSEL PAIINTS INOICATED CONSIDERABLE IODINE PENETRATION INTO THE INTERIOR OF THE COATINGS. A DIFFUSION WITH CHEMICAL-REACTION MECHANISM CAN ADEQUATELY EXPLAIN THE DATA. EFFOPT HAS BEEN DIRECTED TO THE DEVELOPMENT OF A REACTIVF COATING SYSTEM CAPABLE OF ENHANCING ICOINE DEPIISIIIIUN UNOER SERIOUS REACTOP. ACCIDENT CONDITI IONS.

\#CHEMICAL KINETICS + \#COATING, SIJRFACE + \#DEPOSITION + \#FISSION PRODUCT, IDDINE + *SURFACE, PAINTEO + *THERMODYNAMICS + CHEMICAL REACTION + OECONFAMINATION + DIFFUSION + FISSION PRODUT.T TRANSPIRT + ICDIVE + THEORETICAL INVEST IGATION

$7-27067$

GENCO JM + ROSENBERG HS + BERRY DA + BERRY WE + CREMEANS GE + RITZMAN RL + DRAUGLIS EJ + MORRISON DL FISSION-PRODUCT DEPOSITION AND ITS ENHANCEMENT UNDER REACTJR ACCIDENT CDNDITIONS

BATIELLE MEMORIAL INSTITUTE

BMI-X-10229+. 62 PAGES, 16 FIGURES, 22 TABLES, 22 REFERENCES, APRIL, 1968

PROGRESS REPRRT DEALING WITH END EFFECTS ANO ANOMALDUS IOOINE-DEPOSITION BEHAVIOR, LIQUIO-PHASE DEPOSITION OF HI ON CONTAINMENT-SYSTEMS COATINGS, TELLURIUM AND CESIUM

DEPOSITION, VAPOR-PHASE GEPOSITION OF IODINE ON PAINTED SURFAC.ES, REACTIVE COATINGS AS A PASSIVE SAFETY SYSTEM, EVALUATION DF COATING CANDIDATES FIR THE REMOVAL OF ELEMENTAL IDOINE AIR-STREAM MIXTURFS.

AVAILABILITY - CLEARINGHOUSE FOR FEDERAL SCIENTIFIC AND TECHNICAL INFDRMATICN, SPRINGFIELD, VIRGINIA 
CATEGORY 7

FI SSION PRODUCT RELEASE, TRANSPORT, AND REMOVAL

$7-27067$ \#ONTINUED*

$22151 \$ 3.00$ COPY, \$0.65 MICROFICHE

\#CESIUM + \#COATING, SURFACE + \#IODINE * \#ORGANIC IODIDE + \#SURFACE, PAINTED + \#TELLURIUM + OECONTAMINATION + DEPOSITION

$7-27068$

PARKER GW + BUCHHOLZ H

SI ZE CLASSIFICATION OF SUBMICRON PARTICLES BY A LOW-PRESSURE CASCADE IMPACTOR

OAK RIDGE NATIONAL LABDRATORY, OAK RIDGE; TENNESSEE

ORNL-4226 +. 64 PAGES, 22 FIGURES, 10 TABLES, 19 REFERENCES, CONTRACT NO. W-7405-ENG-26, JUNE, 1968

1. THE PRINCIPLE OF THE CASCADE IMPACTOR IS SIMPLE. A GAS WHICH IS CARRYING PARTICLES, IS ACCELERATED THROUGH A NOZZLE AND IMPINGED ON A PLATE. PARTICLES HAVING SUFFICIENT INERTIA

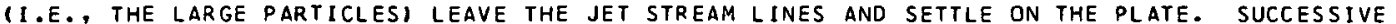
STAGES WITH JETS OF INCREASING VELOCITY REMOVE SUCCESSIVELY SMALLER PARTICLES. OPERATION AT LOW PRESSURE INCREASES THE MEAN FREE PATH OF THE GAS MOLECULES AND THE CUNNINGHAM CORRECTION (FDR THE SLIP OF SMALL PARTICLES BETWEEN GAS MOLECULESI. THIS ENABLES ONE TO DESIGN A CASCADE IMPACTOR OF REASONABLE JET SIZE WHICH WILL SEPARATE SUBMICRON PARTICLES. 2 . IN THIS WORK A COMMERCIAL (ANDERSEN) IMPACTOR, MODIFIED FOR LOW PRESSURE JPERATION, AND AN IMPACTOR OR ORIGINAL DESIGN WERE BUILT, TESTED AND CALIBRATEO. DESIGN DATA AND CALIBRATION CURVES APEE REPORTED. THE PARTICLE SIZE CALIBRATION CURVES ARE REPORTED. THE PARTICLE SIZE RANGE SEPARATED IS FROM ABOUT 0.01 MICRON TO SEVERAL MICRONS DIAMETER. THE ORIGINAL DESIGN IMPACTOR I S ASSEMBLED AND DISASSEMBLED VERY SIMPLY AND EMPLOYS THROW-AWAY IMPACTOR PLATES TO FACILITATE DECONTAMINATION.

AVAILABILITY - CLEARINGHOUSE FOR FEDERAL SCIENTIFIC AND TECHNICAL INFORMATION, SPRINGFIELO, VIRGINIA $22151, \$ 3.00$ COPY $\$ 0.65$ MICROFICHE

* AEROSOL + \#FILTER, CASCADE IMPACTOR + \#PARTICLE SIZE DISTRIBUTION + \#SAMPLING + AIR CLEANIVG * ANALYTICAL TECHNIOUE, CALIBRATION + INSTRUMENTATION, AIR SAMPLING + PARTICLE SIZE

$7-27069$

BENZEL M + BREMEN F + BRAUNF

AN ARRANGEMENT FOR INSERTING, HOLOING AND SEALING EXCHANGEABLE FILTERS INTO DISCHARGE DUCTS FOR POLLUTED AIR

BRITISH PATENT $1,089,730+.4$ PAGES, 4 FIGURES, NOVEMBER 8,1967

THE EQUIPMENT IS OESCRIBED AND IS PARTICULARLY SUITEO FOR AIR DUCTS CARRYING RADIOACTIVE OUST. THE FILTER ELEMENT, WHICH HAS A RIGID RECTANGULAR FRAME WITH A SEALING GASKET BONOED TO THE FRAME, IS INSERTED THROUGH A CLOSEABLE OPENING IN THE OUCT BY TOGGLE LEVERS, AND THE SEALING GASKET IS PRESSED TO A SEALING FLANGE LOCATED INSIDE THE DUCT.

AVAILABILITY - THE PATENT OFFICE, 25 SOUTHAMPTON BUILDING, LONDON, W.C. 2, ENGLAND (499 CENTS/COPYI \#FILTER MAINTENANCE + \#FILTER SYSTEM + \#PATENT + FILTER + FILTER INSTALLATION + FILTER OPERATION

$7-27070$

PIEKAAR HW + CLARENBURG LA

AEROSOL FILTERS - THE TORTUOSITY FACTOR IN FIBROUS FILTERS

CHEMICAL LABORATORY OF THE NATIONAL DEFENCE RESEARCH ORGANIZATION T.N.O., TIJSWIJK Z.H., THE NETHERLANDS

11 PAGES, 6 FIGURES, TABLE, 27 REFERENCES, CHEMICAL ENGINEERING SCIENCE, 22(12), PAGES 1817-1827 (1967)

A THEORETICAL DERIVATION IS GIVEN OF THE TORTUOSITY FACTOR FOR A FLOW THROUGH FIBROUS FILTERS, BASED ON PURELY GSOMETRI CAL CONSIDERATIONS. THE RESULTING EXPRESSION FOR THE TORTUOSITY APPEARS TO BE A FUNCTION OF FILTER AND FIBRE PROPERTIES. FOR LAMINAR AIR FLOU THE TORTUOSITY FACTOR IS CALCULATED AS A FUNCTION OF POROSITY ANO OF FILTER COMPOSITION. ALTHOUGH THE RESULTING CURVES ARE IN QUANTITATIVE AGREEMENT WITH THE EXPERIMENTAL WORK OF SIJLLIVAN, FREQUENTLY REFERRED TO, THERE IS MUCH EVIDENCE THAT SULLIVAN OID NOT MEASURE TORTUOSITY ALONE. FINALIY THE TORTUOSITY FACTOR IS CALCULATED FDR ELECTRICAL FLOW THROUGH FIBROUS FILTERS SATURATED WITH A CONDUCTING LIQUID. THEORETICAL AND EXPERIMENTAL RESULTS ARE IN EXCELLENT AGREEMENT. THEREFORE, IT MAY BE CONCLUDED THAT IT IS NDT JUSTIFIEO TO TAKE THE CONSTANT VALUE (SQUARE ROOT OF 2 ) DERIVED FROM ELECTRICAL MEASUREMENTS FOR THE TORTUOSITY FACTOR OF LAMINAR AIR FLOW THROUGH FIBROUS FILTERS.

*FILTER, FIBER + \#THEORETICAL INVESTIGATION + AIR + FILTER THEORY, DIFFUSION + FILTER THEORY, IMPACTION + FILTER THEORY, INTERCEPTION + FLOW, GENERAL

$7-27071$

FIRST MN + VILES JF + REIST PC + BULBA EA + OBRIEN MJ + WEKER RA + GOLOIN AS + MOELLER DW SEMI ANNUAL PROGRESS REPORT. HARVARD AIR CLEANING LABORATORY. SEPTEMBER 1, $1967-2$ MARCH 1, 1968 HARVARD UNIVERSITY, AIR CLEANING LABDRATORY, SCHOOL OF PUBLIC HEALTH, BOSTON, MASS.

NYO-841-12 +. 76 PAGES, 25 FIGURES, 10 TABLES, 14 REFERENCES, APFIL, 1968

(PART DNE) WALL DEPOSITION OF SODIUM PARTICLES. (PART TWO) FOAM ENCAPSULATION FOR REMOVAL OF AIRBORNE IODINE AND METHYL IODIDE. (PART THREE) IN-PLACE FILTER TEST. (PART FOUR) KRYPTON SEPARATION BY ELECTROSTATIC DIFFUSION. (PART FIVE) FALL ING DROP CONTAINMENT VESSEL CLEAN-UP SYSTEMS. (PART SIX) INTERNATIONAL SYMPOSIUM AND TENTH AEC AIR CLEANING CONFERENCE. 
CATEGORY 7

FI.SSION PRODUCT RELEASE, TRANSPORT, AND REMOVAL

7-27071 *CONT INUED*

AVAILABILITY - CLEARINGHOUSE FOR FEDERAL SCIENTIFIC AND TECHNICAL INFORMATION, SPRINGFIELO, VA. 22151 , $\$ 3.00$ COPY, \$0.65 MICROFICHE

\# $\triangle E R O S O L$ + *AIR CLEANING + *FOAM + \#KRYPTON + \#ORGANIC IODIDE + *SODIUM + \#SPRAY, GENERAL + DECONTAMINATION + DEPOSITION + ELECTROSTATIC PRECIPITATION + FILTER + IODINE + TEST, FILTER + TESTING

7-27072

STEVENS DC

RADIOACTIVE AEROSOLS IN SOME SELECTED AREAS AT A.E.R.E. PARTICLE SIZE DISTRIBUTIONS AND LONG TERM MEAN CONCENTRATIONS MEASURED BY PER.SONAL AND STATIC AIR SAMPLERS.

UKAEA, BERKS HARWELL

AERE-R-5688 +. 18 PAGES, 4 FIGURES, 4 TABLES, 13 REFERENCES, JANUARY, 1968

CENTRIPETERS AND PERSONAL AIR SAMPLERS WERE USEO FOR ONE YEAR TO MEASURE THE PARTICLE SILE OF RADIOACTIVE AEROSOLS IN VARIOUS BUILQINGS AT A.E.R.E., AND TO EXAMINE THE RELATIONSHID BETWEEN PERSUNAL EXPOSURE AND. EXPOSURE MEASUREO BY AN ENVIRONMENTAL (STATIC) SAMPLER. THE ACTIVITY MEDIAN AERODYNAMIC PARTICLE DIAMETER ASSOCIATEO WITH THE AIRBORNE ACTIVITY IN THE INCINERATOR BUILDING AND FILTER HOUSE WAS 5 TO 6 MICRONS FOR BOTH ALPHA AND BETA ACTIVITY, WITH A GEOMETRIC STANDARD DEVIATION OF 2.5 TO 3.0 . SIMILAR SIZE OISTRIBUTIONS WERE OBTAINED FOR BETA ACTIVITY IN THE HIGH-ACTIVITY-HANDLING BUILOING ANO THE WET DECONTAMINATION AREA, BUT AIRBORNE ALPHA ACTIVITY IN THE LATTER HAO A MEOIAN DIAMETER OF 3.5 MICRONS, WITH A GEOMETRIC STANDARD DEVIATION DF 4.3.

AVAILABILITY - CLEARINGHOUSE FOR FEDERAL SCIENTIFIC ANO TECHNICAL INFORMATION, SPRINGFIELD, VIRGINIA $22151, \$ 3.00$ COPY, \$0.65 MICROFICHE

*AEROSOL + *MONITORING PROGRAM, ENVIRONMENTAL + \#PARTICLE SIZE + \#PARTICLE, RADIOACTIVE + \#SAMPLING + AIR CLEANING + ATMOSPHERIC POLLUTION + ENVIRONMENTAL CONDITIDN

7-27092 ALSO IN CATEGORY 8

SYMPOSIUM ON METAL-GAS REACTIONS IN ATMOSPHERES CONTAINING CO2

6 PAGES, BRITISH CORROSION JOURNAL, $2(6)$, PAGES 229-234 (1967)

THE PROGRAMME FOR THIS SYMPOSIUM WAS PREFACED BY THE FOLLOWING OUTLINE OF THE OBJECTIVES OF THE MEETING - IN THE LAST FEW YEARS MUCH WORK HAS BEEN CARRIED OUT ON THE OXIDATION DF BDILER AND FUEL CLADOING MATERIALS IN CARBON DIOXIDE ENVIRONMENTS IN THE TEMPERATURE RANGE $350-850$ C IN CONNECTION WITH THE BRITISH GAS-COOLED NUCLEAR REACTOR PROGRAMME. THIS COVERS RIMMING, SEMI-KILLED ANO LOW ALLOY STEELS AND ALSO 9 PER CENT ANO 12 PEP. CENT CHROMIUM AND AUSTENITIC STEELS. WORK HAS ALSO BEEN DONE IN THE U.K. AND IN EUROPE IN HELIUM ENVIRONMENTS CONTAINING SMALL AMOUNTS OF CO/CO2, RELATING TO MORE ADVANCED NUCLEAR REACTOR CONCEPTS. THE DISCUSSION AT THIS SYMPOSIUM WILL COVER REPORTS OF THIS WORK, AND IN ADDITION CORROSION PROBLEMS ENCOUNTERED IN REFORMERS USEO IN THE GAS INDUSTRY AND ALLIED PLANT, ARISING FROM COMBINED CARBURISINGIOXIDISING REACTIONS ON AUSTENITIC STEELS AND HIGH NICKEL ALLOYS.

\# ALLOY + \#CARBON + \#CARBON DIOXIOE + *CARBON MONOXIDE + \#OXIDATION + \#STEEL + CARBIDE + CHEMICAL KINETICS + CHROMIUM + CLAODING + CORROSION + DRAGON (HTGR) + REACTOR, GCR + REALTOR, HTGR + STEEL, STAINLESS

$7-27093$

JAYE S + GOEDOEL WV

HIGH-TEMPERATURE GAS-COOLED REACTOR FUEL AND FUEL CYCLES - THEIR PROGRESS AND PROMISE

GULF GENERAL ATOMIC INCORPORATED, SAN DIEGO, CALIFORNIA

14 PAGES, 11 FIGURES, 7 TABI,FS, 22 REFERENCES, NUCLEAR ENGINEERING AND DESIGN, $7(4)$, PAGES $283-296$ (APRIL, 19681

DISCUSSES FUEL AND FUEL CYCLES FOR THE HIGH-TEMPERATURE GAS-COOLED REACTOR (HTGR). A SURVEY OF DESIGN FEATURES, ANALYTICAL MODELS, AND IRRADIATION TESTING RESULTS OF PYROLYTIC CARBON CDATED FUEI. PARTICLES IS PRESENTED. SEVERAL POTENTI.ALLY ATTRACTIVE FUEL CYCLE POSSIBILITIES ARE OISCUSSED, AND ALSO TRENOS IN FUEL AND FUEL-CYCLE COSTS FOR LARGE HTGRS.

\#CARBON + \#COATED PARTICLE + \#FUEL INTEGRITY + \#PYPOLYTIC + \#REACTOR, GCR + ANALYTICAL MODEL + DESIGN CRITERIA + DIFFUSION + HICH TEMPERATUPE + IRRADIATION TFSTING

$7-27095$

KASS

THE CORROSION ANO HYOROGEN ABSORPTION CHARACTERISTICS OF ZIRCONIUM ALLOYS

BETTIS ATOMIC POWER LAB, PITTSBURGH

WAPQ-TM-517 +. 61 PAGES, 31 FIGURES, 10 TABLES, 3 REFERENCES, FEBRUARY, 1968

THE CORROSION AND HYDROGEN ABSORPTION PROPERTIES OF ZIRCONIUM-BASE ALLOYS CONTAINING O.5 OR $1.0 \%$ IRON, 0.5 OR $1 \%$ CHROMIUM, AND 0 OR $0.5 \%$ TIN IN HIGH-TEMPERATURE WATER $\triangle N D$ STEAM HAVE BEEN STUDIED. THE ALLOY CONTAINING $0.5 \%$ IRIN AND $1.0 \%$ CHROMIUM WITH OR WITHOUT O.5\% TIN EXHIBITS A VERY LOW CORROSION RATE AND AT THE SAME TIME VERY LOW HYDROGEN PICKUP TENDENCIES. FOR APPLICATIONS AT $680 \mathrm{~F}$ AND 8ELOW, THE CORROSION PROPERTIES OF THE TIN-BEARING ALLOY ARE SUPERIDR. FOR APPLICATIINS ABOVE $60 \mathrm{~F}$, THE TIN-FREE ALLOY IS SUPERIOR.

AVAILABILITY - CLEARINGHOUSE FOR FEDERAL SCIENTIFIC ANO TECHNICAL INFORMATION, SPRINGFIELD, VIRGINIA $22151, \$ 3.00$ COPY, \$0.65 MICROFICHE 
CATEGORY 7

FISSION PRODUCT RELEASE, TRANSPORT, AND REMOVAL

7-27095 \#CONTINUED*

\#ADSORPTION + *ALLOY + *CORROSION + *HYDROGEN + \#ZIRCONIUM + CHROMIUM + HIGH TEMPERATURE + IRON + STEAM + $T I N+$ WATER, GENERAL

$7-27096$

BEZELLA WA

ANALYSES OF THE FISSION GASES RELEASED WITHIN SPENT YANKEE FUEL RODS

WESTINGHOUSE ELECTRIC CORP.. PITTSBURGH, PENNSYLVANIA, ATOMIC POWER DIVISION

WCAP-6087 +. 90 PAGES, 33 FIGURES, 10 TABLES, 25 REFERENCES, FEBRUARY, 1968

1. AN ANALYSIS WAS CONOUCTED OF THE GASES FOUND WITHIN 32 UO2 FUEL RDDS REMOVED FRDM THE YANKEE REACTOR. THESE RODS SELECTED FOR GAS ANALYSIS EXPER IENCED AVERAGE FUEL BURNUPS FROM 3000 MWD/MTU UP TO 36,000 MWK/MTU. IRRADIATION WAS AT RATHER LOW FUEL HEAT RATINGS WHICH RANGED FROM $0.94 \mathrm{KWIFT}$ TO $4.1 \mathrm{KWIFT}$ WITH FUEL AVERAGE PELLET TEMPERATURES DURING IRRADIATION ESTIMATED TO RANGE FROM $785 \mathrm{~F}$ TO $1450 \mathrm{~F}$. 2. THE COMPOSITION OF THE TOTAL GAS COLLECTED FROM THE FUEL RODS WAS DETERMINED SPECTROGRAPHICALLY WITH THE AMOUNT OF THE GAS CONSTITUENTS EVALUATEO VOLUMETRICALLY. THE EVOLVED FISSION GASES (KRYPTON AND XENONI FOUND WITHIN THE FUEL RODS VARIED BETWEEN 0.05 PERCENT AND 8.5 PERCENT OF THE AMOUNT WHICH WAS THEDRETICALLY PRODUCEO. HELIUM GAS FOUND WITHIN THE FUEL ROOS RANGED FROM 1.5 PERCENT TO APPROXIMATELY 100 PERCENT OF THAT GENERATEO AND WAS ATTRIBUTED TO TERNARY FISSIONS. 3. AN ATTEMPT TO CORRELATE THE HELIUM AND THE FISSION GAS (KR AND XE) RELEASE DATA FROM 20 OF THESE FUEL RODS USING A MODIFIED DIFFUSION MODEL MET WITH LIMITED SUCCESS. THE RATHER LOW TEMPERATURE EXPERIENCED BY THE UO2 FUEL, THE RELATIVELY LARGE AMOUNTS OF H2 AND HE GAS PRESENT WITHIN THE FUEL RODS, THE UNCERTAINTIES ASSOCIATED WITH THE PREDICTION OF FUEL ROD THERMAL HISTORIES, AND THE BASIC DIFFUSION MODEL ITSELF PRECLUDEO THE ESTABLISHMENT OF A UNIQUE SET OF CORRELATING DIFFUSION PARAMETERS.

AVAILABILITY - CLEARINGHOUSE FOR FEDERAL SCIENTIFIC AND TECHNICAL INFORMATION, SPRINGFIELD, VIRGINIA $22151, \$ 3.00$ COPY, \$0.65 MICROFICHE

\#FISSIDN GAS RELEASE + *FUEL BURNUP + \#FUEL ELEMENT + \#NOBLE GAS + \#OPERATING EXPERIENCE + \#RELEASE RATE + ANALYTICAL MOOEL + DIFFUSION + FUEL INTEGRITY + HELIUM + HYOROGEN + KRYPTON + REACTOR, PWR + XENON + YANKEE (PWR)

7-27284 ALSO IN CATEGORY 13

$\triangle D D I S O N R A+P O T T E R$ JE + SMITH SE + WHITE PAF

INSTALLATION OF HIGH-EFFICIENCY FILTERS

UKAEA, ATOMIC WEAPONS RESEARCH ESTABLISHMENT, ALDERMASTON, ENGLAND

AWRE-0-81/65 . 19 PAGES, 6 FIGURES, OCTOBER, 1965

SUMMARIZES THE PRINCIPLES EVOLVED OVER SEVERAL YEARS AT AWRE FOR THE INSTALLATION OF HIGH EFFICIENCY AIR FILTERS IN RADIOACTIVE AND TOXIC PROCESS BUILDINGS PARTICULARLY WITH RESPELI TO THE SAFETY ASPECTS OF THE INSTALLATION. IT IS BASED ON A MORE DETAILED REPORT, AWRE REPORT NO. 0-24/65, WHICH CONTAINS DETAILS OF EXPERIMENTAL WORK ETC. CARRIED OUT.

AVAILABILITY - CLEARINGHOUSE FOR FEDERAL SCIENTIFIC AND TECHNICAL INFORMATION, SPRINGFIELD, VA. 22151 , $\$ 3.00$ COPY, \$0.65 MICROFICHE

\#FABR ICATION + \#FILTER + *FILTER INSTALLATION + \#FUEL CONVERSION + \#FUEL ELEMENT + \#FUEL REPROCESSING + \#ORE CONVERSION + \#RAOIOISOTOPE + \#REACTOR, GENERAL + TESTINE

$7-27449$

INCE G + WALMSLEY R

MECHANICAL COUPLING DEVICES ANO NUCLEAR REACTOR FUEL ELEMENTS INCORPORATING THE SAME

UNITED KINGDOM ATOMIC ENERGY AIITHRRITY

BRITISH PATENT $1,068,631+5$ PAGES, 8 FIGURES, MAY 10,1967

DESCRIBES A MECHANICAL DEVICE FOR COUPLING GENERALLY CYLINDRICAL TUBULAR MEMBERS TO ROD-LIKE MEMBERS FITTING INSIDE THE TUBULAR MEMBER. THE MEMBERS ARE NOT DISENGAGED BY ACTIONS REVERSE

TO THOSE USED FOR ENGAGEMENT. THE DEVICE IS INTENDED TO BE INCORPORATED IN FUEL ELEMENTS.

AVAILABILITY - THE PATENT OFFICE, 25 SOUTHAMPTON BUILOING, LONDON, W.C. 2, ENGLAND (49 CENTSICOPY) *EQUIPMENT DESIGN + \#FUEL ELEMENT + \#PATENT + FUEL ELEMENT CLUSTER + FUEL HANDLING MACHINE + UNITED KINGDOM

$7-27471$

SCOTT JL

FUEL-ELEMENT PERFORMANCE

9 PAGES, 4 FIGURES, 3 TABLES, 42 REFERENCES, NUCLEAR SAFETY, 814), PAGES $331-339$ (SUMMER 1967 !

FUEL-ELEMENT OEVELOPMENT WORK IS NOW BEING DIRECTED PRIMARILY TOWARD ADVANCED CONVERTERS AND FAST BREEDER REACTORS. HITH THE TECHNICAL FEASIBILITY OF THE COATED-PARTICLE FUELS. FOR HIGH-TEMPERATURE GAS-COQLED REACTORS ASSURED. EMPHASIS IS CURRENTLY PLACED ON INNOVATIONS THAT HILL REDUCE FUEL-CYCLE COSTS. RECENT HIGH-BURNUP DATA ON MIXED-OXIDE FUEL PINS FOR BOTH ADVANCED CONVERTER AND FAST-BREEDER REACTORS HAVE DELINEATED $8 E T T E R$ THE FORMIDABLE SWELLING AND FISSION-GAS-RELEASE PROBLEMS AT THE HIGH BURNUPS REQUIRED FOR ECONOMICAL FUEL CYCLES. WE CAN EXPECY MANY NEW OEVELOPMENTS IN OXIOE AND CARBIDE FUELS AT HIGH BURNUPS IN THE NEAR FUTURE. 
CATEGORY

FISSION PRODUCT RELEASE, TRANSPORT, AND REMOVAL

7-27471 *CONTINUED*

\#ACCIDENT ANALYSIS + \#FISSION GAS RELEASE + \#FUEL BURNUP + FUEL ELEMENT + OXIDE

7-27472 ALSO IN CATEGORY 5

PITTS 5 H

FACTORS INFLUENCING THE IGNITION OF METALLIC PLUTONIUM

DOW CHEMICAL COMPANY

8 PAGES, 14 FIGURES, 1 TABLE, 17 REFERENCES, NUCLEAR SAFETY, 9(2), PAGES 112-120 (MARCH-APRIL 1968)

THE FACTORS THAT INFLUENCE THE IGNITION OF PLUTONIUM WERE INVESTIGATED EXPERIMENTALLY ANO FOUND TO BE RELATED TO SAMPLE SIZE AND GEOMETRY OR TO THE SURFACE COMPOSITION. THE IGNITION TEMPERATURE DECREASED AS THE SAMPLE SURFACE AREA WAS INCREASED, AS THE WEIGHT OF PLUTONIUM FILINGS WAS INCREASED, AND AS SLOWER HEATING RATES WERE USEO. SAMPLES HEATEO AT CONSTANT, ELEVATEO TEMPERATURES IGNITED AT LOWER TEMPERATURES THAN THOSE HEATED AT A CONSTANTLY INCREASING TEMPERATURE. THIN FOIL COUPONS IGNITEO AT LOWER TEMPERATURES WHEN THEY CONTAINED INDUCED INTERNAL STRESSES. LOWER IGNITION TEMPERATURES WERE OBTAINED BY FORMING PUO ON THE SAMPLE SURFACE.

\#ACCIDENT ANALYSIS + \#CHEMICAL REACTION + \#PLUTONIUM + EXPERIMENT, GENERAL + FIRE + IGNITION + IGNITION TEMPERATURE

$7-27816$

FILTER UNIT INSPECTION AND TESTING SERVICE FISCAL YEAR 1969

U.S. ATOMIC ENERGY COMMISSION

HEALTH ANO SAFETY INFORMATION NO. $268+.4$ PAGES, JULY 1,1968

INSPECTION AND TESTING OF HIGH-EFFICIENCY FILTER UNITS WILL CONTINUE IN THE FISCAL YEAR BEGINNING JULY 1, 1968. THE SER VICE WILL BE PROVIDED WITHOUT CHARGE TO AEC OFFICES AND COST-TYPE CONTRACTORS. SERVICE TO LUMP-SUM AND UNIT-PRICE CONTRACTORS, AEC LICENSEES, AND OTHERS WILL BE SUPPLIED ACCORDING TO THE SCHEDULE OF CHARGES APPENDED. A SEPARATE SCHEDULE OF CHARGES APPLICABLE TO SERVICE FOR FEDERAL AGENCIES OTHER THAN AEC IS AVAILABLE UPON AGENCY REQUEST. INSPECTION AND TESTING WILL CONTINUE TO BE RENDERED AT OAK RIDGE, TENN. AND AT RICHLAND, WASH. TO EXPEDITE SERVICE AT THE PROPER FACILITY, ORGANIZATIONS GRE URGED TO FOLLOW THE PROCEDURE APPENDED.

*FILTER INSPECTION + \#FILTER QUALITY ASSURANCE STATION + \#FILTER TEST REQUIREMENT + FILTER EFFICIENCY + FILTER SAFETY EVALUATION + FILTER, ABSOLUTE + FILTER, HIGH EFFICIENCY

$7-27817$

TANG IN + CASTLEMAN AW

RADIATION-INOUCED DECOMPOSITION OF METHYL IODIDE IN AIR

BROOKHAVEN NATIONAL LABORATORY

2 PAGES, 1 FIGURES, 6 REFERENCES, ANS TRANS, $11(1)$, PAGES 76-77, 1968 ANNUAL MEETING DF THE AMERICAN NUCLEAR SOCIETY AND THE CANADIAN NUCLEAR ASSOCIATION, JUNE 10-13, 1968, TORONTO, CANADA

THE PHOTOCHEMICAL OXIOATION OF CH3I IN A PURE OXYGEN ATMOSPHERE HAS BEEN STUDIED EXTEVSIVELY. HOWEVER, NO DATA ON THE STABILITY OF CHBI IN A COMBINED RADIATION AND OXIOIZING ENVIRONMENT ARE AVAILABLE IN THE LITERATURE. THIS PAFER PRESENTS THE RESULTS OF A STUDY DN THE CO-6O GAMMA-RAY-INOUCED DECOMPOSITION OF CH3I IN AIR. THE INFORMATION IS OF BOTH FUNDAMENTAL ANO PRACTICAL INTEREST SINCE CH3I HAS BEEN SHOWN TO FORM WHEN. CARRIER-FREE AMOUNTS OF IODINE ARE RELEASED UNDER CONDITIONS LIKELY TO EXIST IN A REACTOR ACCIDENT THE TOTAL ABSORBED DOSE AT $50 \%$ DECOMPOSITION IS $7.3 \times$ IOILTHI EV/G OF AIR. METHYL NITRATE ANDETHYL NITRATE ARE THE MAJOR RADIOLYSIS PRODUCTS OBSERVED IN THESE EXPERIMENTS.

*CHEMICAL KINETICS + \#GAMMA + \#ORGANIC IODIDE + \#OXIDATION + \#RADIATION DAMAGE + FISSION PRODUCT, IODINE + IUUINE + KAUIATIÜN EFFECT

$7-27818$

CLEANING TECHNIQUES FOR SODIUM SYSTEM CUMPUNENTS

ATOMICS INTERNATIONAL, CANOGA PARK, CALIFORNIA

2 PAGES, 2 REFERENCES, ANS TRANS. $11(1)$, PAGES 114-115, 1968 ANNUAL MEETING OF THE AMERICAN NUCLEAR

SOCIETY AND CANADIAN NUCLEAR ASSOCIATION, TORONTO, CANADA, JUNE 10-13, 1968

SPECIALIZEO TECHNIQUES ARE REQUIRED FOR CLEANING SURFACES THAT HAVE BEEN IN CONTACT WITH LIQUID SODIUM. ALTHOUGH A GREAT MANY PROCESSES HAVE BEEN INVESTIGATEO, ONLY TWO HAVE PROVED GENERALLY USEFUL FOR A WIDE VARIETY OF APPLICATIONS AT ATOMICS INTERNATIONAL. THESE ARE REACTION WITH STEAM (WITH OR WITHOUT AN INERT GAS OILUENT) FOR MAJOR SYSTEMS AND COMPONENTS, AND REACTION WITH LIOUID 2-BUTOXYETHENOL (ETHYLENE GLYCOL MONOBUTYL ETHER, BUTYL CELLOSOLVE, OOWANOL E.B.I FOR SMALLER ITEMS ANO HOT-CELL APPLICATIONS. IN ADOITION, DIPPING COMPONENTS IN HOT OIL HAS PROVED HELPFUL AS AN INITIAL STEP TO REDUCE THE QUANTITY OF SODIUM REZUIRING REACTION. LIQUID AMMONIA WASHING HAS BEEN SHOWN TO BE APPLICABLE FOR SPECIAL CASES WHERE HYDROGEN EVOLUTION MUST BE MINIMIZED.

* COOLANT CHEMISTRY + *DECONTAMINATION + *SODIUM + *STEAM + METAL, alKALI + METAL, LIQUID + REACTOR, LMCR + RENCTOR, LMFBR 
CATEGORY 7

FISSION PRODUCT RELEASE, TRANSPORT, AND REMOVAL

$7-27819$

ALSO IN CATEGORY 4

MCPHEETERS CC + BIERY JC

THE DYNAMIC CHARACTERISTICS OF A SODIUM OXIDE PLUGGING INDICATOR

LOS ALAMOS SCIENTIFIC LABORATORY, NEW MEXICO

2 PAGES, 6 REFERENCES, ANS TRANS. 11111 , PAGES 115-116, 1968 ANNUAL MEETING OF THE AMERICAN NUCLEAR

SOCIETY AND THE CANADIAN NUCLEAR ASSOCIATION, TORONTO, CANADA, JUNE 10-13, 1968

WORK AT LOS ALAMOS SCIENT IFIC LABORATORY HAS INDICATED THAT THE PLUGGING INDICATOR CAN BE A USEFUL ANALYTICAL INSTRUMENT FOR INDICATING OXYGEN CONCENTRATIONS IN SODIUM. AS COMPARED TO THE DISTILLATION SAMPLER OF EMF CELLS, THE PLUGGING INDICATOR DATA HAD A MUCH LOWER

STATISTICAL STANDARD OEVIATION. HOWEVER, THE METER REQUIRED CALIBRATION. THE PLUGGING

TEMPERATURE WAS CORRELATED WITH FLOW RATE, COOLING RATE, AND OXYGEN CONCENTRATION.

* ANALYTICAL TECHNIQUE, CALIBRATION + \#COOLANT CHEMISTRY + *FLOW ORIFICE + \#OXIDE + \#SODIUM +

METAL, ALKALI + METAL, LIQUID + REACTOR, LMCR + REACTOR, LMFBR

$7-27820$

MCPHEETERS CC

ALSO IN CATEGORY 4

MASS TRANSFER OF OXYGEN IN SODLUM COLD TRAPS

LOS ALAMOS SCIENTIFIC LABORATORY

2 PAGES, 5 REFERENCES, ANS TRANS. 11(1), PAGES 116-117, 1968 ANNUAL MEETING OF THE AMERICAN NUCLEAR

SOCIETY AND THE CANADIAN NUCLEAR ASSOCLATION, TORONTO, CANADA, JUNE 10-13, 1968

COLD TRAPS HAVE BEEN USED EXTENSIVELY FOR CONTROLLING OXYGEN CONCENTRATION IN SODIUM SYSTEMS. COLD TRAPS UTILIZE THE POSITIVE TEMPERATURE DEPENDENCE OF THE SOLUBILITY OF SODIUM MONOXIDE IN SOOIUM AND THE RESULTANT PRECIPITATION OF SODIUM MONOXIDE AT LOW SODIUM TEMPERATURES. SODIUM MONOXIDE PRECIPITATION IS HERE ASSUMED TO BE HETEROGENEDUS BECAUSE OF THE STRONG EFFECT OF SURFACE AREA ON THE PRECIPITATION RATE SHOWN IN PREVIOUS PACKLESS COLD TRAP EFFECT OF SURFACE AREA ON THE PRECIPITATION RATE SHOWN IN PREVIOUS PACKLESS COLD TRAP
EXPERIMENTS. A PACKLESS COLO TRAP OF SIMPLE GEOMETRY AND OPERATING WITH A TEMPERATURE GRADIENT WAS USED IN THIS STUDY. IN THE PRESENCE OF THE TEMPERATURE GRADIENT, THE EFFECTIVE PRECIPIRATION SURFACE AREA WAS A FUNCTION OF THE OXYGEN CONCENTRATION IN THE SODIUM ENTERING THE COLD TRAP.

\#ANALYTICAL TECHNIQUE, CALIBRATION + \#COOLANT CHEMISTRY + \#FLOW ORIFICE + \#OXIDE + \#SODIUM + FILTER, TRAP + METAL, ALKALI + METAL, LIQUID + REACTOR, LMCR + REACTOR, LMFBR

$7-27824$

PARSLY LF + FRANZRE8 JK

STUDIES OF THE REMOVAL OF IODINE VAPOR FROM CONTAINMENT BUILDIVG ATMOSPHERES AT THE NUCLEAR SAFETY PILOT PLANT

OAK RIDGE NATIONAL LABORATORY

2 PAGES, 1 TABLE, 5 REFERENCES, ANS TRANS. $11(11$, PAgES 372-73, 1968 ANNUAL MEETING OF THE AMERICAN

NUCLEAR SOCIETY AND CANADIAN NUCLEAR ASSOCIATION, TORONTO, CANADA, JUNE 10-13, 1968

CONTAINMENT SPRAYS HAVE BEEN PROPOSED AS PART OF THE ENGINEERED SAFETY SYSTEMS FOR A NUMBER OF LARGE POWER REACTORS NOW 8EING DESIGNED AND BUILT. IN THE UNLIKELY EVENT OF A LOSS-OF-COOLANT ACCIDENT, SPRAYS CAN PERFORM THE DUAL FUNCTION OF REMOVING HEAT AND REMOVING AIRBORNE FISSION PRODUCTS, PARTICULARLY IODINE. TO SUBSTANTIATE DESIGN CALCULATIONS FOR IODINE REMOVAL BY SPRAYS, THE NUCLEAR SAFETY PILOT PLANT AT OAK RIDGE HAS BEEN USED TO CARRY DUT ENGINEER.ING-SCALE TESTS OF IODINE VAPOR RSMOVAL FROM SIMULATED LOSS-OF-COOLANT-ACCIDENT ATMOSPHERES.

*ANALYTICAL MODEL + *CONTAINMENT SPRAY + \#IODINE + \#NOZZLE + \#NSPP + FILTER SPRAY +

FISSION PRODUCT, IODINE + OUT OF PILE LOOPS AND EXPERIMENTS + SPRAY, GENERAL

$7-27825$

PATTERSON CS + HUMPHRIES WT

DISTRIBUTION OF IODINE BETWEEN AIR AND AQUEOUS SOLUTIONS

FURMAN UNIVERSITY

1 PAGE, 2 TABLES, 3 REFERENCES, ANS TRANS. 11111 , PAGE 374,1968 ANNUAL MEET ING UF THE AMERICAN NUCLEAR

SOCIETY AND CANADIAN NUCLEAR ASSOCIATION, TORONTO, CANADA, JUNE 10-13, 1968

THE PROGRAM IS CONCERNED WITH THE SEARCH FOR SUITABLE SPRAY SOLUTIONS THROUGH THE LABORATORY EVALUATION OF ADOITIVES HAVING A HIGH AFFINITY FOR IODINE A GAS TITRATION METHOD HAS BEEN DEVELOPED TO DETERMINE THE CAPACITIES OF VARIOUS SOLUTIONS TO REMOVE IODINE FROM AIR STREAMS. DEVELOPED TO DETERMINE THE CAPACITIES OF THRIOUS SOLUTIONS TO REMOVE IODINE FROM AIR STRE A METHOD OF TREATMENT OF THE DATA IS GIVEN WHICH ELIMINATES KINETIC EFFECTS AND YIELDS
STRICTLY SATURATION COMPOSITIONS. THE RESULTS FOR WATER AGREE REASONABLY WELL WITH THE STRICTLY SATURATION COMPOSITIONS. THE RESULTS FOR WATER AGREE REASONABLY WELL WITH THE
LOWEST PUBLISHED DATA. ADOITION OF BORIC ACID DECREASES THE SOLUBILITY OF IODINE IN WATER IODINE CAPACITIES FOR THIOSULFATE AND BASE SOLUTIONS ARE LINEAR IN AODITIVE CONCENTRATION AND ARE CONSISTENT HITH A MOOEL WHICH ASSUMES QUANTITATIVE REACTION WITH THE PRIMARY ADDITIVE.

*ANALYTICAL MODEL + \#ANALYTICAL TECHNIQUE, CALIBRATION + \#CONTAINMENT SPRAY + \#IODINE *' \#SPRAY, GENERAL +. CHEMICAL EQUILIBRIUM + FILTER SPRAY + FISSION PRODUCT, IODINE 
CATEGORY 7

FISSION PRODUCT RELEASE, TRANSPORT, AND REMCVAL

$7-27826$

SOLDANOBA+ WARD WT

UPTAKE OF METHYL IODIDE FROM WIND TUNNEL GASES BY A SUSPENDED DROP OF WATER, PART II

OAK RIOGE NATIONAL LABORATORY

2 PAGES, 1 TABLE, 3 REFERENCES, ANS TRANS, 1111), PAGES 374-75, 1968 ANNUAL MEETING DF THE $\triangle M M E R I C A N$

NUCLEAR SOCIETY ANO CANADIAN NUCLEAR. ASSOCIATION, TORONTO, CANAOA, JUNE 10-13, 1958

STUDIES CONDUCTED ON A DROP OF WATER SUSPENDED IN A WIND TUNNEL INDICATE THAT THE PATE OF PICKUP OF METHYL IODIDE CAN BE OESCRIBED RY AN EQUATION PROVIDEO GY THE AUTHOR.

* ANALYTICAL MOUUEL + \#CHEMICAL KINETICS + \#CONTAINMENT SRRAY + *ORGANIC IDDIDE + \#SPRAY, GENERAL + CHEMICAL EQUILIBRIUM + FILTER SPRAY + FISSION PRDDUCT, IODINE

7-27999 ALSO IN CATEGORY 8

HENZEL N + KLEINE-TEBBE A

STUDY ON CHEMICAL REACTIONS BETWEEN URANIUM DIOXIDE, THE MOST ABUNDANT FISSION PRODUCTS, WATER AND SODIUM BATTELLE-INSTITUT FRANKFURT AM MAIN

104 PAGES, 23 FIGURES, 8 TABLES, 70 REFERENCES, APRIL 25,1968

DEALS WITH CHEMICAL REACTIONS BETWEEN URANIUM DIOXIOE, THE MOST IMPORTANT FISSION PFODUCTS WITH REGARD TO QUANTITY AND RADIOACTIVITY, AND THE CODLANTS WATER (VADOR) AND SCDIUM. BY MEANS OF A NEW SIMPLE METHOD, THE EOUII IRR IUM OF SUCH SYSTEMS CAN BE CALCULATED DND GRAPHICALLY EXTRAPOLATED TO HIGH TEMPERATURES EVEN BEYOND. THE REGION OF KNOWN THERMODYNAMIC DATA. FROM THE REACTION POTENTIALS OBTAINED IN THIS HAY AND THE INITIAL MOLE COVCENTRATIONS OF THE REACTANTS ESTIMATEO AS REALISTICALLY AS POSSIBLE, THE AMOUNTS OF. THERMODYNAMICALLY STABLE REACTION PRQDUCTS ARE DETERMINED, AT LEAST IN THEIR DRDER OF MAGNITUDE, AS A FUNCTION OF TEMPERATURE.

AVAILABILITY - N. MENZEL, FRANKFURT AM MAIN

\#CHEMICAL REACTION + \#FISSION PRODUCT RETENTION + * SODIUM + \#THERMODYNAMICS + \#URANIUM DIOXIDE + *WATER VAPOR + \#WATER, GENERAL + CHEMICAL EQUILIBRIUM + METAL, ALKALI + REACTOR COOLANT +

THEORETICAL INVEST IGATION

7-28049 ALSO IN CATEGORIES 17 AND 13

FILTER FAILURE AT WEST VALLEY PLANT

NUCLEAR FUEL SERVICES, INC., WEST VALLEY, N, Y.

2 PAGES, ATOMIC ENERGY CLEARING hOUSE 14138), PAGE 29 ANO 30, (SEPT. 16, 19681, DOCKET NO. 50-20?

(IWX TO COMPLIANCE) CN SEPT. 4, 1968, ONE FILTER OF 30 IN THE MAIN VENTILATION FILTER BANK FAILED. 1-2\% OF THE FILTER WAS DISCHARGED FROM THE STACK AND FELL ON TO ROOF. PROSASLE CAUSE WAS FILTER PRESSURE DROP, AT UPPER OPERATING LIMIT. HIGH PRESSURE DROP DLARM IS BEING REDUCEO 18\%, ANO LOW PRESSURE OROP ALARM IS ADJUSTED TO INCREASE SENSITIVITY TD SINGLE FILTFP FAILURE. NOT A REPORTABLE INCIDENT BECAUSE ANALYSIS OF ADJACENT FILTER AND STACK SAMPLER INDICATE $11 \%$ OF MONTHLY ALLOWANCE DISCHARGED. SURVEY JF SITE PERIMETER DIO NOT SHOW RADIATION INGP.EASE ARTVF RAC.KGRMIIND.

\#FILTER, DAMAGED + \#PRESSURE DROP + AIRBORNE RELEASE + FUEL REPROCESSING + INCIOENT, EOUIPMENT + NFS + STACK + VFNTILATION SYSTEM

7-28050 ALSO IN CATEGORIES 17 AND 13

NFS SHUTDOHN TO EVALUATE FILTER FAILURE

NUCLEAR FUEL SERVICES, INC., WEST VALLEY, N. Y.

1 PAGE, ATOMIC ENERGY CLEARING HOUSE 14(38), PAGE 30, (SEPT. 16, 1968), DOCKET NO. 50-201

(LETTER. TO NFS, SEPT. 6, 1968) CONFIRMS SEPT. 6 PHONE CALL THÁT HEST VALLEY PLANI IJPEKAIIUNN WILL NOT BE. RESUMED UNTIL THE FOLLOWING IS REVIEWED BY AEC - (1) AMOUNT OF RAUIOACTIVITY RELEASED FROM STACK SEPT. 4,.1968, (2) NFS EVALUATION, INCLUDING PROBABLE CAUSE AND CORRECTIVE ACTION, 13 ) INFORMATION REQUESTED IN ADRIL 2, 1268, LETTER, INCLUDING IMMEDIATF WARNING OF ABNORMAL CONDITIONS IN VENTILATION AND OFFGAS SYSTEMS. ITEMS 1 AND 2 ARE NECESSARY TO.CONFIRM TECH.-SPEC. REQUIREMENTS MET (PARAGRADHS 4.1.1, 7.1.2.2 ANO 7.1.7.31.

* AIRB ORNE RELEASE + *FILTER, DAMAGED + FUEL REPROCESSING + INCIOENT, EOUIPMENT + INSDECTION ANO COMPLIANCE + NFS + OFF GAS + STACK + VENTILATION SYSTEM 
CATEGORY 8

SOURCES OF ENERGY RELEASE UNDER ACCIDENT CONDITIONS

$8-25160$

ÁLSO IN CATEGORY 5

MORRISON DL + WILSON TR

CURRENT RESEARCH ON COOLANT BLOWDOWN IN THE USA

BATELLE MEMORIAL INSTITUTE + PHILLIPS PETROLEUM COMPANY, IOAHO FALLS, IDAHO

34 PAGES, 17 FIGURES, 18 REFERENCES, FROM THE RECORD OF THE THIR.O CREST MEETING, PARIS, NOVEMBER, 1967

THE COURSE ANO CONSEQUENCES OF A LOSS-OF-COOLANT ACCIDENT ARE DIRECTLY RELATED TO THE BLOWOOWN AFTER RUPTURE, AND CURRENT RESEARCH IS CARRIED OUT TO CHARACTERIZE THIS DCCURRENCE. AREAS OF INTEREST ARE - DECOMPRESSION, TWO-PHASE FLOW, MECHANICAL EFFECTS, ETC. THE EFFORT IS SEING PURSUED AT LOFT, CSE, AND IIT. THE DEVELOPMENT OF ANALYTICAL MODELS AND COMPUTER CODES IS ALSO DISCUSSED, AND COMPARISON BETWEEN CALCULATIONS AND EXPERIMENTS IS MADE.

AVAILABILITY - D.L. MORRISON, BATTELLE MEMORIAL INSTITUTE, COLUMBUS LABORATORIES

\#ACCIDENT, LOSS OF COOLANT + \#BLOWDOWN + *CREST + \#CSE + \#LOFT (S-RR) + ANALYTICAL MODEL + COMPUTER PROGRAM + REACTOR, SAFETY RESEARCH

8-27092 ALSO IN CATEGORY 7

SYMPOSIUM ON METAL-GAS REACTIONS IN ATMOSPHERES CONTAINING CO2

6 PAGES, BRITISH CORROSION JOURNAL, $2(6)$, PAGES 229-234 (1967)

THE PROGRAMME FOR THIS SYMPOSIUM WAS PREFACED BY THE FOLLOWING DUTLINE OF THE OBJECTIVES OF THE MEETING - IN THE LAST FEW YEARS MUCH WORK HAS BEEN CARRIED OUT ON THE OXIDATION OF BOILER AND FUEL CLADDING MATERIALS IN CARBON DIOXIDE ENVIRONMENTS IN THE TEMPERATURE RANGE $350-85 O C$ IN CONNECTION WITH THE BRITISH GAS-COOLED NUCLEAR REACTOR PROGRAMME. THIS COVERS RIMMING, SEMI-KILLED AND LOW ALLOY STEELS AND ALSO 9 PER CENT AND 12 PER CENT CHROMIUM ANO $\triangle U S T E N I T I C$ STEELS. WORK HAS ALSO BEEN DONE IN THE U.K. AND IN EUROPE IN HELIUM ENVIRONMENTS CONTAINING SMALL AMOUNTS OF CO/CO2, RELATING TO MORE ADVANCEO NUCLEAR REACTOR CONCEPTS. THE DISCUSSION AT THIS SYMPOSIUM WILL COVER REPORTS OF THIS WORK, AND IN ADDITION CORROSION PROBLEMS ENCOUNTERED IN REFORMERS USED IN THE GAS INDUSTRY AND ALLIED PLANT, ARISING FROM COMBINEO CARBURISING/OXIDISING REACTIONS ON AUSTENITIC STEELS AND HIGH NICKEL ALLOYS.

*ALLOY + \#CARBON + \#CARBON DIOXIDE + \#CARBON MONOXIOE + \#OXIDATION + \#STEEL + CARBIDE + CHEMICAL KINETICS + CHROMIUM + CLADDING + CORROSION + DRAGON (HTGR) + REACTOR, GCR + REACTOR, HTGR + STEEL, STAINLESS

B-27651 ALSD IN CATEGORY 5

WHITE JF

PHYSICO-CHEMICAL STUDIES OF CLAD UO2 IN POTENTIAL MELTOOWN ENVIRONMENT (TASK NO. 1175 )

GENERAL ELECTRIC COMPANY, CINCINNATI, OHIO

GEMP-1104 +. 35 PAGES, FIGURES, TABLES, EXTRACTED FROM SEVENTH ANNUAL REPORT - AEC FUELS AND MATERIALS

DEVELOPMENT PROGRAM, MARCH 29, 1968

SUMMARY OF EXPERIMENTAL WORK BY GE-NMPO DURING CY-67 TOWAROS DETERMINING THE FUEL PIN BEHAVIOR DURING A LOSS-OF-COOLANT ACCIDENT. WORK INCLUDED 111 DYNAMIC DEFORMATION AND FAILURE STUDIFS OF ZIRCALOY-4 TUBES WITH HIGH INTERNAL PRESSURES AT HIGH TEMPERATURES IN ARGON OF STEAM ENVIRONMENTS, (2) CHEMICAL KINETIC STUDIES DF THE OXIDATION OF TYPE 304 STAINLESS STEEL BY STEAM OR AIR, (4) CHEMICAL KINETIC STUDIES OF THE OXIDATION OF UO2 BY STEAM, (5) MEASUREMENTS OF THE TENSILE STRENGTH AND THE THERMAL CONDUSTIVITY TF TYPF TMAI STAIAI, SSE STEEL, APID IGI MLASUREMENIS OF THE TOTAL EMITTANCE OF UNOXIDIZED AND OXIDIZED AIRCALOY-4.

\#AIR + \#BURST PRESSURE + \#CHEMICAL KINETICS + *CHEMICAL REACTION + \#DEFORMATION + \#FUEL ELEMENT + *ME TAL WATER REACTION + \#STEAM + \#STEEL, STAINLESS + \#THERMAL PROPERTY + \#URANIUM DIOXIDE + \#ZIRCALOY * ACCIDENT, LOSS OF COOLANT + CREEP BEHAVIOR + OXIOATION + STRUCTURAL ANALYSIS, OYNAMIS + THERMAL EXPERIMENT

$8-27998$

HENZEL N + KLEINE-TEBBE A

EXPER IMENTAL INVESTIGATION OF REACTIONS BETWEEN URANIUM DIOXIDE ANO WATFR IN NONISOTHERMAL QUASI-ISOBARIC CONOITIUNS

BATTELLE-INSTITUT FRANKFURT AM MAIN

46 PAGES, 21 FIGURES, 2 TABLES, 14 REFERENCES, APRIL 29, 1968

THE CHEMICAL AND PHYSICAL BEHAVIOR OF HOT SOLID UO2 IN LIQUIO WATER WAS EXAMINED UNOER

NONISOTHERMAL, QUASI-ISOBARIC CONDITIONS. VARIOUS SIZE PELLETS. WERE HEATED BY INDUCTION AND

THEN DUMPED INTO THE WATER. THE AMOUNT OF STEAM GENERATED DEPENOED STRONGLY ON THE SPECIFIC

SURFACE OF THE SAMPLE AND THE WATER TEMPERATURE. IT APPFARED THAT LOH-TEMPERATURE WATER IS A PREREQUISITE FOR STEAM EXPLOSIONS. OXIDATION OF THE SAMPLES INCREASED WITH DECREASING SAMPLE SURFACE. FOR 8O0-MICRON PARTICLES, THE OXYGEN-TO-URANIUM RATIO INCREASED BY ABOUT O.OI25.

AVAILABILITY - N. HENZEL, BATTELLE-INSTITUT FRANKFURT AM MAIN

\#CHEMICAL REACTION + \#HEAT TRANSFER, BOILING + \#PRESSURF PIIISE + \#URANIUM DIOXIDE + \#WATER, GENERAL + HEAT TRANSFER, CONVECTION + TEST, BENCH 
8-27999 *CONT INUED*

HENZEL N + KLEINE-TEBBE A

STUDY ON CHEMICAL REACTIONS BETWEEN URANIUM OIOXIDE, THE MOST ABUNDANT FISSION PRODUCTS, HATER ANO SODIUM BATTELLE-INSTITUT FRANKFURT AM MAIN

104 PAGES, 23 FIGURES, 8 TABLES, 70 REFERENCES, APRIL 25, 1968

DEALS WITH CHEMICAL REACTIONS BETWEEN URANIUM DIOXIDE, THE MOST IḾPORTANT FISSION PRODUCTS WITH REGARD TO QUANTITY ANO RADIOACTIVITY, ANO THE COOLANTS WATER (VAPOR) ANO SODIUM. BY MEANS OF A NEW SIMPLE METHOD, THE EQUILIBRIUM OF SUCH SYSTEMS CAN BE CALCULATED AND

GRAPHICALLY EXTRAPOLATED TO HIGH TEMPERATURES EVEN BEYOND THE REGICN OF KNOWN THERMOJYNAMIC DATA. FROM THE REACTION POTENTIALS OBTAINED IN THIS WAY DNO THE INITIAL MOLE CONCENTRATIONS DF THE REACTANTS ESTIMATED AS REALISTICALLY AS POSSIBLE, THE AMOUNTS OF THERMODYNAMICALLY STABLE REACTION PRODUCTS ARE DETERMINED, AT LEAST IN THEIR ORDER OF MAGNITUDE, AS A FUNCTION OF TEMPERATURE.

AVAILABILITY - N. HENZEL, FRANKFURT AM MAIN

\#CHEMICAL REACTION + \#FISSION PRODUCT RETENTION + \#SOOIUM + \#THERMODYNAMICS + \#URANIUM DIOXIDE + *WATER VAPOR + \#WATER, GENERAL + CHEMICAL EQUILIBRIUM + METAL, ALKALI + REACTOR COOLANT +

THEORET ICAL INVESTIGATION 
$9-25699$

KURT-UMEROV VO

A MATHEMATICAL MODEL FOR PREOICTING GRADUAL FAILURES IN SYSTEM ELEMENTS

1 PAGE, ENGLISH ABSTRACT IN AUTOMATION EXPRESS 8(2), PAGE 47 (1966) TRANSLATEO FROM AVTOMATIKA I

TELEMEKHANIKA NO. 2, PAGES 142-46 (FEBRUARY 1966)

A MATHENATICAL MODEL IS PROPOṠED FOR THE VARIATION IN SYSTEM-ELEMENT PARAMETERS. THE AUTHOR DETERMINES THE PARAMETERS OF THE STATISTICAL MODEL CONSTRUCTED ON THE BASIS OF THE HISTORICAL VARIATION IN THE PARAMETERS OF EACH OF THE MONITORED ELEMENTS UNDER OPERATING CONOITIONS. A METHOD IS GIVEN FOR DETERMINING THE FUNCTIONAL RELIABILITY OF ACTUAL ELEMENTS OVER A GIVEN TIME .

\#RELIABILITY, COMPONENT + ANALYTICAL MODEL + INSTRUMENTATION, COMPONENT + MATHEMATICAL TREATMENT + USSR

$9-26139$

KOZLOV BA

RELIABILITY OF ISOLATED SUBSYSTEMS IN A REDUNDANT SYSTEM WITH RESTORATION

5 PAGES, IZVESTIA AKAD. NAUK, TEKHNICHESKAIA KIBERNETIKA NO. 7, PAGES 23-27 (NOVEMBER-DECEMBER 1965), ABSTRACT IN AUTOMATION EXPRESS ISSUE 4, VOL. 8(1), PAGE $26(1066)$

A RESTORABLE SYSTEM OF N+M ELEMENTS IS CONSIDERED (M OF THE ELEMENTS ARE USED AS A SLIDING RESERVE). THE MEAN OPERATING TIME TILL FAILURE IS ESTIMATED FDR A SINGLE ISOLATED OPERATING ELEMENT.

* RELIABILITY ANALYSIS + MATHEMATICAL TREATMENT + REDUNDANCE + USSR

LIQUID SHUTDOWN SYSTEM FOR WINFRITH SGHWR

3 PAGES, FIGURES, NUCLEAR ENGINEERING, $13(144)$, PAGES 418-420 (MAY 1968)

SYSTEM CONSISTS OF BUILT-IN SHUTDOWN TUBES IN THE CALANDRIA WHICH PERMIT RECOVERY OF THE POISON. LOOP CONSISTS OF A U-TUBE, SHUTDOWN VALVE, HIGH PRESSURE HEAD TANK AND A BUFFER TANK. FLUID INLET VELOCITY IS $80 \mathrm{FT/SEC,} \mathrm{WHICH} \mathrm{IS} \mathrm{ARRESTEO} 8 Y$ COMPRESSING HEL IUM IN THE TUBE WHILE DISCHARGING A FRACTION TO A SUFFER TANK THE ABSORBER FLUID CAN BE DRAINED FROM THE TUBES FOR REUSE. VALVE DES IGN IS SUCH THAT OPENING TIME IS 0.1 SEC AND CONSISTS OF A 2-WAY TUBES FOR REUSE, VALVE DES IGN IS SUCH THAT OPENING TIME IS O.I SEC AND CONSISTS OF A 2-WAY
BODY AND SPOOL WITH A $1.5-I N$. STROKE BETWEEN SEALS. SIX COIL SPRINGS PUSH SPOOL TOWARD ITS SEAT WHEN A SPLIT ELECTROMAGNET IS ACTIVATEO.

* SHUTDOHN SYSTEM, SECONDARY + \#SYSTEM DESCRIPTION + *VALVE + CESIGN CRITERIA + REACTOR CONTROL + REACTOR, HWR + REACTOR, PRESSURE TUBE + UNITED KINGDOM

9-26412 ALSO IN CATEGORY 17

PASHOS TJ

CONTROL MATERIALS SYMPOSIUM

4 PAGES, 2 TABLES, 8 REFERENCES, NUCLEAR APPLICATIONS, 416), PAGES 394-4.3? 1.1IINF. 19681

SUMMARI7FS FIVE PAPERS PRESENTED AT THE JUNE 1900 ANS MEETING. IUPICS ARE - (1) MATERIALS FOR CONTROL OF WATER-COOLED POWER REACTORS, (?) USE OF LANTHANID OXIDE ABSORBERS IN 4 WR, (3) CONTROL BLADES PER HFBR, (4) PERFORMANCE OF BORON-CONTAINING RODS IN WATER-COOLED POWER REACTORS, AND (5) PERFORMANCE OF AG-IN-CD IN PWR.

* MATERIAL + *REACTOR CONTROL + BORON + CADMIUM + CONTROL RDD + DYSPROSIUM + EUROPIUM + INDIUM + LANTHANUM + OPERATING EXPERIENCE + REACTOR, BWR + REACTOR, PWR + SILVER

$4-26437$

BATES AEG + EPLER EP + DAKES LC

FEATURES OF, AND OPERATING EXPERIENCE WITH, THE HFIR PROTECTION SYSTEM

OAK RIDGE NATIONAL LABORATORY, DAK RIDGE, TENNESSEE

8 PAGES, 5 FIGURES, I TABLE, 7 REFERENCES, NUCLEAR APPLICATIONS, 4(5), PAGES $289-296$ (MAY, 1968)

THE ORNL SECOND GENERATION OF REACTOR-PROTECTION SYSTEMS HAS BEEN APPLIED SUCCESSFULLY TO THE HFIR. TESTING FOR UNSAFE COMPJNENT FAILURES, ROUTINE MAINTENANCE, ANO MOST REPMIR HJRK ARE DONE ROUTINELY WHILE IHE REACTOR IS AT POWER TWO-OF-THREF COINCIDENCE LOGIC IS USED FOR ON-LINE MAINTENANCE AND TEST ING AND NOT FOR THE USUAL OBJECTIVE OF AVOIDING FALSE SCRAMS. THE PROTECTION SYSTEM, ON-LINE TESTING METHODS, AND THE CIRST 13 MONTHS OF REACTOR OPERATION ARE REVIEWED.

\#OPERATING EXPERIENCE + \#REACTOR SAFETY SYSTEM + HFIR (FTR) + INSTRUMENIATION, COINCIDENT + INSTRUMENTATION, PROTECIIVE + INSTRUMENTATION, TESTING + ORNL + REACTOR, AEC OWNED + REACTJR, FLUX TRAP + REACTOR, RESEARCH + TEST, ON LINE + TEST, SYSTEM OPERABILITY 
CATEGORY

NUCLEAR INSTRUMENTATION, CONTROL, AND SAFETY SYSTEMS

$9-26470$

LONG E

NUCLEAR REACTOR REACTIVITY CONTROL ARRANGEMENTS

ENGLISH ELECTRIC CO.

BRITISH PATENT $1,089,343+.3$ PAGES, 3 FIGURES, NOVEMBER 1,1967

THE DESIGN OF A CONTROL ROD PLACEMENT AND DRIVE MECHANISM FOR REACTOR CORES WITH A PLURALITY OF FUEL CHANNELS IS PRESENTED. THE MECHANISM HANOLES THE CONTROL RODS BY MEANS OF WINDING MECHANISMS WITH FIXED POSITION IN THE REACTOR CORE, A COMMON ORIVE UNIT LOCATED OUTSIDE THE PRESSURE VESSEL, AND A MOVEABLE WINOING MECHANISM WHICH CONNECTS THE FIXED ROD CHANNELS WITH THE DRIVE UNIT.

AVAILABILITY - THE PATENT OFFICE, 25 SOUTHAMPTON BUILDING, LONDON, W.C. 2 , ENGLAND (49 CENTS/COPY) * CONTROL ROD DRIVE + PATENT + UNITED KINGDOM

$9-26471$

CHALLENDER RS

NUCLEAR REACTOR CONTROL MEGHANISMS

UNITEO KINGDOM ATOMIC ENERGY AUTHORITY

BRITISH PATENT $1,087,493+5$ PAGES, 5 FIGURES, OCTOBER 18,1967

A CONTROL ROU ORIVE MECHANISM WHICH UTILIZES BOTH NORMAL OPERATIONAL CONTROL MOVEMENT AND EMERGENCY SHUTDOWN MOVEMENT FOR THE SAME CONTROL ROD IS OESCRIBED.

AVAILABILITY - THE PATENT OFFICE, 25 SOUTHAMPTON BUILDING, LONOON, W.C. 2 , ENGLAND (49 CENTS/COPY)

*CONTROL ROD DRIVE + CONTROL ROD SCRAM MECHANISM + DAMPING + PATENT + UNITED KINGOOM

$9-26472$

BOOTHROYD. AD + CUNDILL BR

BURST-CARTRIDGE DETECTION UNITS

ENGLISH ELECTRIC CO.

BRITISH PATENT 1,093,142 +. 7-PAGES, 3 FIGURES, NOVEMBER 29, 1967.

THE DESCRIPTION OF A BURST-CARTRIDGE-DETECTION UNIT FOR DETECTING FISSION PRODUCTS RELEASED FROM BURST OR DAMAGED FUEL ELEMENT CARTRIDGES IN GAS-COOLED REACTORS IS PRESENTED. THE DETECTION UNIT COMPRISES A SAMPL ING PIPE FROM EACH FUEL ELEMENT LEADING TO AN ELECTROSTATIC PRECIPITATOR CHAMBER. AFTER THE SAMPLED GAS REACHES THE PRECIPITATDR CHAMBER, A FLEXIBLE ELECTRODE COLLECTS THE FISSION PRODUCTS ANO PASSES THEM TO A RADIATION DETECTOR.

AVAILABILITY - THE PATENT OFFICE, 25 SOUTHAMPTON BUILDING, LONDON, H.C. 2, ENGLAND (49 CENTS/COPY)

* instrumentation, detection falled fuel Element + patent + reactor, gCr + United kingdom

$9-26473$

IMPROVEMENTS RELATING TO CONTROL DEVICES FOR PARALLEL TUBULAR NUCLEAR REACTOR ELEMENTS

COMMISSARIAT A L ENERGIE ATOMIQUE, FKANC,

FRENCH PATENT $1,448,295+4$ PAGES 2 FIGURES, JUNE 27,1966, IN FRENCH

THE REACTOR PRESSURE TUBES ARE ARRANGEO IN A CLUSTER IN A REgULAR LATTICE. THE DEVICE CONSISTS OF RETRACTABLE PROBES COMING INTO CONTACT WITH THE TUBES. THE PROBES ARE CONVEYED BY A MOVABLE CARRIAGE FITTED WITH ROLLERS BEARING DN TWO ADJACENT TUBULAR ELEMENTS. THE CARR I AGE INCLUDES A SELF-CONTAINED CONTROL MECHANISM WHICH CONTROLS THE PHYSICAL

CHARACTERISTICS OF THE TUBULAR ELEMENTS AND NOTABLY THEIR THERMAL INSULATION. THE OBJECT IS TÓ REQUCE THE OVERALL DIMEPISIONS OF SUCH CONTROL OEVIC.FS, TN IMPRDVE THEIR MOVEMENT BETWEEN THE PARALLEL TUBES. THE CONTROL DEVICE CAN BE INSERTFD OR WITHDRAWN FROM THE REACTOR OURING DPERATION OR SHUTDOWN.

AVAILABILITY - IT IS OUT UNDERSTANDING THAT FOREIGN PATENTS MAY BE OBTAINED IN PHOTOCOPY FROM THE U. 5 . PATENT DFF ICE, DEPARTMENT OF, COMMERCE, WASHINGTON, D.C. (30 CENTS/PAGE)

* IN CORE MEASUREMENT + *SERVOMECHANISM + FRANCE + INSTRUMENTATION, GENERAL + INSTRUMENTATION, IN CORE + PATENT

$9-26474$

SAFETY DEVICE FOR A NUCLEAR REACTOR

COMMISSARIAT A L FNERGIE ATOMIQUE, FRANCE

FRENCH PATENT 1,451,407 +. 6 PAGES, 2 FICURES, JULY 25, 1966, IN FRENCH

THE REACTOR IS CQOLED BY A LIQUID HHICH ALSO SERVES AS MOOERATOR AND COMPRISES A VERTICAL, DETACHABLE CHANNEL TUBE OF WHICH AT LEAST THE LOWER PART CONTAINS LIOUID WHEN IN PLACE IN THE REACTOR. A MOVABLE ABSORBER RUO IS OISPOSED IN THE CHANNEL TUBE WHILE A CONTR.OL MECHANISM TAKES PIACE IN THE UPPER PART OF THE CHANNEL TUBE AND SUPPORTS THE RDD VIA A DETACHABLE 
$9-26474$ *CONTINUED*

COUPLING. A DAMPING DEVICE IS INTEGRAL WITH THE LOWER PART OF THE CHANNEL IN ORDER TO ABSORB THE KINETIC ENERGY OF THE ROD WHEN IT FALLS IN THE CHANNEL. THE DAMPING DEVICE COMPRISES A HYORAULIC BRAKING COMPONENT AS WELL AS AN ELASTIC MECHANICAL STOPPING DEVICE.

AVAILABILITY - IT IS OUR UNDERSTANOING THAT FOREIGN PATENTS MAY BE OBTAINED IN PHOTOCOPY FROM THE U.S. PATENT OFFICE, OEPARTMENT OF COMMERCE. HASHINGTON, D.C. (30 CENTSIPAGE)

* CONTROL ROD SCRAM MECHANISM + CONTROL ROD + DAMPING + FRANCE + HYDRAULIC EFFECT + PATENT

$9-26475$

HANOL ING DEVICE FOR A NUCLEAR REACTOR

COMMISSARIAT A L ENERGIE ATOMIQUE, FRANCE

FRENCH PATENT 1,455,218 +. 4 PAGES, 3 FIGURES, SEPTEMBER 5, 19.66, IN FRENCH

A NUCLEAR REACTOR LOADING DEVICE IS PROVIDED WITH A ROTATABLE CYLINDER CONTAINING DUCTS IN A

LEAK-PROOF HOOD. THE HOOD HAS A VERTICAL CHANNEL AND CAN BE TIGHTLY COUPLED WITH THE

BIOLOGICAL SHIELD OF THE REACTOR. MEANS ARE PROVIDED TO BRING EACH OF THE DUCTS OF THE CYLINDER INTO ALIGNMENT WITH THE CHANNEL WHEREIN A GRIPPING UNIT IS DISPOSED IN ORDER TO EXCHANGE THE FUEL ELEMENTS.

AVAILABILITY - IT IS OUR UNDERSTANDING. THAT FOREIGN PATENTS MAY BE OBTAINED IN PHOTOCOPY FROM THE U.S. PATENT OFFICE, DEPARTMENT OF COMMERCE, WASHINGTON, D.C. (30 CENTS/PAGE)

\#FUEL HANDLING MACHINE + FRANCE + PATENT

$9-26476$

ARTAMKIN VN + VORONKOV AV

COMPENSATION OF THE REACTIVITY OF NUCLEAR RFACTORS BY LAMINATED BURNABLE POISONS

4 PAGES, 4 FIGURES, 4 REFERENCES, ATOMNAYA ENERGIYA, 22(3), PAGES 215-218 (MARCH 1967)

THE POSSIBILITY OF USING LAMINATED BURNABLE POISONS TO COMPENSATE THE REACTIVITY OF NUCLEAR REACTORS IS DISCUSSED. A METHOD IS PROPOSED FOR COMPUTING THE NEUTRON DISTRIBUTION JUTSIDE THE POISON IN THE P-SUB-I APPROXIMATION. THE SPACE AND TIME DISTRIBUTION OF ABSORBING MATERIAL IN A SLAB OF BURNABLE POISON CONSISTING OF SEVERAL LAYERS OF HETEROGENEOUS MATERIALS IS CALCULATED ON THE ASSUMPTION THAT SCATTERING MAY BE NEGLECTEO.

* POISON, BURNABLE + MATHEMATICAL TREATMENT + POISON, FIXED + THEORETICAL INVESTIGATION + USSR

ELECTRICAL PENETRATIONS OF REACTOR CONTAINMENT BUILDINGS

14 PAGES, 31 FIGURES, 1 TABLE, 24 REFERENCES, POWER REACTOR TECHNOLOGY ANO REACTOR FUEL PROCESSING 1012 I, PAGES 122-135 (SPR ING 1967 )

THIS ARTICLE GATHER.S THE ESSENTIAL FEATIIRES AND WORKINGS OF ELECTRICAL PENETRATIONS DF II REPRE SENTATI VE NUCLEAR POWER PLANTS AND CINSIDERS SOURCES OF LEAKAGE, REMEDIES, AND DASIC SEALING PRINCIPLES. PRESENT PENETRATION DESIGNS ARE DESCRIBED, AS ARE SOME IFAK-RATE-TEST PRACTICES. A LIST OF RECOMMENDATIONS FOR ELECTRICAL-PENETRATION-SYSTEM DESIGN IS INCLUDED.

* CONTAINMENT PENETRATION, ELECTRICAL + DESIGN CRITERIA + ELECTRICAL CONOUCTION + EQUIPMENT DESIGN + INSTRUMENTATION, COMPONENT + OPERATING EXPERIENCE + SEAL + TEST, LEAK RATE

9-26559

CHAUVET G + TOUMIER E + VILLAIN P

REACTIMETER - ITS UTILIZATION

CENTRE D ETUDES NUCLEAIRES DE GRENOBLE, FRANCE + CENTRE D ETUDES NUCLEAIRES DE CADARACHE, FRANCE

11 PAGES, 5 FIGURES, FROM THE INTERNATIONAL CONFERENCE ON THE SAFETY OF FAST NUCLEAR REACTORS, SEPTEMBER, 1967

THE REACTIMETER WHICH MEASURES REACTIVITY CONTINUOUSLY ANO INSTANTANEOUSLY IS A VERY CONVENIENT TOOL TO ANALYZE RAPIOLY AND ACCURATELY THE DIFFERENT PARAMETERS GOVERNING THE REACTIVITY OF A REACTOR EVEN IF SEVERAL OF THESE PARAMETERS DEVELOP NEARLY SIMULTANEDUSLY IFUEL, CONTROL ROOS, POISON DILUTION, TEMPERATURE, XENON, ETC.I.

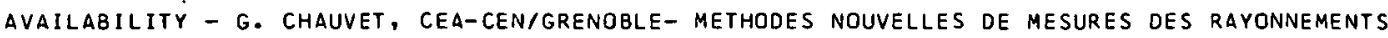

* INSTRUMENTATION, NUCLEAR + *REACTIVITY EFFECT + COMPARISON, THEORY ANO EXPERIENCE + EQUIPMENT OESIGN + FRANCE + INSTRUMENTATION, PERIDD + DPERATING EXPERIENCE + SOLID STATE DEVICE

$9-26560$

ERNSTH + KILIAN P + KISON H

CONTROL ROD CONSIDERATIONS FOR STEAM COOLED FAST BREEDER REACTORS

16 PAGES, 5 FIGURES, 2 TABLES, FROM THE CONFERENCE ON THE SAFETY OF FAST NUCLEAR REACTORS, IV-B/6,

SEPTEMBER, 1967 
CATEGORY 9

NUCLEAR INSTRUMENTATION, CONTROL, AND SAFETY SYSTEMS

9-26560 \#CONTINUED*

A PARAMETRIC STUDY OF REACTOR SHUTDOWN AT LOSS OF STEAM SHOWS THAT THE REACTOR CAN BE SHUT DOWN SAFELY WITH 50-MSEC DELAY TIME, 2-G ACCELERATION, ASSUMING 10/SEC AS THE REACTIVITY RAMP. VARIOUS POSSIBILITIES OF MECHANICAL ARRANGEMENT DF THE CONTROL ROD ORIVES, REACTOR CDRE AND STEAM OUTLET PLENUM ARE DISCUSSED. A NEW CONTROL ROD DRIVE IS PROPOSEO HHICH IS A REVERSED VERSION OF AN EXISTING DRIVE FOR BOILING WATER REACTORS. MECHANIC-HYORAULICAL AND MECHANICAL SYSTEMS ARE DISCUSSED.

\#CONTROL ROD + \#DESIGN CRITERIA + REACTOR, BREEOER + REACTOR, FAST + REACTOR, GCR + STEAM

9-26561 ALSO IN CATEGORY 6

ROUX DP + FRY DN + ROBINSON JC

APPLICATION OF GAMMA-RAY OETECTION FOR REACTOR DIAGNOSIS

OAK RIDGE NATIONAL LABORATORY, OAK RIDGE, TENNESSEE

ORNL-TM-21.44 +. 17 PAGES, 3 FIGURES, 3 TABLES, MARCH 20, 1968

POWER SPECTRAL DENSITY (PSO) MEASUREMENTS OF THE FLUCTUATING CURRENT FROM A GAMMA-SENSITIVE AND A NEUTRON-SENSITIVE IONIZATION CHAMBER ARE COMPARED AS A REACTOR DIAGNDSTIC TOOL IN THE HFIR OPERATING AT POWER. AN ANALYTICAL MODEL IS PRESENTED TO DEMONSTRATE THAT WHEN BOTH OBSERVED GAMMA AND NEUTR ON PSO ARE NORMALIZED BY THE SQUARE OF THE PROMPT MEAN-CURREVT OF THE CHAMBERS, THEY YIELD THE SAME ABSOLUTE PSD. THE ANALYTICAL RESULT IS. VERIFIED EXPERIMENTALLY WITH A MILLTISECTION IONIZATION CHAMBER COMPOSED OF ELECTRICALLY INDEPENDENT CLOSELY LOCATED NEUTRON-SENSITIVE AND GAMMA-SENSITIVE CHAMBERS. IN THE CASE OF THE GAMMA CHAMBER, AN ESTIMATE OF THE CURRENT COMPONENT CAUSED BY THE DELAYED PHOTONS EMITTEO BY THE RADIOACTIVE FISSION PRODUCTS IS NECESSARY TO MEASURE THE ABSOLUTE PSD. IN THIS EXPERIMENT THE DELAYEO CURRENT COMPONENT HAS BEEN ESTIMATED TO BE 13 PER CENT OF THE TOTAL GAMMA CURRENT.

AVAILABILITY - CLEARINGHOUSE FOR FEDERAL SCIENTIFIC AND TECHNICAL INFORMATION, SPRINGFIELD, VIRGINIA 22151 . \$3.00 COPY, \$0.65 MICROFICHE

\# NOISE CROSS CORRELATION + \#REACTOR DYNAMICS + ANALYTICAL MODEL + CHAMBER, ION +

COMPARISON, THEORY AND EXPER IENCE + GAMMA + HFIR (FTR) + INSTRUMENTATION, NUCLEAR + NEUTRON +

NOI SE ANALYSIS + ORNL + REACTOR, AEC OWNED + REACTOR, FLUX TRAP + REACTOR, RESEARCH

$9-26562$

HSU C

CONTROL AND STABILITY ANALYSIS OF SPATIALLY DEPENDENT NUCLEAR REACTOR SYSTEMS

ARGONNE NATIONAL LABORATORY, ARGONNE, ILLINOIS

ANL-7322 +. 81 PAGES, 6 FIGURES, TABLE, 47 REFERENCES, JULY, 1967

AFUNDAMENTAL APPROACH TO THE STUDY OF THE DYNAMICS OF SPATIALLY DEPENDENT NUCLEAR REACTOR SYSTEMS IS DEVELOPED. THIS APPROACH TREATS REACTOR DYNAMICS PROBLEMS FROM THE SYSTEMS PARTIAL-DIFFERENTIAL EQUATIONS WITHOUT FINDING THE SOLUTION OR ENGAGING ANY $\triangle P P R O X I M A T I O N$ TO A LUMPED PARAMETER MODEL - A DYNAMICAL MODEL OF A SPATIALLY DEPENDENT PROCESS IN NUCLEAR REACTORS IS FORMULATED. THE MODEL IS GENERAL AND MAY INCLUDE THE SPATIAL EFFECTS OF DETERMINISTIC PROCESSES SUCH AS CONTROL DEVICES AND TEMPERATURE.

AVAILABILITY - CLEARINGHOUSE FOR FEDERAL SCIENTIFIC AND TECHNICAL INFORMATION, SPRINGFIELO, VIRGINIA 22151 \$3.00 COPY, \$0.65 MICRDFIC.HF

- REACTOR CONTROL + CONTROL SYSTEM + MATHEMATIC.AL TREATMENT + PONTRYAgINS PRINCIPLE + THEORETICAL INVESTIGATION

9-26570. ALSO IN CATEGORY 17

CLARK RH + CARSON JF

EQUIPMENT MALFUNCTIONS AND MOD̃İFICÁTIONS

COMBUSTION ENGINEER ING, INC.

RAW-337 +. 2 PAGES, FROM THE BABCOCK + WILCOX TEST REACTOR LICENSE TR-4 EIGHTH REPORT TO THE ATOMIC ENERGY COMMISSION OIVISION OF REACTOR LICENSING, MAY, 1968, DOC.KF' NO. 50-30

SMALL PLASTIC TUBES SUPPLYING N2-HE TO A DETECTOR EXPERIMENT CAME IN CONTACT WITH HEATER WIRES OF ANOTHER EXPERIMENT. THE GAS-SUPPLY VAIVES WERE CLOSED BEFORE INCIOENT, SO ONLY GAS IN TUBES ESCAPED. SOME INCREASE IN CONTAINMENT PARTICULATE MONITOR WAS NOTED. \#\#NUMEROUS SCRAMS HAVE BEEN CAUSEO BY SHORT-TERM POWER INTERRUPTIONS OF FLUCTUATIONS INITIATED BY A QUICK-ACTING SCRAM RELAY. IN THE PRIMARY PUMP CIRCUIT THERE IS A SECOND RELAY WHICH SERVES SAME PURPOSE BUT IS SLOWER ACTING. THE QUICK-ACTING RELAY IS LESS SAFE SINCE IT CREATES NEED FOR MORE STARTUPS AND WAS PROVIDED WITH DELAY OF 1 TO 2 SEC.

AVAilability - USAEC, Public DOCUMENT ROOM, 1717 H. ST. WASHINGTON, D. C. 20545 (SO.25 CENTSIPAGE)

\#FAILURE, DESIGN ERROR + ACCIDENT, LOSS OF POWER + ELECTRIC POWER, NORMAL + EXPERIMENT, GENERAL + INCIDENT, EQUIPMENT + INSTRUMENTATION, RELAY + MOOIFICATION, SYSTEM OR EOUIPMENT + REACTOR SAFETY SYSTEM + REACTOR, RESEARCH + REPORT, OPERATIONS SUMMARY + SCRAM, SPURIDUS

$9-26703$

RUUX D

PARALLEL-PLATE MULTISECTION IONIZATION CHAMBERS FOR HIGH-PERFORMANCE REACTORS

OAK RIDGE NATIONAL LABORATORY 
CATEGORY 9
NUCLEAR INSTRUMENTATION, CONTROL, AND SAFETY SYSTEMS

9-26703 \#CONTINUED*

STI/PUB/115 + CN-22/53+. 15 PAGES, 8 FIGURES, 4 TABLES, 2 REFERENCES PAGES $3-17$ OF NUCLEAR ELECTRONICS CONFERENCE PROCEEDINGS, BOMBAY, NOVEMBER 22-26, 1965

A NEW MODEL FOR REACTOR CONTROL WAS DEVELOPED. THE ELECTRODES MAY BE COATED WITH BORON-1O FOR USE AS NEUTRON-SENSITIVE CHAMBERS, WITH URANIUM-235 FOR USE AS FISSION CHAMBERS, OR LEFT UNCOATED FOR USE AS GAMMA-SENSITIVE CHAMBERS. ALSO, THE USE OF BDRON-COATED AND UNCOATEO ELECTRODES APPROPRIATELY CONNECTED WILL GIVE A GAMMA-COMPENSATED NEUTRDN-SENSITIVE CHAMBER . ACTIVE SECTIONS MAY BE COMBINED TO ASSEMBLE MULTIPURPOSE DETECTORS FOR DIFFERENT REACTOR CONTROL APPLICATIONS. TO DATE, TWO ORNL REACTORS HAVE BEEN FULLY EQUIPPED WITH THIS CHAMBER MOOEL. OVER A PERIDD OF 20 MONTHS, ND FAILURE HAS OCCURRED.

AVAILABILITY - NATIONAL AGENCY FOR INTERNATIONAL PUBLICATIONS, INC.. 317 EAST $34 T H$ STREET, NEW YORK, N.Y. $10016, \$ 13.50$ COPY/BOOK

+CHAMBER, ION + CHAMBER, FISSION + CHAMBER, GAMMA + CHAMBER, NEUTRON + EQUIPMENT DESIGN + INSTRUMENTATION, NUCLEAR

$9-26704$

ALLEMANDR+ DELCROIXV

NEW POSSIBILITIES DFFERED BY BORON AND URANIUM DETECTORS

CENTRE D ETUDES NUCLEAIRES DE GRENOBLE, FRANCE

STI/PUB/115+CN-22/20+. 11 PAGES, 8 FIGURES, 1 TABLE, 8 REFERENCES, PAGES 45-55 OF NUCLEAR ELECTRONICS CONFERENCE PROCEEDINGS, BOMBAY, NOV. $22-26,1965$

THE IDEA OF COVERING THE TOTAL POHER RANGE BY MEANS OF A SINGLE FISSION CHAMBER OPERATING FIRST AS A PULSE CHAMBER AND THEN AS A CONTINUOUS CURRFNT C.HAMBER IS JUSTIFIED BY THE DEVELOPMENT OF PULSE SYSTEMS POSSESSING A LARGE RANGE AND ENABLING THE PROBLEM OF GAMMA FLUX COMPENSATION TO BE SOLVED BY MEANS OF A FIXED COMPENSATION. IN THE SAME WAY, THE REPLACEMENT OF THE FISSION CHAMBER BY A NONPROPORTIONAL BORON COUNTER HAVING THE ADVANTAGE OF GREATER SENSITIVITY WOULD REPRESENT A FURTHER STEP FORHARD.

AVAILABILITY - NATIONAL AGENCY FOR INTERNATIONAL PUBLICATIONS, INC., 317 EAST 34TH STREET, NEW YORK, N.Y. $10016, \$ 13.50$ COPY/BODK

\#CHAMBER, ION + DESIGN STUDY + INSTRUMENTATION, NUCLEAR

$9-26705$

COX RJ + HARRISON D + GOOOINGS A

USING NEUTRON FLUX DETECTORS IN-PILE

ATOMIC ENERGY ESTABLISHMENT, WINFRITH, DORCHESTER, DORSET

STI/PUB/114 + CN-22/26 + 15 PAGES, 5 FIGURES, 13 REFERENCES, PAGES 57-71 OF NUCLEAR ELECTRONICS

CONFERENCE PROCEEDINGS, BDMBAY, NOV. 22-26, 1965

NEUTRON FLUX DETECTORS HAVE DEVELOPED TO THE STAGE WHERE THEY CAN BE USED WITH CONFIDENCE

IN-PILE IN MOST TYPES OF POWER REACTORS. THE USE OF SUCH DETECTORS CAN RESULT IN A REDUCTION

IN COST OF MEASURING POWER LEVEL FOR CONTROL PURPOSES OR CAN BE USEO FOR LOCALIZEO FLUX

MEASUREMENTS TO IMPROVE THE POWER DISTRIBUTION THROUGHOUT THE REACTOR. INFORMATION ISS GIVEN

ON THE TYPES OF DETECTORS THAT HAVE RECENTLY BEEN DEVELDPEO IN THE UNITEO KINGDOM, INCLUDING

PERFORMANCE DATA AND SOME INOICATION OF THE USES FOR WHICH THEY ARE SUITABLE.

AVAILABILITY - NATIONAL AGENCY FOR INTERNATIONAL PUBLICATIONS, INC., 317 EAST 34 TH STREET, NEW YORK, N.Y. $10016, \$ 13.50$ COPY/BOOK

*INSTRUMENTATION, IN CORE + \#INSTRUMENTATION, RADIATION MONITORING + COUNTER + ELECTRICAL CONDUCTION + HIGH TEMPERATURE + INSTRUMENTATION, COMPONENT + INSTRUMENTATION, NUCLEAR + NEUTRON + UNITED KINGOOM

$9-26706$

BROWN OP

MICROHAVE DETERMINATION OF NEUTRON FLUXES IN REACTORS

BATTELLE MEMORIAL INSTITUTE, RICHLAND, WASH.

STI/PUB/115 + CN-22/54+. I5 PAGES, 8 FIGURES, 8 REFERENCES, PAGES $73-97$ OF NUCLEAR ELECTRONICS

CONFERENCE PROCEEDINGS, BOMBAY, NOVEMBER 22-26, 1965

A TECHNIQUE HAS INVESTIGATED FOR DETERMINING IN-CORE NEUTRON FLUX DENSITIES THROUGH THE USE DF MICROWAVES. THIS TECHNIQUE IS BASED ON THE CHANGE IN RESONANT FREQUENCY OF A MICROWAVE CAVITY THAT CONTAINS A PLASMA PRODUCED BY THE IMPINGING NEUTRONS. EXPERIMENTS CDNDUCTED IN A HANFORO PRODUCTION REACTOR DEMONSTRATED GOOD CORRELATION BETWEEN THE MEASURED FREQUENCY SHIFT AND THE ACTUAL FLUX DENSITY IN THE REACTOR. RESPONSE DF THE MICROHAVE DETECTOR IS

ESSENTIALLY IMMEDIATE, AND TRANSIENT FLUX CHANGES WERE READILY APPARENT.

AVAILABILITY - NATIONAL AGENCY FOR INTERNATIONAL PUBLICATIONS, INC., 317 EAST 34TH STREET, NEW YORK, N.Y. $10016, \$ 13.50$ COPY/BODK

* INSTRUMENTATION, NUCLEAR + COMPARISON, THEORY AND EXPER IENCE + FlUX, INTEGRATED + IN CORE MEASUREMENT + INSTRUMENTATION, COMPONENT + INSTRUMENTATION, IN CORE + NEUTRON 
CATEGORY 9

NUCLEAR INSTRUMENTATION, CONTROL, AND SAFETY SYSTEMS

9-26707 *CONTINUED*

JAIN RD + VENKATESWARLU U

THE NEUTRON FLUX MONITORING SYSTEM AND FLUX DISTRIBUTION IN THE TARAPUR REACTORS

TARAPUR ATOMIC POWER PROJECT, BOMBAY, INDIA

STI/PUB/115 + CN-22/37 +. 7 PAGES, I FIGURE, 2 TABLES, 8 REFERENCES, PAGES 99-105 OF NUCLEAR ELECTRONICS CONFERENCE PROCEEDINGS, BOMBAY, NOVEMSER 22-26, 1965

BECAUSE OF EXCESSIVE THICKNESS OF WATER REFLECTORS IN THE TARAPUR REACTORS, THE FEASIBILITY OF THE USE OF OUT-OF-CORE NEUTRON FLUX DETECTING SYSTEM WAS IN DOUBT. A SCHEME PROPISIVG COMPLETE IN-CORE DETECTING SYSTEM WAS FOUND QUITE INADEQUATE FROM THE POINT OF VIEW OF SAFE OPERATION OF THE STATION. A NFW SCHEME UTILIZING A MIXED IN-CORE AND OUT-OE-CCRE DETECTING SYSTEM BASED ON THE CALCULATIONS OF NEUTRON AND GAMMA-RAY FLUX DISTRIBUTIONS HAS BEEN

EVOLVED. THIS PAPER CONTAINS THE CALCULATIONS OF THE NEUTRON AND GAMMA-RAY DISTRIBUTIONS AND THE DESCRIPTION OF THE LATEST SCHEME OF NEUTRON OETECTING SYSTFM TO BE INSTALLED IN THE TARAPUR REACTORS.

AVAILABILITY - NATIONAL AGENCY FOR INTERNATIONAL PUBLICATION, INC., 317 EAST 34TH STREET, NEW YORK; N.Y. $10016, \$ 13.50$ COPY/BOOK

* Instrumentation, RADiation mONITORING + FluX, INTEgRATED + GaMma + INDIA + NEUTRON + THERMAL NEUTRON

$9-26708$

FURET J + HEILL J

PRESENT STATE OF DEVELOPMENT IN REACTOR CONTROL INSTRUMENTATION DESIGN IN FRANCE

CENTRE D ETUDES NUCLEAIRED DE SACLAY, FRANCE

STI /PUB/115 + CN-22/16 +. 14 PAGES, 7 FIGURES, 3 TABLES, O REFERENCES, PAGES $107-120$ OF NUCLEAR

ELECTRONICS CONFERENCE PROCEEDINGS, BOMBAY, NOVEMBER 22-26, 1965

ONLY NEUTRON DETECTORS ARE DISCUSSED, AND DEVELOPMENT IS CONCENTRATED ON THE FOLLOWING - (A) INCREASING THE DISTANCE BETHEEN ELECTRONIC INSTRUMENTATION ANO THE DETECTORS TO PERMIT OPERATION UNDER ENVIRONMENTAL CONDITIONS, (B) INCREASING. THE MEASURING RANGE OF THE PULSE ASSEMBLIES, WITH IMPROVEMENT IN NEUTRON/GAMMA DISCRIMINATION, ICI USING THE SAME OETECTOR BOTH FOR DIGITAL AND CURRENT TECHNIQUES, AND (D) DEVELOPING DIGITAL MEASURING TECHNIQUES.

AVAILABILITY - NATIONAL AGENCY FOR INTERNATIONAL PUBLICATIONS, INC., 317 EAST 34 TH STREET, NEW YORK, N. Y. $10016, \$ 13.50$ COPY BOOK

* INSTRUMENTATION, CONTROL + DESIGN STUDY + FRANCE + INSTRUMENTATION, COMPONENT + INSTRUMENTATION, NUCLEAR + NEUTRON + SURVEY, GENERAL

9-26709

VENKATESWARLU U + VISWANATHAN L + PANSARE MG + NAGLE AK

SOME OESIGN ASPECTS OF THE CONTROL AND SAFETY INSTRUMENTATION JF THE ZERO-ENERGY REACTOR ZERLINA

ATOMIC ENERGY ESTABLISHMENT TROMBAY, BOMBAY, INDIA

STI/PUB/115 + CN-22/36 +. 12 PAGES, B FIGURES, REFERENCES, PAGES $121-32$ OF NUCLEAR ELECTRONICS CONFERENCE

PROCEEDINGS, BOMBAY, NOVEMBER 22-26, 1965

SOME OF THE SPECIAL CONDITIONS ARE DISCUSSED THAT EXIST IN ZERLINA IZERO-ENERGY REACTOR FOR

LATTICE INVFSTIISATIONS AND STUDY OF NEW ASSEMBLIESI AND HOW THEY INFLUENCE THE DESIGN OF NEUTRON FLUX INSTRUMENTATION USEO FOR MEASUREMENT, CONTROL, AND OVERALL SAFETY OF THE PEACTOR. IN VIEW OF THE POTENTIAL OANGERS INVOLVED IN RESEARCH REACTDR AND THE TYPE OF EXPER IMENTS CONDUCTED, ALL HIGH-LEVEL FLUX MEASURING INSTRUMENTATION SUCH AS LINEAR,

LOG-PERIOD, AND ERROR CHANNELS IN ADOITION TO A NUMBER OF SAFETY CIRCUITS, ARE CONNECTED INTO THE REACTOR TRIP LINE.

AVAILABILITY - NATIONAL AGENCY FOR INTERNATIONAL PUBLICATIONS, INC., 317 EAST 34 TH STREET, NEH YORK, N.Y. $10016, \$ 13.50$ COPY/BOOK

* INSTRUMENTATION, NUCLEAR + *NEUTRON + OESIGN STUDY + FluX, INTEGRATED + INOIA + INSTRUMENTATION, CONTPOL + REACTOR SAFETY SYSTEM + REACTOR, RESEARCH

$9-26710$

HARRISON D + WILSON I + COX RJ

REDUCING THE EFFECTS OF ELECTRICAL INTERFERENCE ON NUCLEAR INSTRUMENTS

UNITED KINGDOM ATOMIC.ENERGY AUTHORITY, WINFRITH

STI/PUB/115 + CN-22/27+. 13 PAGES, 5 FIGURES, 6 REFERENCES, PAGES $157-69$ OF NUCLEAR ELECTRONICS

CONFERENCE PROCEEDINGS, GOMBAY, NOVEMBER S? $\$-? \mathrm{~K}, 1965$

A SPECIAL STUDY WAS MADE OF THE CAUSES OF INTERFERENCE IN NUCLEONIC REACTOR CONTROL INSTRUMENTS HITH THE FOLLOWING OBJECTIVES - (1) TO IDENTIFY ANO UNDFRSTAND THE WAY IN WHICH INTERFERENCE IS CAUSED, (2) TO DEVELOP TECHNIQUES AND RULES FOR INTERFERENCE REDUCTION, (3) TO DEVELOP MEANS OF DIAGNOSING THE SOURCES AND CAUSES OF INTERFERENCE AND TO TEST THE GOODNESS OF A GIVEN INSTALLATION. RECENT TEST METHOOS ARE DESCRIBED, THE RESULTS OF WHICH CAN BE USEO TO DECIDE WHERE TO MAKE CHANGES TO THE INSTALLATION TO EFFECT IMPROVEMENTS.

AVAILABILITY - NATIONAL AGENCY FOR INTERNATIONAL PUBLICATIONS, INE.., 317 FAST $34 T H$ STREET, NEW YORK, N.Y. $10016, \$ 13.50$ COPY/BDOK

*INSTRUMENTATION, ABNORMAL INOICATION + \#INSTRUMENTATION, NUCLEAR + ELECTRICAL CONDUCTION + FAILURE, DESIGN ERROR + FAILURE, INSTALLATION ERROR + INSTABILITY + INSTRUMENTATION, TESTING + INTEGRITY + QUAI, ITY CONTROL 
CATEGORY

NUCLEAR INSTRUMENTATION, CONTROL, AND SAFETY SYSTEMS

$9-26711$

DELCROIX $V$ + HENRY M + LACOUR J + PINON Y + ROCHET A + TATTEGRAIN A

FAST PERIDD METER WITH INTEGRATED CIRCUITS

CENTRE D ETUDES NUCLAIRES DE GRENOBLE + CENTRE D ETUDES NUCLEAIRES DE CADARACHE

STI /PUB/115+CN-22/24+. 16 PAGES, 10 FIGURES, 5 REFERENCES, PAGES $185-200$ OF NUCLEAR ELECTRONICS CONFERENCE PROCEEDINGS, BOMBAY, NOVEMBER 22-26, 1965

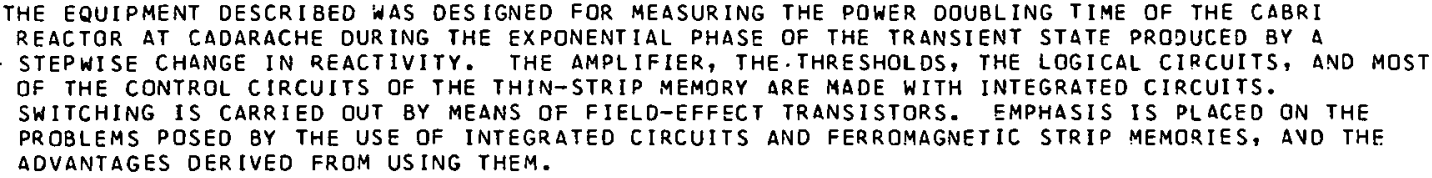

AVAILABILITY - NATIONAL AGENCY FOR INTERNATIONAL PUBLICATIONS, INC., 317 EAST 34 TH STREET, VEW YORK, N. Y. $10016, \$ 13.50$ COPY/BOOK

*INSTRUMENTATION, PERIDD + \#PERIOD METER + FRANCE + SOLID STATE DEVICE

$9-26712$

DA COSTA VIEIRA D + FRIEDLING G + MERITE B + TATTEGRAIN A

APPARATUS FOR MEASURING FAST ODUBLING TIMES OF THE CABRI REACTOR

CENTRE D ETUDES NUCLEAIRES DE CADARACHE

STI/PUB/115+CN-22/8 +. 23 PAGES, 14 FIGURES, PAGES 201-23 OF NUCLEAR ELECTRONICS CDNFERENCE

PROCEEDINGS, BOMBAY, NOVEMBER 22-26, 1965

THE APPARATUS FOR MEASURING DOUBLING TIMES AS SHORT AS 1 MS INCLUDES A CONSTANT-SENSITIVITY AMPLIFIER AND SEVERAL TRIGGERING CIRCUITS IN PARALLEL. THE OUTPUT SIGNALS OF THE TRIGGERING CIRCUITS ARE SERIALIZED ON A SINGLE WIRE, GIVING A TRAIN OF SIX PULSES, THE INTERVALS BETWEEN WHICH DEF INE THE FIVE DOUBLING TIMES. AI IHE RECEPTION END, A REGISTER DISTRIBUTES THE

STOP-GO COMMANDS OF SEVERAL SEALERS. THE APPARATUS DISPLAYS THE RESULTS INSTANTANEOUSLY ON

NIXIE TUBES AND ALSO PROVIDES FOR AN AUTOMATIC PRINT-OUT ON AN IBM MACHINE.

AVAILABILITY - NATIONAL AGENCY FOR INTERNATIONAL PUBLICATIONS, INC., 317 EAST 34TH STREET, NEW YORK, N.Y. $10016, \$ 13.50$ COPY/BOOK

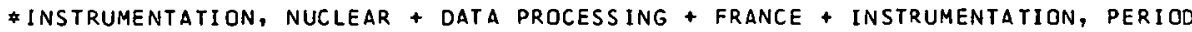

$9-26713$

LAUNOIS $M$

THE USE OF MODULATED GAIN DETECTORS AND A DIGITAL DATA STORAGE UNIT TO RECORD PULSEO PEAGTOR EXCURSIONS

COMMISSARIAT A L ENERGIE ATOMIQUE, PARIS, FRANCE

STI/PUB/115 + CN-22/14 +. 14 PAGES, 12 FIGURES, PAGES 231-44 OF NUCLEAR ELECTRONICS CONFERENCE

PROCEEDINGS, BOMBAY, NOVEMBER $22-26,1965$

TO ENSURE ACCURATE RECORDING OF PULSED REACTOR EXCUR SIONS, A METHOD WAS DEVELOPED IN WHICH USE IS MADE OF A CURRENT DETECTOR FOLLOWED BY A SAMPLING CIRCUIT, A CODER, AND A DIGITAL STORAGE UNIT CONSISTING AT PRESENT OF AN ANALYZER OPERATING AS A MULTISCALER. THE PAPER DISCUSSES

PRSSIRIE $\triangle N O$ PLANNED APPLICATIONS OF THIS SYSTEM TO THE CABRI REACTOR.

AVAILABILITY - NATIONAL AGENCY FOR INTERNATIONAL PUBLICATIONS, INC., 317 EAST $34 T H$ STREET, NEW YORK, N.Y. $10016, \$ 13.50$ COPY $/ B 00 K$

* INSTRUMENTATION, NUCLEAR + DATA PROCESSING + FRANCE + INSTRUMENTATION, RECORDER + REACTOR, PULSEO

$9-26714$

SAKURAI Y + MORI K + ISOZUMI K + KAKIZAWAK

CAPACITANCE-TYPE VOID METER

OSAKA UNIVERSITY, JAPAN

STI/PUB/115 + CN-22/6 +. 14 PAGES, 14 FIGURES, 5 REFERENCES, PAGES 247-60 OF NUCLEAR ELECTRONICS

CONFERENCE PROCEEDINGS, BOMBAY, NOVEMBER 22-26, 1965

A METHOD IS REPORTED FOR VOID-FRACTION MEASUREMENT WHICH IS BASED ON CHANGES OF THE EQUIVALENT DIELECTRIC CONSTANT OF THE TWD-PHASE FLOW. BOTH THE INSTANTANEOUS AND THE LOCAL VOID

FRACTION CAN BE MEASURED WITH A FAST RESPONSE BY THIS METHOD. THE LINEARITY OF THE DEVICE IS GOOD. EXPERIMENTAL RESULTS SHOW THAT A PROBE-TYPE ELECTROOE HAS THE BEST CHARACTERTSTICS FOR BWR DOSE APPLICATIONS.

AVAILABILITY - NATIONAL AGENCY FOR INTERNATIONAL PUBLICATIONS, INC., 317 EAST 34 TH STREET, NEW YORK, N.Y. $10016, \$ 13.50$ CUPY/BUUK

* instrumentation, flow + comparison, theory and experience + flow, two phase + reactor, bwr 
RUPTURED FUEL LOCATION WITH HIGH-RESOLUTION GAMMA-RAY SPECTROMETERS

ATOMIC ENERGY OF CANAOA LTD., CHALK RIVER, ONT.

STI/PUB/115 + CN-22/31 +. 23 PAGES, 9 FIGURES, 3 TABLES, 17 REFERENCES, PAGES $299-321$ OF NUCLEAR

ELECTRONICS CONFERENCE PROCEEDINGS, BOMBAY, NOV. 22-26, 1965

THE GAMMA SPECTRA OF MIXED FISSION PRODUCTS WERE MEASURED IN NRX LOOP EXPERIMENTS USING INTENTI ONALLY PUNCTURED UO2 FUEL. THE PAPER REPORTS TEST OATA ON (A) PHASE DISTRIBUTION OF FISSION PRODUCTS IN THO-PHASE COOLANT FLOW WITH A 0.25-MM ORILLED PUNCTURE, (B) FISSION PRODUCTS APPEARING IN ORGANIC COOLANT AFTER A SUDDEN PUNCTURE AND IMMEDIATE R.EACTOR SHUTDOWN, AND (C) RELEASE OF FISSION PROOUCTS (HALF-LIFE LESS THAN 17 MIN) THROUGH $\triangle$ O.25-MM DRILLED PUNCTURE IN HIGHLY RATED FUEL IN PRESSURIZED WATER.

AVAILABILITY - NATIONAL AGENCY FOR INTERNATIONAL PUBLICATION, INC., $317 \cdot$ EAST.34TH STREET, NEW YORK, N.Y. $10016, \$ 13.50$ COPY/BOOK

* INSTRUMENTATION, DETECTION FAILED FUEL ELEMENT + CANADA + CAVDU (HWR) + REACTOR, HWR + SPECTROMETRY, GAMMA + TEST, INSTRUMENT RESPONSE

$9-26716$

GRAFTIEAUX J + RDGUIN A

DEVELOPMENT OF FISSION-PRODUCT DETECTORS FOR THE DETECTION OF BURST FUEL ELEMENT CANS CENTRE D ETUDES NUCLEAIRES DE SACLAY, FRANCE

ST1/PUB/115 + CN-22/13+. 10 PAGES, 4 FIGURES, 10 REFERENCES, PAGES $323-32$ DF NUCLEAR ELECTRONICS CONFERENCE PROCEEOINGS, BOMBAY, NOV. 22-26, 1965

THE MEASUREMENT OF FISSION GASES BY ELECTRIC COLLECTION IS USEO FOR DETECTING BURST CANS PRINCIPALLY IN GRAPHITE/GAS-REACTOR SYSTEMS. THE METHOO OF ELECTRIC COLLECTION AFTER EXTRACTION OF THE FISSION GASES DISSOLVED IN THE WATER IS ALSO USED FOR MAINTAINING A CHECK ON THE FUEL OF WATER-COOLED REACTORS. HOWEVER, ALTHOUGH IT IS LESS SENSITIVE, THE METHOD OF

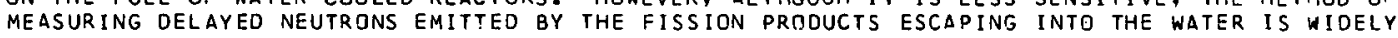
USED BECAUSE OF THE SIMPLICITY OF THE EQUIPMENT. THE METHOD IS USED IN THE EL.3, PEGASE, AND OSIRIS REACTORS. SYSTEMS USED IN THE EOF POWER REACTOR AND IN THE EL.4 REACTOR COOLED BY CARBON DIOXIDE ARE ALSO PRESENT.

AVAILABILITY - NATIONAL AGENCY FOR INTERNATIONAL PUBLICATIONS, INC., 317 EAST 34 TH STREET, NEW YORK, N. Y. $10016, \$ 13.50$ COPY/BOOK

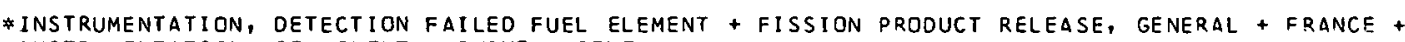
INSTRUMENTATION, COMPONENT + SURVEY, GENERAL

$9-26717$

RAGUPATHY $S+$ VOHRA KG

A MULTICHANNEL ANALYSIS SYSTEM FOR LOW LEVELS OF FISSION PRODUCTS IN REACTOR COOLANTS

ATOMIC, ENERGY ESTABLISHMENT TROMBAY, BOMBAY, INOIA

STI /PUB/115 + CN-22/42+. 7 PAGES, 6 FIGURES, PAGES 333-39 DF NUCLEAR ELECTRONICS CONFERENCE PROCFEDINGS, BOMBAY, NOVEMBER $22-26,1965$

DESCRIBES THE SYSTEM CONSISTING OF A SODIUM IOUIJE CYYSTAL ANO A 256-CHANNEL PULSE-HEIGHT ANALYZER INCORPORATING FERRITE-CORE MEMORY STORAGE. THIS SYSTEM HAS BEEN ADOPTED FOR THE MEASUREMENT OF VERY LOW LEVELS OF FISSION PRODUCTS IN REACTOR COOLANTS SY GAMMA SPECTROMETRY. THE SYSTEM CAN BE USED FOR A VERY LARGE RANGE OF FISSION-PRODUCT ACTIVITY, FROM VERY LOW LEVELS OF ACTIVITY ENCOUNTERED IN NORMAL OPERATIONS TO FAIRLY HIGH LEVELS ENCOUNTEREO IN THE CASE OF A SPLIT ROD. USING THIS SYSTEM, PRELIMINARY STUDIES HAVE BEEN MADE ON INDUCED RADIOACTIVITY AND FISSION-PRODUCT ACTIVITIES IN THE REACTOR COOLING WATER. SAMPLES.

AYAILABILITY - NATIONAL AGENCY FOR INTERNATIONAL PUBLICATIONS, INC., 317 EAST $34 T H$ STREET, NEW YORK, N.Y. $10016, \$ 13.50$ COPY/BOOK

* INSTRumentation, detection failed fuel clement, comparison, theory and experience t

FISSION PRODUCT RELEASE, GENERAL + INDIA + SPECTROMETRY, GAMMA + TEST, INSTRUMENT RESPONSE

$9-26718$

PATWARDHAN PK + INDURKAR VS

A NEW DESIGN OF RATIO CIRCUIT FOR FISSION-FRAGMENT STUDIES

ATOMIC ENERGY ESTADLISIMCNT TROMBAY, BOMBAY, INDIA

STI/PUB/115+CN-22/32+. 10 PAGES, 8 FIGURES, 6 REFERENCES, PAGES $341-50$ OF NUCLEAR ELECTRONICS

CONFERENCE PROCEEDINGS, BOMBAY, NOVEMBER 22-26, 1965

DESCRIBES A PULSE-VOLTAGE DIVIDING CIRCUIT FOR STUOYING THE MASS DISTRIBUTION OF FISSION-FRAGMENTS IN A MULTI-PARAMETER EXPERIMENTAL SET-UP. IN THE DRESENT METHOD, TEMPERATURE-COMPENSATEO AMPLIFIERS AND ZERO-TRIGGER TECHNIQUES ARE USEN TO IMPROVE UPON THE OVERALL SENSITIVITY. THE SPECIAL FEATUPE OF THE CIRCIIIT IS THAT THE OUTPUT IS PRESENTED IN DIGITAL FORM, IMPROVING CONSIOERABLY THE OVERALL CIRCUIT PERFORMANCE IN TERMS OF FLUCTUATIONS AND LINEARITY. 
CATEGORY 9

NUCLEAR INSTRUMENTATION, CONTROL, AND SAFETY SYSTEMS

9-26718 *CONTINUED*

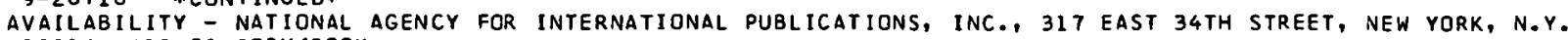
$10016, \$ 13.50$ COPY/BOOK

* instrumentation, detection falled fuel element + fission product release, general +

INSTRUMENTATION, COMPONENT

9-26719

CHAUVET G + GARIDDR + TOURNIER E

REACTIMETER

CENTRE D ETUDES NUCLEAIRES DE GRENOBLE, FRANCE

STI/PUB/115+CN-22/22+. 14 PAGES, 16 FIGURES, 2 TABLES, 7 REFERENCES, PAGES $365-78$ OF NUCLEAR

ELECTRONICS CONFERENCE PROCEEDINGS, BOMBAY, NOV. 22-26, 1965

THE REACTIMETER IS AN APPARATUS BY HHICH THE REACTIVITY IN A REACTOR, PARTICULARLY DURING REACTIVITY TRANSIENTS, CAN BE MEASURED DIRECTLY AND INSTANTANEOUSLY. COMPARATIVE STUDIES WERE CARRIED DUT ON THE BASIS DF CDNVENTIONAL MEASUREMENTS AND AN ACCURACY OF THE ORDER OF +-1\% WAS OBTAINED ON THE FOLLOHING REACTORS - ALIZE, AZUR, AND SILOETTE. WHEN THE PERIOD OF THE REACTOR IS POSITIVE NO PRECAUTIONS NEED TO BE TAKEN WITH REGARD TD THE POSITIONING OF THE CHAMBER. WHEN THE PERIOD IS STRDNGLY NEGATIVE IT IS SUFFICIENT TO ARRANGE THE CHAMBER IN SUCH A WAY THAT PART OF THE CORE IS BETWEEN THE ROD BEING STUDIED AND THE CHAMBER. IN THIS WAY ROD ANT I-REACTIVITY CAN BE MEASURED WITH AN ACCURACY OF +- $\$$.

AVAILABILITY - NATIONAL AGENCY FOR INTERNATIONAL PUBLICATIONS, INC., 317 EAST 34 TH STREFT, VEW YORK, N.Y. $10016, \$ 13.50$ COPY/BOOK

* INSTRUMENTATION, NUCLEAR + \#REACTIVITY EFFECT + COMPARISON, THEORY AND EXPERI ENCE + FRANCE + INSTRUMENTATION, PERIOD + OPERATING EXPERIENCE

$9-26720$

CAILLET C + DEAT M + FURET J + WEILL J

PROCEDURE FOR RAPIO START-UP-ANALYSIS ON AN ANALOG COMPUTER AND COMPARISON WITH RESULTS OF REACTOR TRIALS CENTRE D ETUDES NUCLEAIRES DE SACLAY, FRANCE

STI/PUB/115 + CN-22/21+. 14 PAGES, 3 FIGURES, 4 TABLES, 3 REFERENCES, PAGES $379-93$ OF NUCLEAR

ELECTRONICS CONFERENCE PROCEEDINGS, BOMBAY, NOV. 22-26, 1965

WITH THE AUTOMATIC STARTUP PROCEDURE A REACTOR CAN PASS FROM ANY UNKNOWN SUBCRITICAL STATE TO A SUBCRITICAL STATE VERY CLOSE TO CRITICALITY UNDER SAIISFACTORY CONDITIONS OF SPEED AND SAFETY. RESULTS OBTAINED ON THE ANALOG COMPUTER WERE COMPARED WITH TRIAL VALUES ON THE CABRI REACTOR.

AVAILABILITY - NATIONAL AGENCY FOR INTERNATIONAL PUBLICATIONS, INC., 317 EAST $34 T H$ STREET, VEW YORK, N.Y. $10016, \$ 13.50$ COPY $1 B O 0 K$

\#CONTROL SYSTEM + \#INSTRUMENTATION, STARTUP + \#REACTOR CONTROL + COMPARISON, THEORY AND EXPERIENCE + COMPUTER, ANALOG + FRANCE + SIMULATION

9-26721 ALSO IN CATLGORY 6

C. HERNICK J

NEUTRON DYNAMICS OF BROOKHAVEN(SI HIGH FLUX BEAM REACTOR

BROOKHAVEN NATIONAL LABORATORY, UPTON, N.Y.

STI/PUB/115 + CN-22/52+. 17 DAGES, 13 FIGURES, 7 REFERENCES, PAGES $395-411$ OF NUCLEAR ELECTRQNICS

CONFERENCE PROCEEDINGS, BOMBAY, NOVEMBER 22-26, 1965

BROOKHAVEN(S) HIGH FLUX BEAM REACTOR (HFBR) IS A HIGH-POWER-DENSITY RESEARCH REACTOR WITH MANY NOVEL FEATURES. THESE INCLUDE A COMPACT UNOERMODERATED CORE, COOLED, MODERATED, AVD REFLECTEO BY HIGH-VELOCITY O20. THE LARGE D2O REFLECTOR PLAYS THE DOMINANT ROLE IN NEUTRON MOOERATION AND IN CONTROLLING THE REACTOR. RESULTING SAFETY FEATURES INCLUDE A LONG NEUTRON GENERATION TIME, PLUS NEGATIVE TEMPERATURE AND VOID COEFFICIENTS THROUGHOUT THE CDRE AND REFLECTOR, DYNAMIC CHARACTERISTICS OF THE REACTOR HAVE BEEN EXPLORED BOTH BY ANALDG AND DIGITAL COMPUTING MACHINES.

AVAILABILITY - NATIONAL AGENCY FOR INTERNATIONAL PUBLICATIONS, INC., 317 EAST 34TH STREET, NEW YORK, N.Y. $10016, \$ 13.50$ COPY/BOOK

\#REACTOR CONTROL + \#REACTCR OYNAMICS + HEAVY HATER + HFBR (RR) + REACTOR, AEC OWNED + REACTOR, RESEARCH + REACTOR, RESEARCH + REACTOR, WATER

$9-26722$

BERTRAND J + DESANDRE NAVARRE D + FRIEDLING G + MOURCHOU R

AUTOMATIC CONTROL SYSTEM OF THE PEGGY REACTOR

CENTRE D ETUDES NUCLEAIRES DE CADARACHE, FRANCE

STI/PUB/115 + CN-22/23+. 15 PAGES, 11 FIGURES, PAGES 413-27 OF NUCLEAR ELECTRONICS CONFERENCE

PROCEEDINGS, BOMBAY, NOVEMBER 22-26, 1965

THE PAPER DESCRIBES THE AUTOMATIC CONTROL SYSTEM DESIGNED TO REPLACE THE PREVIOUS SYSTEM OF THE PEGGY REACTOR. THE MAIN CHARACTERISTICS OF THE SYSTEM ARE THAT IS PERMITS (A)

CHANGE-OVER AT A CONSTANT PERIOD OF 20 SEC FROM AN INITIAL TO A FINAL POWER DIFFERING BY A 
CATEGORY 9
NUCLEAR INSTRUMENTATION, CONTROL, ANO SAFETY SYSTEMS

9-26722 *CONT INUED*

FACTOR OF AS MUCH AS I MILLION, (B) ACCURATE STABILIZATION OF THE POWER, THE CHANGE FROM A

TRANSIENT TO A STABILIZED STATE BEING MADE AUTOMATICALLY. PRINCIPLES UNDERLYING THE DESIGN OF THE EQUIPMENT ARE OISCUSSED.

AVAILABILITY - NATIONAL AGENCY FOR INTERNATIONAL PUBLICATIONS, INC., 317 EAST 34TH STREET, VEW YORK, N. Y. $10016, \$ 13.50$ COPY/BOOK

* CONTROL SYSTEM + \#REACTOR CONTROL + EQUIPMENT DESIGN + FRANCE

9-26723

KOVANIC P

P. KOVANIC--SPECIAL CONTRIBUTION TO NUCLEAR ELECTRONICS CONFERENCE PROCEEDINGS, BOMBAY

NUCLEAR RESEARCH INSTITUTE OF THE CZECHOSLOVAK ACADEMY OF SCIENCES IN REZ

STI/PUB/115 + 5 PAGES, FIGURES, PAGES 429-33 OF NUCLEAR ELECTRONICS CONFERENCE PROCEEDINGS, BOMBAY, NQVEMBER 22-26, 1965

OIGITAL EQUIPMENT WAS BUILT TO HANDLE THE IMPULSES OF A FIXED-POSITION PULSED NEUTRON OETECTOR BUT WHICH HAS THE ADVANTAGES USUALLY FOUND WITH MOVABLE DETECTORS. THE FACILITY IS DESIGNED FOR OPERATION AS A FIXED DETECTOR SYSTEM. IN THE LOWER REACTOR-POWER REGION. THIS WORK WAS CARRIED OUT IN THE NUCLEAR RESEARCH INSTITUTE OF THE CZECHOSLOVAK ACADEMY OF SCIENCE IN REZ.

AVAILABILITY - NATIONAL AGENCY FOR INTERNATIONAL PUBLICATIONS, INC., 317 EAST 34TH STREET, NEW YORK, N.Y. $10016, \$ 13.50$ COPY/BOOK

* INSTRUMENTATION, NUCLEAR + CONTROL SYSTEM + INSTRUMENTATION, COMPONENT + INSTRUMENTATION, CONTROL + REACTOR, RESEARCH

$9-26724$

JOVERP + UBERSCHLAG J + FURET J

CONIROL AND SAFETY ASSEMBLY FOR REACTORS OF VERY HIGH FLUX

CENTRE D ETUDES NUCLEAIRES DE SACLAY

STI/PUB/115 + CN-22/15 +. 7 PAGES, 5 FIGURES, 2 REFERENCES, PAGES $435-41$ OF NUCLEAR ELECTRONICS

CONFERENCE PROCEEDINGS, 8OMBAY, NOVEMBER 22-26, 1965

THE DISPLACEMENT OF THE AUTONOMUS LOOPS BEING TESTED IN THE PEgASE HIGH-FLUX REACTOR HAS BEEN THE CAUSE OF DISTURBANCES IN THE CONTROL AND SAFETY ASSEMBLIES BASEO ON NUCLEAR DETECTION. CONSEQUENTLY A SYSTEM HAS BEEN OESIGNED FOR AUTOMATIC CORRECTION OF THE AMPLIFIER GAIN. EACH ASSEMBLY HAS ITS OWN AUTOMATIC SYSTEM FOR CORRECTING DISTURBANCES IN THE DETECTOR TO WHICH IT IS COUPLED. PROVISION HAS BEEN MAOE FOR DISCONNECTING THE CONNECTION SYSTEM IF IT SHOULD FAIL, WHILE ENSURING CONTINUITY OF OPERATION IN CASES WHERE A FAULT OCCURS IN ONE OF THE ELEMENTS.

AVAILABILITY - NATIONAL AGENCY FOR INTERNATIONAL PUBLICATIONS, INC., 317 EAST $34 T H$ STREET, NEW YORK, N. Y. $10016, \$ 13.50$ COPYIBOOK

\#REACTOR CONTROL + \#REACTOR SAFETY SYSTEM + CONTROL SYSTEM + INSTRUMENTATION, AMPLIFIER + INSTRUMENTATION, NUCLEAR + SERVOMECHANISM

$9-26725$

KLIGER

SYNTHESIS OF AN OPTIMAL CONTROL SYSTEM FOR NUCLEAR REACTORS WITH GENERALIZED TEMPERATURE FEEDBACK ARGONNE NAT IONAL LABORATORY

STI/PUB/115+CN-22/55+. 18 PAGES, FIGURES, 4 REFERENCES, PAGES $443-60$ OF NUCLEAR ELECTRONICS CONFERENCE PROCEEDINGS, BOMBAY, NOVEMBER 22-26, 1965

THE SYNTHESIS PROBLEM OF A GENERALIZED REACTOR CONTROL SYSTEM IS DISC.USSED. THE PRDBLEM IS FORMULATED SUCH THAT IT IS APPLICABLE TO A LARGE CLASS DF OPTIMIZATION PROBLEMS IN THE NIIC.LEAR REACTOR FIELD. THE CONTROL SYSTEM IS COMPOSED OF TWO PARTS. THE FIRST CONTROLS THE REACTOR HEAT TRANSFER SYSTEM THROUGH THE COOLANT FLOW AND THE NEUTRON OENSITY. THE SECONO CONTROLLER FORCES THE REACTOR TO GENERATE THE DESIRED NEUTRON FLUX AS DETERMINED BY THE FIRST CONTRULLER。

AVAILABILITY - NATIONAL AGENCY FOR INTERNATIONAL PUBLICATIONS, INC., 317 EAST $34 T H$ STREET, NEW YORK, N.Y. $10016, \$ 13.50$ COPY/BOOK

\#REACTOR CONTROL + CONTROL SYSTEM + CONTROLLER + INSTRUMENTATION, CONTROL + MATHEMATICAL TREATMENT + SIMULATION + THEORETICAL INVESTIGATION

$9-26726$

WE ISS H

POWER MEASUREMENT AND AUTOMATIC REACTOR CONTROL BY GAMMA- OR CERENKOV-RADIATION

ATOMINSTITUT OER OSTERREICHISCHEN HOCHSCHULEN, VIENNA, AUSTRIA

STI/PUB/115 + CN-22/2 +. 14 PAGES, 12 FIGUP.ES, 10 REFERENCES, PAGES $461-74$ OF NUCLEAR ELECTRDNICS

CONFERENCE PROCEEDINGS, BOMBAY, NOVEMBER 22-26, 1965

THE POWER-MEASURING SYSTEM WAS INSTALLED IN THE TRIGA-REACTOR FOR TESTING AND AUTOMATIC

REACTOR CONTROL. WITH THIS METHOD IT IS POSSIBLE TO MOUNT THE DETECTOR AT A DISTANCE FROM 
CATEGORY 9
NUCLEAR INSTRUMENTATION, CONTROL, ANO SAFETY SYSTEMS

9-26726 \#CONT INUED*

THE CORE WITH THE RESULT THAT THE MEASUREMENT IS NOT SO OEPENOENT ON LOCAL FLUX VARIATIONS DUE TO IRRADIATION SAMPLES IN THE CORE, CHANGES OF CONTROL ROD POSITIONS, AND BURNUP OF FUEL AS IF THE NEUTRON DETECTOR HERE MOUNTED AT THE REFLECTOR. THE DETECTORS ARE FREE FROM

NEUTRON ACTIVATION, RAOIATION DAMAGE, ANO SENSITIVITY CHANGES OUE TO NUCLEAR REACTIONS IN THE DETECTOR MATERIAL. FURTHERMORE, THERE ARE NO INSULATION PROBLEMS CAUSED BY IRRADIATION OF INSULATORS.

AVAILABILITY - NATIONAL AGENCY FOR INTERNATIONAL PUBLICATIONS, INC., 317 EAST 34 TH STREET, NEW YORK, N.Y. $10016, \$ 13.50$ COPY/BOOK

\#REACTOR CONTROL + GAMMA EMITTER + INSTRUMENTATION, COMPONENT + INSTRUMENTATION, CONTROL + OPERATING EXPERIENCE + REACTOR POWER + REACTOR, RESEARCH + TRANSFER FUNCTION + TRIGA (RR)

9-26727

MEIFFREN J + OECOOL F

SAFETY SYSTEMS AND THE MEASUREMENT OF NEUTRON FLUX IN THE G-2 AND G-3 REACTORS

CENTRE DE PRODUCTION DU PLUTONIUM, MARCOULE, FRANCE

STI/PUB/115+CN-22/19+. 19 PAGES, 7 FIGURES, PAGES 475-93 OF NUCLEAR ELECTRONICS CONFERENCE

PROCEEOINGS, BOMBAY, NOVEMBER $22-26,1965$

BRIEFLY DISCUSSED ARE THE ORIGINAL FLUX-MEASUREMENT SYSTEM AND SAFETY DEVICES. THE NEW

EQUIPMENT IS DESCR IBEO, GIVING REASONS FOR THE CHOICE MADE. RESULTS ARE PRESENTEO FROM THE

TESTING OF THE EQUIPMENT, AN ACCOUNT OF ITS INSTALLATION AND INITIAL OPERATION, AND THE

OPERATING RESULTS OBTAINEO OVER SEVERAL MONTHS.

AVAILABILITY - NATIONAL AGENCY FOR INTERNATIONAL PUBLICATIONS, INC., 317 EAST $34 T$ STREET, VEW PORK, N.Y. $10016 \$ 13.50 \mathrm{COPY} / \mathrm{BOOK}$

* REACTOR SAFETY SYSTEM + FLUX, INTEGRATED + FRANCE + MEASUREMENT, GENERAL + NEUTRON +

OPERATING EXPERIENCE + TEST, INSTRUMENT RESPONSE

$9-26728$

WILSON I + WHYARD RE + KEATS AB

PULSE CODING TECHNIQUES FOR REACTOR SAFETY LOGIC SYSTEMS

UNITED KINGDOM ATOMIC ENERGY ESTABLISHMENT, WINFR ITH

STI/PUB/115+CN-22/28+. 8 PAGES, 3 FIGURES, 3 REFERENCES, PAGES $497-504$ OF NUCLEAR ELECTRONICS CONFERENCE PROCEEDINGS, BOMBAY, NOVEMBER 22-26, 1965

REACTOR SAFETY LOGIC SYSTEMS FOR USE ON LARGE NUCLEAR POWER STATIONS MUST PROVIDE AN EXTREMELY HIGH RELIABILITY FOR SHUTTING DOWN THE PLANT FOR GENUINE FAULT CONDITIDNS COMBINEO WITH THE CONFLICTING REQUIREMENT OF RELATIVE FREEDOM FROM IJNNECESSARY SHUTOOWNS DUE TO MINOR FAULTS MOST SYSTEMS EMPLOY REDUNDANCY TOGETHER WITH A MAJORITY-VOTE TECHNIQUE. THE USE OF

SOLID-STATE LOGIC ELEMENTS HAS GIVEN RISE TO A RAPIO ADVANCEMENT OF TECHNIQUES. THE PAPER DEALS WITH THE MAJORITY-VOTE PART OF SUCH A SYSTEM AND THE PROBLEM OF BEING ABLE TO TEST THAT THIS PART OF THE SYSTEM IS FUNCTIONING CORRECTLY.

AVAILABILITY - NATIONAL AGENCY FOR INTERNATIONAL PUBLICATIONS, INC., 317 EAST $34 T H$ STREET, NEW YORK, N. Y. $10016 . \$ 13.50$ C.DPY/BDOK

\#REACTOR SAFETY SYSTEM + INSTRUMENTATION, COMPONENT + SOLID STATE DEVICE + TEST, INSTRUMENT RESPONSE

$$
9-26729
$$

$9-2672990$

EVOLUTION OF SAFETY SYSTEMS FOR THE CONTROL OF CEA REACTORS

CENTRE D ETUDES NUCLEAIRES DE SACLAY, FRANCE

STI/PUB/115 + CN-22/17+. 12 PAGES, 10 FIGURES, 13 REFERENCES, PAGES 505-16 OF NUCLEAR ELECTRONICS

CONFERENCE PROCEEDINGS, BOMBAY, NOVEMBER 22-26, 1965

THE EVOLUTION OF SAFETY SYSTEMS IS THE RESULT OF MANY YEARS OF EXPERIENCE IN REACTOR OPERATION, IMPROVED KNOHLEDGE OF REACTOR DYNAMICS, CONSIDERABLE PROGRESS IN SAFETY STIDOIES, NEW CONTROL TECHNIQUES, THE IMPROVED PERFORMANCE OF MEASURING EQUIPMENT, ANO WITH AOVANCES IN ELECTRONIC TECHNOLOGY. IN DESCRIBING THE EVOLUTION OF SAFETY SYSTEMS FOR REACTOR CONTROL THE AUTHOR ANALYSES EACH DF THESE POINTS, TAKING INTO ACCOUNT PAST EXPFRIENCE, CURRENT PROJECTS, OPERATIONAL NEEDS AND PRESENT SAFETY REQUIREMENTS.

AVAILABILITY - NATIONAL AGENCY FOR INTERNATIONAL PUBLICATION, INC., 317 EAST 34TH STREET, NEW YORK, N.Y. $10016, \$ 13.50$ COPY $\$ B O O K$

* REACTOR SAFETY SYSTEM + DESIGN CRITERIA + FRANCE + OPERATING EXPERIENCE + SAFETY REVIEh

$9-26730$

KASARGOD SV

SOLID-STATE LOGIC FOR REACTOR SAFETY SYSTEMS

ATOMIC ENERGY ESTABLISHMENT TROMBAY, BOMBAY, INDIA

$5 T I / P U B / 115+C N-22 / 40+$ + 9 PAGES, FIGURES, 3 REFERENCES, PAGES $517-25$ OF NUCLEAR ELECTRONICS CONFERENCE

PROCEEDINGS, BOMBAY, NOVEMBER 22-26, 1965 
CATEGORY

NUCLEAR INSTRUMENTATION, CONTROL, AND SAFETY SYSTEMS

9-26730 \#CONT INUED*

THIS PAPER DESCRIBES A TRANSISTOR-DIDOE LOGIC SYSTEM FOR REACTOR SAFETY AND INTERLOCK

FUNCTIONS. FACTORS TO $8 E$ CONSIOERED IN THE DESIGN OF SYSTEMS ARE DISCUSSED $8 Y$ TAKINS THE

EXAMPLE OF A TYPICAL REACTOR SCRAM LINE. SOUND DESIGN CALLS FOR PROPER GREUPING OF INPUTS TD

THE SYSTEMS, AND A JUDICIOUS USE OF THE PRINCIPLE OF REDUNDANCY.

AVAILABILITY - NATIONAL AGENCY FOR INTERNATIONAL PUBLICATIONS, INC., 317 EAST 34 TH STREET, NEW YORK, N. Y. $10016, \$ 13.50$ COPY/BOOK

* REACTOR safety sySTEM + design CRITERIA + instrumentation, component + solio state deVICE

$9-26732$

DI GIACOMO G

DESIGN FOR EXPERIMENTAL REACTOR SAFETY CIRCUITS INVOLVING NUMERICAL DATA PROCESSING

GRDUPEMENT ATOMIQUE ALSACIENNE ATLANTIQUE

STI/PUB/115+.CN-22/10+. 12 PAGES, 3 FIGURES, PAGES 545-56 OF NUCLEAR ELECTRONICS CONFERENCE PROCEEOINGS, BOMBAY, NOVEMBER $22-26,1965$

PROBLEMS OF REDUNDANCY OF MEASUREMENTS AND OF INTERSIGNAL COINCIOENCES IS DISCUSSED IV THE DESIGN OF SAFETY CIRCUITS. THE ROLE OF THE DATA-PROCESSING COMPUTER IN THF SAFETY CIRCUITS IS DEFINED, TOGETHER WITH THE EXTENT OF ITS PARTICIPATION IN THE TRIGGERING OF CORRECTIVE ACTION. A BRIEF DESCRIPTION IS GIVEN OF THE GENERAL STRUCTURE OF THE SAFETY CIRCUITS, SHOWING THE APPLICATION OF THE ABOVE PRINCIPLES ANO THE STRUCTURE UF THE NUMERICAL DATA PROCESSING WITH THE ESSENTIAL FEATURES ASSOCIATED WITH SAFETY. THESE INCLUDE IN PARTICULAR THE DUPLICATION OF CERTAIN UNITS AND THE SEPARATION OF MEASUREMENT CHANNELS.

AVAILABILITY - NATIONAL AGENCY FOR INTERNATIONAL PUBLICATIONS, INC., 317 EAST 34 TH STREET, NEW YORK, N.Y. $10016, \$ 13.50$ COPY/BOOK

\#REACTOR SAFETY SYSTEM + DATA PROCESSING + INSTRUMENTATION, COMPONENT + REDUNDANCE + TEST, JN LINE

$9-26733$

PATW ARDHAN PK

THE NEEO FOR A SOPHISTICATION IN MULTIPARAMETER anALYSIS and REAL-TIME DATA PROCESSING

ATOMIC ENERGY ESTABLISHMENT TROMBAY, BOMBAY, INDIA

STI/PUB/115 + CN-22/33 + 19 PAGES, 3 FIGURES, 9 TABLES, 20 REFERENCES, PAGES $575-93$ OF NUCLEAR

ELECTRONICS CONFERENCE PROCEEDINGS, BOMBAY, NOV. 22-26, 1965

\begin{abstract}
DI SCUSSES THE GENERAL REQUIREMENTS OF MULTI-PARAMETER ANALYSERS FOR NUCLEAR RESEARCH. THE USE OF WIRED-PROGRAMME COMPUTERS AND THE CONCEPT OF SYSTEM ORGANIZATION USING AN ON-LINE

SPECIAL-PURPOSE COMPUTER FOR DATA TAKING ANO CLOSED-LOOP CONTROL IS DISCUSSED. A PICTURE OF THE PRESENT STATE OF THE ART AND POSSIBLE TRENDS FOR FUTURE DEVELOPMENT ARE PRESENTED. IMPLEMENTATION OF COMPUTER-BASED CONVENTIONAL AND NUCLEAR REACTOR POWER PLANT CONTROL AND DF IN-PILE LOOP EXPERIMENTS IS ALSO EXPLAINED.
\end{abstract}

AVAILABILITY - NATIONAL AGENCY FOR INTERNATIONAL PUBLICATIONS, INC., 317 EAST $34 T H$ STREET, NEW YORK, N. Y. $10016 . \$ 13.50$ COPY/BOOK

\#DATA PROCESSING + COMPUTFR C.INTRQL + INSTRUMENTATION, CONTROL + REACTOR CONTROL

9-26734 ALSO IN CATEGORY 16

JOSHI CW + INGLE NA + JATHAR NB

AN AUTOMATIC DATA-LOGGING SYSTEM FOR METEOROLOGICAL STUDIES IN REACTOR ENVIRONMENTS

ATOMIC ENERGY ESTABLISHMENT TROMBAY, BOMBAY, INDIA

STI/PUB/115+CN-22/43+. 8 PAGES, 7 FIGURE5, 2 REFERENCES, PAGES 595-602 IN NUCLEAR ELECTRONICS

CONFERENCE PROCEEDINGS, BOMBAY, NOV. 22-26, 1Y65

AN AUTOMATIC DATA-LOGGING SYSTEM WAS DESIGNED FOR METEOROLOGICAL STUDIES FOR THE TARAPUR POWER

REACTOR. THESE STUOIES REQUIP. THE MEASUREMENT TIF WINU SPEED, WIND DIRECTION, ATMOSPHERIC

PRESSURE, TEMPERATURE, ETC., AVERAGED OVER A CERTAIN FIXED PERIOD, AT VARIOUS HEIGHTS ON A

TOWER. THE SYSTEM IS DESIGNEO TO LOG DATA FROM 256 SENSORS. THE DATA ARE FED TO A DIGITAL COMPUTER FOR. ANALYSIS.

AVAILABILITY - NATIONAL AGENCY FOR INTERNATIONAL PUBLICATIONS, INC., 317 EAST 34 TH STREET, NEW YORK, N.Y. $10016, \$ 13.50$. COPY/BOOK

中 DATA PROCESSINC + INSTRUMENTATION, METEDRחI TGITAI + METEOROLOGY

$9-26735$

BLOMBERG PE

P. E. BLOMBERG--SPECIAL CONTRIBUTION TO NUCLEAR ELECTRONICS CONFERENCE PROCEEDINGS, BOMBAY

1 PAGE, PAGE 603 OF NIJ.I,EAR ELECTRONICS CONFERENCE PROCEEDINGS, BOMBAY, NOV. 22-26, 1965

A COMPUTER HILL BE INSTALLED IN SWEOENS SECOND POWER REACTTR, MARVIKEN, A BOILING HEAVY-WATER REACTOR, WITH THE PRIMARY OBJECT OF INCREASING THE SPEED OF STARTUP. EXPERIENCE HAS BEEN GAINED FROM THE AGESTA REACTOR. IN THE MARVIKEN REACTOR, IN-CORE DETECTORS WILL ALSO BE USED FOR INCREASING THE POWER. 
CATEGORY 9

NUCLEAR INSTRUMENTATION, CONTROL, AND SAFETY SYSTEMS

$9-26735$ \#CONTINUED*

AVAILABILITY - NATIONAL AGENCY FOR INTERNATIONAL PUBLICATIONS, INC., 317 EAST $34 T H$ STREET, NEW YORK, N. Y. $10016, \$ 13.50$ COPY/BOOK

\#COMPUTER CONTROL + INSTRUMENTATION, STARTUP + REACTOR CONTROL + REACTOR, BWR + SWEDEN

$9-26736$

KING ESF

STEPPING MOTORS ANO ASSOCIATED ELECTRONIC CIRCUITS FOR REACTOR CONTROL

UNITED KINGOOM ATOMIC ENERGY AUTHORITY, HARWELL

10 PAGES, 10 FIGURES, 1 TABLE, 7 REFERENCES, PAGES 613-22 OF NUCLEAR ELECTRONICS CONFERENCE PROCEEDINGS, BOMBAY, NOVEMBER 22-26, 1968

ELECTRICAL STEPPING MOTORS ARE NOW AVAILABLE WHICH ARE VERY SUITABLE FOR USE WITH REACTOR

CONTROL RODS. THE MOTORS MAY HAVE THREE OR FOUR WINDINGS AND ARE DRIVEN BY D.C.

PULSE-GENERATORS SPECIALLY DESIGNED FOR THE PARTICULAR REACTOR APPLICATION. SIX VERTICALLY

ACTING CONTROL RODS WITH STEPPING MOTORS WILL BE INSTALLED IN THE HIGH-FLUX RESEARCH REACTOR PLUTO.

AVAILABILITY - NATIONAL AGENCY FOR INTERNATIONAL PUBLICATIONS, INC., 327 EAST 34 TH STREET, VEW YORK, N.Y. $10016, \$ 13.50$ COPY $/ B O O K$

*CONTROL ROD DRIVE + DESIGN STUDY + EQUIPMENT DESIGN + INSTRUMENTATION, COMPONENT + UNITED KINGOOM

9-26739 ALSD IN CATEGORY 17

CONTROL ROD STARTERS WITHDRAWN

UNIVERSITY OF CALIFORNIA, LOS ANGELES

1 PAGE, LETTER TO D. J. SKOVHOLT. LETTER TO D. J. SKOVHOLT FROM CRAIG B. SMITH. JUNE 26,1968 . DOCKET 50-142.

DURING THE 19 JUNE 1968 PRESTART CHECKOUT, CONTROL BLADE NO. I DIO NOT RETURN TO THE DOWN POSITION WHEN DROPPED. WHATEVER IS INHIBITING MOTION IS NOT IN THE ORIVE. WE HAVE REMOVED THE FUEL AND ARE UNSTACK ING THE GRAPHITE CENTER ISLANO TO LOCATE THE DIFFICULTY.

AVAILABILITY -- PUBLIC DOCUMENT ROOM, WASHINGTON, O.C.

ARGONAUT (TNG) + FAILURE, SCRAM MECHANISM + REACTOR, RESEARCH

9-26740 ALSO IN CATEGORY 17

MARK T TRIGA CONTROL ROD STICKS

GENERAL DYNAMICS, GENERAL ATOMIC DIVISION

2 PAGES, LETTER TO D. J. SKOVHOLT, DRL. FROM LETTER TO D. J. SKOVHOLT FROM E. CREUTZ. JUNE 28 , 1968. DOCKET 50-163.

ON MAY 29, DURING A ROUTINE PULSE AT THE MARK F, THE SHIM ROD STOPPED 3 IN. SHORT OF FULL INSERTION FOLLOWING THE ROUTINE SCRAM. SHUTDOWN MARGIN WAS 1.27 WITH THIS ROD FULL OUT. 50\% OF THE SUBSEQUENT TEST DROPS SHOWED ROD STOPPED 3 IN. SHIRT, IN $50 \%$ ROD FELL FULLY DOWN. AFTER ADJACENT ELEMENTS WERE CHECKED FOR INTERFERENCE, ROD DROPPED FREELY. REACTOR RETURNED TO SERVICE JUNE 7 AFTER DISCUSSION WITH CAMPLIANCE. EXACT CAUSE NOT RESOLVED, BUT MOST

PROBABLE CAUSE WAS IMPROPERLY SEATED ELEMENT OR TEMPORARY FOREIGN OBJECT IN THE DASH POT.

AVAILABILITY -- PUBLIC DOCUMENT ROOM, WASHINGTON, D.C.

\#FAILURE, SCRAM MECHANISM + FUEL ELEMENT + FUEL HANDLING + OBSTRUCTION + REACTOR, PULSED +

REACTOR, RESEARCH + SAFETY REVIEW + TEST, SYSTEM OPERABILITY + TRIGA (RR)

9-26741 ALSO IN CATEGORY 17

SIX MONTHS OPERATIONS SUMMARY JAN TO JUN 19,1968

UNI VERSITY OF TEXAS

3 PAGES, LETTER TO P. A. MORRIS, DRL. FROM LETTER TO P. A. MORRIS FROM S. J. GAGE. JUNE 20 , 1968, DOCKET 50-192.

TWO FUEL ELEMENTS WERE AODED ANO POWER LEVEL INCREASED TO $250 \mathrm{KW}$ ON APRIL 2 . AN 8400-CURIE CO-60 SOURCE WAS INSTALLED IN THE REACTOR-POOL IRRADIATOR. A 4-IN.-DIA, PORTABLE, VERTICAL BEAM TUBE WAS INSTALLED AFTER REACTOR COMMITTEE DETERMINED IT DID NOT INVOLVE A TECH.-SPEC. CHANGE OR AN UNREVIEWED SAFETY QUESTION. THE LOWER END RESTS ON THE GRAPHITE REFLECTDR, AND THE UPPER END EMERGES NEAR THE BRIDGE, WITH A BEAM CATCHER REDUCING BRIOGE RADIATION TO LESS THAN 50 MRIHR AT $250 \mathrm{KW}$. FOLLOWING COMPLIANCE SUGGESTIONS, AN ELECTRONIC TEST CIRCUIT WAS ADDED TO THE POWER CHANNEL, WHICH ALLOWS CHECKOUT OF ALL COMPONENTS EXCEPT UCIC. JUNE II LETTER SENT DESCRIBING SMALL RAOIOCHEMISTRY LABORATORY.

AVAILABILITY -- PUBLIC DOCUMENT ROOM, HASHINGTON, D.C.

\# BEAM HOLE + FTEST, SYSTEM OPERABILITY + COBALT + INSPECTION AND COMPLIANCE +

INSTRUMENTATION, POWER RANGE + NEUTRON + POWER UPRATING + RADIATION SAFETY AND CONTRQL + RADIOGRAPHY. + REACTOR, RESEARCH + REPORT, OPERATIONS SUMMARY + SAFETY REVIEW + SHIELDING + SOURCE, RADIATION + TRIGA (RTR) 
CATEGORY

NUCLEAR INSTRUMENTATION, CONTROL, ANO SAFETY SYSTEMS

9-26747

GROSE VL

RELIABILITY AND HOW IT GREW

3 PAGFS, EVALUATION ENGINEERING, VOL. 7, PAGES 46-48 (JAN-FE8 1968), ABSTRACT IN RELIABILITY ABSTQACTS ANO TECHNICAL REVIEWS $8(6)$, PAGE 83 (JUNE 1.968)

A HISTORICAL APPROACH. TO THE GROWTH OF INDUSTRIAL RELIABILITY PROGPAMS IS PRESENTED, AND THE IMPORTANCE OF MANAGEMENT PLANNING BY LARGE-SCALE PRDDUCTION FACILITIES IS NOTEO. THE FACT THAT RELIABILITY PROGRAMS GREW BECAUSE OF THE COMPLEXITY ANO UNRELIABILITY OF EOUIPMENT FOLLOWING WORLD WAR II IS NOTED, AS ARE SO-CALLED RELIABILITY GROWING PAINS. MENTION IS MADE UF THE ROLE OF THE STATISTICIAN, THC GENERATION DF GOVERNMENT SPECIFICATIMNS, AND THE IMPETUS OF INCENT IVE CONTRACTING AND SPACE-RELATED RESEARCH PROGRAMS IN FOSTERING CONCERNED RELIABILITY PROGRAMS.

RELIABILITY ANALYSIS + SURVEY, GENERAL

$9-26748$

TIGER B

DOES RELIABILITY PREDICTION HELP MAKE THE SYSTEM GO

R ADIO CORP. OF AMERICAN, BURLINGTON, MASS

3 PAGES, 3 REFERENCES, PAGES 573-75 OF ANNALS OF RELIABILITY AND MAINTAINABILITY- ANNUAL RELIASILITY AND MAINTA INABILITY CONFERENCE, 6TH, COCMA BEACH. FLA., JULY 17-19, 1967, PROCEEDINGS, VOLUME S, NEW YORK SOCIETY OF AUTOMOTIVE ENGINEERS, INC., ABSTRACT IS RELIABILITY ABSTRACTS AND TECHNICAL REVIEWS 8 IEI, HAGE 86 (JUNE 1968 )

UTILITY, PRACTICALITY, AND VALIDITY OF RELIABILITY PREDICTION TOOLS ARE DISCUSSED. THE UNDERSTANDING DF DESIGN, PRODUCT ION, USAGE, AND MANAGEMENT DROSLFMS IS CONSIDERED A MUST BEFORE THE APPLICATION DF MATHEMATIGAL TECHNIQUES CAN BE SUCCESSFULLY APPLIED TO IDENTIFY THE BEST POSSIBLE SYSTEMS AT THE LOWEST POSSIBLE COSTS. IT IS NOTED THAT THE USE OF RELIABILITY PREDICTION HAS BEEN HANDICAPPED BY OVEREMPHASIZING THE SIMPLICITY OF PREDICTION TECHNIQUES. EMPHASIS ON BETTER COMMUNICATION AND GREATER ASSISTANCF IN DECISIJN MAKING DURING DESIGN AND PRODUCTION IS STRESSED. THOSE WHO HAVE BEEN HEAVILY INVOLVED IN RELIABILITY OREDICTIONS WILL RECOGNIZE THE FRUSTRATIONS BEING TOUCHED ON IN THIS PAPER.

* REL I ABILITY anALYSIS

$9-26749$

A SHENDORF G

PITFALLS IN RELIABILITY PREDICTIONS

RADIO CORP. OF AMERICA, NEW YORK

6 PAGES, PAGES 576-581 OF ANNALS OF RELIABILITY AND MAINTAINABILITY. ANNUAL RELIABILITY AND

MAINTAINABILITY CONFERENCE, 6TH, COCOA BEACH, FLA., JULY 17-19, 1967, PROCEEDINGS. VOL. 6, $\triangle B B S T R A C T$ IN

RELIABILITY ABSTRACTS AND TECHNICAL REVIEWS 8(6), PAGE 86 (JUNE 1962 )

PROBLEMS THAT REQUIRE RELIABILITY PREDICTION AS THE BASIS OR ONE OF THE SASES FOR DECISITN MAKING ARE DISCUSSED. WTTH THE NOTE THAT RELIABILITY PRECICTIOV CAPABILITY VARIES WITH EACH SITUATION. FACTORS WHICH CONTRIBUTE TO INACCURACIES IN FINAL PREOICTIONS ARE IOENTIFIEE, AND THE PLACES AT WHICH DECISIONS ARE MADE ARE POINTED JUT. DECISION MAKING PROCESSES ARE REVIEWEO IN THE CHRONOLOCICAL ORDER IN WHICH THEY APPEAR IN THE VARIOUS FUNCTIONAL PHASES OF A DEVELOPMENT PROGRAM FROM THE PROGRAM DEFINITIUN, PRELIMINARY DESIGN AND SYSTEMS DLANNINC, . DETAILED DESIGN, TO THE ACTUAL RELIABILITY DEMONSTRATION. TABLES DETAIL THE RELIABILITY PREDICTION PITFALLS AT EACH OF THESE PHASES. PRACTICALITY AND VALIDITY OF PREDICTIONS ARE DISCUSSED.

\#RELIABILITY ANALYSIS

$9-26750$

PATTERSON RL

RELIABILITY MODELS FUR DEPENDENT ELEMENTS USING A METHOD OF CORRELATIONS UNIVERSITY OF FLORIDA, GAINESVILLE

5 PACES, I REFERENCE, PAGES 364-386 OF ANNALS OF RELIABILITY AND MAINTAINABILITY. ANNUAL RELIABILITY AND MA INTAINABILITY CONFERENCE, GTH, COCOA BEACH, FLA., JULY 17-19, 1967, PROCEEDINGS, VOLUME G. NEW YORK SOCIETY OF AUTOMOTIVE ENGINEERS, INC., ASSTRACT IN RELIABILITY ABSTRACTS AND TECHNICAL PEVIEWS E(6), PAGE 91 (JUNE 1968 )

MODELS ARE GENERATED BASED ON THE ASSUMPTION THAT THE INTERACTION OF COMPONENTS GENERATES LINEAR STATISTICAL CORRELATIONS AMONE THE CONDITIIONS OF GROUPS OF COMPONENTS. THESE INTERACTION EFFECTS MAY BE DUE TO ACTIVE PHYSICAL MECHANISMS OR MAY BE PRESENT EVEN THOUGH THE ELEMENTS OF THE SYSTEM ARE PHYSICALLY INDEPENDENT. FORMULAS ARE OEVELOPED FOR SYSTEMS IN WHICH THE ELEMENTS ARE IN SERIES. THE CASE OF TWO PHYSICALLY SEPARATED FIBERS, EACH SUBJECTED TO A RANDOM LOAD, IS CONSIDERED. IT SHOWS THAT THE RESULTING EQUATION CAN BE APPROXIMATED WHEN THE CORRELATION COEFFICIENT IS LARGE. THIS APPROXIMATION CAN BE GENERALIZED AND RELATED TO THE HAZARD RATES THAT DEFINE FAILURE OF A STAGE. A RELIABILITY MODEL IS ALSO ODTAINED FOR A SYSTEM COMPOSED OF INTERAT.TING STAGES IN PARALLEL.

* RELIABILITY anALYSIS + analytical mOdel + STATISTICAL CORRELATION 
CATEGUKY 9

NUCLEAR INSTRUMENTATION, CONTROL, AND SAFETY SYSTEMS

$9-26751$

GERT SBAKH IB

OPTIMAL CONTROL OF SWITCHING ON RESERVE ELEMENTS

8 PAGES, REFERENCES, TECH. CYBERNETICS, NO. 5, PAGES 106-113 (JAN. 1967), ABSTRACT [N RELIABILITY ABSTRACTS AND TECHNICAL REVIEWS 8(6), PAGE 93 (JUNE 1968)

$\triangle$ RESERVED SYSTEM IS INVESTIGATED, THE TESTING OF WHICH MAY TAKE PLACE JNLY at DETERMINATE POINTS IN TIME. THE NUMBER OF ELEMENTS INCLUDED IN THE HOT RESERVE AFTER THE NEXT CHECK IS SELECTED WITH THE INTENTION OF MINIMIZING THE PROBABILITY OF SYSTEM FAILURE DURING THE COURSE OF THE GIVEN DPERATING TIME. THE ALGORITHM IS PRESENTED FOR FINDING THE OPTIMAL POLICY FOR SWITCHING ON THE RESERVE ELEMENTS, AND SOME OF ITS PROPERTIES ARE INVESTIGATED.

\#RELIABILITY, SYSTEM + REDUNDANCE + TEST, SYSTEM OPERABILITY

$$
9-26752
$$

EL MAWAZINY AH + BUEHLER RJ

CONFIDENCE LIMITS FOR THE RELIABILITY OF SERIES SYSTEMS

IOWA STATE UNIVERSITY, AMES + UNIVERSITY OF MINNESOTA, MINN.

7 PAGES, 8 REFERENCES, JOURNAL OF THE AMERICAN STATISTICAL ASSOCIATION, VOL 62, PAGES 1452-1450 (DECEMBEP 1967), ABSTRACT IN RELIABILITY ABSTRACTS AND TECHNICAL REVIEWS 8(6), PAGE S3 (JUNE 1968)

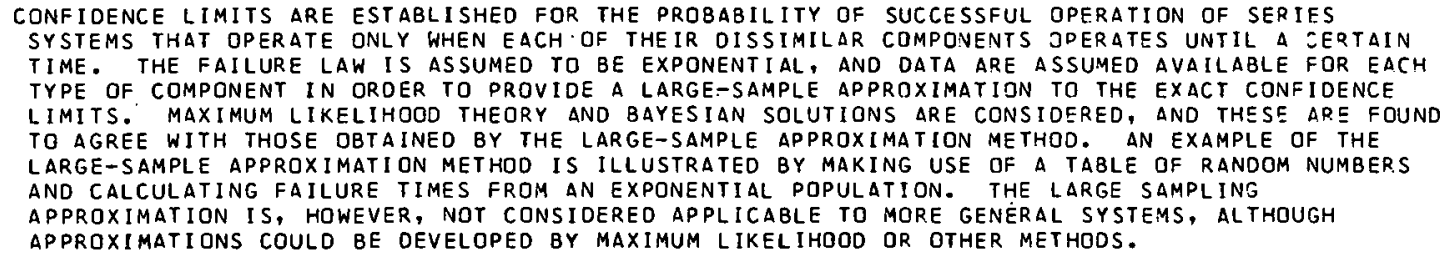

* REL IABILITY ANALYSIS + MATHEMATICAL TREATMENT + RELIABILITY, SYSTEM + THEORETICAL INVESTIGATION

$9-26753$

SEDYAKIN NM

A PHYSICAL RELIABILITY THEORY

9 PAGES, 5 REFERENCES, ENGINEER ING CYBERNETICS, NO. 3, PAGES 295-303 (MAY-JUN 1966), ABSTRACT IN

RELIABILITY ABSTRACTS AND TECHNICAL REVIEHS 8(6), PAGE 93 (JUNE 1968)

HAZARD RATE AND CUMULATIVE HAZARD FUNCTION ARE DEVELOPED OURING THE FORMULATION OF A PHYSICAL - LAW THAT GOVERNS THE RELIABILITY OF MATERIALS ANO SYSTEMS, AND MATHEMATICAL MODELS ARE CONSTRUCTED TO GIVE A QUANTITATIVE DESCRIPTION OF THE PROCESSES THAT. INFLUENCE THE

RELIABILITY OF A BROAD CLASS OF SYSTEMS. A SOLUTION IS OFFERED FOR THE CASE OF A SYSTEM THAT

CONSISTS OF TWO OEVICES, ONE FUNCTIONALLY NECESSARY AND THE OTHER A RESERVE, AND DETAILS ARE

INCLUDED FOR VARIOUS BREAKDOWN SITUATIONS THAT COULD ARISE FOR SUCH A SYSTEM.

\#RELIABILITY ANALYSIS + FAILURE, COMPONENT + MATHEMATICAL TREATMENT + RELIABILITY, CQMPONENT

$9-26754$

NATHAN

SYSTEMS AVAILABILITY MODEL ING, CONSIDERING COMPLEX AND IMPERFECT SPARING

ANATHON, INC., NEW YORK

11 PAGES, 6 REFERENCES, IEEE TRANSACTIONS ON AEROSPACE ANO ELECTRONIC SYSTEMS, SUPPL., VOL. AES-2, PAGES

183-193 (1966), NEW YORK, IEEE, INC., ABSTRACT IN RELIABILITY ABSTRACTS AND TECHNICAL REVIEWS 8(6), PAGE

93 (JUNE 1968

THE IMPOPTANCE OF RLALISTIC SYSTEMS AVAILABILITY IREADINESSI MODELS FOR USEFUL SYSTEMS AND COST EFFECTIVENESS ANALYSIS AND EVALUATION IS DISCUSSED. A METHOD IS PRESENTED WHICH CONSIDERS ( 1 ) DIFFERENT TYPES OF IMPERFECT FAILURE DETECTION, (2) VARIOUS REPLACEMENT STRATEGIES, WITH IMPERFECT REPLACEMENTS AND LIMITED SPARES, (3) DIFFERENT TYPES OF SCHEDULED INSPECTIONS, AND (4) NONINSTANTANEOUS REPLACEMENT RATES AND SOME TYPES OF NONINSTANTANEOUS FAILURE DETECTION

\#REL IABILITY ANALYSIS + ANALYTICAL MOOEL + ECONOMICS + THEORETICAL INVESTIGATION

$9-26755$

BRAY TA + CRAWFORD GB + PROSCHAN F

MAXIMUM LIKELIHOOD ESTIMATION OF A U-SHAPED FAILURE RATE FUNCTION

44 PAGES, REFERENCES, MATHEMATICAL NOTE NO. 534, OCTOBER 1967. ABSTRACT IN RELIABILITY ABSTRACTS ANO TECHNICAL. REVIEWS $8(6)$, PAGE 95 (JUNE 1968)

A MAXIMUM LIKELIHOOD ESTIMATE (MLE) IS DERIVED FOR THE FAILURE RATES AS A FUNCTION OF AGE BASED ON INCOMPLETE OATA, ASSUMING THE FAILURE RATE FUNCTION IS INITIALLY DECREASING AND 
CAT.EGORY 9

NUCLEAR INSTRUMENTATION, CONTROL, AND SAFETY SYSTEMS

$9-26755$ \#CONTINUED*

SUBSEQUENTLY INCREASING, WITH THE TURNING POINT UNKNOWN. ÁN ALGORITHM FOR COMPUTATION OF THE MLE IS DEVELOPED. A SMALL WORKED EXAMPLE IS INCLUDED TO SHOW IN DETAIL THE STEPS OF THE ALGORITHM. A PROGRAM FOR MACHINE COMPUTATION IS PRESENTED. THE MLE IS SHOWN TO BE A CONSISTENT ESTIMATER. NO FURTHER ASSUMPTION IS REQUIREO AS TO THE MATHEMATICAL FORM OF THE LIFE-LENGTH DISTRIBUTION (SUCH AS EXPONENTIAL, WEIBULL, NORMAL, ETC.). THUS THE MODEL MAY BE REALISTICALLY APPLIED IN A VARIETY OF RELIABILITY SITUATIONS, WHERE THE SO-CALLED BATHTUB SHAPED FAILURE RATE IS APPROPRIATE.

*RELIABILITY ANALYSIS + COMPUTER PROGRAM + FAILURE, COMPONENT + MATHEMATICAL TREATMENT + STATISTICAL ANALYSIS + THEORETICAL INVESTIGATION

$9-26756$

FEDUCCIA AJ + KLION J

HOW ACCURATE ARE RELIABILITY PREDICTIONS

8 PAGES, 8 REFERENCES, PAGES 280-287 OF ANNALS OF ASSURANCE SCIENCES. PROCEEOINGS OF THE ANNUAL SYMPOSIUM ON RELIABILITY, BOSTON, MASS, JAN. 16-18, 1968 , ABSTRACT IN RELIABILITY ABSTRACTS $\triangle N D$ TECHNICAL REVIEWS $8(6)$, PAGE 96 (JUNE 1968)

EVALUATION OF ACCURACY OF STRESS-ANALYSIS RELIABILITY PREDICTION TECHNIOUES. METHODS ARE DESCRIBED WHIC.H CAN BE USEO (I) TO COMPUTE CONFIDEVCE INTERVALS ABDUT A PREDICTED VALUE AND (2) TO ADVANTAGEOUSLY DERIVE RELIABILITY DEMONSTRATIDN PLANS THAT CAN REDUCE TEST TIME. (REVIEW) THE APPROACH IS THAT OF TRYING TO FIND THE FREQUENCY DISTRIBUTION OF THE RATIO OF PREDICTED TO OBSERVED MEAN TIME BETWEEN FAILURES, THEN USING THAT INFORMATION AS AN A PRIORI DISTRIBUTION FOR A BAYES ESTIMATE.

* Reliability analysis + failure, component + STATISTICAL anAlysis

$9-26757$

SCHICK GJ

BAYESIAN CONCEPTS FOR RELIABILITY AND CONFIDENCE

9 PAGES, 20 REFERENCES, PAGES 297-405 OF ANNALS OF ASSURANCE SCIENCES, PROCEEDINGS OF THE ANNUAL SYMPOSIUM ON RELIABILITY, BOSTON, MASS, JAN 16-18, 1968, ABSTRACT IN RELIABILITY ABSTRACTS AND TECHNICAL REVIEWS 8(6), PAGE 97 ( JUNE 1968 )

COMPARISON OF THE CLASSICAL ANO BAYESIAN APPROACHES TO RELIABILITY ESTIMATION OF COMPLEX SYSTEMS AT A SPECIFIED CONFIDENCE LEVLE. WHILE THE BASIC ASSUMPTIONS ARE CLEARLY STATED FOR EITHER OF THE TWO APPROACHES, AND WHILE THE TWO METHODS DIFFER CONSIDERABLY, THE PHILOSOPHICAL QUESTIONS UNDERLYING THE ASSUMPTIONS ARE NOT DISCUSSED. SOME OF THE MISUSES OF THE LAPLACE RULE OF SUCCESSION ARE GIVEN THROUGH PRACTICAL EXAMPLES, AND WAYS OF AVDIDING THESE PITFALLS ARE INDICATED. THE BAYESIAN METHOD ANO ITS APPROPRIATE COMPUTER PROGRAM FOR FINDING EXACT CONFIDENCE LIMITS FOR THE SYSTEM RELIABILITY OF COMPLEX MISSILE SYSTEMS IS OISCUSSED IN DETAIL.

\#RFI IABILITY ANALYSIS + COMPUTER PROGRAM + MATHEMATICAL TREATMENT + RELIABILITY, SYSTEM + STATISTICAL ANALYSIS

$9-26758$

AMSTADTER RB

PREDICTION OF SYSTEM RELIABILITY BY METHOD OF BOUNDS

AEROJET-GENERAL CORP., CALIF.

8 PAGES, PAGES 423-430 IN ANNALS OF ASSURANCE SCIENCES. PROCEEDINGS OF THE ANNUAL SYMPOSIUM ON

RELIASILITY, BOSTON, MASS., JAN 16-18, 1968 , ABSTRACT IN RELIABILITY ABSTRACTS AND TECHNICAL REVIEWS

$8(6)$, PAGE 98 (JUNE 1968 )

DEFINITION OF THE REFINEMENT OF A NEW METHOD OF RELIABILITY PREDICTION FOR COMPLEX SYSTEMS. THE METHOD INVOLVES THE CALCULATION OF BOTH UPPER AND LOWER BOUNOS AND PROCEDURE FOR COMBINING THE THO TO YIELD A REALIST ICALLY RRECISE ESTIMATE OF THE TRUE VALUE. THE REFINEMENT INCLUDES THE CONSIDERATION AND USE OF FAILURE MODES AND THEN PROBABILITIES OF OC.CURRENCE. THE METHOO CAN BE USED BOTH AS AN EXCELLENT SUBSTITUTE FOR MORE TIME-CONSUMING QUASI-EXACT PROCEDURES, AND ALSO FOR THOSE SYSTEMS FDR WHICH FXACT PROCECURES CANNJT BE DEVELOPED AND FOR WHICH MONTE CARLO TECHNIQUE ARE EXCESSIVELY COSTLY.

\#RELIABILITY ANALYSIS + PROBABILITY + RELIABILITY, SYSTEM + STATISTICAL ANALYSIS

$9-26759$

DOYON LR + BERSSENBRUGGE MW

SOLVING COMPLEX REL IABILITY MODELS BY COMPUTER

NORTHEASTERN UNIVERSITY + RAYTHEON COMPANY, BEDFORD, MASS

18 PAGES, 11 REFERENCES, PAGES $431-448$ IN ANNALS OF ASSURANCE SCIENCE. PROCEEDINGS DF THE ANVUAL SYMPOSIUM ON RELIABILIT.Y, BOSTON, MASS., JAN. 16-18, 1968, ABSTRACT IN RELIABILITY ABSTRACTS $\triangle N$ I TECHNICAL REVIEWS $8(6)$, PAGE 98 (JUNE 1968)

DISCUSSION OF THE USE OF DIGITAL COMPUTERS TO SOLVE RELIABILITY AVAILABILITY/MTBF (MEAN-TIME-BETWEEN-FAILURE) MODELS OF COMPLEX SYSTSMS. ACTUAL-CASE PROBLEMS WITH SOLUTIONS ARE PRESENTED FOR SOLVING MISSION-RELIABILITY, INSTANTANEOUS-AVAILABILITY, AND INTERVAL-AVAILABILITY PROBLEMS. USE IS MADE OF A METHOD OF TRANSLATING EACH 
CATEGORY

NUCLEAR INSTRUMENTATION, CONTROL, AND SAFETY SYSTEMS

9-26759 \#CONTINUED*

ELECTRONIC-SYSTEM OPERATIONAL STATE DEPICTED IN THE FLOW GRAPHS AS DIFFERENTIAL EQUATIONS IN THE TIME DOMAIN. BY AN ITERATIVE COMPUTER PROCEOURE, SOLUTIONS IN THE TIME DOMAIN ARE OBTAINED WITHOUT HAVING TO TRANSFORM THE EXPRESSIONS TO AND FROM THE COMPLEX DOMAIN. THE COMPUTER PROGRAM IS A DOUBLE-PRECISION DIGITAL PROGRAM CALLED OIFF, FOR SOLVING SETS OF DIFFERENTIAL EQUATIONS WITH AS MANY AS 99 UNKNOWNS.

*RELIABILITY ANALYSIS + ANALYTICAL MDDEL + COMPUTER PROGRAM

$9-26760$

COWAN JD

RELIABLE COMPUTATION WITH UNRELIABLE ELEMENTS

IMPER I AL COLLEGE OF SCIENCE AND TECHNOLOGY, LONDON

17 PAGES REFERENCES OF AD-646625 AND N67-26806, ABSTRACT IN RELIABILITY ABSTRACTS AND TECHNICAL REVIEWS 8(6). PAGE 100 (JUNE 1968)

DISCUSSES COMPUTER SYSTEM DESIGNS FOR OPERATION AT ANY REQUIRED LEVEL OF RELIABILITY, GIVEN UNRELIABLE ELEMENTS. METHODS DISCUSSED ARE - CONTROL OF STATIONARY ERRDRS AND FAULT-MAKING OF TRANSIENT ERRORS.

AVAILABILITY - CLEARINGHOUSE FOR FEDERAL SCIENTIFIC AND TECHNICAL INFORMATION, SPRINGFIELO, VA. 22151 , \$3. 0.0 COPY, \$O.65 MICROF ICHE

*RELIABILITY ANALYSIS + RELIABILITY, COMPONENT

$9-26761$

GILMORE DB

APPLICATION OF A MONTE CARLO METHOD TO THE DETERMINATION DF MEAN TIME TO FAILURE OF COMPLEX SYSTEMS JOHNS HOPKINS UNIVERSITY

6 PAGES, PAGES 391-396 IN ANNALS OF ASSURANCE SCIENCES. PROCEEDINGS OF THE ANNUAL SYMPGSIUM ON RELIABILITY, BOSTON, MASS., JAN. 16-18, 1968, ABSTRACT IN RELIABILITY ABSTRACTS AND TECHNICAL REVIEHS 8(6). PAGE 100 (JUNE 1968)

A MONTE CARLO SIMULATION IS DESCRIBED FOR DETERMINING THE MEAN TIME TO FAILURE OF CDMPLEX ELECTRONIC EQUIPMENT WITH ONE OR MORE ACTIVE JR STANDBY REDUNDANT ELEMENTS. A RELIABILITY BLOCK IS BASED ON THIS DIAGRAM. BOTH BLOCK DIAGRAM AND MATHEMATICAL MODEL ARE PRESENTED FOR A TYPICAL SYSTEM THAT IS THEN ANALYZED BY THE MONTE CARLO STATISTICAL TECHNIQUE THAT REQUIRED LITTLE MATHEMATICAL KNOW-HOW.

*RELIABILITY ANALYSIS + ANALYTICAL MODEL + FAILURE, COMPONENT + MONTE CARLO + REDUNDANCE + RELIABILITY, SYSTEM + STATISTICAL ANALYSIS

$9-26762$

PLYER CH + WOOD WP

BUILDING IN RELIABILITY

MARTIN MARIETTA CORPORATION, MO.

5 PAGES, 8 REFERENCES, PAGES 369-373 IN ANNALS OF RELIABILITY AND MAINTAINARIIITY, $\triangle N N U A L$ RELIABILITY AND MA INTAINABILITY CONFERENCE, 6TH, COCOA REACH. FLA, JULY 17-19 1967, PROCEEOINGS. VOLUME G - ALL SYSTEMS GO. ABSTRACT IN RELIABILITY ABSTRACTS AND TECHNICAL REVIEWS 8(6), PAGE IOII (JUNE 1968)

DISCUSSION OF THE FAILURE MOOE AND EFFECTS ANALYSIS, CRITICAL CHARACTERISTICS DETERMINATION, SAFETY FEATURES, AND TEST EQUIPMENT COMPLEXITY AS THE COMPONENTS OF AN IN-HOUSE PROCESS CONTROL PROGRAM HAVING SPECIAL SIGNIFICANCE IN THEIR HIGH PAYOFF IN PRODUCT INTEGRITY FOR AEROSPACE MISSIONS. RELIABILITY REQUIREMENTS ARE USED TO DEVELOP QUALITY REQUIREMENTS FOR PROCESS CONTROL AND A SIMPLE METHOD FOR IN-PROCESS DATA ANALYSIS IS DESCRIBED. THIS REJECT PATTERN ANALYSIS RELATES THE COST OF FAILURE TO THE COST OF REPAIR. DATA ARE ALSO GIVEN TO PROVE THE NEED FOR PRODUCT BURN-IN AND SCREENING.

\#RELIABILITY, COMPONENT + DESIGN CRITERIA + EQUIPMENT OESIGN + TESTING

$9-26763$

COTIIFRIED P, WEISS DW

RELIABILITY PREOICTION WITH INADEQUATE DATA

BOOZ-ALLEN APPLIED RESEARCH, INC., BETHESDA MD.

8 PAGES, 13 REFERENCES, PAGES 600-607 IN ANNALS OF RELIABILITY AND MAINTAINABILITY, ANNUAL RELIABILITY AND MAINTAINABILITY CONFERENCE, 6TH COCOA BEACH, FLA., JULY 17-19, 1967, PROCEEOINGS. VOL 6--ALL SYSTFMS GO, ABSTRACT IN RELIABILITY ABSTRACTS AND TECHNICAL REVIEWS 8(6), PAGE 102 (JUNE 1968 )

DESCRIPTION OF AN APPROACH TO NONELECTRONIC RELIABILITY PREDICTION WITH INAOEQUATE DATA. THE LACK OF SUFFICIENT DATA CREATES THE NEED TO IMPROVE PREDICTION ACCURACY AND TO OUANTIFY THE UNCERTAINTY ASSOCIATEO WITH THE PREDICTIONS. THE PROPOSED APPROACH WAS DEVELOPEO FOR RELIABILITY PREOICTION IN FLIGHT CONTROL SYSTEMS, BUT ITS TECHNIQUES ARE BELIEVED TO BE BROADLY APPLICABLE.

\#RELIABILITY ANALYSIS 
CATEGORY

NUCLEAR INSTRUMENTATION, CONTROL, AND SAFETY SYSTEMS

9-26764

JORDAN JR + BUCHANAN RL

SYSTEM SAFETYY-A OUANTITATIVE FALLDUT FROM RELIABILITY ANALYSIS

MCDONNELL DOUGLAS CORP., CALI.F.

8 PAGES, 5 REFERENCES, PAGES 653-660 IN ANNALS OF REL IABILITY AND MAINTAINABILITY, ANNUAL RELIABILITY AND

MAINTAINABILITY CONFERENCE, 6TH COCOA BEACH, FLA., JULY 17-19, 1967, PROCEEDINGS. VOL. 6--ALL SYSTEMS

GO. ABSTRACT IN RELIABILITY ABSTRACTS ANO TECHNICAL REVIEWS 8(6), PAGE 102 (JUNE 1968 )

DESCRIPTION OF A METHOOFFOR QUANTITATIVELY EVALUATING THE SAFETY OF A SYSTEM BY UTILIZING EXISTING RELIABILITY TECHNIQUES AND DATA. THE PREMISE DEVELOPED IS THAT CREW SAFETY IS A SPECIAL CASE OF SYSTEM SAFETY. THEREFORE, THE RELIABILITY ANALYSIS AND MATHEMATICAL MODELS DEVELOPED TO EVALUATE CREW SAFETY ARE CONSIDERED APPLICABLE TO A SYSTEM-SAFETY ANALYSIS. SYSTEM SAFETY IS DEVELOPED AS THE PROBABILITY OF SUCCESSFULLY COMPLETING OR SAFELY ABORTING A GIVEN OPERATION OR TEST.

*RELIABILITY, SYSTEM + SAFETY EVALUATION + SAFETY REVIEH

$9-26765$

TROXEL DI + TIGER B

PREOICTING INTEGRATED CIRCUIT RELIABILITY VIA FAILURE MECHANISMS

RADIO CORP. OF AMER ICA, N.J.

9 PAGES, 4 REFERENCES, PAGES 217-225 IN ANNALS OF ASSURANCE SCIENCES, PROCEEDINGS OF THE ANNUAL SYMPOSIUM ON RELIABILITY, BOSTON, MASS. JAN 16-18, 1968 , ABSTRACT IN RELIABILITY ABSIRACTS AVD TECHINICAL REVIEHS

8(6), PAGE 104 (JUNE 1968)

A STRESS SURVIVAL MATRIX TEST AND A PHYSICAL EFFECTS ANALYSIS PROGRAM WERE CONDUCTED ON MONOLITHIC SILICON INTEGRATED CIRCUITS TO DETERMINE RELIABILITY AS A FUNCTION OF FAILURE MECHANISMS. RESULTS INDICATED THAT RELIABILITY OF A PROPERLY USED CIRCUIT WAS NOT PRIMARILY A FUNCTION OF TEMPERATURE, POWER, OR SHOCK DURING USAGE BUT RATHER OIRECTLY DEPENDENT UPON SCREENING EFFECTIVENESS DURING PROOUCTION, PRODUCTION ABERRATIONS THAT CAN LEAD TO FAILURE IN THE FIELO, AND LIFE DISTRIBUTIONS AND ENVIRONMENTAL SUSCEPTIBILITIES OF UNITS UNDERGOING THESE FAILURE MECHANISMS.

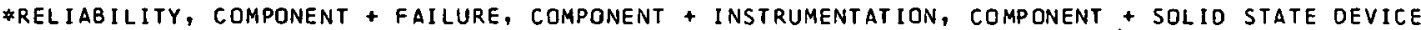

$9-26766$

SEBENY RL

A MONTE CARLO APPROACH TO SPARES PROVISIONING

COLLINS RADIO COMPANY, CEDAR RAPIOS, IOWA.

4 PAGES, PAGES 350-353 IN ANNALS OF ASSURANCE SCIENCES, PROCEEDINGS OF THE ANNUAL SYMPOSIUM ON

RELIABILITY, BOSTON, MASS, JAN, 16-18, 1968, ABSTRACT IN RELIABILITY ABSTRACTS AND TECHNICAL REVIEWS $8(6)$, PAGE 105 (JUNE 1968)

A COMPUTER PROGRAM USING A MONTE CARLO APPROACH IS DESCRIBEO FOR PROVISIONING SPARES FOR A COMPLEX SYSTEM ON THE BASIS OF THEIR IMPACT ON SYSTEM AVAILABILITY AND COST. THE MONTE CARLO TECHNIQUE PERMITS SIMULATION AND ANALYSIS OF A VARIETY OF SYSTEM CONFIGURATIONS AND MAINTENANCE PRACTICES, AND THE INPUT DATA REQUIRED TO USE THE PROGRAM IS GREATLY SIMPLIFIED BY USING A COMPUTER GENERATED TABLE DESCRIBING SYSTEM SUCCESS AS A FUNCTION OF ASSEMBLY STATES. THE INPUT DATA IS USER ORIENTED IN THAT IT REQUIRES ONLY THE KNOWLEDGE OF SYSTEM OPERATION AND MAINTENANCE PRACTICES. THIS APPROACH TO SELECTING SPARES IS UESCRIBED FOR A 'I SYSTEM THAT CONTAINS REDUNDANCY IN PARALLEL UNITS OR SUBSYSTEMS AS WELL AS SIMILAR UNITS THAT: CAN BE INTERCHANGED OR CANN IBALIZED.

* REL IABILITY, SYSTEM + COMPUTER PRDgRAM + MONTE CARLo + REDUNDANCE

9-26930 ALSO IN CATEGQRY 17

MODIFICATION OF ROD DRIVE CONTROL CIRCUITS

UNIVERSITY OF MISSOURI

2 PAGES, I FIGURE, LETTER TO E M HOWARD, DRL, TAKEN FROM A LETTFR TO E. M. HOWARD, DRL FROM D. RAY. MAY 27, 1968. DOCKET 50-123.

PROPOSED MOOIFICATION PLACES AUXILIARY CONTACTS DF THE WITHDRAW SWITCH IN THE ROD-DRIVE CONTROL. CIRCUITS SO THAT BOTH THE RELAY K9 MUST BE ENERGIZED AND EITHER GANG UR INDIVIDUAL WITHDRAW SWITCH CLOSEO FOR THE ROD TO WITHDRAW. WE AWAIT YOUR COMMENTS BEFORE MAKING THE MODIFICATIONS.

AVAILABILITY - PUBLIC DULUMENT ROOM, $171711 \mathrm{gT}$., WASHIMGTON, ח.C.

*CONTRMI, ROD DRIVE + \#INSTRUMENTATION, SWITCH + ACCIDENT, CONTROL ROD HITHDRAWAL + CONTROL SYSTEM +

FAILURE, DESICN EP.P.OR + MOOIFIT.ATION, SYSTEM OR EQUIPMENT + R.EACTOR, RESEARCH

9-26967 ALSO IN CATEGORY 10

TALBOT JE

INSTRUMENTATION(S) JOB IN NUCLEAR POWER GENERATION-INSURE PLANT REI, IABILITY, AVAILABILITY, AND SAFETY 
CATEGORY 9

NUCLEAR INSTRUMENTATION, CONTROL, AND SAFETY SYSTEMS

9-26967 \#CONT INUED*

3 PAGES, INSTRUMENTATION TECHNOLOGY 15(7), PAGES 10-12 (JULY 1968)

THE 11 TH ANNUAL ISA POWER INSTRUMENTATION SYMPOSIUM IN CHICAGO, MAY 1968, HAD AS ITS THEME RELIABILITY, AVAILABILITY, AND SAFETY, FOUR PAPERS TOOK UP THE TOPIC OF NUCLEAR GENERATION. ECONOMICS, OF NUCLEAR INSTRUMENTATION WAS ALSO OISCUSSED. A TRAINING SIMULATOR OF A BWR TO SIMULATE A COMPLETE HOT OR COLD STARTUP WAS PRESENTED BY GENERAL ELECTRIC. INSTRUMENTATION PROBLEMS ASSOCIATED WITH THE EXTREME OPERATING CONDITIONS OF FAST BREEDER REACTORS WERE DISCUSSEO.

*ELECTRIC POWER, GENERAL + *INSTRUMENTATION, GENERAL + CONTROL SYSTEM + ECONOMICS + INSTRUMENTATION, CONTROL + INSTRUMENTATION, INDICATOR + INSTRUMENTATION, PROTECTIVE + REACTOR, BREEDER + REACTOR, FAST + SIMULATION

$9-26968$

SIBLEY FS + SPOONER NF + HALL BF

AGING IN TYPE K COUPLES

HOSKINS MFG. COMPANY

3 PAGES, 4 Figures, INSTRUMENTATION TECHNOLOGY 1517), PAGES 53-55 (JULLY 1968)

CHROMEL-ALUMEL THERMOCOUPLES EXPERIENCE A RELATIVELY UNKNOWN EFFECT CALLEO AGING, IN THE TEMPERATURE RANGE FROM 700 TO $1000 \mathrm{~F}$. AGING TENOS TO RAISE THE LEVEL OF THERMOCOUPLE OUTPUT. RATHER THAN DISCUSS THE THEORY BEHIND AGING, THE AUTHORS STICK TO OBSERVABLE EFFECTS IN COMMON PRACTICE AND SUGGEST WAYS TO MAINTAIN CALIBRATION ACCURACY.

HIGH TEMPERATURE + INSTRUMENTATION CALIBRATION + INSTRUMENTATION, ABNORMAL INOICATION + INSTRUMENTATION, TEMPERATURE + MEASUREMENT, TEMPERATURE + TEST, ON LINE

9-27343 ALSO IN CATEGORY 17

REPORT ON SLOW RELEASE TIME OF SHIM ARM NO. 4

NATIONAL BUREAU OF STANOARDS

5 PAGES, LETTER TO P.A. MORRIS, DRL FROM R.S. CARTER, JULY 19, 1968, DOCKET NO. 50-184

ON JULY 11, THIS CLUTCH WAS FOUND SLIPPING DURING SPECIAL ROD DROP TESTS AND HAD A 230 MSEC RELEASE TIME INSTEAD OF 150-160. THE CLUTCH PLATE HUB HAD BEEN ASSEMBLED WITH MINIMAL

CLEARANCE FROM ITS SUPPORT BRACKET. NEAR FULL OUT, THE COMPRESSED SCRAM SPRING REDUCEO THIS CLEARANCE.

AVAILABILITY - CLEARINGHOUSE FOR FEDERAL SCIENTIFIC AND TECHNICAL INFORMATION, SPRINGFIELO, VA. 22151 $\$ 3.00$ COPY, \$0.65 MICROFICHE

*FAILURE, SCRAM MECHANISM + CONTROL ROD ORIVE + NBS + OPERATING EXPERIENCE + REACTOR, RESEARCH + RESPONSE TIME

9-27344 ALSO IN CATEGORY 17

SELECTEO SAN ONOFRE OPERATING EXPER IENCE

SOUTHERN CAI IFRRNIA FRISONI

13 PAGES, SEMI-ANNUAL OPERATING REPORT NO, 2, JULY 22, 1360 , DOCKET NO. 50-206, TYPE--PWR, MFG--WEST., AE-DECHTEL

FIVE SHUTDOWNS WERE MADE (LEAKING PRIMARY COOLANT, TWO ELECTRICAL CABLE FAILURES, CONTROL ROD CYCLE MALFUNCTION, CONTROL ROD F-10 FOUND BOTTOMED BY REVERSED POLARITY OF THE MOVABLE GRIPPER COIL). RADWASTE RELEASE LINE CHECK VALVE FAILED, SPILLING HATER. \#\#TESTS SHOWED FLOW STRATIFICATION IN REACTOR COOLANT COLD LEG GIVES A HIGH DELTA T OF $5.3 \mathrm{~F}$ (FULL POWERI. FLOW STRATIFICATION IN REACTOR COOLANT COLD LEG GIVES A HIGH DELTA T OF 5.3 F IFULL POWERI. PH REACTIVITY EFFECT IS ABOUT 0.35 PERCENT/PII UNIT AT PH 6.4 . POWER COEFF. VS ROD POSITION
DATA TAKEN. BORON DILUTION HAS BEEN 2.1 PPM/FULL POWER DAY, VS 2.9 PREDICTED. 65 SPECIFIC 'DESIGN CHANGES LISTED.

AVAILABILITY - CLEARINGHOUSE FOR FEDERAL SCIENTIFIC AND TECHNICAL INFORMATION, SPRINGFIELD, VA. 22151 $\$ 3.00$ COPY, \$0.65 MICROF ICHE

*FAILURE, EQUIPMENT + \#FLOW DISTRIBUTION + \#PH REACTIVITY EFFECT + \#POWER COEFFICIENT +

ACCIDENT, CONTROL ROD WITHDRAWAL + FAILURE, SCRAM MECHANISM + FUEL BURNUP +

INSTRUMENTATION, ABNORMAL INDICATION + INSTRUMENTATION, TEMPERATURE + REACTOR, PWR +

REPORT, OPERATIONS SUMMARY + SAN ONOFRE (PHR) + VALVE + WASTE DISPOSAL, LIOUIO

9-27494 ALSO IN CATEGORIES 5 AND 17

WYLIE RD

TENSILE AND IMPACT PROPERTIES OF ELK RIVER REACTOR CONTROL ROD MATERIAL. FINAL REPORT

SOUTHWEST RESEARCH INST., SAN ANTONIO, TEX.

SWRI-1228-55 +. 21 PAGES, FIGURES, 5 REFERENCES, FEB.. 19, 1965

THE BORON STAINLESS STEEL SPECIMENS WHICH WERE REMOVED FROM THE ELK RIVER REACTOR DURING THE SHUT DOWN IN EARLY NOVEMBER 1964 WERE TESTED AT SOUTHWEST RESEARCH INSTITUTE. BOTH SUBSIZE TENSILE ANO IMPACT SPECIMENS WERE INCLUDED IN THE SURVEILLANCE PROGRAM. AN ESTIMATE OF THE FLUX LEVEL WAS MADE BY ALLIS CHALMERS AS $1.3 \times 10120 T H I$ NVT THERMAL AS OF AUGUST 31 , 1964. THIS CORRESPONOS TO APPROXIMATELY 0.22 ATOM PERCENT BURN-UP. THE DUCTILITY OF THE SPECIMENS WAS MEASURED AS 1-2\% ELONGATION WHICH WAS BELOW THE $3.4 \%$ REQUIRED BY THE TECHNICAL 
CATEGORY 9

NUCLEAR INSTRUMENTATION, CONTROL, AND SAFETY SYSTEMS

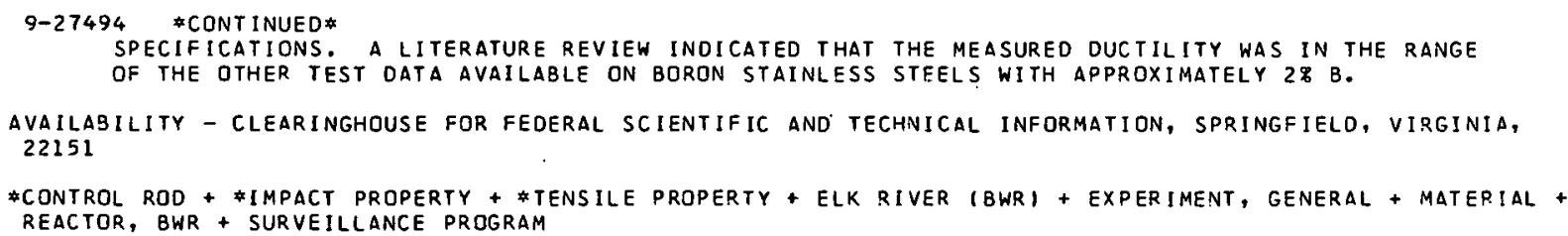

A CONTROL ROD HAS A SCREW CUT INTO ONE ENO AND A CYLINDER AT THE OTHER. IN THE CYLINDER IS A LINK MECHANISM WHICH HOLOS THE ROD AND ENABLES VERTICAL MOTION. A REACTANCE MOTOR IS INSTALLED AT THE SCREWED END TO DRIVE THE ROD UP OR DOWN. A GEAR, ATTACHED TO THE ROTOR, CONNECTS WITH A SEALED SYNCHRO-OSCILLATOR. AN ELECTROMAGNET IS INSTALLED, JUST OUTSIDE THE CYLINDER AT ABOUT THE POSITION OF THE LEVER, SO AS TO MOVE TOGETHER WITH THE DRIVE ROD BY MEANS OF A SIGNAL FROM THE SYNCHRO-OSCILLATOR.

AVAILABILITY - FOREIGN PATENTS MAY BE OBTAINED IN PHOTOCOPY FROM THE U.S. PATENT OFFICE, DEPARTMENT OF COMMERCE, WASHINGTON, D.C. (\$0.30 CENTS/PAGE)

\#CONTROL ROD DRIVE + JAPAN + PATENT

9-27519

HOPKINSON A + LEVELL RW

ANALOGUE AND DIGITAL COMPUT ING TECHNIQUES IN PLANT MODELLING, REDUCTION AND CONTROL STUDIES UNITED KINGOOM ATOMIC ENERGY AUTHORITY, WINFRITH

8 PAGES, 2 FIGURES, 7 REFERENCES, FROM SECOND U.K.A.C. CONTROL CONVENTION ON ADVANCES IN COMPUTER CONTROL, THE UNIVERSITY OF BRISTOL, APRIL $11-14,1967$

DESCRIBES THE TECHNIQUES USED AND EXPERIENCE GAINEO DURING DYNAMIC STUDIES DF A PROPOSEO PROTOTYPE FAST REACTOR POWER PLANT. THE STUOIES INCLUOED DEVELOPMENT OF DYNAMIC MODELS FOR INVESTIGATING THE UNCONTROLLED PLANT UNDER NORMAL CONOITIONS AND FDLLOHING VARIOUS PLANT FAULTS ANO FOR STUOYING PLANT CONTROL OVER A FAIRLY WIDE RANGE OF POWER LEVELS.

AVAILABILITY - C. BALDHIN LTO., TUNBRIDGE WELLS, KENT, ENGLAND

* REACTOR CONTROL + *THEORETICAL INVESTIGATION + ANALYTICAL MODEL + COMPUTER PROGRAM + COMPUTER, ANALOG + COMPUTER, DIGITAL + CONTROL SYSTEM + REACTOR, FAST + REACTOR, LMCR + SODIUM + TRANSFER FUNCTION 
CATEGORY 9

NUCLEAR INSTRUMENTATION, CONTROL, AND SAFETY SYSTEMS

$9-27536$

DICK RS

ON THE FALLACY OF AN AVAILABILITY MEASURE

ITT DEFENSE COMMUNICATION

2 PAGES, 2 REFERENCES, IEEE TRANS. ON RELIABILITY, VOL. R-16, PAGES 137-38 (DECEMBER 1967)

A WELL-KNOWN AVAILABILITY MEASURE WHICH HAS APPEARED IN RECENT TEXTS IS ONLY AN APPROXIMATION TO THE PROBLEM WHERE THE PRODUCT OF FAILURE RATE AND DURATION OF OPERATION IS SMALL ENOUGH THAT THE OCCURRENCE OF MORE THAN ONE FAILURE DURING THE DURATION OF OPERATION IS MINUTE. FOR LARGER VALUES OF THIS PRODUCT, THE NUMBER OF REPAIRS THAT CAN BE PERMITTED DURING THE PERIOD OF OPERATION MUST BE KNOWN.

* RELIABILITY ANALYSIS + ERROR ANALYSIS + MATHEMATICAL TREATMENT

9-27579 ALSO IN CATEGORIES 4 ANO 6

FRIEDMAN ST + RANKIN WD

INDIRECT MEASUREMENT OF NUCLEAR HEATING RATES IN POISON CONTROL VANES

LOS ALAMOS SCIENTIFIC LABORATORY

I PAGE, ANS TRANSACTIONS $11(1)$, PAGE 25, 1968 ANNUAL MEETING OF THE AMERICAN NUCLEAR SOCIETY AND CANADIAN NUCLEAR ASSOCIATION, TORONTD, CANADA, JUNE 10-13, 1968

THE ACCURATE PREDICTION OF NUCLEAR HEATING RATES IN HIGH CAPTURE CROSS-SECTION CONTROL MATERIALS IS A MAJOR RADIATION ANALYSIS PROBLEM. THE PROBLEM IS PARTICULARLY ACUTE IN NUCLEAR ROCKET REACTOR SYSTEMS SUCH AS NERVA HHERE THE RELATIVELY THIN CONTROL VANES ARE LOCATED IN HIGHLY MODERATING BERYLLIUM REFLECTOR REGION IMMEDIATELY ADJACENT TO A HIGH-POWER DENSITY CORE. OPERATIONAL CONSIDERATIONS, INCLUOING EFFECTS ON REACTOR SAFETY AND

RELIABILITY, REQUIRE ACCURATE PREDICTIONS OF VANE HEATING RATES AND AN ADEQUATE FLOW OF LI QUIO HYDROGEN TO THE VANES, DRUMS, REFLECTOR, AND PRESSURE VESSEL, BUT ESPECIALLY TO THE VANES SINCE THESE INVOLVE THE CONTROL SYSTEM.

\#MEASUREMENT, TEMPERATURE + \#NUClEAR ROCKET + HEAT TRANSFER + INSTRUMENTATION, CONTROL + NERVA PROGRAM

$9-27580$

DELLA VILLA LA

RADIATION-HARDENED NERVA PRESSURE TRANSOUCER

AEROJET, SACRAMENTO, CALI FORNIA

1 PAGE, ANS TRANSACTIONS $11(1)$, PAGE 26, 1968 ANNUAL MEETING OF THE AMERICAN NUCLEAR SOCIETY AND CANADIAN NUCLEAR ASSOCIATION, TORONTO CANADA, JUNE 10-13, 1968

THE NERVA ENGINE CONTROL SYSTEM REQUiRES a NOZZLE CHAMBER MEASUREMENT. TO MEET THE

FREQUENCY-RESPONSE REQUI REMENTS, THE TRANSOUCER MUST BE MOUNTED AT THE NOZZLE PASS-THROUGH

BOSS WHICH IS DOWNSTREAM OF THE REACTOR CORE EXIT. THE TRANSDUCER MUST BE NOT ONLY RADIATION

RESISTANT BUT MUST OPERATE WHILE BEING SUBJECTED TO INTERNAL TEMPERATURE GRADIENTS CREATED BY

THE GAMMA FIELO, AND TO TEMPERATURES FROM -200 TO $600 \mathrm{~F}$ CREATEO BY LIQUID HYDROGEN COOLING. SEVERAL OESIGNS WERE TESTED.

* INSTRUMENTATION, PRESSURE + \#TEST, INSTRUMENT RESPONSE + ENVIRONMENTAL CONDITION + HIGH TEMPERATURE + INSTRUMENTATION, COMPONENT + NERVA PROGRAM + NUCLEAR ROCKET

$9-27581$

OZAIR V + ANDREWS DG

OEVELOPMENT OF A SENSITIVE GAMMA COUNTER OIRECT-READING IN FLUX AND DOSE RATE

UNIVERSITY OF TORONTO, ONTARIO, CANADA

2 PAGES, 1 FIGURE, ANS TRANSACTIONS 11111, PAGES 66-67, 1968 ANNUAL MEETING OF THE AMERICAN NUCLEAR

SOCIETY AND CANADIAN NUCLEAR ASSOCIATION, TORONTO, CANADA, JUNE 10-13, 1968

PARTIAL SUCCESS haS BEen ACHIEVED TOWARD THE DEVELOPMENT OF a SENSITIVE gamma COUNTER TUBE THAT CAN BE USED ALTERNATIVELY IN THE ISOFLUX (SAME COUNTS READING, SAME FLUX) AND THE

I SODOSE ISAME COUNTS READING, SAME DOSE RATEI MODE OVER A USEFUL RANGE OF PHOTON ENERGIES, IN

THIS INSTANCE, 0.15 TO 1.5 MEV.

* instrumentation, nuclear + \$SPectrometry, gamma + counter + dosimetry, general + gamma

$9-27582$

RILEY DR + FLECK J

REACTOR AVAILABILITY DRIVER FUEL INSTRUMENTATION

GENERAL ELECTRIC, SCHENECTADY + GENERAL ELECTRIC, SUNNYVALE, CALIF.

1 PAGE, 1 FIGURE, 1 TABLE, ANS TRANSACTIONS 1111 , PAGE 330, 1968 ANNUAL MEETING OF THE AMERICAN NUCLEAR SOCIETY ANO CANADIAN NUCLEAR ASSOCIATION, TORONTO CANADA, JUNE 10-13, 1968

DUR ING THE EVOLUTION OF THE CONCEPTUAL DESIGN OF THE FFTF BACKUP DESIGN, SPECIAL EMPHASIS WAS PLACED ON MAXIMIZING REACTOR PLANT AVAILABILTIY. SEVEN SCHEMES FOR CORE TEMPERATURE SENSING WERE CONCEIVEO, RANGING FROM A SCHEME WITH NO REDUNDANCY HHATEVER TO AN ELABORATE SCHEME

USING FOUR THERMODOUPLES PER CHANNEL AND EXTENSIVE FAILURE-DETECTING CIRCUITRY. THE 
CATEGORY O

\begin{abstract}
9-27582 *CONTINUEO*
UNAVAILABILITY OF EACH SCHEME HAS BEEN PREDICTED, ANO THE ARRANGEMENT RECOMMENDED USES FOUR THERMOCOUPLES PER CHANNEL, WITH THREE OF THEM ACTIVELY CONNECTED AND ONE AS A SPARE. JNE THERMOCOUPLE FROM EACH CHANNEL IS CONNECTEO TO EACH OF THREE OR CIRCUITS, AND THEN THE THPEE ORS ARE CONNEC TED TO TWO-OUT-OF-THREE MAJORITY LOGIC TO PROVIDE THE SCRAM SIGNAL.

FFTF (TR) + INSTRUMENTATION, IN CORE + INSTRUMENTATION, TEMPERATURE + REACTOR, FAST + REACTOR, LMCR
\end{abstract}

$9-27583$

JACKSON CN

RECENT ADVANCES IN REGENERATIVE IN-CORE NEUTRON FLUX MONITORS

BATTELLE NORTHWEST LABORATORY, RICHLAND, WASHINGTON

1 PAGE, 1 FIGURE, 1 TABLE, 2 REFERENCES, ANS TRANSACTIONS $11(1)$, PAGE 336, 1968 ANNUAL MEETING OF THE AMERICAN NUCLEAR SOCIETY AND CANAOIAN NUCLEAR ASSOCIATION, TORONTO CANADA, JUNE 10-13, 1968

THIS PAPER FOCUSES ON RECENT INVESTIGATIONS IN THE DC VELOPMENT OF REGENERATING FLUX MONITORS-A NOVEL DETECTOR CONCEPT THAT EMPLOYS A MIXTURE OF FERTILE ANO FISSILE. URANIUM ISOTOPES IOOF U-234/10\% U-235). IN THIS COATING MATERIAL, U-234 TRANSMUTES BY THERMAL-NEUTRON ABSORDTION TO U-235, REPLACING SIMILAR ATOMS LOST DUE TO BURNOUT, THERBY ACCOMPLISHING THE REGENERATING FUNCTION AND EXTENDING THE USEFUL LIFE OF THE NEUTRON SENSOR.

\# INSTRUMENTATION, IN CORE + \#INSTRUMENIATIION, NUCLEAR + EOUIPMENT DESIGN + FLUX, INTEgRATED + TEST, INSTRUMENT RESPONSE

9-27584 ALSO IN CATEGORY 17

KINZER JE + PARK TA + CHANDLER EM

OPERATING EXPERIENCE WITH A MINIATURIZED NEUTRON FLUX SENSOR.

ATOMICS INTERNATIONAL, CANOGA PARK, CAL IFORNIA

1 PAGE, 2 FIGURES, 1 REFERENCE, ANS TRANSACTION 11111 , PAGE 336,1968 ANNUAL MEETING OF THE AMERICAN NUCLEAR SOCIETY AND CANADIAN NUCLEAR ASSOCIATION, TDRONTO, CANADA, JUNE 10-13, 1068

THE ADIT NEUTRON FLUX SENSOR, WAS DES IGNED TO MEET THE CONTINUING NEED FOR VERY SMALL DYNAMIC SENSORS. THE BASIC APPROACH MEASUREMENT OF FISSION-PRDDUCED TEMPERATURE, HAS BEEN MJDIFIED IO INCREASE OUTPUT SIGNAL AND DECREASE PHYSICAL SILE WHILE MAINTAINING SIMPLICITY. PRDTOTYPE MODELS HAVE BEEN 0.083 IN. IN DIAMETER. SINCE THE TYPE OF FISSIONABLE MATERIAL USED MAY BE CHOSEN TO MATCH THE NEUTRON FLUX ENVIRONMENT OF INTEREST, THIS TYPE OF FLUX SENSER IS APPLICABLE TO BOTH FAST AND THERMAL FLUX MEASUREMENTS AODITIONALLY, THE RELIABILITY AND RELATIVELY LONG LIFE OF THERMOCOUPLES AND THE FACT THAT THE ONLY INSTRUMENTATION REQUIRED IS THE STANDARD THERMOCOUPLE RECOREDER, MAKE THE AOIT FLUX SENSORS ATTRACTIVE FOR IN-CORE DATA ACQUISITION.

* Instrumentation, in core + *instrumentation, nuclear + fluX, integrated + operating experience

$9-27585$

OPERATING EXPERIENCE WITH A MINIATURIZED PRESSURE SENSOR

ATOMICS INTERNATIONAL, CANOGA PARK, CALIFORNIA

1 PAGE, 3 FIGURES, 2 REFERENCES, ANS TRANSACTIONS 11111 , PAGE 337,1968 ANNUAL MEETING OF THE AMERICAN

NUCLEAR SOCIETY AND CANADIAN NUCLEAR ASSOCIATION, TORONTO, CANADA, JUNE 10-131968

THE ADIT (ADVANCEO DEVELOPMENT IRRADIATION TECHNIQUES) PRESSURE SENSOR OPERATES MUCH LIKE A DIAPHRAGM ACTUATED PRESSURE SWITCH. TWO SYMMETRICAL BELLOWS JOINED BY A COUPLING DISK FORM A FORCE 8ALANCE SYSTEM PLUS A DOUBLE SEAL AGAINST FISSION GAS. AN ON-OFF ELECTRICAL CQNTACT, MADE BY A PLATINUM-TIPPED THERMOCOUPLE, INDICATES HHEN THE BALANCING GAS IS IN EQUILIBRIUM WI.IH IHE PRESSURE GEING MEASUREO. THIS THERMOCOUPLE MAK.ES THE DEVICE A TOMMTNATINN PRESSURE-TEMPERATURE SENSOR AND CAN BE USED TO CORRECT FOR. TEMPERATURE CHARACTERISTICS OF THE BELLOWS SYSTEM.

* INSTRUMENTATION, PRESSURE + CHALK RIVER + INSTRUMENTATION, TEMPERATURE + OPERATING EXPERIENCE + TEST, INSTRUMENT RESPONSE

9-27586

AGAZZI A + BROGGI A + DE PARATESI SG + GHIURGHI L

A LIQUID-RIN SHIITNOWN SYSTEM

EUROPEAN ATOMIC ENERGY COMMUNITY, ITALY

2 PAGES, 2 FIGURES, ANS TRANSACTIONS $11(1)$, PAGES 338-9, 1968 ANNUAL MEETING OF THE AMERICAN NUCLEAR SOCIETY AND CANADIAN NUCLEAR. ASSOCIATIDN, TORONTO, CANADA, JUNE 10-13, 1968

RESEARCH IN THE FIELD OF LIQUID-ROD SHUTDOWN EMERGENCY SYSTEMS IS JUSTIFIEO BY THE DESIRABILITY OF AVOIOING THE OIFFICULTIES THAT THE INSTALLATION OF NORMAL SOLID RODS WOULD RAISE IN SOME REACTORS. SINCE 1966 RESEARCH ACTIVITY ON THE SUBJECT HAS BEEN UNDERWAY AT THE CCR-EURATOM-ISPRA, UNDER THE D20-MODERATED REACIUR URGEL PROGRAM. DIFFERENT SYSTEMS HAVE BEEN CONSIOEREO AND NNF HAS BEEN COMPLETELY DESIGNED AND IA THREE-ROO MOCKUP ERECTED. TESTS ON THIS MOCKUP DEMONSTRATED THE FEASIBILITY OF THE SYSTEM AND ITS VERY GOOD OYNAMIC PERFORMANCE. STUDIES TF RELIABILITY HAVE ALSO BEEN CARRIED OUT.

*CONTROL ROD PROGRAM + \#LIQUID + BORON + CONTROL ROD + CONTROL SYSTEM + EQUIPMENT DESIGN + EURATOM + INSTRUMENTATION, CONTR MI. + SYSTEM DESCRIPTION

ACCESSIUN NUMBER $\cdot 9-27582$.TO $9-27586$ 
CATEGORY

NUCLEAR INSTRUMENTATION, CONTROL, ANO SAFETY SYSTEMS

$9-27587$

CLARK RG

OPERATION OF REACTOR SYSTEMS WITH A DIGITAL COMPUTER

BATTELLE NORTHWEST LABORATORY, RICHLAND, WASHINGTON

2 PAGES, 1 REFERENCE, ANS TRANSACTIONS $11(1)$, PAGES 339-40, 1968 ANNUAL MEETING OF THE AMERICAN NUCLEAR

SOCIETY AND CANADIAN NUCLEAR ASSOCIATION, TORONTO, CANADA, JUNE 10-13, 1968

\begin{abstract}
A DIGITAL INSTRUMENT SYSTEM UTILIZING A HIGH-SPEED COMPUTER CONTROLS THE PROCESS SYSTEMS FOR THE HIGH TEMPERATURE LATTICE TEST REACTOR (HTLTR), WHICH WENT CRITICAL IN NOVEMBER 1967. ON-LINE COMPUTATIONS ARE MAOE CONTINUOUSLY AND THE INFORMATION ON THE CRT IS UPDATED AT SHORT INTERVALS OF TIME FOR OPERATOR ACTION OR AUTOMATIC RESPONSE OF THE SYSTEM UNDER PROGRAM DIRECTION. OPERATION OF THE. SYSTEM THROUGH THE COMMAND TYPEWRITER IS RAPID ENOUGH FOR ROUTINE OPERATION, BUT FUNCTIONS THAT REQUIRE IMMEDIATE OPERATOR RESPONSE HAVE INDIVIDUAL CONVENTIONAL CONTROLS SUCH AS THE SCRAM BUTTON.
\end{abstract}

* COMPUTER CONTROL + \#REACTOR CONTROL + BATTELLE NORTHWEST + COMPUTER, DIGITAL + INSTRUMENTATION, CONTROL + INSTRUMENTATION, PROCESS + REACTOR, RESEARCH

$9-27588$

KAUFMAN NC

CALIBRATION OF THE ATR LOBE POWER MONITORING SYSTEM

IOAHO NUCLEAR CORPORATION

1 PAGE, ANS TRANSACTION $11(1)$, PAGE 340,1968 ANNUAL MEETING OF THE AMERICAN NUCLEAR SOCIETY ANO CANADIAN

NUCLEAR ASSOCIATION, TORONTO, CANADA, JUNE 10-13, 1968

THE SERPENTINE FUEL ANNULUS OF THE ADVANCED TEST REACTOR FORMS FiVE POWER-GENERATING LOBES.

KNOWLEOGE OF THE DIVISION OF THE TOTAL REACTOR POWER AMONG THESE LOBES IS IMPORTANT TO

REACTOR OPERATION, BOTH IN CONSIDERATIONS OF REACTOR SAFETY AND IN THE ACHIEVEMENT OF DESIREO

TEST IRRADIATIONS. THE SYSTEM IS UNDERGOING TESTS TO VERIFY THE ACCURACY DF CALCULATION,

PARTI CULARLY UNDER THE INFLUENCE OF EXTREME CHANGES IN EXPERIMENT LOADING, SHIM POSITIONS,

ANO POWER OIVISION. MEASUREMENTS IN ATRC AND CALCULATIONS FROM A COMPUTER MODEL OF THE

SYSTEM INDICATE THAT IN NO CASE SHOULO THE DIFFERENCE BETWEEN CALCULATED. AND INDEPENDENTLY

MEASURED LOBE POWERS EXCEED +-4\%.

ATR (TR) + INSTRUMENTATION CALI BRATION + INSTRUMENTATION, POWER RANGE + REACTOR, AEC OWNEO + REACTOR, TEST

9-27589

LEONARD JH

RADIATION-INDUCED TEMPORARY DECALIBRATION OF THERMOCOUPLES

UNIVERSITY OF CINCINNATI

1 PAGE, 1 FIGURE, 4 REFERENCES, ANS TRANSACTIONS 11111; PAGE 340, 1968 aNNUAL MEETING OF THE AMERICAN

NUCLEAR SOCIETY AND CANADIAN NUCLEAR ASSOCIATION, TORONTO, CANADA, JUNE 10-13, 1968

GIVES RESULTS OF FURTHER EXPERIMENTS SHOWING OIRECT RADIATION EFFECTS ON THERMOCOUPLE

CALIBRATION AT TEMPERATURES COMMON IN CURRENT REACTORS. A MECHANISM WHICH CAN ACCOUNT FOR

SUCH PHENOMENA INVOLVES DIFFERENT DEGREES OF I IME-DEPENDENT CHANGE IN ELECTRON MOBILITY IN

THE TWO THERMOELECTRIC MATERIALS DUE TO APPEARANCE OF RADIATION-PRODUCED SCATTERING CENTERS

FOLLOWED BY SELF ANNEALING. AN IMPORTANT FACTOR APPEARS TO BE THE LOCATION OF THE

TEMPERATURE GRADIENT ALONG THE THERMOCOUPLE WIRES RELATIVE TO THE LOCATIMN MF NEUTRON FLUX

GRADIENT.

* INSTRUMENTATION, ABNORMAL INDICATION + *INSTRUMENTATION, TEMPERATURE + INSTABILITY +

INSTRUMENTATION CALIBRATION + IRRAOIATION TESTING + RADIATION EFFECT

$9-27590$

DAU GJ + BOURASSA RR

RESULTS OF THERMOCOUPLE CALIBRATION IN A PULSED REACTOR

BATTELLE NORTHWEST LABORATORY, RICHLAND, WASHINGTON

1 PAGE, 3 REFERENCES, ANS TRANSACTIONS $11(1)$, PAGE $341 ., 1968$ ANNUAL MEETING OF THE AMERICAN NUCLEAR

SOCIETY AND CANADIAN NUCLEAR ASSOCIATION, TORONTO, CANABA, JUNE 10-13, 1968

A MECHANISM WAS POSTULATED TO INDICATE HOW RADIATION CAN AFFECT THERMOCOUPLE CAL.IBRATION, BUT BECAUSE SOME OF THE CONSTANTS CANNOT BE OBTAINED ACCURATELY, IT WAS NECESSARY TO

EXPER IMENTALLY EVALUATE THE INSTANTANEOUS EFFECTS ON THERMOCOUPLE CALIBRATION. AN EXPERIMENT WAS DESIGNED AND CONNIIS.TFO IN D PIII SFN TRISA BFACTRO IIS IMS GHPOMEL-GHAPIPIEL THERMOCOUTLES. RESULTS OF THE PULSED DATA ON FOUR THERMOCOUPLES. RESULTS OF THE PULSED DATA ON FOUR THERMOCOUPLES INDICATED AN APPARENT TEMPERATURE INCREASE OF LESS THAN $2.5 \mathrm{C}$. IT WAS CONCLUOED THAT THERE ARE NO SIGNIFICANT DOSE RATE RAOIATION EFFECTS ON THERMOCOUPLES OTHER THAN LOCALIZED GAMMA HEATING AT TEMPERATURES UP TO 230 C AND IN FLUXES OF APPRDXIMATELY 10(16TH) WITH A FAST-TO-THERMAL RATIO OF ONE AND A GAMMA PHOTON FLUX OF GREATER THAN 10(IOTH) R/H.

*INSTRUMENTATION, TEMPERATURE + \#IRRADIATION TESTING + INSTRUMENTATION CALIBRATION + INSTRUMENTATION, ABNORMAL INDICATION + RAOIATION EFFECT + REACTOR, RESEARCH + TEST, INSTRUMENT-RESPONSE + TRIGA (RR) 
CATEGORY

NUCLEAR INSTRUMENTATION, CONTROL, AND SAFETY SYSTEMS

$9-27591$

ELLIS JF

AN INSTRUMENT FOR MEASURING MECHANICAL VIBRATIONS IN FAST-PULSE REACTOR CORES

OAK RIDGE NATIONAL LABORATORY

1 PAGE, I FIGURE, ANS TRANSACTIONS $11(1)$, PAGE 342, 1968 ANNUAL MEETING OF THE AMERICAN NUCLEAR SOCIETY ANO CANADIAN NUCLEAR ASSOCIATION, TORONTO, CANADA, JUNE 10-12, 1968

PROXIMITY GAGES ARE ADVANTAGEOUS FOR MEASURING MECHANICAL DISPLACEMENTS AND VIBRATIONS IN PULSE REACTOR CORES BECAUSE THEY REQUIRE NO PHYSICAL ATTACHMENT TO THE CORE MATERIAL. DURING INITIAL TESTS OF THE ARMY PULSE RADIATION FACILITY REACTOR CONDUCTED AT THE OAK RIOGE CRITICAL EXPERIMENTS FACILITY, A NEWLY DEVELOPEO PROXIMITY GAGE WAS TESTEO. IT COMPRISEO A 30-MHZ OSCILLATOR ORIVING A OIFFERENTIAL PROBE WHOSE INPUT AND DUAL OUTPUTS MATCHED THE CONNECTING COAXIAL LINES. THE UNIT WAS OPERATEO WITHIN 0.10 IN. OF THE REACTOR CORE SURFACE. THE DIFFERENTIAL NATURE OF THE INSTRUMENT VIRTUALLY CANCELED T.HE EFFECTS OF RADIATION AND HEATING.

\#INSTRUMENTATION, POSITION + \#VIBRATHON + INSTRUMENTATION, COMPONENT + TEST, INSTRUMENT RESPONSE

$9-27592$

POSEY LD + WALKER JV

THE FISSION-COUPLE DETECTOR - A LOH-RESOLUTION NEUTRON SPECTROMETER FOR PULSED-NEUTRON ENVIRDNMENTS SANOIA CORPORATION, AL BUQUERQUE, NEW MEXICO

2 PAGES, 1 FIGURE, 4 REFERENCES, ANS.TRANSACTIONS $11(1)$, PAGES 342-3, 196B ANNUAL MEETING OF THE AMERICAN NUCLEAR SOCIETY AND CANAOIAN NUCLEAR ASSOCIATION, TORONTO, CANADA, JUNE 10-12, 1968

A NEW TECHNIQUE IS PRESENTED FOR OBTAINING LOW-RESOLUTION SPECTRA OF PULSED-NEUTRON ENVIRONMENTS. THIS TECHNIQUE IS BASED ON THE INTRINSIC THERMOCOUPLE CONCEPT USED PREVIOUSLY, IN THE FORM OF URANIUM FUEL MATERIAL, TO MAKE RELATIVE NEUTRON FLUX MEASUREMENTS OR POWER DENSITY MEASUREMENTS ACROSS A NUCLEAR ASSEMBLY. THROUGH THE USE OF DIFFERENT FISSILE MATERIALS, POSSESSING CROSS SECTIONS OF DIFFER ING ENERGY DEPENDENCE, DETECTORS HAVE BEEN DESIGNED TO OBTAIN CERTAIN DIFFERENTIAL AND INTEGRAL SPECTRAL INFORMATION.

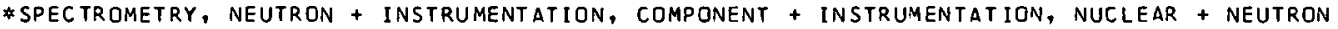

$9-27593$

CLAYTON JR

VIBRATION INSTRUMENTATION DURING THE ADVANCED TEST REACTOR STARTUP

PHILLIPS PETROLEUM COMPANY, AED, IDAHO FALLS, IDAHO

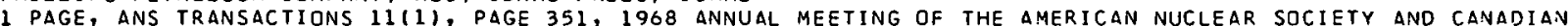

NUCLEAR ASSOCIATION, TORONTO, CANADA, JUNE 10-12, 1968

DURING STARTUP OPERATIONS OF ATR, COOLANT FLOW VIBRATEO THE IN-PILE TUBE AND SAFETY ROD. THE ORIENTATION ANO MAGNITUDE OF THE DISPLACEMENTS BETWEEN THE IN-PILE TUBE $\triangle N$ T THE SURRJUNOING SAFETY ROD WERE REOUIRED TO DETERMINE THE EFFECT OF THE VIBRATION. DISPLACEMENT MEASUREMENTS WERE NECESSARY AT DIFFERENT ELEVATIONS WHILE THE REACTOR SYSTEM OPERATED AT VARIOUS FLOW AND PRESSURE CONDITIONS. AL SO, DYNAMIC PRESSURE TRANSDUCEQ'S WERE USED TO DETERMINE THE CAUSE OF THE VIBRATION. A VIBRATION TRANSFER FUNCTIDN WAS DETERMINED FOR THE IN-PILE TUBE BEFORE AND AFTER THE FIX WAS MADE.

*INSTRUMENTATION, POSITIINN + \#VIBRATION + ATR (TRI + REACTOR, AEC OWNED + REACTDR, TEST + TRANSFER FUNCTION

$9-27594$

TERNEY WB + FENECH H

CONTROL-ROD PROGRAMMING OPTIMIZATION USING DYNAMIC PROGRAMMING

KNOLLS ATOMIC POWER LABURAIURY + MASS. INSTITUTE OF TECIINOLOSY

1 PAGE, 5 REFERENCES, ANS IKANSACTIONS 11111 , PAGE 354, 1 ISQ ANNUAL MEETING DF THE AMERICAN NUCLEAR

SOCIETY AND CANADIAN NUCLEAR ASSOCIATION, TORONTO, CANADA, JUNE 10-13, $1060^{\circ}$

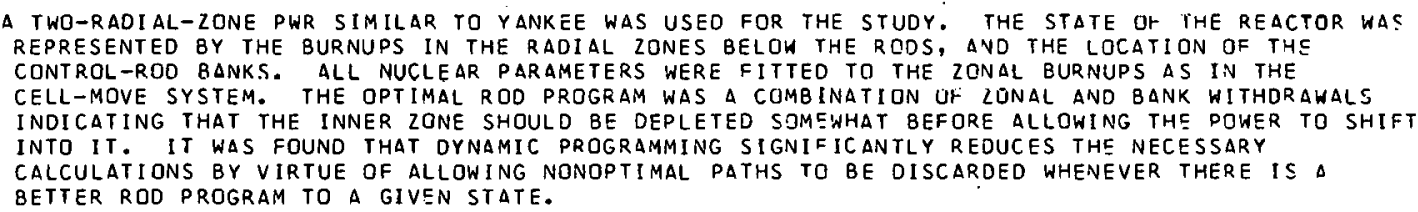

A TWO-RAOIAL-ZONE PWR SIMILAR TO YANKEE WAS USED FOR THE STUDY. THE STATE OF THE REACTOR WAS REPRESENTED BY THE BURNUPS IN THE RADIAL ZONES BELOW THE RODS, AND THE LOCATION OF THE CONTROL-ROD BANKS. ALL NUCLEAR PARAMETERS WERE FITTEO TO THE ZONAL BURNUPS $\triangle S$ IN THE CELL-MOVE SYSTEM. THE OPTIMAL ROD PROGRAM WAS A COMBINATION UF LONAL AND BANK WITHDRAWALS INDICATING THAT THE INNER ZONE SHOULD BE DEPLETED STMEWHAT BEFORE ALLOWING THE POWER TO SHIFT INTO IT. IT WAS FOUND THAT DYNAMIC PROGRAMMING SIGNIFICANTLY REDUCES THE NECESSARY CALCULATIONS BY VIRTUE OF ALLOWING NONOPTIMAL PATHS TO BE DISCARDED WHENEVER THERE IS BETTER ROD PROGRAM TO A GIVEN STATE.

* CONTROL ROD PROGRAM + COMPUTER PROGRAM + CONTPOL ROD INTERACTION

9-27595 ALSO IN CATEGORIES 5 AND 17

HARRIGAN PM + MATTEL J + TOTH WL

OPTICAL, LIGHTING, AND PHOTOGRAPHIC EQUIPMENT FOR THE ENRICO FEPMI $\triangle T O M I C$ POWER PLANT REPAIR PROGRAM POWER REACTOR DEVELOPMENT COMPANY + ATOMIC POWFR DEVELOPMENT ASSOCIATES

1 PAGE, I FIGURE, ANS TRANSACTIONS 11(1), PAGE 358,1968 ANNUAL MEETING OF THE AMERICAN NUCLEAR SOCIETY 
CATEGORY

NUCLEAR INSTRUMENTATION, CONTROL, AND SAFETY SYSTEMS

$9-27595$ \#CONT INUED*

AND CANADIAN NUCLEAR ASSOCIATION, TORONTO, CANADA, JUNE 10-13, 1968

A MELTDOWN OF TWO CORE SUBASSEMBLIES REQUIRED THE USE OF VERY LONG OPTICAL INSTRUMENTS AND LIGHTING EQUIPMENT FOR THE PURPOSE OF INSPECTION OF THE CORE ANO REACTOR COMPONENTS. BECAUSE LITTLE INFORMATION WAS AVAILABLE ON THE DESIGN OF SUITABLE VIEWING ANO LIGHTING EQUIPMENT FOR USE IN SODIUM REACTOR ENVIRONMENTS, MUCH DEVELOPMENTAL WORK ANO TESTING HAD TO $8 E$ DONE TO PROVIDE SUITABLE EQUIPMENT. MUCH DEVELOPMENT WAS REQUIREO TO PROVIOE LIGHTING EOUIPMENT WITH ADEQUATE LAMP LIFE AND MANEUVERABILITY. THE USE OF PHOTOGRAPHY THROUGH THE VIEWING INSTRUMENTS WAS NOT SUCCESSFUL INITIALLY, BUT IMPROVEMENTS BOTH IN TECHNIQUE AND EQUIPMENT LED TO REMARKABLY GOOD RESULTS IN THE LATTER PART OF THE PROGRAM.

* INSTRUMENTATION, IN CORE + \#REMOTE MANIPULATING AND VIEWING + EQUIPMENT DESIGN + FERMI (LMFBR) + INSTRUMENTATION, SURVEILLANCE + MAINTENANCE AND REPAIR + MAINTENANCE, REMOTE + REACTOR, BREEDER + REACTOR, FAST + REACTOR, LMCR

9-27596 ALSO IN CATEGORIES 5 AND 17

DUFFY JG + MATTE J+RYAN JD + WARBERG HS

OBJECT RETRIEVAL TOOLS FOR THE ENRICO FERMI ATOMIC POWER PLANT REPAIR PROGRAM

ATOMIC POWER DEVELOPMENT ASSOCIATES, INC.: DETROIT, MICHIGAN

3 PAGES,- 2 FIGURES, ANS TRANSACTIONS 11111, PAGES 358-360, 1968 ANNUAL MEETING OF THE AMERICAN NUCLEAR SOCIETY AND CANADIAN NUCLEAR ASSOCIATION, TORONTO, CANADA, JUNE 10-13, 1968

THE METHOD OF RETRIEVING FROM THE BOTTOM OF THE FERMI REACTOR AN OBJECT THAT CAUSEO A MELTDOWN INVOLVED PROCEOURES AND TOOLS WHICH ARE UNIQUE AND COULD HAVE APPLICATION IN FUTURE PROBLEMS. TOOLS WERE DEVELOPED TO CUT THE OBJECT INTO PIECES SMALL ENOUGH TO BE REMOVED UPWARO THROUGH THE SUPPORT PLATE. SEVERAL GRIPPERS FOR THIS PURPOSE WERE ALSO DEVELOPED. SIMULTANEOUSLY, SPECIAL TOOCS HERE DEVELOPED TO REMOVE THE OBJECT INTACT VIA THE SODIUM INLET PIPE.

* INSTRUMENTATION, IN CORE + \#REMOTE MANIPULATING AND VIEWING + EOUIPMENT DESIGN + FERMI (LMFBR) + MAINTENANCE AND REPAIR + MAINTENANCE, REMOTE + REACTOR, BREEDER + REACTOR, FAST + REACTOR, LMCR

$9-27597$

ALSO IN CATEGORY 13

HARDTKE FC

TWO METHOOS FOR EVALUATING THE SUSCEPTIBILITY OF IRRADIATED GLASS TO FRACTURE BY ELECTRICAL DISCHARGE UNIVERSITY OF MO., ROLLA, ROLLA, MISSOURI

1 PAGE, 3 REFERENCES, ANS TRANSACTIONS 11111 , PAGE 360,1968 ANNUAL MEETING OF THE AMERICAN NUCLEAR

SOCIETY AND CANAOIAN NUCLEAR ASSOCIATION, TORONTO, CANADA, JUNE 10-13, 1968

USING 200- TO 300-KW ELECTRONS, THO METHODS HAVE BEEN DEVELOPED FOR TESTING SHIELDING GLASS FORMULATIONS FOR THEIR SUSCEPTIBILITY TO DISCHARGE AND FRACTURE UPON RADIATION EXPOSURE. THESE TESTS ARE INTENDED TO SUPERSEDE THOSE THAT HAVE FEATUREO LARGE SAMPLES EXPOSEO TO INTENSE GAMMA SOURCES AS WELL AS THOSE THAT MEASURE DIRECTLY THE INTRINSIC RESISTIVITY AND DIELECTRIC CONSTANT OF THE GLASS.

*GLASS + \#RADIOISOTOPE + *SHIELOING + ELECTRICAL CONDUCTION + FAILURE, COMPONENT + IRRAOIATION TESTING + RADIATION EFFECT + TEST, COMPONENT

$9-27598$

COLLINS RM

UNDERWATER CHARGING MACHINE FOR NUCLEAR IRRADIATION SAMPLE INSERTION

WESTINGHOUSE ASTRONUCLEAR LABORATORY

1 PAGE, 1 FIGURE, ANS TRANSACTIONS 11111 , PAGE 360,1968 ANNUAL MEETING OF THE AMERICAN NUCLEAR SOCIETY

AND CANADIAN NUCLEAR ASSOCIATION, TORONTO. CANADA, IIINE 10-13, 1968

DI SCUSSES DESIGN AND CONSTRUCTION OF A SPECIAL UNDERWATER MACHINE FOR INSERTION OF NUCLEAR

IRRADIATION SAMPLES INTO THE NASA TEST REACTOR AT THEIR PLUM BROOK STATIDN, SANDUSKY, OHIO.

SOME OF THE MAJOR PROBLEMS IN DESIGN AND THEIR RESULTANT SOLUTION ARE DESCRIBED IN BRIEF.

OPERATING PARAMETERS AND CONSTRUCTION MATERIALS RESTRAINTS POSED UNIQUE PROBLEMS REQUIRING

SPECIAL SOLUTIONS. A QUITE SOPHISTICATED SOLID-STATE CONTROL SYSTEM WAS PROVIDED FOR

CARRIAGE POSITION INDICATION, HIGH THRUST MONITORING, AND CLUTCH SLIP SENSING. EXPERIENCE

GATHERED TO DATE INDICATES A SUCCESSFUL APPROACH TO, AND EXECUTION OF, A DIFFICULT

OPERATIONAL AND ENVIRONMENTAL DESIGN PROBLEM.

\#EQUIPMENT DESIGN + \#IRRADIATION TESTING + \#RFMMTE MANIPULATING AND VIEWING + CONTROL SYSTEM + DESIGN STUDY + REACTOR, TEST

9-27599

THOMPSON WM + VACROUX AG

FORCE-REFLECTING SERVOMECHANISMS WITH SIGNAL DELAY

ARGONNE NATIONAL LABORATORY

2 PAGES, 2 FIGURES, 6 REFERENCES, ANS TRANSACTIONS 11111 , PAGES $361-362$, 1968 MEETING OF THE AMERICAN

NUCLEAR SOCIETY AND CANADIAN NUCLEAR ASSOCIATION, TORONTO, CANADA, JUNE 10-13, 1968

FORCE-REFLECTING SERVOMECHANISMS ARE THE CONNECYING LINKS IN ELECTRICALLY CONNECTED

MASTER-SLAVE MANIPULATORS. IF A LARGE DISTANCE SEPARATES THE MASTER AND SLAVE ARMS, OR IF

OTHER SIGNAL-DELAYING MEDIA ARE INVOLVED, THE RESULTING SIGNAL DELAY SIGNIFICANTLY AFFECTS

SYSTEM STABILITY. AN ANALYSIS OF THIS EFFEC.T HAS BEEN MADE. IT ALSO CONSIDERS UNDALANCLD 
9-27599 *CONTINUED*

GAINS OF THE TRANSMISSION CHANNELS. THE RESULTS INDICATE THAT THE APPLICATION OF FORCE-REFLECTING SERVOMECHANISMS WHEN TIME DELAY IS INVOLVEO IS RESTRICTED BECAUSE OF STABILITY CONSIDERATIONS. IN THE SYSTEM INVESTIGATED, ACCEPTABLE RELATIVE STABILITY WAS POSSIBLE ONLY UP TO A CERTAIN MAXIMUM TIME DELAY. BEYOND THIS DELAY, ONE MAY HAVE TO EMPLOY OTHER SYSTEMS SUCH AS THOSE WITHOUT FORCE REFLECTION.

* REMOTE MANIPULATING AND VIEWING + \#SERVOMECHANISM + INSTABILITY + PONTRYAGINS PRINCIPLE

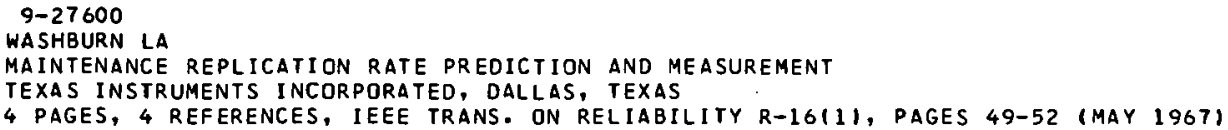

4 DIGITAL COMPUTER TECHNI QUE IS OEVELOPED, USING A MONTE CARLO SIMULATION BASED ON CDMMON PROBABILITY MODELS, WITH WHICH COMPONENT TEST DATA MAY BE TRANSLATED INTO APPROXIMATE SYSTEM RELIABILITY LIMITS AT ANY CONFIDENCE LEVEL. THE.PROBABILITY DISTRIBUTIONS FROM WHICH THE COMPONENT FAILURES ARE ASSUMED TO COME ARE THE EXPONENTIAL, WEIBULL ISHAPE PARAMETER K KNOWN), GAMMA (SHAPE PARAMETER ALPHA KNOWN), NORMAL, AND LOGNORMAL. THE COMPONENTS CAN BE ARRANGED IN ANY SYSTEM CONFIGURATION, SERIES, PARALLEL, OR BOTH, SINCE RELIABILITY PREDICTION IS MEANINGFUL ONLY WHEN EXPRESSED WITH AN ASSOCIATED CONFIDENCE LEVEL, THIS METHOD PROVIDES A VALUABLE AND ECONOMICAL TOOL FOR THE RELIABILITY ANALYST.

* DATA PROCESSING + MMONTE CARLo + *RELIABILITY ANALYSIS + PROBABILITY + RELIABILITY, COMPONENT + RELIABILITY, SYSTEM + SIMULATION

9-27602

BRENDER DM

THE UNCERTAINTY OF SYSTEM FAILURE-RATE PREDICTIONS

7 PAGFS, 5 REFFRENC.FS, IFEF IRANS. ON RELIABILITY R-16(2), PAGES 75-81 (SEPTEMBER 1967 )

THE RELATIVE UNCERTAINTY INVOLVED IN THE PREDICTION OF THE FAILURE RATE DF A. SYSTEM IS OFTEN CONSIDERABLY LESS THAN THE UNCERTAINTY ASSOCIATEO WITH THE FAILURE RATE OF THE AVERAGE COMPONENT. THE RELATIVE UNCERTAINTY ASSOCIATEO WITH THE PREDICTION DF THE NUMBER OF FUTURE SYSTEM FAILURES IS ALWAYS GREATER THAN THAT ASSOCIATED WITH SYSTEM FAILURE RATE. THE PURPOSE SYSTEM FAILURES IS ALWAYS GREATER THAN THAT ASSOCIATED WITH SYSTEM FAILURE RATE. THE PURPOSE
OF THIS PAPER IS TO RELATE (1) THE UNCERTAINTY IN THE NUMBER OF PREDICTED SYSTEM FAILURES TO THE UNCERTAINTY IN THE SYSTEM FAILURE RATE, ANO 121 THE UNCERTAINTY OF THE SYSTEM FAILURE RATE TO THE UNCERTAINTY IN THE FAILURE RATES OF THE COMPONENTS.

\#RELIABILITY ANALYSIS + PROBABILITY + RELIABILITY, SYSTEM

$9-27603$

FAN LT + WANG CS + TILLMAN FA + HWANG CL

OPTIMIZATION OF SYSTEMS RELIABILITY

KANSAS STATE UNIVERSITY, MANHATTAN

6 PAGES, 5 FIGURES, 2 TABLES, 11 REFERENCES, IEEE TRANS. ON RELIABILITY R-16121, PAGES $81-86$ (SEPTEMBER 1967 )

THE PURPOSE OF THIS PAPER IS TO OBTAIN AN OPTIMUM REOUNDANCY OF THE PARALLEL SYSTEM BY A VARIATIONAL TECHNIQUE. THE OB JECTIVE FUNCTION IS TO MAXIMIZE THE SYSTEM PROFIT. A SIMPLE COMPUTATIONAL PROCEDURE IS OBTAINED FOR THE OPTIMUM DESIGN OF THE MULTISTAGE PARALLEL SYSTEMS BYY THIS METHOD. TWO NUMERICAL EXAMPLES ARE GIVEN IN DETAIL.

\#REL IABILITY, SYSTEM + ECONOMICS + REDUNDANCE

9-27604

SPRINGER MO + THOMPSON HE

BAYESIAN CONFIDENCE LIMITS FOR THE. RELIABILITY OF CASCADE EXPONENTIAL SUBSYSTEMS 
9-27604 *CONTINUED*

GENERAL MOTORS, INC

4 PAGES, 1 FIGURE, 7 REFERENCES, IEEE TRANS. ON RELIABILITY R-16(2), PAGES 86-89 (SEPTEMBER 1967)

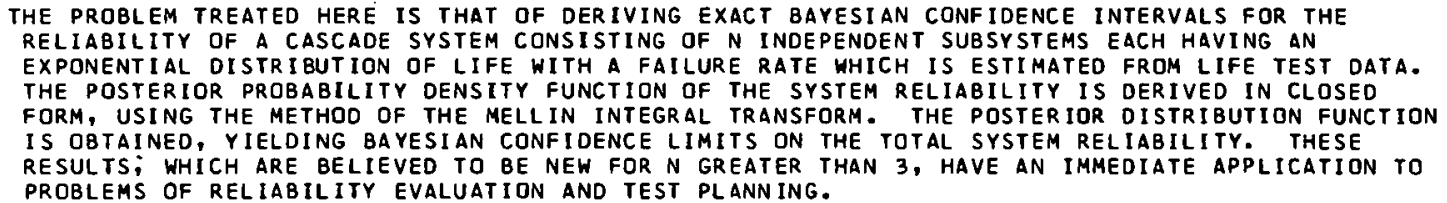

MATHEMATICAL TREATMENT + RELIABILITY, SYSTEM + STATISTICAL ANALYSIS

$9-27605$

KOOI CF

RELATION OF A PHYSICAL PROCESS TO THE RELIABILITY OF ELECTRONIC COMPONENTS

4 PAGES, 5 FIGURES, 6 REFERENCES, IEEE TRANS. ON RELIABILITY R-16(3), PAGES 113-116 (DECEMBER 1967)

AN ENSEMBLE OF ELECTRONIC COMPONENTS HAVING A RANDOM VARIATION OF SOME PARAMETER, SUCH AS SURFACE CONTAMINATION, IS CONSIDERED. A PHYSICAL PROCESS IS POSTULATEO WHICH LEADS TO A CHANGE IN ONE OF THE OPERATING CHARACTERISTICS OF THE DEVICE. WHEN THIS OPERATING CHARACTER ISTIC ATTAINS A VALUE OUTSIDE AN ACCEPTABLE RANGE. THE OEVICE IS CONSIDERED TO HAVE FAILED. THE FAILURE RATE IS CALCULATED DIRECTLY FROM THE TIME BEHAVIOR DF THE PHYSICAL FAILED. THE FAILURE RATE IS CALCULATED DIRECTLY FROM THE TIME BEHAVIOR DF THE PHYSICAL
PROCESS ANO COMPARED, FOR ILLUSTRATION, TO THE WEIBULL FAILURE LAH. THE PARAMETERS OF THE WEIBULL LAW ARE THEN RELATED TO THE PARAMETERS OF THE PHYSICAL PROCESS AND THE DISTRIBUTION OF STARTING PARAMETERS.

\#REL I ABILITY, COMPONENT + FAILURE, COMPONENT + INSTRUMENTATION, COMPONENT + PROBABILITY + STATISIICAL ANALYSIS

9-27606

LOTT JE

RELIABILITY PREDICTIONS AND SYSTEM SUPPORT COSTS

MART IN MARIETTA CORPORATION, ORLANDO, FLA.

8 PAGES, FIGURES, 4 REFERENCES, IEEE TRANS. ON RELIABILITY R-16(3), PAGES 126-133 (DECEMBER 1967I

A CASE STUDY DEMONSTRATES THAT SPARES REQUIREMENTS BASED ON OPERATIONAL RELIABILITY PREDICTIONS RESULT IN THE SYSTEM BEING UNDERSUPPORTED DUR ING ITS BURN-IN AND USEFUL-LIFE PHASES BY AVERAGE FACTORS OF 42.2 AND 4.22, RESPECTIVELY. HOWEVER, SYSTEMS SPARES REQUIREMENTS BASED ON LEGISTICS ESTIMATES RESULT IN THE SYSTEM BEING OVERSUPPORTED DURING ITS BURN-IN PHASE BY AN AVERAGE FACTOR OF 4.26 WITH THIS FACTOR PROBABLY INCREASING AS THE SYSTEM ENTERS THE USEFUL-LIFE PHASE OF ITS LIFE CYCLE. ADEOUATE SYSTEM SUPPORT WITHIN PREDETERMINEO COST ESTIMATES WILL BE ACHIEVED ONLY WHEN RELIABILITY PREDICTIONS ARE ACCURATE AND WHEN SYSTEMS SPARES REQUIREMENTS ARE COMPUTED SEPARATELY FOR THE EQUIPMENT BURN-IN PHASE AND USEFUL-LIFE PHASE.

*COMP ARISON, THEORY AND EXPERIENCE + \#ECONOMICS + \#REL IABILITY, SYSTEM + FAILURE, COMPONENT + PERF ORMANCE LIMIT + TEST, PREOPERATIONAL

$9-27607$

RUBINSTEIN D

STATISTICAL EXPOSITION OF GUIO MANUAL FOR RELIABILITY MEASUREMENT PROGRAM

GENERAL ELECTRIC COMPANY, SYRACUSE, NEW YORK

R68-13862 +. 55 PAGES, REFERENCES, ABSTRACT IN RELIABILITY ABSTRACTS AND TECHNICAL REVIEW 8 I7I, PAGE 111 (JULY 1968)

MATHEMATICAL MODELS AND DERIVATIONS AND STATISTICAL THEORY ARE DISCUSSEO. COMPONENTS AND SYSTEMS, FAILURE AND RELIABILITY, AND LIFE TESTING ARE CONSIDERED, INCLUDING THE JUSTIFICATION OF TRUNCATED LIFE TESTING. STATISTICAL INFERENCE OF SYSTEM RELIABILITY OF A SERIES SYSTEM IS DEVELOPED IN TERMS OF ESTIMATES RELATING TO COMPONENT FAILURE RATES, INFERENCE BASED ON NORMAL DISTRIBUTION, AND EXTENSIONS TO SYSTEMS WITH REDUNDANCY. TAYLORS EXPANSION FOR GUIDE MANUAL ESTIMATES, MOMENTS OF THE NUMBER OF FAILURES AND TEST TERMINATION TIMES, EXPECTED VALUES OF GUIDE MANUAL ESTIMATES, AND THE TERMWISE EXPANSION OF ONE OF THE VALUES ARE DETAILED. A COMPARISON WITH OTHER ME IHUUS IS INCLUDEO. AS IN THE DISTRIBUTION OF VALUES ARE DETAILED. A COMPARISON WITH OTHER MEIHU
UPPER CONFIDENCE LIMITS FOR SYSTEM FAILURE RATES.

\#RELIABILITY ANALYSIS + CODES AND STANDARDS + RELIABILITY, COMPONENT + RELIABILITY, SYSTEM + STATISTICAL ANALYSIS

9-27609

WEITZENFIELD AS + HAPP WW

COMBINATORIAL TECHNIQUES FOR FAULT IDENTIFICATION IN MULTI-TERMINAL NETWORKS

NASA

7 PAGES, 22 REFERENCES, IEEE TRANSACTIONS ON RELIABILITY VOL. R-16, PAGES 93-99 (DECEMBER 1967), ABSTRACT

IN RELIABILITY ABSTRACTS AND TECHNICAL REVIEW 817), PAGE 114 (JULY 1968) 
CATEGORY 9

NUCLEAR INSTRUMENTATION, CONTROL, AND SAFETY SYSTEMS

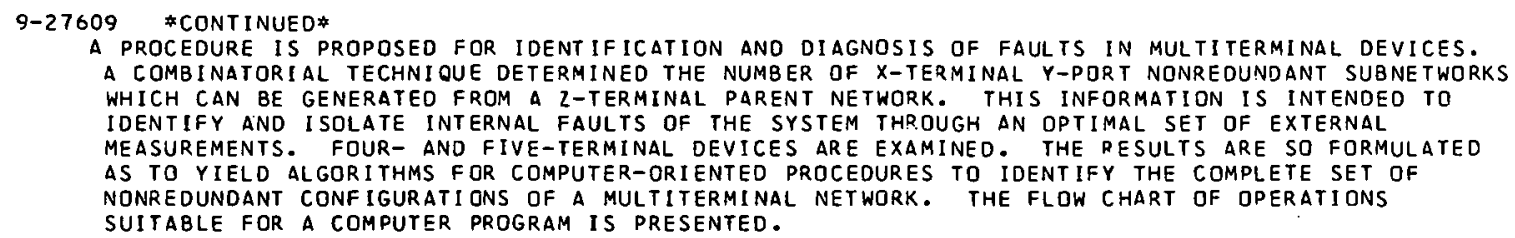

* REL IABILITY ANALYSIS + COMPUTER PROGRAM

$9-27610$

BRENDER OM

THE EFFECT OF K-FACTORS ON THE UNCERTAINTY OF FAILURE-RATE PREDICTIONS

2 PAGES, 1 REFERENCE, IEEE TRANSACTIONS ON RELIABILITY, VOL. R-16, PAGES 135 AND 136, (DECEMBER 1967 ), ABSTRACT IN RELIABILITY ABSTRACTS ANO TECHNICAL REVIEW 817), PAGE 116 (JULY 1968 )

DETERMINATION OF THE UNCERTAINTY INVOLVED WHEN MULTIPLYING A FAILURE RATE BY A K-FACTOR (STRESS FACTOR) TO ACCOUNT FOR THE EFFECT OF A MORE SEVERE ENVIRONMENT. PRAETICAL EVIDENCE OF THIS UNCERTAINTY IS SUPPL IED BY THE LARGE DEVIATIONS FREQUENTLY ENCOUNTERED BETWEEN PREDICTED AND MEASURED RESULTS. THE USE OF BAYESIAN IOEAS TO MEASURE THIS UNCERTAINTY IS DEMONSTRATED.

* REl iabilitr analYSIS * ENVIRONMENTAL CONDITION

9-27611

ANSLEY WG

DEVICE FAILURES OURING EQUIPMENT LIFE FOR LOGNORMAL DISTRIBUTIONS

HEWLETT-PACKARD CO., PALO ALTO, CALIF.

2 PAGES, 1 REFERENCE, IEEE TRANSACTIONS ON RELIABILITY VOL. R-16, PAGES 139-40 (OEC. 1967I, ABSTPACT IN

RELIABILITY ABSTRACTS AND TECHNICAL REVIEH 8(7), PAGE 116 (JULY 1968 )

PRESENTATION OF A SIMPLE GRAPH SHOWING THE TOTAL FRACTION OF DEVICES WHICH WILL FAIL OVER ANY GIVEN TIME FOR LOGNORMAL FAILURE DISTRIBUTIONS. THE RESULT IS A FUNCTION OF THE MEDIAN LIFE AND THE GEOMETRIC DISPERSION.

\#RELIABILITY ANALYSIS + FAILURE, COMPONENT + RELIABILITY, COMPONENT

9-27612

CODIER EO

RELIABILITY GROWTH IN REAL LIFE

GENERAL ELECTRIC COMPANY, UTICA, NEW YORK

12 PAGES, IN ANNALS OF ASSURANCE SC.IFNC.FS, PROCEEOINGS OF THE ANNUAL SYMPOSIUM DN RELIABILITY, BOSTON,

MASS. JAN. 16-18, 1968 , PAGES 458-469. ABSTRACT IN RELIABILITY ABSTRACTS AND TECHNICAL REVIEW B(TI, PAGE

122 (JULY 1968 )

DISCUSSION OF MONITORING, FORECASTING, AND PRESENTATION METHODS OFRELIABILITY PREDICTION THAT: WORK ANO ARE BELIEVABLE. IT IS SHOWN THAT THE DUANE CHART APPEARS TO BE A POWERFUL ANALYTICAL TOOL FOR CONSTRUCTING RELIABLE ESTIMATES OF THE CURRENT STATUS AND RATE OF RELIABILITY GROWTH. IT IS POINTED OUT THAT THE AMOUNT OF EVIDENCE WHICH HAS BEEN ACCUMULATED RELIABILITY GROWTH. IT IS POINTED OUT THAT THE AMOUNT OF EVIDENCE WHICH HAS BEEN ACC
AND INTERPRETED IN THE DUANE MODEL IS AT THIS POINT COMPLETELY CONVINCING THAT THIS ANO INTERPRETED IN THE DUANE MODEL IS AT THIS POINT COMPLETELY CONVI
PARTICULAR MODEL IS AN EFFECTIVE REPRESENTATION OF THE REAL WORLO.

\#RELIABILITY ANALYSIS + ANAIYTTCAI MONFI

$9-27613$

REYNOLOS JO

EFFECTS OF SUSTAINED TEMPERATURE CYCLING ON PARTS

COLLINS RAUIÜ COMPANY, CEOAR RAPIOS, IOWA

8 PAGES, IN ANNALS OF ASSURANCE SCIENCES, PROCEEDINGS OF THE ANNUAL SYMPOSIUM ON RELIABILITY, BOSTON, MASS. PAGES 486-493, JANUARY 16-18, 1968, ABSTRACT IN RELIABILITY ABSTRACTS AND TECHNICAL REVIEW BI7), PAGE 125 (JULY 1968 )

REPORTS A STUDY DF THE EFFECT OF SUSTAINED TEMPERATURE CYCLING ON ELECTRONIC-PART FAILURE RATES. THE TYPICAL MIL-STD-78IA THERMAL ENVIRONMENT IS DESCRIBED, AND THE TYPE OF PARTS AND COMPONENTS FOUND MOST SUSCEPTIBLE TO DEGRADATION OR FAILURE IS DISCUSSED. AN EVALUATION OF EXTENSIVE PAPT =LEVFL SUSTAINFD TFMPFRATIIRE C.YCLING IS MAUE, CORRECTIVE ACTION TAKEN ON CERTAIN PART TYPFS IS REVIEWED. AND RECOMMENDATIONS FOR INDUSTRY AND GOVERNMENT ACTION ARE MADE.

*INSTRUMENTATION, COMPONENT + *RELIABILITY, COMPONENT + FAILURE, COMPONENT + TEMPERATURE TRANSIENT + TEST, COMPONENT + THERMAL MECHANICAL EFFECT 
CATEGORY 9

NUCLEAR INSTRUMENTATION, CONTROL, AND SAFETY SYSTEMS

9-27614 \#CONT INUED*

DRL QUESTIONS EMERGENCY SIGNALS AND POWER

U.S. ATOMIC ENERGY COMMISSION

3 PAGES, LETTER TO M. H. PRATT FROM P. A. MORRIS, JULY 31, 1968, DOCKET 50-220, TYPE--8WR, MFG--G.E., AE--NI AGARA MOHAWK

DRL ASKS 7 SPECIFIC QUESTIONS: (1) ABILITY OF OFFSITE POWER, HITH A FAULT IN OUTSIDE SYSTEM, TO SAFELY SHUTDOWN PLANT. (2) ABILITY OF OFFSITE POWER TO SATISFY CRITERION 39 DESPITE 2 MIN DISCONNECT DELAY. (3) DC POWER FOR SHITCHYARD. (4) DESIGN AGAINST ELECTRICAL CABLE FIRE. (5) CONSEQUENCES OF LOSS OF STATION AIR OR INSTRUMENT AIR. (6) DIESEL START FROM SIGNALS OTHER THAN LOW VOLTAGE, E.G., UPON COOLANT INJECTION. 17 ) DISCUSS ADEQUACY OF CORE SPRAY ACTUATION SIGNALS. DISCUSS LACK OF DIVERSITY FOR ISOLATION VALVE ACTUATION.

AVAILABILITY - USAEC, PUBLIC DOCUMENT ROOM, WASHINGTON, D. $C$.

* PLANT PROTECTIVE SYSTEM + ACCIDENT, LOSS OF POWER + AEC QUESTION + ELECTRICAL CONDUCTION + FIRE + NINE MILE POINT (BWR) + PNEUMATIC SYSTEM + REACTOR, BWR

9-27616 ALSO IN CATEGORIES 17 AND 6

SELECTED SHIPPINGPORT OPERATING EXPERIENCE

BETIIS ATOMIC POWER LABORATORY

WAPD-MRP-122+. 14 PAGES, PAGES 6, 20-41 AND 43 OF PRESSURIZED WATER REACTOR (PWR) PROJECT. TECHNICAL PROGRESS REPORT, JULY 22, OCTOBER 20, 1967

(PAGE 6) NH4OH ADOITION AND DEGASIFICATION RATES INCREASE DRASTICALLY WITH COOLANT PH ABOVE 10.3. (PAGE 20-41) POWER LIMITS FOR VARIOUS CONTROL ROD PROGRAMS PAST 10,000 EFPH WERE CALCULATED. FOR VARIOUS LOAD SWINGS, XENON BURNOUT RATES AND AXIAL PEAK/AV NEUTRON FLUXES WERE MEASURED ANO COMPARED WITH TURBO-ZIP CALCULATIONS. ON THE RETURN TO 100 MWE ON AUGUST 2I, XENON OSCILLATION SET IN, GIVING +-9 IN. CONTROL ROD MOTION. OPERATIONAL DETECTORS LOCATED AT CORE MIDHEIGHT WERE IN PHASE WITH ROD BANK MOTION. WHILE TEST CHAMRFRS ABOVE THE CORE WERE OUT OF PHASE. OPERATING LIMITS FOR PEAK SINGLE CHANNEL NUCLEAR INSTRUMENT READINGS WERE CALCULATED, AS WAS A CONTROL ROD PROGRAM. (PAGE 43) COMPUTER PROGRAM MD 795 HAS PLACED INTO PRODUCTION. MO 795 PERFORMS ALL FUEL ELEMENT PERFORMANCE LIMITS CALCULATIONS FOR CORE 2, INCLUDING MAXIMUM PERMISSIBLE SINGLE CHANNEL, NUCLEAR INSTRUMENT READINGS.

AVAILABILITY - CLEARINGHOUSE FOR FEDERAL SCIENTIFIC AND TECHNICAL INFORMATION, NATIONAL BUREAU OF STANDARDS, SPRINGFIELD, VA. $22151, \$ 3.00$ COPY, \$0.65 MICROFICHE

*CONTROL ROD PROGRAM + *FUEL ELEMENT + *INSTRUMENTATION, ABNORMAL INDICATION + \#PERFORMANCE LIMIT + *XENON OSCILLATION + COMPUTER PROGRAM + COOLANT CHEMISTRY + POWER DISTRIBUTION + REACTOR, PWR + REPORT, OPERATIONS ANALYSIS + SHIPPINGPORT (PWR)

$9-27621$ ALSO IN CATEGORY 17

LACROSSE OPERATIONS OCT 1967

ALLIS-CHALMERS, BETHESOA, MARYLAND

ACNP-67534 +. 20 PAGES, FIGURES, TABLES, OCTOBER 1967, DOCKET 115-5, TYPE--BWR, MFG--A.C., AE--SGT + LUNDY

NO REACTOR OPERATION BECAUSE TESTTS AND MODIFICATIMNS WERF C.MMPIFTFM FOR PMWFR NPFOATINN ROD FAILED TO WITHDRAW AFTER A SCRAM DUE TO A PIECE DF A PHENOLIC BACKUP RING PLUGGING THE HYDRAULIC OIL DISCHARGE ORIFICE.

USAEC, PUBLIC DOCUMENT ROOM, 1717 H ST., WASHINGTON, D.C. 20545 (25 CENTS/PAGE)

FAILURE, SCRAM MECHANISM + LACROSSE (BWR) + REACTOR, BWR + REPORT, OPERATIONS

\section{$9-27650$}

MAJIMA K

AN INTROOUCTION OF RANOOM DRIFT PARAMETERS IN RELIABILITY

IBM JAPAN LTD., KOBE, JAPAN

10 PAGES, ELECTRONICS ANO COMMUNICATIONS IN JAPAN, VOL. 38, PAGES 74-83 (1965), ABSTRACT IN RELIABILITY

ABSTRACTS AND TECHNICAL REVIEW 8(7), PAGE 112 (JULY 1968)

A RANDOM-HALK MODEL IS USED TO DERIVE RANDOM DRIFT PARAMETERS. WITH THF MFAN VALLIE OF THE FLUCTUATING PARAMETER BEING PROPORTIONAL TO TIME AND THE PROBABILITY DISTRIBUTION REPRESENTED BY A THEORETICAL DISTRIBUTION. WHEN THE COEFFICIENTS OF THFSF DRIFT PARAMETERS ARE

SUBSEQUENTLY CHOSEN AS THE PARAMETERS OF LIFE OF RESISTORS, TEMPERATURE CHARACTERISTICS OF

CAPACITORS, AND DEGRADATION OF TUBE TRANSCONDUCTANCE, GOOD RESULTS ARE OBTAINED THAT CAN BE EXPRESSED NUMERICALLY AND BE APPLIED TO THE DETERMINATION OF RELIABILITY. RELIABILITY PKEDICTION WITH RESPECT TO TIME IS DISCUSSED AS IS A METHOD FOR DETECTING VARIATIONS OF CIRCUIT, PARAMETERS WITH THE DRIFT PARAMETERS FOR VARIOUS COMPONENTS.

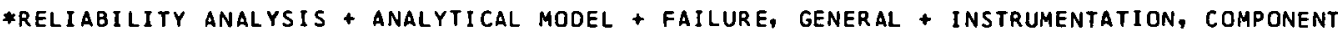

9-27842 ALSO IN CATEGORIES 17 AND 6

LEAD PLATE SHIFT TO CORE ADOS $0.168 \%$ REACTIVITY

PENNSYLVANIA STATE UNIVERSITY

3 PAGES, ATOMIC ENERGY CLEARINGHOUSE, 14(35), PAGES 12-14 (AUGUST 26, 1968) 
CATEGIRY

NUCLEAR INSTRUMENTATION, CONTROL, AND SAFETY SYSTEMS

$9-27842$ *CONTINUED*

(LETTER TO DRL, AUG. 9) ON JULY 24, THE REACTOR OPERATOR WAS OBSERVING XENON BEHAVIOR AND PLOTTING ROD POSITION VS TIME. HE NOTED A 37 UNIT REG ROD WITHDRAWAL IN A FEW SECONDS, A SLIGHT LOG INCREASE, AND A 10 C FUEL TEMP. DECPEASE. REACTOR WAS SHUT DOWN. CAUSE WAS A THICK LEAD PLATE (MOUNTEO BETWEEN CORE AND THERMAL COLUMN) WHICH HAD SWUNG TOWARD THE CORE AS NYLON ROPES SAGGED. LEAD ADDEO $0.084 \%$ ANO REFLECTED MORE NEUTRONS TOWARD THE SERVOCHAMBER, CAUSING A $40 \mathrm{KW}$ POWER DECREASE, WITH THIS FUEL COOLING ADOING $0.084 \%$.

* INSTRUMENTATION, ABNORMAL INDICATION + \#OPERATOR ACTION + BEAM HOLE + CONTROLLER + INCIDENT, EQUIPMENT + INSTRUMENTATIDN, PIWFR RANGE + LEAD + POWER COEFFICIENT + REACTIVITY EFFECT +

REACTIVITY EFFECT, ANOMALOUS + REACTOR POWER + REACTOR, QESEARCH + REFLECTOR + TRIGA (RR)

9-27845 ALSO IN CATEGORIES 17 AND 18

DRL QUESTIONS ON NINE MILE PQINT CONTROL ROOS

U.S. ATOMIC ENERGY COMMISSION

2 PAGES, LETTER TO M.H. PRATT FROM P.4. MORRIS, AUGHST 13, 1968, DOCKET 50-220, TYPE--BWR, MFG--G.F., AE--NI AGARA MOHAWK

COMPLIANCE SAYS DESIGN MODIFICATIONS HAVE BEEN MAOE TO CONTROL ROD DRIVE HYDRAULIC LINF PENETRATION IN CONTAINMENT. THIS SHOULD BE REPORTEO WITH BASES AND SACETY EVALUATION. ASKS FOR SPECIFIC INFORMATION ON WELO REPAIR BETWEEN STUB TUBES AND ROD DRIVE HOUSINGS, III BASES FOR CONTOURING SHOP WELDS, 12 ) FIELD WELOS OEDOSIT OF METAL ON SIDE OF TUBES, AND (3) TLANS

FOR CLEANING AND HYOROTESTING VESSEL, PLUS OETAILED RECORDS OF DYE CHECKS PRIOR TO HYDROTEST.

USAEC, PUBLIC DOCUMENT ROOM, 1717 H ST., WASHINGTON, 0.C. 20545 (25 CENTS/PAGE)

* CONTAINMENT PENETRATION, PIPE + *WELDING + CONTROL ROD DRIVE + INSPECTION AND COMPLIANCE + NINE MILE POINT (BHR) + PRESSURE VESSEL + REACTOR, BWR + TEST, NONDESTRUCTIVE

$9-27879$

SYLI ACCO TE

ALSO IN CATEGORY 10

THE ADAPTIVE RELIABILITY CONTROL SYSTEM

CLEVELAND ELECTRIC ILLUMINAT ING COMPANY, CLEVELAND, DHIO

15 PAGES, 2 FIGURES, 3 TABLES, 5 REFERENCES, IEEE TRANS. ON POWER APPARATUS AND SYSTEMS, PAS-86I5I, PAGES $517-531$ (MAY 1967 )

CONSIDERATIONS NECESSARY FOR THE DESIGN OF A TOTAL CONTROL SYSTEM FDR THE IMPROVEMENT DF THE RELIABILITY OF THE GENERATION-TRANSMISSION SYSTEM ARE DISCUSSEO. THE CONTROL SYSTEM IS MADE OF AUTOMATIC FUNCTIONS, HUMAN PARTICIPATION, AND AN INFORMATION SYSTEM. IN THE FIRST PART OF THE PAPER, THE FRAMEWDRK OF THE DESIGN IS ESTABLISHED AND THE BASIC OVERALL STRATEGY FOR MAINTAINING RELIABILITY IS DESCRIBED. THE SECOND PART DESCRIBES THE THINKING AND THE WORK BEING DONE AT CLEVELAND ELECTRIC ILLUMINATING COMPANY FOR THE PRACTICAL IMPLEMENTATION OF THE DESIGN CONCEPTS ON THIS SYSTEM.

CONTROL SYSTEM + DESIGN STUOY + ECONOMICS + ELECTRIC POWER, GENERAL + EMERGENCY SYSTEM + INSTABILITY + RELIABILITY, SYSTEM

$9-27885$

ALSO IN CATEGORY 5

KARTLUKE H + WICHNER RP + HOFFMAN HW

AN ACOUSYIC INSTRUMENT FOR MEASURING SUBCOOLING IN BOILING SYSTEMS

OAK RIDGE NATIONAL LABORATORY

ORNL-P-1678 + CONF-650946-3 +. 8 PAGES, 1 REFERENCES, FROM 4TH HIGH TEMPERATURE LIOUID-METAL HEAT

TRANSFER TECHNOLOGY CONFERENCE, ARGONNE, ILLINOIS, SEPTEM8ER 28-29, 1965

OESCRIBES AN ACUUSTIC INSIRUMENI CAPABLE OP INOICATING THE DEGREE OF UNDERSATURATION IN A KNOWN FLUIO AT UNKNOWN LOCAL TEMPERATURE AND PRESSURE CONOITIONS. THIS INCIPIENT-BOILING DETECTOR HAS BEEN TESTEO WITH WATER AND SHOWN TO BE EFFECTIVE IN MONITORING THE FLON IN PRESSUPIZED WATER. REACTORS, WHERE BOILING IS UNDESIRABLE AND DANGERDUS. THE CURRENT STUOY IS DIRECTED TO EVALUATING THIS DEVICE FOR POSSIBLE SIMILAR APPLICATION IN LIQUID-METAL

COOLED-FAST REACTORS. PRELIMINARY TESTS IN LIOUIO POTASSIUM ARE DISCUSSED. THE RESULTS WERE INCONCLUS IVE, ANO EXPERIMENTS WITH A HIGHER POWER OSCILLATOR ARE PLANNED.

AVAILABILITY - CLEARINGHOUSE FOR FEDERAL SCIENTIF IC ANO TECHNICAL INFORMATION, NATIONAL BUREAU OF STANDARDS, SPRINGF IELD, VA. $22151, \$ 3.00$ COPY, \$0.65 MICROFICHE - INSTRUMENTATION, CONOI, ANT OISIITY + \#NOISE + \#SUBCOOLING + BOILING + INSTRUMENTATION, GENERAL +

$9-27931$

SHOOMAN ML

RELIABII ITY PHYSICS MODELS

BROOKLYN POLYTECHNIC INSTITUTE

7 PAGES, IEEE TRANSACTIONS ON RELIABII.ITY, VOL. R-17, PAGES 14-20 (MARCH 1968), ABSTRACT' IN RELIABILITY

ABSTRACTS AND TECHNICAL REVIEWS, B(8), PAGE 128 (AUGUST 1968)

OESCRIPTION OF RELIABILITY FAILURE MOOELS BASED ON LOGICAL HYPOTHESES AS TO HOW OBJECTS FAIL. IT IS NOTED THAT THE GENERAL I ZED STRESS-STRENGTH MODEL PREVALENT IN CURRENT LITERATURE IS PERHAPS THE ClOSEST THAT ANALYSTS HAVF COME TO A GENERAL PhYSICAL MODEL. IF A NORMAL 
CATEGORY

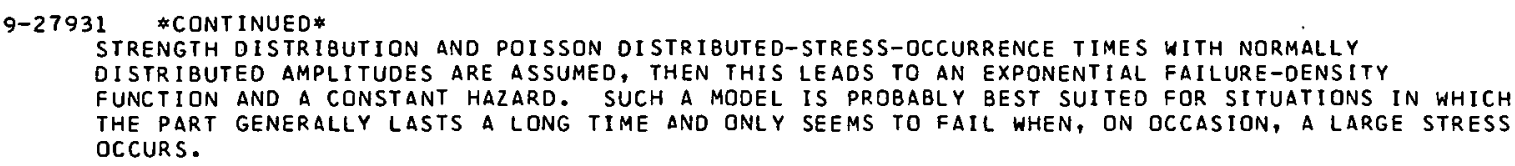

\#ANALYTICAL MODEL + †RELIABILITY ANALYSIS + FAILURE, GENERAL + PROBABILITY + STRESS ANALYSIS

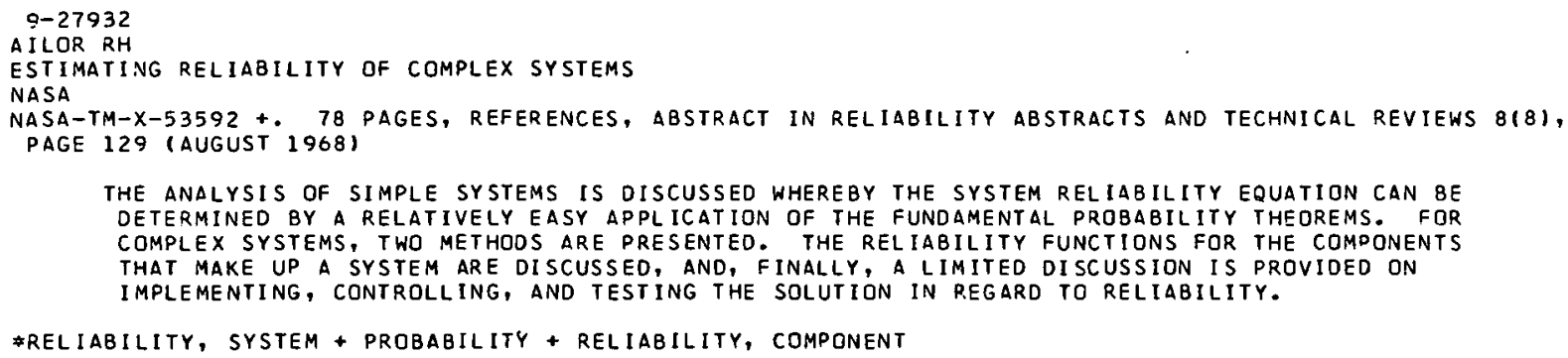

TR-23+AD-642105+N67-17158+ 134 PAGES, REFERENCES, OCTOBER 1966, ABSTRACT IN RELIABILITY ABSTRACTS AND TECHNICAL REVIEWS $8(8)$, PAGE 130 (AUGUST 1968 )

THE INFANT MORTALITY EFFECT OBSERVED IN THE STATISTICAL TREATMENT OF RELIABILITY DENOTES A DECREASING WITH TIME OF THE CONDITIONAL PROBABILITY OF FAILURE OF A DEVICE WHICH EXHIBITS IT. THIS WIDELY PRESENT EFFECT MAY BE UTILIZED TO IMPROVE THE KELIABILITY BY MEANS OF BURN-IN TESTING WHICH SEEKS TO DISCRIMINATE BETWEEN HIGH AND LOW QUALITY UNITS BY ACCUMULATING OPERATING EXPERIENCE UPON ALL UNITS. A GENERAL BURN-IN TEST PROBLEM FOR REPAIRABLE DEVICES IS FORMULATED BASED UPON THE EXPLICITY MODELING OF THE REPAIR PROCESS. THE CASE OF UNREPAIRABLE DEVICES IS TREATED AS A SPECIAL CASE.

*RELIABILITY, COMPONENT + INSTRUMENTATION, COMPONENT + QuALITY CONTROL + TEST, PREOPERATIONAL

9-27935

BRIGGS WG

RELIABILITY STATEMENTS UNDER UNCERTAINTY

HARBRIDGE HOUSE, INC., BOSTON, MASS.

9 PAGES, 12 REFERENCES, THE LOGISTICS REVIEW, VOL 3, PAGES 11-19 (FEBRUARY 1967), ABSTRACT IN RELIABILITY

ABSTRACTS AND TECHNICAL REVIEHS 8(8), PAGE 131 (AUGUST 1968 )

COMPONENT RELIABILITY IS DEFINED, AND THE UNCERTAINTY OF THE FAILURE RATE IS CONSIDERED IN TERMS OF SUBJECTIVE DISTRIBUTIONS AND BAYESIAN ANALYSIS. IT IS SHOWN THAT IF THE FAILURE RATE OF A CONOITIONAL POISSON DISTRIBUTION HAS A GAMMA DISTRIBUTION, THE RESULTING UNCONDITIONAL OISTRIBUTION OF FAILURES IS NEGATIVE BINOMIAL. A COMPUTATION FORM FOR THIS UNCONDITIONAL OISTRIBUTION OF FAILURES IS GIVEN AND SOME NUMERICAL [XAMPLES ARE INCLUDED. ILLUSTRATIVE VALUES OF NEGATIVE BINOMIAL PRORABILITIES ARE TABULATED.

\#RELIABILITY ANALYSIS + \#RELIABILITY, COMPONENT

9-27936

JAIN HC

RELIABILITY OF A COMPLEX SYSTEM WITH TWO TYPES OF SUBSYSTEMS 
CATEGORY 9

NUCLEAR INSTRUMENTATION, CONTROL, AND SAFETY SYSTEMS

9-27936 *CONTINUED*

DEFENSE SCIENCE LABORATORY, OELHI, INDIA

17 PAGES, 5 REFERENCES, THE LOGISTICS REVIEW, VOL 3, PAGES 21-37 (JAN-FEB. 1967), ABSTRACT IN RELIABILITY ABSTRACTS AND TECHNICAL REVIEWS 8(8), PAGE 132 (AUGUST 1968 )

COMPLEX SYSTEM BEHAVIOR IS CONSIDERED THAT OPERATES AT REDUCED EFFICIENCY UPON FAILURE OF ONE COMPONENT (L-SUB-2) ANO COMPLETELY BREAKS DONN UPON THE FAILURE OF ANOTHER COMPONENT

(L-SUB-1). FAILURE AND REPAIR TIMES FOR BOTH THESE COMPONENTS FOLLOW EXPONENTIAL

DISTRIBUTIONS. IF L-SUB-1 FAILS WHILE L-SUB-2 IS BEING REPAIRED, THEN THE REPAIR OF L-SUB-1

TAKES PRECEDENCE. THE RFPAIR OF L-SUB-2 IS RESUMED LATER AT THE POINT WHERE IT WAS

PREEMPTED. BOTH TYPES OF REPAIRS ARE CONSIDERED, AND EXPLICIT SOLUTIONS ARE DERIVED USING

K-ERLANG AND EXPONENTIAL REPAIR TIME OISTRIBUTIONS. STEAOY STATE SOLUTIONS ARE DERIVED BY A

COROLLARY OF ABELS THEOREM, ANO NUMBERICAL EXAMPLES ARE INCLUDED.

\#RELIABILITY, SYSTEM + INSTRUMENTATION, COMPONENT + MAINTENANCE AND REPAIR + RELIABILITY, COMPONENT

$9-27937$

PRINGLE RS + GRESHO PM

A COMPREHENSIVE RELIABILITY ANALYSIS DF REDUNDANT SYSTEMS

DOUGLAS AIRCRAFT CO., INC.. SANTA MONICA, CALIF. + NORTH AMERICAN AVIATION, INC. CALIF.

8 PAGES, 8 REFERENCES, JOURNAL OF SPACECRAFT AND ROCKETS, VOL. 4, PAGES G3I-639 (MAY 1967 ), ABSTRACT IN

RELIABILITY ABSTRACTS AND TECHNICAL REVIEWS 8181, PAGL 133 (AUGUST 1968)

ANALYSIS AND OISCUSSION OF THE GENERAL EFFECT OF REDUNDANCY ON SYSTEM RELIABILITY. THREE TYPES OF REDUNOANCY ARE DESCRIBED--ACTIVE REDUNDANCY, STANDBY REDUNDANCY, AND ACTIVE-STANDBY REDUNDANCY--AND EQUATIONS ARE OEVELOPED FOR EACH TYPE. A RAPID AND ACCURATE APPROXIMATION TECHNIQUE FOR ANALYZING ACTIIVE-STANDBY REOUNDANCY IS ALSO PRESENTED.

*REDUNDANCE + \#RELIABILITY ANALYSIS + \#RELIABILITY, SYSTEM

9-27938

CORNELL CE

MINIMI ZING HUMAN ERRORS

10 PAGES, SPACE/AERONAUTICS, VOL. 49, PAGES 72-81 (MARCH 1968), ABSTRACT [N RELIABILITY ABSTRACTS ANO

TECHNI CAL REVIEWS $8(8)$, PAGE 134 (AUGUST 1968 )

ANALYSIS OF THE CAUSES AND REMEDIES OF HUMAN ERRORS WITH RESPECT TO WORK INVOLVING SPACECRAFT

MANUFACTURING. THE FOUR MAJOR CAUSES OF HUMAN ERROR WHICH ARE DISCUSSEO INCLUDE FAILURE TO

FOLLOW PROCEOURES, INCORRECT DIAGNOSIS OF PARTICULAR SITUATIONS, MISINTERPRETATION OF

COMMUNICATIONS, AND INSUFFICIENT ATTENTION OR CAUTION. THE PROBLEM ASSOCIATED WITH

OUANTIFYING HUMAN ERROR IS ALSO DISCUSSED.

*ERRor anALYSIS + \#FAILURE, aOMINISTRATIVE CONTROL + \#RELIABILITY aNALYSIS + OUALITY CONTROL

$9-27939$

MEISTFR D + FARR DE

THE UTILIZATION OF HUMAN FACTORS INTORMATION BY DESIGNEP.S

BUNKER-RAMO CORP. , CANOGA PARK, CALIF.

AD-642057+N67-15359+. 105 PAGES, REFERENCES, SEPTEMBER 16, 1966, ABSTRACT IN RELIABILITY ABSTRACTS AND TECHNICAL REVIEWS $8(8)$, PAGE 135 (AUGUST 1968 )

THREE DESIGN TESTS WERE DEVELOPEO TO DETERMINE HOW HUMAN FACTORS CRITERIA AND INFORMATION ARE APPLIED TO DESIGN PROBLSMS. TEST RESULTS INDICATE THAT DESIGNERS HAVE LITTLE OP. ND INTEREST IN HUMAN FACTORS AND USUALLY FAIL TO APPLY HUMAN FACTORS CRITERIA TO DESIGN. THE MOST IMPORTANT SUURCE UF INFUKMATION FOR THE DESIONER IS THE DESICN SPECIFIGATION. WHERE A DESIGNER DOES NOT HAVE FORMALLY ASSIGNEO RESPONSIBILITY FOR A DESIGN PARAMETER, HIS ANALYSIS WILL NOT REFLECT THIS FACTOR. IT IS RECOMMENDED THAT DESIGN SPECIFICATIOVS EMPHASIZE HUMAN FACTORS TO THE SAME EXTFNT THAT OTHER FUNCTIONAL PEQUIREMENTS ARE EMPHASIZED.

\#FAILURE, ADMINISTRATIVE CONTROL + \#RELIABILITY ANALYSIS + DESIGN CRITERIL. + DESIGN STUDY + QUALITY CONTROL

$9-27940$

MEISTER D

APPLICATIONS OF HUMAN RELIABILITY TO THE PRODUCTION PROCESS

BUNKER-RAMO CORP. CANOGA PARK, CALIF.

13 PAGES, REFERENCES, PAGES 33-45 IN AFSC SYMPOSIUM ON RELIABILITY OF HUMAN PERFORMANCE IN WORK, MAY 19E7,

ABSTRACT IN RELIABILITY ABSTRACTS AND TECHNICAI. REVIEWS 8(8), PAGE 135 (AUGUST 1 OS8)

PRODUCTION WORKER ERRORS ARE RELATED TO SYSTEM RELIABILITY, AND CHARACTERISTICS THAT

DIFFERENTIATE PRODUCTION ERROR FROM OPERATING ERROR ARE CONSIDERED. FACTORS THAT PREDISPOSE

TO WORKER ERROR ARE ANALYZED IN THE CONTEXT OF THE PRODUCTION PROCESS AS A MAN-MACHINE

SYSTEM. THE IMPORTANCE OF WORKMANSHIP AS A PROBLEM AREA THAT REQUIRES BEHAVIORAL

INVESTICATION IS STRESSED, ANR MEANS OF OETECTING ERRORS AND THEIR CAUSSS ARE PRESENTED. THE

EFFECT OF PRODUCTION ERROR ON RELIABILITY IS TREATEO, AND $\triangle$ TABULATION IS PRESENTED TO

INDICATE UNRELIABILITY RESULTING FROM. SIGNIFICANT HUMAN-INITIATEO FAILURES.

*FAILURE, AOMINISTRATIVE CONTROL + \#RELIABILITY, SYSTEM + INSPECTION AND COMPLIANCE + OUALITY CONTROL 
CATEGORY 9

NUCLEAR INSTRUMENTATION, CONTROL, ANO SAFETY SYSTEMS

S-27941

BARZ ILOVICH YY

THE PROBLEM OF SERVICING CDMPLEX TECHNICAL SYSTEMS

24 PAGES, REFERENCES, TECHNICAL CYBERNETICS NO. 6, PAGES 102-125 (FEBRUARY 14, 1967), ABSTRACT IN

RELIABILITY ABSTRACTS AND TECHNICAL REVIENS 8(8), PAGE 136 (AUGUST 1968)

A BRIEF REVIEW IS OFFERED OF BASIC WORKS IN THE AREA OF CONTROL OF RELIABILITY OF COMPLEX TECHNICAL SYSTEMS DURING OPERATION AND DESIGN. THIS IS A OUALITATIVE REVIEW OF VARIOUS METHODS FOR SERVICING EQUIPMENT. IT CONSIDERS BOTH SCHEOULED AND UNSCHEDULED MAINTENANCE AND VARIOUS STRATEGIES FOR CONSUMING REDUNDANT ELEMENTS.

¥REL IABILITY, SYSTEM + DESIGN STUDY + INSTRUMENTATION, GENERAL + MAINTENANCE AND REPAIR

$9-27942$

WR IGHT LW

AN OVERVIEW OF ELECTRONIC PART FAILURE ANALYSIS EXPERIENCE

JET PROPULSION LAB., PASADENA, CALIF.

5 PAGES, IEEE TRANSACTIONS ON RELIABILITY, VOL R-17, PAGES 5-9 (MARCH 1968), ABSTRACT IN RELIABILITY

ABSTRACTS AND TECHNICAL REVIEWS 8(8), PAGE 138 (AUGUST 1968)

THE ROLE OF PART IOR COMPONENT) FAILURE ANALYSIS IN SYSTEMS DEVELOPMENT IS DISCUSSED, ALONG WITH THE MAJOR CAUSES OF PARTS FAILURES AND CASE HISTORIES FDR ELECTRONIC DEVICES. THE MAJOR PORTION OF PARTS FAILURES THAT HAVE RESULTED IN EQUIPMENT MALFUNCTIONING ARE ATTRIBUTED TO GROSS QUALITY DEFECTS AND MISUSE. TIMEIENVIRONMENT DEPENDENT FAILURE MECHANISIMS ARE GENERALLY MORE INSIDIOUS, MORE DIFFICULT TO PINPOINT, AND RESULT IN FEWER EQUIPMENT MALFUNCTIONS. THERE ARE NUMEROUS TIMEIENVIRONMENT DEPENDENT FAILURE MECHANISMS WHICH ARE NOT UNOERSTOOD SUFFICIENTLY TO PERMIT HIGHLY EFFECTIVE FAILURE ANALYSIS IN RELATION TO CURRENT PROJECTS.

*FAILURE, COMPONENT + \#RELIABILITY, COMPONENT + ENVIRONMENTAL CONDITION + INSTRUMENTATION, COMPONENT + QUALITY CONTRULL

9-27943

RELIABILITY ANO MAINTAINABILITY DATA-SOURCE GUIDE

NAVAL APPLIED SCIENCE LAB. BROOKLYN, N. Y.

AD-659195+N68-10849+. 254 PAGES, JANUARY 1967, ABSTRACT IN RELIABILITY ABSTRACTS ANO TECHNICAL REVIEHS $8(8)$, PAGE 139 (AUGUST 1968 )

THIS DATA-SOURCE GUIDE IDENTIFIES 23 GOVERNMENT RELIABILITY AND MAINTAINABILITY DATA SOURCES AND OVER 95 SOURCES OF TECHNICAL AND SCIENTIFIC INFORMATION FOR RELATED ENGINEERING DATA.

THE TECHNICAL COVERAGE, MISSION, STATUS, AND THE AODRESS OF CONTACTS ASSOCIATED WITH EACH DATA SUURCE ARE SUMMARIZED IN THE GUIDE. THE GUIDE TABULATES RESPONSES RECEIVEO FROM 118 CONTRACTORS IN REPLY TO A QUESTIONNAIRE PREPARED BY ARINC RESEARCH. A MATRIX SHOHS THAT 94 OF THE 118 HAD ESTABLISHED RELIABILITY AND MAINTAINABILITY DATA COLLECTION ACTIVITIES. ALSO PRESENTEO IS A REVIEW OF THE COLLECTED DATA, AS TO ITS UTILITY, OPTIMISM, CURRENCY, AND APPLICABILITY TO MULTICONTRACTOR USE.

*INSTRUMENTATION, GENERAL + \#RELIABILITY ANALYSIS + INFRRMATIMN RFTRIFVAI, \& STATISTIGAL GONRELATIOH

$9-27944$

RUSSOLINI JJ

THE APPLICATION OF OVERSTRESS TESTING-TO-FAILURE TO AIRBORNE ELECTRONICS--A STATUS REPORT

GRUMMAN AIRCRAFT ENGINEERING CORP.

7 PAGES, IEEE TRANSACTIONS OF AEROSPACE AND ELECTRONIC SYSTEMS, VOL AES-4, PAGES 142-148 (MARCH 1968), ABSTRACT IN RELIABILITY ABSTRACTS AND TECHNICAL REVIEWS 818 ), PAGE 143 (AUGUST 1968 )

APPLICATION OF THE CONCEPT OF SAFETY-MARGIN DESIGN AND QVERSTRESS TESTING TO THE DESIGN OF ELECTRUNIC EQUIPMENT. TEST RESULTS ARE PRESENTED WHICH INDICATE THE VALUE OF THE OVERSTRESS TEST-TO-FAILURE TECHNIQUE AS A DESIGN TOOL AND METHOD OF SOURCE SELECTION, RELIABILITY IMPROVEMENT, AND EVALUATION. IT IS SHOWN THAT $65 \%$ OF THE FAILURE OCCURRING UNDER OVERSTRESS ENVIRONMENTS ARE.DUPLICATES OF EXPERIENCED OPERATIONAL FAILURES. IMPROVEMENTS OF 5 TO I IN RELIABILITY LEVELS HAVE RESJLTED FROM APPLICATION DF RESULTS OF OVERSTRESS TESTS WHICH CONSUMED LESS THAN 200 HR OF ACTUAL TEST TIME. THE FIRST IN A REQUIRED SERIES OF INDICES WHICH MAY ASSIST IN THE EVENTUAL USE OF OVERSTRESS TESTING FOR RELIABILITY INDEX MEASUREMENT ARE DISCUSSED.

* InSTRUMENTATION, COMPONENT + \#RELIABILITY, COMPONENT + FAILURE, COMPONENT + TEST, DESTRUCTIVE

9- 28012

DEVICE FOR MONITORING SHUT-DOWN NUCLEAR REACTORS

BELGIAN PATENT NO. $686,624+13$ PAGES, 3 FIGURES, SEPTEMBER 8,1966

4 METHOD OF PREPARING a SAFING WIRE FOR USE IN SAFE-GUARDING A NUCLEAR REACTOR TO DETECT SURREPTITIOUS USE THEREOF, COMPRISING PROVIDING A TUBE OF A HIGH MELTING METAL, PULLING DNE 


\section{9-28012 *CONTINUED*}

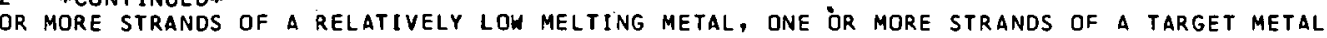
WHICH WILL BECOME RADIOACTIVE IN THE EVENT OF A NEUTRON CHAIN REACTION, ANO ONE OR MORE STRANDS OF A OIFFERENCE METAL THROUGH SAID TUBE, WHILE ALLOWING SAIO LAST-MENTIONED STRANDS

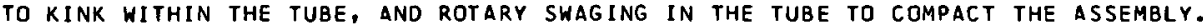

AVAILABILITY - U. S. PATENT OFFICE, DEPT. OF COMMERCE, WASHINGTON, D. C. 20545

*DECOMMISSIONING + *EXAMINATION + *INSPECTION AND COMPLIANCE + ACTIVATION + ADMINISTRATIVE CONTROL + BELGIUM + EQUIPMENT DESIGN + MEASUREMENT, REACTIVITY + PATENT + SURVEILLANCE PROGRAM

$9-28013$

FOTI, G

BEHAVIOR OF FISSION CHAMBER SYSTEM INSIDE THE REACTOR CORE OF THE GARIGLIANO NUCLEAR STATION DURING THE FIRST PERIDD OF OPERATION AT FULL CAPACITY

6 PAGES, 3 FIGURES, ENERGIA ELETTRICA, 42, RAGES 345-50 (1965)

BOILING WATER REACTORS HAVE A NEUTRON FLUX OISTRIBUTION INSIDE THE CORE THAT IS RIGIDLY DEPENDENT ON THE OPERATI ONAL CONDITIONS OF THE INSTALLATION. THIS MAKES IT NECESSARY THAT THE OPERATOR HAVE AT HIS DISPOSAL CONT INUOUSLY ALL INFORMATION OBTAINABLE ON THE FLUX DISTRIBUTION. THE MEASUREMENT SYSTEM IN THE GARIGLI.ANO NUCLEAR POHER PLANT IS BRIEFLY DESCRIBED. THE OPERATIONAL EXPERIENCE OBTAINEO UP TO JUNE 1964 IS SUMMARIZED. THE BEHAVIOR OF THE SYSTEM DURING THE PERIDO FROM JUNE 1964 TO APRIL 1965 AT FULL POWER WAS REPORTED TO AN APPENDIX.

*CHAMBER, FISSION + \#INSTRUMENTATION, NUCLEAR + \#OPERATING EXPERIENCE + FLUX OISTPIBUTION + GARIGLIANO (BWR) + IN CORE MEASUREMENT + INSTRUMENTATION, IN CORE + ITALY + REACTOR, BWR

$9-28014$

SWINTH KL + PHILIPP LD + HOITINK NC

COMPTON SUPPRESSION USING PULSE-SHAPF. DISCRIMINATION AND ANTICOINCIOENCE TECHNIQUES

BATTELLE-NORTHWEST, RICHLAND, WASHINGTON

BNWL-SA-1515 + CONF-680207-3 +. 17 PAGES, MARCH 4, 1958, FROM 11TH SCINTILLATION AND SEMICONOUCTOR COUNTER SYMPOSIUM, WASHINGTON, D. C.

THE USE OF PULSE-SHAPE DISCRIMINATION AND ANTICOINCIDENCE TECHNIQUES IS DESCRIBED IN REDUCING THE CONTINUUM OF THE ENERGY SPECTRUM FROM GAMMA RAYS. IN THE ENERGY REGION FROM 1 OO KEV TO 1.5 MEV. THE SYSTEM IS INTENDED GENERALLY FOR LOW LEVEL COUNTING AND THE DATA PRESENTED PERTAINS

TO COUNTING IN THIS MODE. STUDIES WERE PERFORMED WITH BOTH CS-137 AND FE-59 SOURCES. FOR THE FE-59 SOURCE, AN AVERAGE REDUCTION OF $85 \%$ IN THE CONTINUUM RESUL TED USING A PLANAR DIQDE SQ. 110 SQ. MM BY 2.4 MM DEEP IN AN ANTICOINCIDENCE ANNULUS OF NAIITII. BOTH THE DISTRIBUTION AND NUMBER OF EVENTS REJECTEO VARIES, WITH THE AMPLIFIEP. SHAPING TIME CONSTANTS. RESULTS ARE COMPARED WITH THOSE DBTAINED BY OTHER INVESTIGATORS.

AVAILABILITY - CLEARINGHOUSE FOR FEDERAL SCIENTIFIC AND TECHNICAL INFORMATION, SPRINGFIELD, VA. 22151 , $\$ 3.00$ CDPY, \$0.65 MICROFICHE

\# INSTRUMENTATION, PULSE + COUNTER + GAMMA + INSTRUMENTATION, COINCIDENT + INSTRUMENTATION, COMPONENT + INSTRUMENTATION. NIICLEAR + SOLID STATE DEVICE

$9-28015$

TODT WH

AN IN-CORE RADIATION DETECTOR FOR MONITORING PULSEO REACTOR EXCURSIONS

WESTINGHOUSE ELECTRIC CORPORATION

O PAGES, ? FIGURES, 3 REFEPENCES, NIICLEAR APPLICATIONS 5(3), PAGES 173-178 (SEPTEMBER 1968)

AN IN-CORE RADIATION DETECTOR HAS DEVELOPED TO MEASURE INTENSE RADIATION LEVELS PRESENT IN PULSING REACTOR CORES. TEST RESULTS ARE SHOWN FOR TRIGA AND PULSTAR EXCURSIONS WITH PEAK POWER LEVELS OF 150 AND $1000 \mathrm{MW}$, RESPECTIVELY. LIFE DATA INOICATE NO DETERIORATION IN DETECTOR CHARACTERISTICS AFTER MORE THAN 800 TRIGA PULSES.

* INSTRUMENTATION, IN CURE + *INSTRUMENTATION, RADIATION MONITORING + BORON + CHAMBER, ION + COMPARISON, THEORY AND EXPERIENCE + EQUIPMENT DESIGN + OPERATING EXPERIENCE + REACTOR, PULSEO + REACTOR, RESEARCH + TEST, INSTRUMENT RESPONSE + TRIGA (RR)

$9-28016$

MUEI. LER RE + BRANYAN CE

CALIBRATION MEASUREMENTS OF CONTROI DND SAFETY ROOS IN THE ENRICO FERMI REACTOR ATOMIC POWER DEVELOPMENT OSSOC.IATES, INC., DETROIT

APDA-NTS-18 +. 59 PAGES, 12 FIGURES, 4 TABLES, 13 REFERENCES, APRIL 1968

OURING THE LOW-POWER TESTING OF THE ENRICO FERMI REACTOR, DETAILED CALIBRATION MEASUREMENTS OF THE CONTROL ANO SAFETY RODS WERE MADE TO CONFIRM THE ROD DESIGN AND ALSO TO INVESTIGATE THE ADAPTABILITY OF DIFFERENT CALIBRATIUN TECHNIQUES. WORTHS OF INDIVIDUAL UNSHADOWED AND SHADOWED RODS WERE OBTAINED AS WEL AS GAUGED ROD WORTH. THE MEASUREO ROD WORTH WERE ABOUT G TO 15 PER CENT LESS THAN HAD BEEN PREDICTEO FROM CRITICAL EXPERIMENT DATA. HOWEVER, THIS AGREEMENT IS CONSIDERED SATISFACTORY IN VIEW OF OESIGN CHANGES MADE SINCE THE EXPERIMENT. MEANS BY WHICH THE CALIBRATION PROCEDURE COULD BE IMPROVEO ARE DISCUSSED. 
CATEGORY 9

NUCLEAR INSTRUMENTATION, CONTROL, AND SAFETY SYSTEMS

9-28016 \#CONT INUED*

AVAILABILITY - USAEC DEPOSITORY LIBRARIES IN'THE U.S. AND OVERSEAS

*CONTROL ROD CALIBRATION + *CONTROL ROD INTERACTION + *CONTROL ROD WORTH +

COMPARISON, THEORY AND EXPERIENCE + FERMI (LMFBR) + REACTOR, BREEDER + REACTOR, FAST + REACTOR, LMCR + TEST ING

$9-28017$

PAGE G

REACTOR HIFAR THE CONTROL REVERSAL CIRCUITS

AUSTRALIAN ATOMIC ENERGY COMMISSION RESEARCH ESTABL ISHMENT, LUCAS HEIGHTS

AAECIM4 +. 19 PAGES, 2 FIGURES, OCTOBER 1967

THIS MANUAL DESCRIBES IN DETAIL THE OPERATION OF THE CONTROL REVERSAL CIRCUITS IN MIFAR AND THEIR RELATION TO OTHER PARTS OF THE SAFETY CIRCUITS. THIS MANUAL MUST BE READ IN

CONJUNCTION WITH MANUAL MI (INTRODUCTION TO HIFAR GUARD ANO SAFETY CIRCUITSI. IT IS PART OF

A SERIES OF MANUALS ON THE INSTRUMENTATION OF THE REACTOR HIFAR.

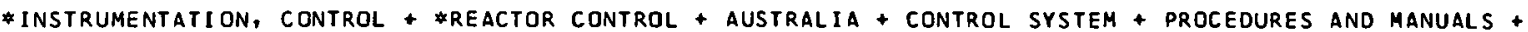
REACTOR SAFETY SYSTEM

$9-28018$

SHIBATA T + KAWAKUBO T + NANJYO T + HAYASHI S + ET. AL.

INITIAL CALIBRATION OF THE KYOTO UNIVERSITY REACTOR

KYOTO UNIVERSITY, JAPAN

158 PAGES, FIGURES, 1965

THE KYOTO UNIVERSITY REACTOR, KUR, BELONGS TO THE RESEARCH REACTOR INSTITUTE, KYOTO UNIVERSITY, OSAKA, JAPAN. TU UBTAIN VARIOUS IMPORTANT CHARACTERISTICS, TEST OPERATIONS HERE FREQUENTLY DONE AFTER THE INITIAL CRITICAL EXPERIMENT, IN PARALLEL WITH SOME TEST IRRADIATION AND TEST EXPERIMENTS WITH NEUTRON BEAM. THE PART OF THE RESULTS OF THOSE INITIAL TESTS AND CALIBRATION IS REPORTED HERE.

*REACTOR DESCRIPTION + CONTROL ROD CALIBRATION + CONIROL ROD HORTH + CRITICALITY EXPERIMENT + FLUX DISTRIBUTION + INSTRUMENTATION CALIBRATION + JAPAN + REACTIVITY EFFECT + REACTDR POWER + REACTOR, RESEARCH + TEST, PLANT RESPONSE

9-28041

DETECTOR HANDBOOK

CALIFORNIA UNIVERSITY, LIVERMORE. LAWRENCE RADIATION LAB.

UCRL-50176 +. 150 PAGES, AUGUST 1967

THIS REPORT EXAMINES LIGHT SENSORS, THEIR CHARACTERISTICS, OPERATION, AND CALIBRATION. THE DECTORS ARE - PHOTODIODES, FLUORS AND RAOIATORS, TEST LIGHT SYSTEMS, LOG DETECTORS, CDMPTON DETECTORS, PHOTOMULTIPLIERS, AND SOME SOLID-STATE DETECTORS. FATIGUE, THE CERENKOV RESPONSE TO GAMMA AND FAST-NEUTRON RADIATION, PULSE RESPONSE, AVD LIGHT COILECTING EFFICIENCY FDR SCINTILLATION COUNTERS ARE EXAMINED FOR VARIOUS DETECTORS.

AVAILABILITY - CLEARINGHOUSE FOR FEDERAL SCIENTIFIC AND TECHNICAL INFORMATION, SPRINGFIELU, VA. 22151 $\$ 3.00$ COPY, $\$ 0.65$ MICROF ICHE

* INSTRUMENTATION, COMPONENT + INSTRUMENTATION CALIBRATION + INSTRUMENTATION, LOGARITHMIC + SOL ID STATE DEVICE + TEST, INSTRUMENT RESPONSE

9-28067 ALSO IN CATEGORIES 11 AND 12

PEDERSEN HN + SPANNER JC

DETECTION, LOCATION, AND CHARACTERIZATION OF FLAW GROWTH IN METALS USING ACOUSTIC EMISSION METHODS

BATELLE-NORTHWEST

CONF-671011 . 2 PAGES, 4 REFERENCES, OCTOBER 1966

BATTELLE-NORTHWEST IN FEBRUARY OF 1966 BEGAN A PROGRAM TO NONDESTRUCTIVELY DETECT INCIPIENT FAILURE OF REACTOR PRESSURE PIPING, USING THE ACOUSTIC EMISSION GENERATEO BY FRACTURE, CLEAVAGE, DISLOCATION UNPINNING, TWINNING, ETC., OF SINGLE OR MIIITIPLE GRAINS OF THE PIPING MATERIAL. IHE PURPOSE OF THE PROGRAM IS - 111 THE, DETECTION OF ACOUSTIC EMISSION AGAINST THE NOISE BACKGROUND OF THE OPERATING REACTOR, (2) THE LOCATION OF THE POINT OF DRIGIN OF THE ACOUSTIC EMISSION, (3) THE CHARACTERIZATION OF THE ACOUSTIC EMISSION BY THE TYPE OF FAILURE OR FLAH-GROWTH MECHANISM IN THE METAL, AND (4) PREDICTION OF THE TIME OF FAILURE.

AVAILABILITY - CLEARINGHOUSE FOR FEDERAL SCIENTIFIC ANO TECHNICAL INFORMATION, SPRINGFIELO, VA. 22151 $\$ 3.00$ CUPY, \$O.65 MICROFICHE

ANALYTICAL TECHNIQUE, CALIBRATION + FLAH + INSTRUMENTATION, SURVEILLANCE + INTEGRITY + METAL + PIPING + TEST, NONDESTRUCTIVE

9-28068 ALSO IN CATEGORIES 11 AND 12 
CATEGORY

NUCLEAR INSTRUMENTATION, CONTROL, AND SAFETY SYSTEMS

$9-28068$ *CONTINUED*

HUTTON PH

ACOUSTIC EMISSION IN METALS AS A NDT TOOL

BATTELLE MEMORIAL INSTITUTE, PACIFIC NORTHWEST LABORATORY, RICHLAND, WASHINGTON

BNWL-SA-1262+CONF-671002-4 +. 8 PAGES, 3 REFERENCES, FOR PRESENTATION AT THE $27 T H$ NATIONAL CONFERENCE OF THE SOCIETY FOR NONDESTRUCTIVE TESTING AT CLEVELAND, OHIO, OC TOBER 18, 1967, SEPTEMBER 1967

SOME OF THE MORE EVIDENT APPLICATIONS OF ACOUSTIC EMISSION, IN ADDITION TO MONITORING FLAW GROWTH IN REACTOR PRESSURE SYSTEMS, ARE - (1) REMOTE AND CONTINUOUS SURVEILLANCE OF

OPERATIDNAL SYSTEMS SUCH AS NATURAL-GAS PIPE LINES AND AIRCRAFT STRUCTURES TO DETECT

FORMATION AND/OR GROWTH OF FLAWS, (2) MONITORING WFI.OS, PARTICULARLY IN HEAVY SECTIONS, AS

THEY COOL TO DETECT INTERNAL CRACKING, (3) USE AS A STUDY TOOL FOR FRACTURE MECHANICS

RESEARCH IN BOTH METALLICS AND NONMETALLICS, 141 MONITORING SPACE VEHICLES FOR MICROMETEORITE PENETRATION.

AVAILABILITY - CLEARINGHOUSE FOR FEDERAL SCIENTIFIC AND TECHNICAL INFORMATION, SPRINGFIELO, VA. 22151 $\$ 3.00$ COPY, \$0.65 MICROFICHE

ANALYTICAL TECHNIQUE, CALIBRATION + FLAW + INSTRUMENTATION, SURVEILLANCE + INTEGRITY + METAL + PIPING + PRESSURE VESSEL + TEST, NONDESTRUCTIVE 
CATEGQRY 10

ELECTRICAL POWER SYSTEMS

ALSO IN CATEGORIES 12 ANO 18
TESTS OF DIESEL GENERATOR PERFORMANCE

ATOMIC POWER EQUIPMENT DEPARTMENT, GENERAL ELECTRIC COMPANY, SAN JOSE, CALIFORNIA

APED-5608 +. 3 PAGES, PAGES 7-1 THROUGH 7-3 OF THE GENERAL ELECTRIC COMPANY ANALYTICAL AND EXPERIMENTAL

PROGRAMS FOR RESOLUTION OF ACRS SAFETY CONCERNS, APRIL 1968

ACRS RECOMMENDED TESTING GENERATORS UNOER SIMULATED EMERGENCY CONOITIONS. GE RESPONDED THAT TESTS WILL BE CONOUCTED AT THE MANUFACTURERS PLANT TO CONFIRM ADEQUACY WITH RESPECT TO START TIMES, SYNCHRONIZATION, AND SIMULATED LOADING. TESTS IFOR SINGLE DIESELI ON STARTING RELIABILITY, START TIMES, ANO SIMULATED LOAD-CARRYING CAPABILITY WERE ALMOST COMPLETE. TESTS OF STARTING AND SYNCHRONIZING TWO OR MDRE DIESELS ARE BEING PLANNED FOR 1968 . SITE TESTS WILL BE CONOUCTED AND INTEGRATEO WITH SPECIFIC PROJECTS.

AVAILABILITY - USAEC, PUBLIC DOCUMENT ROOM

*GENERATOR, ENGINE + \#RELIABILITY, COMPONENT + \#SYSTEM CAPABILITY + *TEST, SYSTEM OPERABILITY + ACRS + . AEC QUESTION + BROWNS FERRY (BWRI + ELECTRIC POWER, SHUTDOWN + EMERGENCY POWER, ELECTRIC + REACTOR, BWR + SYSTEM OPERABILITY IN ACCIDENT

10-26512 ALSO IN CATEGORY 9

VERBER F

I4 PAGES, 31 FIGURES, I TABLE, 24 REFERENCES, POHER REACTOR TECHNOLOGY ANO REACTOR FUEL PROCESSING IO(2), PAGES 122-135 (SPRING 1967)

THIS ARTICLE GATHERS THE ESSENTIAL FEATURES AND WORKINGS OF ELECTRICAL PENETRATIONS OF 11 REPRESENTATIVE NUCLEAR POWER PLANTS AND CONSIDERS SOURCES OF LEAKAGE, REMEDIES, AND BASIC SEALING PRINCIPLES. PRESENT PENETRATION DESIGNS ARE DESCRIBED, AS ARE SOME LEAK-RATE-TEST PRACTICES. A LIST OF RECOMMENDATIONS FOR ELECTRICAL-PENETRATION-SYSTEM DESIGN IS INCLUDED.

*CONTAINMENT PENETRATION, ELECTRICAL + DESIGN CRITERIA + ELECTRICAL CONDUCTION + EQUIPMENT DESIGN + INSTRUMENTATION, COMPONENT + OPERATING EXPERIENCE + SEAL + TEST, LEAK RATE

10-26967 ALSO IN CATEGORY 9

TALBOT JE

INSTRUMENTATION(S) JOB IN. NUCLEAR POWER GENERATION--INSURE PLANT RELIABILITY, AVAILABILITY, AND SAFETY

3 PAGES, INSTRUMENTATION TECHNOLOGY 15(7), PAGES 10-12 (JULY 1968)

THE 11TH ANNUAL ISA POWER INSTRUMENTATION SYMPOSIUM IN CHICAGO, MAY 1968, HAD AS ITS THEME RELIABILITY, AVAILABILITY, AND SAFETY. FOUR PAPERS TOOK UP THE TOPIC OF NUCLEAR GENERATION. ECONOMICS OF NUCLEAR INSTRUMENTATION WAS ALSO OISCUSSED. A TRAINING SIMULATOR OF A BWR TO SIMULATE A COMPLETE HOT OR COLD STARTUP WAS PRESENTED BY GENERAL ELECTRIC. INSTRUMENTATION PROBLEMS ASSOCIATED WITH THE EXTREME OPERATING CONDITIONS OF FAST RREEDER REACTORS WERE DI SCUSSED.

*ELECTRIC POWER, General + \#INSTRUMENTATION, GENERAL + CONTROL SYSTEM + ECONOMICS +

INSTRUMENTATION, CONTROL + INSTRUMENTATION, INDICATOR + INSTRUMENTATION, PROTECTIVE + REACTOR, BREEDER + REACTOR, FAST + SIMULATION

$10-27286$

ALSO IN CATEGORY 17

PHILLIPS JL

MINIMIZING THE HAZARDS ASSOCIATED WITH THE USE OF THE DOUNREAY FAST REACTOR AS AN IRRADIATION FACILITY UKAEA, DOUNREAY WORKS

23 PAGES, 7 FIGURES, 3 REFERENCES, FROM THE INTERNATIONAL CONFERENCE ON THE SAFETY OF FAST NUCLEAR

REACTORS, SEPTEMBER, 1967

REVIEWS EXPERIENCE WITH OPERATION AND EXPERIMENTS. POWER-COEFFICIENT MEASUREMENTS BRIEFLY CONSIDERED. CODLANT IMPURITIES DUR ING INITIAL OPERATION INTERFERED WITH CONTROL-ROD-DRIVE MECHANISM. A HEAT-EXCHANGER-TUBE LEAK, DUE TO DEFECTIVE MANUFACTURING, RESULTED IN AODITIONAL TUBE CORROSION AND OXIDATION DEPOSITS. MORE-SENSITIVE METHODS ARE NEEDED TO DETECT VERY SMALL LEAK RATES. AN AIRLOCK IN FUEL SUPPLY TO DNE DIESEL, AND AN ELECTRICAL FAULT IN ALTERNATOR OF ANOTHER, RESULTED IN SCRAM. WHEN A DIESEL FAILED WITH AN OPEN CIRCUIT FUSE TO SETBACK RELAY, SCRAM OCCURRED. ALSO DISCUSSES FUEL BURNUP AND ELEMENT DESIGN, PLUS EXPERIENCE AND REVIEW TECHNIQUE FOR IRRADIATION EXPERIMENTS.

AVAILABILITY - J.L. PHILLIPS, DQUNREAY EXPERIMENTAL REACTOR ESTABLISHMENT

\#OPERATING EXPERIENCE SUMMARY + COMPARISON, THEORY ANO EXPERIENCE + CONTROL ROD DRIVE + CODLANT QUALITY + CORROSION + DOUNREAY (TR) + FAILURE, SEQUENTIAL + FAILURE, SIMULTANEOUS + FAILURE, TUBING + FUEL BURNUP + GENERATOR, ENGINE + HEAT EXCHANGER + IRRADIATION TESTING + LEAK RATE + OBSTRUCTION + PONER COEFFICIENT + REACTOR, TEST + SAFETY REVIEW + SCRAM, REAL

10-27474 ALSO IN CATEGORIES 17 AND 11

SAFETY EVALUATION FOR PROPOSED 115 MWTH PEACH BOTTOM OPERATION 
CATEGORY 10

ELECTRICAL POWER SYSTEMS

10-27474 \#CONTINUED*

PHILADELPHIA ELECTRIC COMPANY

19 PAGES, NOVEMBER 14, 1966, DOCKET 50-171, TYPE--HTGR, MFG--G.A., AE--BECHTEL.

EXCESS REACTIVITY 10.20 INSTEAD OF 0.15 DUE TO CARBON DENSITY AND THORIUM ABSORPTION CROSS SECTION OVERESTIMATEI WAS ADJUSTED WITH LUMPED BURNABLE POISON TO GIVE AN O.06 SHUTDOWN MARGIN. LIMITS ON REACTIVITY AND FLUX ANOMALIES WILL BE SET. AFTER 1O65 CABLE FIRE IWELEING SLAG INITIATION, CHIMNEY EFFECT), CO2 SYSTEM EXTENDED TO CABLE AREAS, REROUTED TO INCREASE INDEPENDENCE, SMOKE DETECTORS INSTALLED, AND FIREPROOF COVERS AND FIRE STOPS INSTALLEO. HELIUM LEAKAGE IS 10-20 TIMES DESIRED 0.2 L8/DAY. CONTROL ROD DRIVE EALLS $\triangle R E$ NOW IOO PERCENT TESTED AFTER FAILURES FROM INTERNAL DEFECTS. A LARGER CONTAINMENT VACUUM RELIEF IS PROVIDEO.

AVAILABILITY - USAEC, PUBLIC DOCUMENT ROOM, 1717 H ST., WASHINGTON, D.C. 20545 (\$\$O.25 CENTS/COPY)

\begin{abstract}
\# OPERATING EXPERIENCE SUMMARY + \#SAFETY EVALUATION + CONTAINMENT PENETRATION, ELECTRICAL + CONTAINMENT VACUUM BREAKER + CROSS SECTION + ELECTRICAL CONOUCTION + EXAMINATION +

FAILURE, SCRAM MECHANISM + FIRE + INDEPENOENCE + PEACH BOTTOM 1 (HTGR) + POWER UPRATING + REACTIVITY EFFECT, ANOMALOUS + REACTOR, HTGR + SHUTOUWN MARGIN + THORIUM
\end{abstract}

10-27475 ALSU IN CATEGORY 18

ACRS REPORT ON MAINE YANKEE

AEC, DIVISION OF REACTOR LICENS ING

4 PAGES, LETTER TO G.T. SEABDRG, USAEC, JULY 1S, 1968 , DOCKET 50-309, TYPE--PWR, MFG--C.E., AE--STONE + WEBSTER

ACRS APPROVES CONSTRUCTION, CALLING ATTENTION TO PREVIOUS ST.ATEMENTS ON LARGE WATER COOLED POWER REACTORS. ACRS BELIEVES OFF-SITE ELECTRICAL POWER SUPPLY TO ENGINEERED, SAFEGUARDS SHOULD BE MODIFIED SO NO SINGLE FAILURE WILL PREVENT POWER AVAILASILITY. SUGGFSTS REGULATORY STAFF REVIEW CONTROL ROD DRIVE POWER SUPPLY SINCE DESIGN NOT COMPLETED.

AVAILABILITY - USAEC PUBLIC DOCUMENT ROOM, 1717 H ST., WASHINGTON, D.C. 20545 (\$SO.25 CENTS/COPY) \#ACRS + \#ELECTRIC POWER, aLTERNATE + \#EMERgENCY POWER, ELECTOIC + MAINE yANKEE (PWR) + REACTUR, PWH + REPORT, PSAR + REVIEW

10-27502 ALSO IN CATEGORIES 18 AND 11

ACRS REPORT ON RANCHO SECO

UNITED STATES ATOMIC ENERGY COMMISSION

3 PAGES, LETTER TO G.T. SEABORG, USAEC, JULY 19, 1968, DOCKET 50-312, TYPE--PWR, MFG--B,W, AE--BECHTEL

ACRS APPROVES CONSTRUCTION, CALLING ATTENTION TO PREVIOUS STATEMENTS ON LARGE WATER COOLED POWER REACTORS. SUGGESTS FURTHER ANALYSIS OF FAST FLUX DAMAGE TO REACTOR VESSEL, AND AOEQUACY OF VESSEL SURVEILLANCE PROGRAM. ACRS REITERATES BELIEF CONTRDL AND DROTECTION INSTRUMENTATION SHOULD BE INDEPENDENT OF COMMON FAILURE MODES. APPIICANT AND REG. STAFF JIIOULD RCYICH FOR EYETEMATIC, NONRANINM T.NNCIIRRFNT FAILURES OF REOUNDANT DEVICES NOT CONSIDERED IN THE SINGLE FAILURE CRITERION.

AVAILABILITY - USAEC PIIRI. IC DOCUMENT ROOM, 1717 H ST., WASHINGTON, 0.6., 205451 150.25 CENTS/COPYI

*ACRS + \#FAILURE, SIMULTANEOUS + \#PLANT PROTECTIVE SYSTEM + \#PRESSURE VESSEL + \#REVIEW + BRITTLE FRACTURE + RANCHO SECO (PWR) + REACTOR, PWR + REPORT, PSAR + SINGLE FAILURE CRITTERIJN + SURVEILLANIE PRJGRAM

$10-27578$

ELSTON KE

RELIABILITY OF NUCLEAR GENERATING UNITS

CANAOA HYDROELECTRIC POHER COMMISSION

2 PAGES, ANS. TRANSACTIONS $11(1)$, PAGES 6-7, 1968 ANNIIAI. MEET ING QF THE AMERICAN NUCLEAR SOCIETY ANO

CANADIAN NUCLEAR ASSOCIATION, TORONTO, CANAUA, JUNE 10-13, 1968

THE PERFORMANCE OF LARGE NUCLEAR GENERATING UNITS IS OF MAJOR CONCERN HITH REGARD TO SYSTEMS STABILITY AND SYSTEM RESERVE. NUCLEAR PERFORMANCE EXPER IENCE IS VERY LIMITED AND ASSESSMENT OF SUCH EXPERIENCE IS MADE DIFFICULT BY THE NUMBER OF CONCEPTS, IMMATURITY OF THE UNITS, AND THE RAPIO INCREASE IN UNIT SIZE. THEREFORE, EXPERIENCE DATA ARE BEING COLLECTED AND ANALYZEO ON NPO AND DOUGLAS POINT ON OUTAGES AND DERATINGS OF THE UNIT AND COMPARED WITH TARGETS. THIS DATA PERMITS A VARIETY OF RELIABILITY ANALYSIS ON A TIME OR ENERGY BASIS.

\#ELECTRIC POWER, GENERAL + \#RELIABILITY, SYSTEM + CANADA + NPD 2 (HWR) + OPERATING EXPERIENCE + REACTOR POWER + REACTOR, HWR + REACTOR, PRESSURE TUBE + STATISTICAL CORRELATION

10-27614 ALSO IN CATEGORIES 18 AND 9

DRL QUESTIONS EMERGENCY SIGNALS AND POWER

U.S. ATOMIC ENERGY COMMISSION

3 PAGES, LETTER TO M. H. PRATT FROM P. A. MURRLS, JULY 31, 1968, DOCKET 50-220, TYRE--BWR, MFG--G.E., AE-NI AG ARA MOHAWK

DRL ASKS 7 SPECIFIC QUESTIONS. (1) ABILITY OF OFFSITE POWER, WITH A FAULT IN OUTSIDE SYSTEM,

TO SAFELY SHUTDOWN PLANT. 121 ABILITY OF OFFSITE POWER TO SATISFY CRITERION 39 DESPITE 2 MIN 
CATEGORY 10

10-27614 \#CONTINUED*

DISCONNECT DELAY. (3) DC POWER FOR SWITCHYARD. (4) DESIGN AGAINST ELECTRICAL CABLE FIRE. (5) CONSEQUENCES OF LOSS OF STATION AIR OR INSTRUMENT AIR. (6) DIESEL START FROM SIGNALS OTHER THAN LOW VOLTAGE, E.G., UPON CODLANT INJECTION. (7) DISCUSS ADEQUACY OF CORE SPRAY ACTUATION SIGNALS. DISCUSS LACK OF DIVERSITY FOR ISOLATION VALVE ACTUATION.

AVAILABILITY - USAEC, PUBLIC DOCUMENT ROOM, WASHINGTON, D. C.

FPLANT PROTECTIVE SYSTEM + ACCIOENT, LOSS OF POWER + AEC QUESTION + ELECTRICAL CONDUCTION + FIRE + NINE MILE POINT (BWR) + PNEUMATIC SYSTEM + REACTOR, BWR

10-27879 ALSO IN CATEGORY 9

SYLIACCO TE

ABILITY CONTROL SYSTEM

CLEVELAND ELECTRIC ILLUMINATING COMPANY, CLEVELAND, OHIO

15 PAGES, 2 FIGURES, 3 TABLES, 5 REFERENCES, IEEE TRANS. ON POWER APPARATUS AND SYSTEMS, PAS-86(5), PAGES 517-531 (MAY 1967)

CONSIDERATIONS NECESSARY FOR THE DESIGN OF A TOTAL CONTROL SYSTEM FOR THE IMPROVEMENT OF THE RELIABILITY OF THE GENERATION-TRANSMISSION SYSTEM ARE DISCUSSED. THE CONTRDL. SYSTEM IS MADE OF AUTOMATIC FUNCTIONS, HUMAN PARTICIPATION, AND AN INFORMATION SYSTEM. IN THE FIRST PART OF THE PAPER, THE FRAMEWORK OF THE DESIGN IS ESTABLISHED AND THE BASIC OVERALL STRATEGY FOR MAINTAINING RELIABILITY IS DESCRIBED. THE SECOND PART DESCRIBES THE THINKING AND THE HORK BE ING DONE AT CLEVELAND ELECTRIC ILLUMINATING COMPANY FOR THE PRACTICAL IMPLEMENTATION OF THE DESIGN CONCEPTS ON THIS SYSTEM.

CONTROL SYSTEM + DESIGN STUDY + ECONOMICS + ELECTRIC POWER, GENERAL + EMERGENCY SYSTEM + INSTABILITY + RELI ABIL ITY, SYSTEM

VIRGINIA POLYTECHNIC INSTITUTE

4 PAGES, ELECTRICAL WORLD, 170(7), PAGES 73-77 (AUGUST 12, 1968 )

SUMMARIZES A SURVEY BY VPI ENERGY RESEARCH GROUP ON THE STATUS OF ELECTRICAL POWER IN 82 OF $1.30 \mathrm{U} . \mathrm{S}$. UNIVERSITY CURRICULA IN THE EAST AND MIOWEST. TABLES SHOW LSCTURE AND LAB HOURS GRAD AND UNDERGRADI, EQUIPMENT, FACULTY NUMBER, AND COMMUNICATION QUALITY WITH UTILITIES. \# \#69 REQUIREO A POWER COURSE FOR ALL EE MAJORS, 37 HAVE NO POWER COURSE TAUGHT AS AN ELECTIVE. ONLY 7 HAVE UNDERGRADUATE FELLOWSHIPS PROVIDED BY UTILITIES, ONLY 28 COOP HITH UTILITIES. 69 OFFER GRADUATE EE, BUT ONLY 27 GIVE GRAOUATE COURSES IN POWER. 72 OF 163 EE THESES IN PROGRESS ARE IN POWER. ONLY 12 RENORTED GOOD COMMUNICATION WITH UTILITIES. OF 34 SAYING COMMUNICATION WAS NEGLIGIBLE, THE MAJORITY HAVE POWER ORIENTED TEACHER DN THEIR STAFFS.

* STAFFING, tRaINING, QUALIFICATION + ELECTRICAL CONDUCTION + REACTOR, POWER 
CAT.EGORY 11

CONTAINMENT OF NUCLEAR FACILITIES

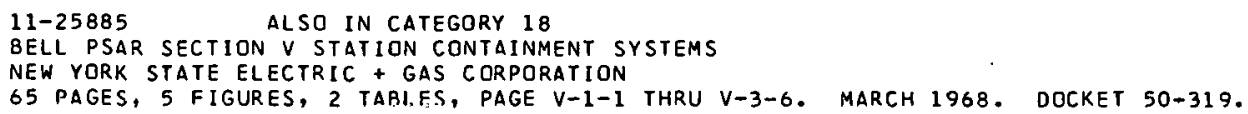

THE SUPPRESSION CHAMBER AND DRY WELL ARE NOW STEEL-LINED RE INFORCED-CONCRETE PRESSURE VESSELS. THE DRY WELL WILL CONSIST OF VERTICAL CYLINOERS AND TRUNCATED CONES TO RETAIN THE LIGHT-BULB SHAPE, WHILE THE SUPPRESSION CHAMBER CONSISTS OF A TORUS HITH A SQUARE CROSS SECTION. OTHERWISE, SYSTEMS ARE AS BEFORE. DRY-WELL DESIGN IS FOR 62 PSIG/300 F, AND POOL IS 62 PSIG/220 F. THE CONCRETE WILL BE 6 FT THICK, AND THE LINER NOT LESS THAN 0.25 IN. DESIGN LEAK RATE IS $0.5 \%$ VOLUME IOAY AI GL PSIG. AIR CONDITIONING WILL KEEP AIR AT I35 F IMAX., I5O F) AND $40 \%$ REL. HUMIDITY.

AVAILABILITY - CLEARINGHOUSE FOR FEDERAL SCIENTIFIC AND TECHNICAL INFORMATION, SPRINGFIELD, VIRGINIA, $22151, \$ 3.00$ COPY, \$0.65 MICROFICHE

*CONCRETE + \#CONTAINMENT, PRESSURE SUPPRESSION + \#STEEL LINER + BELL (BWR) + MODIFICATION, SYSTEM OR EQUIPMENT + REACTOR, BWR + REPORT, PSAR

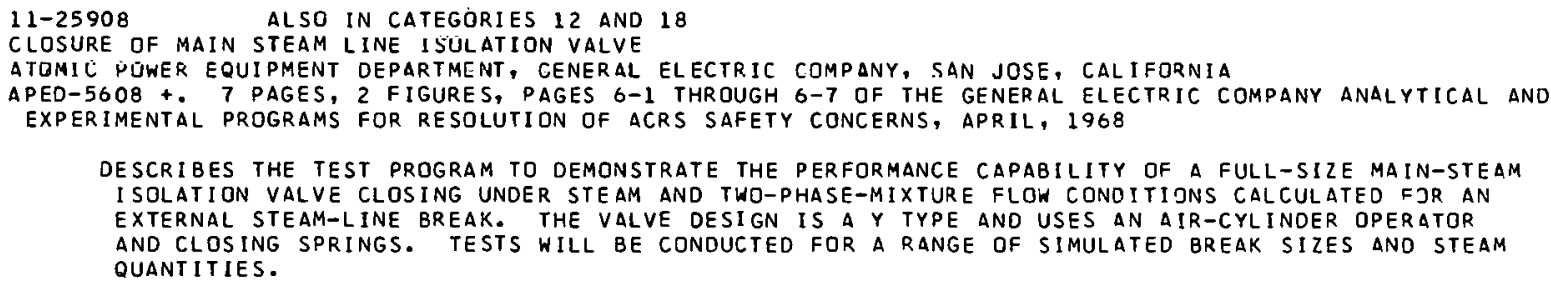

\# ACCIDENT ANALYSIS + *ACCIDENT, STEAM LINE RUPTURE + ACCIDENT MODEL + ACCIDENT, CDNSEQUENCES + ACRS + AEC QUESTION + BROWNS FERRY (BWR) + CONTAINMENT ISOLATION + REACTOR, BWR + RESPONSE TIME

\section{$11-25951$}

HILTSCHER R

IMPROVEMENTS IN NOZZLE CONNECTIONS FOR PRESSURE VESSELS

BRITISH PATENT $1,042,537+9$ PAGES, 4 FIGURES, SEPTEMBER 14, 1966

A METHOD IS DESCRIBED FOR FABRICATION OF UNSYMMETRICAL CONNECTIONS BETWFEN PIPES ANII LURYEO AREAS ON NONSPHERICAL PRESSURE VESSEL HALLS. THE CONSTRUCTION IS SUCH THAT ON THE INNER SIDE OF THE VESSEL WALL WHERE THE REINFORCING EFFECT OF THE EXTERNAL NOZZLE IS LOW OR NONEXISTENT, THE ORIFICE IS ELUNGATEO SO THAT VERY LITTLE STRESS CONCENTRATIDN MCCIURS. OUTSIDE DF THE VESSEL THE NOZZLE REINFORCES THE AREA AND REDUCES STRESS CONCENTRATIONS.

AVAILABILITY - BRIṪISH PATENT OFFICE, 25 SOUTHAMPTON BUILDING, LONDON, W.C. 2, ENGLAND (49 CENTS/COPY) \#CONTAINMENT CONSTRUCTION + \#NOZZLE + \#PRESSURE VESSEL + \#STEEL

$11-25952$

ZIEGLER A

CONCRETE PRESSURE VESSELS FOR NUCLEAR REACTORS ANO METHOD OF MANUFACTURING THE SAME

SIEMENS-SCHUCKERTWERKE, GERMANY

CANADIAN PATENT $752,118+.15$ PAGES, 13 FIGURES, FEBRUARY 7, 1967 


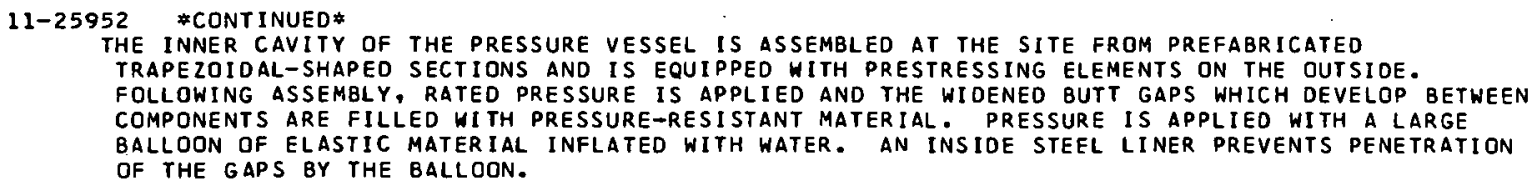

AVAILABILITY - IT IS OUR UNDERSTANDING THAT FOREIGN PATENTS MAY BE DBTAINED IN PHOTOCOPY. FROM THE U.S. PATENT OFFICE, DEPARTMENT OF COMMERCE, HASHINGTON, D.C. (30 CENTS/PAGE)

* CONCRETE, PRESTRESSED + *CONTAINMENT CONSTRUCTION + \#PRESSURE VeSSEL + *STEEL LINER

$11-25953$

PROCESS FOR THE PRODUCTION OF A PRESTRESSED CONCRETE PRESSURE VESSEL FOR A NUCLEAR REACTOR

SIEMENS-SCHUCKERTWERKE, GERMANY

BRITISH PATENT $1,063,235+4$ PAGES, 5 FIGURES, MARCH 30,1967

A METHOD IS DESCRIBED FOR PRODUCING PRESTRESSED CONCRETE CYLINDRICAL PRESSURE VESSELS FOR

NUCLEAR REACTORS. THE ENDS DF THE VESSELS ARE CLOSED BY END WALLS FORMEO BY FRUSTOCONICAL

BLOCKS WHICH ARE SUPPORTED BY A RING OF WEDGE-SHAPED SUPPORTING ELEMENTS. THE FRUSTO-CONICAL

BLOCKS ARE POSITIONED BEFORE THE INTERIOR OF THE VESSEL TS BROUGHT TO ITS RATED OPERATING

PRESSURE.

AVAILABILITY - THE PATENT OFFICE, 25 SOUTHAMPTON BUILDING, LONDON, W.C. 2, ENGLAND (49 CENTS/COPY)

*CONCRETE, PRESTRESSED + \#CONTAINMENT CONSTRUCTION + \#PRESSURE VESSEL

$11-25954$

ZIEGLER + PETERSEN G

SAFETY EQUIPMENT FOR NUCLEAR POWER-REACTOR PLANTS

SIEMENS-SCHUCKERTWERKE, GERMANY

CANADI AN PATENT $749,748+$ +9 PAGES, FIGURE, JANUARY 3,1967

THE REACTOR CONTAINMENT VESSEL HAS A SPRAY SYSTEM FED BY A RESERVOIR AT THE TOO OF THE VESSEL. AN ENCLOSED AIR CHAMBER ABOVE THE RESERVOIR IS CONNECTED TO THE CHAMBER SURROUNDING THE REACTOR PRESSURE VESSEL. THE REACTOR SPACE IS CONNECTED THE BOTTOM SPACE WHERE THE SPRINKLERS OISCHARGE BY LINES CONTAINING BURSTABLE DIAPHRAGMS.

AVAILABILITY - IT IS OUR UNDERSTANDING THAT FOREIGN PATENTS MAY BE OBTAINED IN PHOTOCOPY FROM THE U.S. PATENT OFFICE, DEPARTMENT OF COMMERCE, WASHINGTON, D.C. (30 CENTS/PAGE)

\#CONTAINMENT SPRAY + *CONTAINMENT, PRESSURE REliEF

$11-25955$

FISTEDIS SH

D.FATOR GQPITAIHHENT VEJJEL

U.S. PATENT $3.349,524+$ T PAGES, 7 FIGURES, OCTOBER 31,1967

A CONCRETE CONTAINMENT VESSEL DESIGN FOR A NUCLEAR REACTOR HAVING JACKETEO REINFORCING CABLES EXTENDING ABOUT THE VESSEL THROUGH THE CONCRETE IS GIVEN. EACH CABLE CAN MOVE LENGTHWISE WITHIN ITS JACKET. THUS, WHEN AN EXPLOSION OCCURS AND CRACKS A CERTAIN REGION OF THE CONCRETE, THE RESULTING STRAIN OF ANY CABLE IS NOT LIMITED TO THE SECTION DF THE CABLE WHERE THE CONCRETE CRACKS, BUT IS DISTRIBUTED OVER THE LENGTH OF THE CABLE. THUS, THE CABLE IS NOT LIKFLY TO BREAK, AND THE INTECRITY OF THE CONTAINMENT VESSEL IS PRESERVED IN SPITE OF LOCALIZED CRACKING OF THE CONCRETE.

AVAILABILITY - THE U.S. PATENT OFFICE, DEPARTMENT OF COMMERCE, WASHINGTON, D.C. (25 CENTS/COPY)

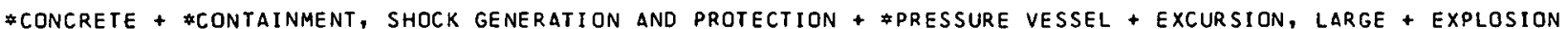

11-25956. ALSO IN CATEGORY 13

DELESTRE L + LEFORT G + PILLERAULT J

IMPROVEMENTS IN OR RELATING TO SEALABLE PORTS

COMMISSARIAT A L ENERGIE ATOMIQUE, FRANCE

BRITISH PATENT $1,065,319+\ldots 3$ PAGES, FIGURE, APRIL 12,1967

A SEALABLE PORT WHICH IS USEO IN A GLQVE BOX IS DESCR IBED. THE PORT CONSISTS OF A NUMBER OF BOLTS OR RODS REGULARLY SPACEO AROUNO THE PERIMETER DF THE PORT MOVING PARALLEL TO THE PORT, AND ACTUATEO BY A SINGLE CONTROL MECHANISM. THE BOLTS ARE SPRING-LOADEO FOR INSERTION INTO NOTCHES PROVIDED FOR THEM ON AN INCLINED FIXEO FRAME. THE BOLTS HAVE CASTERS WHICH ROLL DN THE INCLINED PLANE WHEN THEY ARE ENGAGEO CAUS ING THE DISPLACEMENT OF THE PORT PERPENDICULAR TO ITS PLANE, TIGHTENING UP A SEALED JOINT LOCATED BETWEEN THE PORT AND THE FRAME.

AVAILABILITy - THE PATENT OFFICE, 25 SOUTHAMPTON BUILOING, LONDON, W.C. 2, ENGLAND (49 CENTS/COPY)

*FLANGE + \#GLOVE BOX + SEAL 
CATEGORY 11

CONTAINMENT OF NUCLEAR FACILITIES

$11-25957$

COMPLIANT FLANGE NUCLEAR REACTOR PRESSURE VESSEL CLOSURE

UNITED STATES ATOMIC ENERGY COMMISSION

BRITISH PATENT 1,080,064 +. .7 PAGES FIGURE, AUGUST 23, 1967

A REACTOR CORE CONTAINMENT VESSEL IS PROVIDED WITH A SYSTEM OF FLEXIBLE BELLOWS, ANNULAR SEAL RINGS, AND GASKETS WHICH SEAL BUT ALLOW ENTRY TO THE TOP ACCESS PORT WITHOUT THE USUAL ARRANGEMENT OF BOLTS, DOGS, AND CLAMPS. THE SEAL IS DESIGNEO TO CONDUCT HEAT FROM THE PRESSURE VESSEL, OPERATE AT A LOWER TEMPERATURE THAN THE PRESSURE VESSEL, ANO TO INHERENTLY COMPENSATE FOR SKEW AND UNEVEN MATING SURFACES.

AVAILABILITY - THE PATENT DFFICE, 25 SOUTHAMPTON BUILDING, LONDON, W.C. 2 , ENGLAND (49 CENTS/COPY) *FLANGE + \#SEAL + COOLING, GENERAL + PRESSURE VESSEL + STEEL

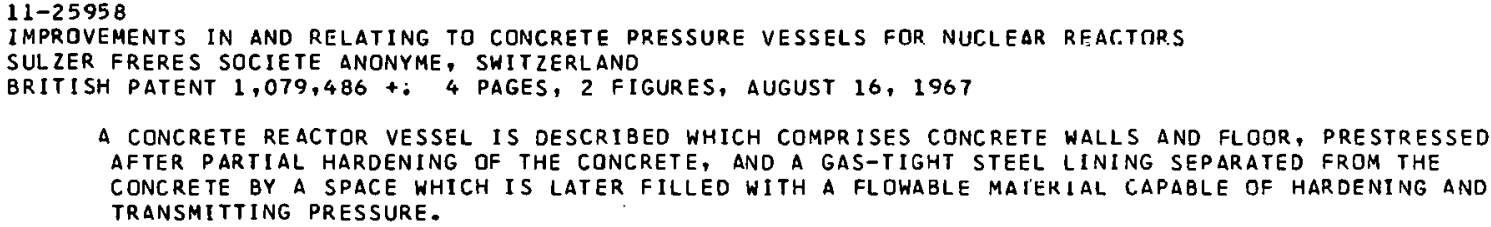

THE SIZE OF STEEL PRESSURE-VESSELS IS LIMITEO BY PRODUCTION POSSIBILITIES. REACTOR CONTAINERS OF PRE-STRESSED CONCRETE, ON THE CONTRARY, CAN BE MADE IN NEARLY EVERY SHAPE ANO SIZE- SO THEY ARE ESPECIALLY QUALIFIED FOR LARGE NUCLEAR PLANTS IN INTEGRATED CONSTRUCTION. THE CONCRETE CONTAINERS WHICH HAVE BEEN BUILT, ARE UNDER CONSTRUCTION, OR ARE DESIGNEO ARE DESCRIBED ANO SHOWN IN SELIIUNAL URANINGS. PARTICULAR PROBLEH3 AJJOCIATCD WITII TIIL CONSTRUCTION OF PRE-STRESSED CONCRETE CONTAINERS ARE ANALYZED. TECHNOLOGY IS DEVELOPED FAP. ENOUGH THAT SECURITY REQUIREMENTS CAN BE FULFILLED.

*CONCRETE, PRESTRESSED + \#DESIGN CRITERIA + \#PRESSURE VESSEL + CONTAINMENT CONSTRUCTION

$11-26310$ ALSO IN CATEGDRIES 15 AND 17

U.S. TESTING CO. CITED FOR NON-COMPLIANCE IN RADIOGRAPHY OPERATIONS UNITED STATES ATOMIC ENERGY COMMISSION

" PACES, LETTEP. TO U.S. TESTING C.M. FRחM F.R. PRICE, NOVEMBER 10, 1965

NONCOMPL IANCE ITEMS INCLUDE PERSONNEL FAILING TO WEAR DOSIMETERS AND BADGES, INADEQUATE PERSONNEL MONITORING RECORDS, PERFORMING RADIOGRAPHY HITHOUT DPERABLE SURVEY INSTRUMENTS, UNQUALIFIED PERSONNEL ACTING AS RADIOGRAPHERS, ASSISTANTS HAD NOT RECEIVED CONIES OF OPERATING AND EMERGENCY PROCEDURES, SURVEILLANCE INADEQUATE TO PREVENT UNAUTHORIZEO ENTRY INTO HIGH RADIATION AREAS, SURVEY INSTRUMENTS WERE NOT CALIBRATED EVERY 3 MONTHS, IMPROPER UTII.TZATION LOOP, AND COMPANY FAILURE TO REPORT AN EMPLOYEE OVEREXPOSURE.

USAEC, PUBLIC DOCUMENT ROOM, 1717 H ST., WASHINGTaN, D.C. 20545 (25 CENTS/PAGE) 
CATEGORY 11

CONTAINMENT OF NUCLEAR FACILITIES

$11-26310 \quad$ *CONT INUED*

\#FAILURE, ADMINISTRATIVE CONTROL * \#AILURE, OPERATOR ERROR * \#INSPECTION AND COMPLIANCE + \#RADIOGRAPHY

11-26413 ALSO IN CATEGORIES 1 AND 7

COTTRELL WB

NUCLEAR SAFETY PROGRAM ANNUAL PROGRESS REPORT FOR PERIOD ENDING DECEMBER 31,1967

OAK RIDGE NATIONAL LABORATORY

ORNL-4228 +. 443 PAGES, FIGURES, TABLES, REFERENCES, APRIL 1968

THE ORNL NUCLEAR SAFETY PROGRAM INVOLVES TASKS IN SEVERAL LABORATORY DIVISIONS AND IS CLOSELY RELATEO TO PROGRAMS AT OTHER LABORATORIES. THIS REPORT IS ONE OF A CONTINUING SERIES STARTING WITH ORNL-3319 IN 1962. IT CONTAINS PROGRESS REPORTS ON VARIOUS ASPECTS OF CHARACTER IZATION ANO BEHAVIOR OF ACCIDENT-RELEASES, FISSION PRODUCTS, FILTRATION AND ADSORPTION TECHNOLOGY, SPRAY AND ADSORPTION TECHNOLOGY, SAFETY STUDIES FDR HIGH-TEMPERATURE GAS-COOLED REACTORS, SAFETY STUDIES FOR MSBR, PRESSURE VESSEL AND PIPING TECHNOLOGY, GENERAL NUCLEAR SAFETY STUDIES, AND NUCLEAR SAFETY INFORMATION.

AVAILABILITY - CLEARINGHOUSE FOR FEDERAL SCIENTIFIC AND TECHNICAL INFORMATION, SPRINGFIELD, VA. 22151 $\$ 3.00$ COPY, $\$ 0.65$ MICROFICHE

\# ADSORPTION + \#FILTRATION + \#FISSIDN PRODUCT RELEASE, GENERAL + \#INFORMATION RETRIEVAL + *NSIC + \#PIPING + \$PRESSURE VESSEL + \#REACTOR, BREEDER + *REACTOR, HTGR + \#REACTOR, MOLTEN SALT + *SAFETY PRJGRAM + \#SPRAY, GENERAL

$11-26558$

COTTRELL WB

ALSO IN CATEGORIES 7 AND 1

ORNL NUCLEAR SAFETY RESEARCH AND DEVELOPMENT PROGRAM BIMONTHLY REPORT FOR MARCH-APRIL 1968

OAK RIDGE NATIONAL LABORATORY, OAK RIDGE, TENNESSEE

ORNL-TM-2230 +. 164 PAGES, FIGURES, TABLES, MAY 30,1968

INCLUDED IN THIS PROGRESS REPORT IS WORK ON VARIOUS CHEMICAL REACTIONS, AS WELL AS THE RELEASE, CHARACTERIZATION, AND TRANSPORT OF FISSION PRODUCTS IN CONTAINMENT SYSTEMS UNDER VARIOUS ACCIOENT CONDITIONS AND ON PROBLEMS ASSOCIATED WITH THE REMOVAL OF THESE FISSION PRODUCTS FROM GAS STREAMS. ALTHOUGH MOST OF THE WORK HAS BEEN AND CONTINUES TO BE IN GENERAL SUPPORT OF WATER POHER-REACTOR TECHNDLOGY, INCLUDING SOME IN DIRECT SUPPORT OF THE LOFT AND CSE PROGRAMS, SEVERAL PROJECTS WERE STARTEO THE FIRST OF THE CALENDAR YEAR IN SUPPORT OF THE HIGH-TEMPERATURE GAS-COOLED REACTOR (HTGR) PROGRAM. THESE PROJECTS INCLUDE BOTH IN-PILE AND OUT-PILE STUDIES OF REACTION RATES AND FISSION PRODUCT RELEASE AND TRANSPORT PHENOMENA RELEVANT TO POTENTIAL HTGR ACCIDENT SITUATIONS. OTHER MAJOR PROJECTS INCLUDE FUEL TRANSPORT SAFETY INVESTIGATIONS, A SERIES OF DISCUSSION PAPERS ON VARIOUS ASPECTS OF SAFETY INVESTIGATIONS, A SERIES OF OISCUSSION PAPERS ON VARIOUS ASPECTS OF WATER REACTOR TECHNOLOGY, AND THE STUDIES ON PRESSURE VESSEL TECHNMI. MGY. EXPERIMENTAL WORK RELATIVE TO PRESSURE VESSEL TECHNOLOGY INCLUOES INVESTIGATIONS OF THE ATTACHMENT OF NOZZLES TO SHELLS AND THE VARIABILITY OF IMPACT DATA ON LOW-ALLOY STEELS.

AVAILABILITY - CLEARINGHOUSE FOR FEOERAL SCIENTIFIC AND TECHNICAL INFORMATION, SPRINGFIELD, VIRGINIA $22151 \$ 3.00$ COPY, \$0.65 MICROF ICHE

\#CHEMICAL KINETICS + \#CONTAINMENT, GENERAL + \#CSE + \#FISSTMN PRDOUCT RETENTION +

\#FISSION PRODUCT TRANSPORT + \$FISSION PROOUCT, AIRBORNE + \#IMPACT PROPERTY + \#IN PILE EXPERIMENT + \#LOFT (S-RR) + \#NOZZLE + \#OUT OF PILE LOOPS AND EXPERIMENTS + \#STEEL + CONTAINMENT SPRAY +

FISSION PRODUCT RELEASE, GENERAL + PRESSURE VESSEL + REACTOR, HTGR

11-26571 ALSO IN CATEGORY 17

DRL COMMENTS ON REPAIR OF FINAL TWO STUB TUBES

DIVISION OF REACTOR LICENSING, AEC

2 PAGES, LETTER TO J. E. LOGAN, JERSEY CENTRAL P + L CO. FROM LETTER TO J. E. LOGAN FROM P. A. MORRIS.

DOCKET 50-219. TYPE--BWR, MFG-G.E., AF--RURNS + ROE

RE SULTS AND DISCUSSIONS GIVE US A BASIS TO CONCLUDE THAT THE TWD REMAINING UNTOUCHED STUB TUBES CAN BE REPAIRED. THEY SHOULD BE CAREFULLY MEASURED AND GIVEN DYE-PENETRANT TESTS BEFORE AND AFTER REMOVING ALL FIELD WELDS, \#*WE ARE STUDYING NEED FOR A SURVEILLANCE PROGRAM OF SENSITIZED SS MATERIAL. YOU SHOULD HAVE ADEQUATE CLAD AND UNCLAD STUB-TUBE MATERIAL (FREE OF $308 L S S$ WELD METAL). \#PERMISSION TO REPAIR TUBES DOES NDT IMPLY APPROVAL OF PROPOSED REPAIR WORK.

AVAILABILITY - PUBLIC DOCUMENT ROOM, WASHINGTON, D.C.

*WELDING + CONTAINMENT PENETRATIDN, PIPE + FAILURE, PRESSURE VESSEL + OYSTER CREEK I (BWRI + PIPING + PRESSURE VESSEL + REACTOR, BWR + STEEL, STAINLESS + SURVEILLANCE PROGRAM

11-26742 ALSO IN CATEGORIES 17 AND 3

ERR COLD HYOROTEST AT 240 PSIG.

RURAL COOPERATIVE POWER ASSDCIATION, ELK RIVER, MINNESOTA

COD-651-60 +. 25 PAGES, 3 FIGURES, 4 TABLES, RURAL COOPERATIVE POWER ASSOCIATIONGS ELK RIVER REACTOR

SIXTY-SEVENTH MONTHLY OPERATING REPORT, MAY, 1968 OOCKET NO. 115-1, TYPE--BWR, MFG--A.C., AE--SGT + LUNDY

REACTOR HAS NOT OPERATED SINCE JANUARY. A 240-PSIG COLD HYDROTEST WITH SR-85 DISPERSED IN THE 
CATEGORY 11

CONTAINMENT OF NUCLEAR FACILITIES

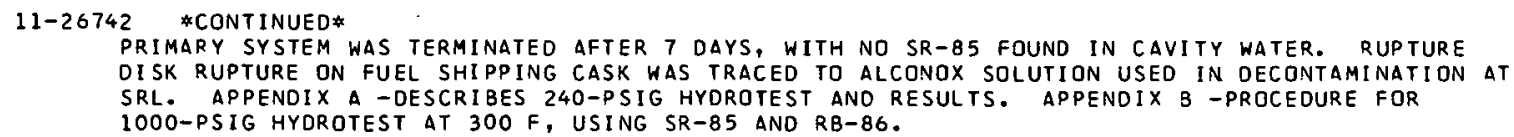

\#PIPING + \#SURVEILLANCE PROGRAM + FAILURE, PIPE + OYSTER CREEK I (BWR) + REACTOR, BWR

$11-27040$

PRESSURE VESSEL AND PIPINC TECHNOLOGY

OAK RIDGE NATIONAL LABORATORY, OAK RIDGE, TENNESSEE

ORNL-4228 +. 37 PAGES, 12 FIGURES, 2 TABLES, 18 REFERENCES, PAGES $311-347$ OF THE NSP ANNUAL PROGRESS REPORT, APRIL, 1968

PROGRESS REPORT DEALING WITH - PRESSURE VESSEL TECHNOLOGY. HEAVY-SECTION STEEL TECHNOLOGY PROGRAM ADMINISTRATION, MATERIAL PROPERTIES AND MATERIAL INTEGRITY, FRACTURE BEHAVIOR, PERIOOIC PROOF TESTING, SIMULATED SERVICE TEST. EXPER IMENTAL AND ANALYTICAL INVESTIGATION OF NOZZLES - ORNL PROGRAM, UNIVERSITY OF TENNESSEEIEXPERIMENTAL STRESS ANALYSIS OF SINGLE NOZZLES ATTACHEO TO SPHERICAL SHELLS), AUBURN UNIVERSITY (EXPERIMENTAL STRESS ANALYSIS UF CLUSTERED NOZZLES ATTACHED TO SPHERICAL SHELLS), UNIVERSITY OF TENNESSEE (EXPERIMENTAL STRESS ANALYSIS DF CLUSTERED NOZZLES ATTACHEO TO FLAT PLATESI, WESTINGHOUSE RESEARCH LABORATORIES (PHOTOELASTIC STUDIES), APPLIED. TECHNOLOGY ASSOCIATES ITHEORETICAL STRESS SOLUTION FOR CLUSTERS OF NOZZLES ATTACHED TO SPHERICAL SHELLSI, AUBURN UNIVERSITY (THEORETICAL STRESS SOLUTION FOR SINGLE NONRADIAL NOZZLES ATTACHED TO SPHERICAL SHELLSI. OESIGN CRITERIA FOR PIPING, PUMPS, AND VALVES - PVRC RESEARCH PROGRAM, ORNL PROGRAM, STRESS INDICES AND PARAMETRIC STUDIES.

*NOZZLE + *PIPING + \#PRESSURE VESSEL + \#PROPERTY, PHYSICAL + \#PUMP + \#STEEL + \#TESTING + \#WELOING + CONTAINMENT RESEARCH AND DEVELOPMENT + CONTAINMEVT, GENERAL + FAILURE, FATIGUE + FAILURE, PRESSURE VESSEL + FRACTURE TOUGHNESS \& IRRAOIATION TESTING + MATERIAL

11-27297 ALSO IN CATEGORY 18

OXIDATION OF PRESTRESSING TENDONS AT ROBINSON 2

CAROL INA POWER + LIGHT CO., RALEIGH, N. C.

1 PAGE, ATOMIC ENERGY CLEARING HOUSE 14131), PAGE 27, (JULY 29, 1968), DOCKET 50-261, TYPE--PWR,

MFG-WE ST., AE--EBASCO

(LETTER, JULY 16$)$ AN UNANTICIPATED MINOR AMOUNT OF OXIDATION HAS FOUND ON THE LOWER SECTION OF VERTICAL PRESTRESSING TENDONS SURFACES. TENDONS ARE SATISFACTORY, BUT CORROSION PROTECTION WILL BE IMPRDVED. ATTACHEO REPORT DESCRIBES WORK TO DETERMINE CAUSES DF CORROSION, TO VERIFY THAT TENDONS ARE STILL SATISFACTORY, AND TO DESCRIBE THE IMPROVED CORROSION PROTECTION. 
CATEGORY 11

CONTAINMENT OF NUCLEAR FACILITIES

11-27297 \#CONTINUED*

\#CONCRETE, PRESTRESSED + \#CORRDSION + \#STEEL + CONTAINMENT CONSTRUCTION +

CONTAINMENT, CORROSION PROTECTION + OPERATING EXPERIENCE + REACTOR, PWR + ROBINSON 2 (PWR)

11-27298 ALSO IN CATEGORY 18

CONTAINMENT VESSEL CRACKS MAY EXIST AT MILLSTONE

MILLSTONE POINT CO. HARTFORD, CONN.

1 PAGE, ATOMIC ENERGY CLEARING HOUSE 14(31), PAGE 28, (JULY 29, 1968), DOCKET 50-245, TYPE--BWR,

MFG--G.E., AE--EBASCO

(LETTER, JULY 17) REQUESTS DATA ON 26 ITEMS. COMPLIANCE STATES THAT CRACKS HAVE BEEN FOUND IN WELDS ON INSERT PLATES ON CONTAINMENT VESSELS SIMILAR TO MILLSTONE VESSEL. WE UNDERSTAND THAT YOU BELIEVE THAT SIMILAR CRACKS ARE NOT PRESENT. WE LACK DETAILED INFORMATION TO SUPPORT YOUR POSITION AND THEREFORE REQUEST A DETAILED REPORT.

\#CONTAINMENT LINER + \#FAULT + \#WELDS + MILLSTONE POINT (BWR) + OPERATING EXPERIENCE + REACTIR, BWR

11-27428 ALSO IN CATEGORY 18

SECTION I - REACTOR VESSEL

NI AGARA MOHAWK POWER CORP.

30 PAGES, 11 FIGURES, 10 TABLES, 3 REFERENCES, PAGE I- 1 THROUGH I-30 OF NINE MILE POINT FSAR VOL. IV

(EXHIBIT D-Z), SEPTEMBER 1967, DOCKET NO. 50-220, TYPE--8WR, MFG--G.E., AE--NIAGARA MOHAWK

INCLUDES APPLICABILITY OF FORMAL CODES AND PERTINENT CERTIFICATIONS, DESIGN ANALYSIS, INSPECTION AND TEST REPORT SUMMARY IMULTIPLE CRACKING OF WELO AT NOZZLE WAS TRACED TO EXCESS MANGANESE IN WIRE AND FLUX USED), AND_SURVEILLANCE PROGRAM.

AVAILABILITY - CLEARINGHOUSE FOR FEDERAL SCIENTIFIC AND TECHNICAL INFORMATION, SPRINGFIFLN, VA. 22LISI $\$ 3.00$ COPY, \$0.65 MICROF ICHE

*FAULT + \#PRESSURE VESSEL + *WELDS + CODES AND STANDARDS + EXAMINATION + NINE MILE POINT (BWR) + NOZZLE + REACTOR, BWR + REPORT, SAR + STRESS ANALYSIS + SURVEILLANCE PROGRAM

11-27429 ALSO IN CATEGORY 18

SECTION II - PRESSURE SUPPRESSION CONTAINMENT

NI AGARA MOHAWK POWER CORP.

14 PAGES, 12 FIGURES, 14 TABLES, 3 REFERENCES, PAGES II-1 THROUGH II-14 OF NINE MILE POINT FSAR VOL. IV

(EXHIBIT D-2), SEPTEMBER 1967, DOCKET NO. 50-220, TYPE--BWR, MFG--G.E., AE--NIAGARA MOHAHK

PROVIDES APPLICABILITY OF FORMAL CODES AND PERTINENT CERTIFICATIONS, DESIGN ANALYSIS, AND INSPECTION AND TEST REPORT SUMMARY.

AVAILABILITY - CLEARINGHOUSE FOR FEDERAL SCIENTIFIC AND TECHNICAL INFORMATION, SPRINGFIELD, VA. 22151 $\$ 3.00$ COPY, $\$ 0.65$ MICROFICHE

* CONTAINMENT, PRESSURE SUPPRESSION + COOES AND STANDARDS + CONTAINMENT OESIGN + EXAMINATION +

MISSILE GENERATION AND PROTECTION + NINE MILE POINT (BWR) + REACTOR,·BWR + REPORT, SAR + STRESS ANALYSIS

11-27432 ALSO IN CATEGORY 18

SECTION $V$ - CONTAINMENT DESIGN REVIEW

NIAGARA MOHAWK POWER CORP.

9 PAGES, 4 REFERENCES, PAGES V-1 THROUGH V-9 OF NINE MILE POINT FSAR VOL. IV (EXHIBIT D-2), SEPTEMBER

1967, DOCKET NO. 50-220, TYPE--BWR, MFG--G.E., AE--NIAGARA MOHAWK

REVIEW OF CB AND I CONTAINMENT ASME STRESS REPORT AND OF NOZZLE EXTENSION BELLOWS BY TEMP. FLEX. TMR CONCLUDES ANALYSIS IS ADEQUATE FOR FUNCTION BUT NOT ADEQUATE TO ESTABLISH ASME III REQUIREMENTS BECAUSE OF INTERPRETATION OF PARAGRAPH N-414. DISAGREEMENT IS IN STRESS

DISCONTINUITY REGIONS AT VESSEL OPENINGS, WHERE CB AND I USEO FORMULA (ALLOWABLE WHERE ONLY

PRESSURE STRESS OCCURSI WHILE TMR BELIEVES AN ANALYSIS IS NEEOED.

AVAILABILITY - CLEARINGHOUSE FOR FEDERAL SCIENTIFIC AND TECHNICAL INFORMATION, SPRINGFIELD, VA. 22151 $\$ 3.00$ COPY, \$0.65 MICROFICHE

\#CODES AND STANDARDS + \#CONTAINMENT DESIGN + \#REVIEW + CONTAINMENT EQUIPMENT HATCH +

CONTAINMENT PENETRATIDN, PIPE + CONTAINMENT, PRESSURE SUPPRESSION + NINE MILE POINT (BWR) + REACTOR. BWR + REPORT, SAR + STRESS ANALYSIS

$11-27448$

SKIRT FOR SUPPORTING A REACTOR

HITACHI, LTD., JAPAN

JAPANESE PATENT 1966-11679+. 2 PAGES, MAY 31,1966

A DESIGN IS GIVEN FOR A CYLINDRICAL SUPPORT-SKIRT WHICH IS INSTALLED ON THE UPPER PART OF A HIGH-TEMPERATURE REACTOR PRESSURE-VESSEL HITH THE UPPER EDGE BEING FIXED TO THE CONCRETE SHIELD, THE SPACE OVER THE PRESSURE-VESSEL, HITHIN THE SKIRT AND ABOVE, IS FILLED HITH 
CATEGORY 11

CONTAINMENT OF NUCLEAR FACILITIES

11-27448 *CONTINUED*

SHIELDING WATER. WITHIN THE SKIRT, IN THE SHIELOING HATER, AT LEAST TWO ANNULAR PLATES ARE PLACED HORIZONTALLY SURROUNDING THE SPHERICAL PART OF THE PRESSURE VESSEL. THESE ANNULAR PLATES ARE LOCATED WITH SOME SPACE BETWEEN THE PLATE AND THE SKIRT AND BETWEEN THE PLATE AND THE VESSEL.

AVAILABILITY - IT IS OUR UNDERSTANDING THAT FOREIGN PATENTS MAY BE OBTAINED IN PHOTOCOPY FROM THE U.S. PATENT OFFICE, DEPARTMENT OF COMMERCE, WASHINGTON, D.C. (30 CENTS/PAGE)

*CUNTAINMENT DESIGN + \#CONTAINMENT STRUCTURF + \#JAPAN + \#PATENT + CONTAINMENT CONSTRUCTIDN + PRESSURE VESSEL

$11-27450$

RACHAIS CG

SUPPORTING SYSTEM FOR THE SKIRT SUPPORTING A NUCLEAR REACTOR

ELECTRICITE DE FRANCE

BRITISH PATENT $1,070,507+.3$ PAGES, 3 FIGURES, JUNE 1,1967

A STRUCTURE DESIGN FOR SUPPORTING THE CORE OF A NUCLEAR REACTOR IS GIVEN. THIS TYPE OF STRUCTURE HAS BEEN DESIGNED TO ALEVIATE UNEQUAL DEFORMATION OF THE FOUNOATION AND SUPPORTING PILLARS WHICH SIIPPORT THE CORE ASSEMBLY. THE STRUCTURE CONSISTS OF A GENERALLY CYLINORICAL SKIRT SUPPDRTING THE CORE AND SURROUNDING THE HEAT EXCHANGER AND A NUMBER OF ANGULARIYY SPACED PILLAR ASSEMBLIES EACH INCLUDING A RESILIENT COMPRESSION BAR FOR TRANSMISSION OF FDRCE FROM THE SKIRT TO THE LOWER PORTION OF THE PRESSURE VESSEL, IN OROER TO MAINTAIN AN EVEN DISTRIBUTION OF THE TOTAL LOAD BETWEEN ALL THE PILLAR ASSEMBLIES.

AVAILABILITY - THE PATENT OFFICE, 25 SOUTHAMPTON BUILDING, LONOON W.C. 2, ENGLAND (49 CENTS/COPY) \#CONTAINMENT CONSTRUCTION + \#PATENT + \#UNITED KINGDOM + CONTAINMENT DESIGN + CONTAINMENT STRUCTURE

11-27474. ALSO IN CATEGORIES 17 ANO 10

SAFETY EVALUATION FOR PROPOSED 115 MWTH PEACH BUTTOM OPERATION PHILADELPHIA ELECTRIC COMPANY

19 PAGES, NOVEMBER 14, 1966, DOCKET 50-171, TYPE--HTGR, MFG--G.A., AE--BECHTEL

EXCESS REACTIVITY 10.20 INSTEAO OF 0.15 DUE TO CARBON DENSITY AND THORIUM ABSORPTIQN CROSS SECTION OVERESTIMATE) WAS ADJUSTED WITH LUMPED BURNABLE POISON TO GIVE AN O.06 SHUTDOWN MARGIN. LIMITS ON REACTIVITY AND FLUX ANOMALIES WILL BE SET. AFTER 1965 CABLE FIRE (WELDING SLAG INITIATION, CHIMNEY EFFECT), CO2 SYSTEM EXTENDED TO CABLE AREAS, REROUTED TO INCREASE INDEPENDENCE, SMOKE DETECTORS INSTALLED, ANO FIREPROOF COVERS AND FIRE STOPS INSTALLED. HELIUM LEAKAGE IS 10-20 TIMES DESIRED 0.2 LB/DAY. CONTROL ROD DRIVE BALLS ARE NOW 100 PERCENT TESTED AFTER FAILURES FROM INTERNAL DEFECTS. A LARGER CONTAINMENT VACUUM RELIEF IS PROVIDED.

AVAILABILITY - USAEC, PUBLIC DOCUMENT ROOM, 1717 H ST., WASHINGTON, 0.C. 20545 (\$O.25 CENTS/COPY)

\#DPERATING EXPERIENCE SUMMARY + \#SAFETY EVALUATION + CONTAINMENT PENETRATION, ELECTRICAL + CONTAINMENT VACUUM BREAKER + CROSS SECTION + ELECTRICAL CONDUCTION + EXAMINATION +

FAILURE, SCRAM MECHANISM + FIRE + INDEPENDENCE + PEACH BOTTOM 1 (HTGR) + POWER UPRATING +

REACTIVITY EFFECT, ANOMALOUS + REACTOR, HTGR + SHUTDOWN MARGIN + THORIUM

11-27502 ALSO IN CATEGORIES 18 AND 10

ACRS REPORT ON RANCHO SECO

UNITEO STATES ATRMIC ENERGY COMMISSION

3 PAGES, LETTER TO G.T. SEABORG, USAEC, JULY 19, 1908, DOCKET 50-312, TYPE--PWR, MFG--B,W, AE--BECHTEL

ACRS APPROVES CGNSTRUCTION, CALLING ATTENTION TO PREVIOUS STATEMENTS DN LARGE WATER COOLEO PUWER REACTORS. SUGGESTS FURTHER ANALYSIS DF FAST FLUX DAMAGE TO REACTOR VESSEL, AND ADEQUACY OF VESSEL SURVEILLANCE PROGRAM. ACRS REITERATES BELIEF CONTRUL ANO PROTECTION INSTRUMENTATION SHOULD BE INDEPENDENT OF COMMON FAILURE MODES. APPLICANT AND REG. STAFF SHOULD REVIEW FOR SYSTEMATIC, NINRANOOM CONCURRENT FAILURES OF REOUNDANT DEVICES NOT CONSIDERED IN THE SINGLE FAILURE CRITERION.

AVAILABILITY - USAEC PUBLIC DOCUMENT ROOM, 1717 H ST., HASHINGTON, 0.C., 20545 (\$SO.25 CENTS/COPY)

\#ALKS + F'PALLURE, 3IMULTAPIOUE + \#PLANT PRMTFC.TIVE SYSTEM + \#PRESSURE VESSEL + \#REVIEW + BRITTLE FRACTURE + RANCHO SECO (PWR) + REACTOR, PWR + REPORT, \$PSAR + SINGLE FAILURE CRITLRIUN + SURVEILLAIVE FROCRAM

11-27504 ALSO IN CATEGORY 17

SELECTEO LACROSSE OPERATING EXPERIENCE

ALLIS-CHALMERS, BETHESDA, MARYLAND

ACNP-68508 +. 11 PAGES, FIGURES, TABLES, JUNE 1968, DOCKET 115-5, TYPE--BWR, MFG--A.C., AE--SGT + LUNDY

REACTOR NOT OPERATED WHILE CONTAINMENT LEAK RATE DETERMINED TO BE $0.6 \%$ PER 24 HR AT 52 PSIG. $95 \%$ OF THIS WAS LEAKAGE THROUGH INTERNAL VENT HEADER 4 IN. VALVE AND THROUGH SHUTDOHN CONOENSER I IN VENT VALVE. THEY WILL BE REPAIRED.

AVAILABILIIY - USAEC PUBLIC DOCUMENT ROOM, 1717 H ST., WASHINGTON, D.C. 20545 (\$SO.25 CENTS/COPY) 
CATEGORY 11

CONTAINMENT OF NUCLEAR FACILITIES

11-27504 *CONTINUED*

*CONTAINMENT, hIGH PRESSURe + \#TEST, LEAK RATE + CONTAINMENT PENETRATION, PIPE +

CONTAINMENT REFERENCE MEASURING SYSTEM + LACROSSE (BWR) + REACTOR, BWR + REPORT, OPEKATIONS

11-27805 ALSO IN CATEGORY 5

BIRSS IR

CALCULATION OF RELATIVE DISPLACEMENT DAMAGE RATES IN DIFFER ING REACTOR TYPES

UNITED KINGDOM ATOMIC ENERGY AUTHOR ITY, DOUNREAY (SCOTLAND)

TRG-REPORT-1561 +. 18 PAGES, 6 FIGURES, 3 TABLES, 10 REFERENCES, 1967

A NUMBER OF MATERIALS NOT NECESSARILY DESTINED FOR USE IN FAST REACTORS, IN WHICH ATOMIC OISPLACEMENTS ARE THE MAIN DAMAGE MECHANISM UNDER OBSERVATION, ARE PRESENTLY BEING IRRADIATEO IN THE DOUNREAY FAST REACTOR. IN THIS PAPER IT IS SHOWN THAT, IF IT CAN BE ACCEPTED THAT THE RATIO OF ATOMIC DISPLACEMENT RATE IN THE TEST REACTOR TO DISPLACEMENT RATE IN THE PARENT REACTOR IS AN ACCEPTABLE PARAMETER FOR COMPARISON PURPOSES, THEN THE ATOMIC DISPLACEMENT ENERGY AND THE ELECTRONIC CUT OFF ENERGY OF A MATERIAL ARE NOT CRITICAL PARAMETERS IN THE DERIVATION OF THIS RATIO. IT IS ALSO SHOWN THAT, IF THE EQUIVALENT FISSION FLUX CONCEPT IS USED TO OESCRIBE REACTOR SPECTRA, IT CAN LEAD TO APPRECIABLE ERRORS IN DERIVING THE DAMAGE RATIO, BUT THAT INTEGRATION OVER THE REAL SPECTRUM IS UNNECESSARY BELOW ABDUT O.1 MEV.

AVAILABILITY - CLEARINGHOUSE FOR FEDERAL SCIENTIFIC AND TECHNICAL INFORMATION, SPRINGFIELD, VA. 22I5I $\$ 3.00$ COPY, \$0.65 MICROFICHE

\# DAMAGE + \#IRRADIATION TESTING + *MATERIAL + IN PILE EXPERIMENT + METAL

11-27827 ALSO IN CATEGORIES I AND 17

MANUAL OF LECTURE NOTES - REACTOR SAFETY COURSE NO. 7

UNITED KINGDOM ATOMIC ENERGY AUTHORITY, RISLEY, WARRINGTON, LANCASHIRE

200 PAGES, FIGURES, TABLES, REFERENCES, SEPTEMBER 23,1968

NINE SECTIONS. (I) INTRODUCTION, 5 LECTURES. (II) FISSION PRODUCT RELEASE, 5 LECTURES, (III) CONTAINMENT ENGINEER ING, 7 LECT JRES. (IVI CONTROL AND INSTRUMENTATION, 7 LECTURES. IVI GAS COOLED REACTORS, 11 LECTURES. (VI) WATER REACTORS, 12 LECTURES. (VII) GENERAL, 5 LECTURES. (VIII) FAST REACTORS, 7 LECTURES. (IX) SITING AND EMERGENCY PROCEDURES, 4 LECTURES. NEW LECTURES APPEAR TO BE (7) ASSESSMENT OF ENVIRONMENTAL HAZARDS FROM FISSION PRODUCT RELEASES. (BA) FISSION PRODUCT BEHAVIOR IN LIQUID COOLED REACTORS. (IOA) CONTAINMENT OF FISSION PRODUCTS WITHIN FUEL ELEMENTS. (24A) METHODS AND PROBLEMS IN REACTOR ASSESSMENTS. (4O) PROBABILITY TECHNIQUES APPLIEO TO WATER REACTORS.

AVAILABILITY - AUTHORITY HEALTH ANO SAFETY BRANCH, U.K.A.E.A., II CHARLES II STREET, LONOON, S. W. 1.

* SAFETY ANALYSIS + \#AFETY REVIEW + FISSION PRODUCT RETENTION + FUEL ELEMENT + PARTITION COEFFICIENT + PROBABILITY + REACTOR, GCR + REACTOR, HTGR + REACTOR, LMFBR + REACTOR, WATER +

SAFETY PRINCIPLES AND PHILOSOPHY + UNITED KINGDOM

11-27882 ALSO IN CATEGQRY 5

VAINOEINDEKG $S K$

STATUS OF PIPE-RUPTURE STUDY AT GENERAL ELECTRIC

8 PAGES, 8 FIGURES, 13 REFERENCES, NUCLEAR SAFETY 8(2), PAGES 148-55 (WINTER. 1966-67)

THIS PIPE-RUPTURE STUDY IS CONCERNED WITH IMPROVING CURRENT UNDERSTANDING OF FAILURE-CAUSING MECHANISMS AND PROVIDING IMPROVED CAPABILITY FOR EVALUATING AND MONITORING REACTOR PIPING SYSTEMS TO MINIMIZE THE PROBABILITY OF FAILURES. THIS STATUS REPORT SUMMARIZES THE ACCOMPLISHMENTS DURING THE INITIAL YEAR OF A BROAD 4-YEAR PROGRAM IN (I) RELIABILITY ENGINELRING OF ACTUAL KEACTOR PIPING SYSTEMS, (2) SOLUTION OF HERETOFORE INTRACTABLE PROBLEMS IN STRESS ANALYSIS, (3) APPLICATION OF FRACTURE MECHANICS. TO DUCTILE MATERIALS, AND (4) FATIGUE STUDIES THROUGH BOTH BENCH-SCAI F OND LARGE-COMTONCNT TESTS.

\#ACCIDENT ANALYSIS + \#FAILURE, PIPE + \#PIPING + ACCIDENT, STEAM LINE RUPTURE + FAILURE, TUBING + PLANT PROTECTIVE SYSTEM

$11-27975 \quad A L S O$ IN CATEGORY

STATUS AND FUTURE TECHNICAL AND FCONOMIC POTENTIAL OT LIGHT WATER REACTORS

JACKSDN ANU MORELAND, S. M. STROLLER ASSOCIATES

WASH-1082 +. 125 PAGES, FIGURE, TABLES, REFERENCES, MARCH 1968

THIS TASK-FORCE STUDY OF LIGHT-HATER REACTORS DISCUSSES $(1)$ THE CURRENT AND FUTURE ECONOMIC POSITION OF BOILING ANO PRFSSURIZED WATER REACTORS (2) FUELS, +UEL MANAGEMENT, FUEL ECONOMICS, AND (3) REACTOR SITING. OF GREATEST SAFETY INTEREST IS THE SECTION ON NEUTRON PLANT SITING (SECTION 4). THIS SECTION DISCUSSES THE PROBLEM, THE NEEO FOR GREATER FLEXI8ILITY, ANTICIPATED DEVELOPMENTS, AND TRENDS IN SITING PRACTICES. THE ASPECTS OF FUTURE SITING TRENOS ARE DISCUSSED (GENERALLY) WITH REGARO TO THE USE OF ENGINEFRED SAFETY FEATURES.

AVAILABILITY - SUPERINTENDENT OF DOCUMENTS, U.S. GOVERNMENT PRINTING OFFICE, WASHINGTON, D. C. 20402

\#CONTAINMENT, GENERAL + \#ECONOMICS + \#SITING, REACTOR + ENGINEERED SAFETY FEATURE + REACTOR, BWR + REACTOR, POWER + REACTOR, PWR + REACTOR, WATER + REGULATION, AEC + SAFETY PRINCIPLES AND PHILOSOPHY 
CATEGORY 11

CONTAINMENT OF NUCLEAR FACILITIES

11-28011 ALSO IN CATEGORY 17

THIRTEENTH MONTHLY OPERATIONAL REPORT ON THE LA CROSSE BOILING HATER REACTOR COVERING THE MONTH OF JULY 1968

ALLIS-CHALMERS, BETHESDA, MARYLAND

ACNP-68509+. 16 PAGES, JULY. 1968 , DOCKET 115-5, TYPE--8WR + MFG--A.C., AE--SGT + LUNDY

REACTOR SHUT DOWN. SHUTDOWN CONDENSER SHOWED NO HELIUM LEAKAGE DESPITE 3 DAYS AT 55 PSIG, BOTH COLD ANO AT $230 \mathrm{~F}$. \# \# A BENT FEEDHATER PIPE HANGER INOICATED THAT THE PIPE MOVED MORE THAN THE $1 / 16$ IN. PREDICTED. CALCULATIONS WILL BE REDONE.

AVAILABILITY - USAEC PUBLIC DOCUMENT ROOM, WASHINGTON, D. C. 20545

COMPARISON, THEORY ANO EXPERIENCE + LACROSSE (BWR) + PIPING + REACTOR, BWR + REPORT, OPERATIONS + STEAM GENERATOR + STRESS ANALYSIS + TEST, LEAK RATE + THERMAL MECHANICAL EFFECT + TUBING

11-28034 ALSO IN CATEGQRY 17

ELK RIVER OPERATING EXPERIENCE

RURAL COOPERATIVE POWER ASSOCIATION

COD-651-63+. 41 PAGES, FIGURES, TABLES, JULY 1968, OOCKET 115-1, TYPE--BWR, MFG-A.C., $\triangle E--S G T+$ LUNOY

REACTOR NOT OPERATED BECAUSE PRIMARY SYSTEM LEAK RATE TESTS CONTINUED USING SR-85 AND R8-86 TRACERS. WHEN RB-86 WAS INJECTED INTO PRIMARY SYSTEM WITH 1100 TSIG STEAM, THE ZEACTOR CAVITY WATER COLLECTION RATE INCREASED FROM 1500 TO 2100 ML/HR, BUT RB-86 NOT FOUND. STEAM WAS INJECTED INTO REACTOR CAVITY TO FLUSH OUT ANY TRACER DEPOSITEO, CONOENSATE SHOWED BOTH RB AND SR TRACERS. \#PROCEDURES GIVEN FOR PERSONNEL ANO FOR EMERGENCY AIR LOCK LEAK RATE

TESTS. CONTAINMENT VESSEL WILL BE LEAK RATE TESTEO NEXT. SHIELD BLOCKS ARE BEING REMOVED FOR VISUAL INSPECTION OF THE VESSEL BOTTOM.

USAEC, PUBLIC DOCUMENT ROOM, 1717 H ST., WASHINGTON, D.C. 20545 (25 CENTS/PAGE)

* TEST, LEAK RATE + CONTAINMENT AIR LOCK + ELK RIVER (BWR) + FAILURE, PRESSURE VESSEL + PRESSURE VESSEL + REACTOR, BWR + REPORT, OPERATIONS + TRACER, RADIOACTIVE

11-28067 ALSO IN CATEGORIES 12 AND 9

PEDERSEN HN + SPANNER JC

DETECTION, LOCATION, AND CHARACTERIZATION OF FLAW GROWTH IN METALS USING ACOUSTIC EMISSION METHODS BATELLE-NORTHWEST

CONF-671011 +. 2 PAGES, 4 REFERENCES, OCTOBER 1966

8ATTELLE-NORTHWEST IN FEBRUARY OF 1966 BEGAN A PROGRAM TO NONDESTRUCTIVELY DETECT INCIOI.ENT FAILURE OF REACTOR PRESSURE PIPING, USING THE ACOUSTIC EMISSION GENERATED SY FRACTURE, CLEAVAGE, DISLOCATION UNPINNING, TWINNING, ETC., OF SINGLE DR MULTIPLE GRAINS OF THE PIPING MATERIAL. THE PURPOSE OF THE PROGRAM IS - $(1)$ THE DETECTION OF ACOUSTIC EMISSION AGAINST THE NOISE BACKGROUNC OF THE OPERATING REACTOR, (2) THE LOCATION OF THE POINT OF ORIGIN OF THE ACOUSTIC EMISSION, (3) THE CHARACTERIZATION OF THE ACOUSTIC EMISSION BY THE TYPE OF FAILURE OR FLAW-GROWTH MECHANISM IN THE MLTAL, AND (4) PREDICTION OF THE TIME OF FAILLIRE.

AVAILABILITY - CLEARINGHOUSE FOR FEDERAL SCIENTIFIC AND .TECHNICAL INFORMATION, SPRINGFIELO, VA. 22151 $\$ 3.00$ CORY, $\$ 0.65$ MICR.OFICHE

ANALYTICAL TECHNIQUE, CALIBRATION + FLAW + INSTRUMENTATION, SURVEILLANCE + INTEGRITY + METAL + PIPING + TEST, NONDESTRUCTIVE

11-28068 ALSO IN CATEGORIES 12 ANO

Hijt

ACOUSTIC EMISSION IN METALS AS A NDT TOOL

BATTELLE MEMORIAL INSTITUTE, PACIFIC NORTHWEST LABORATORY, RICHLAND, WASHINGTON

BNWL-SA-1262+CONF-671002-4+8 PAGES, 3 REFERENCES, FOR PRESENTATION $\triangle T$ THE $27 T H$ NATIONAL CONFERENCF. OF THE SOCIETY FOR NONDESTRUCTIVE TESTING AT CLEVELAND, OHIO, CCTOBER 18, 1967, SEPTEMRER 1957

SOME OF THE MORE EVIDENT APPLICATIONS OF ACOUSTIC EMISSION, IN ADOITIDN TD MONITORING FLAW GROWTH IN REACTOR PRESSURE SYSTEMS, ARE - 11$)$ REMOTE AND CONTINUOUS SURVEILLANCE DF OPERATIONAL SYSTEMS SUCH AS NATURAL-GAS PIPE LINES AND AIRCRAFT STPUCTURES TO DETECT FORMATION AND/OR GRONTH OF FLAWS, 121 MONITORING WELOS, PARTICULARLY IN HEAVY SECTIONS, AS THEY COOL TO DETECT INTERNAL CRACKING, (3) USE AS A STUDY TOOL. FOR FRACTIRE MECHANICS RESEARCH IN BOTH METALLICS AND NONMETALLICS, 141 MONITORING SPACE VEHICLES FOR MICROMETEORITE PENE TRATION.

AVAILABILITY - CLEARINGHOUSE FOR FEDERAL SCIENTIFIC AND TECHNICAL INFORMATION, SPRINGFIELD, VA. 22151 $\$ 3.00$ COPY, BO.65 MICROFICHE

ANALYTICAL TECHNIQUE, CALIBRATION + FLAN + INSTRUMENTATION, SURVEILLANCE + INTEGRITY + METAL + PIPING + PRESSURE VESSEL + TEST, NONDESTRUCTIVE 
12-25903 ALSO IN CATEGORIES 18 AND 5

BRAY AP + IANNI P + MURRAY JL

GENERAL ELECTRIC COMPANY ANALYTICAL AND EXPERIMENTAL PROGRAMS FOR RESOLUTION OF ACRS SAFETY CONCERNS

ATOMIC POWER EQUIPMENT DEPARTMENT, GENERAL ELECTRIC COMPANY, SAN JOSE, CALIFORNIA

$\triangle P E D-5608+.40$ PAGES, 5 FIGURES, 4 TABLES, APRIL, 1968

ACRS REVIEW OF BROWNS FERRY (MAR. 14, 19671 INOICATED THAT ADOITIONAL TESTING OR ANALYSIS WAS

REQUIRED. THE TEST OR ANALYSIS PROGRAM IS OESCRIBED FOR THE FOLLOWING - (I) EFFECTS OF

FUEL-ROD FAILURE ON ECCS PERFORMANCE, $(2)$ EFFECTS OF FUEL-BUNDLE FLOW BLOCKAGE, (3)

VERIFI CATION OF FUEL-DAMAGE-LIMIT CRITERION, (4) EFFECTS OF CLADDING TEMPERATURE AND MATERIAL

ON ECCS PERFORMANCE, (5) CLOSURE OF MAIN-STEAM-LINE ISOLATION VALVE, (6) TESTS OF

DIESEL-GENERATOR PERFORMANCE, (7) STEAM-LINE-BREAK ACCIDENT, ANO (8) DEPRESSURIZATION

PERFORMANCE OF HPCI SYSTEM.

AVAILABILITY - USAEC, PUBLIC DOCUMENT ROOM

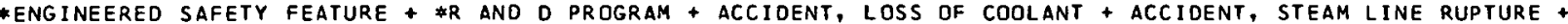
ACRS + $A E C$ QUESTION + BROWNS FERRY (BWR) + CONTAINMENT ISOLATION + CDRE SPRAY + FLOW BLOCKAGE +

FUEL ELEMENT + GENERATOR, ENGINE + PERFORMANCE LIMIT + SYSTEM OPERABILITY IN ACCIDENT

$12-25904 \quad$ ALSO IN CATEGORIES 5 AND 18

EFFECTS OF FUEL ROD FAILURE ON ECCS PERFORMANCE

ATOMIC POWER EOUIPMENT OEPARTMENT, GENERAL ELECTRIC COMPANY, SAN JOSE, CALIFORNIA

APED-5608 +. 4 PAGES, PAGES 2-1 THROUGH 2-5 OF THE GENERAL ELECTRIC COMPANY ANALYTICAL AND EXPERIMENTAL PROGRAMS FOR RESOLUTION OF ACRS SAFETY CONCERNS, APRIL, 1968

ACRS REVIEW OF BROWNS FERRY VOICED CONCERN FOF EFFECT ON HEAT-TRANSFER EFFECTIVENESS OF ECCS RESULTING FROM FUEL-CLAD BULGING OR PERFORATION IN LOSS-OF-COOLANT ACCIDENTS. ANALYTICAL AND EXPERIMENTAL PROGRAMS TO RESOLVE THE CONCERN ARE DESCRIBED. FAILURE TEMPERATURES, WITH SINGLE ROD TESTS HAVING GAS-PLENUM PRESSURES FROM 130 TO 1500 PSIG, WERE 1348 TO $1732 \mathrm{~F}$ NIN-RUD-GUNDLE TESTS SHOWED THAT GROSS FLOW BLOCKAGE DOES NOT OCCUR AS A RESULT OF MULTI-ROD PERFORATIONS. FULL-SIZE HEATER-BUNDLE TESTS WILL BE PERFORMED. ANALYSIS TO BE MADE OF HORST CONFIGURATION OF FLOW PATH AND INCLUDE RADIATION EFFECTS ON CHANNEL WALLS. PROGRESS TO BE COMPLETED IN 1969.

AVAILABILITY - USAEC, PUBLIC DOCUMENT ROOM

* ACCIDENT, LOSS OF CODLANT + \#SYSTEM OPERABILITY IN ACCIOENT + ACRS + AEC QUESTION + BROWNS FERRY (BWRI + CORE SPRAY + EMERGENCY COOLING CONSIDERATIONS + FAILURE, CLAODING + FLOW BLOCKAGE + PERFORMANCE LIMIT + REACTOR, BWR + SYSTEM CAPABILITY + TEST, PROOF

12-25908 ALSO IN CATEGORIES 11 AND 18

CLOSURE OF MAIN STEAM LINE ISOLATION VALVE

ATOMIC POWER EQUIPMENT DEPARTMENT, GENERAL ELECTRIC COMPANY, SAN JOSE, CALIFORNIA

APED-5608 +. 7 PAGES, 2 FIGURES, PAGES 6-1 THROUGH 6-7 OF THE GENERAL ELECTRIC COMPANY ANALYTICAL ANO

EXPERIMENTAL PROGRAMS FOR RESOLUTION OF ACRS SAFETY CONCERNS, APRIL, 1968

DESCRIBES THE TEST PROGRAM TO DEMONSTRATE THE PFRFRRMANF.F TAPARII ITY NE A EULL-EIIF MAIPL CTLAM

I SULAIIUN VALVE CLOSING UNDER STEAM ANO TWO-PHASE-MIXTURE FLOW CONDITIONS CALCULATED FOR AN

EXTERNAL STEAM-LINE BREAK. THE VALVE OESIGN IS A Y TYPE AND USES AN AIR-CYLINDER OPLRATOR

ANO CLOSING SPRINGS. TESTS WILL BE CONDUCTEO FOR A RANGE OF SIMULAIEU BREAK SIZES AND STEAM QUANTITIES.

AVAILABILITY - USAEC, PUBLIC DOCUMENT ROOM

\#CONTAINMENT ISOLATION + *SYSTEM CAPABILITY + \#TEST, PROOF + \#VALVE + ACCIDENT, STEAM LINE RUPTURE + ACRS + AEC QUESTION + BROWNS FERRY (BWR) + FLQW, TWO PHASE + LEAK + REACTOR, BWR + RESPINSE TIME + SYSTEM OPERABILITY IN ACCIDENT

12-25509 ALSO IN CATEGORIES 10 AND 18

TESTS DF DIESEL GENERATOR PERFORMANCE

ATOMIC POWER EOUIPMENT DEPARTMENT, GENERAL ELECTRIC COMPANY, SAN JOSE, CALIFORNIA

APED-5608 +. 3 PAGES, PAGES 7-1 THROUGH 7-3 OF THE GENERAL ELECTRIC COMPANY ANALYTICAL AND EXPERIMENTAL

PROGRAMS FOR RESOLUTION OF ACRS SAFETY CONCERNS, APRIL 1968

ACRS RECOMMENDED TESTING GENERATORS UNDER SIMULATED EMERGENCY CONDITIONS. GE RESPONDED THAT TESTS WILL BE CONDUCTED AT THE MANUFACTURERS PLANT TO CONFIRM ADEQUACY WITH RESPECT TO START TIMES, SYNCHRONIZATION, AND SIMULATED LOAOING. TESTS (FOR SINGLE DIESELI ON STARTING RELIABILITY, START TIMES, AND SIMULATED LOAO-CARRYING CAPABILITY WERE ALMOST COMPLETE. TESTS OF STARTING AND SYNCHRONIZING TWM RR MDRE DIESELS ARE BEINC PLANNED TOR 1968. SITE TESTS WILL BE CONOUCTED AND INTEGRATED WITH SPECIFIC. PROJECTS.

AVAILABILITY - USAEC, PUBLIC DOCUMENT ROOM

*GENERATOR, ENGINE + *RELIABILITY, COMPONENT + \#SYSTEM CAPABILITY + *TEST, SYSTEM OPERABILITY + ACRS + AEC QUESTION + BROWNS FERRY (BWR) + ELECTRIC POWER, SHUTOOWN + EMERGENCY POWER, ELECTRIC + REACTOR, BWR + SYSTEM OPERABILITY IN ACCIOENT 


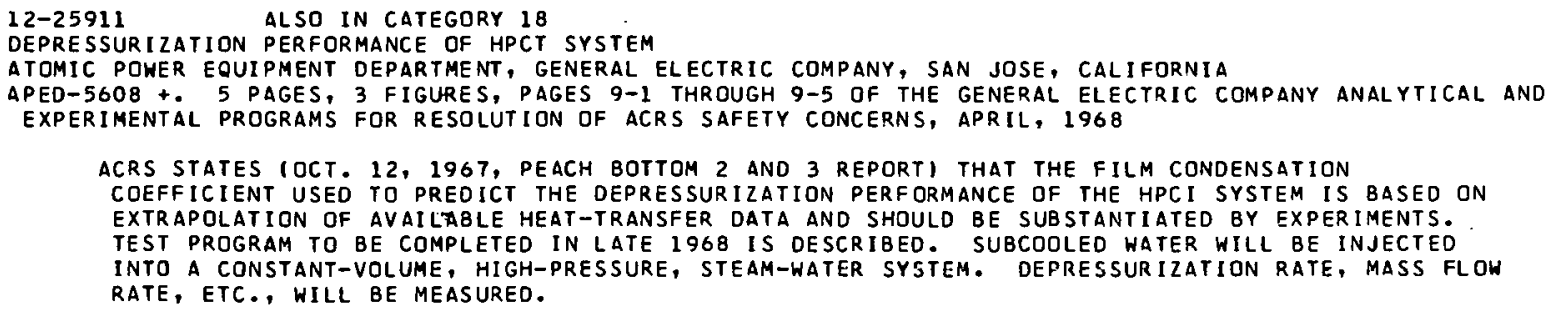

SYSTEM CONSISTS OF BUILT-IN SHUTOOWN TUBES IN THE CALANDRIA WHICH PERMIT RECOVERY OF THE POISON. LOOP CONSISTS OF A U-TUBE, SHUTDOWN VALVE, HIGH PRESSURE HEAD TANK AND A BUFFER TANK. FLUID INLET VELOCITY IS $80 \mathrm{FT/SEC,} \mathrm{WHICH} \mathrm{IS} \mathrm{ARRESTED} \mathrm{BY} \mathrm{COMPRESSING} \mathrm{HEL} \mathrm{IUM} \mathrm{IN} \mathrm{THE} \mathrm{TUBE}$ WHILE DISCHARGING A FRACTION TO A BUFFER TANK. THE ABSORBER FLUID. CAN BE DRAINED FROM THE TUBES FOR REUSE. VALVE DESIGN IS SUCH THAT OPENING TIME IS 0.1 SEC AND CONSISTS OF A 2-WAY BODY AND SPOOL WITH A 1.5-IN. STROKE BETWEEN SEALS. SIX COIL SPRINGS PUSH SPOOL TOWARD ITS BODY AND SPOOL WITH A $1.5-$ IN. STROKE BETWEEN
SEAT WHEN A SPLIT ELECTROMAGNET IS ACTIVATED.

* SHUTDOWN SYSTEM, SECONOARY + \#YSTEM OESCRIPTION + \#VALVE + DESIGN CRITERIA + REACTOR CONTROL. + REACTOR, HWR + REACTOR, PRESSURE TUBE + UNITEO KINGOOM

$12-27282 \quad$ ALSO IN CATEGORY 13

RANDALL JO + BATES EF + SANDEL PS + FELTZ DE

DESIGN ANO PERFORMANCE OF A LOH-COST FISSION-PRODUCT MONITOR SYSTEM

TEXAS A AND M COLLEGE

2 PAGES, FIGURE, 3 REFERENCES, ANS TRANSACTIONS 11111 PAGES 272-273 OF THE 1968 ANNUAL MEETING OF THE AMERICAN NUCLEAR SOCIETY AND THE CANADIAN NUCLEAR ASSOCIATION, TORONTO, CANADA, JUNE IO-18, I968

DESCRIBES EXPERIMENT AND FINAL DESIGN OF A FISSION-PRODUCT MONITORING SYSTEM BASEO ON PARTICLE AND GAS CDUNTING FOR DETECTING FUEL-ELEMENT FAILURES.

\#FISSION PRODUCT RELEASE, GENFRAI + \#MONITOR, RADIATION, GAS + \#REACTOR, GENERAL + CESIUM + FAILURE, FUEL ELEMENT + FISSION GAS RELEASE + KRYPTON + PARTICULATE + RUBIDIUM + XENON

$12-27283$

KUNKEL WD + POLLOCK BD + GUON J + ZWETZIG GB + SILBERBERG M + BERGER S

LMFBR FISSION PRODUCT CONTAMINATION AND CONTROL STUDIES - A STATUS REPORT

ATOMICS INTERNATIONAL

AI-AEC-12687 *. 78 PAGES, 24 FIGURES, 13 TABLES, 29 REFERENCES, JUNE 30,1968

THF STATIIS IS PRESFNTED OF STUDIES ANO EXPERIMENTS BEING CONDUCTED AT ATOMICS INTERNATIONAL TO DESCRIBE THE DISTRIBUTION OF FISSION PRODUCTS AND OTHER CONTAMINATION SOURCES RELEASED TO THE COOLANT OF THE LIQUID METAL FAST BREEDER REACTOR. EXPERIMENTAL RESULTS DERIVED FROM STUDIES OF CESIUM AND SDDIUM IODIDE VAPORIZATION FROM SODIUM SOLUTIONS AND CESIUM CDLD TRAPPING STUDIES $\triangle R E$ PRESENTED. THE FISSION PRODUCT BEHAVIOR LOOP WHICH WILL BE USED FOR A MORE COMPREHENSIVE SERIES OF INVESTIGATIONS OF FISSION PRODUCT BEHAVIOR IN SODIUM IS ALSO DE SCR I BED.

AVAILABILITY - CLEARINGHOUSE FOR FEDERAL SCIENTIFIC AND TECHNICAL INFORMATION, SPRINGFIELD, VA. 22151 , $\$ 3.00$ COPY, \$0.65 MICROFICHE

*FISSION PRODUCT RELEASE, GENERAL + \#REACTOR, FAST + \#REACTOR, LMCR + \#SODIUM + ATOMICS INTERNATIONAL + DEPOSITION + EXPERIMENT, GENERAL + FISSION PRODUCT TRANSPORT + RADIOACTIVITY RELEASE

$12-27285$

WEED RD

DECDNTAMINATION OF THE PLUTONIUM RECYCLE TEST REACTOR (PRTR) PRIMARY SYSTEM

BATELLE NORTHWEST LABORATORY, RICHLAND, WASHINGTON

BNWL-711 + 28 PAGES, 11 TABLES, REFERENCES, MARCH, 1968 
CATEGORY 12

PLANT SAFETY FEATURES

\begin{abstract}
$12-27285$ *CONTINUED*
THE PLUTONIUM RECYCLE TEST REACTOR PRIMARY SYSTEM WAS SUCCESSFULLY DECONTAMINATED IN LATE DECEMBER 1965. AN IMPROVEO DECONTAMINATION PROCESS CONSISTING OF ALKALINE PERMANGANATE FOLLOWEO BY AN INHIBITED OXALIC-CITRATE MIXTURE WAS USED. THE DECONTAMINATING SOLUTIONS EFFECTIVELY REMOVED MORE THAN 31 CI OF RADIOACTIVITY WITH AN EFFECTIVE PRIMARY SYSTEM DECONTAMINATION FACTOR OF 24. CORROSION OF CARBON STEEL AND STAINLESS STEELS DURING THE DECONTAMINATION PROCESS AND DEVELOPMENT DATA FOR THE DECONTAMINATION PROCESS ARE OISCUSSED.
\end{abstract}

AVAILABILITY - CLEARINGHOUSE FOR FEDERAL SCIENTIFIC AND TECHNICAL INFORMATION, SPRINGFIELD, VA. 22I51. $\$ 3.00$ COPY, \$0.65 MICROFICHE

\#OECONTAMINATION + \#ETR (TR) + \#PRTR (TR) + \#REACTOR, GENERAL + CORROSION + HANFORO SITE + IDAHO FALLS + REACTOR, TEST

12-27430 ALSO IN CATEGORY 18

SECTION III - ENGINEERED SAFEGUARDS

NIAGARA MOHAWK POWER CORP.

21 PAGES, 21 FIGURES, 8 REFERENCES, 18 TABLES, PAGES III-1 THROUGH III-2I OF NINE MILE POINT FSAR VOL. IV

(EXHIBIT D-2) SEPTEMBER 1967, DOCKET NO. 50-220, TYPE--BWR, MFG--G.E., AE - NIAGARA MOHAWK

DESCRIBES CONTAINMENT AND CORE SPRAY SEISMIC ANALYSIS AND STRESS REPORT, CONTAINMENT SPRAY

SYSTEM, (CONDENSATION EFFECTIVENESS, SPRAY NOZZLE TESTS), AND VENDOR TESTS AND CERTIFICATIONS.

AVAILABILITY - CLEARINGHOUSE FOR FEDERAL SCIENTIFIC AND TECHNICAL INFORMATION, SPRINGFIELD, VA. 22151 $\$ 3.00$ COPY, \$0.65 MICROFICHE

*ENG INEERED SAFETY FEATURE + CORE SPRAY + EARTHQUAKE ENGINEERING + EXAMINATION +

HEAT TRANSFER, CONDENSATION + NINE MILE POINT (8WR) + NOZZLE + REACTOR, BWR + REPORT, SAR +

STRESS ANALYSIS + TEST, COMPONENT

12-27709 ALSO IN CATEGORIES 17 AND 5

SAXTON-LOSS OF COOLANT ACCIDENT PREVENTION AND PROTECTION

SAXTON NUCLEAR EXPER IMENTAL CORPORATION

150 PAGES, FIGURES, TABLES, JUNE, 1968, DOCKET 50-146, TYPE--PWR, MFG--WEST., AE--GILBERT ASSOC.

RESPONDS TO DEC. 1966, DRL REQUEST FOR REANALYSIS WITH MODERN. TECHNIQUES. SYSTEMS WILL LIMIT CLAD MELT TO LESS THAN 3 PER CENT OF CLAD AREA FOR A DOUBLE ENDED COOLANT LINE RUPTURE. NO EVIDENCE OF REACTOR VESSEL DR STEAM GENERATOR LEAKS. SAFETY VALVE LEAKS HAVE BEEN SHOWN BY BORIC ACID CRYSTALS. \#\#PAST VISUAL AND RADIOGRAPH INSPECTIONS HAVE BEEN GODO, BUT A SPECIFIC INSPECTION PROGRAM WILL BE REPEATED EVERY 5 YEARS. MODIFICATIONS TO BE MADE INCLUDE BETTER I SOLATION BETWEEN BUILDING COMPARTMENTS, RECIRC. PUMP PRESSURE INOICATORS, RELAY RLDUNDANCE IN SAFETY INJECTION SYSTEMS, AND TO PREVENT A SINIIIF FAILURE FROM CLOSING

INJECTION ISOLATION VALVE. APPENDIX D DESCRIBES COMPUTER PROGRAMS USED IFLASH, CHICK-KIN, LOCTA-R I.

USAEC, PUBLIC DOCUMENT ROOM, $1717 \mathrm{H}$ ST., WASHINGTON, D.C. 20545 (25 CENTS/PAGE)

* ACCIDENT ANALYSIS + *ACCIDENT, LOSS OF COOLANT + CORE REFLODDING SYSTEM + EXAMINATION + LEAK + MODIFICATION, SYSTEM OR EQUIPMENT + PIPING + PLANT PROTEC.TIVE SYSTEM + PRESSURE RELIEF + PRESSURE VESSEL + REACTOR, PWR + SAXTON (PWR) + SURVEILLANCE PROGRAM + TEST, NONDESTRUCTIVE

12-27875 ALSO IN CATEGORY 13

CLARKE JH + CUMBERLANO RF + SMYTH MJ

ATOMIC ENERGY RESEARCH ESTABLISHMENT, HARWELL, BERKSHIRE

AERE-R-5724 +. 17 PAGES, 3 FIGURES, 10 TABLES, 3 REFERENCES, APRIL 1968

ĠIVES AN ACCOUNT OF LABORATORY AND PILOT PLANT INVESTIGATIONS INTO THF USE DF D FERRIC HYDROXIDE PRECIPITATION METHOD FOR THE TREATMENT OF LOW LEVEL ACTIVE EFFLUENT AT HARWELL. DETAILS ARE ALSO GIVEN OF THE RESULTS OBTAINED ON THE MAIN TREATMENT PLANT OVER SEVERAL MONTHS OF OPERATION.

AVAILABILITY - CLEARINGHOUSE FOR FEOERAL SCIENTIFIC ANO TECHNICAL INFORMATION, SPRINGFIELO, VA. 22151 $\$ 3.00$ COPY, \$0.65 MICROF ICHE

*FUEL REPROCESSING + *REACTOR, GENERAL + HARWELL + IRON + PRECIPITATION + TESTING + WASTE TREATMENT, GENERAL

12-2787.7 ALSO IN CATEGORIES 13 AND 3

FINNEY BC + LOWRIE RS + WATSON CD

A CONCEPTUAL DESIGN AND A COST ESTIMATE OF AN ON-SITE FACILITY FOR CLEANING, DISASSEMBLING, AND CANNING SHORT-COOLED LMFBR FUEL IN PREPARATION FOR SHIPMENT TO A CENTRAL REPROCESSING PLANT

OAK RIOGE NATIONAL LABORATORY, OAK RIDGE, TENNESSEE

ORNL-TM-2050 +. 29 PAGES, 3 FI IURES, 4 TABLES, 9 REFERENCES, MAY 1968

THIS REPORT PRESENTS A CONCEPTUAL DESIGN ANO A PRELIMINARY COST ESTIMATE FOR A FUEL

PRESHIPMENT PREPARATION FACILITY THAT WOULD BE LOCATED AT A IOOO-MW IELECTRICALI

SOOIUM-COOLED FAST-BREEDER-REACTOR STATION. THIS FACILITY WOULO PROVIDE MEANS FOR CLEANING, 
CATEGORY 12

PLANT SAFETY FEATURES

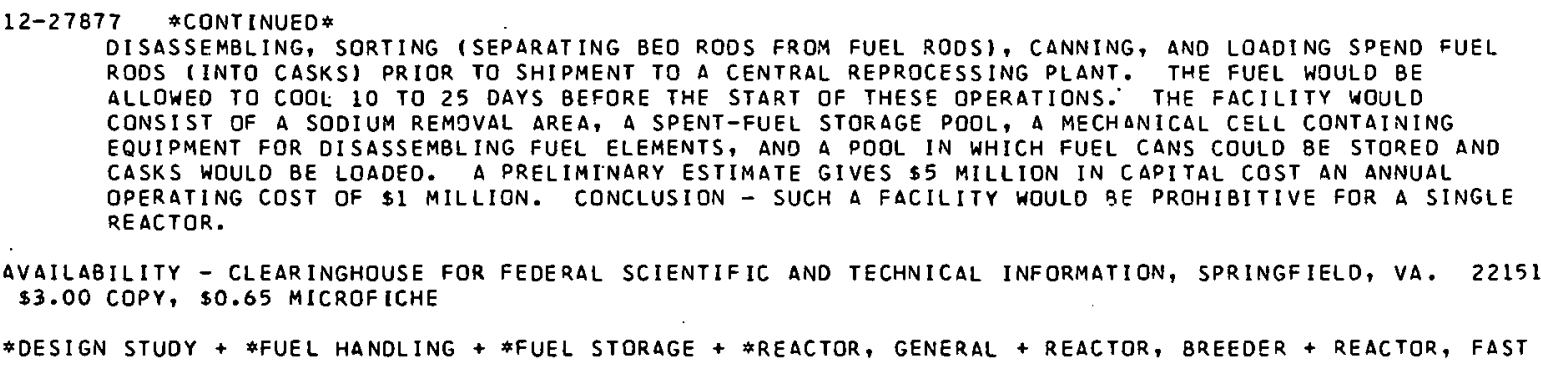

AVAILABILITY - CLEARINGHOUSE FOR FEDERAL SCIENTIFIC AND TECHNICAL INFORMATION, SPRINGFIELD, VA. 2215 I $\$ 3.00$ COPY, $\$ 0.65$ MICROFICHE

\#DESIGN STUDY + \#FUEL HANDLING + \#FUEL STORAGE + \#REACTOR, GENERAL + REACTOR, BREEDER + REACTOR, FAST

12-27980 ALSO IN CATEGORY 13

BURTON JH + PECKINPAUGH CL

CONCEPTUAL DESIGN FOR FAST FLUX TEST FACILITY MAINTENANCE AND DECOMTAMINATION CELL

ATOMICS INTERNATIONAL, CANOGA PARK, CALIF.

NAA-SR-MEMO-12367 +. 116 PAGES, FIGURES, REFERENCES, JULY 27, 1967

FACILITY CONSISTS OF FOUR IN-LINE CELLS - TRANSFER, INSPECTION-CLEANING, REMOTE MAINTENANCE, AND CONTACT MAINTENANCE. ACCESS TO EACH IS PROVIOED TO REACTOR OPERATING FLOOR DIRECTLY ABOVE. TRANSFER BET WEEN CELLS IS PROVIDED. DETAILED SYSTEM DESCRIPTION, PRINCIPLES OF OPERATION, SAFETY PRECAUTIONS, MAINTENANCE, AND DRAWINGS ARE INCLUDED IN THE MEMO.

AVAILABILITY - CLEARINGHOUSE FOR FEOERAL SCIENTIFIC AND TECHNICAL INFORMATION, SPRINGFIELO, VA. 22151 , $\$ 3.00$ COPY, \$0.65 MICROFICHE

*HOT CELL + \#REACTOR, GENERAL + DESIGN STUDY + IRRADIATION FACILITY + MAINTENANCE AND REPAIR + REACTOR, FAST

$12-27981$

ALSO IN CATEGORY 13

ARNE SON SO

IRRADIATION TESTING FACILITIES - NEEDS, LIMITATIONS, ANO AVAILABILITY

BATTELLE-NORTHWEST, RICHLAND, WASHINGTON

BNWL-SA-1754 + CONF-680419-1 +. 4 PAGES, FROM AMERICAN NUCLEAR SOCIETY NATICNAL TOPICAL MEETING,

CINCINNATI, OHIO, APRIL 1,1968

THE NEEDS FOR FAST-REACTOR IRRADIATION-TESTING FACILITIES ARE REVIEWED, AND THE AVAILABILITY OF TESTING REACTORS TO MEET THE NEEDS ARE DISCUSSED. LIMITATIONS OF AVAILABLE FACILITIES ARE IDENTIFIED AND SPACE REQUIREMENTS ARE COMPARED WITH AVAILABILITY. THE NEED FOR CONTINUED AND IMPROVED AVAILABILITY OF EBR-II FOR NEAR-TERM FAST-REACTOR FUELS ANO MATERIALS TESTING IS EMPHASIZED, AND ALTERNATE TESTING FACILITIES SUCH AS FERMI ARE BRIEFLY REVIEWED. THE OVERALL TESTING CAPABILITIES OF THE FAST FLUX TEST FACILITY ARE OISCUSSED.

AVAILABILITY - CLEARINGHOUSE FOR FEDERAL SCIENTIFIC AND TECHNICAL INFORMATION, SPRINGFIELO VA. 22151, $\$ 3.00$ COPY, \$0.65 MICROFICHE

*HOT CELL + *REACTOR, GENERAL + IRRADIATION FACILITY + REACTOR, FAST + TESTING

12-28033 ALSO IN CATEGORY 17

PARTIAL INOPERABILITY OF SAFETY INJECTION SYSTEM

SOUTHERN CALIFORNIA EOISON COMPANY

3 PAGFS. IFTTFR TI P,A. MORRIS, DRL, SEPTEMBER 6, 1968, DOCKET 50-206, TYPE--PWR, MFG--WEST., AE--BECHTEL

ON AUG. 27, 1968, CALIBRATION SHOWED BOILER FEEO PUMP SPEED SWITCHES WERE MADE UP AT 2800 AND 3800 RPM RESPECT IVELY, INSTEAD OF 3200 . SPEED SWITCHES ENSURE UNBORATED WATER FLUSHED OUT BEFORE SAFETY INJECTION BEGINS. A $23 \mathrm{CU}$. FT. DILUTION WAS ANALYZED IN THE FSAR, 10 WOULD HAVE BEEN ADDED HERE. *\#SAFETY INJECTION FLOW COMPARATOR DID NOT CLOSE ONE INJECTION VALVE $850 \mathrm{C}$ ON A HIGH FLOW RATE TEST. A BLOCKING DIODE WAS INSTALLED IN THE COMMON GROUND LEG OF THE AUCTIONEERING RELAYS, AND ALL TIIREE VALVES WORKED PROPERLY. \#\$EACH CONDITION HAD BEEN ANALYZED IN FSAR. NEITHER WOULD HAVE PREVENTED SAFETY INJECTION SYSTEM FROM WORKING.

USAEC, PUBLIC DOCUMENT ROOM, 1717 H ST., WASHINGTON, D.C. 20545 (25 CENTS/PAGE)

* CORE REFLOODING SYSTEM + \#FAILURE, COMPONENT + \#SHUTDOWN SYSTEM, SECONDARY + INSTRUMENTATION CALIBRATION + INSTRUMENTATION, FLOW + PUMP + REACTOR, PHR + SAN ONOFRE (PHR) + SET POINT

12-28067 ALSO IN CATEGORIES 11 AND 9

PEDERSEN HN + SPANNER JC

DETECTION, LOCATION, AND CHARACTERIZATION OF FLAW GROWTH IN METALS USING ACOUSTIC EMISSION METHOOS BATELLE-NORTHWEST

CONF-671011 +. 2 PAGES, 4 REFERENCES, OCTOBER 1966

BATTELLE-NORTHWEST IN FEBRUARY OF 1966 BEGAN A PROGRAM TO NONDESTRUCTIVELY DETECT INCIPIENT FAILURE OF REACTOR PRESSURE PIPING, USING THE ACOUSTIC EMISSION GENERATED BY FRACTURE, CLEAVAGE, DISLOCATION UNPINNING, TWINNING, ETC., OF SINGLE OR MULTIPLE GRAINS OF THE PIPING 
CATEGORY 12

PLANT SAFETY FEATURES

\section{2-28067 *CONTINUEO*}

MATERIAL. THE PURPOSE OF THE PROGRAM IS - (1) THE DETECTION OF ACOUSTIC EMISSION AGAINST THE NOISE BACKGROUND OF THE OPERATING REACTOR, (2) THE LOCATION OF THE POINT OF ORIGIN OF THE ACOUSTIC EMISSION, (3) THE CHARACTERIZATION OF THE ACOUSTIC EMISSION BY THE TYPE OF FAILURE OR FLAW-GROWTH MECHANISM IN THE METAL, AND (4) PREDICTION OF THE TIME OF FAILURE.

AVAILABILITY - CLEARINGHOUSE FOR FEDERAL SCIENTIFIC ANO TECHNICAL INFORMATION, SPRINGFIELD, VA. 22151 $\$ 3.00$ COPY, \$0.65 MICROFICHE

ANALYTICAL TECHNIQUE, CALIBRATION + FLAW + INSTRUMENTATION, SURVEILLANCE + INTEGRITY + METAL + PIPING + TEST, NONDESTRUCTIVE

12-28068 ALSO IN CATEGORIES 11 AND 9

HUTTON P

ACOUSTIC EMISSION IN METALS AS A NDT TOOL

BATTELLE MEMORIAL INSTITUTE, PACIFIC NORTHWEST LABORATORY, RICHLAND, WASHINGTON

BNWL-SA-1262+CONF-671002-4 + 8 PAGES, 3 REFERENCES, FOR PRESENTATION AT THE $27 T H$ NATIONAL CONFERENCE OF THE SOCIETY FOR NONOESTRUCTIVE TESTING AT CLEVELAND, OHIO, OCTOBER 18, 1967, SEPTEMBER 1967

SOME OF THE MORE EVIDENT APPLICATIONS OF ACOUSTIC EMISSIDN, IN ADDITION TO MONITORING FLAH GROWTH IN REACTOR PRESSURE SYSTEMS, ARE - 11 REMOTE ANO CONTINUDUS SURVEILLANCE OF OPERATIONAL SYSTEMS SUCH AS NATURAL-GAS PIPE LINES AND AIRCRAFT STRUCTURES TO DETECT FORMATION AND/OR GROWTH OF FLAWS, 121 MONITORING WELDS, PARTICULARLY IN HEAVY SECTIONS, AS THEY COOL TO OETECT INTERNAL CRACKING, (3) USE AS A STUDY TOOL FOR FRACTURE MECHANICS

RESEARCH IN BOTH METALLICS AND NONMETALLICS, 141 MONITORING SPACE VEHICLES FOR MICROMETEORITE PENETRATION.

AVAILABILITY - CLEARINGHOUSE FOR FEDERAL SCIENTIFIC ANO TECHNICAL INFORMATION, SPRINGFIELD, VA. 22151 \$3.00 COPY, \$0.65 MICROFICHE

ANALYTICAL TECHNIQUE, CALIBRATION + FLAN + INSTRUMENTATION, SURVEILLANCE + INTEGRITY + METAL + PIPING + PRESSURE VESSEL + TEST, NONDESTRUCTIVE

$12-28169 \quad$ ALSO IN CATEGORY 17

BAWTR REACTOR HEADER FAILS TO DROP ON LOSS OF FLOW

BABCOCK + WILCOX CO., LYNCHBURG, VA.

1 PAGE, ATOMIC ENERGY CLEARING HOUSE 14(39), 'PAGE 19, (SEPT. 23, 1968), DOCKET NO. 50-200

(LETTER, SEPT. 9) FAILURE CAUSED BY 3 HEADER GUIDE ROOS BROKEN, WHICH PREVENTEO THEIR ALIGNING THE HEADER AND CAUSED IT TO BIND. THESE BROKE DUE TO REPEATED LOADINGS. WE WILL SHUT DOWN UNTIL TECH.-SPEC. APPROVAL OF OPERATION WITH HEADER LOCKED UP. (HEADER IS APPARENTLY FLAPPER VALVE OPENING ON LOW FLOW).

ACCIDENT, LOSS OF FLOW + ENGINEERED SAFETY FEATURE + FAILURE, EQUIPMENT + REACTOR, POOL TYPE + REACTOR, TEST + TECHNICAL SPECIFICATIONS 
CATEGORY 13

RADIOCHEMICAL PLANT SAFETY

$13-24634$
INDUSTRIAL RADIOACTIVE IN CATEGORIES 17 ANO 14

ROCHESTER COMMITTEE FOR SCIENTIFIC INFORMATION

6 PAGES, ATOMIC ENERGY CLEARING HOUSE 14(16), PAGES 5-10 (APRIL 15, 1968 )

(NO. 3, FEB. 28,1968$)$ - CORRECTS ERRONEOUS DATA IN PREVIOUS DATA EULLETIN. ON DEC. 16,

1967, THE CS-137/SR-90 CONCENTRATION (PCI/1) AT NFS OUTFALL WAS 16C,0O0/86,900, AT BUTTERMILK CREEK, 6,600/4,010. RCSI QUESTIONS OFFICIAL VIEW THAT MEASUREMENTS COMPLY WITH LAW BECAUSE CATTARANGUS CREEK MEETS INDUSTRIAL EFFLUENT RADIOACTIVITY STANOAROS. \#*\#1NO. 2, FEB. 24, 19681 - DISCUSSES EFFLUENT MEASUREMENT REPORTEO OVER A PERIOD OF YEARS. ASSERTS THAT NFS SENOS SLUGS OF VERY HOT EFFLUENT INTO CREEK, AS ACTUAL MEASUREMENTS INDICATE OISCHARGE. $\triangle T$ SEWER OUTLET WAS 30,000 TIMES PERMISSIBLE LIMIT. ASSERTS OFFICIAL SAMPLING IS NOT OONE AT THE PLACE WHERE LIMITS EXCEEDED.

*RADIATION, PUBLIC EDUCATION/ACCEPTANCE + *WASTE OISPOSAL, LIOUID + DILUTION + EFFLUENT +

FUEL REPROCESSING + MAXIMUM PERMISSIBLE CONCENTRATION (MPC) + NFS

ALSO IN CATEGORY 11
DELESTRE L + LEFORT G + PILLERAULT J

IMPROVEMENTS IN OR RELATING TO SEALABLE PORTS

COMMISSARIAT A L ENERGIE ATOMIQUE, FRANCE

BRITISH PAIENT $1,065,319+3$ PAGES, FIGURE, APRIL 12,1967

A SEALABLE PORT WHICH IS USED IN A GLOVE BOX IS OESCRIBED. THE PORT CONSISTS OF A NUMBER OF BOLTS OR RODS REGULARLY SPACED AROUND THE PERIMETER OF THE PORT MOVING PARALLEL TO THE PORT, ANO ACTUATED BY A SINGLE CONTROL MECHANISM. THE BOLTS ARE SPRING-LOADED FOR INSERTION INTO NOTCHES PROVIDED FOR THEM ON AN INCLINED FIXED FRAME. THE BOLTS HAVE CASTERS WHICH ROLL ON THE INCLINED PLANE WHEN THEY ARE ENGAGED CAUSING THE DISPLACEMENT OF THE PORT PERDENDICULAR TO. ITS PLANE, TIGHTENING UP A SEALED JOINT LOCATED BEJWEEN THE PORT AND THE FRAME.

AVAILABILITY - THE PATENT OFFICE, 25 SOUTHAMPTON BUILDING, LONOON, W.C. 2, ENGLANO (49 CENTS/COPY)

* FLANGE + *GLOVE BOX + SEAL

13-26737 ALSO IN CATEGORY 17

CONSTRUCTION OF RADIOCHEMISTRY LABORATORY IN REACTOR LABORATORY

UNIVERSITY OF TEXAS

5 PAGES, 3 FIGURES, LETTER TO E. R. PRICE, OSLR. FROM A LETTER TO EBER R. PRICE FROM S. J. GAGE. JUNE

11,1968 . DOCKET 50-192.

(RE SPONSE TO LETTER OF MAY 17, 1968). ROOM WILL BE USEO FOR RADIOCHEMICAL SEPARATIONS IN TRACE ANALYSIS WITH NEUTRON-ACTIVATION TECHNIQUES. ROOM WILL CONTAIN TERMINUS OF THE PNEUMATIC (RABBIT) TRANSFER SYSTEM, A FUME HOOO, A GLOVE BOX, AND STORAGE. OUTSIDE $\triangle I R$ IS DRAWN DIRECTLY INTO ROOM AND EXHAUSTED FROM GLOVE BOX ANO FUME HOOD TO A $30-F T$ STACK. GLOVE-BOX DUCT HAS A FILTER.

AVAILABILITY -- PUBLIC DOCUMENT ROOM, WASHINGTON, D.C.

GLOVE BOX + IRRAOIATION FACILITY + RAOITISOTOPE + REACTOR, RESEARCH + VENTILATION SYSTEM

$13-27017$

SMITH SR

SUPPRESSION OF RADIOIODINE RELEASES FROM A RAOIOCHEMICAL SEPARATIONS PLANT

SAVANNAH RIVER LABORATORY, E. I. OU PONT DE NEMOURS + CO., AIKEN, SOUTH CAROLINA

4 PAGES, I FIOURE, 2 TAOLES, 7 REFERENCGS, NUCLENR, APDIITATINNS, 5(1), PAGES 20-23 (JULY, 1968)

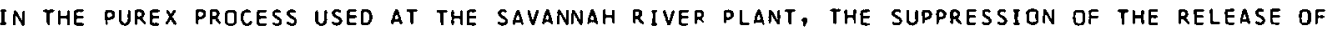
RADIOIODINE BY COMPLEXING IT WITH MERCURY WAS TESTED. SUPPRESSING RADIOIOOINE RELEASE WOULD $B E$ DESIRABLE IF. SHORT-COOLED FUEL WERE INADVERTENTLY CHARGED TO THE DISSOLVER IN THE PLANT. THIS RELEASE IS SUPPRESSED BY ADDING MERCURIC NITRATE TO THE DISSOLVER SOLUTION. WITH O.O4M HGINO3) 2 IN THE DISSOLVER SOLUTION AND A GELATIN CLARIFIER, THE RADIOIODINE ATMOSPHERIC RELEASE WAS REDUCED 55-FOLO.

\# ISSOLUTION + \#UEL REPROCESSING + \#IODINE + MANGANESE + MERCURY + OPERATING EXPERIENCE + SAVANNAH RIVER PLANT + SOLVENT EXTRACTION PROCESS

$13-27018$

I MMERMAN CA + IIOFFMAN TL

CORROSION EVALUATION OF EQUIPMENT USEO FOR REPROCFSSING ZIRCONIUM ALLOY NUCLEAR FUELS

I DAHD NUCLEAR CORPORATION, NATIONAL REACTOR TESTING STATION, IDAHO FALLS, IOAHO

IN-1134 +, 10 PAGES, FIGURE, 4 TA8LES, 8 REFERENCES, FEBRUARY, 1968

CORROSION RATES FOR MONEL -400 AND VARIOUS STAINLESS STEELS IN PROCESS SOLUTIONS WERE DETERMINED IN LABORATORY STUOIES AND PLANT SERVICE. THE PLANT SERVICE PERIOD INCLUDED THE 
CATEGORY 13

RADIOCHEMICAL PLANT SAFETY

$13-27018$ *CONTINUED*

FIRST REPROCESSING OF 2IRCONIUM ALLOY NUCLEAR FUELS USING BORIC $\triangle C I D$ AS A SOLUBLE POISON DURING DISSOLUTION. CORROSION RATES FOR A MONEL-4OO DISSOLVER USING HYOROFLUROIC-FLUOBORIC ACIO DISSOLVENT ANO SULFURIC AND CHROMIC ACIDS FOR CLEANOUT RANGED BETWEEN TWO AND EIGHT MILS PER MONTH. CORROSION RATES FOR STAINLESS STEEL PLATES CONTAINING 8ORON AS A FIXED POISON IN PER MONTH. CORROSION RATES FOR STAINLESS STEEL PLATES CONTAINING $8 O R O N$ AS A FIXED POISON IN
THE FIRST CYCLE PRODUCT EVAPORATOR WERE VERY LOW. THE LOW CORROSION RATES FOR THIS AND OTHER PROCESS EQUIPMENT INDICATE THAT THE SYSTEM CAN BE USED FOR FUTURE AND REPROCESSING OPERATIONS.

AVAILABILITY - CLEARINGHOUSE FOR FEDERAL SCIENTIFIC AND TECHNICAL INFORMATION, SPRINGFIELD, VA. 22151 $\$ 3.00$ COPY, \$0.65 MICROFICHE

*CORROSION + \#FUEL REPROCESSING + \#OPERATING EXPERIENCE + \#TESTING + OISSOLUTION + EQUIPMENT, GENERAL + FLUORIDE + ICRP + METAL + ZIRCONIUM

13-27282 ALSO IN CATEGORY 12

RANOALL JD+ BATES EF + SANDEL PS + FELTZ DE

DESIGN AND PERFORMANCE OF A LOW-COST FISSION-PRODUCT MONITOR SYSTEM

TEXAS A AND M COLLEGE

2 PAGES, FIGURE, 3 REFERENCES, ANS TRANSACTIONS $11(1)$ PAGES, 272-273 OF THE 1968 ANNUAL MEETING OF THE AMERICAN NUCLEAR SOCIETY AND THE CANADIAN NUCLEAR ASSOCIATION, TORONTO, CANADA, JUNE 10-18, 1968

DESCRIBES EXPERIMENT ANO FINAL DESIGN OF A FISSION-PRODUCT MONITORING SYSTEM BASED ON PARTICLE ANO GAS COUNTING FOR DETECTING FUEL-ELEMENT FAILURES.

\#FISSION PRODUCT RELEASE, GENERAL + \#MONITOR, RADIAT.ION, GAS + \#REACTOR, GENERAL + CESIUM +

FAILURE, FUEL ELEMENT + FISSION GAS RELEASE + KRYPTON + PARTICULATE + RUBIDIUM + XENON

13-27284 ALSO IN CATEGORY 7

ADOISON RA + POTTER JE + SMITH SE + WHITE PAF

INSTALLATION OF HIGH-EFFICIENCY FILTERS

UKAEA, ATOMIC WEAPONS RESEARCH ESTABLISHMENT, ALDERMASTON, ENGLAND

AWRE-0-81/65 +. 19 PAGES, 6 FIGURES, OCTOBER, 1965

SUMMARIZES THE PRINCIPLES EVOLVED OVER SEVERAL YEARS AT AWRE FOR THE INSTALLATION OF HIGH EFFICIENCY AIR FILTERS IN RADIDACTIVE AND TOXIC PROCESS BUILDINGS PARTICULARLY WITH RESPECT TO THE SAFETY ASPECTS OF THE INSTALLATION. IT IS BASED ON A MORE DETAILED REPORT, AWRE

REPORT NO. 0-24/65, WHICH CONTAINS DETAILS OF EXPERIMENTAL WORK ETC. CARRIED OUT.

AVAILABILITY - CLEARINGHOUSE FOR FEDERAL SCIENTIFIC AND TECHNICAL INFORMATION, SPRINGFIELD, VA. 22151 , $\$ 3.00$ COPY, \$0.65 MICROFICHE

\#FABR ICATION + *FILTER + \#FILTER INSTALLATION + \#FUEL CONVERSION + \#FUEL ELEMENT + \#FUEL REPROCESSING + \#ORE CONVERSION + \#RAOIOISOTOPE + *REACTOR, GENERAL + TESTING

13-27288 ALSO IN CATEGORY 17

FIRE AND EXPLOSIION SENSITIVITY OF METAL - HAI RGENOTFO STIVENT SYSTEMS

UNI ṪÉ STATES AIOMIC ENERGY COMMISSION, WASHINGTON, D.C.

5 PAGES, I TABLE, 9 REFERENCES, HEALTH AND SAFETY INFORMATION, USAEC, ISSUE NO. 263, MAY 6, 1968

FIRE HAZARDS OF METALS, PARTICULARLY IN FINELY OIVIDED FORM, ARE STRONGLY INFLUENCED BY WIDE NUMBER OF VARI ABLES. HALOGENATED-SOLVENT REACTIVITY CONSIDERABLY MODIFIED BY TEMPERATURE, MOISTURE, CONTAMINANTS, ACIOITY, STABILIZERS, ETC. GIVES RESULTS OF 60 IMPACT TESTS ON TEN DIFFERENT KINDS OF METALLIC POWDERS OR GRANULES (AL, MG, TI, BA, LI, BE, B) AND SIX SOLVENTS (FREONS, CCL4, TRI - AND PERCHLOROETHYLENE, TRICHLOROETHANEI. REFERENCES TO OTHER HA?ARDDUS SYSTEMS INCLUDEO.

USAEC, DIVISION DF OPERATIONAL SAFETY, WASHINGTON, D.C. 20545

\#FABRICATION + \#FUEL CONVERSION + \#FUEL ELEMENT + \#SAFETY PRINCIPLES ANO PHILOSOPHY + CHEMICAL REACTION + DECONTAMINATION + EXPLOSION + FIRE + HALOGEN + INDUSTRIAL SAFETY + METAL + TEST, BENCH

$13-27597$

HARDTKE FC

ALSO IN CATEGORY

TWO METHOOS FOR EVALUATING THE SUSCEPT.IBILITY OF IRRADIATED GLASS TO FRACTURE BY ELECTRICAL DISCHARGE UNIVERSITY OF MO., ROLLA, ROLLA, MISSOURI

1 PAGE, 3 REFERENCES, ANS TRANSACTIONS $11(1)$, PAGE 360,1968 ANNUAL MEETING OF THE AMERICAN NUCLEAR SOCIETY AND CANADIAN NUCLEAR ASSOCIATION, TORONTO, CANADA, JUNE 10-13, 1968

USING 200- TO 300-KW ELECTRONS, TWO METHODS HAVE BEEN DEVELOPED FOR TESTING SHIELDING GLASS FORMULATIONS FOR THEIR SUSCEPTIBILITY TO DISCHARGE AND FRACTURE UPON RADIATION EXPOSURE. THESE TESTS ARE INTENDED TO SUPERSEDE THOSE THAT HAVE FEATURED LARGE SAMPLES EXPOSED TO INTENSE GAMMA SOURCES AS WELL AS THOSE THAT MEASURE DIRECTLY THE INTRINSIC RESISTIVITY ANO DIELECTRIC CONSTANT OF THE GLASS.

*GLASS + \#RADIOISOTOPE + \#SHIELOING + ELECTRICAL CONOUCTION + FAILURE, COMPONENT + IRRADIATION TESTING + RADIATION EFFECT + TEST, COMPONENT 
CATEGORY 13

RADIOCHEMICAL PLANT SAFETY

13-27875 AL'SO IN CATEGORY 12

CLARKE JH + CUMBERLAND RF + SMYTH MJ

THE TREATMENT OF LOW LEVEL RADIOACTIVE EFFLUENT BY A FERRIC HYDROXIDE PRECIPITATION

ATOMIC ENERGY RESEARCH ESTABLISHMENT, HARWELL, BERKSHIRE

AERE-R-5724 t. 17 PAGES, 3 FIGURES, 10 TABLES, 3 REFERENCES, APRIL 1968

GIVES AN ACCOUNT OF LABORATORY AND PILOT PLANT INVESTIGATIONS INTO THE USE DF A FERRIC HYDROXIDE PRECIPITATION METHOD FOR THE TREATMENT OF LOW LEVEL ACTIVE EFFLUENT AT HARWELL. DETAILS ARE ALSO GIVEN OF THE RESULTS OBTAINED ON THE MAIN TREATMENT PLANT OVER SEVERAL MONTHS OF OPERATION.

AVAILABILITY - CLEARINGHOUSE FOR FEDERAL SCIENTIFIC AND TECHNICAL INFORMATION, SPRINGFIELD, VA. 22151 $\$ 3.00$ COPY, \$0.65 MICROFICHE

*FUEL REPROCESSING + *REACTOR, GENERAL + HARHELL + IRON + PRECIPITATION + TESTING + WASTE TREATMENT, GENERAL

\section{$13-27876$}

KOYANAKA $Y$

STURIES ON SEPARATION OF FISSION PRODUCT BY FLOTATION METHOD

JAPAN ATOMIC ENERGY INSTITUTE

NSJ-TR-90 +. 11 PAGES, DECEMBER 1967

FLOTATION HAS PROVED EFFECTIVE IN REMOVING CS-137 FROM ITS AOUEOUS DILUTE SOLUTION, WITH THE AID OF SUITABLE COPRECIPITANT SUCH AS CUPRIC OR NICKEL GERROCYANIDE AND PERTINENT COLLECTOR SUCH AS SODIUM OLEATE AND OCTAOECYLAMINE ACETATE. IT HAS BEEN FOUND IN THE EXPERIMENTS ON SINGLE STAGE FLOTATION THAT 90-99\% OF CS-137 CAN BE REMOVEO BY OPTIMUM CHOICE OF THE CONCENTRATIONS OF COPRECIPITANT ANO COLLECTOR, AS WELL AS OF PH OF FLOTATION MEDIUM. MULTIPLE FLOTATION FOR FOUR SUCCESSIVE STAGES GAVE DECONTAMINATION FACTOR OF $10,-0 \cap O$ TO 1 MILLION, WITH A VOLUME REDUCTION RATIO OF HIGHER THAN 50 .

AVAILABILITY - CLEARINGHOUSE FOR FEDERAL SCIENTIFIC AND TECHNICAL INFORMATION, SPRINGFIELD, VA. 22151 $\$ 3.00$ COPY, \$0.65 MICROFICHE

*FUEL REPROCESSING + \#RADIOISOTOPE + \#HASTE TREATMENT, LIQUID + CESIUM + EXPERIMENT, GENERAL

13-27877 ALSO IN CATEGORIES 12 AND 3

FINNEY BC + LOWRIE RS + WATSON CD

A CONCEPTUAL DESIGN AND A COST ESTIMATE OF AN ON-SITE FACILITY. FOR CLEANING, DISASSEMBLING, AND CANNING SHORT-COOLED LMFBR FUEL IN PREPARATION FOR SHIPMENT TO A CEVTRAL REPROCESSING PLANT

OAK RIDGE NATIONAL LABORATORY, OAK RIDGE, TENNESSEE

ORNL-TM-2050+. 29 PAGES, 3 FIGURES, 4 TABLES, 9 REFERENCES, MAY 1968

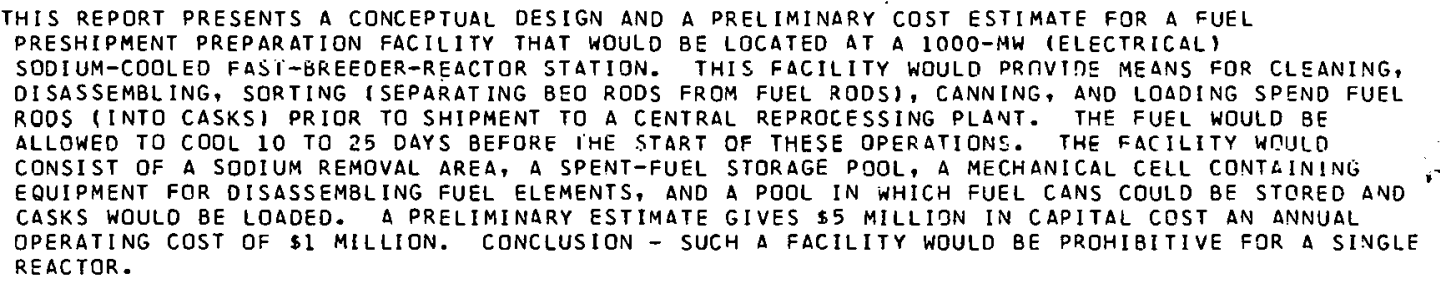

AVAILABILITY - CLEARINGHOUSE FOR FEDERAL SCIENTIFIC AND TECHNICAL INFORMATION, SPRINGFIELD, VA. 22151 $\$ 3.00$ COPY, SU. OS MILIKOPICHE

\#DESIGN STUDY + \#FUEL HANDL ING + \#FUEL STORAGE + \#REACTOR, GENERAL + REACTOR, BREEDER + P.EACTOR, FAST

13-27878

PASHLEY JH + SCHAPPEL RB

ORGDP FUEL REPROCESSING STUDIES - SUMMARY PROGRESS REPORT JANUARY THROUGH JUNE 1967

DAK RIDGE GASEOUS DIFFUSION PLANT, OAK RIOGE, TENNESSEE

$K-1738+.101$ PAGES, 12 FIGURES, 28 TABLES, MAY 9,1968

THE OAK RIDGE GASEOUS OIFFUSION PLANT GASEOUS DIFFUSION DEVELOPMENT DIVISION IS PARTICIDATINR IN STUDIES OF A GROUP OF PROCESSES AIMED AT PURIFYING LND RECOVERING VALUABLE URANIUM AND PLUTONIUM FROM SPENT NIJCLEAR REACTOR FUELS. THE PROGRAM INCLUDES TWO MAIN PHASES - (AI) PREPARAIIUN OF CONCEPTUAL PLANT STUDIES WITH CONCOMITANT OFFINITION OF DRORLEM AREAS ASSUCIATED WITH THE PROCESS AND TECHNOLOGY ANO PLANT DESIGN, AND ( 3 ) COMPONENT DEVELOPMENT, INCLUDING SCALE-UP AND TESTING OF CRUCIAL PROCESS EOUIPMENT ANO AUXILIARIES. THE CURRENT REPDRT IS THE FIFTH IN A SERIES OF PROGRESS REPORTS TO BE ISSUED SEMIANNUALLY.

AVAILABILITY - CLEARINGHDUSE FOR FEDERAL SCIENTIFIC AND TECHNICAL INFORMATION, SPRINGFIELO, VA. 221 IS $\$ 3.00$ COPY, \$0.65 MICROFICHE 
$13-27878$ *CONTINUED*

\#DESIGN STUDY + \#FUEL REPROCESSING + BROMINE + EQUIPMENT, GENERAL + EXPERIMENT, GENERAL + FLUORIDE + TESTING + URANIUM DIOXIDE + VOLATILITY PROCESS

$13-27978$

SCHUL 2 WW

EFFECTS OF SOME SYNERGISTIC AND ANTAGONISTIC AGENTS ON HDEHP EXTRACTION OF STRONTIUM

BATTELLE NORTHWEST LABORATORY

BNWL-759 +. 27 PAGES, 3 FIGURES, 8 TABLES, 40 REFERENCES, JULY 1968

HDEHP, DILUTED WITH TBP AND KEROSENE, IS USED AS THE EXTRACTANT IN THE HANFORD B-PLANT TO

EXTRACT SR-9O FROM VARIOUS RADIOACTIVE WASTE SOLUTIONS. PROCESS-CHEMISTRY-ORIENTED STUDIES WERE PERFORMED TO DETERMINE THE EFFECTS OF VARIOUS KNOWN AND POSSIBLE EXTRACTANT COMPONENTS ON EXTRACTION OF STRONTIUM BY THE B-PLANT SOLVENT. SMALL CONCENTRATIONS OF TBP AND OF THE MORE POWERFUL SYNERGIST DBBP (DIBUTYLBUTYL PHOSPHONATE) ENHANCE EXTRACTION OF STRONTIUM (SYNERGISTIC EFFECT). CONVERSELY, SMALL CONCENTRATIONS OF EITHER H-SUB 2MEHP

(MONO(2-ETHYLHEXYL) PHOSPHORIC ACID) OR 2-ETHYLHEXANOL DEPRESS STRONTIUM DISTRIBUTION

COEFFICIENTS (ANTAGONISTIC EFFECT). CONSEQUENCES OF THESE OBSERVATIONS TO PLANT OPERATION ARE DISCUSSED.

AVAILABILITY - CLEARINGHOUSE FOR FEDERAL SCIENTIFIC AND TECHNICAL INFORMATION, SPRINGFIELO, VA. 22151 , $\$ 3.00$ CPY, \$0.65 MICROFICHE

*FuEl REPROCESSING + *WASTE TREATMENT, LIQUID + EXPERIMENT, general + hanfDRD SITE + SOLVENT EXTRACTION PROCESS + STRONTIUM + TESTING

$13-27979$

TRAUTH CA

A SYSTEMS APPROACH TO CONTAMINATION CONTROL

SANDIA CORPORATION

SC-M-68-235 +. 35 PAGES, REFERENCES, APRIL 1968

THOUGH NOT OIRECTLY APPLICABLE TO RADIOACTIVE CONTAMINATION, THE PARALLEL APPROACH BY OTHERS INVOLVED IN CONTAMINATION CONTROL COULO INVOKE BETTER METHODS OF CONTROL IN THE NUCLEAR INOUSTRY.

AVAILABILITY - C. A. TRAUTH, JR., SANDIAN CORPORATION, aLBUQUERQUE, NEW MEXICO

*CONTROL, GENERAL + \#FUEL CONVERSION + \#FUEL REPROCESSING + \#RADIOISOTOPE + \#SURFACE CONTAMINATION + HOT CELL + THEORETICAL INVESTIGATION

I3-27980

BURTON JH + PECKINPAUGH CL

CONCEPTUAL DESIGN FOR FAST FLUX TEST FACILITY MAINTENANCE AND DECOMTAMINATION CELL

ATOMICS INTERNATIONAL, CANOGA PARK, CALIF.

NAA-SR-MEMO-12367 +. 116 PAGES, FIGURES, REFFRFNF.FS., IIII Y 27, 10G?

FACILITY CONSISTS OF FOUR IN-LINE CELLS - TRANSFER, INSPECTION-CLEANING, REMOTE MAINTENANCE, AND CONTACT MAINTENANCE. ACCESS TO EACH IS PROVIDED TO REACTOR OPERATING FLOOR DIRECTLY ABOVE. TRANSFER BETWEEN CELLS IS PROVIDED. DETAILED SYSTEM DESCRIPTION, PRINCIPLES OF OPERATION, SAFETY PRECAUTIONS, MAINTENANCE, AND DRAWTNGS $\triangle R E$ INCLUDEO IN THE MEMO.

AVAILABILITY - CLEARINGHOUSE FOR FEDERAL SCIENTIFIC AND TECHNICAL INFORMATION, SPRINGFIELD, VA. 22151 , $\$ 3.00$ COPY, SO.65 MICROFICHE

*HOT CELL + *REACTOR, GENERAL + DESIGN STUDY + IRRAOIATION FACILITY + MAINTENANCE AND REPAIR + REACTOR, FAST

$13-27981$

ARNE SON SO

IRRADIATION TESTING FACILITIES - NEEDS, LIMITATIONS, AND AVAILABILITY

BATTELLE-NORTHWEST, RICHLAND, WASHINGTON

BNWL-SA-1754 + CONF-680419-1 +. 4 PAGES, FRMM AMERICAN NUCLEAR SOCIETY NATIONAL TOPICAL MEETING, CINCINNATI, OHIO, APRIL 1,1968

THE NEEDS FOR FAST-REACTOR IRRADIATION-TESTING FACILITIES ARE REVIEWED, AND THE AVAILABILITY OF TESTING REACTORS TO MEET THE NEEDS ARE OISCUSSED. LIMITATIONS OF AVAILABLE FACILITIES ARE IDENTIFIED ANO SPACE REQUIRFMENTS ARE COMPARED WITH AVAILABILITY. THE NEED FOR CONIINUED AND IMPROVED AVAILABILITY OF EBR-II FOR NFAR-TERM FAST-REACTOR FUELS AND MATERIALS TESTING IS

EMPHASIZED, AND ALTERNATE TESTING FACILITIES SUCH AS FERMI ARE BRIEFLY REVIEWED. THE OVFRALL TESTING CAPABILITIES OF THE FAST FLUX TEST FACILITY ARE DISTUSSED.

AVAILABILITY - CLEARINGHOUSE FOR FEDERAL SCIENTIFIC AND TECHNICAL INFORMATION, SPRINGFIELD VA. 22I51, $\$ 3.00$ COPY, \$0.65 MICROFICHE

\#HOT CELL + \#REACTOR, GENERAL + IRRADIATION FACILITY + REACTOR, FAST + TESTING 


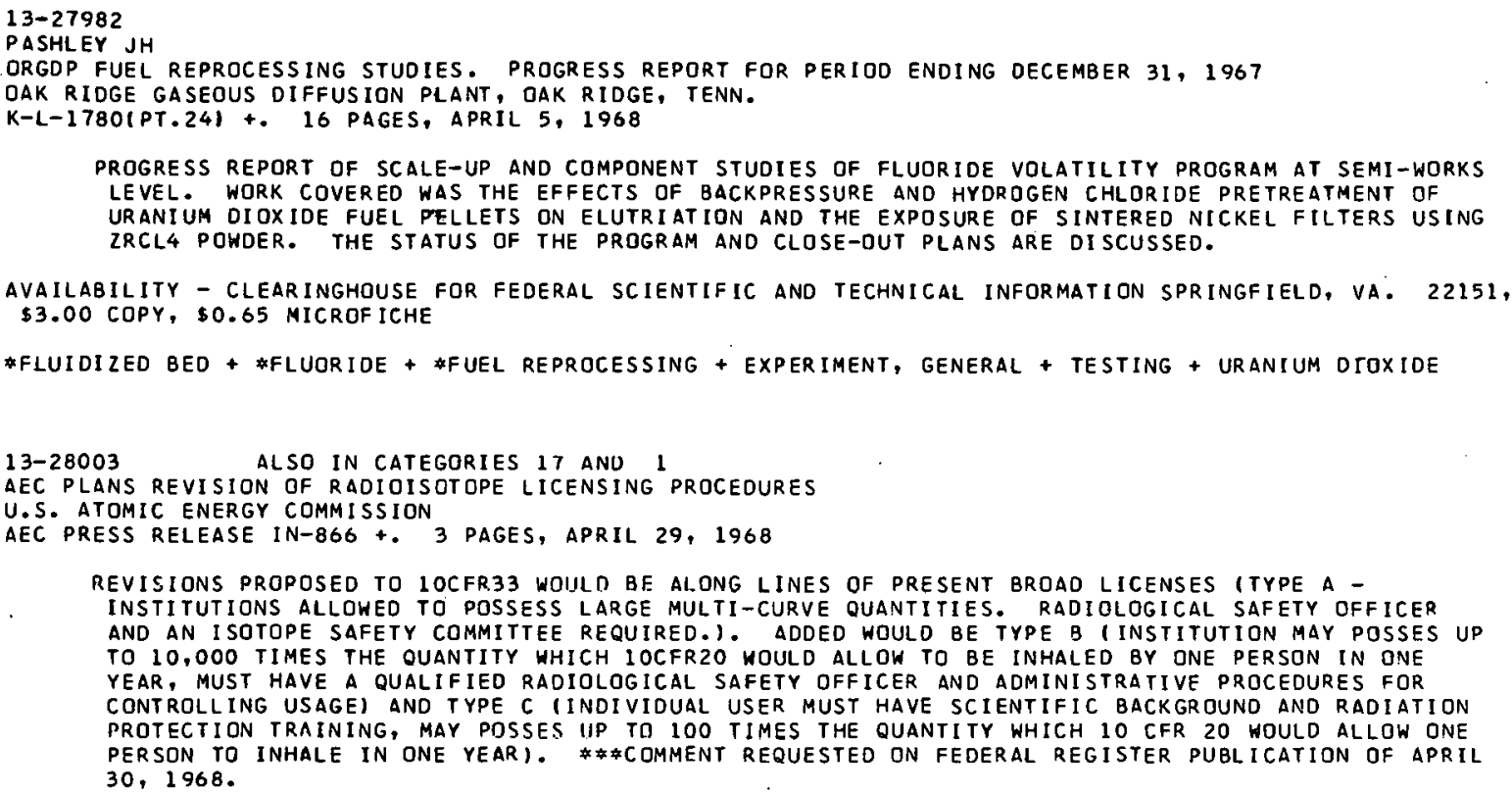

BRIEFLY REVIEWS (FOR AN APPLICANT WITHOUT PRIOR KNOWLEOGE) THE OBJECYIVES AND REQUIREMENTS OF THE REGULATORY PROGRAM, PLUS THE SAFETY RESPONSIBILITIES OF THE USER. A STARTING POINT FOR FURTHER INFORMATION. \#\#REVIEWS RADIOISOTOPE LICENSING, STATE REGULATION, AEC SAFETY. STANDARDS AND REGULATIONS, QUALIFYING FOR A SPECIFIC LICENSE, RESPONSIBILITY OF LICENSEES. APPENDICES INCLUDE RULES AND REGULATIONS, INSTRUCTION SHEETS, AND SAMPLE APPLICATION/LICENSE. REFERENCES.

AVAILABILITY - SUPERINTENDENT OF DOCUMENTS, U, \$. GOVERNMENT PRINTING OFFICE, WASHINGTON, D. C. 20402 \#RADIOISOTOPE + \#REGULATION, AEC + APPLICATION FOR AEC LICENSE + gUIDE

$13-28025$

KING LJ + SHIMOZATO A + HOLMES JM

PILOT PLANT STUDIES OF THE DECONTAMINATION OF LOW-LEVEL PROCESS HASTE BY A SCAVENGING-PRECIPITATION FOAM SEPARATION PROCESS

OAK RIDGE NATIONAL LABORATORY

QP.NL $=3803+57$ PQGES. I. FIGURES, TABLES, 23 REFERENCES, JULY 1968

THE SCAVENGING-PRECIPITATION FOAM-SEPARATION (SPFS) PROCESS FOR TREATING LOW-LEVEL RADIOACTIVE HASTE WATER WAS STUDIED ON A PILOT PLANT SCALE. PROCESSING RATES OF 3OO GPH FDR SCAVENGING PRECIPITATION AND 120 GPH FOR FOAM SEPARATION WERE ACHIEVED. AT ITS PRESENT STAGE OF DEVELOPMENT, THE SPFS PROCESS DOES NOT APPEAR TO BE ECONOMICALLY COMPETITIVE WITH OTHER LOW-LEVEL WASTE TREATMENT PROCESSES.

AVAILABILITY - CLEARINGHOUSE FOR FEDERAL SEIENTIFIC ANO TECHNICAL INFORMATION, SPRINGFIELD, VA. 22151 , $\$ 3.00$ COPY, $\$ 0.65$ MICROFICHE

\#FUEL REPROCESSING + \#RADIOISOTOPE + \#REACTOR, GENERAL + \#WASTE TREATMENT, LIQUID + ECONOMIC STUDY + EXPER IMENT, GENERAL + FOAM + PRECIPITATION

$13-28028$

PHILLIPS JF + HUBER HO

PROCESS FOR THE DISSOLUTION OF ALUMINUM-CLAD THORIA FUEL ELEMENTS

BATTELLE-NORTHWEST, RICHLANO, WASH.

BNWL-240 +. 36 PAGES, 9 FIGURES, 5 TABLES, 22 REFERENCES, JULY 1968 
CATEGORY 13

RAOIOCHEMICAL PLANT SAFETY

\section{3-28028 \#CONTINUED*}

IN AN EFFORT TO DEVELOP A PROCESS FOR SIMULTANEOUS DISSOLUTION OF THORIA AND ITS C-64 ALUMINUM

ALLOY CONTAINER, THE FOLLOHING PROPERTIES WERE MEASURED - (1) ACTIVATION AND DISSOLUTION

CHARACTERISTICS OF THE ALUMINUM ALLOY IN MERCURY-CATALYZED NITRIC ACID, NICKEL (II) NITRATE

SOLUTIONS, (2) THORIA DISSOLUTION RATES IN NITRIC ACID, HYOROGEN FLUORIDE, ALUMINUM NITRATE,

THORIUM NITRATE SOLUTION, AND (3) THE SOLUBILITY OF THORIUM NITRATE IN NITRIC ACID-ALUMINUM

NITRATE. A PROCESS FOR DISSOLVING IS GIVEN.

AVAILABILITY - CLEARINGHOUSE FOR FEDERAL SCIENTIFIC AND TECHNICAL INFORMATION, SPRINGFIELD, VA. 2215I $\$ 3.00$ COPY, \$0.85 MICROFICHE

\#DISSOLUTION + \#FUEL REPROCESSING + *THORIUM + ALUMINUM + EXPERIMENT, GENERAL + TESTING

$13-28029$

ALSO IN-CATEGORY 17

MILES FW

ION-EXCHANGE-RESIN SYSTEM FAILURES IN PROCESSING ACTINIDES

OAK RIDGE NATIONAL LABORATORY, OAK RIDGE, TENNESSEE

13 PAGES, 3 TABLES, 72 REFERENCES, NUCLEAR SAFETY 9(5), PAGES 393-406 (SEPT.-0CT. 1968)

SEVEN INSTANCES OF ION-EXCHANGE-RESIN SYSTEM FAILURES HAVE BEEN REPORTED IN NUCLEAR WORK SINCE JUNE 26, 1962, AND FIVE STUDIES HAVE BEEN MADE OF THE THERMAL STABILITY OF NITRATE-FORM RESINS. ALL INSTANCES APPARENTLY INVOLVEO THE SELF-IGNITION OF NITRATE-FORM RESINS IWITH BOTH AROMATIC AND ALIPHATIC MATRICES) IN STRONG (MORE THAN 7N) NITRIC ACID IN THE PRESENCE OF SOME AMOUNT OF HEAT. THO GROUPS OF PRECAUTIONARY MEASURES ARE SUGGESTED - (1) THOSE

ASSOCIATED WITH THE CHEMISTRY OF RESINS, SUCH AS MAXIMUM OPERATING TEMPERATURE AND IONIC LOADING LIMITS, ANO $(2)$ THOSE COMMON TO CHEMICAL PROCESSING, SUCH AS PRESSURE-RELIEF DEVICES AND ADEQUATE RULES CONCERNING PROCEDURAL CHANGES.

\#ACCIDENT ANALYSIS + \#FUEL CONVERSION + \#FUEL REPROCESSING + \#ION EXCHANGE + \#RADIOISOTOPE + \#RESIN + CURIUM + NEPTUNIUM + PLUTONIUM + THORIUM + URANIUM

13-28049 ALSO IN CATEGORIES 17 AND 7

FILTER FAILURE AT WEST VALLEY PLANT

NUCLEAR FUEL SERVICES, INC., WEST VALLEY, N. Y

2 PAGES, ATOMIC ENERGY CLEARING HOUSE 14(38), PAGE 29 AND 30, (SEPT. 16, 1968), DOCKET NO. 50-201

(TWX TO COMPLIANCE) ON SEPT. 4, 1968, ONE FILTER OF 30 IN THE MAIN VENTILATION FILTER BANK FAILED. 1-2\% OF THE FILTER WAS DISCHARGEO FROM THE STACK AND FELL ON TO ROOF. PROBABLE CAUSE WAS FILTER PRESSURE DROP, AT UPPER OPERATING LIMIT. HIGH PRESSURE OROP ALARM IS BEING CAUSE WAS FILTER PRESSURE DROP, AT UPPER OPERATING LIMIT HIGH PRESSURE OROP ALARM IS BEING
REDUCED $18 \%$, AND LOW PRESSURE DROP ALARM IS AOJUSTED TO INCREASE SENSITIVITY TO SINGLE FILTER FAILURE. NOT A REPORTABLE INCIDENT BECAUSE ANALYSIS OF ADJACENT FILTER AND STACK SAMPLER INDICATE $11 \%$ OF MONTHLY ALLOWANCE DISCHARGED. SURVEY OF SITE PERIMETER DID NOT SHOW RADIATION INCREASE ABOVE BACKGROUND.

\#FILTER, DAMAGEO + \#PRESSURE DROP + AIRBORNE RELEASE + FUEL REPROCESSING + INCIDENT, EQUIPMENT + NFS + STACK + VENTILATION SYSTEM

13-28050 ALSO IN CATEGORIES 17 AND 7

NFS SHUTDOWN TO EVALUATE FILTER FAILURE

NULLEAR FUEL SERVICES, INC., WEST VALLEY, N. Y.

1 PAGE, ATOMIC ENERGY CLEARING HOUSE 14(38), PAGE 30, (SEPT. 16, 1968), DOCKET NO. 50-201

(LETTER TO NFS, SEPT. 6, 1968) CONFIRMS SEPT. 6 PHONE CALL THAT WEST VALLEY PLANT OPERATION WILL NOT BE RESUMED UNTIL THE FOLLOWING IS REVIEWED BY AEC - $(1)$ AMOUNT OF RAOIOACTIVITY RELEASED FROM STACK SEPT. 4, 1968, (2) NFS EVALUATION, INCLUDING PROBABLE CAUSE AND CORRECTIVE ACTION, (3) INFORMAT ION REQUESTED IN APRIL 2, 1968, LETTER, INCLUDING IMMEDIATE WARNING OF ABNORMAL CONDITIONS IN VENTILATION AND OFFGAS SYSTEMS. ITEMS 1 AND 2 ARE NECESSARY TO CONFIRM TECH.-SPEC. REQUIREMENTS MET (PARAGRAPHS 4.1.1, 7.1.2.2 AND 7.1.7.3).

* AIRBORNE RELEASE + *FILTER, DAMAGED + FUEL REPROCESSING + INCIDENT, EQUIPMENT +

INSPECTION AND COMPLIANCE + NFS + OFF GAS + STACK + VENTILATION SYSTEM

13-28167 ALSO IN CATEGORY 17

CORRESPONDENCE RELATIVE TO NFS OFFGAS FILTERS

NUCLEAR FUEL SERVICES, INC.

2 PAGES, ATOMIC ENERGY CLEARING HOUSE 14(39), PAGE 14 AND 15, (SEPT. 23, 1968), DOCKET NO. 50-201

ISEPT. 10 ) MARCH 1968 DOG FILTER FAILURE WAS OUE TO MOISTURE WEAKENING PLYWOOD CASING. ISEPT. 11 TWXS PROVIOES INTERIM TECHNICAL SPECIFICATIONS ON FILTER RESISTANCE AND PRESSURE DROP. (SEPT. 14 TWX) SPECS. CANNOT BE MET WITHOUT EXTENSIVE SHUTDOWN AND REDESIGN OFPLANT. (SEPT. 16 TWX) INTERPRETATIONS SUPPLIED BY NFS OF AEC SEPT. 13 TWX. (SEPT. 16 TWX) AEC NOT AWARE OF NFS SEPT. 14 TWX DURING MEETING OF SEPT. 14. CONFIRM ORAL AGREEMENTS. (SEPT. 17 TWX) DML AGREES NFS MAY OPERATE ACCORDING TO AEC SEPT. 13 SPECIFICATIONS INTFRPRETED BY NFS SEPT. 16 TWX.

\$FILTER, HIGH EFFICIENCY + \#PRESSURE DROP + \#TECHNICAL SPECIFICATIONS + FAILURE, ADMINISTRATIVE CONTROL + FILTER, DAMAGED + FUEL REPROCESSING + INSPECTION AND COMPLIANCE + NFS + OFF GAS 
NUCLEAR FUEL SERVICES, INC.

2 PAGES, ATOMIC ENERGY CLEARING HOUSE 14139), PG 19 AND 20, (SEPT. 23, 1968), DOCKET NO. 50-201

(LETTER, SEPT. 91 DESCRIBES ALTERNATIVES - 11 PIPING WASTE DIRECTLY TO CATTARAUGUS CREEK

WOULD NOT MEET INTENT OF REOUCING DISCHARGE. (2) DEEP WELL DISPOSAL WOULD ALSO TAKE CARE OF TRITIUM. A CONTRACTOR IS NOW INVESTIGATING. (3) SHALE FRACTURING DEMONSTRATION WELL WILL BE COMPLETED BY ORNL AT NFS IN 1969. TIME SCHEOULE IS DIFFICULT TO PREDICT.

FUEL REPROCESSING + NFS + HASTE DISPOSAL, HYORAULIC FRACTURING + WASTE DISPOSAL, LIOUIO

13-28171 ALSO IN CATEGORY 17

CONTAMINATION DUE TO POWER FAILURE AND LOOSE STOPPER

3M COMPANY, ST. PAUL, MINN.

1 PAGE, ATOMIC ENERGY CLEARING HOUSE 14(39), PAGE 26, (SEPT, 23, 1968)

(LETTER TO COMPLIANCE AUG, 14) ON THE MORNING OF JULY 24, ALL HOOD FANS WERE NOT WORKING DUE TO A POWER FAILURE DURING THE NIGHT. IN CHECKING MOOULE IOTN, A SMALL BRASS BOTTLE

CONTAINING 50 CURIES OF SR 90 WAS MOVEO, AND ITS LOOSE TOP NDTED. HIS GLOVE AND SHOE COVERS WERE CONTAMINATED, AND THE HOOD WAS CONTAMINATED TO 2R/HR. TWO EMPLOYEES DRESSED IN FULL ANTI-C SUITS WITH RE.SPIRATORS SPENT 25 MIN CLEANING UP THE HOOD. A SAMPLER SHOWEO THEY WERE EXPOSED TO 14.1 MICROC $/$ ML AIR, GIVING A TECHNICAL OVEREXPOSURE OF 14.7 MPC. URINALYSIS SHOWED NEGATIVE RESULTS. NO CORRECTIVE ACTION IS CONTEMPLATED, ELECTRICAL FAILURES MUST BE EXPECTED.

*CONTAMINATION + *FAILURE, SIMULTANEOUS + \#STRONTIUM + ACCIDENT, LOSS OF POWER + AIRBORNE RELEASE + FAILURE, OPERATOR ERROR + GLOVE BOX + INHALATION + PERSONNEL EXPOSURE, 3AOIATION +

PERSONNEL PROTECTIVE DEVICE + RAOIOISOTOPE 
CATEGORY 14

14-03954 ALSO IN CATEGORY 15

MEREDITH JL + MALONEY JC (ARMY NUCLEAR OEFENSE LAB.) + BRADBURY HG + MILLER WR (GENERAL DYNAMICS)

COLD WEATHER DECONTAMINATION STUDY-MCCOY IV

ARMY NUCLEAR DEFENSE LAB. MARYLAND + GENERAL DYNAMICS, FORT WORTH, TEXAS

113 PAGES- APRIL 1964, NDL-TR-58(PT. I)

THE DECONTAMINATION BY VARIOUS METHODS OF LOSSE SNOW, FROZEN GROUND, THAWING GROUND AND DRY ASPHALT IS DESCRIBED.

* Decontamination + CIVIl DEFEnSE + SNOW + SuRface contamination

14-24634 ALSO IN CATEGORIES 17 AND 13

INDUSTRIAL RADIOACTIVE WASTE BULLETINS

ROCHESTER COMMITTEE FOR SCIENTIFIC INFORMATION

6 PAGES, ATOMIC ENERGY CLEARING HOUSE 14(16), PAGES 5-10 (APRIL 15, 1968)

(NO. 3, FE8, 28, 1968 ) - CORRECTS ERRONEOUS DATA IN PREVIOUS DATA BULLETIN. ON DEC. 16, 1967, THE CS-137/SR-90 CONCENTRATION (PCI/1) AT NFS OUTFALL WAS 160,000/86,900, AT BUTTERMILK CREEK, 6,600/4,010. RCSI QUESTIONS OFFICIAL VIEW THAT MEASUREMENTS COMPLY WITH LAW BECAUSE CATTARANGUS CREEK MEETS INOUSTRIAL EFFLUENT RADIOACTIVITY STANDARDS. \#\#INO. 2 , FEB. 24 , 19681 - DI SCUSSES EFFLUENT MEASUREMENT REPORTEO OVER A PER IOD OF YEARS. ASSERTS THAT NFS SENDS SLUGS OF VERY HOT EFFLUENT INTO CREEK, AS ACTUAL MEASUREMENTS INDICATE DISCHARGE AT SEWER OUTLET WAS 30,000 TIMES PERMISSIBLE LIMIT. ASSERTS OFFICIAL SAMPLING IS NOT DONE AT THE PLACE HHERE LIMITS EXCEEDED.

* RADIATION, PUBLIC EDUCATION/ACCEPTANCE + *WASTE DISPOSAL, LIQUID + DILUTION + EFFLUENT + FUEL REPROCESSING + MAXIMUM PERMISSIBLE CONCENTRATION (MPC) + NFS

14-26618 ALSO IN CATEGORY 17

CLARIFICATION OF A-41 RELEASE CONCENTRATION

WASHINGTON STATE UNIVERSITY

1 PAGE, LETTER TO DRL, FROM LETTER TO DIR., DRL FROM HAROLD W. DODGEN. JUNE $14,1968$. DOCKET 50-27.

THE NOV. 14, 1966, SAFETY ANALYSIS (PG 46-50) CONCLUDED THAT CONTINUOUS RELEASE OF AR-41 AT $1.5 \times 10$ (MINUS $5 T H)$ MICROCURIEICC WOULD NOT VIOLATE 10 CFR 20. WE REQUESTED AUTHORIZATION TD RELEASE AR -41 AT A CONCENTRATION THAT WOULD PRODUCE A YEARLY AVERAGE OF 1.5 X 10 (MINUS STH) WHEN CONTROLLED AND KEPT TO A MINIMUM CONSISTENT WITH EXPERIMENTAL PROGRAMS. AS A RESULT OF AMENDMENT 3 (JULY 12, 1967), WE UNDERSTAND THAT WE ARE AUTHORIZED TO RELEASE AR-41 AT A YEARLY AVERAGE CONCENTRATION OF $1.5 \times 10$ (MINUS STH) MICROCURIE/ML.

AVAILABILITY - PUBLIC DOCUMENT ROOM, WASHINGTON, D.C.

*ARGON + *MAXIMUM PERMISSIBLE CONCENTRATION (MPC) + * SOIIRCE, CDNTINUQUS + POWER UPRATING + REACTOR, RESEARCH + REPORT, SAR + STACK + TECHNICAL SPECIFICATIONS + TRIGA (RR)

$14-26970$

HABASHI F

RADIOACTIVITY IN PHOSPHATE ANIMAL FEED AND FERTILIZERS

MONTANA COLLEGE OF MINERAL SCIENCE AND TECHNOLOGY, BUTTE, MONT.

2 PAGES, I FIGURE, 1 TABLE, 12 REFERENCES, JOURNAL OF THE A.0.A.C. 49(5), PAGES 944-5 (1966)

COMMERCIAL DEFLUORINATED PHOSPHATE ANO DICALCIUM PHOSPHATES MARKETED AS ANIMAL FEED CONTAIN 0.01-0.02 PER CENT URANIUM. IF AN ANIMAL IS FED I LB OF THIS MATERIAL, A DOSE OF ABOUT O.17 MICROCURIE WILL BE GIVEN. HHICH IS ABOUT 20 TIMES THE MAXIMUM PERMISSIBLE LIMIT.

* BIOLOgICAL CONCENTRATION, ANIMAL FEEO + *CALCIUM + \#PHOSPHORUS + *URANIUM +

MAXIMUM PERMISSIBLE DOSE (MPO) + RADIATION SAFETY AND CONTROL

$14-26971$

PARSONS PJ

INTERNATIONAL SYMPOSIUM ON THE DISPOSAL OF RAOIOACTIVE WASTES INTO THE GROUNO

LONDON UNIVERSITY

9 PAGES, 1 TABLE, 2 REfERENCES, NUCLEAR SAFETY 9(4), PAGES 313-21 (JULY-AIIGIIST 19KRI

THE SYMPOSIUM WAS CONCERNEO WITH ALL TYPES DF RADIOACTIVE-WASTE DISPOSAL AND STORAGE IN THE SOIL, INCLUDING THE RELEASE OF RADIOACTIVE EFFLUENTS INTO PITS OR PONDS. THE SHALLOH BURIAL OF SOLIO OR SOLIDIFIED WASTES AND, FOR THE EXPLOITATION OF GEOLOGICAL FORMATIONS, THE DEEP INJECTION OF FLUIO WASTES AND THE USE OF MINES. PAPERS ON HYOROLOGY AND GEOCHEMISTRY CONCERNING THE MINERAL REACTIONS AND MIGRATION RATFS OF RAOIONUCLIDES IN GROUNDWATER WERE ALSO INCLUDED IN THE CONTEXT OF SITE INVESTIGATION ANO THE CHOICE OF SOITABLE AREAS FOR DISPOSAL GROUNDS.

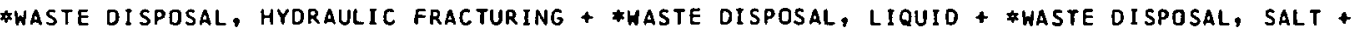

*WASTE DISPOSAL, SOLID + \#WASTE TREATMENT, GENERAL + AUSTRIA + CALCINATION + CONCRETE + GLASS + 
CATEGORY 14

14-26971 *CONTINUED*

ION EXCHANGE + POPULATION EXPOSURE + SOIL + SORPTION + WASTE DISPOSAL, GENERAL

$14-27020$

PURUSHOTHAMAN K + GLOYNA EF

RADIOACTIVITY TRANSPORT IN WATER

UNIVERSITY OF TEXAS

CRWR-21 + EHE-12-6701 +. 120 PAGES, FIGURES, TABLES, 85 REFERENCES, JANUARY, 1968

THE PURPOSE OF THIS STUDY WAS TO EVALUATE THE EFFECT OF INDUCED CLAY SUSPENSIONS ON THE TRANSPORT OF SR-85 AND CS-137 IN AN $\triangle Q U E O U S$ ENVIRONMENT. AN INSTRUMENTED FLUME WAS USED AS A MODEL RIVER TO SIMULATE AN ENVIRONMENT TYPICAL OF A SLOW-MOVING, UNPOLLUTED, TURBID STREAM. MODIFIED LONGITUDINAL DISPERSION RELATIONSHIPS WERE USEO TO DESCRIPE THE TRANSPORT OF RADIONUCLIDES IN TUR8IO STREAMS. DATA WERE DERIVED FROM INSTANTANEOUS RELEASE OF SR-RS AND CS-137 WITH SUSPENOEO ATTAPULGITE AND KAOLINITE CLAYS. CONTINUDUS RELEASE OF CS-137 WITH AN ATTAPULGITE CLAY SIISPENSION HELPED TO ESTABLISH UPTAKE AND TRANSPOFT CHARACTERISTICS FOR ONE ENVIRONMENTAL CONDITION. SUSPENDED CLAY IN THE MODEL RIVER SYSTEM PRUDUCED A SIGNIFICANT REDUCTION IN THE TRANSPORT OF CS-137. CONVERSELY, THE TRANSPORT OF SR-\$5 WAS NOT AFFECTED APPRECIABLY SINCE MOST OF THE SR-85 REMAINEO IN SOLUTION.

AVAILABILITY - CLEARINGHOUSE FOR FEDERAL SCIENTIFIC AND TECHVICAL INFDRMATION, SPRINGFIELO, VA. 22151 $\$ 3.00$ COPY, \$0.65 MICKUFICHE

\#CESIUM + \#MODEL TESTING + \#SEDIMENT + \#STRONTIUM + \#TRANSPORT PROPERTY + DISPERSION + ENVIRONMENTAL CONDITION + HYDROLOGICAL CONSIDERATION, GENERAL + SAMPLING + SOIL + SORPTIDN + WATER, GENERAL

14-27021

FENIMORE JW

TRACING SOIL MOISTURE AND GROUNOWATER FLOW AT THE SAVANNAH RIVER PLANT

SAVANNAH RIVER LABORATORY, E. I. DU PONT DE NEMOURS AND COMPANY, AIKEN, S.C.

DP-MS-68-23 + CONF-680309-1 +. 25 PACES, 14 FIGURES, 7 REFERENC.FS, MARCH, 1968

P.ADIOACTIVE WASTE MANAGEMENT IS A PROBLEM ASSOCIATED WITH THE PRODUCTION OF NUCLEAR MATERIALS AT THE SAVANNAH RIVER PLANT. GROUNDWATER FLOH IS IMPORTANT IN THE MANAGEMENT OF THREE CATEGORIES OF THIS WASTE - BURIED SOLID WASTE, LOW-LEVEL LIOUID WASTE DISCHARGED TO SEEPAGE BASINS, AND HIGH-LEVEL LIQUID WASTE STORED IN UNDERGROUNO TANKS. TRITIUM TRACING METHODS ARE REPORTED FROM THE STANDPOINT OF STRATIGRAPHY, HYDROLOGY, FISSURES, ELEVATION, TYPE OF SOIL, ETC., WITH RESPECT TO EACH OF THE THREE CATEGORIES OF WASTE.

AVAILABILITY - J.W. FENIMORE, SAVANNAH RIVER LABORATORY, E.I. DU PONT DE NEMOURS AND COMPANY, AIKEN, S.C. 29801

\#HYOROLOGICAL CONSIDERATION, GENERAL + \#SOIL, RADIONUCLIDE MOVEMENT THROUGH + \#SURFALE WATER, TRACER + * TRITIUM + GEOLOGICAL CONSIDERATION, GENERAL + WASTE DISPOSAL, LIOUIO + WASTE MANAGEMENT + WASTE STORAGE

$14-27023$

CONTRIBUTION OF TRITIATED WATER AT VARIOUS DEPTHS IN SOIL TO EVAPORATION AT THE SOIL SURFACE SAVANNAH RIVER LABORATORY, E.I. DU PONT DE NEMOURS AND COMPANY, AIKEN, $S$. C.

DP-MS-67-95 +. 23 PAGES, 7 FIGURES, 2 TABLES, 16 REFERENCES, PRESENTED AT THE SYMPOSIUM DN ENVIRONMENTAL SURVEILLANCE IN THE VICINITY OF NUCLEAR FACILITIES, JANUARY 24-25, 1968, AUGUSTA, GEORGIA

TRI TIATED WATER DEPOSITED ON THE SOIL RETURNS DIRECTLY TO THE ATMOSPHERE BY EVAPORATION FROM IHE SÜIL SURPACE AND DY TRANISIRATION BY PLANTS. THF TIMF FRR TRITIATED WATER TO EVAPJRATE FROM A LOAMY SAND WAS MEASURED WHEN TRITIATED HATFR WAS PLACED O TO 14,14 TO 28 , OR 28 TO 42 CM BELOW THE SURFACE AND FOR SOIL WATER CONTENTS OF 0.05 AND $0.10 \mathrm{G} / \mathrm{G}$ OF OVENTORY SOIL. THE. EVAPORATION TIME INCREASEO WITH THE DEPTH OF PLACEMENT ANO WITH A DECREASE IN WATER CONTENT. TRITIATED WATER 14 TO $28 \mathrm{CM}$ BELOW THE SOIL SURFACE DIO NOT EVAPORATE BEFORE 6O HR. TRITIATED WATER 28 TO 42 CM BELOW THE SOIL SURFACE DIO NOT EVAPORATE BEFORE 200 HR FROM SOIL WET TO $0.10 \mathrm{G} / \mathrm{G}$ OF OVEN-ORY SOIL, AND NOT BEFORE 300 HR FROM SOIL WET TO 0.05 G/G OF OVEN-DRY SOIL.

AVAILABILITY - J.C. COREY, SAVANNAH RIVER LABORATORY, E.I. DU PONT DE NEMOURS AND COMPANY, AIKEN, S.C. 29801

\#FCOIIRG ICAL GONSIDERATION + *EVAPORATION + \#SOIL + \#TRITIUM + DEPOSITION

14-27U24

OVERMAN RF + COREY JC + HAHK INS RH

USE OF GAMMA-NEUTRON REACTION FOR DETERMINING D2O IN H2O ANO IN TRACING SOIL MOISTURE

SAVANNAH RIVER LABORATORY, E.I. DU PONT OE NEMOURS AND COMPANY, AIKEN, S.C. 29801

OP-MS-66-9 + 12 PAGES, 10 FIGURES, PRESENTED AT THE $14 T H$ ANNUAL MEETING OF THE AMERICAN NUCLEAR SOCIETY, TORONTO, CANADA, JUNE $9-13,1968$

A NONDESTRUCTIVE METHOD WAS OEVELOPED FOR DETERMINING DEUTERIUM BY THE (GAMMA,N) REACTION: THE METHOD WAS USED TO DETERMINE THE D2O EXTRACTED FROY THE RIVER WATER IN THE FIRST STAGE OF THE HEAVY WATER PRODUCTION PROCESS, AND TO LOCATE O2O IN SOIL MOISTURE STUDIES. THE USE OF THIS RFACTIIDN IS NOT NEW. HOWEVER, ITS APPLICATION HAS BEEN LIMITED BECAUSE A SUITABLE GAMMA 
CATEGORY 14

RADI ONUCLIDE RELEASE AND MOVEMENT IN THE ENVIRONMENT

14-27024 \#CONT INUED*

SOURCE WAS NOT AVAILABLE. SUCH SOURCE SHOULD EMIT A CONSTANT FLUX FOR A LONG TIME. ONE GAMMA SOURCE WAS MADE BY IRRADIATING NA-28 TO GIVE NA-24.

AVAILABILITY - R.F. OVERMAN, SAVANNAH RIVER LABORATORY, E. I. DU PONT DE NEMOURS AND COMPANY, AIKEN, SOUTH CAROLINA 29801

* COUNTER + \#DEUTERIUM + \#GAMMA EMITTER + \#NEUTRON + *SOIL, RAOIONUCLIDE MOVEMENT THROUGH +

* SURFACE WATER, TRACER + \#TRACER, RAOIOACTIVE + DIFFUSION + DISPERSION +

HYDROLOGICAL CONSIOERATION, GENERAL + WATER VAPOR

$14-27025$

COREY JC + FENIMORE JW

TRACING GROUNDWATER WITH CHLORIDE IONS AND TRITIUM THROUGH ACID KAOLINITIC SOIL

SAVANNAH RIVER LABORATORY, E.I. DU PONT DE NEMOURS AND COMPANY, AIKEN, S. C.

OP-MS-67-64 +. 13 PAGES, 4 FIGURES, 13 REFERENCES, PROPOSED FOR PUBLICATION IN INTERNATIONAL JOUPNAL OF

APPLIED RADIATION ANO ISOTOPES, APRIL, 1968

CHLORIDE IONS AND TRITIUM WERE COMPAREO AS GROUNDWATER TRACERS FOR ACID SOILS CONTAINING

KAOLINITIC CLAYS IN LABORATORY ANO FIELD TESTS. THE BREAKTHROUGH FOR CHLORIDE WAS RETARDED

MORE THAN THAT FOR TRITIUM, WHICH INDICATED THAT CHLORIDE IONS INTERACTED WITH THE ACIO

SOILS. THUS CHLORIDE AND OTHER NEGATIVELY CHARGED IONS HAVE LIMITED USEFULNESS AS WATER

TRACERS IN ACID SOILS.

AVAILABILITY - CLEARINGHOUSE FOR FEDERAL SCIENTIFIC AND TECHNICAL INFORMATION, SPRINGFIELO, VA. 2215I

$\$ 3.00$ COPY, \$0.65 MICROFICHE

\#EXPERIMENT, GENERAL + *SURFACE WATER, TRACER + CHLORIDE + DISPERSION + ION EXCHANGE +

SAVANNAH RIVER PLANT + SOIL, RADIONUCLIOE MOVEMENT THRQUGH + TRITIUM

$14-27074$

FINEMAN P

PROGRESS IN WASTE-DISPOSAL RESEARCH AND DEVELOPMENT

10 PAGES, 5 FIGURES, 3 TABLES, 52 REFERENCES, REACTOR AND FUEL-PROCESSING TECHNOLOGY, 11121, PAGES $107-116$ (SPRING 1968 )

AT PACIFIC NORTHWEST LABORATORY (PNL), A PROGRAM IS IN PROGRESS TO DEMONSTRATE ON AN ENGINEERING SCALE THE TECHNICAL, ECONOMIC, AND SAFETY ASPECTS JF VARIOUS SOLIJIFICATION PROCESSES FOR CONVERTING HIGH-LEVEL-ACTIVITY WASTES TO SOL ID FORM THREE PROCESSES HAVE BEFN SELECTED FOR TESTING IN A MULTIPURPOSE FACILITY KNOWN AS THE WASTE-SOLIOIFICATION ENGINEERING PROTOTYPES (WESP). THEY ARE (1) THE PNL SPRAY-SOLIDIFICATION PROGESS, (2) THE ORNL (OAK RIOGE NATIONAL LABORATORY) POT-CALCINATION ANO RISING-LEVEL GLASS PROCESSES, AND (3) THE BNL (BROOKHAVEN NATIONAL LABORATORY) PHOSPHATE-GLASS PROCESS.

*WASTE DISPOSAL, ECONOMICS + *WASTE DISPOSAL, SALT + \#WASTE DISPOSAL, SOLID + \#WASTE TREATMENT, ECONOMICS + *WASTE TREATMENT, FIXATION + \#WASTE TREATMENT, GAS + *WASTE TREATMENT, LIQUID + CALCINATION + GLASS + PHOSPHATE + WASTE STORAGE

14-27075 ALSO IN CATECORY 15

AIR SAMPLING METHOD AND APPARATUS

UNITED STATES ATOMIC ENERGY COMMISSION, WASHINGTON, D.C.

BELGIUM PATENT NO. $674,456+20$ PAGES, 2 FIGURES, DECEMBER 29, 1965, IN FRENCH

THE INVENTION RELATES TO AN IMPROVEO METHOD AND APPARATUS FOR MEASURING AIRBMRNE

CONTAMINATION. A PIECE OF FILTER PAPER IS MOUNTED OVER AN APERTURE IN A DATA-PROCESSING CARD

WHICH IS PRECODED WITH IDENTIFYING INFORMATION. THE CARD. IS PLACEO IN A HOLDER HAVING

OPPOSEO RESILIENT GRASPING MEMBERS FOR HOLOING THE FIIT,TER PAPER TNUT WHILE AIR IS DRAHN

THROUGH IT

AVAILABILITY - IT IS OUR UNDERSTANOING THAT FOREIGN PATENTS MAY BE OBTAINED IN PHOTOCOPY FROM THE U.S. PATENT OFFICE, DEPARTMENT OF C CMMERGE, WASHINGTON, D.C. (30 CENTSIPAGE)

* DATA PROCESSING + \#INSTRUMENTATION, RADIATION MONITORING + \#PATENT + MIR + CONTAMINATION + FILTER + SAMPLING

$14-27078$

COREY JC + HORTON JH

MOVEMENT OF WATER TAGGED WITH H-2, H-3, AND 0-18 THROUGH ACIDIC KAOLINITIC SOIL

SAVANNAH RIVER LABORATORY, E.I. OU PONT DE NEMOURS ANO COMPANY, MIKEN, SOUTH CAROLINA

DP-MS-67-55 +. 25 PAGES, 3 FIGURES, 2 TABLES, 45 REFERENCES, PRESENTED AT THE MEETING OF THE SOIL SCIENCE SOCIETY OF AMERICA, WASHINGTON, D.C. NOVEMBER 10, 1967

MISCIBLE OISPLACEMENT TECHNIQUES WERE USED TO COMPARE THE BEHAVIOR OF DEUTERIUM, TRITIUM, AND 0-18 AS WATER TRACERS. DISPLACEMENT OF A 170-ML PORTION OF TRIPLY TAGGED WATER THROUGH A 186-CM-LONG COLUMN OF WATER-SATURATED ACIDIC KAOLINITIC SOIL BY DISTILLEO HATER REVEALED NO DIFFERENCES IN THE RELATIVE RATES OF MOVEMENT OF DEUTERIUM-, TRITIUM-, AND O-18-TAGGEO WATER.

AVAILABILITY - J.C. COREY + J.H. HORTON, SAVANNAH RIVER LABORATORY, AIKEN, SOUTH CAROLINA ?9BOI 
CATEGORY 14

RADIDNUCLIDE RELEASE AND MOVEMENT IN THE ENVIRONMENT

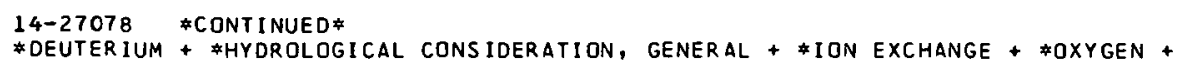

*SOIL, RADIONUCLIDE MOVEMENT THROUGH + \#RITIUM + DIFFUSION + TRACER, RADIDACTIVE

\author{
14-27080 ALSO IN CATEGORY 15 \\ NEWTON D \\ A CASE OF ACCIDENTAL INHALATION OF PROTACTINIUM-231 AND ACTINIUM-227 \\ UKAEA, BER.KS HARWELL \\ 7 PAGES, 3 FIgURES, 14 REFERENCES, HeALTH PHYSICS, 15(1), PAGES 11-1\% 1 JULY, 19681
}

THE BEHAVIOUR OF ACCIDENTALLY INHALED PA-231 AND AC-227 WAS FOLLOWED OVER THE PERIOD 7-9OO DAYS AFTER INTAKE, USING A SINGLE LARGE SODIUM IODIDE DETECTOR. PLACED CLOSE TO THE CHEST. THE RESULTS COULD BE EXPLAINED BY A LONG-TERM CLEARANCE FROM THE THORAX INVOLVING BIOLOGICAL HALF-LIVES OF $1000+-300$ DAYS AND 300-400 DAYS RESPECTIVELY. THERE WAS NEGLIGIBLE MIGRATION OF AC-227 DAUGHTERS FROM THE CHEST.

*ACTINIUM + *DOSE MEASUREMENT, INTERNAL + \#INHALATION + \#PROTACTINIUM + ALPHA EMITIER + HAZAROS ANALYSIS I RADIATION SAFETY AND CONTROL + UNITED KINGDOM

14-27081

BUTLER FE

ALSO IN CATEGORY 15

RAPID BIOASSAY METHODS FOR PLUTONIUM, NEPTUNIUM, ANO URANIUM

SAVANNAH RIVER LABORATORY, AIKEN, SOUTH CAROLINA

7 PAGES, 3 FIGURES, 2 TABLES, 15 REFERENCES, HEALTH PHYSICS, 15(1), PAGES 19-24 (JULY, 1968$)$

VERY SENSITIVE RAPID METHODS WERE DEVELOPEO TO OETERMINE PLUTONIUM, NEPTUNIUM, AND ENRICHED URANIUM IN URINE. CHLOR IDE COMPLEXES OF THE ACTINIDES ARE EXTRACTED FROM OXIDIZED URINE SALTS WITH THE LIQUIO ION EXCHANGER TRI-ISOOCTYLAMINE (TIOA). THE ACTINIDES ARE BACK-EXTRACTED AND THEN COUNTED ON LOW-BACKGROUND SOLID-STATE COUNTERS.

* ANALYTICAL TECHNIQUE, URINE + *BIOLOGICAL CONCENTRATION, MAN + \#NEPTUNIUM + \#PLUTONIUM + \#URANIUM + CHEMICAL ANALYSIS + COUNTER + ION EXCHANGE

14-27082 ALSO IN CATEGORY 15

TAYLOR RW + BOULOGNE AR

RAP ID SEPARATION OF STRONTIUM AND BARIUM

SAVANNAH RIVER LABORATORY, E.I. DU PONT OE NEMOURS AND CO., AIKEN, SOUTH CAROLINA

5 PAGES, 3 FIGURES, TABLE, 6 REFERENCES, HEALTH PHYSICS, i5(1), PAGES 25-29 (JULY, 1968)

AN ANALYTICAL PROCEDURE IS DESCRIBEO FOR THE RAPID DETERMINATION OF SR-89/90 IN THE PRESENCE OF BA/LA-140 AND OTHER FISSION PRODUCTS IN WASTE WATER FROM REACTOR ISOLATION BASINS, WHEN THE BA-140 CONCENTRATION IS GREATER THAN 25\% DF THE SR-89/90 CONCENTRATION. THE METHOD COMBINES A RAPID INORGANIC ION EXCHANGE SEPARATION OF BARIUM FROM STRONTIUM WITH PRECIPITATION OF SRINÜ3) 2 FROM FUMING NITRIC ACIO INTO A 4-HR. METHMO SIITABLE FOR PRE-RELEASE ANALYSIS OF WASTE WATER. DECONTAMINATION FACTDRS FDR THE COMMON FISSION PRODUCTS ARE BETTER THAN 1000. THE RECOVERY OF ADOED STRONTIUM IS $85 \%$, WITH A RELATIVE STANDARD OEVIATION OF $+-7 \%$ AT THE SOF CONFIDENCE LEVEL.

* ANALYTICAL TECHNIQUE, WATER + \#RAOIATION SAFETY AND CONTROL + *REACTOR POWER + \#WASTE TREATMENT, LIOUID + OECONTAMINATION + ENVIRONMENTAL CONDITION + ION EXCHANGE + PRECIPITATION

$14-27083 \quad$ ALSO IN CATEGORY 15

PALMER BD + KURUDA HK

DISTRIBUTION OF STRONTIUM-90 AND CERIUM $\rightarrow 144$ IN THE STRATOSPHERF

DEPARTMENT OF CHEMISTRY, UNIVERSITY OF ARKANSAS, FAYETTEVILLE, ARKANSAS

6 TAGES, 5 FIGURES, TARI, 3 REFERENCES, HEALTH PHYSICS, $15(1)$, PAGES 31-36 (JULY, 1968)

DISTRIBUTION OF SR-90 AND CE-144 IN THE STRATOSPHERE WAS INVESTIGATEO BY ANALYZING HIGH-ALTITUDE AIR FILTER SAMPLES COLLECTED IN 1962 AND 1963. THE HIGHEST CONCENTRATIONS OF SR $(5.4$ DIS/MIN/SCF) AND CE-144 (122 DIS/MIN/SCF) WERE OBSERVED IN APRIL I96Z AT 64-7O DEG N AND AT AN ALTITUDE OF $16.7 \mathrm{KM}$. THE CE-144/SR-90 RATIO IN THE NORTHERN STRATOSPHERE WAS FAIRLY CONSTANT (ABOUT 20 , AS DF JANUARY 1063). THE DISTRIBUTION DATTERNS OF SR-90 AND CE-144 WERE QUITE DIFFERENT FROM THOSE CF MN-54 AND SB-124.

*AIRBURST + \#CERIUM + \#RADIOCHEMICAL ANALYSIS + \#STRATOSPHERE + \#STRONTIUM + AIR * ATMOSPHERIC DIFFUSION, GLOBAL + FILTER + MONITOR, RADIATION, ENVIRONMENTAL + SAMPLING

14-27087 ALSO IN CATEGORY 15

EVANS AG + MARTER WL + REINIG WC

GUIDES LIMITING THE RELEASE OF RADIONUCLIDES BY THE SAVANNAH R.IVER PLANT

SAVANNAI RIVER LABORATORY, E.I DU PONT DE NEMOURS AND COMPANY, AIKEN, SJUTH CAROLINA

9 PAGES, 6 TABLES, 14 REFERENCES, HEALTH PHYSICS, 15(1), PAGES 57-65 (JULY, 1968 )

the savannah river plant has deVeloped plant release guides to define the amCUNT of VARIOUS RADIONUCLIDES THAT CAN BE RELEASED TO THE ENVIRONS IN AIR AND WATER. RELEASES DRE HELD TO 
14-27087 \#CONTINUED*

THE LOWEST PRACTICABLE LEVEL WITHIN PLANT OPERATING GUIDES BASED ON CAREFUL OPERATION AND ARE WELL BELOH THE RADIATION PROTECTION GUIDES RECOMMENDED BY THE FEDERAL RAOIATION COUNCIL FOR NEIGHBORING POPULATIONS.

* MONITOR, RADIATION, ENVIRONMENTAL + \#RAOIOACTIVITY RELEASE + * SURVEILLANCE PROGRAM + FEDERAL RADIATION COUNCIL + PQPULATION EXPOSURE + RADIATION SAFETY AND CONTROL + SAVANNAH RIVER PLANT

14-27293 ALSO IN CATEGORY 16

MELICK R + VAN MIDDLESWORTH L

RADIO-IODINE FALLOUT IN AUSTRALIAN SHEEP

UNIVERSITY OF MELBOURNE DEPARTMENT OF MEDICINE, THE ROYAL MELBOURNE HOSPITAL + DEPARTMENTS OF PHYSIOLOGY AND BIOPHYSICS, UNIVERSITY OF TENNESSEE, U.S.A.

3 PAGES, 2 FIGURES, 2 TABLES, 11 REFERENCES, THE MEDICAL JOURNAL OF AUSTRALIA, 2 , PAGES $930-932$ INOVEMBER 12,19661

SINCE APRIL 1957, THE THYROIO I-131 CONTENT OF VICTORIAN LAMBS HAS BEEN FOLLOWEO. RESULTS UP TO AUGUST 1958 HAVE BEEN REPORTED PREVIOUSLY. THIS PAPER PRESENTS RESULTS UP TO JANUARY 1966. THE RADIOACTIVITY FOUND IN THYROIDS OF VICTORIAN SHEEP HAS BEEN VERY MUCH LESS THAN THAT FOUND IN THE NORTHERN HEMISPHERE, AND PRESENT FOR A MUCH SHORTER TIME.

* BIOLOGICAL CONCENTRATION, ANIMAL + *FISSION PROOUCT, IODINE + ATMOSPHERIC DIFFUSION, GLOBAL + AUSTRALIA + FALLOUT + NUCLEAR DETONATION

$14-27451$

COREY JC

EVALUATION OF DYES FOR TRACING WATER MOVEMENT IN ACID SOILS

SAVANNAH RIVER LABORATORY, E.I. DU PONT DE NEMOURS AND COMPANY, AIKEN, SOUTH CAROLINA

DP-MS-67-41 +. 3 FIGURES, 4 TABLES, 9 REFERENCES, APRIL 1967

THIS REPORT PRESENTS THE USE OF SUITABLE DYES TO STUDY FLOW LINES AROUND GRAVEL LENSES OF

VARIOUS SIZES AND SHAPES TO DETERMINE THE INFLUENCE OF DEPTH OF GRAVEL LENS; SOIL TYPE, AND

INFILTRATION RATE ON THE DIVERSION OF FLOW. THE INFORMATION WILL BE USED TO EVALUATE THE

FEASIBILITY OF STORING SOLID RADIOACTIVE WASTE IN GRAVEL LENSES TO PREVENT LEACHING.

AVAILABILITY - J.C. COREY, SAVANNAH RIVER LABORATORY, AIKEN, SOUTH CAROLINA 29801

* SOIL, RAOI DNUCLIDE MOVEMENT THROUgh + *TRACER, FluORESCENT + \#WSTE DISPOSAL, SOLID + \#WASTE STORAGE + FLOW DISTRIBUTION + MODEL TESTING + RATE + SOIL

14-27619 ALSO IN CATEGORIES 17 AND 15

WATER POLLUTION CONTROL--TECHNICAL TRAINING PROGRAM--BULLETIN OF COURSES

U.S. DEPARTMENT OF THE INTERIOR

66 PAGES, FROM CLEAN WATER, BULLETIN OF COURSES, JULY 1968 TO JUNE 1969

DESCRIBES 27 SHORT COURSES (1-2 WEEKS, GIVEN AT VARITUS REGIONAL CENTERS IN 1968-69) IN THE GENERAL AREAS UF CHEMISTRY (4), MICROB IOLOGY (7), ANO ENGINEERING AND WASTE TREATMFNT (13). NONF SEEM SLANTED AT RADIATION OR AT POWER STATIUNS, BUT SOME DF THE INTRODUCTORY BIOLOGY ANO ECOLOGY COURSES SEEM GFNERALLY APPLICABLE.

\#ECOLOGICAL CONSIDERATION + \#STAFFING, TRAINING, QUALIFICATION + \#WASTE DISPOSAL, LIQUID + THERMAL POLLUTION

14-27855 ALSO IN CATEGORIES 17 AND 15

TRAINING COURSES - NATIONAL CENTER FOR RADIOLOGICAL HEALTH

U.S. DCPARTMENT OF HEALTH, EUUCATION, AND WELFARE

PHS-PUB-1633 REV. +. 33 PAGES, JULY 1968

SIXTY-SIX 1 OR 2 WEEK PRESENTATIONS AT VARIOUS REGIONAL CENTERS IN FY 1969 WILL BF MADE OF ONE OR MORE OF THE 16 COURSES AVAILABLE. AMONG THOSE OF INTEREST ARE - BASIC RADIOLOGICAL HEALTH, RADIOLOGICAL HEALTH FOR NURSES, TWO FOR X-RAY PROTECTION, OCCUPATIONAL RADIATION PROTECTION, REACTOR SAFETY AND HAZARDS EVALUATION, MANAGEMENT OF RADIATION ACCIDENTS, OPERATIONAL ASPECTS OF RADIATION ACCIOENTS, OPERATIONAL ASPECTS OF RAOIATION SURVEILLANCE, MEASUREMENT UL AIRBORNE RADIOACTIVITY, CHEMICAL ANO GAMMA SPECTOSCOPY ANALYSIS OF RADIONUCLIDES, AND RADIUM HAZARDS ANO CONTROL.

AVAILABILITY - U.5. DEPARTMENT OF HEALTH, EOUCATION, AND WELFARE, CENTER FOR RAOIOLOGICAL HEALTH, ROCKVILLE, MARYLANO

*HEALTH PHYSICS IRAINING + \#STAFFING, TRAINING, QUALIFICATION + RADIAT ION INJURY், TREATMENT OF + RADIOLOGICAL ASSISTANCE + RADIUM + REACTOR, POWER + REACTOR, RESEARCH + SURVEY, RADIATION, ENVIRONMENTAL + $X-R A Y$

14-27874 ALSO IN CATEGORY 16

HARDY EP + RIVERA J 
CATEGORY 14

RADI.ONUCLIDE RELEASE AND MOVEMENT IN THE ENVIRONMENT

14-27874 \#CONTINUED*

FALLOUT PROGRAM. QUARTERLY SUMMARY REPORT, MARCH 1--JUNE 1,1968 + APPENOIX TO FALLOUT PROGRAM QUARTERLY SUMMARY REPORT, MARCH 1, 1967--JUNE 1, 1968

U. S. ATOMIC ENERGY COMMISSION

HASL-197 + HASL-197(APP.) +. 832 PAGES, FIGURES, TABLES, REFERENCES, JULY 1, 1968

PRESENTS CURRENT DATA FROM THE HASL FALLOUT PROGRAM, THE UKAERE HEALTH PHYSICS AND MEDICAL DIVISION, EURATOM JOINT NUCLEAR RESEARCH CENTRE, THE NATIONAL RADIATION LABORATORY IN NEW ZEALAND, AND THE OIVIS:ON OF BIOLOGICAL AND MEDICAL RESEARCH AT ARGONNE NATIONAL LABORATORY. THIS REPORT IS DIVIDED INTO FOUR MAIN PARTS - 11 I INTERPRETIVE REPORTS AND NOTES, $(21$ HASL FALLOUT PROGRAM DATA, (3) DATA FROM SOURCES OTHER THAN HASL, AND (4) RECENT PUBLICATIDNS RELATED TO RADIONUCLIDE STUDIES.

AVAILABILITY - CLEARINGHOUSE FOR FEDERAL SCIENTIFIC AND TECHNICAL INFORMATIDN, SPRINGFIELD, VA. 22151, $\$ 3.00$ COPY, $\$ 0.65$ MICROFICHE

* BIBLIOGRAPHY + \#BIOLOGICAL CONCENTRATION, AGRICULTURAL PRODUCE + *BIDLOGICAL CONCENTRATION, MAN + \#DOSE MEASUREMENT, INTERNAL + \#FALLOUT + \#MONITORING PROGRAM, ENVIRONMENTAL + \#SAMPLING, HIGH ALTITUDE + NUCLEAR DETONATION + OCEAN AND SEA + RADIOCHEMICAL ANALYS IS

14-27914 ALSO IN CATEGORY 15

LACHAPELLE DG + TARBOX JL + MALONEY JC + BRADBURY HG + GODBOLT NH + MILLER WH

A FIELD-EXPEDIENT INCINERATOR (PROJECT TEE PEE)

GENERAL DYNAMICS, FORT WORTH, TEXAS + ARMY NUCLEAR DEFENSE LAB

AD-664118+NOL-TR-98+. 132 PAGES, REFERENCES, JANUARY 1969

AN INCINERATOR FOR EXPEOIENT CONCENTRATION OF COMBUSTIBLE RADIOACTIVE WASTE HAS BEEN DESIGNED, BUILT, ANO EVALUATED. IT FEATURES PORTABILITY AND EASE OF ASSEMBLY. THIS INCINERATOR IREFERRED TO AS TEE PEE) EMPLOYS FIVE OIL-FIRED BURNERS THAT IGNITE THE HASTE MATERIAL AND REOUCE THE PARTI.CULATE EMISSION. FOUR INCINERATIONS WERE CONDUCTED WITH ROUGH-CUT LUMBER CONTAMINATED LA-140. THE CONCLUSION BASED ON THESE RESULTS IS THAT THE TEE PEE IS A PRACTICAL DEVICE FOR EFFICIENT FIELD-EXPEDIENT INCINERATION AND CONCENTRATION OF COMBUSTIBLE RADIOACTIVE WASTE.

AVAILABILITY - CLEARINGHOUSE FOR FEDERAL SCIENTIFIC AND TECHNICAL INFORMATION, SPRINGFIELO, VA. 22151 , $\$ 3.00$ COPY, $\$ 0.65$ MICROF ICHE

*AIRBORNE RELEASE + \# INCINERATION + \#LANTHANUM + \#WASTE TREATMENT, SOLID + CONCENTRATION, MAXIMUM + EFFLUENT + MAXIMUM PERMISSIBLE CONCENTRATIDN (MPC)

$14-27918$ ALSO IN CATEGORY 15

BURCH WD + AREHART TA

SAFETY REVIEW PROCEDURES FOR HOT-CELL AND RADIOCHEMICAL PROCESSINGFACILITIES AT ORNL

DAK RIDGE NATIONAL LABORATORY

ORNL-P-3227 + CDNF-671102-3 +. 5 PAGES, I FIGURE, I TABLE, 3 REFERENCES, PAGES 187-191 OF SAFETY REVIEW PROCEDURES FUR HOT CELL AND RADIOCHEMICAL PROCESSING FAC.II.ITIES AT ORNL, FOR PRESENTATION AT I5TH

CONFERENCE ON REMOTE SYSTEMS TECHNOLOGY ANO ATOM FAIR, CHICAGO, ILLINOIS, 1966

RESPONSIBILITY FOR. THE RAUIATIINN SAFETY OF ALL HOT-CELL AND RADIOCHEMICAL PROCESSING

FACILITIES AT ORNL IS ASSIGNED TO THE DIRECTOR OF RAOIATION SAFETY ANU CONTROL, WHO, AIDED BY VARIOUS REVIEW AND AOVISORY COMMITTEES AS WELL AS A FULL-TIME STAFF OF THREE SENIOR EMPLOYEES, HAS ESTABLISHED UNIFORM POLICIES THROUGHOUT THE LABORATORY. ADEQUATE SAFETY REGULATIONS THUS ESTABLISHED HAVE BEEN MAINTAINED SUCH THAT NO RADIATION INCIDENTS OF ANY CONSEQUENCE HAVE OCCURRED WITHIN THE PAST SEVEN YEARS. THIS PAPER DESCRIBES THE ORGANIZATION RESPONSIBLE FOR RADIATION SAFETY AND ALSO DISCUSSES SOME OF THE ESTABLISHED STANDARDS.

AVAILABILITY = CLEARINGIOUSC TON FEDERAL SCIENTIFIS. AND TECHNICAL INFORMATION, SPRINGFIELD, VA. 22151 , \$3. 30 COPY, \$0.65 MICROF ICHE

* OPERATION + \#REACTOR POWER + DESIGN CRITERIA + HOT CELL + MONITOR, RADIATION, GENERAL + RADIATION SAFETY AND CONTROL + RADIOCHEMICAL PLANT SAFETY + RADIOCHEMICAL PROCESSING + VENTILATION SYSTEM + WASTE DISPOSAL, HYDRAULIC FRACTURING + WASTE STORAGE

$14-27930$

REICHERT SO

SOME GFMI DGICAL ASPECTS OF RADIOACTIVE WASTE MANAGEMENT

SAVANNAH RIVER LABORATORY

OP-MS-67-108 + CONF-680202-4 +. 28 PAGES, REFERENCES, DECEMSER 8, 1967, FROM 97TH ANNUAL MEETING OF THE AMER ICAN INSTITUTF OF MINING, METALLURGICAL AND PETROLEUM ENGINEERS, NEW YORK

AT NUCLEAR FACILITIES, THREE TYPES DF RADIOACTIVE WASTE MUST BE MANAGED - $(1)$ HIGH-LEVEL

LIOUID WASTE CONTAINING FISSION PRODUCTS FROM THE CHEMICAL SEPARATION OLE IRRADIATEO URANIUM,

(2) LOW-LEVEL CONDENSATES FROM THE CONCENTRATION OF THE HIGH-LEVEL WASTE, AND (3) DRY SOLIDS

SUCH AS OBSDLETE PROCESS EQUIPMENT, SPENT ION EXCHANGE RESINS, AND IRRADIATED METAL SCRAP.

WITHIN THE GENERAL AREA WHERE THE WASTE ORIGINATES, STUDIES ARE MADE TO LOCATE SEEPAGE BASINS

AND BURIAL GROUNDS IN THE MOST FAVORABLE SITES.

AVAILABILITY - CLEARINGHOUSE FOR FEDERAL SCIENTIFIC AND TECHVICAL INFORMATION, SPRINGFIELD, VA. 2Z15I, $\$ 3.00$ COPY, \$0.65 MICROFICHE

廿 GEOLOCICAL CONSIDERATIIIN. GENFRAL + \#GROUNO WATER, GENERAL + 4SOIL, RADIONUCLIDE MOVEMENT THRMIISH + 


\section{$14-27930$ *CONTINUED*}

\#WASTE MANAGEMENT + HYOROLOGICAL CONSIDERATION, GENERAL + ION EXCHANGE + RADIATION SAFETY AND CONTROL + SOIL + WASTE TREATMENT, ECONOMICS + WATER POLLUTION

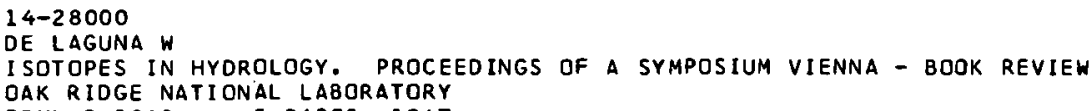

THE SYMPOSIUM PRECEEDINGS WERE COMPRISED OF 41 PAPERS COVER ING THE TOPIC OF HYDROLOGY. THERE WERE 167 PARTICIPANTS FROM 36 COUNTRIES AND SEVEN INTERNATIONAL ORGANIZATIONS. THE PAPERS PRESENTED TOPICS SUCH AS HYDROMETEOROLOGY AND STEAM FLOW. MEASUREMENTS, SEOIMENT STUDIES, GEOCHRONOLOGY AND ENVIRONMENTAL STUDIES, AQUIFER CHARACTERISTICS, UNSATURATEO ZONE, SEEPAGE AND TRACER TECHNOLOGY, AND SURFACE WATER, LIMNOLOGY, AND GLACIOLOGY.

AVAILABILITY - CLEARINGHOUSE FOR FEDERAL SCIENTIFIC AND TECHNICAL INFORMATION, SPRINGFIELD, VA. 22151 , $\$ 3.00$ COPY, \$0.65 MICROFICHE

* geological consideration, general + \#hydrological consideration, general + *SURFACE hater, general + *TRACER, GENERAL + \#TRACER, RADIOACTIVE + AUSTRIA + ENVIRONMENTAL CONDITION + SEDIMENT

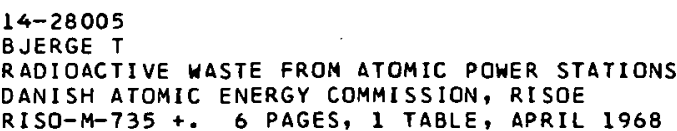

THE IIGHLY RADIOACTIVE WASTE FROM ATOMIC POWER STATIONS IS AT PRESENT IN GENERAL STORED IN LIQUID FORM IN STAINLESS. STEEL CONTAINERS. IT SEEMS POSSIBLE TO FURTHER CONCENTRATE THE WASTES BY SOLIOIFICATION IN THE FORM OF GLASS. EVEN WITH AN ATOMIC POWER PRODUCTIONLEVEL MUCH IN EXCESS OF THE PRESENT TOTAL POWER PRODUCTION LEVEL, THE STORAGE FOR A THDUSAND YEARS OR MORE WILL NOT CONSTITUTE A SERIOUS SPACE-CONSUMING PROBLEM. THE QUESTIONS OF KRYPTON-85 AND TRITIUM ARE ALSO TOUCHEO UPON. THESE DO NO. CONSTITUTE ANY SERIOUS PROBLeMS.

AVAILABILITY - USAEC DEPOSITORY LIBRARIES IN THE U.S. ANO OVERSEAS

\#KRYPTON + \#SINTERING + \#TRITIUM + \#WASTE STORAGE + \#ASTE TREATMENT, FIXATION + REACTOR POWER

$14-28007$

BROWN DJ + HANEY WA

THE ROLE OF GEOLOGY IN THE DISPOSAL OF RADIOACTIVE WASTES

BATTELLE-NORTHWEST, RICHLAND, WASHINGTON

BNWL-SA-57 t. 19 PAGES, 2 REFERENCES, FEBRUARY 28, 1965

THIS PAPER IS A SHORT DISCUSSION ON THE TYPES OF RADINACTIVE WASTES GENERATED IN THE NUCLEAR INDUSTRY, ANU THE KINDS OF GEOLOGIC FORMATIONS WHICH HAVE BEEN SUGGESTED AS POSSIBLE STRIICTURES SUITABLE FOR THE DISPOSAL OR STORAGE Ü RADIOACTIVE WASTES. THE PURPOSE IS TO DESCRIBE THE ROLE WHIC.H GEOLOGY PLAYS IN THE EVALUATION OF DISPOSAL SITES PRIOR TO THEIR USE, AND HOW GEOLOGY IS UTILIZED IN THE INTERPRETATION OF MONITORING RESULTS AFTER THE DISPOSAL FACILITY IS PUT IN OPERATION.

AVAILABILITY - CLEARINGHOUSE FOR FEDERAL SCIENTIFIC AND TECHNICAL INFORMATION, SPRINGFIELD, VA. 22151 , $\$ 3.00$ COPY, \$0.65 MICROF ICHE

* GEOLOgI CAL CONSIDERATION, GENERAL + \#HYOROLOGICAL CONSIDERATION, GeNERAL + \#SITING, GENERAL + *WASTE OISPOSAL, LIQUID + \#WASTE STORAGE + FUEL REPROCESSING + INTFGRITY + ROCK MECHANICS + SOIL

UCRL-50,418 +. 29 PAGES, 14 FIGURES, 4 TABLES, 20 REFERENCES, APRIL, 1968

THIS REPORT DISCUSSES THE MOVEMENT ANO DIFFUSION OF THE EFFLUENT CLOUD PRODUCED BY THE PHOEBUS $1 B$ EP-IV EVENT OF FEBRUARY 23, 1967 . THE CLOUD WAS TRACKED BY AIRCRAFT FOR ALMOST THREE DAYS, AND USEFUL CONCENTRATION MEASUREMENTS WERE OBTAINED FOR ALMOST THO DAYS. PRE- AND POST-RUN CALCULATIONS WERE DONE HITH A COMPUTER GODE FOR LARGE CLDUD DIFFUSION USING

CLIMATOLOGY AND OBSERVED METEOROL OGY RESPECTIVELY. CALCULATIONS DF CONCENTRATIONS AND CLOUO SI ZE ARE COMPARED WITHH THE AVAILABLE MEASUREMENTS. CALCULATIONS. agREe WELL WITH MEASUREMENT FOR THE FIRST FEW HOURS.

AVAILABILITY - CLEARINGHOUSE FOR FEDERAL SCIENTIFIC AND TECHNICAL INFORMATION, SPRINGFIELD, VA. 22151 , $\$ 3.00$ COPY, \$0.65 MICROFICHE

*COMPUTER PROGRAM, METEOROLOGICAL + *METEOROLOGICAL SUPPORT + \#NEVADA TEST SITE. + *RADIOACTIVITY RELEASE + ATMOSPHERIC DIFFUSION + COMPARISON, THEORY AND EXPERIENCE + VUCLEAR ROCKET 
CATEGORY 14

RADI ONUCLIDE RELEASE AND MOVEMENT IN THE ENVIRONMENT

$14-28048$

AMES LL + HAJEK BF

STATISTICAL ANALYSIS OF CESIUM AND STRONTIUM SORPTION ON SOILS

BATTFI, I.F-NORTHWEST, RICHLAND, WASH.

BNWL-CC-539 +. 11 PAGES, MARCH 8, 1966

A STATISTICAL DESIGN TO STUDY REMOVAL OF RADIOISOTOPES BY A SOIL WAS TESTED. A SIMPLE

TWO-LEVEL FACTORIAL UTILIZING NANO3, KNO3, HNO3 AND CAINO3) 2 AS INDEPENDENT VARIABLES YIELDEO SATISFACTORY CESIUM AND STRONTIUM REMOVAL RESULTS. A REGRESSION EQUATION WAS USEO TO PREOUCT CESIUM AND STRONTIUM REMOVAL RESULTS, GIVEN THE LEVEL OF INDEPENDENT VARIABLES. THE RESULTS INDICATE THE STATISTICAL TREATMENT ANO FREDICTION OF RADIOISOTOPE REMOVAL BY SOILS IS FEASIBLE.

AVAILABILITY - CLEARINGHOUSE FOR. FEDERAL SCIENTIFIC AND TECHNICAL INFORMATION, SPRINGFIELD, VA. 22151 $\$ 3.00$ COPY, \$0.65 MICROF ICHE

*CESIUM + *SOIL + *SORPTION + \#STATISTICAL ANALYSIS + *STRONTIUM + RADIOISOTOPE

$14-28170$ ALSO IN CATEGORIES 17 AND 13 ALTERNATIVE IN REDUCING BUTTERMILK CREEK RADIOACTIVITY NULLLEAR FUEL SERVICES, INC.

2 PAGES, ATOHIC ENERGY CLEARING HOUSE 14(39), P(1 19 AND 20, (SEPT. 23, 1968), DOCKET NO. 50-201

(LETTER, SEPT. 9$)$ DESCRIBES ALTERNATIVES - (1) PIPING WASTE DIRECTLY TO CATTARAUGUS CREEK WOULD NOT MEET INTENT OF REDUCING DISCHARGE. 121 DEEP WELL DISPOSAL WOULD ALSO TAKE CARE OF TRITIUM. A CONTRACTOR IS NOW INVESTIGATING. (3) SHALE FRACTURING DEMONSTRATION WELL WILL BE COMPLETED BY ORNL AT NFS IN 196\%. TIME SCHEDULE IS DIFFICULT TO PREDICT.

FUEL REPROCESSING + NFS + haste DISPOSAL, HYDRAULIC FRACTURING + WASTE DISPOSAL, LIQUIO 
CATEGORY 15

ENVIRONMENTAL SURVEYS, MON.ITORING AND RAOIATION EXPOSURE OF MAN

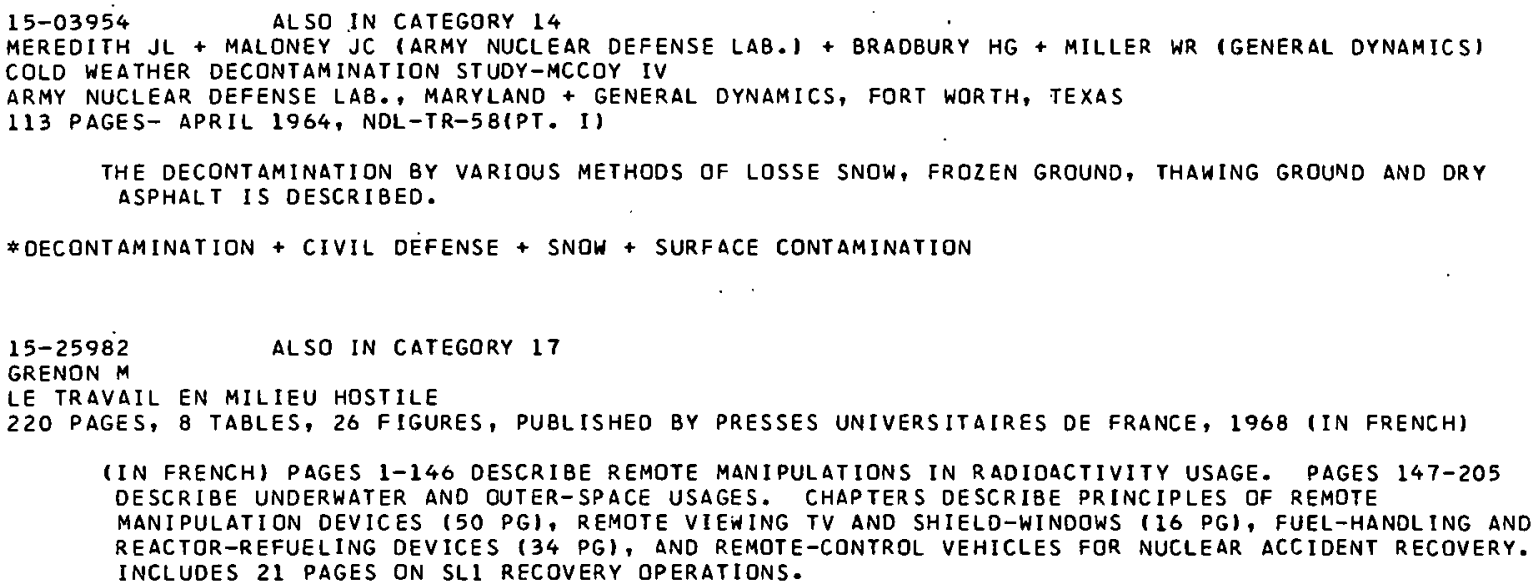

USAEC, PUBLIC DOCUMENT ROOM, 1717 H ST., WASHINGTON, D.C. 20545 (25 CENTS/PAGE)

*RADIOGRAPHY + \#OURCE, RADIATION, LOST + INCIDENT, HUMAN ERROR + INCIDENT, NONREACTOR + OCEAN AND SEA

$15-26307$ ALSO IN CATEGORY 17

RADIOGRAPHY EXPOSURE AT AVONDALE SHIPYARDS INC.

AVONDALE SHIPYARDS

1 PAGES, TWX TO AEC DIVISION OF COMPLIANCE FROM J.K. MCCUE, APRIL 7, 1967

RADIOGRAPHER RECEIVEO ESTIMATED EXPOSURE OF 6 REMS WHEN AN IRIDIUM SOURCE STUCK IN THE CABLE. DOSIMETER DID NOT INDICATE A DOSE. THO FILM BADGES ARE TO BE PROCESSED.

USAEC, PUBLIC DOCUMENT ROOM, 1717 H ST., WASHINGTON, D.6. 20545 125 CENTS/PAFFI

*PERSONNEL EXPOSURE, RADIAT IUN + \#RADIOGRAPHY + INCIDENT, EQUIPMENT + INCIDENT, NONREACTOR

15-26308 ALSO IN CATEGORY 17

QVEREXPOSURE TO RADIOGRAPHER

GENERAL DYNAMICS CORP., GROTON, CONNECTICUT

1 PAGE, ATOMIC ENERGY CLEARING HOUSE, 14(9), PAGE 27 (FEBRUARY 26, 1968 
15-26308 \#CONTINUED*

A RAOIOGRAPHER RECEIVED A CALCULATED DOSE OF 14.5 REMS GAMMA WHILE PERFORMING OPERATIONS WITH A 96 -CURIE IR-192 SOURCE.

USAEC, PUBLIC DOCUMENT ROOM, 1717 H ST., WASHINGTON, D.C. 20545 (25 CENTSIPAGE)

*PERSONNEL EXPOSURE, RADIATION + INCIDENT, NONREACTOR + RADIOGRAPHY

$15-26309$

ALSO IN CATEGORY 17

QNE IL RW

FAILURE TO SURVEY RESULTS IN OVEREXPOSURES TO RADIOGRAPHERS

BOSTON NAVAL SHIPYARD, BOSTON, MASSACHUSETTS

2 PAGES, ATOMIC ENERGY CLEARING HOUSE, 14(9), PAGES 27-28 (FEBRUARY 26, 1968)

\begin{abstract}
A RADIOGRAPHER AND 2 ASSISTANTS WERE EXPOSED TO A 7.2-CURIE SOURCE. WHEN IT FAILED TO RETURN TO ITS SHIELD AND A SURVEY WAS NOT MADE. TWO MEN RECEIVED THEIR OOSE WHILE PERFORMING RADIOGRAPHY, THE THIRD WHILE RETURNING THE TUBE, WHICH CONTAINEO THE UNSHIELDED SDURCE, TO STORAGE. INCIDENT OISCOVERED WHEN ANOTHER RADIOGRAPHER SURVEYED THE STORAGE ROOM. ESTIMATEO EXPOSURES ARE 2.2 REMS, 800 MILLIREMS, ANO A POSSIBLE MAXIMUM OF 230 REMS TO THE THIRO MAN.
\end{abstract}

USAEC, PUBLIC DOCUMENT ROOM, 1717 H ST., WASHINGTON, D.C. 2 ח.545 (2S CENTS/PAGE)

* INCIDENT, HUMAN ERROR + \#PERSONNEL EXPOSURE, RADIATION + \#RAOIOGRAPHY + FAILURE, OPERATOR ERROR + INCIDENT, NONREACTOR

15-26310 ALSO IN CATEGORIES 11 AND 17

U.S. TESTING CO. CITED FOR NON-COMPLIANCE IN RADIOGRAPHY OPERATIONS

UNITEO STATES ATOMIC ENERGY COMMISSION

4 PAGES, LETTER TO U.S. TESTING CO. FROM E.R. PRICE, NOVEMBER 10, 1985

NONCOMPLIANCE ITEMS INCLUDE PERSONNEL FAILING TO WEAR ODSIMETERS AND BADGES, INADEQUATE PERSUNNEL MONITORING RECOROS, PERFORMING RADITGRAPHY WITHOUT OPERABLE SURVEY INSTRUMENTS, UNQUALIFIED PERSONNEL ACTING AS RAOIOGRAPHERS, ASSISTANTS HAO NOT RECEIVEO COPIES DF OPERATING AND EMERGENCY PROCEDURES, SURVEILLANCE INADEOUATE TO PREVENT UNAUTHORIZED ENTRY INTO HIGH RADIATION AREAS, SURVEY INSTRUMENTS WERE NOT CALIBRATED EVERY 3 MONTHS, IMPROPER UTILIZATION LOOP, ANO COMPANY FAILURE TO REPORT AN EMPLOYEE OVEREXPOSURE.

USAEC, PUBL IC DOCUMENT ROOM, 1717 H ST., WASHINGTON, D.C. 20545125 CENTS/PAGE I

\#FAILURE, ADMINISTRATIVE CONTROL + \#FAILURE, OPERATOR ERROR + \#INSPECTION AND COMPLIANCE + \#RADIOGRAPHY

15-26311 ALSO IN CATEGORY 17

OVEREXPOSURE TO FILM BADGE WHILE CALIBRATING INSTRUMENTS

U.S. ARMY, FORT MCPHERSON

4 PAGES, LETTER TO AEC DIVISION OF LICENSING AND REGQLATION FROM G.L. GALLIER, MARCH 25 , 1965

A FILM-BADGL REPORT INOICATED AN EXPOSURE OF 41 REMS (BETA). INVESTIGATION REVEALED THAT EXPOSURE WAS TO FILM BADGE ONLY AND OCCURRED EITHER HHEN OPERATOR PERFURMING INSTRUMENT CALI BRATION LEFT HIS BADEE ON THE TABLE NEXT TO THE SOURCE FOR AN INDEFINITE TIME, OR WHEN HE LEANED OVER THE CALIBRATOR WHILE ITS PORT WAS OPEN ANO THE BADGE WAS ON HIS BELT OVER THE FRONT OF THE RIGHT HIP.

USAEC, PUBLIC DOCUMENT ROOM, 1717 H ST., HASHINGTON, D.C. 20545 (25 (ENTS/PAGE)

*FAILUKE, UPEKATUR ERROR + +INJTRUMENTATION GALIBRATION + \#MONITOR, RADIATION, PERSONNEL +

\#PER SUNNEL EXPOSURE, RADIATION + \$RADIOGRAPHY

15-26312 ALSO IN CATEGORY 17

AEC CITATION FOR DEFICIENCIES IN RADIOGRAPHY OPERATIONS

UNITED STATES ATOMIC ENERGY COMMISSION

2 PAGES, LETTER TO FOSTER WHEELER CORPORATION FROM E.R. PRICE, NOVEMBER 6, 1963

AN AEC INSPECTION ON AUGUST 29, 1963 , RESULTEO IN A CITATION FOR (1) PERMITTING EMPLOYEES TO PEPFORM RADIOGRAPHY BEFORE COMPLETING THE TRAINING COURSE, (2) FAILING TO INCLUDE IN REPORTS OF RADIATION EXPOSURE TO FORMER EMPLOYEES THE STATEMENTS THAT THE REPORT WAS FURNISHED UNDER PROVISIONS OF AEC REGULATIONS AND SHOULO BE PRESERVEO FOP. FUTURE REFERENCE, AND (3) FAILING TO LABEL A SOURC.E C.ONTAINER.

USAEC, PUBLIC DOCUMENT ROOM, 1717 H ST., WASHINGTON, D.C. 20545 (25 CENTS/PAGE)

\#FAILURE, ADMINISTRATIVE CONTROL + \#INSPECTION AND COMPLIANCE + *RADIOGRAPHY + RADIATION SAFETY AND CONTROL + SOURCE, RADIATION + STAFFING, TRAINING, QUALIFICATION 
CATEGORY 15

ENVIRONMENTAL SURVEYS, MONITORING AND RADIATION EXPOSURE OF MAN

15-26314 *CONTINUED*

UNITED STATES ATOMIC ENERGY COMMISSION

3 PAGES, LETTER TO RADIOLOGICAL TESTING LAB FROM L.0. LOW, MARCH 6, 1968

AEC CITED COMPANY FOR FAILING TO (1) SURVEY UNRESTRICTED AREAS, (2) MAINTAIN RECORDS OF

SURVEYS, (3) POST RADIATION AREAS, (4) PERFORM ADEQUATE SURVEYS AFTER EXPOSURES, (5) DIRECTLY

SURVEY TO PROTECT AGAINST UNAUTHORIZED ENTRY DURING OPERATIONS, (6) PREVENT UNAUTHORIZED

PERSONNEL FROM PERFORMING RADIOGRAPHY, ANO (7) POST THE VEHICLE USED FOR TRANSPORTING SDURCE

AND EXPOSURE DEVICE. AEC STATED THAT IMPRDVEMENTS WERE NEEDED IN MANAGEMENT.

USAEC, PUBLIC DOCUMENT ROOM, 1717 H ST., WASHINGTON, D.C. 20545 (25 CENTS/PAGE)

\#FAILURE, ADMINISTRATIVE CONTROL + *INSPECTION AND COMPLIANCE + \#RADIOGRAPHY + SOURCE, RADIATION

15-26315 ALSO IN CATEGORY 17

RADIATION CONTROL OEVICE FOR RADIOGRAPHY ROOM

PARKER INDUSTRIAL X-RAY CORP., NEW HAVEN, CONNECTICUT

1 PAGE, LETTER TO AEC DIVISION STATE AND LICENSEE RELATIONS FROM P.J. ROSENBAUM, NOVEMBER 30, 1964

COMPANY RESPONSE TO AEC CITATION IS THAT THE AREA MONITOR FOR THE RADIOGRAPHY ROOM HAS BEEN REPAIRED. COMPANY DISAGREES WITH AEC RECOMMENDATIOV FJR CALIBRATION OF THE SURVEY METER AND REQUESTS AEC TO INDICATE IF THE CALIBRATION POINTS ARE SUGGESTEO OR MANDATORY.

USAEC, PUBLIC DOCUMENT ROOM, 1717 H ST., WASHINGTON, D.C. 20545 (25 CENTS/PAGE)

* PERSONNEL PROTECTIVE DEVICE + \#RADIOGRAPHY + INSPECTION ANO COMPLIANCE + INSTRUMENTATION CALIBRATION + INSTRUMENTATION, RADIATION MONITORING

15-26216 ALSO IN CATEGORY 17

RADIATION CONTROL OEVICE FOR RADIOGRAPHY ROOM

U. S. ATOMIC ENERGY COMMISSION, WASHINGTON, D.C.

1 PAGE, LETTER TO PARKER INOUSTRIAL X-RAY LABORATORY FROM E.R. PRICE, JANUARY 4, 1965

AEC AGAIN REQUESTS THAT COMPANY SPECIFY STEPS TAKEN TO ENSURE THAT RADIOGRAPHY WILL BE

CONDUCTED IN ROOM ONLY NHEN IT IS EQUIPPED WITH AN OPERABLE CONTROL DEVICE. ALSO, THE SURVEY

INSTRUMENT SHOULD BE CALIBRATED BY CHECKING AT LEAST TWO POINTS ON THE SCALE. THIS WILL BE A

REQUIREMENT WHEN THE LICENSE IS RENEWED.

USAEC, PUBLIC DOCUMENT ROOM, 1717 H ST., WASHINGTON, D.C. 20545 (25 CENTS/PAGE)

* instrumentation cal ibration + *instrumentatinn, raoiation monitoring + mersonnel protective deVice + INSPECTION AND COMPLIANCE + RAOIOGRAPHY

$15-26317 \quad$ ALSO IN CATEGORY 17

RAOIATION CONTROL DEVICE FOR RAOIOGRAPHY ROOM

PARKER INDUSTRIAL X-RAY, NEW HAVEN. T.ONNFC.TITIIT

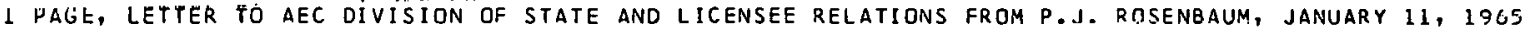

COMPANY RESPONSE TO AEC CITATION FOR LACK UF OPERABLE RADIATION CONTROL DEVICE IN RADIOGRAPHY ROOM STATED THAT (1) DOOR TO ROOM IS EOUIPPED WITH. A BAR ACROSS IT TO PREVENT ACCIDENTAL ACCESS, $(2)$ AN AREA MONITOR MONITORS THE RADIATION LEVEL NEAR THE ENTRANCE TO THE ROOM WHENEVER RADIDGRAPHY IS PERFORMED IN THE ROOM, ANO (3) IF THE PILL FAILS TO RETURN TO THE POT WHEN THE SAFE LIGHT FLASHES, THE AREA MONITOR WOULD INOICATE THIS FACT WHEN THE DOOR IS OPENED. THE MONITOR IS CONSIDERED AS A CONTROL.

USAEC, PUBLIC DOCUMENT ROOM, $1717 \mathrm{H}$ ST., WASHINGTON, D.C. 20545 (25 CENIS/PAGE)

* INSTRUMENTATION, RADIATION MONITORING + INSPECTION AND COMPlianCE + PERSONNEL PROTECTIVE DEVICE + RADI OGRAPHY

15-26318 ALSO IN CATEGORY 17

RADIATION CONTROL DEVICE FOR RADIOGRAPHY ROOM

U.S. ATOMIC ENERGY COMMISSION, WASHINGTON, D.C.

2 PAGES, LETTER TO PARKER INDUSTRIAL X-RAY LABORATORY FROM E.R. PRICE, MARCH 23,1965

CLARIFIES STATEMENTS MADE BY COMPANY CONCERNING THE CONTROL DEVICE'(AREA MONITOR). REGULATIONS STATE THAT THE DEVICE SHALL EITHER CAUSE THE RAOIATION LEVEL TO BE REDUCED WHEN AREA ENTRY OCCURS OR SHALL ENERGIZE A CONSPICUOUS OR AUDIBLE ALARM SUCH THAT THE INOIVIDUAL ENTERING AND THE LICENSEE ARE MADE AWARE OF THE ENTRY. COMPANY CONSIDERS IHE AREA MONITOR AS A CONTROL, AND IT WAS REPAIRED AND OPERATING WITHIN A WEEK AFTER INSPECTION FOUND IT INOPERATIVE.

USAEC, PUBLIC DOCUMENT ROOM, $1717 \mathrm{H}$ ST., WASHINGTON, D.C. 20545 (25 CENTS/PAGE)

* INSPECTION AND COMPLIANCE + *INSTRUMENTATION, RADIATION MONITORING + \#PERSONNEL PROTECTIVE DEVICE + MONITOR, RADIATION, AREA + RADIOGRAPHY 
ENVIRONMENTAL SURVEYS, MANITORING 15

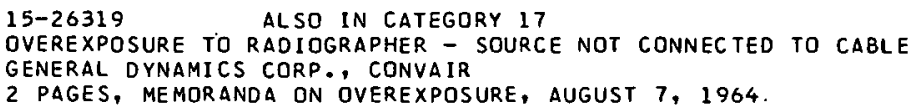

ON AUGUST 6, 1964 , RADIOGRAPHER RECEIVED A DOSE OF 3.8 REMS. AFTER AN EXPOSURE, THE SOURCF WAS RETRACTED, BUT THE LIGHT INDICATING THAT THE SOURCE WAS SAFELY STDRED WAS NDT RECEIVED. WAS RETRACTED, BUT THE LIGHT INDICATING THAT THE SOURCE WAS SAFELY STDRED WAS NOT REC
THE EXPOSURE DEVICE WAS DUTSIDE A TANK, WHILE THE SOURCE TUBE WAS INSIDE. WHEN THE RADI OGRAPHER FOUND HIS DOSIMETER. WAS OFF SCALE, IT WAS DISCOVERED THAT THE SOURCE WAS NOT ATTACHED TO THE OPERATING CABLE. CORRECTIVE ACTION INCLUDED 3 DAYS SUSPENSION WITHOUT PAY AND A REVIEW OF THE INCIDENT AND CORRECT PROCEDURES WITH ALL RADIOGRAPHERS.

USAEC, PUBLIC DOCUMENT ROOM, 1717 H ST:, WASHINGTON, D.C. 20545 (25 CENTS/PAGE)

\#FAILURE, OPERATOR ERROR + INCIDENT, NONREACTOR + PERSONNEL EXPOSURE, RADIATION + RADIOGRAPHY + SOURCE, RADIATION

15-26320 ALSO IN CATEGORY 17

OVEREXPOSURE TO RADIOGRAPHERS

SCHLUMBERGER WELL SURVEYING CORP., HOUSTON, TEXAS

1 PAGE, TEX TU AEC OIVISION JF COMPLIANCE REGION IV FRTM A.C. CHEATHAM, MAY 26,1966

A MONTHLY DOSIMETRY REPORT SHOWED THAT EXPOSURES TO TWO INDIVIDUALS WERE 42 AND 3.5 REMS, APPARENTLY TO COLLIMATED BEAMS. A INVESTIGATION IS UNDERWAY.

USAEC, PUBLIC DOCUMENT ROOM, 1717 H ST, WASHINGTON, D.C. 20545 (25 CENTS/PAGE)

\#PERSONNEL EXPOSURE, RADIATION + \#RAOIOGRAPHY + INCIOENT, NONREACTOR

15-26321 ALSO IN CATEGUÝY 17

AEC CITATION FOR NONCOMPLIANCE WITH RADIOGRAPHY PROCEOURES

U.S. ATOMIC ENERGY COMMISSIOSN, WASHINGTON, D. C.

2 PAGES, LETTER TO GLOBAL X-RAY ANO TESTING CORP. FROM E.R. PRICE, OECEMBER 1 , 1965

AN AEC INSPECTION IN OCTOBER 1965 RESULTED IN CITATION FOR (I) POSSESSING A SOURCE NOT

AUTHORIZED BY LICENSE AND $(2)$ USING A SOURCE IN ANCHOZAGE, ALASKA, CONTRARY TO LICENSE.

USAEC, PUBLIC DOCUMENT RODM, 1717 H ST., WASHINGTON, O.C. 20545 (25 CENTSIPAGE)

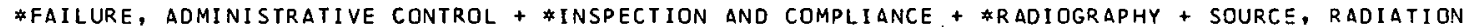

$15-26325$ ALSO IN CATEGORY 17

CITATION FOR DEFICIENCIES IN RADIOGRAPHY PROCEDURES

U.S. ATOMIC ENERGY COMMISSION, WASHINGTON, D. C.

2 PAGES, LETTER TO PIPEWELD X-RAY CORPORATION FRDM E.R. PRICE, JANUARY 28,1965

AEC INSPETTIONS RESULTED IN CITATIONS FOR $(1)$ NOT PROVIDING RADIOGRAPHERS WITH.COPIES OF AEC LICENSE, (2) ALLOWING OPERATIONS BY 3 RAUIUGRAPHERS WHO WERE UVABLE TO READ A SIJRVEY METER CORRECTLY, (3) FAILURE OF RADIOGRAPHERS TO PERFORM RAOIATION SURVEY AFTER EXPOSURES, AND (4) EMPLOYEES NOT KNONING AEC REGULATIONS.

USAEC, PUBLIC DOCUMENT ROOM, 1717 H ST., WASHINGTON, D.C. 20545 (25 CENTS/PAGE)

* INSPECTION AND COMPLIANCE + \#RADIOGRAPHY + FAILURE, ADMINISTRATIVE CONTROL + FAILURE, OPERATOR ERROR + STAFFINC, TRAINING, QULI. IFICATION

15-26326 ALSO IN CATEGORY 17

RADIOGRAPHY EXPOSURE AT GENERAL DYNAMICS CORP.

GENERAL DYNAMICS CORP., GROTON, CONNECTICUT

3 PAGES, LETTER IÚ AEC DIVISION OF LICENSES FROM W. GQRVINE, APRIL 4, 1967

A RADIOGRAPHER RECEIVED A DOSE OF 3.51 REMS WHEN THE SOURCE WAS NOT FULLY RETRACTED INTO ITS SHIELD. BOTH THE RADIOGRAPHER AND ASSISTANT STATED THAT THE STORED LIGHT WAS DN, INDICATING RETRACTION. A SURVEY WAS MADE FROM THE REAR AND SIDE BUT NOT IN FRONT OF THE DEVICE. THE RETRACTION. A SURVEY WAS MADE FROM THE REAR AND SIDE BUT NOT IN FRONT OF THE DEVICE. THE
DEVICE WAS LOCKED AND MOVED TO A NEW POSITION. A SECOND ASSISTANT DISCOVERED THE CONDITION WHEN HE NOTED THAT HIS SURVEY METER WAS READING 5 MR/HR.

USALC, rUBLIC DOCUMENT RחMM, $171 \%$ H ST., WASHINGTON, D.C. 20545 (25 CENTS/PAGE)

\#PERSONNEL EXPOSURE, RADIATION + \#RADIOGRAPHY + INCIOËNT, HUMAN ERROR + INCIDENT, NONREACTOR + SOURCE, RADIATION 
15-26328 ALSO IN CATEGORY 17

AEC CITATION FOR NONCOMPL IANCE WITH RADIOGRAPHY REGULATIONS

U.S. ATOMIC ENERGY COMMISSION, WASHINGTON, D. C.

4 PAGES, LETTER TO SARNIA INSPECTION COMPANY, LTD. FROM E.R. PRICE, OCTOBER 1 , 1965

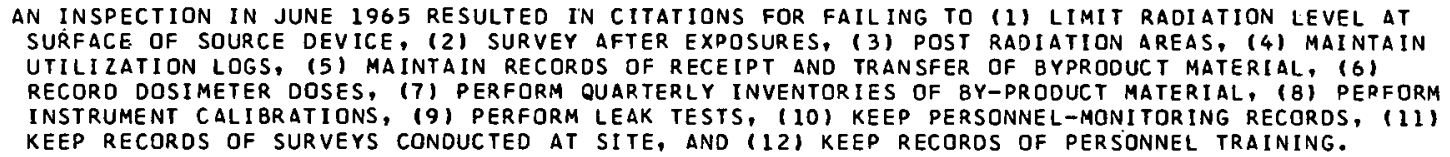

USAEC, PUBLIC DOCUMENT ROOM, 1717 H ST., WASHINGTON, D.C. 20545 (25 CENTS/PAGE)

*FAILURE, AOMINISTRATIVE CONTROL + \#INSPECTION ANO COMPLIANCE + \#RADIOGRAPHY + RADIATION SAFETY AND CONTROL

15-26329 ALSO IN CATEGORY 17

FAILURE TO USE SURVEY METER RESULTS IN OVEREXPOSURE TO RADIOGRAPHER

SCOPE INSPECTION CO.. INC., HOUSTON, TEXAS

2 PAGES, LETTER TO AEC DIVISION OF STATE ANO LICENSE RELATIONS FROM D. THOMAS, MAY 11 , 1967

ON APRIL 23, 1967, RADIOGRAPHER RECEIVED A WHOLE-BODY DOSE OF 6.1 REMS AND A CALCULATEO DOSE OF 162 REMS TO THE LEFT HAND. SOURCE FAILED TO RETURN TO CAMERA, AND RAOIOGRAPHER DID NOT USE SURVEY METER. WHEN FILM WAS PROCESSED, HE BECAME AWARE THAT THE SOURCE WAS STILL IN THE SNORKEL. HE GOT SURVEY METER, CUT PLASTIC SNDRKEL, AND REPLACED THE SOURCE IN THE. CAMERA.

USAEC, PUBLIC DOCUMENT ROOM, 1717 H ST., WASHINGTON, D.C. 20545 (25 CENTS/PAGE)

* INCIDENT, HUMAN ERROR + \#PERSONNEL EXPOSURE, RADIATION + \#RAOIOGRAPHY + INCIDENT, NONREACTOR + SOURCE, RADIATION

15-26350 ALSC IN CATEGORY 17

OVEREXPOSURE TO SUPERVISORS DURING RECOVERY OF EXPOSED SOURCE

U.S. NAVY, PORTSMOUTH NAVAL SHIPYARD, PORTSMOUTH, NEW HAMPSHIRE

3 PAGES, LETTER TO DIVISION OF MATERIALS LICENSING FROM W.C. HUSHING, FEBRUARY 10,1965

AT 3 AM ON JANUARY 13, 1965, A RADIOGRAPHER NOTIFIED HIS SUPERVISOR OF DIFFICULTIES IN RETRACTING A 108-CURIE SOURCE. THE SUPERVISOR AND ASSOCIATE SUPERVISOR RECEIVED OVEREXPOSURES RETURNING THE SOURCE TO THE PROJECTOR (FAILED TO SURVEY THE AREA PROPERLY). ALSO, THE SUPERVISOR TOOK OFF HIS JACKET CONTAINING HIS FILM BADGE OURING THE DPERATION. DOSES WERE 3 AND 3.124 REMS. HAND EXPOSURE WAS ESTIMATED AT 6 REMS. CAUSE OF INCIDENT RADIOGRAPHER FAILED TO CONNECT THE SOURCE TUBE TO THE PROJECTOR.

USAEC, PUBLIC DOCUMENT ROOM, 1717 H ST., WASHINGTON, D.C. 20545 (25 CENTS/PAGE)

\#PERSONNEL EXPOSURE, RAOIATION + \#RADI OGRAPHY. + FAILURE, AOMINISTRATIVE CONTROL + FAILURE, OPERATOR ERROR + INCIDENT, HUMAN ERROR + INCIDENT, NONREACTOR + INCIDENT, RECOVERY FROM

15-26332 ALSO IN CATEGORY 17

RUST INHIBITOR CAUSES OVEREXPOSURE

U.S. ARMY, U.S. ARMY NUCLEAR DEFENSE LABORATORY, EOGEWOOD ARSENAL, MARYLAND

3 PAGES, LETTER TO AEC DIVISION OF STATE AND LICENSEE RELATIONS FROM E.G. WRIGHT, MAY 29, 1尹67

DURING A REMOTE HYDRAULIC TRANSFER OF A TOO-CURIE CO-6O SOURCE THROUGH TUBING, IT STIICK BFC.AISE OF BUILDUP OF OECOMPOSEO RUST INHIBITUK UN THE SOURCE. THE RAOIATION-AREA SUPERVISOR RECEIVED A DOSE IN EXCESS OF 5 R RETURNING THE SOURCE TO THE SHIELD. HE WAS NOT AWARE OF THE CORRECT OPERATING PROCEDURES FOR THE SURVEY METER AND FAILED TO NOTE THAT BATTERIES WERE LOW, RESULTING IN A DECEPTIVELY LÜW READING. THE USE OF THE RUST INHIBITOR WAS DISCONTINUED AND ADDITIONAL TRAINING GIVEN TO OPERATIONAL PERSONNEL.

USAEC, PUBLIC DOCUMENT ROOM, 1717 H ST., WASHINGTON, D.C. 20545125 CENTS/PAGEI

* FAILURE, EQUIPMENT + \#PERSONNEL EXPOSURE, RADIATION + \#RADIOGRAPHY + \#REMOTE MANIPULATING ANO VIEWING + INCIDENT, HUMAN ERROR + INCIDENT, NONREACTOR + SOURCE, RADIATION

15-26333 ALSO IN CATEGORY 17

RESPONSE TO AEC CITATION FOR RAOIOGRAPHY DEFICIENCIES

NATI ONAL TANK COMPANY, TULSA, OKLAHOMA

2 PAGES, LETTER TO AEC, WASHINGTON, D. C. FROM F.L. SILVERS, JUINE 12, 1967

ON MARCH 12, 1967, A RADIGGRAPHER RECEIVED A OOSE OF 4550 MR (APPARENTLY FAILED TO SURVEY AND SOURCE DID NOT RETRACT). COMPANY RESPONSE TO AEC CITATION - 11 ) CALIBRATED AND OPERABLE SURVEY INSTRUMENTS WILL BE AVAILABLE AND USED AFTER EACH EXPOSURE, (2) APOLOGIZEO FOR NOT INCLUDING EXPOSURE INFORMATION IN PREVIOUS LETTER, (3) LOG SHEET IMPROVED, (4) RAOIOGRAPHERS 
$15-26333$ *CONTINUED*

INSTRUCTED TO MAKE SURVEYS AT BEGINNING AND END OF EACH SHIFT (IN ADOITION TO OTHER SURVEYS REQUIRED BY PROCEDURESI, AND (5) A NEW SURVEY INSTRUMENT WITH AUDIBLE-SIGNAL ATTACHMENT WAS PURCHASED.

USAEC, PUBLIC DOCUMENT ROOM, 1717 H ST., WASHINGTON, O.C. 20545 (25 CENTS/PAGE)

\#FAILURE, OPERATOR ERROR + \#PER SONNEL EXPOSURE, RADIATION + INCIDENT, NONREACTOR + INSPECTION AND COMPLIANCE + RADIOGRAPHY + SOURCE, RAOIATION

15-26336 ALSO IN CATEGORY 17

RESPONSE TO AEC CITATION FOR DEFICIENCIES IN RADIOGRAPHY PROCEDURES

SINCO TESTING INC., PORT HURON, MICHIGAN

6 PAGES, LETTER TO AEC, WASHINGTON, D. C., OCTOBER 17, 1966

ON SEPT. 26, 1966, AEC CITED COMPANY FOR 33 DEFICIENCIES. COMPANY PESPONSE - (1) RECORDS NOH ARE ON FILE FOR INSTRUMENT CALIBRATIONS, DUALIFICATION RECOROS OF RADIOGRAPHERS, AND SOURCE LEAK TESTS, (2) STORAGE OF SOURCE IN UNLOCKED CAMERA OCCURRED BECAUSE OF SHORTAGE OF STORAGE CONTAINERS (THE SOURCE HAD DECAYED AND WAS READY TO BE SHIPPED TO SUPPLIER. ANO THE LOCK WAS BEING REPAIRED), (3) RADIOGRAPHERS HAVE BEEN INSTRUCTED TO RECHARGE DOSIMETERS DAILY, AND (4) UNPOSTED AREAS HAVE BEEN POSTED.

USAEC, PUBLIC DOCUMENT ROOM, $1717 \mathrm{H}$ ST., WASHINGTON, D.C. 20545 (25 CENTS/PAGE)

\#FAILURE, ADMINISTRATIVE CONTRDL + \#INSPECTION AND COMPLIANCE + MONITOR, RADIATION, PERSONNEL + RADIOGRAPHY + SOURCE, RADIATION + STORAGE CONTAINER

15-26337 ALSO IN CATEGORY 17

RESPONSE TO AEC CITATION FOR RADIOGRAPHY DEFICIENCIES

SCOPE INSPECTION CO.. INC.. HUIISTON, TEXAS

4 PAGES, LETTER TO AEC DIVISION OF COMPLIANCE FROM D. THOMAS, AUGUST 2, 1967

ON APRIL 27, 1967, RADIOGRAPHER RECEIVED A DOSE OF 6.1 REMS WHILE RETURNING A SOURCE TO SAFE WHICH HAD STUCK IN SNORKEL TUBE. COMPANY RESPONDED TO CITATION THAT (I) ALL EMPLOYEES HAD BEEN NOTIFIED OF INCIDENT AND THAT THE INDIVIDUAL HAD BEEN DISCHARGED (WHICH DID MORE GOOD THAN A WEEK OF LECTURES), (2) RETRAINING OF ALL RADIOGRAPHERS STARTED, (3) IF UNAUTHORIZEO PERSONS VISIT EXPOSURE AREAS, RADIOGRAPHY WILL CEASE, 141 WEEKLY UNANNOUNCED INSPECTION AT ALL OF JOB SITES ARE NOW BEING MADE.

USAEC, PUBLIC DOCUMENT ROOM, 1717 H ST., WASHINGTON, D.C. 20545 (25 CENTSIPAGE)

*FAILURE, ADMINISTRATIVE CONTROL + \#INSPECTION AND COMPLIANCE + \#PERSONNEL EXPOSURE, RADIATION * FAILURE, OPERATOR ERROR + RADIOGRAPHY

15-26338 ALSU'IN CATELUKY IT

RESPONSE TO AEC CITATION FOR RADIOGRAPHY DEFICIENCIES

SARNIA INSPECTION COMPANY, SARNIA, ONTARIO

3 PAGES, LETTER TO AEC DIVISION OF STATE AND LICENSEE RELATIONS FRIJM T. ARNESEN, OCTOBER 26 , 1965

AN AEC INVESTIGATION IN JUNE 1965, AND A CITATION FOR DEFICIENCIES, RESULTED IN COMPANY RESPONDING THAT (1). CRACKS SEEMINGLY DEVELOP OVERNIGHT IN THE LEAD-SHIELDED CAMERAS,

RESULTING IN DOSE RATES IN EXCESS OF 50 MR/HR IALL CAMERAS WILL BE REPLACED WITH THOSE USING DEPLETED URANIUM), (2) OPERATORS HAVE BEEN INSTRUCTED TO USE SURVEY METERS AFTER EXPOSURES, (3) SIGNS WILL BE POSTED OUR ING EXPOSURES. RECORD-KEEPING DEFICIENCIES AT THE ORANGE, TEXAS, OFFICE HAVE BEEN CORRECTED.

USAEC, PUBLIC UUCUMENT ROOM, 1717 H ST̈., HASHINGTON, D.C. 20545 (25 CENTS/PAGE)

\#FAILURE, AOMINISTRATIVE CONTROL + \#FILURE, EQUIPMENT + \#FAILURE, OPERATOR ERROR +

*INSPECTION AND COMPLIANCE + * STORAGE CONTAINER + RADIOGRAPHY + SOURCE, RADIATION

15-26340 ALSO IN CATEGORY 17

RADIATION EXPOSURE TO EXPERIENC ED RADIOGRAPHERS

U.S. NAYY, PUGET SOUND NAVAL SHIPYARD, BREMERTON, WASHINGTON

4 PAGES, MEMORANDIMM OF RADIATION EXPOSURE INCIDENT, SEPTEMBER 6, 1967

RADIOGRAPHER B, WITH 5 YEARS EXPER IENCE, ASSUMED THAT SOURCE HAD BEEN RETRACTED WHEN CRANKING BECAME DIFFICULT. ACTUALLY, MORE EFFORT WAS NEEDED ON LAST TURN TO RETRACT SOURCE ARDUND AN $S$ CURVE IN SHIELD. RADI OGRAPHER A, WITH 10 YEARS EXPERIENCE, SURVEYED FROM REAR ANO OBTAINED NURMAL READINGS SINCE SDURCE WAS SHIELDED BY CAMERA. NEITHER OBSERVED THAT STORAGE LIGHT HAS NOT INDICATING THAT SOURCE HAD BEEN RETRACTED. RADIOGRAPHER A RECEIVED A DOSE OF 3500 MR, AND B $290 \mathrm{MR}$.

USAEC, PU8LIC DOCUMENT ROOM, 1717 H ST., HASHINGTON, D.C. 20545 (25 CENTS/PAGE)

\#FAILURE, OPERATOR ERROR + \#PERSONNEL EXPOSURE, RADIATION + INCIOENT, NONREACTOR + RADIOGRAPHY 
CATEGORY 15

ENVIRONMENTAL SURVEYS, MONITORING AND RADIATION EXPOSURE OF MAN

15-26342 ALSO IN CATEGORY 17

RESPONSE TO AEC CITATION FOR INFRACTION OF SOURCE-HANOLING PROCEOURES

ATOMIC ENERGY OF CANADA LTD., OTTAHA, CANADA

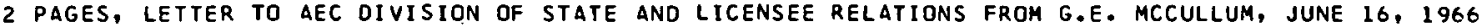

COMPANY RESPONSE INCLUDED - 11 ) WORKERS DID NOT WEAR DOSIMETERS BECAUSE THEY WERE UNABLE TO ZERO' THEM AFTER THE CHARGER WAS DAMAGED. IN FUTURE FIELO TRIPS, EACH PERSON WILL HAND CARRY A CHARGER. (2) ALL FIELO PERSONNEL ARE NOW EQUIPPED WITH AN AUDIBLE PERSONNEL MONITOR AND FILM BADGES FOR HEAD MONITORING.

USAEC, PUBLIC DOCUMENT ROOM, 1717 H ST., WASHINGTON, D.C. 20545 (25 CENTS/PAGEI

* INSPECTION AND COMPLIANCE + \#INSTRUMENTATION, RADIATION MONITORING + \#MONITOR, RADIATION, PERSONNEL + FAILURE, INSTRUMENT + FAILURE, OPERATOR ERROR + PERSONNEL PROTECTIVE DEVICE + RADIOGRAPHY

$15-26344 \quad$ ALSO IN CATEGORY 17

RADIOGRAPHY SOURCE - LOST AND FOUND

SCHLUMBERGER WELL SURVEYING CORP. HOUSTON, TEXAS

1 PAGE, LETTER TO SCHLUMBERGER WELL SERVICES FROM K.N. THOMAS, OCTOBER 16, 1967

A SOURCE WAS PLACED ON THE BUMPER OF A TRUCK PARKED NEXT TO A SECOND TRUCK IN WHICH EOUIPMENT CALIBRATIONS WERE BEING PERFORMED. THE DRIVER DROVE OFF, NOT KNOWING THAT THE SOURCE WAS ON THE BUMPER OF HIS TRUCK; NOR DID HE KNOW THAT IT HAD FALLEN OFF ALONG THE WAY. THE SOURCE WAS FOUND SHORTLY THEREAFTER IN A DITCH BY ONE OF SEVERAL SEARCH PARTIES.

USAEC, PUBLIC DOCUMENT ROOM, 1717 H ST., WASHINGTON, O.C. 20545 (25 CENTS/PAGE)

\#RAOI OGRAPHY + \#SOURCE, RADIATION, LOST + FAILURE, OPERATOR ERROR + INCIDENT, HUMAN ERROR

15-26345

ALSO IN CATEGORY 17

RADI OGRAPHY SOURCE ABANDONED IN OKLAHOMA WELL

SCHLUMBERGER WELL SURVEYING CORP., HOUSTON, TEXAS

2 PAGES, LETTER TO AEC, WASHINGTON, D. C. FROM 0.C. CHEATHAM, SEPTEMBER 21, 1967

ON SEPT. 12, 1967, A 1.5-CURIE CS-137 SOURCE STUCK IN A WELL IN OKLAHOMA. FISHING OPERATIONS CONTINUED UNTIL SEP.T. 18 , WHEN IT WAS DETERMINEO THAT THE SOURCE WAS CLEAR OF THE CEVTER OF THE WELL AND THAT A 4-1/2-IN. CASING COULD BE RUN TO THE PRODUCING ZONE BELOW. TWENTY FEET OF CEMENT WAS SPOTTED BELOW AND ABOVE THE SOURCE, WHICH WAS AT A DEPTH OF 3520 FEET, AND THE SOURCE WAS ABANOONED.

USAEC, PUBLIC DOCUMENT ROOM, 1717 H ST., WASHINGTON, D.C. 20545 (25 CENTSIPAGE)

*RAOIOGRAPHY + *SOURCE, RADIATION, LOST

15-26346 AL SO IN CATEGORY 17

RADIOGRAPHY SOURCE LOST IN PACIFIC OCEAN

SCHLUMBERGER WELL SURVEYING CORP.. HOUSTON, TEXAS

2 PAGES, LETTER TO AEC DIVISION ÖF I.TC.FNSING AND REGULATION FROM O.C. CHEATHAM, AUGUST G, I9GS

ON AUGUST 1, 1965, A 1.5-CURIE CS-137 SOURCE HAS LOST IN A STANDARD OIL CO. OF CALIFORNIA WELL 12 MILES OFF THE COAST OF OREGON. THE SOURCE HAD 4 CONTAINING SHELLS, OF WHICH TWO WERE PRESSURE TESTEO AT 25,000 PSI. THE 12,000-FT WELL WAS ABANDONEO AS A DRY HOLE. THE BOTTOM 200 FT WAS PLUGGED WITH CEMENT CONTAINING JUNK IRON.

USAEC, PUBLIC DOCUMENT ROOM, $1717 \mathrm{H}$ ST., WASHINGTON, D.C. 20545 (25 CENTS/PAGE)

\#OCEAN AND SEA + *RADIOGRAPHY + *SOURCE, RADIATION, LOST

15-26347 ALSO IN CATEGORY 17

RADIOGRAPHY SOURCE LOST IN 4,186 FT. WELL

SCHLUMBERGER WELL SURVEYING CORP., HOUSTON, TEXAS

2 PAGES, LETTER TO AEC DIVISION OF LICENSING AND REGULATION FROM 0.C. CHEATHAM, JUNE 17, 1965

ON JUNE 7, 1965, A 1-CURIE CS-137 SOURCE STUCK AT THE BOITOM OF A $4186-F T$ WELL IN WEST VIRGINIA. RETRIEVAL. EFFORTS WERE DISCONTINUED 5 DAYS LATER. THE BOTTOM 50 FT OF THE WELL WAS FILLED WITH CEMENT AND JUNK IRON TO PRECLUDE REENTRY. THE SOURCE MATERIAL HAD 5 CONT A INING SHELLS, OF WHICH ONE WAS PRESSURE TESTED AT 25,000 PSI. FRESH-WATER ZONES IN THE VICINITY ARE AT DEPTHS NO GREATER THAN 100 FT FROM THE SURFACE.

USAEC, PUBLIC DOCUMENT ROOM, 1717 H ST., WASHINGTON, D.C. 20545 (25 CENTS/PAGE)

\#RADIOGRAPHY + \#SOURCE, RAOIATION, LOST 
CATEGORY 15

ENVIRONMENTAL SURVEYS, MONITORING AND RAOIATION EXPOSURE DF MAN

15-26350 ALSO IN CATEGORY 17

RADIOGRAPHY SOURCE FALLS APART

RADIATION PRODUCTS, BURLINGTON, MASSACHUSETTS

2 PAGES, LETTER TO DIRECTOR DIVISION OF MATERIALS LICENSING FROM R.J. PREST, MARCH 24,1967

A 10-CURIE IRIDIUM-192 SOURCE FELL APART WHILE BEING USED BY WALWORTH CO., GREENSBURG, PA. RETRIEVAL OF THE 5 PELLETS WAS ACCOMPL ISHED WITH MINOR CONTAMINATION AND PERSONNEL EXPOSURES OF 280 AND 5 MR. STEPS WERE TAKEN BY THE FABRICATOR TO EXAMINE AND IMPROVE THE QUALITY OF THE CAPSULE WELDS.

USAEC, PUBLIC DOCUMENT ROOM, 1717 H ST., WASHINGTIN, D.C. 20545 (25 CENTS/PAGE)

*FAILURE, FABRICATION ERROR + \#SOURCE, RAOIATION + PERSONNEL EXPOSURE, RADIATIQN

15-26351 ALSO IN CATEGORY 17

RADIOGRAPHY INCIDENT - CARELESS ATTITUDE TOWARD RADIATION RESULTS IN TERMINATION PITTSBURGH TESTING LABORATORY, PITTSBURGH, PENNSYLVANIA

2 PAGES, LETTER TO AEC DIVISION OF LICENSING ANO REGULATION FROM H.F. HEDDERICH, OCTOBER 2.4 , 1964

THE RADIOLOGICAL SAFETY COORDINATOR DISCOVERED THAT A RADIOGRAPHER HAD EXCEEDED HIS QUARTERLY EXPOSURE LIMIT, ACCORIING TI A PHONE CALL FROM THE FILM-BADGE PROCESSOR. RADIOGRADHER COULD NOT EXPLAIN BUT ADMITTED THAT HIS DOSIMETER HAD GONE BEYOND RANGE ON ONE OCCASION. HE HAS TERMINATED BECAUSE OF CARELESS ATTITUDE TOWARD RADIATION SAFETY, FAILING TO RECORD THE FACT THAT HIS DOSIMETER HAD GONE BEYDND RANGE, FAILING TO REPORT THE OVEREXPOSURE, AND TARDINESS IN FORWARDING A STATEMENT CONCERNING THE EXPOSURE.

USAEC, PUBLIC DOCUMENT ROOM, $1717 \mathrm{H}$ ST., HASHINGTON, D.C. 20545 (25 CENTS/PAGE)

*ADMINISTRATIVE CONTROL + \#PERSCNNEL EXPOSURE, RADIATION + \#RADIOGRAPHY + FAILURE, OPERATOR ERROR + INCIDENT, HUMAN ERROR + INCIDENT, NONREACTOR + RADIATION SAFETY ANO CONIROL

$15-26352 \quad$ ALSC IN CATEGORY 17

RADIOGRAPHY INCIDENT - CHANGING HANDS DURING SOURCE RETRIEVAL RESULTS IN EXPOSURE

PITTSBURGH TESTING LABORATORY, PITTSBURGH, PENNSYLVANIA

4 PAGES, LETTER TO AEC DIVISION OF LICENSING AND REGULATION FROM R.G. GALLAGHAR, OCTOBER 21 , I964

RADIOGRAPHER RECEIVED BODY DOSE OF 3.1 R AND HAND DOSE OF 3.9 . AT THREE AM, AFTER MAKING $\triangle$ AN EXPOSURE, THE RADIOGRAPHER WAS CRANKING THE SOURCE BACK TOWARO THE STORAGE CONTAINER AND CHANGED HANDS DURING THE CRANKING, INVERTING THE SOURCE DP IVE MECHANISM. THE SOURCE HENT BACK DOWN THE TUBE 8 ELOW A THICK CONCRETE FLOOR WHERE IT WAS SHIELOEO FROM THE SURVEY METER. WHEN THE METER REAOING DROPPED BACK TO NORMAL, HE ASSUMED THAT THE SOURCE WAS BACK IN THE SAFE AATE SURVEY.

USAEC, PUBLIC DOCUMENT ROOM, $1717 \mathrm{H}$ ST., WASHINGTON, 0.C. 20545 (25 CENTS/PAGE)

\#INCIDENT, HUMAN ERROR + \#PERSONNEL EXPOSURE, RADIATION + \#RADIOGRAPHY + INCIDENT, NONREACTOR + SOURCE, RADIATION

15-26353 ALSO IN CATEGORY 17

RESPONSE TO AEC CITATION FOR DEFICIENCIES IN RADIOGRAPHY OPERATIONS

PITTSBURGH TESTING LABORATORY, PITTSBURGH, PENNSYLVANIA

6 PAGES, LETTER TO E.R. PRICE, AEC DIVISION OF STATE AND LICENSEE RELATIONS FROM H.F. HEDDERICH, AUGUST 7, 1964

EXPLANATIONS GIVEN FOR EACH OF 8 VIOLATIONS AT THE ALABAMA BRANCH AND 5 VIOLATIONS AT THE PITTSBURGH BRANCH. ALABAMA BRANCH DENIES 11 ) NÜI INSTRUCTING EMPLOYEES DN HAZARDS AVD PRECAUTIONS TO MINIMIZE EXPOSURES, AND $(2)$ USING AN UNAUTHORIZED CONTROL CABLE IN AN EXPOSURE DEVICE. PENNSYLVANIA BRANCH DENIES $(1)$ FAILURE TO MAKE SURVEYS IN UNRESTRICTED AREAS AND (2) ALLOWING RADIATION LEVELS ON SURFACE OF STORAGE CONTAINER TO EXCEED LIMITS. THE CONTAINER WAS RECEIVED THE SAME DAY THE INSPECTOR ARRIVED. HOWEVER, ITS INADEQUACY HAD BEEN ANTICIPATED, AND SPECIAL CONTAINERS HAD BEEN CONSTRUCTED, WHICH WERE BEING PAINTED. THE CONTAINER IN OUESTION HAS SHOWN TO THE INSPFCTOR TO VERIFY THEY HAD ANTICIPATED ITS INADEQUACY.

USAEC, PUBLIC DOCUMENT ROOM, 1717 H ST., HASHINGTON, D.C. 20545 (25 CENTS/PAGE)

*FAILURE, ADMINISTRATIVE CONTROL + *INSPECTION AND COMPLIANCE + \#RADIOGRAPHY + \#STORAGE CONTAINER + FAILURE, OPERATOR ERROR + PERSONNEL EXPOSURE, RADIATION + SOURCE, RADIATION

15-26355 ALSO IN CATEGORY 17

RESPONSE TO AEC CITATION FOR RADIOGRAPHY DEFICIENCIES

PIPEWELD X-RAY CORPORATION, PERRYSBURG, OHIO

3 PAGES, LETTER TO AEC DIVISION OF STATE ANO LICENSEE RELATIONS FROM C. EARLE, JR., FEBRUARY I4, I966 
CATEGORY 15

ENVIRONMENTAL SURVEYS, MONITORING AND RADIATION EXPOSURE OF MAN

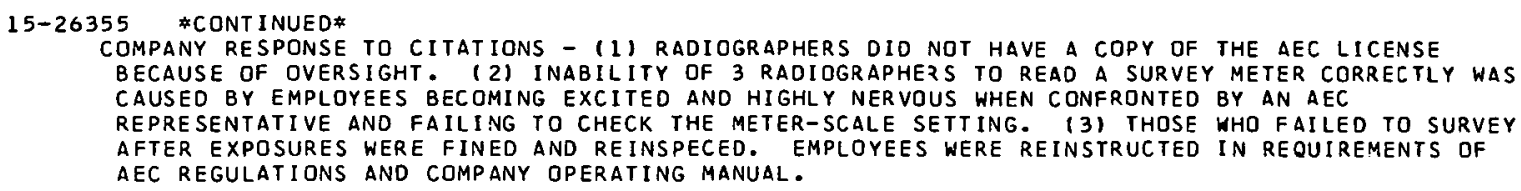

IN THE FUTURE, PERSONNEL WILL SIGN A STATEMENT THAT THEY HAVE RECEIVED INSTRUCTION ON COMPANY RAOIOGRAPHY PROCEDURES. PERSON HAVING COPY OF RAOIOGRAPHERS TEST QUESTIONS AND ANSWERS HAD GOTTEN AN OLDER RADIOGRAPHER TO WRITE THEM OUT FROM MEMORY TO ASSIST HIM IN STUDYING TO CHANGE HIS CLASSIFICATION (REPRESENTED LESS THAN $1 / 2$ OF TEST QUESTIONS). RECURRING VIOLATIONS - FAILURE TO SURVEY AFTER EXPOSURE AND RECORO KEEPING OCCUR BECAUSE AEC DID NOT DIRECT THE CITATIONS TO THE RADIOGRAPHER BUT TO THE COMPANY. ADVOCATES THAT AEC LICENSE (NDT COMPANYI INDIVIDUAL SO THAT THREAT OF REVOCATION WOULO ELIMINATE RADIOGRAPHER LAXITY IN FOLLOWING PROCEDURES.

USAEC, PUBLIC DOCUMENT ROOM, 1717 H ST., WASHINGTON, D.C. 20545 (25 CENTSIPAGE)

\#FAILURE, ADMINISTRATIVE CONTROL + \#INSPECTION AND COMPLIANCE + *RADIOGRAPHY + FAILURE, OPERATOR ERROR + RADIATION SAFETY AND CONTROL + STAFFING, TRAINING, QUALIFICATION

15-26357 ALSO IN CATEGORY 17

RAOIOGRAPHY OVEREXPOSURES FOR CALENDAR QUARTER

PIPEWELO X-RAY CORP. , PERRYSBURG, OHIO

2 PAGES, LETTER TO AEC DIVISION OF LICENSING AND REgULATION FROM C. EARLE, JR., JULY 22,1964

REPORTS THAT SIX RADIOGRAPHERS RECEIVED EXPOSURES FOR QUARTER EXCEEDING 1.25 REMS. MAXIMUM WAS 2.25 REMS. ONE RADIOGRAPHER HAD BEEN LEAVING HIS CLOTHES (AND BADGE) ON A STEAM RAOIATOR AT NIGHT. ANOTHER OVERDOSE WAS ATTRIBUTED TO INACCURATE FILM-BADGE READINGS BECAUSE OF A PARTI ALLY OBLITERATED FILM.

USAEC, PUBLIC DOCUMENT ROOM, 1717 H ST., WASHINGTON, D.C. 20545 (25 CENTS/PAGE)

*FAILURE, ADMINISTRATIVE CONTROL + PPERSONNEL EXPOSURE; RADIATION + \#RADIOGRAPHY + FAILURE, OPERATOR ERROR

15-26359 ALSU IN CATEGURY 17

LOOSE SCREW ON RADIOGRAPHY EQUIPMENT RESULTS IN EXPOSURES

NEW YORK SHIPBUILDING CORPORATION, CAMDEN, NEW JERSEY

3 PAGES, LETTER TO AEC OIVISION OF LICENSING AND REGULATION FROM E.P. ANDERSON, NOVEMBER 15 , 1963

FIVE INDIVIDUALS RECEIVED RADIATION EXPOSURES - 1.2 R, 1.2, 280 MR, 130 MR, 90 MR - WHEN AN ALLEN SET-SCREW ON THE SOURCE DISCONNECT WORKED LOOSE AND CAUSED THE SOURCE TO STICK IN THE SOURCE TUBE ABDUT 2 FT OUT FROM THE SHIELD. THE SOURCE WAS REMOVED BY CUTTING OFF THE OUTBOARD END OF THE SOURCE TUBE AND PLACING THE OPEN END, CONNECTED TO THE CAMERA, INTO A LEAD BALL. THE SOURCE WAS THEN CRANKED OUT INTO THE LEAD BALL AND DISCONNECTED FROM THE OPERATING CABLE. ALL SUPERVISORS WERE INSTRUCTED TO PERIODICALLY CHECK THE DISCONNECTS.

USAEC, PUBLIC DOCUMENT ROOM, 1717 H ST., WASHINGTON, D.C. 20545 125 CENTS/PAGEI

* INCIDENT, EQUIPMENT + \#PERSONNEL EXPOSURE, RADIATION + \#RADIOGRAPHY + INCIDENT, RECOVERY FROM + SOURCE, RADIATION

15-26362 ALSO IN CATEGORY 17

LEAK ING RADIOGRAPHY SOURCE CONTAMINATES EQUIPMENT

NATIONAL TANK COMPANY, TULSA, OKLAHOMA

2 PAGES, LETTER TO E.R. PRICE, AEC DIVISION OF STATE AND LICENSEE RELATIONS FROM F.L. SILVERS, JUNE 25, 1965

A RADIOGRAPHIC CAMERA AND SOURCE TUBE WERE FOUND TO BE CONTAMINATED FROM A LEAKING IRIOIUM SOURCE. INTERCHANGING OF SOURCE TUBES HAD ALSO CONTAMINATED A COBALT SOURCE.

USAEC, PUBLIC DOCUMENT RODM, $1717 \mathrm{H}$ ST., HASHINGTON, D.C. 20545 (25 CENTS/PAGE)

\#CONTAMI NATION + \#RADIOGRAPHY + \#SOURCE, RAOIATION + INCIOENT, NONREACTOR 
CATEGORY 15

ENVIRONMENTAL SURVEYS, MONITORING AND RADIATION EXPOSURE OF MAN

$15-26364$
RLSO IN CATEGORY 17
RADIOGRAPHY OVEREXPOSURE DUE TO FAILURE TO SURVEY

MATERIALS TESTING LAB, EAST HARTFORD, CONNECTICUT

2 PAGES, LETTER TO AEC OIVISION OF LICENSING AND REGULATIONS FROM F. LENT, JULY 26,1965

A RAOIOGRAPHER RECEIVED A OOSE OF 1.74 REMS AS A RESULT OF FAILURE TO SURVEY AFTER COMPLETING AN EXPOSURE. THE SOURCE HAD NOT RETRACTED TO THE STOREO POSITION IV THE CONTAINER. THE INCIDENT WAS DISCUSSED WITH ALL COMPANY RAOIOGRAPHERS, AND AN AUDIBLE RADIATION ALARM WAS INSTALLED IN THE EXPOSURE ROOM.

USAEC, PUBLIC DOCUMENT ROOM, 1717 H ST., WASHINGTON, D.C. 20545 (25 CENTS/PAGE)

* INCIOENT, HUMAN ERROR + *PERSONNEL EXPOSURE, RADIATION + \#RADIQGRAPHY + INCIDENT, NONREACTOR + SOURCE, RAOIATION + SURVEY, RADIATION, GENERAL

$15-26365 \quad$ ALSO IN CATEGORY 17

INCIDENT INVOLVING 3000 CURIE CO-60 THERAPY SOURCE

L.UTHERAN GENERAL HOSPITAL, PARK RIDGE, ILLINOIS

2 PAGES, LETTER TO DIVISION OF MATERIALS LICENSING FROM F.L. HUSSEY, M.0., MARCH 23,1966

A 3000-CURIE COBALT-60 SOURCE WAS DROPPED ONTO IHE TREATMENT ROOM TLLOR OF THE LUTHEPAN GENERAL HOSPITAL WHILE BEING TRANSFERRED FROM ITS SHIPPING CONTAINER INTO A THERAPY MACHINE. BARRICADES AND SIGNS WERE POSTED UNTIL REMOTE-HANOLING EOUIPMENT COULD SE OBTAINED. THE FOLLOWING EVENING THE SOURCE WAS RECOVERED. NO CONTAMINATION RESULTED. (EXPOSURE DOSES NOT GIVEN.)

USAEC., PUBLIC DOCUMENT ROOM, $1717 \mathrm{H}$ ST., WASHINGTON, D. $\dot{C} .20545$ (25 CENTS/PAGE)

\#RADIOLOGY + \#REMOTE MANIPULATING AND VIEWING + \#SOURCE, RAOIATION + INCIOENT, HUMAN ERROR +
INCIDENT, NONREACTOR + INCIDENT, RECOVERY FROM + RADIATION SAFETY AND CONTROL + RADIOGRAOHY

15-26366 ALSO IN CATEGÖRY 17

CITATION FOR DEFICIENCIES IN RADIOGRAPHY PROCEOURES

UNITED STATES ATOMIC ENERGY COMMISSION

2 PAGES, LETTER TO PIPEWELD X-RAY CORPORATION FROM E.R. PRICE, JANUARY 13, 1967

CITEO FOR (1) ALLOWING RAOIOGRAPHY BY PERSONS NOT INSTRUCTEO IN PROCEDURES NOR SHOWN USE OF DEVICES, (2) POOR RECORD KEEPING, AND (3) FAILURE TO SURVEY AFTER EXPOSURES. AEC NOTED THAT ONE RADIOGRAPHER HAO A COPY OF THE QUESTIONS AND ANSWERS TO THE COMPANYS RADIOGRAPHY EXAMINATION. ITEMS 2 AND 3 ARE VIOLATIONS WHICH HAVE BEEN CITEO IN PREVIOUS INSPECTIONS, AND THE REASON FOR THEIR RECURRENCE SHOULD BE IDENTIFIED.

USAEC, PUBLIC DOCUMENT RDOM, 1717 H ST., WASHINGTON, D.C. 20545 (25 CENTSIPAGE)

\#FAILURE, ADMINISTRATIVE CONTROL + \#INSPECTION AND COMPLIANCE + \#RADIOGRAPHY + FAILURE, OPERATOR ERROR

15-26368 ALSO IN CATEGORIES 17 AND

FIRE CONSUMES TRUCK TRANSPORTING RADIOGRADHY SOURCE

LANE-WELLS, HOUSTON, TEXAS

3 PAGES, LETTER TO AEC OIVISION OF STATE AND LICENSE RELATIONS FROM J.C. WILSON, AUGUST 29 , 1966

A FIRE CONSUMED A TRUCK TRANSPORTING A 1-CURIE CESIUM SOURCE. WHEN THE FIRE WAS EXTINGUISHED, THE SOURCE WAS FOUND FLOATING ON THE MOLTEN LEAD FROM THE SHIELO. THE SOURCE WAS RETRIEVED, UNDAMAGED, AND PLACED ON A I ID OF A TOOL BOX. WHILE WAITING FOR A RADIOLOGICAL ASSISTANCE TEAM CALLED BY A HIGHWAY PATROLMAN ON THE SCENE, THE RATROI.MAN PICKED UP THE SOURCE AND HELD IT FOR I MIN. HE RECEIVED A DOSE OF 100 MILLIREMS WHDI.E BODY AND IO REMS TO HANDS. OTHER EXPOSURES WERE MINIMAL.

USAEC, PUBLIC DOCUMENT ROOM, 1717 H ST,, WASHINGTON, D.C. 20545 (25 CENTS/PAGE)

\#FIRE + *RADIOGRAPHY + \#TRANSPORTATION AND HANDLING + INEIDENT, NONREACTOR +

PER SONNEL EXPOSURE, RAOIATION + SOURCE, RAOIATION

$15-26370 \quad$ ALSO IN CATEGORY 17

RADIOGRAPHY SOURCE DROPPEO INTO KAH RIVER

H.R. INSPECTION SERVICE, SHAWNEE, KANSAS

1 PAGE, LETTER TO AEC DIVISION OF LICENSING AND REGULATIONS FROM H.W. ROGERS, APRIL 12, 1964

WHILE MAKING EXPUSURES ON A BRIOGE BEING BUILT OVER THF KAW RIVER, A GUST OF WINO BLEW A WELDERS SCAFFOLD OVER, KNOCKING A CAMERA AND SOURCE INTO 5 FT OF WATER. THE SOURCE GUIOE-TUBE BROKE AND THE SOURCE OISCONNECTED FROM THE CONTROL CABLE. THE SOURCE WAS RETRIEVED WITH A ROPE AND MAGNET. MAXIMUM PERSONNEL EXPOSURE WAS 125 MILLIREMS. A SAFETY CHAIN ON THE CAMERA WILL BE IISED FOR FUTURE EXPOSURES. 
$15-26370$ \#CONT INUED*

USAEC, PUBLIC DOCUMENT ROOM, 1717 H ST., NASHINGTON, D.C. 20545 (25 CENTS/PAGE)

\#RADI OGRAPHY + *SOURCE, RADIATION, LOST + INCIOENT, NONREACTOR + INCIDENT, RECOVERY FROM + RIVER, GENERAL

15-26371 ALSO IN CATEGORY 17

RADIOGRAPHY EXPOSURE AT GENERAL DYNAMICS CORP.

GENERAL DYNAMICS CORPORATION, GROTON, CONNECTICUT

4 PAGES, LETTER TO AEC DIVISION OF LICENSING FROM W. GQRVINE, JULY 20, 1965

RADIOGRAPHER RECEIVED A DCSE OF 4.2 REMS, AS INDICATED BY A FILM BADGE WORN ON HIS LAPEL. CALCULATIONS INDICATED A DOSE OF 9.6 REMS TO THE BJDY MIDSECTION. THE SOURCE WAS NOT COMPLETELY RETRACTED AFTER AN EXPOSURE. DISCOVERY OF THE UNSAFE CONDITION WAS MADE BY A RADIATION AUDITOR DURING A ROUTINE SURVEY, WHO THEN ALERTED THE RADIOGRAPHER THAT THE CONTROL LIGHTS ON THE DEVICE WERE INDICATING THAT THE SOURCE WAS NOT RETRACTED. THE CAUSE WAS ATTRIBUTED TO FAILURE TO FOLLOW PROCEDURES ANO MAKE PROPER SURVEYS.

USAEC, PUBLIC DOCUMENT ROOM, 1717 H ST., WASHINGTON, D.C. 20545 (25 CENTS/PAGE)

*PER SONNEL EXPOSURE, RADIATION + *RADIOGRAPHY + INCIDENT, HUMAN ERROR + INCIDENT, NONREACTOR + SOURCE, RADIATION

15-26372 ALSO IN CATEGORY 17

RAOI OGRAPHY EXPOSURE AT CONSOLIDATED X-RAY SERVICE CORP.

CONSOLIDATED X-RAY SERVICE CORPORATION, DALLAS, TEXAS

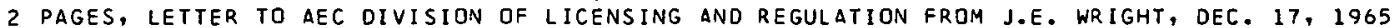

( (LETTER) AT MIONIGHT ON DECEM8ER 4, 1965, FOLLOWING AN EXPOSIIRE, THE SOURCE DID NOT RETURN TO THE CAMERA. AN ASSISTANT RAOIUGRAPHER COILED THE SNORKLE WITH THE END CONTAINING THE SOURCE ABOUT 2 FT FROM HIS HAND, WALKEO TO A DITCH, THEN SET UP FOR ANOTHER EXPOSURE. AFTER WALKING OUT OF THE RADIATION FIELD, IT WAS DISCOVERED THAT THE SOURCE WAS NOT SHIELDED. COPIES OF A COMPILATION OF INCIOENTS WERE SENT TO ALL EMPLOYEES TO EMPHASIZE NECESSITY OF PROPER SURVEYS.

USAEC, PUBLIC DOCUMENT ROOM, $1717 \mathrm{H}$ ST., WASHINGTON, D.C. 20545 (25 CENTS/PAGE)

\#PERSONNEL EXPOSURE, RADIATION + \#RADIOGRAPHY + INCIDENT, HUMAN ERROR + INCIDENT, NONREACTOR + SOURCE, RADIATION

15-26373 ALSO IN CATEGORY 17

RAOIOGRAPHY INCIDENT - SOURCE FELL APART

CONAM INSPECTION, INC., TULSA, OKLAHOMA

2 PAGES, LETTER TO E.R. PRICE (AEC) FROM L.E. COOMBS, SEPTEMBER 30, 1966

SURVEY METER INDICATED THAT SOURCE HAD NOT RETRACTED. THE SOURCE TUBE WAS DISCONNECTED AND SHAKEN SO THE LOOSE SOURCE COULD BE RETRIEVED WITH TONGS. THE SOURCE HAD BECOME UNSCREWED AND FIVE IRIDIUM PELLETS FELL OUT ONTO THE GROUND. THE EARTH WAS SCOOPED UP AND PELLEIS LOCATLD. CONTAMINATEU DIRT WAS SHIPPED TO LOUISIANA FOR DISPOSAL, ANO SOURCE SIIPPLIER WAS NOTIFIED SO ACTIDN GOULD BE TAKEN TO PREVENT A RECIIRRENCE.

USAEC, PUB́LIC DOCUMENT ROOM, 1717 H ST., WASHINGTON, D.C. 20545 (25 CENTS/PAGE)

* INCIDENT, EQUIPMENT + \#INCIDENT, RECOVERY FROM + \#RADIOGRAPHY + SOURCE, RADIATION

15-26374 ALSO IN CATEGORY 17

RADIOGRAPHY EXPOSURE AT CONAM INSPECTION, INC.

CONAM INSPECTION COMPANY

3 PAGES, LETTER TO AEC OIVISION OF LICENSING AND REGULATIONS FROM L.E. COOMBS, JULY 31,1967

RADIOGRAPHER PERFORMING ROUTINE MAINTENANCE ON EXPOSURE DEVICE REMOVED 3 SCREWS FROM CAMERA, WHICH PERMITTED SOURCE TO DISLODGE FROM SHIELDEO POSITION. SOURCE WAS RETURNEO BUT WENT BETWEEN LEAD CONTAINER AND OUTSIDE ALUMINUM CASE. SURVEY METER WAS ON TOP OF EXPOSURE DEVICE (PARTIALLY SHIELOED FROM SOURCE), INOICATING SOURCE WAS IN PROPER PLACE. WITH THE SHIELO AND (PART IALLY SHIELOED FROM SOURCE), INDICATING SOURCE WAS IN PROPER PLACE, WITH THE SHIELO AND
SOURCE IN THE TRUCK, RADIOGRAPHER AND HELPER DROVE 13 HR TO RETUPN TO CONAM FACILITY, WHERE SOURCE IN THE TRUCK, RADIOGRAPHER AND HELPER DROVE 13 HR TO RETURN TO CONAM FACILITY, WHERE
THE UNSHIELDED SOURCE WAS DISCOVERED IMMEDIATELY. FILM BADGE OF ONE READ 24.5 MR. DRIVER OF TRUCK WAS NOT WEARING BADGE. ESTIMATED RANGE OF EXPOSURES WAS $15 R$ TO $300 R$.

USAeC, Public document RDOM, 1717 H ST., WASHINGTON, D.C. 20545. (25 CENTS/PAGE)

* INCIDENT, HUMAN ERROR + \#PERSONNEL EXPOSURE, RADIATION + \#RADIOGRAPHY + INCIDENT, NONREACTOR + SOURCE, RADIATION

15-26375 ALSO IN CATEGORY 17

RADIOLOGIST QUARTERLY DOSE EXCESSIVE

SAINT FRANCIS HOSPITAL, FULSA, OKLAHOMA

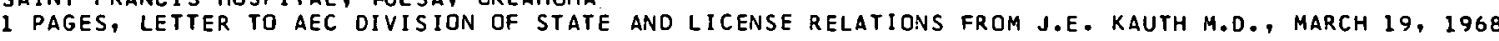


CATEGORY 15

ENVIRONMENTAL SURVEYS, MONITORING ANO RADIATION EXPOSURE OF MAN

$15-26375 \%$ CONTINUED*

RAOIOLOGIST WAS HOLDING PATIENTS WHILE PORTABLE FILMS HERE TAKEN. QUARTERLY DOSE HAS 1874 MILLIREMS. YEARLY DOSE FOR 1967 WAS 6723 MILLIREMS.

USAEC, PUBLIC DOCUMENT RODM, $1717 \mathrm{H}$ ST., WASHINGTON, D.C. 20545 (25 CENTS/PAGE)

*FAILURE, operator ERROR + \#RADIOLgGY + PERSONNEL EXPOSURE, RADIATION + RADIOGRAPHY

15-26376 ALSO IN CATEGORY 17

CITATION FOR DEFICIENCY IN RADIOGRAPHY OPERATIONS

PITTSBURGH TESTING LABORATORY, PITTSBURGH, PENNSYLVANIA

3 PAGES, LETTER TO AEC DIVISION OF STATE ANO LICENSE RELATIONS FROM H.F. HEODERICH, FEBRUARY 23 , 1965

COMPANY RESPONSES TO CITATIONS RESULTING FROM INYESTIGATION DEC. 7HE NATURE AND EXTENT OF EXPOSURE WAS BECAUSE WE COULD -NOT HONESTLY EVALUATE THE EXTENT OF EXPOSURE IN THE ALLJTTED TIME, AND (2) FAILURE TO PERFORM SIX UNANNOUNCED INSPECTIONS IN THE THIRD QUARTER WAS OVERSIGHT BY FORMER EMPLOYEE, AND PERFORMANCE OF ALL SIX WITHIN THO WEEKS WAS DUE TO CHANGE IN PERSONNEL AND NEED TO MEET REQUIREMENT.

USAEC, PIJRI IC DOCUMENT ROOM, 1717 H ST., WASHINGTON, D.C. 20545 (25 CENTS/PAGE)

*FAI LURE, AOMINISTRATIVE CONTROL + \#INSPECTION AND COMPLIANCE + \#RADIOGRAPHY * STAFFING, TRAINING, QUALIFICATION

15-26377 ALSO IN CATEGORY 17

RECOVERY OF UNCOUPLED SOURCE - PLAN MINIMIZEO PERSONNEL EXPOSURE

PITTSBURGH. TESTING LABORATORY, PITTSBURGH, PENNSYLVANIA

4 PAGES, LETTER TO AEC OIVISION OF LICENSING AND REGULATION FROM H.F. HEDDERICH, DECEMBER 8 , 1 O64

ON NOV. 9, 1964, AT $3 / 30$ AM, A RADIOGRAPHER NOTICED THAT THE CRANK HANDLE OF RADIOGRAPHY EXPOSURE DEVICE WAS WORKING TOO FREELY. AN INTERMEDIATE CONNECTION BETWEEN TWO LENGTHS OF SOURCE IUBE HAD WORKED LOOSE. THE SOURCE HAD RUN DUT DF THE TUBE AT. THAT POINT, AND THE CONTROL CABLE HAD EXTENDED BEYOND THE GEAR WHEEL. THE PIGTAIL ALSO BECAME UNCOUPLED WHILE OUTSIDE THE SOURCE TUBE. THE SUPERVISOR, RADIOGRAPHER, AND RADIATION SAFETY OFFICER FORMULATED A PLAN. THE RSO, WHILE STANDING BEHIND STEEL COLUMN AND USING 8-FT HANDLING RODS, MANIPULATED SOURCE AND RETURNED IT TO THE EXPOSURE DEVICE. MAXIMUM EXPOSURE WAS ?SO MR.

USAEC, PUBLIC DOCUMENT ROOM, 1717 H ST., WASHINGTON, D.C. 20545 (25 (ENTS/PAGE)

* INC IDENT, RECOVERY FROM + *RADIOGRAPHY + INCIDENT, NONREACTOR + PERSONNEL EXPOSURE, RADIATION + RADIATION SAFETY ANO CONTROL + SOURCE, RADIATION

15-26378 ALSO IN CATEGORY 17

FILM BADGE REPUKI UT RAOIOLOGIST AT MILWAUR.EE HISPITAL

MILWAUKEE HOSPITAL, MILWAUKEE, HISCONSIN

3 PAGFS, LETTER TO AEC DIVISION OF LICENSING AND REGULATION FROM J.R. CAMEPON, MARCH 1\%, 10G4

SUBSEQUENT TO EXTENSIVE REMODELING OF THE X-RAY DEPARTMENT, A RAOIOLOGICAL FHYSICIST SUKVFYED THE OEPARTMENT AND RECOMMENDED REPORTING THE QUARTERLY. FILM-BADGE QEADINGS FOR 1962 AND 1063 BECAUSE HOSPITAL HAO A BY-PRODUCT LICENSE. OVEREXPOSURES BELIEVEO TO BE DUE TO HEAVY FLUOROSCOPIC WORK LDAD. READINGS WERE 0.32 REM, $1.269,1.404,0.45,2.125,1.587,0.581$, 0.216 .

USAEC, PUBLIC DOCUMENT ROOM, 1717 H ST., WASHINGTON, D.C. 20545 (25 CENTS/PAGE)

\#PERSONNEL EXPOSURE, RADIATION + \#RADIOLDGY + FAILURE, ADMINISTRATIVE LUN'IKUL + RADIATION SAFETY AND CONTROL + RADIOGRAPHY + SOURCE, RADIATION + X-RAY

15-26379 ALSO IN CATEGORY 17

OVEREXPOSURE TO THERAPY TECHNICIAN

U.S. ARMY, WALTER REED ARMY MEOICAL CENTER

8 PAGES, LETTER TO AEC DIVISION OF LICENSING AND REGULATION FROM R. NYSTROM, JR., JANUARY IO, I9E7

A FILM-RADGE REPORT INDICATED THAT A RADIATION-THERAPY TECHNICIAN HAD RECEIVED AN EXPOSURE OF 15.3 REMS GAMMA AND 4.93 BETA FUK IHE PERIOO G NOV. THROUGH 3 DF. .. 1 OGS, ON ONE OCCASION THE TECHNICIAN WAS REQUIREO TO ASSIST A PATIENT FROM THE TREATMENT TABLE WHEN THE 1ESO-CURIE COBALT-60 SOURRE FAILED TO RETRACT. A DOSE OF 3.3 REMS WAS ATTRIBUTED TO THIS INCIDENT. WHEN ANO HOW THE ADOITIOMAL DOSAGE WAS ACQUIREO COULD NOT BE DETERMINED. A COMMITTEF DECLARED THE THERAPY UNIT UNSAFE, SHUT IT DOWN FOR REPLACEMENT, ANO RECOMMENDED TIIAT TECHNICI AN BE RETURNED TO DUTY.

USAEC, PUELIC DOCUMENT ROOM, $1717 \mathrm{H}$ ST., WASHINGTON, D.C. 20545 (25 CENTS/PAGEI

*PERSONNEL EXPOSURE, RADIATION + \#RADIOLOGY + FAILURE, EQUIPMENT + INCIDENT, EQIIIPMENT + INCIOENT, NONREACTOR + RADIOGRAPHY + SOURCE, RAOIATION 
15-26380 ALSO IN CATEGORY 17

SEQUENCE OF EVENTS LEADS TO OVEREXPOSURE

U.S. NAVY

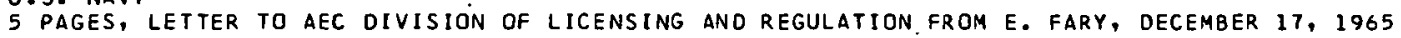

RADIOGRAPHS WERE BEING MADE OF A SUBMARINE UNDERGOING OVERHAUL IN DRYOOCK. ALL WORKMEN HAD LEFT FOR LUNCH. ROPE BARRICADES AND WARNING SIGNS HAO BEEN SET UP, A 4-MIN. EXPOSURE

STARTED, AND THE 2 RADIOGRAPHERS WERE ON GUARD TO PREVENT ENTRY INTO THE RADIATION AREA. NO ANNDUNCEMENT OF THE RADIOGRAPHY WAS MADE BECAUSE THE INTERCOM WAS NOT WORKING. THE LIGHTS IN THE EXPOSURE AREA WENT OUT FOR TRANSFER TO ANOTHER POWER SOURCE. AN OFFICER ON AN INSPECTION TOUR PROCEEDEO FROM ANOTHER DIRECTION IN A CARKENEO PASSAGEHAY, FELT THE SIGN BUT COULONT

TELL WHAT IT SAID, WENT UNDER THE ROPE BARRICADE, NOTICED THE EXPOSURE HEAO, TOUCHEO IT AND WAS THEN OBSERVED BY THE RADIOGRAPHERS, WHO WARNED HIM OUT OF THE RADIATION AREA. DOSE WAS 5 REMS WHOLE-BODY, AND 350 TO FINGERTIPS OF LEFT HANO.

USAEC, PUBLIC DOCUMENT ROOM, $1717 \mathrm{H} \mathrm{ST.,} \mathrm{WASHINGTON,} \mathrm{D.C.} 20545$ (25 CENTS/PAGE)

\#FAILURE, SEQUENTIAL + \#PERSONNEL EXPOSURE, RADIATION + \#RADIOGRAPHY + FAILURE, EQUIPMENT +

INCIDENT, HUMAN ERROR + INCIDENT, NONREACTOR + RADIATION SAFETY AND CONTROL

15-26381 ALSO IN CATEGORY 17

CLUSS RD

DVEREXPOSURE TO RADIOGRAPHER DURING STORAGE OF SOURCE

U.S. NAVY, MARE ISLAND SHIPYARD

3 PAGES, LETTER. TO AEC OIVISION OF MATERIALS LICENSING FROM CHIEF OF BUREAU OF SHIPS, APRIL 14 , 1965

ON MARCH 10, 1965, A RADI OGRAPHER RECEIVED AN ESTIMATED DOSE OF 46.6 REMS TO THE LEFT HAND AND 400 MREM WHOLE BDDY. A PROJECTOR WITH SOURCE HAD BEEN OAMAGEO WHEN A TRANSFER WAGON OVERTURNED. TWO BOLTS HOLOING THE CONTROL BOX TO THE PROJECTOR WERE BROKEN, AND UNKNOWN TO THE OPERATORS, THE THREAOS OF THE REMAINING TWO BOLTS WERE STRIPPED. THE PRDJECTOR HAS BEING RETURNED TO STORAGF. AND, WHILE SUSPENDED FROM A CRANE, THE WEIGHT DF THE CABLES CAUSED THE CONTROL BOX, PIGTAIL, ANO SOURCE TO PULL FREE. THE RAOIOGRAPHER PICKEO UP THE PIGTAIL ANO RETURNED THE SOURCE TO THE PROJECTOR.

USAEC, PUBLIC DOCUMENT ROOM, 1717 H ST., WASHINGTON, D.C. 20545 (25 CENTS/PAGE)

\#FAILURE, OPERATOR ERROR + \#PERSONNEL EXPOSURE, RADIATION + \#RADIOGRAPHY + FAILURE, EQUIPMENT + INCIDENT, HUMAN ERROR + INCIDENT, NONREACTOR

15-26382 ALSO IN CATEGORY 17

FARY EJ INADEQUATE SURVEY RESULTS IN OVEPEXPOSURE TO RADIOGRAPHER

INADEQUATE

3 PAGES, LETTER TO AEC DIVISION OF LICENSING AND REgULATION FROM COMMANDER OF SAN FRANCISCO BAY NAVAL SHIPYARD, JULY 7, 1965

DUR ING THE MIONIGHT TO 8 AM SHIFT ON JUNE 10,1964, A RADIOGRAPHERS HELPER RECEIVEO A DOSE OF 12.5 REMS, THE RADIOGRAPHER 0.09. AFTER AN EXPOSURE, THE SOURCE DI N NOT T NMDLETELY NLTURII TO THE SHIELD. ANR MN TMADGQUATC SURUCY'PAILEU IU RLVEAL YHE NARROW RADIATION BEAM. THE CONNECTOR OF THE SHIELDING NOZZLE WAS MISALIGNED, WIIICH COULD CAUSE THE SOURCE TO HANG IN THE PARTI ALLY SHIELOED POSITION. THE SURVEY METER HAD A RESPONSE LAG TIME WHEN SWITCHED FROM OFF TO DN, WHICH MAY HAVE CONTRIBUTED TO INADEQUATE SURVEY.

USAEC, PUBLIC DOCUMENT ROOM, 1717 H ST., WASHINGTON, D.C. $20545 \cdot(25$ CENTS/PAGE)

* PER SONNEL EXPOSURE, RADIATION + \#RADIOGRAPHY + FAILURE, EQUIPMENT + FAILURE, OPERATOR ERRTR + INC IDENT, HUMAN ERROR + INCIDENT, NINREACTOR

15-26383 ALSO IN CATEGORY 17

GVEREXPOSURE TO RAOIOGRAPHERS

U.S. NAVY, PHILAOELPHIA NAVAL SHIPYARD

2 PAGES, LETTER TO AEC DIVISION OF LICENSING AND REgULATION FROM R.A. MOUNT, NOVEMBER 18 , 1965

ON NOVEMBER 2, 1965 , TWO RAOI OGRAPHERS RECEIVED OVEREXPOSURES OF 2.5 AND 3.5 REMS WHEN THEY TRIED TO RETURN THE SOURCE TO THE SHIELD. THEY HAD SUPPOSEDLY CONNEC,TFN THF S RIIRCE CABLE TO THE DRIVE CABIF.

USAEC, PUBLIC DOCUMENT ROOM, 1717 H ST., WASHINGTON, D.C. 20545 (25 CENTS/PAGE)

*FAILURE, OPERATOR ERROR + \#PERSONNEL EXPOSURE, RADIATION + \#RADIOGRAPHY + INCIDENT, HUMAN ERROR + INCI DENT, NONREACTOR

15-26384 ALSO IN CATEGORY 17

RESPONSE TO AEC CITATION FOR NONCOMPLIANCE IN RADIOGRAPHY OPERATIONS 
15-26384 \#CONTINUED*

UNITED STATES TESTING COMPANY, HOBOKEN, N.J.

5 PAgES, LETTER TO AEC DIVISIDN OF STATE AND LICENSE RELATIONS FROM A. L. BRASSELL, NOVEMBER 26 , 1965

PERSONNEL CHANGES RESULTED IN RELAXATION OF EMPLOYEE TRAINING. SHORTAGES OF DOSIMETERS RECTIFIED BY PURCHASE OF OTHERS. FILM BADGES NOW ASSIGNED TO PERSONNEL. RECORD-KEEPING SYSTEM WAS REVISED, MONTHLY EQUIPMENT INVENTORY STARTED TO ENSURE THAT PERSONNEL WILL HAVE SURVEY METERS AND THAT REGULAR CALIBRATION IS PERFORMED. RETRAINING PROGRAM GIVEN TO ALL

RADIOGRAPHERS AND ASSISTANTS, ALL WORKERS WERE ISSUED COPIES OF EMERGENCY PROCEDURES, RADIATION SAFETY OFFICER NOH REVIEWS DAILY THE UTILIZATION LOG.

USAEC, PUBLIC DOCUMENT ROOM, $1717 \mathrm{H}$ ST., WASHINGTON, D.C. 20545125 CENTS/PAGEI

*FAILURE, aDMINISTRATIVE CONTROL + \#FAILURE, OPERATOR ERROR + *inSPECTION ANO COMPLIANCE + \#RADIOGRAPHY

15-26385 ALSO IN CATEGORY 17

CONTAMINATION FROM LEAKING RADIOGRAPHY SOURCE

TWIN CITY TESTING AND ENGINEERING LABORATORY, INC., ST. PAUL, MINNESOTA

2 PAGES, LETTER TO AEC, WASHINGTON, D.C. FROM H. T. SCHULZE, SEPTEMBER 30,1966

AFTER FILM WAS FOUND. FOGgED WHILE STORED NEXT TD THE SOURCE TUBES AND CONTROL CABLES, CONTAMINATION FROM A LEAKING IRIDIUM-192 SOURCE WAS FOUND ON THE PLANT FLOORS, SUURCE STORAGE PIGS. ALSO, TRUCKS PARKED IN THE BACK OF THE PLANT WERE CONTAMINATEO TO $5-10$ MR/HR BY DIRECT READING. A TARPAULIN IN THE TRUNK OF A WORKMANS PRIVATE CAR CONTAINED ACTIVITY UP TO IOO C/SECOND. A SINGLE IRIDIUM PARTICLE HAS FOUND IN THE DRIVEWAY, WHICH READ I3OO MR/HR. HEALTH PHYSICIST RECOMMENDED THAT CABLES BE SURVEYED EACH TIME THEY ARE REMOVED FROM THE SHIELDED CONTAINER TO PREVENT SUCH INCIDENT.

USAEC, PUBLIC DOCUMENT ROOM, $1717 \mathrm{H}$ ST., HASHINGTON, D.C. 20545 (25 CENTS/PAGE)

* CONT AMINATION + \#FAILURE, EQUIPMENT + \#RAOIOGRAPHY + \#SOURCE, RADIATION + FAILURE, ADMINISTRATIVE CONTROL + RADIATION SAFETY AND CONTROL

$15-26386$ ALSO IN CATEGORY 17

FORGETFULNESS RESULTS IN OVEREXPOSURE TO RADIOGRAPHER

TWIN CITY TESTING AND ENGINEERING LABORATORY, INC., ST. PAUL, MINNESOTA

3 PAGES, LETTER TO AEC DIVISION OF STATE AND LICENSE RELATIONS FROM H. T. SCHULZE, NOVEMBER 2 , 1967

AFTER PERFORMING 15 EXPOSURES, RADIOGRAPHER SURVEYED IN THE USUAL MANNER TO ASCERTAIN THAT SOURCE WAS IN THE SAFE POSITION, BUT THIS ONE TIME HE FORGOT TO PUSH THE KEY-OPERATE? LOCK IN, WHICH WOULD LOCK THE SOURCE IN THE EXPOSURE DEVICE. OURING THE TRANSFER TO ANOTHER LOCATION, THE CRANK CAUGHT ON AN OBSTRUCTION AND FORCED THE SOURCE TO AN EXPOSED POSITION. WHILE SETTING ÜP FOR THE NEXT EXPOSURE HIS FILM BADGE IN THE SHIRT POCKET WAS 3 FT FROM THE 90-CURIE SOURCE. HIS LEFT THIGH WAS 6 TD 12 IN. AWAY. FILM BADGE READ 8.8 REMS. ESTIMATED DOSE TO THIGH WAS 70 REMS.

USAEC, PUBLIC DOCUMENT ROOM, $1717 \mathrm{H}$ ST., WASHINGTON, D.C. 20545 (25 CENTS/PAGE)

* INCIOENT, HUMAN ERROR + \#PERSONNEL EXPOSURF, RADIATION + \#RADIOGRAPHY + INCIDENT, NONREACTOR + SOURCE, RAOIATION

15-26387 ALSO IN CATEGORY 17

RESPONSE TO AEC CITATION FOR NONCOMPLIANCE IN RADIOGRAPHY PROCEDURES

TWIN CITY TESTING AND ENGINEERING LABORATORY, INC., ST. PAUL, MINNESOTA

3 TACES; LETTER TI AFF. DIVISION OF COMPLIANCE FROM C. W. BRITZIUS, JANUARY 22, 1968

AEC COMPLIANCE CITEO FOUR ITEMS OF NONCOMPLIANCE - (1) RAOIOGRAPHER FAILED TO LOCK EXPOSURF DEVICE AFTER EXPOSURE, AND FAILED TO REPORT DISCHARGE OF DOSIMETER, (2) SURVEY WAS NOT MADE TO DETERMINE EXTENT OF DOSE RECEIVED BY RADIOGRAPHER, (3) AEC NOT NOTIFIED IMMEDIATELY OF EXPOSURE INCIDENT, AND $(4)$ STORAGE OF MATERIAL AT PLACE NOT SPECIFIED BY LICENSE. COMPANY RESPONSE - (1) ITEM REVIEWED WITH ALL RADIOGRAPHERS, (2) SURVEY TECHNIQUES WERE REVIEWED AND RAOIOGRAPHERS INSTRUCTEO TO LEAVE SURVEY METERS ON AT ALL TIMES, (3) FAILED TO MARK ENVELOPE CONTAINING BADGE, SO THAT RESULTS OF REAOING WERE DELAYED, $(4)$ COMPANY MOVEO 2 BLULKS AWAY ANO NEGLECTED TO INFORM AEC.

USAEC, PUBLIC DOCUMENT ROOM, $1717 \mathrm{H} \mathrm{ST.,} \mathrm{WASHINGTON,} \mathrm{D.C.} 20545125$ CENTS/PAGEI

*FAILURE, aOMINISTRATIVE CONTROL + \#INSPECTION AND COMPLIANCE + *RADIOGRAPHY + FAILURE, uPERATUK ERROQ * RADIATION SAFETY ANO CONTROL

15-26388 ALSO IN CATEGORY 17

FAILURE TO SURVEY RESULTS IN OVEREXPOSURE TO RADIOGRAPHER

VESTER J. THOMPSON, JR., INC., MOBILE, ALABAMA

2 PAGES, LETTER TO AEC UIVISION OF LICENSING AND REgULATION FROM V. J. THOMPSON, JR., JULY 1, 1965

RADIOGRAPHER RECEIVED A QUARTERLY DOSE OF $1820 \mathrm{MR}$, OF WHICH 1050 WAS RECEIVED IN ONE EXPOSURE AS A RESULT OF FAILING TO SURVEY TO ENSURE THE RETURN OF A SOURCE TO A SAFE POSITION. THE OVEREXPOSURE AND CAIJSE HERE OISCUSSED WITH ALL THE EMPLOYEES, AND THE RADIOGRAPHER WAS 
CATEGORY 15

ENVIRONMENTAL SURVEYS, MONITORING AND RADIATION EXPOSURE OF MAN

15-26388 \#CONT INUEO*

RELIEVED OF HIS DUTIES.

USAEC, PUBLIC DOCUMENT ROOM, $1717 \mathrm{H}$ ST., HASHINGTON, D.C. $20545^{\circ}$ (25 CENTSIPAGEI

* INCIDENT, HUMAN ERROR + \#PERSONNEL EXPOSURE, RAOIATION + \#RADIOGRAPHY + INCIDENT, NONREACTOR + SOURCE, RADIATION

15-26389 ALSO IN CATEGORY 17

RADIATION DAMAGE TO HANDS DISCOVERED 2 WEEKS AFTER EXPOSURE

TECHNICAL OPERATIONS RESEARCH, BURLINGTON, MASSACHUSETTS

7 PAGES, LETTER TO AEC OIVISION OF LICENSING AND REGULATION FROM E. T. CLARKE, APRIL 16, 1965

THE RIGHT HANOS OF TWO MEN BECAME SWOLLEN AND TENDER 2 WEEKS AFTER AN ESTIMATED EXPOSURE OF $250 R$ GAMMA AND 1000 RODS BETA. TO DISLODGE IRRADIATED IRIDIUM PELLETS ADHERING TO AN ALUMINUM SPOOL BY CORROSION, THE MEN STOOD BEHIND A LEAD SHIELD AND TOOK TURNS FOR 10 MIN RAPPING THE CAPSULE CORE AGAINST THE INNER WALL OF A LEAD CONTAINER. TEN-INCH-LONG TWEEZERS WERE USED, BUT THE HANDS AERE IMMEDIATELY ABOVE THE ACTIVITY. NEITHER MAN WORE FILM BADGES OR DOSIMETERS. FUTURE HANDLING TO BE DONE UNDER SURVEILLANCE DF RADIATION SAFETY OFFICER.

USAEC, PUBLIC DOCUMENT ROOM, 1717 H ST., HASHINGTON, D.C. 20545 (25 CENTS/PAGEI

\#PERSONNEL EXPOSURE, RADIATION + \#RADIOGRAPHY + CORROSION + INCIDENT, HUMAN ERROR + INCIDENT, NONREACTOR + SOURCE, RADIATION

$15-26390 \quad$ ALSO IN CATEGORY 17

RADIATION EXPOSURE IS QUESTIONABLE

WARD W. SPARROW HOSPITAL, LANSING, MICHIGAN

2 PAGES, LETTER TO AEC DIVISION OF COMPLIANCE FROM J. C. SPENCER M.D., JANUARY 14,1965

A FILM-BADGE REPORT FOR THE PERIOD 10-26-64 THROUGH 11-8-64 INDICATED THAT ONE EMPLOYEES BADGE WAS TOO DARK TO READ. DARKENING OF THE FILM IN THE BADGE TO THAT DEGREE REQUIRES AN EXPOSURE DF 500 TO $1000 R$. INVESTIGATION AND QUESTIONING OF THE EMPLOYEE FAILED TO PROVIDE AN EXPLANATION. THE EMPLOYEE IS WELL, AND BLOOD COUNTS ARE NORMAL. THE FILM BADGE MAY HAVE BEEN DEFECTIVE.

USAEC, PUBLIC DOCUMENT ROOM, 1717 H ST., WASHINGTON, D.C. 20545 (25 CENTS/PAGE)

*PERSONNEL EXPOSURE, RADIATION + *RADIOGRAPHY + INCIDENT, NONREACTOR

15-26391 ALSO IN CATEGORY 17

RADIOGRAPHY INCIDENT AT SINCO TESTING INC.

SINCO TESTING INC., PORT HURON, MICHIGAN

4 PAGES, LETTER TO AEC OSLR FROM A. SAUCIER, OCTOBER 3, 1966

ON JULY 7, 1966, A RADIOGRAPHER RECEIVEO AN ESTIMATED DOSE OF 4000 R TO THE SKIN TF HIS HANDS. WHILE ATTEMPTING TO DISCONNECT A SOURCE FROM THE CONTRDL CABLE, HE JERKEO IT FROM THE STORAGE CONTAINER. THE 27 -CURIE SOURCE LANDED IN HIS HAND AND MADC CONTACT FOR 1 SEC.

USAEC, PUBLIC DOCUMENT ROOM, $1717 \mathrm{H}$ ST., WASHINGTON, D.C. 20545 (25 CENTS/PAGE)

\#INCIDENT, HUMAN ERROR + \#PERSONNEL EXPOSURE, RAOIATION + \#RADIOGRAPHY + INCIDENT, NONREACTOR + SOURCE, RADIATION

15-26392 ALSO IN CATEGORY 17

THIRD DEGREE BURNS SUSTAINED FROM RADIOGRAPHY INCIDENT

PI TTSBURGH TESTING L.AB, BIRMINGHAM, ALABAMA

2 PAGES, LETTER TO AEC DIV. OF LICENSING AND REGULATION, APRIL 7, 1964

A 47.7-CURIE COBALT-60 SOURCE BECAME UNCOUPLED AND JAMMED IN THE RADIOGRAPHY SOURCE TUBE I FOOT FROM THE STORAGE CONTAINER. AN ATTEMPT TO RECTIFY THE MALFUNCTION RESULTED IN ONE RADIOGRAPHER RECEIVING THIRD-DEGREE BURNS ON THREE FINGERS OF HIS LEFT HAND. FILM BADGE, WORN ON HIS BELT, READ $3.45 \mathrm{R}$. THE OTHER RADIOGRAPHER RECEIVEO AN ESTIMATED TOSE TO THE HANDS OF 1000 RADS, AND 2.05 RADS WHILLE BUOY.

USAEC, PUBLIC DOCUMENT ROOM, 1717 H ST., WASHINGTON, D.C. 20545 (25 CENTS/PAGE)

- INCIDENT, HUMAN ERROR + \#PERSONNEL EXPOSURE, RADIATION + \#RAOIOGRAPHY + FAILURE, EQUIPMENT + INCIDENT, NONREACTOR + SOURCE, RADIATION

$15-26393 \quad$ ALSO IN CATEGORY 17

FLUOROSCOPIC RADIATION EXPOSURE AT MILWAUKEE HOSPITAL

MILWAUKEE HOSPITAL, MILWAUKEE, WISCONSIN

2 PAGES, LETTER TO AEC DIVISION OF STATE AND LICENSE RELATIONS, MAY 22, 1964 
CATEGORY 15

ENVIRONMENTAL SURVEYS, MONITORING ANO RADIATION EXPOSURE OF MAN

15-26393 *CONTINUED*

A TECHNICIANS FILM-BADGE EXPOSURES FOR 2 QUARTERS OF 1963 WERE 2.125 AND 1.587 REMS AS A RESULT DF IMPROPER SHIELDING ON A NEW FLUOROSCOPIC UNIT. CORRECTIVE $\triangle C T I O N$ INCLUDED PROPER SHIELDING, WEARING OF HEAVY LEAD APRONS FOR ALL FLUOROSCOPY, AND USE OF MORE TECHNICIANS TO LESSEN INDIVIDUAL EXPOSURES.

USAEC, PUBLIC DOCUMENT RODM, 1717 H ST., WASHINGTON, D.C. 20545 (25 CENTS/PAGE)

*PERSONNEL EXPOSURE, RADIATION + \#RADIOLOGY

15-26394 ALSO IN CATEGORY 17

LOST SOURCE USED FOR DENSITY GAUGE

THE SHERWIN-WILLIAMS CO. , CHICAGO, ILLINOIS

1 PAGE, LETTER TO AEC DIV. OF COMPL IANCE FROM W. A. STARKOVICH, APRIL 2, 1968

IN EARLY DEC. 1967, COMPANY DISCOVERED THAT A 50-MILLICURIE CESIUM-137 SEALED SOURCE IPART OF A DENSITY GAUGE) WAS MISSING BUT FAILED TO NOTIFY AEC UNTIL MARCH 26, 1968. DURING THE INTERIM, AN EXTENSIVE SEARCH WAS MADE. ONE EMPLOYEE STATED THAT HE REMEMBERED CLEANING UP THE AREA AND HAD THROWN THE MATERIAL IN THE WASTE DUMPSTER. THE COMPANY WAS CITED FOR FAILURE TO NOTIFY.

USAEC, PUBLIC DOCUMENT ROOM, 1717 H ST., WASHINGTON, D.C. 20545 (25 CENTS/PAGE)

\#RADI OGRAPHY + \#SOURCE, RAOIATION, LOST + FAILURE, ADMINISTRATIVE CONTROL + RADIATION SAFETY AND CONTROL

$15-26644$

SIVINTSEV YV

ALSO IN CATEGORY 17

RADIATION SAFETY IN NUCLEAR REACTORS

640 PAGES, REFERENCES, MOSCOW, ATOMIZDAT, 1967, IN RUSSIAN

THE STANDARDS FOR RADIATION SAFETY. IN NUCLEAR REACTORS ARE REVIEHED IN OETAIL. THE MAXIMUM PERMISSIBLE RADIATION LEVELS ARE OUTLINED. METHOOS USED FOR THE DOSIMETRY OF EXTERNAL RADIATION AND THE SHIELDING NECESSARY ARE GIVEN. THE RETENTION OF FISSION PROOUCTS IN THE FUEL AND PRIMARY COOLANT OF NUCLEAR REACTORS IS DISCUSSED. THE PRECAUTIONS REQUIRED FOR RADIOACTIVE GASES AND AEROSOLS IN REACTORS ARE DESCRIBED. METHODS USED FOR MEASURING THE INTERNAL RADIATION OF REACTORS ARE GIVEN.

* RADIATION SAFETY AND CONTROL + MAXIMUM PERMISSI8LE DOSE (MPD) + REACTOR, BWR + REACTOR, POWER + REACTOR, PWR + USSR

$15-27019$

HULL AP

1965 ENVIRONMENTAL MONITORING RAOIATION LEVELS AT BROOKHAVEN NATIONAL LABORATORY

BROOKHAVIN NATIONAL LABORATORY

BNL-50093 +. 27 PAGES, 16 FIGURES, 30 TABLES, 18 REFERENCES, SEPTEMBER, 1967

SUMMART ZES MFASIIREMENTS OF NATURAL BACKGROUND RADIATION LEVELS AND OF INCREMENTS ATTRIBUTABLE TO LABORATORY OPERATIONS OBTAINED ON SITE ANO IN THE VICINITY OF BROOKHAVEN NATIONAL LABORATORY DURING 1965. THESE INCREMENTS INCLUDE CONTRIBUTIONS FROM THE GASEOUS AND PART I CULATE EFFLUENT OF THE BROOKHAVEN GRAPHITE RESEARCH REACTOR STACK, FROM MULTICURIE FIELD GAMMA SOURCES, AND FROM THE DISCHARGE OF FLOW-LEVEL LIQUID WASTES FROM THE LABORATORYS SANITARY WASTE TREATMENT PLANT INTO THE HEADWATERS OF THE PECONIC RIVER. THE ENVIRONMENTAL MONITORING PROGRAM HAS ESTABL ISHED THAT DURING 1965 RADIATION LEVELS ATTRIBUTABLE TO LABORATORY OPERATIONS WERE MAINTAINED WELL BELOW THE ESTABLISHED RADIATION PROTECTION STANDARDS OF THE AEC. FIR FXTFRNAI FXPOSURES. AIR PARTICULATE CONCENTRATIONS, AND LIOUID EFFLUENT CONCENTRATIONS. RADIATIINN LEVELS ATTRIBUTABLE TO FALLOUT WERE ALSO WELL BELOH THE ESTABL I SHED LIMITS.

AVAILABILITY - CLEARINGHOUSE FOR FEDERAL SCIENTIFIC ANO TECHNICAL INFORMATION, SPRINGFIELD, VA. 2215I $\$ 3.00$ COPY, \$0.65 MICROF ICHE

* AIRBORNE RELEASE + *BIOLÜgICAL CONCENTRATION, AQUATIC ORgANISMS + *BIOLOGICAL CONCENTRATION, MILK + *EFFLUENT + \# IODINE + *MONITOR, RADIATION, BACKGROUNO + \#MONITOR, RADIATION, ENVIRONMENTAL + \#SEOIMENT + *WASTE TREATMENT, GENERAL + AIR + BNL + PARTICULATE + RADIATIDN SAFETY AND CONTROL + STACK + TRACER, RADIOACTIVE

15-27075 ALSO IN CATEGORY 14

AIR SAMPLING METHOD AMO APPARATUS

UNITED STATES ATOMIC ENERGY COMMISSION, HASHINGTON, D.C,

BELGIUM PATENT NO. 674,456 +. 10 PAGES, 2 FIGURES, DECEMBER 29, 1965, IN FRENCH

THE INVENTION RELATES TO AN IMPROVED METHOD AND APPARATUS FOR MEASUR ING AIRBORNE CONTAMINATION. A PIECE OF FILTER PAPER IS MOUNTED OVER AN APERTURE IN A DATA-PROCESSING CARD WHICH IS PRECODEO WITH IDENTIFYING INFORMATIUN. THE CARO IS PLACEO IN A HOLDER HAVING OPPOSED RESILIENT GRASPING MEMBERS FOR HOLDING THE FILTER PAPER TAUT WHILE AIR IS DRAWN THROUGH IT.

AVAILABILITY - IT IS OUR UNDERSTANDING THAT FOREIGN PATENTS MAY BE OBTAINED IN PHOTOCOPY FROM THE U.S. 
CATEGORY 15

ENVIRONMENTAL SURVEYS, MONITORING AND RADIATION EXPOSURE OF MAN

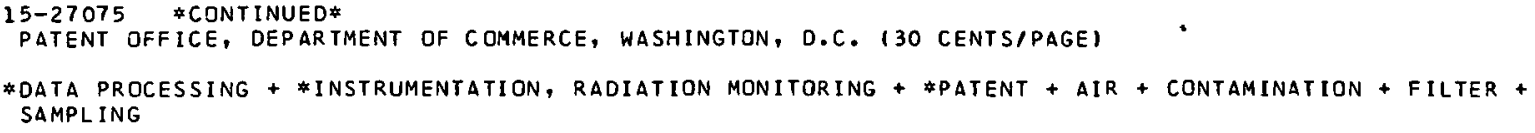

\#FALLOUT + \#NUCLEAR EXPLOSION DEBRIS + \#TRACER, RADIOACTIVE + BIOLOGICAL CONCENTRATION, AQUATIC ORGANISMS + MAXIMUM PERMISSIBLE CONCENTRATION (MPC) + UNITED KINGDOM + WASTE DISPOSAL, OCEAN

A CASE OF ACCIDENTAL INHALATION OF PROTACTINIUM-231 AND ACTINIUM-227

UKAEA, BERKS HARWELL

7 PAGES, 3 FIgURES, 14 References, health PHYSICS, 15(1), PAGES $11-17$ (JULY, 1968 )

THE BEHAVIOUR. OF ACCIDENTALLY INHALEO PA-231 AND AC-227 WAS FOLLOWED OVER THE PERIOD $7-900$ DAYS AFTER INTAKE, USING A SINGLE LARGE SODIUM IODIDE DETECTOR PLACED CLOSE TO THE CHEST. THE RESULTS COULD BE EXPLAINED BY A LONG-TERM CLEARANCE FROM THE THORAX INVOLVING BIOLOGICAL HALF-LIVES OF $1000+-300$ DAYS AND 300-400 DAYS RESPECTIVELY. THERE WAS NEGLIGIBLE MIGRATION OF AC-227 DAUGHTERS FROM THE CHEST.

\#ACTINIUM + \#DOSE MEASUREMENT, INTERNAL + \#INHALATION + \#PROTACTINIUM + ALPHA EMITTER + HAZARDS ANALYSIS + RADIATION SAFETY AND CONTROL + UNITED KINGDOM

15-27081 ALSO IN CATEGORY 14

BUILER FE

RAPID BIOASSAY METHODS FOR PLUTONIUM, NEPTUNIUM, AND URANIUM

SAVANNAH RIVER LABORATORY, AIKEN, SOUTH CAROLINA

7 PAGES, 3 FIGURES, 2 TABLES, 15 REFERENCES, HEALTH PHYSICS, 15(1), PAGES 19-24 (JULY, 1968 )

VERY SENSITIVE RAPID METHODS WERE DEVELOPEO TO DETERMINE PLUTONIUM, NEPTUNIUM, AND ENRICHEO URANIUM IN URINE. CHLORIDE COMPLEXES OF THE ACTINIDES ARE EXTRACTED FROM OXIDIZED URINE SALTS WITH THE LIQUID ION EXCHANGER TRI-ISOOCTYLAMINE (TIOA). THE ACTINIDES ARE BACK-EXTRACTED AND THEN COUNTED ON LOW-BACKGROUND SOLID-STATE COUNTERS.

*ANALYTICAL TECHNIQUE, URINE + \#BIOLOGICAL CONCENTRATION, MAN + \#NEPTUNIUM + \#PLUTONIUM + \#URANIUM + CHEMICAL ANALYSIS + COUNTER + ION EXCHANGE

15-27082 ALSO IN CATEGORY 14

TAYLOR RW + BOULOGNE AR

RAPIO SEPARATION OF STRONTIUM AND BARIUM

SAVANNAH RIVER LABORATORY, E.I. DU PONT DE NEMOURS ANO CO., AIKEN, SOUTH CAROLINA

5 PAGES, 3 FIGURES, TABLE, 6 REFERENCES, HEALTH PHYSICS, 15(1), PAGES 25-29 (JULY, 1968) 
15-27082 *CONTINUED

AN ANALYTICAL PROCEDURE IS DESCRIBED FOR THE RAPID DETERMINATION OF SR-69/90 IN THE PRESENCE OF BA/LA-140 AND OTHER FISSION PRODUCTS IN WASTE WATER FROM REACTOR ISOLATION BASINS, WHEN THE BA-140 CONCENTRATION IS GREATER THAN $25 \%$ OF THE SR-89/90 CONCENTRATION. THE METHOD COMBINES A RAPIO INDRGANIC ION EXCHANGE SEPARATION OF BARIUM FROM STRONTIUM WITH

PRECIPITATION OF SRINO3)2 FROM FUMING NITRIC ACID INTJ A 4-HR METHOD SUITABLE FOR PRE-RELSASE ANALYSIS OF WASTE WATER. DECONTAMINATION FACTORS FOR THE COMMON FISSION PRODUCTS ARE BETTER THAN 1000. THE RECOVERY OF ADDED STRONTIUM IS $85 \%$, WITH A RELATIVE STANDARD DEVIATION DF $+-7 \%$ AT THE $90 \%$ CONFIDENCE LEVEL.

* ANALYTICAL TECHNIQUE, WATER + \#RADIATION SAFETY AND CONTROL + \#REACTOR POWER + \#WASTE TREATMENT, LIQUIO + DECONTAMINATION + ENVIRONMENTAL CONDITION + ION EXCHANGE + PRECIPITATION

DISTRIBUTION OF SR-9G AND CE-144 IN THE STRATOSPHERE WAS INVESTIGATED 9Y ANALYZING HIGH-ALTITUDE AIR FILTER SAMPLES COLLECTED. IN 1962 AND 1963. THE HIGHEST CONCENTRATIONS DF SR (5.4 DIS/MIN/SCF) AND CE-144 (122 DIS/MIN/SCF) WERE OBSERVED IN APRIL 1963 AT 64-7D DEG N AND AT AN ALTITUDE OF $16.7 \mathrm{KM}$. THE CE-144/SR-90 RATIO IN. THE NORTHERN STRATOSPHERE WAS FAIRLY CONSTANT (ABOUT 20, AS OF JANUARY 1963). THE DISTRIBUTION PATTERNS OF SR-9O AND CE-144 WERE QUITE OIFFERENT FROM THOSE OF MN-54 ANO SB-124.

\#AIRBURST + \#CERIUM + \#RAOIOCHEMICAL ANALYSIS + \#STRATOSPHERE + *STRONTIUM + AIR + ATMOSPHERIC DIFFUSION, GLOBAL + FILTER + MONITOR, RADIATION, ENVIRONMENTAL + SAMPLING

15-27085

BRADY JM + AARESTAD NO + SWARTZ HM

IN VIVO DOSIMETRY BY ELECTRDN SPIN RFSINANCE SPECTROSCOPY

WALTER REED ARMY MEDICAL CENTER, WASHINGTON, D.C

5 PAGES, 8 FIGURES, 7 REFERENCES, HEALTH PHYSICS, 15(1), PAGES 43-47 (JULY, 1969)

SEVERAL TISSUES, ESPECIALLY HARD TISSUES, SHOWED PERSISTENT ELECTRON-SPIN RESONANCES FOLLOHING IN VIVO OR IN VITRO IRRADIATIONS. THE RESONANCES HAD A LINEAR RELATION TD DOSE. DOSE MEASUREMENTS WERE MADE IN TEETH AT LESS THAN 100 RAOS OF CO-60 RADIATION. THE METHOD APPEARS TO BE APPLICABLE FCR DOSIMETRY OF ACCIDENTAL IRRADIATIONS, ESPECIALLY X- OR GAMMA-RAY EXPOSURES.

* biological concentration, animal + \#Blological concentration, man + *oose measurement, internal + *DOSIMETRY, GENERAL + GAMMA EMITTER + RADIATION SAFETY ANO CONTROL + X-RAY

$15-27086$

ATTIX FH

GASIC GAMMA-RAY OOSIMETRY

NAVAL RESEARCH LABORATORY, WASHINGTON, D.C.

8 PAGES, 6 FIGURES, 4 REFERENCES, HEALTH PHYSICS, 15(1), PAGES 49-56 (JULY, 1968)

TO DO MEANINGFUL DOSIMETRY IT IS FIRST NECESSARY TO DECIDE WHAT YOU ARE TRYING TO MEASURE, AND THEN TO CHOOSE THE BEST METHOD OF MEASUR ING IT. IT IS OFTEN NOT EASY TO ANSWER EVEN THE FIRST, APPARENTLY TRIVIAL, QUESTION. IN ANY CASE, IT REQUIRES AT LEAST AN UNDERSTAND.ING OF THE 2-STEP PROCESS BY WHICH GAMMA RAYS DEPOSIT ENERGY IN MATTER, AND DF THE CONCEPTS OF T.HAR,FERTPARTIIIF FOIIII IARIIIM. AIR IMR TISSUE) EQUIYALENCE, ENERGY DEPENDENCE, FLUENCE, KERMA, $\triangle B S D R B E D$ DOSF, AND EXPOSURE.

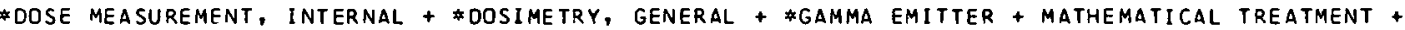
RAOIATION SAFETY ANO CUNIRUL

15-27087 ALSO IN CATEGORY 14

EVANS AG + MARTER WL + REINIG HC

GUIDES LIMITING THE RELEASE OF RAOIONUCLIDES BY THE SAVANNAH RIVER PLANT

SAVANNAH RIVER LABORATORY, E:I. DU PONT DE NEMOURS AND COMPANY, AIKEN, SOUTH CAROLINA

9 PAGES, 6 TABLES, 14 REFERENCES, HEALTH PHYSICS, 15(1), PAGES 57-65 (JULY, 1968 )

the savanNah RIVER PLANT has deVEloped planf release guides to define the amount of Varidous RAOIONHILLIDFS THAT T.AN RF RFIFASEO TO THE ENVIRUNS IN AIR AND WATER. RELEASES ARE HELO TO THE LOWEST PRACTICABLE LEVEL WITHIN PLANT OPERATING GUIDES BASED ON CAREFUL OPERATION AND ARE WELL BELOW THE RADIATION PROTECTION GUIDES RECOMMENDEO BY THE FEDERAL RAOIATION COUNCIL FOR NEIGHBORING POPULATIONS.

\#MONITOR, RADIATION, ENVIRONMENTAL + \#RAOIOACTIVITY RELEASE + * SURVEILLANCE PROGRAM *

FEDERAL RAOIATION COUNCIL + POPULATION EXPOSURE + RADIATION SAFETY AND CONTROL + SAVANNAH RIVER PLANT 
CATEGQRY 15

ENVIRONMENTAL SURVEYS, MONITORING ANO RADIATION EXPOSURE OF MAN

$15-27089$

SCHIMMERLING $W+$ SASS RE

EXPERIENCE WITH A COMMERCIAL FILM BADGE SERVICE

HEALTH PHYSICS GROUP, PRINCETON UNIVERSITY, PRINCETON, NEW JERSEY

10 PAGES, 6 FIGURES, 4 TABLES, 11 REFERENCES, HEALTH PHYSICS, 15(1), PAGES 73-82 (JULY, 1968)

THE PERFORMANCE OF A COMMERCIAL FILM-BAOGE SERVICE WAS STUDIED OVER A PERIOO OF 3 YR. KNOWN DOSES WERE ADMINISTERED TO 800 FILM BADGES IN THIS TIME AND THE REPORTED RESULTS ANALYZED. SCME OF THE PROBLEMS INHERENT IN NEUTRON DOSIMETRY IN THE VICINITY OF HIGH-ENER.GY

ACCELERATION ARE PRESENTED. THE NEED FOR IMPROVED NEUTRON PERSONNEL DOSIMETERS IS

CONSIDEREO, ANO THE RELATION OF FILM BADGE REAOINGS TO PER SONNEL DOSE IS BRIEFLY DISCUSSED.

BETA EMITTER + DOSE MEASUREMENT, EXTERNAL + DOSIMETRY, GENERAL + GAMMA EMITTER +

MONITOR, RADIATION, ENVIRONMENTAL + MONITOR, RADIATION, PERSJVNEL + NEUTRON + STATISTICAL ANALYSIS

$15-27290$

RIEL GK + DUFFEY D

MONITORING OF RADIOSOTOPES IN ENVIRONMENTAL WATER

U. S. NAVY + UNIVERSITY OF MARYLAND

2 PAGES, TABLE, 5 REFERENCES, ANS TRANSACTIONS 11111 PAGES 52-53 FROM THE TRANSACTIONS OF THE 1962 ANNUAL MEETING OF THE AMERICAN NUCLEAR SOCIETY AND CANADIAN NUCLEAR ASSOCIATION, TORONTO, CANADA, JUNE IO-IB, 1968

THE ARTICLE PROPOSES THE ELIMINATION OF OFF-SITE MONITORING BY THE USE OF AN ON-SITE MONITORING SYSTEM, COMPLETE AND CONTINUOUS. A GAMMA-RAY SPECTROMETER WOULD $8 E$ USED BELOW THE SURFACE OF THE COOLING DISCHARGED WATER TO GIVE THE OPERATOR OF THE REACTOR A CONTINUDUS RECORD OF RADIOACTIVITY DISCHARGED TO THE WATER. THE SPECTROMETER WOULD GIVE A SENSITIVITY READING IN THE PICOCURIE-PER-LITER RANGE.

*ION EXCHANGE + \#MONITOR, RADIATION, ENVIRONMENTAL + \#RESIN + *SPECTROMETRY, GAMMA + REACTOR, POWER

$15-27331$

TURNER DB

DF ATMOSPHERIC DISPERSION ESTIM

U.S. DEPARTMENT OF HEALTH, EDUCATION, AND WELFARE, PUBLIC HEALTH SERVICE, CINCINNATI, OHIO

PHS-9S9-AP-26 +. 84 PAGES, FIGURES, TABLES, 1967

THIS WORKBOOK PRESENTS METHODS OF PRACTICAL APPLICATION OF THE BINOMIAL CONTINUOUS PLUME DISPERSION MODEL TO ESTIMATE CONCENTRATIONS OF AIR POLLUTANTS. ESTIMATES OF DISPERSION ARE THOSE OF PASQUILL AS RESTATED BY GIFFORD. EMPHASIS IS ON THE ESTIMATION OF CONCENTRATIONS FROM CONTINUOUS SOURCES FOR SAMPLING TIMES OF $10 \mathrm{MIN.}$ SOME OF THE TOPICS DISCUSSED ARE OETERMINATION OF EFFECTIVE HEIGHT OF EMISSION, EXTENSION OF CONCENTRATIDN ESTIMATES TO LONGER SAMPL ING INTERVALS, INVERSION BREAK-UP FUMIGATION CONCENTRATIONS, AND CONCENTRATIONS FROM AREA, LINE, AND MULTIPLE SOURCES. TWENTY-SIX EXAMPLE PROBLEMS AND THEIR SOLUTIONS ARE GIVEN. SOME GRAPHICAL AIDS TO COMPUTATION ARE INCLUDED.

AVAILABILITY - DiB. TURNER, AIR RESOURCES FIELD RESEARCH OFFICE, ENVIRONMENTAL SCIENCE SERVICES ADMINISTRATION, U.S. DEPARTMENT OF HEALTH, EDUCATION, AND WELFARE, PUBLIC HEALTH SERVICE, CINCINNATI, OHIO

*HEALTH PHYSICS TRAINING + \#METEOROLOGY + *STAFFING, TRAINING, QUALIFICATION + ATMOSPHERIC POLLUTION + METEOROLOGICAL SUPPORT + REACTOR, POWER + REACTOR, RESEARCH

$15-27441$

STRAIN WH + PORIES WJ + ZARESKY SA + DATTILO E

HEALTH HAZARDS FROM ZN-65 POLLUTION

ROCHESTER UNIVERSITY

2 PAGES, 1 TABLE, 6 REFERENCES, PAGES 60-61 OF TRANSACTIONS OF THE 1968 ANNUAL MEETING OF THE AMERICAN

NUCLEAR SOCIETY AND CANADIAN NUCLEAR ASSOCIATION, TORONTO, CANADA, JUNE 10-18, 1968

ZINC-65, A RECOGNIZED POLLUTANT FROM NUCLEAR BOMBS AND REACTORS, ACCUMULATES IN THE

ENVIRONMENT AND CAN BECOME A PUBLIC HEALTH HAZARD. TO STUDY THIS DANGER, WE HAVE

INVESTIGATED THE INFLUENCE OF AGE AND SEX ON THE RETENTION OF THE RADIONUCLIOE AFTER

INGESTION BY RATS. THE WORK IS AN EXTENSION OF EARLIER STUDIES ON THE PROMOTION DF EXCRETION

OF RADIOZINC BY ZINC DISODIUM EDTA.

* ATMOSPHERIC POLLUTION + \#ZINC + BIOLOGICAL CONCENTRATION, ANIMAL + BIOMEDICAL + ENVIRONMENTAL CONDITION + INGESTION + NUCLEAR DETONATION

$15-27442$

SUNTHARALINGAM N

THERMOLUMINESCENCE IN RADIATION MEASUREMENTS

1 PAGE, PAGE 68 OF THE TRANSACTIONS OF THE 1968 ANNUAL MEET ING OF THE AMERICAN NUCLEAR SOCIETY AND

CANADIAN NUCLEAR ASSOCIATION, $11(1)$, TORONTO, CANAOA, JUNE 1968 


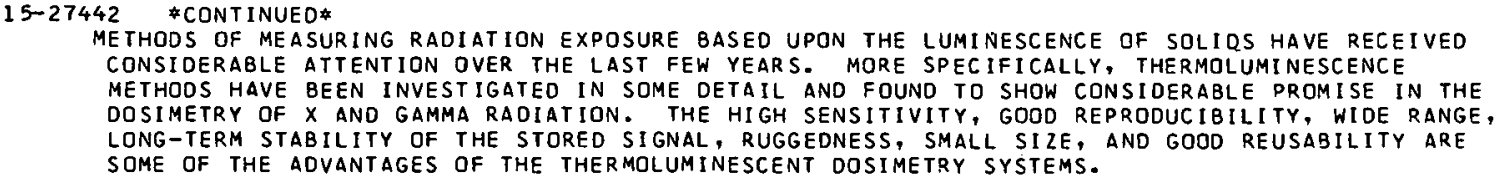

A NEW TYPE OF QUARTZ DOSIMETER SUITABLE FOR USE IN THE 5- TO 50-KRAD RANGE IS DESCRIBED. THE DOSIMETER IS PRODUCED BY EXPOSING A PLATE OF VERY PURE FUSED OR NATURAL CRYSTALLINE QUARTZ TO $10(8 \mathrm{TH})$ TO $10(10 \mathrm{TH})$ RAOS OF CO-60 GAMMA RADIATION. THE IRRADIATION IS FOLLDWED RY AN ANNEALING TREATMENT AT A TEMPERATURE BETHEEN 200 AND 400 C FOR A PERIOD OF APPROXIMATELY 24 H. AT THIS POINT THE DOSIMETER IS READY FOR USE.

* DOSIMETRY, GENERAL + \#INSTRUMENTATION, RADIATION MONITORING + COBALT + GAMMA EMITTER + IPRADIATION TESTING

$15-2744.4$

BAYLISS RJ

RADON LEAKAGE FROM SEALEO RADIUM SOURCES IN MEOICAL USE

DEPARTMENT OF PUBLIC HEALTH, N.S.W.

3 PAGES, 1 TABLE, 2 REFERENCES, THE MEOICAL JOURNAL OF AUSTRALIA, 1, PAGES 406-498 (MARCH 11 , 1967 )

RADIUM, COMBINED AS THE SULPHATE AND SEALED IN VARIOUS TYPES OF CAPSULES, IS USED IN A NUMBER OF HOSPITALS AND PRIVATE SURGERIES FOR INTRACAVITARY AND EXTERNAL IRRADIATION. RADIUM IS COMMONLY SEALED IN THREE WAYS--NAMELY, IN NEEDLES, IN TUBES, AND IN PLAOUES. THERE IS A SIGNIFICANT DOSAGE OF BETA RAYS FROM THE PLAQUE, USE OF WHICH IS MAOE IN SUPERFICIAL SKIN SIGNIFICANT DOSAGE OF BETA RAYS FROM THE PLAQUE, USE OF WHICH IS MAOE IN SUPERFICIAL
THERAPY. OWING TO THE PROPERTIES DF RADIUM, ITS USE IN A FAULTY CAPSULE CAN LEAD TO CONSIDERABLE PUBLIC HEALTH PROBLEMS. IF RADON GAS LEAKS FROM THE SOURCE, CONTAMINATION OF STORAGE CONTAINERS AND HANDLING EOUIPMENT IS INEVITABLE. ANY DEFECT IN THE CONTAINER WHICH GIVES RISE TO THE ESCAPE OF RADON GAS MAY, WITH CARELESS TREATMENT, WIDEN AND PRODUCE LEAKAGE OF THE FINELY DIVIDED RADIUM SALT.

\#LEAK + \#RADIUM + \#RADON + \#SOURCE, RADIATION + BIOMEDICAL + CONTAMINATION

$15-27445$

WHITEHOUSE WJ

THE POINT SUURC,F, METHOD OF DOSE CALCULATION IN MEDIA OF VARYING OFNSITY HITH SPECIAL REFERENCE TC BETA-PARTICLES

UKAEA, BERKS HARWELL

AERE-R-5679+. 22 PAGES, JANUARY, 1968

THE POINT SOURCE METHOD IS ADAPTED TO CALCULATING THE ENERGY DEPOSITION IN MEDI A OF VARYING DENSITY AND DISCUSSED, WITH SPECIAL REFERENCE TO THE DOSE FROM BETA PARTICLES IN TRABECULAR BONE. THE DOSE RECIPROCITY THEOREM IS RESTATEO, IN A FORM CONSISTENT WITH THE

BONE THE DOSE RECIPROCITY THEOREM IS RESTATEO, IN A FORM CONSISTENT WITH THE
OENSITY-DGPENDENT POINT SDURCF FRRMULA. BY WAY OF ILLUSTRATION THE LOEVINGER POINT SOURCE FORMULA FOR BETA RAYS IS USEO TO SOLVE TWO MODELS, (A) ALTERNATING INFINIIE SLABS UF DIFFERENT SUBSTANCES, (B) A HOLLOW SPHERE FILLEO WITH ONE SUBSTANCE, AND SURROUNDED BY ANOTHER. THE NUMER ICAL VALUES USED IN THESE SOLUTIONS CORRESPOND TO THE BONE-SEEKING NUCLIDES SR-90, Y-90 AND P-32, AND TO SUSSTANCES WITH THE DENSITY AND MEAN COMPOSITIDN OF TRABECULAR BONE.

AVAILABILITY - CLEARINGHOUSE FOR FEDERAL SCIENTIFIC AND TECHNICAL INFORMATIDN, SPRINGFIELD, VA. 2215 I $\$ 3.00$ COPY, \$0.65 MICROF ICHE

*BETA EMITTER + \#OSSE CALCULATION, INTERNAL + \#MAHEMATICAL TREATMENT + \#SOURCE, PDINT + PHOSPHORUS + STRONTIUM + UNITED KINGDOM + YTTRIUM

15-27013 ALSO IN CATEGORIES 17 AND 14

WATER POLLUTION CONTROL--TECHNICAL TRAINING PROGRAM--BULLETIN OF COURSES

U.S. DEPARTMENT DF THE INTERIOR

66 PAGES, FROM CLEAN WATER, BULLETIN OF COURSES, JULY 1968 TO JUNE 1969

DESCRIBES 27 SHORT COURSES (1-2 WEEKS, GIVEN AT VARIOUS REGIONAL CENTERS IN 1968-69) IN THE GENERAL AREAS OF CHEMISTRY (4), MICKOBIOLOGY (7), AND ENGINEERING AND WASTE TREATMENT (13) NONE SEEM SLANTEO AT RADIATION OR AT POWER STATIONS, BUT SOME OF THE INTRODUCTORY BIOLOGY AND ECOLOGY COURSES SEEM GENERALLY APPLICABLE.

\#ECOLOGICAL CONGIDERATION + \#STAFFING, TRAINING, QUJALIFICATION + \#WASTE DISPOSAL, LIOUID + 
NELLIS DO + HUDSPETH EL + MORGAN IL + BUCHANAN PS + BOGGS RF TRITIUM CONTAMINATION IN PARTICLE ACCELERATOR OPERATION

U.S. DEPARTMENT OF HEALTH, EDUCATION AND WELFARE, PUBL IC HEAL.TH SERVICE

PHS-PUBL. 999-RH-29+. 47 PAGES, 15 FIGURES, 5 TABLES, 8 REFERENCES, NOVEMBER 1967

TRITIUM-METALLIC TARGETS ARE FREQUENTLY USED IN MANY PARTICLE ACCELERATORS FOR THE PRODUCTION OF HIGH-ENERGY NEUTRONS. THE PURPOSE OF THIS STUDY WAS TO INVESTIGATE THE PROBLEMS ANO HAZARDS ASSOCIATED WITH THE USE OF THESE TRITIUM TARGETS $\$$ SO THAT APPROPRIATE STEPS CAN BE TAKEN TO MINIMIZE THE POTENTIAL RADIOLOGICAL HEALTH HAZARDS. THIS STUOY SHOWED THAT BOMBARDMENT OF TRITIUM TARGETS RESULTS IN THE LOSS OF ABOUT I TRITIUM ATOM FOR EACH BOMBAROING DEUTERON, AND THAT MOST OF THE TRITIUM IS IN A GASEOUS FORM WHEN IT LEAVES THE TARGET. IT WAS ALSO DETERMINED THAT A RELATIVELY SMALL AMOUNT OF THE TRITIUM RELEASEO FROM THE TARGET ACTUALLY REMAINS WITHIN THE ACCELERATOR ITSELF. MOST OF THE TRITIUM LOST BY A BOMBARDED TARGET IS TRAPPED IN THE ELEMENTS OF AN ION PUMP OR RELEASED THROUGH THE VACUUM SYSTEM EXHAUST.

AVAILABILITY - PUBLIC HEALTH SERVICE, WASHINGTON, D.C., FREE

\#CONTAMINATION + \#TRITIUM + ACCELERATOR + MONITOR, RADIATION, gAS

$15-27828$

CRIMMINS TH + GIBSON NN + PELLETIER AM + JACOBSON JR

EXPOSURE-RATE DEPENDENCE OF SELECTED GAMMA OOSIMETERS

ARMY, NUCLEAR DEFENSE LABORATORY, EDGEWTDO ARSENAL, MARYLAND

NDL-TR-94 +. 32 PAGES, FIGURES, TABLES, 9 REFERENCES, JANUARY 1968

THIS EXPERIMENT STUOIED THE EFFECTS OF EXPOSURE RATE ON THE RESPONSE OF THE FOLLOWING GAMMA DOSIMETERS - SILVER-ACTIVATED METAPHOSPHATE GLASS PLATES AND RODS, LITHIUM FLUDRIDE AND MANGANESE-ACTIVATED CALCIUM FLUORIDE MICROTHERMOLUMINESCENT DOSIMETERS, AND COBALT-ACTIVATED BOROSILICATE GLASS PLATES. THE EXPERIMENT WAS CONDUCTED AT THE FLASH X-RAY FACILITY OF THE ION PHYSICS CORPORATION OF BURLINGTON, MASS. DATA WERE OBTAINED IN THE EXPOSURE RANGE OF ABOUT 1,500 TO $45,000 \mathrm{R}$ AT EXPOSURE RATES FROM $5.2 \times 10$ TO THE $10 \mathrm{R}$ TO THE MINUS 1 TO 2.2 X 10 TO THE $11 R$ TO THE MINUS 1 . THE RESULTS OF THIS EXPERIMENT INDICATE THAT NO DIFFERENCES EXIST IN THE RELATIVE RESPONSES OF THE VARIOUS DOSIMETERS THAT MAY BE ATTRIBUTED TO EXPOSURE RATE OR TO AN INTERACTION BETWEEN EXPOSURE AND EXPOSURE RATE.

\#DESIGN STUDY + \#DOSIMETRY, GENERAL + \#EQUIPMENT, GENERAL

15-27855 ALSO IN CATEGORIES 17 AND 14

TRAINING COURSES - NATIONAL CENTER. FOR RADIOLOGICAL HEALTH

U.S. DEPARTMENT OF HEALTH, EOUCATION, AND WELFARE

PHS-PUB-1633 REV. +. 33 PAFFS. IIIY IOKR

SIXTY-SIX I OR 2 WEEK PRESENTATIONS AT VARIOUS REGIONAL CENTERS IN FY 1969 WILL BE MADE OF ONF OR MORE OF THE 16 COURSES AVAILAELE. AMONG THOSE OF INTEREST ARE - BASIC RADIDLOGICAL HEALTH, RADIOLOGICAL HEALTH FOR NURSES, TWO FOR X-RAY PROTECTION, OCCUPATIONAL RADIATION PROTECTION, REACTOR SAFETY AND HAZAROS EVALUATION, MANAGEMENT OF RADIATION ACCIDENTS, OPERATIONAL ASPECTS OF RAOIATION ACCIDENTS, OPERATIONAL ASPECTS OF RADIATION SURVEILLANCE, MEASUREMENT OF AIRBORNE RADIOACTIVITY, CHEMICAL AND GAMMA SPECTOSCOPY ANALYSIS OF RADIONUCLIDES, AND RADIUM HAZARDS AND CONTROL.

AVAILABILITY - U.S. DEPARTMENT OF HEALTH, EDUCATION, AND WELFARE, CENTER FOR RADIOLOGICAL HEALTH, ROCKVILLE, MARYLAND

*HEALTH PHYSICS TRAINING + \#STAFFING, TRAINING, QUALIFICATION + RADIATION INJURY, TREATMENT OF + RADIOLOGICAL ASSISTANCE + RADIUM + REACTOR, POWER + REACTOR, RESEARCH + SURVEY, RADIATION, ENVIRONMENTAL + $X-R A Y$

15-27856 AISN IN CATEGORIES 17 AND I

TRAINING MANUAL - MANAGEMENT OF RADIATION ACCIDENTS

U.S. DEPARTMENT OF HEALTH, EDUCATION, AND WELFARE

150 PAGES, FIGURES, TABLES, 39 REFERENCES, SEPTEMBER 12, 1966

- SET OF COURSE NOTES FOR 29 LECTURES IN THE GENERAL SUBJECT AREAS OF - I, RADIATION ACCIDENT CONTROL PLANNING AND RESPONSE (4). II, TYPES OF ACCIDENTS (5). III, RADIATION CDNTAMINATION MONITORING (31. IV, EVALUATION AND CONTRDL OF ACCIDENTAL EXPOSURE (7). V, NUCLEAR REACTOR HAZARDS (6). MEDICAL ASPECTS OF RADIATION ACCIOENTS $(4)$. \#FOR USE IN. A ONE WEEK CDURSE PRESENTED BY NCR.H.

AVAILABILITY - DIVISION OF RADIOLOGICAL HEALTH, ROCKVILLE, MARYLAND 20852

* STAFFING, TRAINING, QUALIFICATION + HEALTH PHYSICS TRAINING + RADIATION INJURY, TREATMENT DF + RADIATION SAFETY ANO CONTROL + RADIOLOGICAL ASSISTANCE + SURVEY, RADIATION, EMERGENCY 


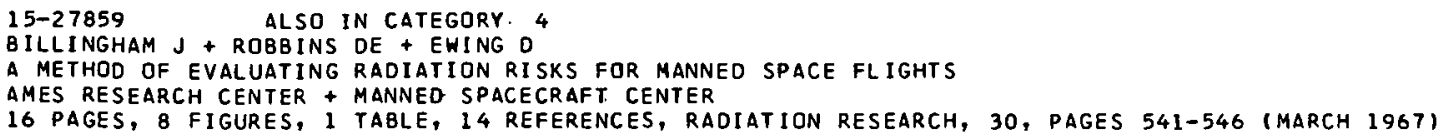

PROBLEMS CONCERNING AN EVALUATION OF THE HAZARD FROM DOSES OF IONIZING RADIATION DURING MANNED SPACE FLIGHT ARE DISCUSSED. A METHOD IS GIVEN FDR STATIST ICALLY COMBINING SOLAR FLARE DATA WITH ASSESSMENTS OF THE LIKELIHOOD FOR BIOLOGICAL RESPONSES. THIS APPROACH IS AIMED AT SYNTHESIZING RADIOPHYSICAL AND RADIOBIOLOGICAL DATA SO THAT THE INTERFACES BETHEEN RADIATIDN, CREW SAFETY, AND MISSION SUCCESS CAN BE BETTER RELATED TO OTHER HAZARDS DURING MISSIMN PLANNING.

* AIRCRAFT + \#OSE CALCULATION, EXTERNAL + \#DOSE CALCULATION, INTERNAL + \#RADIATION SAFETY AND CONTROL + \#RADIOBIOLOGY + \#SPACECRAFT + ATMOSPHERIC POLLUTION + HAZARDS ANALYSIS + METEOROLOGICAL SUPPORT

\author{
$15-27860$ \\ BUSH WR \\ ANALYSIS OF RADIATION EXPOSURES IN 1967 \\ ATOMIC ENERGY OF CANADA, LTO., CHALK RIVER, ONTARIO \\ AECL-3063 +. 16 PAGES, 8 FIGURES, 2 TABLES, MARCH, 1968
}

EXPOSURES TO EXTERNAL BETA AND GAMMA RADIATION ANO TO INTERNAL RADIATION FROM TRITIATEO WATER (HTO) ARE ANALYSED AND COMPARED WITH EXPOSIRES IN PREVIOUS YEARS. THE TOTAL, AVERAGE, AND HIGHEST EXPOSURES RECEIVED AT AECL SITES IN 1967 ARE GIVEN. ABOUT $85 \%$ OF THE EXTERNAL AND $100 \%$ OF THE INTERNAL EXPOSURE WAS RECEIVED AT CRNL, OF WHICH NEARLY $10 \%$ WAS RECEIVED BY OPERATING, MAINTENANCE AND RAOIATION CONTROL PERSONNEL, MOSTLY IN THE NRX AND NRU REACTOR BUILDINGS. THE COMBINED DTSES FROM EXTERNAL AND INTERNAL EXPOSURES TO THE WHOLE BODY, EYE LENSES, AND SKIN, AND THEIR OISTRIBUTION AMONG BRANCHES ANO INOIVIDUALS, ARE PRESENTED IN GRAPHICAL FORM.

AVAILABILITY - CLEARINGHOUSE FOR FEDERAL SCIENTIFIC AND TECHNICAL INFORMATION, SPRINGFIELD, VA. 22151 $\$ 3.00$ COPY, \$0.65 MICROFICHE

\#BIOLOGICAL CONCENTRATION, MAN + \#OOSIMETRY, GENERAL + \#RADIATION SAFETY ANO CONTROL + CHALK RIVER + GROSS BETA + GROSS GAMMA + MONITOR, RADIATION, PERSONNEL + TRITIUM

$15-27861$

YOSHIDA Y + DENNIS JA

A PROPORTIONAL COUNTER FOR PERSONNEL NEUTRON DOSIMETRY

UNITED KINGDOM ATOMIC ENERGY AUTHORITY, HARWELL, BERKSHIRE

AERE-R-5656 + 21 PAGES, 6 FIGURES, 3 TABLES, 23 REFERENCES, MARCH 1968

A PROPORTIONAL COUNTER WAS DEVELOPEO AS A SOLUTION TO THE SPECIFIC PROBLEM OF MEASURING THE DOSE EQUIVALENT TO PERSONNEL FROM NEUTRONS WITH ENERGIES GREATER THAN IO KEV. THE DIMENSIONS OF THE PROTOTYPE COUNTER ARE $12 \times 3 \times 1$ CM. IT CONSISTS OF THREE CELLS WITH CONOUCTIVE PLASTIC WALLS WITH ATOMIC COMPOSITION EQUIVALENT TO TISSUE AND FILLED WITH HYDROGENEOUS GAS. IT IS SUGgESTED THAT IT HILL BE POSSIBLE TO MODIFY THE COUNTER TO MEASURE WITH REASONABLE ACCURACY THE DOSE EQUIVALENT FROM THE NEUTRONS DVER THE ENTIRE ENERGY RANGE FROM THERMAL TO 20 MEV.

AVAILABILITY - CLEARINGHOUSE FOR FEDERAL SCIENTIFIC ANO TECHNICAL INFORMATION, SPRINGFIELD, VA. 22151 $\$ 3.00$ COPY, \$0.65 MICROFICHE

\#COUNTER + \#INSTRUMENTATION, RADIATION MONITORING + *MONITOR, RADIATION, PERSONNEL + \#RADIATION SAFETY ANO CONTROL + DESIGN CRITERIA + NEUTRON + UNITED KINGDOM

$15-27862$

EAKINS JD

THE DETERMINATION OF PLUTONIUM ALPHA ACTIVITY IN URINE BY SURFACE AOSORPTION AND ION EXCHANGE ATOMIC ENERGY RESEARCH ESTABL ISHMENT, HARWELL, BERKSHIRE

AERE-R-3037 +. 12 PAGES, 1 FIGURE, 5 TABLES, 14 REFERENCES, DECEMBER 1967

DESCRIBES WORK CARRIED OUT TO SELECT AND EVALUATE AN ION EXCHANGE PROCEDURE WHICH, IN CONJUNCTION WITH THE SURFACE AOSORPTION METHOD FOR OETERMINING GROSS ALPHA ACTIVITY IN URINE, GIVES A HIGHLY SPECIFIC PROCEDURE FOR PLUTONIUM ALPHA ACTIVITY. THE CHOSEN PROCEDURE IS EXAMINED WITH REFERENCE TO DECONTAMINATION FROM OTHER ACTINIDE ELEMENTS, RECOVERY ACTINIDE ELEMENTS ARE IN EXCESS OF 100 IN ALL CASES. THE OVERALL RECOVERY OF PLUTONIUM IS $89+-4 \%$, AND THE BACKGROUND ACTIVITY OBTAINED FROM THE URINE OF UNEXPOSED PEOPLE IS $0.015+-0.005$ PCI/1500 ML. THE PROCEOURE IS SUITABLE FOR ANALYSING LARGE NUMBERS OF SAMPLES AND REQUIRES LITTLE OPERATOR EXPERTISE. THE USE OF THE PROCEOURE FOR GROSS ALPHA ACTIVITY ANO PLUTUNIUM HAS ADVANTAGES BOTH IN ECONOMY OF MATERIALS AND EASE OF STAFF TRAINING.

AVAILABILITY - CLEARINGHOUSE FOR FEDERAL SCIENTIFIC ANO TECHNICAL INFORMATION, SPRINGFIELO, VA. 22151 $\$ 3.00$ COPY, \$0.65 MICROFICHE

ADSORPTION SURFACE + BIOLOGICAL CONCENTRATION, MAN + OECONTAMINATION FACTOR + GROSS ALPHA + ION EXCHANGF + 
15-27862 \#CONTINUED*

PLUTONIUM + UNITED KINGOOM

$15-27865$

HANKINS DE + HANSEN GE

REVISED DOSE ESTIMATES FOR THE CRITICALITY EXCURSION AT LOS ALAMOS SCIENTIFIC LABORATORY, MAY 21 , I946 LOS ALAMOS SCIENTIFIC LABBORATORY

LA-3861 +. 13 PAGES, 7 FIGURES, 3 TABLES, DECEMBER 1967

PRESENTS REVISED ESTIMATES OF THE DOSE RECEIVED BY PERSONNEL EXPOSED IN THE LOS ALAMOS CRITICALITY EXCURSION THAT OCCURRED MAY 21, 1946. THE REVISED DOSES ARE BASEO ON A CALCULATION OF THE LEAKAGE NEUTRON SPECTRUM FROM THE CRITICAL SYSTEM AND THE RESULTS OBTAINEO FROM A RECENT STUDY OF BLOOD-SODIUM ACTIVATION.

AVAILABILITY - CLEARINGHOUSE FOR FEOERAL SCIENTIFIC AND TECHNICAL INFORMATION, SPRINGFIELD, VA. 22151 , $\$ 3.00$ COPY, \$0.65 MICROFICHE

*CRITICAL ASSEMBLY FACILITY + *CRITICALITY SAFETY + \#DOSE CALCULATION, EXTERNAL +

*DOSE CALCULATION, INTERNAL + LASL + NEUTRON

$15-27866$

HANK INS DE

STUDY OF SELECTED CRITICALITY - DOSIMETRY METHODS

LOS ALAMOS SCIENTIFIC LABORATORY

LA-3910 +. 56 PAGES, FigURES, TABLES, 48 REFERENCES, DECEMBER 1967

SEVERAL METHODS FOR DETERMINING THE DOSE RECEIVED BY PERSONS ACCIDENTALLY EXPOSED TO A CRITICALITY EXCURSION HAVE BEEN INVESTIGATED. THIS STUDY INDICATES THAT CONSIDERABLE INFORMATION MUST BE AVAILABLE BEFORE AN ACCURATE ASSESSMENT OF A PERSONS DOSE CAN BE MADE. IF NO INFORMATION ABOUT THE ACCIDENT IS AVAILABLE, DOSIMETRY USING A RATIO OF THE HAIR AND BLOOD-SODIUM ACTIVATION WILL GIVE THE DOSE TO WITHIN PLUS OR MINUS 20 TO $30 \%$ EXCEPT WHERE MASSIVE URANIUM OR IRON SHIELDING OCCURS

AVAILABILITY - CLEARINGHOUSE FOR FEDERAL SCIENTIFIC AND TECHNICAL INFORMATION, SPRINGFIELD, VA. 22151 , $\$ 3.00$ COPY, \$0.65 MICROFICHE

\#CRITICAL ASSEMBLY FACILITY + \# OOSE + \#DOSIMETRY, GENERAL + *SHIELDING + CDUNTER + GAMMA EMITTER + PHANTOM, HUMAN BODY + THERMAL NEUTRON

$15-27867$

GOODALL G

THE DETERMINATION OF STRONTIUM IN BONE, MILK AND VEGETABLE ASHES USING ION EXCHANGE SEPARATION AND FLAME PHOTOMETRY

UNITED KINGDOM ATCMIC ENERGY AUTHORITY, CAPENHURST, GREAT BRITAIN

PG-815 (CA) +. 12 PAGES, 3 FIGURES, 4 TABLES, 12 REFERENCFS, $19 K 9$

A RAPIO AND SENSITIVE METHOO FOR DETERMINING SR IN THE PRESENCE OF LARGE AMOUNTS OF CA AND OTHER INTERFERING ELEMENTS FOUND IN BIOLOGICAL MATERIALS H HAS BEEN DEVELOPED USING CATION EXCHANGE AND FLAME PHOTOMETRY. AMMONIUM LACTATE IS USED AS ELUANT, ANO THE SR IN THE ELUATE IS DETERMINED DIRECTLY BY FLAME PHOTOMETRY. THE METHOD HAS A NEGATIVE BIAS OF 3\%, AND THE SR CONTENT OF 0.2 OF BONE ASH CAN BE DETERMINEO WITH A COEFFICIENT OF VARIATION OF $2 \%$.

AVAILABILITY - CLEARINGHOUSE FOR FEOERAL SCIENTIFIC AND TECHNICAL INFORMATION, SPRINGFIELD, VA. 22ISI, $\$ 3.00$ COPY, \$0.65 MICROF ICHE

\# BIOLOgICAL CONCENTRATION, MAN + \#CHROMATOGRAPHY + *ION EXCHANGE + \#STRONTIUM + CALCIUM + CHEMICAL ANALYSIS

$15-27868$

ROHWER PS + KAYE SV

AGE-DEPENDENT MODELS FOR ESTIMATING INTERNAL DOSE IN FEASIBILITY EVALUATIONS OF PLOWSHARE EVENTS.

PLOWSHARE RESEARCH AND DEVELOPMENT PROGRESS REPORT, DCTOBER 1, 1967-APRIL 1, 1968

DAK RIDGE NATIONAL LABORATORY

DRNL-TM-2229 +. 36 PAGES, FIGURES, REFERENCES, APRII 1,1968

PRESENTS AGE-DEPENDENT MDDELS WHICH ARE USED IN THE INREM COMPUTER CODE FOR CALCULATING THE RADIATION DOSE RESULTING FROM INHALATION OR INGESTION OF RADIONUCLIDES. USE OF AGE-DEPENDENT MODELS IN FEASIBILITY STUDIES PERMITS INDENTIFICATION OF THE CRITICAL SEGMENT OF THE POPULATION AND PROVIDES THE GUIOANCE NECESSARY FOR PLANNING OF REMEOIAL ACTION. RESULTS OF EXAMPLE DOSE CALCULATIONS ARE PRFSFNTFE FOR TRITIUM AND I-131 TO ILLUSTRATE USE OF TIIE INRTM CODE. THE RADIONUCLIDE INPUT USED FOR THE TRITIUM EXAMPLE IS BASED ON ESTIMATED CONCENTRATIONS RELEASED TO AIR AFTER COMBUSTION OF NATURAL GAS STORED IN THE PROJECT KETCH RESERVOIR. THE I-131 EXAMPLE ILLUSTRATES THE INFLUENCE OF THE AGE-DEPENOENT PARAMETERS IN THE DOSE MODEL UPON THE RESULTING DOSE ESTIMATES.

AVAILABILITY - CLEARINGHOUSE FOR FEDERAL SCIENTIFIC AND TECHNICAL INFORMATION, SPRINGFIELD, VA. 22151 , $\$ 3.00$ COPY, $\$ 0.65$ MICROFICHE

\#DOSE CALCULATION, INTERNAL + \#IODINE + \#POPULATION EXPOSURE + \#RADIATION MODEL + \#TRITIUM + INGESTION + 
CATEGORY 15

ENVIRONMENTAL SURVEYS, MONITORING AND RADIATION EXPOSURE OF MAN

15-27868 \#CONTINUED*

PLOWSHARE PROGRAM

15-27880 ALSO IN CATEGORY 16

RICHARDSON LC

PHILLIPS PETROLEUM COMPANY

IDO-17261 +. 136 PAGES, FIGURES, 3 TABLES, 5 REFERENCES, JUNE $1 \% 68$

THIS REPORT IS A MANUAL FOR THE FORTRAN VERSION OF THE RSAC COMPUTER CODE. THE MATHEMATICAL MODEL AND EQUATIONS ARE DESCRIBED IN IDO-17151, RSAC--A RADIOLOGICAL SAFETY ANALYSIS COMPUTER PROGRAM, BY R. L. COATES AND N. R. NORTON, MAY 1966. THE PROGRAM COMPUTES THE POTENTIAL RAOIOLOGICAL DOSES RESULTING FROM EITHER A CONTINUOUS OR INSTANTANEOUS RELEASE OF RADIOACTIVE FISSION PRODUCTS TO THE ATMOSPHERE. THE DOSES CONSIDERED ARE CLQUD GAMMA, DEDOSITION GAMMA, INGESTION, AND INHALATION AND ARE BASED UPON THE RELEASE OF UP TO 450 ISOTOPES, THE RELATIVE ABUNDANCE OF EACH ISOTOPE BEING DEP ENDENT UPON THE OPERATING HISTORY OF THE NUCLEAR REACTOR UNDER CONSIDERATION.

AVAILABILITY - CLEARINGHOUSE FOR FEDERAL SCIENTIFIC AND TECHNICAL INFORMATION, NATIONAL BUREAU OF STANOAROS, SPRINGFIELD, VA. 22151, \$3.00 COPY, \$0.65 MICROFICHE

FCOMPUTER PROGRAM + \#DOSE CaLCULATION, EXTERNAL + \#OOSE CALCULATION, INTERNAL + \#SOURCE, CONTINUOUS + * SOURCE, INSTANTANEOUS + DEPOSITION + INGESTION + INHALATION

$15-27897$

SUTTON OC + KELLY JJ

SR -90 AND CS-137 MEASUREMENTS OF LARGE COLUME SEA WATER SAMPLES

U. S. ATOMIC ENERGY COMMISSION

HASL $-196+.44$ PAGES, 3 FIGURES, 4 TABLES, 15 REFERENCES, APRIL 1968

METHODS REQUIRING LESS SAMPLE HANDL ING AND FEWER REAGENTS THAN THOSE OF OTHER INVESTIGATORS HAVE BEEN DEVELOPED FOR THE MEASUREMENT OF SR-90 AND CS-137 IN AVERAGE 55-LITER SURFACE OR DEEP SEA SAMPLES. DURING FOUR YEARS, SR AND CS YIELDS AVERAGED 75 PLUS OR MINUS 15 AND 70 PLUS OR MINUS 10\%, RESPECTIVELY. IN THE OESCRIPTION DF THE METHODS, EMPHASIS IS PLACEO ON SAMPLE PREPARATION, CS I SOLATION IFROM AMMONIUM PHOSPHOMOLYBDATE, ITS COLLECTING REAGENT, ATTAINED BY A SINGLE ION EXCHANGE PASS IN THE PRESENCE OF EDTAI, SOOIUM CARBONATE OR AMMONIUM CARBONATE AS PRECIPITANTS FOR SR COLLECTION, REAGENT AND SAMPLE OUALITY CONTRDL, BETA

COUNTING, ANO DATA ANALYSIS. APPENDED ARE DERIVATIONS OF EQUATIONS USEO TO CALCULATE SR-OO FROM Y-9O COUNTING DATA AND A PROGRAM IN FORTRAN IV FOR AN IBM $360 / 30$ COMPUTER WHICH RESOLVES THE Y-90 DATA.

AVAILABILITY - CLEARINGHOUSE FOR FEDERAL SCIENTIFIC AND TECHNICAL INFORMATION, SPRINGFIELD, VA. 22151 , $\$ 3.00$ COPY, \$0.65 MICROFICHE

\#CESIUM + \#DATA PROCESSING + \#EQUIPMENT, GENERAL + \#EXPERIMENT, GENERAL + \#STRONTIUM + COUNTER + OCEAN AND SEA + RADIATION SAFETY AND CONTROL

$15-27900$

PROCEEDINGS FOR THE CONFERENCE ON PRINCIPLES OF RADIATION PROTECTION, AUGUST 24-26, 1966, OAK RIDGE, TENNESSEE

DAK RIDGE NATIONAL LABORATORY

CONF-660815 +. 172 PAGES, FIgURES, TABLES, REFERENCES, AUGUST 26,1968

THE CONFERENCE WAS DESIGNED TO REVIEW RECENT RESEARCH IN RADIATION PROTECTION AND HEALTH PHYSICS AND TO DESCRIDE THE INTERESTINC OPPORTUNITIES FOR TEACHING, RESEARCH AND APPLIED ACTIVITIES IN THE BROAD FIELD OF HEALTH PHYSICS. PAPERS GIVEN DURING THE MEETING INCLUDED SUBJECTS AS RADIATION PROTECTION, EVOLUTION OF DATA, RESEARCH HORIZONS, RAOIOBIOLOGY AND BIOMEDICINE, DOSIMETRY AND SHIELDING, MEDICAL PHYSICS, AND HEALTH PHYSICS ENGINEERING.

AVAILABILITY - CLEARINGHOUSE FOR FEDERAL SCIENTIFIC AND TECHNICAL INFORMATION, SPRINGFIELD, VA. 22151 , $\$ 3.00$ COPY, $\$ 0.65$ MICROFICHE

* DESIGN CRITERI A + \#OSIMETRY, GENERAL + \#EMERGENCY SYSTEM + *HEALTH PHYSICS TRAINING +

* INSTRUMENTATION, RADIATION MONITORING + \#RADIATION SAFETY AND CONTROL + \#SITING, REACTOR * BIOL OGICAL CONCENTRATION, MAN + BIOMEDICAL + FILTER + MAXIMUM PERMISSIBLE BODY BUROEN + MAXIMUM PERMISSIBLE DOSE (MPD) + R AND D PROGRAM + RADIATION DAMAGE + RADIOLOGY + SHIELOING + STACK + WASTE DISPOSAL, GENERAL + X-RAY

$15-27911$

ENVIRONMENTAL CONTAMINATION BY RADIOACTIVE SUBSTANCES

U.S. DEPARTMENT OF HEALTH, EOUCATION, AND WELFARE, PUBLIC HEALTH SERVICE, ROCKVILLE, MARYLAND 20852 24 PAGES, REPORT TO THE OIRECTOR, NATIONAL CENTER FOR RADIOLOGICAL HEALTH PUBLIC HEALTH SERVICE, DECEMBER 1. 1967

THIS REPORT IS CONCERNED PRIMARILY WITH THE NEED FOR A NATIONWIDE SURVEILLANCE TO MEASURE THE LEVELS OF RADIOACTIVE CONTAMINATION OF AIR, WATER, FOOD, ANO OTHER VECTORS OF JUMAV EXPOSURE TO RADIOACTIVE SUBSTANCES. THE COMMITTEE HAS IDENTIFIED THE REQUIREMENTS OF A NATIONAL SURVEILLANCE SYSTEM TO MEET PROGRAM OBJECTIVES AND HAS OUTLINED THE RESPONSIBILITIES OF 
CATEGORY 15

ENVIRONMENTAL SURVEYS, MONITORING AND RAOIATION EXPOSURE OF MAN

15-27911 \#CONTINUED*

FEDERAL AND STATE AGENCIES. IN ORDER FOR THE NATIONAL CENTER FOR PADIOLOGICAL HEALTH TO MEET ITS RESPONSIBILITIES FOR PRDTECTING PUBLIC HEALTH, THE COMMITTEE, IN THIS REPORT, MAKES A NUMBER OF RECOMMENDATIONS TO THE DIRECTOR AND URGES THAT APPROPRIATE ACTION BE TAKEN FOR THEIR I MPLEMENTATION.

AVAILABILITY - U.S. DEPARTMENT OF HEALTH, EDUCATION, AND WELFARE, PUBLIC heALTH SERVICE

AEROSPACE SAFETY + BIOLOGICAL CONCENTRATION, FOOD + BIOLOGICAL CONCENTRATION, GENERAL + BIOLOGICAL CONCENTRATION, MAN + BIOLOGICAL CONCENTRATION, MILK + BIOLOGICAL CONCENTRATION, VEGETATION + MONITOR, RADIATION, ENVIRONMENTAL + NUCLEAR DETONATION + RADIATION SAFETY AND CONTROL + RADIOISOTOPE + RADIOLOGICAL ASSISTANCE + REACTOR POWER + SHIPPING ANALYSIS + SURVEILLANCE PROGRAM + TRANSPGRTATION AND HANDL ING + WASTE MANAGEMENT

$15-27914$ ALSO IN CATEGORY 14

LACHAPELLE DG + TARBOX JL + MALONEY JC + BRADBURY HG + GODBOLT NH + MILLER WH A FIELD-EXPEDIENT INCINERATOR (PROJECT TEE PEE)

GENERAL OYNAMICS, FORT WORTH, TEXAS + ARMY NUCLEAR DEFENSE LAB

AD-664118 + NOL-TR-98 +. 132 PAGES, REFERENCES, JANUARY 1968

AN INCINERATOR FOR EXPEDIENT CONCENTRATION OF COMBUSTIBLE RAOIOACTIVE WASTE HAS BEEN DESIGNED, BUILT, ANO EVALUATED. IT FEATURES PORTABILITY AND EASE OF ASSEMBLY. THIS INCINERATOR (REFERREO TO AS TEE PEE) EMPLOYS FIVE OIL-FIRED BURNERS THAT IGNITE THE WASTE MATERIAL ANO REOUCE THE PARTICULATE EMISSION. FOUR INCINERATIONS WERE CONDUCTED WITH ROUGH-CUT LUMBER CONTAMINATED LA-140. THE CONCLUSION BASEO ON THESE RESULTS IS THAT THE TEE PEE IS A PRACTICAL DEVICE FOR EFFICIENT FIELD-EXPEDIENT INCINERATION ANO CONCENTRATION OF COMBUSTIBLE RAOIOACTIVE WASTE.

AVAILABILITY - CLEARINGHOUSE FOR FEOERAL SCIENTIFIC AND TECHNICAL INFORMATION, SPRINGFIELD, VA. 22I5I, \$3. 00 COPY, SO.65 MICROF ICHE

*AIRBORNE RELEASE + \#INCINERATION + \#LANTHANUM + \#WASTE TREATMENT, SOLID + CONCENTRATION, MAXIMUM + EFFLUENT + MAXIMUM PERMISSIBLE CONCENTRATION (MPC)

$15-27917$

DENHAM DH

HEALTH PHYSICS AT THE LRL-LIVERMORE TRANSURANIC PROCESSING FACILITY

UNIVERSITY OF CALI FORNIA, LIVERMORE, CALIFORNIA

ORNL-P-3227 + CONF-671102-3+. B PAGES, 4 TABLES, 16 REFERENCES, PAGES 179-186 OF SAFETY REVIEW PROCEDURES FOR HOT CELL AND RADIOCHEMICAL PROCESSING FACILITIES AT ORNL, FOR PRESENTATION AT I5TH CONFERENCE ON REMOTE SYSTEMS TECHNOLOGY AND ATOM FAIR, CHICAGD, ILLINOIS, I966

THIS REPORT DESCRIBES THE LRL TRANSURANIC FACILITY AND OISCUSSES THE HEALTH PHYSICS CONTROLS USED TO LIMIT PERSONNEL EXPOSURE AND TO MAINTAIN COMPLETE CONFINEMENT OF THE HIGHLY RADIOACTIVE AND. RADIOTOXIC MATERIALS, AND ENUMERATES SOME OF THE SPECIAL HAZARDS OF HANOLING THE TRANSURANIUM ELEMENTS.

AVAILABILITY - CLEARINGHOUSE FOR FEDERAL SCIENTIFIC AND TECHNICAL INFORMATION, SPRINGFIELD, VA. 22151 , \$3.00 COPY, \$0.65 MICROF ICHE

\#HAZARDS ANALYSIS + \#MONITOR, RADIATION, PERSONNEL + \#RADIATION SAFETY AND CONTROL + * TRANSURANIUM ELEMENT + MONITOR, RADIATION, AIR + MONITOR, RADIATION, GeNERAL + SURVEILLANCE PROGRAM + VENTILATION SYSTEM

15-27918 ALSO IN CATEGORY 14

BURCH HD + AREHART TA

SAFETY REVIEW PROCEDURES FOR MOT-CELL AND RADIOCHEMICAL PROCESSINGFACILITIES AT ORNL

OAK RIDGE NATIONAL LABORATORY

ORNL-P-3227+CONF-671102-3+.5 PAGES, 1 FIGURE, 1. TABLE, 3 REFERENCES, PAGES 187-191 OF SAFETY REVIEW PROCEDURES FOR HOT CELL AND RADIOCHEMICAL PROCESSING FACILITIES AT ORNL, FOR PRESENTATION AT ISTH CONFERENCE ON REMOTE SYSTEMS TECHNOLOGY ANO ATOM FAIR, CHICAGO, ILLINOIS, 1966

RESPONSIBILITY FOR THE RADIATION SAFETY OF ALL HOT-CELL AND RADIOCHEMICAL PROCESSING FACILITIES AT ORNL IS ASSIGNEO TO THE DIRECTOR OF RADIATION SAFETY AND CONTROL. WHO, AIDED BY VARIOUS REVIEW AND AOVISORY COMHITTEES AS WELL AS A FULL-TIME STAFF TF THRFF SFNITR EMPLOYEES, HAS ESTABLISHED UNIFORM POLICIES THROUGHOUT THE LABORATORY. ADEQUATE SAFETY REGULATIONS THUS ESTABLI SHEO HAVE BEEN MAINTAINEO SUCH THAT NO RAOIATION INCIDENTS OF ANY CONSEQUENCE HAVE OCCURRED WITHIN THE PAST SEVEN YEARS. THIS PAPER DESCRIBES THE ORGANIZATION RESPONSIBLE FOR RADIATION SAFETY AND ALSO DISCUSSES SOME OF THE ESTABLISHED STANDARDS.

AVAILABILITY - CLEARINGHOUSE FOR FEDERAL SCIENTIFIC AND TECHNICAL INFORMATION, SPRINGFIELD, VA. 22151 , $\$ 3.00$ COPY, \$0.65 MICROF ICHE

* OPERATION + *REACTOR POWER + DESIGN CRITERIA + HOT CELL + MONITOR, RADIATION, GENERAL + RAOIATION SAFETY AND CONTROL + RADIOCHEMICAL PLANT SAFETY + RADIOCHEMICAL PROCESSING + VENTILATION SYSTEM + WASTE DISPOSAL, HYDRAULIC FRACTURING + WASTE STORAGE 
ENVIRONMENTAL SURVEYS, MONITORING AND RAOIATION EXPOSURE OF MAN

15-27976 \#CONTINUED*

MORRIS EC

REMOTE TRITIUM AIR MONITORING SYSTEM

SAVANNAH RIVER LABORATORY

OPSPU-67-30-1 + SM-95-50+CONF-670705-7+. S PAGES, REFERENCES, APRIL 1967, FROM IAEA SYMPOSIUM ON

INSTRUMENTS AND TECHNIQUES FOR THE ASSESSMENT OF AIRBORNE RADIOACTIVITY IN NUCLEAR OPFRATIONS, VIENNA, AUSTRIA

TRITIUM IS PRODUCEO IN HEAVY-WATER-MOOERATED REACTORS THROUGH NEUTRON CAPTURE BY DEUTERIUM. THE RATE UF TRITIUM PRODUCTION IS A FUNCTION OF NEUTRON FLUX NVD IRRAOIATION TIME. ANY TRITIUM OXIDE, SUBSEQUENTLY PRODUCED, IS RELEASED TO THE ATMOSPHERE READILY SY VAPORIZATION WHENEVER THE MODERATOR IS EXPOSED, FOR EXAMPLE ON THE SURFACES OF FUEL BEING DISCHARGED. THE ATTENDENT HEALTH HAZARD IS ONE OF TRITIUM ABSORPTION EITHER DIRECTLY THROUGH THE SKIN OR THROUGH THE RESPIRATORY SYSTEM. THIS HAZARD IS BEST CONTROLLEO BY THOROUGHLY TRAINING PERSONNEL, ACCURATELY KNOWING THE CONDITIONS TO WHICH PERSONS ARE EXPOSED, AND PRESCRIBING PROPER PROTECTIVE CLOTHING. AT THE SAVANNAH RIVER PLANT, aLL THESE MEANS ARE USED TO DROVIDE EFFECTIVE CONTROL.

AVAILABILITY - CLEARINGHOUSE FOR FEDERAL SCIENTIFIC AND TECHNICAL INFORMATION, SPRINGFIELO, VA. 22I5I, $\$ 3.00$ COPY, \$0.65 MICROF ICHE

\#AIRBURNE RELEASE + HHEALTH PHYSICS TRAINING + \#REACTOR, HWR + \#TRITIIIM + INHALATION +

INSTRUMENTATION, RADIATION MONITORING + RADIATION SAFETY AND CONTROL + SAVANNAH RIVER DLANT + SORPTION + VAPOR, VAPOR PRESSURE

$15-27977$

COOLEY RC

CONTROLLING TRITIUM HAZARDS AROUND HEAVY WATER MODERATED REACTORS

SAVANNAH RIVER LABORATORY

DPSPU-66-30-13 + CONF-680607-1 +. 15 PAGES, TABLES, MAY 1968, FROM 13TH ANNUAL HEALTH PHYSICS SOCIETY MEETING, DENVER, COLORAUU

IN HEAVY-WATER-MDOERATED REACTORS, TRITIUM IS- FORMED AS NEUTRONS ARE ABSORBED BY THE HEAVY WATER. HAZARDS FROM TRITIUM RELEASED TO PERSONNEL ZONES DURING REDAIR ANU MAINTENANCE OPERATIONS ARE MINIMIZED BY PROPER JOB EVALUATION ANO SELECTION OF CORRECT PROTECTIVE

EQUIPMENT. AT SAVANNAH RIVER PLANT, BASIC INFORMATION HAS BEEN DEVELOPED TO FACILITATE THIS PROCESS. DATA IS GIVEN RELATIVE TO BUILDUP OF TRITIUM IN MODERATOR, AIRBORNE CONCENTRATION OF TRITIUM, CONCENTRATION OF TRITIUM IN SPILLED MODERATOR AND WATER, ASSIMILATION OF TRITIUM BY PERSONNEL THROUGH INHALATION AND BODY CONTACT, AND DOSE RECEIVED BY URINE ANALYSIS.

AVAILABILITY - CLEARINGHOUSE FOR FEOERAL SCIENTIFIC AND TECHNICAL INFORMATION, SPRINGFIELD, VA. 22151 , $\$ 3.00$ COPY, \$0.65 MICROFICHE

\#MONITORING SYSTEM, RAOIATION + \#REACTOR, HWR + \#TRITIUM + ANALYTICAL TECHNIOUE, URINE * BIOLOGICAL CONCENTRATION, MAN + HAZARDS ANALYSIS + INHALATION + RADIATION SAFETY AND CONTROL + SORPTION

15-27990 ALSO IN CATEGORY 17

AEC SPECTAL FELLOWSHIPS IN HEALTH PHYSICS

OAK RIDGE ASSOCIATED UNIVERSITIES

45 PAGES, SEPTEMBER 1966

DESCRIBES WHO MAY APPLY AND TYPE OF PROGRAM, TENURE, CONDITIONS, FEES AND STIPENOS, 16 PAGESI. DESCRIBES COURSES AND REQUTREMENTS AT 14 APPROVED UNIVERSITIES $(29$ PAGESI. DESCRTBES 8 AEC LOCATIONS WHERE 3 MONTHS APPLIED HEALTH PHYSICS TRAINING IS GIVEN 16 PAGESI.

AVAILABILITY - OAK RIDGE ASSHCIATED UNIVERSITIES, OAK RIDGE, TENNESSEE

*HEALTH PHYSICS TRAINING + USAEC

$15-27995$

RINGS AND CANCER

1 PAGE, TIME 92(11), PAGE 66 (SEPTEMBER 13, 1968 )

GOLD CAPSULES (CONTAINING RADON GAS, USED IN IRRAOIATING CANCER) HAVE BEEN USED TO MAKE RINGS ANO JEWELRY AFTER THE RADON RADIATION IS GONE. HOWEVER THE RADON TURNS INTO PB-21O (22-YEAR HALF-LIFE) WHICH HAS CAUSEO SEVERAL CANCERS T.O DEVELOP ON RIING, FINGFRS. SOME ARE CONCERNED THAT OTHER CONTAMINATED GOLD MAY HAVE FOUND ITS WAY INTO DENTURES AND JEWELRY.

-COATAMINATION + \#OIIO + \#RADIOLOGY + LEAO + PERSONNEL EXPOSURE, RADIATION

$15-28008$

ENORES GW + GLASS WA + HAVERFIELD AJ

TISSUE EQUIVALENT PROPORTIUNAL COUNTER FOR SEPARATING DOSES DUE TO GAMMA AND NEUTRON RADIATION BATTELLE-NORTHWEST, RICHLAND, WASHINGTON

BNWL-SA-1632 + CONF-680607-6+. 28 PAGES, TABLES, FROM 13TH ANNUAL HEALTH PHYSICS SOCIETY MEETING, DENVER, COLORADO, MAY 1968

SÉYERAL METHODS USEU IU MEASURE THE NEUTRON RAOIATION FIELDE MMO P.ELATE TO ARSTRRFO DISE IN 
CATEGORY 15

ENVIRONMENTAL SURVEYS, MONITORING AND RADIATION EXPOSURE OF MAN

15-28008 \#CONTINUED*

TISSUE HAVE PROVED INADEQUATE WHEN MEASUR ING NEUTRONS IN A MIXED GAMMA-NEUTRON RADIATION FIELD. THE APPROACH USED IN THE WORK TO BE REPORTED HERE IS ONE OF DIRECT MEASUREMENT CF ABSORBED DOSE ACCOMPLISHED WITH A TISSUE-EQUIVALENT PROPORTIONAL COUNTER (TEPC). THESE TECHNIQUES ARE CLASSED UNDER THE GENERAL FIELD OF MICRODOSIMETRY, WHICH IS A STUDY DF THE MANNER IN WHICH RADIATION DEPOSITS ENERGY IN MATTER.

AVAILABILITY - CLEARINGHOUSE FOR FEDERAL SCIENTIFIC AND TECHNICAL INFORMATION, SPRINGFIELO, VA. 22151 , $\$ 3.00$ COPY, \$0.65 MICROFICHE

\# BIOLOGICAL CONCENTRATION, MAN + \#DEPOSITION + *DOSE MEASUREMENT, INTERNAL + *DQSIMETRY, GENERAL + \$ GAMMA EMITTER + *INSTRUMENTATION, RADIATION MONITORING + \#NEUTRON + COUNTER +

RADIATION SAFETY AND CONTROL

$15-28042$

HONSTEAD JF

A SURVEY OF ENVIRONMENTAL DOSE EVALUATIONS

BATTELLE MEMORIAL INSTITUTE

10 PAGES, 7 FIGURES, NUCLEAR SAFETY, 9(5), PAGES 383-392 (SEPT.-0CT. 1968)

ENVIRONMENTAL DOSE CALCULATIONS ARE USED AS A BASIS FOR EVALUATING ENVIRONMENTAL SURVEILLANCE DATA. DOSE EVALUATIONS ARE CONS ISTENT WITH THE RECOMMENDATIONS OF THE FEDERAL RADIATION COUNCIL (FRC) AND THE INTERNATIONAL COMMISSION ON RADIOLCGICAL PROTECTION BUT ARF NOT NOW REQUIREO BY THE REGULATIONS GOVERNING THE OPERATION OF NUCLEAR FACILITIES. HANFORD IS THE ONLY U.S. SITE AT WHICH REGULAR ANNUAL DOSE E.VALUATIONS ARE PUBLISHED. THE FOLLOWING BENEFITS MIGHT BE DERIVEO FROM DOSE EVALUATIONS AT MORE U.S. SITES - (1) DEMONSTRATION OF THE FRC RANGE APPROPRIATE FOR EACH SITE, (2) OPTIMIZATION OF THE SCOPE OF ENVIRONMENTAL MONITORING PROGRAMS, (3) ASSURANCE THAT ANY ENVIRONMENTAL RECONCENTRATION PROCESSES WILL BE DETECTED, AND (4) READY ACCOMMODATIDN OF NEW SOURCES OF EXPOSURE IN THE ENVIRONMENT.

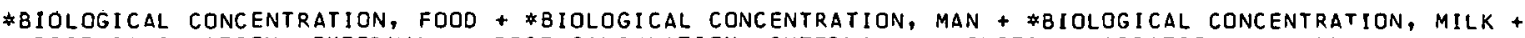
\#DOSE CALCULATION, EXTERNAL + \#DOSE CALCULATION, INTERNAL + \#MONITOR, RADIATION, ENVIRONYEVTAL + *RIVER, CLINCH + \#SURVEILLANCE PROGRAM + DIETARY HABIT + FEDERAL RAOIATION COUNCIL + ICRP + RADIATION SAFETY AND CONTROL

$15-28043$

HEFT RE + STEELE WA

PROCEDURES FOR THE SYSTEMATIC SEPARATION AND ANALYSIS OF RADIOACTIVE PARTICLES FROM NUCLEAR DETONATIONS

CALIFORNIA UNIV., LIVERMORE, LAWRENCE RADIATION LAB.

UCRL-50428+. 32 PAGES, 9 FIGURES, 3 TABLES, 10 REFERENCES, MAY. 17,1968

A SET OF PROCEDURES FOR THE SYSTEMATIC SEPARATION AND ANALYSIS OF VELOPED TO PROVIDE THIS INFORMATION. PARTICLE GROUPS WAS DEVELOPED FOR USE IN A REEXAMINATION OF EARLY TIME AERIAL FILTER AND LOCAL FALLOUT SAMPLES OF RADIOACTIVE PARTICLES FROM NUCLEAR DETONATIONS. ASSESSMENT OF THE OVERALL BIOLOGICAL EFFECT OF A PAPTICULAR. NUCLEAR DETONATION REQUIREO THAT FOR THE COMPLETE PARTICLE POPULATION, WE KNOW THE SIZE OISTRIBUTION, THE RADIO-ISOTOPIC COMPOSITION AS A FUNCTION OF SIZE, AND, FINALLY, THE

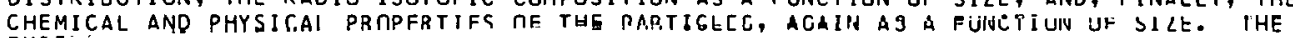
EXPEERIMENTAL PROCEDURES DESCRIBED HERE WERE DE

AVAILABILITY - CLEARINGHOUSE FOR FEDERAL SCIENTIFIC AND TECHNICAL INFORMATION, SPRINGFIELD, VA. 22151 $\$ 3.00$ COPY, \$0.65 MICRCFICHE

* ANALyTICAL TECHNIQUE, GENERAL + \#PARTICLE SIZE + \#PARTICLE SIZE DISTRIBUTION + \#RADIOISOTOPE + * SPECTROMETRY, GAMMA + FALLOUT + FILTER + MEASUREMENT, GENERAL + NUCLEAR DETONATION + RADIATION SAFETY AND CONTROL + SEPARATOR

- 
CATEGORY 16

METEOROLOGICAL CONSIDERATIONS

16-25668

HARDY EP + RIVERA J

HEALTH AND SAFETY LABORATORY FALLOUT PROGRAM QUARTERLY SUMMARY REPORT IOECEMBER 1 , 1967 THROUGH MARCH 1 . 19681

AEC, HEALTH AND SAFETY LABORATORY

HASL-193 (APP.) +. 250 PAGES, FIGURES, TABLES, APRIL 1,1968

THIS REPORT PRESENTS CURRENT DATA FROM THE HASL FALLOUT PROGRAM, THE DIVISION OF BIOLOGICAL ANO MEOICAL RESEARCH AT ARGONNE NATIONAL LABORATORY, THE NATIONAL RADIATION LABORATORY IN NEH ZEALAND, THE INSTITUTE OF NUCLEAR SCIENCES IN NEW ZEALAND, AND EURATOM JOINT NUCLEAR RESEARCH CENTRE. RADIONUCLIDE LEVELS IN STRATOSPHER IC AIR, SURFACE AIR, FALLOUT, MILK, DTHER DIET COMPONENTS, AND TAP WATER ARE GIVEN IN TABULAR FORM. THE INITIAL SECTION CONSISTS OF INTERPRETIVE REPORTS AND NOTES COVERING THE FOLLOHING TOPICS - COMPARISON OF FALLOUT COLLECTORS, STRATOSPHERIC RADIOACTIVITY LEVELS THROUGH JANUARY 1968, ISOLATION OF RADIOACTIVE PARTICLES IN FALLOUT, AN OCE AN FALLOUT EXPERIMENT, ANO PREDICTED SR-9O LEVELS IN DIET COMPOMENTS. A BIBLIDGRAPHY OF RECENT PUBLICATIONS RELATED TO RADIONUCLIDE STUDIES IS ALSO PRESENTEO.

AVAILABILITY - CLEARINGHOUSE FOR FEDERAL SCIENTIFIC AND TECHNICAL INFORMATION, SPRINGFIELD, VIRGINIA $22151, \$ 3.00$ COPY, $\$ 0.65$ MICROFICHE

\#F ILLOUT + \#MONITORING PROGRAM, FNVIRINMENTAL + CONCENTRATION, GROUND LEVEL +

INSTRUMENTATION, AIR SAMPLING + SAMPLING, HIGH ALTITUDE + STRATOSPHERE + STRONTIUM

16-25883 ALSO IN CATEGORIES 18 AND 2

BELL PSAR SECTION II, STATION SITE AND ENVIRONS

NEH YORK STATE ELECTRIC + GAS CORPORATION

100 PAGES, 17 FIGURES, 12 TABLES. PAGE II-1-1 THRU II-6-2. MARCH 1968. DOCKET $50-319$.

INCLUOES PRELIMINARY (JAN. 68) REPORTS ON METEOROLOGY (B. E. DETHIER) AND LIMNOLOGY OF CAYUGA LAKE AND INTERRELATIONS WITH NUCLEAR POWER PLANT (J. F. STORR). \#\#NOCTURVAL. JRAINAJE WIND FLOWS UP RIVER FROM ITHACA 113 MILES AWAY) TOWARO THE SITE. ON-SITE TOWER BEING INSTALLED. * EXTENSIVE MIXING OF WATER EXPECTED. A SURVEY IS BEING MADE, BASEO ON FOSSIL PLANT DISCHARGE. A HATCHERY FOR TROUT AND COHO SOLUTION IS PLANNEO TO USE THE THERMAL ENRICHMENT PROVIDED BY CONDENSER DISCHARGE.

AVAILABILITY - CLEARINGHOUSE FOR FEDERAL SCIENTIFIC ANO TECHNICAL INFORMATION, SPRINGFIELD, VIRGINIA, $22151, \$ 3.00$ COPY, \$0.65 MICROFICHE

* LAKE + \#THERMAL POLLUTION + BELL (BWR) + DIFFUSION + ON SITE WORK + REACTOR, BWR + REPORT, PSAR + TOPOGRAPHY

$16-25978$

HOLZWORTH GC

ESTIMATES OF MEAN MAXIMUM MIXING DEPTHS IN THE CONTIGUDUS UNITED STATES

U.S. WEATHER BUREAU RESEARCH STATION, CINCINNATI, OHIO

8 PAGES, 16 FIGURES, 2 TABLES, 3 REFERENCES, MONTHLY WEATHER REVIEW $92(5)$, PAGES $235-42$ (MAY 1964 )

MEAN RADIUSUNUE UBSERVATIONS AND NORMAL MAXIMUM SURFACE TEMPERATURES ARE USED TO ESTIMATE MONTHLY MEAN MAXIMUM MIXING DEPTHS (MMOS) FOR 45 STATIJNS IN THE CDNTIGUOUS UNITED STATES. FROM THESE DATA ISOPLETH ANALYSES OF MEAN MMDS ARE PRESENTED FOR EACH MONTH. SIXTEEN OF THE AVAILABLE 45 RADIOSONDE STATIONS ARE SELECTED AS GENERALLY REPRESENTATIVE OF THE U.S. AND ARE SUBJECTED TO FURTHER CONSIDERATIONS. THESE CONSIDERATIONS ARE 111 THE RELATIONSHIP BETWEFN MONTHLY MEAN MMOS COMPUTEO FROM MEAN OBSERVATIONS AND FROM INOIVIOUAL DSSERVATIONS, (2) COMPARI SON OF MONTHLY MEAN MMDS BASED ON OBSERVATIONS FOR 1 YEAR WITH THOSE BASED ON OBSERVATIONS FOR 10 YEARS, AND (3) THE STANDARD DEVIATIONS OF DAILY MMDS.

\#METEOROLOGY + \#MIXING DEPTH + ATMOSPHERIC DIFTUSIÜ, CLIMATOLOGY + ATMOSPHERIC POLLUTION + ATMOSPHERIC STABILITY + SURVEY, GENERAL

16-26734 NLSO IN CATEGORY O

JDSHICW + INGLE NA + JATHAR NB

AN AUTOMATIC OATA-LOGGING SYSTEM FOR METEOROLOGICAL STUDIES IN REACTOR ENVIRONMENTS ATOMIC ENERGY ESTABLISHMENT TROMBAY, BOMBAY, INDIA

STI/PUB/115 + CN-22/43+. 8 PAGES, 7 FIGURES, 2 REFERENCES, PAGES 595-602 IN NUCLEAR ELECTRONICS COATCREAGE RROCEEDINGS, BOMBAY, NOV. $22=26,1965$

AN AUTOMATIC DATA-LOGGING SYSTEM WAS DESIGNED FOR METEOROLOGICAL STUDIES FOR THE TARAPUR POWER REACTOR. THESE STUDIES REQUIRE THE MEASUREMENT OF WIND SPEED, WIND DIRECTION, ATMOSPHERIC PRESSURE, TEMPERATURE, ETC., AVERAGEU UVER A CERTAIN FIXED PERIOD, DT VARIOUS HEIGHTS ON A TOWER. THE SYSTEM IS DESIGNEU TÜ LÜG UATA FROM 256 SENSORS. THE DATA ARE FED TB A OIGITAL COMPUTER FOR ANALYSIS.

AVAILABILITY - NATIONAL AGENCY FOR INTERNATIONAL PUBLICATIONS, INC., 317 EAST 34 TH STREET, VEW YORK, N.Y. $10016, \$ 13.50$ COPY 1 BOOK

* oATA pRocessing + instrumentation, meteorological + METEOROLOGY 
CATEGORY 16

METEOROLOGICAL CONSIDERATIONS

$16-26795$

DABBERDT WF

TOWER-INDUCED ERRORS IN WIND PROFILE MEASUREMENTS

UNIVERSITY OF WISCONSIN, MAOISON

8 PAGES, 12 FIGURES, REFERENCES, JOURNAL OF APPLIED METEOROLOGY 7(3), PAGES 359-66 (JUNE 1968)

AN INVESTIGATION OF THE EFFECT OF A METEOROLOGICAL TOWER ON THE MEASUREMENT OF WIND SPEED HAS CONDUCTED AT BROOKHAVEN NATIONAL LABORATORY. REDUCTIONS UP TO 35 PER CENT OCCUR IN THE WAKE. THE DISTRIBUTION OF THE VELOCITY DEFICIT IN THE WAKE IS NEARLY GAUSSIAN. CORRECTIONS BASED ON THIS OISTRIBUTION HAVE IMPROVED WIND DATA IN A TRIAL CASE. A SLIGHT DEPENDENCE ON

ATMOSPHERIC STABILITY WAS DETECTED. THE DEFICIT APPEARS TO BE INDEPENDENT OF THE WIND SPEEO.

* ATMOSPHERIC STABILITY + \#ERRDR ANALYSIS + \#WIND PROFILE + BNL + MICROMETEOROLOGY + STACK + WIND STATISTICS

$16-26796$

DABBERDT WF

WINO DISTURBANCE BY A VERTICAL CYLINOER IN THE ATMOSPHERIC SURFACE LAYER

UNIVERSITY OF WISCONSIN, MADISON

5 PAGES, 9 FIGURES, I TABLE, REFERENCES, JOURNAL OF APPLIED METEOROLOGY 7(3), PAGES 367-371 (JUNE 1968)

THE VELOCITY DISTRIBUTION IN THE NEIGHBORHOOD OF A CYLINDRICAL OBSTACLE WAS MEASURED OVER THE FROZEN SURFACE OF LAKE MENOOTA, MAOI SON, WIS. NON-DIMENSIONAL ISOTACH PATTERNS WERE CONSTRUCTED DEPICTING THE VELOCITY DISTRIBUTION AT TWO LEVELS WITHIN THE ATMOSPHERIC SURFACE LAYER. DIFFERENCES IN THE VERTICAL SHEAR BETHEEN THE TWO LEVELS IS SEEN TO AFFECT THE NATURE OF THE PATIERNS. HIND SPEED REDUCT IONS OF O PER CENT ARE NOTED UPWIND OF THE CYIINDER AND IN EXCESS OF 40 PER CENT DOWNWIND. THE UPWIND PATTERN IS FAIRLY WELL REPRESENTED BY THE POTENTIAL SOLUTION. THE MORE COMPLEX DOWNWIND PATTERN IS ASYMMETRICAL. LARGE VERTICAL COMPONENTS OF THE VELOCITY WERE COMPUTED.

\#ERROR ANALYSIS + *STACK + *WIND STATISTICS + ATMOSPHERIC STABILITY + MICROMFTERROLDGY + WIND PROFILE

$16-26797$

DAVIS FK + NEWSTEIN H

THE VARIATION OF GUST FACTORS WITH MEAN WIND SPEED AND WITH HEIGHT

DREXEL INSTITUTE OF TECHNOLOGY, PA.

7 PAGES, 13 FIGURES, I TABLE, REFERENCES, JOURNAL OF APPLIED METEDROLOGY 7(3), PAGES 372-78 (JUNE 1968)

RECORDS FROM WIND INSTRUMENTS INSTALLED ON A 1000-FT TOWER WERE ANALYZED FOR GUSTINESS

CHARACTERISTICS. THE RESULTS SHOW THAT GUST FACTORS DECREASE WITH INCREASING WIND SPEED,

DECREASE WITH INCREASING HEIGHT, AND HAVE NO OBVIOUS RELATIONSHIP TO THE TEMPERATURE LAPSE

RATE.

* TURBULENCE, STATISTICS + \#WIND STATISTICS + ATMOSPHERIC STABILITY + MICROMETEOROLOGY + SURVEY, GENERAL + WIND PROFILE

$16-26798$

SIEWART RE

ATMOSPHERIC DIFFUSION OF PARTICULATE MATTER RELEASED FROM AN ELEVATED CONTINUOUS SOURCE

UNIVERSITY OF FLORIDA, GAINESVILLE

8 PAGES, 8 FIGURES, 3 TABLES, REFERENCES, JOURNAL OF APPLIED METEOROLOGY $7(3)$, PAGES $425-32$ (JUNE 1968 )

DUSTFALL-SIMULATION EXPERIMENTS WERE CONDUCTED TO ESTIMATE THE GROUND-LEVEL OEPOSITION

PATTERN. BATCHES OF DIFFERENT SIZE GLASS MICROSPHERES WERE CONTINUOUSLY RELEASED INTO THE

ATMOSPHERE FROM AN ELEVATED POINT SOURCE. THE DATA AND DATA OBTAINED BY PREVIDUS

INVESTIGATORS WERE COMPARED WITH THEORY. TWO MATHEMATICAL MODELS WERE USED IN THE COMPARISON

- A THREE-DIMENSIONAL CLASSICAL MODEL BY DENISOV, ANO A THREE-DIMENSIONAL STATISTICAL MODEL

BY CSANADY.

* CONCENTRATION, GRGUND LEVEL + \#ARTICULATE + \#SOURCE, CONTINUOUS + \#SOURCE, ELEVATED +

ATMOSPHERIC DIFFUSION EXPERIMENT + COMPARISON, THEORY AND EXPERIENCE + OEPOSITION

$16-26799^{\circ}$

PETERSON KR

CONTINUDUS POINT SOURCE PLUME BEHAVIOR OUT TO 160 MILES

AIR RESOURCES LABORATORY, MD.

10 PAGES, 14 FIGURES, REFERENCES, JOURNAL OF APPLIED METEOROLOGY 7(2), PAGES $217-226$ (APRIL 1968 I

RADIDACTIVE AR-41 WAS MEASUREO BY AN AIRBORNE GAMMA-RAY SPECTROMETER AS FAR AS $160 \mathrm{~N}$ MILES DOWNWIND OF BNL ON A DAY WITH NEUTRAL STABILITY. A VERTICAL CROSS SECTION AT 144 N MILES SHOWS THE PLUME TO BE WELL ORGANIZED, WITH A NEARLY UNIFORM VERTICAL DISTRIBUTION TO AT LEAST $2000 \mathrm{FT}$. THE PEAK CONCENTRATION, WHEN CORRECTED FOR RADIOACTIVE DECAY, DECREASES BY A FACTOR DF 7-10 OVER A DISTANCE OF $150 \mathrm{~N}$ MILES AND A TRAVEL TIME OF 10-12 HR. THE LATERAL STANDARD DEVIATION OF THE PLUME APPEARS TO FIT AN EXTENSIDN OF THE PASOUILL-GIFFORD D CURVE WITH DISTANCE, WHERE THE LATERAL STANDARD DEVIATION IS APPROXIMATELY EQUAL TO TWO-THIRDS OF THE 
CATEGORY 16

METEOROLOGICAL CONSIDERATIONS

16-26799 *CONTINUEO*

TRAVEL TIME IN HOURS.

*CONCENTRATION, ISOPLETH + *SOURCE, CONTINUDUS + *SOURCE, ELEVATED + ATMOSPHERIC DIFFUSION EXPERIMENT + BNL + CONCENTRATION, MAXIMUM + PLUME BEHAVIOR, GENERAL + SOURCE, POINT

16-26800

DANIELSEN EF

STRATOSPHERIC-TROPOSPHER IC EXCHANGE BASED ON RADIUACTIIVITY, OZONE AND POTENTIAL VORTICITY

UNIVERSITY OF HAWAII, HONOLULU

17 PAGES, 14 FIGURES, REFERENCES, JOURNAL OF THE ATMOSPHERIC SCIENCES 25(3), PAGES 502-518 (MAY 1968 )

VERTICAL CROSS SECTIONS OF POTENTIAL VORTICITY, COMPUTEO ANO CONTOURED BY HAND, AND HEMISPHERIC DISTRIBUTIONS OF POTENTIAL VORTICITY, COMPUTEO AND CONTOURED BY MACHINE, ARE COMPARED TO BOTH DISCRETEAND CONTINUOUS MEASUREMENTS OF RADIOACTIVITY MADE DURING PROJECT SPRINGFIELD. COMPARISONS MADE IN THE UPPER TROPOSPHERE AND. LOWER STRATOSPHERE SHOW A POSITIVE CORRELATION BETWEEN POTENTIAL VORTICITY AND RADIOACTIVITY OF STRATOSPHERIC AIR FROM HIGH LATITUDES IS TRANSPORTED SOUTHWARD AND DOWNWARD INTO THE TROPOSPHERE AS THE TROPOPAUSE FOLDS.

\#ATMOSPHERIC DIFFUSION, GLOBAL + AEROSOL, RADIOACTIVE + COMPARISON, THEORY ANO EXPERIENCE + FALLOUT + OZONE + SAMPLING, HIGH ALTITUDE + STRATOSPHERE + TROPOSPHERE

$16-27291$

ROBINS OL + MATTIA MM

COMPUTER PROGRAM HELPS DESIGN STACKS FOR CURBING AIR POLLUTION

DAY AND ZI MMERMANN, INC.

4 PAGES, 2 FIGURES, 13 REFERENCES, CHEMICAL ENGINEERING, 75(3), PAGES 119-122 (JANUARY 29 , 1968 )

DESCRIBES A COMPUTER PROGRAM FOR DETERMINING THE EFFECT OF STACK HEIGHT AND THE GRDUND-LEVEL CONCENTRATION OF GASES AND PARTICLES. THE PROGRAM PERMITS A RAPID AND COMPREHENSIVE ANALYSIS OF STACK DISPERSION. METEOROLOGICAL PARAMETERS ARE TREATED ONLY SUPERFICIALLY, AND THE EFFECT OF TOPOGRAPHY ON GROUND-LEVEL CONCENTRATION IS COMPLETELY NEGLECTED.

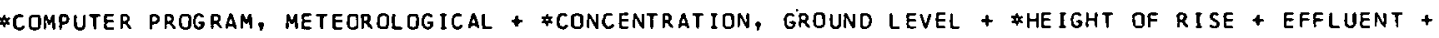
PARTICULATE + STACK

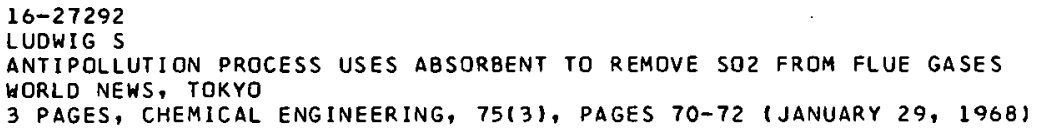

DESCRIBES A PILOT PLANT THAT USES MNO2 AS AN ABSORBENT OF SO2 FROM THE FLUE GAS OUTPUT OF AN DIL-BURNING POHER PLANT, AND AMONIUM SULFATE IS RECOVERED AS A BYPROOUCT. THE PLANT DBTAINED AN SO2 REMOVAL RATE OF BETTER THAN $90 \%$. THE ECONOMICS OF THE SYSTEM ARE PRESENTED.

*ADSORPTION + *EQUIPMENT DESIGN + *SULFUR DIOXIDE + AIR CLEANING + ATMOSPHERIC POLLUTION + ECONOMICS + EFFLUENT + JAPAN

16-27293 ALSO IN CATEGORY 14

MELICK R + VAN MIDOLESWORTH L

RADIO IODINE FALLQUT IN AUSTPALIAN SHEED

UNIVERSITY OF MELBOURNE OEPARTMENT OF MEDICINE, THE ROYAL MELBOURNE HOSPITAL + DEPARTMENTS OF PHYSIOLOGY

ANO BIOPHYSICS, UNIVERSITY OF TENNESSEE, U.S.A.

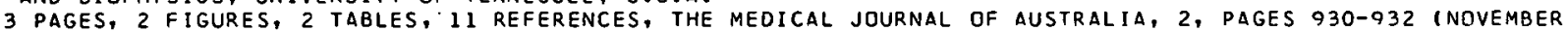
12,19661

SINCE APRIL 1957, THE THYROID I-131 CONTENT OF VICTORIAN LAMBS HAS BEEN FOLLOWED. RESULTS UP TO AUGUST 1958 HAVE BEEN REPORTED PREVIOUSLY. THIS PAPER PRESENTS RESULTS UP TO JANUARY 1966. THE RADIDACTIVITY FOUND IN THYROIDS OF VICTORIAN SHEEP HAS BEEN VERY MUCH LESS THAN THAT FOUNO IN THE NORTHERN HEMISPHERE, AND PRESENT FOR A MUCH SHORTER TIME.

\#BIOLOGICAL CONCENTRATION, ANIMAL + \#FISSION PRODUCT, IODINE + ATMOSPHERIC DIFFUSION, GLOBAL + AUSTRALIA + FALLOUT + NUCLEAR DETUNAIIUN

$16-27295$

BOURTSEY JJ + MALAKHOV SG

FALLOUT BY THE PRECIPITATIONS OF THE DIVISION PRODUCTS FROM THE SUBCLOUD LEVEL OF THE ATMOSPHERE

7 PAGES, 5 FIGURES, 13 REFERENCES, FIZIKA ATMOSFERY I OKEANA, 4(3), PAGES 328-334 (1968) IN RUSSIAN

THE SELF-CLEANING OF THE LOWER TROPOSPHERE OF RADIOACTIVE AEROSOLS WAS STUDIED FOR THE PERIDD OF NUCLEAR TESTS. MEASUREMENTS WERE CARRIED OUT AT THE HIGH-ALTITUDE STATIONS IN CAUCASUS. THE SUBCLOUO LEVEL IS CLEANED TO A CONSIDERABLE EXTENT BY PRECIPITATIONS OF SMALL INTENSITY. THE WASHOUT COEFFICIENT OF FALLOUT PRODUCTS WITH AN AGE OF 4-5 MONTHS WAS $5.9 \times 10(M I N U S 5 T H)$ 
CATEGORY 16

METEOROLOGICAL CONSIDERATIONS

16-27295 \#CONTINUED*

PER SEC FOR SNOW AND $3.1 \times 1 O(M I N U S$ 5TH) PER SEC FOR RAIN.

* AEROSOL, RADIOACTIVE + \#PRECIPITATION + *WASHOUT + FALLOUT + NUCLEAR DETONATION + RAINOUT + SNOW + TROPOSPHERE

$16-27331$

TURNER DB

U.S. DEPARTMENT OF HEALTH, EDUCATION, AND WELFARE, PUBL IC HEALTH SERVICE, CINCINNATI, OHIO

PHS-999-AP-26 +. 84 PAGES, FIGURES, TABLES, 1967

THIS WORKBOOK PRESENTS METHODS OF PRACTICAL APPLICATION DF THE BINOMIAL CONTINUDUS PLUME DISPERSION MODEE TO ESTIMATE CONCENTRATIONS OF AIR POLLUTANTS. ESTIMATES OF DISPERSION ARE THOSE OF PASQUILL AS RESTATED BY GIFFORD. EMPHASIS IS ON THE ESTIMATION OF CONCENTRATIONS FROM CONTINUOUS SOURCES FOR SAMPLING TIMES OF 10 MIN. SOME OF THE TOPICS DISCUSSED ARE DETERMINATION OF EFFECTIVE HEIGHT OF EMISSION, EXTENSION OF CONCENTRATION ESTIMATES TO LONGER SAMPLING INTERVALS, INVERSION BREAK-UP FUMIGATION CONCENTRATIONS, AND CONCENTRATIONS FROM AREA, LINE, AND MULTIPLE SOURCES. THENTY-SIX EXAMPLE PROBLEMS AND THEIR SOLUTIONS ARE GIVEN. SOME GRAPHICAL AIOS TO COMPUTATION ARE INCLUDED.

AVAILABILITY - D.B. TURNER, AIR RESOURCES FIELD RESEARCH OFFICE, ENVIRONMENTAL SCIENCE SERVICES ADMINISTRATION, U.S. DEPARTMENT OF HEALTH, EDUCATIDN, AND WELFARE, PUBLIC HEALTH SERVICE, CINCINNATI, OHIO

*HEALTH PHYSICS TRAINING + *METEOROLOGY + *STAFFING, TRAINING, QUALIFICATION + ATMOSPHERIC POLLUTION + METEOROLOGICAL SUPPORT + REACTOR, POWER + REACTOR, RESEARCH

$16-27468$

TLLLES U

RD CADLES PARTICLES IN THE ATMOSPHERE AND SPACE (BOOKREVIEW)

2 PAGES, GEOCHIM COSMOCHIM ACTA, 31(5), PAGES $911-912$ (MAY 1967)

ONE-THIRD OF THE BOOK IS DEVOTED TO PARTICLES IN THE ATMOSPHERE-TROPOSPHERE, STRATOSPHERE, AND MESOSPHERE. ANOTHER QUARTER IS OEVOTED TO GLOBAL RADIOACTIVE FALLOUT AND ATMOSPHERIC CIRCULATION. ANOTHER THIRD IS DIVIDED AMONG ZODIACAL LIGHT, METEORITES AND METEOROIOS, THE ORIGIN AND SURFACE OF THE MOON, OTHER PLANETS, COMETS, GALACTIC AND INTERPLANETARY DUST, AND TERTITES.

* aER OSOl PROPERTIES + \#ATMOSPHERIC CIRCULATION, GLOBAL + \#FALLOUT + BIBLIOGRAPHY + MESOSPHERE + PARTICULATE + STRATOSPHERE + TROPOSPHERE

16-27620 ALSO IN CATEGORIES 18 AND 5

RUSSELVILLE SUPPLEMENT 6 - TORNADO ANALYSIS

ARKANSAS POWER AND LIGHT COMPANY

8 PAGES, 12 REFERENCES, PAGES $1-8$ OF SUPPLEMENT 6 TO THE APPLICATION FOR RUSSELVILLE LICENSES IDOCKET 50-3131 JULY 11,1968

PROVIOES REVISED PSAR PAGES AND (RESPONOING TO INFORMAL URL QUESTIONSI JUSTIFICATION QF TORNAOO DESIGN CRITERIA ANO BEHAVIOR OF SPENT FUEL POOL DURING TORNADO. DESCRIBES BEST OBSERVATIONAL DATA FOR WIND VELOCITY IUSE 300 MPH BROAD FRONT WIND INSTEAD OF 200 MPH VORTEX), PRESSURE DROP $(1.7$ PSI/4 SEC), WATER LOSS FROM POOLS AND WELLS $(2$ FT MOUND OF WATER APPEARS FROM LOW PRESSURE, SPRAY AND SUCKING DISPLACE WATER, SURVEY REOUESTED IN PILGRIM

STATION REVIEW WILL BE COMPLETED SEPT. 1968 BUT SO FAR RESULTS NEGATIVE), AND MISSILES (ONLY LIGHT WEIGHT MISSILES WOULO REACH REFUELING FLOOR 50 FT ABOVE GRADE, MISSILES FROM REFUELING FLOOR ARE MOSTLY SIDING AND HANO CARTSI.

USAEC, PUBLIC DOCUMENT ROOM, 1717 H ST., WASHINGTON, D.C. 20545 (25 CENTS/PAGE)

\#DESIGN CRITERIA + \#DESTRUCTIVE WINO + \#UEL STORAGE + BIBLIOGRAPHY + CONTAINMENT. DESIGN + MISSILE GENERATION AND PROTECTION + PRESSURE TRANSIENT + PRESSURE, SUBATMOSPHERIC + REACTOR, PWR + REPORT, PSAR

$16-27815$

SLADE DH

METEOROLOGY AND ATOMIC ENERGY, 1968

UNITED STATES ATOMIC ENERGY COMMISSION, OIVISION OF TECHNICAL INFORMATION

TID-24190+. 445 PAGES, FIGURES, TABLES, REFERENCES, JULY 1968

A REVISION OF METEOROLOGY AND ATOMIC ENERGY, AECU-3066, PIIBLISHEO IN 1955. THE OVERALL SCOPE OF THE VOLUME IS INDICATED BY THE CHAPTER HEADINGS AS FOLLOWS - (I) INTRODUCTION TO THE METEOROLOGY-ATOMIC ENERGY RELATION, (II) METEOROLOGICAL FUNDAMENTALS FOR ATMOSPHERIC TRANSPORT AND DIFFUSION STUDIES, (III) AN OUTLINE OF THE THEORIES OF DIFFUSION IN THE LOKER LAYERS IN THE ATMOSPHERE, (IV) DIFFUSION AND TRANSPORT EXPERIMENTS, (V) PROCESSES OTHER THAN NATURAL TURBULENCE AFFECTING EFFLUENT CONCENTRATIONS, (VI) METEOROLOGICAL INSTRUMENTS FOR USE IN THE ATOMIC ENERGY INDUSTRY, (VII) RADIOACTIVE CLOUD-DOSE CALCULATIONS, (VIII) ENVIRONMENTAL SAFETY ANALYSIS.

AVAILABILITY - CLEARINGHOUSE FOR FEDERAL SCIENTIFIC AND TECHNICAL INFORMATION, SPRINGFIELD, VA. 22151 
$16-27815 \%$ CONT INUED*
$\$ 3.00 \mathrm{COPY}, \$ 0.65 \mathrm{MICROFICHE}$

* ATMOSPHERIC DIFFUSION + \#BIBLIOGRAPHY + \#METEOROLOGY + \#PLUME BFHAVIOR, GENERAL + ATMOSPHERIC DIFFUSION EXPERIMENT + ATMOSPHERIC STABILITY + DEPOSITION + GAUSSIAN PLUME FORMULA + K THEORY + METEOROLOGICAL SUPPORT + RAINOUT + SITE CLIMATOLOGY + STAFFING, TRAINING, OUALIFICATION + TURBULENCE, STATISTICS + WIND STATISTICS

16-27833 ALSO IN CATEGORIES 18 AND 2

BRUNSWICK STEAM ELECTRIC PLANT UNITS $1+2$, PRELIMINARY SAFETY ANALYSIS REPORT, VOLUME III CAROL INA POWER + LIGHT COMPANY

275 PAGES, FIGURES, TABLES, JULY 1968, DOCKET 50-324/325

FOUR APPENOICES - (A) GEOLOGICAL ANALYSIS, FOUNOATION ENGINEERING, SEISMIC OESIGN CRITERIA, SEISMIC DESIGN RESPONSE SPECTRA, PRELIMINARY MARINE BIJLOGY AND OCEANCGRAPHY, STORM TIJES, AND WILMINGTON 1959-63 WINOIF WINO OIFFUSION STUDY. THEN FOLLOWS THE USUAL - (B) JET PUMP OEVELOPMENT, (C) CORE SPRAY TEST PROGRAM, AND (D) COMPARATIVE EVALUATION WITH AEC OESIGN CRITERIA (A LISTING OF APPROPRIATE PSAR SECTIONS FOR EACH CRITERIA).

availability - uSAEC PUblic DOCUMENT ROOM, WASHINGTON, D. C.

* AEC DESIGN CRITERIA + *EARTHQUAKE ENGINEERING + BRUNSWICK (BWR) + REACTOR, RWR + RFPRRT, PSAR

16-27834 ALSO IN CATEGORIES 18 AND 5

BRUNSWICK STEAM ELECTRIC PLANT UNITS $1+2$, PRELIMINARY SAFETY ANALYSIS REPORT, VOLUME II CAROLINA POWER + LIGHT COMPANY

400 PAGES FIGURES, TABLES, JULY 1968, DOCKET 50-324/325

VOL. II CONTAINS SECT. VII IINSTRUMENTATION ANO CONTROL - INCLUDES AUTO LOAD OISPATCH FROM RALEIGH, N. C.), VIII (ELECTRICAL POWER - 4 DIESELS), IX (RAD WASTE), X (DUXILIARIES), XI (POWER CONVERSION), XII (PLANT OPERATIONS - PERSONNEL WILL BE AVAILABLE FROM ROBINSON ?I, XIII (TECH. SPECS.), AND XIV (SAFETY AND ACCIOENT ANAIYSIS). 40 PAGES DESCPIBE THE DFFSITE DOSE CALCULATION MODEL USED IN RADOS COMPUTER CODE, ISOTOPE FRACTIONS RELEASED FROM FUEL IN EXPERIMENTS ANO IN THESE ACCIDENTS, ANO PROVIDES BOTH A CONSERVATIVE BASE CASE AND $\triangle$ BEST ESTIMATE (MARGINS RANGE FROM FACTORS OF 8400 TO 16,700 ), 6 PAGES PROVIDE A SENSITIVITY ANALYSIS AND A SPECIAL COMPARISON WITH TIO 14844 AND RECENT AEC-DRL SAFETY EVALUATION.

AVAILABILITY - USAEC PUBLIC DOCUMENT ROOM, WASHINGTON, D. C.

\#DOSE + \#OFF SITE + ACCIDENT MODEL + BRUNSWICK (BHR) + COMPARISON, THEORY AND EXPERIENCE + ERROR ANALYSIS + REACTOR, BWR + REPORT, PSAR + SAFETY EVALUATION + STAFFING, TRAINING, QUALIFICATION

$16-27835$

BRAR SS + SVIHLA G + NELSON DM I GUSTAFSON PF

HAS THE HASL ION-EXCHANGE COLUMN BEEN SERIOUSLY IN ERROR

AEC, HEALTH AND SAFETY LABORATORY

HASL-193+. 16 PAGES, 2 IABLES, APRII 1, 1968

COMPARES TWO FALLOUT COLLECTORS USED BY HASL - THE STEEP-WALLED STAINLESS-STEEL POTS AND THE PLASTIC ION-EXCHANGE COLUMN FUNNEL COLLECTORS. RESULTS INDICATE THAT BOTH SYSTEMS ARE VALID COLLECTORS. WHEN COMPARED WITH SYSTEMS USED BY THE UNITED KINGDOM, CANADA, NEW ZEALAND, AND AUSTRALIA, THE ION-EXCHANGE SYSTEM WAS LOHER, PROBÁ2BLY DUE TO IMPROPER MAINTENANCE. A AUSTRALIA, THE ION-EXCHANGE SYSTEM WAS LOHER, PROBABLY DUE TO IMPROPER MAINTENANCE. A
CONVECTION FACTOR WAS COMPUTED TO CORRECT THE GLOBAL FALLOUT DATA FOR EACH TEN-DEGREE LATI TUDE BAND, BASED ON THE FRACTION OF ALL COLUMN COLLECTORS IN THE BAND.

AVA ILABILITY - CLEARINGHOUSE FOR FEDERAL SCIENTIFIC. AND TECHNICAL INFORMATION, SPRINGFIELD, VIRGINIA $22151, \$ 3.00$ COPY, \$0.65 MICROFICHE

*FALlOUT + \#INSTRUMENTATION, aIR SAMPLING + \#MONITORING PROgRAM, ENVIRONMENTAL *

ATMOSPHERIC DIFFUSION, GLOBAL + COMPARISON, THEORY ANO EXPERIENCE + STRONTIUM

16-27874 ALSO IN CATEGORY 14

HARDY EP + RIVERA J

FALLOUT PROGRAM. QUARTERLY SUMMARY REPORT, MARCH 1--JUNE 1,1968 + APPENOIX TO FALLOUT PROGRAM QUARTERLY

SUMMARY REPORT, MARCH 1, 1967--JUNE 1 , 1968

U. S. ATOMIC ENERGY COMMISSION

HASL-197 + HASL-197(APP,) +. 832 PAGES, FIGURES, TABLES, REFERENCES, JULY 1, 1968

PRESENTS CURRENT DATA FROM THE HASL FALLOUT PRTGRAM, THE UKAERE HEALTH PHYSICS ANO MEDICAL DIVISION, EURATOM JOINT NUCLEAR RESEARCH CENTRE, THE NATIONAL RADIATION LABORATORY IN NEW ZEALAND, AND THE DIVISION OF BIOLOGICAL AND MEDICAL RESEARCH AT ARGONNE NATIONAL LABORATORY. THIS REPORT IS DIVIOED INTO FOUR MAIN PARTS - (I) INTERPRETIVE REPORTS ANO NOTES, (2) HASL FALLOUT PROGRAM DATA, (3) OATA FROM SOURCES OTHER THAN HASL, ANO (4) RECENT PUBLICATIONS RELATED TO RADIONUCLIDE STUDIES.

AVAILABILITY - CLEARINGHOUSE FOR FEDERAL SCIENTIFIC AND TECHNICAL INFORMATION, SPRINGFIELO, VA. 22151 , $\$ 3.00$ COPY, \$0.65 MICROF ICHE 
CATEGORY 16

METEOROLOGICAL CONS IDERATIONS

16-27874 *CONT INUED*

* BIBLIOGRAPHY + \#BIOLOGICAL CONCENTRATION, AGRICULTURAL PRODUCE + \#BIOLOGICAL CONCENTRATION, MAN + * DOSE MEASUREMENT, INTERNAL + \#FALLOUT + \#MONITORING PROGRAM, ENVIRONMENTAL + *SAMPLING, HIGH ALTITUDE + NUCLEAR DETONATION + OCEAN AND SEA + RADIOCHEMICAL ANALYSIS

16-27880 ALSO IN CATEGORY 15

RICHARDSON LC GOR THE FORTRAN VERSION OF RSAC. A RADIOLOGICAL SAFETY ANALYSIS COMPUTER PROGRAM

PHILLIPS PETROLEUM COMPANY

IDO-17261 +. 136 PAGES, FIGURES, 3 TABLES, 5 REFERENCES, JUNE 1968

THIS REPORT IS A MANUAL FOR THE FORTRAN VERSION OF THE RSAC COMPUTER CODE. THE MATHEMATICAL MODEL AND EOUATIONS ARE DESCRIBED IN IDO-17151, RSAC--A RADIOLDGICAL SAFETY ANALYSIS COMPUTER PROGRAM, BY R. L. COATES AND N, R. NORTON, MAY 1966. THE PROGRAM COMPUTES THE POTENTIAL RADIOLOGICAL DOSES RESULTING FROM EITHER A CONTINUDUS OR INSTANTANEOUS RELEASE OF RADIOACTIVE FISSION PRODUCTS TO THE ATMOSPHERE. THE DOSES CONSIDERED ARE CLOUD GAMMA, DEPOSITION GAMMA, INGESTION, AND INHALATION AND ARE BASED UPON THE RELEASE OF UP TO 450 ISOTOPES, THE RELATIVE ABUNDANCE OF EACH ISOTOPE BEING DEPENDENT UPON THE OPERATING HISTORY, OF THE NUCLEAR REACTOR UNDER CONSIDERATION

AVAILABILITY - CLEARINGHOUSE FOR FEDERAL SCIENTIFIC AND TECHNICAL INFORMATION, NATIONAL BUREAU OF STANDARDS, SPRINGFIELO, VA. $22151, \$ 3.00$ COPY, \$0.65 MICROFICHE

* COMPUTER PROgRAM + \#OOSE CALCULATION, EXTERNAL + \#DOSE CALCULATION, INTERNAL + \#SOURCE, COVTINUDUS + \#SOURCE, INSTANTANEOUS + DEPOS ITION + INGESTION + INHALATION

$16-28022$

C.DTE 0

FLUIO DYNAMICS ANALOG STUDIES RELATED TO THE DISPERSION OF PARTICLES IN THE UPPER ATMOSPHERE. FINAL REPORT GCA CORP., BEDFORD, MASS.

SC-CR-67-2812+.67 PAGES, FIGURES, 2 TABLES, REFERENCES, MARCH 1968

MOTIONS PRODUCED BY THERMAL CONVECTION IN A ROTATING FLUID-FILLED ANNULUS BEAR SIMILARITY TO MOTIONS IN THE EARTHS UPPER ATMOSPHERE. TO EXPLORE THE USEFULNESS OF THIS SIMILATION TO UNDERSTANDING OF TRANSPORT AND MIXING PROCESSES IN THE ATMOSPHERE, FLOW VISUALIZATION EXPERIMENTS USING OYE TRACES IN THE ANNULUS WERE PERFORMED. VALUABLE QUALITATIVE AND QUANTITATIVE INFORMATION ON DISPERSAL RATES WAS OBTAINED WHICH PROVIDES INSIGHT INTO SIMILAR PROCESSES IN THE ATMOSPHERE AND COMPARES WITH OTHER STUDIES OF TRANSPORT AND DIFFUSIJN PROCESSES.

AVAILABILITY - CLEARINGHOUSE FOR FEDERAL SCIENTIFIC AND TECHNICAL INFORMATION, SPRINGFIELD, VA. 22151 , $\$ 3.00$ COPY, \$0.65 MICROF ICHE

\#ANNULUS + \#ATMOSPHERIC CIRCULATION, GLOBAL + \#IMULATION + EXPERIMENT, GENERAL + THEORETICAL INVESTIGATION

I $K-28 \cap 23$

CRAWFORD TD

AI SA IM TATESORPY 14

THE LONG RANGE OIFFUSION OF THE EFFLUENT CLOUD FROM THE PHOEBUS 1B EP-IV REACTQR TEST OFF FFRRIIARY ?3. I9G7

UNIVERSIIY UT LALI HURNIA, LIVERMORE

UCRL-50,418 +. 29 PAGES, 14 FIGURES, 4 TABLES, 20 REFERENCES, APRIL 1968

THIS REPORT DISCUSSES THE MOVEMENT AND DIFFÚSION OF THE EFFLUENT CLOUD PRODUCED BY THE PHOEBUS

IB EP-IV EVENT OF FEBRUARY 23, 1967. THE CLOUD WAS TRACKED BY AIRCRAFT FOR ALMOST THREE

DAYS, AND USEFUL CONCENTRATION MEASUREMENTS WERE RBTAINED FOR ALMOST TWO DAYS. PRE- AND

POST-RUN CALCULATIONS WERE DONE WITH A COMPUTER CODE FOR LARGE CLOUD DIFFUSION USING

CLIMATOLOGY AND OBSERVED METEOROLOGY RESPECTIVELY. CALCULATIONS OF CONCENTRATIONS AND CLDUD

SIZE ARE COMPARED WITH THE AVAILABLE MEASUREMENTS. CALCULATIONS AGREE WELL WITH MEASUREMENT

FOR THE FIRST FEW HOURS.

AVAILABILITY - CLEARINGHOUSE FOR FEOERAL SCIENTIFIC AND TECHVICAL INFORMATION, SPRINGFIELD, VA. 22151 , $\$ 3.00$ COPY; $\$ 0.65$ MICROFICHE

\#COMPUTER PROGRAM, METEOROLOGICAL + \#METEOROLOGICAL SUPPORT + \#NEVADA TEST SITE + \#RADIOACTIVITY RELEASE + ATMOSPHERIC DIFFUSION + COMPARISON, THEORY AND EXPERIENCE + NUCLEAR ROCKET 
CATEGORY 17

OPERATIONAL SAFETY AND EXPERIENCE

17-24634 ALSO IN CATEGORIES 14 ANO 13

INDUSTRIAL RADIOACTIVE WASTE BULLET INS

ROCHESTER COMMITTEE FOR SCIENTIFIC INFORMATION

6 PAGES, ATOMIC ENERGY CLEARING HOUSE 14(16), PAGES 5-10 (APRIL 15, 1968)

(NO. 3, FEB. 28,1968 ) - CORRECTS ERRONEOUS DATA IN PREVIOUS DATA BULLETIN. ON DEC. 16, 1967, THE CS-137/SR-90 CONCENTRATION (PCI/1) AT NFS OUTFALL WAS 16C,003/86,909, AT BUTTERMILK CREEK, 6,600/4,010. RCSI QUESTIONS OFFICIAL VIEW THAT MEASUREMENTS COMDLY WITH LAW RECAUSE CATTARANGUS CREEK MEETS INDUSTRIAL EFFLUENT RADIOACTIVITY STANDARDS. \$\# 1 NC. 2 , FFB. 24, $1968)$ - DIST.USSFS EFFLUENT MEASUREMENT REPORTED OVER A PERIOD OF YEARS. ASSERTS THAT NFS SENDS SLUGS OF VERY HOT EFFLUENT INTO CREEK, AS ACTUAL MEASUREMENIS INDICATE DISCHARGE AT SEWER OUTLET WAS 30,000 TIMES PERMISSIBLE LIMIT. ASSERTS OFFICIAL SAMPLING IS NOT DONE AT THE PLACE. WHERE LIMITS EXCEEDED.

\#RADIATION, PUBLIC EOUCATION/ACCEPTANCE + \#ASTE DISPOSAL, LIOUID + DILUTION + EFFLUENT + FUEL REPROCESSING + MAXIMUM PERMISSIBLE CONCENTRATION (MPC) + NFS

17-25884 ALSO IN CATEGORIES 18 ANO 5

BELL PSAR SECT 3.3 .7 DESCRIPTION DF CORE ANALYSIS

NEW YORK STATF ELECTRIC + GAS CORPORATION

85 PAGES, 20 FIGURES, 5 TABLES, PAGE III-3-5 THRU -7. MARCH 1 Y 68 50-319.

A COMPUTER PROGRAM (UNSPECIFIED) IS USED TO ANALYZE THE THERMAL AND HYDRAULIC CHARACTERISTICS OF THE CORE AS A WHOLE. OUTPUT AND INPUT OISCUSSEO BRIEFLY. RLCENT MODIFICATIONS IN CORE OESIGN AND IN THERMAL HYORAULIC EVALUATION TECHNIQUES ALLOW HIGHER FSEONATER TFMP. WITHOUT ENCROACHING ON THERMAL MARGINS. THE ITEMS AND THEIP. EFFECT ON INLET SUBCOOLING (BTU/LB) MCHFR ARE - (1) INLET ENTHALPY NOW BASED ON $1 \% 20$ PSIA DOME PRESSURE, RATHER THAN IOSO INLET $(+41+.06)$. (2) CORE BYPASS FLOW NOW ESTABLISHED AS $7 \%(-1+0.03)$. (3) CORE MIDPLANE PRESSURE. OF $1035 \mathrm{NOW}$ USED INSTEAD OF INLET PRESSURE $(-1-.02)$. (4) 2 IRCONIUM SPACER TEST DATA 1 $-1-.021$. \#THE NET EFFECT, WHEN FEEDHATER INCREASED TO $420 \mathrm{~F}$, IS TO INCREASE SUBCOJLING C. 3 BTU/LB ANO MCHFR BY 0.0 ?

AVAILABILITY - CLEARINGHOUSE FOR FEDERAL SCIENTIFIC AND TECHNICAL INFORMATIDN, SPRINGFIELO, VIRGINIA, $22151, \$ 3.00$ COPY, \$0.65 MICROFICHE

\# ANALYTICAL MODEL + \#COMPUTER PROGRAM + \#SUBCOOLING + BELL (BWR) + COMPARISON, THEORY AND EXPERIENCE + HEAT FLUX, CRITICAL + HEAT TRANSFER, BOILING + REACTOR, BWR + REPORT, PSAR + SAFETY MARGIN

17-25935 ALSO IN CATEGORIES 1 AND 5

MACPHERSON RE

FAST REACTOR SAFETY CONFERENCE

GAK RIDGE NATIONAL LABORATORY, OAK RIDGE, TENNESSEE

8 PAGES, TABLE, REFERENCE, NUCLEAR SAFETY, 9(3), PAGES 202-209 (MAY-JUNE, 1968)

BRIEFLY SUMMARIZES THE SESSIONS COVERING (1) CORE MELTDOWN ACCIDENTS, (2) SODIUM BOILING ANO SUPERHEATING, (3) INCIUENTS IN REACTORS, AND (4) SAFETY. MALFUNCTIONS IN THE RRS WERE (I) FUEL-ELEMENT LEAKS CAUSED BY HEATER SHORTING, PLUS AIR IN LEAKAGE CAUSING MASSIVE SODIUM OXIDE PLUGGING, AND (2) REACTIVITY PERTURBATIONS DUE TO ENTRAINMENT OF ARGON BY THE SOOIUM STREAM. AAPLUGGING OF SUBASSEMBLIES BY OXIDE HAS BEFN DETECTEO PRIMARILY BY THE EFFECT ON PRIMARY FLOW. A PANEL DISCUSSION SHOWED THAT ATTENTION IS SWITCHING FROM THE LARGE, LESS PROBABLE ACCIDENT TO THE SMALLER, MORE FREQUENT ACCIDENTS WHICH AFFECT PLANT USE.

\#REACTOR, FAST + \#REACTOR, FAST + \#SAFETY PRINCIPLES AND PHILOSOPHY + \#SAFETY PRINCIPLES AND PHILOSOPHY + ACCIDENT ANALYSIS + ACCIDENT ANALYSIS + ACCIDENT, MAXIMUM CREDIBLE (MCA)

ACCIDENT, MAXIMUM CREDIBLE (MCA) + COOLANT QUALITY + COOLANT QUALITY + FLOW BLOCKAGE + FLOW BLOCKAGE + INC IDENT, GENERAL + INCIOENT, GENERAL + REACTOR, LMCR + REACTOR, LMCR + REVIEW + REVIEW + SIDIUM MACPHERSON RE

FAST REACTOR SAFETTY CONFERENCE

UAK RIOGE NATIONAL LABORATORY, DAK RIDGE, TENNESSEE

8 PAGES, TABLE, REFERENCE, NUCLEAR SAFETY, 9(3), PAGES 202-209 (MAY-JUNE, 1968 )

BRIEFLY SUMMARIZES THE SESSIONS COVERING $(1)$ CORE MELTDOWN ACCIDENTS, (2) SODIUM BOILING AND SUPERHEATING, (3) INCIDENTS IN REACTORS, AND 141 SAFETY. MALFUNCTIONS IN THE BRS WERE (I) FUEL-ELEMENT LEAKS CAUSED BY HEATER SHORTING, PLUS AIR IN LEAKAGE CAUS ING MASSIVE SDDIUM OXIOE PLUGGING, AND (2) REACTIVITY PERTURBATIONS DUE TO ENTRAINMENT OF ARGON BY THE SODIUM STREAM. \# PLUGGING OF SUBASSEMBLIES BY OXIDE HAS BEEN DETECTED PRIMARILY BY THE EFFECT ON PRIMARY FLOW. A PANEL DISCUSSION SHOWED THAT AFTENTION IS SWITCHING FROM THE LARGE, LESS PR.OBABLE AC.T.INFNT TO THE SMALLER, MORE FREQUENT ACCIDENTS WHICH AFFECT PLANT USE.

FRER

$17-25981$

HEIDER LH + JUNES RF

PRIMARY TO SECONDARY LEAKAGE IN STEAM GENERATORS ANO SUBSEQUENT TUBE REPAIRS

YANKEE ATOMIC ELECTRIC COMPANY, ROWE, MASSACHUSETTS

YAEC $1021+$ +. 30 PAGES, 7 FIGURES, 2 TABLES, NOVEMBER 1, 1967

TUBES IN VARIOUS STEAM GENERATORS WERE PLUGGEO AT REFUELING SHUTDOWNS 6/62, $10 / 63$, AND $8 / 64$, USING A DRIVEN TAPEREO PLUG, HELDED TO THE TUBE. RADIATION LEVELS OF 2-20 R/HR WERE INSIDE 
CATEGORY 17

OPERATIONAL SAFETY AND EXPERIENCE

$17-25981$ \#CONTINUED*

THE SECONDARY HAND MOLES, AND 5-15 R/HR INSIDE THE PRIMARY WATER BOX. NO DETECTABLE BETA. LEAKS WERE LOCATED IN THE TUBES BY A SIMPLE MOVABLE PLUG. CHEMICAL ANO WIRE-BRUSH DECONTAMINATION WAS NOT FEASI BLE BECAUSE OF THE IRREGULAR SURFACES AND SHINE DOWN THE TUBES. REWELOING THE DIAPHRAGM BACK ON WAS COMPLICATED BY FITTING PPOBLEMS AND BY WATER DRIPPING ON THE ARC.

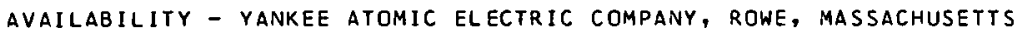

\#FAILURE, TUBING + \#MAINTENANCE AND REPAIR + *STEAM GENERATOR + OECONTAMINATION + OPERATING EXPERIENCE + REACTOR, PWR + WELOING + YANKEE (PWR)

$17-25982$

ALSO IN CATEGORY 15

GRENON M

LE TRAVAIL EN MILIEU HOSTILE

220 PAGES, 8 TABLES, 26 FIGURES, PUBLISHED BY PRESSES UNIVERSITAIRES DE FRANCE, 1968 (IN FRENCH)

IIN FRENCHI PAGES 1-146 DESCRIBE REMOTE MANIPULATIONS IN RADIOACTIVITY USAGE. PAGES 147-205 DESCRIBE UNDERWATER AND OUTER-SPACE USAGES. CHAPTERS DESCRIBE PRINCIPLES OF REMOTE

MANIPULATION DEVICES (50 PGI, REMOTE VIEWING TV AND SHIELO-WINOOWS (16 PG), FUEL-HANDLING AND REACTOR-REFUELING DEVICES (34 PG), AND REMOTE-CONTROL VEHICLES FOR NUCLEAR ACCIDENT RECOVERY. INCLUDES 21 PAGES ON SLI RECOVERY OPERATIONS.

AVAILABILITY - PRESSES UNIVERSITAIRES DE FRANCE, 108, BOULEVARD SAINT-GERMAIN, PARIS

* INCIDENT, RECOVERY FROM + \#REMOTE MANIPULATING AND VIEWING + INCIDENT, SL 1 + REACTOP, DOWER

17-25987 NLSO IN CATEGORY $\epsilon$

COSTNER RA + CRAMER EN + SCOTT RL

REACTOR OPERATOR. STUDY HANOBOOK VOLUME III - REACTOR PHYSICS

OAK RIDGE NATIONAL LABORATORY

ORNL-TM-2034, VOL. III +. 222 PAGES, 51 FIGURES, JUNE 1968

A SELF-TEACHING (PROGRAMMED INSTRUCTION) MANUAL COVERING NEUTRON REACTIONS, DESCRIPTION OF REACTORS, REACTIVITY AND REACTOR PERIOD, FUEL BURNUP, XENON- AND SAMARIUYM-POISONING EFFECTS, TEMPERATURE EFFECTS, AND NEUTRON FLUX DISTRIBUTION. EACH SECTION CONTAINS BACKGROUNO MATERIAL FOR UNDERSTANDING, EXAMPLE TO CLARIFY UNDERSTANDING, AND QUESTION FOR SELFTESTING. MATERIAL IS PRESENTED IN FORM OF PARAGRAPHS, AND IN FOLLOWING PARAGRAPHS, A BLANK MAY BE LEFT FOR STUOENT TO FILL IN WITH THE MAIN WORO OR IDEA.

AVAILABILITY - CLEARINGHOUSE FOR FEDERAL SCIENTIFIC AND TECHNICAL INFORMATION, SPRINGFIELD, VA. 22151 , $\$ 3.00$ COPY, \$0.65 MICROFICHE

\#PROCEOURES AND MANUALS + \#REACTOR PHYSICS + \#TAFFING, TRAINING, QUALIFICATION + FLUX DISTRIBUTION + FUEL BURNUP + NEUTRON INTERACTION + REACTIVITY EFFECT + REACTOR DESCRIPTION + REACTOR, RESEARCH + SAMARIUM + TEMPERATURE REACTIVITY EFFECT + XENON

17-26005 ALSO IN CATEGORY 1

FUEL CLAUOING FAILURE

USAEC, DIVISION OF OPERATIONAL SAFETY

ROE 68-7 +. 2 PAGES, AEC BULLETIN, OPERATING EXPERIENCES, REACTOR SAFETY, MAY 27,1968

ALUMINUM-CLAD, 168-G U235, FLAT-PLATE, ETR-TYPE ELEMENTS WERE NORMALLY USED TO 200,000 MWD/T. SPENT ELEMENTS WERE NORMALLY STOREO IN CADMIUM-LINED HOLSTLRS INSIDE THE REACTOR VESSEL. A CHANGE REQUIRED STORAGE IN THE STORAGE POOL, WITH ONLY FILTRATION FOR TREATMENT. A

LOW-BURNUP ELEMENT ( $5 \mathrm{R}$ AT CONTACT), EXAMINED BEFORE REPLACEMENT, HAD A BLISTER COMPLETELY THROUGH THE 0.015-IN. CLAD. ALTHOUGH CORROSION WAS NOTED ON ALL 11 ELEMENTS STORED ISOME FOR AS LONG AS 13 MONTHSI THIS WAS THE ONLY DEFECT.

USAEC, DIVISION OF OPERATIONAL SAFETY, WASHINGTON, D.C. 20545

*COOLANT QUALITY + \#FAILURE, CLADDING + \#FUEL STORAGE + ALUMINUM + COOLANT PURIFICATION SYSTEM + FAILURE, AOMINISTRATIVE CONTROL + REACTOR, AEC OWNED + REACTOR, RESEARCH

$17-26300$

REACTOR ENGINEERING DIVISION ANNUAL REPORT

ARGONNE NATIONAL LABORATORY, ARGONNE, ILLINOIS

ANL $-7290+.234$ PAGES, FIGURES, TABLES, REFERENCES, APRIL 1967

TOPICS DISCUSSED ARE (1) EBR-II PLANT IMPROVEMENTS AND EXPERIMENTAL SUPPORT, (2) AARR TITLE-1 DESIGN AND SUPPORTING. RESEARCH, (3) EBWR REPAIRS AND REACTOR KINETICS, (4) NUCLEAR ROCKET PROGRAM, (5) FAST-REACTOR R AND D, (6) LIQUID-METAL HEAT-TRANSFER PROGRAM, (7)

MAGNETOHYDRODYNAMICS, (8) REACTOR SAFETY RESEARCH PROGRAM COVERING COOLANT DYNAMICS, REACTOR CONTROL ANO STABILITY, FUEL MELTDOWN STUDIES, AND CONTAINMENT, AND (9) FEASIBILITY STUDY OF ASSS, USING 10,000-MW SODIUM-COQLED FAST BREEDER

AVAILABILITY - CLEARINGHOUSE FOR FEDERAL SCIENTIFIC AND TECHNICAL INFORMATION, SPRINGFIELD, VIRGINIA 22151 \$3.00 COPY, SO.65 MICROFICHE 
CAT.EgORY 17

DPERATIONAL SAFETY AND EXPERIENCE

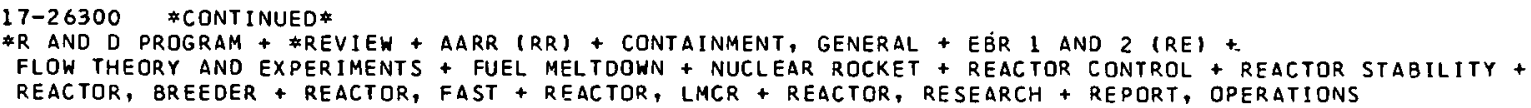

USAEC, PUBLIC DOCUMENT ROOM, $1717 \mathrm{H} \mathrm{ST.,} \mathrm{WASHINGTON,} \mathrm{D.C.} 20545$ (25 (SNTS/PAGE)

\#PERSONNEL EXPOSURE, RADIATION + \#RADIOGRAPHY + INCIDENT, NONREACTOR + SCURCE, RADIATION

17-26306 ALSD IN CATEGORY 15

COBALT 60 RADIOGRAPHY SOURCE DROPPED INTO GULF OF MEXICO

GLOBAL X-RAY AND TESTING CORPORATION

1 PAGE, TWX TO AEC OIVISION OF COMPLIANCE FROM I. ST ROMAIN, JUNE, 1966

GLOBAL X-RAY AND TESTING CO. REPORTS THAT A 7.8-CURIE CO-60 SOURCE WAS DROPPED INTO THE GULF OF MEXICO 50 MILES SOUTH OF LEESVILLE, LA. DEPTH OF WATER WAS I5O FT. AN UNSUCCESSFJL ATTEMPT WAS MADE TO RETRIEVE THE SOUR.CE WITH A LARGF MAGNFT. THE CRANK AND SOURCE TUBE HAD BEEN REMOVED FOR TRANSFER TO A NEW LOCATION. WHEN RADIOGRAPHER WAS READY FOR NEXT EXPOSURE, HE NOTICED PIGTAIL WAS GONE. DOSE WAS 10 MR FOR 3 DAYS WORK.

USAEC, PUBLIC DOCUMENT ROOM, 1717 H ST., WASHINGTON, D.C. 20545 (25 CENTS/PAGE)

\#RADIOGRAPHY + *SOURCE, RADIATION, LOST + INCIDENT, HUMAN ERROR + INCIDENT, NONREACTDR + ICEAN AND SEA

17-26307 ALSO IN CATEGORY 15

KAUUI OGRAPH'Y EXPOSURL AT AVOPDALE EHIPYAP.DS INT.

AVONDALE SHIPYARDS

1 PAGES, TWX TO AEC DIVISION OF COMPLIANCE FROM J.K. MCCUE, APRIL 7, 1967

RADIOGRAPHER RECEIVED ESTIMATED EXPOSURE OF 6 REMS WHEN AN IRIDIUM SOURCE STUCK IN THE CABLE. DOSIMETER DID NOT INDICATE A DOSE. TWO FILM BADGES ARE TO BE PROCESSFD.

USAEC, PUBL IC DOCUMENT ROOM, $1717 \mathrm{H} 51$. , WASHINGTON, D.C. 20545 (25 CENTS/PAGE)

\#PERSONNEL EXPOSURE, RADIATION + \#RAOIOGRAPHY + INCIDENT, EQUIPMENT + INCIOENT, NONREACTOR

17-26308 ALSE IN CATEGORY 15

OVEREXPOSURE TO RADIOGRAPHER

GENERAL OYNAMICS CORF., GROTON, CONNECTICUT

1 PAGE, ATOMIC ENERGY CLEARING HOUSE, 14(9), PAGE 27 (FEBRUARY 26,1968

A RAOIOGRAPHER RECEIVED A CALCULATED DOSE OF 14.5 REMS GAMMA WHILE PERFORMING OPERATIONS WITH A 96 -CURIE IR-192 SOURCE.

USAEC, PUBLIC DOCUMENT ROOM, 1717 H ST., WASHINGTON, D.C. 20545 (25 CENTS/PAGE)

*PERSENNEL EXPOSURE, RACIATION + INCIOENT, NONREACTOR + RADIOGRAPHY 
A RADIOGRAPHER ANO 2 ASSISTANTS WERE EXPOSEO TO A 7.2-CURIE SOURCE WHEN IT FAILED TO RETURN TO ITS SHIELD AND A SURVEY WAS NOT MADE. TWO MEN RECEIVED THEIR DOSE WHILE PERFORMING RADI OGRAPHY, THE THIRD WHILE RETURNING THE TUBE, WHICH CONTAINED THE UNSHIELDED SOURCE, TO STORAGE. INCIDENT DISCOVERED WHEN ANOTHER RADIOGRAPHER SURVEYED THE STORAGE ROOM. ESTIMATED EXPOSURES ARE 2.2 REMS, 800 MILLIREMS, AND A POSSIBLE MAXIMUM OF 230 REMS TO THE THIRD MAN.

USAEC, PUBLIC DOCUMENT ROOM, 1717 H ST., WASHINGTON, D.C. 20545 (25 CENTS/PAGE)

* INCI DENT, HUMAN ERROR + \#PERSONNEL EXPOSURE, RADIATION + \#RAOIOGRAPHY + FAILURE, OPERATOR ERROR + INC I DENT, NONREACTOR

17-26310 ALSO IN CATEGORIES 11 AND 15

U.S. TESTING CO. CITED FOR NON-COMPLI I ANCE IN RAOIOGRAPHY OPERATIONS

UNITED STATES ATOMIC ENERGY COMMISSION

4 PAGES, LETTER TO U.S. TESTING CO. FROM E.R. PRICE, NOVEMBER 10, 1965

NONCOMPLIANCE ITEMS INCLUDE PERSONNEL FAILING TO WEAR DOSIMETERS AND BADGES, INADEQUATE PERSONNEL MONITORING RECORDS, PERFORMING RADIOGRAPHY WITHOUT OPERABLE SURVEY INSTRUMENTS, UNQUAL IFIED PERSONNEL ACTING AS RADIOGRAPHERS, ASSISTANTS HAD NOT RECEIVED COPIES OF OPERATING AND EMERGENCY PROCEDURES, SURVEILLANCE INAOEQUATE TO PREVENT UNAUTHORIZEO ENTRY INTO HIGH RADIATION AREAS, SURVEY INSTRUMENTS WERE NOT CALIBPATED EVERY 3 MONTHS, IMPROPER UTILIZATION LOOP, AND COMPANY FAILURE TO REPORT AN EMPLOYEE OVEREXPOSURE.

USAEC, PUBLIC DOCUMENT RDOM, 1717 H ST, WASHINGTON, D.C. 20545 (75 (.ENTS/PAGE)

* FAILURE, ADMINISTRATIVE CONTROL + \#AILURE, OPERATOR ERROR — \#INSPECTION AND COMPLIANCF + \#RADIOGRAPHY

17-26311 $\triangle L S O$ IN CATEGORY 15

OVEREXPOSURE TO FILM BADGE WHILE CALIBRATING INSTRUMENTS

U.S. ARMY, FORT MCPHERSON

4 PAGES, LETTER TO AEC DIVISION OF LICENSING AND REGULATION GROM G.L. GALLIER, MARCH 25 , 1965

A FILM-BADGE REPORT INDICATED AN EXPOSURE OF 41 REMS (BETA). INVESTIGATION REVEALED THAT EXPOSURE WAS TO FILM BADGE ONLY ANO OCCURRED EITHER WHEN OPERATOR PERFORMING INSTRUMENT CALIBRATION LEFT HIS BADEE ON THE TABLE NEXT TO THE SOURCE FOR AN INDEFINITE TIME, OR HHEN HE LEANED OVER THE CALIBRATCR WHILE ITS PORT WAS OPEN AND THE BADGE WAS ON HIS BELT OVER THE FRONT OF THE RIGHT HIP.

USAEC, PUBLIC DOCUMENT ROOM, 1717 H ST., WASHINGTON, D.C. 20545 (25 CENTS/PAGEI

*FAILURE, OPERATOR ERROR + \#INS IRUMENTATION CALI BRATION + \#MONITOR, RADIATION, DERSONNEL + \#PER SONNEL EXPOSURE, RADIATION + \#RADIOGRAPHY

17-26312 ALSO IN CATEGORY 15

AEC CITATION FOR OEFICIENCIES IN RADIOGRAPHY OPERATIONS

UNITED STATES ATOMIC ENERGY COMMISSION

2 PAGES, LETTER TO FOSTER WHEELER CORPORATION FROM E.R. PRICE, NOVEMBER 6,1963

AN AEC INSPECTION UN AUGUST 29, 1963, RESULTÉD IN A CITATION FOR $(1)$ PERMITTING EMPLOYEES TO PERFORM RADIOGRAPHY BEFORE COMPLETING THE TRAINING COURSE, (2) FAILING TO INCLUDE IN REPORTS OF RADIATION EXPOSURE TO FORMER EMPLOYEES THE STATEMENTS THAT THE REPORT WAS FURNISHED UNDER DROVISIONS OF AEC REGULATIONS AND SHOULD BE PRESERVED FOR FUTURE REFERENCE, AND (3) FAILINF, TO LABEL A SOURCE CONTAINER.

USAEC, PUBLIC DOCUMENT ROOM, 1717 H ST., WASHINGTON, D.C. 20545 (25 CENTS/PAGE)

\#FAILURE, ADMINISTRATIVE CONTROL + \#INSPECTION ANO COMPLIANCE + \#RADIOGRAPHY + RADIATION SAFETY AND CONTROL + SOURCE, RADIATION + STAFFING, TRAINING, QUALIFICATION

17-26314 ALSO IN CATEGORY 15

CITATION FOR NONCOMPLI ANCE TO RADIOGRAPHY REGULATIONS

UNITED STATES ATOMIC ENERGY C.RMMISSION

3 PAges, LETTER TO RADIOLOGICAL TESTING LAB FROM L.0. LOW, MARCH 6, 1968

AEC CITED COMPANY FOR FAILING TO 111 SURVEY UNRESTRICTED AREAS, $(2)$ MAINTAIN RECORDS OF SURVEYS, (3) POST RADIATION AREAS, (4) PERFORM ADEQUATE SURVEYS AFTER EXPOSURES, (5) DIRFCTLY SURVEY TO PROTECT AGAINST UNAUTHORIZED ENTRY DURING OPERATIONS, (6) PREVENT UNAUTHORIZED PERSONNEL FROM PERFORMING RADIOGRAPHY, AND (7) POST THE VEHICLE USED FOR IRANSPORTING SOURCE 
CATEGORY 17

DPERATIONAL SAFETY AND EXPERIENCE

17-26314 \#CONTINUED*

ANO EXPOSURE DEVICE. AEC STATED THAT IMPROVEMENTS WERE NEEDED IN MANAGEMENT.

USAEC, PUBLIC DOCUMENT ROOM, 1717 H ST., WASHINGTON, D.C. 20545 (25 CENTS/PAGE)

*FAILURE, ADMINISTRATIVE CONTROL + \#INSPECTION AND COMPLIANCE + \#RADIOGRAPHY + SOURCE, RADIATION

17-26315 ALSO IN CATEGORY 15

RADIATION CONTROL DEVICE FOR RADIOGRAPHY ROOM

PARKER INDUSTRIAL XTRAY CORP.. NEW HAVEN, CONNECTICUT

1 PAGE, LETTER TO AEC DIVISION STATE AND LICENSEE RELATIONS FROM P.J. ROSENBAUM, NOVEMBER 30, I964

COMPANY RESPONSE TO AEC CITATION IS THAT THE AREA MONITOR FOR THE RADIOGRAPHY ROOM HAS BEEN REPAIRED. COMPANY DISAGREES HITH AEC RECOMMENDATION FOR CALIBRATION OF IHE SURVEY METER AND REQUESTS AEC TO INOICATE IF THE CALIBRATION POINTS ARE SUGGESTED OR MANDATORY.

USAEC, PUBLIC DÜCUMENT ROOM, $1717 \mathrm{H}$ ST.. HASHINGTON, 0.C. 20545 (25 CENTS/PACSE)

* PERSONNEL PROTECTIVE DEVIGE + \#RADIOGRAPHY + INSPECTION AND COMPLIANCE + INSTRUMENTATION CALIBRATION + INSTRUMENTATION, RADIATION MONITORING

17-26316 ALSO IN CATEGORY 15

RADIATION CONTROL DEVICE FOR RADIOGRAPHY ROOM

U.S. ATOMIC ENERGY COMMISSION, WASHINGTON, D.C.

I PAGE, LETTER TO PARKER INDUSTRIAL X-RAY LABORATORY FROM E.R. PRICE, JANUARY 4 , 1965

AEC AGAIN REQUESTS THAT COMPANY SPECIFY STEPS TAKEN TO ENSURE THAT RADIOGRAPHY WILL BE CONOUCTED IN ROOM ONLY HHEN IT IS EQUIPPED WITH AN OPERABLE CONTRDL DEVICE. ALSO, THE SURVEY INSTRUMENT SHOULD BE CALIBRATEO BY CHECKING AT LEAST TWO POINTS ON THE SCALE. THIS. WILL BE A REQUIREMENT WHEN THE LICENSE IS RENEHED.

USAEC, PUBLIC DOCUMENT ROOM, 1717 H ST., WASHINGTON, D.C. 20545 (25 CENTS/PAGE)

* INSTRUMENTATION CALIBRATION + \#INSTRUMENTATION, RADIATION MONITORING + \#PERSONNEL PROTECTIVE DEVICE + INSPECTION AND COMPL IANCE + RADIOGRAPHY

17-26317 ALSO IN CATEGORY 15

RADIATION CONTROL DEVICE FOR RADIOGRAPHY ROOM

PARKER INDUSTRI AL X-RAY, NEW HAVEN, CONNECTICUT

1 PAGE, LETTER TO AEC DIVISION OF STATE AND LICENSEE RELATIONS FROM P.J. ROSENBAUM, JANUARY 11 , 1965

COMPANY RESPONSE TO AEC CITATION FOR LACK OF OPERABLE RADIATION CONTROL DEVICE IN RADIOGRAPHY ROOM STATEO THAT (1) DOOR TO ROOM IS EQUIPPED HITH A BAR ACROSS IT TO PREVENT ACCIDENTAL ACC.ESS, (2) AN AREA MONITOR MONITORS THE RAOIATION LEVEL NEAR THE ENTRANCE TO THE ROOM WHENEVER RADIOGRAPHY IS PERFORMED IN THE ROOM, AND (3) IF THE PILL FAILS TO REIURN TO THE POT WHEN THE SAFE LIGHT FLASHES, THE AREA MONITOR WOULO INDICATE THIS FACT WHEN THE DOOR IS OPENED. THE MONITOR IS CONSIOEREN AS A CONTROL.

USAEC, PUBLIC DOCUMENT ROOM, 1717 H ST., WASHINGTON, D.C. 20545 (25 CENTS/PAGE)

* instrumentation, radiation monitoring + inspection and compliance + personnel protective deVice + RADIDGRAPHY

17-26318 ALSO IN CATEGORY 15

RADIATION CONTROL DEVICE FOR RAOIOGRAPHY ROOM

U.S. ATOMIC ENERGY COMMISSION, WASHINGTON, D.C.

2 PAGES, LETTER TO PARKER INDUSTRIAL X-RAY LABORATORY FROM E.R. PRICE, MARCH 23,1965

CLARIFIES STATEMENTS MADE BY COMPANY CONCERNING THE CONTROL DEVICE (AREA MONITOR).

REGULATIONS STATE THAT THE DEVICE SHALL EITHER CAUSE THE RADIATION LEVEL TO BE REDUCED WHEN AREA ENTRY OCCURS OR SHALL ENERGIZE A CONSPICUOUS OR AUOIBLE ALARM SUCH THAT THE INDIVIOUAL ENTERING AND THE LICENSEE ARE MADE AWARE OF THE ENTRY. COMPANY CONSIDERS THE AREA MONITOR AS A CONTROL, AND IT WAS REPAIRED AND OPERATING WITHIN A WEEK AFTER INSPECTION FOUND IT INOPERATIVE.

USAEC, PUBLIC DOCUMENT ROOM, 1717 H ST., WASHINGTON, D.C. 20545 (25 CENTS/PAGE)

* INSPECTION ANO COMPLIANCE + \#INSTRUMENTATION, RAOIATION MONITORING + \#PERSONNEL PROTECTIVE DEVICE + MONITOR, RADIATION, AREA + RADIOGRAPHY

17-26319 ALSO IN CATEGORY 15

OVEREXPUSSURE TO RADIOGRAPHER - SOURCE NOT CONNECTED TO CABLE

GENERAL DYNAMICS CORP., CONVAIR

2 PAGES, MEMORANDA ON OVEREXPOSURE, AUGUST 7,1964 
CATEGORY 17
OPERATIONAL SAFETY AND EXPER IENCE

17-26319 *CONT INUED*

ON AUGUST 6, 1964 , RADIOGRAPHER RECEIVED A DOSE OF 3.8 REMS. AFTER AN EXPOSURE, THE SOURCE WAS RETRACTED, BUT THE LIGHT INOICATING THAT THE SOURCE WAS SAFELY STORED WAS NOT RECEI VED. THE EXPOSURE DEVICE WAS OUTSIDE a TANK, WHILE THE SOURCE TUBE WAS INSIDE. WHEN THE

RADIOGRAPHER FOUNO HIS DOSIMETER WAS OFF SCALE, IT WAS DISCOVERED THAT THE SOURCE HAS NOT

ATTACHED TO THE OPERATING CABLE. CORRECTIVE ACTION INCLUDED 3 DAYS SUSPENSION WITHOUT PAY ANO A REVIEW OF THE INCIDENT AND CORRECT PROCEDURES WITH ALL RADIOGRAPHERS.

USAEC, PUBLIC DOCUMENT ROOM, $1717 \mathrm{H}$ ST., WASHINGTON, D.C. 20545125 CENTS/PAGEI

* FAILURE, OPERATOR ERROR + INCI DENT, NONREACTOR + PERSONNEL EXPOSURE, RADIATION + RADIOGRAPHY + SOURCE, RADIATION

17-26320 ALSO IN CATEGORY 15

OVEREXPOSURE TO RADIOGRAPHERS

SCHLUMBERGER WELL SURVEYING CORP., HOUSTON, TEXAS

1 PAGE, TEX TO AEC DIVISION OF COMPLIANCE REGION IV FROM 0.C. CHEATHAM, MAY 26,1966

A MONTHLY DOSIMETRY REPORT SHOWED THAT EXPOSURES TO TWO INDIVIDUALS WERE 42 AND 3.5 REMS, APPARENTLY TO COLLIMATED BEAMS. A INVESTIGATION IS UNDERWAY.

USAEC, PUBLIC DOCUMENT ROOM, 1717 H ST., WASHINGTON, D.C. 20545 (25 CENTS/PAGE)

*PER SONNEL EXPOSURE, RADIATION + \#RAOIOGRAPHY + INCIDENT, NONREACTOR

17-26321 ALSO IN CATEGORY 15

AEC CITATION FOR NONCOMPLIANCE WITH RADIOGRAPHY PROCEDURES

U.S. ATOMIC ENERGY COMMISSION, WASHINGTON, D, C.

2 PAGES, LETTER TO GLOBAL X-RAY AND TESTING CORP. FROM E.R. PRICE, DECEMBER 1, 1965

AN AEC INSPECTION IN OCTOBER 1965 RESULTED IN CITATION FOR 11 POSSESSING A SOURCE NOT

AUTHORI ZED BY LICENSE AND (2) USING A SOURCE IN ANCHORAGE, ALASKA, CONTRARY TO LICENSE.

USAEC, PUBLIC DOCUMENT ROOM, 1717 H ST., WASHINGTON, D.C. 20545125 CENTS/PAGEI

*FAILURE, ADMINISTRATIVE CONTROL + *INSPECTION AND COMPLIANCE + *RADIOGRAPHY + SOURCE, RADIATION

17-26325 ALSO IN CATEGORY 15

CITATION FOR DEFICIENCIES IN RADIOGRAPHY PROCEDURES

U.S. ATOMIC ENERGY COMMISSION, WASHINGTON, D. C.

2 PAGES, LETTER TO PIPEWELD X-RAY CORPORATION FROM E.R. PRICE, JANUARY 28,1965

AEC INSPECTIONS RESULTED IN CITATIONS FOR (1) NOT PROVIDING RAOIOGRAPHERS WITH COPIES OF AEC LICENSE, (2) ALLOWING OPERATIONS BY 3 RADIOGRAPHERS WHO WERE UNABLE TO READ A SURVEY METER CORRECTLY, (3) FAILURE OF RADIOGRAPHERS TO PERFORM RAOIATION SURVEY AFTER EXPOSURES, AND (4) EMPLOYEES NOT KNOWING AEC REGULATIONS.

USAEC, PUBLIC DOCUMENT ROOM, 1717 H ST., WASHINGTON, D.C. 20545 (25 CENTS/PAGEI

* INSPECTION AND COMPLIANCE + \#RADIOGRAPHY + FAILURE, ADMINISTRATIVE CONTROL + FAILURE, OPERATOR ERROR + STAFFING, TRAINING, QUALIFICATION

$17-26326 \quad$ ALSO IN CATEGORY 15

RADIOGRAPHY EXPOSURE AT GENERAL OYNAMICS CORP.

GENERAL OYNAMICS CORP., GROTON, CONNECTICUT

3 PAGES, LETTER TO AEC DIVISION OF LICENSES FROM W. GORVINE, $\triangle P R I L 4,1967$

A RADIOGRAPHER RECEIVED A DOSE OF 3.51 REMS WHEN THE SOURCE WAS NOT FULLY RETRACTED INTO ITS SHIELD. BOTH THE RADIOGRAPHER AND ASSISTANT STATED THAT THE STORED LIGHT WAS ON, INDICATING RETRACTION. A SURVEY WAS MADE FROM THE REAR AND SIDE BUT NOT. IN FRONT OF THE DEVICE. THE DEVICE WAS LOCKED AND MOVED TO A NEW POSITION. A SECOND ASSISTANT DISCOVERED THE CONDITION WHEN HE NOTED THAT HIS SURVEY METER WAS READING 5 MR/HR.

USAEC, PUBLIC DOCUMENT ROOM, 1717 H ST., WASHINGTON, D.C. 20545 (25 CENTS/PAGE)

\#PERSONNEL EXPOSURE, RADIATION + \#RADIOGRAPHY + INCIDENT, HUMAN ERROR + INCIOENT, NONREACTOR + SOURCE, RADIATION

17-26328 ALSO IN CATEGORY 15

AEC CITATION FOR NONCOMPLIANCE WITH RADIOGRAPHY REGULATIONS

U.S. ATOMIC ENERGY COMMISSION, WASHINGTON, D. C.

4 PAGES, LETTER TO SARNIA INSPECTION COMPANY, LTO. FROM E.R. PRICE, OCTOBER 1 , 1965

AN INSPECTION IN JUNE 1965 RESULTED IN CITATIONS FOR FAILING TO (1) LIMIT RAOIATION LEVEL AT SURFACE OF SOURCE DEVICE, (2) SURVEY AFTER EXPOSURES, (3) POST RADIATION AREAS, (4) MAINTAIN 
CATEGORY 17

OPERATIONAL SAFETY ANO EXPERIENCE

17-26328 \#CONTINUED*

UTILIZATION LOGS, (5) MAINTAIN RECOROS OF RECEIPT AND TRANSFER OF BYPRODUCT MATERIAL, (6)

RECORD DOSIMETER DOSES, (7) PERFORM OUARTERLY INVENTORIES OF BY-PRODUCT MATERIAL, (8) PERFORM

INSTRUMENT CALIBRATIONS, (9) PERFORM LEAK TESTS, 110 ) KEEP PERSONNEL-MONITORING RECOROS, (11)

KEEP RECORDS OF SURVEYS CONDUCTED AT SITE, AND 112$)$ KEEP RECORDS OF PERSONNEL TRAINING.

USAEC, PUBLIC DOCUMENT ROOM, $1717 \mathrm{H}$ ST., WASHINGTON, D.C. 20545 (25 CENTS/PAGE)

*FAILURE, ADMINISTRATIVE CONTROL + \#INSPECTION AND COMPLIANCE + \#RADIOGRAPHY + RADIATION SAFETY AND CONTROL

17-26329 ALSO IN CATEGORY 15

FAILURE TO USE SURVEY METER RESULTS IN OVEREXPOSURE TO RADIOGRAPHER

SCOPE INSPECTION CO., INC., HOUSTON, TEXAS

2 PAGES, LETTER TO AEC DIVISION OF STATE AND LICENSE RELATIONS FROM D. THOMAS, MAY 11, I967

ON APRIL 23, 1967, RADIOGRAPHER RECEIVEO A WHOLE-BODY DOSE OF 6.1 REMS AND A CALCULATED DOSE OF 162 REMS TO THE LEFT HANO. SOURCE FAILED TO RETURV TJ CAMERA, AND RADIDZRAPHER UIO NOT USE SURVEY METER. WHEN FILM HAS PROCESSED, HE BECAME AWARE THAT THE SOUPCE WAS STILL IN THE SNORKEL. HE GOT SURVEY METER, CUT PLASTIC SNORKEL, AND REPLACED THE SOURCE IN THE CAMERA.

USAEC, PUBLIC DOCUMENT ROOM, 1717 H ST., HASHINGTON, D.C. 20545 (25 CENTS/PASE)

*INCI DENT, HUMAN ERROR + \#PERSONNEL EXPOSURE, RADIATION + \#RADIOGRAPHY + INCIOENT, NONREACTOR + SUURCE, RAOIATION

17-26330 ALSO IN CATEGORY 15

OVEREXPOSURE TO SUPERVISORS DURING RECOVERY OF EXPOSEO SOURCE

U.S. NAVY, PORTSMOUTH NAVAL SHIPYARO, PORTSMOUTH, NEW HAMPSHIRE

3 PAGES, LETTER TO DIVISION OF MATERI ALS LICENSING FROM W.C. HUSHING, FEBRUARY 10 , 1965

AT 3 AM ON JANUARY 13, 1965, A RADIOGRAPHER NOTIFIED HIS SUPERVISOR OC OIFFICULTIES IN RETRACTING A 108-CURIE SOURCE. THE SUPERVISOR ANO ASSOCIATE SUPERVISOR RECEIVEO

OVEREXPOSURES RETURNING THE SOURCE TO THE PROJECTOR (FAILED TO SURVEY THE AREA PROPERLYI. ALSO, THE SUPERVISOR TOOK OFF HIS JACKET CONTAINING HIS FILM BADGE DURING THE OPERATION. DOSES WERE 3 AND 3.124 REMS. HANO EXPOSURE WAS ESTIMATEO AT 6 REMS. CAUSE OF INCIDENT RADIOGRAPHER FAILED TO CONNECT THE SOURCE TUBE TO THE PROJECTOR.

USAEC, PUBLIC DOCUMENT ROOM, 1717 H ST., WASHINGTON, D.C. 20545 (25 CENTS/PAGE

\#PERSONNEL EXPOSURE, RAOIATION + \#RADIOGRAPHY + FAILURE, ADMINISTRATIVE CONTROL + FAILURE, OPERATOR ERROR + INCIDENT, HUMAN ERROR + INCIDENT, NONREACTOR + INCIDENT, RECOVERY FROM

17-26332 ALSO IN CATEGORY 15

RUST INHIBITOR CAUSES OVEREXPOSURC

U.S. ARMY, U.S. ARMY NUCLEAR DEFENSE LABORATORY, EDGEWOOD ARSENAL, MARYLAND

3 PAGES, LETTER TO AEC DIVISION OF STATE AND LICENSEE RELATIONS FROM E.G. WRIGHT, MAY 29,1967

DUR ING A REMOTE HYDRAULIC TRANSFER OF A 700-CURIE CD-60 SOURCE THROUGH TUBING, IT STUCK BECAUSE OF BUILDUP OF DECOMPOSED RUST INHIBITOR ON THE SOURCE. THE RADIATION-AREA SUPERVISOR RECEIVED A DOSE IN EXCESS OF 5 R RETURNING THE SOURCE TO THE SHIELD. HE WAS NOT AWARE TF THE CORRECT OPERATING PROCEDURES FOR THE SURVEY METER AND FAILED TO NOTE THAT BATTERIES HERE LOW, CORRECT OPERATING PROCEDURES FOR THE SURVEY METER AND FAILED TO NOTE THAT BATTERIES HERE LOW,
RESULTING IN A DECEPTIVELY LOW READING. THE USE OF THE RUST INHIBITOR HAS DISCONTINUEO AND ADOITIONAL TRAINING GIVEN TO OPERATIONAL PERSONNEL.

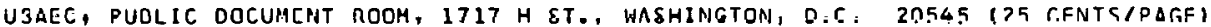

\#FAILURE, EQUIPMENT + \#PERSONNEL EXPOSURE, RADIATION + \#RADIOGRAPHY + \#REMOTE MANIPULATING AND VIEWING + INCIDENT, HUMAN ERROR + INCIDENT, NONREACTOR + SOURCE, RADIATION

17-26333 ALSO IN CATEGORY 15

RESPONSE TO AEC CITATION FOR RADIOGRAPHY DEFICIENCIES

NATIONAL TANK COMPANY, TULSA, OKLAHOMA

2 PAGES, LETTER TO AEC, WASHINGTON, D. C. FROM F.L. SILVERS, JUNE 12, 1967

ON MARCH 12, 1967, A RADIOGRAPHER RECEIVED A DOSE OF 4550 MR (APPARENTLY FAILED TO SURVEY AND SOURCE DIO NOT RETRACT). COMPANY RESPONSE TO AEC CITATION - (1) CALIBRATEO AND DPERABLE SURVEY INSTRUMENTS WILL BE AVAILABLE AND USED AFTER EACH EXPOSURE, (2) APOL OGIZED FOR NOT INCLUDING EXPOSURE INFOPMATION IN PREVIOUS LETTER, (3) LOG SHEET IMPROVEO, (4) RADIOGRAPHERS INSTRUCTEO TO MAKE SURVEYS AT BEGINNING AND END OF EACH SHIFT (IN ADOITION TO OTHER.SURVEYS REQUIRED BY PROCEDURESI, AND (5) A NEW SURVEY INSTRUMENT WITH AUDIBLE-SIGNAL ATTACHMENT WAS PURCHASEO.

USAEC, PUBLIC DOCUMENT ROOM, 1717 H ST., WASHINGTON, D.C. 20545 (25 CENTS/PAGE)

*FAILURE, OPERATOR ERROR + \#PERSONNEL EXPOSURE, RADIATION + INCIDENT, NONREACTOR + INSPECTION AND COMPLIANCE + RADIOGRAPHY + SOURCE, RADIATION 
CATEGORY 17

OPERATIONAL SAFETY ANO EXPERIENCE

17-26336 ALSO IN CATEGORY 15

RESPONSE TO AEC CITATION FOR DEFICIENCIES IN RAOIOGRAPHY PROCEOURES

SINCO TESTING INC., PORT HURON, MICHIGAN

6 PAGES, LETTER TO AEC, WASHINGTON, D. C., OCTOBER 17, 1966

ON SEPT. 26, 1966, AEC CITED COMPANY FOR 33 DEFICIENCIES. COMPANY RESPONSE - (1) RECOROS NOH ARE ON FILE FOR INSTRUMENT CALIBRATIONS, QUALIFICATION RECORDS OF RADIOGRAPHERS, AND SOURCE LEAK TESTS, (2) STORAGE EF SOURCE IN UNLOCKED CAMERA OCCURRED BECAUSE OF SHORTAGE OF STORAGE CONTAINERS (THE SOURCE HAD DECAYED AND WAS READY TO BE SHIPPED TO SUPPLIER, AND THE LOCK WAS BEING REPAIRED), (3) RADIOGRAPHERS HAVE BEEN INSTRUCTEO TO RECHARGE DOSIMETERS DAILY, AND (4) UNPOSTED AREAS HAVE BEEN POSTED.

USAEC, PUBLIC DOCUMENT ROOM, 1717 H ST., WASHINGTON, D.C. 20545 (25 CENTS/PAGE)

\#FAILURE, ADMINISTRATIVE CONTROL + \#INSPECTION AND COMPLIANCE + MONITOR, RADIATION, PERSONNEL + RAOIOGRAPHY + SOURCE, RADIATION + STORAGE CONTAINER

17-26337 ALSO IN CATEGORY 15

RESPONSE TO AEC CITATION FOR RADIOGRAPHY DEFICIENCIES

SCOPE INSPECTION CO., INC. HOUSTON, TEXAS

4 PAGES, LETTER TO AEC DIVISION OF COMPLIANCE FROM D. THOMAS, AUGUST 2,1967

ON APRIL 27, 1967, RADIOGRAPHER RECEIVEO A DOSE OF 6.1 REMS WHILE. RETURNING A SOURCE TO SAFE WHICH HAD STUCK IN SNORKEL TUBE. COMPANY RESPONDED TO CITATIDN THAT (I) ALL EMPLOYEES HAD BEEN NOTIFIED OF INCIDENT AND THAT THE INDIVIDUAL HAD BEEN DISCHARGED (WHICH OID MDRE GOOD THAN A WEEK OF LECTURESI, (2) RETRAINING OF ALL RADIOGRAPHERS STARTED, (3) IF UNAUTHORIZED PERSONS VISIT EXPOSURE AREAS, RADIOGRAPHY WILL CEASE, 14 ) WEEKLY UNANNOUNCED INSPECTION AT ALL OF JOB SITES ARE NOW BEING MADE.

USAEC, PUBLIC DOCUMENT ROOM, 1717 H ST., HASHINGTON, D.C. 20545 (25 CENTSIPAGE)

*FAILURE, ADMINISTRATIVE CONTROL + \#INSPECTION AND COMPLIANCE + *PERSONNEL EXPOSURE, RADIATION + FAILURE, OPERATOR ERROR + RADIOGRAPHY

17-26338 ALSO IN CATEGORY 15

RESPONSE TO AEC CITATION FOR RADIOGRAPHY DEFICIENCIES

SARNIA INSPECTION COMPANY, SARNIA, ONTARIO

3 PAGES, LETTER TO AEC DIVISION OF STATE AND LICENSEE RELATIONS FROM T. ARNESEN, OCTOBER 26 , 1965

AN AEC INVESTIGATION IN JUNE 1965, AND A CITATION FOR DEFICIENCIES, RESULTEO IN COMPANY RESPONOING THAT 11 CRACKS SEEMINGLY DEVELOP OVERNIGHT IN THE LEAD-SHIELDED CAMERAS, RESULTING IN DOSE RATES IN EXCESS OF 50 MR/HR (ALL CAMERAS WILL BE REPLACED WITH THOSE USING DEPLETED URANIUM), (2) OPERATORS HAVE BEEN INSTRUCTED TO USE SURVEY METERS AFTER EXPOSURES, (3) SIGNS WILL BE POSTED OURING EXPOSURES. RECORD-KEEPING DEFICIENCIES AT THE ORANGE, TEXAS, DFFICE HAVE BEEN CORRECTED.

USAEC, PUBLIC DOCUMENT ROOM, 1717 H ST., HASHINGTON, D.C. 20545 (25 CENTS/PAGE)

*FAILURE, ADMINISTRATIVE CONTROL + *FAILURE, EQUIPMENT + \#FAILURE, OPERATOR FRRTR +

* INSPECTION AND COMPLIANCE + *STORAGE CONTAINER + RAOIOGRAPHY + SOURCE, RADIATION

$17-26339$

RADIOGRAPHY SOURCE LOST FOR TWO DAYS

PITTSBURGH TESTING LAB, PITTSBURGH, PENNSYLVANIA

6 PAGES, LETTER TO AEC DIVISION OF LICENSING AND REGULATION FROM H. F. HEDDERICH, SEPTEMBER 2 , I966

ON JULY 26, 1966, A 14-CURIE IR-192 SOURCE WAS LOST FROM AN EXPOSURE DEVICE. WHILE BEING CARRIED FROM ONE AREA TO ANOTHER THE LOCK SNAPPED OPEN ANO THE SOURCE FELL OUT. ON JULY 28 , THE SOURCE WAS FOUND NEAR THE WALK AREA. THE MAXIMUM EXPOSURE FOR THE INCIDENT AND RECOVERY HAS 76 MILLIREMS.

USAEC, PUBLIC DOCUMENT ROOM, 1717 H ST., WASHINGTON, D.C. 20545 (25 CENTS/PAGE)

* SOURCE, RADIATION, LOST + INCIOENT, NONREACTOR + RADIOGRAPHY

17-26340 ALSO IN CATEGORY 15

RADI ATION EXPOSURE TO EXPERIENCED RADIOGRAPHERS

U.S. NAVY, PUGET SOUND NAVAL SHIPYARD, BREMERTON, WASHINGTON

4 PAGES, MEMORANOUM OF RADIATION EXPOSURE INCIDENT, SEPTEMBER 6, 1967

RADIOGRAPHER 8, WITH 5 YEARS EXPER IENCE, ASSUMED THAT SOURCE HAD BEEN RETRACTED WHEN CRANKING BECAME DIFFICULT. ACTUALLY, MORE EFFORT WAS NEEDED DN LAST TURN TO RETRACT SOURCE ARDUND AN $S$ CURVE IN SHIELD. RADIOGRAPHER A, HITH 10 YEARS EXPERIENCE, SURVEYED FROM REAR AND DBTAINED NORMAL REAOINGS SINCE SOURCE HAS SHIELDED BY CAMERA. NEITHER OBSERVED THAT STORAGE LIGHT WAS 
CATEGORY 17

OPERATIONAL SAFETY AND EXPERIENCE

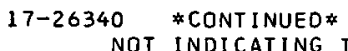

NOT INDICATING THAT SOURCE HAD BEEN RETRACTED. RADIOGRAPHER A RECEIVED A DOSE OF 3500 MR, AND B 290 MR.

USAEC, PUBLIC OOCUMENT ROOM, 1717 H ST., WASHINGTON, D.C. 20545 (25 CENTS/PAGE)

\#FAILURE, OPERATOR ERROR + \#PERSONNEL EXPOSURE, RADIATION + INCIDENT, NONPEACTOR + RADIOGRAPHY

$17-26341$

RESPONSE TO AEC CITATION FOR RADIOGRAPHY DEFICIENCIES

MATERIALS TESTING LAB, CHICAGO, ILL INOIS

2 PAGES, LETTER TO AEC DIVISION OF STATE ANO LICENSEE RELATIONS FROM W.R. WINTERS, MARCH 22, 1966

COMPANY RESPONSE INCLUDED - 11 LICENSE IS TO BE MODIFIED TO ELIMIVATE REQUIREMENT FOR A CONTROL DEVICE SINCE EXPOSURE ROOMS ARE TO BE UNDER CONSTANT SURVEILLANCE. I2I THE

CALIBRATION OF SURVEY METERS AT REGULAR INTERVALS WAS RE-EMPHASIZED. (3) DAILY RECORDING OF DOSIMETER READINGS ARE NOW BEING MADE. (4) PERFORMANCE OF SURVEYS AFIER EXPOSURES WAS RE-EMPHASIZED.

USAEC, PIIRI IC. DOCUMENT ROOM, 1717 H ST., WASHINGTON, 0.C. 20545 (25 CENTS/PAGE)

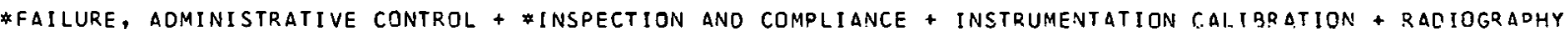

17-26342 ALSO IN CATEGORY 15

RESPONSE TO AEC CITATICN FOR INFRACTION OF SOURCE-HANDLING PROCEDURES

ATOMIC ENERGY OF CANADA LTD., OTTAWA, CANADA

2 PAGES, LETTER to AEC OIVISION OF STATE AND LICENSEe RELATIDNS FROM G. E. MCCULLUM, JUNE 16 . 1966

COMPANY RESPONSE INCLUDED - (1) WORKERS DID NOT WEAR DOSIMETERS BECAUSE THEY WERE UNABLE TO 2ERO THEM AFTER THE CHARGER WAS DAMAGED. IN FUTURE FIFLD TRIPS, EACH PER SON WILL HAND CAPRY A CHARGER. (2) ALL FIELO PERSONNEL ARE NOW EOUIPPED WITH AN AUOIRLE PERSONNEL MONITOR ANC FILM BADGES FÚR HEAD MONITORING.

USAEC, PUBLIC DOCUMENT ROOM, 1717 H ST., WASHINGTON, D.C. 20545 (25 CENTS/PAGE)

*INSPECTION ANC COMPLIANCE + \#INSTRUMENTATION, RADIATION MONITORING + \#MONITOR, RADIATION, PER SONNEL + FAILURE, INSTRUMENT + FAILURE, OPERATOR ERROR + PERSONNEL PROTECTIVE DEVICE + RADIOGRAPHY

$17-26344$

ALSO IN CATEGORY 15

RADIOGRAPHY SOURCE - LOST AND FOUND

SCHLUMBERGER WELL SURVEYING CORP. , HOUSTON, TEXAS

1 PAGE, LETTER TO SCHLUMBERGER WELL SERVICES FROM K.N. THOMAS, OCTOBER 16, 1967

A SOURCE WAS PLACEO ON THE BUMPER OF A TRUCK PARKED NEXT TO $A$ SECQND TRUCK IN WHICH EQUIPMENT CALISRATIONS WERE BEING PERFORMED. THE ORIVER DROVE OFF, NOT KNONING THAT THE SOURCE WAS ON THF BUMPER OF HIS TRUCK, NOR OID HE KNOW THAT IT HAD FALLEN OFF ALONG THE WAY. THE SOURCE WAS FOUNO SHORTLY THERLAFTER IN A OITCH BY ONE OF SEVERAL SEARCH PARTIES.

USAEC, PUBLIC DOCUMENT ROOM, 1717 H ST., WASHINGTON, D.C. 20545 (25 CENTS/PAGE)

*RAOI OGRAPHY + \#OURCE, RADIATION, LOST + FAILURE, OPERATOR ERROR + INCIDENT, HUMAN ERROR

17-26345 ALSU IN LAIEGURT 19

RADIOGRAPHY SOURCE ABANOONEO IN OKLAHOMA WELL

SCHLUMBERGER WELL SURVEYING CORP., HOUSTON, TEXAS

2 PAGES, LETTER TO AEC, WASHINGTON, O. C. FROM O.C. CHEATHAM, SEPTEMBER 21,1967

ON SEPT. 12, 1967, A 1.5-CURIE CS-137 SOURCE STUCK IN A WELL IN OKLAHOMA. FISHING OPERATIONS CONTINUIED UNTIL SEPT. 18, WHEN IT WAS DETERMINED THAT THE SOURCE WAS CLEAR OF THE CEVTER DF THE WELL AND THAT A 4-1/2-IN. CASING COULD BE RUN TO THE PRODUCING ZONE BELOW. THENTY FFFT OF CEMENT WAS SPOTTED BELON AND ABOVE THE SOURCE, WHICH WAS AT A DEPTH gF 3520 FEET, AND THE SOURCE WAS ABANODNED.

USAEC, PUBLIC OMTIIMENT RDOM, 1717 H ST., WASHINGTON, D.C. 20545 125 CENTS/PAGEI

\#RADI OGRAPHY + \#SOURCE, RADIATION, LOST

17-26346 ALSO IN CATEGORY 15

RADIOGRAPHY SOURC.E LOST IN PACIFIC OCEAN

SCHLUMBERGER WELL SURVEYING CORP., HOUSTON, TEXAS

2 PAGES, LETTER TO AEC DIVISION DF LICENSING AND REgULATION FROM 0.C. CHEATHAM, AUGUST 6, 1965

ON AUGUST 1, 1965, A 1.5-CURIE CS-137 SOURCE WAS LOST IN A STANDARD OIL CO. OF CALIFORNIA WELL 12 MILES OFF THE COAST OF OREGON. THE SOURCE HAD 4 CONTAINING SHELLS, OF WHICH TWO WERE PRESSURE TESTED AT 25,000 PSI. THE $12,000-F T$ HELL WAS ABANDONED AS A DRY HOLE. THE BOTTOM 
CATEGORY 17

OPERATIONAL SAFETY AND EXPERIENCE

$17-26346$ *CONT INUED*

200 FT WAS PLUGGED WITH CEMENT CONTAINING JUNK IRON.

USAEC, PUBLIC DOCUMENT ROOM, $1717 \mathrm{H} \mathrm{ST.,} \mathrm{WASHINGTON,} \mathrm{D.C.} 20545$ (25 CENTS/PAGE)

\#OCEAN AND SEA + \#RADIOGRAPHY + \#OURCE, RADIATION, LOST

17-26347 ALSO IN CATEGORY 15

RADI OGRAPHY SOURCE LOST IN 4,186 FT. WELL

SCHLUMBERGER WELL. SURVEYING CORP., HOUSTON, TEXAS

2 PAGES, LETTER TO AEC DIVISION OF LICENSING AND REGULATION FROM 0.C. CHEATHAM, JUNE 17, 1965

ON JUNE 7, 1965, A 1-CURIE CS-137 SOURCE STUCK AT THE BOTTOM OF A 4186-FT WELL IN WEST VIRGINIA. RETRIEVAL EFFORTS WERE DISCONTINUED 5 DAYS LATER. THE BOTTOM 50 FT OF THE WELL WAS FILLED WITH CEMENT AND JUNK IRDN TO PRECLUDE REENTRY. THE SOURCE MATERIAL HAD 5 CONTAINING SHELLS, OF WHICH ONE WAS PRESSURE TESTED AT 25,000 PSI. FRESH-WATER ZONES IN THE VICINITY ARE AT DEPTHS NO GREATER THAN 100 FT FROM THE SURFACE.

USAEC, PUBLIC DOCUMENT ROOM, 1717 H ST., WASHINGTON, 0.C. 20545 (25 CENTS/PAGE)

\#RADI OGRAPHY + \#SOURCE, RADIATION, LOST

17-26350 ALSO IN CATEGORY 15

RADIOGRAPHY SOURCE FALLS APART

RADIATION PRODUCTS, BURLINGTON, MASSACHUSETTS

2 PAGES, LETTER TO DIRECTOR DIVISION OF MATERIALS LICENSING FROM R.J. PREST, MARCH 24,1967

A 10-CURIE IRIOIUM-192 SOURCE FELL APART WHILE RFTNG USED BY WALWORTH CO., GREENSBURG, PA. RETRILVAL DF THE 5 PELLETS WAS ACCOMPLISHEO WITH MINOR CONTAMINATIDN AND PERSONNEL EXPOSURES OF 280 ANO 5 MR. STEPS WERE TAKEN BY THE FABRICATOR TO EXAMINE AND IMPROVE THE QUALITY OF THE CAPSULE WELDS.

USAEC, PUBLIC DOCUMENT ROOM, 1717 H ST., HASHINGTON, D.C. 20545 (25 CENTS/PAGE)

\#FAILURE, FABRICATION ERROR + \#QURCE, RADIATION + PERSONNEL EXPOSURE, RADIATION

17-26351 ALSO IN CATEGORY 15

RADIOGRAPHY INCIDENT - CARELESS ATTITUDE TOWARD RADIATION RESULTS IN TERMINATION

PITTSBURGH TESTING LABORATORY, PITTSBURGH, PENNSYLVANIA

2 PAGES, LETTEK TO AEC DIVISION OF LICENSING AND REGULATION FROM H.F. HEDDERICH, OCTOBER 24, 1964

THE RADIOLOGICAL SAFETY COORDINATOR DISCOVERED THAT A RADIOGRAPHER HAO EXCEEDED HIS QUARTERLY EXPOSURE LIMIT, ACCORDING TO A PHONE CALL FROM THE FILMTBADGE PROCSSSOR. RAOIOGRAPHER COULD NOT EXPLAIN BUT ADMITTED. THAT HIS DOSIMETER HAD GONE BEYOND RANGE ON ONE OCCASION. HE WAS TERMINATED BECAUSE OF CARELESS ATTITUDE TOWARD RAOIATION SAFETY, FAILING TO RECORD THE FACT THAT HIS DOSIMETER HAD GONE BEYONR RANGF. FAII TMS TO PSRONT TIIC OVIREXPOSURE, AIVU IAKUINESS IIN FUKWAKUING A STATEMENT CONCERNING THE EXPOSURE.

USAEC, PUBLIC DOCUMENT ROOM, 1717 H ST., WASHINGTON, D.C. 20545 (25 CENTS/PAGE)

\#ADMINISTRATIVE CONTROL + \#PERS ONNEL EXPOSURE, RADIATION + \#RADIOGRAPHY + FAILURE, OPERATOR ERROR + INC IDENT, HUMAN ERROR + INCIDENT, NONREACTOR + RADIATION SAFETY AND CONTROL

17-26352 ALSO IN CATEGORY 15

RADIOGRAPHY INC IDENT - CHANGING HANDS DURING SOURCF RFTRIEVAL RESULTS IN EXPOSURE

PITTSBURGH TESIING LABORATORY, PITT SBURGH, PENNSYLVANIA

4 PAGES, LETTER TO AEC DIVISION OF LICENSING AND REGULATION FROM R.G. GALLAGHAR, OCTOBER 21 , I964

RADIOGRAPHER RECEIVEO BODY DOSE OF 3.1 R ANO HAND DOSE OF 3.9. AT THREE AM, AFTER MAKING AN EXPOSURE, THE RADIOGRAPHER WAS CRANKING THE SOURCE BACK TOWARD THE STORAGE CONTAINER AND CHANGED HANDS DURING THE CRANKING, INVERTING THE SOURCE DRIVE MECHANISM. THE SOURCE WENT BACK DOWN THE TUBE BELOW A THICK CONCRETE FLODR WHERE IT WAS SHIELDED FROM THE SURVEY METER. WHEN THE METER READING OROPPED BACK TO NORMAI. HF ASSIIMFO THAT THE SOURCE WAS DACK IN IFE SAFE AAIT SURVEY.

USAEC, PUBLIC DOCUMENT ROOM, 1717 H ST., WASHINGTON, D.C. 20545 (25 CENTS/PAGE)

*INCIDENT, HUMAN ERROR + \#PERSONNEL EXPQSURE, RADIATION + \#RADIOGRAPHY + INCIOENT, NONREACTOR + SOURCE, RADIATION

17-26353 ALSO IN CATEGORY 15

RESPONSE TO $\triangle E C$ CITATION FOR DEFICIENCIES IN RADIOGRAPHY OPERATIONS

PITTSBURGH TESTING LABORATORY, PITTSBURGH, PENNSYLVANIA

6 PAGES, LETTER TO E.R. PRICE, AEC DIVISION OF STATE AND LiCENSEE RELATIONS FROM H.F. HEDOERICH, AUGUST 7, 1964 
CATEGORY 17

OPERATIONAL SAFETY AND EXPERIENCE

17-26353 \#CONTINUED*

EXPLANATIONS GIVEN FOR EACH OF 8 VIOLATIONS AT THE ALABAMA BRANCH AND 5 VIOLATIONS AT THE PITTSBURGH BRANCH. ALABAMA BRANCH DENIES (1) NOT INSTRUCTING EMPLOYEES ON HAZARDS AND PRECAUTIONS TO MINIMIZE EXPOSURES, ANO $(2)$ USING AN UNAUTHORIZED CONTROL CABLE IN AN EXPOSURE DEVICE. PENNSYLVANIA BRANCH DENIES (1) FAILURE TO MAKS SURVEYS IN UNRESTRICTED AREAS AND 121 ALLOWING RADIATION LEVELS ON SURFACE OF STORAGE CONTAINER TO EXCEEO LIMITS. THE CONTAINER WAS RECEIVED THE SAME DAY THE INSPECTOR ARRIVED. HOWEVER, ITS INADEQUACY HAD BEEN ANTICIPATEO, ANO SPECIAL CONTAINERS HAD BEEN CONSTRUCTED, WHICH WERE BEING PAINTED. THE CONTAINER IN QUESTION WAS SHOWN TO THE INSPECTOR TO VERIFY THEY HAD ANTICIPATED ITS INADEQUACY.

USAEC, PUBLIC DOCUMENT ROOM, 1717 H ST., WASHINGTON, O.C. 20545 (25 CENTS/PAGE)

*FAILURE, aDMINISTRATIVE CONTROL + \#INSPECTION AND COMPLIANCE + \#RADIOGRAPHY + \#STORAGE CDNTAINER + FAILURE, OPERATOR ERROR + PERSONNEL EXPOSURE, RADIATION + SOURCE, RADIATION

17-26355 ALSO IN CATEGORY 15

RESPONSE TO AEC CITATION FOR RADIOGRAPHY DEFICIENCIES

PIPEWELD X-RAY CORPORATION, PERRYSBURG, OHIO

3 PAGES, LETTER to AEC OIVISION OF STATE AND LICENSEE RELATIONS FROM C. EARLE, JR., FEBRUARY I4, I966

COMPANY RESPONSE TO CITATIONS - 11 I RADIOGRAPHERS DIO NOT HAVE A CDPY OF THE AEC LICENSE BECAUSE OF OVERSIGHT. (2) INABILITY OF 3 RADIOGRAPHERS TO READ A SURVEY METER CORRECTLY WAS CAUSED BY EMPLDYEES BECOMING EXCITEO ANO HIGHLY NERVOUS WHEN CONFRONTED BY AN $\triangle E C$ REPRESENTATIVE AND FAILING TO CHECK THE METER-SCALE SETTING. (3) THOSE WHO FAILED TO SURVEY AFTER EXPOSURES WERE FINED AND REINSPECED. EMPLOYEES WERE REINSTRUCTED IN PEQUIREMENTS OF AEC REGULATIONS AND COMPANY OPERATING MANUAL.

USAEC, PUBLIC DOCUMENT ROOM, 1717 H ST., WASHINGTON, D.C. 20545 (25 CENTS/PAGE)

*INSPECTION AND COMPLIANCE + *RADIOGRAPHY + FAILURE, ADMINISTRATIVE CONTROL + FAILURE, DPERATOR ERROR + SURVEY, RADIATION, GENERAL.

17-26356 ALSO IN CATEGORY 15

RESPONSE TO AEC RADIOGRAPHY CITATION

PIPEWELD X-RAY CORPORATION, PERRYSBURG, OHIO

5 PAGES, LETTER TO AEC DIVISION OF STATE AND LICENSEE RELATIONS FROM C. EARLE, JR., JANUARY 30 , 1967

IN THE FUTURE, PERSONNEL WILL SIGN A STATEMENT THAT THEY HAVE RECEIVED INSTRUCTION ON COMPANY RADIOGRAPHY PROCEDURES. PERSON HAVING COPY OF RADIOGRAPHERS TEST QUESTIONS AND ANSWERS HAD GOTTEN AN OLDER RAOIOGRAPHER TO WRITE THEM OUT FROM MEMORY TO ASSIST HIM IN STUDYING TO CHANGE HIS CLASSIFICATION (REPRESENTED LESS THAN $1 / 2$ OF TEST QUESTIONS). RECURRING VIOLATIONS - FAILURE TO SURVEY AFTER EXPOSURE ANO RECORO KEEPING OCCUR BECAUSE AEC OID NOT DIRECT THE CITATIONS TO THE RADIOGRAPHER BUT TO THE COMPANY. ADVOCATES THAT AEC LICENSE INOT COMPANY) INDIVIOUAL SO THAT THREAT OF REVOCATION WOULO ELIMINATE RADIOGRAPHER LAXITY IN FOLLUWING PROCEOURES.

USAEC, PUBLIC DOCUMENT ROOM, 1717 H ST., WASHINGTON, D.C. 20545 (25 CENTS/PAGEI

*FAILURE, ADMINISTRATIVE CONTROL + *INSPECTION AND COMPLIANCE + *RAOIOGRAPHY + FAILURE, OPERATgR EPROO + RADIATION SAFETY AND CONTROL + STAFFING, TRAINING, QUALIFICATION

17-26357 ALSO IN CATEGORY 15

RADIOGRAPHY OVEREXPOSURES FOR CALENDAR QUARTER

PIHEWLLU X-RAT' CORP.; PERRYSOURC, OHIO

2 PAGES, LETTER TO AEC DIVISION OF LICENSING ONO REGIILATION FROM C. EARLE; JR., JULLY 22, 1964

REPORTS THAT SIX RAOIOGRAPHERS RECEIVED EXPOSURES FOR QUARIER EXCEEDING 1.25 REMS. MAXIMUM WAS 2.25 REMS. ONE RADIOGRAPHER HAD BEEN LEAVING HIS CLOTHES (AVD BADGE) ON A STEAM RADIATOR AT NIGHT. ANOTHER OVERDOSE WAS ATTRIBUTED TO INACCURATE FILM-BADGE READINGS BECAUSE OF A PARTIALLY OBLITERATED FILM.

USAEC, PUBLIC DOCUMENT ROOM, $1717 \mathrm{M}$ ST., WASHINGTON, O.C. 20545 (25 CENTS/PAGE)

\#FAILURE, ADMINISTRATIVE CONTROL + \#PERSONNEL EXPOSURE, RAOIATION + \#RAOIOGRAPHY + FAILURE, OPERATOR ERROR

17-26359 ALST IN CATEGORY 15

LOUSE SLKEW ON RADIOORAPIIY COUI PMENT RESULTS IN EXPRSIIRFS

NEW YORK SHIPBUILOING CORTORATION, CAMDEN, NEW. IERSEY

3 PAGES, LETTER TO AEC DIVISION OF LICENSING AND REGULATION FROM E.P. ANDERSON, NOVEMBEK 15, I96?

FIVE INDIVIDUALS RECEIVEO RAOIATION EXPOSURES - 1.2 R, 1.2, 280 MR, 130 MR, 90 MR - WHEN AN ALLEN SET-SCREW ON THE SOURCE DISCONNECT WORKEO LOOSE ANO CAUSED THE SOURCE TO STICK IV THE SOURCE TUBE ABOUT 2 FT OUT EROM THE SHIELD. THE SUURCE HAS REMOVEC BY CUTTING DEF THE OUTBOARD END OF THE SOURCE TUBE AND PLACING THE OPEN END, CONNECTED TO THE CAMEP.A, INTO A LEAD BALL. THE SOURCE WAS THEN CRANKED OUT INTO THE LEAD BALL AND DISCONNECTED FROM THE OPERATING CABLE. ALL SUPERVISORS WERE INSTRUCTED TO PERIOCICALLY CHECK THE DISCONNECTS. 
CATEGORY 17

OPERATIONAL SAFETY ANO EXPERIENCE

17-26359 *CONTINUED*

USAEC, PUBLIC DOCUMENT ROOM, 1717 H ST., WASHINGTON, D.C. 20545 125 CENTSIPAGEI

* INCIDENT, EQUIPMENT + \#PERSONNEL EXPOSURE, RADIATION + \#RADIOGRAPHY + INCIDENT, RECOVERY FROM + SOURCE, RADIATION

17-26362 ALSO IN CATEGORY 15

LEAKING RAOIOGRAPHY SOURCE CONTAMINATES EQUIPMENT

NATIONAL TANK COMPANY, TULSA, OKLAHOMA

2 PAGES, LETTER TO E.R. PRICE, AEC DIVISION OF STATE ANO LICENSEE RELATIONS FROM F.L. SILVERS, JUNE 25 , 1965

A RADIOGRAPHIC CAMERA AND SOURCE TUBE WERE FOUND TO BE CONTAMINATED FROM A LEAKING IRIDIUM SOURCE. INTERCHANGING OF SOURCE TUBES HAD ALSO CONTAMINATED A COBALT SOURCE.

USAEC, PUBLIC DOCUMENT ROOM, 1717 H ST., WASHINGTON, O.C. 20545 (25 CENTS/PAGE)

*CONTAMINATION + \#RADIOGRAPHY + \#SOURCE, RADIATION + INC IDENT, NONREACTOR

17-26364 ALSO IN CATEGORY 15

RADI OGRAPHY OVEREXPOSURE DUE TO FAILURE TO SURVEY

MATERIALS TESTING LAB, EAST HARTFORD, CONNECTICUT

2 PAGES, LETTER TO AEC OIVISION OF LICENSING AND REgULATIONS FROM F.LENT, JULY 26,1965

A RADIOGRAPHER RECEIVED A DOSE OF 1.74 REMS AS A RESULT OF FAILURE TO SURVEY AFTER COMPLETING AN EXPOSURE: THE SOURCE HAD NOT RETRACTED TO THE STORED POSITION IN THE CONTAINER. THE. INCIDENT WAS DISCUSSEO WITH ALL COMPANY RADIOGRAPHERS, AND AN AUDIBLE RADIATION ALARM WAS INSTALLED IN THE EXFOSURE ROOM.

USAEC, PUBLIC DOCUMENT ROOM, 1717 H ST., WASHINGTON, 0.C. 20545 (25 CENTS/PAGE)

\# INCIDENT, HUMAN ERROR + \#PERSONNEL EXPOSURE, RADIATION + \#RADIOGRAPHY + INCIDENT, NONREACTOR + SOURCE, RADIATION + SURVEY, RADIATION, GENERAL

17-26365 ALSO IN CATEGORY 15

INCIDENT INVOLVING 3000 CURIE CO-60 THERAPY SOURCE

LUTHERAN GENERAL HOSPITAL, PARK RIDGE, ILLINOIS

2 PAGES, LETTER TO DIVISION OF MATERIALS LICENSING FROM F.L. HUSSEY, M.D., MARCH 23,1966

A 3000-CURIE COBALT-60 SOURCE WAS DROPPED ONTC THE TREATMENT ROOM FLOOR OF THE LUTHERAN GENERAL HOSPITAL WHILE BEING TRANSFERRED FROM ITS SHIPPING CONTAINER INTO A THERAPY MACHINE. BARRICADFS AND SIGNS WERE POSTED UNTIL REMOTE-HANDLIVG SQUIPMENT COULD BE OBTAINED. THE FOLLOWING EVENING THE SOURCE WAS RECOVERED. NO CONTAMINATION RESULTED. IEXPOSURE DOSES NOT GIVEN.I

USAEC, PUBLIC DOCUMENT ROOM, $1717 \mathrm{H}$ ST, WASHINGTON, $0, \dot{C}, 20545$ I? CFNTSIDASEI

*FADIOLOGY + \#REMOTE MANIPULATINC ANO VIEWING + \#SOURCE, RAUIATION + INCIDENT, HUMAN ERROR + INCIDENT, NONREACTOR + INCIDENT, RECOVERY FROM + RADIATION SAFETY AND CONTKUL + RADIOGRAPHY

17-26366 ALSO IN CATEGORY 1S

CITATION FOR DEFICIENCIES IN RAOIOGRAPHY PROCEDURES

UNITFN STATES ATOMIC ENERGY COMMISSION

2 PAGES, LETTER TO PIPEWELD X-RAY CORPORATION FROM E.R. PRICE, JANUARY 13,1967

CITCD FOR (1) ALLOWING RAUIUGRAPHY BY PERSONS NOT INSTRUCTED IN PROCEOURES NOR SHOWN USE OF DEVICES, (2) POOR, RECORD KEEPING, ANO (3) FAILURE TO SURVEY AFTER EXPOSURES. AEC NOTED THAT ONE RADIOGRAPHER HAD A. COPY OF THE QUESTIONS AND ANSWERS TO THE COMPANYS RADIOGRAPHY

EXAMINATION. ITEMS 2 AND 3 ARE VIOLATIONS WHICH HAVE BEEN CITED IN PREVIOUS INSPECTIONS, AND THE REASON FOR THEIR RECURRENCE SHOULD $8 E$ IDENTIFIED.

USAEC, PUBLIC DOCUMENT ROOM, 1717 H ST., WASHINGTON, D.C. 20545 (25 CENTS/PAGE)

*FAILURE, ADMINISTRAIIVE CONTROL + \#INSPECTION AND COMPLIANCE + \#RADIDGRAPHY + FAILURE, OPERATOR ERROR

17-26368 ALSO IN CATEGORIES 3 AND 15

FIRE CUNSUME 5 TRUCK TRANSPORTING RAOIOGRAPHY SOURCE

LANE-WELLS, HOUSTON, TEXAS

3 PAGES, LETTER TO AEC DIVISION OF STATE AND LICENSE RELATIONS FROM J,C, WIISTN. DIISIIST $20 ; 1966$

A FIRE CONSUMED A TRUCK TRANSPORTING A 1-CURIE CESIUM SOURCE. WHEN THE FIRE WAS EXTINGUISHED, THE SOURCE WAS FOUND FLOATING DN THE MOLTEN LEAD FROM THE SHIELD. THE SOURCE WAS RETRIEVED, UNDAMAGED, AND PLACED ON A LIO OF A TOOL BOX. WHILE WAITING FOR A RADIOLOGICAL ASSISTANCE TEAM CALLED BY A HIGHWAY PATROLMAN ON THE SCENE, THE PATROLMAN PICKED UP THE SOURCE AND HELD IT FOR 1 MIN. HE RECEIVED A DOSE OF 100 MILLIREMS WHOLE BODY AND 10 REMS TO HANOS. OTHER 
CATEGORY 17

OPERATIONAL SAFETY AND EXPERIENCE

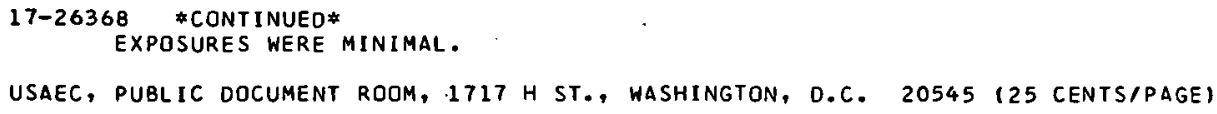

USAEC, PUBLIC DOCUMENT ROOM, 1717 H. ST., WASHINGTON, D.C. 20545 (25 CENTS/PAGE)

*RADIOGRAPHY + \#OURCE, RADIATION, LOST + INCIDENT, NONREACTOR + INCIDENT, RECOVERY FROM + RIVER, GENERAL

17-26371 ALSO IN CATEGORY 15

RADIOGRAPHY EXPOSURE AT GENERAL DYNAMICS CORP.

GENERAL DYNAMIT.S CORPORATION, GROTON, CONNECTICUT

4 PAGES, LEITER TO AEC DIVISIION OF LICENSING FROM W. GORVINE, JULY 20,1965

RADIOGRAPHER RECEIVEO A DGSE OF 4.2 REMS, AS INDICATED BY A FILM BADGE WORN ON HIS LAPEL. CALCULATIONS INDICATEO A OOSE OF 9.6 REMS TO THE BODY MTDSECTION. THE SOURCE WAS NOT COMPLETELY RETRACTED AFTER AN EXPOSURE. OISCOVERY OF THE UNSAFE CONDITION WAS MADE BY A RAOIATION AUDITOR DURING A ROUTINE SURVEY, WHO THEN ALERTED THE RADIOGRAPHER THAT THE CONTROL LIGHTS ON THE DEVICE WERE INOICATING THAT THE SUURCE WAS NOT RETRACTED. THE CAUSE WAS ATTRIBUTED TO FAILURE TO FOLLOW PROCEDURES AND MAKE PROPER SURVEYS.

USAEC, PUBLIC DOCUMENT ROOM, 1717 H ST., WASHINGTON, O.C. 20545 (25 CENTS/PAGE)

\#PER SONNEL EXPOSURE, RAOIATION + \#RAOIOGRAPHY + INCIDENT, HUMAN ERROR + INCIDENT, NONREACTOR + SDURCE, RADIATION

17-26372 ALSO IN CATEGQRY 15

RADIOGRAPHY EXPOSURE AT CONSOLIDATED X-RAY SERVICE CORP.

CONSOLIDATED X-RAY SERVICE CORPORATION, DALLAS, TEXAS

2 PAGFS, LETTER TO AEC DIVISION OF LICENSING AND REGULATION FROM J.E. WRIGHT, DEC. 17, 1965

((LETTER) AT MIDNIGHT ON DECEMBER 4, 1965, FOLLOHING AN EXPOSURE, THE SOURCE DID NOT RETURN TO THE CAMERA. AN ASSISTANT RADIOGRAPHER COILED THE SNORKLE WITH THE ENO CONTAINING IHE SOURCE ABOUT 2 FT FROM HIS HANO; WALKED TO A DITCH, THEN SET UP FOR ANOTHER EXPOSUKE. DFTER WALKING OUT OF THE RADIATION FIELD, IT WAS DISCOVERED THAT THE SOURCE WAS NOT SHIELDED. COPIES OF A COMPILATION OF INCIDENTS WERE SENT TO ALL EMPLOYEES TO EMPHASIZE NECESSITY OF PROPER SURVEYS.

USAEC, PUBLIC DOCUMENT ROOM, 1717 H ST., WASHINGTON, D.C. 20545 (25 CENTS/PAGE)

\#PERSONNEL EXPOSURE, RADIATION + \#RADIOGRAPHY + INCIDENT, HUMAN ERROR + INCIOENT, NONREACTOR + SIIIRCE, RADIATION

17-26373 ALSO IN CATEGORY 15

RADIOGRAPHY INCIDENT - SOURCE FELL APART

CONAM INSPECTION, INC., TULSA, GKLAHOMA

2 PAGES, LETTER TO E.R. PRICE (AEC) FRMM I..E. COOMBS, SEPTEMBER 30, 1966

SURVEY METER INDICATED THAT SOURCE HAD NOT RETRACTED. THE SOURCE TUBE WAS DISCONNECTED AND SHAKEN SO THE LOOSE SOURCE COULD BE RETRIEVED WITH TONGS. THE SOURCE HAD BECDME UNSCREWED AND FIVE IRIDIUM PELLETS FELL DUT ONTO THE GROUND. THE EARTH WAS SCOOPED UP AND PELLETS LOCATCD. CONTAMINATED DIP.T WAS SHIOPFN TO LQUISIANA FOR DISPOSAL, AND SOURCE SUPPLIER WAS NOTIFIED SO ACTION COULD BE TAKEN TO PREVENT A RECURRENCE.

USAEC, PUELIC DOCUMENT ROOM, 1717 H \$T., WASHINGTON, D.C. 20545 (25 CENTS/PAGEI

\# INCIDENT, EQUIPMENT + \#INCIDENT, RECUVERY FROM + ARADIOGRAPHY + SOURCE, RADIATION

17-263\%4 ALSO IN CATEGORY 15

RADIOGRAPHY EXPOSURE AT CONAM INSPECTION, INC.

CONAM INSPECTION COMPANY

3 PAGES, LETTER TO AEC DIVISION OF LICENSING AND REgULATIONS FROM L.E. COOMBS, JULY 31 , 1967 
$17-26374$ *CONT INUED*

RADIOGRAPHER PERFORMING ROUTINE MAINTENANCE ON EXPOSURE DEVICE REMOVED 3 SCREWS FROM CAMERA, WHICH PERMITTEO SOURCE TO DISLODGE FROM SHIELOED POSITION. SOURCE WAS RETURNED BUT WENT BETWEEN LEAD CONTAINER AND OUTSIDE ALUMINUM CASE. SURVEY METER WAS ON TOP OF EXPOSURE DEVICE (PARTIALLY SHIELDED FROM SOURCE), INOICATING SOURCE WAS IN PROPER PLACE. WITH THE SHIELO AND SOURCE IN THE TRUCK, RADIOGRAPHER ANO HELPER DROVE 13 HR TO RETURN TO CONAM FACILITY, WHERE THE UNSHIELDED SOURCE WAS DISCOVERED IMMEOIATELY. FILM BADGE OF ONE READ 24.5 MR. ORIVER OF TRUCK WAS NOT WEARING BADGE. ESTIMATED RANGE OF EXPOSURES WAS $15 R$ TO $300 R$.

USAEC, PUBLIC DOCUMENT ROOM, $1717 \mathrm{H}$ ST., WASHINGTON, D.C. 20545 (25 CENTS/PAGE)

* INC IDENT, hUMAN ERROR + \#PERSONNEL EXPOSURE, RADIATION + \#RADI OGRAPHY + INCIDENT, NONREACTOR + SOURCE, RADIATION

$17-26375$
RADIOLOGIST QUARTERLY IN CATEGORY 15
DOSE EXCESSIVE

SAINT FRANC IS HOSPITAL, TULSA, OKLAHOMA

1 PAGES, LETTER TO AEC DIVISION OF STATE AND LICENSE RELATIONS FROM J.E. KAUTH M.D., MARCH 19,1968

RAOIOLOGIST WAS HOLDING PATIENTS WHILE PORTABLE FILMS WERE TAKÉN. OUARTERLY DOSE WAS 1874 MILLIREMS. YEARLY DOSE FOR 1967 WAS 6723 MILLIREMS.

USAEC, PUBLIC DOCUMENT ROOM, 1717 H ST., WASHINGTON, D.C. 20545 (25 CENTS/PAGE)

*FAILURE, operator ERROR + \#RADIOLOGY + PERSONNEL EXPOSURE, RADIATION + RADIOGRAPHY

17-26376 ALSO IN CATEGORY 15

CITATION FOR DEFICIENCY IN RADIOGRAPHY OPERATIONS

PITTSBURGH TESTING LABORATORY, PITTSBURGH, PENNSYLVANIA

3 PAGES, LETTER TO AEC OIVISION OF STATE ANO LICENSE RELATIONS FROM H.F. HEDDERICH, FEBRUARY 23 , I965

COMPANY RESPONSES TO CITATIONS RESULTING FROM INVESTIGATION DEC. 7HE NATURE AND EXTENT OF EXPOSURE WAS BECAUSE WE COULD NOT HONESTLY EVALUATE THE EXTENT OF EXPOSURE IN THE ALLOTTED TIME, AND (2) FAILURE TO PERFORM SIX UNANNOUNCEO INSPECTIONS IN THE THIRD QUARTER HAS OVERSIGHT BY FORMER EMPLOYEE, AND PERFORMANCE OF ALL SIX WITHIN TWO WEEKS WAS DUE TO CHANGE IN PERSONNEL AND NEED TO MEET REQUIREMENT.

USAEC, PUBLIC DOCUMENT ROOM, 1717 H ST., WASHINGTON, D.C. 20545 (25 CENTS/PAGE)

\#FAILURE, ADMINISTRATIVE CONTROL + \#NSPECTION AND COMPLIANCE + \#RADIOGRAPHY +

STAFFING, TRAINING, QUALIFICATION

17-26377 ALSO IN CATEGORY 15

RECOVERY OF UNCOUPLED SOURCE - PLAN MINIMIZED PERSONNEL EXPOSURE

PITTSBURGH TESTING LABORATORY, PITTSBURGH, PENNSYLVANIA

4 PAGES, LETTER TO AEC DIVISION OF LICENSING AND REGULATION FROM H.F. HEDDERICH, DECEMBER 8 , 1964

ON NOV. 9, 1964, AT 3/30 AM, A RADIDGRAPHER NOTICED THAT THE CRANK HANDLL OF RADIOGRAPHY EXPOSURE DEVICE WAS WORKING TOO FREELY. AN INTERMEDIATE CONNFT.TIDN BETHEEN THO LENGTHS OF SOURCE TUBE HAO WORKED LODSE. THE SOURCE HAD RUN OUT OF THE TUBE AT THAT POINT, AND THE CONTROL CABLE HAD EXTENDED BEYOND THE GEAR WHEEL. THE PIGTAIL ALSO BECAME UNCOUPLED WHILE OUTSIDE THE SOURCE TUBE. THE SUPERVISOR, RADIOGRAPHER, AND RADIATION SAFETY OFFICER

FORMULATED A PLAN. THE RSO, WHILE STANDING BEHIND STEEL COLUMN AND USING 8-FT HANDLING ROOS, MANIPULATEO SOURCE AND RETURNED IT TO THE EXPOSURE DEVICE. MAXIMUM EXPOSURE WAS 250 MR.

USAEC, PUBLIC DOCUMENT ROOM, $1717 \mathrm{H}$ ST., WASHINGTON, D.C. 20545 (25 CENTS/PAGE)

* INCIOENT, RECOVERY FROM + \#RADIOGRAPHY + INCIOENT, NONREACTOR + PERSONNEL EXPOSURE, RADIATION + RADIATION SAFETY AND CONTROL + SOURCE, RAOIATION

17-26378 ALSO IN CATEGORY 15

FILM BADGE REPORT OF RADIOLOGIST AT MILWAUKEE HOSPITAL

MILWAUKEE HOSPITAL, MILWAUKEE, WISCONSIN

3 PAGES, LETTER TO AEC OIVISION OF LITENSING AND REGULATION FROM J.R. CAMERON, MARCH 19, 1964

SUBSEQUENT TO EXTENSIVE REMODELING OF THE X-RAY DEPARTMENT, A RADIOLOGICAL PHYSICIST SURVEYED THE DEPARTMENT AND RECOMMENDED REPORTING THE QUARTERLY FILM-BADGE READINGS FOR 1962 AND 1963 BECAUSE HOSPITAL HAO A BY-PRODUCT LICENSE. OVEREXPOSURES BELIEVED TO BE OUE TO HEAVY FLUOROSCOPIC WORK LOAD. READINGS WERE 0.32 REM, $1.269,1.404,0.45,2.125,1.587,0.581$, 0.216.

USAEC, PUBLIC DOCUMENT ROOM, $1717 \mathrm{HST}$, WASHINGTON, D.C. 20545 (25 CENTS/PAGE)

\#PERSONNEL EXPOSURE, RADIATION + \#RADIOLOGY + FAILURE, ADMINISTRATIVE CONTROL +

RADIATION SAFETY AND CONTROL + RADIOGRAPHY + SOURCE, RADIATION + X-RAY 
CATEGORY 17

OPERATIONAL SAFETY AND EXPERIENCE

17-26379 ALSO IN CATEGORY 15

OVEREXPOSURE TO THERAPY TECHNICIAN

U.S. ARMY, WALTER REED ARMY MEDICAL CENTER

8 PAGES, LETTER TO AEC DIVISION OF LICENSING AND REGULATION FROM R. NYSTROM, JR., JANUARY I9, I967

A FILM-BAOGE REPORT INOICATEO THAT A RADIATION-THERAPY TECHNICIAN HAD RECEIVED AN EXPOSURE OF 15.3 REMS GAMMA AND 4.93 BETA FOR THE PERIOD 6 NOV. THROUGH 3 DEC. 1966 . ON ONE OCCASION THE TECHNICIAN WAS REQUIRED TO ASSIST A PATIENT FROM THE TREATMENT TABLE WHEN THE $1850-$ CURIE COBALT-60 SOURCE FAILED TO RETRACT. A DOSE OF 3.3 REMS WAS ATTRIBUTED TO THIS INCIDENT. WHEN AND HNW THE ADDITIONAL DOSAGE WAS ACQUIRED COULO NOT BE DETERMINEO. A COMMITTEE DECLARED THE THERAPY UNIT UNSAFE, SHUT IT DOWN FUR REPLACEMENT, AND RECOMMENDED THAT TECHNICIAN BE RETURNED TO DUTY.

USAEC, PUBLIC DOCUMENT ROOM, 1717 H ST., HASHINGTON, D.C. 20545 (25 CENTS/PAGE)

\#PERSONNEL EXPOSURE, RADIATION + \#RADIOLOGY + FAILURE, EQUIPMENT + INCIDENT, EQUIPMENT + INCI DENT, NONREACTOR + RADIOGKAPHYY + SOURCE, RADIATION

17-26380 ALSO IN CATEGORY 15

SEQUENCE OF EVFNTS LEADS TO OVEREXPOSURE

U.S. NAYY

5 PAGES, LETTER TO AEC DIVISION OF LICENSING AND REGULATION FROM E. FARY, DEC.FMBER I7, I965

RADIOGRAPHS WERE BEING MADE OF A SUBMARINE UNDERGOING OVERHAUL IN DRYDOGK. ALL WORKMEN HAD LEFT FOR LUNCH. ROPE BARRICADES ANO WARNING SIGNS HAD BEEN SET UP, A 4-MIN. EXPOSURE STARTED, AND THE 2 RAOIOGRAPHERS WERE ON GUARD TO PREVENT ENTRY INTO THE RADIATION AREA. NO ANNOUNCEMENT OF THE RADIOGRAPHY WAS MADE BECAUSE THE INTERCOM WAS NOT HORKING. THE LIGHTS IN THE EXPOSURE AREA WENT OUT FOR TRANSFER TO ANOTHER POWER SOURCE. AN OFFICER ON $\triangle N$ INSPECTION TOUR PROCEEDED FROM ANOTHER OIRECTION IN A DARKENEO PASSAGEWAY, FELT THE SIGN BUT COULONT TELL WHAT IT SAID, WENT UNDER THE ROPE BARRICADE, NOTICED THE EXPOSURE HEAD, TOUCHED IT ANO WAS THEN OBSERVED BY THF RADIOGRAPHERS, WHO WARNEO HIM OUT OF THE RADIATION AREA. DOSE WAS 5 REMS HHOLE-BODY, AND 350 TO FINGERTIPS OF LEFT HAND.

USAEC, PUBLIC DOCUMENT ROUM, 1717 H ST., WASHINGTON, D.C, 20545 (2.5 C.ENTS/PAGE)

*FAILURE, SEQUENTIAL + \#PERSONNEL EXPOSURE, RADIATION + \#RAOIOGRAPHY + FAILURE, EQUIPMENT + INCIDENT, HUMAN ERROR + INCIDENT, NONREACTOR + RADIATION SAFETY AND CONTROL

$17-26381$

ALSO IN CATEGORY 15

CLUSS RD

ADIOGRAPHER DURING STORAGE OF SOURCE

OVEREXPOSURE TO RADIOGRAPHER DURI
U.S. NAVY, MARE ISLAND SHIPYARD

3 PAGES, LETTER TO AEC DIVISION OF MATERIALS LICENSING FROM CHIEF OF BUREAU OF SHIPS, APRIL 14 , 1965

ON MARCH 10, 1965, A RADIGGRAPHER RECEIVED AN ESTIMATED DOSE OF 46.6 REMS TO THE LEFT HAND AND 400 MREM WHOLE BODY. A PROJECTOR WITH SOURCE HAD BEEV DAMAGEO WHEN A TRANSFER WAGON OVERTURNED. TWO BOLTS HOLOING THE CONTROL BOX TO THE PROJECTOR WERE BROKEN, AND UNKNOWN TO THF OPERATORS, THE THREAOS OF THE REMAINING THO BOLTS WERE STRIPPED. THE PROJECTOR WAS BEING RETURNED TO STORAGE, AND, WHILE SUSPENUEU FRAM A CRANE, THE WEICHT OF THE CABLFS CAUSED THE CONTROL BOX, PIGTAIL, AND SOURCE TO PULL FREE. THE RADIOGRAPHER PICKED UP THE PIGTAIL AND RETURNED THE SOURCE TO THE PROJECTOR.

USAEC, PUBLIC DOCUMENT ROOM, 1717 H ST., WASHINGTON, D.C. 20545 (25 CENTS/PAGE)

\#FAILURE, OPERATOR ERROR + \#PER SONNEL EXPOSURE, RADIATION + \#RAOI OGRAPHY + FAILURE, EQUIPMENT + INCIDENT, HUMAN ERROR + INCIDENT, NONREACTOR

$17-26382$

FARY EJ

ALSO IN CATEGORY IS

INADEQUATE SURVEY RESULTS IN OVEREXPOSURE TO RADIOGRAPHER

U.S. NAVY

3 PAGES, LETTER TO AEC DIVISION OF LICENSING AND REGULATION FROM COMMANDER OF. SAN FRANCISCD BAY NAVAL SHIPYARD, JULY 7, 1965

OURING THE MIDNIGHT TO 8 AM SHIFT ON JUNE 10, 1964, A RAOIOGRAPHERS. HELPER RECEIVED A DOSE OF 12.5 REMS, THE RADIOGRAPHER 0.09. AFTER AN EXPOSURE, THE SOURCE DID. NOT .COMPLETELY RETURN CO THE SHIELD, AND ON INADEQUATE SURVEY FAILED TO REVEAL THE NARROW RADIATION BEAM. THE CONNECTOR OF THE SHIELDING NOZZLE WAS MISALIGNED, HHICH COULD CAUSE THE SOURCE TD HANG IN THE PARTIALLY SHIELDED POSIIIINN. THE SURVEY METER HAD A RESPONSE LAG. TIME WHEN SWITCHED FROM OFF TO ON, WHICH MAY HAVE CONTRIDUTCD TO INADEQUATE SIIRVFY.

USAEC, PUBLIC DOCUMENT ROOM, 1717 H ST., WASHINGTON, D.C. 20545 (25 (ENTS/PAGE)

\#PERSONNEL EXPOSURE, RADIATION + *RADIOGRAPHY + FAILURE, EQUIPMENT + FAILURE, OPERATOR ERROR + INC IDENT, HUMAN ERROR + INC.IDENT, NONREACTOR 
CATEGORY 17

OPERATIONAL SAFETY AND EXPERIENCE

17-26383 ALSO IN CATEGORY 15

OVEREXPOSURE TO RADIOGRAPHERS

U.S. NAVY, PHILADELPHIA NAVAL SHIPYARO

2 PAGES, LETTER TO AEC OIVISION OF LICENSING AND REgULATION FROM R. A. MOUNT, NOVEMBER 18,1965

ON NOVEMBER 2, 1965, TWO RADI OGRAPHERS RECEIVEO DVEREXPOSURES OF 2.5 AND 3.5 REMS WHEN THEY TRIED TO RETURN THE SOURCE TO THE SHIELD. THEY HAD SUPPJSEOLY CONNECTED THE SOURCE CABLE TO THE DRIVE CABLE.

USAEC, PUBLIC DOCUMENT ROOM, 1717 H ST., WASHINGTON, D.C. 20545 (25 CENTS/PAGE)

\#FAILURE, OPERATOR ERROR + *PERSONNEL EXPOSURE, RADIATION + \#RADIOGRAPHY + INCIDENT, HUMAN ERROR + INCIDENT, NONREACTOR

17-26384 ALSO IN CATEGORY 15

RESPONSE TO AEC CITATION FOR NONCOMPLIANCE IN RADIOGRAPHY OPERATIONS

UNITED STATES TESTING COMPANY, HOBOKEN, N. J.

5 PAGES, LETTER TO AEC OIVISION OF STATE ANO LICENSE PELATIONS FROM A. L. BRASSELL, NOVEMBER 26,1965

PERSONNEL CHANGES RESULTED IN RELAXATION OF EMPLOYEE TRAINING. SHORTAGES OF DOSIMETERS RECTIFIED BY PURCHASE OF OTHERS, FILM BADGES NOW ASSIGNED TO PERSONNEL, RECORD-KEEPIVG SYSTEM WAS REVISED, MONTHLY EQUIPMENT INVENTORY STARTED TO ENSURE THAT PERSONNEL HILL HAVE SURVEY METERS AND THAT REGULAR CALIBRATION IS PERFORMED. RETRAINING PROGRAM GIVEN TO ALL

RADIOGRAPHERS AND ASSISTANTS, ALL WORKERS WERE ISSUED COPIES OF EMERGENCY PROCEDURES,

RADIATION SAFETY OFFICER NOW REVIEWS DAILY THE UTILIZATION LOG.

USAEC, PUBLIC DOCUMENT ROOM, 1717 H ST., WASHINGTON, D.C. 20545 (25 CENTS/PAGE)

\#FAILURE, AOMINISTRATIVE CONTROL + \#FAILURE, OPERATOR ERROR + \#INSPECTION AND COMPLIANCE + *RADIOGRAPHY

17-26385 ALSO IN CATEGORY 15

CONTAMINATION FROM LEAKING RADIOGRAPHY SOURCE

TWIN CITY TESTING AND ENGINEERING LABORATORY, INC., ST. PAUL, MINNESOTA

2 PAGES, LETTER TO AEC, WASHINGTON, D.C. FROM H. T. SCHULZE, SEPTEMBER 30,1966

AFTER FILM HAS FOUND FOGGED WHILE STORED NEXT TO THE SOURCE TUBES AND CONTROL CABLES, CONTAMINATION FROM A LEAKING IRIDIUM-192 SOURCE WAS FOUND ON THE PLANT FLOORS, SOURCE STORAGE

PIGS. ALSO, TRUCKS PARKED IN THE BACK OF THE PLANT WERE CONTAMINATEO TO 5-IO MR/HR BY DIRECT

READING. A TARPAULIN IN THE TRUNK OF A WORKMANS PRIVATE CAR CONTAINED ACTIVITY UP TO IOO

C/SECOND. A SINGLE IRIDIUM PARTICLE WAS FOUND IN THE DRIVEWAY, WHICH READ 1300 MR/HR.

HEALTH PHYSICIST RECOMMENDED THAT CABLES BE SURVEYED EACH TIME THEY ARE REMOVEO FROM THE

SHIELDED CONTAINER TO PREVENT SUCH INCIDENT.

USAEC, PUBLIC DOCUMENT ROOM, 1717 H ST., WASHINGTON, D.C. 20545 (25 CENTS/PAGE)

*CONTAMINATION + *FAILURE, EQUIPMENT + *RADIOGRAPHY + *SOURCE, RADIATION +

FAILURE, ADMINISTRATIVE CONTROL + RADIATION SAFETY AND CONTROL

17-26386 ALSO IN CATEGORY 15

FORGETFULNESS RESULTS IN OVEREXPOSURE TO RAOIOGRAPHER

TWIN CITY TESTING AND ENGINEERING LABORATORY, INC., ST. PAUL, MINNESOTA

3 PAGES, LETTER TO AEC DIVISION OF STATE AND LICENSE RELATIONS FROM H. T. SCHULZE, NOVEMBER 2 , I967

AFTER PERFORMING 15 EXPOSURES, RADIOGRAPHER SURVEYED IN THE USUAL MANNER TO ASCERTAIN THAT SOURCE WAS IN THE SAFE POSITION, BUT THIS ONE TIME HE FORGOT TO PUSH THE KEY OPERATED LOCK IN, WHICH WOULD LOCK THE SOURCE IN THE EXPOSURE DEVICE. DURING THE TRANSFER TO ANOTHER LOCATION, THE CRANK CAUGHT ON AN OBSTRUCTION AND FORCEO THE SOURCE TO AN EXPOSED POSITION. WHILE SETTING UP FOR THE NEXT EXPOSURE HIS FILM BADGE IN THE SHIRT POCKET WAS 3 FT FROM THE 90-CURIE SOURCE. HIS LEFT THIGH WAS 6 TO 12 IN. AWAY. FILM BADGE READ B.8 REMS. ESTIMATED DOSE TO THIGH WAS 70 REMS.

USAEC, PUBLIC DOCUMENT ROOM, 1717 H ST., WASHINGTON, D.C. 20545 (25 CENTS/PAGE)

\# INCIDENT, HUMAN ERROR + \#PERSONNEL EXPOSURE, RADIATION + \#RADIOGRAPHY + INCIDENT, NONREACTOR + SOURCE. RADIATION

17-26387 ALSO IN CATEGORY 15

RESPONSE TO AEC CITATION FOR NONCOMPLIANCE IN RADIOGRAPHY PROCEDURES

TWIN CITY TESTING AND ENGINEERING LABORATORY, INC., ST. PAUL, MINNESOTA

3 PAGES, LETTER TO AEC DIVISION OF COMPLIANCE FROM C. H. BRITZIUS, JANUARY 22,1968

AEC COMPLIANCE CITED FOUR ITEMS OF NONCOMPLIANCE - (1) RADIOGRAPHER FAILED TD LOCK EXPOSURE DEVICE AFTER EXPOSURE, AND FAILED TO REPORT DISCHARGE OF DOSIMETER, (2) SURVEY WAS NOT MADE TO DETERMINE EXTENT OF DOSE RECEIVED BY RADIOGRAPHER, (3) AEC NOT NOTIFIED IMMEDIATELY OF 
CATEGORY 17

OPERATIONAL SAFETY AND EXPERIENCE

$17-26387$ *CONT INUED*

EXPOSURE INCIDENT, AND (4) STORAGE OF MATERIAL AT PLACE NDT SPECIFIED SY LICENSF. COMPANY RESPONSE - (1) ITEM REVIEWED WITH ALL RADIOGRAPHERS, ( 2 ) SURVEY TECHNIQUES WEPE REVIEWED AND RAOIOGRAPHERS INSTRUCTEO TO LEAVE SURVEY METERS ON AT ALL TIMES, (3) FAILED TO MARK ENVELOPE CONTAINING BADGE, SD THAT RESULTS OF READING WERE DELAYED, 141 COMPANY MOVED 2 BLDCKS AWAY ANO NEGLECTED TO INFORM AEC.

USAEC, PUBLIC DOCUMENT ROOM, $1717 \mathrm{H} \mathrm{ST.,} \mathrm{WASHINGTON,} \mathrm{D.C.} 20545$ (25 CENTS/DAGE)

*FAILURE, DOMINISTRATIVE CONTROL + *INSPECTION AND COMPLIANCE + *RADIOGRAPHY + FAILURE, oPERATOR ERROR + RADIATION SAFETY AND *CONTROL

17-26388 ALSO IN CATEGORY 15

FAILURE IO SURVEY RESULTS IN OVEREXPOSURE TO RADIDGRAPHER

VESTER J. THUMPSON, JR., INC., MOBILE, ALABAMA

2 PAGES, LETTER TO AEC OIVISION GF LICENSING ANO REGULATION FROM V. J. THOMPSON, JR., JULY 1, I965

RAOIOGRAPHER RECEIVED A QUARTERLY DOSE OF $1820 \mathrm{MR}$, OF WHICH 1050 WAS RECEIVED IN ONE FXODSUPE AS A RESULT OF FAILING TO SURVEY TO ENSURE THE RETURN DF A SOURCE TO A SAFE POSITION. THF OVEREXPOSURE AND CAUSE WERE DISCUSSED WITH ALL THE EMPLOYEES, AND THE RADIOGRAPHER WAS RELIEVED OF HIS DUTIES.

USAEC, PUBLIC DOCUMENT ROOM, $1717 \mathrm{H}$ ST., WASHINGTON, D.C. 20545 (25 CENTS/PAGE)

* INC IDENT, hUMAN ERROR + \#PERSONNEL EXPOSURE, RADIATION + \#RADIOGRAPHY + INCIDENT, NONREACTOR + SOURCE, RADIATION

17-26389 ALSO IN CATEGORY 15

RADIATIDN DAMAGE TO HANDS DISCOVERED 2 WEEKS AFTER EXPOSURE

TECHNICAL OPERATIONS RESEARCH, BURLINGTON, MASSACHUSETTS

7 PAGES, LETTER TO AEC DIVISION OF LICENSING AND REgULATION FROM E. T. CLARKE, APRIL 16, 1965

THE RIGHT HANDS OF TWO MEN BECAME SWOLLEN ANO TENDER 2 WEEKS AFTER AN ESTIMATED EXPOSURE OF $250 \mathrm{R}$ GAMMA ANO 1000 RODS BETA. TO DISLODGE IRRADIATED IRIDIUM PSLLETS AOHERING TO AN ALUMINUM SPOOL BY CORROSION, THE MEN STOOD BEHIND A LEAD SHIELD $\triangle N O$ TOOK TURNS FOR IC MIN RAPPING THE CAPSULE CORE AGAINST THE INNER WALL OF A LEAD.CONTAINER. TSN-INCH-LONG TWEEZERS WERE USFO, BUT THE HANOS WERE IMMEDIATELY ABOVE THE ACTIVITY. NEITHER MAN WORE FILM $84 D G E S$ OR DOSIMETERS. FUTURE HANOL ING TO BE DONE UNDER SURVEILLANCE OF RADIATION SAFETY OFFICER.

USAEC, PUBLIC DOCUMENT ROOM, $1717 \mathrm{H}$ ST., WASHINGTON, D.C. 20545 (25 CENTS/PAGE)

\#PER SONNEL EXPOSURE, RADIATION + \#RAOIOGRAPHY + CORROSION + INCIDENT, HUMAN ERROR + INCIOENT, NONREACTOR + SOURCE, RADIATION

17-26390 ALSO IN CATEGORY 15

RADIATION EXPOSURE IS OUESTIONABLE

WARD H. SPARROW HOSPITAL, LANSING, MIT.HIGAN

2 PAGES, LETTER TO AEC DIVISION OF COMPLIANCE FROM J. C. SPENCER M.D., JANUARY 14, 1965

A FILM-BADGE REPORT FOR THE PERIOO 10-26-64 THROUGH 11-8-64 INDICATED THAT ONE EMPLOYEES BADGE WAS TOO DARK TO READ. DARKENING OF THE FILM IN THE BADGE TO THAT DEGREE REQUIRES" AN EXPOSURE OF 500 TO $1000 \mathrm{R}$. INVESTIGATION AND QUESTIONING OF THE EMPLOYEE FAILEO TO PPOVIDE AN EXPLANATION. THE EMPLOYEE IS WELL, ANO BLOOD COUNTS ARE NORMAL. THE FILM BADGE MAY HAVE BEEN DEFECTIVE.

USAEC, PUBlic document ROOM, 1717 H St., hASHINGTON, D.C, 20545 (25 CENTS/PAGE)

\#PERSONNEL EXPOSURE, RADIATION + *RADIOGRAPHY + INCIDENT, NONREACTOR.

17-26391 ALSO IN CATEGORY 15

RADIOGRAPHY INCIDENT AT. SINCO TESTING INC.

SINCO TESTING INC., PORT HURON, MICHIGAN

4 PAGES, LETTER TO AEC OSLR FROM A. SAUCIER, OCTOBER 3, 1966

ON JULY 7, 1966, A RAOIOGRAPHER RECEIVED AN ESTIMATED DOSE OF 4000 R TO THE SKIN OF HIS HANOS. WHILE ATTEMPTING TO DISCONNECT A SOURCE FROM THE CONTROL CABLE, HE JERKED IT FROM THE STORAGE CONTAINFR. THE 27-CUR.IE SOURCE LANDED IN HIS HAND AND MADE CONTACT FOR 1 SEC.

USAEC, PUBLIC DOCUMENT ROOM, 1717 H ST. WASHINGTON, D.C. 20545 (.25 CENTS/PAGE)

* INCIOENT, HUMAN ERROR + \#PERSONNEL EXPOSURE, RADIATION + \#RADIOGRAPHY + INCIDENT, NONREACTOR + SOURCE, RADIATION

17-26392 ALSO IN.CATEGORY 15

THIRD DEGREE BURNS SUSTAINED FROM RADIOGRAPHY INCIDENT 
CATEGORY 17

OPERATIONAL SAFETY AND EXPERIENCE

17-26392 \#CONTINUED*

PITTSBURGH TESTING LAB, BIRMINGHAM, ALABAMA

2 PAGES, LETTER TO AEC OIV. OF LICENSING AND REGULATION, APRIL 7, 1964

A 47.7-CURIE CQBALT-60 SDURCE BECAME UNCOUPLED AND JAMMED IN THE RADIDGRAPHY SOURCE TUBE 1 FOOT FROM THE STORAGE CONTAINER. AN ATTEMPT TO RECTIFY THE MALFUNCTION RESULTED IN DNE RADI OGRAPHER RECEIVING THIRD-DEGREE BURNS ON THREE FINGERS OF HIS LEF.T HAND. FILM BADGE, WOR.N ON HIS BELT, READ $3.45 \mathrm{R}$. THE OTHER RADIOGRAPHER RECEIVED AN ESTIMATED DOSE TO THE HANDS OF 1000 RADS, AND 2.05 RADS WHOLE BOOY.

USAEC, PUBLIC DOCUMENT ROOM, 1717 H ST., WASHINGTON, D.C. 20545 (25 CENTS/PAGE)

* INCIDENT, HUMAN ERROR + \#PERSONNEL EXPOSURE, RADIATION + \#RAOIOGRAPHY + FAILURE, EQUIPMENT + INCIDENT, NONREACTOR + SOURCE, RADIATION

17-26393 ALSO IN CATEGORY 15

FLUOROSCOPIC RADIATION EXPOSURE AT MILWAUKEE HOSPITAL

MILWAUKEE HOSPITAL, MILWAUKEE, WISCONSIN

2 PAGES, LETTER TO AEC DIVISION OF STATE AND LICENSE RELATIONS, MAY 22,1964

A TECHNICIANS FILM-BADGE EXPOSURES FOR 2 QUARTERS OF 1963 WERE 2.125 AND 1.587 REMS AS A RESULT OF IMPROPER SHIELDING ON A NEW FLUOROSCOPIC UNIT. CORRECTIVE ACTION INCLUDED PROPER SHIELDING, WEARING OF HEAVY LEAD APRONS FOR ALL FLUOROSCOPY, AND USE OF MORE TECHNICIANS TO LESSEN INOIVIDUAL. EXPOSURES.

USAEC, PUBLIC DOCUMENT ROOM, $1717 \mathrm{H}$ ST., WASHINGTON, D.C. 20545 (25 (ENTS/PAGE)

\#PERSONNEL EXPOSURE, RADIATION + \#RADIOLOGY

17-26394 ALSO IN CATEGORY 15

LOST SOURCE USED FOR DENSITY GAUGE

THE SHERWIN-WILLIAMS CO., CHICAGO, ILLINOIS

1 PAGE, LETTER TO AEC DIV. OF COMPLIANCE FROM W. A. STARKOVICH, APRIL 2, 1968

IN EARLY DEC. 1967, COMPANY DISCOVERED THAT A 50-MILLICURIE CFSIUM-137 SEALED SOURCE IPART OF A DENSITY GAUGE) WAS MISSING BUT FAILED TO NOTIFY AEC UNTIL MARCH 26,1968 . DUR. ING THE INTERIM, AN EXTENSIVE SEARCH WAS MADE. ONE EMPLOYEE STATED THAT HE REMEMBERED CLEANING UP THE AREA AND HAD THROWN THE MATERIAL IN THE WASTE DUMPSTER. THE COMPANY WAS CITED FOR FAILURE TO NOTIFY.

USAEC, PUBLIC DOCUMENT ROOM, $1717 \mathrm{H}$ ST., WASHINGTON, D.C. 20545 (25 CENTS/PACE)

\#RADIOGRAPHY + \#SOURCE, RADIATION, LOST + FAILURE, AOMINISTRATIVE CONTROL + RADIATION SAFETY AND CONTROL

$17-26408$

DICKERMAN CE

HIGHLIGHTS OF THE AIX CONFERENCE ON FAST REACTOR SAFETY

3 PAGES, 35 REFERENCES, REACTOR AND FUEL-PROCESSING TECHNOLOGY, 11(1), PAGES 1-3 (WINTFR, 13A7-19GRI

VERY BRIEF SUMMARY OF TOPICS DISCUSSED. MUCH ATTENTION OEVOTED TO DESCRIBING AND CALCULATING TRANSIENT SODIUM BOILING AND EXPULSION BY VAPORIZATION. SESSION ON OPERATING EXPERIENCE INCLUDED FOLLOWING - 11 ) DOUNREAY - NAK LEAK WAS IN ONE OF 24 LINKS BETWEEN PRIMARY COOLANT CIRCUIT AND THE REACTOR VESSEL, $(2)$ RAPSODIE - PROBLEMS IN STARTUP INCLUDED THERMAL-STRESS DIFF ICULTIES IN ORIGINAL DESIGN, (3) BR-5 - EXTENSIVE OXIDE PLIGGING EXPERIENCED AFTER EXPOSURE OF URAINEU CORE TO AIR, GAS ENTRAPMENT, AND LEAKS. IN HEAT EXCHANGER, (4) FERMI PARTIAL MELTDOWN DUE TO OBJECT IN INLET PLENUM BRIEFLY COVERED.

* OPERATING EXPERIENCE + BOILING + DOUNREAY (TR) + FERMI (LMFBR) + FLOW BLOCKAGE + FUEL MELTDOWN + LEAK + MAIN COOLING SYSTEM + MATHEMATICAL TREATMENT. + REACTOR STARTUP EXPERIENCE + REACTOR, LMCR + REACTOR, TEST + SODIUM + STRESS + THERMAL MECHANICAL EFFECT

$17-26409$

SKAARDAL RC

OPERATIONAL PROBLEMS AND SOLUTIONS

10 PAGES, 10 FIGURES, 3 TABLES, 13 REFERENCES, REACTOR AND FUEL-PROCESSING TECHNOLOGY, 11 (1), PAGES $17-26$ (WINTER, $1967-1968$ )

DISCUSSES CASES OF COMPQNENT FAILURES REPORTED AT 1967 CONFERENCE HELD BY REACTOR UPEZATIONS DIV. OF ANS. HYDRIDING OF ZR PROCFSS TUBES IN HANFORD PRODUCTIOV REACTOR HAS OCLURRED AT RATE OF 25 TO 30 PPMIYEAR AT LOW TEMPERATURES. CAUSE NOT DETERMINED. BOWING OF ALUMINUM RATE OF 25 TO 30 PPM/YEAR AT LOW TEMPERATURES. CAUSE NOT DETERMINED. BOWING OF ALUMINUM
SHIM RODS AT ORR FROM FAST-NEUTRON DAMAGE WAS MEASURED. HEAT-EXCHANGER-TUBE VIBRATIONS AT HFBR LOCALIZED TO U BENDS. MODIFICATION MADE TO LIMIT SHELL-SIDE VELOCITIES TO ONE-HALF. TUNSTEN CARBIDE SEAL FAILURE ON CIRCULATION PUMP AT BIG ROCK POINT AND REPAIR EXPERIENCE COVERED.

* DPERATING EXPERIENCE + BIG ROCK POINT (BWR) + CHEMICAL REACTION + CONTROL ROD BURNUP + CORE COMPONENTS + DAMAGE + FAILURE, EQUIPMENT + FAST NEUTRDN + HANFORD (PR) + HEAT EXCHANGER + HFBR (RR) + HYDRIDE + MAINTENANCE AND REPAIR + MODIFICATION, SYSTEM OR EQUIPMENT + ORR (RR) + PUMP + REATTOR, PRODUCTION + 
CAT.EGORY 17

OPERATIONAL SAFETY AND EXPERIENCE

17-26409 *CONTINUED*
REACTOR, RESEARCH + SEAL + TUBING + VIBRATION + 2IRCALOY

17-26412 ALSO IN CATEGORY 9

PASHOS TJ

CONTROL MATERIALS SYMPOSIUM

4 PAGES, 2 TABLES, 8 REFERENCES, NUCLEAR APPLICATIONS, 4(6), PAGES $396-432$ (JUNE, 1968)

SUMMARIZES FIVE PAPERS PRESENTED AT THE JUNE 1960 ANS MEETING. TOPICS ARE - (1) MATERIALS FOR CONTROL OF WATER-CODLED POWER REACTORS, (2) USE OF LANTHANID OXIOE ABSORBERS IN PWR, (3) CONTROL BLADES PER HFBR, (4) PERFORMANCE OF BORON-CONTAINING RODS IN WATER-COOLED POWER REACTORS, AND (5) PERFORMANCE OF AG-IN-CD IN PWR.

* MATERIAL + \#REACTOR CONTROL + BORON + CADMIUM + CONTROL ROD + DYSPROSIUM + EUROPIUM + INOIUM + LANTHANUM + OPERATING EXPERIENCE + REACTOR, BWR + REACTOR, PWR + SILVER.

17-26515 ALSO IN CATEGORIES 18 AND 1

QUESTIONAIRE ON PROPOSED WATERTREACTOR SAFETY SCHOOL

IDAHO OPERATIONS DFFICE, AEC

16 PAGES, LETTER FKÜM W. L. GINKEL, JULY 1,1968

PROPOSED SCHOOL IAI NKTS, IOAHOI WOULD PROVIDE $9-$ TO 12-WEEK SESSIONS (RIINNING SUCESSIVELY FOR FOUR YEARS) TO DISSEMINATE (HITH REOUCED TIME IAG) THE LATEST REACTOR-SAFETY TECHNJLOGY AND PHILOSOPHY TO INDUSTRY, UNIVERSITIES, AND GOVERNMENT. CURRICULUM COULO SE LIFTED ALMOST DIRECTLY FROM THE WATER-REACTOR ACCIDENT TREE AND WCULD INCLUDE BASIC PHENOMENA AND

ANALYTICAL TECHNIQUES. SYLLABUS INCLUDES - BACKGROUND (6 HR), NATURE OF REACTOR SAFEGUARDS

( $24 \mathrm{HR})$, HISTORY OF ACCIDENTS $(6 \mathrm{HR})$, REACTOR SAFEGUAROS (24 HR), REGULATORY AND R-AND-D

FUNCTIONS $(6 \mathrm{HR})$, ACCIDENT ANALYSIS $(48 \mathrm{HR})$, QUALITY ASSURANCE (I2 HR), CLASS PROJECTS (S6 HRI, AND SUMMATION SESSIONS $(28$ HRI. TUITION - \$2000-\$4000.

AVAILABILITY - R. F. MAKEUS, EDUCATIDN OFFICER, USAEC, IDAHO OPERATIONS OFFICE, P. O. BOX 2108 , IDAHO FALLS, IDAHO 83401

* SAFETY PROGRAM + \#STAFFING, TRAINING, QUALIFICATION + NRTS + REACTOR, BWR + REACTOR, PWR + REACTOR, WATER

$17-26533$

PEACH BOTTOM MONTHLY OPERATICNS REPORT NO. 26

PHILAOELPHIA ELECTRIC COMPANY, PHILADELPHIA

21 PAGES, APRIL 1968 , DOCKET 50-171, TYPE--HTGR, MFG.--G. A., AE--BECHTEL

FAILED FUEL ELEMENT C05.05 REMOVED FROM CORE, AS WAS ELEMENT E05.05, WHICH APDEARED TO BE CRACKEO, BUT SUBSEQUENT HOT-CELL EXAMINATION SHOWED IT WAS NOT. MISSING

VIEWING-DEVICE-REFLECTOR SEARCH UNSUCCESSFUL. PSC (FT. ST. VRAIN) TYPE UNPURGED FUEL ELEMENT

LUAUED IN POSITION AII.11. ALL 90 DEMONSTRATION TFSTS WERE COMPLETED, HITH 5 DISCQEPANCIES

REMAINING, ALL OF WHICH INVOLVE FUEL-HANDL ING EQUIPMENT.

AVAILABILITY - USAEC, PUBLIC UILUMENT ROOM, WASHINGTON, D. C.

\#REPORT, OPERATIONS + FAILURE, FUEL ELEMENT + PEACH BOTTOM I (HTGR) + REACTOR, HTGP +

TEST, SYSTEM OPERABILITY

17-26564 ALSO IN CATEGORY 2

LUMMENTS ON THE PROPOSCD PIUCLEAR POWER PLANT ON THE HIINSIN RIVER OPPOSITE THE SARATOGA NATIJNAL HISTORICAL PARK, AS REQUESTED BY AEC LETTER MAR.CH 20, 1988.

DIVISION OF REACTOR LICENSING, AEC

8 PAGES, LETTER TO G. T. SEABDRG, AEC. MAY 27, 1968. DOCKET 50-300. TYPE--BWR, MFG--G.F., AE--STQNE + WEBSTER

REPORT CONCLUDES THAT MASS ANO SCALE OF STRUCTURES WOULD HAVE A SIGNIFICANT ADVERSE VISUAL IMPACT AND WOULD MATERIALLY ULTRACT FROM INTERPRETATION OF THE EVENTS EMBOOISO BY THF DARK. REFERRING TO SECT. 106 OF NATIONAL HISTORICAL PRESERVATION ACT OF IOSS IREQUIRING AEC TO TAKE INTO ACCOUNT EFFECT ON NATIONAL-REGISTEP. PROPERTIESI, COUNCIL CONCLUDES AEC SHOULD NOT ISSUE A CONSTRUCTION PERMIT UNLESS THERE IS NO FEASIBLE ALTERNATIVE SITE, ANO THEN WITH ALL

POSSIBLE PLANNING TO MINIMIZE AOVERSE (VISUAL) EFFECT. CRITERIA INCLUDED.

AVAILABILITY - PUBLIC DOCUMENT RODM, WASHINGTON, D.C.

LUNSTRUCTION PERMIT PROCESS + EASTON (BWR) + RFAT.TOR. BWR + SITING, REACTOR

$17-26565$

I I L-54 I. IC.ENSE CHANGED TO POSSESSION ONLY

DIVISION OF REACTOR LICENSING, AEC

13 PAGES, AMENCMENT 8 TO FACILITY LICENSE R-3, LETTER TO R. V. MOLER FROM D. J. SKOVHOLT. JUNE 26 , 1968 . DOCKET $50-1$. 
CATEGORY 17

OPERATIONAL SAFETY ANO EXPERIENCE

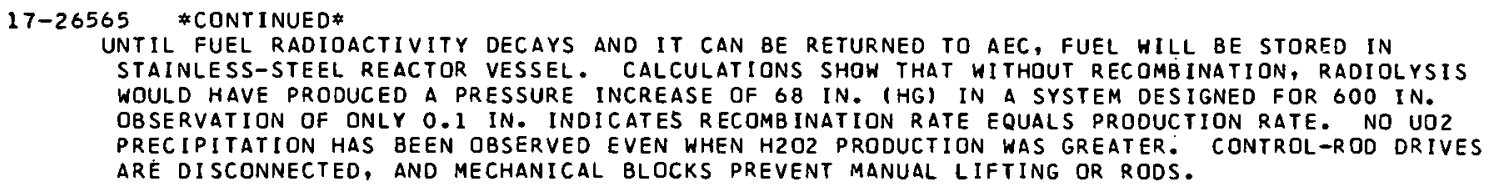

AVAILABILITY -- PUBLIC DOCUMENT ROOM, WASHINGTON, D.C.

*DECOMMISSIONING + REACTOR, INTERNAL SUPERHEAT + SAFETY EVALUATION + TECHNICAL SPECIFICATIONS + VESR (ISR)

$17-26569$

CLARKRH + CARSON JF

BAWTR DPERAIING REPORT FOR PERIDD OCT 1067 THRU MARCH 1968

BABCOX AND WILCOX COMPANY, LYNCHBURG, VIRGINIA

BAW-337 +. 9 PAGES, FIGURES, TABLES, 7 REFERENCES, MAY, 1963, DOCKET NO. 50-200

\begin{abstract}
CAUSES OF SCRAMS - (1) THE NO.-1 SAFETY-ROD MAGNET HAD HIGH LEAKAGE CURRENT WHICH ALLOWED ROD IO RELEASE ON MINOR POWER FLUCTUATIONS. 121 THREE SCRAMS RESULTED FROM LOSS OF FLOW INDICATION, CAUSED BY MOISTURE OR FOREIGN MATTER IN COMPRESSED AIR SUPPLY. (3) A PERIOD SCRAM OCCURRED WHILE SUBCRITICAL DUE TO RANDOM NOISE IN CIRCUITS. \# \# SEVEN POWER REDUCTIONS OCCURRED, FIVE WERE DUE TO OPERATOR ERRORS IFAILURE TO RANGE INSTRUMENTS, USE PROPER SETTINGS, AND ADJUST SHIMS PROPERLYI. TWO WERE CAUSED BY SWITCHING TRANSIENTS DURING TESTS. PRESENTS RESULTS OF CONTAINMENT LEAK TESTS, SAFETY-ROD OROP TESTS, AND EOUIPMENT MALFUNCTIONS AND MODIFICATIONS.
\end{abstract}

AVAILABILITY - USAEC, PUBLIC DJCUMENT ROOM., 1717 H. ST., HASHINGTON, D.C. 20545 (\$\$O. 25 CENTS/PAGE)

* SCRAM, REAL + CONTAINMENT INTEGRITY + FAILURE, INSTRUMENT + FAILURE, OPERATOR ERROR + FAILURE, SCRAM MECHANISM + MODIFICATION, SYSTEM OR EQUIPMENT + NOISE + REACTOR, RESEARCH + REPORT, OPERATIONS SUMMARY + TEST, LEAK RATE

17-26570 ALSO IN CATEGORY 9

C.I ARK RH + CARSDN JF

EQUIPMENT MALFUNCTIONS AND MODIFICATIONS

COMBUSTI ON ENG INEERING, INC.

BAW-337 + 2 PAGES, FROM THE BABCOCK + WILCOX TEST REACTOR LICENSE TR-4 EIGHTH REPORT TO THE ATOMIC ENERGY COMMISSION DIVISION OF REACTOR LICENSING, MAY, 1968, OOCKET NO. 50-30

SMALL PLASTIC TUBES SUPHLYING N2-HE TO A DETECTOR EXPERIMENT CAME IN CONTACT WITH HEATER WIRES OF ANOTHER EXPERIMENT. THE GAS-SUPPLY VALVES WERE CLOSED BEFORE INCIDENT, SO ONLY GAS IN TUBES ESCAPED. SOME INCREASE IN CONTAINMENT PARTICULATF MONITOR WAS NOTED. \$\$\#NUMEROUS SCRAMS HAVE BEEN CAUSED BY SHORT-TERM POWER INTERRUPTIONS OF FLUCTUATIONS INITIATED BY A QUICK-ACTING SCRAM RELAY. IN THE PRIMARY PUMP CIRCUIT THERE IS A SECOND RELAY WHICH SERVES SAME PURPOSE BUT IS SLOWER ACTING. THE QUICK-ACTING RELAY IS LESS SAFE SINCE IT CREATES NEED FOR MORE STARTUPS AND WAS PROVIDED WITH OELAY OF 1 TO 2 SEC.

AVAILABILITY - USAEC, PUBLIC DOCUMENT ROOM, 1717 H. ST. WASHINGTON, 0. C. 20545 (\$0.25 CENTSIPAGE)

\#FAILURE, DESIGN ERROR + ACCIDENT, LOSS OF POWFR + ELECTRIC POWER, NORMAL + EXPERIMLNT, GENERAL + INCIDENT, EQUIPMENT + INSTRUMENTATION, RELAY + MODIFICATION, SYSTEM OR EQUIPIAENT + REACTOR SAFETY SYSTEM + REACTOR, RESEARCH + REPORT, OPERATIONS SUMMARY + SCRAM, SPURIOUS

17-26571 ALSO IN CATEGDRY 11

DRL COMMENTS ON REPAIR OF FINAL TWO STUB TUBES

DIVISION OF REACTOR LICENSING, AEC

2 PAGES, LETTER TO J. E. LOGAN, JERSEY CENTRAL P + L CO. FROM LETTER TO J. E. LOGAN FROM P. A. MORRIS.

DOCKET 50-219. TYPE--BWR, MFG--G.E., AE--BURNS + ROE

RE SULTS AND DISCUSSIONS GIVE US A BASIS TO CONCLUDE THAT THE TWO REMAINING UNTOUCHED STUB TUBES CAN BE REPAIRED. THEY SHOULD BE CAREFULLY MEASURED AND GIVEN DYE-PENETRANT TESTS BEFORE AND AFTER REMOVING ALL FIELD WELDS \#WF ARE STUOYING NEED FOR A SURVEILLANCE PROGRAM OF SENSITIZED SS MATERIAL. YOU SHOULD HAVE ADEQUATE CLAD AND UNCLAD STIIR-TURE 


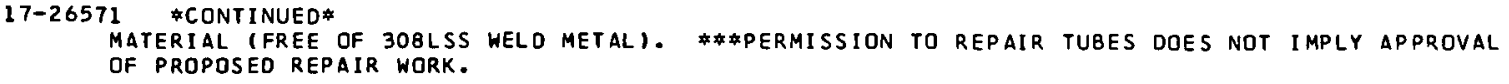

*WELDING + CONTAINMENT PENETRATION, PIPE + FAILURE, PRESSURE VESSEL + OYSTER CREEK I (BHRI + PIPING + PRESSURE VESSEL + REACTOR, BWR + STEEL, STAINLESS + SURVEILLANCE PROGRAM

\section{$17-26588$}

ESCAPE OF LUBRICATING OIL INTO THE EBOR PRIMARY SYSTEM ANO SUBSEQUENT CLEANUP GENERAL DYNAMICS CORP. , SAN DIEGO, CALIFORNIA

GA-7802 +. 55 PAGES; JANUARY 10,1967

GIVES A VERY DETAILED DISCUSSION OF THE. CLEANUP PROCEOURES USED TO REMOVE 56 GAL OF OIL FROM THE PRIMARY SYSTEM. FAILURE OF A MAIN HELIUM BLOWER SHAFT-SEAL ALLOWED LUBRICATING OIL TO ENTER SYSTEM. MATERIALS USED. INCLUDEO TURCO 4324-OR DETERGENT, A THINNER, AMMONIA, AND HYDRAZINE.

AVAILABILITY - CLEARINGHOUSE FOR FEOERAL SCIENTIFIC ANO TECHNICAL INFORMATION, SPRINGFIELD, VIRGINIA 22151, \$3.00 T.OPY, \$0.65 MIC.RTFICHF

*FAILURE, EQUIPMENT + *INCIDENT, RECOVERY FROM + \#SEAL + CONTAMINATION + COOLANT QUALITY + DECONTAMINATION + DECONTAMINATION + EBOR (GCR) + LUBRICATION + MAIN COOLING SYSTEM + REACTOR, GCR

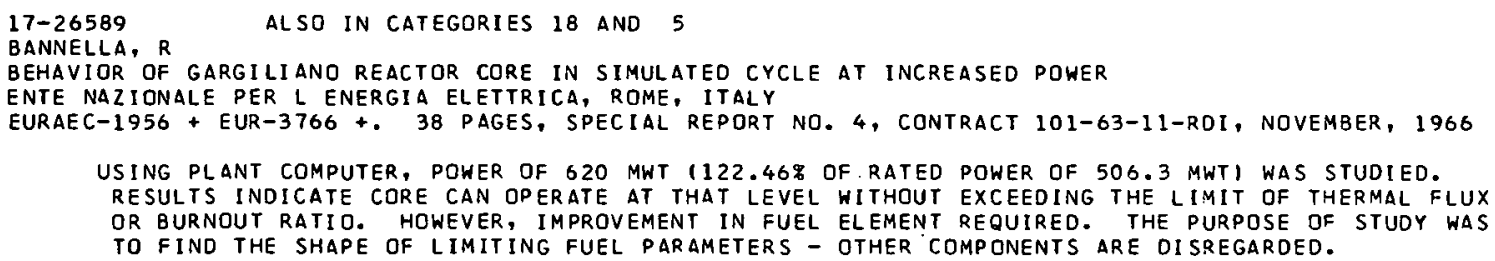


CATEGORY 17

OPERATIONAL SAFETY AND EXPERIENCE

\author{
$17-26592$ \\ RESEARCH PROGRAM FOR THE GARIGLIANO NUCLEAR PLANT \\ ENTE NAZI ONALE PER L ENERGIA ELETTRICA, ROME, ITALY \\ EURAEC-1958+EUR-3767+. 10 PAGES, REPORT NO. 14, JULY 1-OCTOBER 31, 1967, NOVEMBER 1 , 1967 \\ PROGRESS REPORT ON PROGRAM TO DETERMINE POWER-LIMITING FEATURES OF GARIGLIANO. A CALCULATION \\ CODE WAS PREPARED TO PROCESS DATA FROM CORE WIRE IRRADIATION. COMPUTER CALCULATIDNS \\ CONFIRMED POSSIBILITY OF OPERATING CORE AT 620 MHT. \\ AVAILABILITY - AEC DEPOSITORY LIBRARIES IN THE U.S. AND OVERSEAS \\ \#POWER UPRATING + \$R AND D PROGRAM + COMPUTER PROGRAM + DATA PROCESSING + FLUX DISTRIBUTION + \\ GARIGLIANO (BWR) + IRRADIATION TESTING + PERFORMANCE LIMIT + REACTOR, BWR + REPORT, OPERATIONS ANALYSIS + \\ SENN
}

$17-26616$

APPLICATION FOR EXTENSION OF PEACH BOTTOM 1 TEMPORARY LICENSE EXPIRATION DATE

PHILADELPHIS ELECTRIC COMPANY

11 PAGES, LETTER TO P. A. MORRIS, DRL.. FROM LETTER TO P. A. MORRIS FROM V. P. MCOEVITT. JUNE 19, 1968. DOCKET 50-171. TYPE--HTGR, MFG--G.A., AE--BECHTEL

POINTS OUT THAT FULL-POWER OPERATION WAS ACHIEVEO IN MAY 1967, AND ON JAN. 11, I968, PLANT HAD ACCUMULATED 168.8 FULL-POWER DAYS BEFORE FIRST EXTENDED SHUTDOWN. PLANT HAS JUST RETURNED TO FULL POWER ON MAY 6, 1968 , AND MAIN COOLING SYSTEM ACTIVITY HAS INCREASED TWICE TO NEW EQUILIBRIUM VALUES. REQUESTS LICENSE DPR-12 BE EXTENDEO 17 MONTHS TO CONTINUE EVALUATION OF FUEL-ELEMENT PERFORMANCE ANO OF THE HIGHER THAN EXPECTED STEAM-GENERATOR-SHELL TEMPERATURES.

AVAILABILITY - PUBLIC DOCUMENT ROOM, WASHINGTON, D.C.

*FAILURE, FUEL ELEMENT + *HIGH TEMPERATURE + *STEAM GENERATOR + OPERATING LICENSE PP.OCESS +

PEACH BOTTOM 1 (HTGR) + REACTOR, HTGR

$17-26617$

YEARLY REPORT OF FACILITY CHANGES

UNIVERSITY OF KANSAS

2 PAGES, LETTER TO DRL, FROM LETTER TO DIR., ORL FROM RUSSELL B. MESLER. JUNE 18, 1968 . DDCKET 50-148.

NO CHANGES TO FACILITY OR PROCEOURES HAVE BEEN MADE IN THE LAST YEAR THAT ARE AS DESCRIBED IN THE SAFETY-ANALYSIS REPORT. CURRENT MEMBERSHIP IN COMYITTEES JN RADIATION SOURCES AND ON NUCLEAR REACTOR LISTED. \# \#LL 30 INNER, AL-CLAD CONCRETE BEAM-PORT PLUGS WERE DRILLED WITH 1/8-IN. HOLES TO RELIEVE ANY INTERNAL PRESSURE. FIVE HAD PRESSURE. FUEL AND CONTROL-ROD INSPECIIUN SHUWEO NOTHING SUSPICIOUS.

AVAILABILITY -- PUBLIC DOCUMENT ROOM, WASHINGTON, D.C.

*BEAM HOLE + \#PRESSURE, INTERNAL + *SHIELDING + CONCRETE + FAILURE, EQUIPMENT + REACTOR, RESEARCH + REPORT, OPERATIONS SUMMARY + SAFETY REVIEW

$17-26 E 18$ ALSC IN CATEGRRY 14

CLARIFICATION OF A-41 RELEASE CONCENTRATION

WASHINGTON STATE UNIVERSITY

1 PAGE, LETTER TO DRL, FROM LETTER TO DIR., ORL FROM HAROLO W. DODGEN. JUNE 14, 1968. DOCKET 50-27.

THE NOV. 14, 1966, SAFETY ANALYSIS (PG 46-50) CONCLUDED THAT CONTINUOUS RELEASE OF AR-41 AT 1. $5 \times 10$ (MINUS $5 T H$ ) MICROCURIE/CC HOULD NOT VIOLATE 10 CFR 20. WE REQUESTED AUTHORIZATION TO RELEASE AR -41 AT A CONCENTRATION THAT WOULD PRODUCE A YEARLY AVERAGE OF 1.5 X 1O(MINUS 5TH) RELEASE AR -41 AT A CONCENTRATION THAT WOULD PRODUCE A YEARLY AVERAGE OF 1.5 X $10(M I N U S 5 T H)$
WHEN CONTROLLED AND KEPT TO A MINIMUM CONSISTENT HITH EXPERIMENTAL PROGRAMS. AS A RESULT OF AMENDMENT 3 (JULY 12, 1967), WE UNDERSTAND THAT WE ARE AUTHORIZED TO RELEASE AR-41 AT A

YEARLY AVERAGE CONCENTRATION OF $1.5 \times 10(M I N U S$ STH) MICROCURIEIML.

AVAILABILITY -- PUBLIC DOCUMENT ROOM, WASHINGTON, D.C.

* ARGON + \#MAXIMUM PERMISSIBLE CONCENTRATION (MPC) + \#SOURCE, CONTINUOUS + POWER UPRATING +

REACTOR, RESEARCH + REPORT, SAR + STACK + TECHNICAL SPECIFICATIONS + TRIGA (RR)

$17-26619$

GENERAL POL ICY ON OPERATING DURING A LABOR STRIKE

CONNECTICUT YANKEE ATOMIC POWER COMPANY

2 PAGES, LETTER TO H. L. PRICE, AEC DIRECTOR OF REGULATION. JUNE 25, 1968. 00CKET 50-29. TYPE--PUR, MFG--WEST., AE--STONE + WEBSTER

NORMAL COMPLEMENT AT ROWE IS 66. THIRTY NINE IN IBEW INCLUDE 10 CONTROL-ROOM OPERATORS, 10 AUX. OPERATORS, AND 19 OTHERS. THE NORMAL OPERATION STAFF IS 5 SRO AND 10 RO. AT PRESENT, 10 SRO AND 2 RO ARE NOT IN IBEW. \$\$DURING A STRIKE, THERE WILL BE SAME NUMBER OF PEOPLE (SI) 
CATEGORY 17

OPERATIONAL SAFETY AND EXPERIENCE

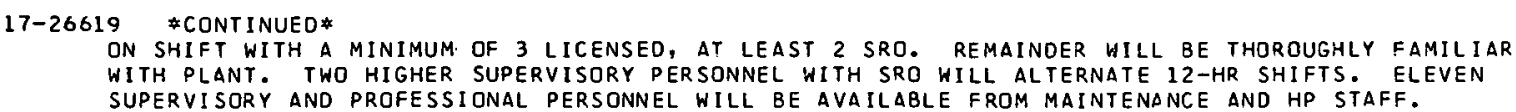

AVAILABILITY -- PUBLIC DOCUMENT ROOM, WASHINGTON, D.C.

\#PER SONNEL EXPOSURE, RAOIATION + \#PH REACTIVITY EFFECT + CHEMICAL SHIM + FUEL BURNUP + FUEL HANOLING + MAINTENANCE AND REPAIR + REACTOR, PWR + REFUELING + REPORT, OPERATIQNS + YANKEE (PWR)

$17-26622$

BARCELO H

PROGRAM OF INSTRUCTION FOR PRNC REACTOR OPERATORS (ACADEMIC PLAN)

PUERTO RICO WATER NUCLEAR CENTER

PRNC $-17+28$ PAGES, JUNE, 1968

PROVIDES SCOPE NOTES AND LECTURE OUTLINES FOR 6-MONTH COURSE. (1) MATHEMATICS, 71 HR, 7 PG.

(2) PHYSICS, 61 HR, 4 PG. (3) NUCLEAR ENGINEERING, 66 HR, 6 PG. (4) ELECTRD-MECHANICAL

ENGINEERING, 96 HR, 6 PG. (5) HEALTH PHYSICS AND CHEMISTRY, 39 HR, 3 PG. (6) PLANT

INFORMATION, 21 HR, 2 PG。

AVAILABILITY - CLEARINGHOUSE FOR FEOERAL SCIENTIFIC ANO TECHNICAL INFORMATION, SPRINGFIELO, VIRTINIA $22151 \$ 3.00$ COPY, $\$ 0.65$ MICROF ICHE

*STAFFING, TRAINING, QUALIFICATION + REACTOR, POOL TYPE + REACTOR, RESEARCH

17-26644 ALSO IN CATEGORY 15

SIVINTSEV YV

RADIATION SAFETY IN NUCLEAR REACTORS

640 PAGES, REFERENCES, MOSCOW, ATOMIZOAT, 1967, IN RUSSIAN

THE STANDARDS FOR RADIATION SAFETY IN NUCLEAR REACTORS ARE REVIEWED IN DETAIL. THE MAXIMUM PERMISSIBLE RADIATION LEVELS ARE OUTLINED. METHODS USED FOR THE DOSIMETRY OF EXTERNAL RAOIATION ANO THE SHIELDING NECESGARY ARE GIVEN. THE RETENTION OF EISSION DROOUCTS IN THE FUEL AND PRIMARY COOLANT OF NUCLEAR REACTORS IS DISCUSSED. THE PRECAUTIONS REQUIRED FOR RADIOACTIVE GASES AND AEROSOLS IN REACTORS ARE DESCRIBED. METHODS USED FOR MEASURING THE INTERNAL RADIATION OF REACTORS ARE GIVEN.

*RADIATION SAFETy AND CONTROL + MAXIMUM PERMISSIBLe dOSE (MPDI + REACTDR, BWR + REACTOR, POWER + REACTOR, PWR + USSR 
CATEGORY 17

OPERATIONAL SAFETY AND EXPERIENCE

17-26737 ALSO IN CATEGORY 13

CONSTRUCTION OF RADIOCHEMISTRY LABORATORY IN REACTOR LABORATORY

UNIVERSITY OF TEXAS

5 PAGES, 3 FIGURES, LETTER TO E. R. PRICE, DSLR. FROM A LETTER TO.EBER R. PRICE FROM S. J. GAGE. JUNE

11,1968 . DOCKET 50-192.

(RESPONSE TO LETTER OF MAY 17, 1968). ROOM WILL BE USED FOR RADIOCHEMICAL SEPARATIONS IN TRACE ANALYSIS WITH NEUTRON-ACTIVATION TECHNIQUES. ROOM WILL CONTAIN TERMINUS DF THE

PNEUMATIC (RABBIT) TRANSFER SYSTEM, A FUME HOOD, A GLOVE BOX, AND STORAGE. OUTSIDE AIR IS

ORAHN DIRECTLY INTO ROOM ANO EXHAUSTED FRDM GLOVE BOX AND FUME HOOD TO A 30-FT STACK.

GLOVE-BOX DUCT HAS A FILTER.

AVAILABILITY -- PUBLIC DOCUMENT ROOM, WASHINGTON, D.C.

GLOVE BOX + IRRAOIATION FACILITY + RADIOISOTOPE + REACTOR, RESEARCH + VENTILATION SYSTEM

$17-26738$

REPORT ON FUEL TRANSFER INCIDENT 4 JAN 1968

$\triangle M E S$ LABORATORY

4 PAGES, I TABLE, LETTER TO P. A. MORRIS, DRL. FROM LETTER TO P. A. MORRIS FROM GLENN MURPHY. JUNE 26,

1968. DOCKET 50-116.

LOW-POWER CORE WAS BEING REPLACED BY HOT CORE IN STORAGE PIT. AFTER 4 COLD ELEMENTS WERE TAKEN TO STORAGE, THE FIRST HOT ELEMENT FELL OUT OF THE TRANSFER CASK INTD THE FUEL BOX WHEN THE CASK DOOR WAS OPENEO. FUEL ELEMENT END WAS NICKED, BUT NEITHER CONTAMINATION NOR RADIATION WAS EXCESSIVE, AND IT WAS RETURNED TO STORAGE, \#\# INCIDENT HAS RECONSTRUCTED WHEN (A) HOLD-DOWN SCREW WAS NOT TIGHT AGAINST THE ELEMENT LIFTING ATTACHMENT, (B) WINCH CABLES ALLOWED TO SLACKEN BY RESTING CASK ON ITS DOOR, (C) CABLES AND ELEMENT PICKUP ROTATED INTO THE UNLOCKING DIRECTION.

AVAILABILITY - PUBLIC DOCUMENT ROOM, WASHINGTON, D.C.

*ACCIDENT, REFUELING + *FUEL HANDLING MACHINE + FAILURE, FUEL ELEMENT + OPERATING EXPERIENCS + REACTOR, RESEARCH

17-26739 ALSO IN CATEGORY 9

CONTROL ROD STARTERS WITHDRAWN

UNIVERSITY OF CALIFORNIA, LOS ANGELES

I PAGE, LETTER TO D. J. SKOVHOLT. LETTER TO D. J. SKOVHOLT FROM CRAIG B. SMITH. JUNE 26,1968 . DOCKET $50-142$.

DURING THE 19 JUNE 1968 PRESTART CHECKOUT, CONTROL BLAOE NO. 1 DIO NOT RETURN TO THE DOWN

POSITION WHEN DROPPED. WHATEVER IS INHIBITING MOTION IS NOT IN THE DRIVE. WE HAVE REMOVED

THE FUEL AND ARE UNSTACKING THE GRAPHITE CENTER ISLAND TO LOCATE THE DIFFICULTY.

AVAILABILITY -. PUBLIC DOCUMENT ROOM, WASHINGTON, D.C.

ARGONAUT (TNG) + FAILURE, SCRAM MECHANISM + REACTOR, RESEARCH

17-26740 ALSO IN CATEGORY 9

MARK F TRIGA CONTROL ROD STICKS

GENERAL OYNAMICS, . GENERAL ATOMIC DIVISION

2 PAGES, LETTER TO D. J. SKOVHOLT, DRL. FROM LETTER TO D. J. SKOVHOLT FROM E. CREUTZ. JUNE 28 , 1968.

DOCKET 50-163.

DN MAY 29, DURING A ROUTINE PULSE AT THE MARK F, THE SHIM ROD STOPPED 3 IN. SHORT OF FULL INSERTION FOLLOWING THE ROUTINE SCRAM. SHUTDOWN MARGIN WAS 1.27 WITH THIS ROD FULL OUT. $50 \%$ OF THE SUBSEQUENT TEST DROPS SHOWED ROD STOPPED 3 IN. SHORT, IN $50 \%$ ROD FELL FULLY DOWN. AFTER ADJACENT ELEMENTS WERE CHECKED FOR INTERFERENCE, ROD DROPPED FREELY. REACTOR RETURNED TO SERVICE JUNE 7 AFTER DISCUSSION WITH COMPLIANCE. EXACT CAUSE NOT RESOLVED, BUT MOST PROBABLE CAUSE WAS IMPROPERLY SEATED ELEMENT OR TEMPORARY FOREIGN OBJECT IN THE DASH POT.

AVAILABILITY -- PUBLIC DOCUMENT ROOM, WASHINGTON, D.C.

* FaILURE, SCRAM MECHANISM + FUEL ELEMENT + FUEL HANOLING + nRSTRUCTION + REACTOR, PULSEO +

REACTOR, RESEARCH + SAFETY REVIEH + TEST, SYSTEM OPERABILITY + TRIGA (RR)

17-26741 ALSO IN CATEGORY 9

SIX MONTHS OPERATIONS SUMMARY JAN TO JUN 19,1968

UNIVERSITY OF TEXAS

3 PAGES, LETTER TO P. A. MORRIS, DRL. FROM LETTER TO P. A. MORRIS FROM S. J. GAGE. JUNE 20, 1968, DOCKET 50-192.

TWO FUEL ELEMENTS WERE ADDED ANO POWER LEVEL INCREASED TO $250 \mathrm{KW}$ ON APRIL 2 . AN 8400-CURIE 
CATEGORY 17

OPERATIONAL SAFETY AND EXPERIENCE

17-26741 \#CONTINUED*

CO-60 SOURCE WAS INSTALLED IN THE REACTOR-POOL IRRAOIATOR, A 4-IN, -DIA, PORTARLE, VEPTICAL BEAM TUBE WAS INSTALLED AFTER REACTOR COMMITTEE DETERMINED IT DID NOT INVOLVF A TECH.-SPEC. CHANGE OR AN UNREVIEWED SAFETY QUESTION. THE LOWER END RESTS ON THE GRAPHITE REFLECTOR, ANO THE UPPER END EMERGES NEAR THE BRIDGE, WITH A BEAM CATCHER REDUCING BRIDGE RADIATION TO LESS THAN 50 MRIHR AT $250 \mathrm{KW}$. FDLLOWING COMPLIANCE SUGGESTIONS, AN ELECTRONIC TEST CIRCUIT WAS ADOED TO THE POWER CHANNEL, WHICH ALLOWS CHECKOUT DF ALL COMPONENTS EXCEPT UCIC. JUNE 11 LETTER SENT DESCRIBING SMALL RAOIDCHEMISTRY LABORATORY.

AVAILABILITY -- PUBLIC DOCUMENT ROOM, WASHTNGTON, D.C. .

* BEAM HOLE + *TEST, SYSTEM OPERABILITY + COBALT + INSPECTION AND COMPLIANCE +

INSTRUMENTATION, POWER RANGE + NEUTRON + POWER UPRATING + RAOIATION SAFETY AND CONTROL + RADIOGPAPHY + REACTOR, RESEARCH + REPORT, OPERATIONS SUMIARY + SAFETY REVIEW + SHIELOING + SOURCE, RADIATION +

TRIGA (RR)

17-26742 ALSO IN CATEGORIES 11 AND 3

ERR COLD HYDROTEST $\triangle T$ T 240 PSIG.

RURAL COOPERATIVE POWER ASSOCIATION, ELK RIVER, MINNESOTA

COO-651-60+ 25 PAGES, 3 FIGURES, 4 TABLES, RURAL COOPERATIVE POWER ASSOCIATION\%S ELK RIVER REACTOR

SIXTY-SEVENTH MONTHLY OPERATING REPORT, MAY, 1968 DOCKET NO. 115-1, TYPE--BWR, MFG--A.C., AE--SGT + LUNOY

REACTOR HAS NOT OPERATED SINCE JANUARY. A 240-PSIG COLD HYDROTEST WITH SR-85 DISPERSED IN THE PRIMARY SYSTEM WAS TERMINATED AFTER 7 DAYS, WITH NO SR-85 FOUND IN CAVITY WATER. RUPTURE DISK RUPTURE ON FUEL SHIPPING CASK WAS TRACED TO ALCONOX SOLUTION USEO IN DECONTAMINATION AT SRL. APPENDIX A -DESCRIBES 240-PSIG HYOROTEST AND RFSULTS. APPENDIX B -PROCEDURE FOR $1000-P S I G$ HYDROTEST AT $300 \mathrm{~F}$, USING SR-85 AND RB-86.

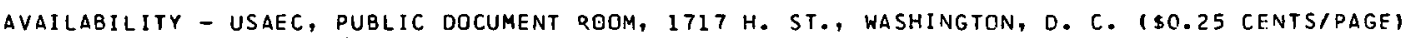

\#MAIN COOLING SYSTEM + \#TEST, PROOF + CORROSION + DECONTAMINATION + ELK RIVER (BWR) + FAILUPE, EQUIPMENT + FAILURE, PRESSURE VESSEL + PRESSURE RELIEF + PRESSURE VESSEL + PP.FSSUR.E, INTERNAL +

PROCEDURES AND MANUALS + REACTOR, AEC OWNED + REACTOR, BWR + REPORT, DPERATIONS + RUBIDIUM +

SHIPPING CONTAINER + STRONTIUM + TRACER, RAUIUACIIVE

17-26743 ALSO IN CATEGORIES 11 AND 1

ELK RIVER TECHNICAL SUPPORT CONTRACT, REACTOR VESSEL LEAKS

RURAL COOPERATIVE POWER ASSOCIATION

CO0-651-57+. 22 DAGES, 5 FIGURES, FEBRUARY, 1968, DOCKET NO. 115-1, TYPE--BWR, MFG--A.C., AE--SGT + LUNOY

REACTOR SHUT DOWN ENTIRE MONTH BECAUSE RCPA AND AGC CONTRACTURAL NEGOTIATIONS WERE IN PRDGRESS REGARDING THE TECHNICAL-SUPPORT SUBCONTRACTOR ITECHNICAL SPECIFICATIONS REQUIRE THERE BE ONE 1. \# \#EACTOR CAVITY WATER, WHICH HAD ACCUMULATED AT ABOUT 1 GALIDAY IN THE LAST THREE MONTHS, ACCUMULATED AT ABOUT 250 MLIDAY, MAINLY DUE TO CONDENSATION. CAVITY DRAIN SAMOLES WERE MAINLY NA-24, BUT CAVITY VENT SAMPLES HAD LESS RB-88 THAN CONTAINMENT AIR.

AVAILABILITY - USAEC, PUBliC DOCUMENT ROOM, 1717 H. ST., WASHINGTON, 0. C. 20545 (\$\$O.25 CENTS/PAGE)

*FAILURE, pRESSURE vesSEL + *LEAK RATE + \#SAFETY REVIEW + ELK RIVER (BWR) + REACTOR, aEC OWNED + REACTOR, BWR + REPORT, OPERATIONS + SAMPLING + TECHNICAL SPECIFICATIONS

$17-26744$

POWER UPRATING OF KSU TRIGA MARK II

DIVISION OF REACTOR LICENSING, AEC

20 PAGES, PROPOSED AMENDMENT 3 TO KANSAS STATE U LICENSE. FRUM LETTER TO W. R. KIMEL FROM D. J. SKOVHOLT. JUNE 26,1968 . DOCKET 50-188.

RAISES ALLOWABLE POWER FROM $100 \mathrm{KW}$ TO 250 AND ALLOWS $\$ 2.00$ PULSING. \#\#\#ROVIDES A COMPLETE SET OF TECHNICAL SPECIFICATIDNS. OPERATION AT $280 \mathrm{KW}$ ALLOWED TO TEST FULL-POWER SAFETY CIRCUITS. PULSES THAT EXCEED 250 MW REQUIRE SAFEGUARDS-COMMITTEE INVESTIGATION AND TEMPORARY CESSATION OF PULSATION. SFMIANNIIAL \$1.00 PULSES WILL CHECK PEAK POWER AND FUEL TEMP.

AVAILABILITY -- PUBLIC DOCUMENT ROOM, WASHINGTON, D.C.

\#POWER UPRATING + \#TEGHNICAL SPECIFICATIONS + REACTOR, PULSED + REACTOR, RESEARCH + SAFETY EVALUATION + TRIGA LRR

$17-26745$

ANNUAL OPERATION REPORT OF AGN 201 JUNE 11967 TO MAY 31,1968

TEXAS A AND M COLLEGE

5 PAGES, LETTER TO DRL, FROM LETTER TO P. A. MORRIS FROM R. G. COCHRAN. JUNE 14, 1968. DOCKET $50-59$

REACTOR WAS OPERATED 35.5 HR FOR 4 COURSES. SUBCRITICAL TANK IEAK WAS REPAIRED. LEAKS IIN CORRDDED CHANNELS 1 AND 3 CANISTERS WERE FIXED BY REPLACEMENT HITH A PLASTIC CANISTER. ON THE ADVICE OF COMPLIANCE, RG 58/U COAXIAL CABLE IN CHANNEL I WAS REPLACED BY RG 59/U TO GIVE A HIGHER VOLTAGE RATING HITHOUT CHANGING PERFORMANCE. SAFETY-REVIEW COMMITTEE ADPROVED A SECOND FISSION PLATE FOR THE SUBCRITICAL TANK. 
17-26745 *CONTINUED*

AVAILABILITY -- PUBLIC DOCUMENT ROOM, WASHINGTON, D.C.

\#CORROSION + AGN (TNG) + BEAM HOLE + ELECTRICAL CONDUCTION + INSPECTION AND COMPLIANCE + INSTRUMENTATION, POWER RANGE + REACTOR, TRAINING + REPORT, OPERATIONS SUMMARY + SAFETY REVIEH

17-26746 ALSO IN CATEGORY 6

PULSTTAR DOPPLER COEFFICIENT WITH A GRAPHITE REFLECTOR

WESTERN NUCLEAR RESEARCH CENTER

4 PAGES, 2 FIGURES, LETTER TO D. J. SKOVHOLT, DRL, FROM LETTER TO D. J. SKOVHOLT FROM P. T. BURNETT. JUNE 21,1968 . DOCKET 5 C -57 .

AS. REQUIRED IN LICENSE CHANGE 30, SEVEN PULSES WERE MADE AT 4 DIFFERENT REACTIVITIES WITH FOUR GRAPHITE ELEMENTS ALONG ONE SIDE OF THE 4 XS CORE. THE COEFFICIENT WAS OBTAINED BY DIVIDING THE PROMPT REACTIVITY INSERTEO BY THE TEMPERATURE RISE FROM A PREVIOUSLY PUBLISHEO CURVE OF FUEL TEMP. VS ENERGY DENSITY (WNY-20). THE 7 POINTS FELL WITHIN $10 \%$ OF A CURVE OF DK/DEG F VS AV. FUEL TEMP. PLOTTED FOR WATER REFLECTOR, ON JUNE 2, THE REVISED STEADY-STATE CORE SHOWED A REACTIVITY LOSS OF 0.00581 OK AND A TEMP. RISE OF 245 F ON GOING TO 1.25 MH. THIS DOPPLER COEFFICIENT IS $97 \%$ OF THE WATER-REFLECTED VALUE, AND WE CONCLUDE THAT THE GRAPHITE HAS NOT CHANGEO THE COEFFICIENT.

AVAILABILITY -- PUBLIC DOCUMENT ROOM, WASHINGTON, D.C.

*DOPPLER COEFFICIENT + *MEASUREMENT, REACTIVITY + \#REFLECTOR + COMPARISON, THEORY AND EXPERIENCE + GRAPHITE + PULSTAR (RR) + REACTOR, PULSED + REACTOR, RESEARCH

$17-26790$

REPLACEMENT DF HEAT EXCHANGER

RHODE ISLANO ATOMIC ENERGY COMMISSION

1 PAGE, LETTER TO DRL, JANUARY 30, 1968. DOCKET 50-193.

CHANGE 3, APRIL 14, 1967, TO THE TECHNICAL SPECIFICATIONS ALLOWED US TO REPLACE THE ALUMINUM HEAT-EXCHANGER. ALSO REPLACEO THE ALUMINUM SHELL WITH A STAINLESS-STEEL SHELL. TO AVOID CONFUSION, PLEASE CHANGE OUR TECHNICAL SPECIFICATIONS, PERHAPS IN THE PENDING CHANGE FOR HIGHER-POWER OPERATION.

AVAILABILITY - PUBL IC DOCUMENT ROQM, WASHINGTON, D.C.

*ALUMINUM + \#CORROSION + \#HEAT EXCHANGER + \#MOOIFICATION, SYSTEM OR EQUIPMENT + OPERATING EXPERIENCE + REACTOR, RESEARCH + STEEL, STAINLESS

\section{7-26794}

SCHEDULE FOR INFORMATION NEEDED FOR INDIAN POINT I LONG TERM LICENSE

CONSOLIDATED EOISON COMPANY OF NEW YORK

2 PAGES, LETTER TO P. A. MORRIS, DRL, FROM LETTER TO P. A. MORRIS FROM A. N. ANDERSON. DOCKET 5O-3. TYPE--PWR, MFG--R+H, AF- C.NN ED

IT AHPEARS IMPOSSIBLE TO PREPARE THE REQUESTED INFORMATION BEFORE PROVISIONAL LICENSE

EXPIRATION DATE, SO, IN SEPT, 1968 WE WILL APPLY FOR AN EXTENSION. WE PLAN ON THE FOLLOWING

SCHEDULE - SEPT. 1 (FACILITY INFORMATION), NOV. 1 (COMPARISON WITH CURRENT CRITERIAI, JAN.

15, 1969 (ANALYSES OF TOPICS OF SPECIAL INTEREST TO ACRS), AND FEB. 15 (TECHNICAL

SPECIFICATIONS AND BASESI. AT A LATER DATE, FORMAL SUBMITTALS WOULD BE PRESENTED ON THE

BASIS OF INFORMAL SUBMITTALS.

AVAILABILITY - PUBLIC DOCUMENT ROOM, WASHINGTON, D..C.

*RESPONSE TIME + INDIAN POINT I (PWR) + NPERATING LICENSE PROCESS + REACTOR, PWR

17-26930 ALSO IN CATEGORY 9

MEDIFICATION OF ROD ORIVE CONTROL CIRCUITS

UNIVERSITY OF MISSOURI

2 PAGES, I FIGURE, LETTER TO E M HOWARD, DRL, TAKEN FROM A LETTER TO E, M. HOWARD, DRL FROM D. RAY. MAY

27, 1968. DOCKET 50-123.

PROPOSED MODIFICATION PLACES AUXILIARY CONTACTS OF THE WITHDRAW SWITCH IN THE ROD-ORIVE

CONTROL CIRCUITS SO THAT BOTH THE RELAY KS MUST BE ENERGIZED AND EITHER GANG OR INDIVIDUAL WITHDRAW SWITCH CLOSED FOR THE ROD TO WITHORAW. WE AHAIT YOUR COMMENTS BEFORE MAKING THE MOOIFICATIONS.

AVAILABILITY - PUBLIC DOCUMENT ROOM, 1717 H ST., HASHINGTON, O.C.

\#CONTROL ROD DRIVE + \#INSTRUMENTATION, SWITCH + ACCIOENT, CONTROL ROD WITHDRAWAL + CONTROL SYSTEM +

FAILURE, DESIGN ERROR + MODIFICATION, SYSTEM OR EQUIPMENT + REACTOR, RESEARCH 
CAT.EGORY 17

OPERATIONAL SAFETY AND EXPERIENCE

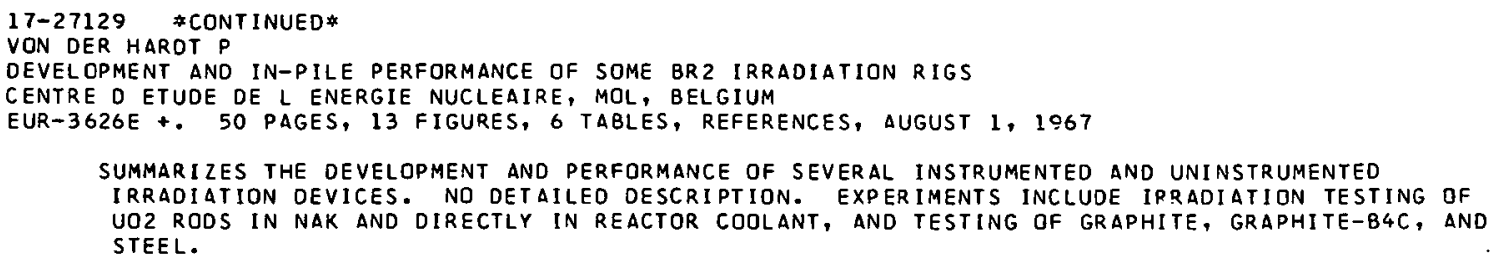

DISCUSSES FAILURES RESULTING IN 9 MONTHS OF LOST TIME IN 1067. TWO MONTHS ATTRIBUTED TO HOLE. IN CALANDRIA TUBE, CAUSED BY ROTATION AND VIBRATION OF BOOSTER CONTROL ROD BECAUSE A BOOSTEP JOINT LOCKING TAB BROKE. LOCKING MECHANISM LATER MODIFIED. \#\#SEVSN MONTHS DOWNTIME REOUIRED FOR REPAIR AND MODIFICATION OF PRIMARY COOLANT PUMPS. PUMP DAMAGE CAUSED BY VARIETY OF REASONS, INCLUDING IMPROPER DESIGN OF LUBR ICATING SYSTEM, LARGE CLEARANCE IN MOTDR BEARINGS, CLOSE CLEARANCES BETWEEN FLYWHEEL AND HOUSING, ETC. TO MINIMIZE HEAVY-WATER LOSS, BOILER ROOM WAS SEALEO TO ELIMINATE VENTILATION SYSTEM, EXHAUSTING LEAKAGE OUT THE STACK.

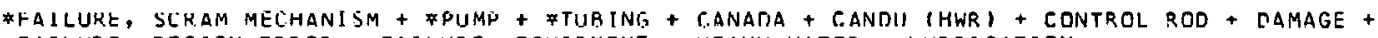
FAILURE, DESIGN ERROR + FAILURE, EQUIPMENT + HEAVY WATER + LUBRICATION +

MODIFICATION, SYSTEM OR EQUIPMENT + REACTOR, HWR + SEAL + VENTILATION SYSTEM

$17-27142$

SCOTT RL

CURIUH DLCOPITAMINATION OF WATER COOLED TEACTORE

OAK RIDGE NATIONAL LABORATORY, DAK PIDGE, TENNESSEE

2 PAGES, 7 REFERENCES, NUCLEAR SAFETY, 9(4), PAGES 322-323 (JULY-AUGUST, 19681

CURIUM CONTAMINATION OF PRIMARY COOLANT SYSTEMS OCCURRED IN 1967 AT ORNL HIGH FLUX ISRTOPE REACTOR AND BELGIUMS DR-2. SOME CURIUM PLATED OUT ON THE PIPING. LANTHANUM WAS ADOED TO THE SYSTEM, WHICH CHANGED THE STATE OF THE CURIUM SO THAT THE SUSPENDED MATERIAL WAS REMOVED BY DEMINERALIZERS AND THAT WHICH HAD PLATED OUT WAS RELEASED FRUM THE PIPE WALLS ANO SUBSEQUENTLY REMOVED BY DEMINERALI ZERS.

\#CURIUM + \#DECONTAMINATION + \#MAIN COOLING SYSTEM + BELGIUM + BR 2 (RR) + COOLANT CHEMISTRY + COOLANT PURIFICATION SYSTEM + HFIR (FTR) + ION EXCHANGE + LANTHANUM + PIPING + REACTOR, AEC OWNED + REACTOR, FLUX TRAP + REACTOR, RESEARCH

17-27143 ALSO IN CATEGORY 6

TAXELIUS TG

QUARTERLY TECHNICAL REPORT, SPERT PROJECT, JANUARY, FEBRUARY, MARCH 1967

PHILLIPS PETROLEUM COMPANY, ATOMIC ENERGY DIVISION, IDAHO FALLS

IDO- $17260+.46$ PAGES, 36 FIGURES, 5 TABLES, 18 REFERENCES, FEBRUARY, 1968

IN (SPERT-III OXIDE CORE KINETICS PROGRAM) TESTS DEMONSTRATED THAT AS REACTOR PERIOD SECOMES SHORTER, POWER LEVEL DECREASES MORE ABRUPTLY AFTER REACHING ITS PEAK SECAUSE OF INCREASED EFFECT OF DOPPLER COEFF. SPERT-IV CDC SUBASSEMBLY TEST PROGRAM - TQANSIENT TESTS WITH PERIODS DOWN TO 3 MILLISEC WERE PERFORMEO ON FUEL ROOS MODIFIED TC IMPROVE WATERTIGHT 
CATEGORY 17

OPERATIONAL SAFETY AND EXPERIENCE

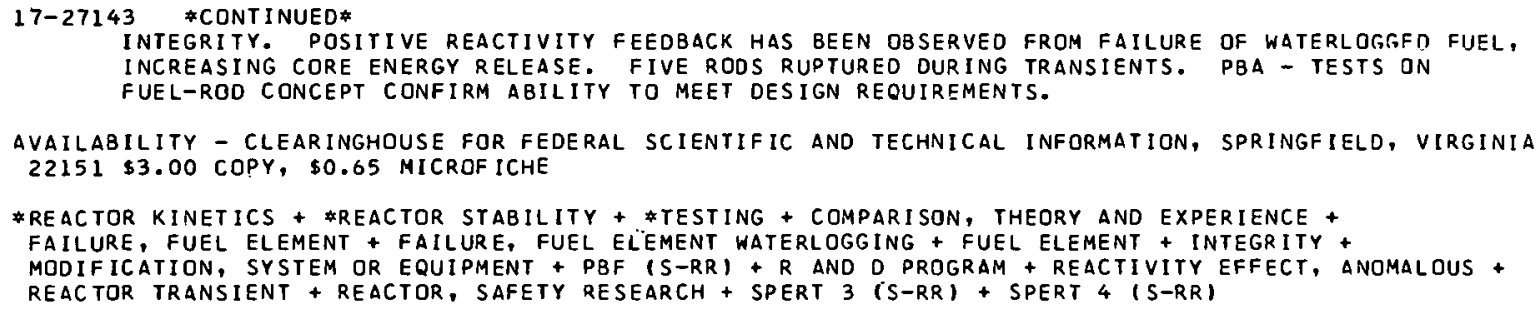

* REACTOR KINETICS + \#REACTOR STABILITY + \#TESTING + COMPARISON, THEORY AND EXPERIENCE + FAILURE, FUEL ELEMENT + FAILURE, FUEL ELEMENT WATERLOGGING + FUEL ELEMENT + INTEGRITY + MODIFICATION, SYSTEM OR EQUIPMENT + PBF (S-RR) + R AND D PROGRAM + REACTIVITY EFFECT, ANOMALOUS + REACTOR TRANSIENT + REACTOR, SAFETY RESEARCH + SPERT 3 (S-RR) + SPERT 4 (S-RR)

$17-27145$

GUPPY WH + MASCHE GC

NUCLEAR PLANT TRAINING

COMMONWEALTH EDISON COMPANY, CHICAGO ILLINOIS + GENERAL ELECTRIC COMPANY, SAN JOSE, CALIFORNIA

4 PAGES, 3 TABLES, POWER ENGINEERING, 72(7), PAGES 38-41 (JULY, 1968)

DESCRIBES THE SIMULATOR BUILT BY GE LOCATED ADJACENT TO DRESDEN FOR TRAINING EWR OPERATOR TRAINEES. NINETY \& OF THE SYSTEMS HAVE BEEN MODELED IN REAL TIME. THE 12-WESK PROGRAM CONSISTS OF 112 HR OF CONTROL-ROOM DUTY, 145 VIDFO-TAPFD LECTURES, 100 SYSTEMS STUDIES INSICE DRESDEN, 86 HR OF STUDY, 13 QUIZZES, 16 FINAL EXAMS, 8 ORAL EXAMS. CENTER HAS 13 FULL-TIME GE OPERATIONS PERSONNEL WITH 4 TRAINEES PER INSTRUCTOR, WHICH PERMITS CONSIOERABLE MAN-TO-NAN DISCUSSION. PURPOSE IS TO PROVIDE OPERATOR WITH KNOWLEDGE TO PASS AEC LICENSE EXAM ON DRESDEN-2. OPERATORS FROM OTHER UTILITIES WILL ONLY HAVE TO LEARN DETAILS OF THEIR OWN PLANTS.

\#COMPUTER, DIGITAL + \#SIMULATION + \#STAFFING, TRAINING, QUALIFICATION + DRESDEN 2 (8WR) + OPERATION + REACTOR, BWR

17-27286

PHILLIPS JL

ALSO IN CATEGORY 10

MINIMIZING THE HAZAROS ASSOCIATEO WITH THE USE OF THE DOUNREAY FAST REACTOR AS AN IRRAOIATION FACILITY UKAEA, DOUNREAY WORKS

23 PAGES, 7 FIGURES, 3 REFERENCES, FROM THE INTERNATIONAL CONFERENCE DN THE SAFETY OF FAST NUCLEAR REACTORS, SEPTEMBER, 1967

REVIEWS EXPER IENCE WITH OPERATION AND EXPERIMENTS. POWER-COEFFICIENT MEASUREMENTS BRIEFLY CONSIDERED. COOLANT IMPURITIES DURING INITIAL OPERATION INTERFERED WITH CONTROL-ROD-DRIVE MECHANISM. A HEAT-EXCHANGER-TUBE LEAK, DUE TO DEFECTIVE MANUFACTURING, RESULTED IN ADOITIONAL TUBE CORROSION AND OXIDATION DEPOSITS. MORE-SENSITIVE METHODS ARE NEEOED TO DETECT VERY SMALL LEAK RATES. AN AIRLOCK IN FUEL SUPPLY TO ONE DIESFI., DND AN ELECTRICAL FAULT IN ALTERNATOR OF ANOTHER, RESULTED IN SCRAM. WHEN A DIESEL FAILED WITH AN OPEN CIRCUIT FUSE TO SETBACK RELAY, SCRAM OCCURRED. ALSO DISCUSSES FUEL BURNUP AND ELEMENT DESIGN, PLUS EXPERIENCE AND REVIEW TECHNIQUE FOR IRRADIATION EXPERIMENTS.

AVAILABILITY - J.L. PHILLIPS, OOUNREAY EXPERIMENTAL REACTOR ESTABLISHMENT

* OPERATING EXPERIENCE SUMMARY + COMPARISON, THEORY AND EXPERIENCE + CONTROL ROD DRIVE + COOLANT QUALITY + CORROSION + DOUNREAY (TR) + FAILURE, SEQUENTIAL + FAILURE, SIMULTANEOUS + FAILURE, TUBING + FUEL BURNUP + GENERATOR, ENGINE + HEAT EXCHANGER + IRRADIATION TESTING + LEAK RATE + OBSTRUCTION + POWER COEFFICIENT + REACTOR, TEST + SAFETY REVIEW + SCRAM, REAL

$17-27287$

IQUID HYDROGEN SPILL DURING TRANSFER OPERATION

UNITED STATES ATOMIC ENERGY COMMISSIDN, WASHINGTON, D.C.

3 PAGES, SERIOUS ACCIOENTS, USAEC, ISSUE NO. 286, FEBRUARY 8,1968

WHEN A LIQUID-HYOROGEN-TRAILER BAYONET FITTING FAILED, VAPOR SPRAY ENVELOPEO THE HAND SHUTOFF VALVE. EMERGENCY-TRAINED PERSONNEL WEARING PROTECTIVE CLOTHING CLOSED VALVE. CONCLUSIDNS (1) WORKING IN MIDST OF CRYOGENIC SPILL IS HIGHLY HAZARDOUS. (2) TANK SHOULD HAVE AN ACCESSIBLE AUXILIARY SHUTOFF VALVE. (3) RE-EXAMINE EMERGENCY PROCEOURES. \#\#NO SERIOUS ACCESSIBLE AUXILIARY SHUTOFF VALVE. (3) RE-EXAMINE EMERGENCY PROCEOURES. \#\#NO SERIDUS
CONSEQUENCES EXCEPT THAT EMERGENCY PER SONNEL SUFFERED MINOR FROST BITE OF FEET WHEN SHOES BECAME FROZEN TO WATER-WETTED REAR DECK OF TRAILER. \# \# LOSE HOSE-FLANGE CONNECTION AI.I OWFO COLD FLUIO TO LEAK THROUGH FLUOROCARBON-LUBRICATED BAYONET SEAL, SHRINKING BUNA-N D-RING SEAL, PERMITTING LIQUID HYDROGEN LEAKAGE TO ATMOSPHERE.

USAEC, DIVISION OF OPERATIONAL SAFETY, WASHINGTON, D.C. 20545

\#ACCIDENT, NONNUCLEAR + *SAFETY PRINCIPLES AND DHILOSOPHY + CRYOGENICS + EMERGENCY PROCEDIRE + FAILURE, EQUIPMENT + FAILURE, SEQUENTIAL + HYDRDGEN + INDUSTRIAL SAFETY + SEAL

17-27288 ALSO IN CATEGORY 13

FIRE AND EXPLOSION SENSITIVITY OF METAL - HALOGENATED SOLVENT SYSTEMS

UNITEO STATES ATOMIC ENERGY COMMISSION, WASHINGTON, D.C.

5 PAGES, 1 TABLE, 9 REFERENCES, heALTH AND SAFETY INFORMATION, USAEC, ISSUE NO. 263 , MAY 6, 1968 


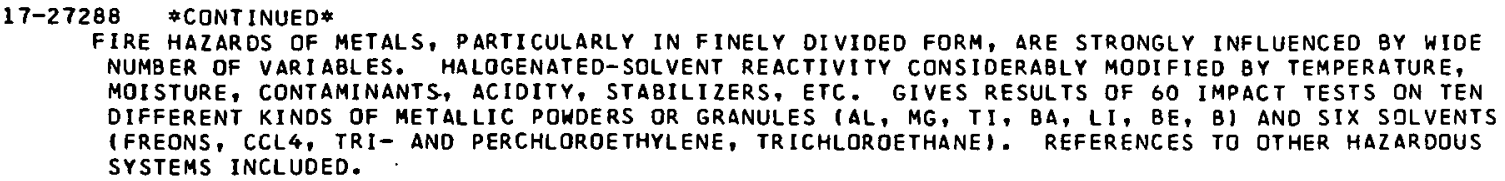

FIRE HAZAROS OF METALS, PARTICULARLY IN FINELY DIVIDED FORM, ARE STRONGLY INFLUENCED BY WIDE NUMBER OF VARI ABLES. HALOGENATED-SOLVENT REACTIVITY CONSIDERABLY MODIFIED BY TEMPERATURE, MOISTURE, CONTAMINANTS, ACIDITY, STABILIZERS, ETC. GIVES RESULTS OF GO IMPACT TESTS ON TEN DIFFERENT KINDS OF METALLIC POWDERS OR GRANULES (AL, MG, TI, BA, LI, BE, B) ANO SIX SOLVENTS (FREONS, CCL4, TRI - ANO PERCHLOROETHYLENE, TRICHLOROETHANE). REFERENCES TO OTHER HAZARDOUS SYSTEMS INCLUDED.

USAEC, DIVISION OF OPERATIONAR SAFETY, WASHINGTON, D.C. 20545

*FABR ICATION + \#FUEL CONVERSION + \#FUEL ELEMENT + *SAFETY PRINCIPLES AND PHILOSOPHY + CHEMICAL REACTION + DECONTAMINATION + EXPLOSION + FIRE + HALOGEN + INDUSTRIAL SAFETY + METAL + TEST, BENCH

$17-27289$

GRAHAM WW + WALKER. DM

SAFETY ANALYSIS REPORT FOR THE 5 MW GEORGIA TECH RESEARCH REACTOR

GEORGIA INSTITUTE OF TECHNOLOGY

GT-NE-7 +. 194 PAGES, 45 FIGURES, TA8LES, REFERENCES, DECEMBER, 1967

REPORT SUPPORTS REQUEST FOR LICENSE CHANGE TO PERMIT POWER UPRATING FROM 1 MW TO 5 MWT.

REACTOR IS CP-S TYPE, HEAVY-WATER MODERATEO AND COOLED. FUEL IS CURVED AL-U ALLOY PLATES, CONTROL ROOS ARE FLAT HOLLOW BL $\triangle D E S$ TF C.D CLAD WITH AL. THERE ARE 41 VERTICAL EXPERIMENT

FACILITIES, 10 HORIZONTAL BEAM PORTS, 7 ADDITIONAL HORI ZONTAL EXPER IMENT TUBES, A THERMAL

COLUMN, AND A BIOMEDICAL IRRAOIATION FACILITY. THE MCA IS A LOSS OF COOLANT HITH COMPLETE

CORE MELTOOWN, RESULTING IN A THYROID DOSE OF 300 REMS IN 2 HR 164 FT FROM CONTAINMENT

VESSEL, AND 25 REMS EXTERNAL DOSE IN 2 HR AT $70 \mathrm{FT}$.

AVAILABILITY - CLEARINGHOUSE FOR FEDERAL SCIENTIFIC AND TECHNICAL INFORMATION, SPRINGFIELD, VA. 22151 $\$ 3.00$ COPY, \$0.65 MICROFICHE

\#REPORT, SAR + ACCIDENT, LOSS OF COOLANT + ACCIDENT, MAXIMUM CREDIBLE (MCA.) + OOSE + FUEL MELTDOWN + UFF SIIE + POWER UPRATING + REACTOR DESCRIPTION + REACTOR, HWR + REACTOR, RCSEARCH

$17-27294$

STEAM GENERATOR BOTTOM HEAO COOLING UNIT MODIFICATION PHILADELPHIA ELECTRIC COMPANY

24 PAGES, 2 FIGURES, TABLE, PEACH BOTTOM MONTHLY OPERATIONS REPORT NO. 27, MAY, 1968, DOCKET NO. 50-171, TYPE--HTGR, MFG-G.A., AE--BECHTEL

(PGS 20-241 DURING INITIAL RISE TO POWER IN EARLY 1967, STEAM GENERATOR GAS-EXIT AND BOTTOM-HEAD TEMPERATURES WERE HIGHER THAN EXPECTEO. INTERNAL BAFFLING AND AN EXTERNAL COOLING SYSTEM WERE ADDED, BUT HIGH TEMPERATURES AT FULL POWER CONTINUED. SHIPPING LUGS WERE REMOVED (THOUGHT TO BE CONDUCTING HEAT FROM SHROUD TO SHELL). IN MAY 1968, THE LIMITING STEAM-GENERATOR TEMPERATURE WAS REACHED AT $78 \%$ POWER. THE RADIATION BAFFLE HAS REMOVED AND THE INSULATION-SKIRT RETAINER WAS LOWERED 10 IN., PERMITTING INCOMING COOLANT TO CONTACT THE VESSEI. IN THE ARFA OF THE HOT SPOT. TEMP. LIMIT NOW AT $94 \%$ OF POWER. FULL POWER CAN NOW BE ACHIEVED BY INCREASING HELIUM FLOW AND REDUCING HELIUM AND STEAM TEMPERATURES.

AVAILABILITY - USAEC, PUBLIC DOCUMENT ROOM, 1717 H ST. WASHINGTON, D.C.

* AUXILIARY COOLING SYSTEM + *FLOH DISTRIBUTION + \#MOOIFICATION, SYSTEM OR EOUIPMENT + \#STEAM GENERATOR + COOLING, GENERAL + FAILURE, DESIGN ERROR + HEAT TRANSFER + HIGH TEMPERATURE + PEACH BOTTOM I (HTGR) + REACTOR, HTGR + REPORT, OPERATIONS + TECHNICAL SPECIFICATIONS + TEMPERATURE GRADIENT

$1.7-2.7331$

TURNER DB

ALSO IN CATEGORIES 16 ANO 15

WORKBOOK OF ATMOSPHERIC DISPERSION ESTIMATES

U.S. DEPARTMENT OF HEALTH, EOUCATION, ANO WELFARE, PUBLIC HEALTH SERVICE, CINCINNATI, OHIO PHS-999-AP-26 +. 84 PAGES, FIGURES, TABLES, 1967

THIS WORKBOOK PRESENTS METHODS OF PRACTICAL APPLICATION OF THE BINOMIAL CONTINUOUS PLUME DISPERSIDN MODEL TO ESTIMATE CONCENTRATIONS OF AIR POLLUTANTS. ESTIMATES OF DISPERSIDN ARE THOSE OF PASQUILL AS RESTATED BY GIFFORD. EMPHASIS IS ON THE ESTIMATION OF CONCENTRATIDNS FROM CONTINUOUS SOURCES FOR SAMPLING TIMES OF $10 \mathrm{MIN}$. SOME OF THE TOPICS DISCUSSED ARE DETERMINATION OF EFFECTIVE HEIGHT OF EMISSION, EXTENSION OF CONCENTRATION ESTIMATES TO LONGER SAMPL ING INTERVALS, INVERSION BREAK-UP FUMIGATION CONCENTRATIONS, AND CONCENTRATIONS FROM AREA, LINE, AND MULTIPLE SOURCES. THENTY-SIX EXAMPLE PROBLEMS AND THEIR SOLUTIONS ARE GIVEN. SOME GRAPHICAL AIDS TO COMPUTATION ARE INCLUDED.

AVAII ARIIITYY - D.B. TURNER, AIR RESOURCES FIELD RESEARCH OFFICE, ENVIRONMENT ADMINISTRATION, U.S. DEPARTMENT OF HEALTH, EDUCATION, AND WELFARE, PUBLIC HEALTH SERVICE, CINCINNATI, OHIO

\#HEALTH PHYSICS TRAINING + METEOROLOGY + \#STAFFING, TRAINING, QUALIFICATION + ATMOSPHERIC POLLUTION + METEOROLOGICAL SUPPORT + REACTOR, POHER + REACTOR, RESEARCH

$17-27334$

AEC DEVELOPS BASIC TEXT ANO COURSE FOR INDUSTRIAL RADIOGRAPHERS

UNITED STATES ATOMIC ENERGY COMMMISSION 
CATEGORY 17

OPERATIONAL SAFETY AND EXPERIENCE

17-27334 \#CONTINUED*

2 PAGES, AEC PRESS RELEASE L-169, JULY 25,1968

THE AEC AND OFFICE OF EDUCATION HAVE PUBLISHED A 3-VOLUME TEXT FOR TRAINING INOUSTRIAL RADIOGRAPHERS. (OE 84036) (NDUSTRIAL RADIOGRAPHY MANUAL, \$1.25, (OE 84035) INDUSIRIAL RADIOGRAPHY STUDENT GUIDE AND LABORATORY EXERCISES, \$0.55. (OE 84034 ) INOUSTRIAL RADIOGRAPHY INSTRUCTOR GUIDE, \$0.40. \#\#\#TEXT IS DESIGNED FOR AN 80-HR 8ASIC COURSE FOR HIGH SCHODL GRADUATES AND WAS WRITTEN BY H.D. RICHARDSON OF LOUISIANA STATE U.

USAEC, DIVISION OF PUBLIC INFORMATION, WASHINGTON, D.C. 20545

*RAOIOGRAPHY + \#STAFFING, TRAINING, QUALIFICATION

$17-27338$

SELECTED YANKEE OPERATING EXPER IENCE

YANKEE ATOMIC ELECTRIC COMPANY

6 PAGES, FIGURES, TABLES, LETTER FROM W. P. JOHNSON TO DRL, YANKEE OPERATION REPORT 90, JUNE 1968, DOCKET 50-29, TYPE--PWR, MFG--WEST., AE--STONE + WEBSTER

LOAD VARIEO BETWEEN 175.6 AND 181 MWE AS RIVER TEMPERATURE VARIEO FROM 55. TO 45 F. MONTHLY ROD EXCERCISE SHOWED RODS 17, 21 , AND 22 HAVE DIFFICULTY IN OUTWARO MOVEMENT. FIRST AIR CHARGE SHOWED A CONTAINMENT LEAK RATE OF $0.047 \%$ IDAY, BUT SECOND CHARGE SHOWS $0.024 \% 10 A Y$. REACTIVITY DEPLETION OF $0.8 \%$ DK/K PER 1000 MWD/MTU ANO 0.152 PPM BORON PER MWD/MTU CONTINUES. PH AVERAGES 5.3.

AVAILABILITY - CLEARINGHOUSE FOR FEOERAL SCIENTIFIC AND TECHNICAL INFORMATION, NATIONAL BUREAU OF STANDARDS, SPRINGFIELD, VA. $22151, \$ 3.00$ COPY, \$0.65 MICROFICHE.

*REPORT, OPERATIONS + CHEMICAL SHIM + CONTAINMENT, HIGH PRESSURE + CONTROL ROD + FUEL BURNUP + LEAK RATE + OBSTRUCTION + REACTOR, PWR + YANKEE (PWR)

$17-27340$

PROPOSED HUMBOLDT BAY FULL TERM LICENSE

PACIFIC GAS AND ELECTRIC COMPANY

OPERATING LICENSE OPR-7 +. 95 PAGES, FIGURES, TABLES, 12 REFERENCES, JULY 22, 1968, DOCKET NO. 50-133, TYPE--BWR, MFG--G.E., $A E--B E C H T E L$

BASIS FOR DRL SAFETY EVALUATION WAS (1) CONTAINMENT LEAK RATE TESTING REQUIREMENTS, (2) REACTIVITY TRANSIENT EFFECTS, (3) PROTECTION AGAINST TSUNAMIS, $(4)$ EMERGENCY CORE CODLING, (5) ELECTRIC POWER RELIABILITY, (6) PRIMARY SYSTEM INSPECTION AND SURVEILLANCE, (7) MANAGEMENT AND ORGANIZATION PERFORMANCE, (8) OPERATING HISTORY. \#\#LEAK RATE TESTING EVERY TWO YEARS APPROVED. ROD DRIVE THIMBLE SUPPORT INSTALLED. NO SYSTEM OF ORGANIZATION

DEGRADATION, BUT TECH SPECS REVISED TO ASSURE LONG TERM ASSURANCE OF TEC.HNICAL COMPETENCE FAILED SS FUEL WAS REPLACED WITH ZIRC-CLAD FUEL. FLOW ANOMALIES HAVE NOT RECURRED AFTER REPLACING ADMIRALTY METAL FEEDWATER HEATERS WITH SS TUBES.

AVAILABILITY - CLEARINGHOUSE FOR FEDERAL SCIENTIFIC AND TECHNICAL INFORMATION, SPRINGFIFLD, VA. ?215I $\$ 3.00$ COPY, $\$ 0.65$ MICROF ICHE

* SAFETY EVALUATION + *TECHNICAL SPECIFICATIONS + ACRS + FAILURE, FUEL ELEMENT + OPERATING LICENSE PROCESS + REACTOR, BWR + STAFFING, TRAINING, QUALIFICATION + SURFACE FILM DEPOSIT

17-27341

PROPOSED TECHNICAL SPECIFICATIONS

JERSEY CENTRAL POWER AND LIGHT COMPANY

57 PAGES, FIGURES, TABLES, AMENDMENT 17, TECHNICAL SPECIFICATIONS FOR OYSTER CREEK POWER PLANT UNIT NO. 1, SEPTEMBER 18, 1967, DOCKET NO. 50-219, TYPE--BWR, MFG--G.E., AE--BURNS + ROE

NEW STYLE. LIMITS POWER ACCORDING TO COOLANT FLOW ANO FEEDWATER TEMP. PROVIDES STACK GASEOUS RELEASE RATE LIMITS OF 0.6 (AVERAGE ANNUAL), 2 (NOT TO EXCEED 48 HR IN ANY 7 CONSECUTIVE DAYS, AND 8 CURIES/SEC (NOT TO EXCEED 15 MIN IN ANY HOUR). SURVEILLANCE STANDARDS DIVIDED INTO 2 GROUPS - CONTINUOUSLY OPERATING EQUIPMENT AND ENGINEERED SAFETY FEATURES IPERIODIC PERFORMANCE TESTSI.

AVAILABILITY - CLEARINGHOUSE FOR FEOERAL SCIENTIFIC AND TECHNICAL INFORMATION, SPRINGFIELD, VA. 22I5I $\$ 3.00$ COPY, \$0.65 MICROFICHE

OYSTER CREEK I (BWR) + REACTOR, BHR + TECHNICAL SPECIFICATIONS

17-27343 ALSO IN CATEGORY 9

REPQR T ON SLOW RELEASE TIME OF SHIM ARM NO. 4

NATIONAL BUREAU OF STANDAROS

5 PAGES, LETTER TO P.A. MORRIS, DRL FROM R.S. CARTER, JULY 19, 1968, DOCKET NO. 50-184

ON JULY 11, THIS CLUTCH WAS FOUND SLIPPING DURING SPECIAL ROD OROP TESTS AND HAD A 230 MSEC

RELEASE TIME INSTEAO OF 150-160. THE CLUTCH PLATE HUB HAD BEEN ASSEMBLED WITH MINIMAL

CLEARANCE FROM ITS SUPPORT BRACKET. NEAR FULL OUT, THE COMPRESSED SCRAM SPRING REDUCED THIS

CLEARANCE. 
$17-27343$ *CONTINUED*

AVAILABILITY - CLEARINGHOUSE FOR FEDERAL SCIENTIFIC ANO TECHNICAL INFORMATION, SPRINGFIELO, VA. 22151 $\$ 3.00$ COPY, \$0.65 MICROF ICHE

*FAILURE, SCRAM MECHANISM + CONTROL ROD DRIVE + NBS + OPERATING EXPERIENCE + REACTOR, RESEARCH + RESPONSE TIME

17-27344 ALSO IN CATEGORY

SELECTED SAN ONOFRE OPERATING EXPERIENCE

SOUTHERN CALI FORNIA EDISON

13 PAGES, SEMI-ANNUAL OPERATING REPORT NO. 2, JULY 22, 1968 , DOCKET NO. 50-206, TYPE--PWR, MFG--WEST., AE- BECHTEL

FIVE SHUTOOWNS WERE MAOE ILEAKING PRIMARY COOLANT, TWO ELECTRICAL CABLE FAILURES, CONTROL ROD CYCLE MALFUNCTION, CONTROL ROD F-10 FOUND BOTTOMED BY REVERSED POLARITY DF THE MOVABLE GRIPPER COIL). RADWASTE RELEASE LINE CHECK VALVE FAILED, SPILLING WATER. \# \$TSTS SHOWED FLOW STRATIFICATION IN REACTOR COOLANT COLD LEG GIVES A HIGH DELTA T OF 5.3 F (FULL POWER). PH REACTIVITY EFFECT IS ABOUT 0.35 PERCENTIPH UNIT AT PH 6.4. POWER COEFF. VS ROD POSITIDN DATA TAKEN. BORON DILUTION HAS BEEN 2.1 PPM/FULL POWER DAY, VS 2.9 PREOICTED. 65 SPECIFIC DESIGN CHANGES LISTED.

AVAILABILITY - CLEARINGHOUSE FOR FEDERAL SCIENTIFIC AND TECHNICAL INFORMATION, SPRINGFIELO, VA. 22151 $\$ 3.00$ COPY, \$0.65 MICROFICHE

*FAILURE, EQUIPMENT + \#FLOW DISTRIBUTION + \#PH REACTIVITY EFFECT + \#POWER COEFFICIENT + ACCIDENT, CONTROL ROD WITHORAWAL + FAILURE, SCRAM MECHANISM + FUEL BURNUP + INSTRUMENTATION, ABNORMAL INDICATION + INSTRUMENTATION, TEMPERATURE + REACTOR, PWR + REPORT, OPERATIONS SUMMARY + SAN ONOFRE (PWR) + VALVE + WASTE DISPOSAL, LIQUID

$17-27345$

PROPOSED TECH SPEC CHANGE 17- CHLORIDE CONCENTRATION

FIRST ATRMIC. TRANSPORT, INC., HOBOKEN, NEW JERSEY

7 PAGES, 2 FIGURES, LETTER TO P.A. MORRIS, DRL FROM R.D. MEHANN, APRIL 10, 1968, DOCKET ND. 50-238, TYPE--PWR, MFG--B+W, AE--G.G. SHARP

TO REQUIRE SULFITE TREATMENT ANO BLOWDOWN WHEN CHLORIDES EXCEED 1 PPM, 8UT ALLOW 48 HR TO RETURN BELOW 1 PPM. SHUTOOWN MANDATORY IF LEVEL EXCEEDS 100 PPM OR IF LEVEL EXCEEDS 5 PPM AND SOURCE NOT SHUT OFF IN 2 HR. \# \#CURRENT MANDATORY SHUTDOWN IMPOSES A 10 HR DELAY BEFORE TREATMENT CAN BEGIN, WHICH WOULD BE ADEQUATE TO REDUCE A 368. PPM LEVEL TO 5 . THE EXCESS SULFITE PRECLUOES THE OXYGEN NECESSARY TO DAMAGE THE STEAM GENERATOR TUBES.

AVAILABILITY - CLEARINGHOUSE FOR FEDERAL SCIENTIFIC AND TECHNICAL INFORMATION, SPRINGFIELO, VA. 22151 $\$ 3.00$ COPY, \$0.65 MICROFICHE

\#ADDITIVE + \#LEAK + \#MAIN COOLING SYSTEM + CHLORIDE + COOLANT CHEMISTRY + EMERGENCY PROCEDURE + NS SAVANNAH (PWR) + REACTOR, PWR + STEAM GENERATOR + STRESS CORROSION + TECHNICAL. SPECIFICATIONS + TURBINE

$17-27346$

DAIRYLAND TAKES OVER LACROSSE BWR

UNITED STATES ATOMIC ENERGY COMMISSION

PROVISIONAL OPERATING AUTHORIZATION DPRA-6 + 49 PAGES, 2 FIGURES, 1 TABLE, JULY $12,1968,$. DOCKET NO.

115-5, TYPE--BWR, MFG--A.C., AE-SGT + LUNDY

TRANSFERS AUTHORIZATION FROM ALLIS CHALMERS TO DAIRYLAND POWER CORP., PROVIDING A-C FILES A REPORT ON THE 28 DAY POWER RUN, OLD STYLE TECHNICAL SPECIFICATIONS CONTINUEO WITH A FEW CLARIFICATIONS AND MINOR CHANGES, ACRS REVIEW NOTED NECESSITY FOR MAINTAINING CONTINUITY AND COMPETENCE IN THE SMALL STAFF.

AVAILABILITY - CLEARINGHOUSE FOR FEDERAL SCIENTIFIC AND TECHNICAL INFORMATION, SPRINGFIELD, VA. 22151 $\$ 3.00$ COPY, $\$ 0.65$ MICROF ICHE

* SAFETY EVALUATION + *TECHNICAL SPECIFICATIONS + LACROSSE (BWR) * OPERATING LICENSE PROCESS I REACTOR, BWR + STAFFING, TRAINING, QUALIFICATION

$17-27347$

SELECTED LACROSS OPERATING EXPERIENCE

ALLIS-CHALMERS MFG. CO., BETHESDA, MARYLAND

ACNP-68507 +. 61 PAGES, FIGURES, TABLES, ELEVENTH MONTHLY OPERATIONAL REPORT ON THE LACROSSE BOILING

WATER REACTOR COVERING THE MONTH OF MAY 1968, DOCKET NO, 115-5, TYPE--BWR, MFG--A.C., AE-TSGT + LUNOY

SHIELDING SURVEY, IN-CORE FLUX MEASUREMENTS, AND NOISE ANALYSIS COMPLETED AT 25\% POWER. ON MAY 30 , TWO STEAM INLET AND ONE OUTLET VALVES OF SHUTDOWN CONDENSER FAILED TO OPEN DURING THEIR TEST. \$REACTOR WATER LEVEL INDICATORS IN THE CONTROL ROOM SHOWS VOIOED LEVEL IAT 38 MWTH) IS 28 IN. HIGHER THAN UNVULIOED LEVEL 10 IN. OUE TO VOIOS ANO 22 . OUE TO STANDPIPE TEMP. BEING COOLER THAN REACTOR WATER). RESPONSE TO TURBINE TRIP, STEAM VALVE CLOSURE, RECIRCULATION FLOW CHANGES, INCLUDING RECIRC. PUMP TRIP, WERE GOOD.

AVAILABILITY - CLEARINGHOUSE FOR FEDERAL SCIENTIFIC AND TECHNICAL INFORMATION, SPRINGFIELO, VA. 22151 
CATEGORY 17

OPERATIONAL SAFETY AND EXPERIENCE

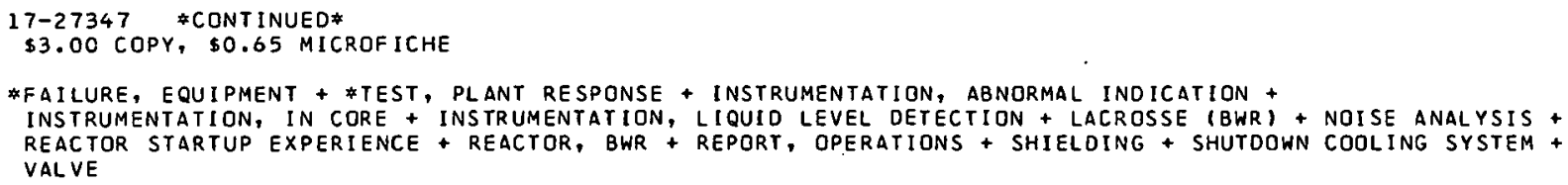

FOR ORGANIZATION AND REVIEW OF SAFETY PROGRAMS IN ACCELERATOR LABORATORIES. TO BE CONSIDERED OY MANAGEMENT IN DEVELOPINC POLICIES AND STANOAROS. SECTIONS INCLUDE III MANAGEMENT SAFETY GUIDELINES, 2 PG. (II) BUILDING ANO FACILITY GUIDELINES, 4 PG. (III) EXPERIMENTAL

EQUIPMENT, 9 PG. (IV) OPERATING PROCEDURES, 17 PG. IIN MOST CASES, AOVICE IS RENOEREO IN SHORT, SEPARATE ITEMS. (E.G., DESIGN AND TEST PRESSURES FOR .... SHOULD BE SPECIFIED.

PRESSURE GAGES... IN PLACES WHERE SYSTEMS MAY BE ISOLATED BY VALVESI.

AVAILABILITY - CLEARINGHOUSE FOR FEDERAL SCIENTIFIC AND TECHNICAL INFORMATION, SPRINGFIELD, VA. 22151 $\$ 3.00$ COPY, \$0.65 MICROF ICHE

* ACCELERATOR + * SAFETY REVIEW + ADMINISTRATIVE CONTROL + DESIGN CRITERIA + OPERATING EXPERIENCE SUMMARY + RADIATION SAFETY ANO CONTROL + SAFETY PRINCIPLES AND PHILOSOPHY

17-27474 ALSO IN CATEGORIES 10 AND 11

SAFETY EVALUATION FOR PROPOSED 115 MWTH PEACH 8OTTOM OPERATION

PHILADELPHIA ELECTRIC COMPANY

19 PAGES, NOVEMBER 14, 1966, DDCKET 50-171, TYPE--HTGR, MFG--G.A., AE--8ECHTEL

CXCESS REACTIVITY 10.20 INSTEAD OF 0.15 DUE TO CARBON DENSITY AND THORIUM ABSORPTION CROSS SECTION OVERESTIMATE) WAS ADJUSTED WITH LUMPED BURNABLE POISON TO GIVE AN 0.06 SHUTDOWN MARGIN. LIMITS ON REACTIVITY AND FLUX ANOMALIES WILL BE SET. AFTER 1965 CABLE FIRE IHELDING SLAG INITIATION, CHIMNEY EFFECTI, CO2 SYSTEM EXTENDED TO CABLE AREAS, REROUTED TO INCREASE INDEPENDENCE, SMOKE DETECTORS INSTALLED, AND FIREPROOF COVERS AND FIRE STOPS INSTALLED. HELIUM LEAKAGE IS 10-20 TIMES DESIRED 0.2 LB/DAY. CONTROL ROD DRIVE BALLS ARE NOW 100 HELIUM LEAKAGE IS 10-20 TIMES DESIRED 0.2 LB/DAY. CONTROL ROD DRIVE BALLS ARE NOW IOO
PERCENT TESTED AFTER FAILURES FROM INTERNAL DEFECTS. A LARGER CONTAINMENT VACUUM RELIEF IS PROVIDED.

AVAILABILITY - USAEC, PUBLIC DOCUMENT ROOM, 1717 H ST, WASHINGTON, D.C. 20545 (\$0.25 CENTS/COPY)

*OPERATING EXPERIENCE SUMMARY + *SAFETY EVALUATION + CONTAINMENT PENETRATION,..ELECTRICAL + CONTAINMENT VACUUM BREAKER + CROSS SECTION + ELECTRICAL CONDUCTION + EXAMINATION + FAILURE, SCRAM MECHANISM + FIRE + INDEPENDENCE + PEACH BOTTOM 1 (HTGR) + POWER UPRATING + REACTIVITY EFFECT, ANOMALOUS + REACTOR, HTGR + SHUTOOWN MARGIN + THORIUM 
CATEGORY 17

OPERATIONAL SAFETY AND EXPERIENCE

$17-27478$

HUMBOLDT BAY LATEST TECHNICAL SPECIFICATION

PACIFIC GAS AND ELECTRIC COMPANY

66 PAGES, FIgURES, TABLES, JUNE 7, 1968, DOCKET 50-133, TYPE--BWR MFG--G.E., $\triangle E--B E C H T E L$

AS-REVISED COPY OF JUNE 7, 1968. NO INDICATION OF REVISIONS MADE GR REASONS FOR REVISED COPY. STILL IN OLD FORMAT.

AVAILABILITY - USAEC PUBLIC DOCUMENT ROOM, 1717 H ST., WASHINGTON, D.C. 20545 (\$0.25 CENTS/COPY)

\#TECHNICAL SPECIFICATIONS + HUMBOLT BAY (BWR) + REACTOR, BWR

$17-27494$
WYLIE RD ALSO 1 N CATEGORIES 5 AND 9

ALSO IN CATEGORIES 5 AND

TENSILE AND IMPACI PROOPERTIES OF ELK RIVER REACTOR CONTROL ROD MATERIAL. EINAL REPORT

SOUTHWEST RESEARCH INST., SAN ANTONIO, TEX.

SWRI-1228-55 +. 21 PAGES, FIGURES, 5 REFERENCES, FEB. 10, 1965

THE BORON STAINLESS STEEL SPECIMENS WHICH WERE REMOVED FROM THE FLK RIVER REACTOR DURING THE SHUT DOWN IN EARLY NOVEMBER 1964 WERE TESTED AT SOUTHWEST RESEARCH INSTITUTE. BOTH SUASIZE TENSILE AND IMPACT SPECIMENS WERE INCLUDED IN THE SURVEILLANCE PROGRA.4. AN ESTIMATE OF THE FLUX LEVEL WAS MAOE BY ALLIS CHALMERS AS $1.3 \times 10120 T 111$ NVT THERMAL AS OF AUGUST 31.1964. THIS CORRESPONOS TO APPROXIMATELY 0.22 ATOM PERCENT BURN-UP. THE DUCTILITY CF THE SPECIMENS WAS MEASUREO AS 1-2\% ELUNGATION WHICH WAS BELOW THE $3.4 \%$ REQUIREO BY THE TECHNICAL SPECIFICATIONS. A LITERATURE REVIEW INDICATED THAT THE MEASURED DUCTILITY WAS IN THE RANGE OF THE OTHER TEST DATA AVAILABLE ON BORON STAINLESS STEELS WITH APPROXIMATELY $2 \% 8$.

AVAILABILITY - CLEARINGHOUSE FOR FEOERAL SCIENTIFIC AND TECHNICAL INFORMATION, SPRINGFIELD, VIRGINIA, 22151

*CONTROI. RID + \#IMPACT PROPERTY + *IENSILE PROPERTY + ELK RIVER (BWR) + EXPERIMENT, GENERAL + MATERIAL + REACTOR, BWR + SURVEILLANCE PROTRAM

17-27504 ALSO IN CATEGORY 11

SELECTED LACROSSE DPERATING EXPERIENCE

ALLIS-CHALMERS, BETHESDA, MARYLAND

ACNP-68508 +. 11 PAGES, FIGURES, TABLES, JUNE 1968, DOCKET 115-5, TYPE--BWR, MFG--A.C., AE--SGT + LUNDY

REACTOR NOT OPERATED WHILE CONTAINMENT LEAK RATE DETERMINED TO BE $0.6 \%$ PER 24 HR AT 52 PSIG. 95\% OF THIS WAS LEAKAGE THROUGH INTERNAL VENT HEAOER 4 IN. VALVE AND THROUGH SHUTDOWN CONDENSER 1 IN VENT VALVE. THEY WILL BE REPAIRED.

AVAILABILITY - USAEC PUBLIC DOCUMENT ROOM, 1717 H ST., WASHINGTON, D.C. 20545 (\$80.25 CENTS/COPY)

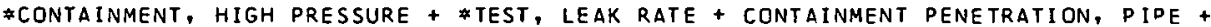

CONTAINMENI KEFERENCE MEASURING SYSTEM + LACROSSE (BWR) + REACTOR, BWP + REPORT, DPERATIONS

17-27576 ALSO IN CATEGORY 5

HBWR QUARTERLY PROGRESS REPORT, JULY TO SEPTEMBER 1966

INSTI TUTT FOR ATOMENERGI, HALDEN, NORWAY

HPR-69+. 102 PAGES, 34 FIGURES, 12 TABLES, 16 REFERENCES, NOVEMBER 1966

THIS QUARTERLY PROGRESS REPORT IS THE TWENTY-SECOND FROM THE OECD HALDEN REACTOR PROJECT TO RECEIVE GENERAL DISTRIBUTION, AND COVERS ACTIVITIES WITHIN THE THREE YEAR JOINT PROGRAM COMMENCED ON I JANUARY 1964. THE PROGRAM COMPRISES FUEL IRRADI $\triangle T T M N$ AND DEVELOPMENT OF IN-CORE INSTRUMENTATION. OTHER PROCRAM ITEMS ARE BURNUP AND STABII ITY STUDIES AND WATER-CHEMISTRY EXPERIMENTS. THE REPORT DOES NDT INTEND TO GIVE A SUMMARY OF ALL ACTIVITIES WITHIN THE OECD HALDEN REACTOR PROJECT BUT RATHER CONCENTRATE ON ITEMS OF GENERAL INTEREST ABOUT THE DEVELOPMENTS AT THE HALDEN BOILING HATER REACTOR.

AVAILABILITY - USAEC DEPOSITORY LIBRARIES IN THE U.S. ANO OVERSEAS

*ACCIDENT ANALYSIS + \#HEAT TRANSFER + \#REACTOR TEST FACILITY + CHEMICAL REACTION +

FISSION PRODUCT RELEASE, GENERAL + FUEL BURNUP + OECD

17-27584 ALSO IN CATEGORY.9

KINZER JE + PARK TA + CHANDI.ER EM

OPERAIING EXPERIENEE WITH A MINIATURIZED AEUTRON FLUX SENSOR

ATOMICS INTERNATIONAL, CANOGA PARK, CALIFORNIA

1 PAGE, 2 FIGURES, 1 REFERENCE, ANS TRANSACTION $1111 \%$, PAGE 336,1968 ANNUAL MEETING OF THE AMERICAN

NUCLEAR SOCIETY AND CANADIAN NUCLEAR ASSOCIATION, TORONTO, CANADA, JUNE 10-13, 1968

THE ADIT NEUTRDN FLUX SENSOR, WAS DESIGNEO TO MEET THE CONT INUING NEED FOR VERY SMALL DYNAMIC SENSORS. THE BASIC APPROACH MEASUREMENT OF FISSION-PRODUCED TEMPERATURE, HAS 8 EEN MJOIFIED 
CATEGORY 17

OPERATIONAL SAFETY AND EXPERIENCE

17-27584 \#CONTINUED*

TO INCREASE OUTPUT SIGNAL AND DECREASE PHYSICAL SIZE WHILE MAINTAINING SIMPLICITY. PROTOTYPE MODELS HAVE BEEN 0.083 IN. IN DIAMETER. SINCE THE TYPE OF FISSIONABLE MATERIAL USED MAY BE CHOSEN TO MATCH THE NEUTRON FLUX ENVIRONMENT OF INTEREST, THIS TYPE OF FLUX SENSOR IS APPLICABLE TO BOTH FAST AND THERMAL FLUX MEASUREMENTS. AODITIONALLY, THE RELIABILITY AND RELATIVELY LONG LIFE OF THERMOCOUPLES ANO THE FACT THAT THE ONLY INSTRUMENTATION REOUIRED IS THE STANDARD THERMOCOUPLE RECOREDER, MAKE THE AOIT FLUX SENSORS ATTRACTIVE FOR IN-CORE DATA ACQUISITION.

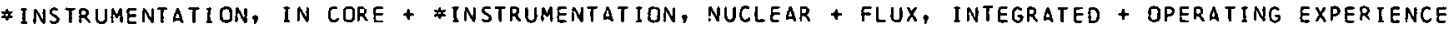

$17-27585$

KINZER JE + BABBE EL

OPERATING EXPERIENCE WITH A MINIATURIZED PRESSURE SENSOR

ATOMICS INTERNATIONAL, CANOGA PARK, CALIFORNIA

1 PAGE, 3 FIGURES, 2 REFERENCES, ANS TRANSACTIONS 11111 , PAGE 337,1968 ANNUAL MEETING OF THE AMERICAN

NUCLEAR SOCIETY AND CANADIAN NUCLEAR ASSOCIATION, TORONTO, CANADA, JUNE $10-131968$

THE ADIT (ADVANCED OEVELOPMENT IRRADIATION TECHNIQUES) PRESSURE SENSOR OPERATES MUCH LIKE A DIAPHRAGM ACTUATED PRESSURE SWITCH. TWO SYMMETRICAL BELLOWS JOIVED BY A COUPLING DISK FORM A FORCE BALANCE SYSTEM PLUS A DOUBLE SEAL AGAINST FISSION GAS. AN ON-OFF ELECTRICAL CONTACT, MADE BY A PLATINUM-TIPPED THERMOCDUPLE, INDICATES WHEN THE BALANCING GAS IS IN EQUILIBRIUM WITH THE PRESSURE BEING MEASURED. THIS THERMOCOUPLE MAKES THE DEVICE A COMBINATION PRESSURE-TEMPERATURE SENSOR AND CAN BE USED TO CORRECT FOR TEMPERATURE CHARACTERISTICS OF THE BELLOWS SYSTEM.

* INSTRUMENTATION, PRESSURE + CHALK RIVER + INSTRUMENTATION, TEMPERATURE + OPERATING EXPERIENCE + TEST, INSTRUMENT RESPONSE

17-27595 ALSO IN CATEGORIES 9 AND 5

HARRIGAN PM + MATTEL J + TOTH WL

OPTICAL, LIGHTING, ANO PHOTOGRAPHIC EQUIPMENT FOR THE ENRICO FERMI ATOMIC POWER PLANT REPAIR PROGRAM POWER REACTOR DEVELOPMENT COMPANY + ATOMIC POWER OEVELOPMENT ASSOCIATES

1 PAGE, 1 FIGURE, ANS TRANSACTIONS $11(1)$, PAGE 358,1968 ANNUAL MEETING OF THE AMERICAN NUCLEAR SOCIETY AND CANAOIAN NUCLEAR ASSOCIATION, TORONTO, CANADA, JUNE 10-13, 1968

A MELTOOWN OF TWO CORE SUBASSEMBLIES REQUIRED THE USE OF VERY LONG OPTICAL INSTRUMENTS ANO LIGHTING EQUIPMENT FOR THE PURPOSE OF INSPECTION OF THE CORE AND REACTOR COMPONENTS. BECAUSE LITTLE INFORMATION WAS AVAILABLE ON THE DESIGN OF SUITABLE VIEWING AND LIGHTING EQUIPMENT FOR USE IN SODIUM REACTOR ENVIRONMENTS, MUCH DEVELOPMENTAL WORK ANO TESTING HAD TO BE DONE TO USE IN SOOIUM REACTOR ENVIRONMENTS, MUCH DEVELTPMENTAL WORK AND TESTING HAD TO BE DONE TO
PROVIDE SUITABLE EQUIPMENT. MUCH DEVELOPMENT WAS REQUIRED TO PROVIOE LIGHTING EQUIPMENT WITH ADEQUATE LAMP LIFE AND MANEUVERABILITY. THE USE OF PHOTOGRAPHY THROUGH THE VIEWING

INSTRUMENTS WAS NOT SUCCESSFUL INITIALLY, BUT IMPROVEMENTS BOTH IN TECHNIQUE AND EQUIPMENT

LED TO REMARKABLY GOOD RESULTS IN THE LATTER PART OF THE PROGRAM.

* INSTRUMENTATION, IN CORE + \#REMOTE MANIPULATING ANO VIEWING + EQUIPMENT DESIGN + FERMI (LMFBR) + INSTRUMENTATION; SURVEILLANCE + MAINTENANCE AND REPAIR + MAINTENANCE, REMOTE + REACTOR, BREEDER + REACTOR, FAST + REACTOR, LMER.

17-27596 ALSO IN CATEGORIES 9 AND 5

DUFFY JG + MATTE J + RYAN JD + WARBERG HS

OBJECT RETRIEVAL TOOLS FOR THE ENRICD FERMI ATOMIC POWER PLANT REPAIR PROGRAM

ATOMIC POWER DEVELOPMENT ASSOCIATES, INC., DETROIT, MICHIGAN

3 PAGES, 2 FIGURES, ANS TRANSACTIONS 1111 , PAGES $358-360,1968$ ANNUAL MEETING OF THE AMERICAN NUCLEAR

SOCIETY AND CANAOIAN NUCLEAR ASSOCIATION, TORONTO, CANADA, JUNE 10-13, 1968

THE METHOD OF RETRIEVING FROM THE BOTTOM OF THE FERMI REACTOR AN OBJECT THAT CAUSED A MELTDOHN INVOLVED PROCEDURES AND TOOLS WHICH ARE UNIQUE AND COULD HAVE APPLICATION IN FUTURE PROBLEMS. TOOLS WERE DEVELOPED TO CUT THE OBJECT. INTO PIECES SMALL ENOUGH TO BE'REMOVEO UPWARD THROUGH THE SUPPORT PLATE. SEVERAL GRIPPERS FOR THIS PURPOSE WERE ALSO DEVELOPED. SIMULTANEOUSLY, SPECIAL TOOLS WERE DEVELOPED TO REMOVE THE OBJECT INTACT VIA THE SODIUM INLET PIPE.

* INSTRUMENTATION, IN CORE + \#REMOTE MANIPULATING AND VIEWING + EQUIPMENT DESIGN + FERMI ILMFBRI + MAINTENANCE AND REPAIR + MAINTENANCE, REMOTE + REACTOR, BREEDER + REACTOR, FAST + REACTOR, LMCR

17-27615 ALSO IN CATEGORIES 18 AND 2

ACRS REPORT ON ZION I AND 2

U.S. ATOMIC ENERGY COMMISSION

8 PAGES, LETTER TO G.T. SEABORg (AEC PRESS RELEASE L-178), AUGUST 24, 1969, D0CKETS 50-295/304, TYPE--PhR, MFG--WEST., AE--SGT + LUNDY

ZION IS LARGEST REACTOR TO DATE IN A RELATIVELY HIGH POPULATION DENSITY. REACTOR CAVITY FLODDING FOLLOWING A LONGITUOINAL SPLIT IN IHE REACTOR VESSEL MAY BE INSTALLED FOLLOWING STUDY OF VESSEL FAILURE PROBABILITY FROM THERMAL SHOCK FOLLOWING CORE FLOODING ACTION. CONTROL AND SAFETY SIGNALS SHOULD BE INDEPENDENT. CONTAINMENT SPRAY SHOULD HAVE A FULL TEST. * * IN 3 PAGES DF REMARKS BY OKRENT, HE DISCUSSES VESSEL SPLIT PROBLEM. RECOMMENDS (FOR HIGH POPULATION DENSITIESI ADDITIONAL DESIGN CONSERVATISM AND QUALITY ASSURANCE, WELL DEFINEO R AND D FOR SAFETY ISSUES NOT RESOLVED AT CONSTRUICTION PERMIT STAGE, EXTRA MARGIN IN ENCINEERED 
CATEGORY 17

OPERATIONAL SAFETY ANO EXPERIENCE

17-27615 \#CONTINUED

SAFETY FEATURES IN LIEU OF A DEMONSTRATION UNOER ACCIDENT CONDITIONS, AND MORE STUOY TO REDUCE PROBABILITY OF SMALL ACCIDENTAL RELEASES.

USAEC, PUBLIC DOCUMENT ROOM, 1717 H ST., WASHINGTON, D.C. 20545 (25 CENTS/PAGE)

* FAILURE, PRESSURE VESSEL + ACRS + CONTAINMENT SPRAY + CORE REFLDODING SYSTEM + REACTOR, PWR + REPORT, PSAR + REVIEW + SAFETY MARGIN + TEST, PREOPERATIONAL + TEST, PROOF + IHERMAL MECHANICAL EFFECT + ZION 1 AND 2 (PWR)

17-27616 ALSO IN CATEGORIES 6 AND 9

SELECTED SHIPPINGPORT OPERATING EXPERIENCE

BETTIS ATOMIC POWER LABORATORY

WAPO-MRP-122 +. 14 PAGES, PAGES 6, 20-41 AND 43 OF PRESSURIZED WATER REACTOR (PWR) PROJECT. TECHNICAL PROGRESS REPORT, JULY 22, OCTOBER 20, 1967

(PAGE 6) NH4OH AODITION AND DEGASIFICATION RATES INCREASE DRASTICALLY WITH COOLANT PH ABOVE 10.3. (PAGE 20-41) POWER LIMITS FOR VARIOUS CONTROL ROD PROGRAMS PAST 10,000 EFPH WERE CALCULATED. FOR VARIOUS LOAD SWINGS, XENON BURNOUT RATES AND AXIAL PEAKIAV NEUTRON FLUXES WERE MEASURED AND COMPAREO WITH TURBO-ZIP CALCULATIONS. ON THE RETURN TO 100 MWE ON AUGUST 21, XENON OSCILLATION SET IN, GIVING +-9 IN. CONTROL ROD MOTION. OPERATIONAL DETECTORS LOCATED AT CORE MIDIEIGHT WERE IN PHASE WITH ROD BANK MUTION, WHILE TEST CHAMBERS ABOVE THE CORE WERE DUT OF PHASE. OPERATING LIMITS FOR PEAK SINGLE CHANNEL NUCLEAR INSTRUMENT REAOINGS WERE CALCULATED, AS WAS A CONTRDL ROD PROGRAM. (PNGE 43 ) COMPUTFR PROGRAM MO 795 WAS PLACED INTO PRODUCTION. MO 795 PERFORMS ALL FUEL ELEMENT PERFORMANCE LIMITS CALCULATIONS FDR CORE 2. INCLUDING MAXIMUM PERMISSIBLE SINGLE CHANNEL, NUCLEAR INSTRUMENT READINGS.

AVAILABILITY - CLEARINGHOUSE FOR FEOERAL SCIENTIFIC AND TECHNITIAL INFORMATION, NATIONAL BUREAU OF STANDARDS, SPRINGFIELD, VA. $22151, \$ 3.00$ COPY, \$0.65 MICROFICHE

*CONTROL ROD PROGRAM + \#FUEL ELEMENT + *INSTRUMENTATION, ABNDRMAL INOICATION + FPERFORMANCE LIMIT + \#XENON OSCILLATION + COMPUTER PRDGRAM + COOLANT CHEMISTRY + POWER DISTRIBUTION + REACTOR, PWR + REPORT, OPERATIONS ANALYSIS + SHIPPINGPORT (PWR)

$17-27617$

SHIPPINGPORT SEED 2 CORROSION IN PROOF TEST. TECHNICAL PROGRESS REPORT OCT. 21, TO JAN. 26,68 BETYIS ATOMIC POWER LABORATORY

WAPD-MRP-123 +. 3 PAGES, 1 FIGURE, PAGES $12,45-46$ IN TECHNICAL PROGRESS REPORT FOR THE PERIOD OCTOBER 21 , 1967 TO JANUARY 26, 1968. PRESSURIZED WATER REACTOR (PWR) PROJECT

FIBER OPTIC INSPECTION OF THE CLAD OF SEED 2 ASSEMBLIES FOUND RAISED AREAS OF EXCESSIVE GRAY ANO WHITE CORROSION PRODUCT. TESTS SHOWED THIS WAS A SUPERFICIAL LOCAL CARBON CONTAMINATION (RESIDUE OF MASKING TAPE ADHESIVE ON COPPER SPACERS USED DURING SUSASSEMBLY WELDING) WHICH PROTECTED THOSE AREAS OF CLAD FROM THE PICKLING SOLUTION. EXTENOED CORROSION TEST IN STEAM ANO IN WATER INDICATED NORMAL BEHAVIOR AFTER INITIAL EXPOSURE. THE AREAS ARE RAISED O.OO38 IN.

AVAILABILITY - CLEARINGHOUSE FOR FEDERAL SCIENTIFIC AND TECHNICAL INFORMATION, NATIONAL BUREAU DF STANDARDS, \$PKINGFIEI.N, VA. 22151, \$3.00 COPY, \$0.65 MICROFICHE

*CORROSION + \#FAILURE, FABRICATION ERROR + \#FUEL ELEMENT + \#SURFACE FILM DEPOSIT + CLADDING + EXAMINATION + FABRICATION + REACTOR, PWR + REPORT, OPERATIONS ANALYSIS + SHIPPINGPORT (PWR) + ZIRCALOY

17-27618 ALSO IN CATEGORY

SHIPFINGTORT ICACTOR PHYSICS

BETTIS ATOMIC POWER LABORATORY

WAPO-MRP-123 +. I6 PAGES, FIGURES, PAGES 21-36 OF TECHNICAL PROGRESS REPORT FOR THE PERIUIJ UCTOBER 21,

1967 TO JANUARY 26, 1968, PRESSURIZED WATER REACTOR (PWR) PRDJECT

FOLLOWING THE 4TH $100 \%$ POWER DEMONSTRATION ON NOVEMBER 10 , XENON BURNOUT $\triangle T$ PEAK XENON AT $72 \%$ POWER WAS ESTIMATED AT 0.0000026 DK/SEC BASED ON A TEST AT 63\%. FLUX WIRES AT ICOF POWER SHOWEO THE AXIAL FLUX UNDER ESTIMATED IN THE LOWER AND OVER ESTIMATED IN THE UPPER PORTION OF THE CORE (TURBO-ZIP CODE). INCLUSION OF AN AXIALLY VARIABLE MODERATOR TEMP. GAVE BETTER FLUX SHAPES, BETTER ROD POSITION PREDICTIONS AND RESULTANT BETTER POWER SHAPES AND FUEL DISTRIBUTIONS. THE FUEL OISTRIBUTION WITH AND W/O THIS CORRECTION DIVERGES WITH BURNUP, BEING 4\% DIFFERENT AT 7700 EFPH.

AVAILABILITY - CLEARINGHOUSE FOR FEDERAL SCIENTIFIC AND TECHNICAL INFORMATION, NATIONAL B.UPEAU OF STANDARDS, SPRINGFIELO, VA. $22151, \$ 3.00$ COPY, \$0.65 MICROFICHE

\#COMPARISON, THEORY AND EXPERIENCE + \#COMPUTER PROGRAM + \#FUEL BURNUP + \#ODWER DISTRIBUTION + FLUX DISTRIBUTION + REACTOR, PWR + SHIPPINGPORT (PWR) + XENON

17-27619 ALSO IN CATEGORIES 14 AND 15

WATER POLLUTION CONTROL--TECHNI CAL TRAINING PROGRAM--BULLETIN OF COURSES

U.S. DEPARTMENT OF THE INTERIOR

66 PAGES, FROM CLEAN WATER, BULLETIN OF COURSES, JULY 1968 TO JUNE 1969 
17-27619 *CONTINUED*

DESCRIBES 27 SHORT COURSES (1-2 HEEKS, GIVEN AT VARIOUS REGIONAL CENTERS IN 1968-69) IN THE GENERAL AREAS OF CHEMISTRY (4), MICROBIOLOGY (7), AND ENGINEERING AND WASTE TREATMENT (13). NONE SEEM SLANTED AT RADIATION OR AT POWER STATIONS, BUT SOME OF THE INTROOUCTORY BIOLOGY AND ECOLOGY COURSES SEEM GENERALLY APPLICABLE.

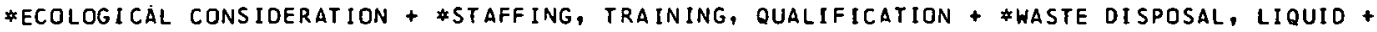
THERMAL POLLUTION

17-27621 ALSO IN CATEGORY

LACROSSE OPERATIONS OCT 1967

ALLI S-CHALMERS, BETHESOA, MARYLAND

ACNP-67534 +. 20 PAGES, FIGURES, TABLES, OCTOBER 1967, DOCKET 115-5, TYPE--BWR, MFG--A.C., AE--SGT + LUNDY

NO REACTOR OPERATION BECAUSE TESTS AND MODIFICATIONS WERE COMPLETED FOR POWER OPERATION. A ROD FAILED TO WITHDRAW AFTER A SCRAM OUE TO A PIECE OF A PHENOLIC BACKUP RING PLUGGING THE HYORAULIC OIL DISCHARGE ORIFICE.

USAEC, PUBLIC DOCUMENT ROOM, 1717 H ST., WASHINGTON, D.C. 20545 (25 CENTSIPAGE)

FAILURE, SCRAM MECHANISM + LACROSSE (BWR) + REACTOR, GHR + REPORT, OPERATIONS

$17-27622$

LACROSS OIFFICULTY WITH PUMPS AND VALVES

ALLIS-CHALMERS, BETHESDA, MARYLAND

ACNP-68500 +. 20 PAGES, FIGURES, TABLES, DECEMBER 1967, DOCKET 115-5, TYPE--BWR, MFG--A.C., AE--SGT + LUNOY

FORCED CIRCULATION PUMP ROTOVALVES FAILED TO CLOSE SEVERAL TIMES (COOLING THE LOOP FROM 577 F

TO $450 \mathrm{~F}$ IN SEVERAL MINUTES) BECAUSE LEATHER CUPS ON THE HYDRAULIC ACTUATOR PISTONS WERE

HARDENED AND SPLIT. VARIOUS DIFFICULTIES IAIR BINDINGS, PRESSURE CONTROLLER SENSITIVITY,

SEAL WATER TEMP. TOO LOW) AFFECTED THE SEAL WATER INJECTION TO THE MAIN PUMP SEALS.

USAEC, PUBLIC DOCUMENT ROOM, $1717 \mathrm{H}$ ST., WASHINGTON, D.C. 20545 (25 CENTS/PAGE)

\#FAILURE, EQUIPMENT + \#PUMP + \#VALVE + LACROSSE (BWR) + MAIN COOLING SYSTEM + REACTOR, BWR + REPORT, OPERATIONS

17-27709 ALSO IN CATEGORIES 5 AND 12

SAXTION-LOSS OF COOLANT ACCIDENT PREVENT ION AND PROTECTION

SAXTON NUCLEAR EXPERIMENTAL CORPORATION

150 PAGES, FIGURES, TABLES, JUNE, 1968 , DOCKET 50-146, TYPE--PWR, MFG--WEST., AE--GILBERT ASSOC.

RESPONOS TO DEC. 1966, DRL REQUEST FOR REANALYSIS WITH MODERN TECHNIQUES. SYSTEMS WILL LIMIT CLAD MELT TO LESS THAN 3 PER CENT OF C.LAN AREA FOPR A DOUBLE ENDSD COOLANT LINE RUPTURE. NO EVIDENCE OF REACTOR VESSEL OR STFAM GFNFRATRR I FIKS SAEGTY VALVE LEAKS IIAVE DELH JIIONIS OH BURIC ACIO CRYSTALS. \#\#PAST VISUAL AND RADIOGRAPH INSPECTIONS HAVE BEFN GODO, BUT $A$ SPECIFIC INSPECTION PROGRAM WILL BE REPEATEO EVERY 5 YEARS. MODIFICATIDNS TO BE MADE INCLUDE BETTER ISOLATION BETWEEN BUILDING COMPAETMENTS, RECIRC. PUMP PRESSURE INDICATORS, RELAY REDUNDANCE IN SAFETY INJECTION SYSTEMS, AND TO PREVENT A SINGLE FAILURE FROM CLOSING INJECTION ISOLATION VALVE. APPENOIX D DESCRIBES COMPUTER PROGRAMS USED IFLASH, CHICK-KIN, LOCTA-R 2 I.

USAEC, PUBLIC DOCUMENT ROOM, 1717 H ST., WASHINGTON, D.C. 20545 (25 (ENTS/PAGF)

\# ACCIDENT ANALYSIS + *ACCIDENT, LOSS OF COOLANT + CORE REFLOODING SYSTEM + EXAMINATION + LEAK + MODIFICATION, SYSTEM OR EQUIPMENT + PIPING + PLANT PRRTECTIVE SYSTEM + PRESSURE RELIEF + PRFSSURE VESSEL + REACTOR, PWR + SAXTON (PWR) + SURVEILLANCE PROGRAM + TEST, NONDESTRUCTIVE

17-27827 ALSO IN CATEGORIES 1 AND 11

MANUAL OF LECTURE NOTES - REACTOR SAFETY COURSE NO. 7

UNITEO KINGOOM ATOMIC ENERGY AUTHORITY, RISLEY, WARRINGTON, LANCASHIRE

200 PAGES, FIGURES, TABLES, REFERENCFS, SEPTEMBER 23, 1968

NINE SECTIONS. (I) INTRODUCTION, 5 LECTURES. (II) FISSION PRODUCT RELEASE, 5 LECTURES, (III) CONTA I NMENT ENGINEER ING, 7 LECTJRES. (IVI CONTROL AND INSTRUMENTATION, 7 LECTURES. (VI) GAS COOLED REACTORS, 11 LECTURES. (VI) WATER REACTORS, 12 LECTURES. (VII) GENERAL, 5 LECTURES. (VIII) FAST REACTORS, 7 LECTURES. (IX) SITING AND EMERGENCY PROCEOURES, 4 LECTURES. NEW LECTURES APPEAR TO BE (T) ASSESSMENT OF ENVIRONMENTAL HAZARDS FROM FISSION PRODUCT RELEASES. (EA) FISSION PRODUCT BEHAVIOR IN LIQUIO COOLED REACTORS. (IOA) CONTAINMENT OF FISSION PRODUCTS WITHIN FUEL ELEMENTS. (24A) METHOOS AND PROBLEMS IN REACTOR ASSESSMENTS. (40) PROBABILITY TECHNIQUES APPLIEO TO WATER REACTORS.

AVAILABILITY - AUTHORITY HEALTH AND SAFETY BRANCHi U.K.A.E.4., 11 CHARLES II STREET, LONDON, S. W. 1.

* SAFETY ANALYSIS + \#SAFETY REVIEW + FISSION PRODUCT RETENTION + FUEL ELEMENT + PARTITION COEFFICIENT + PROBABILITY + REACTOR, GCR + REACTOR, HTGR + REACTOR, LMFBR + REACTOR, WATCR +

SAFETY PRINCIPLFS AND PHILOSOPHY + UNITEO KINGDOM 


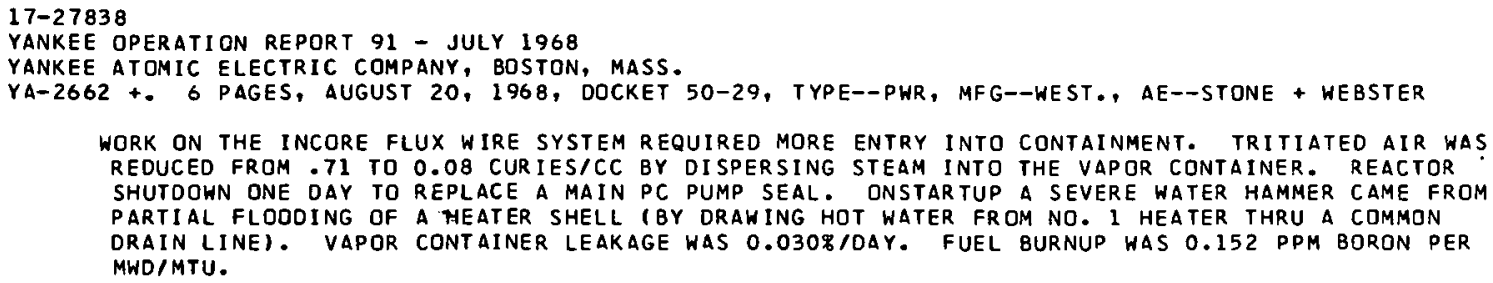

USAEC, PUBLIC DOCUMENT ROOM, 17.17 H ST., WASHINGTON, D.C. 20545 (25 (CENTS/PAGE)

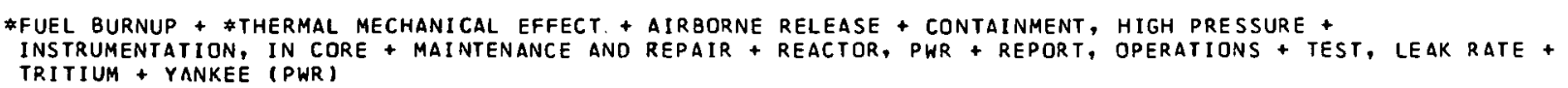

IF IT IS DISCOVEREO THAT A SYSTEM IS INOPERABLE OR DOES NOT MEET ITS SPECIFIEO CONDITIONS OF DPERATION WHILE IN AN OPERATING MODE WHERE THE SYSTEY IS REQUIRED BY THESE TECHNICAL

SPECIFICATIONS TO BE OPERABLE OR TO MEET PARTICULAR CONDITIONS OF OPERATION, IMMEDIATE STEPS WILL BE TAKEN TO CORRECT THE CONDITION PROMPTLY OR TO PLACE THE REACTOR IN A MOOE FOR WHICH OPERABILITY OF THE PARTICULAR SYSTEM IS NOT REQUIRED. SUCH PERIODS OF OPERATION AS FALL UNOER THE REQUIREMENTS OF THIS PARAGRAPH WILL NOT BE CONSIDERED A VIOLATION OF THESE TECHNICAL SPECIFICATIONS.

USAEC, PUBLIC OOCUMENT RODM, 1717 H ST., WASHINGTON, D.C. 20545 (25 CENTS/PAGE)

*FAILURE, EQUIPMENT + *TECHNICAL SPECIFICATIONS + EMERGENCY PROCEDURE + INCIDENT, EQUIPMENT + REACTOR, INTERNAL SUPERHEAT + REACTOR, POWER + REACTOR, RESEARCH + SAFETY PRINCIPLES AND PHILOSOPHY. + VESR (ISR)

17-27842 ALSO IN CATEGORIES 6 AND 9

LEAD PLATE SHIFT TO CORE ADDS $0.168 \%$ REACTIVITY

PENNSYLVANIA STATE UNIVERSITY

3 PAGF, ATOMIC. FNFRGY CLEARINGHOUSE, 14(35), PAGES 12-14 (AUGUST 26, 1968)

(LETTER TO DRL, AUG. 9) ON JULY 24, THE REACTOR OPERATOR WAS OBSERVING XENON BEHAVIUR AND PLOTTING ROD POSITION VS TIME. HE NOTED A 37 UNIT R.EG ROD WITHDRAWAL IN A FEW SECONDS, A SLIGHT LOG INCREASE, AND A 10 C FUEL TEMP. DECREASE REACTOR WAS SHUT DOWN CAUSE WAS A THICK LEAD PLATE (MOUNTED BETWEEN CORE AND THERMAL COLUMN). WHICH HAD SWUNG TOHARD THE CORE AS NYLON ROPES SAGGED. LEAD ADDEO $0.084 \%$ AND REFLECTED MORE NEUTRONS TOWARD THE SERVOCHAMBER, CAUSING A $40 \mathrm{KW}$ POWER DECREASE, WITH THIS FUEL COOLING ADDING $0.084 \%$.

* INSTRUMENTATION, ABNORMAL INDICATION + \#OPERATOR ACTION + BEAM HOLE + CONTROLLER + INCIDENT, EQUIPMENT + INSTRUMENTATION, POWER RANGE + LEAD + POWER COEFFICIENT + REACTIVIIY EFFECT +

REACTIVITY EFFECT, ANOMALOUS + REACTOR POWER + REACTOR, RESEARCH + REFLECTOR + TRIGA (RR)

$17-27843$

INCREASED POOL LEAK RATE

UNIVERSITY OF VIRGINIA

1 PAGE, ATOMIC ENERGY ClearinghOUSE, 14135), PAGE 15 (AUGUST 26, 1968 )

(LETTER, AUG. 8) THE WATER LOSS RATE HAS BEEN 200-400 GAL/DAY BUT INCREASED IN JULY TO 600-800 GAL/UAY. THOUGH THERE IS NO EXTERNAL PHYSICAL EVIDENCE, SOME OF THE WATER EVDS UP IN 
CATEGORY 17

OPERATIONAL SAFETY AND EXPERIENCE

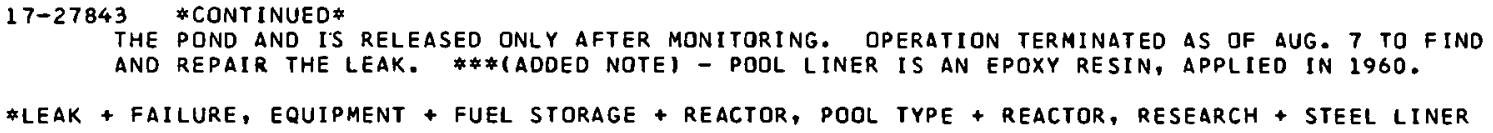

USAEC, PUBLIC DOCUMENT ROOM, 1717 H ST., WASHINGTON, D.C. 20545 (25 CENTS/PAGE)

*CHEMICAL REACTION + \#SODIUM + OECOMMISSIONING + HALLAM (LMR) + HEAT EXCHANGER + MAIN COOLING SYSTEM + REACTOR, LMCR + REPORT, OPERATIONS

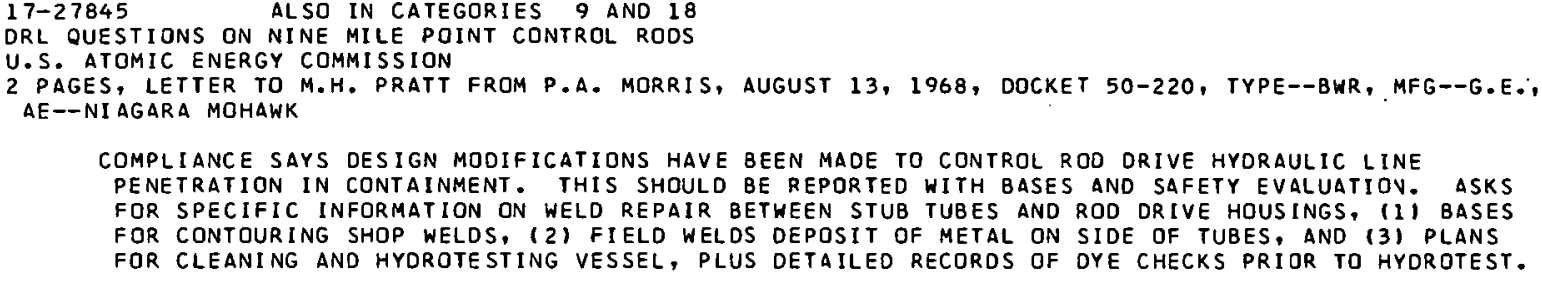

SIXTY-SIX 1 OR 2 WEEK PRESENTATIONS AT VARIOUS REGIDNAL CENTERS IN FY 1969 WILL BE MAOE OF ONE OR MORE OF THE 16 COURSES AVAILABLE. AMONG THOSE DF INTEREST ARE - BASIC RADIOLOGICAL HEALTH, RADIOLOGICAL HEALTH FOR NURSES, TWO FOR X-RAY PROTECTION, OCCUPATIONAL RADIATION PROTECTION, REACTOR SAFETY ANO HAZARDS EVALUATION, MANAGEMENT OF RADIATION ACCIDENTS, 


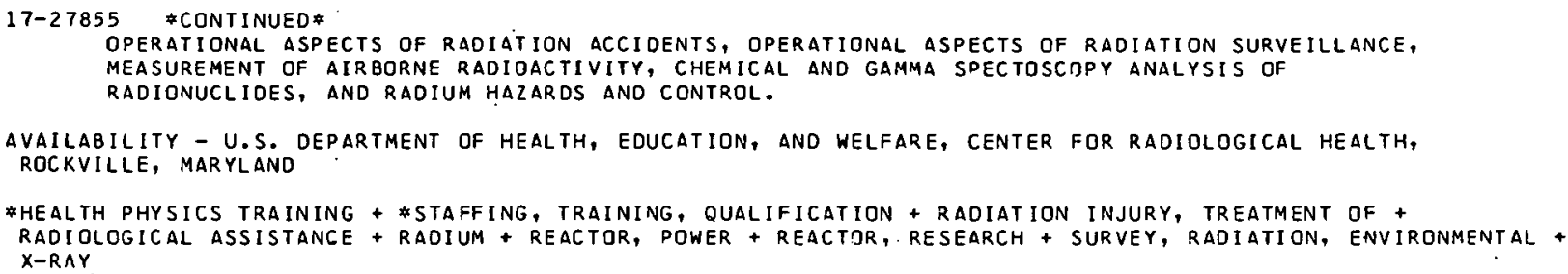

(COMPLIANCE LETTER, JUNE G) A FE8. 68 INSPECTION REVEALED ITEMS OFNONCOMPLIANCE - (1) DIRECT SURVEILLANCE WAS NOT DONE TO PROTECT AGAINST UNAUTHORIZED ENTRY TO AN EXPOSED 25-CURIE IR-192 SOURCE AT JOHN HANCOCK BLOG., CHICAGO. (2) HIGH RADIATION AREA WAS NOT POSTED. (3) SAFETY PLUG WAS NOT INSERTED AFTER USAGE. (4) RECORDS OF SURVEYS WERE NOT MAINTAINED. IPTL REPLY, JULY 181 WE HOPE THESE ITEMS WILL NOT HAPPEN AGAIN. OUR RAD SAFETY COOROINATOR HAS SENT A LETTER TO ALL RADIOGRAPHERS.

\#INSPECTION AND COMPLIANCE + \#RADIOGRAPHY + FAILURE, OPERATOR ERROR

17-27902 ALSO IN CATEGORIES 18 AND 1

THE POQS OF NUCLEAR POHER PLANT LICENSING

ATE PDQS OF NUCLEAR POWER

37 PAFF, 14 REFERENCES, REMARKS AT THE AIF WORKSHOP ON POWER REACTOR LICENSING, FEBRUARY 12 , 1968

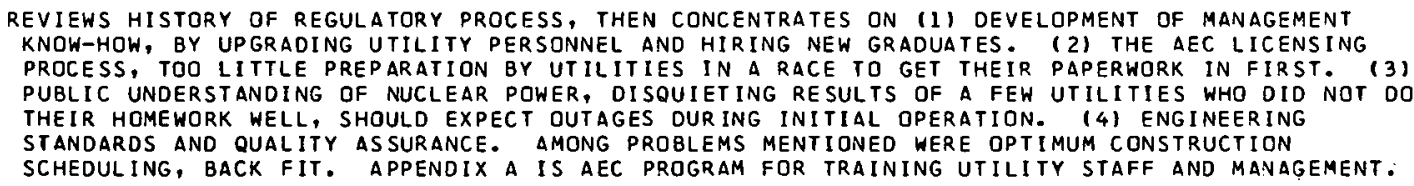

AVAILABILITY - ATOMIC INDUSTRIAL FORUM, 850 THIRD AVE, NEW YORK, N.Y. 10022

* CONSTRUCTION PERMIT PROCESS + \#REACTOR, POWER + \#STAFFING, TRAINING, QUALIFICATION + QUALITY CONTROL + RADIATION, PUBLIC EOUCATION/ACCEPTANCE + REGULATION, AEC

$17-27903$

ALSO IN CATEGORY 18

RAMEY JT

ROGRAM FOR TRAINING UTILITY MANAGEMENT AND STAFF

APPENDIX A, AEC PROGRAM FOR
ATOMIC ENERGY COMMISSION

2 PAGES, REMARKS AT THE AIF WORKSHOP ON POWER REACTOR LICENSING, FEBRUARY 12,1968

IN VIEW OF CONTINUING RAPID GROWTH OF NUCLEAR POWER, AND UTILITIES NOT HAVING PRIDR NUCLEAR EXPERIENCE, AEC URGES UTILITIES DEVELOP TECHNICAL AND MANAGERIAL INHOUSE CAPABILITY.

RESPONSIBILITY RESTS WITH INDUSTRY. OPERATOR TRAINING NOT A PROBLEM, EXCEPT FOR PROPER TYPE REACTOR TO GAIN EXPERIENCE ON. AEC ACTIONS INCLUDE (A) ESTABLISHMENT OF SUGGESTED STANDARDS OF TECHNICAL COMPETENCE, (B) DESCRIPTION OF A NUCLEAR TRAINING AND ORIENTATION PROGRAM, (C) STRENGTHENING FACILITIES FOR OPERATOR TRAINING, (D) REEMPHASIS OF EXISTING WORK EXPERIENCE TRAINING PROGRAM AT AEC SITES. (E) EXPANSION OF UNIVERSITY COURSES.

AVAILABILITY - ATOMIC INDUSTRIAL FORUM, 850 THIRD AVE., NEW YORK, N.Y. 10022

*STAFFING, TRAINING, QUALIFICATION + ADMINISTRATIVE CONTROL + REACTOR, BWR + REACTDR, POWER + 
CATEGORY 17

OPERATIONAL SAFETY ANO EXPERIENCE

17-27903 \#CONTINUED\#
REACTOR, PWR + SAFETY REVIEW

17-27904 ALSO IN CATEGORIES 18 AND 1

JOSL IN M

ON THE REGULATORY PROCESS

ATOMIC ENERGY COMMISSION

7 PAGES, REMARKS AT THE AIF WORKSHOP ON POWER REACTOR LICENSING, FEBRUARY 12, 1968

NEWS JF FAILURES ALERTS THE OTHER FELLOW TO PROFIT BY THE EXPERIENCF OF OTHERS. DISCUSSES EVOLUTION OF UTILITY-REGULATORY RELATIONS. AVOID DEPENDENCE ON SUPPLIER, UTILITY IS ALONE RESPONSIBLE TO AEC. DRESDEN 3 WAS GIVEN EXTENSIVE CORE COOLING SYSTEMS, WHICH COULD HAVE BEEN DONE AT LOWER COST IF THOUGHT DUT IN AOVANCE. URGES UTILITIES TO EDUCATE AEC ON SPECIAL FEATURES OF UTILITY ECONOMICS. NOTES NEED FOR UTILITIES OWN EXPERTS AND TOP MANAGEMENT INVOLVEMENT. CONSIDERS MOST SIGNIFICANT FOR UNBIASEO COOPERATION.

AVAILABILITY - ATOMIC INOUSTRIAL FORUM, 850 THIRO AVE., NEH YORK, N.Y. 10022

\#OPERATING EXPER IENCE SUMMARY + \#REGULATION, AEC + CODES ANO STANDARDS + CORE SPRAY + DRESDEN 3 (BWR) + ECONOMICS + INFORMATION RETRIEVAL + STAFFING, TRAINING, QUALIFICATION

$17-27984$

REED GA

STAFFING AND TRAINING FOR NUCLEAR POWER

WISCONSIN MICHIGAN POWER COMPANY

6 PAGES, POWER, $112(5)$, PAGES 88-91 (MAY 1968 )

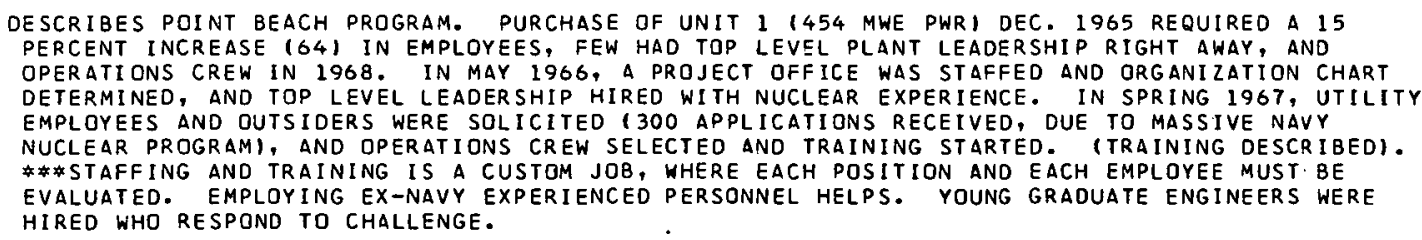

* OPERATING EXPERIENCE SUMMARY + *STAFFING, TRAINING, QUALIFICATION + POINT 8EACH 1 AND 2 (PHR) + REACTOR, MILITARY + REACTOR, POWER + REACTOR, PWR

$17-27985$

EOUCATIONAL PROGRAMS AND FACILITIES IN NUCLEAR SCIENCE AND ENGINEERING

OAK RIDGE ASSOCIATED UNIVERSITIES + UNITEO STATES ATOMIC ENERGY COMMISSION

101 PAGES, SEPTEMBER 1968

4 LISTING OF 261 EDUCATIONAL INSTITUTIONS (GIVING ADDRESS, CONTACT PERSON, DEGREE GRANTED IN NUCLEAR FIELD, GRAD STUDENT APPOINTMENTS AVAILABLE, SPEC IAL FACILITIES AND PROGRAMSI TAKING 73 PAGES, 13. PAGES OF A SUMMARY TABULATION OF THE SAME INFORMATION, AND 3 PAGFS ON SPECIAL FELLOWSHIP PROGRAMS.

AVAILABILITY - OAK RIDGE ASSOCIATEO UNIVERSITIES, OAK RIOGE, TENNESSEE

* stafFing, training, qualification

$17-27986$

UTILITY INDUSTRY PARTICIPATES IN AEC WORK EXPERIENCE PROGRAM

UNITED STATES ATOMIC ENERGY COMMISSION

AEC PRESS RELEASE L-207 * 2 PAGES, SEPTEMBER 4, 1968

IN 1958-68, 265 INDUSTRY REPRESENTATIVES FROM 180 ORGANIZATION HAVE SPENT AN AVERAGE OF 100

DAYS EACH IN THE PROGRAM. ABOUT HALF CAME FROM THE ELECTRICAL UTILITY INDUSTRY. AEC

FACILITIES ARE AVAILABLE TO SUPPLEMENT INOUSTRIAL FACILITIES IN MEETING TRAINING REQUIREMENTS

CAUSED BY RECENT SURGE IN NUMBER OF POWER REACTORS. PAST USES HAVE BEEN IN SUCH OIVERSE

SUBJECTS AS RAOIATION PROTECTION PROCEDURES, FUEL FABR ICATION TECCHNOLOGY, REACTOR OPERATIONS,

EVALUATION OF UTILITY PLANT CONCEPTS, AND CHEMICAL REPROCESSING. \#\#政TACT OIVISION DF

INOUSTRIAL PARTICIPATION, USAEC, WASHINGTON, D.C., 20545.

*STAFFING, TRAINING, QUALIFICATION + FUEL REPROCESSING + HEALTH PHYSICS TRAINING + REACTOR, AEC OWNED + USAEC

17-27987 ALSO IN CATEGORY 1

WORK EXPERIENCE PROGRAM

UNITED STATES ATOMIC ENERGY COMMISSION

6 PAGES, CHAPTER 7604 FROM THE AEC MANUAL, FEgRUARY 20, 1964 
CATEGORY 17

OPERATIONAL SAFETY AND EXPERIENCE

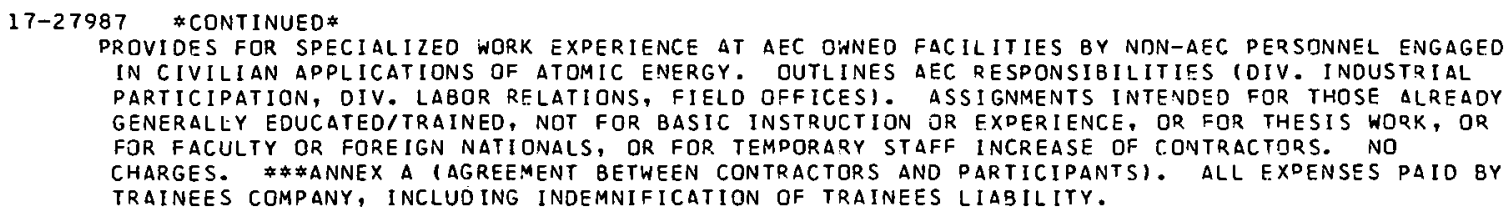

\#STAFFING, TRAINING, QUALIFICATION + USAEC

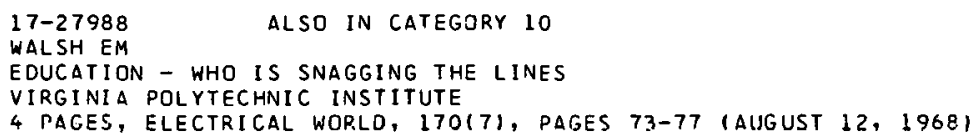

SUMMARIZES A SURVEY BY VPI ENERGY RESEARCH GROUP ON THE STATUS OF ELECTRICAL POWER IN 82 OF 130 U.S. UNIVERSITY CURR ICULA IN THE EAST ANO MIOWEST. TABLES SHOW LECTURE AND LAB HOURS GRAD AND UNOERGRAOI, EQUIPMENT, FACULTY NUMBER, AND COMMUNICATION QUALITY WITH UTILITIES. *\$69 REQUIRED A POWER COURSE FOR ALL EE MAJORS, 37 HAVE NO POWER COURSE TAUGHT AS AN ELECTIVE. ONLY 7 HAVE UNOERGRADUATE FELLOWSHIPS PROVIDED BY UTILITIES, DNLY 20 COOP WITH UTILITIES. 69 DFFER GRAOUATE EE, BUT ONLY 27 GIVE GRADUATE CCURSES IN POWER. 72 OF 163 ES THESES IN PROGRESS ARE IN POWER. ONLY 12 REPORTEO GOOO COMMUNICATION WITH UTILITIES. OT. 34 SAYING COMMUNICATION WAS NEGLIGIBLE, THE MAJORITY HAVE DOWER ORIENTED TEACHER ON THEIR STAFFS.

*STAFFING, TRAINING, QUALIFICATION + ELECTRICAL CONDUCTION + REACTOR, POHER

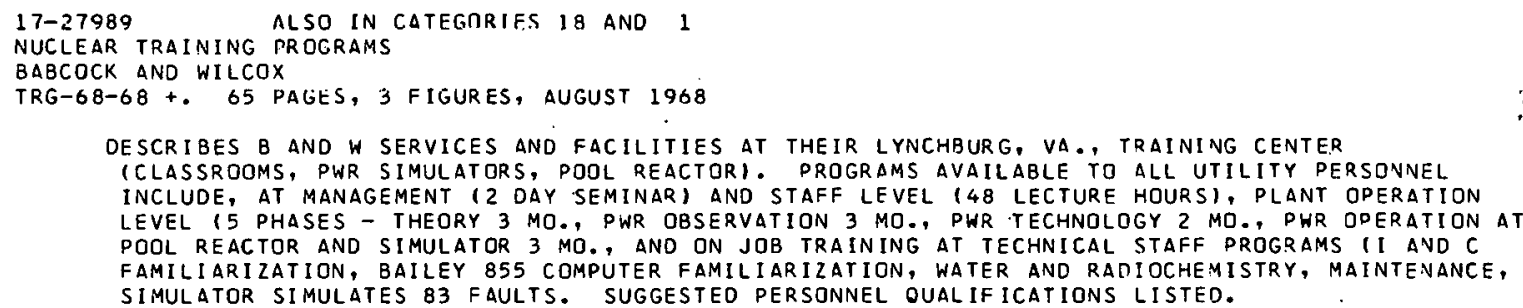

AVAILABILIIY - UAK KIUGE ASSUIIATEU UIVIVERSITIE3, OAK RIDGE, TCHPESEEE

* HEALTH PHYSICS TRAINING + USAEC

17-27991 ALSO IN CATEGORY 1

AEC SPECIAL FELLOWSHIPS IN NUCLEAR SCIENCE ANO ENGINEER ING

OAK RIDGE ASSOCIATED UNIVERSITIES

36 PAGES, SEPTEMBER 1966

DESCRIBES WHO MAY APPLY AND TYPE DF PROGRAMS, TENURE, CONDITION, FEES AND STIPENOS (6 PAGESI. OTHER PAGES LIST 66 PARTICIPATING SCHOOLS, GIVING FELLOWSHIP ADVISOR, DEGREES OFFERED, ANU AREAS OF EMPHASIS.

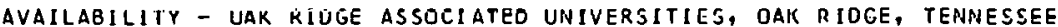

* STAFFING, tRAINING, Qualification + USAEC

17-27992 ALSO IN CATEGORY

ENGINEERING MANPOHER NEEOS OF THE INVESTOR OWNED ELECTRIC UTILITY INDUSTRY EOISON ELECTRIC INSTITUTE

EEI-PUB-68-27+. 5? PAGES, FIGURES, TABLES, FEBRUARY 1968 
CATEGORY 17

OPERATIONAL SAFETY AND EXPERIENCE

17-27992 \#CONTINUED*

REPORT OF COMMITTEE FORMED IN 1.966. RECOMMENDS 11 ) UTILITIES REINSPECT NEEDS, AS INDUSTRY UNOERESTIMATES NEEDS. IN 5 YEARS 15-20 PERCENT OF ENGINEERS HIRED WILL $8 E$ MS. (2) UTILITIES SHOULD REPORT 10-20 SCHOOLS OF EXCELLENCE. $(3,4)$ BETTER COMMUNICATION AND SUPPORT OF SCHOOLS. $(5,6)$ UTILIZE TECHNICIAN EMPLOYEES BETTER, AND RECRUIT HIGH SCHOOL GRADUATES. * $\#$ APPENDICES PROVIDE MANPOWER SURVEY, UNIVERSITY DEGREE PRODUCTION, AND AN ANALYSIS OF ONE UTILITIES NEEDS. \#UTILITY ESTIMATES ARE FOR 1100 ENGINEERS/YEAR AND 75 MS/YEAR IIO NUCLEAR POWER). COMMITTEE ESTIMATES ARE 2500-5000/YEAR (7-14 PERCENT OF CURRENT GRADUATE ENGINEER RATEI, AND 40/YEAR MS NUCLEAR ENGINEERING.

AVAILABILITY - EDISON ELECTRIC INSTITUTE, 750 THIRD AVE., NEW YORK, N.Y. 10017

* staffing, training, qualification + Reactor, power

$17-27993$

TECHNICIAN EDUCATION YEARBOOK

236 PAGES, 1967

LISTS 1024 INSTITUTIONS IN THE U.S. BY STATES, GIVING CONTACT PERSONS AND LISTING 2 YEAR CURRICIJLA (NOT COURSES) OFFERED. ALSO HAS A FEW 2 PAGE ARTICLES ABOUT DIFFERENT CURRICULA ANO $\triangle B O U T$ EDUCATIONAL PROBLENS. \#ELEVEN ARE LISTED AS HAVING A NUCLEONICS CURRICULA. TWELVE AS HAVING RADIATION TECHNOLOGY, AND TWENTY-ONE AS HAVING A COMBUSTION POWER TECHNOLOGY CURRICULA (USUALLY INTERNAL COMBUSTION). MOST SEEM TO HAVE ONE OR MORE ELECTRONICS ANO MECHANICAL ENGINEERING OPTIONS.

* StafFing, training, qualification

$17-27994$

KOVNER EA

TRAINING NUCLEAR TECHNICIANS AT OLO DOMINION COLLEGE

4 PAGES, PAGES 129-132 OF TECHNICIANS EOUCATION YEARBOOK, 1967

SUMMARIZES STARTUP (1962), INITIAL ACCEPTANCE, CURRICULUM, AND EQUIPMENT FOR A 2 YEAR PROGRAM (NUCLEAR OPTION IN THE ELECTRONIC ENGINEERING TECHNOLOGY CURRICULUM). IN THE LAST 2 SEMESTERS, 6 COURSES (20 SEMESTER HOURS) TREAT NUCLEONICS, NUCLEAR INSTRUMENTATION, REACTOR TECHNOLOGY, ANO POWER PLANTS.

*STAFFING, TRAINING, QUALIFICATION + OPERATING EXPER. IENCE SUMMARY

$17-27996$

SCHUMAN SD

AL SO IN CATEGORIES 18 AND 1

DESCRIPTION WESTINGHOUSE REACTOR OPERATOR TRAINING PROGRAM

WESTINGHOUSE ELECTRIC CORP., PITTSBURGH, PA.

WCAP-7170 +.45 PAGES, FEBRUARY 1968

INTENDED FOR CONTRACTED PWR STAFF TRAINING. INCLUDES SELECTION HELP IAHIIIUUE TEST FOR 24 PERSONNEL, ADMINISTERED 6 MONTHS BEFORE START OF. TRAIVING RFSULTING IN SELECTION DF 6 SUPERVISORS, 6 SHIFT SUPERVISORS, AND 10 OPERATORSI. PHASE I 111 WEEKS BASIC LECTURF WITH PDOL REACTOR OPERAIIUN AT WREC), PHASE II $(24$ WEEKS SAXTON PWR OPERATING EXPERIENCE $\triangle N D$

LICENSE EXAM), PHASE III (6 WEEKS LECTURE SERIES AT WAPD), PHASE IV (DNE YEAR DN-SITE

TRAINING FOR OPERATOR LEVEL MATERIAL). LESSON OUTLINES GIVEN FOR EACH LECTURE.

AVAILABILITY - S. D. SCHUMAN, WESTINGHOUSE ELECTRIC CORPORATION, ATOMIC POWER DIVISION, PENN CENTER SITE, P. O. BOX 355, PITTSBURGH, PA. 15230

*STAFFING, TRAINING, QUALIFICATION + REACTOR, POWER + REACTOR, P.WR + SAXTON (PWR

17-27997 ALSO IN CATEGORIES 18 AND 1

COMMENTS FROM BRIEFING CONFERENCE ON NUCLEAR POWER, SEPT. 3-6, 1968

YANKEE ATOMIC ELECTRIC CO.

15 PAGES, ATOMIC ENERGY CLEARING HOUSE, 14(37), PAGE 8-11 AND 19-29, (SEPTEMAER 9, 1968 )

(ROGER CDE) - INNUMERABLE ECONOMIC FORECASTS BUT I ITTIF HINRSITHT INFDPMATION. UIECUSSED YANKEE, CONN. YANKEE, AND HUMBOLDT BAY ECONOMICS. (JAMES T. RAMEY) - NOT LIKELY TO SEPARATE REGULATORY FUNCTION·FROM AEC FOR AT LEAST 5 YEARS. EVOLUTION.EXPECTEO. (JOHN B. ANDERSON) DETAILEO DISCUSSION OF LEGISLATIVE BILLS ON SITING, THERMAL EFFECTS, SMALL UTILITY PARTICIPATION, PRACTICAL VALUE. (H. L. PRICE) - SUGGESTED APPROVING A NUCLEAR STEAM SUPPLY SYSTEM OUTSIDE THE CONSTRUCTION PERMIT PROCESS. (P. A. MORRIS) - CONSTRUCTION PERMIT TAKE 12.4 MONTHS BECAUSE OF 12 TECHNICAL AND 4 GENERAL ITEMS NOT SPECIFICALLY TREATED IN PSAR. (R. LOWENSTEM) - LICENSING DELAYS COST APPLICANT ONE MILLION \$/MONTH. HE ADVISES APPLICANT TO:PLAN ON 18 MONTHS FOR A CONSTRUCTION PERMIT, ONE YEAR FOR OPERATING LICENSE AFTER FILING FSAR (WHICH TAKES 6 MONTHS TO PREPARE).

AEC QUESTION + CONGRESSIONAL ACTIVITY + CONSTRUCTION PERMIT PROCESS + ECONOMICS + OPERATING LICENSE PROCESS + REACTOR, POWER + REACTOR, WATER + REGULATION, AEC + REPORT, PSAR + REPORT, SAR + RESPONSE FIME 
CAT.EGORY 17

OPERATIONAL SAFETY AND EXPERIENCE

$17-28001$

WAITE DA

PILOR PROGRAM FOR TRAINING RADIATION ANO NUCLEAR TECHNICIANS

OKLAHOMA STATE UNIVERSITY, STILLWATER, OKLAHOMA

2 PAGES, TECHNICAL EDUCATION NEWS 27(3), PAGES 13 AND 14 (APRIL 1968)

- SHORT DESCRIPTION OF OKLAHOMA STATE UNIVERSITY PROGRAM, FUNDED BY USPHS, TO PROVIDE A 2 YEAR ASSOCIATE DEGREE PROGRAM. PROVIDES 35 COLLEGE HOURS IV 2 YEARS (MOSTLY ON RADIOLOGICAL HEALTH), COMPARED WITH THE USUAL 24-28 HOUR MAJOR IN A 4 YEAR COURSE. GRADUATES ARE NOW WORKING. MOST EMPLOYERS GIVE THEM A CHANCE TO WORK TOWARD A BS OR MS WHILE ON THE JOB.

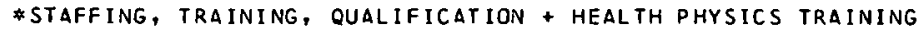

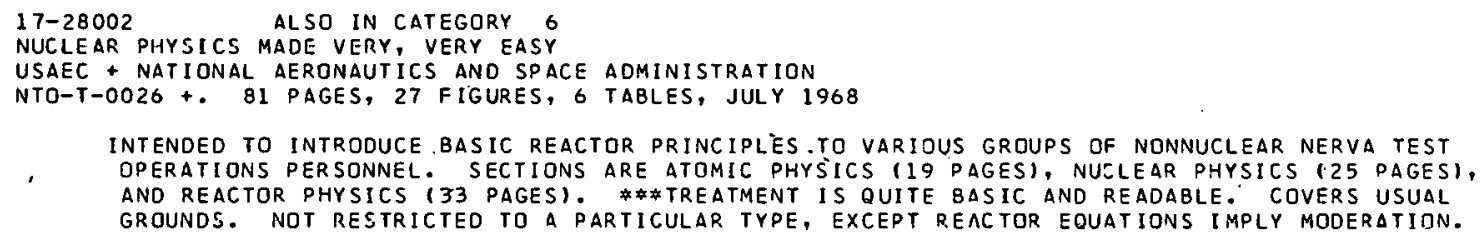

INTENDED TO INTRODUCE BASIC REACTOR PRINCIPLES.TO VARIOUS GROUPS OF NONNUCLEAR NERVA TEST OPERATIONS PER SONNEL. SECTIONS ARE ATOMIC PHYSICS (19 PAGES), NULLEAR PHYSICS (25 PAGESI, ANO REACTOR PHYSICS (33 PAGES). *\#TREATMENT IS QUITE BASIC AND READABLE. COVERS USUAL GROUNDS. NOT RESTRICTED TO A PARTICULAR TYPE, EXCEPT REACTOR EOUATIONS IMPLY MODERATIDN.

\#REACTOR PHYSICS + \#STAFFING, TRAINING, QUALIFICATION + NERVA PRQGRAM + REACTOR, POHER + REACTOP, SPACE

17-28003 ALSO IN CATEGORIES 1 AND 13

AEC PLANS REVISION OF RAOIOISOTOPE LICENSING PROCEDURES

U.S. ATOMIC ENERGY COMMISSION

AEC PRESS RELEASE IN-866 . 3 PAGES, APRIL 29,1968

REVISIONS PROPOSED TO 1OCFR33 WOULD BE ALONG LINES OF PRESENT BROAD LICENSES ITYPE A INSTITUTIONS $\triangle L L O W E D$ TO POSSESS I. ARGF MIILTI-CIIRVE DUANTITIES. RADIQLOSICAL SAFETY OFFICER AND AN ISOTOPE SAFETY COMMITTSE REQUIRED.). ADOED WOULO BE TYPE B (INSTITUTION MAY POSSES UP TO 10,000 TIMES THE QUANTITY WHICH IOCFR2O WOULO ALLOW TO BE INHALED BY ONE PERSON IN ONE YEAR, MUST HAVE A QUALIFIEO RADIOLOGICAL SAFETY OFFICER AND ADMINISTRATIVE PROCEDURES FOR CONTROLLING USAGE) AND TYPE C (INDIVIDUAL USER MUST HAVE SCIENTICIC BACKGROUND AND RADIATION PROTECTION TRAINING, MAY POSSES UP TO 100 TIMES THE QUANTITY WHICH 10 CFR 20 WOULO ALLOW ONE PERSON TO INHALE IN ONE YEAR). \$COMMENT REQUESTED ON FEDERAL REGISTER PUBL ICATION OF APRIL 30,1968 .

*RADIOISOTOPE + \#REGULATION, AEC + APPLICATION FOR AEC LICENSE

17-28004 ALSO IN CATEGORIES I AND 13

HOW TO CET A LICENSE TO USE R.NDIOISOTODES

U.S. ATOMIC ENERGY COMMISSION

35 PAGES, JULY 1967

BRIEFLY REVIEWS (FOR AN APPLICANT WITHOUT PRIOR KNOWLEDGE) THE OBJECTIVES ANO REQUIREMENTS OF “. THE REGULATORY PROGRAM, PLUS THE SAFETY RESPONSIBILITIES OF THE USER. A STARTING POINT FOR FURTHER INFORMATION. \# \#REVIEWS RADIOISOTOPE LICENSING, STATE REGULATION, AEC SAFETY STANDARDS AND REGULATIONS, QUALIFYING FOR A SPECIFIC LICENSE, RESPONSIBILITY OF LICENSEES. APPENDICES INCLUDE RULES AND REGULATIONS, INSTRUCTION SHEETS, ANO SAMPLE APPLICATIDN/LICENSE. REFERENCES.

AVAILABILITY - SIIPFRINTFNIFNT OF DOCUMENTS, U.S. GOVERNMENT PRINTING OFFICE, WASHINGTON, O. C. 2 C4O2 \# RDIOISOTOPE + \#REGULATICN, AEC + APPLICATION FOR AEC LICENSE + GUIDE

$17-28009$

THUMPSON TJ + HILBERRY NE

MITS THOMPSDN FORESEES SERIOUS SHORTAGE OF NUCLEAR ENGINEERS

2 PAGES, NUCLEONICS WEEK, $9(36)$, PAGES 6-7 (SEPT. 5, 1968)

T. J. THEMPSON AND N. E. HILBERRY POINT DUT THIS YEAR 600 NUCLEAR ENGINEERS GRADUATED, 120 WITH SKILLS FOR NUCLEAR POWER CAREERS, BUT THE MAJORITY NERE INTERESTED IN R AND D. . PNLY A HANDFUL HIREO BY UTILITIES. THE 1970 CROP WILL BE HALF THAT UNLESS UTILITIES APPRECIATE THEIR NEEDS, WHICH ARE 200-300 RIGHT AWAY. OPERATOR-LEVEL TRAINING CANNOT POSSISLY PRNVIDE DEPTH OF KNOWLERTEF NFEDFD, WHIT.H FXTENDS INTO REACTOR DHYSICS, HEAT TRANSFER AND ECONDMICS. FEI TASK FORCE REPORT SUGGESTS SAME UNDERESTIMATIDN.

* STAFFIng, tRaINING, QUALIFICATION + REACTOR, BWR + REACTOR, POWER + REACTOP, PWR 
17-28010 ALSO IN CATEGORY 6

THE STARTUP TEST PROGRAM FOR THE CONNECTICUT YANKEE YANKEE REACTOR

CONNECTICUT YANKEE ATOMIC POWER COMPANY, HADDAM

NYD-3250-11 +. 37 PAGES, FIGURES, TABLES, DOCKET 50-213, TYPE--PWR, MFG--WEST., AE--STONE + WEBSTER

REPORTS WORK DURING MONTH OF JULY 1967. FUEL LOADED WITH WATER AT 2650 PPM BORON, THEN BORON DILUTED SLOWLY TO GO CRITICAL. ZERO POWER MEASUREMENTS WERE MADE AT 10 MWTH. AGREEMENT ON COLD TOTAL EXCESS REACTIVITY AND WORTHS OF GROUPS AB WAS EXCELLENT WITH PREDICTION, BUT THE HOT WORTH OF CD WAS LOW BY 0.035 REACTIVITY $\%$. MEASUREMENTS MADE OF SINGLE ROD WORTHS IFOR STUCK AND EJECTED RODSI AGREED WELL WITH PREDICTIONS. DIFFERENTIAL BORON WORTH CURVE IS STEEPER THAN EXPECTED, PERHAPS BECAUSE RODS ARE IN CORE. TEMPERATURE COEFFICIENTS TAKEN BY USING BORON CHANGES IS ALSO STEEPER THAN PREDICTED.

AVAILABILITY - CLEARINGHOUSE FOR FEDERAL SCIENTIFIC AND TECHNICAL INFORMATION, SPRINGFIELD, VA. 22151 , $\$ 3.00$ CPY, \$O.65 MICROFICHE

\#CONTROL RDD WORTH + \#REACTOR STARTUP TESTING + COMPARISON, THEORY AND EXPERIENCE + HADDAM NECK (PWR) + REACTIVITY, EXCESS + REACTOR, PWR

17-28011 ALSO IN CATEGORY 11

THIRTEENTH MONTHLY OPERATIONAL REPORT ON THE LA CROSSE BOILING WATER REACTOR COVERING THE MONTH OF JULY 1968

ALLIS-CHALMERS, EETHESDA, MARYLAND

ACNP-68509 +. 16 PAGES, JULY 1968, DOCKET 115-5, TYPE--BWR + MFG--A.C., AE--SGT + LUNDY

REACTOR SHUT DOWN. SHUTOGWN CONDENSER SHOWED NO HELIUM LEAKAGE DESPITE 3 DAYS AT 55 PSIG, BOTH COLD AND AT $230 \mathrm{~F}$. \#\# BENT FEEDWATER PIPE HANGER INDICATEO THAT THE PIPE MOVED MORE THAN THE I/IG IN. PREDICTED. CALCULATIONS WILL BE REDONE.

AVAILABILITY - USAEC PUBLIC DOCUMENT ROOM, WASHINGTON, D. C. 20545

COMPAKISON, THEORY AND EXPERIENCE + LACROSSE (BWR) + PIPING + REACTOR, BWR + REPORT, OPERATIONS + STEAM GENERATOR + STRESS ANALYSIS + TEST, LEAK RATE + THERMAL MECHANICAL EFFECT + TUBING

$17-28029$

ALSO IN CATEGORY 13

MILES FW

ION-EXCHANGE-RESIN SYSTEM FAILURES IN PROCESSING ACTINIDES

OAK RIOGE NATIONAL LABORATORY, OAK RIDGE, TENNESSEE

13 PAGES, 3 TABLES, 72 REFERENCES, NUCLEAR SAFETY 9(5), PAGES 393-406 (SEPT.-DCT. 1968)

SEVEN INSTANCES OF ION-EXCHANGE-RESIN SYSTEM FAILURES HAVE BEEN REPORTED IN NUCLEAR WORK SINCF JUNE 26,1962 , AND FIVE STUDIES HAVE BEEN MADE OF THE THERMAL STABILITY OF VITRATE-FJRM RESINS. ALL INSTANCES APPARENTLY INVOLVED THE SELF-IGNITION OF NITRATE-FORM RESINS IWITH BOTH AROMATIC AND ALIPHATIC MATRICES) IN STRONG (MORE THAN 7NI NITRIC ACIO IN THE PRESENCE OF SOME AMOUNT OF HEAT. TWO GROUPS OF PRECAUTIONARY MEASURES ARE SUGGESTED - I1I THOSE

ASSOCIATED WITH THE CHEMISTRY OF RESINS, SUCH AS MAXIMUM OPERATING TEMPERATURE AND IONIC LOADING LIMITS, AND (2) THOSE COMMON TO CHEMICAL PROCESSING, SUCH AS PRESSIIRE-RELIEF DEVICES AND $A O E Q U A T E$ RULES CONCERNING PROCEOURAL CHANGES.

* ACCIDENT ANALYSIS + \#FUEL CONVERSION + \#FUEL REPROCESSING + \#ION EXCHANGF + \#RAOIOISOTOPE + \#RESIN + CURIUM + NEPTUNIUM + PLUTONIUM + THORIUM + URANIUM

$17-28030$

LEAK RATE TESTS OF LACBWR SHUTOCWN CONOENSER

ALLIS-CHALMERS

3 PAGES, LETTER. TO P.A. MORRIS, DRL, AUGUST 30, 1968, DOCKET 115-5, TYPE--BWR, MFG--A.C., AE--SGT + LUNDY

JULY-AUGUST TESTS FOLLONED FINDING ACTIVITY ON THE SHELL SIDE IN MAY. TESTS WITH A HELIUM-AIR MIXTURE AND A MASS SPECTROMETER PROBE WERE MADE OF WELDS AND TUBES - 111 COLD AND 55 PSIG, (2) $230 \mathrm{~F}$ AND 15 PSIG, (3) COLD AND 50 PSIG. LEAKAGE WAS LESS THAN 0.001 CC/SEC. THE 95 PSIG AIR TEST VALUE REPORTEO AS 0.24 CCISEC WAS ACTUALLY THE HIGHEST OBTAINED, AND EVEN THEN LESS THAN 1/1OTH THAT PERMITTED BY TECH. SPECS. \# \#CONDENSER WILL BE RETURNED TO SERVICE AND SHELL SIOE SAMPLED MONTHLY OR AFTER CONDENSER OPERATION.

AVAILABILITY - USAEC PUBLIC DOCUMENT ROOM, 1717 H ST., WASHINGTON, D.C. 20545 (\$O.25 CENTS/COPY)

FAILURE, TUBING + HEAT EXCHANGER + LACROSSE (BWR) + REACTOR, 8WR + REPORT, DPERATIONS ANALYSIS + SHUTDONN COOLING SYSTEM + TEST, LEAK RATE

17-28033 ALSO IN CATEGORY I2

PARTIAL INOPERABILIYY OF SAFETY INJECTION SYSTEM

SOUTHERN CALIFORNIA EOISON COMPANY

3 PAGES, LETTER TO P.A. MORRIS, DRL, SEPTEMBER 6, 1968, DDCKET 50-206, TYPT--PWR, MFG--WEST., AE--BECHTEL 
CATEGORY 17

OPERATIONAL SAFETY AND EXPERIENCE

17-28033 *CONTINUED*

ON AUG. 27, 1968, CALIBRATION SHOWED BOILER FEED PUMP SPEED SWITCHES HERE MADE UP AT 2800 AND 3800 RPM RESPECTIVELY, INSTEAD OF 3200. SPEED SWITCHES ENSURE UNBDRATEO WATER FLUSHED OUT BEFORE SAFETY INJECTION BEGINS. A 23 CU. FT. DILUTION WAS ANALYZED IN THE FSAR, 10 WOULD HAVE BEEN ADDED HERE. \#\#SAFETY INJECTION FLOW COMPARATOR DID NOT CLOSE ONE INJECTION VALVE $850 \mathrm{C}$ ON A HIGH FLOW RATE TEST. A BLOCKING DIODE WAS INSTALLED IN THE COMMON GROUND LEG OF THE AUCTIONEERING RELAYS, AND ALL THREE VALVES WORKED PROPERLY. \# \$EACH CONDITION HAD BEEN ANALYZED IN FSAR. NEITHER WOULD HAVE PREVENTED SAFETY INJECTION SYSTEM FROM WORKING.

USAEC, PUBLIC DOCUMENT ROOM, 1717 H ST., WASHINGTON, D.C. 20545 (25 CENTS/PAGE)

* CORE REFLODOING SYSTEM + \#FAILURE, COMPONENT + *SHUTOOWN SYSTEM, SECONDARY + INSTRUMENTATION CALIBRATION + INSTRUMENTATION, FLOW + PUMP + REACTOR, PWR + SAN ONOFRE (PHR) + SET POINT

17-28034 ALSO IN CATEGORY 11

ELK RIVER OPERATING EXPERIENCE

RURAL COOPERATIVE POWER ASSOCIATION

CO0-651-63 +. 41 PAGES, FIGURES, TABLES, JULY 1968, DOCKET 115-1, TYPE--BWR, MFG-A.C., AE--SGT + LUNDY

REACTOR NOT OPERATEC BECAUSE PRIMARY SYSTEM LEAK RATE TESTS CONTINUED USING SR-85 ANO RB-86 TRACERS. WHEN RB-86 WAS INJECTED INTO PRIMARY SYSTEM WITH 1100 PSIG STEAM, THE REACTOR CAVITY WATER COLLECTION RATE INCREASED FROM 1500 TO $2100 \mathrm{ML} / \mathrm{HR}$, BUT RB-86 NOT FOUNO. STEAM WAS INJECTED INTO REACTOR CAVITY TO FLUSH OUT ANY TRACER DEPOSITED, CONDENSATE SHOWED BOTH RB AND SR TRACERS. \# \#PROCEOURES GIVEN FOR PERSONNEL ANO FOR EMERGENCY $\triangle$ IR LOCK LEAK RATE TESTS. CONTAINMENT VESSEL WILL BE LEAK RATE TESTEO NEXT. SHIELD BLOCKS ARE BEING REMOVED FOR VISUAL INSPECTION OF THE VESSEL BOTTOM.

USAEC, PUBLIC DOCUMENT ROOM, 1717 H ST., WASHINGTON, D.C. 20545 (25 CENTS/PAGE)

* TEST, LEAK RATE + CONTAINMENT AIR LOCK + ELK RIVER (BHR) + FAILURE, PRESSURE VESSEL + PRESSURE VESSEL + REACTOR, BWR + REPORT, OPERATIONS + TRACER, RADIOACTIVE

17-28049 ALSO IN CATEGORIES 13 AND 7

FILTER FAILURE AT WEST VALLEY PLANT

NUCLEAR FUEL SERVICES, INC., WEST VALLEY, N. $Y$.

2 PAGes, atomi energy Clearing hOUSE $14(38)$, PAGE 29 AND 30, (SEPT. 16, 1968), DOCKET NO. $50-201$

(TWX TO COMPLIANCE) ON SEPT. 4, 1968, ONE FILTER OF 30 IN THE MAIN VENTILATION FILTER BANK FAILED. 1-2\% OF THE FILTER WAS DISCHARGED FROM THE STACK AND FELL ON TO ROOF. PROBABLE CAUSE WAS FILTER PRESSURE DROP, AT UPPER OPERATING LIMIT. HIGH PRESSURE DROP ALARM IS. BEING REDUCED 18\%, AND LOW PRESSURE DROP ALARM IS ADJUSTED TO INCREASE SENSITIVITY TO SINGLE FILTER FAILURE. NOT A REPORTABLE INCIDENT BECAUSE ANALYSIS OF ADJACENT FILTER AND STACK SAMPLER INDILATE II $\%$ OF MONTHLY ALLOWANCE DISCHARGED. SURVEY OF SITE PERIMETER DID NOT SHOW RADIATION INCREASE ABOVE BACKGROUND.

*FILTER, DAMAGED + \#PRESSURE DROP + AIRBORNE RELEASE + FUEL REPROCESSING + INCIDENT, EOUIDMENT + NFS + STACK + VENTILATIUN SYSTEM

17-28050 ALSO IN CATEGORIES 13 ANO 7

NFS SHUTDOWN TO EVALUATE FILTER FAILURE

NUCLEAR FUEL SERVICES, INC., WEST VALLEY, N. Y.

1 PAGE, ATOMIC ENERGY CLEARING HOUSE 14(38), PAGE 30, (SEPT. 16, 1968), DOCKET ND. 50-2C1

(LETTER TO NFS, SEPT. 6, 1968) CONFIRMS SEPT. 6 PHONE CALL THAT WEST VALLEY PLANT OPERATIDN WILL NOT BE RESUMED UNTIL THE FOLLOWING IS REVIEWED BY AEC - (1) AMOUNT DF RADIOACTIVITY RELEASEU FRUM STALK SEPT. 4, 1908, 121 NAS EVALUATION, INCLUOING PROBABLE CAU3E AND CORRECTIVE ACTION, (3) INFORMATION REOUESTED IN APRIL 2, 1968, LETTER, INCLUDING IMMEDIATE WARNING OF ABNORMAL CONOITIONS IN VENTILATION AND OFFGAS SYSTEMS. ITEMS 1 AND 2 ARE NECESSARY TO CONFIRM TECH.-SPEC. REQUIREMENTS MET (PARAGRAPHS 4.1.1, 7.1.2.2 AND 7.1.7.3).

\#AIRBORNE RELEASE + \#FILTER, DAMAGED + FUEL REPROCESSING + INCIDENT, EQUIPMENT +

INSPECTION AND COMPLIANCE + NFS + OFF GAS + STACK + VENTILATION SYSTEM

17-28167 ALSO IN CATEGORY 13

CORRESPONDENCE RELATIVE TO NFS OFFGAS FILTERS

NUCLEAR FUEL SERVICES, INC.

2 PAGES, ATOMIC ENERGY CLEARING hOUSE 14(39), PAGE 14 AND 15, (SEPT. 23, 1968), DOCKET NO. $50-201$

(SEPT. 10) MARCH 1968 DOG FILTER FAILURE WAS OUE TO MOISTURE WEAKENING PLYWOOO CASING. ISEPT. 11 TWXI PROVIDES INTERIM TECHNICAL SPECIFICATIONS ON FILTER RESISTANCE AND PRESSURE DROP. (SEPT. 14 TWX) SPECS. CANNOT BE MET WITHOUT EXTENSIVE SHUTDOWN AND REDESIGN OFPLANT. (SEDT. 16 TWX) INTERPRETATIONS SUPPLIED BY NFS OF AEC SEPT. 13 TWX. (SEPT. 16 TWX) AEC NOT AWARE OF NFS SEPT. 14 TWX DUR ING. MEET ING OF SEPT. 14. CONFIRM ORAL AGREEMENTS. (SEPT. 17 TWX) OML AGREES NFS MAY DPERATF ACC.ORIING TO AEC SFPT. 13 SPECIFICATIONS INTERPRETED BY NFS SEPT. 16 TWX.

\#FILTER, HIGH EFFICIENCY + \#PRESSURE DROP + \#TECHNICAL SPECIFICATIONS + FAILURE, ADMINISTRATIVE CONTRQL + FILTER, DAMAGED + FUEL REPROCESSING + INSPECTION ANO COMPLIANCE + NFS + OFF GAS 
$17-28168$

POOL LEAK TO BE REPAIRED

UNIVERSITY OF VIRGINIA, CHARLOTTESVILLE, VA.

1 PAGE, ATOMIC ENERGY CLEARING HOUSE 14(39), PAGE 20, (SEPT. 23, 1968), DOCKET 50-62

(LETTER, SEPT. 6) REPORT DESCRIBES PLANS TO REPAIR POOL LEAK BY REPLACING CURRENT EPOXY RESIN LINING MATERIAL IFARBOCOAT 731. ANALYZES ASSOCIATED HAZAROS.

\# MAINTENANCE AND REPAIR + \#RESIN + \#STEEL LINER + COATING, SURFACE + FAILURE, GENERAL + FUEL STORAGE + LEAK + REACTOR, POOL TYPE + REACTOR, RESEARCH

17-28169 ALSO IN CATEGORY 12

BAWTR REACTOR HEAOER FAILS TO DROP ON LOSS OF FLOW

BABCOCK + WILCOX CO., EYNCHBURG, VA.

1 PAGE, ATOMIC ENERGY CLEARING HOUSE 14139), PAGE 19, (SEPT, 23, 1968), DOCKET NO. 50-200

(LETTER, SEPT. 9) FAILURE CAUSED BY 3 HEADER GUIDE RODS BROKEN, WHICH PREVENTED THEIR ALIGNING THE HEAOER AND CAUSEO IT TO BIND. THESE BROKE DUE TO REPEATED LOADINGS. WE WILL SHIT DOWN UNTIL TECH. -SPEC. APPROVAL OF OPERATION WITH HEAOER LOCKED UP. (HEAOER IS APPARENTLY FLAPPER VALVE OPENING ON LOW FLOW).

ACCIOENT, LOSS OF FLOW + ENGINEEREO SAFETY FEATURE + FAILURE, EQUIPMENT + REACTOR, POOL TYPE + REACTOR, TEST + TECHNICAL SPECIFICATIONS

17-28170 ALSO IN CATEGORIES 13 AND 14

ALTERNATIVE IN REDUCING BUTTERMILK CREEK RADIOACTIVITY

NUCLEAR FUEL SERVICES, INC.

2 PAGES, ATOMIC ENERGY CLEARING HOUSE 14(39), PG 19 AND 20, (SEPT, 23, 1968), DDCKET NO. 50-201

(LETTER, SEPT. 9) DESCRIBES ALTERNATIVES - 11 ) PIPING WASTE DIRECTLY TO CATTARAUGUS CREEK

WOULD NOT MEET INTENT OF REDUCING DISCHARGE. (2) DEEP WELL DISPOSAL WOULD ALSO TAKE CARE OF

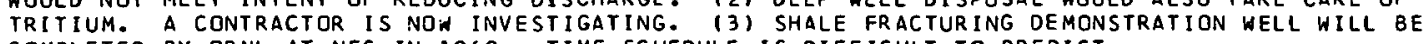
COMPLETED BY ORNL AT NFS IN 1969. TIME SCHEDULE IS DIFFICULT TO PREDICT.

FUEL REPROCESSING + NFS + WASTE DISPOSAL, HYDRAULIC FRACTURING + WASTE DISPOSAL, LIQUID

17-28171 ALSO IN CATEGORY 13

CONTAMINATION DUE TO POWER FAILURE AND LOOSE STOPPER

3M COMPANY, ST. PAUL, MINN.

1 PAGE, ATOMIC ENERGY CLEARING HOUSE 14(39), PAGE 26, (SEPT. 23, 1968)

(LETTER TO COMPLIANCE AUg. 14) ON THE MORNING OF JULY 24, ALL HOOD F.ANS WERE NOT WORKING DUE TO A POWER FAILURE DURING THE NIGHT. IN CHECKING MDDULE 107N, A SMALL BRASS BOTTLE CONTAINING 50 CURIES DF SR-90 WAS MOVED, AND ITS LOOSE TOP NOTED. HIS GLOVE AND SHOE COVERS WERE CONTAMINATED, AND THE HOOD WAS CONTAMINATEO TO 2R/HR. TWO EMPLOYEES DPESSED IN FULL ANTI-C SUITS WITH RESPIRATORS SPENT 25 MIN CLEANING UP THE HOOD. A SAMPLER SHOWED THEY WERE EXPOSEO TO 14.1 MICROC/ML AIR, GIVING A TECHNICAL OVEREXPOSURE OF 14.7 MPC. URINALYSIS SHOWED NEGATIVE RESULTS. NO CORRECTIVE ACTION IS CONTEMPLATED, ELECTRICAL FAILURES MUST BE SHOWED NEGA
EXPECTEO.

*CONTAMINATION + \#FAILURE, SIMULTANEQUS + \#STRONTIUM + ACCIDENT, LOSS OF PDWER + AIRBORNE RELEASE + FAILURE, OPERATOR ERROR + GLOVE BOX + INHALATION + PERSONNEL EXPOSURE, RADIATION +

PERSONNEL PROTECTIVE DEVICE + RADIOISOTOPE 
CATEGORY 18

SAFETY ANALYSIS AND DESIGN REPORTS

$18-25342$

PREOPERATIONAL AND STARTUP TESTS

MILLSTONE POINT CO.

24 PAGES, 1 TABLE, PAGE B-1 THROUGH B-24 OF APPENDIX 3 TO MILLSTONE POINT SAFETY ANALYSIS REPORT, VOL. 3 , MAY 2, 1968, DOCKET 50-245, TYPE--BWR, MFG--G.E., AE--EBASCO

RELATIVE SEQUENCE, POWER LEVELS ANO CONDITIONS, AND SINGLE-PARAGRAPH SUMMARIES OF (I)

PREOPERATIONAL TESTS, 8 PG, (II) OPEN VESSEL TESTS, $($ III) HEATUP TESTS, (IVI POWER TESTS, AND IVI WARRANTY TESTS. MILLSTONE PERSONNEL WILL CONDUCT TESTS, WITH THE TEST PROGRAM UNDER THE RESPONSIBLE TECHNICAL DIRECTION OF GE.

AVAILABILITY - USAEC PUBLIC DOCUMENT ROOM, WASHINGTON, D. C.

*TEST, PLANT RESPONSE + *TEST, PREOPERATIONAL + MILLSTONE POINT (BWR) + REACTOR STARTUP TESTING + REACTOR, BWR + REPORT, SAR

$18-25882$

BELL STATION PSAR VOL I

NEW YORK STATE ELECTRIC + GAS CORPORATION

80 PAGES. MARCH 1968. DOCKET 50-319.

A 2436-MWTH 1866-MWE GROSS CURRENT, STANDARD BHR SIMILAR TO COOPEP. OR EASTON BUT WITH $\triangle$ STEEL-LINED REINFORCED-CONCRETE DRY WELL AND TORUS, AND 50 F HOTTER (420 F) FEEDWATER TEMP. LOCATED ON LAKE CAYUGA, $40 \mathrm{M}$ SW OF SYRACUSE, NEXT TO $270-M W E$ MILLIKEN STATION. OPERATIONAL MAY 1973. \$ VOL. I INCLUDES SECTION II (SITE AND ENVIRONS), III (REACTOR CORE), IV (REACTOR COOLANT SYSTEM), VI (CONTAINMENT), VI (ENGINEERED SAFEGUARDS).

AVAILABILITY - CLEARINGHOUSE FOR FEDERAL SCIENTIFIC AND TECHNICAL INFORMATION, SPRINGFIELD, VIRGINIA, 22151 , \$3.00 COPY, \$0.65 MICROFICHE

BELL (BWR). + REACTDR, BWR + REPORT, PSAR

18-25883 ALSO IN CATEGORIES 2 AND 16

BELL PSAR SECTION II, STATION SITE AND ENVIRONS

NEW YORK STATE ELECTRIC + GAS CORPORATION

100 PAGES, 17 FIGURES, 12 TABLES. PAGE II-1-1 THRU 11-6-2. MARCH 1968. DOCKET 50-319.

INCLUDES PRELIMINARY (JAN. 68) REPORTS ON METEOROLOGY (B. E. DETHIER) AND LIMNOLOGY OF CAYUGA LAKE AND INTERRELATIONS WITH NUCLEAR POWER PLANT (J. F. STORR) \#\#NOCTURNAL DRAINAGE WIND FLOWS UP RIVER FROM ITHACA (13 MILES AWAY) TOWARO THE SITE. ON-SITE TOWER BEING INSTALLED. FLOWS UP RIVER FROM ITHACA (13 MILES AWAY) TOWARO THE SITE. ON-SITE TOWER BEING INSTAL
\#\#EXTENSIVE MIXING OF WATER EXPECTED. A SURVEY IS BEING MADE, BASED ON FOSSIL PLANT DISCHARGE. A HATCHERY FOR TROUT AND COHO SOLUTION IS PLANNED TO USE THE THERMAL ENRICHMENT PROVIDED BY CONOENSER DI SCHARGE.

AVAILABILITY - CLEARINGHOUSE FOR FEDERAL SCIENTIFIC AND TECHNICAL INFORMATION, SPRINGFIELD, VIRGINIA, $22151, \$ 3.00$ CUPY, \$O.65 MICROFICHE

* LAKE + \#THERMAL POLLUTION + BELL (BWR) + DIFFUSION + ON SITE WORK + REACTOR, BWR + REPORT, PSAR + TOPOGRAPHY

18-25884 ALSO IN CATEGORIES 5 AND 17

BELL PSAR SECT 3.3 .7 DESCRIPIION OF CORE ANALYSIS

NEW YORK STATE ELECTRIC + GAS CORPORATION

85 PAGES, 20 FIGURES, 5 TABLES, PAGE III-3-5. THRU -7. MARCH 1968 50-319.

A COMPUTER PROGRAM (UNSPECIFIEDI IS USED TO ANALYZE THE THERMAI. AND HYDRAULIC CHARACTERISTICS OF THE CORE AS A WHOLE OUTPUT AND INPUT DISCUSSED BRIEFLY RECENT MODIFICATIONS IN CORE DESIGN AND IN THERMAL HYDRAULIC EVALUATION TECHNIQUES ALLOW HIGHER FEEDWATER TEMP. WITHOUT ENCROACHING ON THERMAL MARGINS. THE ITEMS ANO THEIR EFFECT ON INLET SUSCOOLING (BTU/LB) MCHFR ARE - (1) INLET ENTHALPY NOW BASED ON 1920 PSIA DOME PRESSURE, RATHER THAN 1050 INLET $(+41+.06)$. (2) CORE BYPASS FLOH NOH ESTABLISHED AS $7 \%(-1+0.03)$. (3) CORE MIDPLANE PRESSURE OF 1035 NOW USED INSTEAO OF INLET PRESSURE $1-1-.021$. (4) 2IRCONIUM SPACER TEST DATA (

$-1-.02)$. \# \#THE NET EFFECT, WHEN FEEDHATER INCREASED TO $420 \mathrm{~F}$, IS TO INCREASE. SUBCODLING O.3 BTU/LB AND MCHFR BY 0.02

AVAILABILITY - CLEARINGHOUSE FOR FEDERAL SCIENTIFIC AND TECHNICAL INFORMATION, SPRINGFIELD, VIRGINIA, $22151, \$ 3.00$ COPY, \$0.65 MICROFICHE

* ANALYTICAL MODEL + \#COMPUTER PROGRAM + \#SUBCOOLING + BELL (BWR) + COMPARISON, THEORY AND EXPERIENCE + HEAT FCUX, CRITICAL + HEAT TRAPGFER, BOILING + REACTOR, BWP + REPDRT, PSAR + SAFETY MARGIN 
CATEGORY 19

SAFETY ANALYSIS AND DESIGN REPORTS

$18-25885$ \#CONTINUED*

65 PAGES, 5 fIgURES, 2 TABLES, PAGE V-1-1 THRU V-3-6. MARCH 1968. DOCKET 50-319.

THE SUPPRESSION CHAMBER AND DRY WELL ARE NOW STEEL-LINED RE INFORCEO-CONCRETE PRESSURE VESSELS. THE DRY WELL WILL CONSIST OF VERTICAL CYLINDERS AND TRUNCATEO CONES TO RETAIN THE LIGHT-BULB SHAPE, WHILE THE SUPPRESSION CHAMBER CONSISTS OF A TORUS WITH A SOUARE CROSS SECTION. OTHERWISE, SYSTEMS ARE AS BEFORE. DRY-WELL DESIGN IS FOR 62 PSIG/300 F, AND PODL IS 62 PSIG/220 F. THE CONCRETE WILL BE $6 \mathrm{FT}$ THICK, AND THE LINER NOT LESS THAN 0.25 IN. DESIGN LEAK RATE IS $0.5 \%$ VOLUME IOAY AT 62 PSIG. AIR CONDITIONING WILL KEEP AIR AT I35 F IMAX., I5O F) AND $40 \%$ REL. HUMIDITY.

AVAILABILITY - CLEARINGHOUSE FOR FEOERAL SCIENTIFIC AND TECHNICAL INFORMATION, SPRINGFIELO, VIRGINIA, $22151, \$ 3.00$ COPY, \$0.65 MICROFICHE

*CONCRETE + *CONTAINMENT, PRESSURE SUPPRESSION + \#STEEL LINER + BELL (BWR) +

MODIFICATION, SYSTEM OR EQUIPMENT + REACTOR, BWR + REPORT, PSAR

$18-25903 \quad$ ALSO IN CATEGORIES 5 AND 12

BRAY AP + IANNI P + MURRAY JL

GENERAL ELECTRIC COMPANY ANALYTICAL AND EXPERIMENTAL PROGRAMS FOR RESOLUTION OF ACRS SAFETY CONCERNS ATOMIC POWER EOUIPMENT DEPARTMENT, GENERAL ELECTRIC COMPANY, SAN JOSE, CALIFORNIA

$A P E O-5608+.40$ PAGES, 5 FIGURES, 4 TABLES, APRIL, 1968

ACRS REVIEW OF BROWNS FERRY (MAR. 14, 1967) INOICATED THAT ADOITIONAL TESTING OR ANALYSIS WAS REQUIRED. THE TEST OR ANALYSIS PROGRAM IS DESCRIBED FOR THE FOLLOWING - (1) EFFECTS DF FUEL-ROD FAILURE ON ECCS PERFORMANCE, (2) EFFECTS OF FUEL-BUNDLE FLOW BLOCKAGE, (3) VERIFICATION OF FUEL-DAMAGE-LIMIT CRITERION, (4) EFFECTS OF CLADDING TEMPERATURE AND MATERIAL ON ECCS PERFORMANCE, (5) CLOSURE OF MAIN-STEAM-LINE ISOLATION VALVE, (6) TESTS OF DIESEL-GENERATOR PERFORMANCE, (7) STEAM-LINE-SREAK ACCIDENT, AND (8) DEPRESSURIZATION PERFORMANCE OF HPCI SYSTEM.

AVAILABILITY - USAEC, PUBLIC DOCUMENT ROOM

\#ENGINEERED SAFETY FEATURE + \&R AND D PROGRAM + ACCIDENT, LOSS OF CODLANT + ACCIDENT, STEAM LINE RUPTURE + ACRS + AEC QUESTION + BROWNS FERRY (BWR) + CONTAINMENT ISOLATION + CORE SPRAY + FLOW BLOCKAGE + FUEL ELEMENT + GENERATOR, ENGINE + PERFORMANCE LIMIT + SYSTEM OPERABILITY IN ACCIOENT

$18-25904$ ALSO IN CATEGORIES 12 AND 5

EFFECTS OF FUEL ROD FAILURE ON ECCS PERFORMANCE

ATOMIC POWER EQUIPMENT DEPARTMENT, GENERAL ELECTRIC COMPANY, SAN JOSE, CALIFORNIA

APED-5608 +. 4 PAGES, PAGES 2-1 THROUGH 2-5 OF THE GENERAL ELECTRIC COMPANY ANALYTICAL AND EXPERIMENTAL

PROGRAMS FOR RESOLUTION OF ACRS SAFETY CONCERNS, APRIL, 1968

ACRS REVIEW OF BROWNS FERRY VOICED CONCERN FOR EFFECT ON HEAT-TRANSFER EFFECTIVENESS OF ECCS RE SULTING FROM FUEL-CLAO BULGING OR PERFORATION IN LOSS-OF-COOLANT ACCIDENTS. ANALYTICAL AND EXPERIMENTAL PROGRAMS TO RESOLVE THE CONCERN ARE DESCRIBED. FAILURE TEMPERATURES, WITH SINGLE ROD TESTS HAVING GAS-PLENUM PRESSURES FROM 130 TO 1500 PSIG, HERE 1348 TO $1732 \mathrm{~F}$. NIN-ROD-BUNDLE TESTS SHOWED TIIAT GROSS FLOW BLOCKAGE ODES NOT OLCUR AS A RESULT OF MULTI-ROD PERFORATIONS. FULL-SIZE HEATER-BUNDLE TESTS WILL BE PFRFRRMED. ANALYSIS TO BE MADE OF WORST

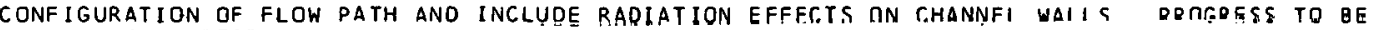
LUMPLEILD IN 1969.

AVAILABILITY - USAEC, PUBLIC DOCUMENT ROOM

\#ACCIDENT, LOSS OF COOLANT + \#SYSTEM OPERABILITY IN ACCIDENT + ACRS + AEC QUESTION + BROWNS FERRY (BWR) + CORE SPRAY + EMERGENCY COOLING CONSIDERATIONS + FAILURE, CLADDING + FLOW BLOCKAGE + PERFORMANCE LIMIT + REACTOR, BWR + SYSTEM CAPABILITY + TEST, PROOF

18-25905 ALSO IN CATEGORY 5

EFFECTS ON FUEL BUNDLE FLOW BLOCKAGE

ATOMIC POWER EQUIPMENT DEPARTMENT, GENERAL ELECTRIC COMPANY, SAN JOSE, CALIFORNIA

APED-5608 +. 4 PAGES, 1 TABLE, PAGES 3-1 THROUGH 3-3 OF THE GENERAL ELECTRIC COMPANY ANALYTICAL ANO

EXPERIMENTAL PROGRAMS FOR RESOLUTION OF ACRS SAFETY CONCERNS, APRIL, 1968

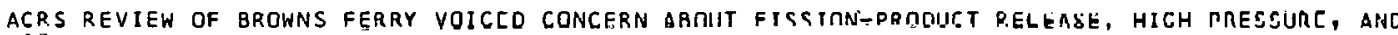
SEOUENTIAL FUEL-ELEMENT FAILURE RESULTING FROM INLET-COOLANT-ORIFICE BLOCKAGE. PROGRAM TO RESOLVE CONCERN EARLY IN 1969 IS DESCRIBED. THE TWO ASPECTS TO BE INVESTIGATED ARE (1) BOILOUT ANO HEATUP FOLLOWING PARTIAL OR COMPLETE FLOW BLOCKAGE AND (2) WATER EXPULSIDN AND PRESSURE-RISE EFFECTS DUE TO OVERHEATING AND REENTRY OF HATER TO THE OVERHEATED PORTION.

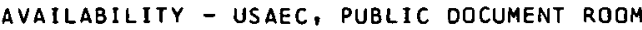

* ACCIDENT, CONSEQUENCES + *FLOW BLOCKAGE + AC.CINENT, LOSS OF FLOW + ACRS + AEC QUESTION + BROWNS FERRY (BWR) + FAILURE, FUEL ELEMENT + FAILURE, SEQUEVTIAL + FLOW ORIFICE + FLOW THEORY AND EXPERIMENTS + R AND D PROGRAM + REACTOR, BHR

18-25906 ALSO IN CATEGORY 5

VERIFICATION OF FUEL DAMAGE LIMIT CRITERION 
CATEGORY 18

SAFETY ANALYSIS AND DESIGN REPORTS

18-25906 *CONTINUED*

ATOMIC POWER EQUIPMENT DEPARTMENT, GENERAL ELECTRIC COMPANY, SAN JOSE, CALIFORNIA

APED-5608 +. 6 PAGES, 3 TABLES, PAGES 4-1 THRQUGH 4-6 OF THE GENEFAL ELECTRIC COMPANY ANALVTICAL AND

EXPERIMENTAL PROGRAMS FOR RESOLUTION OF ACRS SAFETY CONCERNS, APRIL, 1968

ACRS RECOMMENDS THAT TESTS INCLUDE HEAT-GENERATION RATES IN EXCESS OF THOSE CALCULATEO FOR WORST TRANSIENT AND FUEL BURNUPS. GE STATES LIMIT DF 28 HW/FT ICORRESPONDING TO I\% PLASTIC STRAIN) IS ADEQUATELY SUPPORTED BY 6 TO 7 YEARS OF DEVELOPMENT PROGRAMS AND EXPER IENCE. SEVEN HEAVILY (1400 PPM) HYDRIDED ZIRCALOY-CLAD ROOS OPERATING WITH CENTERLINE MELTING WERF TESTED IN GETR AT HEAT-GENERATION RATES UP. TO $22 \mathrm{KW/FT,} \mathrm{WITH} \mathrm{CLAD} \mathrm{STRAINS} \mathrm{UP} \mathrm{TO} 0.6 \%$. NO DETRIMENTAL EFFECTS. TABLES SUMMARIZE PRODUCT-FUEL AND DEVELOPMENT-FUEL IRRADIATION EXPERIENCE, LISTING EXPOSURE, HEAT FLUX, PEAK GENERATION RATE, AND TIME IN CORE.

AVAILABILITY - USAEC, PUBLIC DOCUMENT ROOM

\#CENTERLINE MELTING + \#FUEL BURNUP + \#OPERATING EXPERIENCE SUMMARY + \#PERFQRMANCE LIMIT + ACRS + $\triangle E C$ QUESTION + BROWNS FERRY (BWR) + FAILURE, CLADOING + FUEL ELEMENT + FUEL INTEGRITY + HYORIDE + IRRADIATION TESTING + REACTOR, BWR + ZIRCAI, OY

1 R $\rightarrow 5907$ ALSO IN CATEGORY 5

EFFECTS OF CLADOING TEMPERATURE ANO MATERIALS ON ECCS PERFORMANCE

ATOMIC POWER EQUIPMENT DEPARTMENT, GENERAL ELECIKIC COMPANY, SAN JOSE, CALIFORNIA

APED-5608 +. 4 PAGES, PAGES 5-1 THROUGH 5-4 OF THE GENERAL ELECTRIC COMPANY ANALYTICAL AND EXDERIMENTAL PROGRAMS FOR RESOLUTION OF ACRS SAFETY CONCERNS, APRIL, 1968

ACRS RECOMMENDS TESTING ECCS EFFECTIVENESS AT FUEL TEMPERATURES HIGHER THAN THOSE USED TO DATE. TESTS HAVE BEEN MADE WITH PEAK TEMPERATURES OF $24 C 0 \mathrm{~F}$. GE RESPONDS THAT TESTS WILL BE EXTENDED AFTER DEVELOPING A ZIRCALOY-CLAD ELECTRICAL HEATER AND SUITABLE INSTPUMSNTATION FOR USE AT TEMPERATURE IN EXCESS OF $25 \mathrm{CO}$ F. TEST PROGRAM. IS OESCRIBED.

AVAILABILITY - USAEC, PUBLIC DOCUMENT RDOM

\#CLADOING + *CORE REFLOODING SYSTEM + \#CORE SPRAY +* \#IGH TEMPERATURE + *SYSTEM OPEPABILITY IN ACCIDENT + \#TEST, PROOF + ACCIDENT, LOSS OF COOLANT + $\triangle C R S$ + $\triangle E C$ QUESTION + BROWNS FERRY (BWR) +

EMERGENCY COOLING CONSIOERATIONS + FUEL ELEMENT + INSTRUMENTATION, TEMPERATURE + REACTOR, BWR + STEEL, STAINLESS + ZIRCALOY

18-25908 ALSO IN CATEGORIES 12 ANO 11

CLOSURE OF MAIN STEAM LINE ISOLATION VALVE

ATOMIC POWER EQUIPMENT DEPARTMENT, GENERAL ELECTRIC COMPANY, SAN JOSE, CALIFDRNIA

APED-5608 +. 7 PAGES, 2 FIGURES, PAGES 6-1 THROUGH 6-7 DF THE GENERAL ELECTRIC COMPANY ANALYTICAL AND EXPERIMENTAL PROGRAMS FOR RESOLUTION DF ACRS SAFETY CONCERNS, APRIL, 1968

DESCRIBES THE TEST PROgRAM TO DEMONSTRATE THE PERFORMANCE CAPABILITY DF A FULL-SIZE MAIN-STEAM I SOLATION VALVE CLOSING UNDER STEAM AND TWO-PHASE-MIXTURE FLOH CONDITIONS CAL.CULATED FOR AN EXTERNAL STEAM-LINE BREAK. THE VALVE DES IGN IS A Y TYPE AND USCS AN AIR-CYLINDER OPERATOR. AND CLOSING SPRINGS. TESTS HILL BE CONDUCTED FOR A RANGE OF SIMULATEO BREAK SIZFS ANO STEAM QUANTITIES.

AVAILABILITY - USAEC, PUBLIC DOCUMENT ROOM

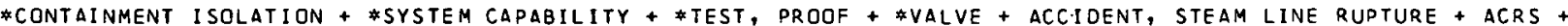
AEC QUESTION + BROWNS FERRY (BWR) + FLOW, TWO PHASE + LEAK + REACTOR, BWR + RESPONSE TIME + SYSTEM OPERABILITY IN ACCIDENT

18-25909 ALSO IN CATEGORIES 12 ANO 10

TESTS OF DIESEL GENERATOR PERFORMANCE

ATOMIC POWER EQUIPMENT DEPARTMENT, GENERAL ELECTRIC COMPANY, SAN JOSE, CALIFORNIA

APED-5608 +. 3 PAGES, PAGES 7-1 THROUGH 7-3 OF THE GENERAL ELECTRIC COMPANY ANALYTICAL AND EXPERIMENTAL

PROGRAMS FOR RESOLUTION OF ACRS SAFETY CONCERNS, $\triangle P K I L 1968$

ACES RECOMMENDED TESTING GENERATORS UNDER SIMULATED EMERGENCY CONDITIDNS. GE RESPONDED THAT TESTS HILL BE CONDUCTED AT THE MANUFACTURERS PLANT TO CONFIRM ADEQUACY WITH RESPECT TO START TIMES, SYNCHRONIZATION, AND SIMULATED LOAOING. TESTS IFOR SINGLE DIESELI ON STARTING RELIABILITY, START TIMES, AND SIMULATEO LOAD-CARRYTNG CAPABILITY WERE ALMOST COMPLETE. TESTS MF STARTING AND SYNCHRONIZING TWO OR MORE DIESELS ARE BEING PLANNED FOR 1968 . SITE TESTS

WILL BE CONDUCTED AND INTEGRATED WITA SPECIFIC PROJECTS.

AVAILABILITY - USAEC, PUBLIC DOCUMENT ROOM

\#GENERATOR, ENGINE + \#RELIABILITY, COMPONENT + \#SYSTEM CAPABILITY + *TEST, SYSTEM DPERABILITY + ACRS + AEC QUESTION + BROWNS FERRY (BWR) + ELECTRIC POWER, SHUTDOWN + EMERGENCY POWER, ELECTRIC + REACTOR, BWR + SYSTEM OPERABILITY IN ACCIDENT

18-25910 ALSO IN CATEGORIES 5 AND 11 REEVALUATION OF STEAM LINE BREAK ACCIDENT

ATOMIC POWER EQUIPMENT DEPARTMENT, GENERAL ELECTRIC COMPANY, SAN JOSE, CALIFORNIA

APEO-5608 *: 2 PAGES, PAGFS $8-1$ THRQUIGH 8-2 OF THE GENERAL ELECTRIC COMPANY ANALYTICAL AND EXPERIMENTAL 
CATEGORY 18

SAFETY ANALYSIS AND DESIGN REPORTS

$18-25910$ \#CONTINUED

PROGRAMS FOR RESOLUTION OF ACRS SAFETY CONCERNS, APRIL, 1968

ACRS RECOMMENDS IN JUNE 15, 1967, VERMONT YANKEE REVIEW FURTHER EVALUATION OF FUEL CLAD TEMPERATURES FOLLOWING A STEAM-LINE BREAK. GE WILL DEVELOP AN IMPROVED ANALYTICAL MODEL, AND ANALYSIS WILL BE COMPLETED IN FALL OF 1968, BASED ON STEAM-LINE-ISOLATION-VALVE CLOSURE IN 3-10 SEC.

AVAILABILITY - USAEC, PUBLIC DOCUMENT ROOM

* ACCIDENT ANALYSIS + \# ACCIDENT, STEAM LINE RUPTURE + ACCIDENT MODEL + ACCIDENT, CDNSEQUENCES + ACRS + $\triangle E C$ QUESTION + BROWNS FERRY (BWR) + CONTAINMENT ISOLATION + REACTOR, BWR + RESPONSE TIME

18-25911 ALSO IN CATEGORY 12

DEPRESSURIZATION PERFORMANCE OF HPCT SYSTEM

ATOMIC POWER EQUI PMENT DEPARTMENT, GENERAL ELECTRIC COMPANY, SAN JOSE, CALIFORNIA

APED-5608 +. 5 PAGES, 3 FIGURES, PAGES 9-1 THROUGH 9-5 OF THE GENERAL ELECTRIC COMPANY ANALYTICAL AND EXPERIMENTAL PROGRAMS FOR RESOLUTION OF ACRS SAFETY CONCERNS, APRIL, 1968

ACRS STATES IOCT. 12, 1967, PEACH BOTTOM 2 AND 3 REPORTI THAT THE FILM CONDENSATION COEFFICIENT USED TO PREDICT THE DEPRESSURIZATION PERFORMANCE OF THE HPCI SYSTEM IS BASED ON EXTRAPOLATION OF AVAILABLE HEAT-TRANSFER OATA AND SHOULO BE SUBSTANTIATEO BY EXPERIMENTS. TEST PROGRAM TO BE COMPLETED IN LATE 1968 IS OESCRIBED. SUBCOOLEO WATER WILL BE INJECTED INTO A CONSTANT-VOLUME, HIGH-PRESSURE, STEAM-WATER SYSTEM. DEPRESSURIZATION RATE, MASS FLOW RATE, ETC., WILL BE MEASUREO.

AVAILABILITY - USAEC, PUBLIC DOCUMENT ROOM

\#BLOWDOWN + \#CORE SPRAY + *HEAT TRANSFER COEFFICIENT + *SYSTEM CAPABILITY + ACCIDENT, LOSS OF COOLANT + ACRS + AEC QUESTION + PEACH BOTTOM 2 AND 3 (BWR) + REACTOR, BWR + SYSTEM OPERABILITY IN ACCIDENT + TEST, PRDOF

$18-25935$

ALSO IN CATEGORY 17

MACPHERSON RE

FAST REACTOR SAFETY CONFERENCE

OAK RIDGE NATI ONAL LABORATORY, OAK RIOGE, TENNESSEE

8 PAGES, TABLE, REFERENCE, NUCLEAR SAFETY, 9(3), PAGES 202-209 (MAY-JUNE, 1968)

BRIEFLY SUMMARIZES THE SESSIONS COVERING 111 CORE MELTOOWN ACCIDENTS, $(2)$ SODIUM BDILING AND SUPERHEATING, (3) INCIDENTS IN REACTORS, AND (4) SAFETY. MALFUNCTIONS IN THE BRS WERE (1) FUEL-ELEMENT LEAKS CAUSED BY HFATER, SHORTING, PLUS AIR IN LEAKACE CAUSING MASSIVE SODIUM OXIDE PLUGGING, AND (2) REACTIVITY PERTURBATIONS DUE TO ENTRAINMENT OF ARGON BY THE SODIUM STREAM. \#PLUGGING OF SUBASSEMBLIES BY OXIDE HAS BEEN DETECTED PRIMARILY BY THE EFFECT ON PRIMARY FLOW. A PANEL DISCUSSION SHOWED THAT ATTENTION IS SWITCHING FROM THE LARGE, LESS PROBABLE ACCIDENT TO THE SMALLER, MORE FREQUENT ACCIDENTS WHICH AFFECT PLANT USE.

\#REACTOR, FAST + \#SAFETY PRINCIPLES AND PHILOSOPHY + ACCIDENT ANALYSIS + ACCIDENT, MAXIMUM CREDIBLF IMCAI + COOLANT QUALITY + FLOW BLOCKAGE + INCIDENT, GFNERAL + REACTOR, LMCR + REVIEW + SODIUM

$18-26082$

SEFOR SUPPLEMENT 17

GENERAL ELECTRIC CO., SAN JOSE, CAL IFORNIA

220 PAGES, FiguRES, TABLES, MAY 1968, DOCKET No. 50-231

RESPONDS TO DRL QUESTIONS DF MAY 3, 1968, REGARDING FACILITY DESIGN, CONTAINMENT, PHYSICS, REACTOR VESSEL, INSTRUMENTATION, REFLECTOR-CONTROL SYSTEM, REFUELING CELL, SAFETY ANALYSES, AND ENVIRONS AND RADIOIMGICAL EFFECTS.

AVAILABILITY - CLEARINGHOUSE FOR FEDERAL SCIENTIFIC AND TECHNICAL INFDRMATION, SPRINGFIELD, VIRGINIA, $22151, \$ 3.00$ COPY, \$0.65 MICROFICHE

AEC QUESTION + REACTOR, LMCR + REPORT, SAR + SEFOR (RE)

$18-26101$

POINT BEACH AMENOMENT 4

WISCONS IN ELECTRIC POWER COMPANY, MIL WAUKEE, WISCONSIN

5 PAGES, TABLES, JUNE 6, 1968, DOCKET NO. 50-301, TYPE--PWR, MFG $\rightarrow$ WEST., AE--BECHTEL

PROVIDES COST DATA IN RESPONSE TO ORL QUESTIONS OF MAY 27, 1968. TOTAL COST IS \$58.65 MILLION FOR NUCLEAR PLANT, $\$ 2.989$ MILLION FOR TRANSMISSION PLANT, ANO \$15.59 MILLION FOR INITIAL CORE. CASH REQUIREMENTS FOR 1968-72 LISTED.

AVAILABILITY--CLEARINGHOUSE FOR FEDERAL SCIENTIFIC AND TECHNICAL INFORMATION, SPRINGFIELD, VIRGINIA 22151

$\$ 3.00$ COPY, \$0.65 MICROFICHE

* ECONOMICS + POINT BEACH 1 ANO 2 (PWR) + REPORT, PSAR 
CATEGORY 18

SAFETY ANALYSIS AND DESIGN REPORTS

$18-26302$

ARGONNE $\triangle D V A N C E D$ RESEARCH REACTOR

ARGONNE NATIONAL LABORATORY, ARGONNE, ILLINOIS

$\triangle N L-7290+.92$ PAGES, 48 FIGURES, 14 TABLES, 6 REFERENCES, PAGES $27-119$ OF THE REACTOR ENGINEERING

DIVISION ANNUAL REPORT, APRIL 1967

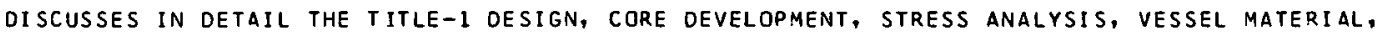
FLOW STUDIES, CORROSION ANO COMPATIBILITY OF MATERIALS, AND SYSTEM TRANSIENTS. DOES NOT REFLECT OESIGN REVISION TO USE HFIR FUEL ELEMENTS OF U308-ALUMINUM CERMET.

AVAILABILITY - CLEARINGHOUSE FOR FEDERAL SCIENTIFIC AND TECHNICAL INFORMATION, SPRINGFIELO, VIRGINIA $22151 \$ 3.00$ COPY, \$0.65 MICROFICHE

\#R ANO D PROGRAM + \#REACTOR DESCRIPTION + AARR (RR) + CORROSION + FLON THEORY ANO EXPERIMENTS +

PRESSURE VESSEL + REACTOR TRANSIENT + STRESS ANALYSIS

18-26515 ALSO IN CATEGORIES 17 AND

QUESTIONAIRE ON PROPOSED WATER-REACTOR SAFETY SCHOOL

IDAHD OPERATIONS OFFICE, AEC

16 PAGES, I.ETTER FROM W. L. GINKEL, JULY 1,1968

PROPOSED SCHOOL (AT NRTS, IDAHO) WUULU PROVIOE 9- TO 12-WEEK SESSIONS (RUNNING SUCESSIVELY FQR FOUR YEARS) TO DISSEMINATE (WITH REDUCED TIME IAG) THE LATEST REACTOR-SAFETY TECHNOLOGY AND PHILOSOPHY TO INDUSTRY, UNIVERSITIES, AND GOVERNMENT. CURRICULUM COULO BE LIFTED ALMOST DIRECTLY FROM THE WATERTREACTOR ACCIDENT TREE AND WOULD INCLUDE BASIC PHENOMENA AND

ANALYTICAL TECHNIQUES. SYLLABUS INCLUDES - BACKGROUND $(6$ HR), NATURE OF REACTOR SAFEGUAROS

( 24 HR), HISTORY OF ACCIDENTS 16 HR), REACTOR SAFEGUARDS (24 HR), REGULATORY AND R-AND-D

FUNCTIONS (6 HR), ACCIDENT ANALYSIS (48 HR), QUALITY ASSURANCE $(12$ HR), CLASS PROJECTS 166 HR), AND. SUMMATION SESSIONS $(28$ HR). TUITION - \$2000-\$400O.

AVAILABILITY - R. F. MAKEUS, EDUICATION OFFICER, USAEC, IDAHO DPERATIONS OFFICE, P. O. BOX 2108 , IDAHO FALLS, IDAHO 83401

* SAFETY PROGRAM + *STAFFING, TRAINING, QUALIFICATION + NRTS + REACTOR, BWR + REACTOR, PWR + REACTOR, WATER

$18-26563$

PRAIRIE ISLAND 1 AND 2 CONSTRUCTION PERMIT

NORTHERN STATES POWER COMPANY

6 PAGES, CONSTRUCTION PERMITS CPPR-45 AND -46. LETTER TO D. R. MCELROY FROM P. A. MORRIS. JUNE 26 , 1968.

DOCKET 50-282 AND 50-306. TYPE--PWR, MFG--WEST., AE--PIONEER SERV.

ALLOWS CONSTRUCTION OF TWO 1650-MW TH PWRS LOCATEO NW OF RED WING, MINNESOTA.

AVAILABILITY -- PUBLIC DOCUMENT ROOM, WASHINGTON, D.C.

\#CONSTRUCTION PERMIT PROCESS + PRAIRIE ISLANO 1 AND 2 (PHR) I REACTOR, PWR.

18-26586 ALSO IN CATEGORY 5

TWISTED TAPE BOILING WATER REACTOR

ALIGENEINE ELEKTRICITAET'S-GESELLSCHAFT, FRANKFURT AM MAIN, WEST GERMANY

EUR-3651 +. 109 PAGES, REFERENCES, FINAL REPORT, JULY 1965-SEPTEMBER, 1966, SOCIETE NATIONALE D CTUDE ET DE CONSTRUCTION DE MOTEURS D AVIATION, SURESNES (FRANCE), SEPTEMBER 15, 1967

AN OUT-OF-PILE EXPERIMENT WAS CONDUCTED ON A 9-ROD TWISTED-TADE BUNDLE. NO FRETTING CORROSION WAS UBSERVEO: THERMAL TESTS WERE PERFORMED, AND $A$ ROD SURFACF TFMPERATURE RISE WAS DETECTED AT IHE OUTLET BUT COULD NOT BE CORRELATED WITH THE LOCATION OF BIJR.NOUT. DISCUSSES PARAMETRIC AND ECONOMIC STUDIES, PLUS FABRICATION OF A PROTOTYPE FUEL BUNOLE.

AVAILABILITY - AEC DEPOSITORY LIBRARIES IN THE U.S. AND OVERSEAS

\#HEAT TRANSFER AUGMENTATION + \#R AND D PROGRAM + BURNOUT HEAT FLUX + CORROSION + ECONOMICS + EURATOM + FLOW THEORY AND EXPERIMENTS + FRANCE + GERMANY + HEAT TRANSFER EXPERIMENT +

OUT DF PILE LOOPS ANO EXPERIMENTS + REACTOR, BWR

18-26589 ALSO IN CATEGORIES 17 AND 5

BANNELLA, R

BEHAVIOR OF GARGILIANO REACTOR CORE IN SIMULATED CYCLE AT INCREASED POWER

ENTE NAZIONALE PEK L ENERGIA ELETTRICA, ROME, ITALY

EURAEC-1956 + EUR-3760 +. 38 PAGES, SPECIAL REPORT NO, 4, CONTRACT 101-63-11-RDI, NOVEMBER, 1966

USING PLANT COMPUTER, POWER OF 620 MWT $1122.46 \%$ OF RATED POWER OF $50 S .3$ MWTI WAS STUDIEO. RESULTS INDICATE CORE CAN OPERATE AT THAT LEVEL WITHOUT EXCEEDING THE LIMIT OF THERMAL FLUX OR BURNOUT RATIO. HIWEVER, IMPROVEMENT IN FUEL ELEMENT REQUIRED. THE PURPOSE OF STUDY WAS TO FIND THE SHAPE OF LIMITING FUEL PARAMETERS - OTHER COMPONENTS ARE DISREGAKDED. 
18-26589 \#CONTINUED*

AVAILABILITY - CLEARINGHOUSE FOR FEDERAL SCIENTIFIC AND TECHNICAL INFORMATION, SPRINGFIELD, VIRGINIA $22151, \$ 3.00$ COPY, S0.65 MICROFICHE

\#PERF ORMANCE LIMIT + \#REACTOR POWER + *THEORETICAL INVESTIGATION + EURATOM + GARIGLIANO (BWR) + HEAT TRANSFER ANALYSIS + POWER UPRATING + REACTOR, BWR

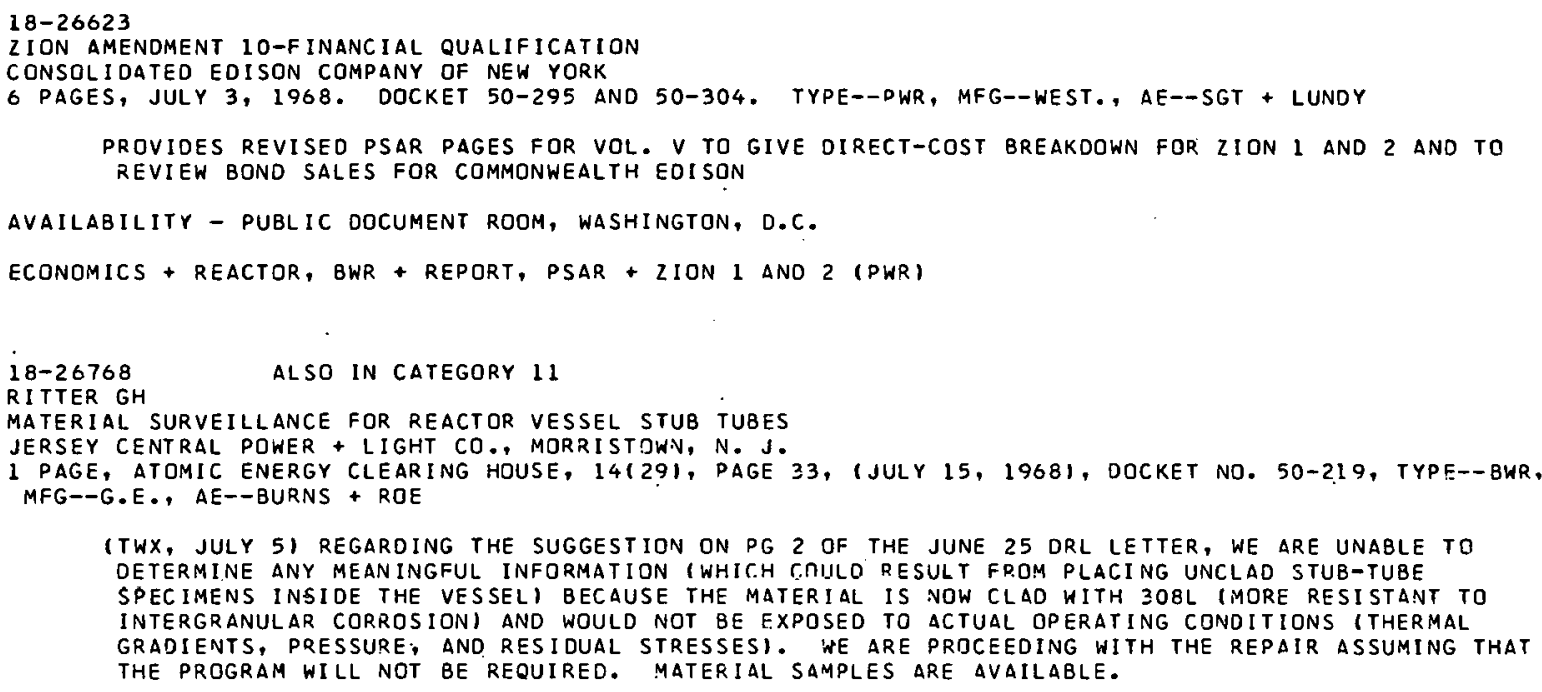

\#PIPING + \#SURVEILLANCE PROGRAM + FAILURE, PIPE + OYSTER [REEK I (BWR) + REACTOR, BWR

$18-26966 \quad$ ALSO IN CATEGORY 6
18

FLUHARTY RG + SIMPSON FB + RUSSELL GJ + MORRIS RH

A PROPOSAL FOR A REPETITIVELY PULSED TEST FACILITY (RPTF)

I DAHO NUCLEAR CORP., IDAHO FALLS

IN-1149+. 119 PAGES, FIGURES, TABLES, RËFERENCES, DECEMBER 1967

STUDY TO BE COMPLETED BY JULY 1968, DESIGN BY 1971, AND CONSTRUCTION COMPLETION IN 1973.

REACTOR IS A SMALL PLUTONIUM REACTOR (3 TO 10 MH AVERAGE POWER) DULSED BY ROTATING FUEL OR A CHARGED-PARTICLE NEUTRON SOURCE AT O TO 200 PULSES/SEC, WITH POWER PEAKS OF 3000 MW,

PRODUC ING NEUTRON FLUX INTENSITY PEAKS OF 1O(18TH). \# \#ESCRIBES REACTOR USEFULNESS AS A

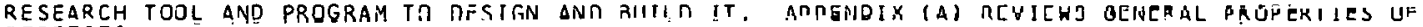
REPETITIVELY PULSED SYSTEMS, IF) MODERATOR OPTIMIZATION.

AVAILABILITY - CLEARINGHOUSE FOR FEDERAL SCIENTIFIC ANO TECHNICAL INFORMATION, SPRINGFIELD, VA. 22151 , $\$ 3.00$ COPY, \$0.65 MICROFICHE

*DESIGN STUDY + \#IRRADIATION FACILITY + PLUTONIUM + REACTOR KINETICS + REACTDR, PULSED

$18-26972$

SALEM AMENDMENT 9

PUBLIC SERVICE ELECTRIC AND GAS

AMENOMENT 9 TO SALEM LICENSE APPLICATION, (DOCKET 50-272 AND 50-311), TYPE--P'NR, MFG--WEST., AE--PUBLIC

SERVICE OF N.J. MAY 21, 1968.

PROVIDES REVISED PSAR PAGES AND ANSWERS SEVERAL ORAL DUESTIONS.

AVAILABILITY - CLEARINGHOUSE FDR FEDERAL, SCIENTIFIC ANO TECHNICAL INFORMATION, SPRINGFIELO, VIRGINIA, $22151, \$ 3.00$ COPY, \$0.65 MICRQFICHE

AEC QUESTION + REACTOR, PWR + REPORT, PSAR + SALEM 1 ANO 2 (DWR)

$18-27103$

U. OF MO. RESEARCH REACTOR FACILITY HAZARDS SUMMARY REPORT

UNIVERSITY OF MISSOURI, COLUMBIA, MISSOURI

360 PAGES, FIGURES, TABLES, REFERENCES, JULY 1, 1955

DESCRIBES REACTOR WHICH USES U-AL ALLOY FUEL CLAO WITH AL, POWER OF 5 MWT, WITH A $1.5-I N$. FLUX TRAP IN CENTER OF CORE, BE REFLECTOR, ANO REFLECTOR COVTROLLED WITH 4 BORAL PLATES. ONE STAINLESS-STEEL PLATE IS USED AS REGULATING ROD. CONTAINMENT IS POUPED CONCRETE WALLS. THE MCA IS BOILING AND EXPULSION OF STEAM AND WATER, RESULTING IN IO\% MELTDOWN AND PARTIAL 
CATEGORY 18

SAFETY ANALYSIS AND DESIGN REPORTS

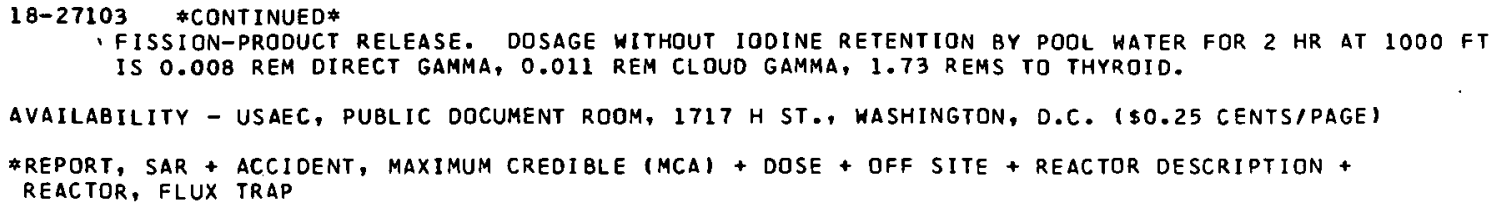

AN OFFICIAL AEC STATEMENT SAYS THAT ALTERNATE PLANS FOR A NUCLEAR POWER AND DESALTING PLANT FOR SOUTHERN CALIFORNIA ARE BEING EXAMINED BECAUSE ALL PARTICI PANTS AGREE THAT THE 8JLSA ISLAND PROJECT IS NOT ECONOMIC AT $\$ 765$ MILLION. PARTICIPANTS AGREED THAT CONCEPT SHOULD BE CONTINUED AND WILL EXPLORE MEANS TO RECONSTITUTE IT ON A MORE ECONDMIC BASIS.

\#ECONOMICS + BOLSA ISLAND + REACTOR, DESALINATION

18-27297 ALSO IN CATEGORY 11

OXIDATION OF PRESTRESSING TENOONS AT ROBINSON 2

CAROL INA POWER + LIGHT CO., RALEIGH, N. C.

1 PAGE, ATOMIC ENERGY CLEARING HOUSE 14(31), PAGE 27, (JULY 29, 1968), DOCKET 50-261, TYPE--PWR, MFG-WEST., AE--EBASCO

(LETTER, JULY 16) AN UNANTICIPATED MINOR AMOUNT OF OXIDATION WAS FOUND ON THE LOWER SECTION OF VERTICAL PRESTRESSING TENDONS SURFACES. TENOONS ARE SATISFACTORY, BUT CORROSION PROTECTION WILL BE IMPROVED. ATTACHED REPORT DESCRIBES WORK TO DETERMINE CAUSES OF CORROSION, TO VERIFY THAT TENDONS ARE STILL SATISFACTORY, AND TO DESCRIBE THE IMPRDVED CORROSION PROTECTION.

\#CONCRETE, PRESTRESSED + \#CORROSION + \#STEEL + CONTAINMENT CONSTRUCTION +

CONTAINMENT, CORROSION PROTECTION + OPERATING EXPERIENCE + REACTOR, PWR + ROBINSON 2 (PWR)

18-27298 ALSO IN CATEGORY 11

CONTAINMENT VESSEL CRACKS MAY EXIST AT MILLSTONE

MILLSTONE POINT CO., HARTFORD, CONN.

1 PAGE, ATOMIC ENERGY CLEARING HOUSE 14131), PAGE 28, (JULY 29, 1968), DJCKET 50-245, TYPE--BWR, MFG- -G.E., AE--EBASCU

(LETTER, JULY 17) REQUESTS DATA ON 26 ITEMS. COMPLIANCE STATES THAT CRACKS HAVE BEFN FOUNO IN WELDS ON INSERT PLATES ON CONTAINMENT VESSELS SIMILAR TO MILLSTONE VESSEL. WE UNDERSTAND THAT YOU BELIEVE THAT SIMILAR CRACKS ARE NOT PRESENT. WE LACK DETAILEO INFORMATION TO SUPPORT YOUR POSITION AND THEREFORE REQUEST A DETAILED REPORT.

\#CONTAINMENT LINER + \#FAULT + \#WELS + MILLSTONE POINT (BWR) + OPERATING EXPERIENCE + REACTOR, BWR

$18=27299$

AI SO IN CATEGRBY?

SEISMICITY OF VERMONT YANKEE

VERMONT YANKEE NUCLEAR POWER CORP

2 PAGES, ATOMIC ENERGY CLEARING HOUSE 14131), PAGE 29 AND 30, 1 JULY 29, 19681, DOCKET 50-27!, TYPE--BWR,

$M F G--G . E, \triangle E--E B A S C U$

(LETTER, JULY 10) YOUR LETTER OF MAR, 8, 1968, HAS NOT CLEARED UP MY CONCERN REGAROING SEISMICITY OF VERMONT YANKEE, 4 MILES AWAY. YOUR EXPLANATION OF COMPATABILITY IBETWEEN NO VERIFIED RECORD DF SEISMIC ACTIVITY WITHIN 45 MILES, AND NO DEMONSTRABLE CONTROLSI IS A PLAY ON WORDS, A DISTINCTION WITHOUT A DIFFERENCE. IT MATTERS NOT WHERE CONTROLS MAY CONCENTRATE EFFECTS IF (AS HAPPENED IN MY HOME 4 MILES AWAY) AN EARTHOUAKE EFFECT IS VIOLENT ENOUGH TO CRACK HALLS AND CEILINGS AND TO CAUSE DOOR TO SPRING OPEN SUDDENLY FOR A LONG TIME

THEREAFTER. WHAT PROGRESS HAS BEEN MAOE ON PROVIDING ACRS WITH INTERIM GUIDELINES FDR 
18-27299 *CONTINUED*

REACTOR DESIGN AGAINST EARTHQUAKES.

*EARTHQUAKE ENGINEERING + ACRS + EARTHQUAKE RECORDS + RADIATION, PUBLIC EDUCATION/ACCEPTANCE + REACTOQR, BWR + VERMONT YANKEE (BWR)

$18-27333$

BILLURIS G + PFLASTERER R + HOLFE B

THE SEFOR EXPERIMENTAL PROGRAM AND ITS INFLUENCE ON REACTOR DESIGN

GENERAL ELECTRIC COMPANY, SUNNYVALE, CALIFORNIA

37 PAGES, 3 FIGURES, 2 TABLES, 19 REFERENCES, FROM THE INTERNATION CONFERENCE ON THE SAFETY DF FAST NUCLEAR REACTORS, SEPTEMBER, 1967

PRIMARILY A OESCRIPTION OF ROD OSCILLATOR ANO STEP REACTIVITY (NEAR SI) TESTS, THE FEATURES INCORPORATED INTO SEFOR AND ITS DATA ACQUISITION SYSTEM, AND THE APPROACH TO ENSURE SAFETY DURING TRANSIENT TESTS.

* DOPPLER COEFFICIENT + \#OSCILLATOR, REACTIVITY + DATA PROCESSING + IN CORE MEASUREMENT + R AND D PRCGRAM + REACTOR, FAST + SAFETY REVIEW + SEFOR (RE)

$18-27342$

FINANCIAL QUALIFICATIONS

YANKEE ATOMIC POWER COMPANY, BOSTON, MASSACHUSETTS

58 PAGES, FIGURES, TABLES, AMENDMENT 13 TO THE LICENSE APPLICATION FOR THE MAINE YANKEE ATOMIC POWER

STATION, JULY 16, 1968 , DOCKET NO. 50-309, TYPE--PWR, MFG-C.E., AE--STONE + WEBSTER

UPDATES THE LICENSE APPLICATION ITSELF, SHOWING OWNERSHIP AND COST DETAILS.

AVAILABILITY - CLEARINGHOUSE FOR FEDERAL SCIENTIFIC ANO TECHNICAL INFORMATION, SPRINGFIELD, VA. 22151 $\$ 3.00$ COPY, \$0.65 MICROF ICHE

MAINE YANKEE (PWR) + REPORT, PSAR

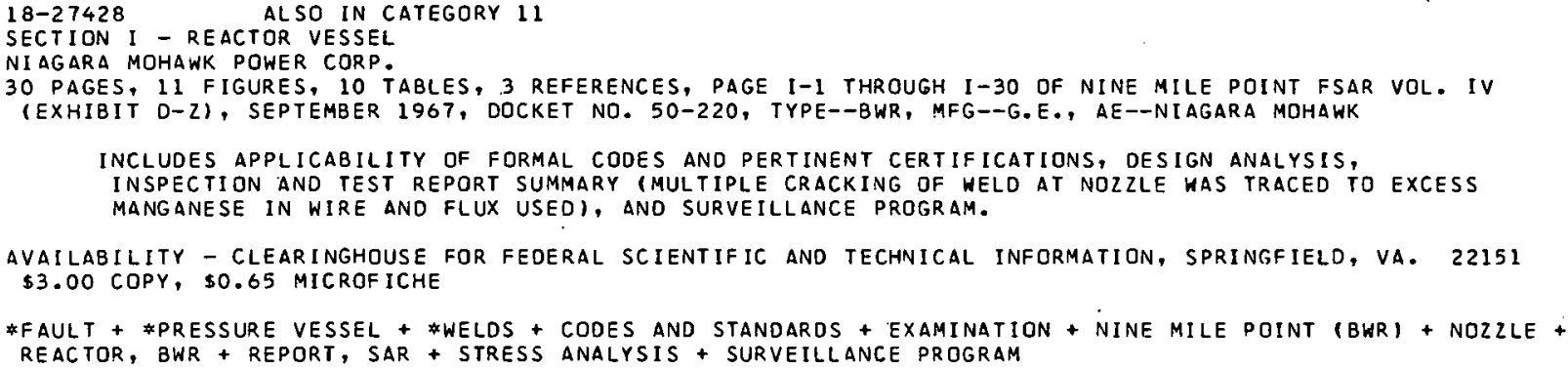

AVAILABILITY - CLEARINGHOUSE FOR FEDERAL SCIENTIFIC AND TECHNICAL INFORMATION, SPRINGFIELD, VA. 22151 $\$ 3.00$ COPY, \$0.65 MICROFICHE

\#CONTAINMENT, PRESSURE SUPPRESSION + CODES AND STANDAROS + CONTAINMENT DESIGN + EXAMINATION +

MISSILE GENERATION AND PROTECTION + NINE MILE POINT (BWRI + REACTOR, BWR + REPORT, SAR + STRESS ANALYSIS

18-27430 ALSO IN CATEGORY 12

SECTION III - ENGINEERED SAFEGUARDS

NIAGARA MOHAWK POWER CORP.

21 PAGES, 21 FIGURES, 8 REFERENCES, 18 TABLES, PAGES III-1 THROUGH III-21 OF NINE MILE POINT FSAR VOL. IV

(EXHIBIT D-2) SEPTEMBER 1967, DOCKET NO. 50-220, TYPE--BWR, MFG--G.E., AE--NIAGARA MOHAWK

DESCRIBES CONTAINMENT AND CORE SPRAY SEISMIC ANALYSIS AND STRESS REPORT, CONTAINMENT SPRAY

SYSTEM, (CONDENSATION EFFECTIVENESS, SPRAY NOZZLE TESTS), AND VENDOR TESTS ANO CERTIEICATIONS.

AVALLABILITY - CLEARINGHOUSE FOR FEDERAL SCIENTIFIC AND TECHNICAL INFORMATION, SPRINGFIELD, VA. 22ISI

$\$ 3.00$ COPY, $\$ 0.65 \mathrm{MICROFICHE}$ 
CATEGORY 18

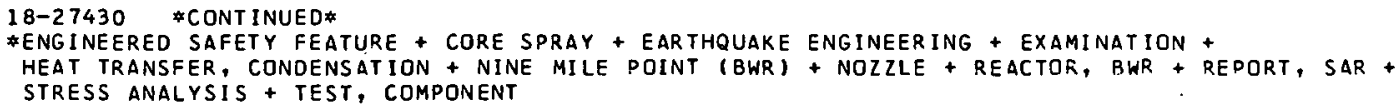

REVIEW OF CB AND I CONTAINMENT ASME STRESS REPORT AND OF NOZZLE EXTENSION BELLOWS BY TEMP. FLEX. TMR CONCLUDES ANALYSIS IS ADEQUATE FOR FUNCTION BUT NOT ADEQUATE TO ESTABLISH ASME III REQUIREMENTS BECAUSE OF INTERPRETATION OF PARAGRAPH N-414. DISAGREEMENT IS IN STRESS DISCONTINUITY REGIONS AT VESSEL OPENINGS, WHERE CB AND I USEO FORMULA (ALLOWABLE WHERE ONLY PRESSURE STRESS OCCURSI WHILE TMR BELIEVES AN ANALYSIS IS NEEDED.

AVAILABILITY - CLEARINGHOUSE FOR FEDERAL SCIENTIFIC AND TECHNICAL INFORMATION, SPRINGFIELD, VA. 22151 $\$ 3.00$ COPY, \$0.65 MICROFICHE

*CODES AND STANDAROS + \#CONTAINMENT DESIGN + \#REVIEH + CONTAINMENT EQUIPMENT HATCH + CONTAINMENT PENETRATION, PIPE + CONTAINMENT, PRESSURE SUPPRESSION + NINE MILE POINT (BHR) + REACTOR, BWR + REPORT, SAR + STRESS ANALYSIS

$18-27475 \quad$ ALSO IN CATEGORY 10

ACRS REPORT ON MAINE YANKEE

AEC, OIVISION RF RFACTOR LICENSING

4 PAGES, LETTER TO G.T. SEABORG, USAEC, JULY 19, 1968, DOCKET 50-309, TYPE--PWR, MFG--C.E., $\triangle E--S T O N E+$ WEBSTER

ACRS APPROVES CONSTRUCTION, CALLING ATTENTION TO PREVIOUS STATEMENTS ON LARGE WATER CODLED POWER REACTORS. ACRS BELIEVES OFF-SITE ELECTRICAL POWER SUPPLY TD ENGINEERED, SAFEGUARDS SHOULO BE MOOIFIED SO NO SINGLE FAILURE HILL PREVENT POWER AVAILABILITY. SUGGESTS REGULATORY STAFF REVIEW CONTROL ROD DRIVE POWER SUPPLY SINCE DESIGN NOT COMPLETED.

AVAILABILITY - USAEC PUBLIC DOCUMENT ROOM, $1717^{\circ}$ H ST., WASHINGTON, D.C. 20545 (\$0.25 CENTS/COPY)

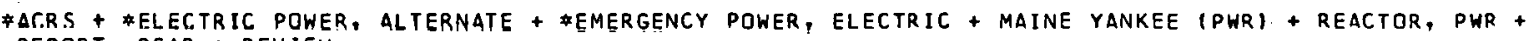
REPORT, PSAR + REVIEW

$18-27479$

AMENDMENT 1 TO QUAD CITES CONSTRUCTION PERMIT

COMMONWEALTH EOISON COMPANY, IOWA-ILLINOIS GAS AND ELECTR.IC COMPANY

CPPR $23+24+$ +. 9 PAGES, JULY 18, 1968, DOCKET 50-254/265, TYPE--BWR, MFG--G.E., AE--SGT + LUNDY

CHANGE ONLY REFLECTS OWNERSHIP CHANGE TO 75 PERCENT BY COMMONHEALTH EDISON AND 25 PERCENT BY IOWA-ILLINOIS GAS AND ELECTRIC CO.

AVAILABILITY - USAEC PUBLIC DOCUMENT RODM, 1717 H ST., WASHINGTON, D.C. 20545 (\$0.25 CENTS/COPY)

C.ONSTRIICTION PERMIT PROCESS + QUAD CITIES I AND 2 (BWR) + REACTOR, BHR

18-27488 ALSO IN CATEGORY 5

HEALZER JM + HENCH JE + JANSSEN E + LEVY S

DESIGN BASIS FOR CRITICAL HEAT FLUX CONDITION IN BOILING HATER REACTORS

GENERAL ELECTRIC, SAN JOSE, CALIF.

APED-5286 +. 50 PAGES, FIGURES, TABLES, 11 REFERENCES, SEPTEMBER 1966, D0CKETS 50-259/260, TYPE--8HR, MFG--G.E., AE--TVA 
CATEGORY 18

18-27488 \#CONTINUEO*

A NEW DESIGN BASIS FOR PREDICTING THE CRITICAL HEAT FLUX IN BOILING WATER REACTORS WAS

DEVELOPED. THE DESIGN BASIS IS FORMULATED UPON EXTENSIVE TESTS WITH MULTIROD GEOMETRIES WHICH ACCURATELY DUPLICATE THE REACTOR FUEL ASSEMBLY FLOW CONDITIONS. THE FEST RESULTS WERE EMPLOYED TO FORMULATE LIMIT LINES WHICH FALL BELOW THE EXPERIMENTAL DATA. AN ANALYTICAL MODEL TO PREOICT LOCAL FLOW AND STEAM QUALITY IN CDMPLEX GEOMETRIES WAS ALSO DEVELOPED. THE MODEL WAS APPLIED TO THE REACTOR FUEL ASSEMBLIES AND TO THE MULTIROD TEST SECTIONS TO SHOW THAT THE TEST SECTIONS SATISFACTORILY MOCKUP THE IN-REACTOR BEHAVIOR.

AVAILABILITY - USAEC PUBLIC DOCUMENT ROOM, 1717 H ST., WASHINGTON, 0.C., 20545 (\$O.25 CENTS/COPY)

\#HEAT FLUX, CRITICAL + BROWNS FERRY (BWR) + REACTOR, BWR

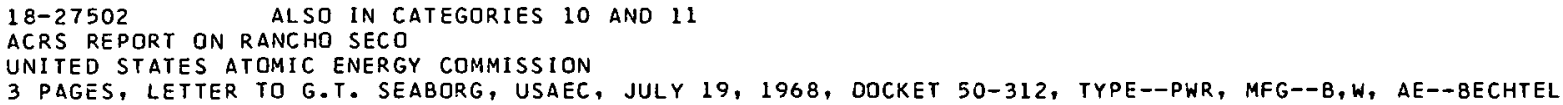

ACRS APPROVES CONSTRUCTION, CALLING ATTENTION TO PREVIOUS STATEMENTS ON LARGE HATER CODLED POWER REACTORS. SUGGESTS FURTHER ANALYSIS OF FAST FLUX DAMAGE TO REACTOR VESSEL, AND ADEQUACY OF VESSEL SURVEILLANCE PROGRAM. ACRS REITERATES BELIEF CONTROL AND PROTECTION INSTRUMENTATION SHOULD BE INDEPENDENT OF COMMON FAILURE MODES. APPLICANT ANO REG. STAFF SHOULD REVIEW FOR SYSTEMATIC, NONRANDOM CONCURRENT FAILURES OF REOUNDANT DEVICES NOT CONSIDERED IN THE SINGLE FAILURE CRITERION.

AVAILABILITY - USAEC PUBLIC DOCUMENT ROOM, 1717 H ST., WASHINGTON, D.C., 20545 (\$\$O.25 CENTS/COPY)

\#ACRS + \#FAILURE, SIMULTANEOUS + \#PLANT PROTECTIVE SYSTEM + \#PRESSURE VESSEL + \#REVIEW + BRITTLE FRACTURE + RANCHO SECO (PWR) + REACTOR, PWR + REPORT, PSAR + SINGLE FAILURE CRITERION + SURVEILLANCE PROGRAM

$18-27503$

BROWNS FERRY 3 CONSTRUCTION PERMIT

TENNESSEE VALLEY AUTHORITY

CONSTRUCTION PERMIT CPPR-48 +. 3 PAGES, JULY 3, 1968, DOCKET 50-296, TYPE--BWR, MFG--G.E., AE--TVA

AUTHORIZES CONSTRUCTION OF A 3293-MWTH BWR, COMPLETION DATE FEB.-OCT. 1972

AVAILABILITY - USAEC PUBLIC DOCUMENT ROOM, $1717 \mathrm{H}$ ST., WASHINGTON, D.C. 20545 (\$O.25 CENTS/COPY)

*CONSTRUCTION PERMIT PROCESS + BROWNS FERRY 3 (BWR) + REACTOR, BWR

$18-27562$

COOK AMENDMENT

INDIANA + MICHIGAN ELECTRIC COMPANY

300 PAGES, FIGURES, TABLES, AMENOMENT 2 (VOL. IV OF PSAR) TO COOK LICENSE APPLICATION, JUNE 6, 1968, DOR.KFT $50-315 / 316$

ANSWERS 65 DRL QUESTIONS (IN A LETTER OF MAY 22, 1968), PROVIDES SUPPLEMENTARY INFORMATION (BASED ON DISCUSSIONS WITH AEC STAFF IN APRIL ANO MAY), aNU PROVIDES CORRECTED PSAR PAGES.

AVAILABILITY - CLEARINGHOUSE FOR FEOERAL SCIENTIFIC ANO TECHNICAL INFORMATION, SPRINGFIELO, VIRGINIA $22151, \$ 3.00$ COPY, \$0.65 MICROFICHE

AEC QUESTION + COOK I ANO 2 (PWR) + REACTOR, PWR + REPORT, PSAR

18-27614 ALSO IN CATEGORIES 10 AND

DRL QUESTIONS EMERGENCY SIGNALS ANO POWER

U.S. ATOMIC ENERGY COMMISSION

3 PAGES, LETTER to M. H. PRATt FROM P. A. MORRIS, JULY 31, 1968, DOCKET 50-220, TYPE--BHR, MFG--G.E. AE - NI AGARA MOHAWK

DRL ASKS 7 SPECIFIC QUESTIONS, I1) ABILITY OF OFFSITE POWER, WITH A FAULT IN OUTSIDE SYSTEM, TI SAFFIY SHIJTOOWN PLANT. (2) ABILITY OF OFFSITE POWER TO SATISFY CRITERION 39 DESPITE 2 MIN DISCONNECT DELAY. (3) DC POWER FOR SWITCHYARD. (4) DESIGN AGA INST ELECTRICAL CABLE FIRE. (5) CONSEQUENCES OF LOSS OF STATION AIR OR INSTRUMENT AIR. (6) DIESEL START FROM SIGNALS OTHER THAN LOW VOLTAGE, E.G., UPON CODLANT INJECTION. 171 DISCUSS ADEQUACY OF CORE SPRAY ACTUATION SIGNALS. DISCUSS LACK OF DIVERSITY FOR ISOLATION VALVE ACTUATION.

AVALLABILITY - USAEC, PUBLIC DOCUMENT ROOM, WASHINGTON, D. C.

* PLANT PROTECTIVE SYSTEM + ACCIDENT; LOSS OF POWER + AEC QUESTION + ELECTRICAL CONDUCTION + FIRE + NINE MILE POINT (BWR) + PNEUMATIC SYSTEM + REACTOR, BWR

18-27615 ALSO IN CATEGORIES 17 AND 2

ACRS REPORT ON ZION 1 AND 2 
18-27615 \#CONTINUED*

U.S. ATOMIC ENERGY COMMISSION

8 PAGES, LETTER TO G.T. SEABORG (AEC PRESS RELEASE 2-178), AUGUST 24, 1968, 00CKETS 50-295/304, TYPE--PWR; MFG--WEST., AE--SGT + LUNDY

2ION IS LARGEST REACTOR TO DATE IN A RELATIVELY HIGH POPULATION DENSITY. REACTOR CAVITY FLOODING FOLLOWING A LONGITUDINAL SPLIT IN THE REACTOR. VESSEL MAY BE INSTALLED FOLLOWING STUDY OF VESSEL FAILURE PROBABILITY FROM THERMAL SHOCK FOLLOWING CORE FLOOOING ACTION. CONTROL AND SAFETY SIGNALS SHOULD BE INDEPENDENT. CONTAINMENT SPRAY SHOULD HAVE A FULL TEST. * \# IN 3 PAGES OF REMARKS BY OKRENT, HE OISCUSSES VESSEL SPLIT PROGLEM. RECOMMENDS (FDR HIGH POPULATION DENSITIESI ADOITIONAL DESIGN CONSERVATISM AND QUALITY ASSURANCE, WELL DEFINED P. AND FOR SAFETY ISSUES NOT RESOLVED AT CONSTRUCTION PERMIT STAGE, EXTRA MARGIN IN ENGINEERED SAFETY FEATURES IN LIEU OF A DEMONSTRATION UNDER ACCIDENT CONDITIDNS, AND MORE STUDY TO REDUCE PROBABILITY OF SMALL ACCIDENTAL RELEASES.

USAEC, PUBLIC DOCUMENT ROOM, $1717 \mathrm{H} \mathrm{ST.,} \mathrm{WASHINGTON,} \mathrm{D.C.} \mathrm{20545.} \mathrm{(25} \mathrm{CENTS/PAGE)}$

* FAILURE, PRESSURE VESSEL + ACRS + CONTAINMENT SPRAY + CORE REFLOODING SYSTEM + REACTOR, DWR + REPORT, PSAR + REVIEW + SAFETY MARGIN + TEST, PREOPERATIONAL + TEST, PRODF + THERMAL MECHAVICAL EFFERT + ZION 1 AND 2 (PWR)

18-27620 ALSO IN CATEGORIES 16 ANO

RUSSELVILLE SUPPLEMENT 6 - TORNADO ANALYSIS

ARKANSAS POWER ANU LIGHT COMPANY

8 PAGES, 12 REFERENCES, PAGES $1-8$ OF SUPPLEMENT 6 TO THE APPLICATION FOR RUSSELVILLE LICENSES IDOCKST $50-313)$ JULY 11,1968

PROVIDES REVISEO PSAR PAGES AND (RESPONOING TO INFORMAL DRL QUESTIDNS) JUSTIFICATION OF TORNADO DESIGN CRITERIA AND BEHAVIOR OF SPENT FUEL POOL DURING TORNADD. OESCRIBES BEST OBSERVATIONAL DATA FOR WIND VELOCITY IUSE $300 \mathrm{MPH} B R O A D$ FRONT WIND INSTEAD DF 200 MPH OBSERVATIONAL DATA FOR WIND VELOCITY (USE 300 MPH BROAD FRONT WIND INSTEAD OF 200 MPH
VORTEX), PRESSURE DROP $(1.7$ PSI/4 SECI, WATER LOSS FROM POOLS AND WELLS 12 FT MOUND OF WATER APPEARS FROM LOW PRES SURE, SPRAY AND SUCKING DISPLACE WATER, SURVEY REQUESTED IN PILSRIM STATION REVIEW WILL BE COMPLETED SEPT. 1962 BUT SO FAR RESULTS NEGATIVEI, AND MISSILES IONLY LIGHT WEIGHT MISSILES WDULD REACH R.EFUEL ING FLONR 50 FT ABOVE GRADE, MISSILES FROM REFUFLING FLDOR ARE MOSTLY SIDING ANO HANO CARTSI.

USAEC, PUBLIC DOCUMENT ROOM, 1717 H ST., WASHINGTON, D.C. 20545 (25 CENTS/PAGE)

* DESIGN CRITERIA + \#DESTRUCTIVE HIND + \#FUEL STORAGE + BIBLIOGRAPHY + CONTAINMENT DESIGN + MISSILE GENERATION AND PROTECTION + PRESSURE TRANSIENT + PRESSURE, SUBATMOSPHERIC + REACTOR, PWR + REPORT, PSAR

$18-27745$

BROWNS FERRY 3 AMENDMENT 4

TENNESSEE VALLEY AUTHORITY, CHATTANOOGA, TENNESSEE

33 PAGES, FIGURES, TABLES, AFRIL 5, 1268, DOCKET NO, 50-29\%, TYPF--RWR, MFG--G.E., AE--TVA

INFORMATION IN RESPONSE TO AEC COMMENTS OF MARCH 28, 1968, INCLUDES (2) PUMP NPSH FOLLOWING LOSS OF COOL ANT ACCIOENT, (3) WATERLIGHT SEALING OF SAFETY FEATURE PUMP ROOMS, (4) OIFSFI. GENERATOR LOADS, OPERATION AND LOAD REJECTION, (5) SEISMIC DESIGN OF THE TORUS.

USAEC, PUBLIC DOCUMENT ROOM, $1717 \mathrm{H} \mathrm{ST.,} \mathrm{WASHINGTON,} \mathrm{D.C.} 20545$ (25 CENTS/PAGE)

*AEC QUESTION + BROWNS FERRY 3 (BWR) + REACTOR, BWR + REPORT, PSAR

$18-27832$

BRUNSWICK STEAM ELECTRIC PLANT UNITS 1 + 2 PRELIMINARY SAFETY ANALYSIS REPORT, VOLUME I CAROLINA POWER + LIGHT COMPANY

450 PAGES, FIGURES, TABLES, JULY 1968 , DOCKET 50-324/325

TWO 2436 MWTH 847 MWE 8WRS 18 MILES S OF WILMINGTON, N. C., ON CAPE FEAR, FOR 1973 AND 74 OPERATION. 105\% TURBINE BYPASS ANO SCRAM OF $10 \%$ OF THE ROOS IMPQOVES LLOAD REJECTION. VDLUME I CONTAINS SECT. II (SITE AND ENVIRONS), III (REACTOR CORE), IV (REACTOR COOLANT SYSTEM); V (PLANT STRUCTURE ANO CONTAINMENT), AND VI (ENGINEERED SAFETY FEATURE).

AVAILABILITY - USAEC PUBLIC DOCUMENT ROOM, HASHINGTON, D. C.

BRUNSWICK (BWR) + REACTOR, BWR + REPORT, PSAR + SITING, REACTOR

18-27633 ALSO IN CATEGORIES 2 ANO 16

BRUNSWICK STEAM ELECTRIC PLANT UNITS $1+2$, PRELIMINARY SAFETY ANALYSIS REPORT, VDLUME III CAROL INA POWER + LIGHT COMPANY

275 PAGES, FIGURES, TABLES, JULY 1968, DOCKET 50-324/325

FOUR APPENDICES - (A) GEOLOGICAL ANALYSIS, FOUNOATION ENGINEERING, SEISMIC DESIGN CRITERIA, SEISMIC DESIGN RESPONSE SPECTRA, PRELIMINARY MARINE BIDLOGY AND OCEANOGRAPHY, STORM TIDES, AND WILMINGTON 1959-63 WINDIF WIND DIFFUSION STUDY. THEN FOLLOWS THE USUAL - (B) JET PUMP DFVELOPMENT, (C) CORE SPRAY TEST PROGRAM, AND (D) COMPARATIVE EVALUATION WITH AEC DESIGN 
$18-27833$ \#CONTINUED*

CRITERIA (A LISTING OF APPROPRIATE PSAR SECTIONS FOR EACH CRITERIA).

AVAILABILITY - USAEC PUBL IC DOCUMENT ROOM, WASHINGTON, D. C.

\# $\triangle E C$ DESIGN CRITERIA + \#EARTHQUAKE ENGINEERING + BRUNSWICK (BWR) + REACTOF, BWR + REPORT, PSAR

I8-27834 ALSO IN CATEGORIES 16 AND 5

BRUNSWICK STEAM ELECTRIC PLANT UNITS 1 + 2 , PRELIMINARY SAFETY ANALYSIS REPGRT, VOLUME II

CAROL INA POWER + LIGHT COMPANV

4 CO PAGES FIGURES, TABLES, JULY 1968 , DOCKET 50-324/325

VOL. I I CONTAINS SECT. VII IINSTRUMENTATION AND CONTROL - INCLUDES AUTO LOAD DISPATCH FROM RALEIGH, N. C.), VIII (ELECTRICAL POWER - 4 DIESELS), IX (RAD WASTE), X (AUXILIARIES), XI (POWER CONVERSION), XII (PLANT OPERATIONS - PERSONNEL WILL BE AVAILABLE FROM ROBINSON 2 ), $X I I I$ ITECH. SPECS.), AND XIV (SAFETY AND ACCIDENT ANALYSIS). 40 PAGES DESCRIBE THE OFFSITE DOSE CALCULATION MODEL USED IN RADOS COMPUTER CODE, ISOTOPE FRACTIONS RELEASED FROM FUEL IN EXPER IMENTS AND IN THESE ACCIDENTS, AND PROVIDES BOTH A CONSERVATIVE BASE CASE AND A BEST ESTIMATE (MARGINS RANGE FROM FACTORS OF 8400 TO 16,700$), 6$ PAGES PROVIDE A SENSITIVITY

ANALYSIS AND A SPECIAL COMPARISON WITH YID 14844 AND RECENT AEC-DRL SAFETY EVALUATION.

AVAILABILITY - USAEC PUBLIC DOCUMENT ROOM, WASHINGTON, D. C.

\#DOSE + \#OFF SITE + ACCIDENT MODEL + BRUNSWICK (BWR) + COMPARISON, THEORY AND EXPERIENCE + ERROR ANALYSIS + REACTOR, BWR + REPORT, PSAR + SAFETY EVALUATION + S.TAFFING, TRAINING, QUALIFICATIDN

18-27836 ALSO IN CATEGORIES I AND

DEPT. OF INTERIOR. SPEAKS ON THERMAL POLLUTION

DEPT: OF INTERIOR, WASHINGTON, D. C.

6 PAGES, ATOMIC. ENERGY CLEARING HOUSE, 14(34), PAGE 1-6, (AUGUST 19, 1968 )

J. I. BREGMAN (DEPUTY ASST. SEC. OF INTERIOR FOR WATER POLLUTION CONTROL) IN A KEYNOTE ADDRESS AT A NATIONAL SYMPOSIUM ON THERMAL POLLUTION AT VANDERBILT U NOTED THE ELECTRIC POWER

INDUSTRY IS THE PRIMARY SOURCE OF THERMAL POLLUTION. CITED 4 SOLUTIONS (INCREASED EFFICIENCY

IN GENERATION AND DISSIPATION, OISPOSAL TO AIR, AND PRODUCTIVE USE) URGED USE OF WASTE HEAT

PROOUCTIVELY. URGED DEPT. OF INTERIOR CERTIFICATION OF A PLANT DISPOSAL MEANS AND LIMITS.

* thermal pollution + regulation, general

18-27840 ALSO IN CATEGORIES 17 AND 1

EVESR TECHNICAL SPECIFICATION - SECTION IX - G OPERATIONAL PRINCIPLES ANO REQUIREMENTS

GENERAL ELECTRIC COMPANY, SAN JOSE, CALIFORNIA

PAGE 37 OF AMENDMENT 11 (TECHNICAL SPECIFICATION) TO THE EVESR LICENSE APPLICATION JUNE 7 , 1963, DOCKET

$50-183$

IF IT IS DISCOYERED THAT A SYSTFM IS INMPFRARIF OP NOES MOT MEET ITE COCGITICO CONBITIOHS OF OPERATION WHILE IN AN OPERATING MODE WHERE THE SYSTEM IS REQUIRED BY THESE TECHNICAI SPECIF ICATIONS TO BE UPERABLE OR TO MEET PARTICULAR CONOITIONS OF OPERATION, IMMEDIATE STEPS WILL BE TAKEN TO CORRLCT THE CONDITION PROMPTLY UR TU PLALE THE REACTOR IN A MDDE FOR WHICH OPERABILITY OF THE PARTICULAR SYSTEM IS NOT REQUIRED: SUCH PERIODS OF OPERATION AS FALL UNDER THE REQUIREMENTS OF THIS PARAGRAPH WILL NOT BE CONSIDERED A VIOLATION OF THESE TECHNICAL SPECIFICATIONS.

USAEC, PUBLIC DOCUMENT ROOM, 1717 H ST., WASHINGTON, D.C. 20545 (25 CENTS/PAGF)

*FAILURE, EQUIPMENT + *TECHNICAL SPECIFICATIONS + EMERGENCY PROCEDURE + INCIDENT, EQUIPMENT + REACTOR, INTERNAL SUPERHEAT + REACTOR, POWER + REAC.TIR, RESEARGH + SAFETY PRINCIPLES AND PHILOSOPHY + VESR (ISR)

18-27841 ALSO IN CATEGORIES 2 AND 1

EASTON BWR PROJECT CANCELLED DUE TO THERMAL EFFECTS CRITERIA

NIAGARA MOHAWK POWER CORPORATION

1 PAGE, ATOMIC ENERGY CLEARING HOUSE, 14!33), (AUGUST 12, 1968), DOCKET 50-300, TYPE--BWR, MFG--G.E., $A E--S T O N E+$ WEBSTER

DIFFICULTIES ANO DELAYS IN SECURING REGULATORY APPROVAL FOR THE EASTON SITE HAVE LEAD TO ITS CANCELLATION. DECISIVE FACTOR WAS CONTINUDUS SITUATION WHEREBY STATE HEALTH $\triangle$ GENCIES COULD NOT MAKE UP THEIR MIND AS TO THERMAL EFFECTS CRITERIA. NIAGARA MOHAWK WILL PARTICIPATE IN AN OIL FIRED PLANT READY IN LATE 1971. NY STATE POWER AUTHORITY WILL ASSUME THE CONTRACT, AND BUILD THE PLANT NEXT TO THE NINE MILE POINT PLANT, WITH NIAGARA MOHAWK TO OPERATE THE PLANT BEGINNING IN 1973 .

\#CONSTRUCTION PERMIT PROCESS + *REGULATION, STATE + \#THERMAL POLLUTION + EASTON (BWR) + REACTOR, BWR + SITING, REACTOR + STATE PROGRAM 
18-27845 ALSO IN CATEGORIES 17 AND 9

DRL QUESTIONS ON NINE MILE POINT CONTRDL RODS

U.S. ATOMIC ENERGY COMMISSION

2 PAGES, LeTter tO M.H. PRATT FROM P.A. MORRIS, aUgUSt 13, 1968, DOCKET 50-220, TYPE--BWR, MFG--G.E:, AE--NI AGARA MOHAWK

COMPLIANCE SAYS DESIGN MODIFICATIONS HAVE BEEN MADE TO CONTROL ROD DRIVE HYDRAULIC LINE PENETRATION IN CONTAINMENT. THIS SHOULD BE REPORTED WITH BASES AND SAFETY EVALUATION. ASKS FOR SPECIFIC INFORMATIDN ON WELD REPAIR BETWEEN STUB TUBES AND ROD DRIVE. HOUSINGS, (1) BASES FOR CONTOURING SHOP WELDS, (2) FIELD WELDS DEPOSIT OF METAL ON SIDE OF TUBES, AND (3) PLANS

FOR CLEANING AND HYDROTESTING VESSEL, PLUS DETAILED RECORDS OF DYE CHECKS PRIOR TO HYDROTEST.

USAECं, PUBl. IC DOCUMENT ROOM, 1717 H ST., WASHINGTON, D.C. 20545 (25 CENTS/PAGE)

\#CONTAINMENT PENETRATION, PIPE + \#WELOING + CONTROL ROD DRIVE + INSPECTION AND COMPLIANCE + NINE MILE POINT (BWR) + PRESSURE VESSEL + REACTOR, BWR + TEST, NONDESTRUCTIVE

18-27902 ALSO IN CATEGORIES 17 AND 1

RAMEY JT

THE PDOS OF NUCLEAR POWER PLANT LICENSING

ATOMIC ENERGY COMMISSION

37 PAGES, 14 REFERENCES, REMARKS AT THE AIF WORKSHOP ON POWER REACTOR LICENSING, FEBRUARY 12 , 1968

REVIEWS HISTORY OF REGULATORY PROCESS, THFN C.INC.ENTRATES ON (1) DEVELOPMENT OF MANAGEMENT KNOW-HOW, BY UPGRADING UTILITY PERSONNEL AND HIRING NEW GRADUATES. (2) THE AEC LICENSING PROCESS, TOO LITTLE PREPARATION BY UTILITIES IN A RACE TO GET THEIR PAPERWORK IN FIRST. (3) PUBLIC UNDERSTANDING OF NUCLEAR POWER, DISQUIETING RESULTS OF A FEW UTILITIES WHO DID NOT DO THEIR HOMEWIORK WEI_l, SHDII.D EXPECT OUTAGES DURING INITIAL OPERATION. (4) ENGINEERING STANDARDS AND QUALITY ASSURANCE. AMONG PROBLEMS MENTIONED WERE OPTIMUM CONSTRUCTION SCHEDULING, BACK FIT. APPENDIX A IS AEC PROGRAM FOR TRAINING UTILITY STAFF AND MANAGEMENT.

AVAILABILITY - ATOMIC INDUSTRIAL FORUM, 850 THIRO AVE, NEW YORK, N.Y, 10022

*CONSTRUCTION PERMIT PROCESS + \#REACTOR, POWER + \#STAFFING, TRAINING, QUALIFICATION + QUALITY CONTROL + RADIATION, PUBLIC EDUCATION/ACCEPTANCE + REGULATION, AEC

$18-27903$

RAMEY JT

APPENDIX A, AEC PROGRAM FOR TRAINING UTILITY MANAGEMENT AND STAFF

ATOMIC ENERGY COMMISSION

2 PAGES, REMARKS AT THE AIF WORKSHOP ON POWER REACTOR LICENSING, FEBRUARY 12, 1068

IN VIEW OF CONTINUING RAPID GROWTH OF NUCLEAR POWER, AND UTILITIES NOT HAVING PRIOR NUCLEAR EXPERIENCE, AEC URGES UTILITIES DEVELOP TECHNICAL AND YANAGERIAL INHOUSE CAPABILITY. RESPONSIBILITY RESTS WITH INDUSTRY. OPERATOR TRAINING NOT A PROBLEM, EXCEPT FOR PROPER TYPE REACTOR TO GAIN EXPERIENCE ON. AEC ACTIONS INCLUDE (A) ESTABLISHMENT OF SUGGESTEO STANDAROS OF TECHNICAL COMPETENCE, (B) DESCRIPTION OF A NUCLEAR TRAINING AND ORIENTATION PQOGRAM, (C) STRENGTHENING FACILITIES FOR OPERATOR TRAINING, IDI REEMPHASIS OF EXISTING WORK $5 X P E R I E N C E$. TRAINING PROGPAM AT AEC SITES. (E) EXPANSION OFF UNNTVRRSITY COURSES.

AVAILABILITY - ATOMIC INDUSTRIAL FORUM, 850 THIRO AVE,. NEW YORK, N.Y. 10022

* STAFFING, TRAINING, QUALIFICATION + AOMINISTRATIVE CONTROL + REACTOR, BWR + REACTOR, POWER + REACTOR, PWR + SAFETY REVIEW

18-27904 ALSO IN CATEGORIES 17 AND 1

JOSLIN M

SCME OBSERVATIONS ON THE REGULATORY PROCESS

ATOMIC ENERGY COMMISSION

7 PAGES, REMARKS AT THE AIF WORKSHOP ON POWER REACTOR LICENSING, FEBRUARY 12,1958

NEWS OF FAILURES ALERTS THE OTHER FELLOW TO PROFIT BY THE EXPERIENCE OF CTHERS. DISCUSSES EVOLUTION OF UTILITY-REGULATORY RELATIONS. AVOID DEPENDENCE ON SUPPLIER, UTILITY IS ALONE RESPONSIBLE TO AEC. DRESDEN 3 WAS GIVEN EXTENSIVE CORE CODLING SYSTEMS, WHICH COULD HAVE BEEN DONE AT LOWER COST IF THOUGHT OUT IN ADVANCE. URGES UTILITIES TO EDUCATE AEC ON SPECIAL FEATURES OF UTILITY ECONDMICS. NOTES NEED FOR UTILITIES OWN EXPERTS AND TOP MANAGEMENT INVOLVEMENT. CONSIDERS MOST SIGNIFICANT FOR UNBIASED CODPERATION.

AVAILABILITY - ATOMIC INDUSTRIAL FORUM, 850 THIRD AVE., NEW YORK, N.Y. 10022

\#OPERATING EXPERIENCE SUMMARY + \#REGULATION, AEC + CODES ANO STANDARDS + CORE SPRAY + DRESOEN 3 IBWR + ECONOMICS + INFORMATION RETRIEVAL + STAFFING, TRAINING, QUALIFICATION

18-27989 ALSO IN CATEGORIES 17 AND 1 
CATEGORY 18

SAFETY ANALYSIS AND DESIGN REPORTS

$18-27989$ *CONTINUED*

NUCLEAR TRAINING PROGRAMS

BABCOCK AND WILCOX

TRG-68-68+. 65 PAGES, 3 FIGURES, AUGUST 1968

DESCRIBES B AND W SERVICES AND FACILITIES AT THEIR LYNCHBURG, VA., TRAINING CENTER

(CLASSROOMS, PWR SIMULATORS, POOL REACTOR). PRDGRAMS AVAILABLE TO ALL. UTILITY PERSONNEL

INCLUDE, AT MANAGEMENT $(2$ DAY SEMINAR) AND STAFF LEVEL 148 LECTURE HOURS), PLANT OPERATION

LEVEL 15 PHASES - THEORY 3 MO., PWR OBSERVATION 3 MO.. PWR TECHNOLOGY 2 MO., PWR DPERATION AT

POOL REACTOR AND SIMULATOR 3 MO., AND ON JOB TRAINING AT TECHNICAL STAFF PROGRAMS II AND C

FAMILIARIZATION, BAILEY 855 COMPUTER FAMILIARIZATION, WATER AND RADIOCHEMISTRY, MAINTENANCE,

SIMULATOR SIMULATES 83 FAULTS. SUGGESTED PERSONNEL QUALIFICATIONS LISTED.

AVAILABILITY - BABCOCK AND WILCDX, NUCLEAR TRAINING CENTER, P.0: BOX 1260, LYNCHBURG, VA. 24505

* STAFFING, TRAINING, QUALIFICATION + REACTOR, PWR + SIMULATION

18-27996 ALSO IN CATEGORIES 17 AND 1

SCHUMAN SD

DESCRIPTION WESTINGHOUSE REACTOR OPERATOR TRAINING PROGRAM

WESTINGHOUSE ELECTRIC CORP., PITTSBURGH, PA.

WCAP-7170+. 45 PAGES, FEBRUARY 1968

INTENDED FOR CONTRACTED PWR STAFF TRAINING. INCLUDES SELECTION HELP (APTITUDE TEST FOR 24

PERSONNEL, ADMINISTERED 6 MONTHS BEFORE START OF TRAINING RESULTING IN SELECTION OF 6

SUPERVISORS, 6 SHIFT SUPERVISORS, ANO 10 OPERATORSI. PHASE I 111 WEEKS BASIC LECTURE WITH

POOL REACTOR OPERATION AT WREC), PHASE II $(24$ WEEKS SAXTON PWR OPERATING EXPERIENCE AND

LICENSE EXAM). PHASE III (6 WEEKS LECTURE SERIES AT WAPOI. PHASE IV IONE YEAR ON-SITE

TRAINING FOR OPERATOR LEVEL MATERIAL). LESSON OUTLINES GIVEN FOR EACH LECTURE.

AVAILABILITY - S. D. SCHUMAN, WESTINGHOUSE ELECTRIC CORPORATION, ATOMIC POHER DIVISION, PENN CENTER SITE, P. O. BOX 355, PITTSBURGH, PA. 15230

\#STAFFING, TRAINING, QUALIFICATION + REACTOR, POWER + REACTOR, PWR + SAXTON (PWR)

18-27997 ALSO IN CATEGORIES 1 AND 17

COMMENTS FROM BRIEFING CONFERENCE ON NUCLEAR POWER, SEPT. 3-6, 1968

YANKEE ATOMIC ELECTRIC CO.

15 PAGES, ATOMIC ENERGY CLEARING HOUSE, 14(37), PAGE 8-11 AND.19-29, (SEPTEMBER 9, 1968 )

(ROGER COE) - INNUMMERABLE ECONOMIC FORECASTS BUT LITTLE HINDSIGHT INFORMATION. OISCUSSED YANKEE, CONN. YANKEE, AND HUMBOLDT BAY ECONOMICS. (JAMES T. RAMEY) - NOT LIKELY TO SEPARATE REGULATORY FUNCTION FROM AEC FOR AT LEAST 5 YEARS. EVOLUTION EXPECTED. (JOHN B. ANDERSON) OETAILED DISCUSSION OF LEGISLATIVE BILLS ON SITING, THERMAL EFFECTS, SMALL UTILITY

PARTICIPATION, PRACTICAL VALUE. (H. L. PRICE) - SUGGESTED APPROVING A NUCLEAR STEAM SUPPLY SYSTEM OUTSIDE THE CONSTRUCTION PERMIT PROCESS. (P. A. MORRIS) - CONSTRUCTION PERMIT TAKE 12.4 MONTHS BEC AUSE OF 12 TECHNICAL AND 4 GENERAL ITEMS NOT SPECIFICALLY TREATED IN PSAR. (R. LOWENSTEM) - LICENSING DELAYS COST APPLICANT ONE MILLION \$/MONTH. HE ADVISES APPLICANT TO PLAN ON 18 MONTHS FOR A CONSTRUCI IUN PERMIT, ONE YEAR FOR OPERATING LICENSE AFTER FILING FSAR (WHICH TAKFS 6 MINTHS TO PREPAR.E).

AEC QUESTION + CONGRESSIONAL ACTIVITY + CONSTRUCTION PERMIT PROCESS + ECONOMICS + OPERATING LICENSE PROCESS + REACTOR, POWER + REACTOR, WATER + REGULATION, AEC + REPORT, PSAR + REPORT, SAR + RESPONSE TIME 
CATEGORY 19

BIBLIOGRAPHIES

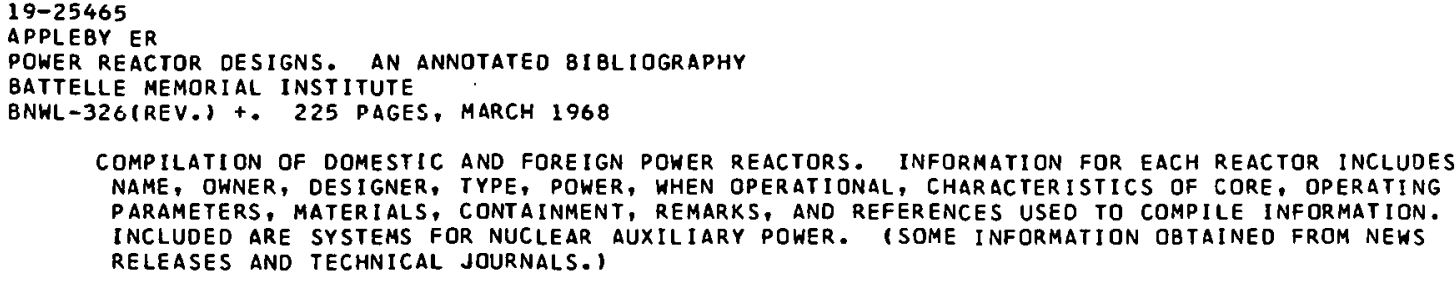

THIS REPORT IS ONE OF AN ANNUAL SERIES AND ANNOUNCES FORMAL RESEARCH AND DEVELOPMENT REPORTS AND TECHNICAL ARTICLES PUBLISHED DURING 1967 BY BATTELLE-NORTHWEST. THE REPORTS AND ARTICLES ARE GROUPED BY BROAD SUBJECT CATEGORIES AND ARRANGEO ALPHABETICALLY BY AUTHOR WITHIN EACH CATEGORY. AUTHOR INDEX INCLUDED. NEHS RELEASES NOT INCLUDED. OTHER REPORTS IN THIS SERIES ARE BNWL-218 AND BNWL-387.

AVAILABILITY - CLEARINGHOUSE FOR FEDERAL SCIENTIFIC AND TECHNICAL INFORMATION, SPRINGFIELO, VIRGINIA $22151 \$ 3.00$ COPY, $\$ 0.65$ MICROF ICHE

* BI BLIOGRAPHY + CRITICALITY SAFETY + ENVIRONMENTAL CONOITION + INSTRUMENTATION, GENERAL

19-27042 ALSO IN CATEGORY 1

NUCLEAR SAFETY INFORMATION

OAK RIDGE NATIONAL LABORATORY, OAK RIDGE, TENNESSEE

ORNL-4228 +. 58 PAGES, 5 FIGURES, 3 TABLES, 10 REFERENCES, PAGES $379-436$ OF THE NSP ANNUAL PRDGRESS REPORT, $A P R I L, 1968$

PROGRESS REPORT, DEALING WITH THE FOLLOWING - NUCLEAR SAFETY INFORMATION CENTER - ORGANIZATION AND SCOPE, COMPUTERIZED OPERATIONS, MEETINGS AND CONFERENCES, STATUS OF REVIEHS AND REPORTS, SUMMARY OF INFORMATION ACTIVITIES. COMPUTER HANDLING OF REACTOR OATA - SAFETY (CHORD-SI INITIAL DEVELOPMENT OF COMPUTERIZED INFORMATION SYSTEM, PREPARATION OF REACTOR SAFETY INFORMATION FOR COMPUTER PROCESSING, COMPUTER DUTPUT OF REACTOR SAFETY DATA TO USERS OF INFORMATION SYSTEM. NUCLEAR SAFETY (A TECHNICAL PROGRESS REVIEW) - PUBLICATION SCHEDULE, FEATURE ARTICLES. BIBLIOGRAPHY. ORGANIZATION CHART.

\#BIBLIOGRAPHY + \#COMPUTER PROGRAM + \#NSIC + \#REVIEW + \#SAFETY PRINCIPLES AND PHILOSOPHY + \#SAFETY REVIEW + ACCIOENT ANALYSIS + AEROSPACE SAFETY + FISSION PRODUCT TRANSPORT + INSTRUMENTATION, GENERAL + METEOROLOGY + REACTOR TRANSIENT + SHIPPING ANALYSIS + SITING, GENERAL

19-27318 ALSO IN CATEGORY 5

LUIKOV AV

IOGRAPHY - RUSSIAN WORKS

HEAT AND MASS TRANSFER INSTITUTE OF THE B.S.S.R. ACADEMY OF SCIENCE, 25 PODLESNAYA, MINSK, B.S.S.R., U.S.S.R.

15 PAGES, INTERNATIONAL JOURNAL OF HEAT AND MASS TRANSFER, 101121, PAGES 1875-1889 (DECEMBER 1967) 
CATEGORY 19

19-27318 *CONTINUED*

AN EXTENSIVE BIBLIOGRAPHY OF RUSSIAN LITERATURE ON HEAT AND MASS TRANSFER.

\#HEAT TRANSFER + \#MASS TRANSFER + \#THERMODYNAMICS + \#TRANSPORT PROPERTY + BIBLIOGRAPHY + USSR

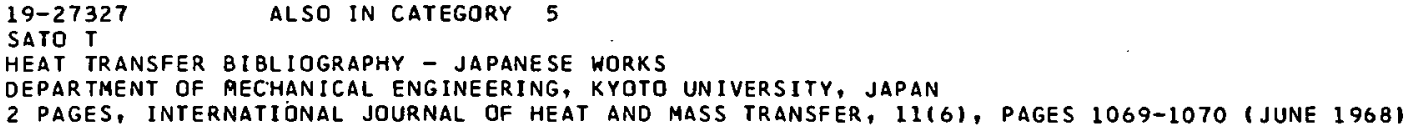

* BIBL IOGRAPHY + \#HEAT TRANSFER + \#MASS TRANSFER + BOUNDARY LAYER + FLOW, TWO PHASE + FLUIDIZED BED + HEAT TRANSFER, CONOUCTION + HEAT TRANSFER, NATURAL CONVECTION + HEAT TRANSFER, RADIANT + HOT CHANNEL + MEASUREMENT, GENERAL + METAL, LIQUID + REACTOR, PEBBLE BED + THERMODYNAMICS + TRANSPORT PROPERTY + TRANSPORT THEORY 
INFORMATION AT NSIC IS DIVIDED INTO 19 CATEGORIES. AN ITEM OF INFORMATION MAY BE KEYED TO AS MANY AS THREE OF THESE. A COLLECTION OF SELECTORS DR KEYWORDS IS USED TO DENOTE THE MAIN SAFETY RELATED POINTS COVERED IN AN ARTICLE. THE FOLLOWING INDEX IS AN ALPHABETICAL LISTING OF SELECTORS GIVING REFERENCES TO EACH ARTICLE WHICH WAS KEYED TO IT. THE CATEGORY NUMBER IS GIVEN FIRST, FOLLOWED BY THE ACCESSION NUMBER. THE ACCESSION NUMBERS ARE USED TO LOCATE BIBLIOGRAPHIC ITEMS WITHIN A CATEGORY.

AARR (RR)

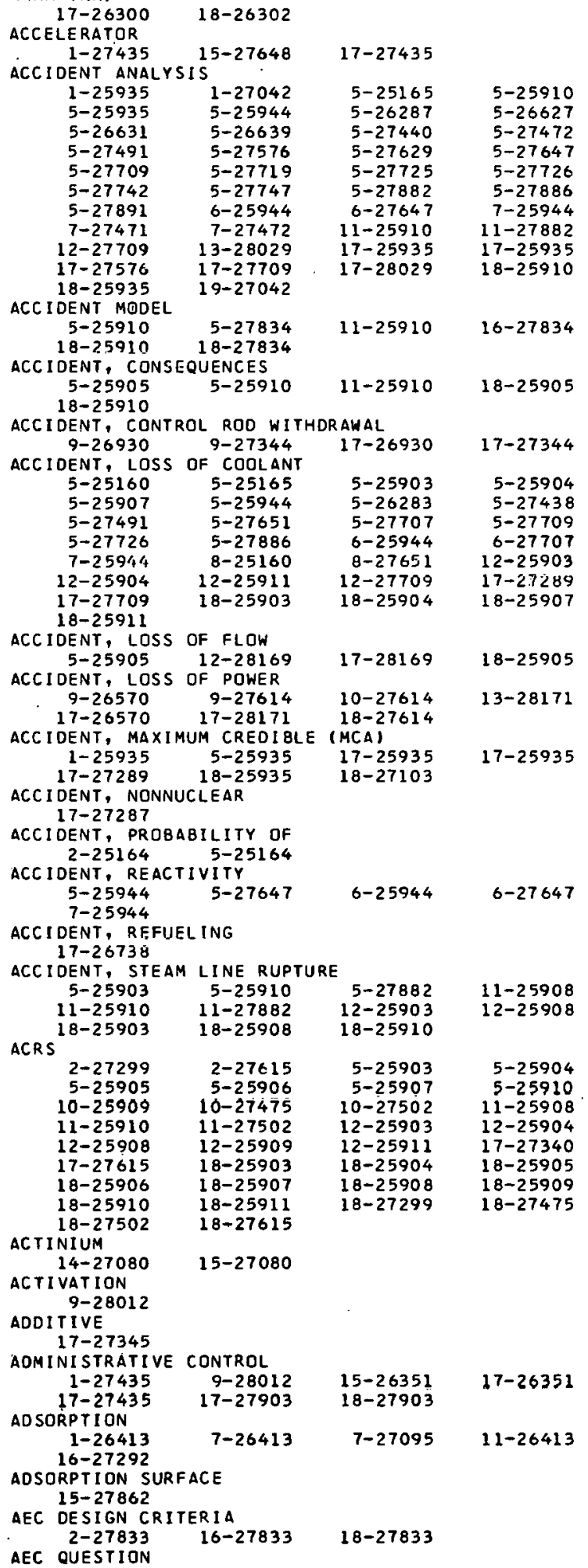

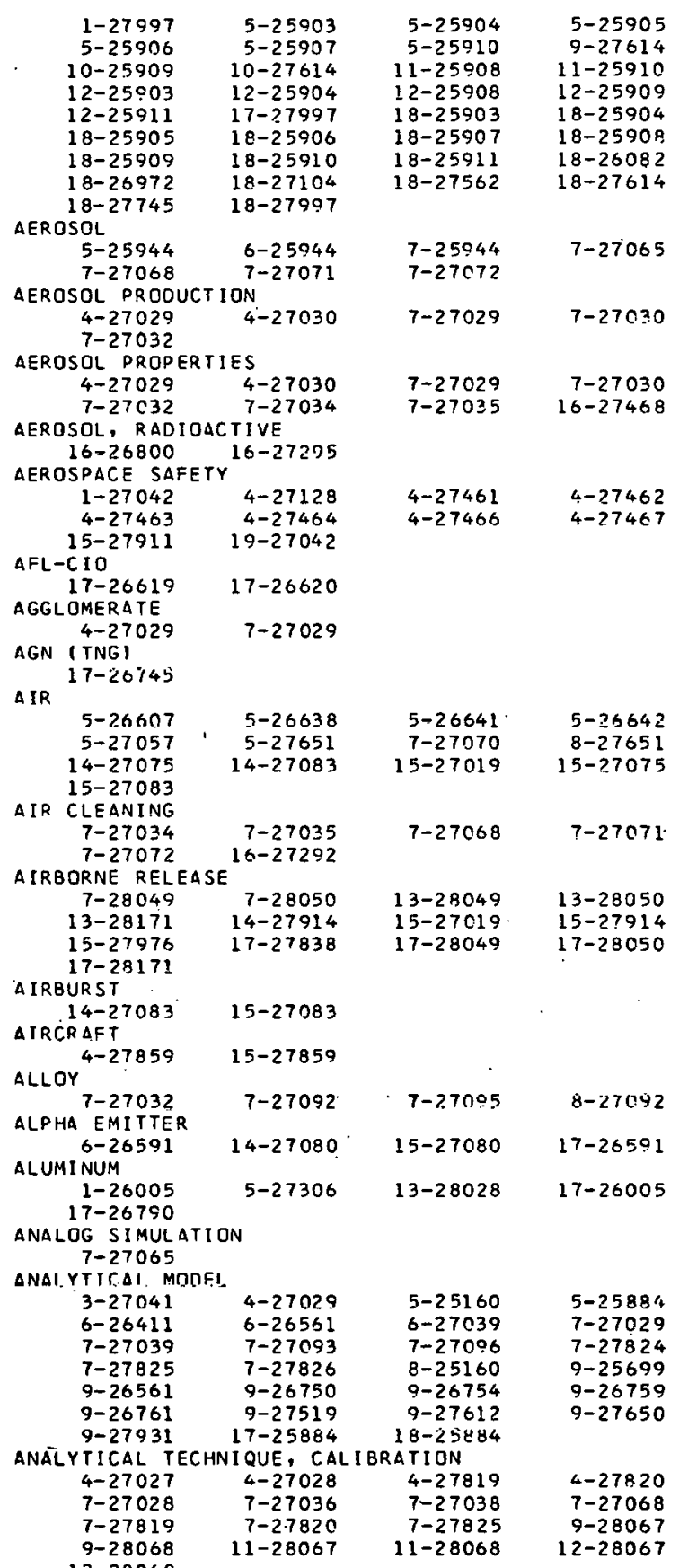

ANALYTICAL TECHNIQUE, GENERAL

$15-2,8043$

ANALYTICAL TECHNIQUE, URINE

14-27081 15-27081

ANALYTICAL TECHNIQUE, WATER

14-27082 15-27082

ANNULUS

16-28022

APPLICATION FOR AEC LICENSE

$\begin{array}{cccc}1-28003 & 1-28004 & 13-28003 & 13-28004 \\ 17-28003 & 17-28004 & & \end{array}$ 


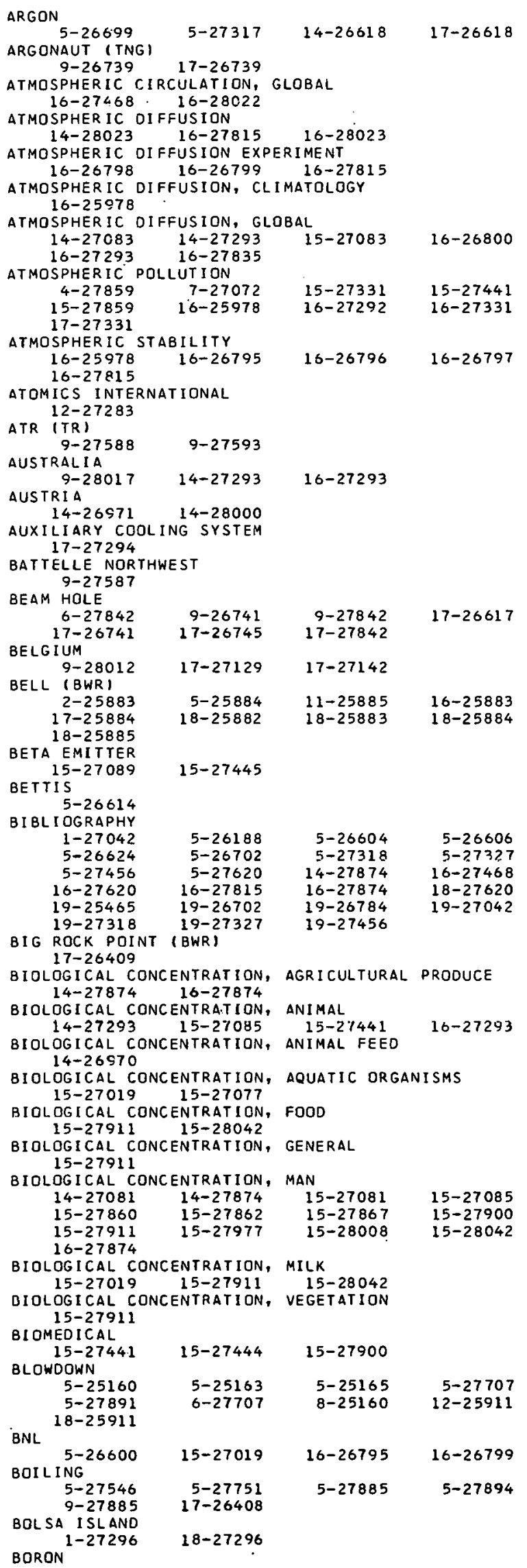

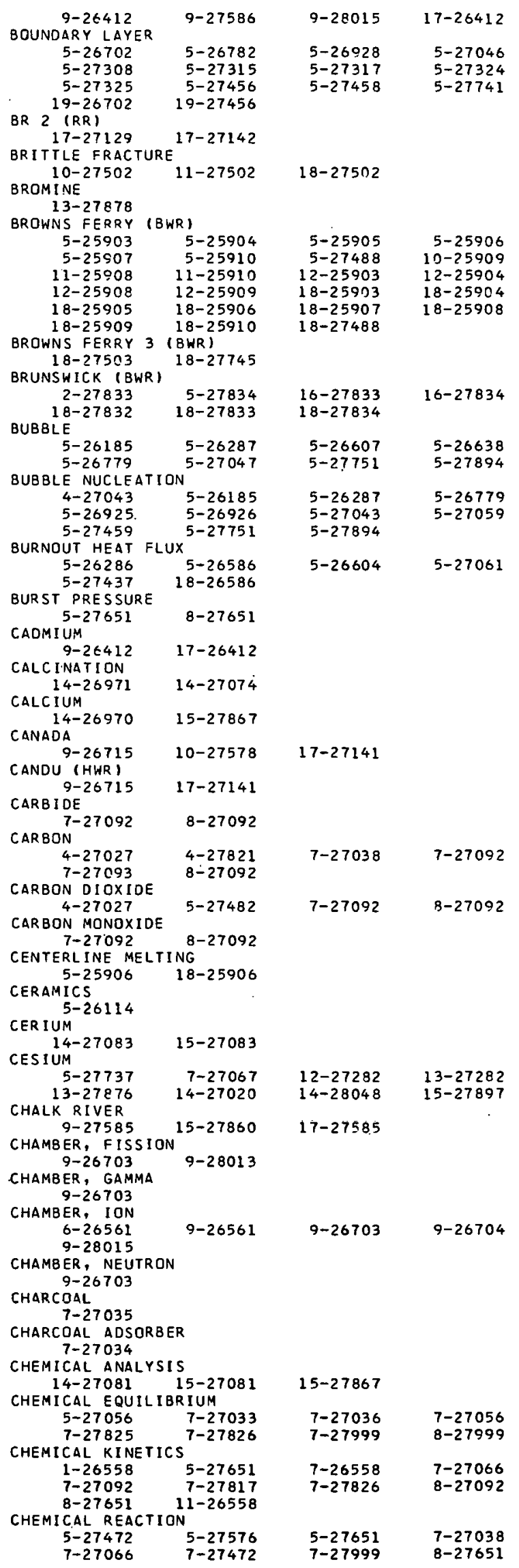




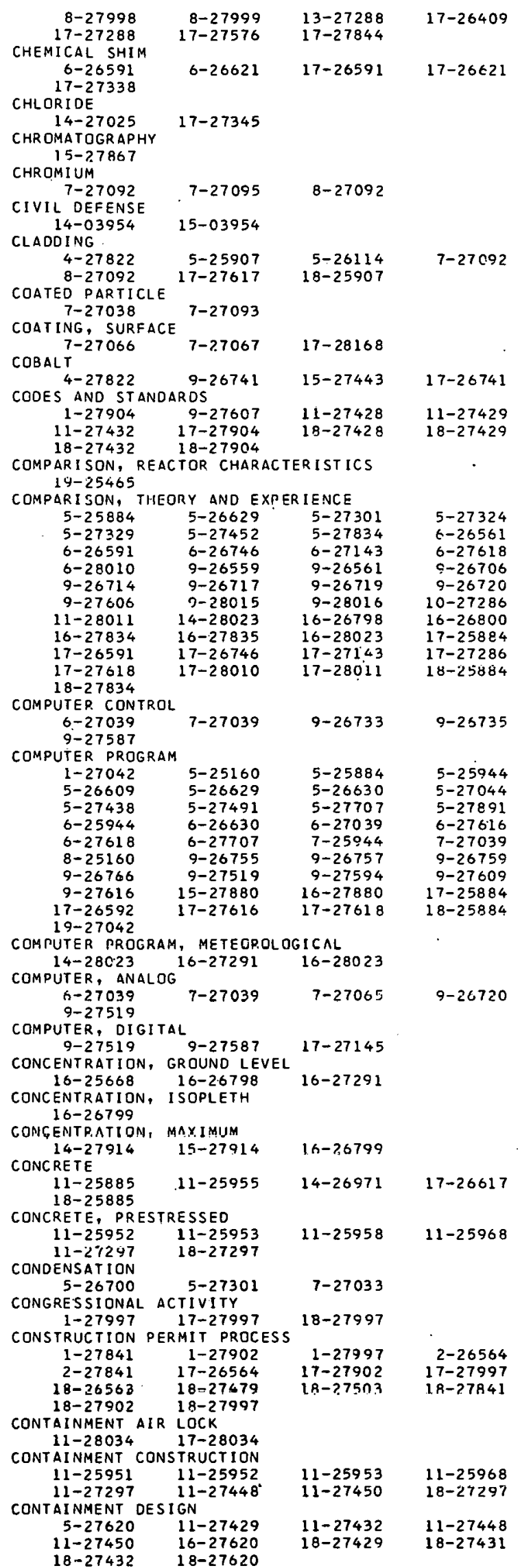

CONTAINMENT EQUIPMENT HATCH $11-27432 \quad 18-27432$

CONTAINMENT INTEGRITY

$$
17-265 \in 9
$$

CONTA INMENT I SOLATION

$\begin{array}{rrrr}5-25003 & 5-25910 & 11-25009 & 11-25910 \\ 12-25903 & 12-25908 & 18-25003 & 18-25908\end{array}$

$18-25910$

CONTA INMENT LINER

\begin{tabular}{l}
$1-27298 \quad 18-27298$ \\
\hline
\end{tabular}

CONTAINMENT PAINT $6-25944 \quad 7-25944$

$\begin{array}{rrr}5-25944 & 6-25944 & 7-25944 \\ \text { CONTAIN,4ENT } & \text { PENETRATION, ELECTRICAL }\end{array}$

$\begin{array}{rrrr}9-26512 & 10-26512 & 10-27474 & 11-27474\end{array}$

$17-27474$

CONTAINMENT PENETRATION, DIPE

9-27845 $11-26571 \quad 11-27432 \quad 11-27504$.

$\begin{array}{llll}17-26571 & 17-27504 & 11-27432 & 11-27504 \\ 18-27845 & 19-27432\end{array}$

$18-27845$

CONTAINMENT REFERENCE MEASUR ING SYSTEM 11-27504 17-27504

CONTAINMENT RESEARCH AND DEVELINPMENT $11-2704 C$

CUNIAINMENT SORAY

$\begin{array}{rrrr}1-26558 & 2-27615 & 7-26558 & 7-27824 \\ 7-27825 & 7-27826 & 11-25554 & 11-26558 \\ 17-27615 & 12-27615 & & \end{array}$

CONTA INMENT STRUCTURE

$$
11-27448 \quad 11-27450
$$

CONTAINMENT VACUUM BREAKER

$\begin{array}{ccc}10-27474 & 11-27474 & 17-27474\end{array}$

CONTAINMENT VESSEL LOADING $5-25165$

CONTAINMENT, CORROSION PROTECTION

$11-27 ? 99, \quad 18-27297$

CONTA INMENT, GENERAL

$$
\begin{array}{rrrr}
1-26558 & 2-27975 & 7-26559 & 11-75558 \\
11-27040 & 11-27975 & 17-26300 & \\
\text { CONTAINMENT, HIGH ORESSURE } & & \\
11-27504 & 17-27338 & 17-27504 & 17-27838 \\
\text { CONTAINMENT, PRESSURE RELIEF } & \\
11-25954 & 11-25959 & & \\
\text { CONTAINMENT, PRESSURE SUPPRESSION } & \\
7-27037 & 11-25885 & 11-25059 & 11-27429 \\
1.1-2743 \text { ? } & 18-25885 & 18-27429 & 18-2743 ? \\
\text { CONTAINMENT, PRESSURE VENTING } & \\
5-27747 & &
\end{array}
$$

CONTAINMENT, SHOCK GENERATI DN AND PROTECTION $11-25055$

CONTAMINATION

$3-20976 \quad 13-28171 \quad 14-2707515-26362$ $\begin{array}{llll}3-25976 & 13-28171 & 14-27075 & 15-26362 \\ 15-26385 & 15-27075 & 15-27444 & 15-27648\end{array}$ $\begin{array}{llll}15-27995 & 17-26362 & 17-26385 & 17-26588\end{array}$

$17-29171$ TROI: ROD

$5-27494$
$9-27494$

$9-27500$

$17-27338$

$9-26474$

$9-27586$

$17-27494$

$9-25560$

CONTROL ROD BURNUP

17-26409

CONTROL ROD CALIBRATION 9-28016 9-28018

CONTROL ROD DRIVE

OL ROO ORIVE

$9-27343 \quad 9-27499$

$9-27343 \quad 17-27499$
$10-27286 \quad 17-26930$

$17-27845 \quad 18-27845$

$9-26736$

$0-27501$

$17-27286$

$9-26930$

$9-27845$

NTROL ROD INTERACTION

9-27594 9-28016

CONTROL $P$ OD PROGRAM

6L POD PROGRAM

$9-27586$

$9-27594$

$9-27616$

CONTROL ROD SCRAM MECHANISM $9-26471$ S-26474. $9-27500$

CONTROL ROD WORTH

6-29010 9-28016 9-28018

17-28010

CONTROL SYSTEM 9- 26562 $9-26724$

$9-26720$

$9-26722$

$9-26030$

$9-27508$

9-26723

$0-26967$

$9-27879$

CONTROL, GENERAL

0-26967

13-27979

CONTROLLER 6-27842 9-26725

$17-26930$

CONVECTIVE BOILING

$\begin{array}{ll}5-26284 & 5-26285 \\ 5-26604 & 5-26611 \\ 5-26640 & 5-26772 \\ 5-27064 & 5-27305 \\ 5-27439 & 5-27440\end{array}$

$9-27842$

$17-27842$

$5-26286$

$5-26625$

$5-26779$

$5-27330$

$5-26600$

$5-26635$

$5-26924$

$5-27437$
$5-27470$ 


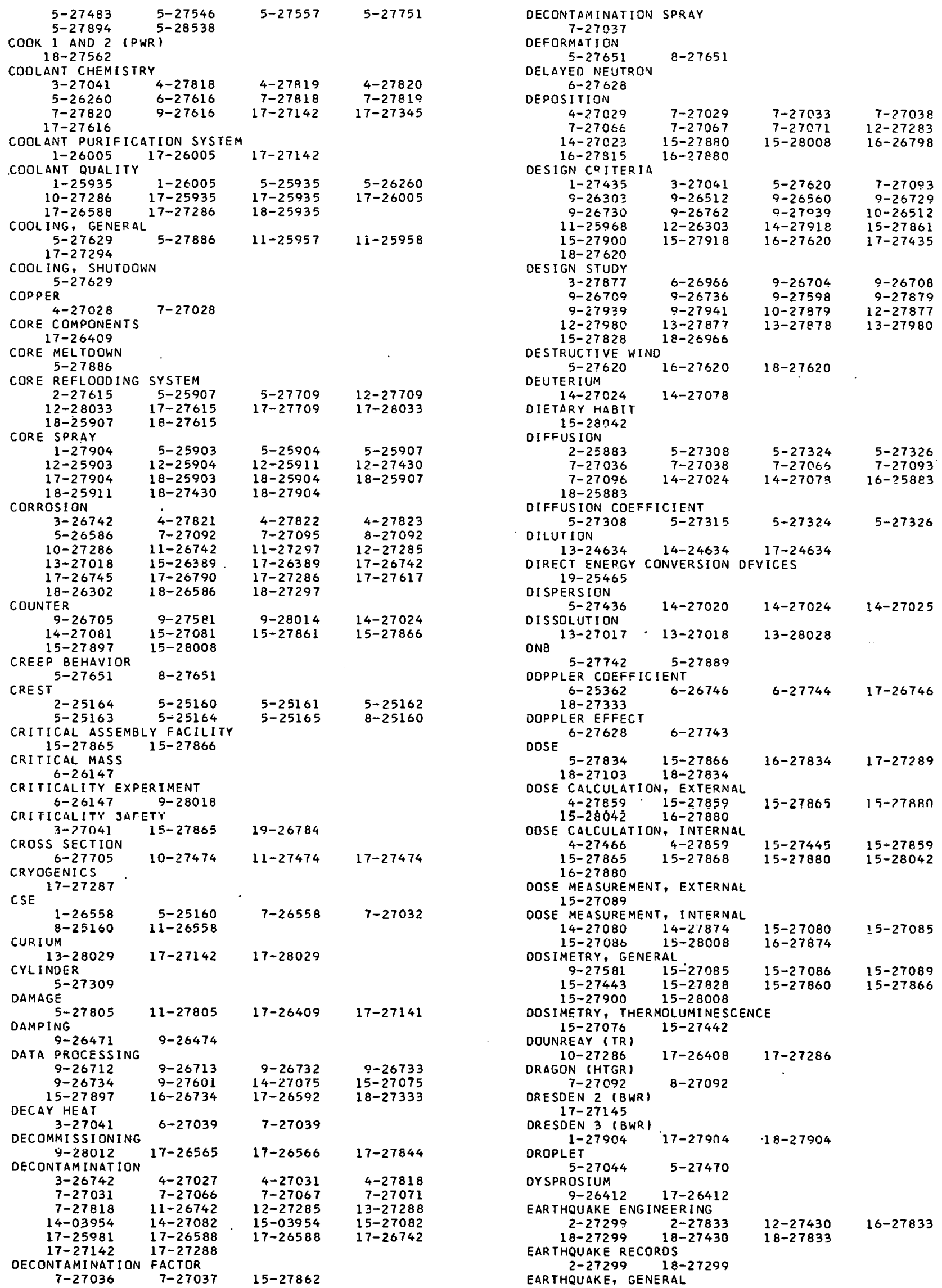




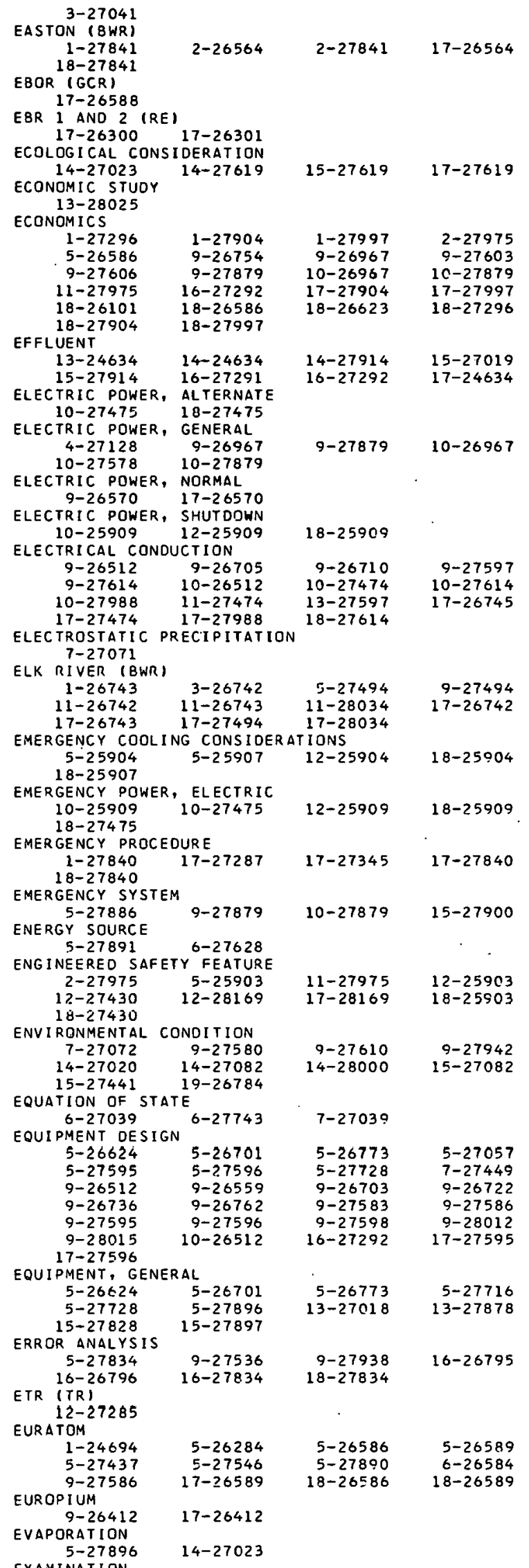

\begin{tabular}{|c|c|c|c|}
\hline & & & \\
\hline $5-27709$ & $6-26.591$ & $9-28012$ & $10-27474$ \\
\hline $11-27428$ & $11-27429$ & $11-27474$ & $12-27430$ \\
\hline $12-27709$ & $17-26591$ & $17-27474$ & $17-27617$ \\
\hline $17-27709$ & $18-27428$ & $18-27429$ & $18-27430$ \\
\hline $\begin{array}{c}18-27431 \\
\text { EXCURSION, LA }\end{array}$ & & & \\
\hline $5-26630$ & $6-26630$ & $6-27628$ & $6-27743$ \\
\hline $11-25955$ & & & \\
\hline ER IMENT, G & NERAL & & \\
\hline $5-27439$ & $5-27472$ & $5-27494$ & $5-27719$ \\
\hline $7-27472$ & $9-26570$ & $9-27494$ & $12-27283$ \\
\hline $13-27876$ & $13-27878$ & $13-27978$ & $13-27982$ \\
\hline $13-28025$ & $13-28028$ & $14-27025$ & $15-27897$ \\
\hline $16-28022$ & $17-26570$ & $17-27494$ & \\
\hline XPLOSION & & & \\
\hline $5-25161$ & $5-26630$ & $6-26630$ & $11-25955$ \\
\hline $13-27288$ & $17-27288$ & & \\
\hline FABR ICATI DN & & & \\
\hline $\begin{array}{r}7-27284 \\
17-27617\end{array}$ & $13-27284$ & $13-27288$ & $17-27288$ \\
\hline $17-27617$ & & & \\
\hline FAILURE, ADMI & ISTRATIVE CON & IROL & \\
\hline $1-26005$ & $9-27938$ & $9-27939$ & $9-27940$ \\
\hline $11-26310$ & $13-28167$ & $15-26310$ & $15-26312$ \\
\hline $15-26214$ & $15-26321$ & $15-26325$ & $15-26328$ \\
\hline $15-26330$ & $15-26336$ & $15-26337$ & $15-26338$ \\
\hline $15-26353$ & $15-26355$ & $15-26356$ & $15-26357$ \\
\hline $15-26366$ & $15-26376$ & $15-26378$ & $15-26384$ \\
\hline $15-26385$ & $15-26387$ & $15-26394$ & $17-26005$ \\
\hline $17-26310$ & $17-26312$ & $17-26314$ & $17-26321$ \\
\hline $17-26325$ & $17-26328$ & $17-263 \times 0$ & $17-26336$ \\
\hline $17-26337$ & $17-26338$ & $17-26341$ & $17-26353$ \\
\hline $17-26355$ & $17-26356$ & $17-26 \geq 57$ & $17-26366$ \\
\hline $17-26376$ & $17-26378$ & $17-26384$ & $17-26385$ \\
\hline $17-26387$ & $17-263.94$ & $17-28167$ & \\
\hline FAILURE, CLAD & ING & & \\
\hline $1-26005$ & $5-25904$ & $5-25906$ & $6-26411$ \\
\hline $12-25904$ & $17-26005$ & $18-25904$ & $18-25906$ \\
\hline FAILURE, COMP & NENT & & \\
\hline $9-26753$ & $9-26755$ & $9-26756$ & $9-26761$ \\
\hline $9-26765$ & $9-27597$ & $9-27005$ & $0-27000$ \\
\hline $9-27611$ & $9-27613$ & $9-27942$ & $9-27944$ \\
\hline $12-28033$ & $13-27597$ & $17-28033$ & \\
\hline ILURE, DES I & $N$ ERROR & & \\
\hline $9-26570$ & $9-26710$ & $9-26030$ & $17-26570$ \\
\hline $17-26930$ & $17-27141$ & $17-27204$ & \\
\hline FAILURE, EQUI & MENT & & \\
\hline $1-27840$ & $3-26742$ & $5-27 \Omega 86$ & $9-27344$ \\
\hline $11-26742$ & $12-28159$ & $15-26332$ & $15-26339$ \\
\hline $15-26379$ & $15-26390$ & $15-26381$ & $15-26392$ \\
\hline $15-26385$ & $15-26392$ & $17-26332$ & $17-26338$ \\
\hline $17-25379$ & $17-26380$ & $17-26381$ & $17-25382$ \\
\hline $17-26385$ & $17-26302$ & $17-26409$ & $17-25588$ \\
\hline $17-26617$ & $17-26742$ & $17-27141$ & $17-27287$ \\
\hline $17-27344$ & $17-27347$ & $17-27622$ & $17-27940$ \\
\hline $17-27843$ & $17-28169$ & $18-27840$ & 21-croves \\
\hline URE, FABR & ATION ERROR & & \\
\hline $15-26350$ & $17-26350$ & $17-27617$ & \\
\hline FAILURE, FAT! & & & \\
\hline $11-27040$ & & & \\
\hline FAILURE, FUEL & ELEMENT & & \\
\hline $5-25905$ & $6-27143$ & $12 .-27 ? 82$ & $13-27282$ \\
\hline $17-26533$ & $17-26616$ & $17-2<739$ & $17-27143$ \\
\hline $17-27340$ & $18-25905$ & & \\
\hline FAILURE, FUEL & ELEMENT WATER & LOGGING & \\
\hline $6-26411$ & $6-27143$ & $17-27143$ & \\
\hline FAILURE, GENE & & & \\
\hline $9-27650$ & $9-27931$ & $17-28169$ & \\
\hline ILURE, INST & LLATION EREOR & & \\
\hline $0-26710$ & & & \\
\hline FAILURE, INST & UMENT & & \\
\hline $15-26342$ & $17-26342$ & $17-26569$ & \\
\hline FAILURE, OPER & TOR ERROR & & \\
\hline $11-26310$ & $1,3-28171$ & $15-2.6309$ & $15-26310$ \\
\hline $15-26311$ & $15-26319$ & $15-26325$ & $15-25330$ \\
\hline $15-26333$ & $15-26337$ & $15-26 \geq 38$ & $15-26340$ \\
\hline $15-26342$ & $15-26344$ & $15-26351$ & $15-25353$ \\
\hline $15-26355$ & $15-26356$ & $15-26357$ & $15-26 \geq 66$ \\
\hline $15-26375$ & $15-26381$ & $15-26382$ & $15-26,98=$ \\
\hline $15-26384$ & $15-26387$ & $17-26309$ & $17-25 \geqslant 10$ \\
\hline $17-26311$ & $17-26319$ & $17-26325$ & $17-2633 C$ \\
\hline $17-26333$ & $17-26337$ & $17-26338$ & $17-26340$ \\
\hline $17-26342$ & $17-26344$ & $17-26351$ & $17-26 \geq 5=$ \\
\hline $17-20355$ & $17-26350$ & $17-20357$ & $17-26200$ \\
\hline $17-26375$ & $17-26381$ & $17-26392$ & $17-26383$ \\
\hline $17-26384$ & $17-26387$ & $17-2.6569$ & $17-27898$ \\
\hline $17-28171$ & & & \\
\hline LURE, PIPE & & & \\
\hline $5-27982$ & $11-26768$ & $11-27882$ & $18-26769$ \\
\hline URE, PRES & RE VESSEL & & \\
\hline $1-26743$ & $2-27615$ & $3-26742$ & \\
\hline $11-25742$ & $11-? 6743$ & $11-27040$ & $11-29034$ \\
\hline
\end{tabular}




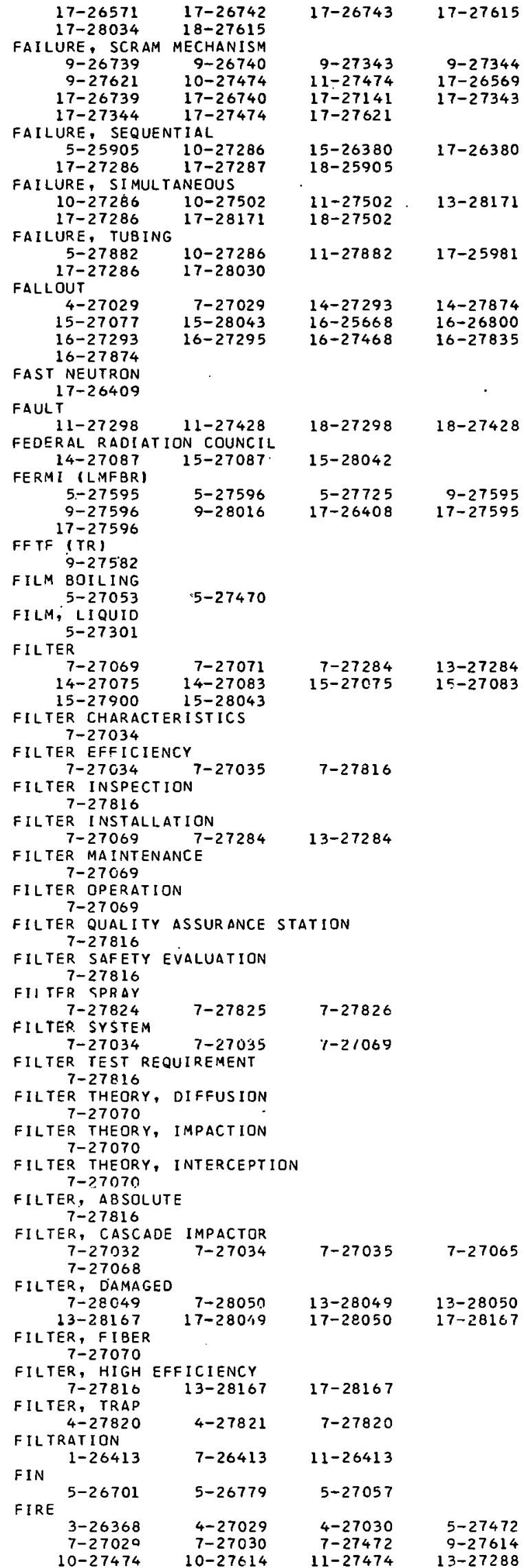

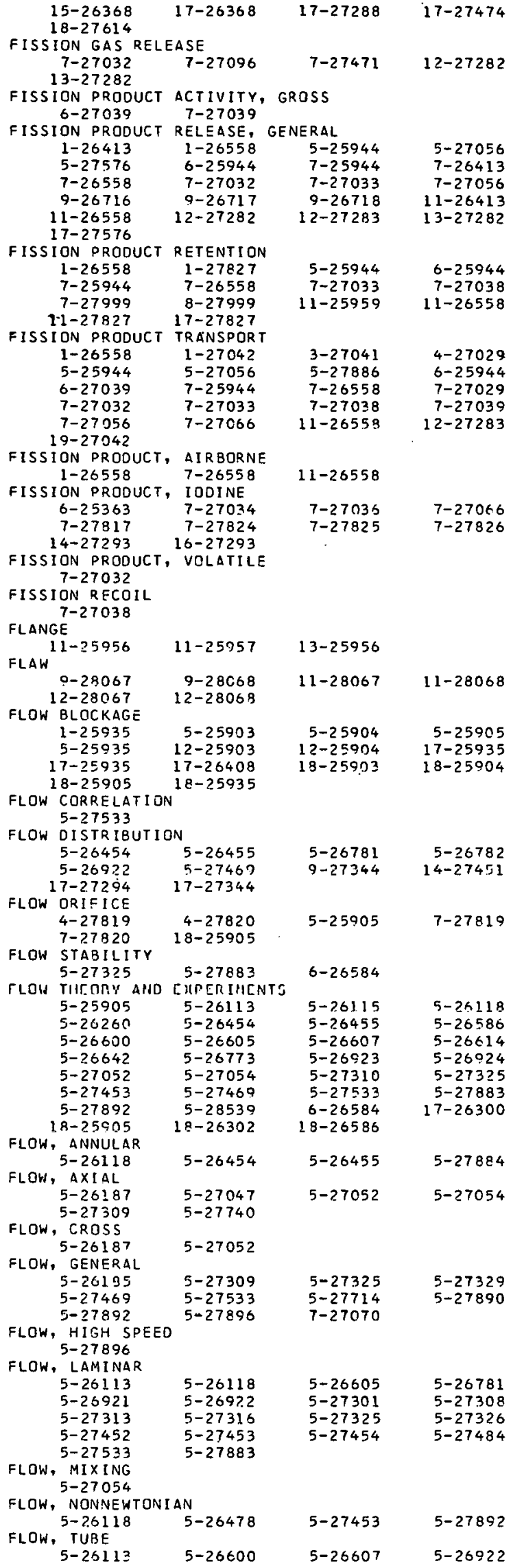




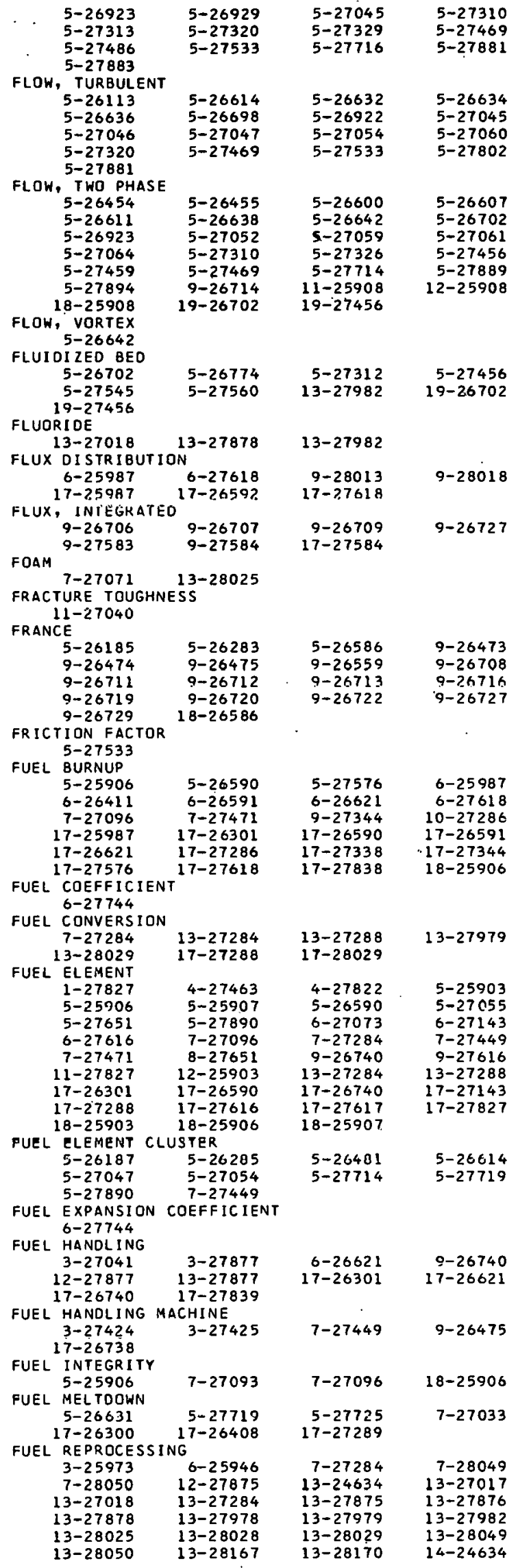

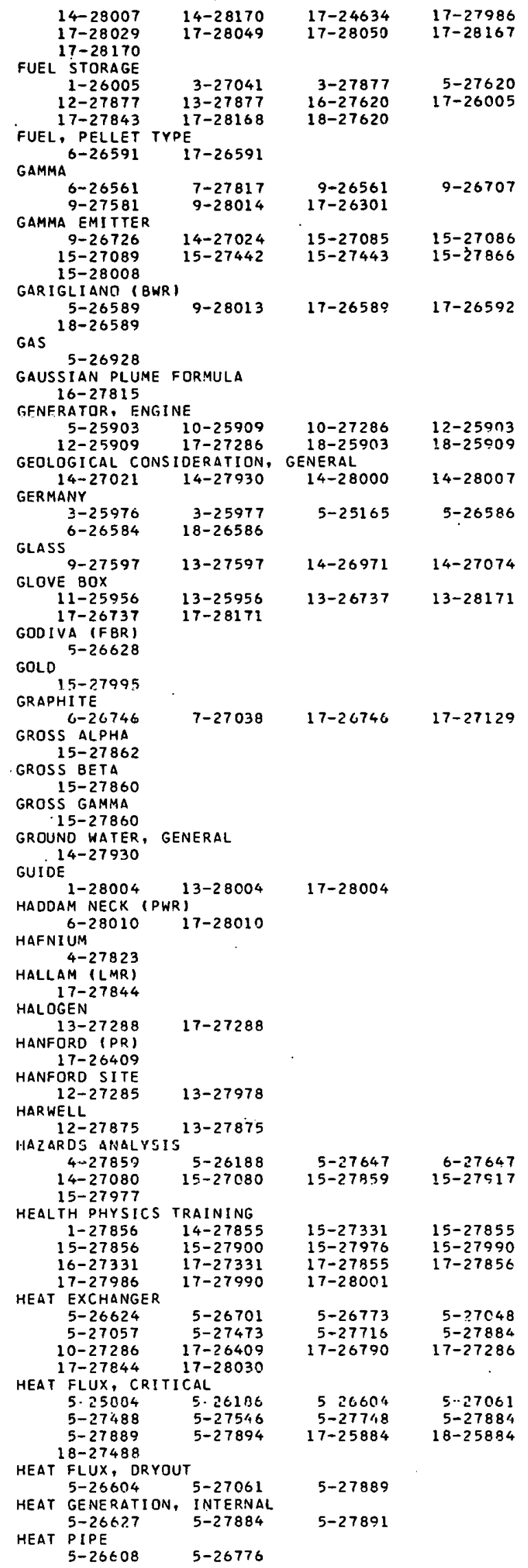


HEAT TRANSFER

TRANSF

5-26113

$5-26186$

$5-26260$

5-26608

5-26633

$5-26640$

$5-26701$

$5-26775$

$5-26922$

$5-26928$

$5-27049$

$5-27061$

$5-27312$

$5-27318$
$5-27329$

5- 27455

$5-27470$

$5-27482$

$5-27486$
$5-27547$

$5-27547$
$5-27740$

$5-27887$

5-27894

6-26411

17-27294

19-27327

TRANSFER ANALYSIS

$5-26187 \quad 5-26188$

$5-26608$

$5-26627 \quad 5-26637$

$5-26700 \quad 5-26775$

$5-26781 \quad 5-26782$

$5-26928 \quad 5-26929$

$5-27046 \quad 5-27048$

$5-27302 \quad 5-27309$

$5-27320 \quad 5-27321$

5-27454 5-27455

$5-27470 \quad 5-27480$

$5-27560 \quad 5-27647$

$\begin{array}{ll}5-27803 & 5-27887 \\ 5-27892 & 6-27647\end{array}$

HEAT TRANSFER AUGMENTATION

5-26586 18-26586

HEAT TRANSFER COEFFICIENT

$\begin{array}{ll}5-26774 & 5-26778 \\ 5-27436 & 5-27545\end{array}$

$5-27436$
$18-25911$

HEAT TRANSFER CORRELATION

5-26114 5-26186

$5-26114$

$\begin{array}{ll}5-26772 & 5-26773 \\ 5-26929 & 5-27045\end{array}$

$\begin{array}{ll}5-26929 & 5-27045 \\ 5-27312 & 5-27319\end{array}$

$\begin{array}{ll}5-27312 & 5-27319 \\ 5-27545 & 5-27546\end{array}$

HEAT TRANSFER EXPERIMENT

$5.36478 \quad 5.26401$

5-26608 5-26634

$5-26775 \quad 5-26779$

$5-27055 \quad 5-27060$

$5-27314 \quad 5-27319$

$5-27459 \quad 5-27470$

$5-27483 \quad 5-27484$

$5-27545 \quad 5-27560$

$5-27748 \quad 5-27802$

5-28538 18-26586

HEAT TRANSFER, BOILING

5-25884, 5-26284

$5-26286 \quad 5-26600$

5-26625 5-26640

5-26924 5-26926

$5-27064 \quad 5-27322$

$5-27438 \quad 5-27439$

$5-27470$. 5-27483

5-28538 8-27998

HEAT TRANGFER, CONDENSATION

$\begin{array}{ll}5-26606 & 5-26700 \\ 5-27314 & 5-27315\end{array}$

$5-27314$
$18-27430$

$5-27315$

HEAT TRANSFER, CONDUCTION

$\begin{array}{lcrr}\text { TRANSFE, CONDUCIIN } & & \\ 5-26116 & 5-26118 & 5-26606 & 5-26702 \\ 5-26775 & 5-26776 & 5-26778 & 5-26927 \\ 5-27321 & 5-27327 & 5-27456 & 5-27457 \\ 5-27740 & 5-27803 & 19-26702 & 19-27327 \\ 19-27456 & & & \\ \text { TRANSFER, CONVECTIION } & & \\ 5-26113 & 5-26116 & 5-26118 & 5-26186 \\ 5-26187 & 5-26189 & 5-26284 & 5-26286 \\ 5-26604 & 5-26606 & 5-26632 & 5-26637 \\ 5-26701 & 5-26774 & 5-26782 & 5-26921\end{array}$

\begin{tabular}{|c|c|}
\hline $\begin{array}{r}5-25165 \\
5-26116 \\
5-26188 \\
5-26481 \\
5-26627 \\
5-26636 \\
5-26698 \\
5-26772 \\
5-26778 \\
5-26926 \\
5-27046 \\
5-27057 \\
5-27302 \\
5-27315 \\
5-27321 \\
5-27453 \\
5-27457 \\
5-27480 \\
5-27484 \\
5-27545 \\
5-27576 \\
5-27802 \\
5-27890 \\
5-28538 \\
7-25944 \\
19-26702\end{array}$ & $\begin{array}{r}5-25944 \\
5-26118 \\
5-26189 \\
5-26606 \\
5-26632 \\
5-26637 \\
5-26700 \\
5-26774 \\
5-26921 \\
5-26927 \\
5-27048 \\
5-27060 \\
5-27305 \\
5-27316 \\
5-27327 \\
5-27454 \\
5-27458 \\
5-27481 \\
5-27485 \\
5-27546 \\
5-27716 \\
5-27803 \\
5-27892 \\
6-25944 \\
9-27579 \\
19-27318\end{array}$ \\
\hline $\begin{array}{r}5-26118 \\
5-26189 \\
5-26609 \\
5-26640 \\
5-26776 \\
5-26922 \\
5-27044 \\
5-27049 \\
5-27313 \\
5-27452 \\
5-27457 \\
5-27482 \\
5-27740 \\
5-27889 \\
17-26589\end{array}$ & $\begin{array}{r}5-26186 \\
5-26481 \\
5-26611 \\
5-26698 \\
5-26780 \\
5-26927 \\
5-27045 \\
5-27064 \\
5-27316 \\
5-27453 \\
5-27458 \\
5-27491 \\
5-27741 \\
5-27890 \\
18-26589\end{array}$ \\
\hline $\begin{array}{l}5-27060 \\
5-27802\end{array}$ & $\begin{array}{r}5-27312 \\
12-25911\end{array}$ \\
\hline $\begin{array}{l}5-26478 \\
5-26922 \\
5-27059 \\
5-27454 \\
5-27802\end{array}$ & $\begin{array}{l}5-26606 \\
5-26926 \\
5-27061 \\
5-27481 \\
5-27895\end{array}$ \\
\hline $\begin{array}{l}526506 \\
5-26699 \\
5-27045 \\
5-27305 \\
5-27322 \\
5-27473 \\
5-27485 \\
5-27726 \\
5-27881\end{array}$ & $\begin{array}{l}56600 \\
5-26700 \\
5-27053 \\
5-27306 \\
5-27330 \\
5-27481 \\
5-27486 \\
5-27742 \\
5-27894\end{array}$ \\
\hline $\begin{array}{r}5-26284 \\
5-26604 \\
5-26779 \\
5-27053 \\
5-27330 \\
5-27440 \\
5-27485 \\
17-25884\end{array}$ & $\begin{array}{r}5-26285 \\
5-26606 \\
5-26780 \\
5-27059 \\
5-27437 \\
5-27459 \\
5-27557 \\
18-25884\end{array}$ \\
\hline $\begin{array}{l}5-26929 \\
5-27319\end{array}$ & $\begin{array}{r}5-27044 \\
12-27430\end{array}$ \\
\hline $\begin{array}{r}5-26606 \\
5-26778 \\
5-27456 \\
19-26702\end{array}$ & $\begin{array}{r}5-26702 \\
5-26927 \\
5-27457 \\
19-27327\end{array}$ \\
\hline $\begin{array}{l}5-26118 \\
5-26284 \\
5-26632 \\
5-26782\end{array}$ & $\begin{array}{l}5-26186 \\
5-26286 \\
5-26637 \\
5-26921\end{array}$ \\
\hline
\end{tabular}

$5-25165$

$5-2618$

$5-26627$

$5-26636$

$5-26698$

$5-26772$
$5-26778$

-1
$5-27046$

$5-27302$

$5-27576$

$5-27802$

$-26186$

26611

26780

$-26927$

27316

列

$-27491$

$-27890$

$-27312$

$-25911$

26606

27061

$5-27895$

$-27053$

$5-27306$
-27330

$-27486$

$-27742$

$-26285$

$-26780$

27059

27459

$-25884$

4
8
9
6
2
7
0
1
7
8
0
5
6
7
4
8
1
5
6
3
2
4
9
8

\section{2}

$5-26922$

5-27057 5-27048

$5-27312 \quad 5-27313 \quad 5-27060$

$5-27320 \quad 5-27327 \quad 5-27329$

$5-27452 \quad 5-27453 \quad 5-27483$

$5-27486 \quad 5-27547 \quad 5-27560$

$5-27748 \quad 5-27802 \quad 5-27881$

HEAT TRANSFER, GAS

5-26189, 5-26606 5-27481 5-27484

HEAT TRANSFER, NATURAL CONVECTION

$5-26284 \quad 5-26478 \quad 5-26606 \quad 5-26625$

$5-26698 \quad 5-26701 \quad 5-26702$

$5-27316 \quad 5-27453 \quad 5-27454$

$5-27483 \quad 5-27742 \quad 5-27748$

19-26702, 19-27456

HEAT TRANSFER, RADIANT

$\begin{array}{lrrr}5-26606 & 5-26702 & 5-26927 & 5-26928 \\ 5-27306 & 5-27327 & 5-27454 & 5-27455 \\ 5-27456 & 5-27480 & 5-27482 & 5-27547\end{array}$

HEAT TRANSFER, SUPERCRITICAL $5-27322,5-27330$

$19-27456$

HEAT TRANSFER, TWO PHASE

$5-28538$

$5-26606$ 5-26702 5-27061 5-27064

$5-27052$

$5-27305$

$5-27059$ 19-26702

HEAVY WATER

6-26721
HEIGHT OF RISE

$9-26721$

$17-27141$

$16-27291$

HEL IUM

$5-27802 \quad 7-27096$

HFBR TRR)

6-26721 9-26721 17-26409

HFIR (FTR)

$6-26561 \quad 9-26437 \quad 9-26561$
$17-27854$

$17=27142$

5-25907

$\begin{array}{lllr}3-27041 & 4-27822 & 4-27823 & 5-25907 \\ 5-26116 & 5-26633 & 7-27093 & 7-27095 \\ 9-26705 & 9-26968 & 9-27580 & 17-26616\end{array}$

HOT CELL

$9-26968$
$9-27580$

$\begin{array}{rrrr}6-26591 & 6-26591 & 12-27980 & 12-27981 \\ 13-27979 & 12-27980 & 13-27981 & 14-27918 \\ 15-27918 & 17-26591 & 17-26591 & \end{array}$

HOT $15-27918$

CHANNEL

$5-26481 \quad 5-26605 \quad 5-26632 \quad 5-26635$

$5-26640 \quad 5-26702$

$5-27052$

$5-27714$

$5-27456 \quad 5-27557$

$5-27714$
$19-26702$

$5-27452$

$5-27740$

HOT CHANNEL ANALYSIS 5-27452

HUMBOLT BAY (BWR)

IIUAIOIT

$17-27434 \quad 17-27478$

$$
7-27034
$$

HYDRAULIC EFFECT

HYDRIOE

IOE

5-25906 17-26409 18-25906

HYDROOYNAMIC ANALYSIS

$\begin{array}{rrrr}5-26285 & 5-26605 & 5-26609 & 5-26702 \\ 5-26924 & 5-27557 & 5-27714 & 19-26702\end{array}$

HYDROGEN

$5-27883$

$17-27287$

$7-27037$

$7-27095$

7-27096

HYDROLOGICAL CONSIDERATION, GENERAL

14-27020 14-27021 $14-27024 \quad 14-27078$

ICRP

$14-27020 \quad 14-27021 \quad 14-27024$

$14-27078$

13-27018 15-28042

IOAHO FALLS
$12-27285$

I GNITION

$$
\text { 5-27472 7-27035 }
$$

$14-28007$

TION TEMPERATURE

IGNITION $5-27472 \quad 7-27472$

IMPACT PROPERTY

$$
\begin{array}{rr}
1-26558 & 3-27427 \\
9-27494 & 11-26558
\end{array}
$$

S SHOCK

IN CORE MEASUREMENT

IN $9-26473 \quad 9-26706$

9-2 2473 TIMENT
$9-26$

$\begin{array}{ll}1-26558 & 5-26283 \\ 7-26558 & 7-27032\end{array}$

$11-26558$

$11-27805$

$9-28013$

$18-27333$

5-26631 5-27805

$7-27035$ 


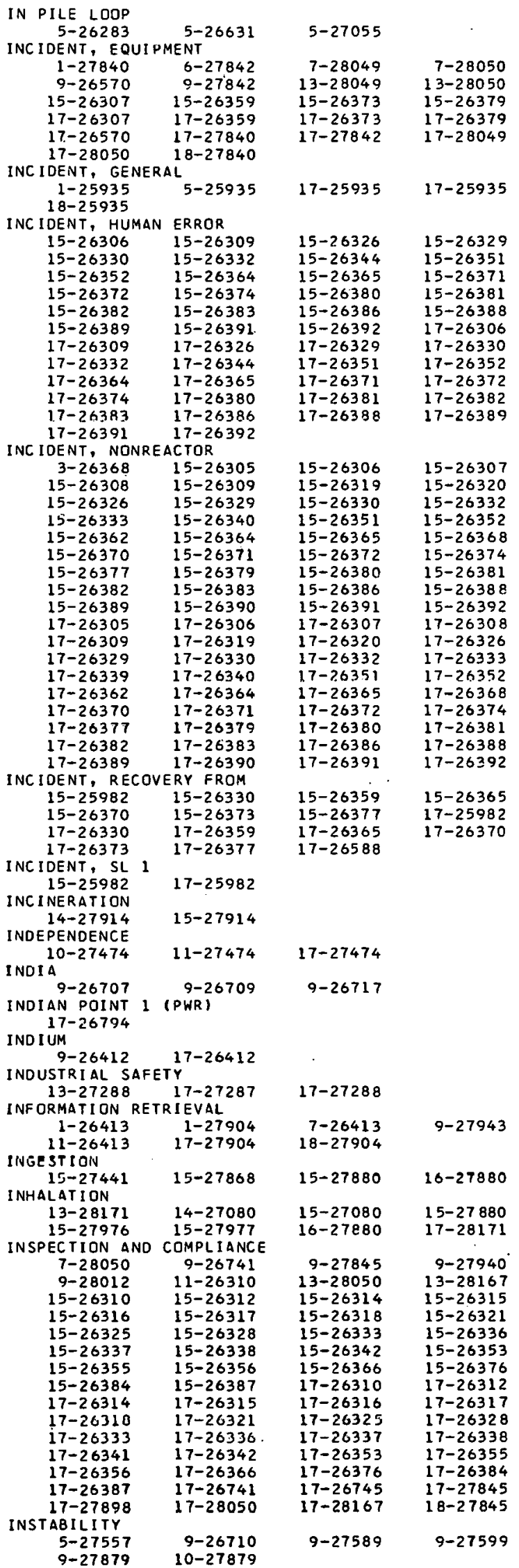

$\begin{array}{cc}9-27879 & 10-27879 \\ \text { INSTRUMENTATION } & \text { CALIBRATION }\end{array}$

\begin{tabular}{|c|c|c|c|}
\hline $9-26968$ & $9-27588$ & $-2758^{\circ}$ & $9-27590$ \\
\hline $9-28018$ & $9-28041$ & $12-28033$ & $15-26311$ \\
\hline $15-26315$ & $15-26316$ & $17-26311$ & \\
\hline $17-26316$ & $17-26341$ & $17-28033$ & \\
\hline INSTRUMENTATION, & ABNORMAL I & INOICATION & \\
\hline $\begin{array}{l}6-27616 \\
9-27344\end{array}$ & $\begin{array}{l}6-27842 \\
0-77589\end{array}$ & $\begin{array}{l}9-26710 \\
9-27500\end{array}$ & $9-26968$ \\
\hline $\begin{array}{l}9-27344 \\
9-27842\end{array}$ & $\begin{array}{r}9-27589 \\
17-27344\end{array}$ & $\begin{array}{l}9-2750 \\
17-27347\end{array}$ & $17-27616$ \\
\hline $17-27942$ & & & \\
\hline \multirow{2}{*}{\multicolumn{4}{|c|}{ 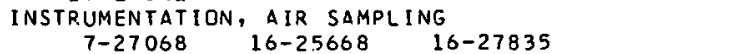 }} \\
\hline & $16-25668$ & $16-27835$ & \\
\hline INSTRUMENTATION, & AMPLIFIFR & & \\
\hline \multicolumn{4}{|c|}{$9-26724$} \\
\hline \multicolumn{4}{|c|}{$\begin{array}{c}9-26437 \\
9-28014\end{array}$} \\
\hline \multicolumn{4}{|c|}{ INSTRUMENTATION, COMPONENT } \\
\hline $\begin{array}{l}9-25699 \\
0-26708\end{array}$ & $9-26512$ & $9-26705$ & $\begin{array}{l}9-26706 \\
9-26723\end{array}$ \\
\hline $\begin{array}{l}9-26708 \\
9-26726\end{array}$ & $\begin{array}{l}9-26716 \\
9-26728\end{array}$ & $\begin{array}{l}9-26718 \\
9-26730\end{array}$ & $\begin{array}{l}9-26723 \\
9-26732\end{array}$ \\
\hline $9-26736$ & $9-26765$ & $9-27580$ & $9-27591$ \\
\hline $9-27592$ & $9-27605$ & $0-27613$ & $9-27650$ \\
\hline $9-27934$ & $9-27936$ & $9-27942$ & $9-27944$ \\
\hline $9-28014$ & $9-28041$ & $10-26512$ & \\
\hline \multicolumn{4}{|c|}{ INSTRUMENTATION, CONTROL } \\
\hline $4-27579$ & $6-27579$ & $9-26708$ & $9-26709$ \\
\hline $9-26723$ & $9-26725$ & $9-26726$ & $0-26733$ \\
\hline $9-26967$ & $9-27500$ & $9-27579$ & $9-27586$ \\
\hline $9-27587$ & $9-28017$ & $10-26967$ & \\
\hline \multirow{2}{*}{\multicolumn{4}{|c|}{$\begin{array}{c}\text { INSTRUMENTATION, COOLANT QUALITY } \\
5-27885\end{array}$}} \\
\hline & & & \\
\hline $\begin{array}{l}\text { INSTRUMENT AT ION, } \\
9-26472\end{array}$ & DETECTION & FAILED FUEL & ELEMENT \\
\hline $\begin{array}{l}9-26472 \\
9-26718\end{array}$ & $9-26715$ & $9-26716$ & $9-26717$ \\
\hline \multicolumn{4}{|c|}{$\begin{array}{l}99-26718 \\
\text { INSTRUMENTATION, FLOW }\end{array}$} \\
\hline $9-26714$ & $12-29033$ & $17-28033$ & \\
\hline $\begin{array}{l}\text { NSTRUMENTATION, } \\
17-26301\end{array}$ & FUEL SCANN & NING & \\
\hline INSTRUMENTATION, & GENERAL & & \\
\hline $1-27042$ & $5-27885$ & $9-26473$ & $9=26967$ \\
\hline $9-27885$ & $9-27941$ & 9.27943 & $10-26967$ \\
\hline $19-26784$ & $19-27042$ & & \\
\hline INSTRUMENTATION, & IN CURE & & \\
\hline $5-27595$ & $5-27596$ & $9-26473$ & $9-26705$ \\
\hline $9-26706$ & $9-27582$ & $9-27583$ & $9-27584$ \\
\hline $9-27595$ & $9-27596$ & $9-28013$ & $9-28015$ \\
\hline $17-27347$ & $17-27584$ & $17-27595$ & $17-27596$ \\
\hline $17-27838$ & & & \\
\hline $\begin{array}{l}\text { NSTRUMENTATION, } \\
9-26967\end{array}$ & INDICATOR & & \\
\hline ISTRUMENTATION, & LIQUID LEV & VEL OETECTION & \\
\hline $17-27347$ & & & \\
\hline ISTRUMENTATION, & LOGARITHMI & & \\
\hline $9-28041$ & & & \\
\hline QUMENTATION, & METEOROLOG & GICAL & \\
\hline $9-26734$ & $16-26734$ & & \\
\hline INSTRUMENTATI ON, & NUCLEAR & & \\
\hline $6-26561$ & $9-26559$ & $9-26561$ & $9-26703$ \\
\hline $9-26704$ & $9-26705$ & $9-26706$ & $0-26708$ \\
\hline $9-26709$ & $9-26710$ & $9-26712$ & $9-26713$ \\
\hline $9-26710$ & $9-26723$ & $9-26724$ & $9-27581$ \\
\hline $9-27583$ & $9-27584$ & $9-27592$ & $9-28013$ \\
\hline $9-28014$ & $17-27584$ & & \\
\hline RUMENTATION, & PERIOD & & \\
\hline $9-26559$ & $9-26711$ & $9-26712$ & $9-26719$ \\
\hline $\begin{array}{l}\text { TRUMENTATION, } \\
9-27591\end{array}$ & POSITION & & \\
\hline $\begin{array}{l}9-27591 \\
\text { INSTKUMENIATION, }\end{array}$ & $9-27593$ & & \\
\hline $\begin{array}{l}\text { INSTKUMENIATIUN, } \\
6-27842\end{array}$ & $\begin{array}{l}\text { HOWEK KANE } \\
9-26741\end{array}$ & & $\dot{y}=2784 z$ \\
\hline $\begin{array}{r}6-27842 \\
17-26741\end{array}$ & $\begin{array}{r}9-26741 \\
17-26745\end{array}$ & $\begin{array}{l}17-27842 \\
17\end{array}$ & \\
\hline STRUMENTATION, & PRESSURE & & \\
\hline $5-25161$ & $9-27580$ & $9-27585$ & $17-27585$ \\
\hline STRUMENTATION, & PROCESS & & \\
\hline $\begin{array}{c}9-2.7587 \\
\text { INSTRUMENTATION, }\end{array}$ & PRDTECTIVE & & \\
\hline $9-26437$ & $0-26597$ & $10-26967$ & \\
\hline STRUMENTATION, & PULSE & & \\
\hline $\begin{array}{l}9-28014 \\
\text { INSTRUMENTATION, }\end{array}$ & & & \\
\hline $\begin{array}{l}\text { INSTRUMENTATION, } \\
9-26705\end{array}$ & $\begin{array}{l}\text { RADIATICN } \\
9-26707\end{array}$ & $\begin{array}{c}\text { MUNITORING } \\
9-28015\end{array}$ & $14-27075$ \\
\hline $15-26315$ & $15-26316$ & $15-26317$ & $15-26318$ \\
\hline $15-26342$ & $15-27075$ & $15-27076$ & $15-27442$ \\
\hline $15-27443$ & $15-27831$ & $19-27000$ & $15-27976$ \\
\hline $15-28008$ & $17-26301$ & $17-2$ & \\
\hline $17-26317$ & $17-26318$ & $17-26342$ & \\
\hline NSTRUMENTATION, & RECORDER & & \\
\hline $9-26713$ & & & \\
\hline $\begin{array}{l}\text { INSTRUMENTATION, } \\
9-26570\end{array}$ & $\begin{array}{l}\text { REL } A Y \\
17-26570\end{array}$ & & \\
\hline INSTRUMENTATION, & STARTUP & & \\
\hline $9-26720$ & $9-26735$ & & \\
\hline INSTRUMENTATION, & , SURVEIL & & \\
\hline
\end{tabular}




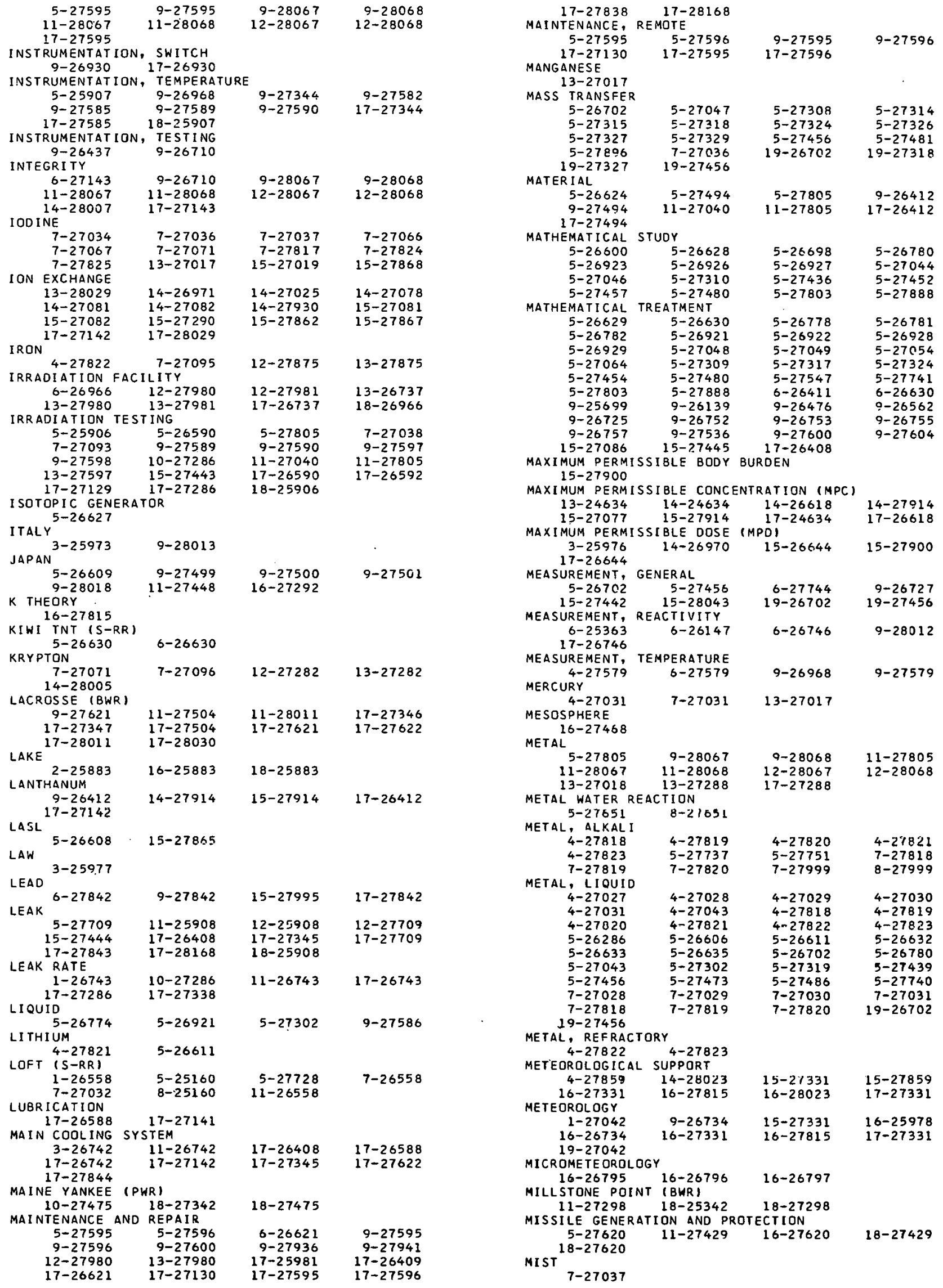


MIXING DEPTH 16-25978

MODEL TESTING

$14-27020 \quad 14-27451$
MODIFICATION, SYSTEM OR EQUIPMENT

$\begin{array}{rrrr}5-27709 & 6-26591 & 6-27143 & 9-26570 \\ 9-26930 & 11-25885 & 12-27709 & 17-26409 \\ 17-26569 & 17-26570 & 17-26591 & 17-26790 \\ 17-26930 & 17-27141 & 17-27143 & 17-27294\end{array}$

$17-27709 \quad 18-25885$

$\begin{array}{rr}6-27039 & 7-27039\end{array}$

MOLYBDENUM

4-27822

MONITOR, RADIATION, AIR

$15-27917$

MONITOR, RADIATION, AREA 15-26318 17-26318

MONITOR, RADIATION, BACKGR OUND $15-27019$

MONITOR, RADIATION, ENVIRONMENTAL $15-27083 \quad 15-27087 \quad 15-27089$ 15-27911 15-28042

MONITOR, RADIATION, GAS 12-27282 13-27282

MONITOR, RADIATION, GENERAL

MONITOR, 27918 15-27917

15-26311 $15-26336 \quad 15-26342$

$15-27860 \quad 15-27861 \quad 15-27917$

17-26336 17-26342

MONITORING PROGRAM, ENVIRONMENTAL $\begin{array}{lll}7-27072 \quad 14-27874 & 16-25668\end{array}$ $16-27874$

MONITORING SYSTEM, RADIATION 15-27977

MONTE

MSRE IRE $5-27455$

$9-26761$

$4-26766$

NAK $6-27039$

$7-27039$

$17-27130$

4- 27031

$4-27821$

5-26634

NBS 9-27343 17-27343

NEPTUNIUM

$13-28029$

$14-27081$

$15-27081$

$17-28029$

NERVA PROGRAM 4-27462 4-27467

NEUTRON $6-28002 \quad 9-27579$

6-26561

$9-26561$

$9-26708$ $\begin{array}{rr}9-26741 & 9=27592 \\ 15-27861 & 15-27865\end{array}$

NEUTRON INTERACT ION 6-25987 I 7-25987

NEVAOA TEST SITE

14-28023 16-28023

NF S

7-28049 7-28050

$13-28050 \quad 13-28167$

14-28170 $17-24634$

17-28167 17-28170

MINE MILE POINT IRWR

9-27614 9-2784

$11-27429 \quad 11-27432$

$18-27428 \quad 18-27429$

$18-27432 \quad 18-27614$

NIOBIUM

4-27821 4-27823

NI TROGEN

4-27821 5-26699

NOBLE GAS

NOISE

7-27035 7-27096

NOISE ANALYSIS

$y=27889$

$17-2090$

5-27885

$6-26561$

$17=27347$

NOISE R.ROSS CORRELATION

NO $Z 2 L$ LE 6-26561 9-26561

$1-26558$

$7-26558$
$11-27040$

$11-27040$

13-24634

$13-28170$

$17-28049$

$13-28049$

$14-24634$

$10-27614$

$12-27430$

$18-27430$

$18-27845$

11-27428

$17-27845$

18-27431

$9-26561$

$9-27885$

$18-2742$

$18-27430$

$7-27824$
$11-27426$

$11-25951$
$12-27430$

NPD 2 (HHR)

NRTS 10-27578

$1=26515 \quad 17-26515$

$18-26515$
NS SAVANNAH (D:AR)

17-27245 17-27839

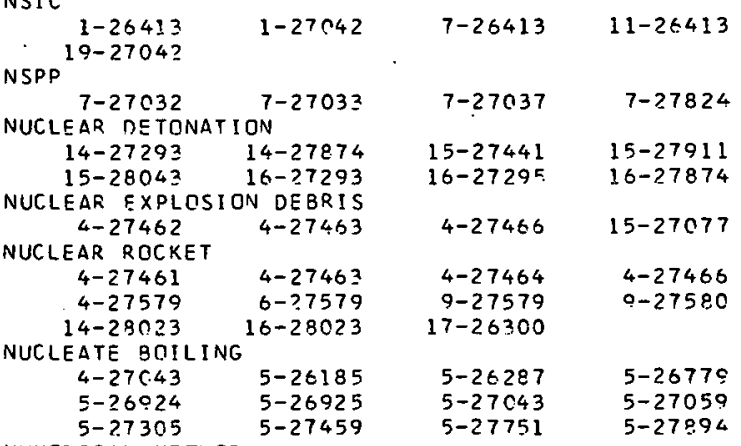

NUMER ICAL METHOD $5-27455 \quad 5-27547$

OBSTRUCTIDN

9-26740 10-27286 $17-27338$

OCEAN AND SEA $3-25976$ 15-26346 $17-26346$

$15-27897$

OECD

5-27576 17-27576

OFF GAS $7-29050$

$13-28 \cap 50$ $17-281$

OFF SITE

$$
\text { 5-27834 }
$$

$16-27834$ $18-27834$

ON SITE WDRK $2-25883 \quad 15-25833$

OPERATING EXDFRIENCE

3-25973

4-27031

9-26412

$9-26719$

$9-27343$

$9-28015$
$11-27200$

$17-26408$

$17-26790$

$10-26512$

$13-27017$ $18-27297$

$17-26400$

$17-27343$ ATING EXPERIENCE SUMMARY

$\begin{array}{ccrr}1-27435 & 1-27904 & 5-25906 & 5-26590 \\ 10-27286 & 10-27474 & 11-27474 & 17-26590 \\ 17-27286 & 17-27435 & 17-27474 & 17-27904 \\ 17-27084 & 17-27994 & 18-25906 & 18-27904\end{array}$

OPERATING LICENSE PROCESS $\begin{array}{rr}1-27007 & 17-26615 \\ 17-27346 & 17-27434\end{array}$ $\begin{array}{ll}17-27346 & 17-2743.4 \\ 17-27997 & 18-27097\end{array}$

$17-26794$

$17-27839$

$17-27340$

OPERATION

14-27918 15-27918 17-27145

OPERATOR ACTION

6-27842

9-27842

I 7-27842

ORE CONVERSION

7-27284

$13-27284$

DRGANIC IDDIOE $7-27034$

$7-27036$

$7-27036$
$7-27817$

$7-27037$
$7-27826$

$7-27067$

ORNL 5-27060

5-27716 9-26437 9-26561

$5-27748$

$6-26561$

ORR ( RR )

5-27055

7. -27032

$17-26409$

OSCILLATION

OSCILLATOR, REACTIVITY $18-27333$

OUT OF PILE LOOPS ANO EXPERIMENTS 1.- PILE LOOPS ANO EXPERIMENTS $5-26285$ $7-27031$

$5-26586$
$7-27532$

$7-27 \mathrm{c32}$

$7-27824$

$11-26558$

$5=26185$
$5-26790$
$7-27034$

$7-27034$

$18-26586$

OXIDATION 5-27651

$7-27038$

$7-27092$

$8-27651$

OXIDE 8-27092

4-27030 4-27029 $4-27820$

$7-27029$

4-27031 7-27471

$7-27819$

$7-27030$

5-27056 7-27056

14-27078

$7-27096$

$0-2655$

$0-29013$

$11-27297$
$17-25981$

17-26738

$7-27595$

$17-27946$

5-? 6 ? R3

$7-26558$

$7-27817$

4-27819

$7-27031$

$5-27056$
OYSTER CREEK \& (BWR) 


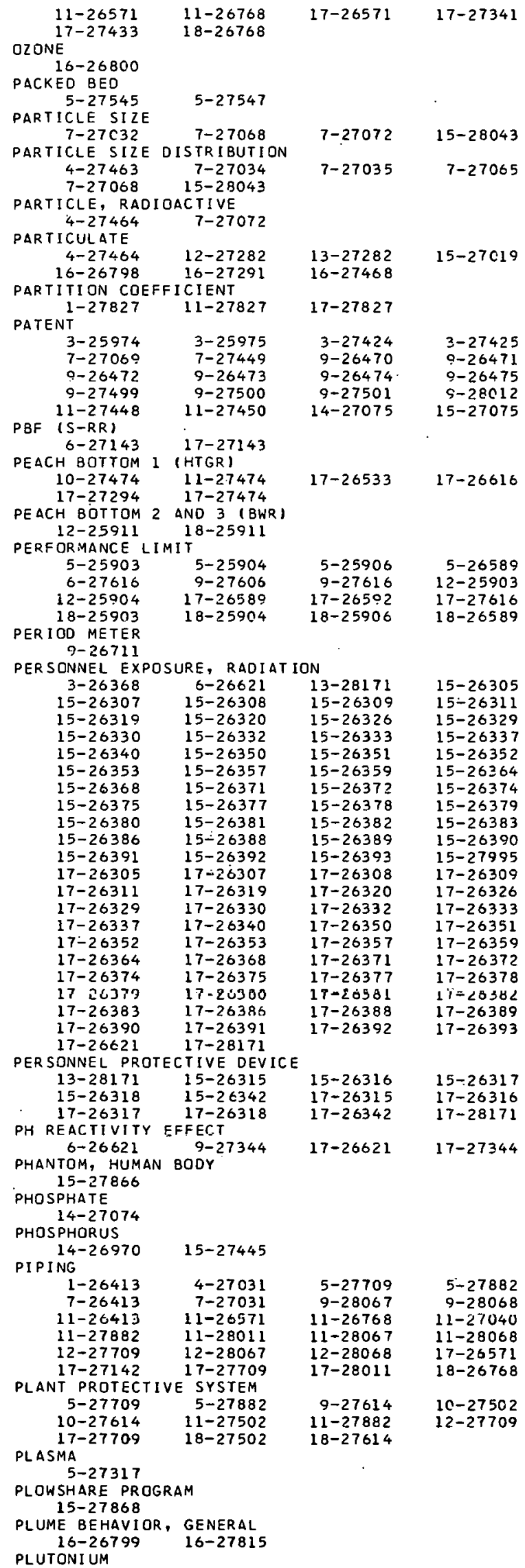

$5-27709$

$5-27882$
$9-28068$

$17-28011$

$18-26768$

$9-27614 \quad 10-27502$ $11-27882 \quad 12-27709$

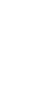

$6-26147$

$13-28029 \quad 5-26591$

$\begin{array}{ll}17-28029 & 14-27081 \\ 17-26591 & 17-28029\end{array}$

PLUTONIUM DIDXIDE

$5-26500 \quad 17-26590$

PNEUMATIC SYSTEM
$9-27614 \quad 10-27614$

POINT BEACH 1 AND 2 (PMR)

$17-27994 \quad 18-26101$

POISON, BUPNABLE

$9-26476$

POISON, FIXED

$9-26476$

POISON, SOLUBLE 4-27467

PONTRYAGINS PRINCI PLE $9-26562 \quad 9-27599$
$9-961 N C I P L E$

POOL

5-26284 5-26625 5-27322 5-27485

POPULATION EXPOSURE

$\begin{array}{llll}14-26971 & 14-27087 & 15-27087 & 15-27868\end{array}$

POTASSIUM

$4-27043 \quad 4-27821$

$\begin{array}{ll}4-27043 & 4-27821 \\ 5-26611 & 5-27043\end{array}$

$5-26284$

5-27319

$5-26608$

POWER COFFFICIENT

$$
\begin{array}{rr}
6-27842 & 9-27344 \\
17-27286 & 17-27344
\end{array}
$$$$
17-27286 \quad 17-2
$$

POWER DISTRIBUTIION

$$
\begin{array}{ll}
6-27616 \quad 6-27618
\end{array}
$$

$17-27618$

$6-27618$

$9-27842$
$17-27842$

$5-27439$

POWER UPRATING

5-26589

$\begin{array}{ll}14-26618 & 17-26589 \\ 17-26741 & 17-26744\end{array}$

$18-26589$

$\begin{array}{ll}17-26592 & 11-27474 \\ 17-27589 & 17-26618\end{array}$

$17-27289 \quad 17-27474$

PRAIRIE ISLAND 1 AND 2 (PWR)

18-26563

PRECI I I TATION

$$
\begin{array}{llll}
12-27875 & 13-27875 & 13-28025 & 14-27082
\end{array}
$$

$15-27082$
PRESSURE OFDP

$16-27295$

5-26605

$5-26921$

$5-27437$

$5-26921$

$13-280,49$

PRESSURE PULSE $13-28167$ 8-27998

PRESSURE RELIEF

$$
\begin{array}{rr}
3-26742 & 5-27709 \\
17-26742 & 17-27709
\end{array}
$$

PRESSURE TRANSIENT 5-27620 5-27747

PRESSURE VESSEL

$1-26413$

7-26413

$1-26558$

$7-26558$

$10-27502$.

$11-2595 i$

$11-25055 \quad 11-25957$

$11-26413 \quad 11-26558$

$11-27040 \quad 11-27423$

$11-28034 \quad 11-28068$

$17-26571 \quad 17-26742$

$17-28 \mathrm{C} 34$

18-26302 $18-27845$

PRESSURE, INTERNAL

3-26742 6-26411

17-26742

PRESSURE, SUBATMOSPHERIC $5-27620 \quad 16-2.7620$

PROBABILITY

$$
\text { 1-27827 9-26758 }
$$
9-27605

$9-27931$

17-27827

PROCEDURES AND MANUALS

$$
\begin{array}{rr}
3-26742 & 6-25987 \\
17-25987 & 17-26742
\end{array}
$$

PROPERTY, PHYSICAL

$$
\text { 4-27028 } 7-27028
$$

$14-27082$

$5-26: 23$

$5-27883$

5-27310

$17-28049 \quad 17-28167$

$11-26742 \quad 12-27709$

$16-27620$

$18-27620$

$3-26742$

9-27845

$11-25952$

$11-25958$

$11-26571$

$11-27448$

12-27709

$17-27709$

$18-27428$

$5-27709$

9-28068

$11-25953$
$11-25968$

$11-26742$

$11-27502$

$12-28068$
$17-27845$

18-27502

$11-26742$

$17-26617$

$18-27620$

$9-27601$

9-27932

$9-27602$

11-27827

9-28017 11-26742

$17-27130$

PROTACT 27028

15-27080

14-27080

(TR)

5-26590

12-27285

$17-26590$

6-26746

17-26746

PUMP

$11-27040$
$17-27622$

$12-28033$

$17-28033$

17-26409

$17-27141$
PYROLYTIC

7-27093

QUAD CITIES I AND 2 (BWR) 
$18-27479$ $1-27902$
$9-27938$ $9-27939$
$18-27902$ $9-26710$ $9-27934$ $9-27938$ $18-27902$

$R$ AND D PROGRAM

$\begin{array}{lrrr}4-27128 & 5-25903 & 5-25905 & 5-26586 \\ 6-26584 & 6-27143 & 12-25903 & 15-27900 \\ 17-26300 & 17-26592 & 17-27143 & 18-25903\end{array}$

RADIATION DAMAGE 7-27037 $18-26302 \quad 18-26586$

$18-27333$

RADIATION EFFECT $\begin{array}{lll}1-24694 & 7-27037 & 7-27817\end{array}$ $\begin{array}{lll}1-24694 & 7-27037 & 7-27817\end{array}$

RADIATION IN PERSPECTIVE $1-24694$

RADIATION INJURY, TREATMENT OF $\begin{array}{llll}1-27856 & 14-27855 & 15-27855 & 15-27856 \\ 17-27855 & 17-27856 & & \end{array}$ RADIATION MODEL $15-27868$

RADIATION SAFETY AND CONTROL

$\begin{array}{rrr}1-27435 & 1-27856 & 4-27859 \\ 14-26970 & 14-27080 & 14-27082 \\ 14-27918 & 14-27930 & 15-26312 \\ 15-26351 & 15-26356 & 15-26365 \\ 15-26378 & 15-26380 & 15-26385 \\ 15-26394 & 15-26644 & 15-27019 \\ 15-27080 & 15-27082 & 15-27085 \\ 15-27087 & 15-27856 & 15-27859 \\ 15-27861 & 15-27897 & 15-27900 \\ 15-27917 & 15-27918 & 15-27976 \\ 15-28008 & 15-28042 & 15-28043 \\ 17-26328 & 17-26351 & 17-26356 \\ 17-26377 & 17-26378 & 17-26380 \\ 17-26387 & 17-26394 & 17-26644 \\ 17-27435 & 17-27856 & \end{array}$

$17-26387 \quad 17-26394$

$17-26644$

RAOIATION, PUBLIC EOUCATION/ACCEPTANCE

$\begin{array}{cccc}1-24694 & 1-27902 & 2-27299 & 13-24634 \\ 14-24634 & 17-24634 & 17-27902 & 18-27299 \\ 18-27902 & & & \end{array}$

RADIOACTIVITY RELEASE

$\begin{array}{lrrr}12-27283 & 14-27087 & 14-28023 & 15-27087\end{array}$
16-28023

$1-24694 \quad 4-27859 \quad 15-27859$

RAOIOCHEMICAL ANALYSIS

$\begin{array}{ll}14-27083 & 14-27874 \\ & 140\end{array}$

$15-27083 \quad 16-27874$

14-27918 15-27918

RADIOCHEMICAL PROCESSING

14-27918 15-27918

RADI OGRAPHY

$3-26368$

15-26306

$15-26310$

$15-26315$

$15-26319$

$15-26326$

$15-26332$

15-26338

$15-26345$

$15-26352$

$15-26357$

$15-26365$

$15-26371$

$15-26375$

15-26379

$15-26383$

$15-26387$

$15-26391$

$17-26306$

$17-26310$

17-26315

$17-26319$

$17-26326$

17-26332

17-26338

17-26342

17-26347

17-26355

17-26362

17-26368

$17-26373$

$17-26377$

17-26381

17-26385

17-26389

17-26394

RADITISOTOPE
9-26741

15-26307

15-26311

15-26316

$15-26320$

5-26328

$15-26333$

$15-26340$

$15-26353$

$15-26359$

$15-26366$

15-26372

15-26376

$15-26380$

15-26384

$15-26388$

$15-26392$

17-26307

$17-26311$

$17-26316$

$17-26328$

$17 \quad 26333$

$17-26339$

$17-26344$

$17-26351$

$17-26356$

17-26364

$17-26370$

$17-26374$

1 7-26378

$17-26382$

$17-26386$

$17-26390$

17-26741
11-26310

15-26308

15-26312

$15-26317$

15-26321

15-26329

$15-26336$
$15-26342$

15-26347

15-26355

15-26362

15-26368

$15-26373$

$15-26377$

15-26381

$5-26385$

5- 26389

$15-26394$
$17-26308$

$17-26312$

$17-26317$

17-26321

$17-26329$

$17-26336$

$17-26340$

$17-26345$

$17-26352$

-

$17-26371$

$17-26375$

$17-26379$

17-26383

$17-26387$

$17-26391$

17-27334
9-26741

14-27087

15-26328

15-26377

15-26387

15-27860

15-27911

$15-27977$

$17-26312$
$17-26365$

17-26385

17-26741

$15-27087$

15-26305

15-26309

$15-26314$

15-26318

$15-26325$
$15-26330$

15-26337

15-26344

15-26351

15-26356

15-26364

$15-26370$

15-26374

15-26378

$15-26386$

$15-26390$

17-26390

17-26309

$17-26314$

17-26318

$17-26325$

17-26330

$17=26337$

1 7-26341

17-26346

17-26353

17-26359

$17-26366$

$17-26372$

17-26376

17-26380

$17-26384$
$17-26388$

$17-26392$

17-27898
$15-27076$

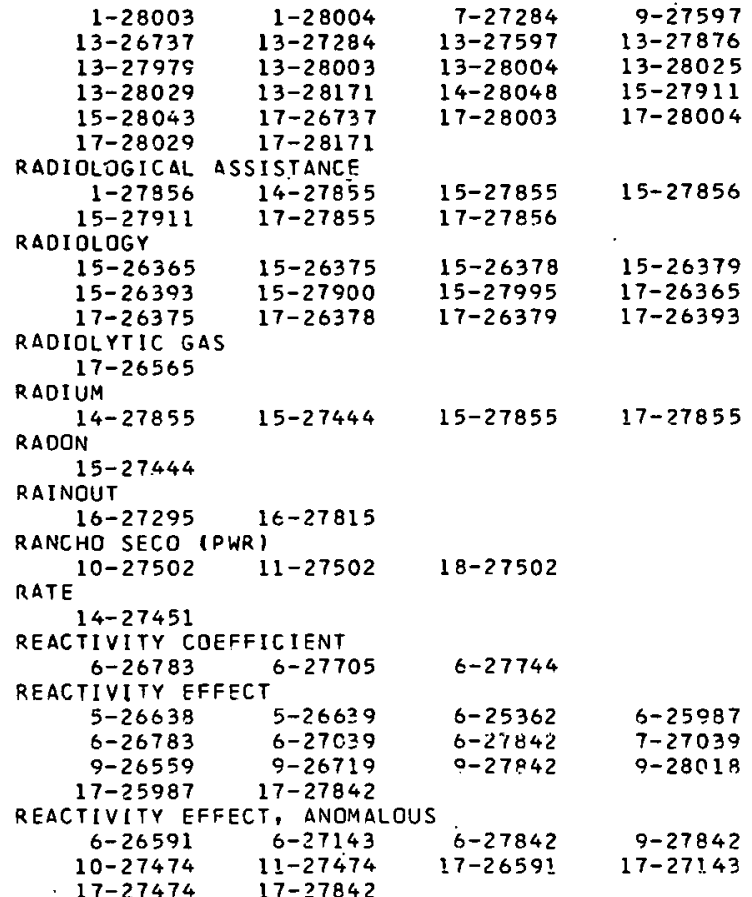

REACTIVITY EFFECT, FXPANSION

$$
\text { 6-26783 }
$$

REACTIVITY FFFECT, VNID

5-26639 $5-26639$
REACTIVITY, EXCESS $6-2 B O 10$

REACTOR CONTROL

5-27047 6-26721

9-26562 $0-26720$

$0-26724 \quad 9-26725$

$9-26735 \quad 9-27519$

$12-26303 \quad 17-26300$

REACTOR COOLANT

5-26260 7-27999

REACTOR DE SCRIPTION

$5-25609 \quad 5-27728$

$9-28018 \quad 17-25987$

18-26302 18-27103

REACTOR DYNAMICS

$$
\text { 5-26287 } \quad 5-266 ? 9
$$

5-27707 6-26561

6-27707 $\quad 0-26561$

REACTOR KINETICS

5-25944 5-27647

$6-26966 \quad 6-27073$

$6-27707 \quad 7-25944$

REACTOR PHYSICS

$6-25987 \quad 6-26591$

17-26591 17-28002

REACTOR POWER

- $5-20589$

$\begin{array}{rr}9-27842 & 9-28018 \\ 14-27018 & 14-28005\end{array}$

15-27918 17-26589

REACTOR SAFETY SYSTEM

S-26437 $\quad$ - 26570

9-26727 9-26728

$9-26732 \quad 9-28017$

REACTOR STASILITY

6-26584 6-27030

17-26300 17-27143

RFACITR STAPTUP EXPERIENCE

17-26408 17-27347

REACTOR STARTUP TESTING 6-28010 17-28010

KEACTOR TEST PACILITV

$$
\text { 5-27576 } 17-27576
$$

REACTOR TRANSIENT

1-27042 5-26285

6-27143 17-27143

$6-27143$
REACTOR, $\triangle E C$. NWNFD

$1-26005 \quad 1-26743$

5-27894 6-26561

S-26561

$11-26743$
$11-26721$

$6-26584$

$9-26303$

$9-26721$

$9-26726$

$9-27587$

$17-26412$

$9-26412$

$0-26722$

$9-26733$

9-28017

$8-27999$

$5-2774$ ?

17-2728\%

19-25465

$3-20030$

$6-26630$

9-26721

5-27707

6-27143

$17-27143$

6-28002

$6-25987$

$17-27854$

$5-27047$

$5-26721$

$6-25944$

$6-27647$
$18-26066$

$17-25987$

$0-27842$

$10-27578$

$15-27082$

17-27842

9-26709

$9-26729$

$17-26570$

$6-27143$ 


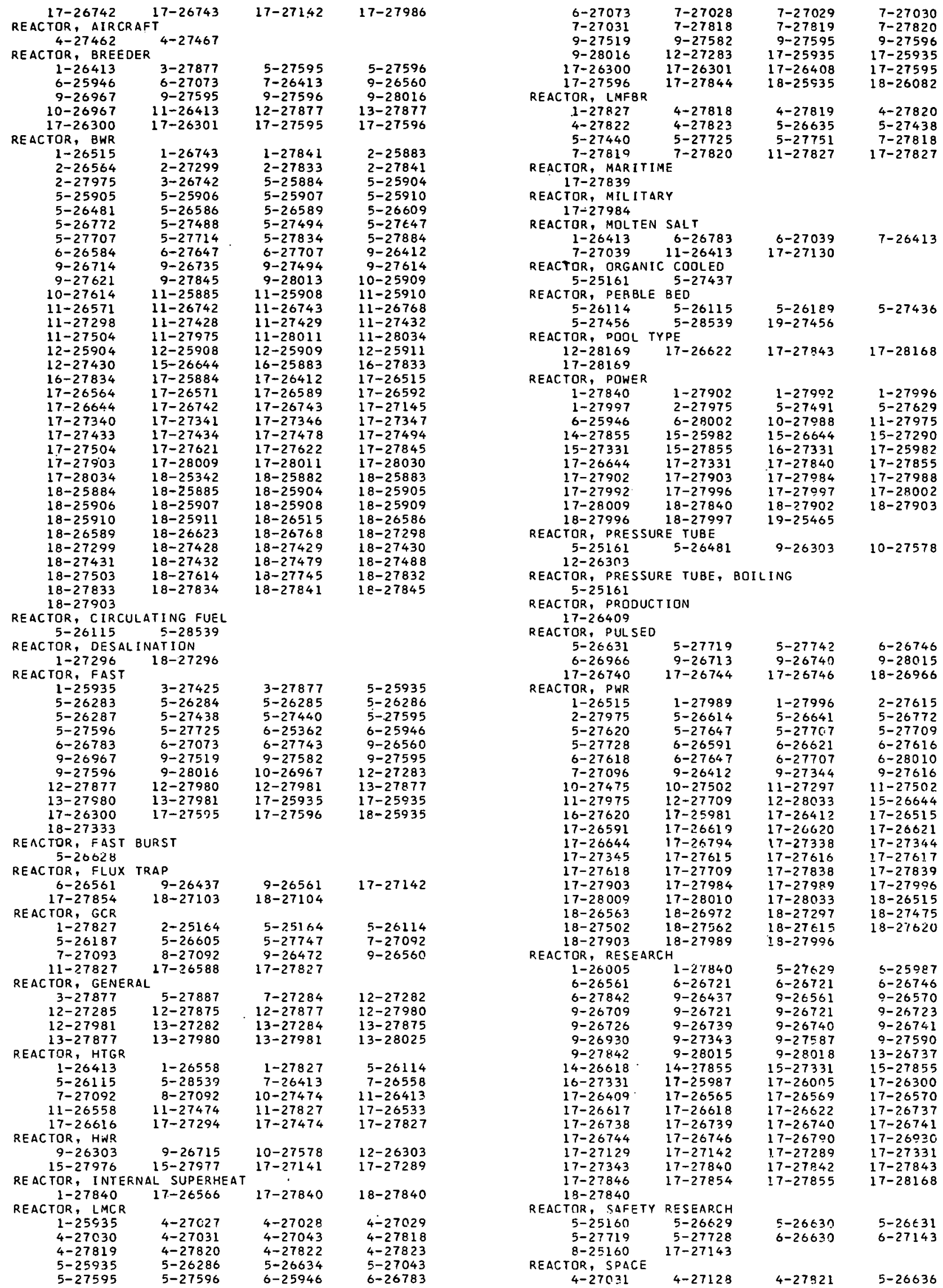




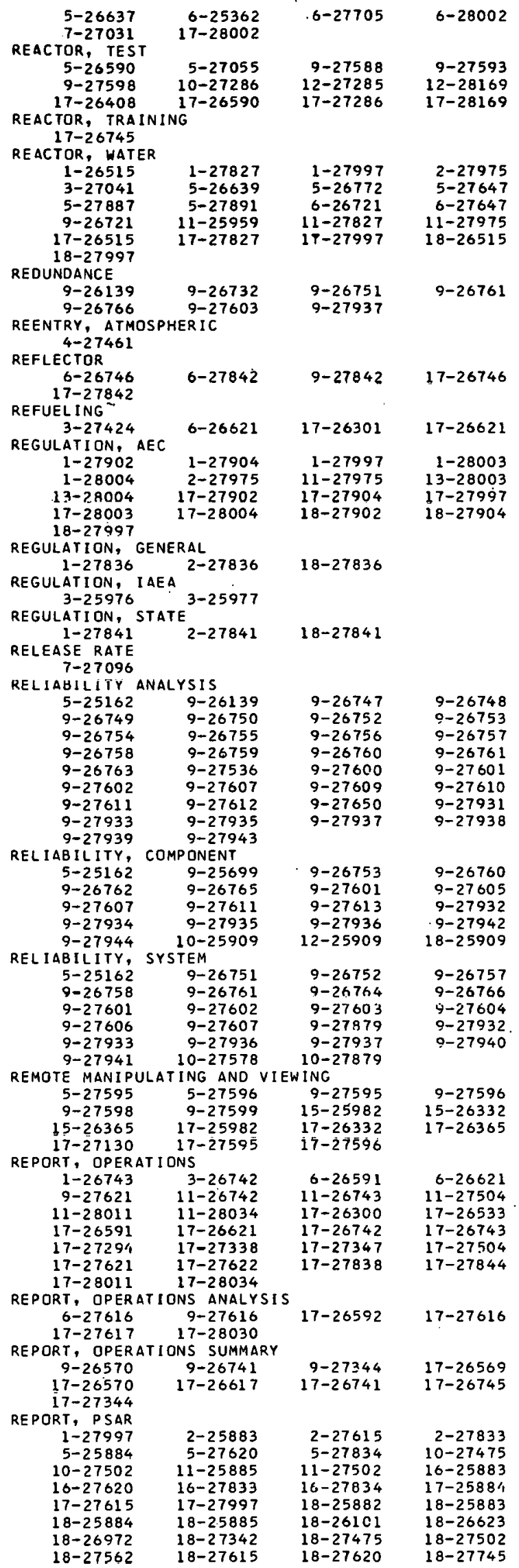

$\begin{array}{rrrr}18-27832 & 18-27833 & 18-27834 & 18-27997 \\ \text { REPORT, SAR } & & & \\ 1-27997 & 11-27428 & 11-27429 & 11-27432 \\ 12-27430 & 14-26618 & 17-26618 & 17-27289 \\ 17-27997 & 18-25342 & 18-26082 & 18-27103 \\ 18-27104 & 18-27428 & 18-27429 & 18-27430 \\ 18-27431 & 18-27432 & 18-27997 & \\ \text { RESIN } & & & \\ 13-28029 & 15-27290 & 17-28629 & 17-28168 \\ \text { RESPONSE TIME } & & & \\ 1-27997 & 5-25910 & 9-27343 & 11-25908 \\ 11-25910 & 12-25908 & 17-26794 & 17-27343 \\ 17-27997 & 18-25908 & 18-25910 & 18-27997 \\ \text { REVIEH } & & & \\ 1-25935 & 1-27042 & 2-27615 & 5-25035 \\ 5-26188 & 5-26606 & 10-27475 & 10-27502 \\ 11-27432 & 11-27502 & 17-25935 & 17-25935 \\ 17-26300 & 17-27615 & 18-25935 & 18-27432 \\ 18-27475 & 18-27502 & 18-27615 & 19-27042\end{array}$

RIVER, CLINCH

15-28042

RIVER, GENERAL

15-26370

$17-26370$

ROBINSON 2 (PWR)

$11-27297$
MECHANICS

$18-27297$

14-28007

ROVER PROGRAM

RUBIOIUM

5-26636

5-26637

$3-26742$

5-27737

13-27282

17-26742

$11-26742$

$12-27282$

SAFETY ANALYSIS

1-27827

5-26285

$11-27827$

SAFETY EVALUATION

$$
\text { 2-25164 5-25164 }
$$

$2-25164$
$10-27474.11-27474$

$17-26566 \quad 17-26744$

$17-27474 \quad 18-27931$

$5-27834$

$16-27834$

$17-27340$

$9-26764$

$17-26565$

SAFETY MARGIN

$\begin{array}{lr}2-27615 & 5-25884 \\ 18-25884 & 18-27615\end{array}$

$17-25884$

$17-27346$

$18-25884$

$17-27613$

SAFETY PRINCIPLES AND PHILOSOPHY

$1-25935 \quad 1-27042 \quad 1-27435 \quad 1-27827$

$\begin{array}{llll}1-27840 & 2-27975 & 3-27041 & 5-25935\end{array}$

$\begin{array}{llll}11-27827 & 11-27975 & 13-27288 & 17-25935\end{array}$

$\begin{array}{llll}17-25935 & 17-27287 & 17-27288 & 17-27435\end{array}$

$\begin{array}{llll}17-27827 & 17-27840 & 18-25935 & 18-27940\end{array}$

SAFETY PROGR

$\begin{array}{llll}1-26413 & 1-26515 & 7-26413 & 11-26413\end{array}$

SAFETY REVIEW

$\begin{array}{lrrr}\text { TY REVIEW } & & & \\ 1-26743 & 1-27042 & 1-27435 & 1-27227 \\ 3-27041 & 4-27030 & 5-27629 & 7-27030 \\ 9-26729 & 0-26740 & 9-26741 & 9-26764 \\ 10-27286 & 11-26743 & 11-27827 & 17-26617 \\ 17-26740 & 17-26741 & 17-26743 & 17-26745 \\ 17-27286 & 17-27435 & 17-27827 & 17-27903\end{array}$

SALEM 1 AND 2 (PWR)

$18-26972$

SAMAR IUM

SAMPL ING

6-25987 17-25987

$1-26143$

$1-21032$

$\begin{array}{rr}14-27065 & 7-27068 \\ 14-27020 & 14-27075\end{array}$

15-27083 17-26743

SAMPLING, HIGH ALTITUDE

$\begin{array}{llll}14-27874 & 16-25668 & 16-26800 & 16-27874\end{array}$

SAN ONOFRE (PWR)

$9-27344 \quad 12-28033$

SAVANNAH RIVER PLANT

$\begin{array}{llll}13-27017 & 14-27025 & 14-27 C 87 & 15-27087\end{array}$

$15-27976$

$\begin{array}{rrrr}1-27996 & 5-27709 & 6-26591 & 12-27709 \\ 17-26591 & 17-27709 & 17-27096 & 18-27096\end{array}$

SCRAM, REAL

IU-27286 17-26569

$17-27286$

SCRAM, SPURIOUS

SEAL $9-26570$

$17-26570$

9-26512

$10-26512$

$13-25956$

$17-26409$ $17-27287$

SEDIMENT

14-27020 14-28000 15-27019

11-2595

$17-27141$

SEFOR (RE) 


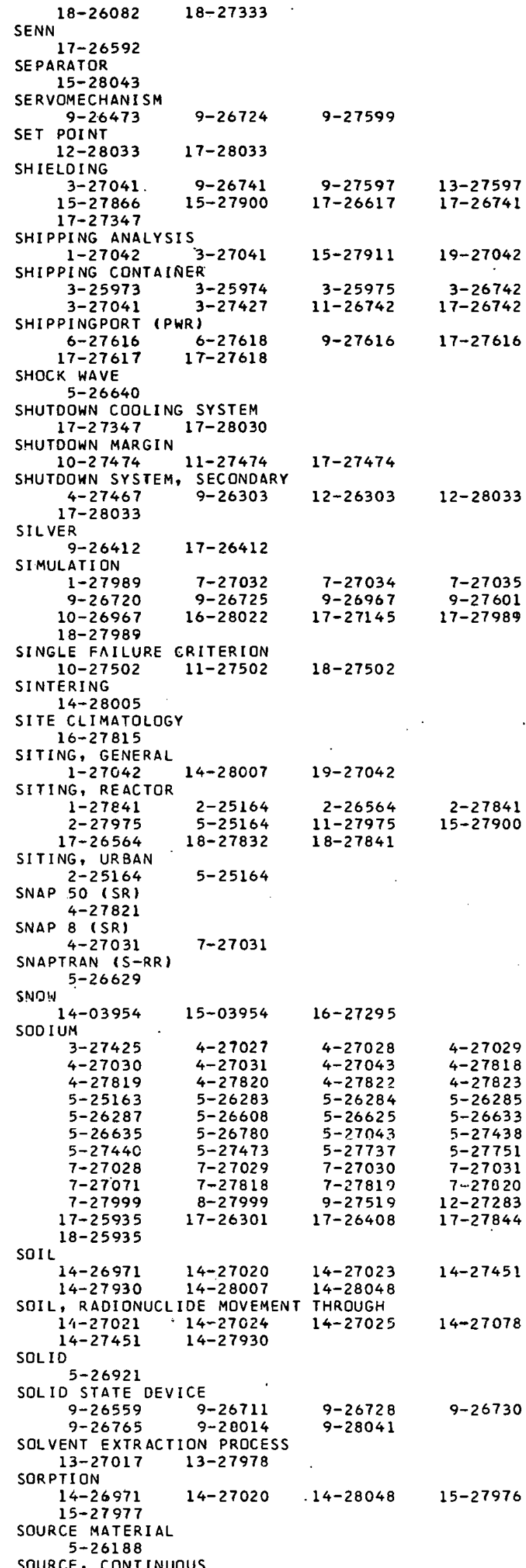

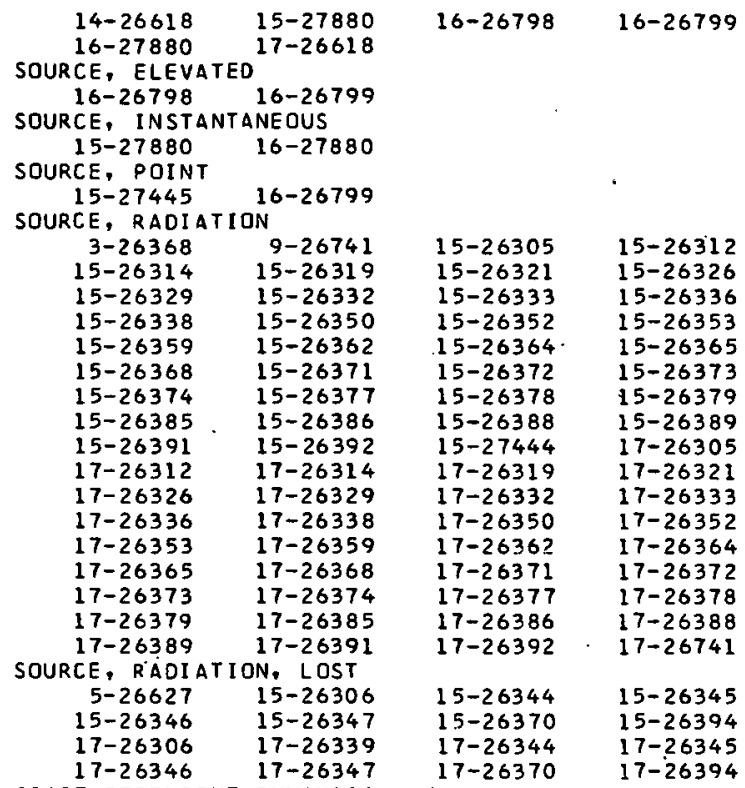

SPACE DEPENDENT DYNAMICS

5-25944 6-25944

7-25944

4-27859 15-27859

SPECTROMETRY, GAMMA

9-26715 $9-26717 \quad 9-27581 \quad 15-27290$

SPECTROMETRY, NEUTRON

9-27592

SPERT 3 (S-RR)

$\begin{array}{cc}6-27143 & 17-27143\end{array}$ $\begin{array}{cc}\text { SPERT } 4 \text { (S-RR) } \\ 6-27143 & 17-27143\end{array}$

SPHERE

5-26189 5-26633 $5-27308 \quad 5-27324$

SPRAY, GENERAL $1-26413$ 7-27071

$7-26413$

$5-26927$
$5-27545$

$5-27302$

ST ACK 11-26413

$7-28049$

$14-26618$

$7-27036$

$7-27037$
$7-27826$

$3-28049$

$7-28050$
$15-27019$

$13-28049$
$15-27900$

$15-27900$
$17-26618$

$13-28050$

$16-26796$

$16-27291$

ATION

$\begin{array}{llll}1-20519 & 1-27856 & 1-27902 & 1-27904\end{array}$

$1-27987 \quad 1-27989.1-27991 \quad 1-27992$

$\begin{array}{rrrr}1-27987 & 1-27989 & 1-27991 & 1-27992 \\ 1-27996 & 5-27834 & 6-25987 & 6-28002\end{array}$

$14-27855$

15-26376

$15-27856$

$17-25087$

$17-26376$

$17-2 € 622$

$17-27340$

$17-27856$

$17-27984$

$17-27988$

$17-27993$

$17-2800$ ?

$18-27902$

$18-27902$
$18-27996$

$17-27996 \quad 17-28001$

$18-26515 \quad 18-27834$ $18-27904$

$18-27834$
$18-27989$

STATE PROGRAM

$1-27841$
STATISTICAL ANALYSIS

2-27841

$18-27841$

$15-26312$

$15-27331$

16-27331

$17-26515$

$17-26515$

$17-27145$
$17-27346$

17-27902

$17-27985$

$17-27989$

$17-27994$

$17-28009$

$18-27903$

$\begin{array}{llll}9-26755 & 9-26756 & 9-26757 & 9-26758\end{array}$

9-26761 9-27604

$9-27607$

STEAM STICAL CORRELATION

$$
\begin{array}{cr}
4-27818 & 5-26454 \\
5-26699 & 5-27301 \\
5-27651 & 7-27034 \\
7-27818 & 8-27651 \\
\text { STEAM GENERATOR } & \\
11-28011 & 17-25981 \\
17-27345 & 17-28011
\end{array}
$$$$
\text { 9-27943 }
$$

$10-27578$

STEEL

$$
\begin{array}{rr}
5-26455 & 5-26607 \\
5-27314 & 5-27482 \\
7-27038 & 7-27095 \\
9-26560 & \\
17-26616 & 17-27294
\end{array}
$$




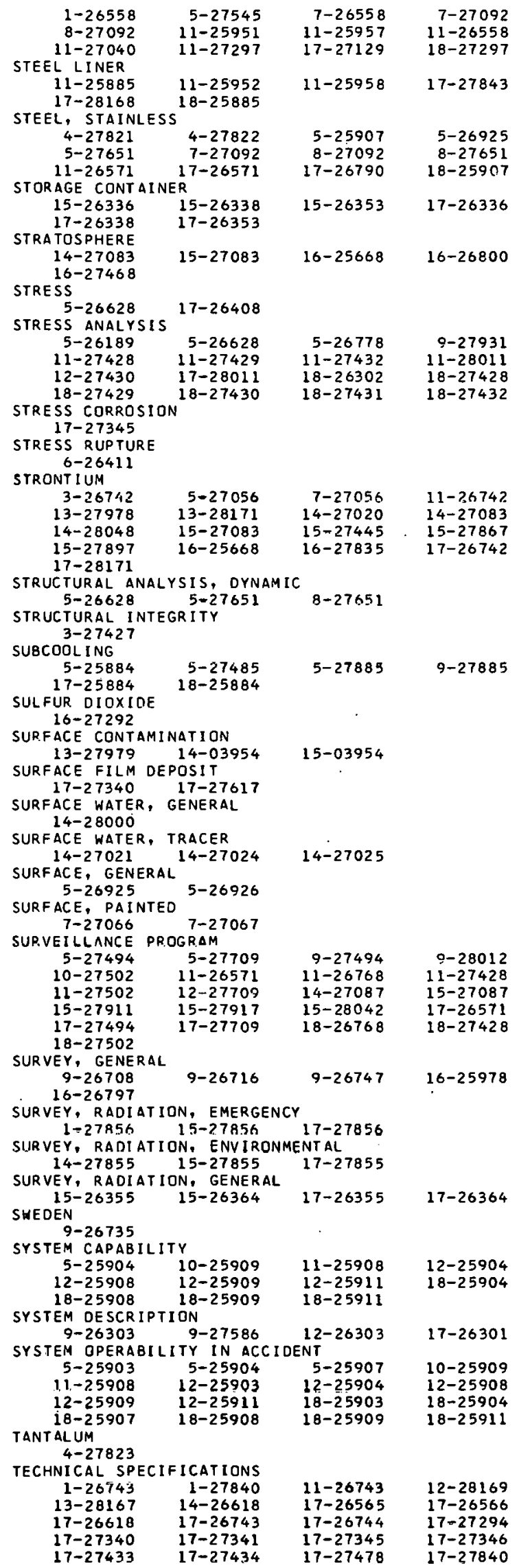

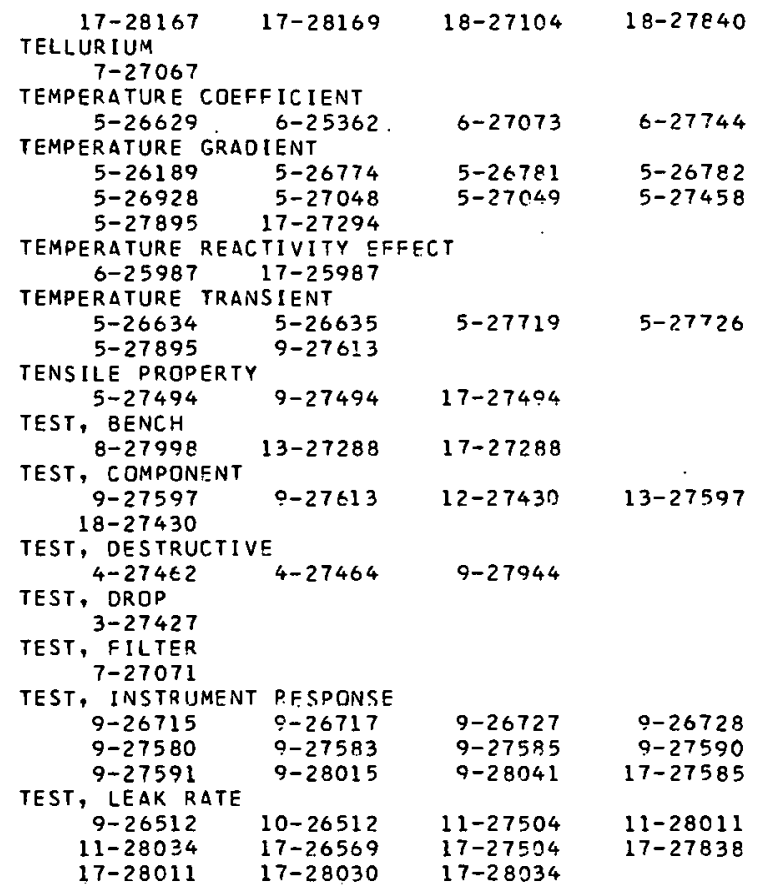

TEST, NONDESTRUCTIVE $\begin{array}{llll}5-27709 & 9-27845 & 9-28067 & 0-28068\end{array}$ $\begin{array}{llll}11-28067 & 11-28068 & 12-27709 & 12-28067\end{array}$ $\begin{array}{llll}12-28068 & 17-27709 & 17-27845 & 18-27431\end{array}$ TEST, ON LINE $9-26437 \quad 9-26732 \quad 9-26968$

TEST, PLANT RESPONSE

$\begin{array}{ll}9-28018 & 17-27347\end{array}$

TEST, PREOPERATIONAL $\begin{array}{rr}2-27615 & 9-27606 \\ 18-25342 & 18-27615\end{array}$

$18-25342$

$9-27934$

$17-27615$ TEST, PROOF

2-27615 3-26742

$11-25908 \quad 11-26742$

$12-25911 \quad 17-26742$

$18-25907 \quad 18-25908$

TEST, SYSTEM OPERABILITY $9-26437 \quad 9-26740$ 9-27933 10-25909

$17-26740 \quad 17-26741$ TESTING

$4-27464$

$6-26584$

$7-27284$

$11-27040$

$9-26762$

$13-27284 \quad 13-27875$

THEORETICAL INVESTIGATION 5-26589 5-27306 $5-27322 \quad 5-27457$ 6-26591 6-27628 $7-27065 \quad 7-27066$ 8-27999 9-26476 9-26752 9-26754 13-27979 16-28022

THERMAL ANALYSIS $5-26114 \quad 5-2737.1$

THERMAL CONSIDERATION 15-27076

THERMAL EXPERIMENT

$\begin{array}{cccr}4-27822 & 4-2.7823 & 5-27651 & 8-27651 \\ \text { THERMAL MECHANICAL EFFECT } & & 9-27613 & 11-28011 \\ 2-27615 & 5-26628 & 9-2768 & 17-278011 \\ 17-26408 & 17-27615 & 17-27838 & 17-28011 \\ 18-27615 & & & \end{array}$

5-25904 5-25007

$12-25004 \quad 12-25908$

$17-27615 \quad 18-25904$

$18-25911 \quad 18-27615$

$9-26741 \quad 9-26751$
$12-25909 \quad 17-26533$

$12-25909$

17-2653?

6-27143

$9-27933$

$12-27981$

$13-27878$

$7-27071$

9-28016

13-27018

$13-27978$

$17-27143$

$5-27313$

$5-27458$

6-27705

$7-27071$

$9-26755$

$17-2658.9$

$5-27316$

5-27547

6-27743

$7-27994$

$9-26723$

$17-26591$

THERMAL NEUTRON

$$
\text { 9-26707 15-27866 }
$$

THERMAL POLLUTION

$\begin{array}{rrrr}1-27836 & 1-27841 & 2-25883 & 2-27836 \\ 2-27841 & 14-27619 & 15-27619 & 16-25883 \\ 17-27619 & 18-25883 & 18-27836 & 18-27841\end{array}$

THERMAL PROPERTY

$$
\begin{array}{ll}
3-27041 & 4-27043 \\
5-27436 & 5-27651
\end{array}
$$

5-26699

$5-27043$ $5-27436$ 


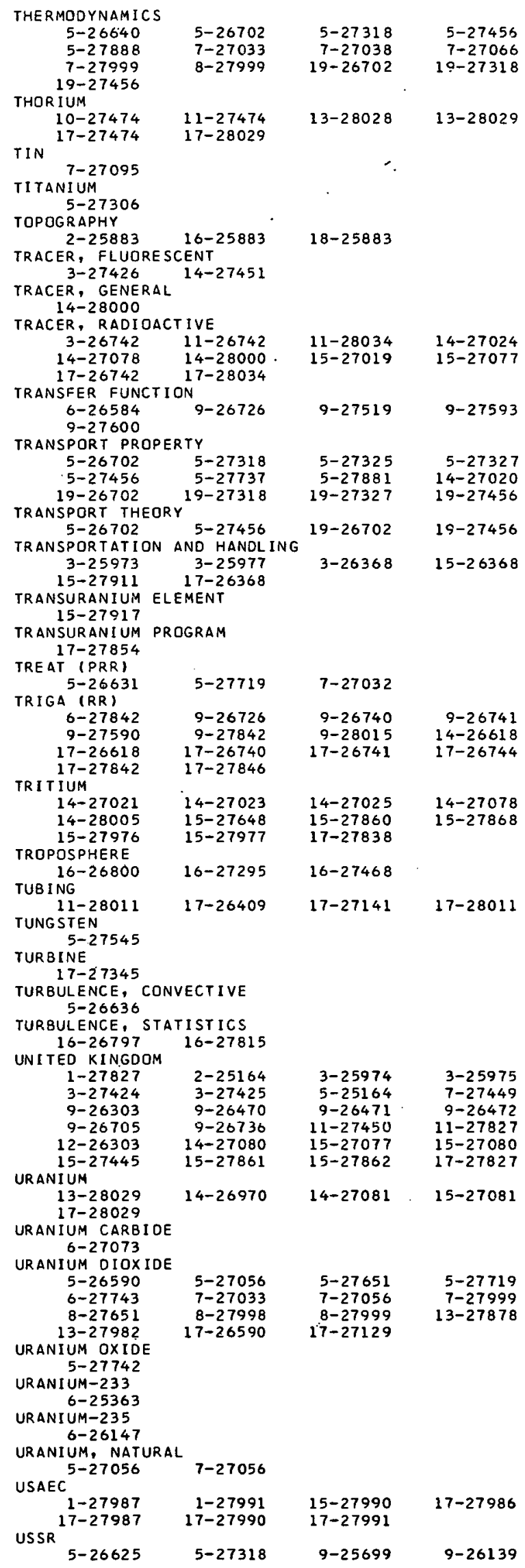

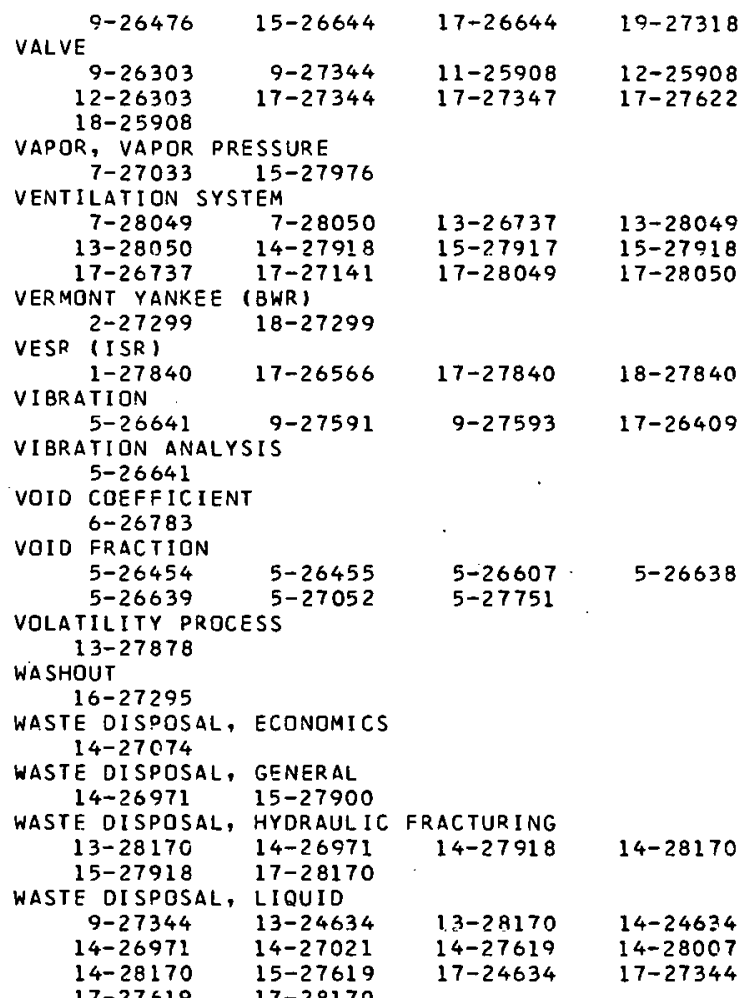

$\begin{array}{cc}17-27619 & 17-28170\end{array}$

WASTE DISPOSAL, OCEAN 15-27077

WASTE DISPOSAL, SALT 14-26971, 14-27074 WASTE DISPOSAL, SOLID 14-26971, 14-27074 14-27451 WASTE MANAGEMENT $14-27021 \quad 14-27930 \quad 15-27911$

WASTE STORAGE 14-27021 14-27074

$15-2791$ $\begin{array}{lll}14-28005 & 14-28007 & 14-27451\end{array}$

WASTE TREATMENT, ECONOMICS 14-27074 14-27930

WASTE TREATMENT, FIXATION 14-27074 14-28005

WASTE TREATMENT, GAS 14-27074

WASTE TREATMENT, GENERAL $12-27875$ 13-27875 WASTE TREATMENT, LIOUID 13-27876 13-27978 14-27082 15-27082

WASTE TREATMENT, SOLID 14-27914 15-27914 WATER POLLUTION 14-27930

WATER VAPOR $7-27036$
$14-27024$

WATER, GENERAL

$\begin{array}{lrll}5-25163 & 5-26607 & 5-26614 & 5-26641 \\ 5-26642 & 5-26780 & 5-27314 & 5-27726 \\ 5-27881 & 7-27095 & 7-27999 & 8-27998\end{array}$

14-26971 15-27019

13-28025 14-27074 $8-27990$

WAVE, STRESS $5-2.51 .61$

WELDING

$\begin{array}{rrrr}9-27845 & 11-26571 & 11-27040 & 17-25981\end{array}$

WELDS

$\begin{array}{llll}17-26571 & 17-27845 & 18-27431 & 18-27845\end{array}$

$11-27298 \quad 11-27428 \quad 18-27298$

$18-27428$

WIND PR TF ILE
16-26795

WIND STATISTICS

$X-R A Y$ $16-26795 \quad 16-26796 \quad 16-26797$

16-27815

3-27426 14-27855 15-26378 15-27085. $\begin{array}{llll}15-27442 & 15-27855 & 15-27900 & 17-26378\end{array}$ XENON

$17-26378$ 6-25987 
13-27282 17-25987 17-27618

XENON OSCILLATION

$$
\text { 6-27616 9-27616 17-27616 }
$$

YANKEE (PWR)

6-26621 17-26621

$17-25981$ $17-27338$

$17-26619$

YTTRIUM

15-27445

ZINC
$15-27441$

ZION 1 AND 2 (PWR)

2-27615 17-27615 18-26623.18-7.7615

ZIRCAL OY

4-27921 5-25906

8-27651 $27-26409$

$18-25307$

$Z$ IRCONIUM

$7-27032 . \quad 7-27095 \cdot 13-27018$ $\begin{array}{rr}5-25007 & 5-27 \leq 5 ! \\ 17-27617 \quad 18-? 5 \div 26\end{array}$ 
FOLLOWING IS A LIST OF AUTHORS WHOSE DOCUMENTS HAVE BEEN ABSTRACTED IN THIS PUBLICATION

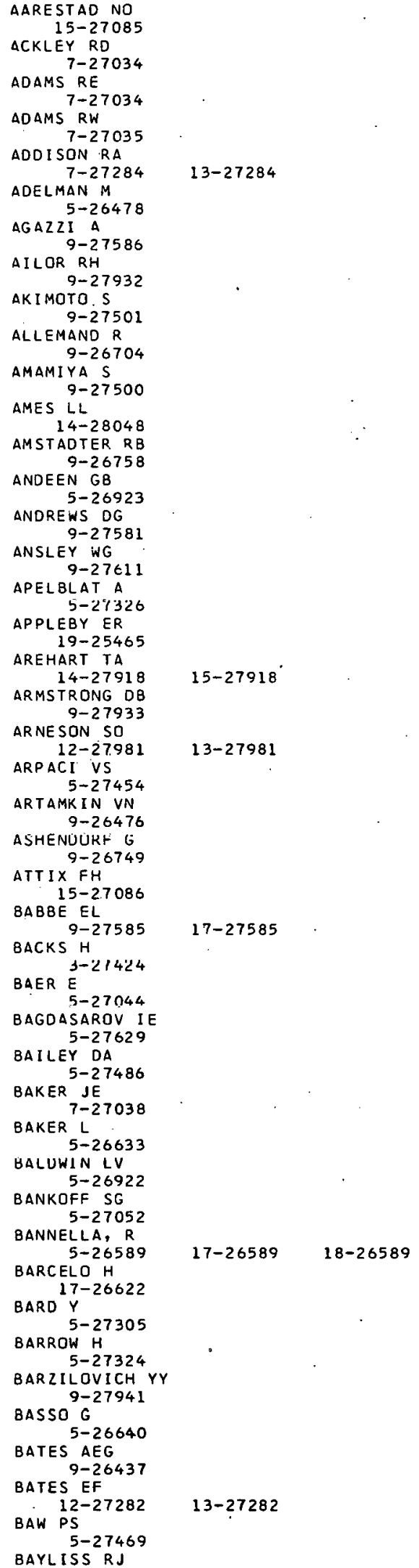

$13-27282$

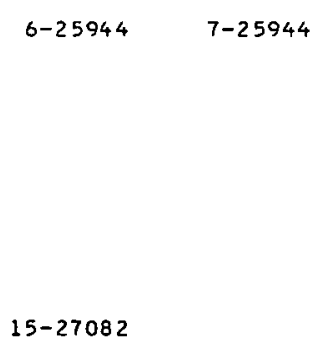


BRADFIELD WS 5-27485 BRADLEY N $11-25959$

BRADY JM

15-27085

BRAESS 0 6-27628 5-26699

BRANDON CA 5-27055

BRANYAN CE 9-28016

BRAR SS

16-27835

BRAUN $F$ 7-27069

BRAY. AP

5-25903 TA 9-26755

BREHM RL $6-25362$

BREMEN $F$ 7-27069 BRENDER DM 9-27602

BRIGGS HG 9-27935

BRIGHT GO 5-27647

BROGGI A 9-27586 BROWN DJ 14-28007

BROWN DP

$$
\text { 9-26706 }
$$

BROWN PS O-ŻitOS BUCHANAN PS 15-27648 BUCHANAN RL O-26764

BUCHHOL $2 \mathrm{H}$ 7-27035 BUEHLER RJ 9-26752

BULBA EA 7-27071

BURCH WD 14-27918 BURCH WM 15-27076 BURCHILL WE BURTON JH

$$
\text { 12-27980 }
$$

EUSH WR 15-27.860 BUSSOLINI J J BUTLER FE

$$
\text { 14-27081 }
$$$$
\text { CAILLET C }
$$$$
\text { 9-26720 }
$$$$
\text { CAMPBEI.I. EE }
$$
4-27463

CARBIENER WA 5-25944

CARPENTER SG 6-27744

CARSON JF 9-26570 CASTLEMAN AW
$7-27817$

CHALLENDER RS 9-26471

CHALMERS JH 6-26147 CHAMBRE $P L$ 5-27049

CHANDLER EM 9-27584

CHATO JC 5-26113

CHAUVET $G$ S-26559

CHEESEWR I GHT - R 5-27316

17-27584

$9-26719$

$6-27743$

$9-27610$

$6-27647$

7-27068

$15-27918$

$13-27980$

$15-27081$
$12-25903 \quad 18-25903$

6-25944 7-25944

$17-26569 \quad 17-26570$

CHERNICK J

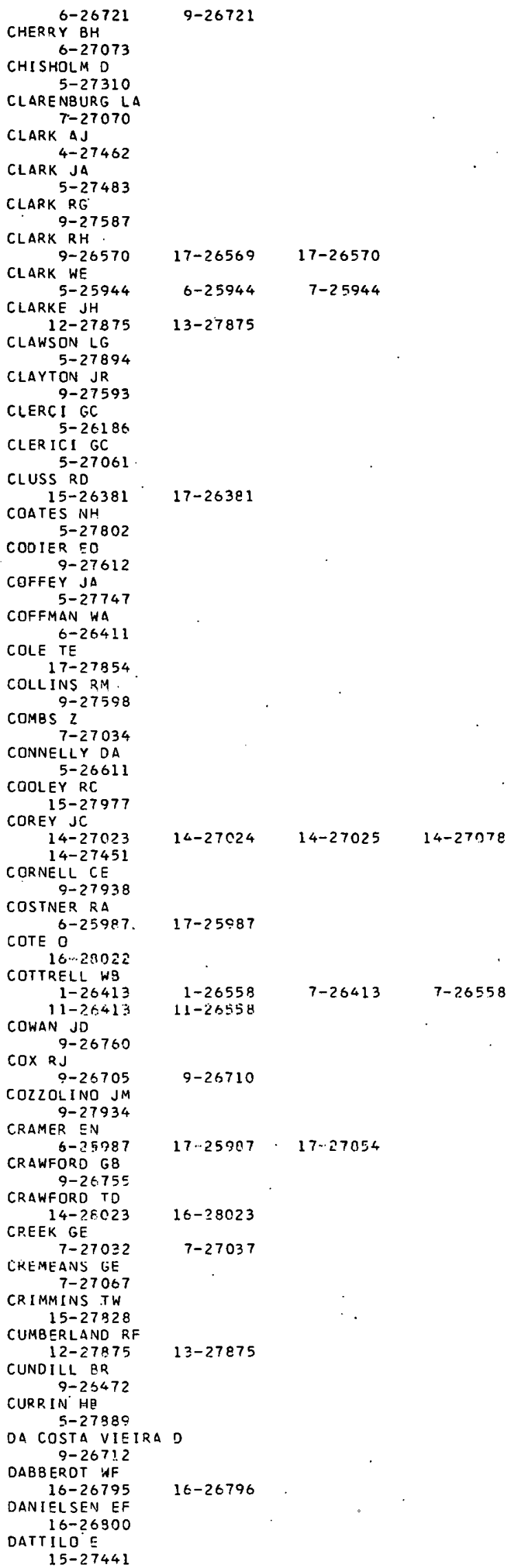

$14-27024 \quad 14-27025 \quad 14-27078$

$1-26558$

$1-26558$

$9-26710$

$17 \cdot 25387 \cdot 17 \cdot 27054$

$6-28023$
$7-27037$

$13-27875$

$16-26796$ 


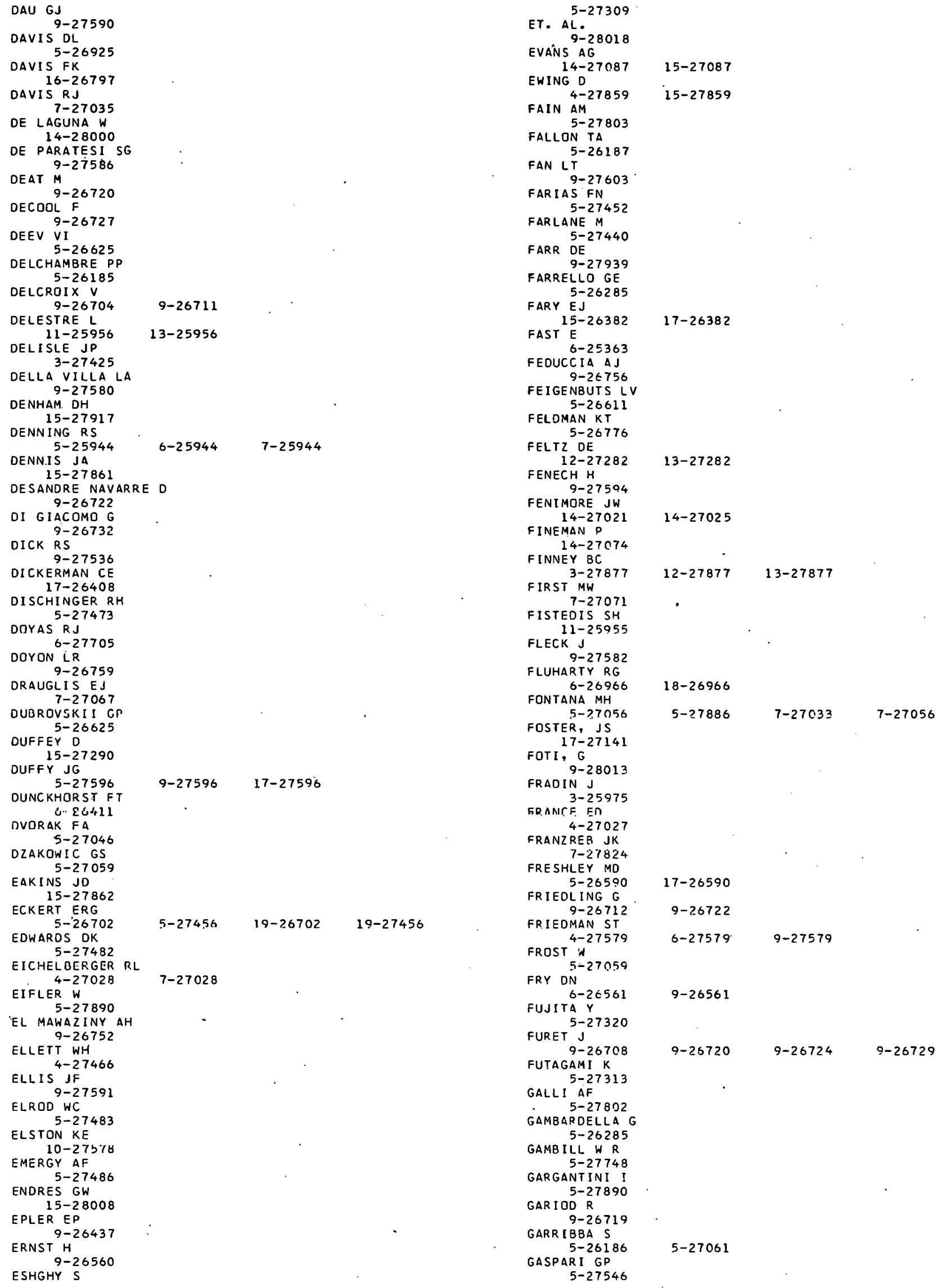


GENCO JM

$5-27491$
GERT SBAKH IB
$9-26751$

GHIURGHI L

$9-27586$

GIBSON NN

15-27828

GIEDT WH 5-27481

GIESEKE JA

5-25944

$5-25944$
$J S$
$7-27035$

GILMORE DB 9-26761

GLASS WA

15-28008

GLASSEN LK

5-27482

GLOYNA EF

14-27020

GODBOLT NH

14-27914

GODIN D

3-27424

GOEDDEL WV

7-27093

GIJLOBERG $P$

5-27894

GOLDIN AS

7-27071

GOLDSMITH S

5-26590

GOLDSTEIN R J

GOODALL G

$15-27867$

GOODINGS A

$y-26705$

GORLAND $S$

GOSE EE

4-27031

5-27044

GOTTIFRIED

9-26763

GRAFTIEAUX J

GRAHAM WW

17-27289

GRANT ID

5-26188

GRASS $G$

5-25163

GREEN

5-26779

GREENFIELD MA

4-27029

GRENON $M$

15-25982

GRESHO PM

9-27937

GRIFFITH P

5-26923

GROSE VL

$9-26747$

GUALTIERI G

3-25973

GUNTER AY

5-27057

GUON $\mathrm{J}$

$12-27283$

GUPPY WH

17-27145

GUSTAFSON PF

16-27835

HABASHI F

14-26070

HABERSTROH RD 5-26922

HAJEK BF

14-28048

HALL BF

9-26968

HALL WF 5-27742

HAMMITT FG

$$
\text { 5-26642 }
$$

HANEY WA

14-28007

HANKINS DE

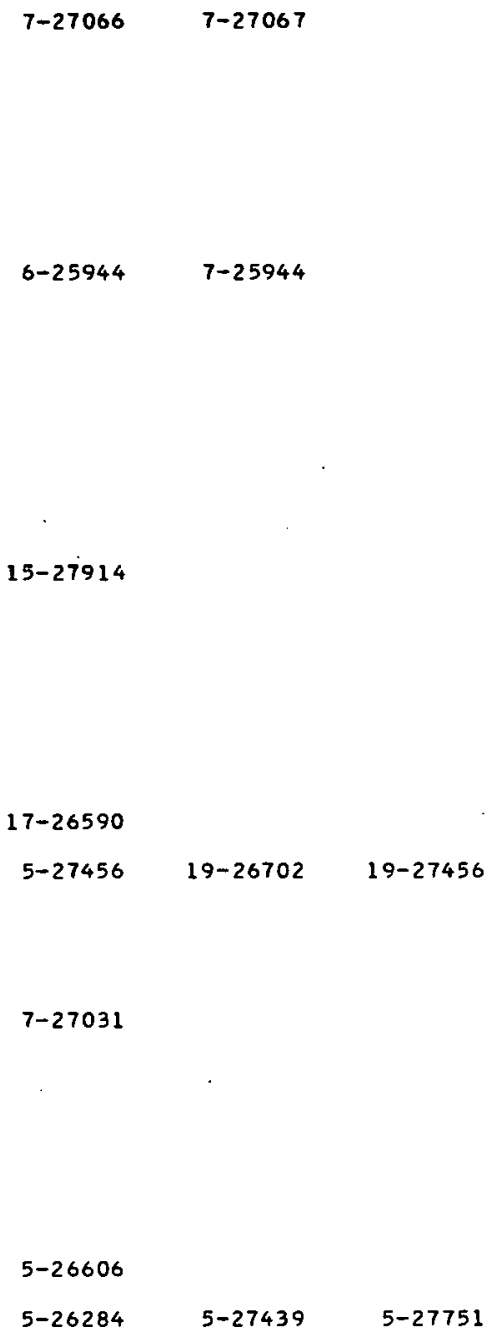

$17-25982$
15-27865

15-27865

HAPP WW

$9-27609$

HAROTKE FC

- 9-27597

HAROY EP

14-27874

HARGROVE HG 4-27464

HARRIGAN PM

5-27595

HARR I SON D

9-26705

HARTNETT JP

5-26928

HASEGAWA $S$

5-27320

HAUPTMANN EG

5-27325

HAUSER WC

5-27482

HAUSKNECHT DF$$
\text { 4-27029 }
$$

HAVERFIELO AJ

15-28008

HAWKINS RH

14-27024

HAWORTH DR

5-26633

HAY N

5-27458

HAYASHI 5

HEAD MR

$$
-28018
$$

5-27046

HEALZER JM

5-27488

HEOERT GM

HEFT RE RE

15-28043

HEIDER LH

17-25981

HENCH JE

HENRY ${ }^{5-27488}$ $9-2671$

HENZEL N

7-27999

HERKENRATH H

5-26772

HETSRONI G 5-26614

HILBERRY NE

17-28009

HILL FB

15-27443

HILTSCHER $R$

$11-25951$

HIRAKAWA N

HISE EC

5-26630

17-27130

HITCHCOCK JE $5-27484$

HUCHRE ITER LE 5-26634

HOFFMAN HW 5-27885

HOFFMAN TL

13-27018

HOGAN OL

$4-27466$

HOITINK NC

9-28014

HDI.MFS .IM

13-28025

HOLTBECKER H 5-25161

HULY $2 \mathrm{~J}$

5-26189

HOL ZWORTH GC

16-25978

HONSTEAD JF

15-28042

HOPKINSON A

9-27519

HORNBECK RH

5-27309 is-27866

13-27597

$16-25668$

$16-27874$

9-27595 17-27595

9-26710

$7-27029$

$18-27488$

$18-27488$

$8-27998 \quad 8-27999$

$5-27725 \quad 6-26630$

$9-27885$

$5-26778$ 


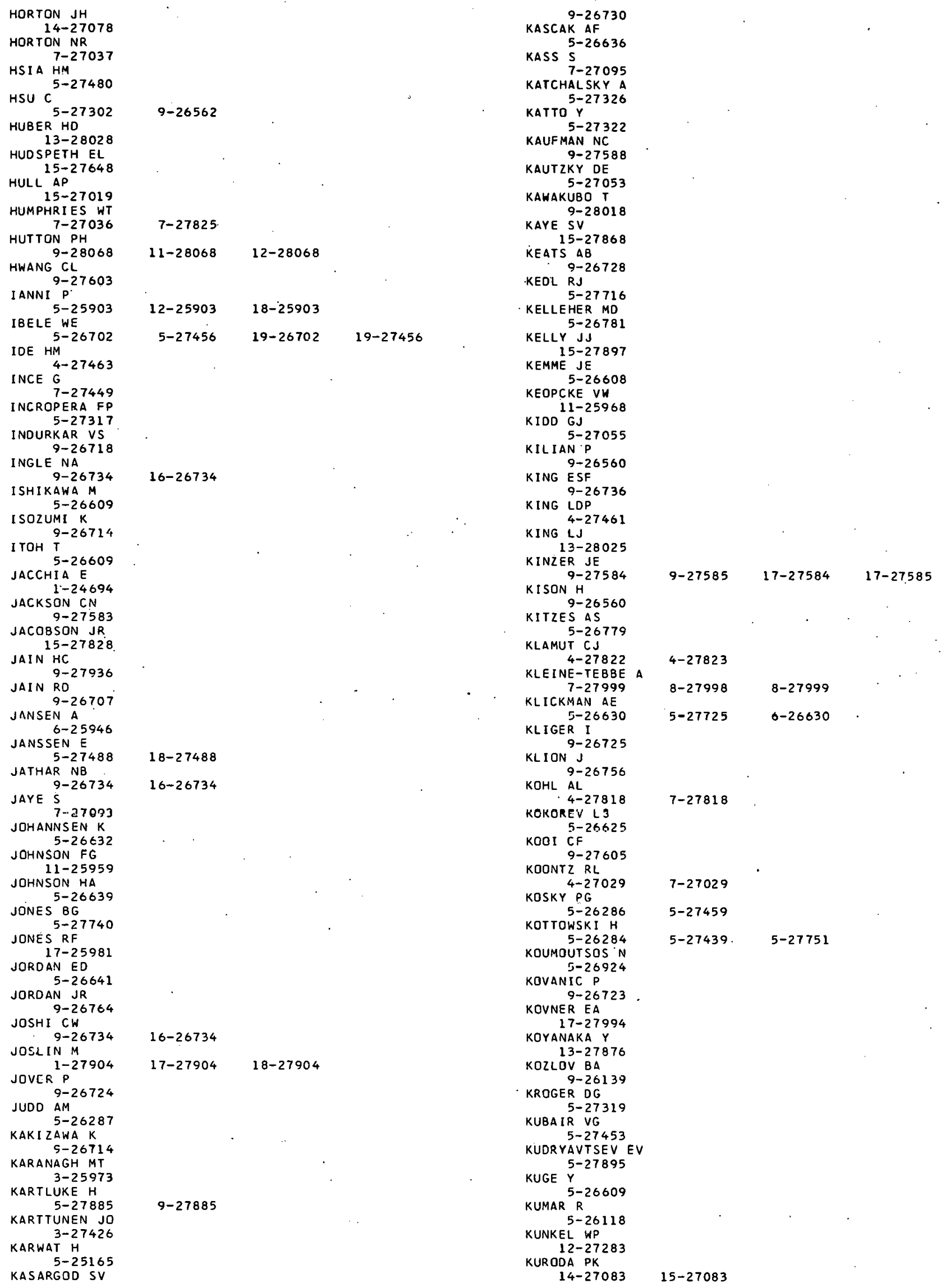




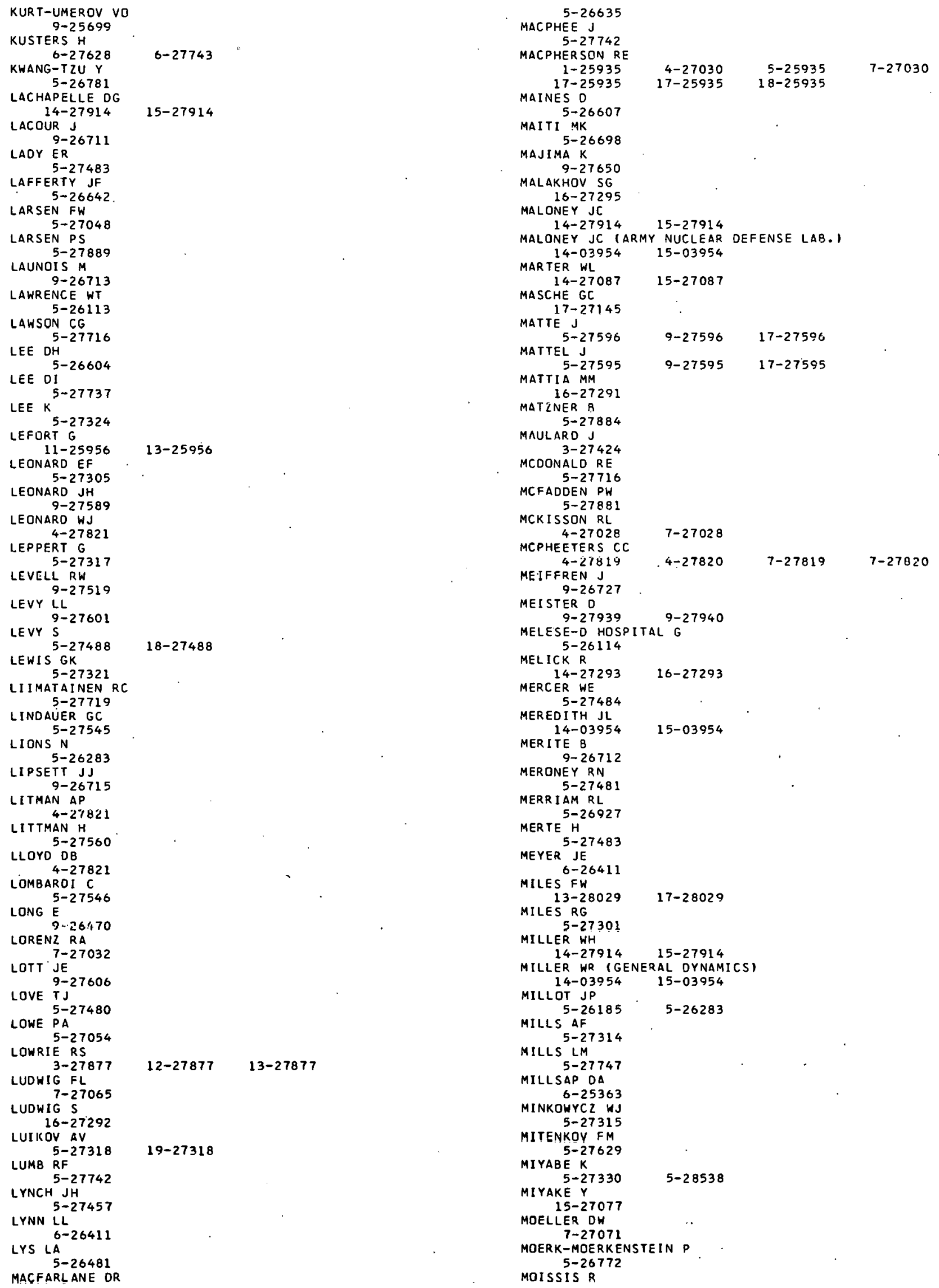




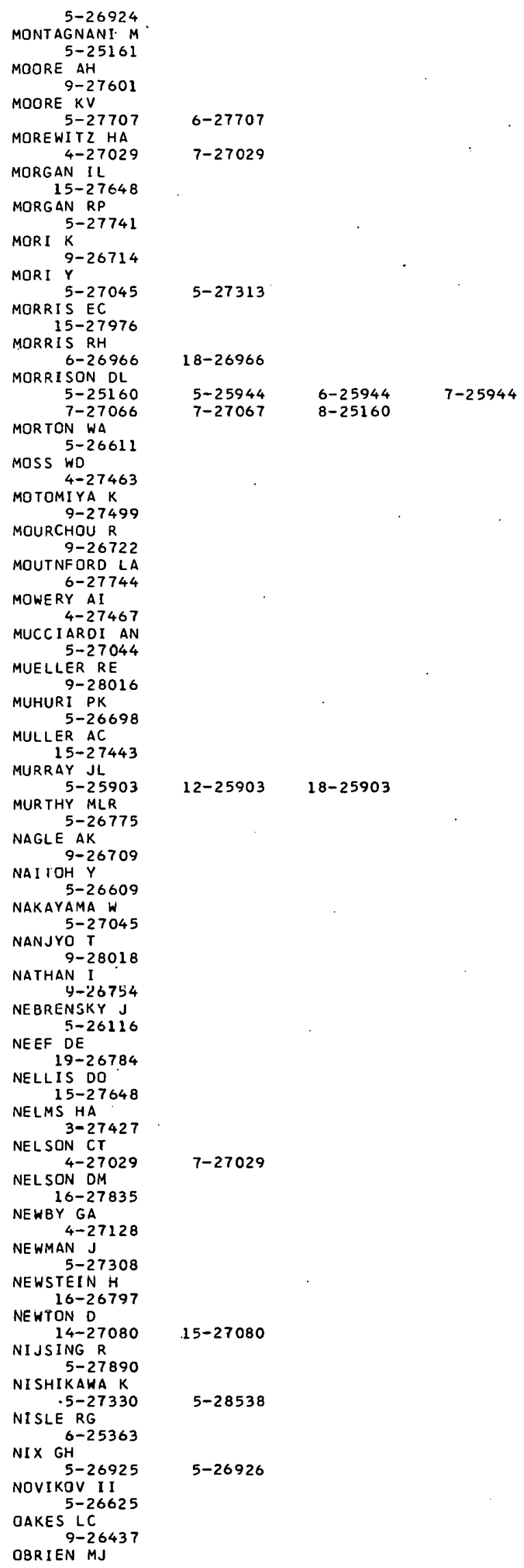

OLI VER DR

5-27892

ONEIL RW

15-26309

ORTENBERG LI

OSBORNE MF

7-27032

OVERHOLSER LG 7-27038

OVERMAN RF

14-27024

OZAIR V

9-2758

PAGE $G$

9-28017

PAGE RJ

5-27741

PALMER BD

14-27083

PANSARE MG

9-26709

PARK TA

9-27584

PARKER GW

PARSLY LF

$Y$ LF

PARSONS

SDNS PJ.

$14-26971$
PASHLEY JH

13-27878

PASHOS T

PATE NC

5-27714

PATTERSON CS 7-27036

PATTERSON RL 9-26750

PATHARDHAN PK

9-26718

9-26718

5- 27728

PEARCE WM 5-27484

PECKINPAUGH CL

12-27980

PEDERSEN HN

9-28067

PEI DCT

5-27453

PELLETIER AM

15-27828

PESKIN RL

G=27460

PETERSEN $G$

11-25954

PETERSUN KR

16-26799

PETROVICHEV VI

$$
\text { 5-26625 }
$$

PFLASTERER R

18-27333

PHILIPP LD 9-28014

PHILLIPS JF 13-28028

PHILLIPS JL

10-27286

PIEKAAR HW 7-27070

17-27286

$13-27980$

11-28067

12-28067

7-26309

$15-27083$

$7-27584$

$7-27068$

$17-26412$

$7-27825$

$9-26733$

PILLERAult

$$
\begin{aligned}
& 11-25956 \quad 13-25956
\end{aligned}
$$

PINCHASKI MS

$5-27629$
PINCHERA GC 5-26285

PINEISKI $A$ A

PINON $Y$ $-27629$

9-26.711

P ISCHIN WK 5-27629

PITTS SH

5-27472

CH

9-26762

$7-27472$

POLLOCK 80

12-27283

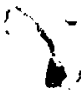

. 


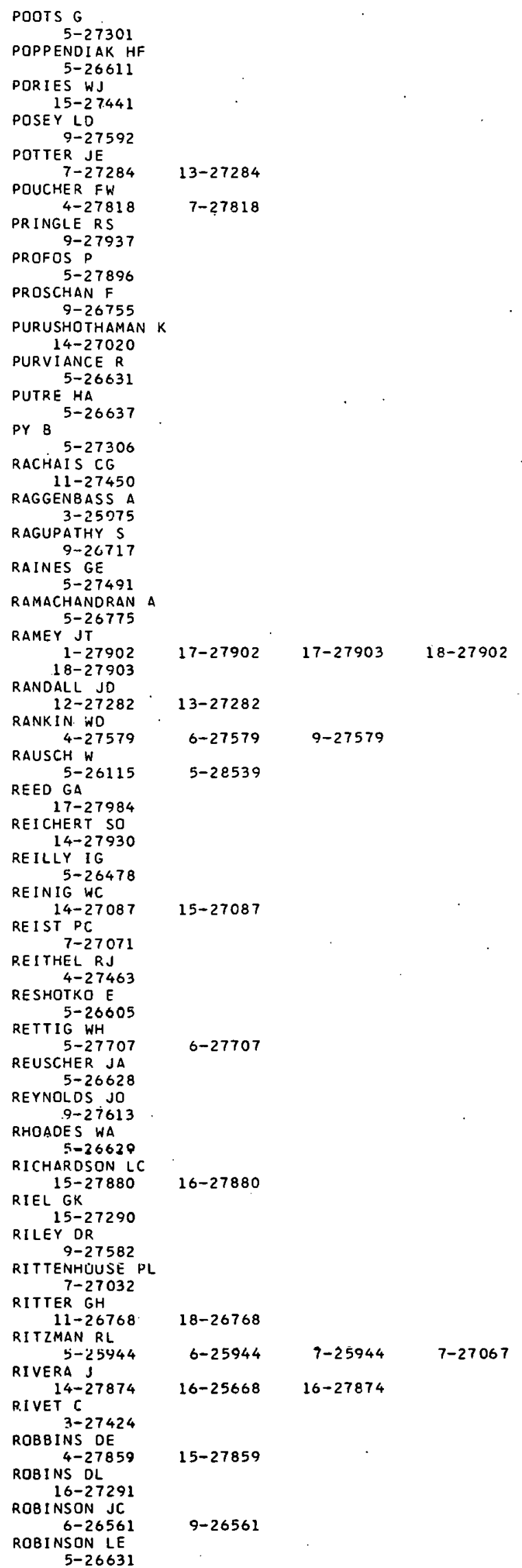

ROCHET A

ROGUIN A

9-26716

ROHSENOW WM

$5-27319$

ROHWER PS

15-27868

ROMANO AJ

ROOS $\mathrm{J}_{5-2.7894}^{4-27822}$

ROSE JW $5-26700$

ROSEN M

${ }_{5-26638}^{M}$

ROSENBERG HS $7-27066$

ROUHANI SZ

ROUX 0

5-26454 5-26455

$9-26703$

RÜUX OP

$6-2.5561$

STEIN D

9-27607

RUSSELL GJ

RYAN JD

-26966 18-26966

$5-27596$

SABIN CM

SADOY $5-26611$ $M$

$5-27315$

SAKURAI $Y$

9-26714

SALA R

5-26186 5-27061

SANDEL PS

12-27282 13-27282

SASS RE

$15-27089$

SATO T $5-27327$

5-27327 19-27327

SATO

$9-27501$

SCHAPPEL RB

13-27878

SCHICK GJ

SCHICK GJ $9-26757$

SCHIMMERL ING

15-27089

SCHLUNDER EU

5-2732?

SCHMIOT $G$

5-2b115

SCHROCK VE

SCHUL 2 WW

2 WW

SCHUMAN SO

1-27996

SCHUSTER JR

5-26929

SCOTT JL

SCOTT QL

6-25987

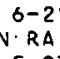

SEBAN $\cdot R A$
$5-27314$

SEBENY RL

9-26766

SEDYAKIN NM

9-26753

SEMERIA $R$

5-27438

SESONSKE A SHAV ${ }_{M K}-26634$

9-26303

12-26303

SHIBATA T

9-28018

SHIMOZATO A

13-28025

SHOOMAN ML

$9-27931$

SHOTK IN I.M

$5-26600$

$3-28539$

5-26639

17-27096 I8-27996

17-25987 17-27142

SHUSTER WW

5-26638

$5-27064$

SIBLEY FS 


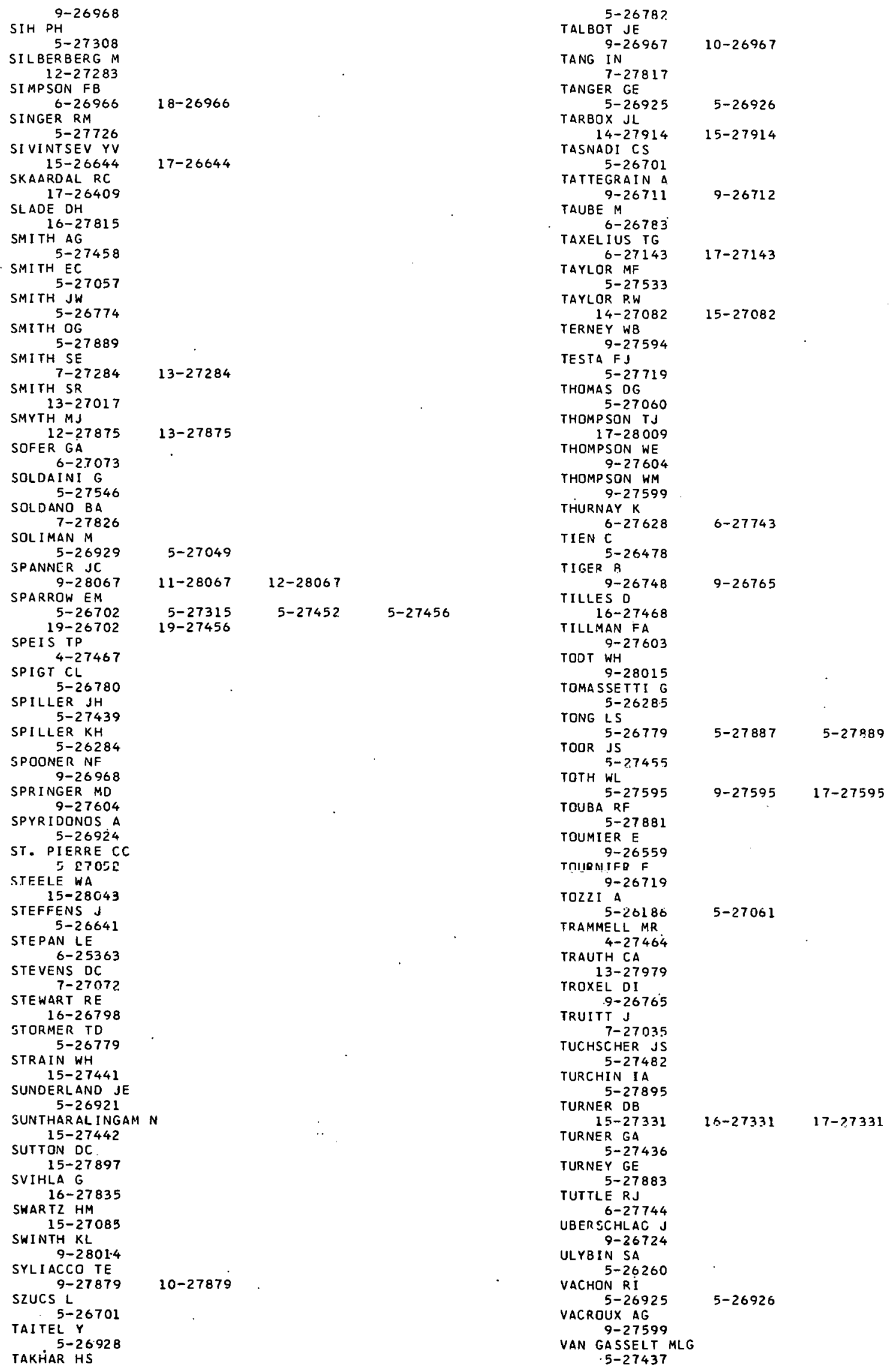


VAN MEEL DA

5-27437

VAN MIODLE SWORTH L

14-27293 16-27293

VAN WI JNGAARDEN L $5-27047$

VANDENBERG SR

$\begin{array}{cc}5-27882 & 11-27882 \\ \text { VENKATESWARLU } & \text { U } \\ 9-26707 & 9-26709 \\ \text { VERBER F } & \\ 9-26512 & 10-26512\end{array}$

VERTUT J

3-25975

VICTORY SP 5-27057

VILES JF $7-27071$

VILLAIN P 9-26559

VISKANTA $R$

5-26927 5-27455

VISWANATHAN $L$ 9-26709

VOHRA KG

VOLTA ${ }^{9-26717}$

5-25162

VON DER HARDT $P$ 17-27129

VORONKOV AV

9-26476

WAAGE JM

5-27891

WACHTEL $5 \mathrm{~J}$ $4-27822$

WAITE DA

17-28001

WALKER OM

17-27289

WALKER JAJ 4-27027

WALKER JV 9-27592

WALMSLEY $R$

$$
\text { 7-27449 }
$$

WALSH EM

10-27988

WALTERS CT

WANG CS

$$
\text { 9-27603 }
$$

WARBERG HS

5-27596

W-27826

WARNSING $R$

5-27751

WA SHBURN LA 9-27.600

WASMUND $B$ 5-26774

WATSON CD

$\begin{array}{lll}3-27877 & 12-27877 & 13-27877\end{array}$

WATTS JL

6-27705

$9-27596 \quad 17-27596$
HEED RD

12-27

$9-26708$

$9-26720$

WEISS DW

$9-26763$

WE ISS $H$

9-26726

WE I TZENF I ELD AS 9-27609

WEKER RA

7-27071

WESTWATER JW 5- 27053

WHITE JF

5-27651

WHITE PAF

$7-27284$

WHITEHOUSE WJ

15-27445

WHITING GH

5-26776

WHYARD RE

9-267.28

WICHNER R.P

5-27885

WILLIS L

5-26631

WILSCN I

9-26710

WILSON TR

. $5-25160$

'WINOLE GV

11-25959

WITTE LC

5-26633

WOLFE $B$

$18-27333$

WOOD WP

9-26762

WOOTON RO

5- 25944

WR IGHT LW 9-27942

WYLIE RD

5-27494

YAROSH MM

4-27043

YOKOYA $S$

5-27322

YOSHIDA Y

15-27861

ZABRODSKY SS 5-27312

ZARESKY SA

15-27441

ZAVATTARELLI R

5-27546

ZERKLE RD

5-26921

2 IEGLER A

11-25:52

$Z$ IMMERMAN CA

$13-27018$

ZWETZIG GB

$12-27283$
$9-27885$

8-27651

13-27284

$9-26729$

$8-25160$

$6-25944$

$7-25944$

$9-27494$

$17-27494$

5-27043

$11-25954$ 
THE ONLY REPORTS DISTRIBUTED BY NSIC ARE THOSE GENEFATED BY THE CENTER, I.E., THOSE WITH ORNL-NSIC NUMBERS. UNDER NO CIRCUMSTANCES $\triangle R E$ COPIES OF THE OTHER REPORTS REFERENCED IN THIS BIBLIOGRAPHY FURNISHED, ALTHOUGH ALL AVAILABLE DOCUMENTS MAY BE EXAMINED AT THE CENTER BY QUALIFIED PCRSONNEL.

NSIC HAS INITIATED A NEW FORMAT FOR DOCUMENT AVAILABILITY AND PRICE. THIS INFORMATION IS NOW PRESENTED, WHERE APPL ICABLE AND AVAILABLE, IN A LINE TO ITSELF FOLLOWING THE DOCUMENT ABSTRACT. WHERE PREVIOUSLY THE NAME OF THE SOURCE ORGANIZATION APPEARED AT THE END OF THE LINE PRECEEDING THE ABSTRACT AND WAS ABBREVIATED, IT IS NCW SPELLED OUT IN THE NEW LOCATION. SINCE IT WILL TAKE SOME TIME TO CONVERT CLMPLETELY TO THE NEW SYSTEM, NSIC WILL CONTINUE TO FURNISH A KEY TO THE ABBREVIATIONS. THIS KEY ALONG WITH THE ADDRESSES OF THE SOURCE ORGANIZATIONS FOLLOWS.

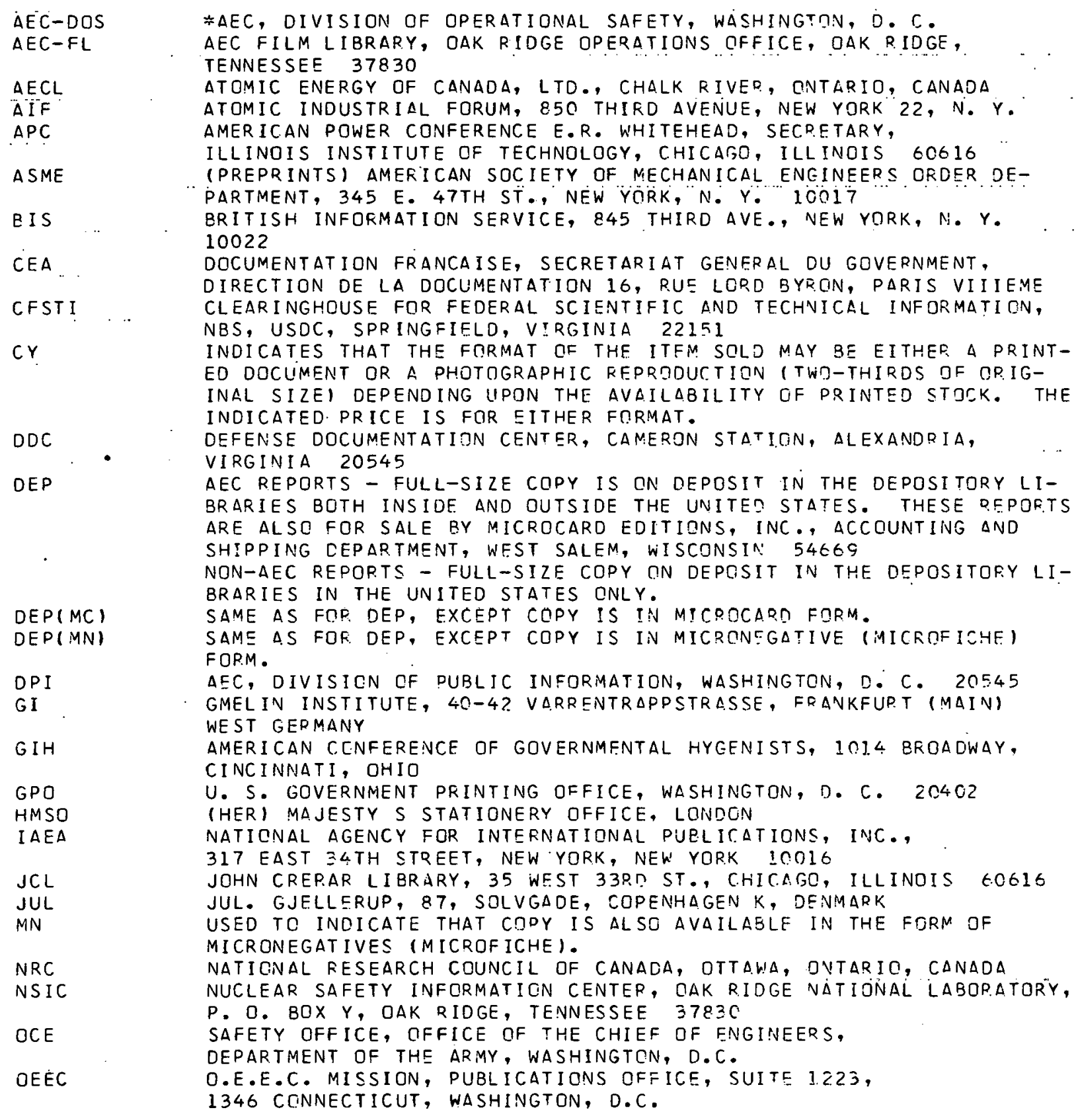

$J C L$

JUL

MN

NRC

NSIC

OCE

OEEC

*AEC, DIVISION OF OPERATIONAL SAFETY, WASHINGTIN, D. C. AEC FILM LIBRARY, OAK RIDGE OPERATIONS CFFICE, OAK RIDGE, TENNESSEE 37830

ATOMIC ENERGY OF CANADA, LTO., CHALK RIVED, CNTARIO, CANAOA ATOMIC INDUSTRIAL FORUM, 850 THIRD AVENUE, NEW YORK $22, \mathrm{~N} . \mathrm{Y}$. AMER ICAN POWER CONFERENCE E.R. WHITEHEAD, SECPETARY, ILLINOIS INSTITUTE OF TECHNOLOGY, CHICASO, ILLINOIS 60616 (PREPRINTS) AMERI CAN SOCIETY OF MECHANICAL ENEINEERS ORDER DEPARTMENT, 345 E. 47TH ST̈., NEW YÖRK, N. Y. $10 O 17$ BRITISH INFORMATION SERVICE, 845 THIRD AVE., NEW YORK, N. Y. 10022 DOCUMENTATION FRANCAISE, SECRETARIAT GENERAL DU GOVERNMENT, DIRECTION DE LA DOCUMENTATION 16, RUS LORD BYKON, PARIS VIIIEME CLEARINGHOUSE FOR FEDERAL SCIENTIFIC AND TECHNICAL INFORMATION, NBS, USOC, SPR INGFIELO, VIRGINIA 22151

INDICATES THAT THE FORMAT OF THE ITFM SCLD MAY BE EITHER A PRINTEO DOCLIMENT OR A PHOTOGRAPHIC REPRIDUCTION ITWD-THIRDS DF OPIGINAL SIZEI DEPENDING UIPON THE AVAILABILITY OF PRINTED STOCK. THE

INDICATED. PRICE IS FOR EITHER FORMAT.
DEFENSE DOCUMENTATION CENTER, CAMERON STATION, ALEXANDRIA, VIRGINIA 20545

AEC REPORTS - FULL-SIZE COPY IS CN DEPOSIT IN THE DEPOSITORY LIBRARIES BOTH INSIDE AND OUTSIDE THE UNITE STATES. THESE PEPOF.TS ARE ALSO FOR SALE BY MICROCARD EDITIONS, INC., ACCOUNTING $\triangle N D$ SHIPPING CEPARTMENT, WEST SALEM, WISCONSIN! 54669 NON-AEC REPORTS - FULL-SIZE COPY ON DEPOSIT IN THE DEPOSITOFY LIBRARIES IN THE UNITED STATES QNLY. SAME AS FOP DEP, EXCEPT COPY IS IN MICOOCARO FORM. SAME $\triangle S$ FOF. DEP, EXCEPT COPY IS IN MICRONEGATIVE (MICROFICHE) FOPM.

$\triangle E C$, DIVISICN CF PUBLIC INFORMATION, WASHINGTON, D. C. 20545 GMEL IN INSTITUTE, 4Q-4? VARRENTRAPPSTRASSE, FRANKFUP.T (MAIN) WEST GEPMANY

AMERICAN CENFERENCE OF GOVERNMFNTAL HYGENISTS, 1014 BROADWAY, CINCINNATI, OHIO

U. S. GOVERNMENT PRINTING OFFICE, WASHINGTON, D. C. 20402

(HER) MAJESTY S STATIONERY OFFICE, LONDGN

NATICNAL AGENCY FOR INTERNATIONAL PUELICATIONS, INC.,

317 EAST 34 TH STREET, NEW YORK, NEW YORK 10016

JOHN CREP.AR LIBRARY, 35 WEST 33P D ST., C.HIC.ASO, ILLINOIS t.0616

JUL. GJELLERUP, 87, SOLVGADE, COPENHAGEN K, DENMARK

USED TO INOICATE THAT COPY IS ALSO AVAILABLE IN THE FORM OF MICRONEGATIVES (MICROFICHE).

NATICNAL FESEARCH COUNCIL OF CANACA, OTTAWA, ONTARIC, CANADA NUCLEAR SAFETY INFORMATION CENTER, OAK RIDGE NATIONAL LABOPATORY, $P$. 0 . BOX $Y$, OAK RIDGE, TENNESSEE $3783 \mathrm{C}$

SAFETY OFFICE, OFFICE OF THE CHIEF OF ENGINEERS, DEPARTMENT OF THE ARMY, WASHINGTCN, D.C.

O.E.E.C. MISSION, PUBLICATIONS OFFICE, SUITE 1.2.23, 1346 CONNECTICUT, WASHINGTON, D.C. 


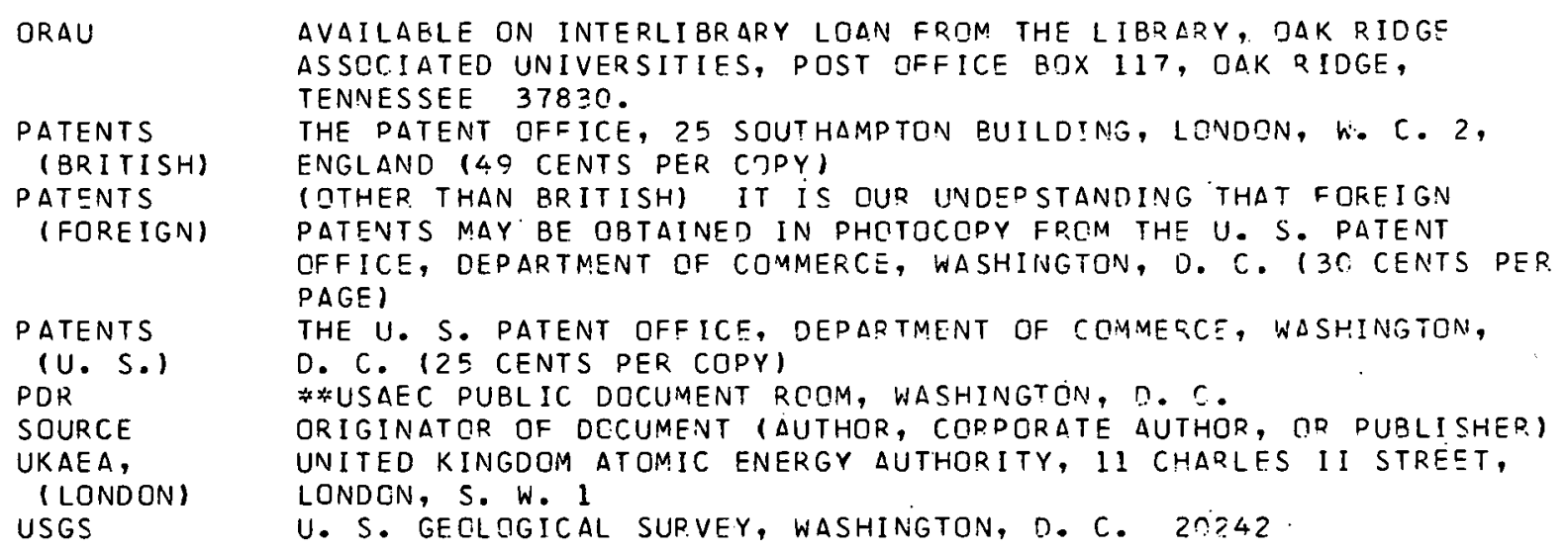


THIS PAGE

\section{WAS INTENTIONALLY LEFT BLANK}


INTFRNAL

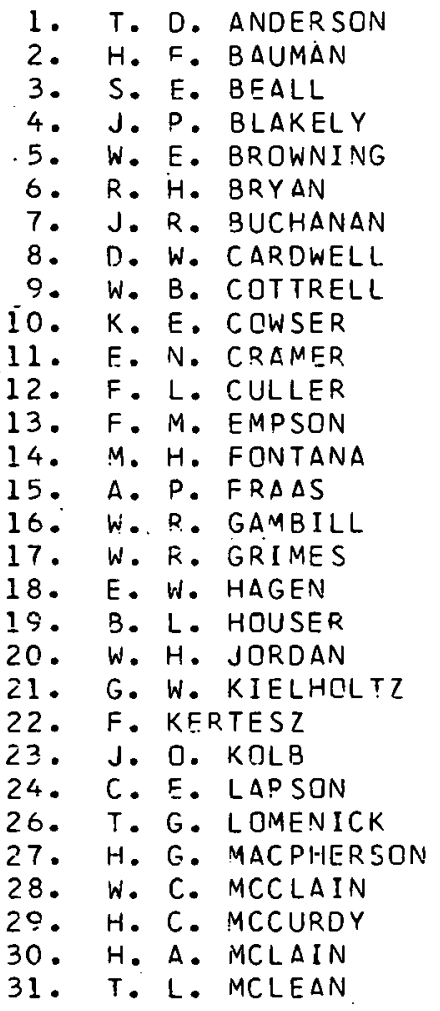

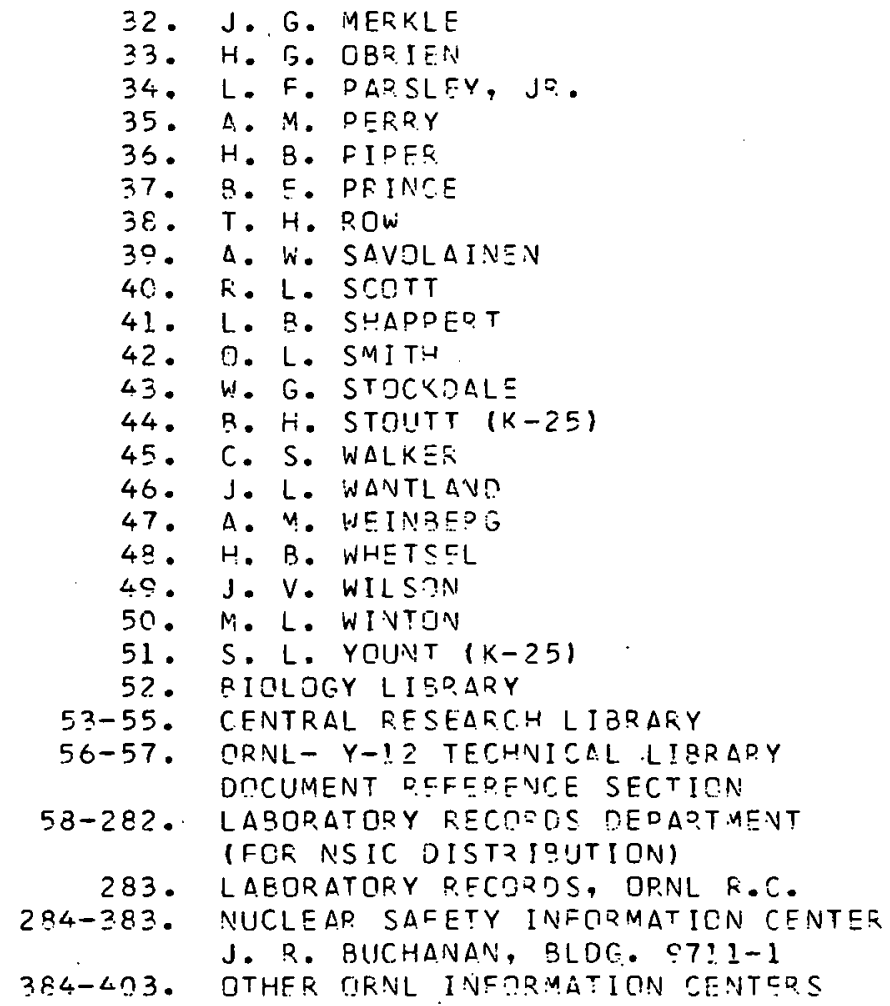

EXTER:NAL

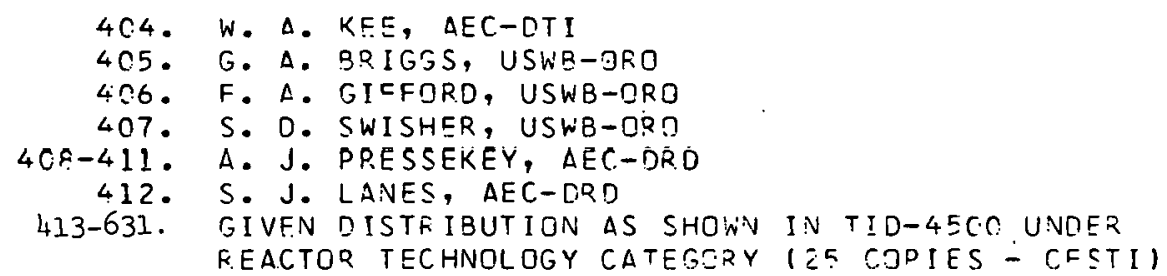

